\title{
The Cayo del Oso Site (41NU2) Volume II Results of Archeological Monitoring of Spur 3, Corpus Christi, Nueces County, Texas 2000-2007
}

Barbara M. Meissner

Steve A. Tomka

Raba Kistner

Jennifer A. Thompson

Raymond P. Mauldin

Center for Archeological Research, University of Texas at San Antonio

Follow this and additional works at: https://scholarworks.sfasu.edu/ita

Part of the American Material Culture Commons, Archaeological Anthropology Commons, Environmental Studies Commons, Other American Studies Commons, Other Arts and Humanities Commons, Other History of Art, Architecture, and Archaeology Commons, and the United States History Commons

Tell us how this article helped you.

This Article is brought to you for free and open access by the Center for Regional Heritage Research at SFA ScholarWorks. It has been accepted for inclusion in Index of Texas Archaeology: Open Access Gray Literature from the Lone Star State by an authorized editor of SFA ScholarWorks. For more information, please contact cdsscholarworks@sfasu.edu. 


\section{The Cayo del Oso Site (41NU2) Volume II Results of Archeological Monitoring of Spur 3, Corpus Christi, Nueces County, Texas 2000-2007}

\section{Licensing Statement}

This is a work produced for the Texas Department of Transportation (TxDOT) by the report producer. TxDOT and the report producer jointly own all rights, title, and interest in and to all intellectual property developed under TXDOT's contract with the report producer. The report may be cited and brief passages from this publication may be reproduced without permission provided that credit is given to both TXDOT and the report producer. Permission to reprint an entire chapter, section, figures or tables must be obtained in advance from either the Supervisor of the Archeological Studies Branch, Environmental Affairs Division, Texas Department of Transportation, 125 East 11th Street, Austin, Texas, 78701 or from the report producer. 


\section{The Cayo del Oso Site (41NU2)}

Volume II

Results of Archeological Monitoring of Spur 3,

Corpus Christi, Nueces County, Texas 2000-2007

by

Barbara M. Meissner, Steve A. Tomka, Jennifer A. Thompson and Raymond P. Mauldin

with contributions by

Vaughn M. Bryant, Linda S. Cummings, J. Philip Dering, Charles D. Frederick, Russell D. Greaves, Darden Hood, Leonard Kemp, Richard B. Mahoney, Manuel R. Palacios-Fest, Jason B. Perez, R.A. Varney, Barbara Winsborough and Chad Yost

Texas Antiquities Permit Number: 2445

Work Authorization: 57514 SA005

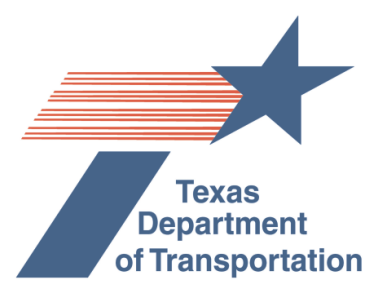

Environmental Affairs Division Texas Department of Transportation Archeological Studies Program, Report No. 114

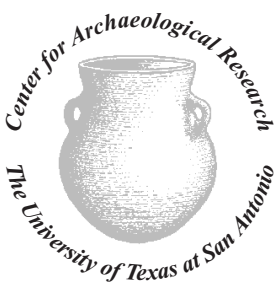

Center for Archaeological Research The University of Texas at San Antonio Archaeological Report, No. 390 

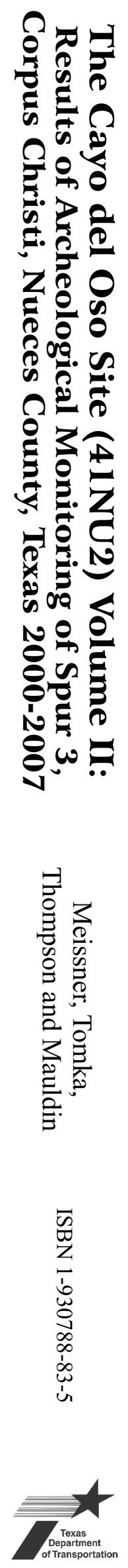

AR \#390

ASPR \# 114

2009 


\section{The Cayo del Oso Site (41NU2)}

\section{Volume II \\ Results of Archeological Monitoring of Spur 3, Corpus Christi, Nueces County, Texas 2000-2007}

by

Barbara M. Meissner, Steve A. Tomka, Jennifer A. Thompson and Raymond P. Mauldin with contributions by

Vaughn M. Bryant, Linda S. Cummings, J. Philip Dering, Charles D. Frederick, Russell D. Greaves, Darden Hood, Leonard Kemp, Richard B. Mahoney, Manuel R. Palacios-Fest, Jason B. Perez, R.A. Varney, Barbara Winsborough and Chad Yost

Texas Antiquities Committee Permit No. 2445

Principal Investigator

Raymond P. Mauldin

Former Principal Investigator

Robert J. Hard

Work Authorization No. 57514 SA005

Contract No. 575 XX SA005

Prepared for:

Environmental Affairs Division

Texas Department of Transportation

Archeological Studies Program, Report No. 114

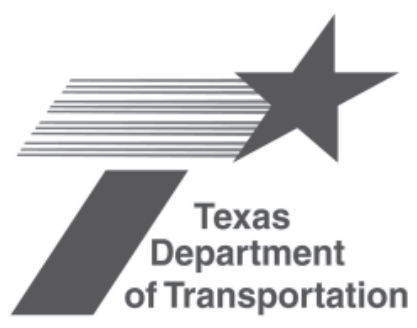

CSJ No. 3596-01-002

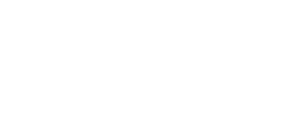

Prepared by:

Center for Archaeological Research

The University of Texas at San Antonio Archaeological Report No. 390 


\title{
The Cayo del Oso Site (41NU2)
}

\section{Volume II \\ Results of Archeological Monitoring of Spur 3, Corpus Christi, Nueces County, Texas 2000-2007}

\author{
Copyright ${ }^{\circledR} 2009$ \\ Texas Department of Transportation (TxDOT) and Center for Archaeological Research, \\ The University of Texas at San Antonio (CAR-UTSA)
}

\begin{abstract}
All rights reserved
TxDOT and CAR-UTSA jointly own all rights, title, and interest in and to all data and other information developed for this project under Contract 57514SA005. Brief passages from this publication may be reproduced without permission provided that credit is given to TxDOT and CAR-UTSA. Permission to reprint an entire chapter, section, figures or tables must be obtained in advance from the Supervisor of the Archeological Studies Program, Environmental Affairs Division, Texas Department of Transportation, 125 East $11^{\text {th }}$ Street, Austin, 78701. Copies of this publication have been deposited with the Texas State Library in compliance with the State Depository requirements.
\end{abstract}

Printed by Blue Tape, San Antonio

2009

jointly published by

Texas Department of Transportation

Environmental Affairs Division

Archeological Studies Program

Scott Pletka, Ph.D., Supervisor

Archeological Studies Program, Report No. 114

A. McGraw, Series Editor

and

Center for Archaeological Research

The University of Texas at San Antonio

Archaeological Report, No. 390

ISBN: 1-930788-83-5 


\begin{abstract}
:
This report is the second volume in a two volume set (see Jackson et al. 2004) detailing the archeological work conducted at site $41 \mathrm{NU} 2$ over several years. This volume focuses on the results of construction monitoring associated with road improvements to Spur 3, in Corpus Christi. The work was conducted under Texas Antiquities Committee Permit Number 2445, originally issued to Dr. Robert Hard, who served as the Principal Investigator during the early phases of the project. In 2001, the permit was transferred to Dr. Raymond P. Mauldin, who served as the Principal Investigator the remainder of the project.
\end{abstract}




\section{Table of Contents:}

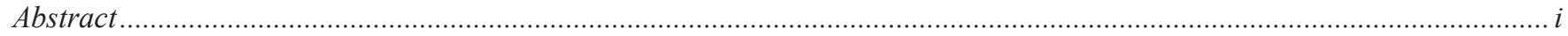

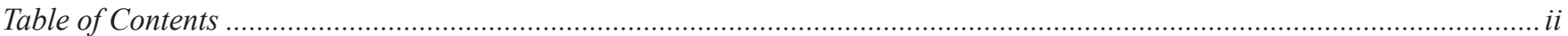

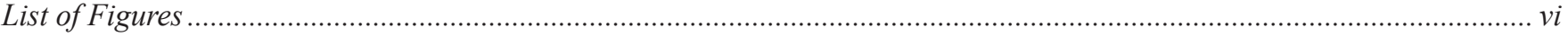

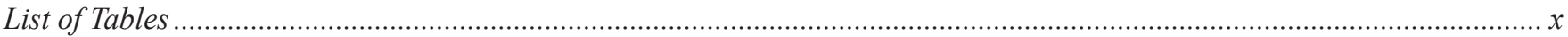

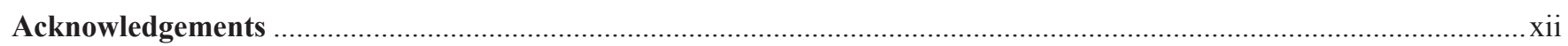

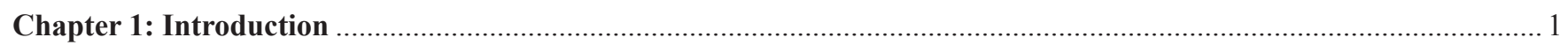

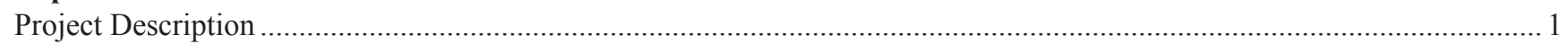

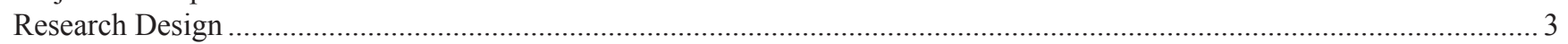

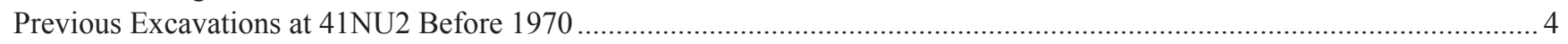

Archeological Projects Associated with the Spur 3 TxDOT Project ................................................................................ 4

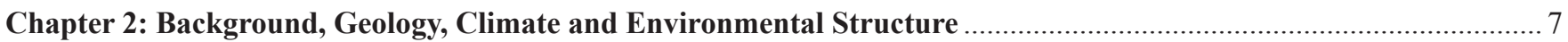

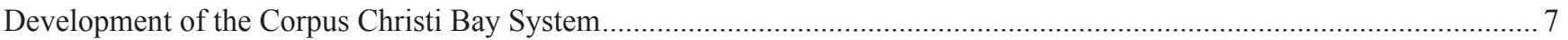

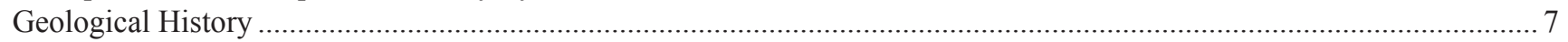

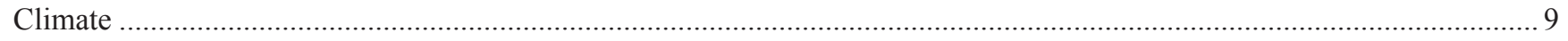

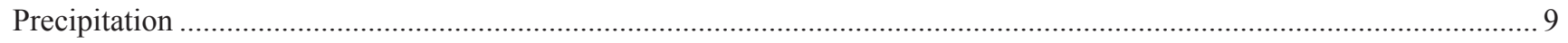

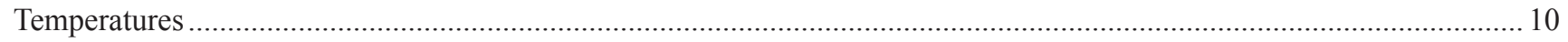

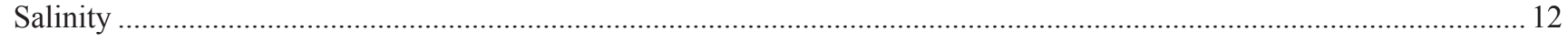

Environmental Structure

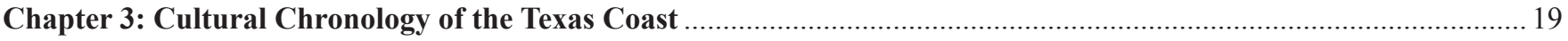

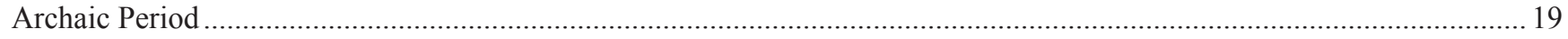

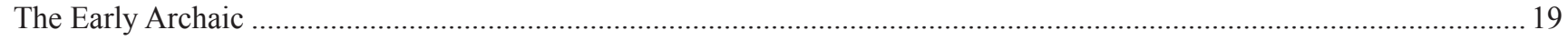

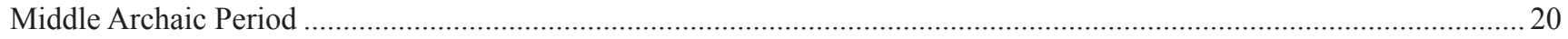

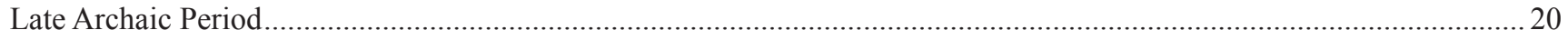

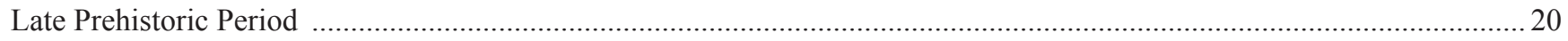

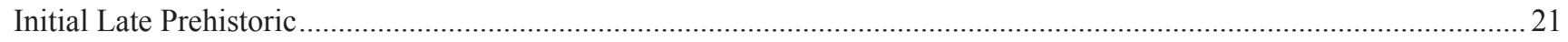

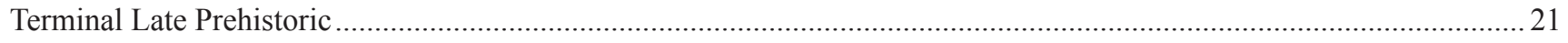

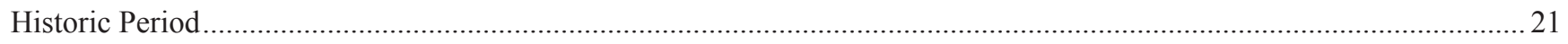

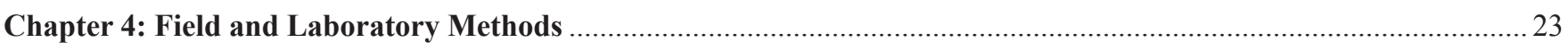

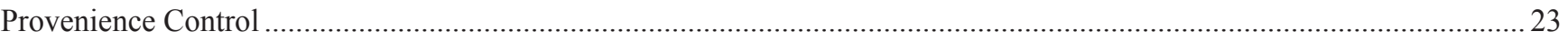

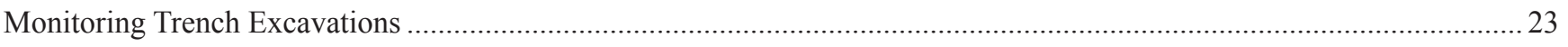

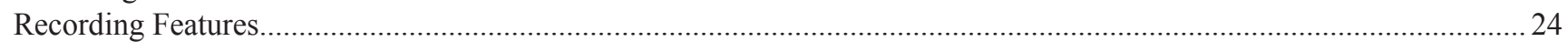

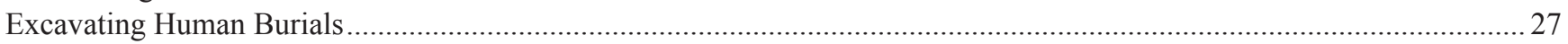

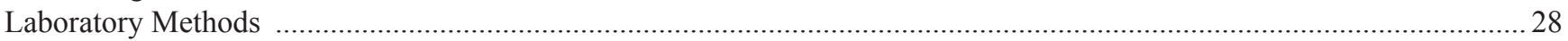

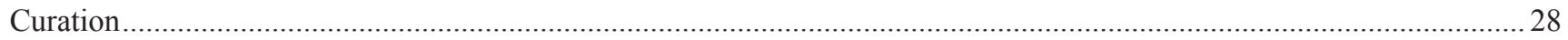

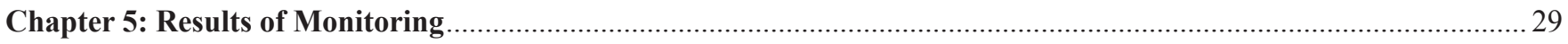

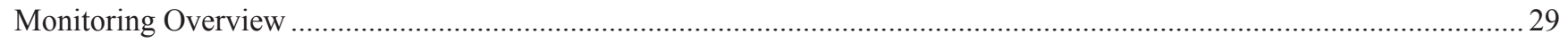

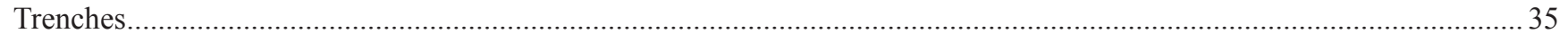

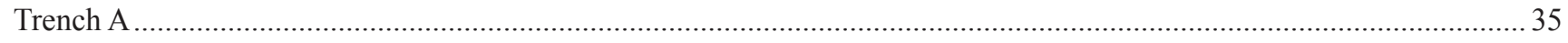

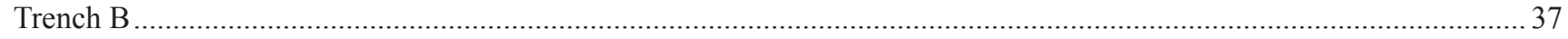

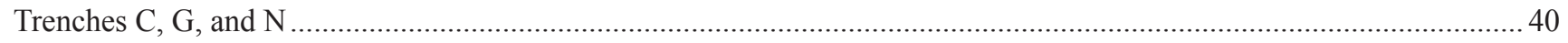

Trench D

Trench E

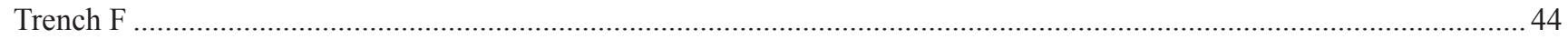




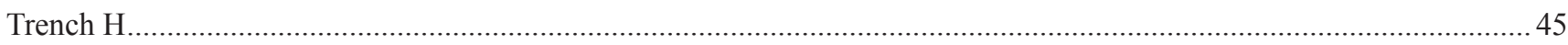

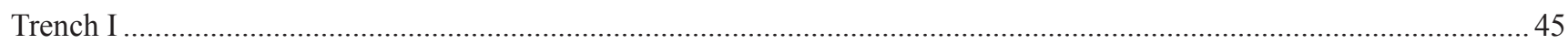

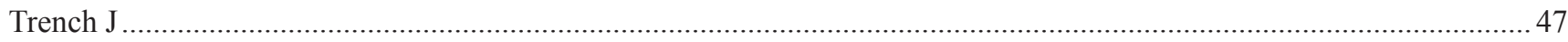

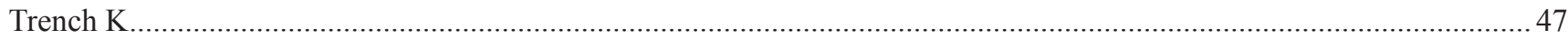

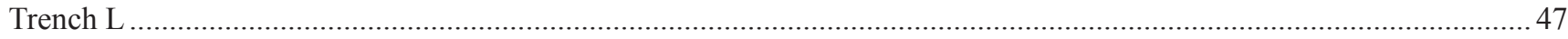

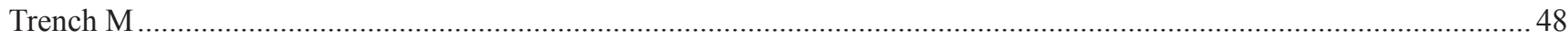

Trench O

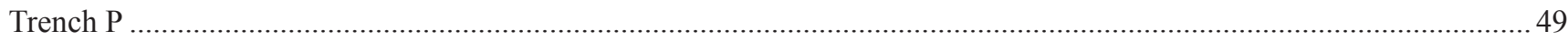

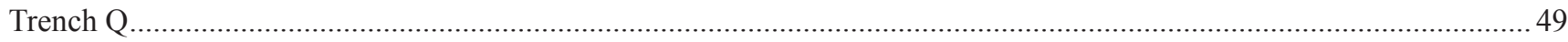

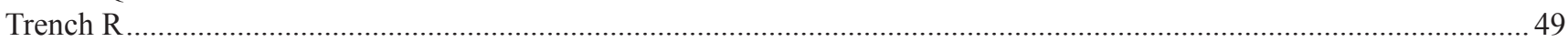

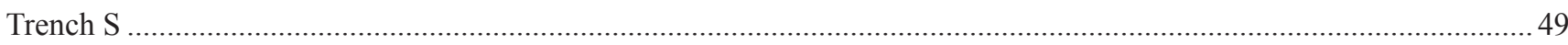

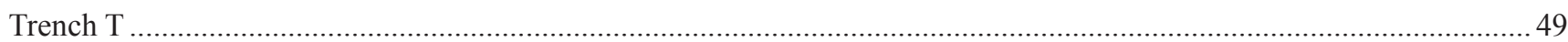

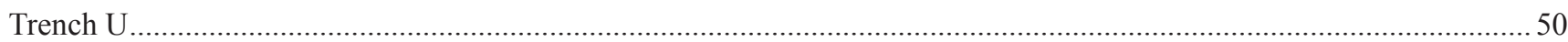

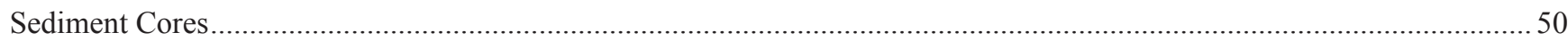

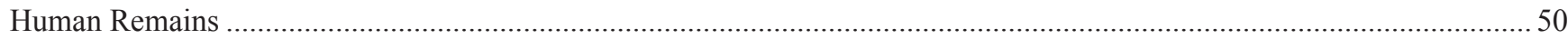

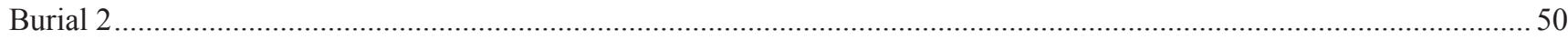

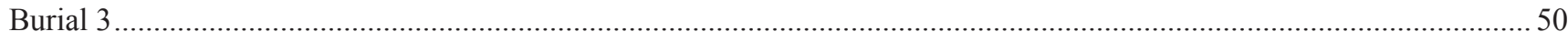

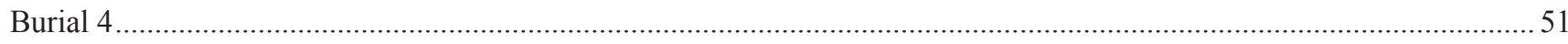

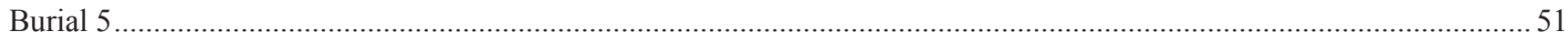

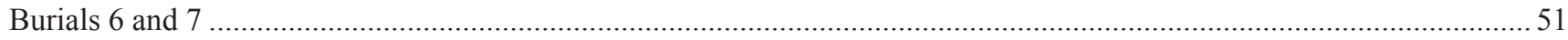

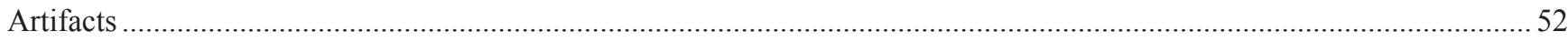

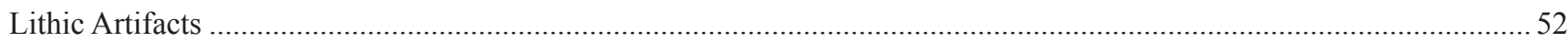

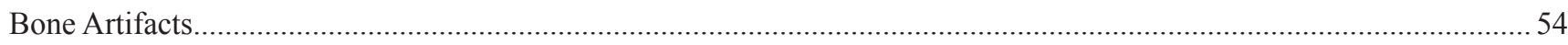

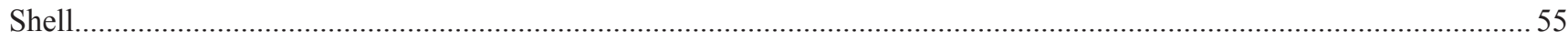

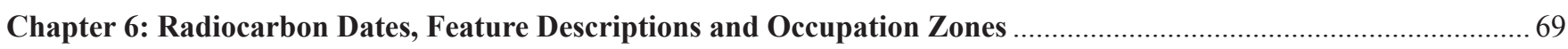

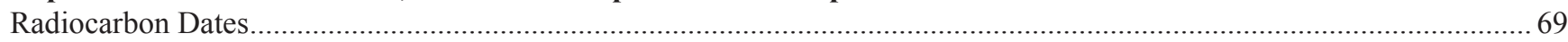

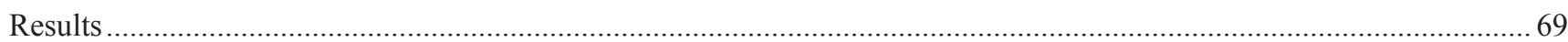

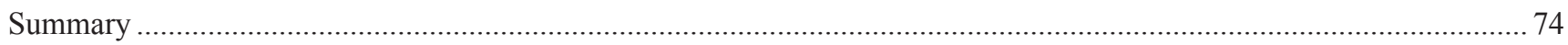

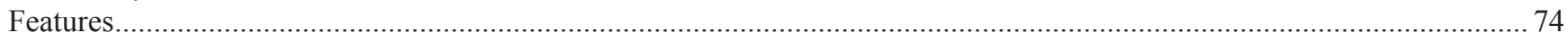

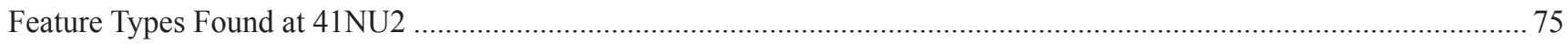

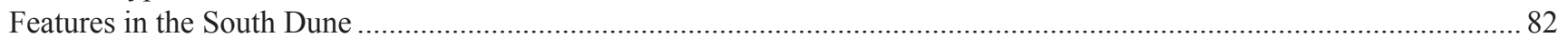

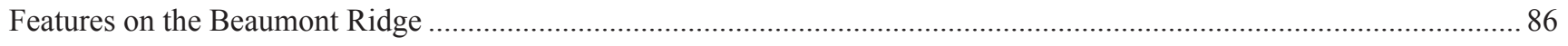

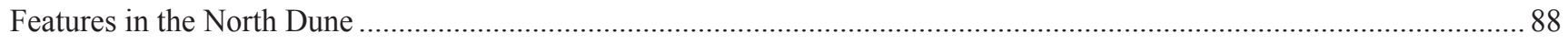

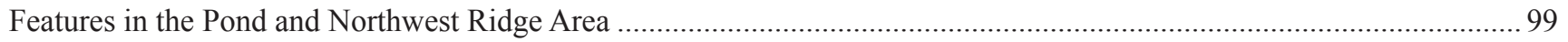

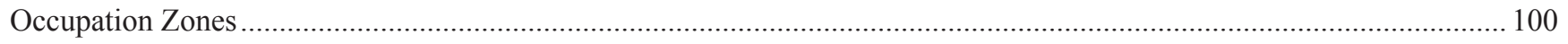

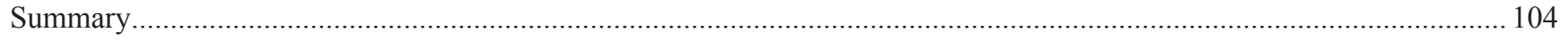

Chapter 7: Theoretical Framework: Modeling Hunter-Gatherer Adaptations ...................................................... 105

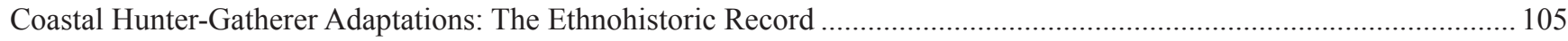

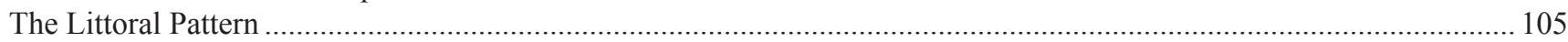

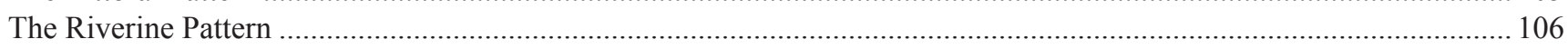

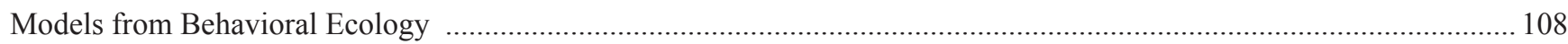

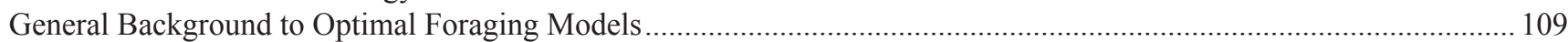

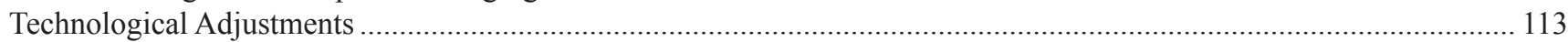

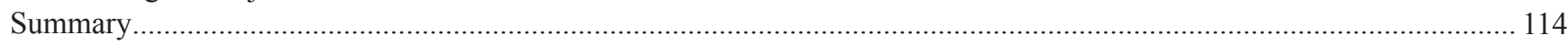

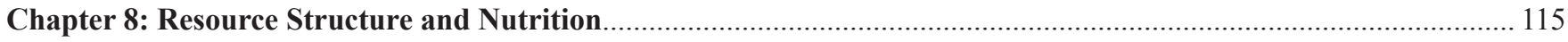

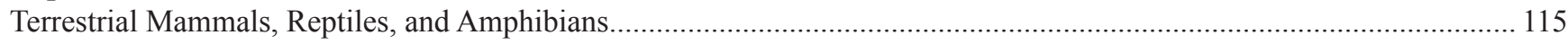

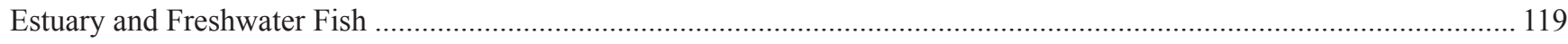

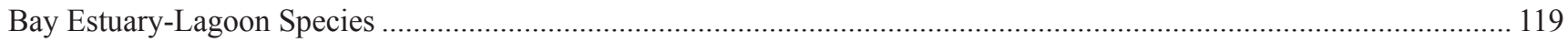

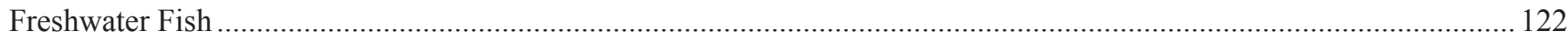

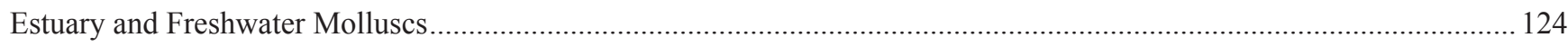

Bay-Estuary-Lagoon Molluscs............................................................................................................................ 125 


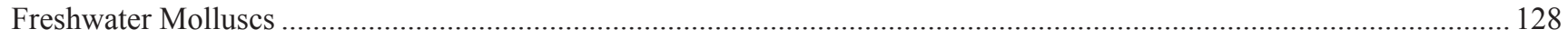

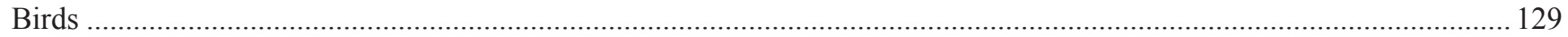

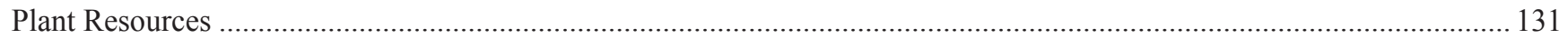

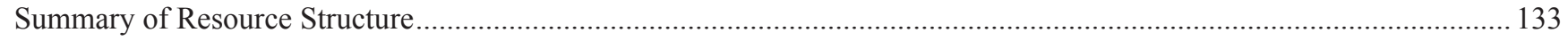

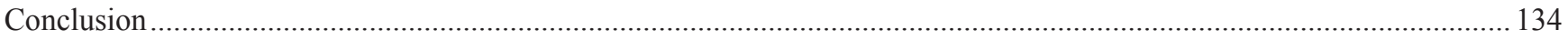

Chapter 9: Modeling Archeological Expectations and the Archeological Record ..................................................... 137

Applying the Habitat Choice Model to Coastal Hunter-Gatherers.................................................................................. 137

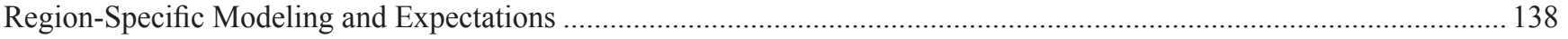

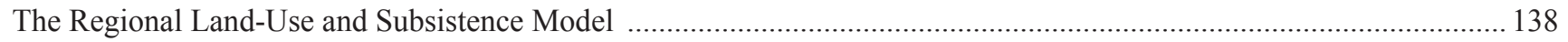

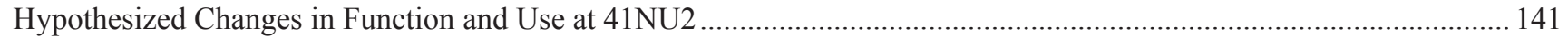

Defining Research Problems, Data Types and Analytical Approaches ........................................................................ 144

Research Problem: The Need For a Site-Specific Paleoclimate Record ..................................................................... 144

Research Problem: Dating of the Human Occupation Sequences Present At 41NU2 .................................................... 147

Research Problem: Developing a Quantified Set of Optimal Foraging Models and Expectations .................................. 148

Research Problem: Reconstruction of Regional Land Use Patterns ........................................................................... 149

Research Problem: Reconstruction of Subsistence Practices ………......................................................................... 150

Research Problem: Relationship Between Distribution of Cemetery Sites and Territoriality ......................................... 150

Research Problem: Completion of the Inventory of Human Remains for Nagpra Purposes ........................................... 151

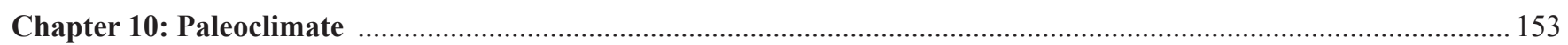

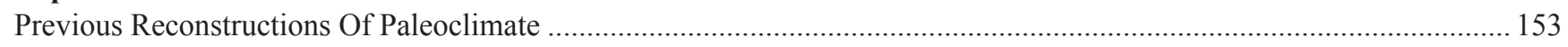

Coastal Occupation Patterns and Paleoenvironmental Conditions ............................................................................. 155

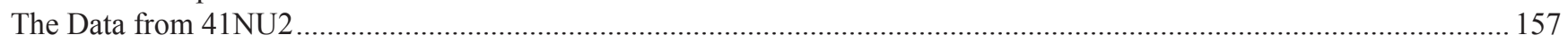

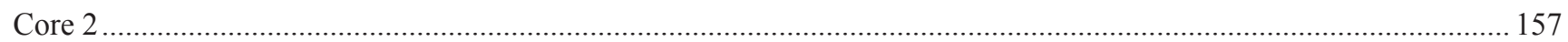

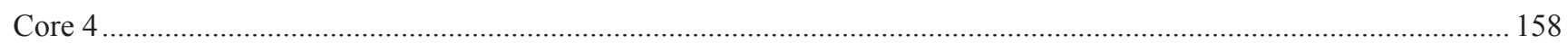

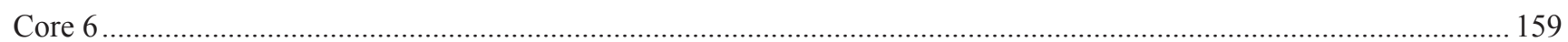

The Combined Picture:

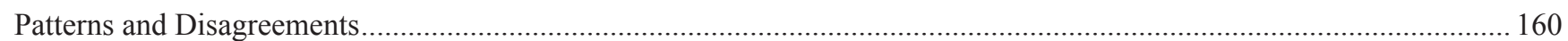

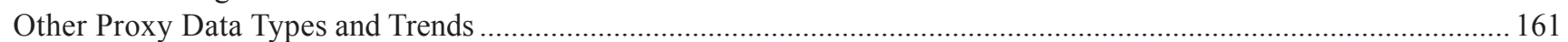

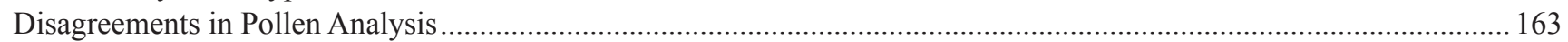

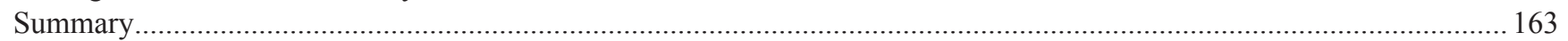

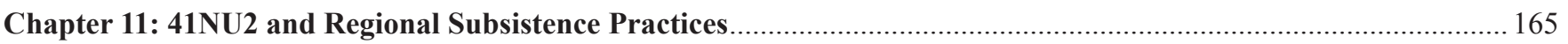

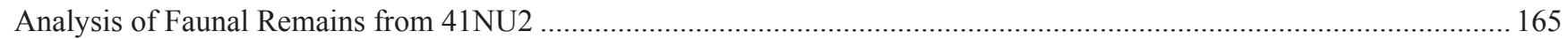

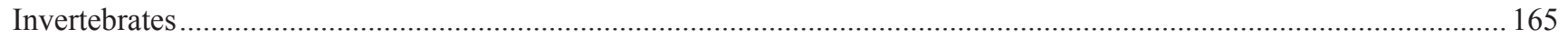

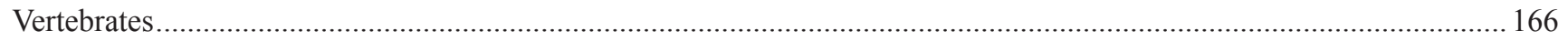

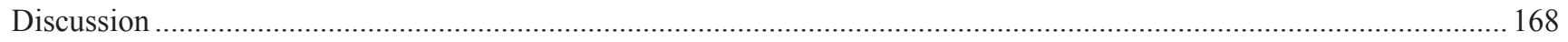

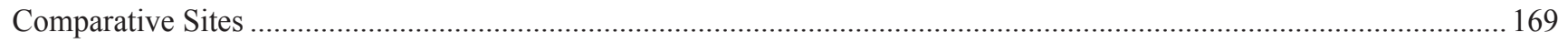

Comparing Subsistence in Three Habitats ..................................................................................................... 171

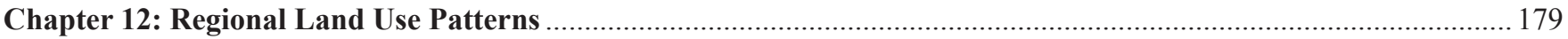

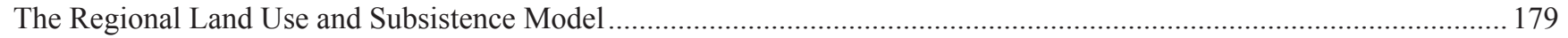

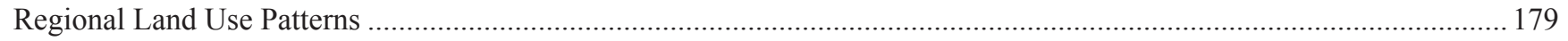

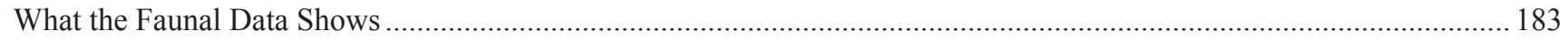

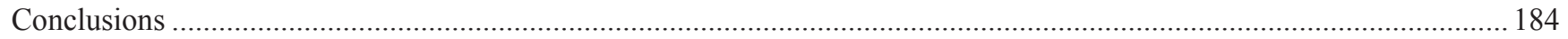

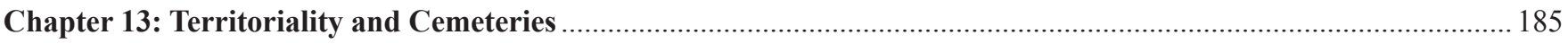

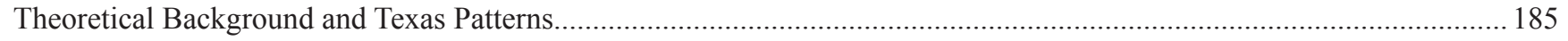

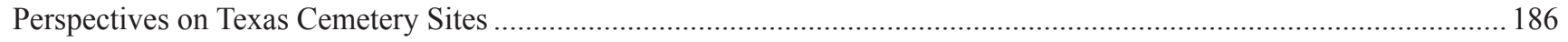

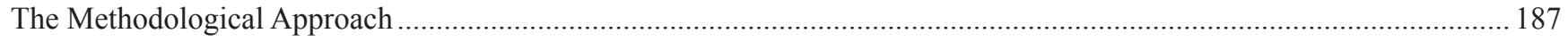

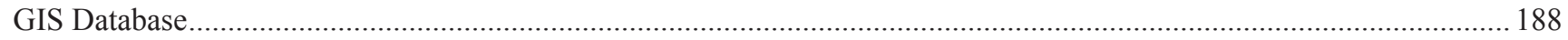

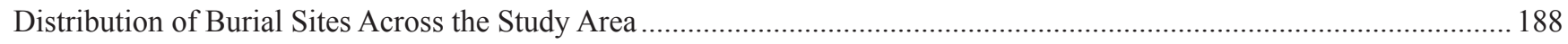


Distribution of Burial Sites Across the Gulf Coastal Plains through Time. 190

Distribution of Single and Multiple Interments at Burial Sites across the Gulf Coastal Plains through Time

Conclusions

Chapter 14: Summary and Conclusions

References

Appendix A: Pollen and Phytolith Analysis of Stratigraphic Core Samples from the Cayo Del Oso Site (41NU2), Copus Christi, Texas.

Appendix B: Pollen Analysis Of Pond Core Samples: Oso Bay Site, Nueces County, Texas 243

Appendix C: Plant Remains from 41NU2.

Appendix D: Diatom Paleoenvironmental Analysis of Core Sediments from the Cayo Del Oso Site, 41NU2, Nueces County, Texas.

Appendix E: Late Holocene Paleoenvironmental History of Cayo Del Oso Bay, Nueces County, Texas: Geoarchaeological Implications

Appendix F: Evaluating the Paleoclimatic Potential of Coastal Clay Dunes at the Cayo del Oso Site

Appendix G: Radiocarbon Results 


\section{List of Figures:}

Figure 1-1. Map of the Corpus Christi Bay system, including Nueces Bay, Oso Bay and the northern

Laguna Madre.

Figure 1-2. A map of the Cayo del Oso site superimposed on an aerial photograph taken in 2004.

Figure 2-1. The False Oso mudflats as they usually appear, taken from the northern end of the Cayo del Oso site, facing east. Ward Island and TAMU-CC are in the background.................................................................. 8

Figure 2-2 Weather station locations within the coastal and near coastal region along the Texas Gulf Coast.

Figure 2-3. The mean monthly rainfall for the 53 coastal locations compared to th average monthly rainfall from the remaining 544 weather stations in Texas.....

Figure 2-4. The mean monthly rainfall for the Upper, Middle, and Lower coastal regions. The inset defines these regions.

Figure 2-5. Mean monthly rainfall totals for the Middle Texas Coast and Corpus Christi (1971-

2000).

Figure 2-6. Annual rainfall at Corpus Christi between 1932-1973. Based on data from Kier and

White (1978).

Figure 2-7. Mean annual temperatures of coastal weather stations compared to inland weather stations.

Figure 2-8. Mean January and July temperatures in the Texas Coastal regions.

Figure 2-9. Relationship of mean monthly temperature at Corpus Christi and the average for the Middle Coast region..

Figure 2-10. Seasonal and annual relationship between rainfall and salinity in Oso Bay during 19721978.

Figure 2-11. The Coastal Prairies subregion of the Gulf Costal Plains geographic regions, of the

Gulf Coast of Texas.

Figure 2-12a. Natural environmental zones and biological assemblages in the vicinity of Corpus

Christi Bay, identified by the Bureau of Economic Geology.....

Figure 2 12b. Color key for Figure 2 12 a

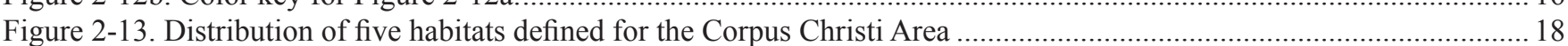

Figure 4-1. Trench with sides stepped down to allow CAR monitors to enter safely.........................................................24

Figure 4-2. Monitoring trench excavation near the location where it is believed Jackson's 1933 excavations took place. Facing east.

Figure 5-1. Detail of project map between 34+120 and 34+325 (including all work on Ocean Dr.) showing locations of all monitored excavations, burials, and sediment cores.

Figure 5-2. Detail of project map between 33+900 and 34+120, showing locations of all monitored excavations, burials and sediment cores.

Figure 5-3. Detail of project map between 34+120 and 33+700, showing locations of all monitored excavations.

Figure 5-4. Detail of project map between $33+500$ and $33+700$, showing locations of all monitored excavations and sediment cores

Figure 5-5. Detail of project map between $33+320$ and 33+500, showing locations of all monitored excavations.

Figure 5-6. Schematic profile of NU2, looking west from the False Oso mudflats, showing the Beaumont Ridge with dune deposits to the north and south.

Figure 5-7. Schematic profile of the northern part of NU2, along Ocean Dr showing Beaumont clay ridge to west, the pond area, and the slope down to the False Oso, near its mouth at Corpus Christi Bay..

Figure 5-8. Aerial photograph of 41NU2 taken in 1936, showing NU2 before urban development.

Note the pond near Corpus Christi Bay.

Figure 5-9. A schematic profile of the South Dune and Beaumont Ridge, looking west, showing profiles from Trench A at three locations. 
Figure 5-10. Profile of the east side of the South Dune in Trench B at 33+566-567, showing estimated dates for three paleosols.

Figure 5-11. Photographs of Beaumont Ridge zone at 33+689, showing large, naturally refilled erosional channel. Note shell at bottom of erosional channel and modern fill above the natural laminated sand and clay fill.

Figure 5-12. A schematic profile of the North Dune and Beaumont Ridge, looking west, showing profiles from three locations in Trench B.

Figure 5-13. Photograph showing Trench B at approximately $34+080$, as the first half of a new section has been completed, showing the wall at the center of the trench (foreground) and the wall at the western edge of the trench (background). Looking southwest.

Figure 5-14. A series of 20-cm strip profiles of the west wall of Trench $\mathrm{G}$ at the beginning of the North Dune. Note: First gap is $4.5 \mathrm{~m}$ due to a disturbance, all other gaps are $2 \mathrm{~m}$.

Figure 5-15. A photograph of the west wall of Trench G, showing Feature 149 in OZ J.....

Figure 5-16. Profile of the west wall of Trench N, showing north dune deposits ending and pond deposits beginning, between $34+177$ and $34+190$. . .

Figure 5-17. A series of eight 20-cm strip profiles of the north wall of Trench N, $3 \mathrm{~m}$ apart, from $3+258$ to $3+279$, documenting the western edge of the pond deposits and OZ K.

Figure 5-18. Profile of Trench F, at location of Feature 18.

Figure 5-19. Photograph of northern-most point in the North Dune in Trench F, $71.6 \mathrm{~m}$ north of the Ocean Dr. centerline. Facing west.

Figure 5-20. Profile of the north wall of Trench H, showing the uneven surface of the Beaumont Clay Formation and the black deposits left by small ephemeral ponds forming in lower elevations of the surface.

Figure 5-21. Profile of the south wall of the western end of Trench L at about $33+520$ between

10 and $20 \mathrm{~m}$ west of the centerline, showing Features 127, 128, and 135

Figure 5-22. Immature bison bones in pond deposits in Trench M, ca. $1 \mathrm{~m} \mathrm{bgs..............................................................} 48$

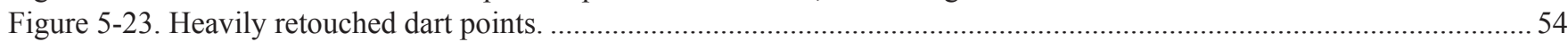

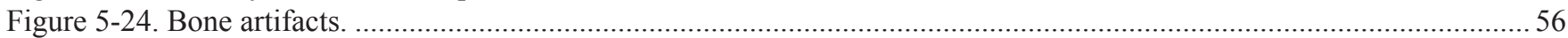

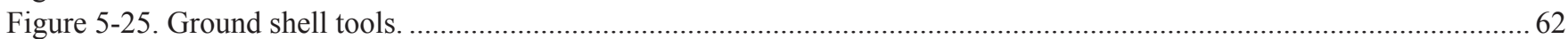

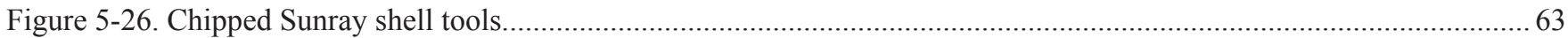

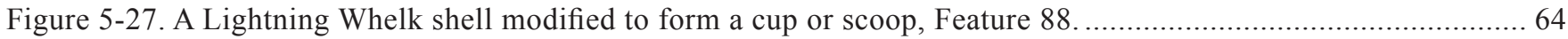

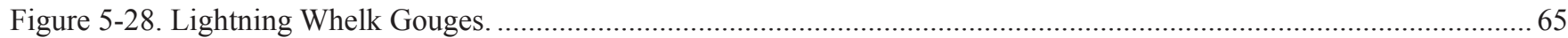

Figure 5-29. Lightning Whelk scrapers and "smoothers"

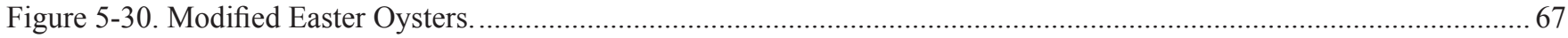

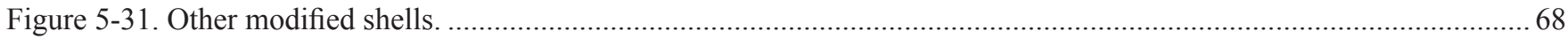

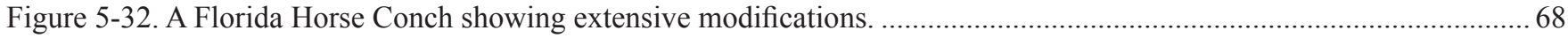

Figure 6-1. Radiocarbon dates associated with monitoring at 41NU2. Plotted at 2-sigma.............................................. 71

Figure 6-2. Top - Radiocarbon dates from the North Dune. Bottom - Radiocarbon dates from the

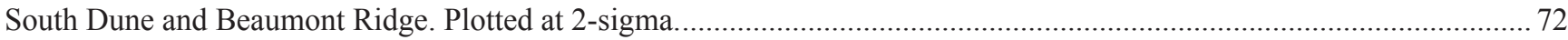

Figure 6-3. Comparison of marine (blue) and atmospheric (red) calibration curves from A.D. 1 to A.D. 1500 .

Figure 6-4. Plot of mid-point of the 2-sigma range for paired marine shell and organic samples from 41NU2.

Figure 6-5. Detail of project map between 34+120 and 34+325 showing locations of features and occupation zones.

Figure 6-6. Detail of project map between 33+900 and 34+120 showing locations of features and occupation zones.

Figure 6-7. Detail of project map between 34+120 and 33+700 showing locations of features and occupation zones.

Figure 6-8. Detail of project map between $33+500$ and 33+700 showing locations of features and occupation zones.

Figure 6-9. Detail of project map between $33+320$ and $33+500$ showing locations of features and occupation zones.

Figure 6-10. Feature 38, showing an example of a dense shell cluster. 
Figure 6-11. Feature 27, an example of a small surficial hearth................................................................................... 82

Figure 6-12. Feature 67, an example of a shallow basin hearth: a) plan view; b) profile.................................................... 82

Figure 6-13. Feature 102, a small pit densely packed with Lightning Whelks: a) surface of pit

(note pit was dug into light sediments); b) Pit fill from Feature 102, showing dense packing of shells................................ 83

Figure 6-14. Close up of Feature 107, showing masses of Rabdotus shells........................................................................8 84

Figure 6-15. Feature 13: a) profile showing the naturally filled gully in which Feature 13 was

located; b) after clearing of the upper layer of horse bones; c) the lower level of horse bones. Note

that the humerus and radio-ulna are in anatomical position.

Figure 6-16. The numerous scallops in the north end of Feature 57, in the Beaumont Ridge area.

Note the numerous burned clay nodules.

Figure 6-17. Feature 54, a large hearth in the Beaumont Ridge area: a) the top of Feature 54 (note

western half of Trench B, visible at the top of the picture, had reached the Beaumont, truncating

the northern corner of the feature); b) a profile showing the double basin and the layer of charcoal

in the southern basin that was partially removed in the northern basin.

Figure 6-18. Profile of Feature 31, showing hearth filled with burned clay nodules and charcoal. ........................................90

Figure 6-19. Feature 41: a) when first located; b) after removal of contents. Note the unusually

square shape.

Figure 6-20. Feature 64, showing close-up of hearth basin filled with burned clay nodules. .............................................. 96

Figure 6-21. Feature 75: a) when first observed; b) east wall of trench showing the profile of the pit,

dug from OZ D.....

Figure 6-22. Feature 170: a) wall of gully after removal of bone within Trench T. Note laminated

sand and clay fill and white sand beneath bone bed.

Figure 6-23. Scattered shell, charcoal and bone fragments in OZ-B............................................................................... 101

Figure 6-24. OZ-C in Trench I, showing density of shells and sharply delineated western edge. ...................................... 102

Figure 6-25. The bottom of OZ F in Trench I, showing the density of shell frequently seen in this OZ............................. 103

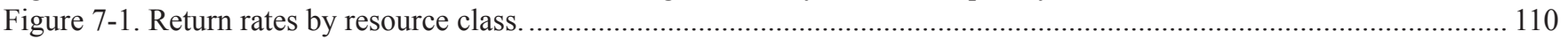

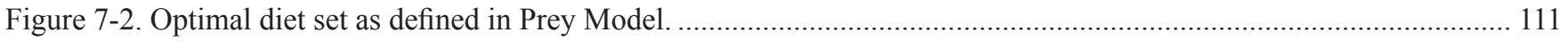

Figure 8-1. Hypothesized historic bison population distribution across Texas ................................................................... 119

Figure 8-2. Abundance of all birds in the Blind Oso, Oso Bay, Texas (March 1991-March 1992)..................................... 130

Figure 8-3. Changes in the number of edible plant species by season of availability. ........................................................ 131

Figure 10-1. Comparison of climatic sequences..................................................................................................... 154

Figure 10-2. Corrected radiocarbon dates from shell and charcoal samples reflecting middle

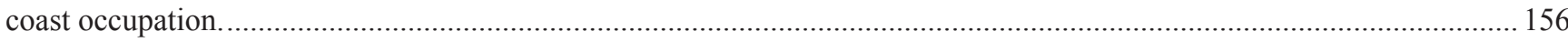

Figure 10-3. Plot of mni counts of seven invertebrate species by time period.............................................................. 162

Figure 11-1. Percentage of identified vertebrate species (excluding fish) from 41NU2 and 17 comparative sites grouped into habitat type categories. ........................................................................................... 172

Figure 11-2. Comparison of the relative utilitzation of mammals in five body-size categories in sites

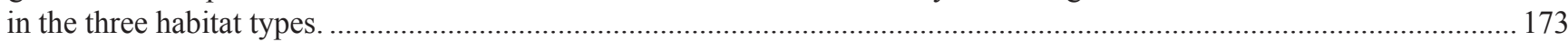

Figure 11-3. Percent of total NISP of shells in each of the three site habitat categories that were

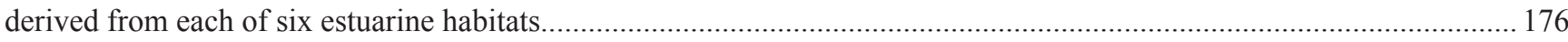

Figure 11-4. Percent of Total NISP of species found in the sites in the three habitat categories categorized into Terrestrial, Riverine/Brackish, and Marine environments ....................................................................... 177

Figure 12-1. Site distribution across habitats in Aransas, Nueces, Refugio and San Patricio Counties................................. 180

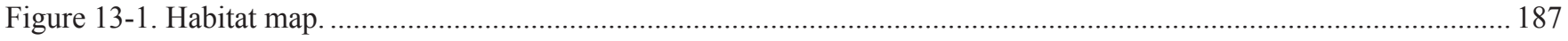

Figure 13-2. Distribution of burial sites across the study area. ............................................................................. 188

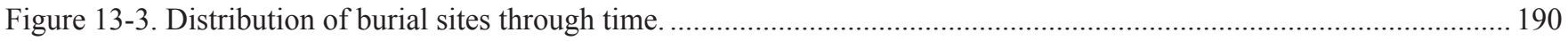

Figure 13-4. Distribution of single and multiple interment sites across time and habitat. .................................................. 192

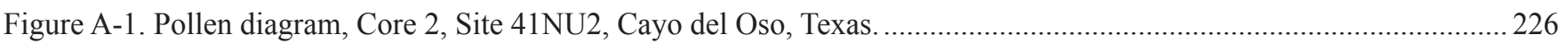

Figure A-2. Phytolith diagram for Core 2, Site 41NU2, Cayo del Oso, Texas.......................................................................2230

Figure A-3. Diagram of bilobate ecological indicators, Core 2, Site 41NU2, Cayo del Oso, Texas......................................231

Figure A-4. Phytolith diagram for Core 4, Site 41NU2, Cayo del Oso, Texas................................................................2235

Figure A-5. Phytolith diagram for Core 6, Site 41NU2, Cayo del Oso, Texas.................................................................2 237

Figure B-1. Examples of Degraded Pollen Beyond Recognition in the Core Samples...................................................... 247 
Figure B-2. Fossil Asteraceae Pollen Types Recovered from the Core Samples. ..............................................................256

Figure B-3. Fossil Cheno-Ams Pollen Types Recovered from the Core Samples. ..............................................................225

Figure B-4. Fossil Poaceae Pollen Types Recovered from the Core Samples..................................................................258

Figure B-5. Fossil Pollen Types from Various Taxa Recovered from the Core Samples. ................................................. 259

Figure E-1. Limnocythere staplini, euryhaline continental water ostacode common in marginal marine systems. Female, right valve view.

Figure E-2. Ammonia beccarii, benthic foraminifera common in nearshore, lagoonal, and estuarine environments. Umbilical view.

Figure E-3. Physa virgata, small freshwater gastropod common in continental and marginal marine

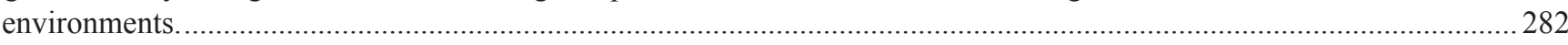

Figure E-4. Particle-size analysis from ostracode samples (cores 2, 4, and 6) for establishing the site paleohydraulics with the micro-invertebrate and foraminifera populations.

Figure E-5. Core 2 ostracode and foraminifera population total and relative abundance with core paleosalinity index diagram.

Figure E-6. Core 4 ostracode and foraminifera population total and relative abundance with core paleosalinity index diagram.

Figure E-7. Core 6 ostracode and foraminifera population total and relative abundance with core paleosalinity index diagram.

Figure E-8. Chronostratigraphic correlation of paleosalinity indices among the three cores from Cayo del Oso Bay, Nueces County, Texas.

Figure F-1. An expanded drawing showing the core stratigraphy, Munsell color, and inferred depositional units in the North Dune core.

Figure F-2. An illustration of the core stratigraphy, Munsell color, and inferred depositional units in the South Dune core.

Figure F-3. Plot of the stratigraphy, radiocarbon dates, and physical properties of the North Dune core at the Cayo del Oso site.

Figure F-4. Plot of the stratigraphy, radiocarbon dates, and physical properties of the South Dune core at the Cayo del Oso site

Figure F-5. Upper panel. Plot of $\delta 13 \mathrm{C}$ for radiocarbon dated soils in the north dune and the south dune at $41 \mathrm{NU} 2$. 


\section{List of Tables:}

Table 2-1. General Characteristics of the Submerged or Partially Submerged Natural

Environments and Biological Assemblages.

Table 2-2. General Characteristics of the Terrestrial Natural Environments and Biological

Assemblages, Including Fresh and Brackish Water Ponds That Occur in All Habitats ................................................... 17

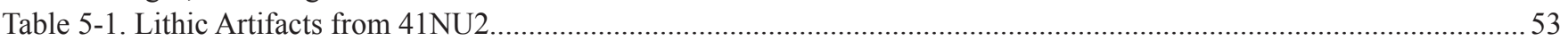

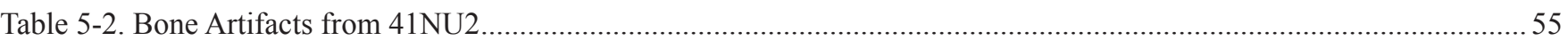

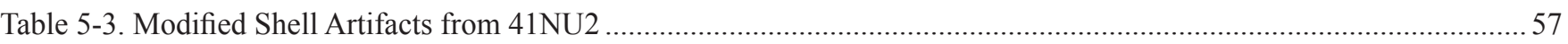

Table 6-1. Radiocarbon Results from Features and Occupation Zones .......................................................................... 70

Table 6-2. Dates for Matched Samples (Organics - Shell) at 2-Sigma, 41NU2 ….......................................................73

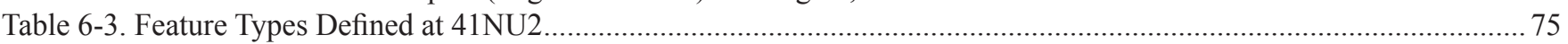

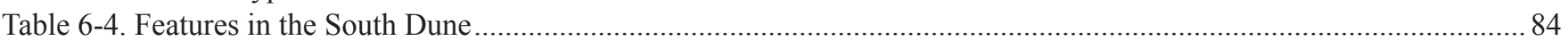

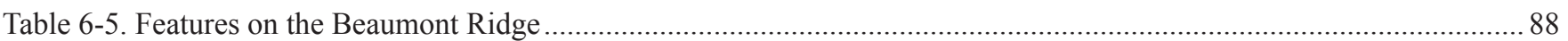

Table 6-6. Features in North Dune and the Pond/ Northwest Ridge Area ........................................................................90

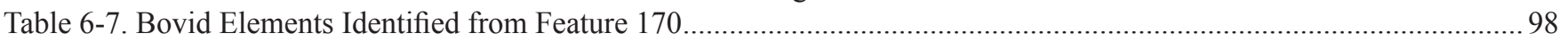

Table 8-1. Mammalian Species Found in Terrestrial Settings of the Gulf Coastal Plains and Marshes............................... 115

Table 8-2. Breakdown of Mammalian Species by Body Size Category ........................................................................... 117

Table 8-3. List of Marine Fish that Regularly Invade Gulf Coast Freshwater Habitats .................................................... 120

Table 8-4. Freshwater Fish Species within the Gulf Coastal Plains and Marshes .......................................................... 122

Table 8-5. Common Molluscs Species Present in the Bay-Estuary-Lagon Habitat............................................................ 126

Table 8-6. Common Freshwater Molluscs Found in the Streams, Lakes and Ponds of the Gulf Coastal

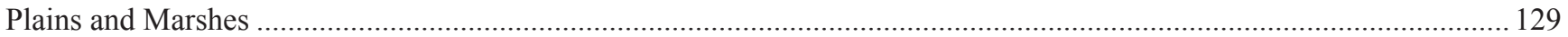

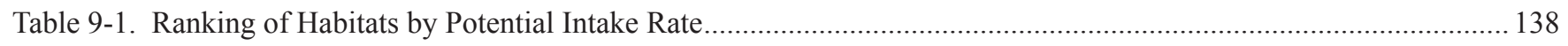

Table 11-1. Invertebrate Species Identified from Heavy Fraction Floatation Samples .................................................... 165

Table 11-2. Invertebrate Taxa from 41NU2, Showing the Ubiquity of Each, and Noting Association

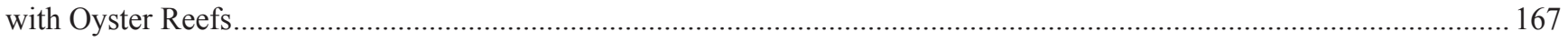

Table 11-3. Vertebrate Species Identified from Heavy Fraction of Floatation Samples .................................................. 167

Table 11-4. Seasonal Presence and Absence in Estuaries for Eight Fish Species........................................................... 168

Table 11-5. Six Features, the Multiple Fish Species Present, and Estimate Months of Utilization...................................... 168

Table 11-6. Mammalian Bone Weight in Three Size Categories ..................................................................................... 169

Table 11-7. Sites Used in Comparison of Regional Subsistence Practices, Including Their Habitat and

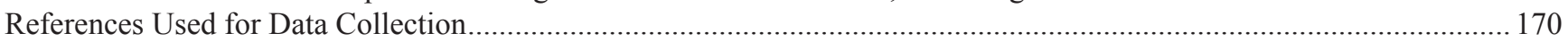

Table 11-8. Counts of Selected Vertebrates from 17 Coastal Sites Grouped by Habitat ...................................................... 172

Table 11-9. Count of Bones from Selected Species of Fish from Sites by Habitat ............................................................ 174

Table 11-10. Counts of Marine Shells from 17 Sites Grouped by Habitat ....................................................................... 175

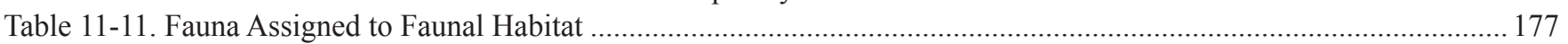

Table 11-12. Distribution of Fauna from Riverine-to-Brackish Habitat by Site Habitat..................................................... 178

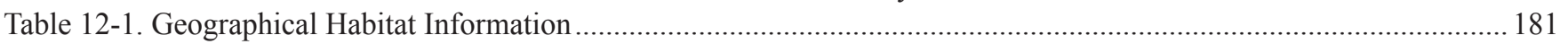

Table 12-2. Breakdown of Sites by Size Group within Four Habitats.......................................................................... 182

Table 12-3. Components per Habitat Through Time ...................................................................................................... 183

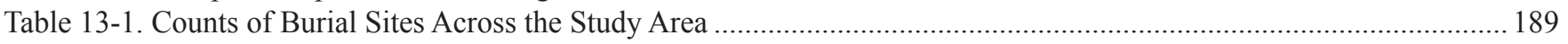

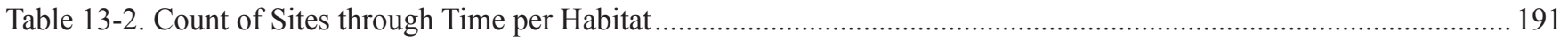

Table 13-3. Count of Interment Number through Time per Habitat ......................................................................... 191

Table A-1. Provenience Data for Samples from the Cayo dl Oso Site (41NU2)...........................................................223

Table A-2. Pollen Types Observed in Samples from the Cayo del Oso Site (41NU2) ..................................................227

Table A-3. Data for Samples from the Cayo del Oso Site (41NU2) ......................................................................231

Table B-1. Pollen samples collected and processed from core sediments extracted from the pond

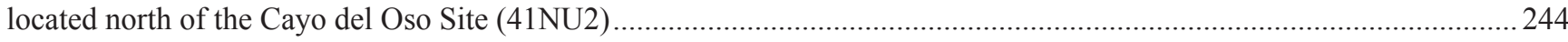

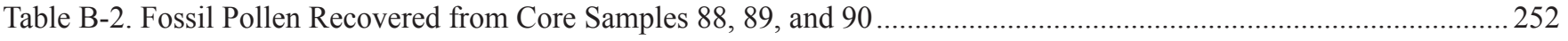


Table B-3. Fossil Pollen Recovered from Core Samples 91, 92, and 93 ...................................................................252

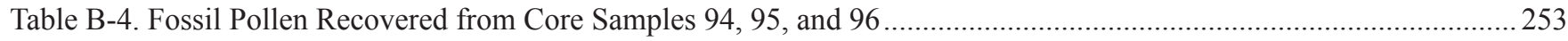

Table B-5. Fossil Pollen Recovered from Core Samples 97, 98, and 99 .....................................................................25

Table B-6. Fossil Pollen Recovered from Core Samples 100, 101, and 102 …........................................................254

Table B-7. Fossil Pollen Recovered from Core Samples 178, 179, 180, 181, 275, 276, 277, and 278 …..........................254

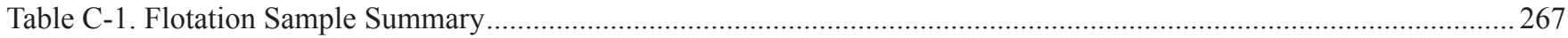

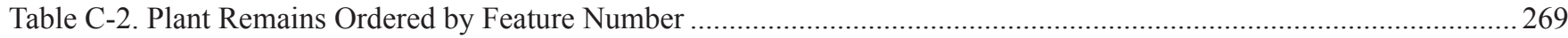

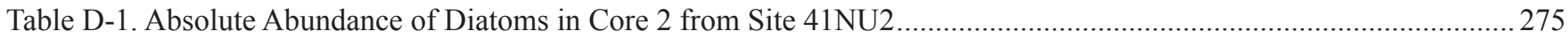

Table D-2. Absolute Abundance of Diatoms in Core 6 from Site 41NU2 ....................................................................2.276

Table D-3. Absolute Abundance of Diatoms in Core 4 from Site 41NU2 _........................................................................... 277

Table E-1. Sample Identification, Radiocarbon Dates and Textural Classification of Sediment

Residues Including Munsell's Color Code from Cores 2, 4, and 6 of Cayo del Oso Bay, Nueces

County, Texas.

Table E-2. Micropaleontologic Composition of Cores 2, 4, and 6 from Cayo del Oso Bay, Nueces

County, Texas, Including Taphonomic Parameters

Table E-3. Ecological Requirements of Ostracode Species Recovered from Site 41NU2, Cayo del

Oso Bay, Nueces County, Texas ......

Table E-4a. Ostracode Composition Including Total and Relative Abundance, Adulthood and

Disarticulation Ratios, and Paleosalinity Index by Core and Environment.

Table E-4b. Ostracode Composition Including Total and Relative Abundance, Adulthood and

Disarticulation Ratios, and Paleosalinity Index by Core and Environment.

Table E-5. Ecological Requirements of Foraminifera Species Recovered from Site 41NU2, Oso Bay,

Nueces County, Texas

Table E-6. Foraminifera Composition Including Total and Relative Abundance of Species Present.

Table E-7. Ecological Requirements of Mollusc Species Recovered from Site 41NU2, Oso Bay,

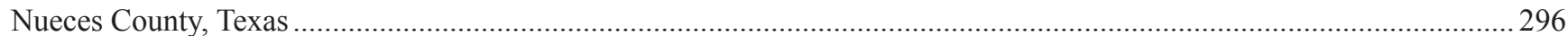

Table E-8. Mollusc Composition Including Total and Relative Abundance of Species Present .........................................296

Table E-9. Quaternary Ostracode Assemblages Used in this Study to Identify Environments of

Deposition

Table F-1. Results of Lab Work Obtained for Samples Derived from Core 4

Table F-2. Results of Lab Work Obtained for Samples Derived from Core 6

Table F-3. Results of Lab Work Obtained for Samples Derived from Core 2 


\section{Acknowledgements:}

Naturally any multi-year project such as the construction monitoring at 41NU2, involves a large number of individuals and it is only through their cooperation and hard work that project deliverables materialize. In our case, the successful completion of this report began with the exceptional cooperation and assistance offered by Randy Moff, TxDOT Job Superintendent. Special thanks are due to the crews working for Haas-Anderson Construction, Ltd. and King Isle, Inc., the two construction contractors that performed the mechanical excavations along the project ROW. Specifically, we want to thank Antonio Suarez, Project Superintendent for Haas-Anderson, for his coordination with the CAR and the archeological monitors. Israel Seguoa and Otis Hinze, inspectors for, respectively, the City of Corpus Christi and TxDOT, also provided help with coordination.

This project would have been almost impossible without two heavy equipment operators who dug the trenches and other excavations that CAR monitored: Ralph Gustafson of TxDOT, and Don Biesh, of King Isle. The monitoring required working closely with these men, and their skill and precision made the examination of NU2 by heavy equipment far more productive of data than it would otherwise have been, and kept us safe while we worked. In addition their friendship made the months of work far easier.

When we began the project, the head of the archeological section of the TxDOT-ENV was Dr. Nancy Kenmotsu. Near the midway point of the project, Dr. Owen Lindauer took over the oversight of the archeology section and he was in turn followed by Dr. Lain Ellis and most recently Dr. Scott Pletka. We want to express our gratitude for their cooperation and guidance during this lengthy project. The complexity of the project required close team work between the Corpus Christi District Office, the Austin office of TxDOT and the CAR, the fact that the roadway is now in use is testament to the high level of professionalism and cooperation achieved by all parties involved.

The fieldwork could not have been completed without the capable efforts of a number of staff archeologists that at times monitored different segments of this construction project over its four year duration. Cynthia L. Tennis was Project Archeologist from August to October 2000. The Project Archeologist for the remainder of the project was Barbara A. Meissner. Project monitors and field technicians involved in various efforts on site included the following individuals some of whom are no longer at the CAR, especially Dr. Russell Greaves and Bryant Saner as well as Cory Broehm, Donna Edmondson, Owen Ford, Chris Hartman, David Hafernick, Cynthia Muñoz, Maggie Moore, Jennifer Neel-Hartman, Jason Perez, Stephen "Waldo" Troell, Jason Weston, and José Zapata. Laboratory processing and curation preparation was overseen by Marybeth Tomka and carried out by Cyndi Dickey and Bryant Saner.

The graphics illustrated herein contribute to the clarity of this report. The diligent work of Bruce K. Moses, with the able assistance of Rick Young, Jon J. Dowling and Leonard Kemp are greatly appreciated. Bruce also served as Technical Editor for the final version of this report.

The specialized analyses referred to in the body of the text have been carried out by a distinguished group of scientists including in alphabetical order: Vaughn Bryant, Linda Scott Cummings, Phil Derring, Charles Frederick, Darden Hood, Manuel PalaciosFest, and Barbara Winsborough. Many thanks to each of them for sticking with deadlines and providing drafts in a timely fashion. We would also like to acknowledge Dr. Robert A. Ricklis for his assistance in providing us copies of his reports on excavations on the coast, and especially for sharing his extensive knowledge of the archeology of the Coastal Bend, and his interest in the project. 


\section{Chapter 1: Introduction}

\section{Barbara M. Meissner and Jennifer A. Thompson}

\section{Project Description}

In August 2000, archeologists with the Center for Archaeological Research (CAR) of the University of Texas at San Antonio, under contract with the Texas Department of Transportation (TxDOT), began monitoring road, utility improvements, and other construction activities in the rightof-way (ROW) of Spur 3, Ennis Joslin Road, in Corpus Christi, Texas (Figure 1-1). This archeological monitoring took place under Antiquities Permit No. 2445, issued by the Texas Historical Commission (THC), to Dr. Raymond P. Mauldin, Principal Investigator. This is Volume II of a series reporting the results of archeological work at 41NU2 (see Jackson et al. 2004).

The archeological work was necessary to address the requirements of Section 106 of the National Historic Preservation Antiquities Code of 1966, as amended, the implementing regulations of 36 CFR Part 800, and the Texas Antiquities Code, because the construction impacts land owned by the State of Texas and because the Federal Highways Administration (FHWA) is partially funding the project.

The purpose of the construction was to rebuild and widen Ennis Joslin Road and the eastern-most section of South Alameda Street in order to facilitate transportation from Highway 358 (South Padre Island Drive) to the campus of Texas A\&M University - Corpus Christi (TAMU-CC), on Ward Island in the mouth of Oso Bay (Figure 1-2). The road to be rebuilt was known to cross over site 41NU2, the Cayo del Oso site, and the planned road and utility improvements were expected to disturb this prehistoric cemetery and campsite. The site lies on clay dunes along the northwestern shore of Oso Bay and extends from a small creek that empties into the western side of Oso Bay to Corpus Christi Bay, approximately $960 \mathrm{~m}$ to the north (Figure 1-2). The width of the site is known only

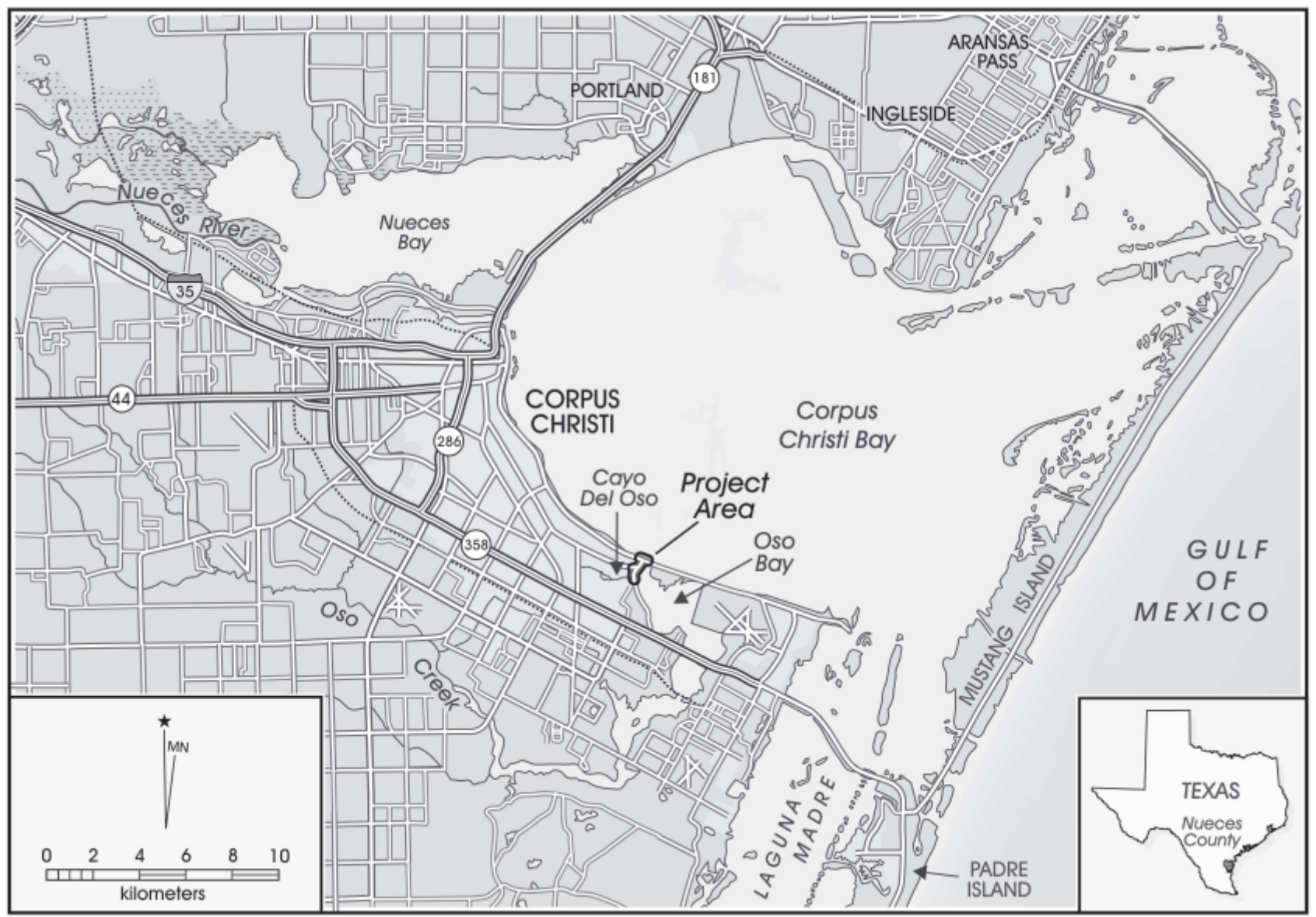

Figure 1-1. Map of the Corpus Christi Bay system, including Nueces Bay, Oso Bay and the northern Laguna Madre. 


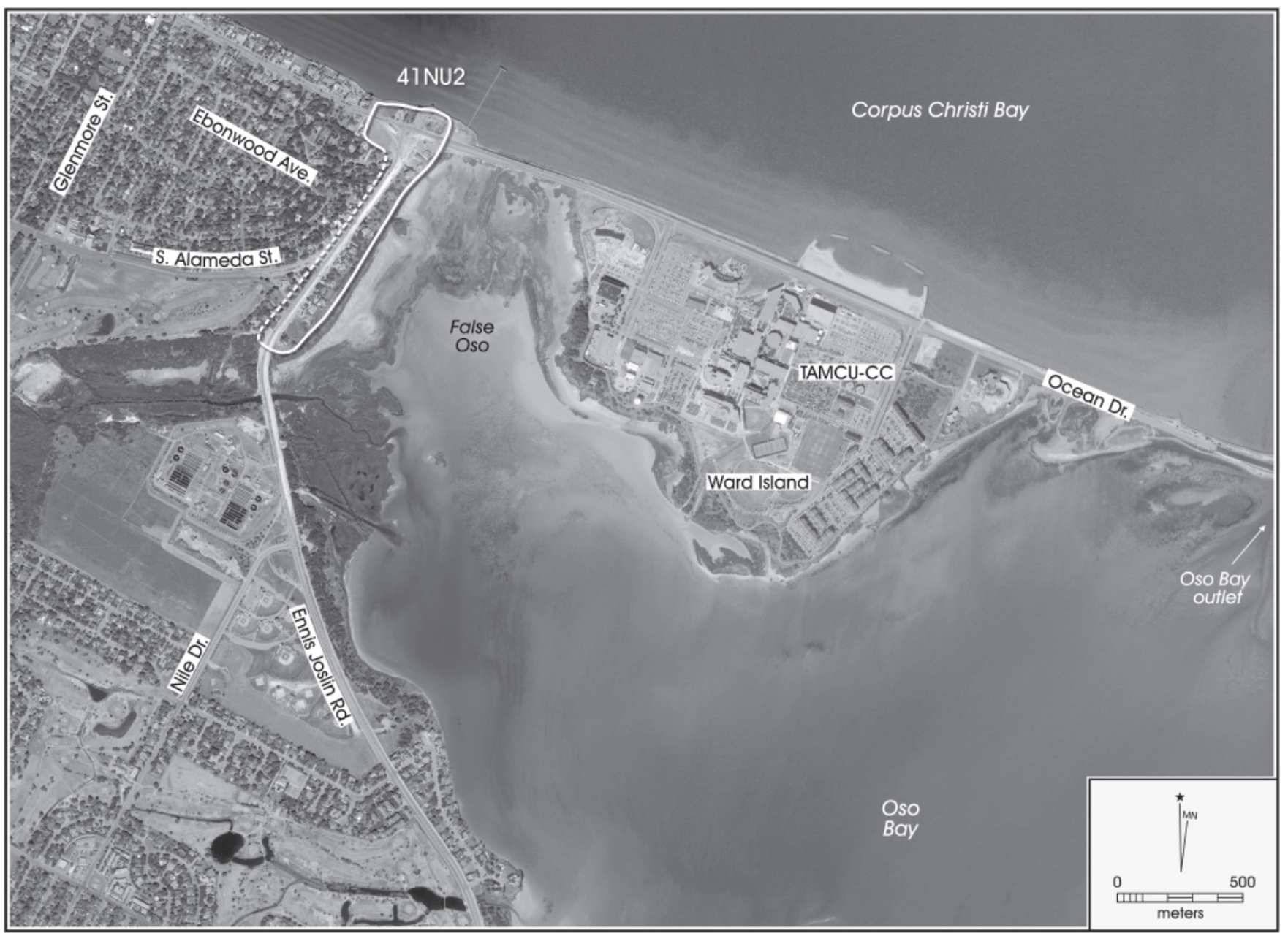

Figure 1-2. A map of the Cayo del Oso site superimposed on an aerial photograph taken in 2004.

on its northern border, on a bluff overlooking Corpus Christi Bay. At that point, the site is approximately $200 \mathrm{~m}$ wide. The area is a busy urban residential neighborhood, with a small commercial area along Ocean Drive.

The general locale has been known by a number of different names, including Callo del Oso, Calle del Oso, Cale del Oso and Cayo del Oso. Cayo means key (i.e., low, coastal island) in Spanish and is probably the correct name, as there are many small, ephemeral, and constantly changing islets all over the mudflats, and Ward Island (see Figure 1-2) could definitely be classified as a "key." Even though most of the previous literature about the site refers to it as Callo del Oso (Martin 1930; Meissner 2000, 2003; Ricklis 1997), probably following Martin (1930), the area, also known as the False or Blind Oso (Figure 1-2), is referred to as Cayo del Oso in government documents (see General Land Office 2008), including the TxDOT construction maps for this project. Beginning with Volume I of this series, therefore, we have chosen to refer to the site as Cayo del Oso.
The site has been known as a prehistoric cemetery and campground since at least the last quarter of the nineteenth century. For instance, in a footnote to a paper published in 1898 , there is a reference to boyhood memories of the area by an acquaintance of the author, who reported "[human] bones on the Cala del Oso have been found in quantities" (Coopwood 1898:117).

Volume I of this series (Jackson et al. 2004).provides a detailed history of what is known about excavations by various amateur and professional archeologists in the 1920s to the 1960s. These investigations are briefly summarized in the last section of this chapter. It is known that many of the burials excavated from the site were scattered to various locations and their whereabouts are no longer known (Jackson et al. 2004:17). Remains of at least 110 individuals that were excavated before 1970 are curated at the Texas Archaeological Research Laboratory (TARL), and it is known that there were many more excavated at the site. Of the 110 burials curated at TARL, 105 came from the excavations led by A. T. Jackson 
of the University of Texas at Austin, under the auspices of the Works Progress Administration (WPA) during the summer of 1933. Volume I of this series published, for the first time, Jackson's draft report of his excavations, on file for more than 70 years at TARL (Jackson et al. 2004).

As mentioned above, the location of the site has been known for a century or more. The site has been actively excavated since at least the late 1920s (Baird 2006; Martin 1930) and possibly longer. Examination of field notes and photographs from excavations at the site in the 1930s indicated that there had been extensive erosion of the clay dunes, and it was known that the site had been subjected to many years of excavation by both amateur and professional archeologists, and many casual diggers. Because of this, it was considered unlikely that the site still contained undisturbed sediments with substantial research potential (e. g. Hall 1995a:49). However, the number of burials recovered at the site in the past made it important to test the project ROW within the site boundaries to determine how likely it was that the project would disturb human burials or important cultural materials. Therefore, in 1996 TxDOT contracted with Coastal Archaeological Research, Inc. to test selected areas of the ROW (Ricklis 1997). The testing encountered one human burial in the southern part of the site, as well as many areas where undisturbed sediments contained cultural materials in a series of sealed strata (Ricklis 1997:30, 33, 72-73). Ricklis' (1997) results will be discussed in more detail in the last section of this chapter. As a result of the testing, Ricklis (1997:72-73) recommended that all construction within the site boundaries be monitored by professional archeologists. TxDOT then contracted with CAR to provide this service.

The purpose of the monitoring was to identify any cultural remains that may be within areas of impact and to “... complete the documentation of features and the exhumation of any human burials as quickly as possible to allow the construction contractor to regain access to the area" (Exhibit 1, WA \#573 11SA002). With intermittent interruptions, construction monitoring continued from August 2000 until February 2006.

This volume reports the results of the construction monitoring, as well as a pilot study in Human Behavioral Ecology (HBE), which focuses on the material recovered from 41NU2. The document is organized into fourteen chapters and seven appendices. The remainder of this chapter includes a very brief presentation of the nature of the research design developed for this report, and a summary of archeological work that has occurred at 41NU2.

Following this introductory chapter, Chapters 2 and 3 provide information on the geology, environmental structure, and cultural history of the Corpus Christi area. Chapter 4 contains a detailed presentation of the field and laboratory methods employed. Chapter 5 summarizes the work accomplished, the human remains identified, and the artifacts recovered during monitoring. Chapter 6 discusses the correspondence between radiocarbon dates obtained on charcoal and shell from the site, the ages of the archeological components, and the features and occupation zones defined. Chapter 7 lays out the theoretical framework and Chapter 8 describes the regional resource structure. Chapter 9 presents a model of hunter-gatherer adaptation and regional and site-specific expectations. Chapters 10-13 contain discussions of paleoenvironemntal reconstructions (Chapter 10), subsistence (Chapter 11), land use (Chapter 12), and mortuary practices (Chapter 13). Chapter 14 presents the conclusions, bringing the information in the previous chapters to bear on the HBE model to determine its usefulness in future research projects on the Texas Coast. Appendices A through G are the reports provided by experts in the fields of pollen and phytoliths (Appendix A and B); macrobotanical analysis (Appendix C); diatom analysis (Appendix D); ostracod, foraminifer, and micro molluscs analyses (Appendix E); several geological analyses (Appendix F); and radiocarbon sample data forms $(G)$.

\section{Research Design}

The research design, developed as a collaborative effort between CAR and the TXDOT Environmental Affairs Division, focuses on the interpretation of data made available by the monitoring project at Spur 3 (Tomka et al. 2006). Using principles derived from the habitat choice model (Sutherland 1996), we developed a general model of coastal huntergatherer settlement pattern and subsistence practices. Next, we defined a series of site-specific expectations related to the function and use of $41 \mathrm{NU} 2$ and how the nature of site use may have changed over time. As a test of these expectations, we proposed to study several data types recovered from 41NU2 and compare trends within them to data types from a small number of previously excavated sites reported in the regional literature. The pilot study served as a test case of the usefulness HBE approaches as a research tool to model hunter-gatherer behavior.

The research goals described in the research design (Tomka et al. 2006) rely on the assumption that the materials observed and collected by CAR from 41NU2 cannot be interpreted if viewed in isolation. This perspective is especially germane to sites located along the Gulf Coastal strip since ethnohistoric and Late Prehistoric settlement pattern reconstructions (see Ricklis 1997, 2004, Ricklis and Weinstein 2005) indicate a 
strong reliance by hunter-gatherer groups on both coastal and inland zones.

To provide the needed perspective, detailed data was collected from site reports on 18 sites near 41NU2 for use in the comparative studies described in this volume. In addition, less inclusive data on all prehistoric sites in Nueces County and three adjacent counties, Aransas, Refugio, and San Patricio, was collected from THC's online Texas Archeological Site Atlas (THC 2008). This data is limited by the variability of information included on Site Report forms in more than forty years of site data recording stored at TARL. To the extent possible, given these limitations, this data was used in GISbased studies of prehistoric settlement patterns across the four counties. A more detailed GIS-based study of prehistoric cemeteries in South Texas has also been completed and the results are presented in Chapter 13.

\section{Previous Excavations at 41NU2}

Volume I of this series (Jackson et al. 2004) describes early excavations at 41NU2 between 1900 and 1970 and includes a manuscript of A. T. Jackson's report of his work at the site. This section of Chapter 1 provides a very brief review of the work conducted at the site prior to 1970 (Jackson et al. 2004), followed by brief summaries of the archeological investigations done by Coastal Archaeological Research, CAR, and SWCA Environmental Consultants associated with the Spur 3 construction project.

\section{Before 1970}

As mentioned above, a detailed discussion of what is known about excavations at 41NU2 between about 1928 and 1970, including the first publication of Jackson's draft report on his 1933 excavations, is available in Volume I of this series (Jackson et al. 2004).

While the site was known at least since the late 1890 s (Coopwood 1898), by the late 1920s rumors of the site had reached the ears of George C. Martin, an avid amateur archeologist who had, with his friend Wendell H. Potter, just completed a massive survey of the central upper southern Texas coast (Martin and Potter n.d.). Though a few copies of their privately printed report still exist, no date of publication is available.

During exploration of the site in 1929, Martin (1930) was interviewed John B. Dunn, who told him he had worked on the property during the Civil War and that the land was then heavily vegetated in brush. Mr. Dunn claimed there was no sign of a prehistoric site there at the time. Martin (1930) while excavating at the site, was told by the land owner that after the great hurricane of 1900, he returned to his property and saw human bones eroding out of the clay dunes in numbers he described as "over 5000" individuals (Martin 1930:9). While it is easy to suppose that this number is a gross exaggeration, it is clear that the man had seen a large number of bones he believed to be human. Mr. Dunn also indicated that the hurricane had heavily eroded the site, exposing burials and other cultural materials (Martin 1930:9). Martin recorded finding a total of 53 skulls during several trips to the site (Jackson et al. 2004).

At some time after Martin's excavation (probably in late 1931), E.B. Sayles excavated a single test pit and recovered 9 more burials (Sayles n.d.). His results and Martin's (1930) report encouraged A. T. Jackson, of the University of Texas, to put together a field season at the site, under the auspices of the WPA, during the summer of 1933. He excavated an area known as the "bone pit", recovering what he believed at the time to be 93 individuals. Later investigations at the site consisted of small-scale excavations by such professional archeologists and anthropologists as Alex Kreiger and T. N. Campbell, as well as such scientists as W. A. Price, a geologist who published descriptions of how clay dunes accumulate (Huffman and Price 1949; Price and Kornicker 1961) and others who returned their findings to TARL. In addition, a large number of individuals, amateur archeologists and collectors, undoubtedly also dug at the site (Jackson et al. 2004).

\section{Archeological Projects Associated with the Spur 3 TxDOT Project}

When Corpus Christi State University, located on Ward Island, was transferred to the Texas A \& M University System in 1989, and renamed in 1993 as Texas A \& M University - Corpus Christi, a plan was developed to enlarge the campus (TAMU - CC 1989). As part of this plan, the City of Corpus Christi and TxDOT noted that Ennis Joslin Road, the street most students and faculty used to get to campus, was inadequate in width for the increased volume of traffic to TAMU - CC. The road had been originally planned as a small residential street and by the mid-1990s was deteriorating rapidly under the pressure of the increasing volume of traffic. Plans were made to widen Ennis Joslin Road and improve its intersections with various side roads and Ocean Drive (see Figure 1-2). As part of these road improvements, the City of Corpus Christi would take the opportunity to reorganize and upgrade the city underground utilities along the road (R. Moff, personal communication 2000). Recognizing that this might adversely impact 41NU2, in 1996 TxDOT began to 
explore the condition of the site within the proposed project area, the Area of Potential Effect (APE).

\section{Coastal Archaeological Research, Inc.}

Coastal Archaeological Research, Inc. was contracted to conduct testing within the archeological APE. In 1996, Ricklis (1997:16) excavated a series of thirty 2-inch cores and twenty test units. The test units were dug with a Gradall excavator and were roughly 1.5 by $2.2 \mathrm{~m}$ (see Ricklis 1997:25 for locations of these units). The units exposed three major soil profiles, all underlain by the culturally sterile Pleistocene Beaumont Clay (see Chapter 2). These were: 1) disturbed clay loam over a gray brown sandy clay characterized as a "upland prairie soil profile" (Ricklis 1997:29); 2) a series of lenses of light and dark sandy clays consistent with clay dune formation; and 3) a black homogenous highly organic clay described as pond sediment, representing a Late Holocene ephemeral pond that developed behind a clay dune (Ricklis 1997).

Ricklis (1997) reported cultural material from previously undisturbed strata in fourteen of the units. Cultural deposits included scatters and concentrations of estuarine shells, charcoal, burned clay nodules, a few lithics, shell and bone tools, and faunal bone within the darker bands of the clay dune and directly above the Beaumont Clay in the non-dune center of the site. In Unit 5, located on the east side of Ennis Joslin Road in the southern part of the project area, a single relatively intact human burial was encountered (Ricklis 1997:23, 29).

Though he noted the thinness of the cultural deposits he encountered and did not believe that the camp debris would provide important archeological information if excavated, Ricklis' recorded six features in addition to the burial (Ricklis 1997:35-41) His recommendations (Ricklis 1997: 73-73) included the need for archeological monitoring of construction at the site within the TxDOT ROW. He also noted that Rightof-Access issues had limited the areas he had tested, leaving unknown the likelihood of undisturbed cultural deposits and/ or human burials in those areas (Ricklis 1997:3, 73).

\section{Center for Archaeological Research}

In 2000, under contract with TxDOT, CAR began monitoring the construction excavations for exposure of important archeological components and human interments and reported findings in a series of interim reports submitted to TxDOT (Meissner 2000, 2003, 2004, 2005). Between August 15 and October 3, 2000 a total of 16 features, consisting of concentrations of shell, charcoal and vertebrate faunal remains were excavated, screened, and all recovered cultural materials collected, as required by TxDOT (see Chapters 4 and 5). On October 3, 2000 TxDOT decided to stop the project temporarily while considering the unexpected number of utilities that were not on any city utility maps, as well as the possibility that construction plans would be changed.

The original plans for details of construction, including utility placement, and scheduling of each component of the construction were changed. While this was being done, construction activities at $41 \mathrm{NU} 2$ were sporadic, consisting of digging to locate and/or move underground utilities and grading of an area that would be temporarily paved as a bypass during later construction (Meissner 2003). Whenever construction took place on the site, TxDOT personnel informed CAR and archeologists were present to monitor activities.

Beginning in April 2003 and continuing to November 2005, with occasional brief interruptions, CAR monitored the remainder of the project. A total of 20 major utility trenches, as well as 14 lateral trenches that crossed the road and numerous shallow trenches to attach homes and business to the new system, were completed. In addition, several large pits were dug to place manhole boxes. Ten large areas where sheet midden deposits were seen in profile were identified as Occupation Zones (Meissner 2004, 2005). A total of 170 features, including the 16 found in 2000, were identified in the field. However, beginning in April 2003, TxDOT required that features be minimally recorded (see Chapter 4) and stated that locating human remains before they were disturbed by construction activities, should be the major focus of CAR's monitoring.

Six human burials were encountered during the monitoring. Only Burial 2, the first (as the burial located by Ricklis (1997:42) was considered Burial 1) located, was completely intact. Burials 3 to 5 were incomplete, being disarticulate bones found in the trench fill of old utility trenches and presumably disturbed and reburied during the earlier utility construction. Burials 6 and 7 were the partially disturbed remains of a child and an adult. Though the condition of the bones and the degree of disturbance made it difficult to be sure, it appeared that the adult burial had been disturbed by the burial of the child. As one of the deliverables under this project, in addition to a standard osteometric analysis, the CAR completed the NAGPRA human remains inventory. This inventory and the results of the analysis were submitted to TxDOT-ENV in 2007 (Mahoney and Shafer 2003).

In February 2006, CAR monitors returned to observe the planting of palm trees in previously undisturbed areas. No new features were identified. In August 2007, CAR archeologists returned with the geomorphologist Charles 
Frederick to bore a total of six cores in order to obtain soil samples for various specialized analyses, including lithology, pollen, phytolith, ostracod and diatom studies. Results of these studies are incorporated into this report and can be found in the Appendices.

\section{SWCA Environmental Consultants}

In March and April 2006, SWCA Environmental Consultants, under SWCA's blanket Texas Antiquities permit \#3740, and with Kevin A. Miller acting as Principal Investigator, monitored the excavation of three electrical conduit poles and 48 light pole footers (Miller et al. 2006:3). The majority of excavations monitored by SWCA were in areas that had previously been disturbed by the placement of utilities during the period of the project monitored by CAR. Three features (all defined as "non-significant" under the terms of the instructions given by TxDOT, see Chapter 4) were identified, each consisting of a concentration of shells, animal bone and charcoal. As per the TxDOT instructions, no samples of feature fill were taken (Miller et al. 2006:1415). The location of the excavations and the three features were mapped a (see Chapter 6). 


\title{
Chapter 2: Background, Geology, Climate and Environmental Structure
}

\author{
Steve A. Tomka and Raymond P. Mauldin
}

This chapter briefly summarizes the geology of the Corpus Christi Bay system. The summary is followed by a discussion of the modern climate of the area. The environmental structure that results from the geology and climate of the area is then discussed.

\section{Development of the Corpus Christi Bay System}

\section{Geological History}

During the last glacial maximum ca. 20,000 B.P., the area that is now Corpus Christi was located on uplands near the deeply incised proto-Nueces River valley. The coast was approximately 200 kilometers east-southeast of the current coastline, as sea levels were about $100 \mathrm{~m}$ lower than modern levels (Brown et al. 1976; Ricklis 1995a:18). During an earlier interglacial, a thick layer of clays and sandy clays, known as the Beaumont Clay Formation, was deposited as a result of fluvial and colluvial processes that created a deltaic plain across most of what is now the Gulf Coast of Texas (Brown et al. 1976:20). The Pleistocene Nueces River deeply incised into this formation as the sea level dropped during the most recent glacial maximum.

When the most recent interglacial began ca. 18,000 B.P., ice melted and the sea level began to rise. The details of the rate at which this occurred are still being researched (Ricklis 1997:6), however, there is a consensus that sea level rise was rapid beginning at 18,000 B.P. until about 9000 B.P., after which the rise became more intermittent. Each time there was a significant rise in sea level, estuary systems formed since the previous sea level rise were inundated, decreasing their potential for production, until a new estuarine environment could develop at the higher level (Ricklis 1997:6).

The inundation of the Pleistocene Nueces River Valley near Corpus Christi started about 9000 B.P. with the incursion of marine water up the channel of the river in its deep valley as far as $13 \mathrm{~km}$ north of the current mouth. The Nueces River began a headward delta formation that was later inundated as the sea level rose again. At this time, about 7500-7000 B.P., the entire valley was inundated, creating a narrow, deep bay (Brown et al. 1976:20-21). During the next few thousand years wave action and storms eroded the edges of the bay, widening it except at the point where today Nueces Bay feeds into Corpus Christi Bay through a fairly narrow channel (see Figure 1-1). New erosion continued filling in the deep Pleistocene valley, as the Nueces River and Oso Creek gradually prograded headward, creating the deltas through which they now enter the bays.

Some postulate a highstand as much as one meter above the current sea level from about 5300 to 2800 B.P (Paine 1991; Ricklis 1997:7). If this highstand did, indeed, occur, it could explain the formation of the False Oso mudflats, as the northwestern side of this larger and wider Oso Bay would have been more susceptible to wave action, as it was downwind of the prevailing winds (c.f. Brown et al. 1976:22). When the waters receded to the current level, the western side of Ward Island had accumulated more sediment than the eastern and was no longer an outlet into Corpus Christi Bay except during storm events.

The development of the modern Corpus Christi Bay environment began when roughly modern sea level was established allowing the development of new shallow estuarine environment. At the same time, sands and clays off the coast began to form small shoals about 5,000 years B.P., developing into a series of small, narrow islands (Fisk 1959). There is some difference in the estimates of when these islands coalesced into roughly the shape and extent of the modern barrier islands of the coast of Texas. Estimates range from roughly 4000 B.P. (Fisk 1959:123) to 2800 B.P. (Brown et al. 1976:21), to between 2,500 and 2,000 years ago (Morton and Paine 1984:12). Similarly, Ricklis (1995a), based on his research along the Nueces Bay shoreline, concludes that the isolated barrier islands coalesced sometime after 3000 B.P. giving rise to the estuarine conditions characteristic of the Nueces and Corpus Christi Bay region today (Ricklis1995a:142). In any case, open marine conditions in Corpus Christi Oso Bay ended as tidal inlets closed. As the number and depth of passes between the barrier islands decreased, the freshwater entering Corpus Christi Bay had only two or three narrow passages out to the sea. In general, the salinity of the bays decreased, although in periods of extreme drought the salinity in the bay can be as much as 45ppm (Brown et al. 1976). At the same time, the erosion of the bay edges made the bay more shallow, and large areas of estuarine marshes and sea grass flats (see below) developed, creating an ideal environment for many plant and animal communities, as well as nursery grounds for many marine fishes (see Chapter 8).

\section{The Modern Corpus Christi Bay Estuary}

Today Corpus Christi Bay is a large, shallow bay that covers a little more than 39,000 hectares $\left(390 \mathrm{~km}^{2}\right)$ in surface area, not including Nueces Bay and Oso Bay (Anderson 1960), 
and has a maximum depth of $4 \mathrm{~m}$ (Harwood 1980). Corpus Christi Bay receives freshwater inflows from the Nueces River and Oso Creek. The bay is connected to the Gulf of Mexico through two channels: the largest of these is Aransas Pass, a ship channel; the second is Fish Pass dredged near the southern end of Mustang Island (Morton and Pieper 1977). Diurnal tidal fluctuations within the bay have mean amplitudes of $10 \mathrm{~cm}$ while astronomical tidal fluctuations range from $0-60 \mathrm{~cm}$. Wind direction and velocity influence the duration and amplitude of inundation of exposed tidal flats.

Oso Bay is an enclosed, soft-sediment, estuarine secondary bay located on the southwestern shore of Corpus Christi Bay. The only major freshwater inflow it receives is from Oso Creek. The average depth of Oso Bay is less than $1 \mathrm{~m}$. Tidal exchange with Corpus Christi Bay occurs through a small pass located east of Ward Island. The wind-tide flat west of Ward Island is approximately 28 hectares (Figure 1-2). This flat is known as the False Oso or Blind Oso, and it is on the western shore of the False Oso that site 41NU2 is located (Figure 1-2).

The mudflats of the False Oso slope gradually under water to the south, where the bay remains no more than a few centimeters deep for several hundred meters. The False Oso mudflats are regularly submerged for a few hours during unusually high tide events, particularly when these high tides are combined with strong southeasterly winds or tropical storms, or when there is a large influx of fresh water from Oso Creek during major inland rain events (Figure 2-1). The mud flats of the False Oso are the source of the clay dunes that enclose the Cayo del Oso site (Price and Kornicker 1961).

\section{Clay Dune Formation}

As mentioned above, the Cayo del Oso site is located on the northwestern shore of Oso Bay, adjacent to a wind-tide flat, on two clay dunes resting on top of the Pleistocene Beaumont Clay Formation. Similar clay dunes are a feature of the Texas coast from Copano Bay to the Rio Grande delta (Huffman and Price 1949:118). They are always found adjacent to the lee of wind-tide flats that are only occasionally inundated. As these flats dry after a rain storm or an inundation, they form a thin crust, consisting of particles of clay and/or silt and salt crystals bound together by algae. As this crust dries, it tends to crack, exposing a more friable layer. Under the pressure of almost constant prevailing winds sand-sized particles of clay, salt crystals and algae form, which are susceptible to aeolian uptake and redeposit onto the shore, over time developing into a clay dune (Huffman and Price 1949:120). The amount of clay deposited varies a great deal, depending on season, weather, and climatic conditions. Small amounts of clay may accumulate during the dry months of summer. During droughts, when vegetation on the flats dies, large amounts of

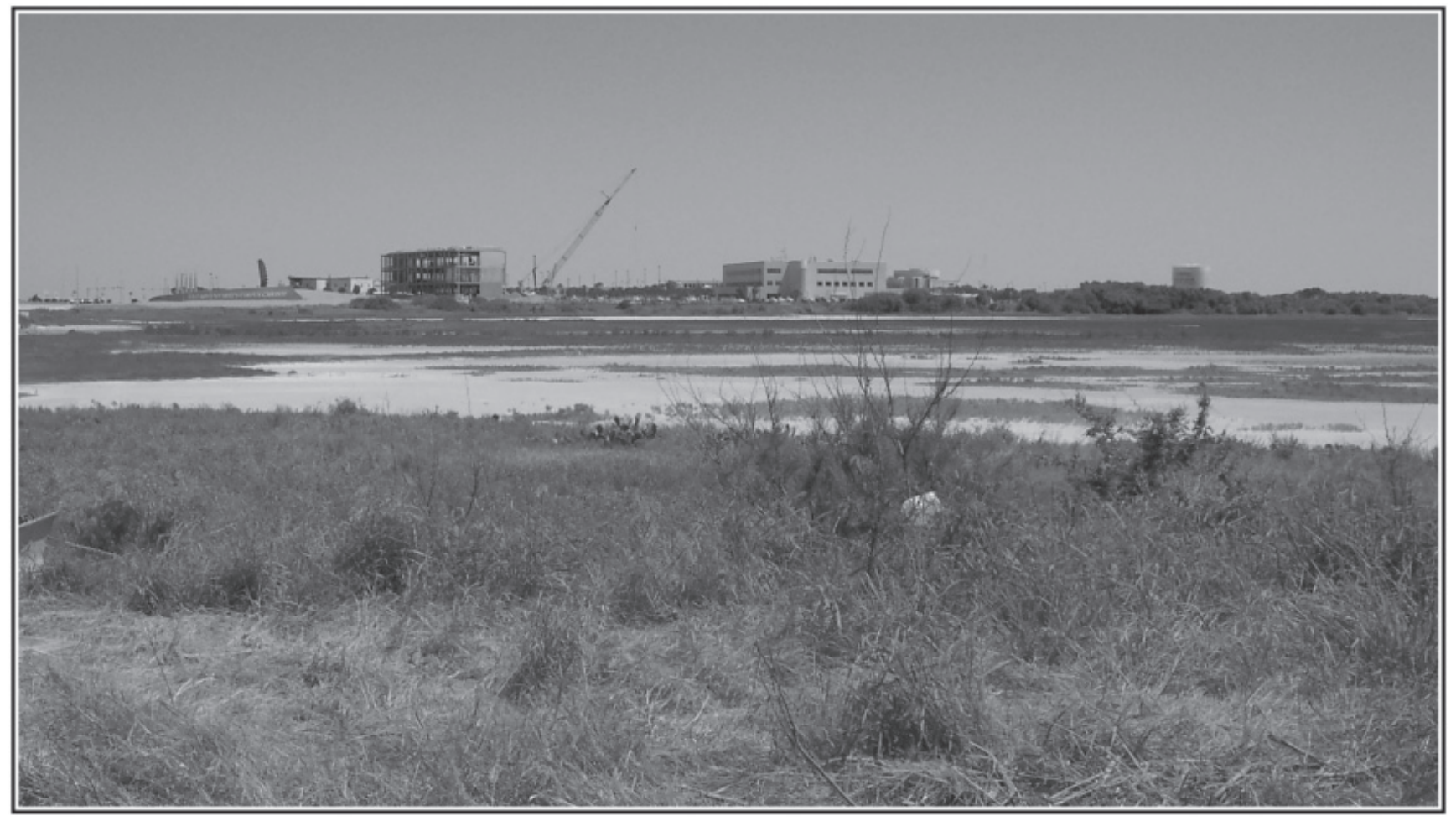

Figure 2-1. The False Oso mudflats as they usually appear, taken from the northern end of the Cayo del Oso site, facing east. Ward Island and TAMU-CC are in the background. 
clay particles are blown by prevailing winds onto the surface of the dune (Huffman and Price 1949:120).

Unlike sand dunes, the clay particles do not continue to be susceptible to movement by subsequent winds, as the clay particles "melt" into the compacted clay of the surface of the dune when any moisture is present. Even the dew of the morning is enough to complete this process (Huffman and Price 1949:124). Clay dunes are susceptible to erosion through runoff, especially after a drought when vegetation on the surface of the dune is sparse. The rains that end the drought often cut deeply into the surface of the dune. These erosional features are then gradually filled in. Hurricanes and other big storms can cause a great deal of erosion to clay dunes while at the same time depositing course-grained materials.

During periods when there is sufficient rain, the dunes stabilize and vegetation grows thickly on the surface leading to reduced sheet erosion. Over time a much darker, more organic, soil is formed, until it is buried by rapid accumulation of clay during long droughts.

\section{Climate}

This section provides a summary of the present climate of the Texas coastal region. Here we define the coastal and near-coastal setting as a roughly $125-\mathrm{km}$-wide strip of land following the current gulf coastline, roughly including both the Coastal Prairies and Interior Coastal Plains sub-regions of the Gulf Coastal Plains.

Figure 2-2 indicates the area we have defined as the coastal and near-coastal region, an area we will refer to simply as coastal. Also identified in the figure are the locations of 53 weather stations that provide data for the discussion of the modern climate of the area. These data are based on 30 year normal precipitation and temperature records from 1971 through 2000, and come from a data base with nearly 600 stations from across Texas (NCDC 2004).

\section{Precipitation}

Figure 2-3 presents the average monthly rainfall for the 53 coastal locations shown in Figure 2-2, along with rainfall patterns from 53 randomly selected sites from the remaining 544 weather stations from across the state. Comparisons of the two curves clearly suggest that while both data sets reflect a bimodal pattern, coastal stations have different peaks, with most rainfall occurring in September, and a secondary peak occurring in June. In contrast, the 53 stations from the remainder of the state have highest rainfall totals in May, with a lower, secondary peak in October. In addition, in this noncoastal data set the lowest rainfall totals occur, on average, in January, while February and March are the lowest totals for the coastal locations. Finally, note that in every month of the year, coastal sites exceed the average rainfall of more inland settings. At a yearly time scale, the average rainfall for the coastal sites (40.56 in.) exceeds the non-coastal sample average (32.57 in.) by about 8 in., with most of that difference occurring over the mid-summer and early fall months of July through October.

An examination of precipitation data from the 53 coastal stations suggests that there is considerable variability in the annual rainfall totals, from a high of 62.75 in. near the Louisiana border, to a low of $21.69 \mathrm{in}$. near the southern coastal border with Mexico. In order to explore that variability, we partitioned the data set into three groups by location, with the

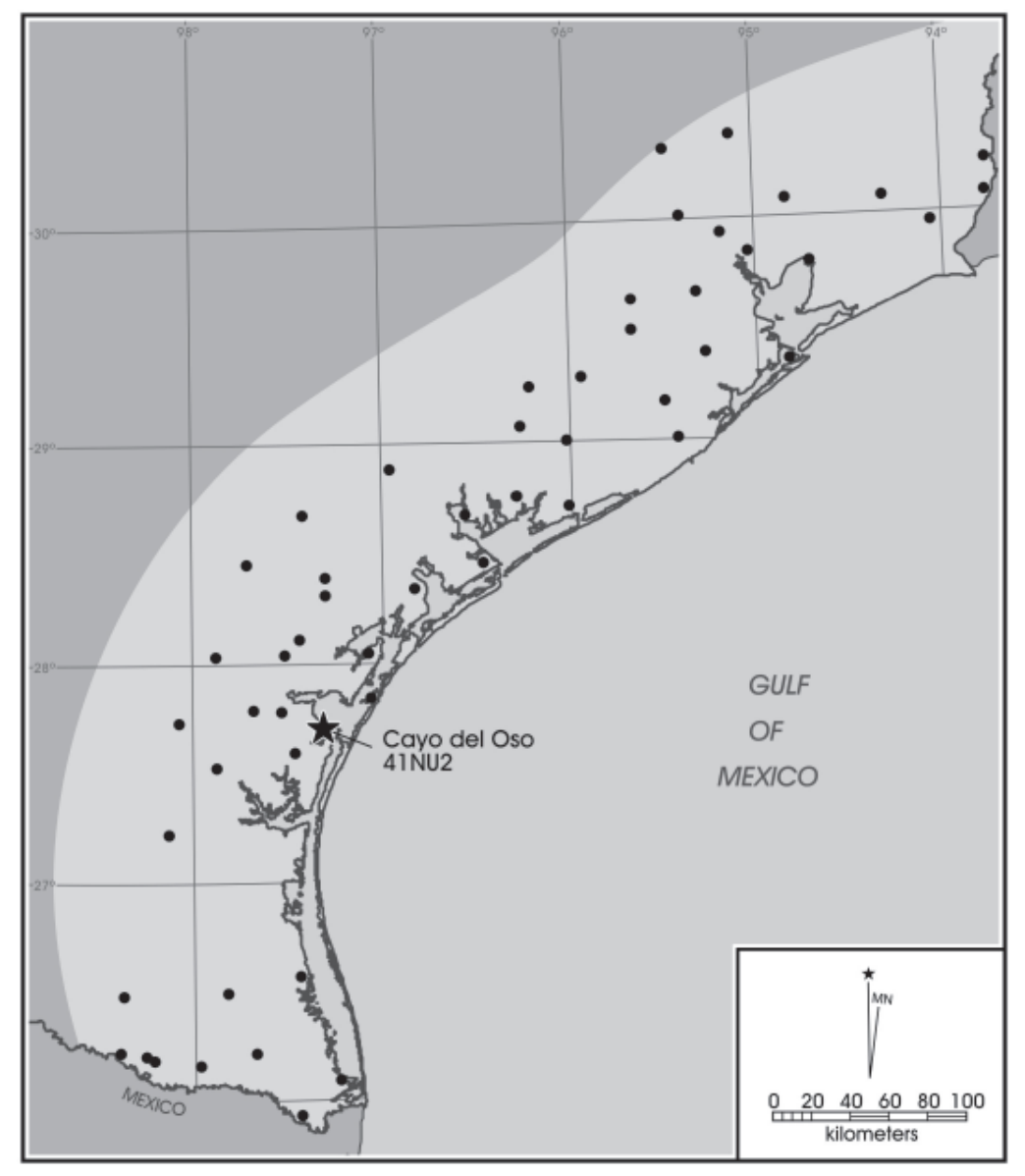

Figure 2-2 Weather station locations within the coastal and near coastal region along the Texas Gulf Coast (NCDC 2004). 


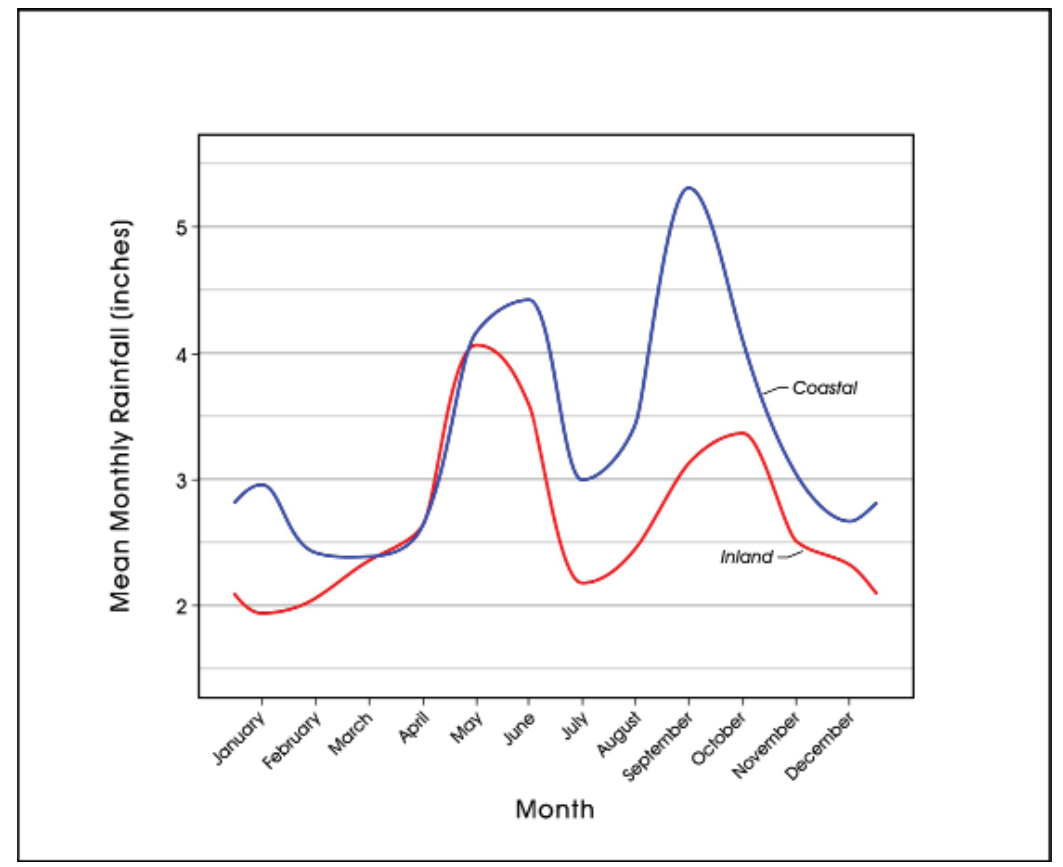

Figure 2-3. The mean monthly rainfall for the 53 coastal locations compared to th average monthly rainfall from the remaining 544 weather stations in Texas. Based on data from NCDC (2004).

first group consisting of 13 stations located in the Southern or Lower section of the coast, a second group of 22 stations in the Middle Coastal region, and a group of 18 stations located in the Upper Coastal area. Figure 2-4 presents these locations (insert), along with their respective monthly average totals between 1971 and 2000. Examination of the figure will show that there is a south to north trend in the rainfall data, with the Upper Coast having significantly higher rainfall and the Lower Coast having significantly lower rainfall. At a yearly scale, the Lower Coastal stations average 25.78 in., with the Middle Coast averaging 39.01 in., and the Upper Coast averaging 53.12 in. The Figure 2-4 line graph patterns suggest that while September peaks are roughly comparable in all three coastal sections, there is significantly more precipitation in the remaining months of the year as one proceeds up the Texas coastline. In fact, the Lower Coast is, on average, drier than the 53 randomly selected stations from the remaining portion of the state.

Figure 2-5 presents mean monthly rainfall totals from 1971 through 2000 for Corpus Christi, located at the southern end of our Middle Coastal region. Overlain on that plot is the monthly averages for the Middle Coast (see Figure 2-4). While following the general shape of the rest of the Middle Coast, monthly rainfall is lower at Corpus Christi than the average for the Middle Coast region, with much of this deficit coming in the late fall, winter, and early spring months, between November and March.

Kier and White (1978) present 42 years of monthly data for Corpus Christi between 1932 and 1973 which allows an assessment of year to year variability (Figure 2-6). In these data, annual rainfall totals varied from a low of $14.66 \mathrm{in.} \mathrm{(1963)}$ to a high of 44.25 in. (1960), with an average yearly amount of $28.71 \mathrm{in}$. over these 42 years. The year to year variability is substantial, a factor also shown by monthly differences. The highest monthly total during these 42 years was 20.33 in. of precipitation, recorded in September of 1967. While high totals are frequently associated with the summer months of August, September, and October, probably as a result on late summer gulf storms, high totals occur in several other months, including $10.78 \mathrm{in}$. of rainfall during January 1958 (Kier and White 1978).

\section{Temperatures}

Figure 2-7 presents box plots of average annual temperatures $\left({ }^{\circ} \mathrm{F}\right)$ for the 53 coastal stations as well as 53 non-coastal locations selected at random from the remaining portions of

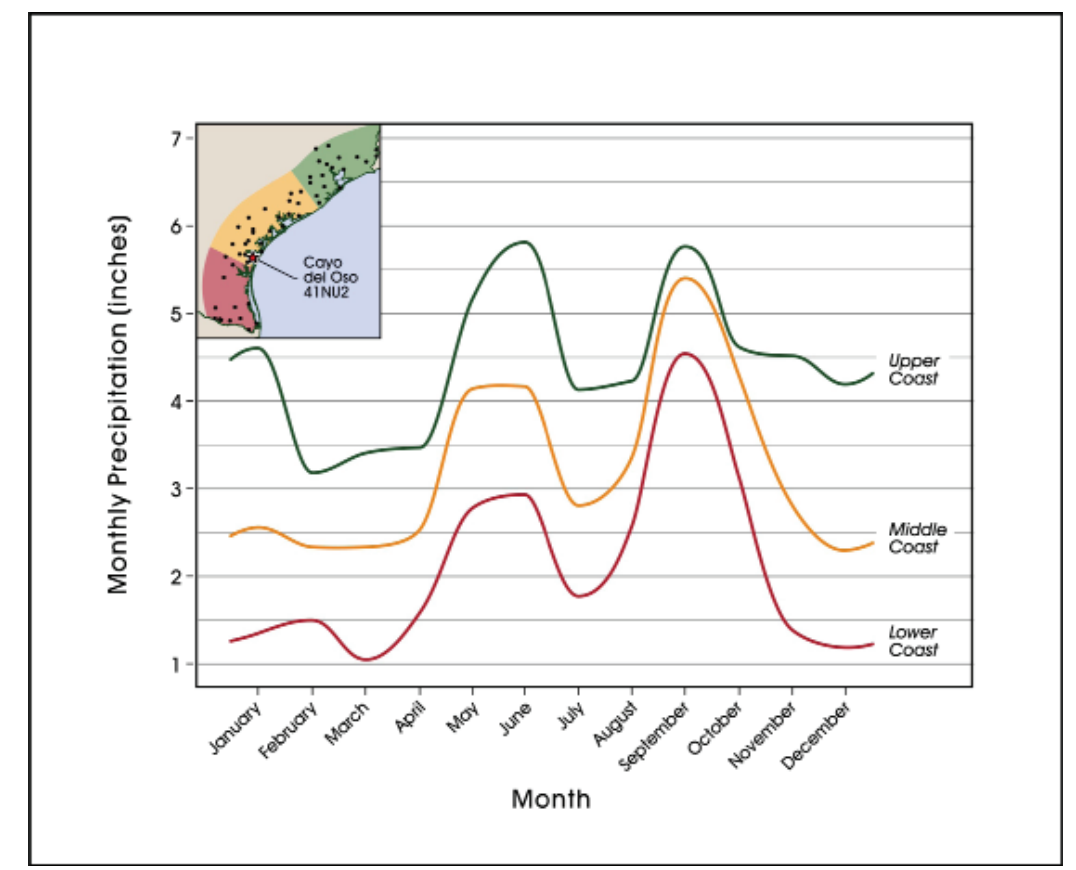

Figure 2-4. The mean monthly rainfall for the Upper, Middle, and Lower coastal regions. The inset defines these regions. Based on data from NCDC (2004). 


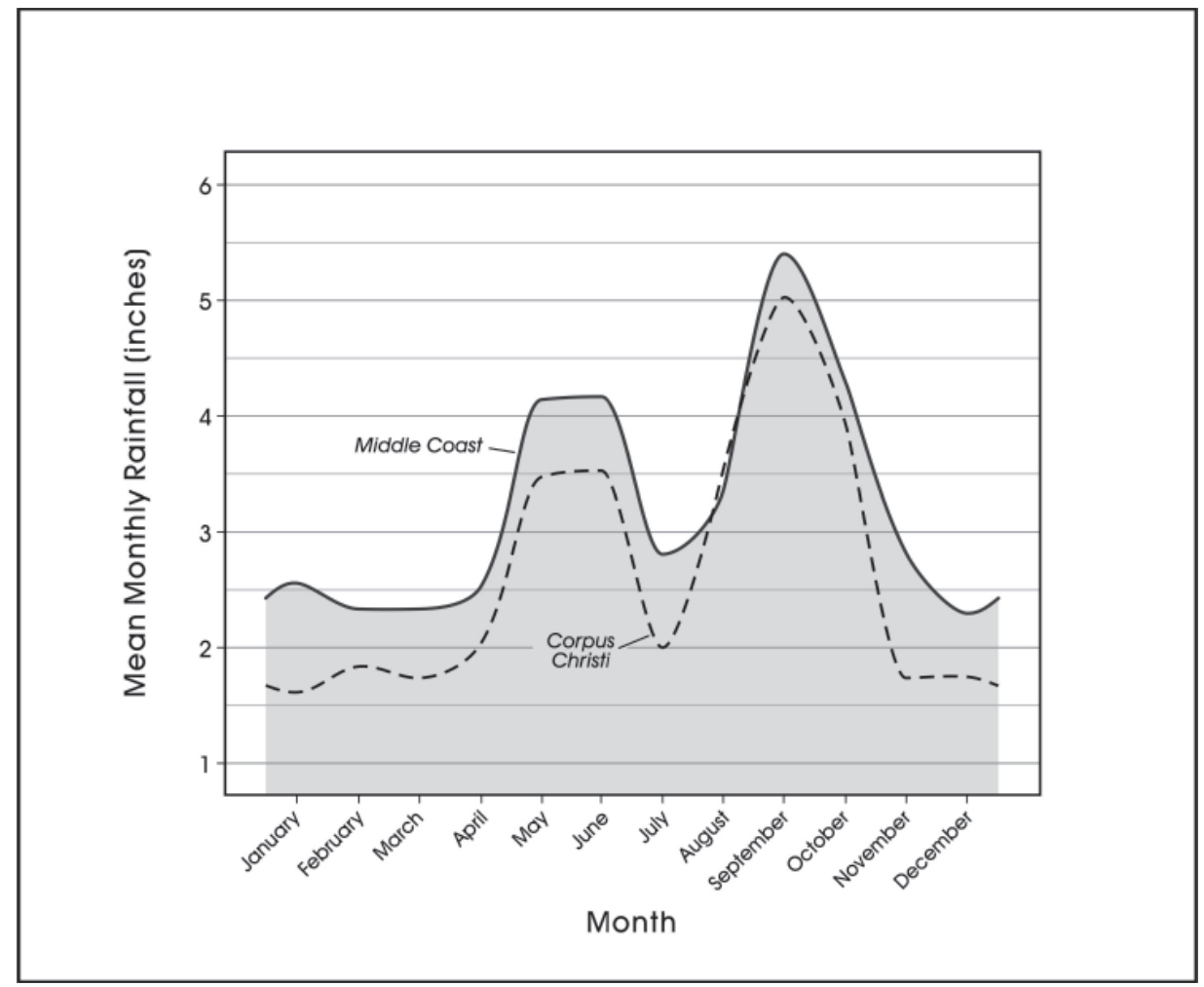

Figure 2-5. Mean monthly rainfall totals for the Middle Texas Coast and Corpus Christi (1971-2000). Based on data from NCDC (2004).

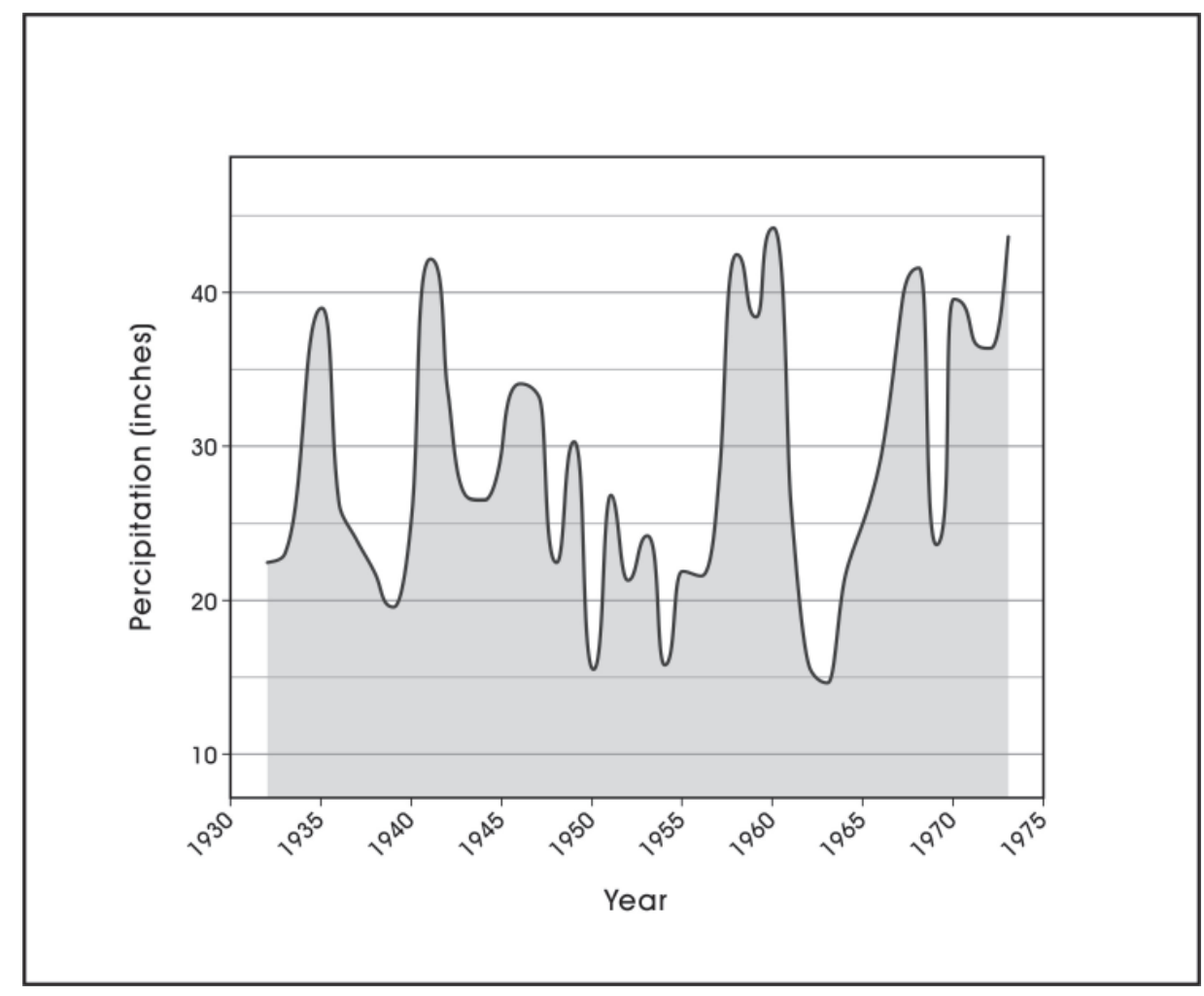

Figure 2-6. Annual rainfall at Corpus Christi between 1932-1973. Based on data from Kier and White (1978). 


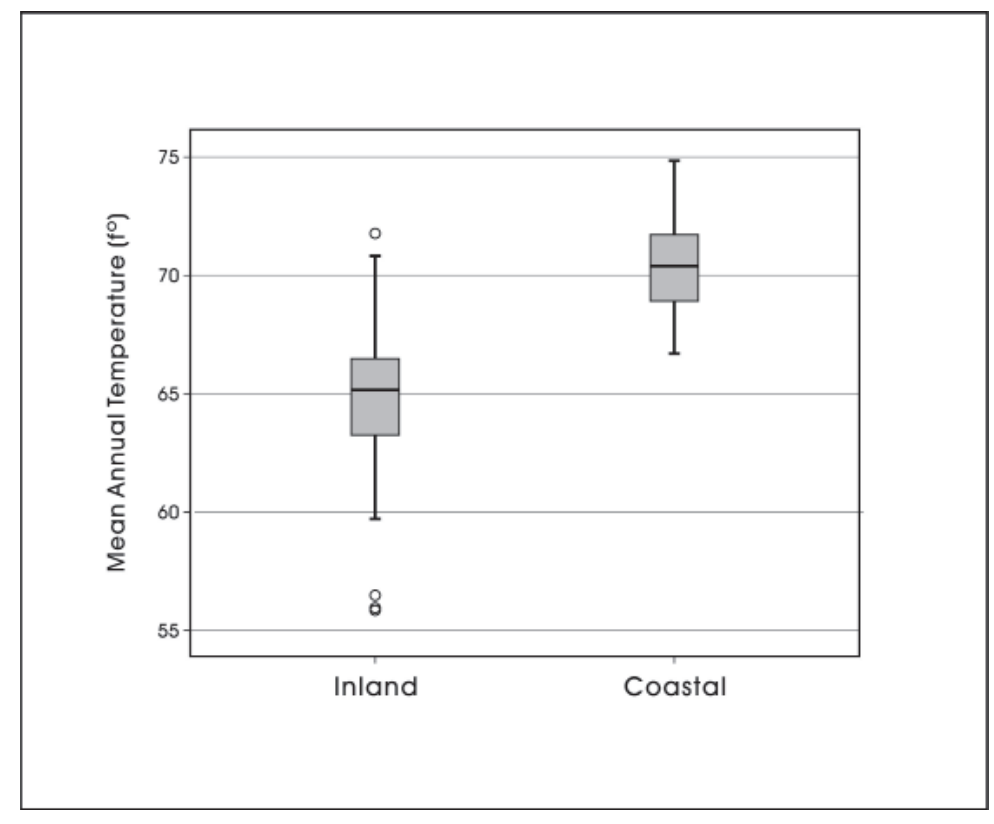

Figure 2-7. Mean annual temperatures of coastal weather stations compared to inland weather stations. Based on data from NCDC (2004).
Corpus Christi Bay water temperatures vary from a low of $7^{\circ} \mathrm{C}$ in the winter to $29^{\circ} \mathrm{C}$ in the summer (Harwood 1980).

\section{Salinity}

Average annual salinity for the bay is around 30 parts per thousand (ppt). In periods of high rainfall and runoff, salinity can drop to as low as $11 \mathrm{ppt}$, while periods of low rainfall and high temperatures may increase salinity to $45 \mathrm{ppt}$ (Brown et al. 1976). Figure 2-10 shows the clear relationship between rainfall and average salinity in Oso Bay (Brown et al. 1976). The same pattern also should replicate on a seasonal basis in Corpus Christi Bay proper, although the amplitude of the effects should be less due to the size and depth of the larger bay.

Southeasterly winds are typical of the area throughout much of the year. However, strong northerly fronts are common in the winter and can result in below-freezing the state. Clearly, coastal settings are significantly warmer during the 1971 to 2000 period, with mean yearly temperatures for the coastal group exceeding the random samples average by $5.65^{\circ} \mathrm{F}$. As with rainfall, there are also significant temperature differences between our three geographical distinctions as can be seen in the box plots in Figure 2-8. Average January (Top) and July (Bottom) temperatures are significantly higher in the lower coastal area, while the upper coast has the lowest temperatures. Finally, Figure 2-9 compares average monthly temperatures at Corpus Christi with those from the Middle Coast. Corpus is warmer during several months, though the differences are minimal.

Overall, then, the modern climate of the coastal regions are wetter and warmer than the rest of the state. Along the coast as such, the Lower Coast is significantly warmer and drier relative to the Middle and Upper sections. The pattern at Corpus Christi and falling within the Middle Coastal region, is more reminiscent of the Lower Coastal pattern, a function of the southern location of this weather station within the Middle Coast. The climate reflected in the Corpus Christi data sets is also highly variable, especially with regards to precipitation. Mean annual evaporation rates range from $90-115 \mathrm{~cm}$ but may also reach 150 $\mathrm{cm} /$ year during drought periods. Because evaporation rates exceed precipitation, the region is under a constant moisture deficit. Summer high temperatures average $33.3^{\circ} \mathrm{C}$, while winter lows average $8.3^{\circ} \mathrm{C}$.

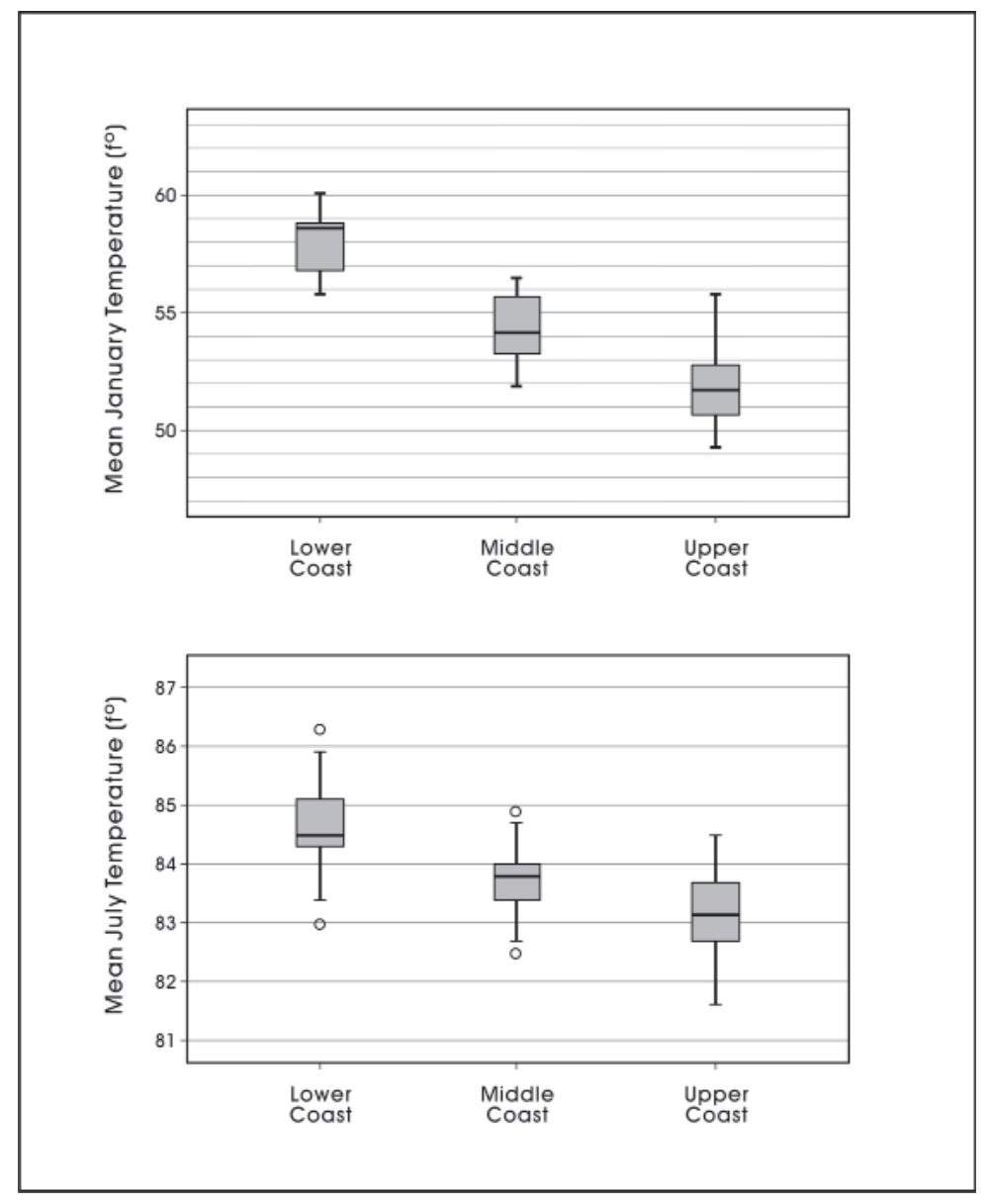

Figure 2-8. Mean January and July temperatures in the Texas Coastal regions. Based on data from NCDC (2004). 


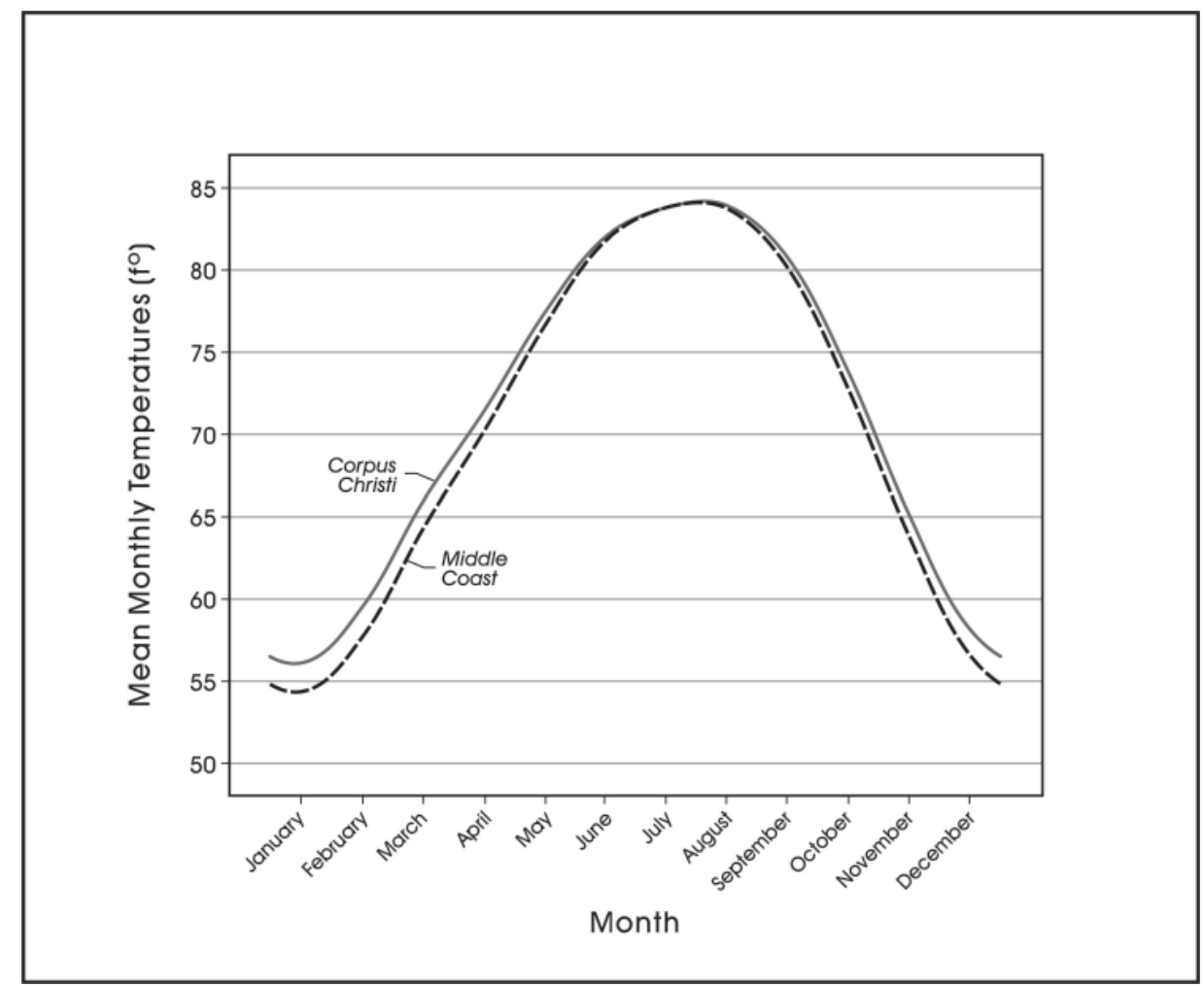

Figure 2-9. Relationship of mean monthly temperature at Corpus Christi and the average for the Middle Coast region. Based on data from NCDC (2004).

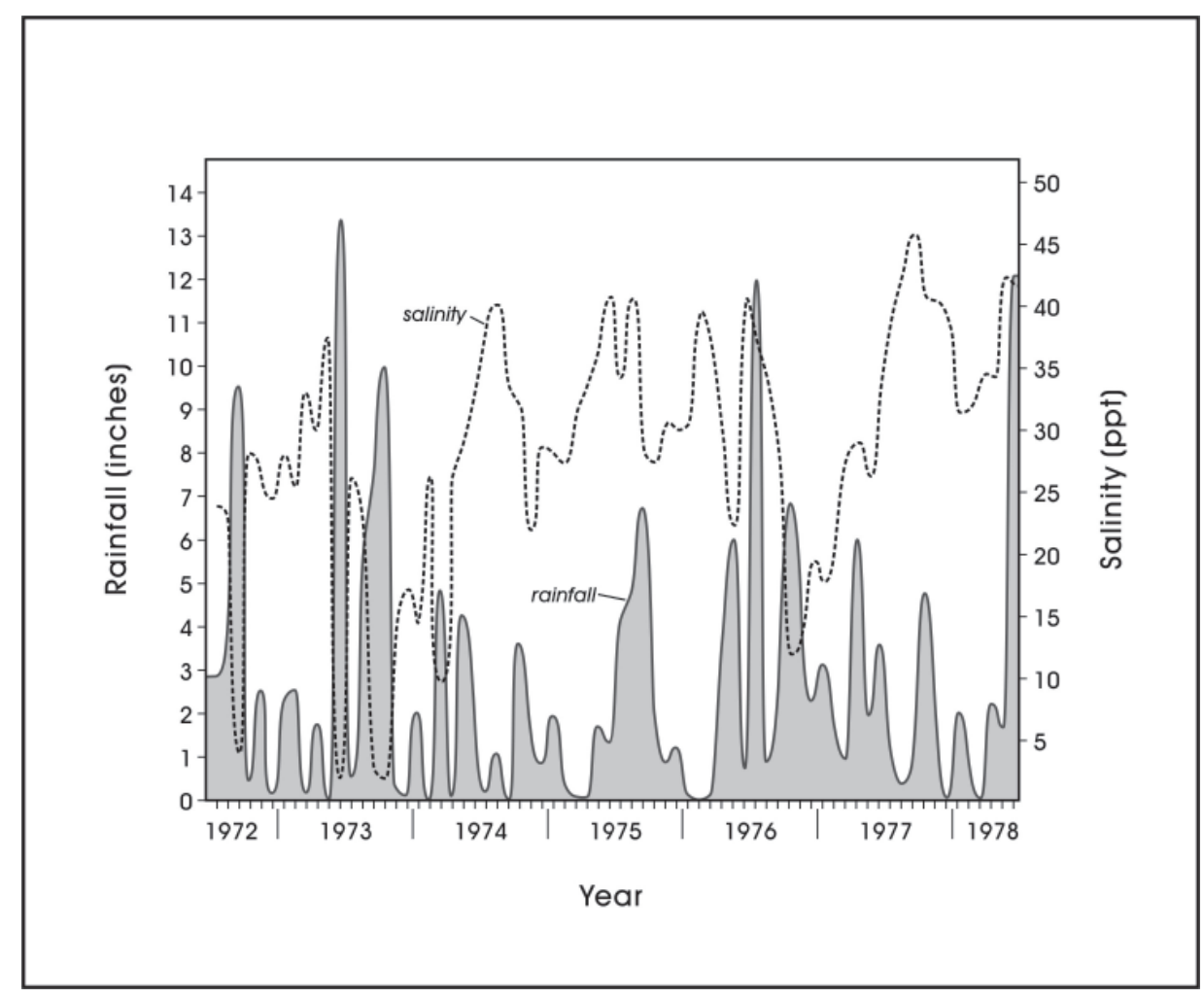

Figure 2-10. Seasonal and annual relationship between rainfall and salinity in Oso Bay during 1972-1978. (Based on data from Brown et al. 1976). 
temperatures and low tides for several days following the passage of the front (Chabreck 1990). It is the combination of rainfall, temperature, and salinity that strongly influence habitat conditions for fish and molluscs.

\section{Environmental Structure}

Corpus Christi Bay is only one of several large bays along the Texas shores of the Gulf of Mexico. It lies within the Coastal Prairies sub-region of the Gulf Coastal Plains physiographic region of Texas (Brown et al. 1976). The Coastal Prairies sub-region forms an approximately 40-mile strip of land that parallels the shoreline, from Galveston Bay at the eastern edge of the state and progressing westward and south to the Rio Grande River (Figure 2-11).

In environmental and biological terms, the 40-mile-wide strip of the Coastal Prairies that is defined as the Corpus Christi area (Figure 2-11) by the Bureau of Economic Geology (Brown et al. 1976) encompasses all or parts of seven counties (Aransas, Bee, Jim Wells, Kleberg, Nueces, Refugio, and San Patricio). This area encompasses the northern portion of the Laguna Madre and Laguna Larga at its southern end and portions of Copano and Aransas Bays at its northern end. Mustang Island, St. Joseph Island and the northern end of Padre Island are the barrier islands off the mainland (Figure 2-11).

The BEG survey of the Corpus Christi area (Brown et al. 1976) identified a mosaic of 36 natural environmental zones and biological assemblages (Figure 2-12). These natural environments and biological assemblages can be grouped into habitats. A habitat is defined as an aggregation of biological communities that contain a relatively homogenous group of resources that are the product of longterm evolutionary dynamics and forces (i.e., the relationship between primary biomass and secondary biomass, primary productivity versus species diversity and the body size of the resident species), and as an aggregate are more similar to each other, based on the niche requirements of the resident biological assemblages and complementarity, than to adjacent habitats.

The 36 zones defined by Brown et al. (1976) can be divided into two broad categories: submerged or partially submerged environments $(n=15)$, and terrestrial environments $(\mathrm{n}=21)$. Of the 15 submerged/ partially submerged settings, 11 may have been accessible to humans. Ten of these submerged or partially submerged natural areas can be combined to form the highly diverse BayEstuary-Lagoon Habitat (Table 2-1). Fresh and brackish water ponds and lakes, the eleventh submerged setting, is found dispersed throughout the prairie uplands and it is therefore included within the terrestrial habitats mentioned below (Table 2-2). Table 2-1 summarizes those characteristics of the ten submerged environments that make up the Bay-EstuaryLagoon Habitat that are most likely to impact the species composition and density of taxa present in these environments. In terms of area, the largest component of the Bay-EstuaryLagoon Habitat is the open bays $\left(165.9 \mathrm{mi}^{2}\right)$, followed by grass flats at shallow bay margins $\left(53.4 \mathrm{mi}^{2}\right)$, enclosed bays with reefs $\left(38.0 \mathrm{mi}^{2}\right)$, and bay and lagoon margins $\left(31.7 \mathrm{mi}^{2}\right.$; Brown et al. 1976:Table 7). The Bay-Estuary-Lagoon Habitat covers a combined $385.7 \mathrm{mi}^{2}$ of the Corpus Christi area. A variety of fish, snails, clams, oysters and molluscs and a multitude of bird species inhabit these environments.

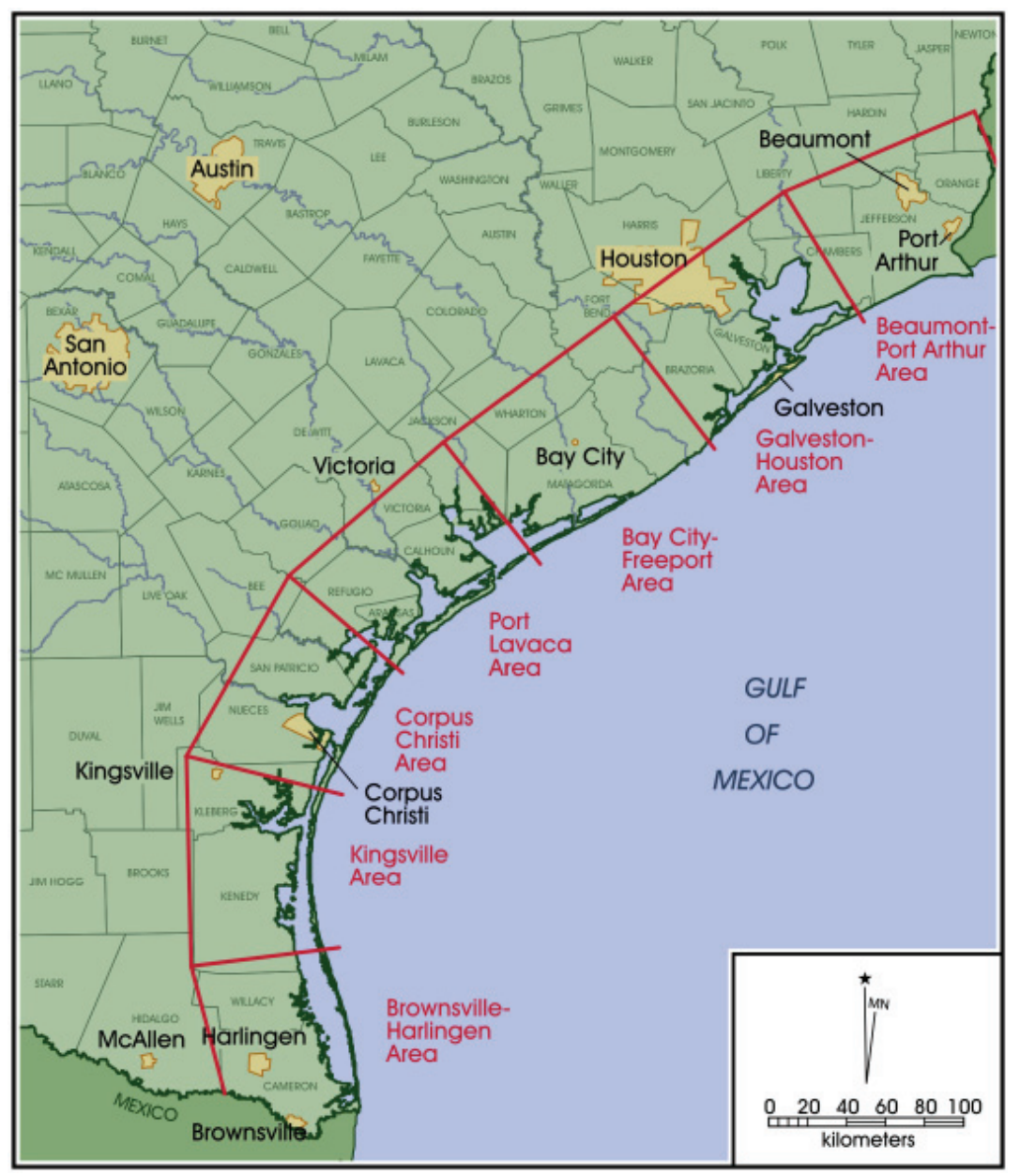

Figure 2-11. The Coastal Prairies subregion of the Gulf Costal Plains geographic regions, of the Gulf Coast of Texas (after Brown et al. 1976). 


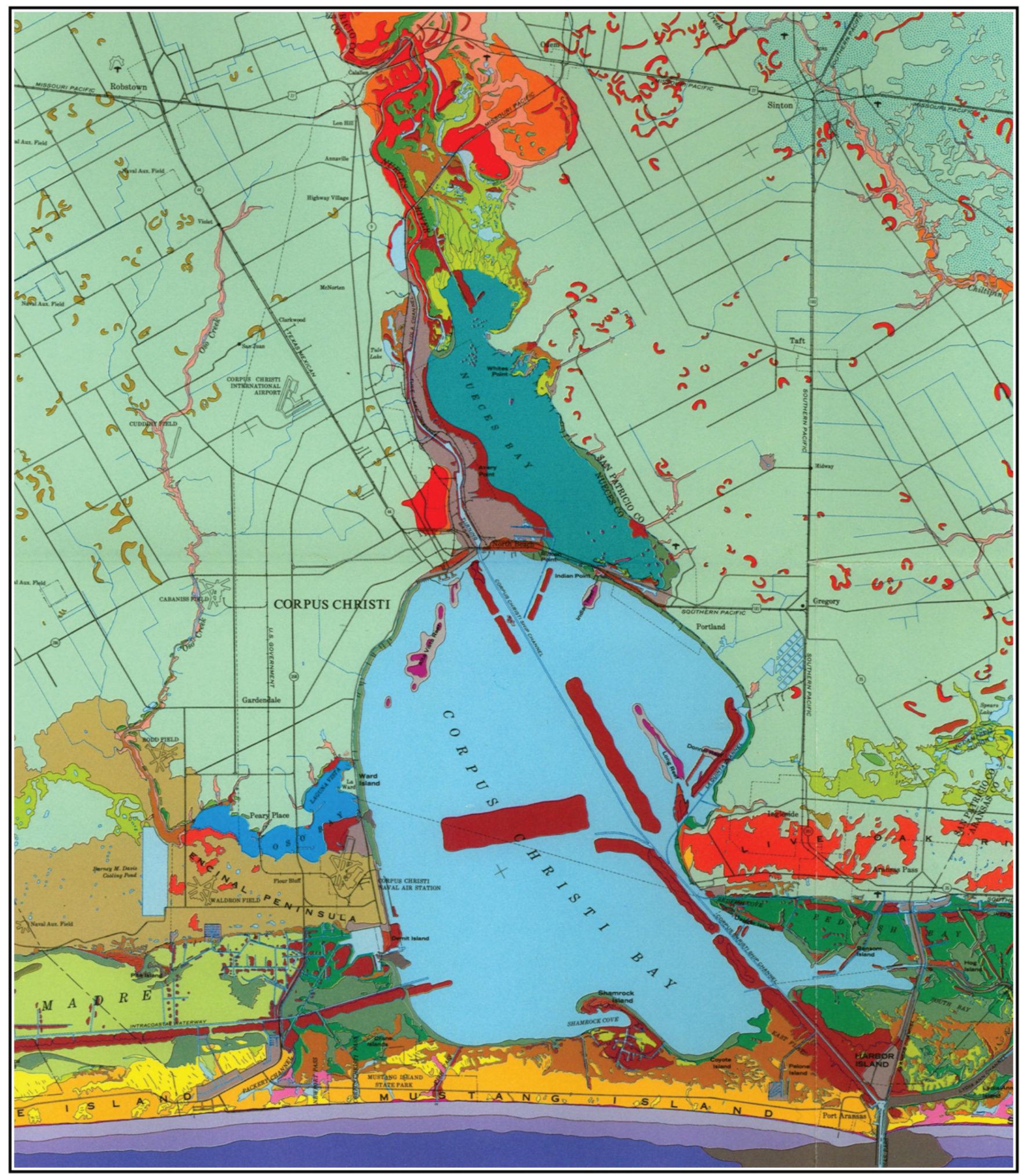

Figure 2-12a. Natural environmental zones and biological assemblages in the vicinity of Corpus Christi Bay, identified by the Bureau of Economic Geology (Brown et al. 1976). 


\section{Explanation * \\ Subaqueous Environments and Assemblages}

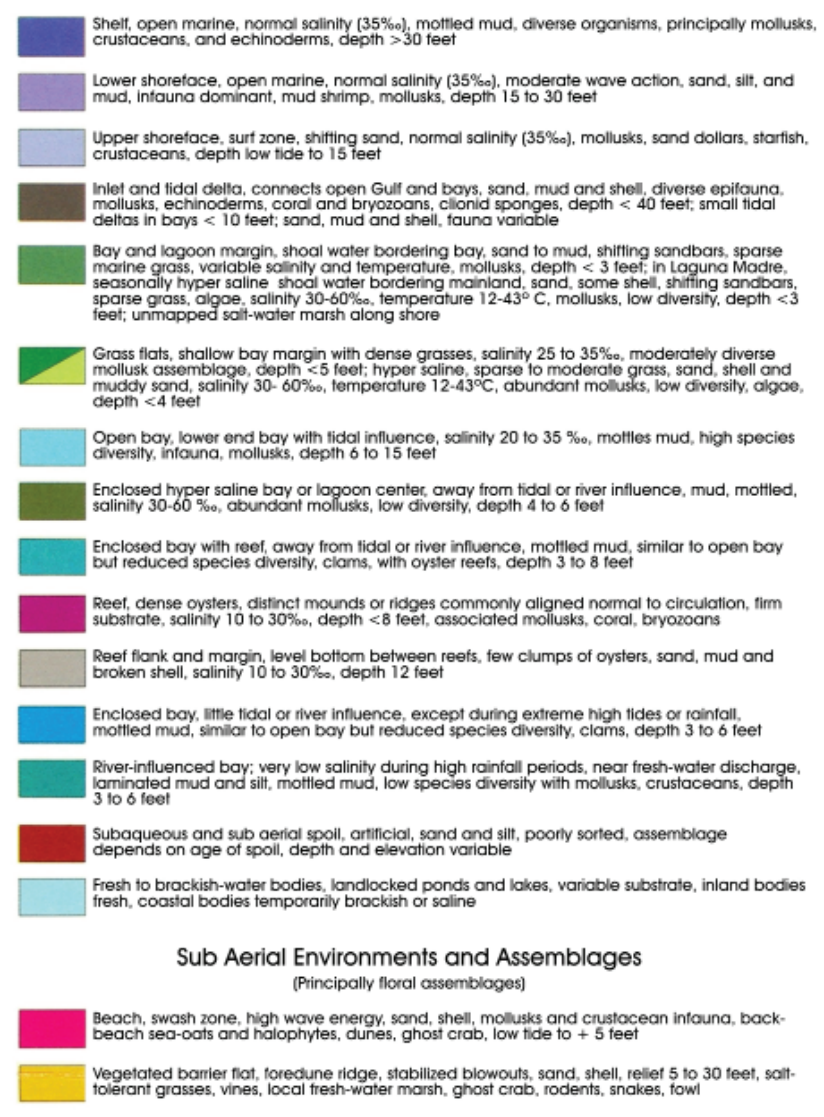

Lower shoretace, open marine, normal salinity (35\%), moderate wave action, sand, silt, and

Upper shoreface, surt zone, shititing sand, normal sainity $35 \%$, mollusks, st

Inlet and fidal delta, connects open Gulf and bays, sand. mud and shell. diverse epifoune mollusk, echinoderms, coral and buryazoans, cilionid sponges,
deltas in bays < 10 teet; sand, mud and sheil, tauna variable

Bay and logoon margin, shoal water bordering bay, sand to mud, shifting sandbars, sparse mastine gillss, variable salinity and sparse grass, algoe, solinity $30-60 \%$ o, temperature $12-43^{\circ} \mathrm{C}$, mollusks, low diversity, depth
feet; unmapped salt-water marsh along shore

Grass flats, shallow bay margin with dense grasses, salinity 25 to $35 \%$, moderately diverse

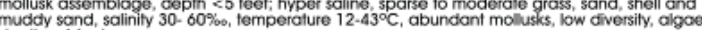

Enclosed hyper saline bay or logoon center, away from fidgl or river influence, mud, mottled, Enclosed bay with reet, away from tidal or tiver infivence, mottled mud, similar to open bay

Reet, dense oysters, distinct mounds or ridges commonty aligned nomal to circulation, firm , salinity 10 to $30 \%$, depth $<8$ feet, as River-influenced bay; very low salinity during high rainfall periods, near fresh-water discharge. 3106 leel

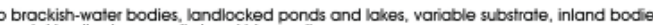

Sub Aerial Environments and Assemblages Principally floral assemblages

Vegetated barrier flot, foredune ridge, stabilized blowouts, sand, shell, reliet 51030 teet, scll grasses, vines, local fresh-water marsh, ghost crab, rodents, snakes, fow

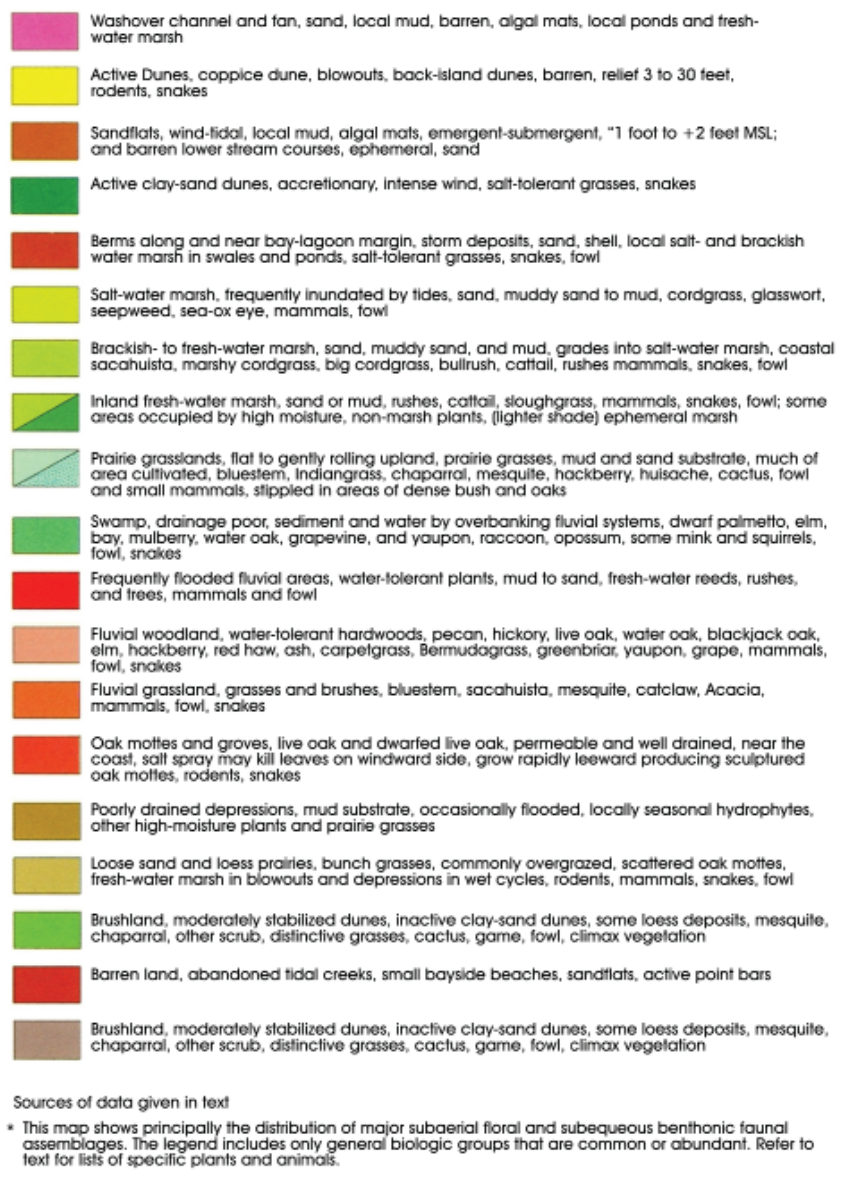

Figure 2-12b. Color key for Figure 2-12a.

Table 2-1. General Characteristics of the Submerged or Partially Submerged Natural Environments and Biological Assemblages

\begin{tabular}{|c|c|c|}
\hline & $\begin{array}{l}\text { Natural Environment/ } \\
\text { Biological Assembalge }\end{array}$ & Principal Characteristics \\
\hline \multirow{7}{*}{ 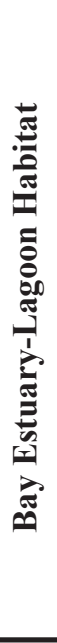 } & Inlet and tidal deltas & $\begin{array}{l}\text { Connect open Gulf and bays; sand, mud and shell substrate; clams and oysters; } \\
\text { small tidal deltas }<10 \text {-feet deep; }\end{array}$ \\
\hline & Bay and lagoon margins & $\begin{array}{l}\text { Sand and mud substrate; clams; salinity ranges from } 30-60 \mathrm{ppt} \text {; temperatures range } \\
\text { from } 12-43^{\circ} \mathrm{C} ;<3 \text {-feet deep; low diversity of mollusks; }\end{array}$ \\
\hline & Grass flats & $\begin{array}{l}\text { Shallow bay margins } \mathrm{w} \text {. dense grasses; salinity ranges from } 25-60 \mathrm{ppt} \text {; temperatures } \\
\text { range from } 12-43^{\circ} \mathrm{C} ;<5 \text {-feet deep; moderate to high mollusk diversity; }\end{array}$ \\
\hline & Open bays & $\begin{array}{l}\text { Deeper ends of bays under tidal influence; mottled mud substrate; salinity range } \\
\text { from 20-35 ppt; 6-15-feet deep; high species diversity; }\end{array}$ \\
\hline & $\begin{array}{l}\text { Enclosed hypersaline bay and } \\
\text { lagoon centers }\end{array}$ & $\begin{array}{l}\text { Located away from tidal or river influences; mottled mud substrate; salinity range } \\
\text { from 30-60 ppt; abundant mollusks but low species diversity; 4-6 feet deep; }\end{array}$ \\
\hline & Enclosed bays with reefs & $\begin{array}{l}\text { Located away from tidal or river influences; mottled mud substrate; clams and } \\
\text { oyster reefs; low species diversity; 3-8 feet deep; }\end{array}$ \\
\hline & Reefs & $\begin{array}{l}\text { Firm substrate; salinity range from } 10-30 \mathrm{ppt} \text {; dense oyster populations and } \\
\text { associated mollusks; < } 8 \text {-feet deep; }\end{array}$ \\
\hline
\end{tabular}


Table 2-1. Continued...

\begin{tabular}{|c|c|c|}
\hline & $\begin{array}{l}\text { Natural Environment/ } \\
\text { Biological Assembalge }\end{array}$ & Principal Characteristics \\
\hline \multirow{3}{*}{ 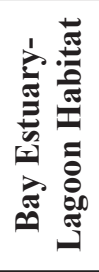 } & Reef flanks and margins & $\begin{array}{l}\text { Level bottoms between reefs; sand, mud and broken shell substrate; salinity range } \\
\text { 10-30 ppt; clumps of oysters; depth < } 12 \text {-feet; }\end{array}$ \\
\hline & Enclosed bays & $\begin{array}{l}\text { Little tidal or river influence except during high tides and rainfall; mottled mud } \\
\text { substrate; clams; low-moderate species diversity; 3-6 feet deep; }\end{array}$ \\
\hline & River influenced bays & $\begin{array}{l}\text { Near freshwater discharge zones; very low salinity during high rainfall periods; } \\
\text { mud, mottled mud and sand subtrate; low mollusk species diversity; 3-6 feet deep; }\end{array}$ \\
\hline
\end{tabular}

Table 2-2. General Characteristics of the Terrestrial Natural Environments and Biological Assemblages, Including Fresh and Brackish Water Ponds That Occur in All Habitats

\begin{tabular}{|c|c|c|}
\hline Habitat & $\begin{array}{l}\text { Natural Environment/ } \\
\text { Biological Assembalge }\end{array}$ & Principal Characteristics \\
\hline \multirow{7}{*}{ 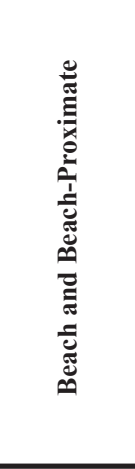 } & Beaches & Exposed to high wave action and low tides, may cover up to 5-feet; mollusks and crustacean fauna; \\
\hline & Vegetated barrier flats & $\begin{array}{l}\text { Relief from 5-30 feet; salt-tolerant grasses, vines, chenopodium; mesquite, hackberry, prickly ash; } \\
\text { rodents, snakes and waterfowl; }\end{array}$ \\
\hline & Washover channels & $\begin{array}{l}\text { Mostly barren; scattered stands of cordgrass, glasswort, saltwort; contain localized ponds and } \\
\text { freshwater marshes; }\end{array}$ \\
\hline & Active sand dunes & Largely barren; scattered stands of salt-tolerant grasses; relief 3-30 feet; rodents, snakes; \\
\hline & Sand flats & Occasionally covered by water from wind and tidal action; may be only 2 -feet amsl; cordgrass; \\
\hline & Active clay dunes & $\begin{array}{l}\text { Accretional in nature and subject to intense winds; salt-tolerant grasses (buffalograss, whitegrass) help } \\
\text { stabilize surface; mesquite, pricklypear and Spanish dagger common; snakes, small mammals; }\end{array}$ \\
\hline & Berms at bay-lagoon margins & $\begin{array}{l}\text { Localized salt and brackish-water marshes and ponds; salt-tolerant grasses; mesquite, salt cedar; } \\
\text { snakes and waterfowl; }\end{array}$ \\
\hline \multirow{3}{*}{ 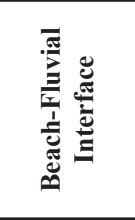 } & Salt water marshes & $\begin{array}{l}\text { Frequently inundated by tides; cordgrass, glasswort, saltwort, saltgrass, black mangrove; crabs, snails, } \\
\text { waterfowl, racoons, and small mammals; }\end{array}$ \\
\hline & Brackish to freshwater marshes & $\begin{array}{l}\text { Coastal sacahuista, marshy cordgrass, big cordgrass, bullrush, cattail, rushes, mammals, snakes, } \\
\text { waterfowl; }\end{array}$ \\
\hline & Inland freshwater marshes & $\begin{array}{l}\text { Coastal sacahuista, seacoast bluestem, balsamgrass, buffallograss, Indiangrass, husache, mesquite, } \\
\text { hackberry, oaks; mammals, snakes, waterfowl; }\end{array}$ \\
\hline \multirow{4}{*}{ } & Swamps & $\begin{array}{l}\text { Dwarf palmetto, elm, mulberry, water oak, yaupon, grape, racoon, opossum, some mink, squirrel, } \\
\text { snakes, waterfowl; }\end{array}$ \\
\hline & Frequently flooded fluvial areas & $\begin{array}{l}\text { Water-tolerant plants; freshwater reeds, rushes, cattail, and trees (i.e., willow); various mammals } \\
\text { similar to swamps; waterfowl; }\end{array}$ \\
\hline & Fluvial woodlands & $\begin{array}{l}\text { Water-tolerant hardwoods, pecan, hickory, live oak, water oak, blackjack oak, cedar elm, anacua, hackberry, } \\
\text { red haw, ash; carpetgrass, Bermudagrass, greenbriar, yaupon, grape; squirrels, fox, racoon, opossum, other } \\
\text { small mammals, rodents, fowl, snakes; March-June and August-October large numbers of birds; }\end{array}$ \\
\hline & Fluvial grasslands & $\begin{array}{l}\text { Bluestem, coastal sacahuista, mesquite, catclaw, rabbits, opossum, skunk, fox, quail, other fowl, small } \\
\text { mammals, snakes; }\end{array}$ \\
\hline \multirow{5}{*}{ : } & Oak mottes and groves & Live oak and dwarfed live oak; small rodents and snakes; \\
\hline & Brushland & $\begin{array}{l}\text { Mesquite, chaparral, pricklypear, Spanish dagger, buffalograss, whitegrass, coastal sacahuista, } \\
\text { mesquitegrass, bermudagrass; deer, turkey, quail and other fowl; }\end{array}$ \\
\hline & Prairie grasslands & $\begin{array}{l}\text { Bluestem, Indiangrass, chaparral, mesquite, hackberry, husache, pricklypear, small mammals, } \\
\text { waterfowl, localized dense areas of brush and oak mottes; }\end{array}$ \\
\hline & Loose sand and loess prairies & $\begin{array}{l}\text { Scatteredd live oak mottes ; blowouts that formed areas of freshwater marshes; bunch grasses; small } \\
\text { rodents, mammals, snakes, fowl; }\end{array}$ \\
\hline & Poorly drained depressions & $\begin{array}{l}\text { Prairie grasses ( bluestem, buffalograss), water-tolerant plants (sloughgrass, rush); distribution and size } \\
\text { tied to seasonal wet periods; }\end{array}$ \\
\hline $\begin{array}{c}\text { Within all } \\
\text { terrestrial } \\
\text { habitats }\end{array}$ & $\begin{array}{l}\text { Fresh and brackish water ponds } \\
\text { and lakes }\end{array}$ & Landlocked pond and lakes; variable substrate; inland bodies fresh and coastal bodies brackish water; \\
\hline
\end{tabular}


Of the 21 terrestrial natural environments and biological assemblages, 19 would have been available to human inhabitants of the coast. These can be combined into four habitats, the Beach and Beach-Proximate Habitat, the BeachFluvial Habitat, the Prairie-Riverine Habitat, and the Prairie Habitat. Table 2-2 summarizes the general characteristics of these 19 terrestrial environments and biological assemblages that make up these four habitats as well as the fresh and brackish water ponds and lakes from the submerged category, because they are found within all four of the terrestrial habitats.

As can be seen in Figure 2-12a, areas near the coastline have a wide variety of inter-fingered natural environments and biological assemblages, such that any given area near the coast may be within one such environment but have several others closely adjacent. Fluvial-deltaic and marsh-swamp natural environment contains eight $(42 \%)$ of the 19 natural terrestrial areas. Coastal beaches and barrier islands (barrier-strandplain and eolian natural systems) in combination contain seven (37\%) of the 19 terrestrial assemblages present in the Corpus Christi area. Coastal prairie uplands tend to be more homogeneous containing only 3 of the $19(16 \%)$ natural areas. They are dominated by grasslands, oak mottes and brush communities.

In terms of area, the largest terrestrial biological community in the Corpus Christi area is the prairie grasslands (1455.3 $\mathrm{mi}^{2}$ ), followed by sand and loess prairies $\left(93.7 \mathrm{mi}^{2}\right)$, fluvial woodlands $\left(61.1 \mathrm{mi}^{2}\right)$, frequently flooded fluvial areas $\left(52.3 \mathrm{mi}^{2}\right)$, and fluvial grasslands $\left(40.0 \mathrm{mi}^{2}\right)$. Saltwater marshes $\left(10.7 \mathrm{mi}^{2}\right)$, brackish to freshwater marshes $\left(8.6 \mathrm{mi}^{2}\right)$, and inland fresh-water marches $\left(29.9 \mathrm{mi}^{2}\right)$ also are a significant component in the Corpus Christi area (Brown et al. 1976). These 19 terrestrial environments, combined, are home to a rich mix of small and medium-bodied mammals, fowl, snakes, prairie grasses, oak mottes, and moisture-tolerant plant species.

As expected, the Prairie Habitat occupies the largest area $\left(1,623 \mathrm{mi}^{2}\right)$, followed a distant second by the Prairie-Riverine habitat $\left(154 \mathrm{mi}^{2}\right)$, the
Beach and Beach-Proximate Habitat $\left(92 \mathrm{mi}^{2}\right)$, and the BeachFluvial Interface Habitat $\left(49 \mathrm{mi}^{2}\right)$. Figure 2-13 is a graphic representation of the distribution of the five habitats we have defined in the vicinity of Corpus Christi Bay and that may also be present near other bays along the coast. In summary, within the coastal prairies geographic area, the Prairie Habitat (e.g., prairie uplands) constitutes the largest habitat although it has the least biological diversity. As one moves to low-lying parts of the coastal plains and beach-proximate settings, the diversity of biological assemblages increases but the extent of the habitats decreases. The Prairie-Riverine Habitat with its more diverse biological assemblages extends into the prairie grasslands providing linear corridors of greater biological diversity (Figure 2-13). Biologically, the most diverse communities are located at the interface of land and saline, brackish and freshwater bodies, and consist of the Beach-Fluvial Interface and Bay-Estuary-Lagoon habitats.

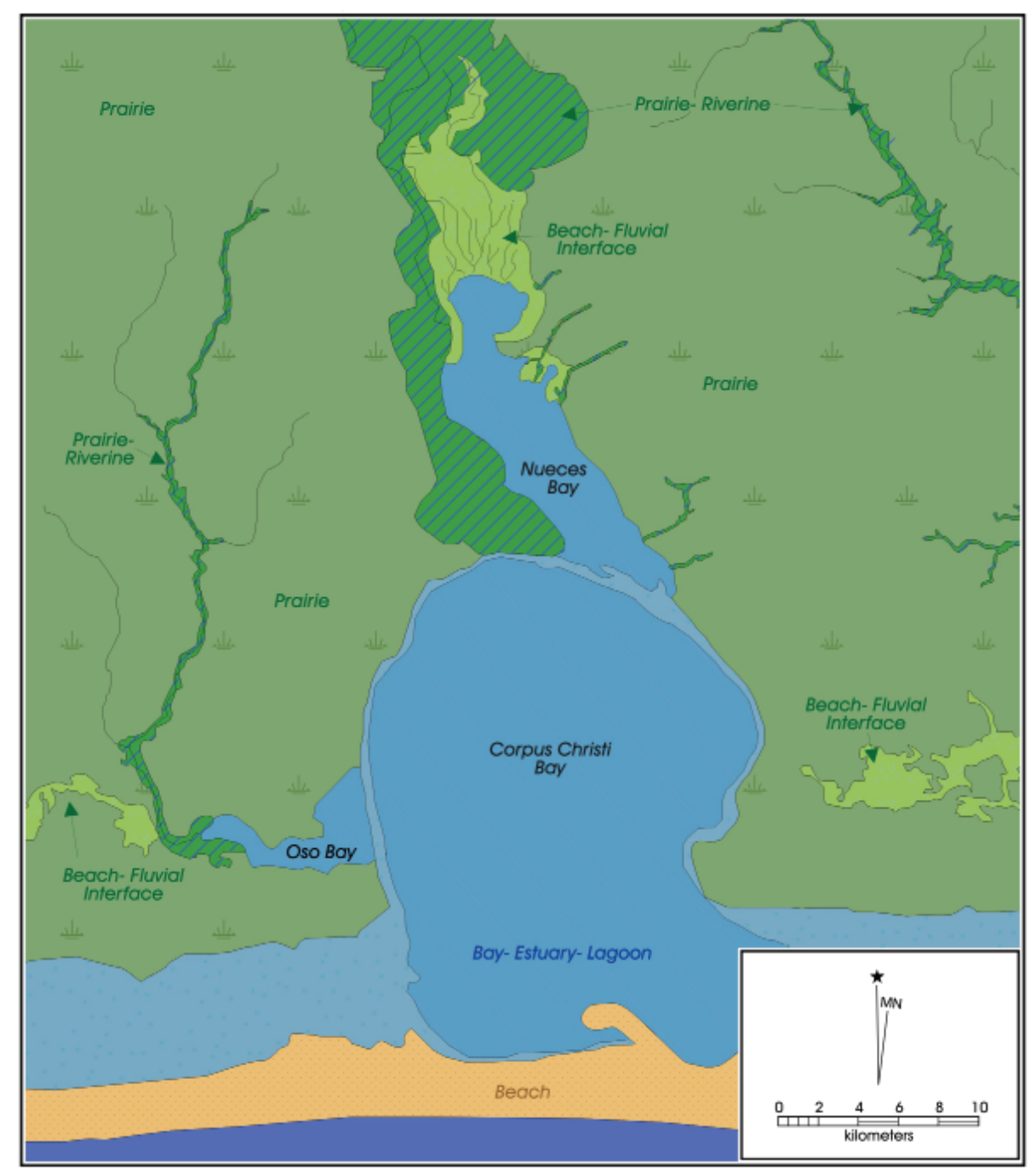

Figure 2-13. Distribution of five habitats defined for the Corpus Christi Area (after Brown et al. 1976). 


\title{
Chapter 3: Cultural Chronology of the Texas Coast
}

\author{
Jennifer A. Thompson
}

Much of the known archeological record along the Texas Coast has been examined by Ricklis (1996, 2004; Ricklis and Blum 1997). He has addressed the cultural developments of coastal groups in an ecological setting fitting to the Human Behavioral Ecology framework used in this study. Therefore, we draw upon his work for much of the cultural history described in this chapter. The chronology begins with the Archaic Period rather than the Paleoindian Period because during the Paleoindian Period, the last glacial period was just ending, and ocean levels were so much lower that the coast line was still some distance from the modern coast line. Any Paleoindian sites recorded on the present-day coast would represent inland groups from a terrestrial/riverine adaptation rather than coastal groups, as what is now Corpus Christi Bay was probably not inundated until ca. 7500-7000 B.P., during the Early Archaic period (Brown et al. 1976:20-21).

\section{Archaic Period}

The Archaic Period began around 8,000 B.P. and lasted until the appearance of bow and arrow and ceramic technology between about 1500 and 1000 B.P. This long period has been divided by researchers into three sub-periods, the Early, Middle, and Late Archaic.

\section{The Early Archaic}

Ricklis (2004:161) cites two major periods of occupation during the Early Archaic. The gap between these two periods, roughly 6800 to 5900 B.P. is represented by few archeological sites in the area (Ricklis 2004:164). Ricklis believes that geologic evidence suggests that sea level may have been rising rapidly at this time (Paine 1991; Ricklis 2004:176; Thomas and Anderson 1994), so that the food-rich shoreline shallows would have been inundated, and new shallows had not yet developed as a result of silting.

\section{Initial Early Archaic Occupation Period: 7500-6800 B.P.}

The earliest known occupation period has been dated to 7500-6800 B.P. (Ricklis 2004:161:161-162) at a few sites overlooking Nueces Bay. Sites 41SP136, 41SP153, 41NU266, and 41NU281 (Ricklis 1993, 1995b) returned dates from shell to this initial Early Archaic occupation (Ricklis 2004:160, Table 5.2). Site 41 NU266 is located on a bluff above the Nueces River delta, while the others are located on a bluff above a cove of Nueces Bay. The large number of estuarine molluscs associated with these dates suggests strongly that the incursion of marine waters within the narrow valley had progress at least as far as 41NU266 and there had been enough time for shallows to develop at or near the mouth of the river.

These components are thin but dense with oyster shell within Holocene deposits, often sitting directly on the Beaumont Formation. The excavations at these sites consisted of testing, and the units containing the Early Archaic materials were widely scattered. The excavated strata contain few artifacts within the dense, though thin shell lenses, suggesting that they were short term camps visited by small groups of people, likely there to harvest the shellfish. The small number of artifacts cannot support much inference about the material culture. Debitage and a core were recovered from 41SP153 and utilized flakes were recovered from 41NU266. Edgeflaked sunray venus shell tools were identified (Ricklis 1993, 1995a). These tools apparently continued in use to the Late Prehistoric Period (Ricklis 2004). Reports from these sites suggest that either bone preservation is very poor, or that the inhabitants of the camps did not expend much effort in hunting and fishing.

\section{Terminal Early Archaic Occupation Period: 5800-4200 B.P.}

This Terminal Early Archaic period is better documented than the earlier occupations and well dated. Twentyfour radiocarbon assays date fifteen discrete stratigraphic components from the Coastal Bend on the shores of Nueces Bay, Baffin Bay, the Nueces River delta, The Lavaca River delta, and Ingleside Cove (Ricklis 2004:Tables 5:1, 5:2). As in the Initial Early Archaic occupation, most components of the Terminal Early Archaic are thin shell lenses, with few bones and other artifacts (Ricklis 2004). More components are recorded for the Terminal Early Archaic period occupation, though sites from both this and the earlier occupation rest on the eroded surface of the Beaumont Formation and could have eroded during the Middle Holocene (Ricklis 2004:165). The McKenzie Site, 41NU221, located about $3 \mathrm{~km}$ upstream of 41NU266, contains a large thick shell deposit with hundreds of flakes, five dart points, a stone end scraper and shell tool (Ricklis 1988). At the Means site, 41NU184, extensive excavations produced debitage and some surface dart points near a shell midden (Ricklis and Gunter 1986). The site also contained a series of post molds in a semi-circular configuration, interpreted by Ricklis and Gunter (1986) as 
the remains of a structure. Excavations at site 41SP156 on the Nueces Bay revealed an occupation dating from 5592 to 4614 B.P. (Ricklis 1993). An Andice barb and a possible reused Gower point were found within the dated shell stratum. Site 41NU267, also on Nueces Bay, produced deep deposits containing early triangular points with oyster shells dating to 4986-4862 B.P. (Ricklis 1995b).

Otolith remains at many sites dating from the end of the Early Archaic indicate the presence of estuary fishes. Some identified species include black drum, spotted sea trout, redfish, Atlantic croaker, and catfish. These, along with the presence of dart points and shell lenses, indicate that some hunting likely contributed to a diet that also included fish and shellfish. Shell studies from oyster lenses on the Nueces Bay shore suggest shellfish gathering occurred during the winter and spring months, when plants were scarce and game was lean. Results of otolith analysis from 41NU221 (Ricklis 2004:165) indicated similar dependence on fishing at this site.

The postulated highstand with sea level about a meter higher than it is today was taking place at this time (Paine 1991; Ricklis 1997:7). This may explain why 41NU221, located about $6 \mathrm{~km}$ from the current mouth of the river, contained oysters (Crassostrea virginica). Oysters require water levels at least 8 feet deep and a minimum salinity of $15-40 \%$. In addition, there were large numbers of the Brown Rangia (Rangia flexosa), a clam with a normal salinity tolerance that ranges from $5-19 \%$.

\section{Middle Archaic}

Ricklis (2004: 164-165) defines another gap in the archeological record on the Central Texas coast that occurs during the Middle Archaic between 4200 and 3100 B.P. $\mathrm{He}$ believes that shallow water and marshes may have been reduced affecting the abundance of available aquatic resources to coastal groups. The dearth of Middle Archaic archeological sites on the coast is not likely due to sampling. Many sites have dated zones of occupation above and below the Middle Archaic geologic deposits (Ricklis 2004). This component was seen at 41NU2 with dated features falling between 4200 and 3500 B.P.

\section{Late Archaic}

By the beginning of the Late Archaic, the current coastal environment of bays and lagoons were beginning to take shape. At about this same time, the postulated highstand would have ended (Paine 1991; Ricklis 1997:7). Sea levels stabilized, promoting formation of the barrier islands, which coalesced into islands similar to the modern forms sometime between about 3000 B. P. (Ricklis1995a:142) and about 2500-2000 B.P. (Morton and Paine 1984:12). The barrier islands allowed backwater shallows to develop landward, as river sediments filled the bays forming marshes and lagoons along the shoreline, around Nueces Bay, the Nueces River delta, and Oso Bay. The broad shallow waters were optimal for fish spawning and likely served as a catalyst for a booming fish population.

The availability of resources from these wetlands attracted coastal groups, as evident by the archeological record. Sites from the Late Archaic are larger, thicker, and include a greater quantity and variety of artifacts. Faunal bone assemblages consisting of more than 100 specimens occur for the first time and suggest that fishing and hunting were part of the Late Archaic subsistence strategies. An increase in the number of fish otoliths coincides with the formation of the barrier islands and the estuaries and marshlands that formed as a result (Ricklis 2004:165). The abundance of estuarine resources encouraged population growth among the human population, as well, and may explain the increased site density across the region and richness of the archeological deposits.

Excavated coastal sites with Late Archaic components include the Kent Crane site (41AS3), Mustang Lake (41CL3), 41SP43, and 41SP120 (Ricklis 1996:36-56). Bone, stone, and shell tools have all been recovered from Late Archaic sites as well as indirect evidence of basketry i.e., basketry-impressed asphaltum at the Holmes Site, 41SP120; (Ricklis 1996:41). Late Archaic components also contain the first recognized cemeteries along the Texas coast. The rise of cemeteries along with increased population may indicate increased territoriality associated with prime hunting or fishing grounds (Ricklis 2004:169).

\section{Late Prehistoric Period}

The Late Prehistoric period is marked on the Texas coast as it is throughout the state, by the arrival of the bow and arrow and ceramics (Ricklis 2004:171). Coastal groups continued to rely on the estuarine resources for subsistence at least part of the year, as evident in the amount of fish bone and mollusc shell present in archeological components. Identified fish species include black drum (Pogonias cromis), red drum (Sciaenops ocellatus), spotted seatrout (Cynoscion nebulosua), and Atlantic croaker (Micropogonias undulates), all of which are fish that spawn in or near Corpus Christi Bay, where young fish can find places to hide in the sea grass beds (Ricklis 1995, 1996). Shellfish, such as oyster (Crassostrea virginica), lightning whelk (Busycon sinistrum) and bay scallop (Argopectin irradians), continued to be present in Late Prehistoric shell lenses. Hunting is evident through the presence of arrow points and vertebrate faunal remains of deer and bison (Ricklis 1996). 


\section{Initial Late Prehistoric}

Ricklis identifies two sub-periods of occupation within the Late Prehistoric. The Initial Late Prehistoric lasted from A.D. 1000-1300. The distinction is based on well-dated terminal Archaic stratum at A. D. 1000 beneath a discrete component with Fresno arrow points and abundant fish bone dated from two shells to A.D. 1022-1212 and A.D. 1024-1209 (Ricklis 1993). Initial Late Prehistoric Scallorn arrow points have been recovered from the Mustang Lake site, the Kendrick's Hill site, and at the Anaqua site (41JK8), where they were found with sand-tempered pottery (Ricklis 2004:171).

\section{Terminal Late Prehistoric}

The Terminal Late Prehistoric sub-period along the coast is defined by the emergence of a particular artifact assemblage, the Rockport Phase (A.D. 1300-1700), similar in many ways to the Toyah Phase assemblage of Central Texas. Both include Perdiz arrow points, small unifacial end scrapers, thin bifacial knives, chert drills, sandstone metates, and prismatic blades and cores. The ceramic assemblage sets the Rockport Phase apart from the inland Toyah assemblage of the Terminal Late Prehistoric. Rockport phase shell tools include conch and whelk adzes, awls, hammers and the edgeflaked Sunray Venus clamshell knives and scrapers that were seen in components dating 6000 years earlier. Shell beads and perforated shells have also been discovered in Terminal Late Prehistoric assemblages (Ricklis 2004).

The Rockport Phase ceramic collection contains few complete specimens though some inferences from sherds indicate that vessel forms include bowls, jars, and ollas sometimes decorated with asphaltum, incised, and crenulated along the vessel rim. These Rockport Phase ceramics have been found along the coast in association with bone tools, bone beads, and shell tools from Matagorda Bay and the lower Colorado River to northern Baffin Bay and up to $40 \mathrm{~km}$ inland with Toyah Phase artifacts (Ricklis 2004:172). Suhm and Jelks (1962) defined three pottery types with the Rockport Phase ceramic tradition: Rockport Plain with no decoration; Rockport Black and Gray, with asphaltum bands painted both inside and out after firing; and Rockport Incised, decorated with geometric lines incised around the sub-lip area externally.

Ricklis $(1990,1996)$ revised the typology adding a fourth type and two varieties to the Suhm and Jelks (1962) typology. The Rockport Crenellated type has a plain body with a notched rim decoration and occasionally an asphaltum band at the lip. Rockport Black on Gray was divided into two varieties. Variety I includes wide mouthed bowls and jars with an external asphaltum band and no internal decoration. Variety
II includes small-mouthed neckless or constricted ollas, with asphaltum lines from the lip to the base and asphaltum coating the interior of the vessel (Ricklis 1990, 1996).

Subsistence seems to have shifted during the Terminal Late Prehistoric to more reliance on fish than shellfish and the inclusion of bison. Hunting camps with bison and deer faunal remains attributed to the Rockport Phase have been found inland overlooking drainages in prairie settings at 41NU221, 41NU193, 41NU255, 41NU46, 41SP159, 41SP160, 41SP161, 41SP167, and 41SP170. These sites are smaller with fewer artifacts than Rockport Phase coastal sites, which cover a larger area and have a relatively higher artifact density. Settlement patterns may reflect seasonal use of aquatic resources during fall and early spring at coastal camps and hunted prey from late spring through summer at stream valley hunting camps in the prairie. The larger coastal sites versus the smaller riverine prairie sites might also indicate population aggregation at the coast before dispersal to the prairie for hunting forays (Ricklis 2004).

\section{Historic Period}

Early European encounters along the Texas coast have provided us an ethnohistoric record of the indigenous groups, collectively known as the Karankawa, who lived roughly from Galveston to Corpus Christi Bay. The first extant record of European contact with natives on the Texas coast is from the Narváez expedition in 1528. An excellent recent short review of the story told by the treasurer of the expedition, Álvar Núñez Cabeza de Vaca, and his three companions who arrived in Vera Cruz more than seven years after being shipwreck on what was probably Galveston Island, is available at the Texas Beyond History website (Thoms 2008). The 1555 edition of La relacion y comentarios del gouernador Aluar nuñez cabeça de vaca, de lo acaescido en las dos jornadas que hizo a las Indias is available, with facsimiles of each page and an English translation (Cabeza de Vaca 1555). La Relación, describes the Narváez expedition, the shipwreck off what was almost certainly Galveston Island, and the lifeways of the Native Americans who kept them alive during their first winter. It then describes the attempt by survivors of that first winter to find the way to Spanish-controlled Mexico. Although the route of their wanderings is still in dispute, it is possible that the first part of their trip was from the mainland near Galveston to an area that seems to have been the lower Guadalupe River and San Antonio Bay. After this, they turned inland. Of the eighty men who came ashore on Galveston Island, only four had survived, eventually reaching other Spanish speaking people (Thoms 2008).

Another account of Karankawa lifeways, more than a century later, comes from the interrogation of two French brothers, 
Pierre and Jean-Baptiste Talón, who along with several siblings, were children saved by Karankawa women during the massacre of the last remnants of the French colony Fort St. Louis, near Matagorda Bay (Bell 1987; R.B. Campbell 2003:41-46). An account of the colony by LaSalle's friend Henri Joutel (Foster 1998) is a more complete story but is less interesting from an ethnographic perspective, as the story told by the brother years later in France relates the lifeways of both the Karankawa and the Cenis, an inland farming Native American group. The brothers were taken away from their lives with the Karankawa and Cenis during the expedition by the de Leon expedition, sent to find the French encampment after learning of the La Salle expedition (R.B. Campbell 2003: 46). The Spanish, who had come to challenge what they considered a French land grab, returned the boys to Mexico, where they were held until adulthood, at which time the two oldest boys joined the Spanish Navy, and eventually made their way back to France (Bell 1987).

Another French account comes from François Simars deBellisle, who was marooned near Galveston Bay in 1719 (Weddle and Lemée 2003). DeBellisle was a French officer with the French West Indies Company sailing for Louisiana. Missing the Mississippi River, the ship landed in Galveston Bay where Bellisle and four others went ashore to assess their location and were left. Only deBellisle survived until he was encountered by an Atákapan band, who spoke one of the Karankawa dialects. He remained throughout the summer and the winter of 1720. A letter passed from tribe to tribe reached the French colony at Fort Saint-Jean-Baptiste, who sent a few Hasinais, and inland group, to rescue deBellisle. DeBellisle then remained with the Hasinais for several months before finally reaching the French settlement at Natchitoches in February 1721 (Weddle and Lemée 2003:23).

Other accounts of the native Texas population come from the Spanish reports from missions. In 1690, as a result finding what was left of the LaSalle colony, the Spanish began securing the northern border of New Spain, expanding their interests in east Texas to counter any French expansion across the Mississippi River. The Marqués de San Miguel de Aguayo scouted Texas for possible mission locations for coastal tribes (Ricklis 1996). The relationship between the Spanish colonists and coastal Native groups was hostile, likely fueled by real and perceived threats on both sides to life, land and property. As they had done, with limited success, with the farming communities in East Texas (Ricklis 1996:126), the Spanish attempted to use missions as a method to convert the Native Americans to Catholicism, and, hopefully, to Spanish dominance. The first near-coast Spanish mission, Nuestra Señora del Espíritu Santo, begun in 1722, originally occupied near the old Fort Saint Louis, which had been rebuilt by the Spanish. This mission later relocated with the presidio to the Guadalupe River valley near what is now Victoria, in 1726, and then to Goliad in 1749. Nuestra Señora del Rosario was established in the mid-1700s, again to convert the coastal indigenous population near La Bahía and to exert Spanish control over the coast. Again, the mission met with little success in converting the Karankawa groups who abandoned the mission by the 1780s (Ricklis 1996:150). Nuestra Señora del Refugio mission was established in 1795 as a final attempt at assimilation of the native population and met with some success with conversions to Christianity. During this time, the Karankawa agree to a treaty with the Spanish that was the start of 40 years of peace (Ricklis 1996:152-153).

European colonization of the eighteenth century changed the demographics of the indigenous populations everywhere across the continent. In coastal Texas, Karankawa populations began to decline, largely due to the introduction of new diseases, and began to merge with interior populations displaced to the coast by southward expanding Apaches and Comanches. Ricklis (1996:139; Figure 26) identifies a period of several decades after 1685 that saw a seventy percent reduction in Karankawa population followed by a period of relative stability until the early nineteenth century when Anglo-Americans began receiving land grants on the coastal prairies near traditional Karankawa territory. The Karankawa population declined again until around 1840 when numbers dwindled to less than 100 (Ricklis 1996:140; Table10). Remaining survivors then likely moved south into Mexico and merged with other groups (Newcomb 1983).

The French and Spanish accounts of indigenous populations prior to and during colonization provide information on group size, camp locations, and subsistence strategies that support the findings in the archeological record of pre-contact sites. Both suggest a pattern of large groups camping on the shores during winter and spring, then dispersal inland in smaller groups to the prairie for hunting during summer and fall. These subsistence and land use strategies are summarized in greater detail in Chapter 7. 


\title{
Chapter 4: Field and Laboratory Methods
}

\author{
Barbara M. Meissner
}

The methods for recording archeological deposits exposed during construction were determined by TxDOT. TxDOT was primarily concerned with avoiding or carefully monitoring impacts to any human interments. The methods for excavating any burial located were determined at the beginning of the project and did not change. The recording of artifacts and features seen during monitoring in the construction trenches changed during the course of the project, and the changes will be detailed below.

\section{Provenience Control}

For a number of reasons, providing for provenience control during this project was very difficult. In addition to the overall size and topographic layout of the site, the fact that heavy equipment would be rolling over virtually every part of the ROW within the site boundary made setting a single datum impossible. From the beginning, in 2000, Cindy Tennis, who was the Project Archeologist at the time, designated the center line of the new road as the horizontal datum. This line, carefully surveyed by the construction subcontractor, Haas-Anderson Inc., was marked every 20 meters either by paint on the paved areas or by labeled stakes on open ground. It extended from one end of the project, at the intersection with the access road on the north side of State Highway 358, to the center of the intersection with Ocean Drive, following Ennis Joslin roughly north and south. Another centerline ran the extent of the project on Ocean Drive running roughly east and west. The centerline was frequently re-surveyed, whenever the wear-and-tear of construction activities made the pavement marking illegible or the stakes were damaged or removed by vandals. The road centerline provided us with secure horizontal provenience that would remain the same throughout the project, and could be reconstructed in the future by knowing that the inner edge of the curb on the new road was $11 \mathrm{~m}$ from the centerline. Any given point along the centerline could easily be identified by measuring from the nearest known identified point. The provenience of any given location could thus be described as a certain distance, in a given cardinal direction, from the centerline at a specific point along that line. Thus a point might be described as being 11.63 meters east of the centerline at station $33+579.51$ on the Ennis Joslin centerline, or $23.2 \mathrm{~m}$ north at station $3+425$ on the Ocean Dr. centerline. While this method ideally had the potential to measure accurately to the nearest centimeter, in practice, getting the exact location from the centerline could sometime be difficult and, not infrequently, dangerous, due to the extremely heavy traffic. For ordinary purposes, then, distance from the centerline was measured from the edge of the trench. Only for very important findings, such as the six human burials, was the distance from the centerline measured directly.

In the field, horizontal provenience was determined by depth below ground (bgs) or road surface (brs), with notes made whether this was the surface of the old road or the new road. The ground and road surfaces were mapped both before and after the new road surface was completed, so that an estimate of the elevation of any given point on the surface could be made.

\section{Monitoring Trench Excavations}

Throughout the project, TxDOT was meticulous in notifying CAR when construction activities that would break the ground surface were planned. TxDOT officials made it very clear to all subcontractors working at the site that they were to follow instructions from the monitors, when, for instance, monitors requested that an activity be stopped so that the monitor could take a closer look at the walls or bottom of a trench or record a feature.

In order to allow time to deal with any human burials or important cultural materials that might have been found during construction, most of the utility trenches were excavated well before, sometimes months or even years before, the plans called for actual placement of utilities in the trench. Trenches were, for the most part, dug with a Gradall, at a rate of roughly $2-3 \mathrm{~cm}$ at a time, in sections roughly $3.5 \mathrm{~m}$ long. Most of the long trenches that ran parallel to the road were either 1 or 3 meters wide. A backhoe was used when the trench was to be less than 1 meter wide, or when the compacted road base was particularly dense and difficult to break up. A large track hoe with a $2.4 \mathrm{~m}$ bucket was used to re-dig trenches that had already been cleared. For safety reasons, once trenches were cleared they were backfilled, either at the end of the day, or when a section was completed, depending on the location of the trench.

In general, the trenches were dug to the depth of the utility grade plus about $10 \mathrm{~cm}$ or to the top of the Pleistocene Beaumont Clay Formation (see Chapter 2), which ever came first. The TXDOT superintendent and/or the foreman for the subcontractor provided both the location of the trenches and the depth of the utility grade at various locations. The depth of the trenches varied from about $50 \mathrm{~cm}$ to as much as $3 \mathrm{~m}$. When trenches extended below the OSHA safety standards, 
CAR personnel did not enter unless the walls of the trench were stepped down on each side until the lowest part of the trench was shallow enough to meet the safety standards (Figure 4-1). In some cases profiles of the lower reaches of a deep trench were drawn by standing in the partially excavated next segment of the trench when it was no deeper than OSHA safety standards and measuring deeper soil changes from that point.

CAR monitors were always present when the ground surface was penetrated. Monitors stood as close as was safe to the edge of the trench in a location that allowed as much of a view of the bottom of the trench as possible (Figure 4-2). The long trenches were not always dug in a continuous way, particularly on the east side of Ennis Joslin. Due to various exigencies inherent in the attempt to completely rebuild a road while it

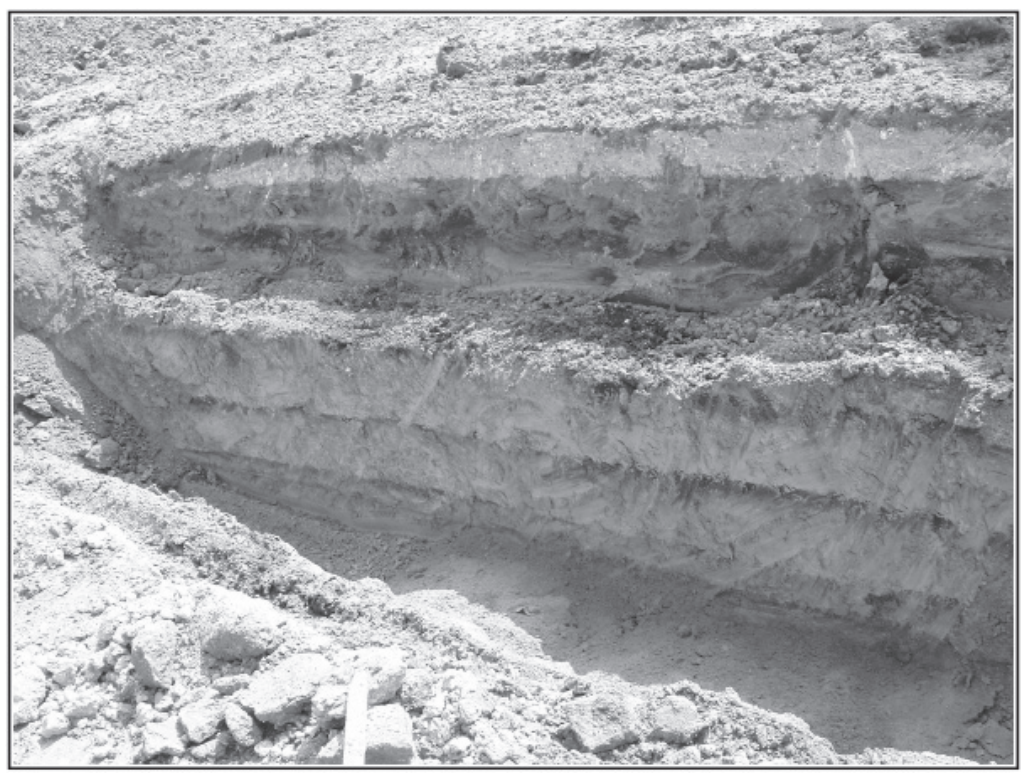

Figure 4-1. Trench with sides stepped down to allow CAR monitors to enter safely. was still being heavily used, and without blocking the many residents from their driveways, the trenches were often dug in sections of various lengths. Beginning in May 2003, a "trench map" was created as the longer trenches were cleared, so that it was possible to keep track of what portions

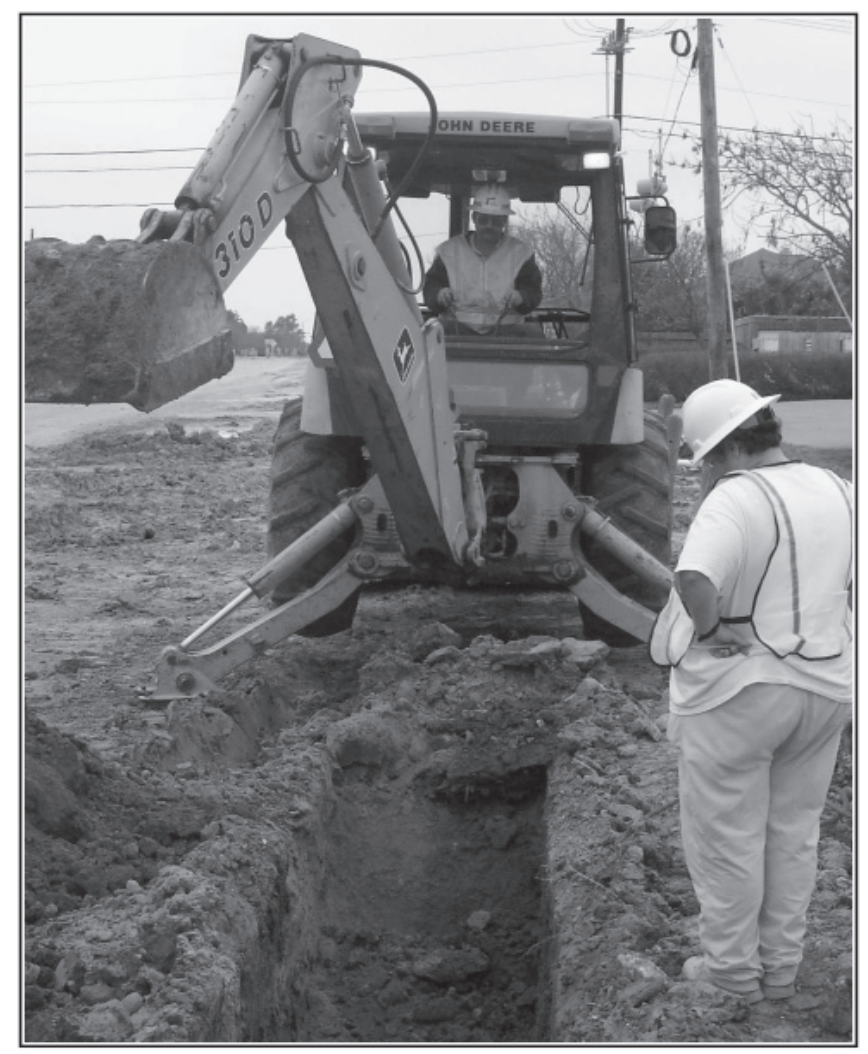

Figure 4-2. Monitoring trench excavation near the location where it is believed Jackson's 1933 excavations took place. Facing east. of each trench had been completed. Features were drawn to scale on the map, and location of buried utilities or isolated finds were noted. The trench maps also became invaluable as Trench I was dug next to Trench B, allowing correlation of partial features and Occupation Zones (OZs) across the trenches (see Chapter 6).

During Phase III (see below), when trenches were dug and utilities placed immediately, and when long stretches of road bed were being graded, special attention was given to avoiding anything that would slow the progress of the construction. For instance, profiles, when needed, were sometimes drawn while the subcontractor's workers were away at lunch.

\section{Recording Features}

\section{Phase I: August 15 to October 3, 2000}

The original methods requested by TxDOT for monitoring the trench excavations, recording features, and the excavation and collection of any human remains encountered were discussed in mid-August 2000, the day before the excavations of the first trenches were to begin. At that time, the intention was to clear the entire ROW not yet paved (C. Tennis, Field Notes, 8/14/00), leaving only the sediments under the road itself to clear later. Nancy Kenmotsu, the representative of the Environmental Affairs Division of TxDOT, in meeting with the Project Archeologist and Dr. Robert Hard, at that time Director of CAR and Principal Investigator, stated the following requirements for CAR staff working at the site: 
1. All TxDOT safety regulations were to be followed. All federal Occupation Safety and Health Administration (OSHA) regulations were to be followed.

2. As the project had the potential to encounter human burials, and possibly many human burials, and given the sensitivity of the situation if that were to occur, it was imperative that dissemination of information to the public and press flow through TxDOT. All questions from the news media and the general public regarding human burials were to be passed to the person at the Corpus Christi TxDOT District responsible for public relations.

3. The protocol in the event that a human burial was encountered was as follows:

a. The Project Archeologist was to call the TxDOT superintendent of the project and inform him of the situation. All work in the immediate area of the burial was to cease immediately and the area should be closed off with barricades, if it was deemed necessary. In any case, an attempt should be made to keep the sight of the burial from all but authorized personnel.

b. The Project Archeologist, and/or physical anthropologist on the site should clear enough of the bone to determine if it was human, or was likely to be human, and if so, to estimate how likely it was that the burial was intact as well as the position of the stillburied portions of the remains.

c. The Project Archeologist would then call the head of the TxDOT District Office in Corpus Christi, and the Director of CAR with this information. A discussion of the particular situation would then be initiated between the Director of CAR and TxDOTENV offices in Austin.

d. Once a protocol for dealing with the specific situation had been worked out, the Project Archeologist would make whatever arrangements were necessary to complete the excavation of the burial, being sure to keep the TxDOT District Office and the TxDOTENV office informed of progress. If it was necessary to leave the burial overnight, arrangements were to be made to protected it to insure that it could not be vandalized (i.e., hiring off-duty police as guards).

e. The human remains were to be excavated as quickly as possible while maintaining professional archeological standards of data retrieval. When removed, the bones were to be protected from any possible damage and returned to the CAR laboratory as soon as possible.

4. The protocol for recording non-burial features was as follows:

a. The feature was to be exposed, photographed, drawn, and mapped. A sample of the fill was to be excavated in a $1 \times 1 \mathrm{~m}$ unit. All material from this excavation was to be screened through $1 / 4 "(0.64 \mathrm{~cm})$ hardware cloth and all cultural materials, including vertebrate and invertebrate fauna, was to be collected, and returned to the CAR lab for processing and analysis. If the feature was very large, more than one excavation unit would be opened.

b. A bulk soil sample would be taken of each feature.

5 . The trench wall would be profiled every $5 \mathrm{~m}$ and an attempt made to tie features to the stratigraphy.

Excavations began on August 15, 2000 on the west side of Ennis Joslin at station $33+680$. A few days later, the project engineers informed TxDOT that the plan to excavate and backfill everything within the ROW would leave the walls of the undisturbed sediments beneath the pavement unsupported, and would make the road very susceptible to collapse. TxDOT informed CAR that only the actual utility trenches would be excavated from this point forward.

Shortly after the work began, in an attempt to allow a faster pace of excavation, it was decided that only concentrations of shell or animal bone that included charcoal were to be defined as features. The following designations and treatment protocols were to be used during the monitoring:

1. A feature was defined as a dense concentration of shell and/or animal bone that contained charcoal. Features identified were to be hand-excavated in $10 \mathrm{~cm}$ levels, screened through 1/4" $(0.64 \mathrm{~cm})$ mesh, and soil samples were to be collected for floatation. Feature forms were to be completed detailing provenience, contents, context, and size. A profile of the trench wall adjacent to the feature was to be drawn. Photographs were taken, and drawings made when appropriate.

2. A concentration was defined as a deposit of shell and/ or animal bone that was less dense than a feature and did not contain charcoal. Concentrations were to be handexcavated, but not screened. Provenience information and a brief description of the concentration and its context were to be recorded in the field notes and collection-bag $\log$. Soil samples were to be collected for humate dating and/or floatation. Photographs were to be taken, and drawings made when appropriate.

3. A scatter was a collection of shell and/or animal bone that was not in a concentration or was reasonably defuse. Provenience information and a brief description of the scatter and its contents were to be recorded in the field notes and collection-bag log. Samples of the scattered shell or bone and soil samples for flotation were to be collected if considered appropriate. 
At the end of the period, in early October, a total of 16 features had been excavated and notes and soil samples taken from a few "concentrations" and "scatters" but these were a very small part of the total volume of material returned to the CAR Lab.

On October 3, 2000, after a large water main that did not appear on city utility maps was broken during excavation near the southern end of the site, TxDOT decided to halt archeological monitoring until plans could be made to deal with the fact that utility maps were not accurate. In the mean time, TxDOT planned to concentrate on the southern part of Spur 3, near Highway 358, far outside the site limits.

\section{Phase II: October 15, 2001 to April 23, 2003}

After a year, CAR was once more called to $41 \mathrm{NU} 2$ to monitor ground disturbing construction at the site. Traffic was to be diverted to a temporary bypass built to the west of Ennis Joslin and the west lane, so that the east lane could be closed for construction. Later, the west lane was closed and traffic moved onto the two new lanes on the east side of Ennis Joslin while construction of the two west lanes was completed. During this phase, the protocol for recording nonburial cultural materials again was changed. Since almost all the sediments to be excavated at this time were believed to be previously disturbed, consisting largely of fill over old utility trenches, only notes were to be taken if cultural materials were observed in undisturbed sediments, as these areas would be disturbed again in a later phase and could be examined closely at that time.

During this roughly 18 month period, work was intermittent, running two or three weeks at a time to as little as a few hours with long gaps between. CAR monitored the following activities:

Utility Location. A large number of small trenches or pits, were dug to locate and map the location of utilities, especially lines making connection to the many houses and commercial buildings lining the roadway. These excavations almost exclusively dug into previously disturbed sediments.

Utility Relocation. In several locations, especially along the west side of Ennis Joslin south of the intersection with Alameda Street, existing utilities had to be temporarily relocated to the west so that a temporary one-lane bypass could be constructed. Most of this activity was at the center of the site, where the Beaumont clay was very near or at the surface, however, monitoring was still performed.

Road Grading. During this phase only the area intended for the bypass lane mentioned above was graded.
During the grading, a monitor walked behind the maintainer, closely observing the newly scraped ground surface. Later in the project, large areas of previously undisturbed sediments were graded. However, during this phase, the grading was exclusively over either previously disturbed sediments or undisturbed Beaumont clay.

Traffic Island Removal. The complex intersection of Ennis Joslin and Alameda Street was controlled by a series of traffic islands. To create the bypass, these islands had to be removed. Monitors were present during this process, in case previously undisturbed sediments would be impacted.

Clearing Trenches for Future Utility Placement. Although most of the monitoring during Phase II consisted of the activities listed above, four trench laterals that crossed Ennis Joslin between Alameda Street and the southern end of the site, were monitored in advance of utility placement with all four completed on one Saturday, when traffic disruption was minimal.

\section{Phase III: April 24,2003-November 3, 2006}

Shortly before Phase III began, in a meeting with TXDOT officials, CAR staff were told that the protocol for recording features and cultural deposits was to be changed. The changes to the protocol, which did not apply to human burials, were as follows:

1. Features would no longer be excavated, nor would any sediments be screened in the field except during investigation of burials.

2. Features should be recorded as quickly as possible. The surface of a feature was to be cleaned enough to estimate size and composition. Scale drawings of the feature would be done only if it was very unusual, and should only be done in a fashion that would not delay the progress of construction. Photographs could be taken and should be the major form of documentation of the feature. Feature forms were to be filled out using estimates when exact measurements could not be determined. Soil samples could be taken if deemed necessary.

3. With the exception of temporally diagnostic tools, collection of artifacts and faunal remains should be minimal and should not impede the progress of construction.

4. Any bone observed during excavation, whether in a feature or as an isolated find, was to be carefully excavated by hand and examined to determine if it could be human.

5. Profiles of trench walls would no longer be drawn at 5 meter intervals. The Project Archeologist should determine when a profile was needed, but the number of profiles should be kept to a minimum, and be 
accomplished as quickly as possible, making every effort not to slow construction.

Monitoring activities during Phase III included:

Trench Monitoring: During this phase, twenty trenches (including a re-alignment of the southern end of Trench B) were dug, and most were then re-dug during utility placement. Though most trenches had been previously cleared, the re-excavation and utility placement was monitored because of the possibility that either reexcavation or the extension of a trench to allow building of a manhole box would encounter a burial in previously undisturbed sediments.

Utility Removal. Once the new utilities were in place, old utilities were removed. This required excavation of a narrow trench with a backhoe to the level of the old utility lines. After the old lines were removed, the monitor occasionally observed areas of undisturbed sediments. These areas were profiled before the trenches were backfilled. In two instances, during the re-excavation of old utility trenches the monitor observed disturbed human remains (e. g. Burials 3 and 5) in the trench fill. As soon as this occurred, the protocol regarding human burials was implemented both in terms of notification procedures and excavation methods.

Monitoring New Road Grading. Old roadbed was removed and sediments were removed to the new sub-grade. The depth of the new grade cut into previously undisturbed sediments from $0 \mathrm{~cm}$ to approximately $35 \mathrm{~cm}$. CAR archeologists monitored this grading by following the maintainer and noting presence of cultural debris. All observed bone was excavated by hand. When identifiable features or occupation zones were located, the work was stopped as briefly as possible so that notes and measurements could be taken. Otherwise, grading was allowed to proceed under careful observation. Once the new grading had been completed, approximately 30 $\mathrm{cm}$ of caliche and gravel road base was laid for the new road, except in areas where utility work and manholes had not been completed. Grading also occurred in the traffic islands north of the intersection of Ennis Joslin and Alameda Street. Sediments were removed to a depth slightly below the adjacent new road surface, and then backfilled with a gravel and caliche mix. The work was done primarily with a maintainer, with some use of a backhoe in the narrow islands to the north of the intersection. No undisturbed sediments were observed during the island grading.

Bases for Street Light and Utility Poles. Though most of these bases were dug during Phase V (see below), a few were dug while CAR was present during Phase III. The holes for the pole bases were either $0.60 \mathrm{~m}(2 ")$ or
$0.90 \mathrm{~m}\left(3^{\prime}\right)$ in diameter and were dug with an auger to a depth of $1.8 \mathrm{~m}\left(6^{\prime}\right)$. Monitors watched this process closely.

Electrical Trenches. Electrical trenches, for laying conduit to connect streetlights and lights in planted areas of the intersection of Ocean Drive and Ennis Joslin, were dug the length of the project area on both sides. With very few exceptions, these trenches were dug into the stabilized sand and gravel that was used to backfill the utility trenches. Monitors observed this digging when the trenches crossed areas that had not been previously undisturbed. All trenches were roughly $0.3 \mathrm{~m}$ (1') deep.

A total of 164 features, 11 occupation zones, and six burials were encountered during the first three phases of this monitoring project. Chapter 6 summarizes the features and occupation zones and the information they provide regarding patterns of site occupation.

\section{Phase IV: February 2006}

For three days in early February 2006, a CAR archeologist returned to $41 \mathrm{NU} 2$ to monitor the digging of holes for the planting of large palm trees, in the new traffic islands. These holes were dug with augurs to a depth of roughly $1.2 \mathrm{~m}$. The backdirt from the augurs, and as much of the profile as could be seen, was observed. No features or burials were encountered.

\section{Phase V (SWCA): March 8-April 24, 2006}

After field work by CAR had been completed, TxDOT contracted with SWCA Environmental Consultants, Inc., to monitor excavations of 48 street light pole bases and three shallow trenches for more electrical conduits. With only occasional exceptions, the digging during this project was in sediments already disturbed by the construction monitored by CAR. TxDOT requested that features be designated only if they were considered significant. Three small concentrations of shell and animal bones were observed but were not considered significant. Nothing was collected from the site.

\section{Excavating Human Burials}

Whenever human remains were encountered, CAR notified the Project Superintendent and the Director of CAR immediately. The CAR Director in turn notified the TxDOT Environmental Affairs Division in Austin, as required by the established protocol. After an assessment of the nature and context of the remains, CAR was given instructions on how to proceed in each case. Specific excavation details and 
circumstances are described in the discussion of the individual interments in Chapter 5. Once excavated, all human remains were returned immediately to the CAR laboratory at The University of Texas at San Antonio where the remains were cleaned and cataloged. During their processing, all remains were kept in a processing facility with limited access. The analysis of the human remains excavated by Ricklis (1997) and reported by Mahoney and Shafer (2003) was integrated into the summary of the human remains recovered by CAR.

\section{Laboratory Methods}

The collection from 41NU2 consists largely of samples of feature matrix. With some exceptions, artifacts were not collected. All the cultural materials that were collected were returned to the Center for Archaeological Research. Initial processing of recovered artifacts prior to special analyses consisted of washing, sorting, counting and/or weighing, and storing in archival-quality bags with provenience noted on acid-free paper tags in each bag. Specific analytical methods for special analyses are described in the Appendixes of special reports and under chapters addressing faunal and skeletal analysis.

All artifacts and faunal remains recovered during Phase I of the monitoring project were returned to the CAR laboratory for processing and analysis (Meissner 2000). All soil samples from features were floated, and the light and heavy fractions were dried. The light fractions were sent for macrobotanical analysis. Artifacts and faunal remains extracted from the heavy fraction were processed and analyzed. The results of the artifact analyses are presented in Chapter 5.

\section{Curation}

All cultural materials along with documents generated during field work including the field notes, forms, and photographs were processed for long term curation as directed by guidelines set forth by the Texas Archeological Research Laboratory where this collection is permanently curated. Human skeletal remains also were transferred to TARL. 


\section{Chapter 5: Results of Monitoring}

\author{
Barbara M. Meissner
}

Twenty-one major trenches, and several smaller trenches, were dug during this project. We collected data on 164 features exposed in these trenches, identified 11 occupation zones, recovered seven human burials, and collected 125 artifacts. Fifty-eight radiocarbon dates were obtained during the project, including 12 humate dates associated with coring activities, and 46 dates on charcoal, organic material, and shell associated with features or occupation zones. This chapter describes the trenches, the human burials, and the small collection of artifacts. The subsequent chapter provides information on feature associated radiocarbon dates, features, and the 11 occupation zones identified.

\section{Monitoring Overview}

It is a truism that archeologists often feel as if they spend all their time in the field writing notes and taking picturesonly to complain later, when they return to the lab to write up the project, that they did not take enough notes and pictures. This was certainly true in this case. When this project began, no one expected it to last as long as it did or for the site to be as complex as it was. This chapter is based on notes and photos taken by a number of people over a period of seven years, during which the period of intense daily activity lasted two and a half years. There were two primary Project Archeologists (PAs) during the project, Cynthia L. Tennis during Phase I, and Barbara A. Meissner for the remainder of the project. In addition, over the course of the project there were short periods of time when other qualified staff members of the CAR were required to fill in. These instances were infrequent and of brief duration.

Unfortunately, some data have been lost completely. On the night of May 12, 2004, the CAR vehicle, parked at the motel where CAR personnel were staying, was burglarized and a number of items, including tools and a camera, were stolen. A plastic case containing profiles, feature maps, and, most importantly, the field notebook containing notes on the project dating from March 26, 2003, to November 10, 2003, was taken. CAR notified the TxDOT Environmental Affairs Division of the event. Although this loss of data was disastrous, it could have been a great deal worse, as much of the data in the notebook was also listed on Feature forms, the Field Sack Log, and on the trench maps, all of which were not in the vehicle. Project photographs and the weekly reports also provide a source of backup information. Although detailed descriptions of daily activities between late March and early November, 2003, were lost, information on what cultural deposits were observed was recoverable from these other sources.

Between August 15, 2000, and November 3, 2005, CAR monitored construction activities associated with road and utility improvements in the right-of-way of Spur 3 within the site boundary of 41NU2. Major improvements included: 1) rebuilding and widening Ennis-Joslin; 2) ending Alameda Street at a T-intersection with Ennis-Joslin; 3) rebuilding the portion of Alameda Street that would now become Ennis Joslin; 4) simplifying the Ocean Drive/Ennis-Joslin intersection; and 5) replacing storm and sanitary sewers, water, and gas lines in the area and remove old utility lines. Monitoring of large tree plantings took place in February 2006. Monitoring of the placement of some additional street light footers and shallow trenches for electrical conduits that connected them was carried out by SWCA Environmental Consultants, Inc. The results of that project are included at the end of this chapter. And finally, once in June and again in August 2007, CAR staff was also present to help extract the soil cores used for a number of the special studies in this report. Detailed project maps, showing the location of all monitored excavations, including all new utility trenches, utility locations pits, and the pits dug to either place or remove manhole boxes are presented in Figures 5-1 through 5-5. The figures (5-1, 5-2 and 5-4) also show the locations of the three soil cores extracted by the project geomorphologist.

The understanding of the nature of the site, its geomorphology and site formation processes, evolved over time. In the early stages of the project, the complexity of the subsurface sediments was not entirely recognized. Similarly, the spatial relationship between the two dunes and the ridge of Pleistocene deltaic Beaumont Clay Formation (the Beaumont) was not entirely comprehended until sufficient numbers of trenches were excavated along the project ROW to allow us to piece together the spatially isolated pictures into a composite contiguous image. As a result, some of the information presented in this report differs from interpretations provided in the four interim reports (Meissner 2000, 2003, 2004, 2005) previously submitted to TxDOT-ENV. The differences are a natural product of the evolution of our understanding of the site and the landform upon which it sits.

Figure 5-6 shows a schematic profile of the site, looking west from the False Oso, showing the complex nature of the geomorphology. Note that the horizontal scale in Figure 5-6 is 20 times the vertical scale. This is necessary to present the 


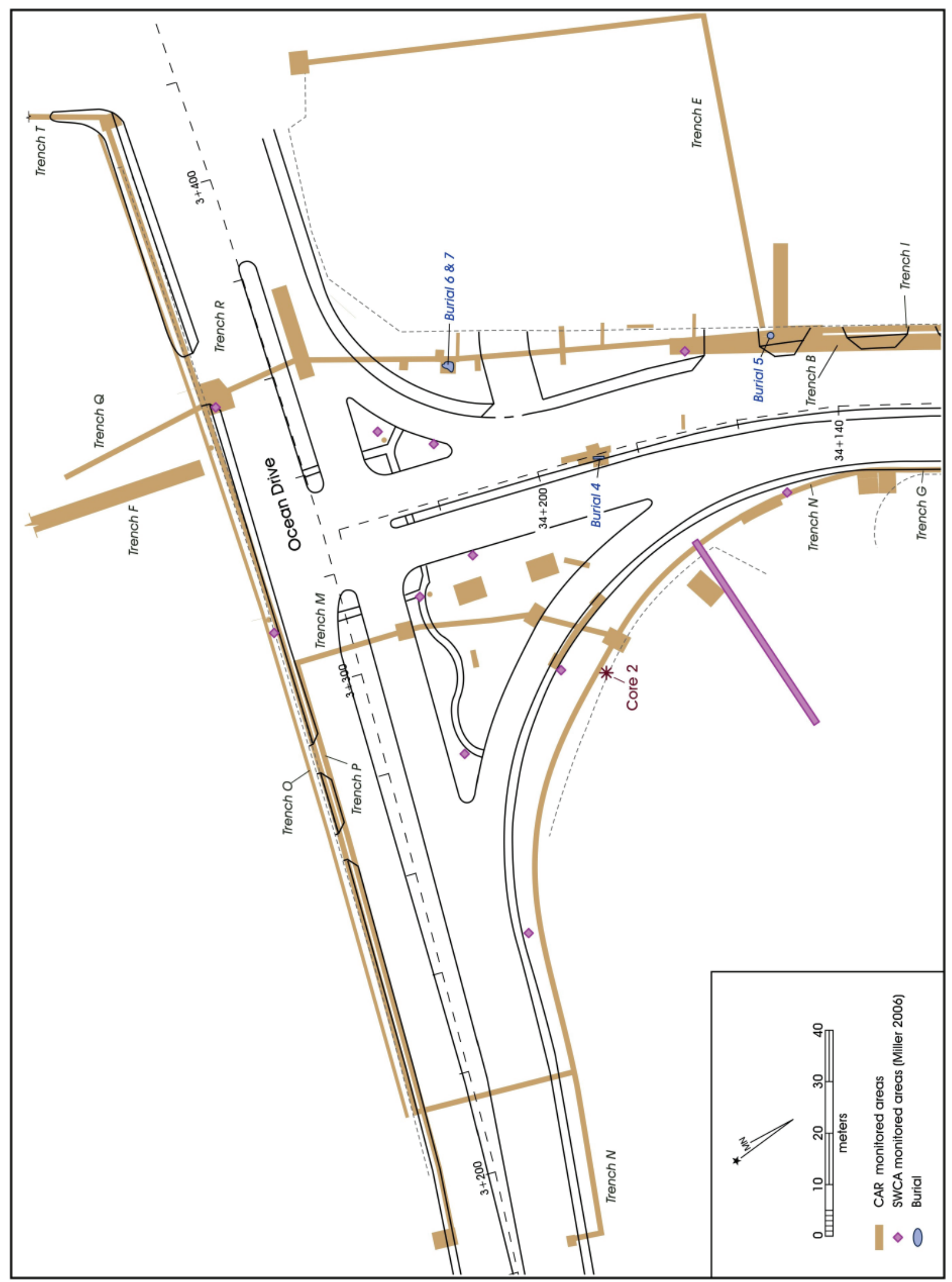

Figure 5-1. Detail of project map between 34+120 and 34+325 (including all work on Ocean Dr.) showing locations of all monitored excavations, burials, and sediment cores. 


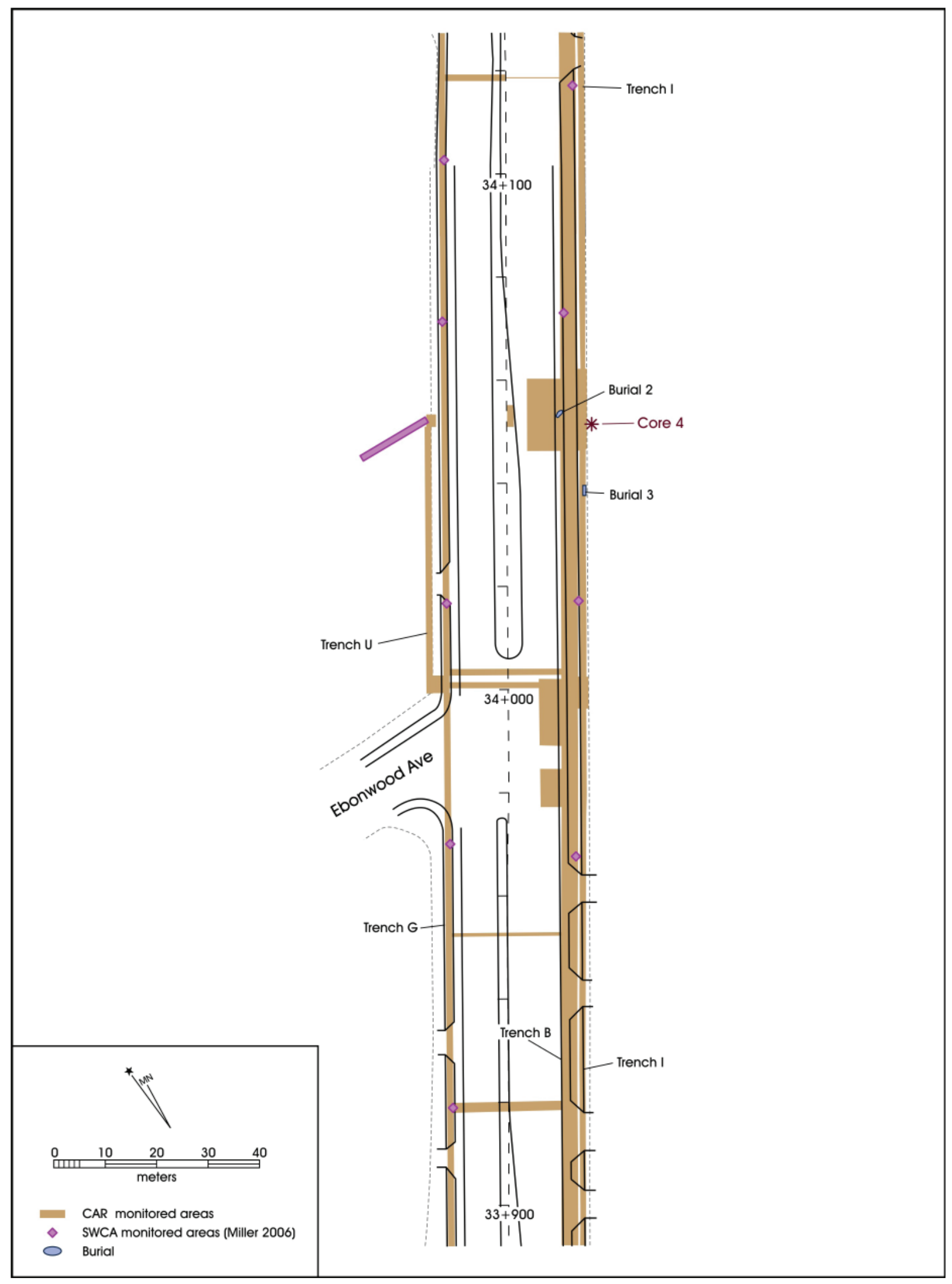

Figure 5-2. Detail of project map between 33+900 and 34+120, showing locations of all monitored excavations, burials and sediment cores. 


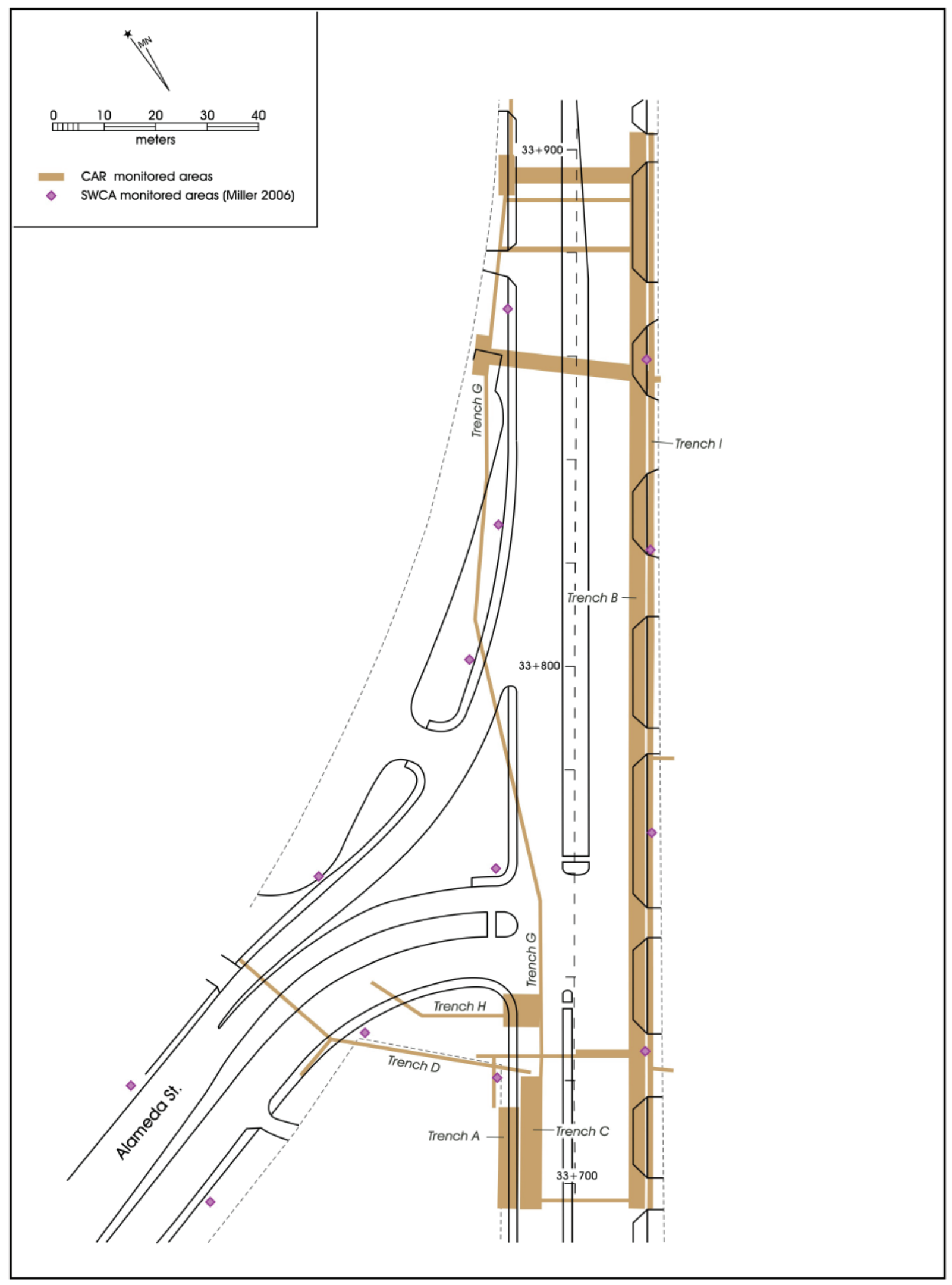

Figure 5-3. Detail of project map between $34+120$ and 33+700, showing locations of all monitored excavations. 


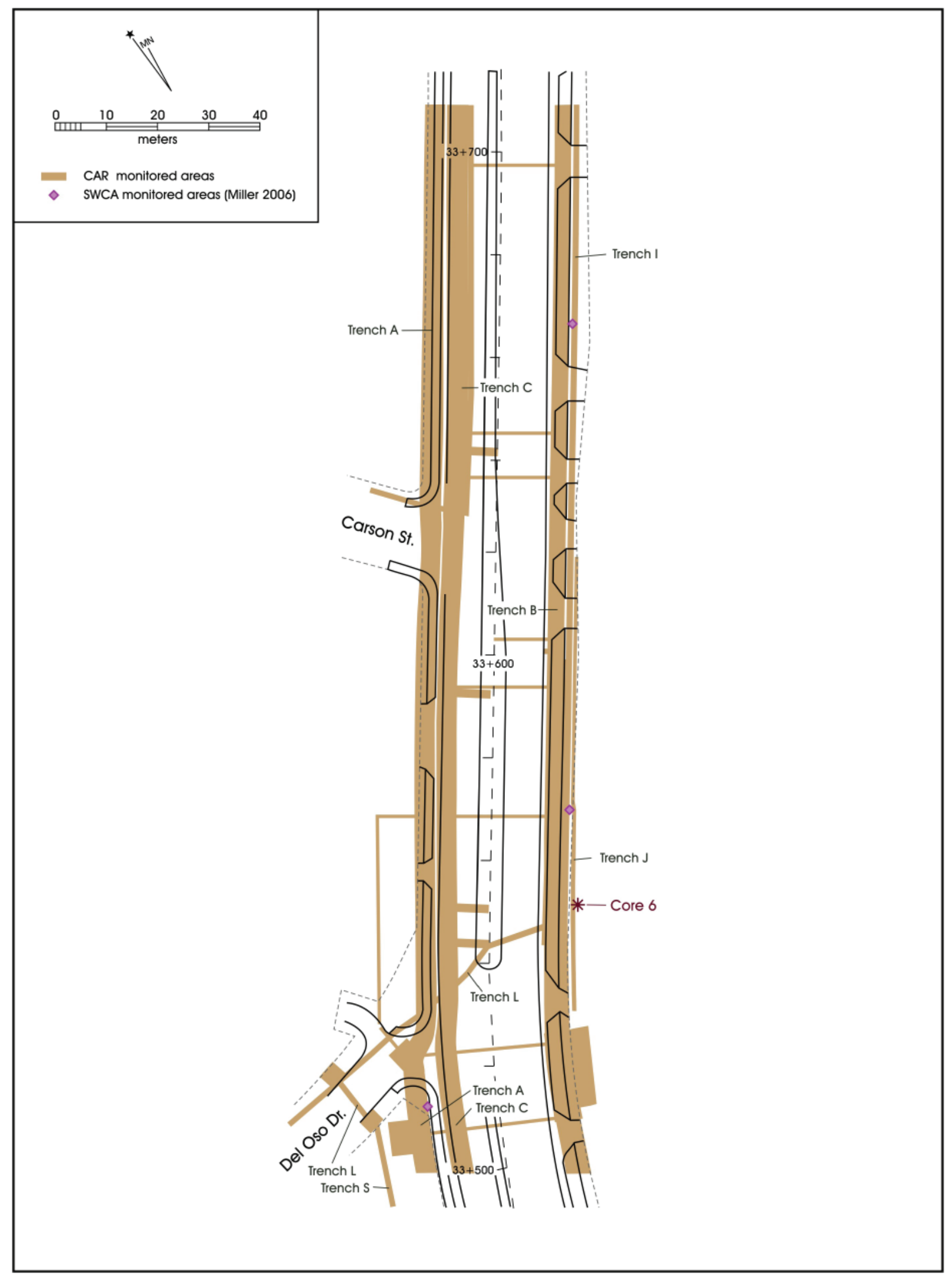

Figure 5-4. Detail of project map between $33+500$ and 33+700, showing locations of all monitored excavations and sediment cores. 


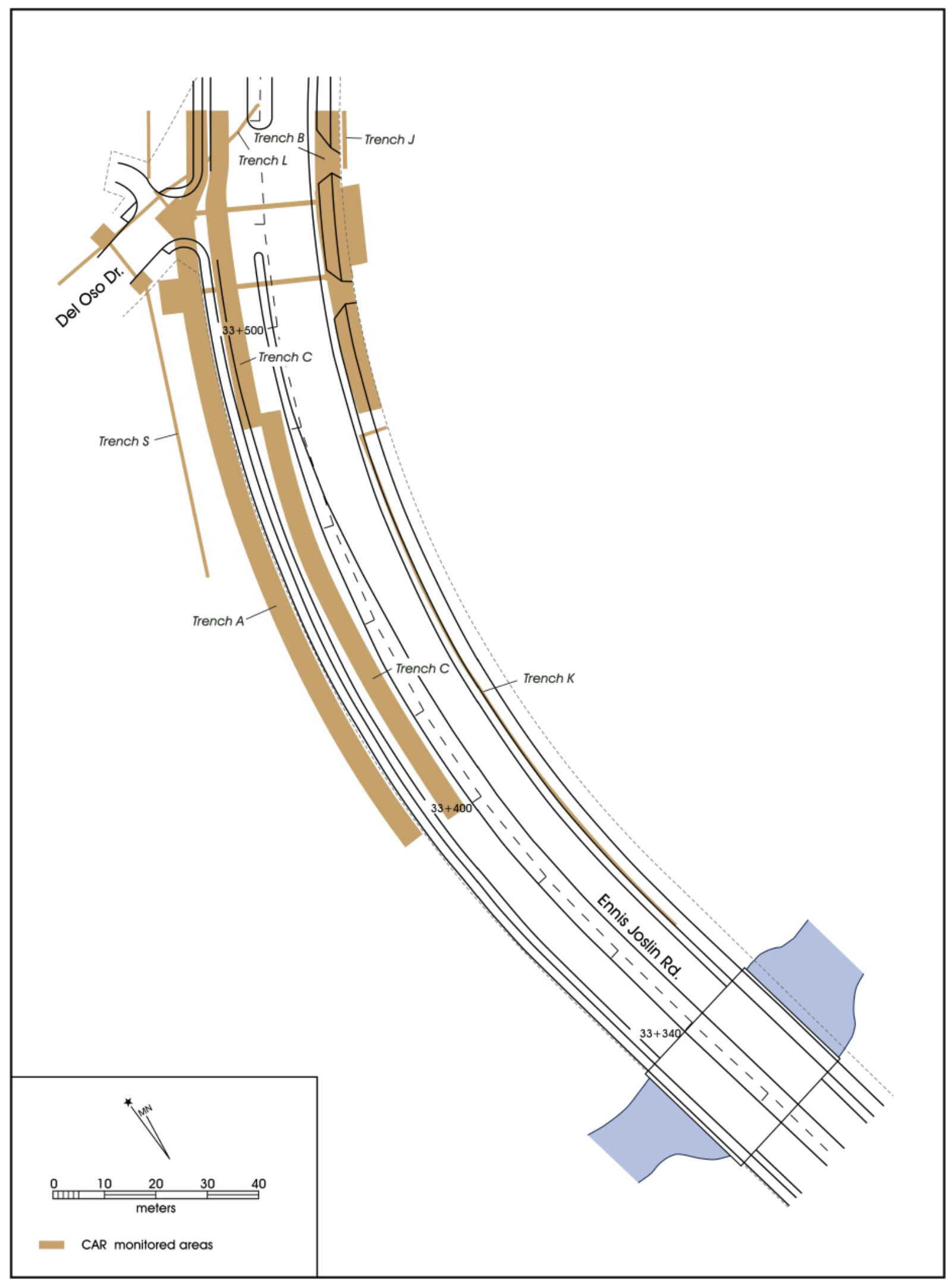

Figure 5-5. Detail of project map between $33+320$ and 33+500, showing locations of all monitored excavations. 


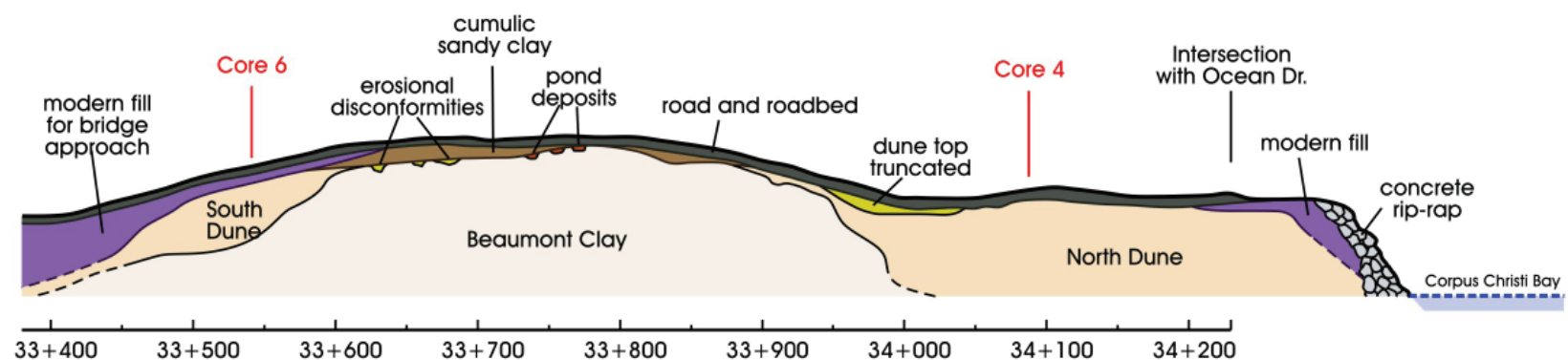

note - vertical exaggeration $20 x$

Figure 5-6. Schematic profile of NU2, looking west from the False Oso mudflats, showing the Beaumont Ridge with dune deposits to the north and south. Note that horizontal scale is 20 times the vertical scale, thus grossly overemphasizing elevation changes. Based on profiles of Trenches $B, I$, and $F$.

north/south extent of the site on a single page, but results in a gross overemphasis of elevation changes. Utility trenches and other modern disturbances are not shown, and the location of erosional channels and depressions filled with pond deposits on the Beaumont ridge are approximate.

Figure 5-7 is a schematic profile running east/west along Ocean Drive roughly $80 \mathrm{~m}$ south of the bluff above Corpus Christi Bay. Note that the ridge of Beaumont to the west and the adjacent North Dune forms part of the depression in which the large ephemeral pond seen in old maps and photographs of the site developed (e. g. Figure 5-8). No information is available to estimate how far the North and South Dunes extend to the west except at the northern-most part of the site.

Although other excavations were monitored during the project, trenches dug to place new utilities were considered the most likely places in which human burials or other important cultural remains could be encountered. Therefore, we begin the discussion of the findings of the monitoring with the descriptions of the trenches.

\section{Trenches}

\section{Trench A}

Trench A, was excavated entirely during Phase I of the project between August-October 2000. This trench, which was $4 \mathrm{~m}$ wide, was located on the west side of Ennis Joslin, beginning

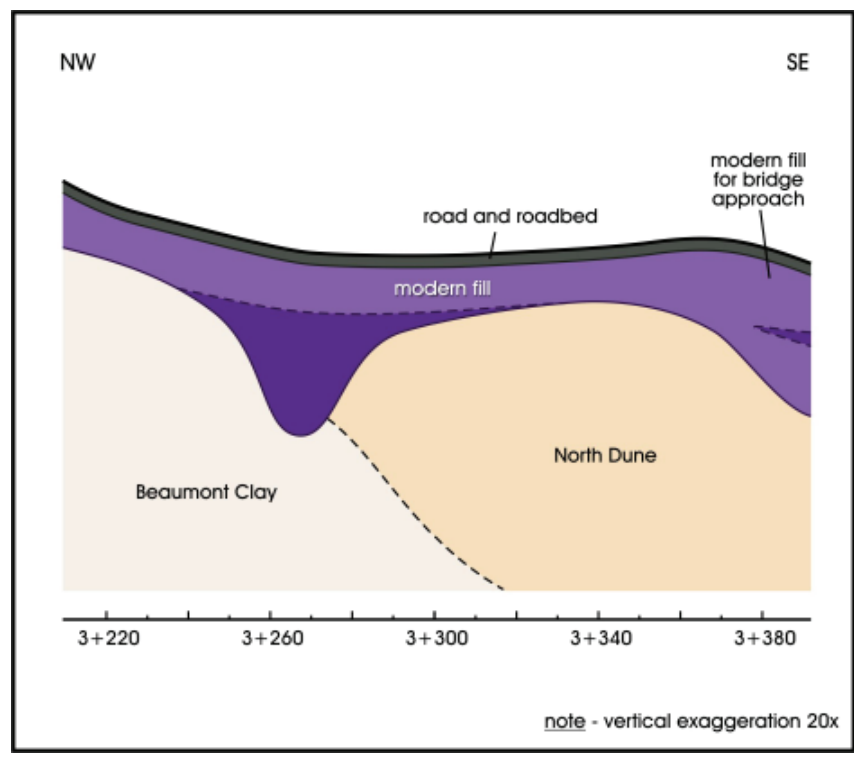

Figure 5-7. Schematic profile of the northern part of NU2, along Ocean Dr showing Beaumont clay ridge to west, the pond area, and the slope down to the False Oso, near its mouth at Corpus Christi Bay. Note that horizontal scale is 20 times the vertical scale, thus grossly overemphasizing elevation changes. Based on profiles in Trenches $M$ and $R$.

just south of the intersection with Alameda Street. The center of the trench was $12 \mathrm{~m}$ west of the project centerline (CL) at station $33+714$ (Figures 5-3 to 5-5). It continued south, with two interruptions, moving away from the CL, to $33+406$ (Figure 5-5). At that point, the center of the trench was roughly $18 \mathrm{~m}$ from the $\mathrm{CL}$. The trench varied in depth from $80 \mathrm{cmbs}$ to $260 \mathrm{cmbs}$. 


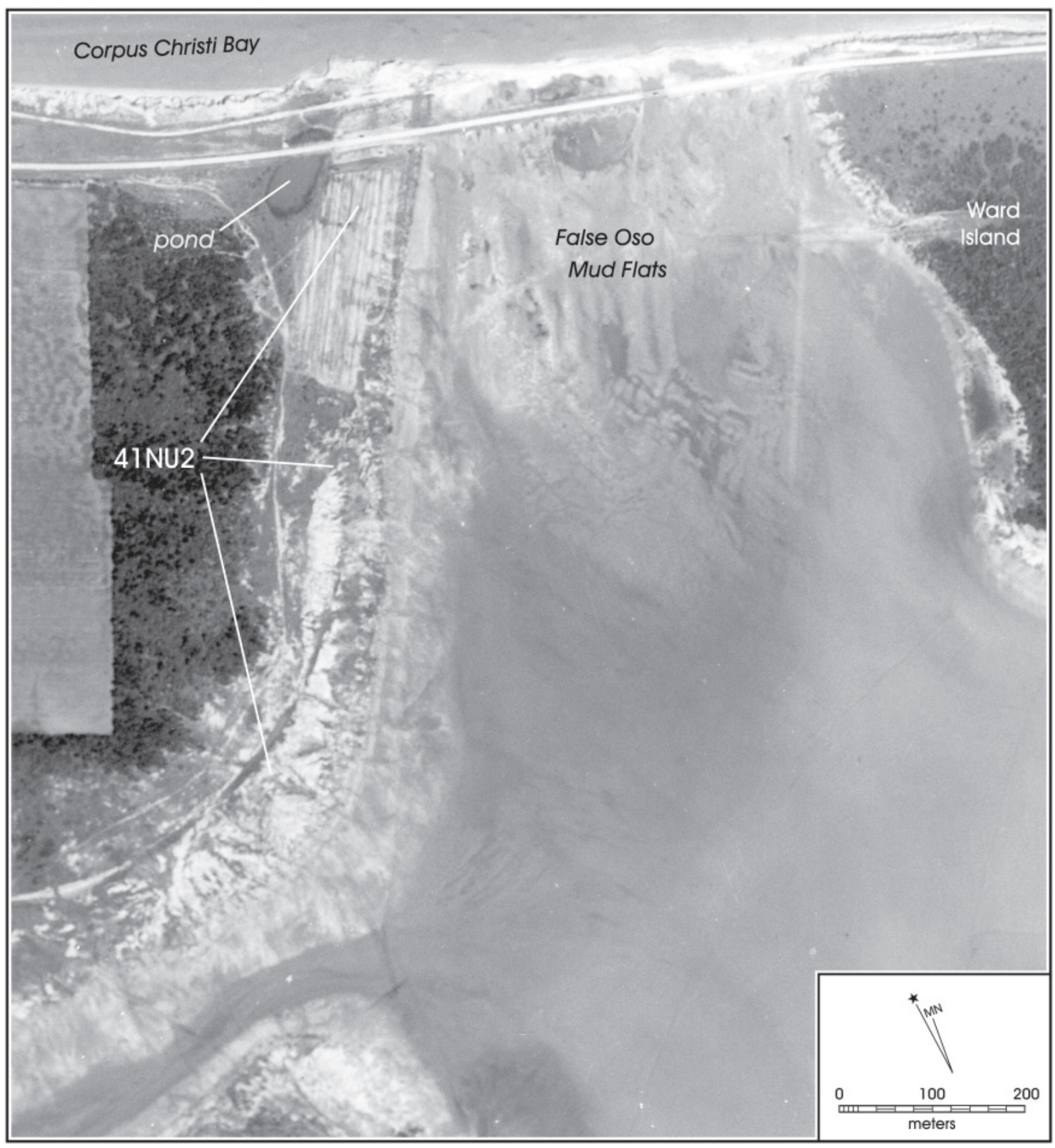

Figure 5-8. Aerial photograph of 41NU2 taken in 1936, showing $41 N U 2$ before urban development. Note the pond near Corpus Christi Bay.

Trench A provided the first view of the way in which the simple stratigraphy at the center of the site noted by Ricklis (1997:20-21,31) changed to the "striped" appearance typical of clay dune deposits (Huffman and Price 1949:118; Ricklis 1997:37; see also Figure 2-1). Profile 1 in Figure 5-9 shows a typical profile of the South Dune. Four paleosols are evident, separated by thick layers of light colored clay. Unfortunately, the exact location in Trench A at which the dune deposits end, replaced by the rising Beaumont Ridge, was destroyed by previous utility trenches.
As Trench A continued north (Profile 2 in Figure 5-9), the sediments become relatively shallow clay dune deposits sitting above the Beaumont clay, which has dropped about $50 \mathrm{~cm}$ in the $200 \mathrm{~m}$ between the two locations profiled. The banding of dark and light sediments is beginning to fade, and by the time Trench A reaches Profile 3 in Figure 5-9, near the center of the site, the strata have become much simplified, showing only a dark brown sandy or silty clay loam that has accumulated on top of the remnant of the Beaumont Clay Formation we are calling the Beaumont Ridge (see Chapter 2), with no sign 


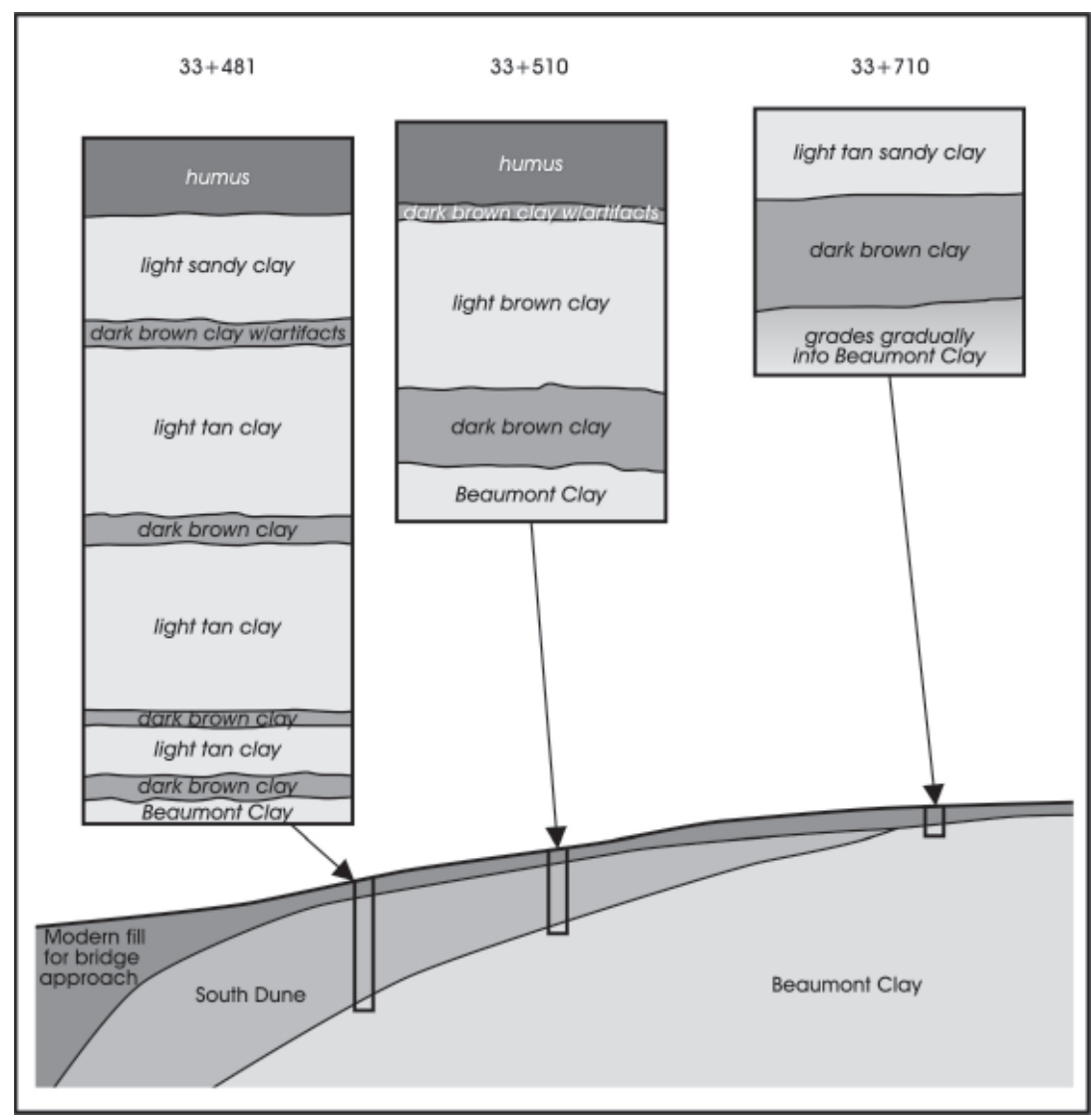

Figure 5-9. A schematic profile of the South Dune and Beaumont Ridge, looking west, showing profiles from Trench $A$ at three locations.

of dune deposits. In some areas near the highest point on the current landscape within the site boundaries, the Beaumont clay actually lies directly beneath the old road bed, presumably because the cumulic deposits were removed during the initial construction of Ennis Joslin and S. Alameda Street.

When completed, Trench A crossed two of the four subsurface zones of the site, the South Dune and the Beaumont Ridge (Figures 5-6 and 5-7). Nine features were recorded in this trench (Features 1-5, 7, and 9-11). Their locations can be seen in Figures 5-3 to 5-5.

\section{Trench B}

The first part of Trench B was excavated during Phase I (Figure $5-4)$. This section ran from $33+525$ north to $33+595$. The trench was $2.4 \mathrm{~m}$ wide with the center about $11.5 \mathrm{~m}$ east of the CL. During this early part of the excavation of Trench B, five features were encountered (Figure 5-4). Trench B was discontinued when TxDOT decided that there were too many existing utilities for which they had no maps. CAR's part of the Spur 3 project was put on hold while new plans for the monitoring methodology and the actual construction plans themselves were considered.
During Phase III, beginning in April 2003, the remainder of the trench was excavated. In the interim, some construction plans had been changed, resulting in a change in the location of Trench B to center at $12.0 \mathrm{~m}$ east of the CL, and widening the trench to $3 \mathrm{~m}$ (Figure 5-4). This required the re-excavation of part of the trench that had been dug in 2000. The depth of the sterile Beaumont varied a great deal on the east side of the road, as it did on the west, from immediately below the roadbed between about $33+720$ to $33+800$ to an unknown depth more than $240 \mathrm{~cm}$ below the ground surface in the areas south of $33+440$, and more than 3 $\mathrm{m}$ below the ground surface north of $34+003$ (Figure 5-6).

Excavation of Trench B provided a view of the subsurface of almost the entire site in a line, running roughly north and south, about 73 to $105 \mathrm{~m}$ west of the currently stabilized bluff above the False Oso mud flats. This resulted in a much better understanding of the structure of the site from south to north (Figure 5-6).

It was evident from Trench B that the remnant ridge of Beaumont clay, seen by Ricklis (1997) and also present in Trench A, had separate dune deposits built up on both the southern and northern faces as seen in Figure 5-6. Between about 33+600 and $33+880$ in Trench B, the top of the Beaumont clay is near the ground surface. Both south and north of this area, the upper surface of the Beaumont clay slopes down and is covered with Holocene clay dune deposits (Figure 5-6).

\section{Through the South Dune}

Figure 5-10 is a profile of the east wall of Trench B at 33+566567, about 5 m north of Ricklis' Test Unit 5 (Ricklis 1997:25). Examination of Ricklis' profile of Unit 5 (Ricklis 1997: 28) shows almost identical layers of dark and light sediment, although the uppermost paleosol is darker in Figure 5-10. Note that the lowest level in both profiles (Ricklis 1997:28 and Figure 5-10) appears to be a continuation of OZ-G, found in a $30 \mathrm{~cm}$ thick paleosol in Trench I (see Trench I section below). The top of this $30 \mathrm{~cm}$ paleosol was observed to drop from $80 \mathrm{~cm}$ bgs at $33+600$ to $110 \mathrm{~cm}$ bgs at $33+584$, where it could readily be seen to continue south, below the level of the trench bottom. It is not unreasonable, therefore to tentatively equate the lowest paleosol in Figure 5-10, whose top is at about $120 \mathrm{~cm} \mathrm{bgs,} \mathrm{whose} \mathrm{thickness} \mathrm{is} \mathrm{an} \mathrm{unusual} 30 \mathrm{~cm}$, 


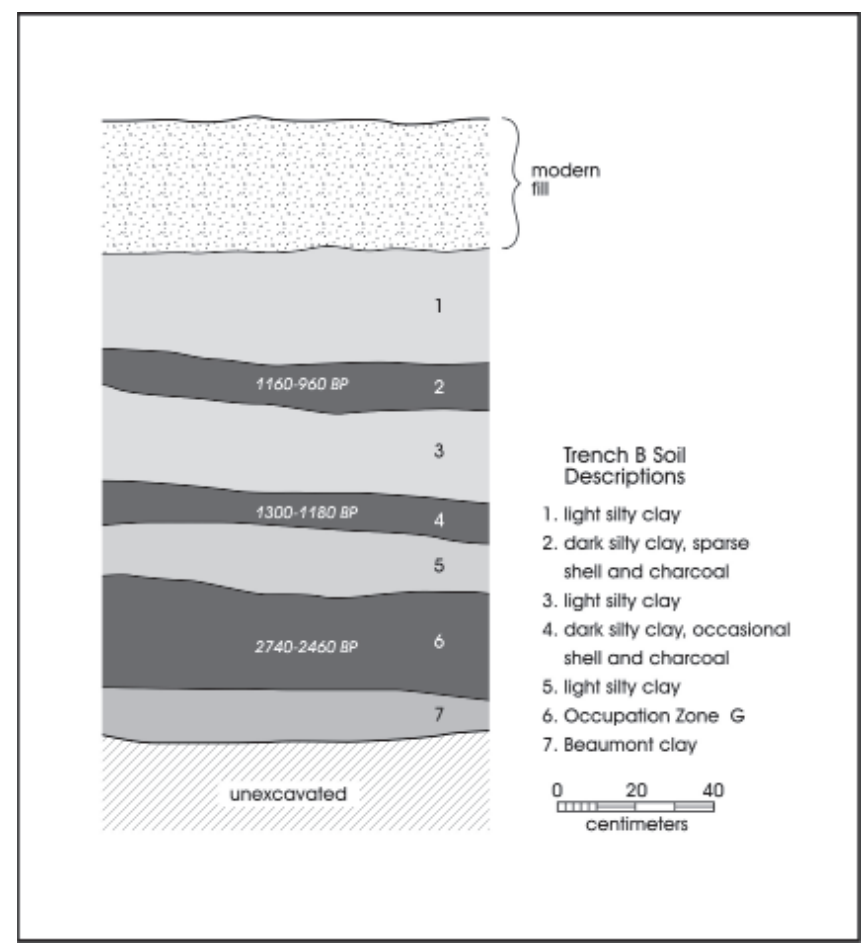

Figure 5-10. Profile of the east side of the South Dune in Trench $B$ at 33+566-567, showing estimated dates for three paleosols.

and which is full of cultural debris such as shell, charcoal, and burned clay, with OZ-G, as seen in Trench I. A detailed discussion of OZ-G is provided in Chapter 6.

\section{Through the Beaumont Ridge}

By about $33+605$, the thin remnants of OZ-G are lying directly on top of the Beaumont clay surface, beneath the dark brown cumulic sandy clay that overlies the Beaumont were there is no dune deposit. Because of unfortunately placed old utilities, this is the only place on the site where the upper edges of dune deposits can be observed in contact with the Beaumont clay.

On the east side of the site, between about $33+607$ and $33+980$, the Beaumont lies near the ground surface, with varying amounts of cumulic fine sandy clays above it. Naturally refilled erosional channels were seen most often in the Beaumont Ridge area (Figure 5-11).

For the most part, the dark sediments above the Beaumont, when present, were sterile of cultural remains except for an occasional shell. However, an occasional scatter of shell and charcoal or distinct feature was located, always lying either directly on or just above the Beaumont clay surface. The largest such feature, Feature 57, was located in both Trenches $\mathrm{B}$ and I at about $33+716$. This feature lay directly on top of the Beaumont clay. Another interesting feature, which will be discussed in Chapter 6 is Feature 54, a large pit hearth, was dug into the Beaumont clay.

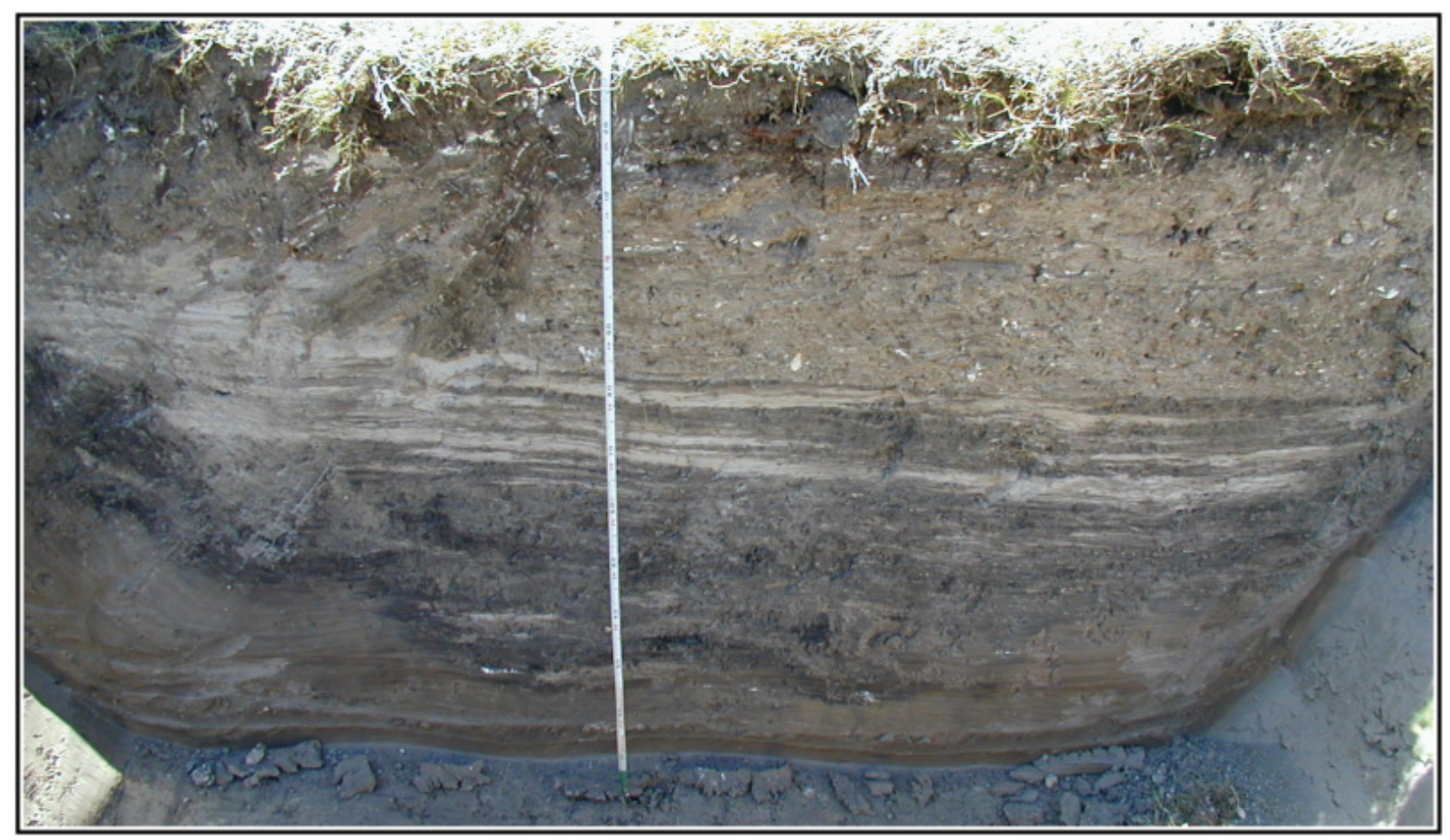

Figure 5-11. Photographs of Beaumont Ridge zone at 33+689, showing large, naturally refilled erosional channel. Note shell at bottom of erosional channel and modern fill above the natural laminated sand and clay fill. 


\section{Through the North Dune}

The top of the Beaumont clay began to drop in elevation around $33+800$ and by $33+920$ the edge of another series of dune deposits became noticeable. In a profile drawn of the west wall at 33+923-925 (Profile 1 in Figure $5-12)$, the early indications of the North Dune are becoming apparent, and the north wall of a lateral immediately west of Trench B at 33+985 (Profile 2 in Figure 5-12) shows the increasing complexity of the dune deposits and the increasing depth of the Beaumont clay.

Only $11 \mathrm{~m}$ further north, in a profile of the west wall of a large pit dug to place a large manhole box (Profile 3 in Figure 5-12), the complexity of the southern part of the North Dune becomes more apparent. It should not be assumed, however that the complex strata shown in Profile 3 continue more or less in this fashion to the bluff above Corpus Christi Bay. Unlike the South Dune which displayed a relatively simple series of three to four paleosols $10 \mathrm{~cm}$ or thicker, the stratigraphy of the North Dune varied over its length and width in Trench B, and the variation continued passed Trench B (see Trench F, below).

This variation was manifested largely in the darkness and thickness of paleosols. None of these were as dark or as thick as those recorded in the south dune. They could vary a great deal over a relatively short distance, becoming darker and thicker, then becoming so thin and so light that they would be almost impossible to separate from light clays, then becoming darker and thicker again (Figure 5-13).

As Trench B continued north across the north dune, layers of sediment began to slope upwards, as can be seen in Figure 5-6, a trend that continued until about $34+060$, after which the layers of sediment tended to slope slightly downwards to the north, towards Corpus Christi Bay (Figure 5-6). Throughout the North Dune seen in Trench B, the sediments also tended to slope down to the east, towards the False Oso mudflats.

As Trench B continued north, the contrast between the dark and light layers below about
$1 \mathrm{~m}$ under the road surface decreased somewhat, and many of the thinner dark layers faded out almost completely. As Figure 5-13 shows, the amount of change that can take place over even the approximately $3 \mathrm{~m}$ between the center wall of Trench B (about $12 \mathrm{~m}$ east of the centerline, shown in

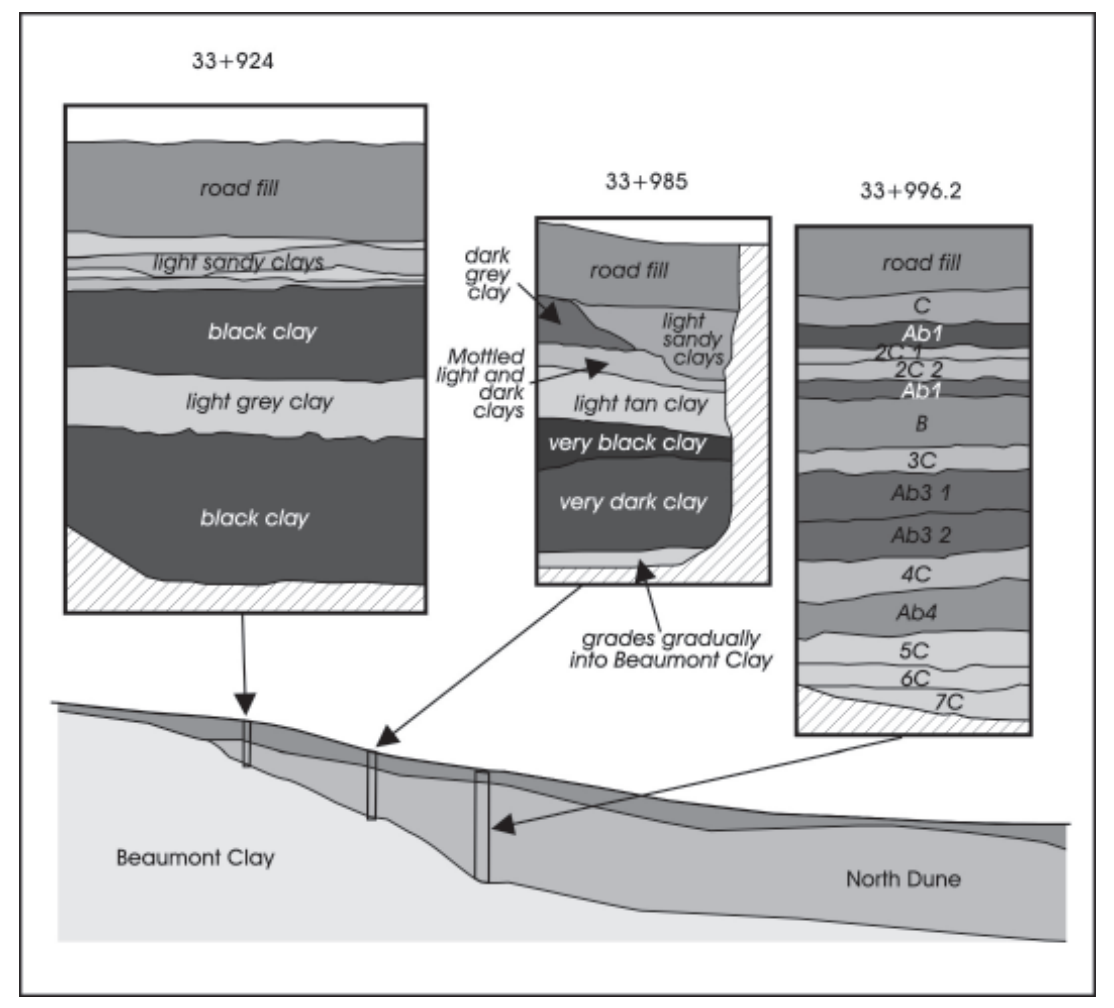

Figure 5-12. A schematic profile of the North Dune and Beaumont Ridge, looking west, showing profiles from three locations in Trench $B$.

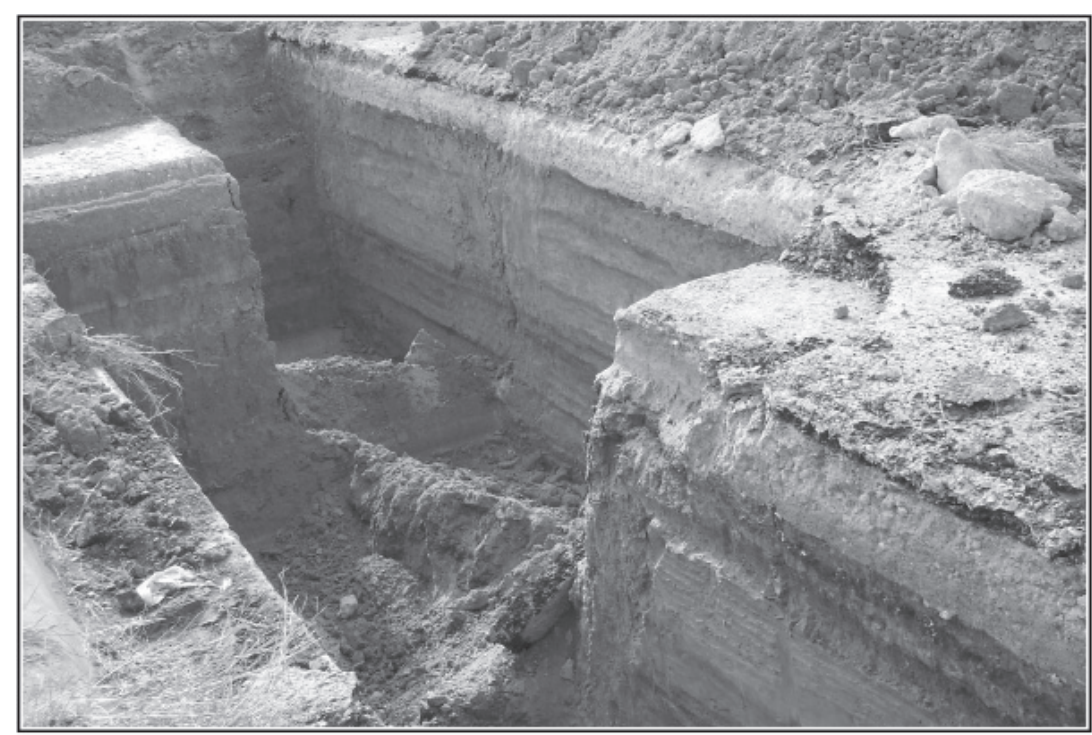

Figure 5-13. Photograph showing Trench B at approximately 34+080, as the first half of a new section has been completed, showing the wall at the center of the trench (foreground) and the wall at the western edge of the trench (background). Looking southwest. 
the foreground of the photograph), to the west wall (about $10.5 \mathrm{~m}$ east of the centerline, shown in the upper part of the photograph) is remarkable.

In this area of the North Dune, the two upper-most paleosols were only about $10-15 \mathrm{~cm}$ apart at the center of the trench but most of the upper paleosol has been removed by road construction in the western half of the trench and, since OZ-E does not extend to the west wall, the second paleosol is only faintly visible (Figure 5-13). These two paleosols continue to get closer to each other as they progress east, so much so that in Trench I, adjacent to the east of Trench B, it was difficult to separate them during excavation, given the technique in use.

Beginning at roughly $34+000$, with evidence seen in the Ab1 layer in Greaves' (2004) figure reproduced in Profile 3 of Figure 5-12, there was an increasing scatter of charcoal fragments, tiny burned clay fragments and shell fragments in the uppermost paleosol. This was merely noted at first, but when this scatter became denser and persisted for $42 \mathrm{~m}$, it was designated an occupation zone. Examination of notes taken previously indicated that a similar phenomenon had been noted in Trench $\mathrm{C}$ (see below). This first $\mathrm{OZ}$ was designated OZ-A, while the first $\mathrm{OZ}$ in Trench $\mathrm{B}$ was designated OZ-B. Three more OZs were identified in Trench B, OZs -D, -E, and -F. They will be discussed in the following chapter.

In December 2003, a single human burial, Burial 2, was located in Trench B, with the top of the skull found 10 $\mathrm{cm}$ below the bottom of the road bed, $10.63 \mathrm{~m}$ east of the centerline at $34+053$. This burial will be discussed in greater detail in a later section of this chapter.

Trench B ended at 34+170, however a large percentage of the last 15 meters was disturbed by previous utility trenches. Once the clearing had proceeded nearly to the north end of the trench, Trench B was re-excavated and several utility lines, including a storm sewer, water, gas, and sanitary sewer lines were installed. CAR personnel monitored this re-excavation, as previously undisturbed sediments were sometimes impacted in the process of re-digging this trench, especially when widening it for manhole boxes, etc. Later, the curb of the new road and a sidewalk were installed above the trench.

Sixty-six features was identified within Trench B (Figures 5-1 through 5-5), including the five features discovered during the initial excavations of the trench in 2000 (Meissner 2000). These features are described in the following chapter.

\section{Trenches $\mathbf{C}, \mathbf{G}$, and $\mathbf{N}$}

Trenches $\mathrm{C}, \mathrm{G}$, and $\mathrm{N}$ are in reality a single trench dug at different times. The trench sections were given different designations in the field and in the interim reports, but for this final report, they will be described together. They form a western version of Trench B, and provide a view of the west side of Ennis Joslin from 33+400 north up Ennis Joslin and old S. Alameda Street with a turn to the west just south of Ocean Drive (Figures 5-1 through 5-5).

\section{Trench C}

Trench C was excavated in the earliest part of Phase III of the project, after changes in utility construction plans moved the location of a large storm sewer, originally intended to go into Trench A, 5 meters east. Trench $\mathrm{C}$ was centered about 7 meters from the centerline, east of Trench A and extended from $33+725$ south to $33+400$, with a gap at the Del Oso intersection (see Figure 5-4). Trench $\mathrm{C}$ was $2.2 \mathrm{~m}$ wide and varied in depth from $1 \mathrm{~m}$ to $2.9 \mathrm{~m}$, depending on the proposed grade of the storm sewer and the depth of the Beaumont clay. Beginning at about $33+490$, a layer of modern fill was observed above typical clay dune sediments. As the trench continued south, the surface of undisturbed dune sediments dropped lower in the profile and the percentage of fill increased until, at 33+460, the entire profile was modern fill. The trench cut through modern fill until it ended at $33+400$.

The first of eleven OZs was located in this trench. At the time it was simply described as an area within which a thin layer of highly scattered shell, charcoal, and animal bones extended for roughly $18 \mathrm{~m}$ in the trench between $33+558$ and $33+576$ and at a depth of $70-80 \mathrm{~cm}$. This $\mathrm{OZ}$ contained a number of areas in which the shell scatter was denser, however only one such concentration was designated as a feature at the time, Feature 17. It was not until the OZs in Trench B were discovered that previous notes were reexamined and OZ-A was designated, based on the description (Meissner 2004).

\section{Trench $G$}

Trench G was a northern extension of Trench C (see Figure 5-3), on the west side of Spur 3. Unlike Trench C, Trench $\mathrm{G}$ was only $1 \mathrm{~m}$ wide. It was approximately $220 \mathrm{~cm}$ deep. At first, it extended across the empty lot at the junction of Alameda Street and Ennis Joslin Road and then turned north, crossed several traffic islands and ended in the middle of the right lane of Alameda (Figure 5-3). This was an area at the top of the Beaumont clay ridge, and no dune deposits or cultural features were noted. In one area between roughly $33+755$ and $33+758$, however, a layer of extremely black, glossy, highly 
organic clay, truncated at the top by previous construction, was noted. It is believed that this deposit represents the remnants of a small ephemeral pond (see Figure 5-6), similar to the one shown on old maps of the site near Ocean Drive (see Figure 5-8). This deposit was only about $30 \mathrm{~cm}$ deep in Trench G (see Trench H).

Trench $\mathrm{G}$ was later extended, continuing north under the new sidewalk on the west side of Ennis Joslin to a large manhole box at $34+132$, beyond which it was designated as Trench $\mathrm{N}$ (Figures 5-1 to 5-3). During most of its length, this section was dug to ca. $215 \mathrm{~cm}$ bgs. However, from $34+102$ to the end, it was only dug $155 \mathrm{~cm}$ deep. The southern part of this extension of Trench $\mathrm{G}$ was located on the Beaumont Clay ridge and no features or other signs of cultural materials were noted when sediments were undisturbed. North Dune sediments did not appear in Trench G until approximately 33+990-994 (Figure 5-14). At 34+012, the uppermost dark paleosol began to contain a thin layer of shells and shell fragments, scattered charcoal and small burned clay nodules and scatters of fish and mammal bone. As Trench G continued north, it became clear that this was another OZ. It was designated OZ-J (Figure 5-15). It extended to ca. 34+120 in Trench G, beyond which most of Trench $\mathrm{G}$ appeared to be dug through previous disturbances. OZ-J contained ten Features: 148-152, 154156, 159, and 161, all but the latter of which were in Trench G. Three additional features were encountered in Trench G: one (Feature 153) was above OZ-J and two (Features 157 and 158) were below OZ-J (see Chapter 6) for a total of twelve features identified in this trench. All of the features in OZ$\mathrm{J}$ were truncated to some extent on the eastern side of the trench, due to construction of the original sidewalk.

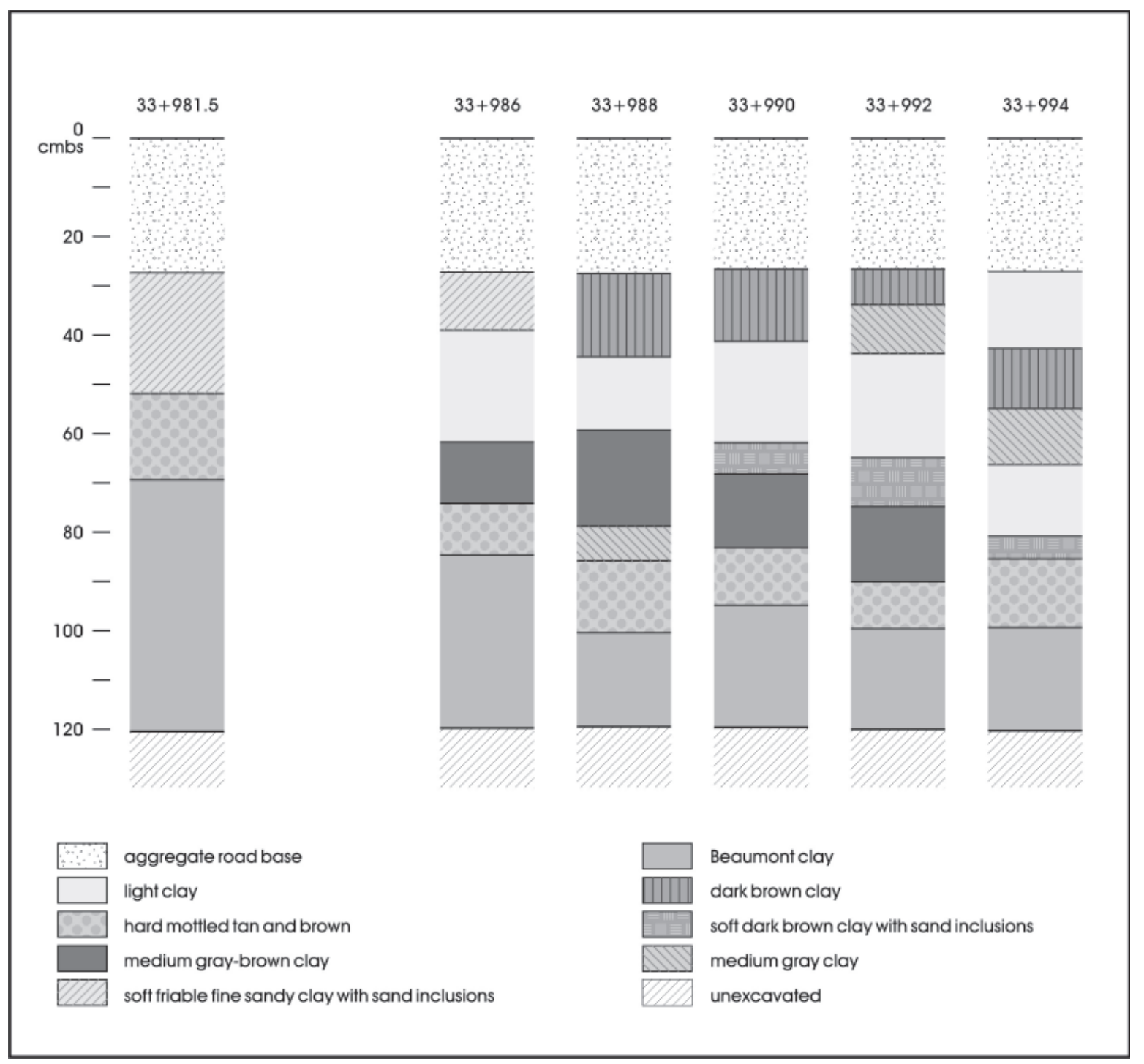

Figure 5-14. A series of 20-cm strip profiles of the west wall of Trench $G$ at the beginning of the North Dune. Note: First gap is $4.5 \mathrm{~m}$ due to a disturbance, all other gaps are $2 \mathrm{~m}$. 


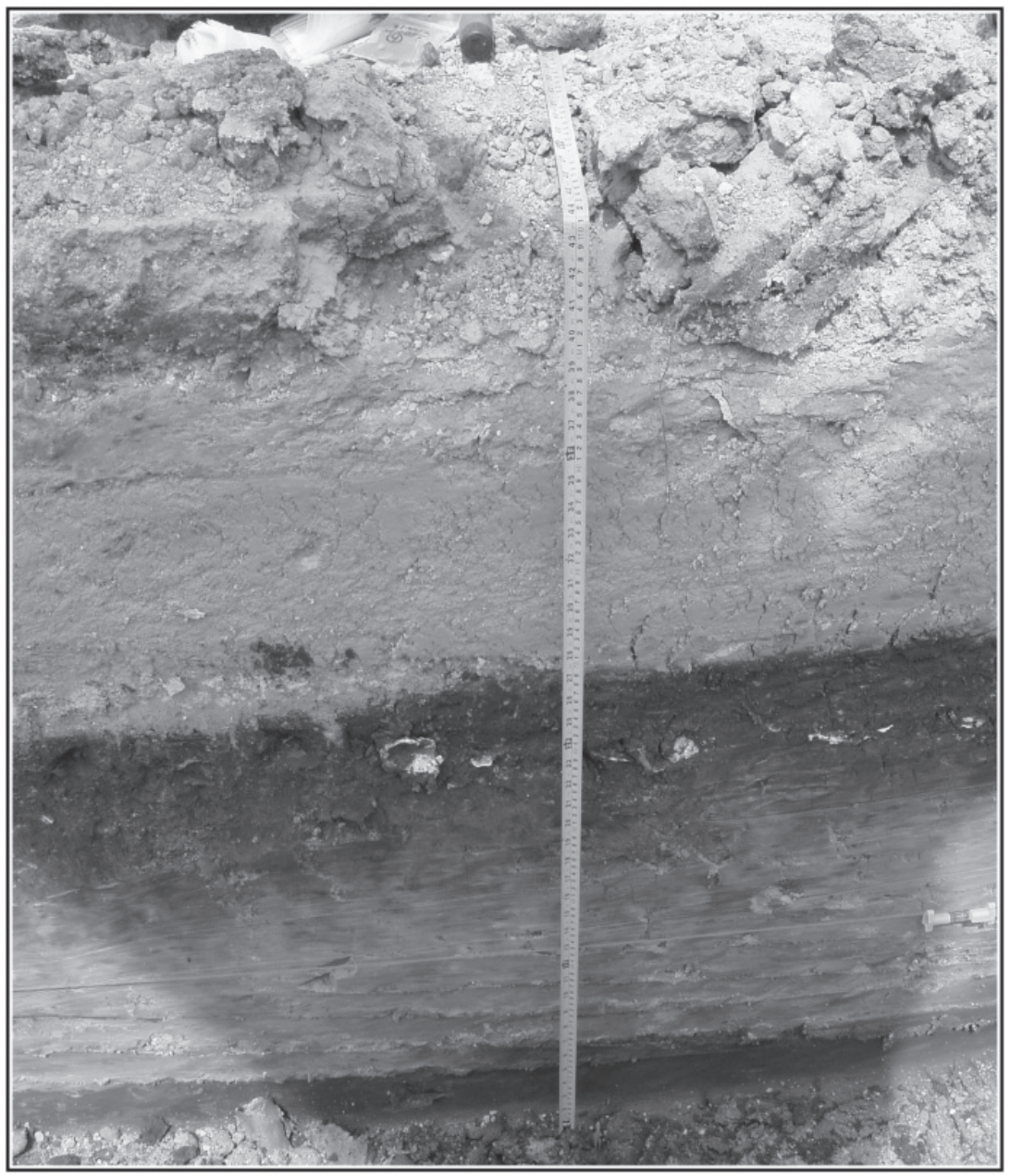

Figure 5-15. A photograph of the west wall of Trench G, showing Feature 149 in $O Z J$.

\section{Trench $N$}

Trench $\mathrm{N}$ is a continuation of Trench $\mathrm{G}$, beginning at the manhole box at $34+132$ and continuing around the curve from the west side of Ennis Joslin to the south side of Ocean Drive (Figure 5-1). The southern-most part of Trench N was in the northern dune deposit, but as the trench continued north to about $34+179$, the extremely black pond deposits were seen above the dune deposits, which dropped sharply until they were no longer seen in the trench (Figure 5-16). These pond deposits continued as Trench $\mathrm{N}$ made the curve to the west, ending at about $3+260$ on Ocean Drive (see Figure 5-1). However, the northern dune deposits did not return. Instead, Beaumont Clay emerged from beneath the black pond deposits, with dark loamy sediment developing above the Beaumont (Figure 5-17). The pond deposits became very shallow and disappeared as the trench continued to the west. A thin layer of shells and flecks of charcoal was observed in the dark loam above the Beaumont clay, especially between about $3+260$ and $3+257$ but was

\section{Trench D}

too scattered to define as a feature (Figure 5-17). It was later determined that this thin layer of shells was probably part of OZ-K (see Chapter 6).

Between $3+232$ and 3+235, Feature 147 was encountered. This feature consisted of three small $(30-45 \mathrm{~cm})$ pits, one of which was dug into the Beaumont Clay beneath the feature. The pits were densely packed with Oyster (Crassostrea virginica) and Lightning Whelk (Busycon perversum), and surrounded by a dense scatter of shell, fish and mammal bone, charcoal, and small burned clay nodules. Feature 160 was a small concentration of shell about $10 \mathrm{~cm}$ above the Beaumont Clay.

By about $3+210$, the Beaumont Clay was beneath just $10 \mathrm{~cm}$ of topsoil. Although the surface of the Beaumont Clay dropped slightly as the trench continued to the west along Ocean Drive, the dark loamy clay above it contained no more than an occasional shell west of Feature 160. Features 147 and 160 were the only feature identified in Trench $\mathrm{N}$. The trench ended at $3+185$.

Taken together, Trenches $\mathrm{C}, \mathrm{G}$, and $\mathrm{N}$ had fourteen features and two OZs. This is substantially less than the roughly equivalent Trench B on the east side of the road.

Trench D was excavated during Phase II of the project. It began on the west side of Ennis Joslin Road at 33+724 and continued west to the curb of the south edge of S. Alameda Street where it turned northwest to cross the street (see Figure 5-3). The trench was $60 \mathrm{~cm}$ wide and was dug to a depth of $120 \mathrm{~cm}$. Below about $20 \mathrm{~cm}$, the sediments in the trench were undisturbed until the edge of Alameda Street was reached, where old utilities, most of which were no longer functional, had been installed. Other than an occasional shell, there were no cultural materials observed. Near the eastern end of the trench, the sediments above the Beaumont included a thin (ca. 10-15 cm) layer of unusually dark highly organic clay. Later excavations to the north of Trench D (see Trench H, below) showed more of this sediment that developed in an area where rainwater collected in depressions in the impermeable Beaumont clay and formed small, ephemeral ponds (see Chapter 2). 


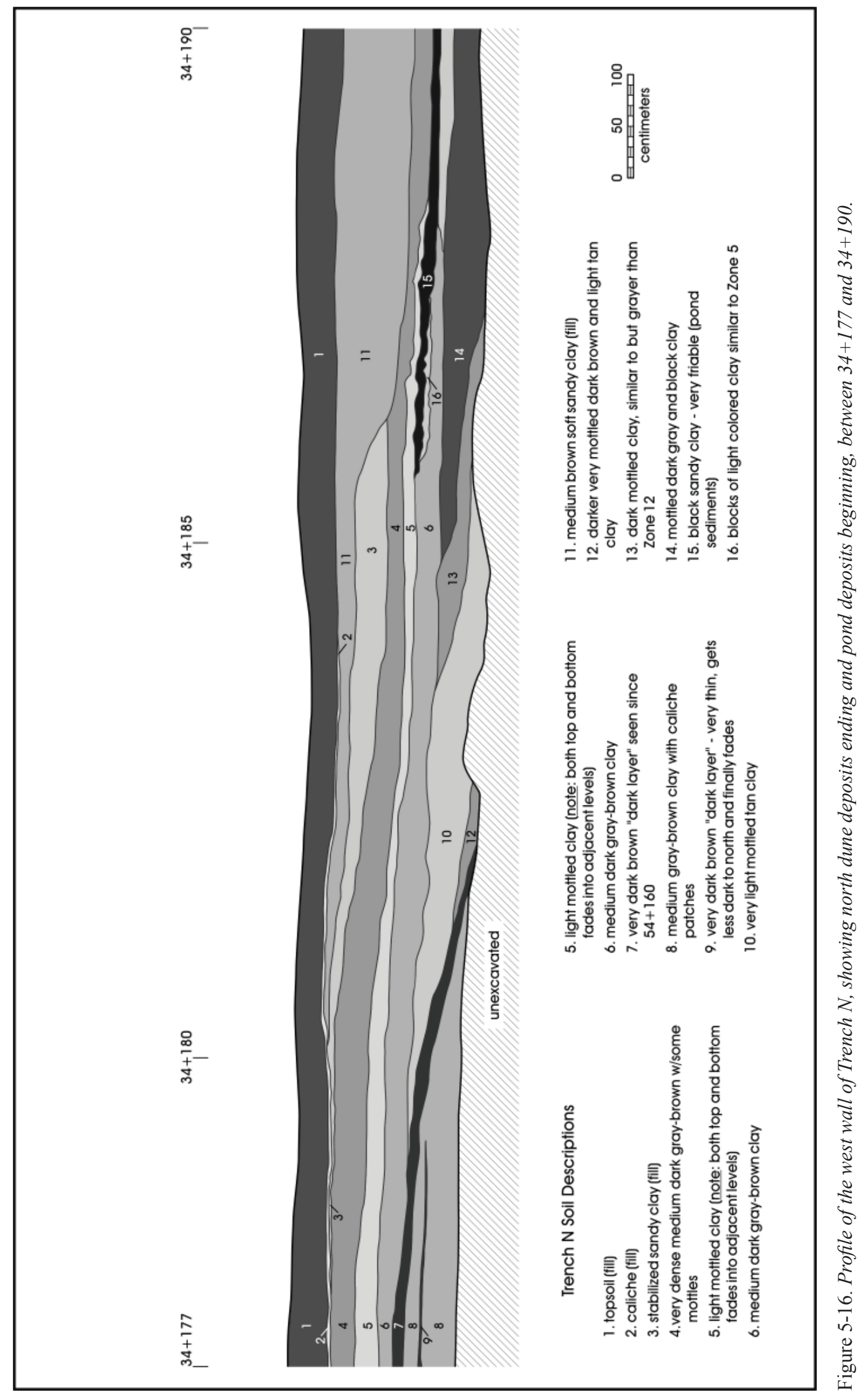




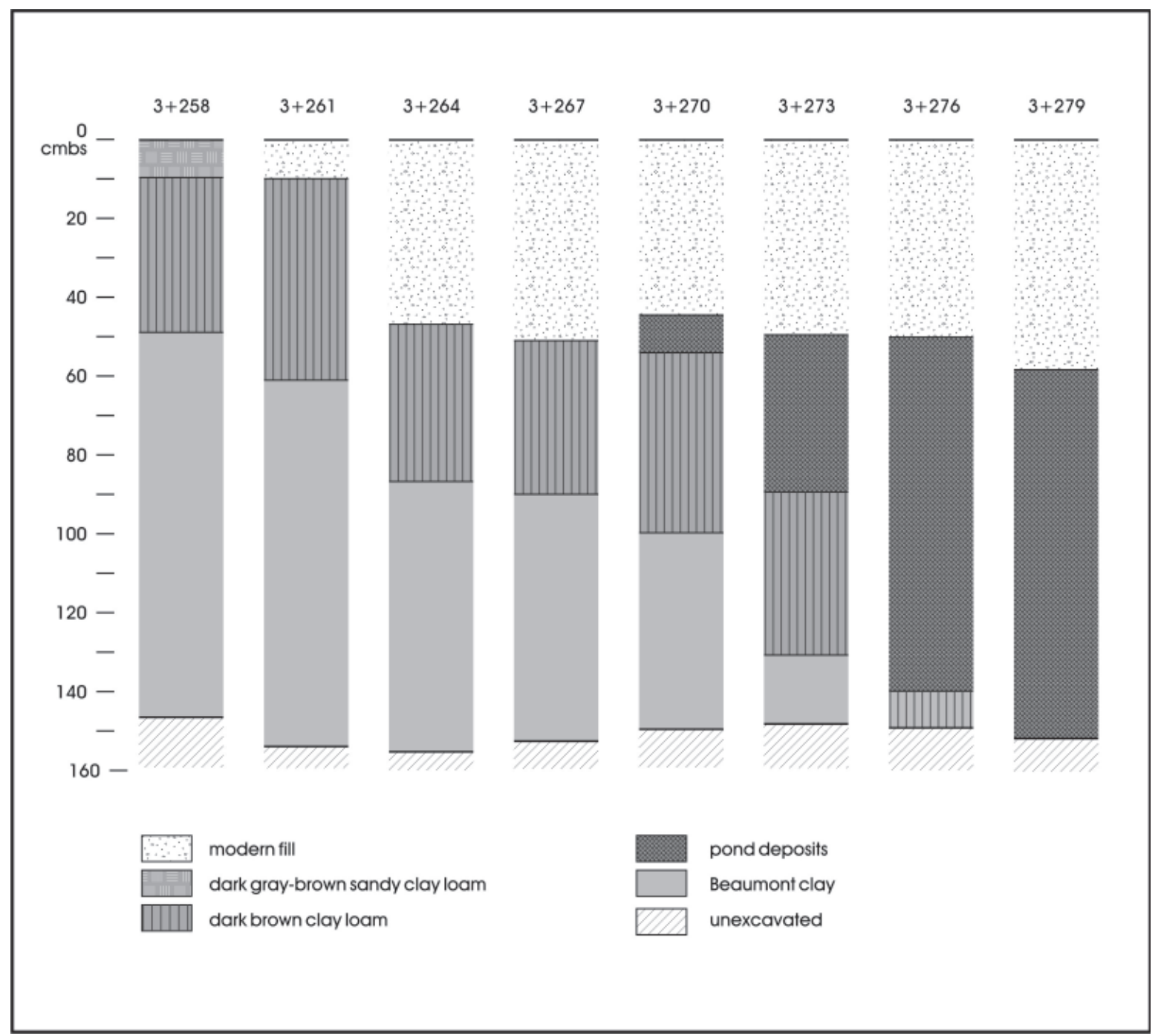

Figure 5-17. A series of eight 20-cm strip profiles of the north wall of Trench $N, 3 \mathrm{~m}$ apart, from $3+258$ to $3+279$, documenting the western edge of the pond deposits and $\mathrm{OZ} K$.

\section{Trench E}

Trench E was excavated during Phase II of the project. It began in an area that would later be Trench B at $34+152$, and was dug east to a point just west of the edge of the stabilized bluff above the northern False Oso mudflats, then turned north to a point just south of Ocean Drive, roughly $155 \mathrm{~m}$ in total (Figure $5-1)$. Trench E was $120 \mathrm{~cm}$ wide and $180 \mathrm{~cm}$ deep. The first $20 \mathrm{~m}$, on the western end of the trench, exposed undisturbed clay dune sediments, in which there were occasional shells. The remainder of the trench was dug through either disturbed sediments or modern fill including large amounts of modern trash, much of it in black plastic bags, in a sandy matrix which extended across most of the north-south portion of the trench. It appears that this garbage and sand mixture was used as landfill behind a stabilizing wall of jumbled, reused concrete slabs and blocks referred to as "riprap" by one of the TxDOT inspectors (O. Hinze, personal communication 2004). This informal "seawall" is the method used in this area to protect the bluff from damage by storm surges on Corpus Christi Bay near the False Oso, and in some locations, along the bluff above the mudflats east of the site.

\section{Trench F}

Trench $\mathrm{F}$ was located in the parking lot of the restaurant north of Ocean Drive on a bluff above Corpus Christi Bay (Figure 5-1). This trench, dug to place a large storm sewer outlet, was $3 \mathrm{~m}$ wide and $2.95 \mathrm{~m}$ deep and extended $63 \mathrm{~m}$ from 18 $\mathrm{m}$ north of the Ocean Drive centerline at $3+328$ to Corpus Christi Bay.

The complex layering of the North Dune was still clearly visible in Trench F. One dense concentration of sunray venus 
clam and lightning whelk shells (Feature 18) was located in this trench (Figure 5-18). With the exception of a large sand-filled pit, roughly $8 \mathrm{~m}$ across and $2 \mathrm{~m}$ deep, beginning about $35 \mathrm{~m}$ north of the southern end of the trench, the dune deposits seen in this trench were undisturbed until about 72.3 $\mathrm{m}$ north of the Ocean Drive centerline. The pit had modern trash at the bottom, including a machine-made bottle. With the exception of Feature 18, no extensive prehistoric cultural deposits were noted.

Profiles of the trench showed that beneath roughly $30 \mathrm{~cm}$ of modern fill were clay dune deposits to the bottom of the trench. In a few places, the bottom layer seen in the trench showed the remarkable pale green color typical of sediments that have undergone gleying, that is, the sediments had been subjected to long periods of submersion in anaerobic conditions. This was confirmed when, after some time in the air, the sediment became a mottled tan and orange color, a phenomenon typical of gleyed sediments. In fact, Trench $F$ broached the water table and the lowest part of the trench was submerged within a few minutes of finishing each segment (Figure 5-19). Figure 5-19 shows

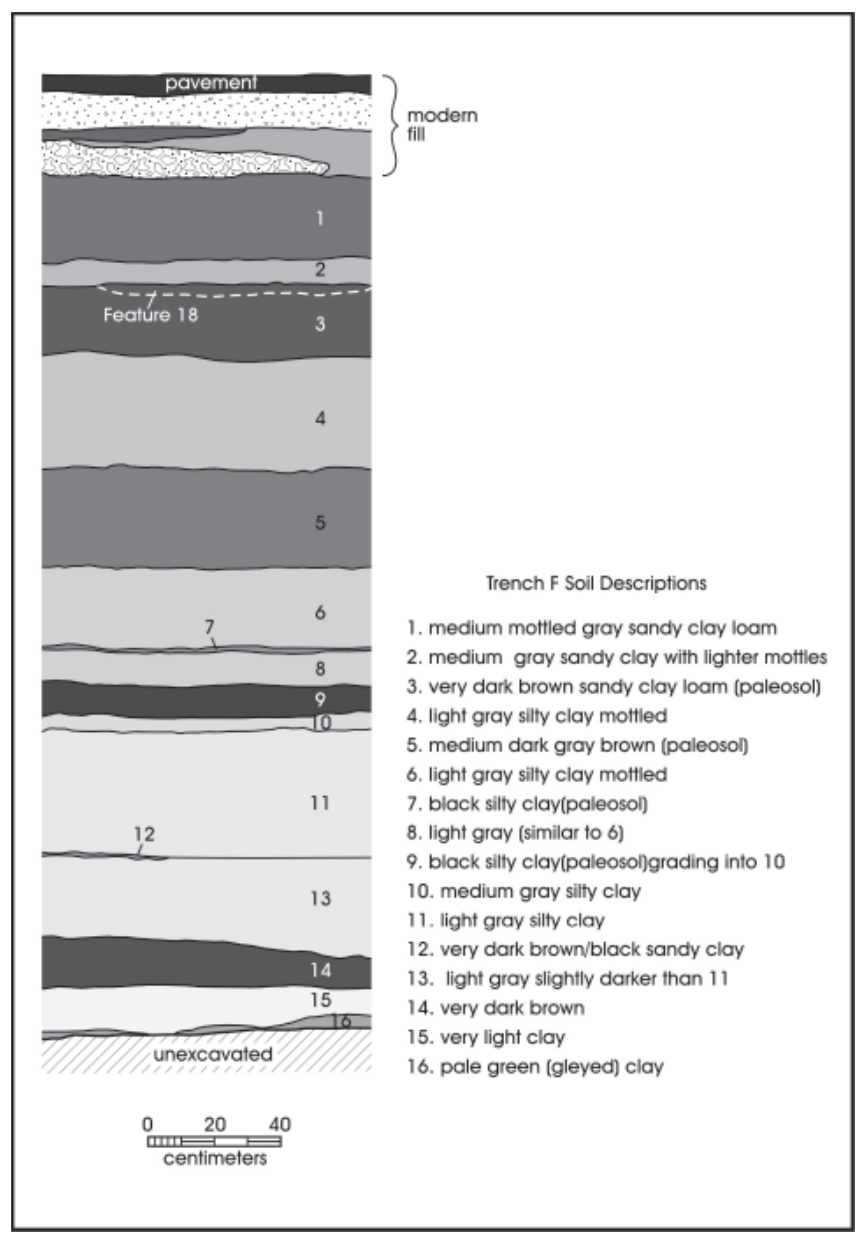

Figure 5-18. Profile of Trench F, at location of Feature 18. the northern-most intact portion of the North Dune at approximately $71.6 \mathrm{~m}$ north of the Ocean Dr. centerline. Just north of this location the dune sediments were replaced with modern fill for another $5 \mathrm{~m}$ to the edge of the bluff above Corpus Christi Bay. Note the changes in the dune between Figure 5-18 and Figure 5-19, located about $52 \mathrm{~m}$ further north. Also note that the dark sediments are fading out as the dune reaches the original edge of the bluff above Corpus Christi Bay. No evidence of Beaumont clay was seen in any portion of this trench.

\section{Trench H}

Trench $\mathrm{H}$ was dug from Trench $\mathrm{G}$ northwest across the empty lot at the junction of Alameda (Figure 5-3). The portion of the trench nearest Trench $G$ was expanded to make room for a large concrete manhole box. The upper $50 \mathrm{~cm}$ of the entire trench was highly disturbed. Beneath that was more of the dense black, highly organic clay deposits seen in Trenches D and G. Beneath these deposits, the Beaumont clay was very uneven, with the top varying from immediately beneath the disturbed sediments to as deep as $2 \mathrm{~m}$ bgs. No cultural deposits were seen in Trench $\mathrm{H}$ (Figure 5-20).

This trench crossed the part of the site where the Beaumont Ridge is highest. The Beaumont Clay Formation is almost completely impermeable to water so that, in the past, rain collected in the depressions on the undulating top of the ridge and remained there until it evaporated (Figure 5-20). These small ponds were usually very ephemeral except during rainy periods.

\section{Trench I}

Trench I was a 1-m-wide trench located roughly $50 \mathrm{~cm}$ east of Trench B, and originally extended from $33+530$ to $34+145$ (Figures 5-1 to 5-5). Unlike Trench B, this trench was only dug to about $120 \mathrm{~cm}$ bgs unless the Beaumont clay was encountered above this level. Not surprisingly, many of the larger features and all of the occupation zones seen in Trench B were also identified in Trench I. In addition, twenty-six features and two additional occupation zones were identified in this trench.

The stratigraphy of Trench I generally matched that of Trench B, except that matching paleosols of the north dune were somewhat lower in Trench I, as the layers of the entire dune slope to the east. On the other hand, ground surface in Trench I was consistently higher, sometimes as much as 50-60 $\mathrm{cm}$ higher, than the surface of the road through which Trench B was dug. This ground surface may represented 


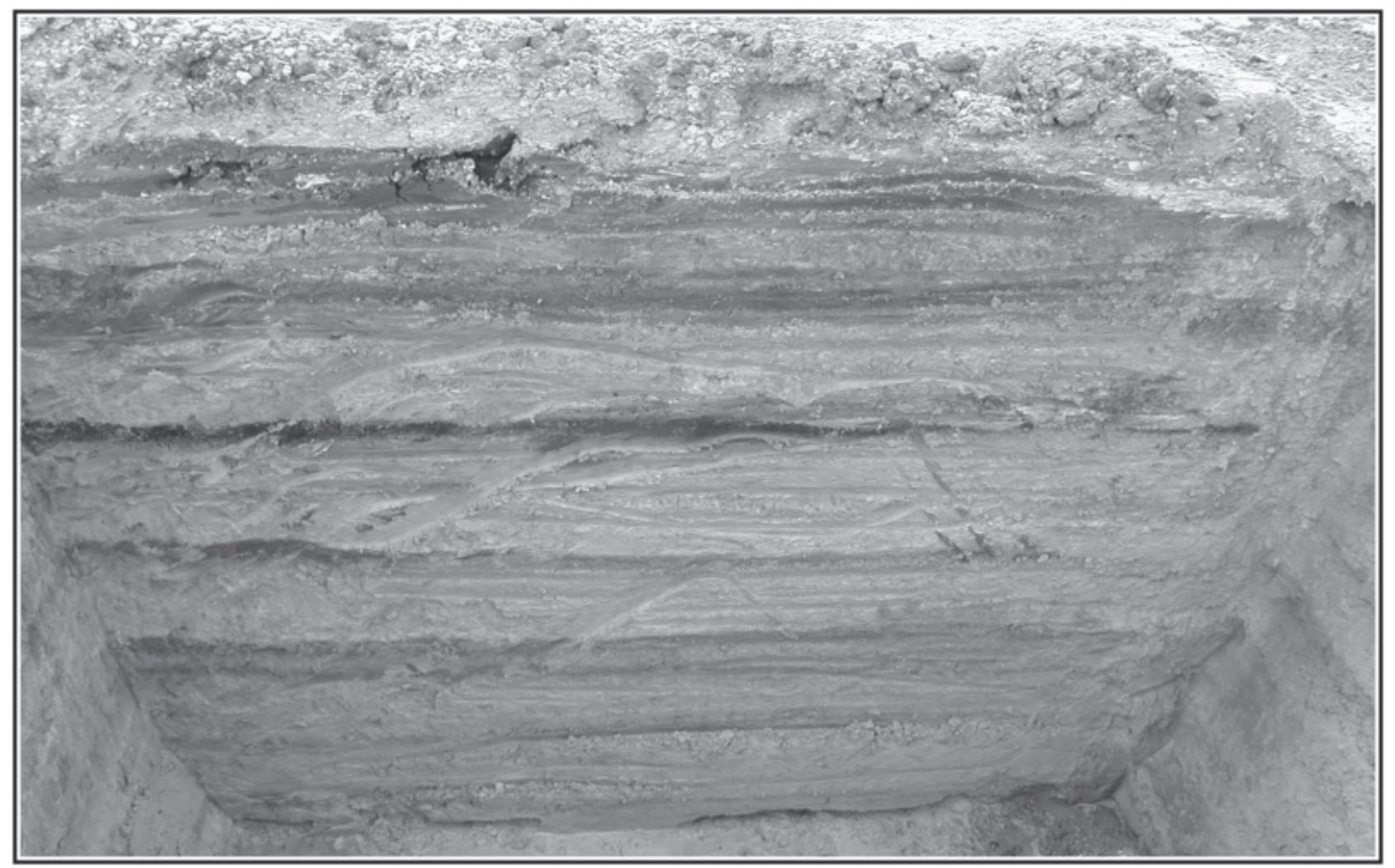

Figure 5-19. Photograph of northern-most point in the North Dune in Trench F, $71.6 \mathrm{~m}$ north of the Ocean Dr. centerline. Facing west.

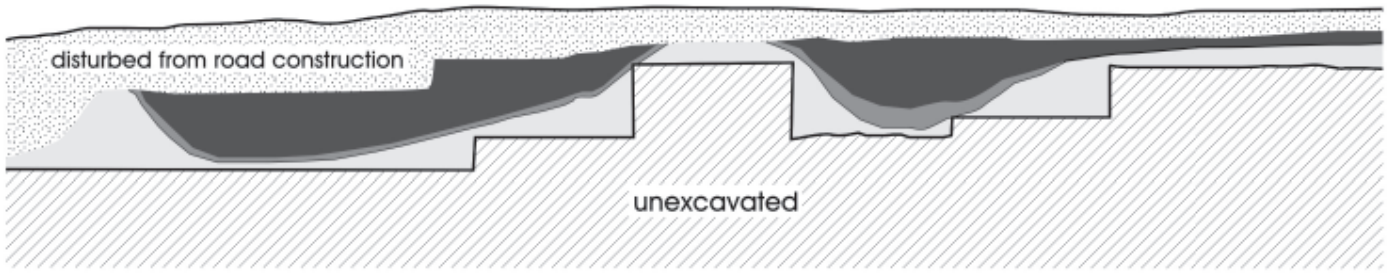

Pond sediments

Beaumont Clay Formation

Pond grading to Beaumont

Clay Formation

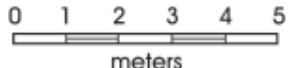

Figure 5-20. Profile of the north wall of Trench H, showing the uneven surface of the Beaumont Clay Formation and the black deposits left by small ephemeral ponds forming in lower elevations of the surface.

the natural ground surface in areas that had not been graded for landscaping. Thus, some features and occupation zones clearly visible in the upper part of Trench I were poorly defined or not seen in Trench B, presumably because they had been truncated by the road construction.
For example, OZ G was identified in Trench I but not in Trench B. Although the same $30 \mathrm{~cm}$ thick dark layer containing the occupation zone was seen in Trench B, it was noted at the time (during Phase I) as a dark layer with a thin scatter of shell fragments, charcoal and burned clay 
specks. Since Trench B was not, at that time, continued to the north, it was not understood that this layer containing scattered cultural materials continued across more than 20 $\mathrm{m}$ of trench, and could be seen in the adjoining trench to the east. The cultural material in $\mathrm{OZ} \mathrm{G}$ was also clearly far denser in Trench I.

Trench I was later continued from $34+145$ on Ennis Joslin Road across Ocean Drive to a large manhole box at 3+361 on the northern edge of Ocean Drive. Although a number of large utility trenches had been dug in this area, undisturbed dune sediments were still present. Cultural materials were relatively rare within them, consisting for the most part of a few scattered shells, most of which were in the uppermost of the paleosols of the dune. While digging this trench, Burial 5, which consisted of a few disarticulated bone fragments in the backdirt of an old utility trench, was located at 34+151 (Figure 5-1). Burials 6 and 7, the disturbed but partially articulated remains of an adult and a juvenile, respectively, also were located in this trench at $34+212$. More information about these burials can be found in a later section of this chapter.

\section{Trench J}

Trench $\mathrm{J}$ was a 50 -cm-wide trench cut just east of Trench I to lay a temporary water line from about $33+530$ to $33+618$ (Figure 5-4). This trench was very shallow, usually no more than $70 \mathrm{~cm}$ bgs and for the most part did not encounter previously undisturbed sediments. No features or OZs were identified in this trench.

\section{Trench K}

Trench $\mathrm{K}$ was a footer trench for a retaining wall that began at the bridge abutment on the east side of Ennis Joslin Road at $33+353$ and continued north to $33+478$ (Figure 5-5). This trench was $2 \mathrm{~m}$ deep at the south end and became gradually shallower as it went north. The only undisturbed sediments seen were in the northern-most $5 \mathrm{~m}$, at the very bottom of the trench. No prehistoric cultural deposits were noted.

\section{Trench L}

Trench L began at 33 +544 on the east side of Ennis Joslin Road and extended west-southwest to the centerline, where it turned to the southwest, crossed Trenches A and C, and continued down the northern edge of Del Oso Drive to a large manhole box $38 \mathrm{~m}$ west of the centerline at $33+520$ (Figure 5-4) where it turned south across Del Rio to a manhole box at $33+512$. It was $1 \mathrm{~m}$ wide and varied in depth from $220 \mathrm{~cm}$ under Ennis Joslin to $120 \mathrm{~cm}$ near its western end. Five features (124, $125,127,128$, and 135) and OZ $\mathrm{H}$ were identified in Trench L. A profile of the western end of the trench (Figure 5-21) shows that Features 128 and 135 are both sitting at the top of a light clay layer, while Feature 127 is within it. The profile becomes more complex as it moves east, suggesting that the eastern side is showing some beginnings of dune sediments. If we compare Figure 5-21 with Profile 2 in Figure 5-9, we can see that these profiles, only about $10 \mathrm{~m}$ apart, seem very different. It is important to note that these two profiles are in a transitional zone between the Beaumont Ridge and the South Dune. It is not possible to correlate a given stratum in

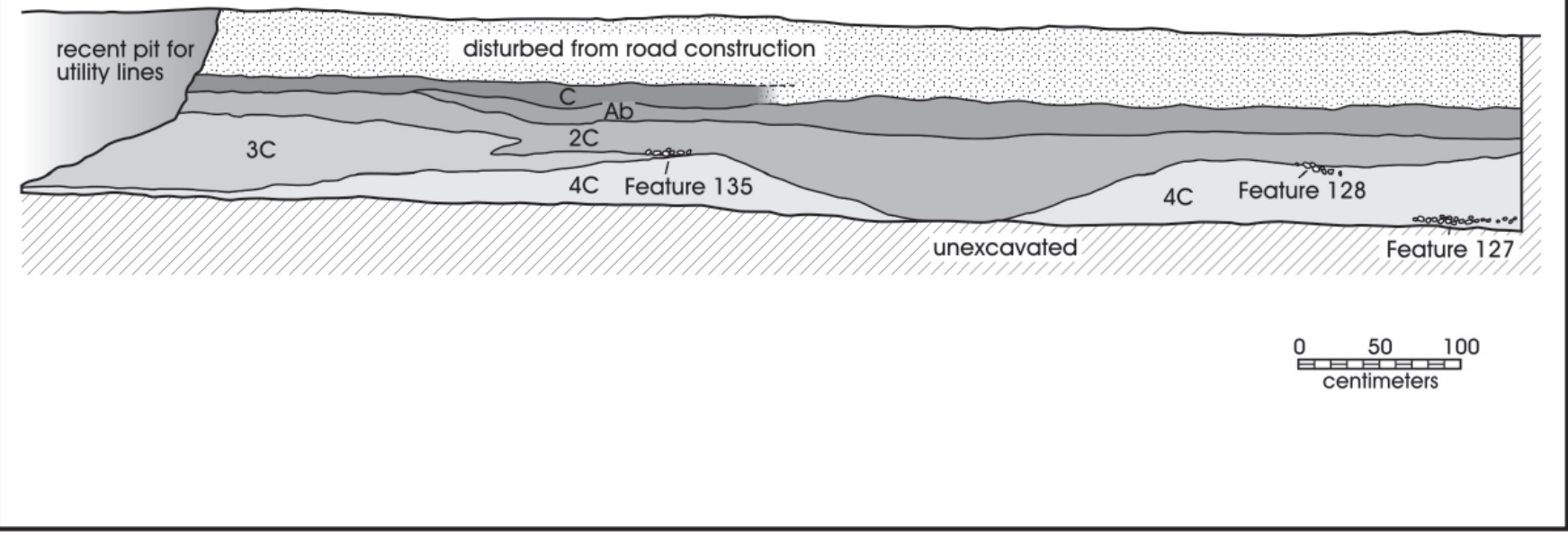

Figure 5-21. Profile of the south wall of the western end of Trench $L$ at about $33+520$ between 10 and $20 \mathrm{~m}$ west of the centerline, showing Features 127, 128, and 135. 
Figure 5-21 to those seen in Profile 2 in Figure 5-9 with any certainty, given that it is not known how much sediment was removed above the intact deposits shown in Figure 5-21.

\section{Trench M}

Trench $M$ crossed Ocean Drive near the intersection with Ennis Joslin Road (Figure 5-1), beginning and ending at storm sewer inlets. The trench extended from $3+295.5$, on the northern curb of Ocean Drive, to a drainage inlet on the new curb line on the southern edge of the right turn lane from Ocean Drive onto Ennis Joslin Road (Figure 5-1). The trench was approximately $2 \mathrm{~m}$ wide and roughly $100-180 \mathrm{~cm}$ deep, with the deepest part of the trench located to the north. Most of Trench $\mathrm{M}$ transects an area where a large ephemeral pond is marked on old maps and is seen in old aerial photographs (e.g. 1934 aerial in Figure 5-8). The profile of the trench showed evidence of this pond, consisting of relatively uniform, dense, extremely black and rather glossy sediment that appeared to have a high organic content. When the removal of two old storm sewer boxes was monitored not far east of Trench $\mathrm{M}$ ( $16.5 \mathrm{~m}$ west of the centerline at ca. $34+204$ and $18 \mathrm{~m}$ west of the centerline at ca. $34+218$, see Figure 5-2), this very black sediment was seen to extend to a depth of $2 \mathrm{~m}$ bgs in those areas. With the exception of one or two shells, no evidence of cultural activity was seen in this black sediment, however, the scattered remains of an American Bison calf (Bison bison), including several long bones with unsealed epiphyses, ribs, phalanges, and a portion of mandible with both permanent and deciduous teeth, were encountered between 90 and 110 cm bgs (Figure 5-22).

The bones were disarticulated, and scattered over an area of about $3 \mathrm{~m}$ north/south and an unknown distance east/west. There was no evidence of cultural activity associated with these bones, and since it was perceived as non-cultural it was not assigned a feature number. Nonetheless, the bones were collected for identification and closer examination in the laboratory. The results of the examination are presented in the faunal analysis section of Chapter 11 .

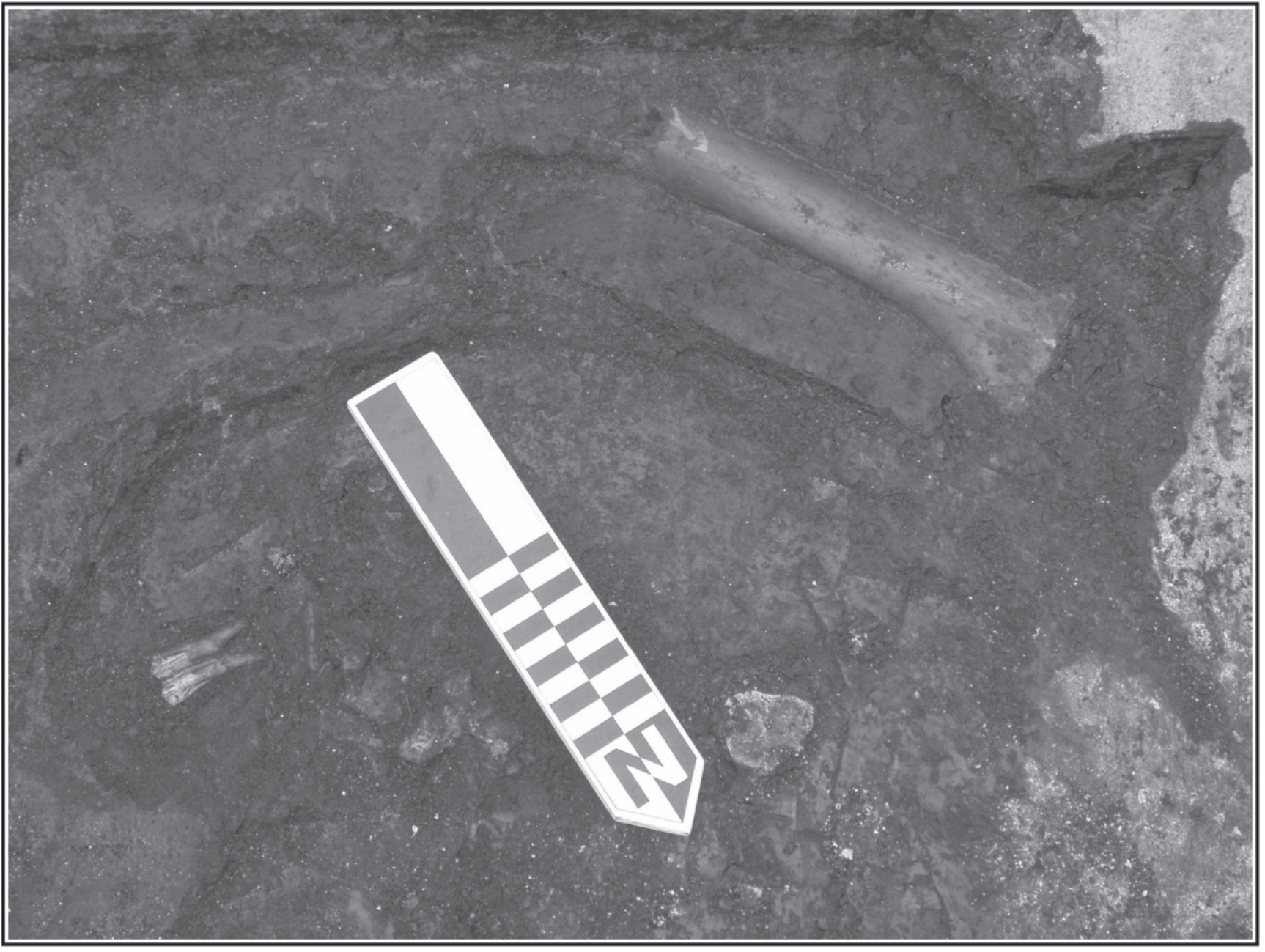

Figure 5-22. Immature bison bones in pond deposits in Trench M, ca. $1 \mathrm{~m}$ bgs. 


\section{Trench $\mathbf{O}$}

Trench $\mathrm{O}$ was dug to lay a temporary water line along the northern side of Ocean Drive (Figure 5-1). It ran from 3+215 to $3+400$, approximately $60-100 \mathrm{~cm}$ north of Trench R. It was ca. $50 \mathrm{~cm}$ wide and $60 \mathrm{~cm}$ deep. The western $20 \mathrm{~m}$ of the trench was dug into Beaumont Clay, but with the exception of a small area between $3+271$ and $3+280$ all the sediments exposed were disturbed fill until ca. $3+345$. East of this point, undisturbed sediments were seen in the bottom 10-15 cm of the trench. A single feature, Feature 163, was located in a previously undisturbed area at $3+275$.

\section{Trench $\mathbf{P}$}

Trench $\mathrm{P}$ was dug to replace the existing storm drain with a larger capacity pipe on the north side of Ocean Drive (Figure 5-1). It extended from $3+305$ to $3+189$. The trench was approximately $1.5 \mathrm{~m}$ wide and about $1.9 \mathrm{~m}$ deep. The trench extended about $20 \mathrm{~cm}$ below the original trench and roughly $30 \mathrm{~cm}$ wider on each side. The sediments observed in this trench consisted of dune deposit under a thick (40 to 60$\mathrm{cm}$ ) layer of fill and old road bed, until approximately $3+290$, where Beaumont clay was observed in the bottom of the trench. By $3+280$, the entire profile consisted of fill material above Beaumont clay, and the fill continued to the end of the trench at $3+189$. Occasional shells were seen in undisturbed dune sediments, but no features were observed.

\section{Trench Q}

Trench Q was dug to connect a new sanitary sewer from the manhole at $3+360$ to the restaurant north of the intersection of Ennis Joslin Road and Ocean Drive. It extended to a point about halfway across the parking lot, east of Trench F (Figure 5-1). It was ca. $90 \mathrm{~cm}$ wide and $120 \mathrm{~cm}$ deep. Two features (164 and 165) were identified in this trench. Both were just below the fill under the parking lot, in a paleosol that had been removed by road construction further south.

\section{Trench $\mathbf{R}$}

Trench $\mathrm{R}$ was dug along the northern edge of Ocean Drive. It extended from $3+215$ to $3+417.6$ (Figure 5-1). It was ca. $2 \mathrm{~m}$ wide and varied in depth from $2.2 \mathrm{~m} \mathrm{bgs}$ on the eastern end to ca. $0.9 \mathrm{~m}$ bgs on the western end. Trench $\mathrm{R}$ ran immediately to the north of Trench P and south of Trench O. The eastern end of this trench was located on a causeway which extends from the edge of the top of the dune deposit to the point where Ocean Drive crosses the False Oso. At this end of the trench there was approximately $70 \mathrm{~cm}$ of fill above an old roadbed (see Figure 5-7). Beneath this was another $80 \mathrm{~cm}$ of fill above undisturbed dune deposit. The surface of these undisturbed deposits rose sharply as the trench continued west, towards the top of the dune. The lower roadbed disappeared and the fill became shallower until about $3+380$, where the fill was only about $50 \mathrm{~cm}$ deep. West of this area, the upper surface of undisturbed dune deposit remained approximately the same depth to about $3+300$, when it began to deepen, and by about $3+280$, fill was present to the bottom of the trench. After about $3+290$, the Beaumont Clay formation was seen below the fill in the trench. From this point to the end of the trench at $3+215$, the profile consisted of fill material over Beaumont Clay. There were three features found in this trench: Features 166, 167, and 169. All three were at the surface of the undisturbed clay dune and had been partially disturbed by previous construction. A small bird bone bead was found in Feature 169 (see Artifacts section, below). Additionally, at the contact between disturbed and undisturbed sediments at $3+328$, a single very small $(\mathrm{ca} .1 \mathrm{~cm})$ sherd of sandypaste ceramic was found, apparently within the undisturbed context). Though there were a few shells near the ceramic, it was not associated with a distinct feature. This was the only piece of Native American ceramics recognized in the field during the project, although Martin (1930) describes Native ceramic fragments scattered on the surface in some areas of the site. Another piece of Native ceramics was located during floating of soil samples in the lab (see Artifact section).

\section{Trench S}

Trench S was dug to place a storm sewer outlet from two inlets on Del Oso to a shallow ditch leading to the unnamed drainage at the southern end of the site (Figure 5-5). It began at $33+519$ at a storm sewer inlet, crossed under Del Oso to another inlet box and then turned to the south roughly parallel to Ennis Joslin Road. It was $1 \mathrm{~m}$ wide and varied in depth from $190 \mathrm{~cm}$ on the north end to $\mathrm{ca} .30 \mathrm{~cm}$ at the southern end, where the storm drain would emerge from the ground. Beginning at about $33+480$, the amount of fill above undisturbed clay dune deposit, which had been only about $20 \mathrm{~cm}$ deep, began to get deeper, as the surface of the undisturbed dune began to drop towards the unnamed drainage to the south. By $33+465$, the trench was dug entirely through this fill. Feature 168 was located in this trench.

\section{Trench T}

Trench $\mathrm{T}$ extended north from a manhole at the end of Trench $\mathrm{R}(3+417.8)$ under a curb near the eastern end of the restaurant parking lot, extending $25.5 \mathrm{~m}$ and then turning to the east to connect to the water line for the Oso Pier building east of the restaurant (Figure 5-1). The trench crossed a concrete seawall at approximately $3+430$ and extended another $15 \mathrm{~m}$. The trench was $1 \mathrm{~m}$ wide to a point about $1 \mathrm{~m}$ north of the 
curb and $50 \mathrm{~cm}$ wide beyond that point. It was $1.2 \mathrm{~m}$ deep. The trench exposed about $60 \mathrm{~cm}$ of parking lot and gravel over undisturbed clay dune. The surface of the clay dune dropped sharply as the trench extended east, and the depth of the fill increased. By about $3+425$ there were no undisturbed sediments in the trench.

At the point immediately beneath the curve of the curb (see Figure 5-1) the backhoe operator dug out a large scoop to make his cut below the curb without breaking it, instead of scraping a few centimeters at a time as was his normal practice. Immediately beneath the curb he removed a large number of bovid bones. After removing this bone from the backdirt, the remaining bone within the trench was cleared enough to see that the bone bed (Feature 170) consisted of the articulated lower legs of several bovids. Feature 170 will be discussed in more detail in the Features section of Chapter 6.

\section{Trench U}

Trench $\mathrm{U}$ was dug to place a sanitary sewer line between $34+002$ and $34+053$ on the west side of Ennis Joslin, west of Trench G (Figure 5-2). It was $1 \mathrm{~m}$ wide and ca. $1.2 \mathrm{~m}$ deep. The upper $65 \mathrm{~cm}$ of the trench was topsoil fill brought in for landscaping the lawn. Below this, the northern clay dune was clearly present and Features 141 and 142 were identified.

\section{Sediment Cores}

In August 2007, the Project Archeologist and a Field Technician accompanied the Project Geomorphologist to Corpus Christi to extract three sediment cores to be subsampled for a series of specialized analyses outlined in the project research design. This visit was the second attempt at the extraction of the cores after the first one, in June 2007, was not successful following catastrophic equipment failure.

Cores were to be extracted from the pond deposit, the north dune, and the south dune, respectively. Core segments were to be initially inspected in the field after extraction to ensure that they sampled intact deposits. Core 2 was extracted from a former pond deposit pictured in a 1934 aerial of the area (Figure 5-8). The north dune is represented by Core 4 that was collected from near the intersection of Ocean Drive and Ennis Joslin Road. The south dune, represented by Core 6, was cored along the south side of Ennis Joslin Road near its intersection with Del Oso Road. The core extraction locations are shown on Figures 5-1, 5-2 and 5-4.

The cores were collected from the project right-of-way immediately adjacent to Ennis Joslin Road, and not from the summit of each dune. The core extraction process, the sub-sampling methodology and stratigraphic descriptions are presented in Appendix F. The results of the specialized analyses performed on the sediment samples are presented in Appendixes A-G.

\section{Human Remains}

Ricklis (1997) discovered one human burial during his project. We have designated that burial as Burial 1. During the CAR monitoring project, six additional burials were discovered: one complete, intact burial (Burial 2, Figure 5-2), three collections of disturbed, disarticulated human skeletal remains (Burials 3, 4, and 5; Figures 5-1 and 5-2), and two collections of partially disturbed human remains (Burials 6 and 7; Figure 5-1). Below, we briefly summarize the discovery and excavation of these remains. The analysis and a complete description of these remains were completed by CAR under a separate report in compliance with the NAGPRA inventory of human remains from the site. This report was submitted to the TxDOT-ENV as part of a separate deliverable of this project (Mahoney and Shafer 2003).

\section{Burial 2 \\ Richard B. Mahoney}

Burial 2, the remains of a single individual, was encountered and excavated in December 2003. It was designated as Feature 61 (Figure 5-2). The feature consisted of the remains of adult individual in a tightly flexed position in a well-defined burial pit. The top of the skull was located $10.63 \mathrm{~m}$ east of the centerline at $34+53.9$. The top of the skull was only $10 \mathrm{~cm}$ below the surface of previously undisturbed sediments. The burial was on its right side, with left hand near the face and right arm extended under the drawn-up knees.

During excavation, it was apparent that all skeletal elements were present, and this burial represents a single, primary interment. Taphonomic forces, however, have severely degraded the bone structure. Consequently, each individual element fractured or disintegrated upon removal. This fragmentation has precluded the observation and recordation of many metric and morphological traits.

\section{Burial 3}

On August 8, 2004, during monitoring of the removal of old utility lines in the vicinity of $34+038$ about $16 \mathrm{~m}$ east of the centerline, several human bones were noted in the backfill of the trench (Figure 5-2). These consisted initially of a cranial fragment, a molar, and a possible mandibular fragment. All 
bone recovered was disarticulated and fragmented and came from backdirt removed from a trench that was entirely within previous excavations to bury gas, water, and sewer lines.

Following instructions from TxDOT Environmental Affairs Division, the backdirt in that vicinity was screened with a $1 / 4$-inch mesh. In addition, the walls of the backhoe trench were examined for signs of previously undisturbed sediments and possible undisturbed portions of the burial represented by the recovered disarticulated bones. Both of the walls and the floor exhibited backfill sediments and there was no evidence of any intact soils.

\section{Burial 4}

On August 31, 2004 more human remains were discovered in backdirt from an old utility trench (Figure 5-1). The human remains were initially seen in an area at about $34+187$, less than $1 \mathrm{~m}$ east of the centerline, when a layer of fill was knocked into a previously dug trench. Bones were initially identified as human from a distal humerus, a proximal radius, and a patella, all of which were readily identified in the field. Although all bone was disarticulated and fragmented, they were collectively designated Burial 4 . It was later discovered that the bone all came from a trench (Feature 136) that had been machine-dug at some time in the past into approximately $120 \mathrm{~cm}$ of builders' sand that had been filled over an old storm sewer that runs roughly east-west across the traffic islands located just south of Ocean Drive. Feature 136 was later completely excavated and its contents screened. It extended between $34+185.5$ and $34+187.7$, from $0 \mathrm{~m}$ to $1 \mathrm{~m}$ west of the centerline.

All bone was disarticulated and fragmented and was found in a gray sandy clay matrix that was very different from any of the sediments, whether disturbed or undisturbed, seen in the vicinity. This matrix had clearly been disturbed and contained small limestone rocks and gravel (which is not locally available rock), as well as metal and plastic fragments. Within this matrix, were clumps of dense clay that more closely resembled the sediments usually seen at the site.

The evidence suggests that Burial 4 was encountered by a construction crew at some time after the storm sewer was constructed. In order to rebury these remains, the small trench was dug into the sand above the storm sewer, and the remains, along with a sandy matrix that did not come from the immediate area, were deposited and covered with several layers of fill. The original location of Burial 4 cannot be ascertained. Although most of the bones were fragmented, they were in relatively good condition.

\section{Burial 5}

Burial 5, identified on September 9, 2004, consisted of a few highly fragmented human bones found in the fill above an old cement sanitary sewer line. The first bone was found 16 $m$ east of the centerline at 34+152 (Figure 5-1). The matrix in the trench in the immediate vicinity of the location of the first bone was screened and several other human bones were collected. The bone was found in a sandy matrix immediately above the sewer pipe, with a second layer of sandy matrix above it. The human bones were only found in the matrix immediately above the pipe, in an area extending north about $70 \mathrm{~cm}$ from the location of the original find. Backdirt in an area about $2 \mathrm{~m}$ on each side of this location was closely examined, as instructed by TxDOT Environmental Affairs Division, but no other human bones were recovered at that time. However, several days later, the excavation around the old sewer trench was expanded and several more bones that appeared to be human were identified at $34+155$. Again, the matrix from the trench in the immediate area was screened and the back dirt in an area about $2 \mathrm{~m}$ to the north of this area and south to the portion of the trench already examined (roughly $30-40 \mathrm{~cm}$ ), was closely examined. No other possible human remains were recovered.

Burial 5 is clearly another case of previous construction activities impacting on a burial. Unlike the bones of Burial 4, these bones were in poor condition, some showing indications of atmospheric weathering, suggesting that the bones had, at some time in the past, been exposed above the ground surface for some time. The bones were found in two locations approximately $3 \mathrm{~m}$ apart, but the general appearance, color, and condition, as well as the fact that they were found in the same layer of fill material over the sewer pipe, suggested they were from a single burial. Since the bone was scattered over a wide area, and as the fragments were quite small, it is possible that the construction workers were not aware that they had disturbed a human burial.

\section{Burials 6 and 7 \\ Russell D. Greaves}

On October 13, 2004, during expansion of Trench I around a broken segment of the same concrete sewer line along which the disturbed bones of Burial 5 were located, the partially disturbed burials of two individuals were encountered. These burials were 29.1-29.3 $\mathrm{m}$ east of the centerline at $34+208.5$ to $34+209.3$ (Figure 5-1). Initially one long bone fragment was encountered at the margin of the trench. On the basis of the size and morphology, it was determined that the disturbed bone was probably human and CAR notified TxDOT that another probable burial had been found. 
Although the first bone identified seemed to be that of an adult, additional careful troweling uncovered very small ribs that appeared to be in anatomical position. A deciduous tooth root and what was later identified as an unerupted permanent premolar were found approximately where the cranium might have been. Additional excavation was directed toward uncovering the horizontal extent of this burial. The partially disturbed burial of a small child was uncovered. The long bones and ribs were, as far as could be determined, articulated, however, the bones were in extremely fragile condition, and the cranium, with the exception of the unerupted tooth cap and the deciduous tooth root, was not evident.

As the area around the burial was excavated, additional ribs, pelvis, and long bones were located just eastward of the child burial and at a slightly higher elevation. These bones were clearly those of an adult. They were not in anatomical position, and it was initially unclear what form of commingling was represented between the juvenile and adult remains. At the end of the day the remains were photographed and mapped.

The following day, heavy rain prevented any attempts at excavation of the burials. Excavation was resumed on October 15. Mechanical removal of some of the overburden was performed to determine whether additional remains could be identified or if a grave pit was visible within the soil. Backhoe excavation was stopped well above the elevation where the highest bone had been encountered. Recent disturbances seen along the northwest, southwest and southern sides were very close to the remaining bones. It is likely that several additional elements on the western side were removed during one or more previous construction efforts. No grave pit outline was identified.

The child burial was at a lower elevation (74-82 centimeters below surface $[\mathrm{cmbs}]$ ) than the adult remains (primarily $62-70 \mathrm{cmbs}$, with one fragment recovered at $82 \mathrm{cmbs}$ ). As excavation continued, it appeared that the child's burial had been excavated through part of the adult grave. Even the adult bones that were in the intact prehistoric sediments were jumbled. The disarticulation of the adult bones could represent a secondary burial, but in any case it appears that the adult remains had been disturbed by digging of the child's grave, and then again by modern construction activities. The adult burial was designated Burial 6 and the juvenile as Burial 7.

In summary, Burials 6 and 7 appear to be the disturbed remains of burials which were not contemporaneous. The adult burial may have been secondary, but this cannot be clearly established, due to the highly disturbed nature of the context and evidence of considerable previous construction activity nearby. Burial 7, though in very poor condition, may have been essentially undisturbed. Preliminary examination of the unerupted tooth cap recovered from Burial 7 suggests that it belonged to a child between the ages of 3.5 and 6.5 years.

It is likely that other bones from Burial 6 were removed during that previous construction. It is even possible that the bones found roughly $50 \mathrm{~m}$ south of Burial 6, which were designated Burial 5, are some of those missing from Burial 6. It is highly unlikely that it will be possible to prove or disprove this speculation, and only the fact that Burial 6 was apparently disturbed by placement of the same sewer line near which Burial 5 was found makes the suggestion tenable.

\section{Artifacts}

The methods used during the monitoring project at $41 \mathrm{NU} 2$, combined with the nature of most of the artifacts, made recognition difficult. Most artifacts that were recognized are made of shell, and most were surrounded by hundreds, if not thousands of shells that had not been modified. There is no doubt that many artifacts were present but not seen from the top of the trench. The small number of artifacts presented here should not be considered evidence that few artifacts were, or are, present at $41 \mathrm{NU} 2$. This section can serve to show the sorts of artifacts that can be expected at similar sites, but it cannot serve to suggest what proportion of each type is likely to be found in the future.

A total of 123 artifacts was identified during this project, of which 33 were lithics (26.8 percent), 7 were bone (5.7 percent) and 83 were shell ( 67.5 percent). These artifacts will be described and discussed below.

\section{Lithic Artifacts}

Jason B. Perez

Thirty-three lithic artifacts were recovered from 41NU2 (Table $5-1)$. Of these, 25 (76\%) came from feature matrix and were recovered during flotation. Eleven features $(1,41,57,65$, $73,75,81,90,110,117,166)$ contained lithic artifacts. Of these, Feature 65 had ten specimens, Feature 73 had three, Features 57, 75 and 90 had two each and all others had one specimen each. All of the feature associated lithic artifacts are unmodified lithic debitage. Of the 33 lithic artifacts, only two are dart points, all others are unmodified lithic debitage. 
Table 5-1. Lithic Artifacts from 41NU2

\begin{tabular}{|c|c|c|c|c|c|c|c|c|}
\hline $\begin{array}{l}\text { FS \# } \\
\text { Lot }\end{array}$ & Feature & $\begin{array}{c}\text { Depth } \\
\text { (cm bgs) }\end{array}$ & $\begin{array}{l}\text { Artifact } \\
\text { Category }\end{array}$ & Completeness & Cortex & Flake Type & $\begin{array}{l}\text { Max } \\
\text { Dimension } \\
(\mathbf{m m})\end{array}$ & Comments \\
\hline 129 & near F-40 & 83 & dart point & proximal frag & - & - & - & $\begin{array}{l}\text { Possible Matamoros dart point; heavy } \\
\text { rejuvenation; stem appears to have } \\
\text { a slight neck which does not fit with } \\
\text { Matamoros type }\end{array}$ \\
\hline 406 & - & backdirt & dart point & complete & - & - & - & $\begin{array}{l}\text { Matamoros or heavily rejuvenated } \\
\text { Tortugas dart point }\end{array}$ \\
\hline $238-1$ & 57 & $60-70$ & unmodified deb. & proximal frag & secondary & hard hammerstone & 19.2 & $\begin{array}{l}\text { Coarse grained chert with corticate } \\
\text { platform }\end{array}$ \\
\hline $238-2$ & 57 & $60-70$ & unmodified deb. & complete & secondary & hard hammerstone & 7.5 & Small corticate platform flake \\
\hline 449 & - & 72 & unmodified deb. & distal frag & tertiary & indeterminate & 17.3 & Fine-grained chert \\
\hline 270 & 65 & 45 & unmodified deb. & complete & tertiary & pressure & 4.3 & Single faceted flake \\
\hline 534 & 166 & 50 & unmodified deb. & longitudinal frag & tertiary & pressure & 7.4 & Dark fine-grained chert \\
\hline 447 & - & 72 & unmodified deb. & proximal frag & secondary & hard hammerstone & 16.9 & Single faceted platform \\
\hline 130 & - & 83 & unmodified deb. & proximal frag & tertiary & indeterminate & 22.5 & Two platform facets; fine-grained chert \\
\hline 229 & 81 & 80 & unmodified deb. & angular debris & secondary & indeterminate & $\mathrm{n} / \mathrm{a}$ & - \\
\hline 270 & 65 & 45 & unmodified deb. & complete & tertiary & pressure & 5.7 & Multiple faceted \\
\hline 270 & 65 & 45 & unmodified deb. & complete & tertiary & pressure & 5.3 & Single faceted platform \\
\hline 270 & 65 & 45 & unmodified deb. & complete & tertiary & pressure & 4.4 & Single faceted platform \\
\hline 270 & 65 & 45 & unmodified deb. & complete & tertiary & pressure & 5.8 & Single faceted platform \\
\hline 270 & 65 & 45 & unmodified deb. & complete & tertiary & pressure & 3.8 & Single faceted platform \\
\hline 270 & 65 & 45 & unmodified deb. & proximal frag & tertiary & pressure & 4.4 & Single faceted platform \\
\hline 270 & 65 & 45 & unmodified deb. & distal frag & tertiary & pressure & 4.3 & - \\
\hline 270 & 65 & 45 & unmodified deb. & distal frag & tertiary & pressure & 5 & - \\
\hline 246 & 90 & $90-110$ & unmodified deb. & longitudinal frag & tertiary & pressure & 5 & Longitudinally split \\
\hline 246 & 90 & $90-110$ & unmodified deb. & angular debris & tertiary & indeterminate & - & - \\
\hline Lot 363 & - & - & unmodified deb. & complete & tertiary & biface thinning & 26.8 & $25 \mathrm{~mm}$ long multi-faceted \\
\hline 209 & 75 & $71-90$ & unmodified deb. & medial frag & secondary & indeterminate & 13.8 & Medial frag; fine-grained chert \\
\hline 209 & 75 & $71-90$ & unmodified deb. & medial frag & tertiary & indeterminate & 4.3 & Medial; fine-grained chert \\
\hline 321 & 117 & $32-42$ & unmodified deb. & complete flake & tertiary & pressure & 6.3 & Multiple faceted platform \\
\hline 7 & 1 & $95-100$ & unmodified deb. & medial frag & tertiary & indeterminate & 7.7 & Medial frag; fine-grained chert \\
\hline 450 & - & 73 & unmodified deb. & medial frag & tertiary & indeterminate & 12.4 & Medial frag; fine-grained chert \\
\hline 199 & 73 & 45 & unmodified deb. & proximal frag & tertiary & pressure & 6.5 & Proximal frag, single faceted \\
\hline 199 & 73 & 45 & unmodified deb. & angular debris & tertiary & indeterminate & - & Small debris \\
\hline 199 & 73 & 45 & unmodified deb. & complete & tertiary & pressure & 9.8 & Single faceted platform \\
\hline 135 & 41 & $74-78$ & unmodified deb. & proximal frag & tertiary & biface & 15.6 & Moderately large proximal frag; \\
\hline 269 & 65 & 60 & unmodified deb. & distal frag & secondary & indeterminate & 19.8 & Moderately large distal flake frag \\
\hline 293 & 110 & 155 & unmodified deb. & complete & secondary & indeterminate & 16.7 & Moderately large flake \\
\hline Lot 42 & - & - & unmodified deb. & medial frag & tertiary & pressure & 6.5 & - \\
\hline
\end{tabular}

\section{Dart Points}

Both dart points are complete and neither was associated with a feature. Of the two points, one, a triangular specimen, appears to be a Tortugas point made of yellow fine-grained chert (Figure 5-23a). While the specimens is relatively short $(23.3 \mathrm{~mm})$ and wide (base width 25 $\mathrm{mm}$ ), both faces contain broad base thinning flake scars that are similar in width to those found on Tortugas rather than the smaller Matamoros points (see Tomka
2002). The margins of the blade have rather steep retouch although it is rather unsystematic and does not classify as beveling. The point has been heavily retouched although examination under both short and long-waive ultraviolet light does not show differential patina of the point. This indicates that the reworking occurred during the use-life of the specimens or shortly thereafter. This point was found on the surface in the North Dune area near 34+041, after removal of a pile of backdirt. Thus, no provenience information is available. 


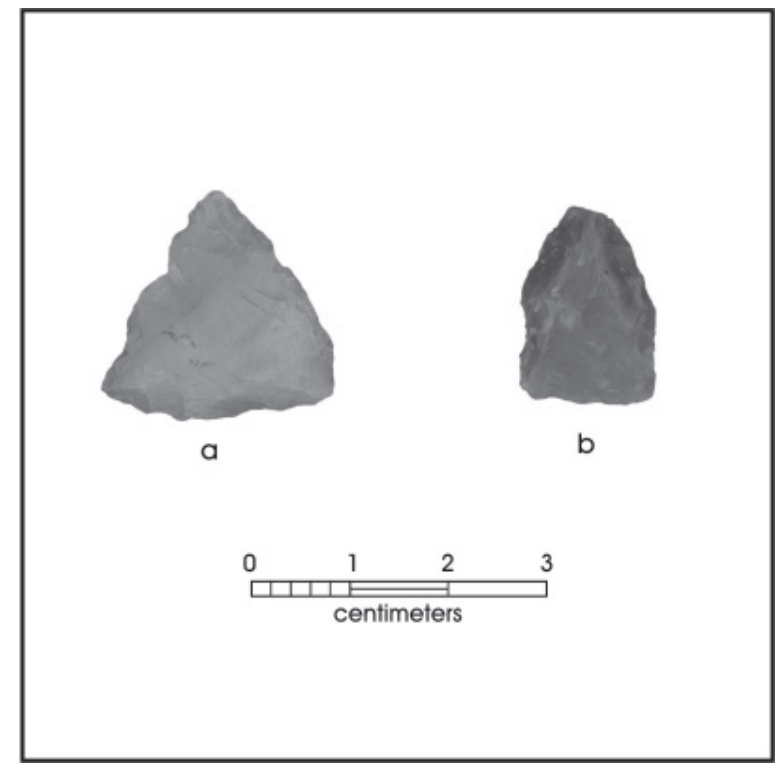

Figure 5-23 Heavily retouched dart points: a) Tortugas; b) untyped slightly expanding stemmed point.

The second specimen is also roughly triangular although its final appearance is the product of heavy rejuvenation. It is an untyped straight-based and parallel to very slightly expanding stemmed dart point made on translucent brownish flint (Figure 5-23b). Its blade has been so heavily reworked that it is actually shorter $(10.4 \mathrm{~mm})$ than its stem $(10.9 \mathrm{~mm})$. A small portion of its distal tip is missing due to an impact fracture. The slightly expending stem (neck width 13.4 $\mathrm{mm}$; base width $14.5 \mathrm{~mm}$ ) gives it the appearance of a Darl point although this typological assignment cannot be made with certainty. It was recovered near Feature 40, in OZ-B. A charcoal sample from this $\mathrm{OZ}$ was dated to $2300-1880$ B.P., which cross-cuts the Transitional Archaic, and seems consistent with the possibility that the point is a Darl.

\section{Unmodified Debitage}

Thirty-one pieces of unmodified lithic debitage have been recovered from the site. Only five of these are not associated with features (Table 5-1). Of the 31 pieces, three are angular debris, one of them has cortex the other two are decorticate. Tertiary unmodified debitage $(n=25)$ greatly outnumber secondary pieces. On average they are small (mean maximum dimension $=8.7 \mathrm{~mm}$ ) and have small platforms and diffused bulbs of percussion. These traits indicate that the majority of them were removed by pressure flaking either during tool rejuvenation or the final stages of tool manufacture. Secondary flakes are on average larger $(15.6 \mathrm{~mm})$ than tertiary specimens. The fact that two of them have corticated platforms in combination with their larger size suggests that the raw materials they represent may not have been obtained far from the site, though to date no source for chert cobbles closer than the one described by Chandler (1984:27) has been found. Chandler's (1984) report described a chert gravel outcrop being eroded by the Nueces River at a point about $54 \mathrm{~km}$ upstream of the mouth of the river in Nueces Bay and about $57 \mathrm{~km}$ from $41 \mathrm{NU} 2$.

\section{Bone Artifacts}

Eight artifacts made of bone, most of them fragmentary, were recovered during the project. The complete list is provided in Table 5-2. Bone artifacts of particular interest were two beads, and two bone tools made on the metatarsals of artiodactyls.

\section{Beads}

Bone beads are inherently fragile and small, and therefore it is not surprising, that only one was identified during monitoring. The one complete bead was made out of bird bone, and was found in Feature 169 (Figure 5-24a). It is unusually short for a bird bone bead, but wear-polish on both sides indicate the bead was not broken.

A bone bead with unusually detailed workmanship was found in the soil sample from Feature75 (Figure 5-24b). This bead was carved out of a solid piece of mammalian bone. The faces are concave, the hole is large and appears quite circular. The outer rim of the bead has a groove cut into it. The remaining bead fragment appears to be not quite half of the original bead, which would have had a diameter of roughly $7.8 \mathrm{~mm}$.

\section{Metatarsal tools}

Two bone tools were made of the proximal diaphysis of the metatarsal of artiodactyls, probably deer (Odocoileus virginianus). The first of these was an isolated find, still intact until the weight of the Gradall bucket slid over it. This is an unusually well-made tool, symmetrically smoothed, highly polished, still very sharp (Figure 5-24c). Only minor chemically and biologically induced damage is visible on its surface. The specimen has an oval cross-section. Tools like these have traditionally been referred to as awls. Microscopic scratches running parallel to the long axis are present across $15.5 \mathrm{~mm}$ of the distal end. These appear to have been acquired during use.

The second specimen is a fragmentary metatarsal tool similar to the one described above although it may have been somewhat shorter when complete (Figure 5-24d). It is encrusted with a layer of calcium carbonate and the 
Table 5-2. Bone Artifacts from 41NU2

\begin{tabular}{|c|c|c|c|c|c|}
\hline Provenience & Feature & $\begin{array}{c}\text { Length } \\
(\mathrm{mm})\end{array}$ & $\begin{array}{l}\text { Width } \\
(\mathrm{mm})\end{array}$ & $\begin{array}{l}\text { Wgt. } \\
\text { (g) }\end{array}$ & Notes \\
\hline $\begin{array}{l}15 \mathrm{~m} \mathrm{~N} \text { of CL at } \\
409.1,140 \mathrm{cmbs}\end{array}$ & 169 & 5.9 & 6.0 & 0.1 & Small, complete bird bone bead. Figure 5-25a; \\
\hline $\begin{array}{l}13.2 \mathrm{E} \text { of } \mathrm{CL} \text { at } \\
34+090.5,71-90 \\
\text { cmbs }\end{array}$ & 75 & 6.5 & 2.8 & 0.3 & $\begin{array}{l}\text { Bone bead fragment, not made from bird bone, but the } \\
\text { fragment is too small to be identifiable. The bead was very } \\
\text { well made, with concave faces, and a groove cut on the outer } \\
\text { edge. It would have been ca. } 7 \mathrm{~mm} \text { in diameter. Figure } 5-25 \mathrm{~b} \text {; }\end{array}$ \\
\hline $\begin{array}{l}11.09 \mathrm{~m} \mathrm{E} \text { of } \mathrm{CL} \\
\text { at } 33+595.2,64 \\
\mathrm{cmbs}\end{array}$ & - & 116.2 & 15.9 & 11.9 & $\begin{array}{l}\text { Beautifully made bone tool, complete until it was broken by } \\
\text { the Gradall. Highly polished and still with an extremely sharp } \\
\text { point that was broken from the tip. Figure } 5-25 \mathrm{c} \text {; }\end{array}$ \\
\hline $\begin{array}{l}14.6 \mathrm{~m} \mathrm{E} \mathrm{CL} \text { at } \\
34+095.2,80 \\
\mathrm{cmbs}\end{array}$ & 74 & 65.4 & 12.5 & 4.1 & $\begin{array}{l}\text { Bone tool made on a fragment of artiodactyl metatarsal, with } \\
\text { small areas of the anterior left on the tool. Well smoothed, } \\
\text { with distal end broken. Figure } 5-25 \mathrm{~d} \text {; }\end{array}$ \\
\hline $\begin{array}{l}1 \mathrm{~m} \mathrm{~W} \text { of CL at } \\
34+185.51 .20- \\
120 \mathrm{cmbs}\end{array}$ & 136 & 54.0 & 6.4 & 1.2 & $\begin{array}{l}\text { Highly polished fish bone, possibly a spine, smoothed and } \\
\text { shaped, found in the same backdirt in which the disarticulated } \\
\text { elements of Burial } 4 \text { were located. Figure } 5-25 \mathrm{e} \text {; }\end{array}$ \\
\hline $\begin{array}{l}14.6 \mathrm{~m} \mathrm{E} \text { of CL } \\
\text { at } 34+139.2,25- \\
32 \mathrm{cmbs}\end{array}$ & 114 & 4.5 & 9.0 & 0.1 & Fragment of a bone tool, heavily burned and polished; \\
\hline $\begin{array}{l}10.73 \mathrm{~m} \mathrm{E} \text { of CL } \\
\text { at } 34+012,84 \\
\mathrm{cmbs}\end{array}$ & - & 27.6 & 11.7 & 1.3 & $\begin{array}{l}\text { Small fragment of a bone tool, with clear shaping and } \\
\text { smoothing that is too small to identify further; }\end{array}$ \\
\hline
\end{tabular}

bone surface appears more weathered than the complete specimen. It may not have been finished, as remnants of the anterior portion of the metatarsal are still present on the bone and the polish is uneven.

\section{Other Bone Artifacts}

One artifact of unknown use was made on a fish bone, probably a dorsal or haemal spine of a large fish. The bone is very highly polished and lightly burned (Figure 5-24e). It appears to have been only minimally shaped. The bone is broken on both ends, but a series of microscopic scratches cutting through the polish and running perpendicular to the length of the bone can be seen at the distal end near the break. This tool was found in the same backdirt which contained Burial 4. It is impossible to know if it was associated with the burial.

One fragment of a bone tool only $11.5 \mathrm{~mm}$ long was recovered from the soil sample from Feature 114. The fragment is heavily burned and highly polished, and appears to be a segment near the distal end of a pointed tool. Another fragment from Trench B in the North Dune shows clear evidence of shaping and smoothing but is too small to identify further.

\section{Shell}

There were 83 modified shells identified during this project, although as mentioned above, these artifacts were often surrounded by many shells that were simply the remains of a meal. Six species of mollusk showed evidence of tool manufacture or other deliberate modification. By far the most common shells modified into tools were those of Sunray Venus clams (Macrocallista nimbosa, $\mathrm{n}=38$ ) and Lightning Whelks (Busycon sinistrum, $\mathrm{n}=32$ ). Nine perforated Eastern Oyster shells (Crassostrea virginica) and one oyster shell ground into a tool were also recovered. One shell each of Florida Horse Conch (Pleuroploca gigantea), Southern Quahog (Mercenaria campechiensis) and Banded Tulip (Fasciolaria lillium) also showed modifications. All modified shells are listed in Table 5-3. In addition, some modified shells of particular interest are shown in Figures 5-25 through 5-32 and discussed below. The discussion of the modified shells is organized by shell species rather than tool form.

\section{Modified Sunray Venus shells}

The thin but dense shells of Sunray Venus clams were commonly used for tools along the Texas coast, in many cases replacing stone tools where chert and other stone was so difficult to obtain (Ricklis 2004). The shells of 


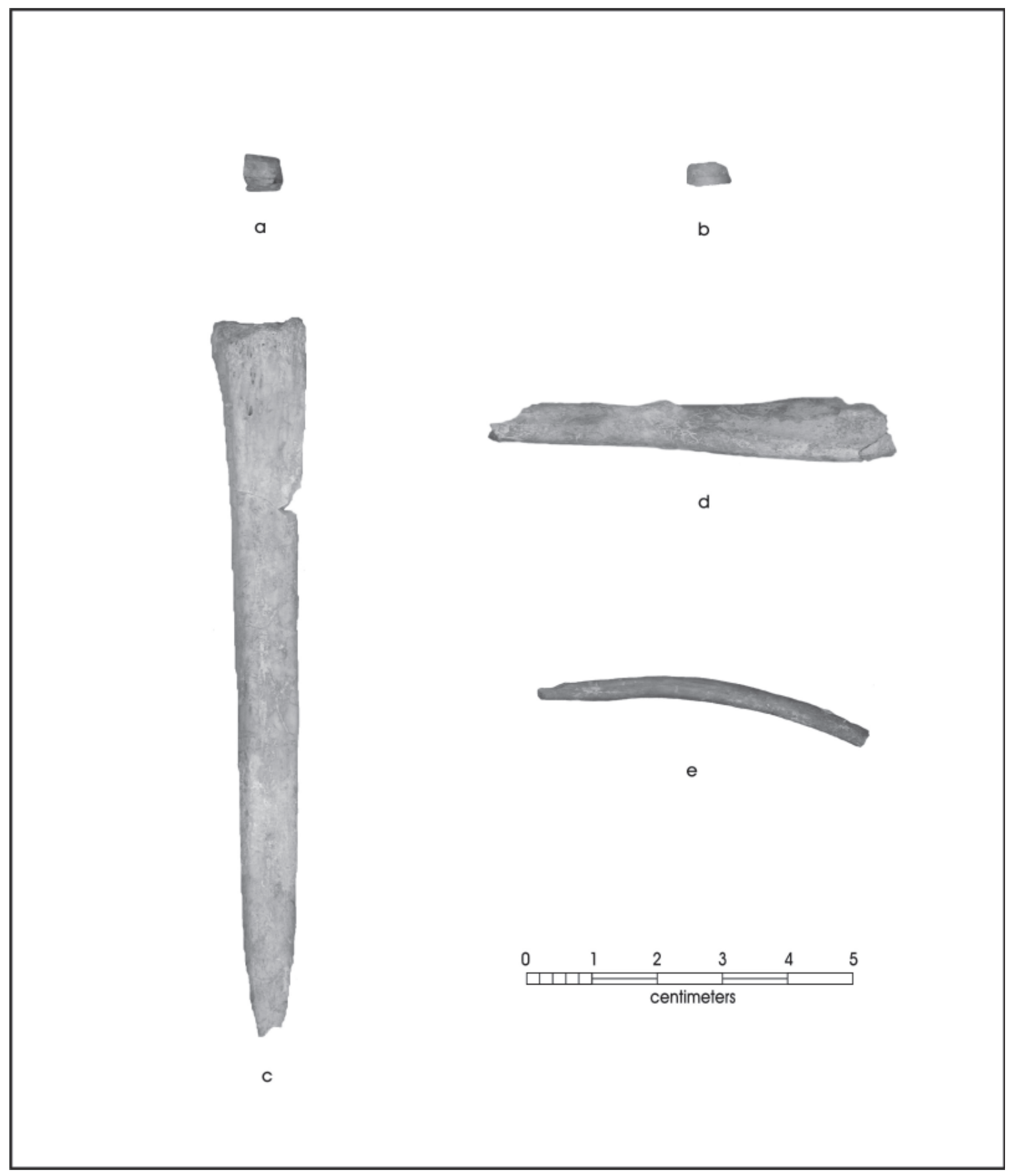

Figure 5-24. Bone artifacts: a) bird bone bead from Feature 169; b) bone bead fragment from Feature 75; c) complete metatarsal tool; d) fragmentary metatarsal tool; e) fish bone tool.

Sunrays can be ground or chipped to shape them into useful impediments.

Ground shell tools. Eighteen ground Sunray shells were identified during the project (Table 5-3), six of the more complete ones are discussed in some detail. Tools made by grinding Sunray shells typically made use of the way that Sunray shells naturally break, which often leaves a long edge with some of the harder outer shell removed. In these cases the inner shell was often ground down so the edge became very sharp. Figure 5-25a shows a tool in which an S-curved break was sharpened by grinding. A large portion of this edge has broken off, but some of the grinding is still visible under the microscope. Also visible are a number of deep scratches running perpendicular to the long axis of the shell, suggesting that after the sharp edge was broken away, the tool was used at least briefly as a scraper. 
Another tool, roughly triangular in shape was also ground (Figure 5-25b), though again, most of the ground edge has broken away. Both the grinding and the scratches that are presumably part of the use-wear on this tool are readily visible under the microscope. The third specimen (Figure $5-25 \mathrm{c})$ is a rectangular shell fragment that has been ground on two edges. The third edge is the naturally thinned ventral edge of the shell, and the fourth edge is a break. The fourth ground shell tool (Figure 5-25d) is a triangular shaped tool, with the hinge plate forming one edge. The single ground edge is still sharp enough to break the skin and shows little use damage, unlike the tools described above.

The fifth specimen (Figure 5-25e) is a ground Sunray shell tool of particular interest because it was found among the cattle bone in Feature 170. It is a long sliver of Sunray shell ground along one edge. Although most of the evidence of grinding has been removed by post-depositional breakage, grinding is clearly visible on the distal end. The development of a fairly thick patina prevents examination for use-wear scratches. Because the cattle bone were dumped into an erosional gully and later covered by a natural infilling process, this shell tool and one other found in the same location (see below) were not likely associated with the cattle bone discard. However, their presence does open the possibility that Feature 170 represents a Protohistoric component at the site.

The sixth tool (Figure 5-25f) was recovered from Feature 151. It was made by breaking away the shell hinge plate and then grinding the hinge plate into a long thin tool. The end has broken off so there is no way to tell if it was pointed or flat.

Chipped Shell Tools. The shells of Sunrays are very dense, though quite thin, and the Native Americans of the Texas Coast found that they could be chipped in much the same way as chert. Ten chipped Sunray shell tools were identified. Four are discussed in some detail below.

Most chipped shell tools seem to be made by simply chipping the ventral edges of the shells and leaving the rest or most of the rest of the shell intact. The specimens shown in Figures 5-26a and 5-26b are broken examples of chipped shell tools with unifacial chipping along the ventral edges of the shells.

Table 5-3. Modified Shell Artifacts from 41NU2

\begin{tabular}{|c|c|c|c|c|c|}
\hline Provenience & Feature & $\begin{array}{c}\text { Length } \\
(\mathrm{mm})\end{array}$ & $\begin{array}{l}\text { Width } \\
(\mathrm{mm})\end{array}$ & $\begin{array}{l}\text { Wgt. } \\
\text { (g) }\end{array}$ & Notes \\
\hline \multicolumn{6}{|c|}{ Sunray Venus Clam (Macrocallista nimbosa) } \\
\hline \multicolumn{6}{|r|}{ Ground } \\
\hline $\begin{array}{l}\text { Backdirt near } 34+062 \text { on } \\
\text { west side }\end{array}$ & - & 95.2 & 42.6 & 24.2 & $\begin{array}{l}\text { A large Sunray with a curved break that has been ground to an edge. Most of } \\
\text { this edge has been broken away but the remnants of the grinding is still visible. } \\
\text { Figure 5-26a; }\end{array}$ \\
\hline $3.28 \mathrm{~m} \mathrm{E}$ of $\mathrm{Cl}$ at $33+919.2$ & 76 & 76.9 & 37.5 & 7.1 & $\begin{array}{l}\text { Large triangular fragment of Sunray shell, ground to an edge on all sides, with two } \\
\text { sides showing some random chipping that may be use wear. Figure 5-26b; }\end{array}$ \\
\hline $\begin{array}{l}14.6 \mathrm{~m} \mathrm{E} \text { of CL at } 34.074 .1 \\
49 \mathrm{cmbs}\end{array}$ & 65 & 37.8 & 29.9 & 4.6 & $\begin{array}{l}\text { Sunray shell fragment, roughly rectangular though it is broken on two edges. Two } \\
\text { edges have been ground smooth. Figure } 5-26 \mathrm{c} \text {; }\end{array}$ \\
\hline $\begin{array}{l}14.3 \mathrm{~m} \mathrm{E} \text { of CL at } \\
34+047.7,46 \mathrm{cmbs}\end{array}$ & 98 & 57.8 & 30.3 & 12.5 & $\begin{array}{l}\text { Sunray Venus shell snapped into a triangle, with one edge sharpened by grinding. } \\
\text { Figure 5-26d; }\end{array}$ \\
\hline $\begin{array}{l}19.7 \mathrm{~m} \mathrm{~N} \text { of CL at } 3+412.6 \text {, } \\
97 \mathrm{cmbs}\end{array}$ & 170 & 52.4 & 10.2 & 2.9 & $\begin{array}{l}\text { Long Sunray fragment ground along one edge. Only the distal end still shows } \\
\text { grinding. Found in association with cattle bone in Ftr. 170, but could easily have } \\
\text { been washed into the gully. Figure 5-26e; }\end{array}$ \\
\hline $\begin{array}{l}12.2 \mathrm{~W} \text { of } \mathrm{CL} \text { at } 34+058.5 \text {, } \\
57-62\end{array}$ & 151 & 43.7 & 14.8 & - & $\begin{array}{l}\text { Sunray shell, with hinge plate extending from the umbo ground into a long thin } \\
\text { extention, which has broken. Figure 5-26f; }\end{array}$ \\
\hline $\begin{array}{l}11.3 \mathrm{~m} \mathrm{E} \text { of CL at } \\
34+084.5,45 \mathrm{cmbs}\end{array}$ & 73 & 22.3 & 16.5 & 1.2 & Sunray shell tool made on a small triangular chip, with ground edges; \\
\hline $\begin{array}{l}13.2 \mathrm{~m} \mathrm{E} \text { of CL at } \\
34+090.5,71-90 \mathrm{cmbs}\end{array}$ & 75 & 65.2 & 24.5 & 14.8 & A Sunray shell snapped parallel to the umbo, then ground to sharpen; \\
\hline $\begin{array}{l}14.7 \mathrm{~m} \mathrm{E} \text { of CL at } 33+589, \\
110 \mathrm{cmbs}\end{array}$ & 84 & 26.5 & 15.7 & 2.0 & $\begin{array}{l}\text { Sunray shell fragment, roughly rectangular though it is broken on two edges. Two } \\
\text { edges have been chipped to make an edge; }\end{array}$ \\
\hline $\begin{array}{l}14.7 \mathrm{~m} \mathrm{E} \text { of CL at } \\
34+060.4,42 \mathrm{cmbs}\end{array}$ & 100 & 20.8 & 21.5 & 1.9 & A Sunray shell fragment with one edge ground to sharpen; \\
\hline $\begin{array}{l}14.7 \mathrm{~m} \mathrm{E} \text { of } 34+064,42 \\
\mathrm{cmbs}\end{array}$ & 100 & 16.0 & 10.0 & 0.2 & Thin fragment of a Sunray shell ground to a very sharp edge on two sides; \\
\hline
\end{tabular}


Table 5-3. Continued...

\begin{tabular}{|c|c|c|c|c|c|}
\hline Provenience & Feature & $\begin{array}{c}\text { Length } \\
(\mathrm{mm})\end{array}$ & $\begin{array}{l}\text { Width } \\
\text { (mm) }\end{array}$ & $\begin{array}{l}\text { Wgt. } \\
\text { (g) }\end{array}$ & Notes \\
\hline \multicolumn{6}{|c|}{ Sunray Venus Clam (Macrocallista nimbosa) } \\
\hline \multicolumn{6}{|r|}{ Ground } \\
\hline $14.5 \mathrm{~m} \mathrm{E}$ of $\mathrm{CL}$ at $34+136$ & 114 & 23.4 & 13.1 & 1.0 & $\begin{array}{l}\text { Small fragment of Sunray shell that appears to have been sharpened, but also is too } \\
\text { weathered to tell for sure; }\end{array}$ \\
\hline $\begin{array}{l}14.6 \mathrm{~m} \mathrm{E} \text { of CL at } \\
34+139.2,25-32 \mathrm{cmbs}\end{array}$ & 114 & 21.6 & 15.0 & 1.2 & $\begin{array}{l}\text { Sunray shell fragment, roughly rectangular though it is broken on three edges, and } \\
\text { ground to an edge. The entire tool fragment is heavily patinated; }\end{array}$ \\
\hline $\begin{array}{l}14.4 \mathrm{~m} \mathrm{E} \text { of the } \mathrm{CL} \text { at } \\
33+902.6,110-115 \mathrm{cmbs}\end{array}$ & 121 & 22.0 & 16.3 & 1.3 & $\begin{array}{l}\text { Fragment of Sunray shell ground on one edge to sharpen. This appears to be a } \\
\text { fragment of a larger tool; }\end{array}$ \\
\hline $\begin{array}{l}2 \mathrm{~m} \mathrm{E} \text { of } \mathrm{Cl} \text { at } 34+174.5 \\
55-60 \mathrm{cmbs}\end{array}$ & 139 & 16.2 & 13.9 & 0.3 & $\begin{array}{l}\text { Small chip of Sunray shell, ground into a roughly square shape. Two edges show } \\
\text { microscopic chipping that may be use wear; }\end{array}$ \\
\hline $\begin{array}{l}2 \mathrm{~m} \mathrm{E} \text { of } \mathrm{Cl} \text { at } 34+174.5 \\
55-60 \mathrm{cmbs}\end{array}$ & 139 & 30.2 & 17.5 & 2.1 & Chip of Sunray shell, ground to sharpen. This is a small piece of a larger tool; \\
\hline $\begin{array}{l}14.5 \mathrm{~m} \mathrm{~N} \text { of CL at } 3+275 \\
30-40 \mathrm{~cm} \text { bs }\end{array}$ & 163 & 43.0 & 21.4 & 3.1 & $\begin{array}{l}\text { Fragment of Sunray shell which appears to have been ground along two edges, } \\
\text { though patination makes this uncertain; }\end{array}$ \\
\hline $\begin{array}{l}14.6 \mathrm{~m} \mathrm{E} \text { of CL at } 34+02.5, \\
78 \mathrm{cmbs}\end{array}$ & - & 32.9 & 19.2 & 1.8 & Small Sunray fragment that has been cut on one edge, and ground to a sharp edge; \\
\hline \multicolumn{6}{|r|}{ Chipped } \\
\hline $\begin{array}{l}14.1 \mathrm{~m} \mathrm{E} \text { of CL at } 34+100 \\
75 \mathrm{cmbs}\end{array}$ & 74 & 64.3 & 31.0 & 8.0 & Broken fragment of a chipped Sunray shell tool. Figure 5-27a; \\
\hline $\begin{array}{l}1 \mathrm{~m} \mathrm{~W} \text { of CL at } 34.148 .5 \\
\text { found on surface }\end{array}$ & - & 78.8 & 42.5 & 14.5 & Sunray shell, with umbo removed, and shell edge flaked. Figure 5-27b; \\
\hline $\begin{array}{l}16.0 \mathrm{~m} \text { E if CL at } 34+041, \\
10-60 \mathrm{cmbs}\end{array}$ & - & 32.1 & 20.0 & 2.3 & $\begin{array}{l}\text { Sunray shell fragment, roughly rectangular though it is broken on two edges. Two } \\
\text { edges have been chipped to make an edge.Figure } 5-27 \mathrm{c} \text {; }\end{array}$ \\
\hline $\begin{array}{l}14.7 \mathrm{~m} \text { E of } 34+064,42 \\
\mathrm{cmbs}\end{array}$ & 100 & 20.5 & 8.4 & 0.5 & $\begin{array}{l}\text { Small fragment of chipped Sunray shell that appears to have been used as blade. } \\
\text { Tiny chips were removed bifacially along the two long edges. Figure 5-27d; }\end{array}$ \\
\hline $\begin{array}{l}14.5 \mathrm{~m} \text { E of CL at } 34.087, \\
58 \mathrm{cmbs}\end{array}$ & 65 & 41.3 & 31.8 & 8.9 & Sunray shell tool with chipped edge; \\
\hline $\begin{array}{l}12.3 \mathrm{~m} \mathrm{E} \text { of CL at } 34+105 \\
73-80 \mathrm{cmbs}\end{array}$ & 74 & 15.4 & 12.4 & 0.8 & Fragment of chipped Sunray shell tool; \\
\hline $\begin{array}{l}12.3 \mathrm{~m} \mathrm{E} \text { of CL at } 34+105 \\
73-80 \mathrm{cmbs}\end{array}$ & 74 & 31.6 & 18.2 & 1.6 & Fragment of chipped Sunray shell tool; \\
\hline $3.2 \mathrm{~m} \mathrm{E}$ of $\mathrm{CL}$ at $33+919.5$ & 76 & - & - & - & $\begin{array}{l}\text { Eight small fragments of Sunray shell that may have been chipped in the process of } \\
\text { making a tool. They are quite different from the normal break pattern seen in this } \\
\text { shell type, but it is not possible to be certain that they are shell tool "debitage"; }\end{array}$ \\
\hline $\begin{array}{l}8 \mathrm{~m} \mathrm{E} \text { of CL } 34+003,110 \\
\mathrm{cmbs}\end{array}$ & 90 & 34.6 & 13.3 & 1.6 & Fragment of Sunray shell tool with chipped edge; \\
\hline $\begin{array}{l}8 \mathrm{~m} \mathrm{E} \text { of CL } 34+003,110 \\
\mathrm{cmbs}\end{array}$ & 90 & 22.2 & 12.7 & 0.8 & Fragment of Sunray shell tool with chipped edge; \\
\hline $\begin{array}{l}5 \mathrm{~m} \mathrm{E} \text { of CL at } 34+212.8, \\
65 \mathrm{cmbs}\end{array}$ & 133 & 23.8 & 13.6 & 0.6 & Thin fragment of a Sunray shell with chipped semi-circles along one edge; \\
\hline \multicolumn{6}{|c|}{ Lightning Whelk (Busycon sinistrum) } \\
\hline \multicolumn{6}{|c|}{ "Cups/Scoops" } \\
\hline $\begin{array}{l}15.6 \mathrm{~m} \mathrm{E} \text { of CL at } 33+635 \\
92-110 \mathrm{cmbs}\end{array}$ & 88 & 104.3 & 84.2 & 180.0 & $\begin{array}{l}\text { Large Lightning Whelk with the lip of the body whorl cut and smoothed, the } \\
\text { columnella below the outer body whorl cut off and smoothed. Three impacts are } \\
\text { evident, one on top of whorl, and two on the outer body whorl, and one of these } \\
\text { broke a hole in the shell. This artifact is a type sometimes referred to as a "cup" or } \\
\text { "scoop". Figure 5-28; }\end{array}$ \\
\hline $\begin{array}{l}12.9 \mathrm{~m} \mathrm{E} \text { of } \mathrm{CL} \text { at } 33+905 \text {, } \\
113-122 \mathrm{cmbs}\end{array}$ & 53 & 68.4 & 44.0 & 27.4 & $\begin{array}{l}\text { Small Lightning Whelk shell with columnella cut short and smoothed. The edge of } \\
\text { the body whorl may hav been cut and smoothed, but it has been broken except at } \\
\text { the end near the columnella cut; }\end{array}$ \\
\hline
\end{tabular}


Table 5-3. Continued...

\begin{tabular}{|c|c|c|c|c|c|}
\hline Provenience & Feature & $\begin{array}{c}\text { Length } \\
(\mathrm{mm})\end{array}$ & $\begin{array}{l}\text { Width } \\
(\mathrm{mm})\end{array}$ & $\begin{array}{l}\text { Wgt. } \\
\text { (g) }\end{array}$ & Notes \\
\hline \multicolumn{6}{|c|}{ Lightning Whelk (Busycon sinistrum) } \\
\hline \multicolumn{6}{|r|}{ "Cups/Scoops" } \\
\hline $\begin{array}{l}15.5 \mathrm{~m} \mathrm{~W} \text { of } \mathrm{CL} \text { at } 34+22.5 \\
95-105 \mathrm{cmbs}\end{array}$ & 141 & 72.0 & 55.7 & 22.0 & $\begin{array}{l}\text { Medium-small Lightning Whelk with edge of body whorl cut and smoothed and the } \\
\text { end of the columnella cut off and smoothed. Most of the spire is missing; }\end{array}$ \\
\hline \multicolumn{6}{|r|}{ "Gouges" } \\
\hline $\begin{array}{l}14.5 \mathrm{~m} \mathrm{~N} \text { of the } \mathrm{Cl} \text { at } \\
3+275,30-40 \mathrm{cmbs}\end{array}$ & 163 & 120.9 & 80.40 & 115.4 & $\begin{array}{l}\text { Large Lightning Whelk with edge of body whorl cut and smoothed and the end of } \\
\text { the columnella shaped into a flat point. Figure 5-29a; }\end{array}$ \\
\hline $\begin{array}{l}16.7 \mathrm{~m} \mathrm{E} \text { of } \mathrm{CL} \text { at } 33+656, \\
15 \mathrm{cmbs}\end{array}$ & - & 64.2 & 38.9 & 12.6 & $\begin{array}{l}\text { Small Lightning Whelk with the edge of the body whorl cut and smoothed and the } \\
\text { end of the columnella shaped into a point, the the adjacent edge of the body whorl } \\
\text { thinned to a sharp edge. Though reminiscent of a gouge, the shell would have been } \\
\text { extremely fragile, so whatever was to be gouged would have to have been very } \\
\text { soft. Figure 5-29b; }\end{array}$ \\
\hline $\begin{array}{l}17.5 \mathrm{~m} \mathrm{E} \text { of } \mathrm{CL} \text { at } 33+657 \\
15 \mathrm{cmbs}\end{array}$ & - & 42.6 & 6.0 & 1.6 & Lightning Whelk columnella fragment ground into a blunt point. Figure 5-29c; \\
\hline $\begin{array}{l}11.4 \mathrm{~m} \mathrm{~W} \text { of CL at } 34+020 \\
65 \mathrm{cmbs}\end{array}$ & - & 57.5 & 9.5 & 3.3 & $\begin{array}{l}\text { Lightning Whelk columnella fragment ground into a very sharp point. Figure } \\
5-29 \mathrm{~d} \text {; }\end{array}$ \\
\hline $\begin{array}{l}\text { Backdirt near } 34+015 \text { on } \\
\text { west side. }\end{array}$ & - & 42.7 & 3.8 & 0.7 & $\begin{array}{l}\text { Columnella of a small Lightning Whelk, ground smooth with two sharp points. } \\
\text { Figure 5-29e; }\end{array}$ \\
\hline $\begin{array}{l}9 \mathrm{~m} \mathrm{~W} \text { of CL at } 34+006.5 \\
140 \mathrm{cmbs}\end{array}$ & 137 & 81.9 & 8.5 & 4.3 & $\begin{array}{l}\text { Lightning Whelk columnella fragment ground into a a flat point, which subsequently } \\
\text { broke off. The proximal end was also ground to a blunt, rounded point. Figure } \\
\text { 5-29f; }\end{array}$ \\
\hline $\begin{array}{l}11.7 \mathrm{~m} \mathrm{~W} \text { of } \mathrm{CL} \text { at } 34+017 \text {, } \\
79 \mathrm{cmbs}\end{array}$ & 148 & 51.3 & 10.1 & 3.5 & $\begin{array}{l}\text { Lightning Whelk columnella with most of body whorl removed, the distal end } \\
\text { smoothed. At the distal end a small part of the body whorl has been left, and } \\
\text { smoothed into a sort of "tooth" adjacent to the smoothed scoop of the distal } \\
\text { columnella, probably to use as a type of gouge. Figure } 5-29 \mathrm{~g} \text {; }\end{array}$ \\
\hline $\begin{array}{l}10.2 \mathrm{~m} \mathrm{E} \text { of CL at } 33+560 \\
143 \mathrm{~cm} \text { bs }\end{array}$ & 15 & 91.0 & 50.8 & 29.8 & $\begin{array}{l}\text { Medium-small Lightning Whelk with edge of body whorl cut and smoothed and the } \\
\text { end of the columnella shaped into a point; }\end{array}$ \\
\hline $\begin{array}{l}32.2 \mathrm{~m} \mathrm{E} \text { of } \mathrm{CL} \text { at } 34.151 \\
73 \mathrm{cmbs}\end{array}$ & 99 & 26.2 & 9.4 & 1.5 & Lightning Whelk columnella fragment ground into blunt point; \\
\hline $\begin{array}{l}14.6 \mathrm{~m} \mathrm{E} \text { of } \mathrm{CL} \text { at } \\
34+139.2,25-32 \mathrm{cmbs}\end{array}$ & 114 & 17.3 & 6.0 & 0.3 & $\begin{array}{l}\text { Columnella fragment of a very small Lightning Whelk with the distal end ground } \\
\text { to a blunt, flat point; }\end{array}$ \\
\hline $\begin{array}{l}7.4 \mathrm{~m} \mathrm{E} \text { of CL at } 33+546.5 \\
152 \mathrm{cmbs}\end{array}$ & 125 & 34.1 & 8.8 & 1.8 & Broken tip of a smoothed Lightning Whelk columnella; \\
\hline $\begin{array}{l}7.4 \mathrm{~m} \mathrm{E} \text { of CL at } 33+546.5 \\
152 \mathrm{cmbs}\end{array}$ & 125 & 43.1 & 8.9 & 3.5 & Broken tip of a smoothed Lightning Whelk columnella; \\
\hline $\begin{array}{l}11.7 \mathrm{~m} \mathrm{~W} \text { of CL at } 34+017 \\
79 \mathrm{cmbs}\end{array}$ & 148 & 42.0 & 15.5 & 1.5 & $\begin{array}{l}\text { Small Lighning Whelk, with most of body whorl removed and the columnella } \\
\text { ground to a sharp point; }\end{array}$ \\
\hline $\begin{array}{l}11.7 \mathrm{~m} \mathrm{~W} \text { of } \mathrm{CL} \text { at } 34+017 \text {, } \\
79 \mathrm{cmbs}\end{array}$ & 148 & 62.6 & 12.7 & 1.5 & $\begin{array}{l}\text { Columnella fragment of a small Lightning Whelk with the distal end ground to a } \\
\text { blunt, flat point; }\end{array}$ \\
\hline $\begin{array}{l}14.5 \mathrm{~m} \mathrm{~N} \text { of the } \mathrm{Cl} \text { at } \\
3+275,30-40 \mathrm{cmbs}\end{array}$ & 163 & 52.8 & 27.3 & 7.8 & $\begin{array}{l}\text { Small Lightning Whelk with edge of body whorl cut back but the edge along the } \\
\text { suture not smoothed. The end of the columnella was cut at an angle and smoothed; }\end{array}$ \\
\hline $\begin{array}{l}14.5 \mathrm{~m} \mathrm{~N} \text { of the } \mathrm{Cl} \text { at } \\
3+275,30-40 \mathrm{cmbs}\end{array}$ & 163 & 44.0 & 20.0 & 3.7 & $\begin{array}{l}\text { Small Lightning Whelk with end of the columnella was cut at an angle and } \\
\text { smoothed; }\end{array}$ \\
\hline $\begin{array}{l}16.5 \mathrm{~m} \mathrm{E} \text { of } \mathrm{CL} \text { at } \\
33+653.5 \text {, found in backdirt }\end{array}$ & - & 60.7 & 9.8 & 3.3 & $\begin{array}{l}\text { Lightning Whelk columnella fragment ground into a flattened, somewhat rounded } \\
\text { point; }\end{array}$ \\
\hline $16.5 \mathrm{~m} \mathrm{E}$ of CL at $33+653.5$ & - & 43.3 & 7.5 & 1.5 & $\begin{array}{l}\text { Columnella of a small Lightning Whelk, with distal end smoothed into a scoop } \\
\text { shape; }\end{array}$ \\
\hline $\begin{array}{l}16.5 \mathrm{~m} \mathrm{E} \text { of CL at } \\
33+653.5,15 \mathrm{cmbs}\end{array}$ & - & 45.3 & 7.5 & 2.1 & Lightning Whelk columnella fragment ground into a sharp point; \\
\hline
\end{tabular}


Table 5-3. Continued...

\begin{tabular}{|c|c|c|c|c|c|}
\hline Provenience & Feature & $\begin{array}{c}\text { Length } \\
(\mathrm{mm})\end{array}$ & $\begin{array}{l}\text { Width } \\
(\mathrm{mm})\end{array}$ & $\begin{array}{l}\text { Wgt. } \\
\text { (g) }\end{array}$ & Notes \\
\hline \multicolumn{6}{|c|}{ Lightning Whelk (Busycon sinistrum) } \\
\hline \multicolumn{6}{|c|}{ Scrapers and smoothers } \\
\hline $\begin{array}{l}16.7 \mathrm{~m} \mathrm{~S} \text { of } \mathrm{CL} \text { at } 3+233 \text {, } \\
25 \mathrm{cmbs}\end{array}$ & 147 & 148.5 & 53.1 & 62.2 & $\begin{array}{l}\text { Large Lightning Whelk with entire outer body whorl removed and edge near suture } \\
\text { smoothed to an edge, possibly for use as a scraper. The columnella does not appear } \\
\text { to have been modified. Figure 5-30a; }\end{array}$ \\
\hline $\begin{array}{l}\text { Backdirt near } 34+004.5 \text { on } \\
\text { west side }\end{array}$ & - & 94.3 & 52.9 & 40.3 & $\begin{array}{l}\text { Medium-sized Lightning Whelk with outer body whorl removed and edge near the } \\
\text { suture smoothed, possibly for use as a scraper. Figure 5-30b; }\end{array}$ \\
\hline $\begin{array}{l}\text { Backdirt near } 27 \mathrm{~m} \text { E of } C L \\
\text { at } 34+192.5 \text { on west side }\end{array}$ & - & 139.0 & 58.3 & 116.4 & $\begin{array}{l}\text { Large Lightning Whelk with outer body whorl cut off and the edge smoothed to the } \\
\text { suture line, which is highly polished. The end of the columnella has been sharpened } \\
\text { as well, though it is broken. Figure 5-30c; }\end{array}$ \\
\hline $\begin{array}{l}13 \mathrm{~m} \mathrm{E} \text { of CL at } 33+856 \text {, } \\
75 \mathrm{cmbs}\end{array}$ & 91 & 72.7 & 59.7 & 39.5 & $\begin{array}{l}\text { Medium-small Lightning Whelk with outer body whorl removed and edge near the } \\
\text { suture smoothed, possibly for use as a scraper. The columnella was shaped into a } \\
\text { point, but has been broken; }\end{array}$ \\
\hline $\begin{array}{l}15.5 \mathrm{~m} \mathrm{~W} \text { of CL at } 34+22.5 \\
95-105 \mathrm{cmbs}\end{array}$ & 141 & 72.0 & 37.3 & 15.4 & $\begin{array}{l}\text { Small Lightning Whelk with outer body whorl removed and edge near the suture } \\
\text { smoothed, possibly for use as a scraper; }\end{array}$ \\
\hline $\begin{array}{l}11.7 \mathrm{~m} \mathrm{~W} \text { of } \mathrm{CL} \text { at } 34+017 \\
79 \mathrm{cmbs}\end{array}$ & 148 & 43.2 & 34.6 & 7.8 & $\begin{array}{l}\text { Small Lightning Whelk with about half the outer body whorl removed and the } \\
\text { edge near the suture smoothed, possibly for use as a scraper. Most of this has } \\
\text { broken away. The columnella is broken near the expansion of the body whorl and } \\
\text { somewhat smoothed after the break; }\end{array}$ \\
\hline $\begin{array}{l}14.5 \mathrm{~m} \mathrm{~N} \text { of the } \mathrm{Cl} \text { at } \\
3+275,30-40 \mathrm{cmbs}\end{array}$ & 163 & 36.9 & 28.4 & 8.4 & $\begin{array}{l}\text { Small Lightning Whelk with edge of body whorl cut back about half way around } \\
\text { and smoothed, and the edge along the suture smoothed. The end of the columnella } \\
\text { was cut and smoothed; }\end{array}$ \\
\hline $\begin{array}{l}19.7 \mathrm{~m} \mathrm{~N} \text { of } \mathrm{CL} \text { at } 3+412.6 \\
97 \mathrm{cmbs}\end{array}$ & 170 & 44.5 & 21.0 & 3.6 & $\begin{array}{l}\text { Small Lightning Whelk, with body whorl partailly removed, and edge of shell at } \\
\text { suture smoothed. Columnella is shaped into a flat point; }\end{array}$ \\
\hline $\begin{array}{l}4 \mathrm{~m} \mathrm{~W} \text { of } \mathrm{CL} \text { at } 33+485 \text {, in } \\
\text { backfill of old trench }\end{array}$ & - & 73.6 & 43.5 & 31.8 & $\begin{array}{l}\text { Medium-small Lightning Whelk with outer body whorl removed and edge near the } \\
\text { suture smoothed; }\end{array}$ \\
\hline \multicolumn{6}{|r|}{ "Adze Blanks" } \\
\hline $\begin{array}{l}8 \mathrm{~m} \mathrm{E} \text { of CL } 34+003,90- \\
110 \mathrm{cmbs}\end{array}$ & 90 & 70.1 & 57.6 & 32.0 & $\begin{array}{l}\text { Possible "adze" blank, removed from Lightning Whelk body whorl, but no further } \\
\text { work done; }\end{array}$ \\
\hline $\begin{array}{l}15.5 \mathrm{~m} \mathrm{~W} \text { of } \mathrm{CL} \text { at } 34+22.5 \text {, } \\
95-105 \mathrm{cmbs}\end{array}$ & 141 & 174.4 & 78.4 & 122.8 & $\begin{array}{l}\text { Section of the body whorl of a very large Lightning Whelk that has been removed, } \\
\text { and one section cut off. There is no evidence that the piece itself was used as a tool; }\end{array}$ \\
\hline \multicolumn{6}{|c|}{ Eastern Oyster (Crassostrea virginica) } \\
\hline \multicolumn{6}{|r|}{ Ground } \\
\hline $\begin{array}{l}15.0 \mathrm{~m} \mathrm{E} \text { of CL at } 33+763 \text {, } \\
60-67 \mathrm{cmbs}\end{array}$ & 89 & - & - & - & $\begin{array}{l}\text { An oyster shell fragment ground to sharpen. Would have been fragile, so could only } \\
\text { be used on soft materials. Figure 5-31a; }\end{array}$ \\
\hline \multicolumn{6}{|r|}{ Perforated } \\
\hline $\begin{array}{l}11.8 \mathrm{~m} \mathrm{~W} \text { of CL at } \\
34+034.5,52-55 \mathrm{cmbs}\end{array}$ & 149 & 136.7 & 65.2 & 69.5 & $\begin{array}{l}\text { A large oyster with a hole cut near the umbo. The hole is triangular, and the upper } \\
\text { layers were cut in a triangular shape from the outside, while the lower levels were } \\
\text { cut in a smaller triangle, measuring } 11.3 \mathrm{~mm} \text { long and } 6.4 \mathrm{~mm} \text { at the base. There } \\
\text { may be slight evidence of wear at the point of the trangle.Figure } 5-31 \mathrm{~b} \text {; }\end{array}$ \\
\hline $\begin{array}{l}12.1 \mathrm{~m} \mathrm{~W} \text { of } \mathrm{Cl} \text { at } 34+83.2 \\
46-50 \mathrm{cmbs}\end{array}$ & 155 & 74.6 & 48.0 & 20.3 & $\begin{array}{l}\text { Perferated oyster shell, with hole } 10.1 \mathrm{~mm} \text { long, and some evidence of wear on } \\
\text { one corner. Figure 5-31c; }\end{array}$ \\
\hline $\begin{array}{l}14.6 \mathrm{~m} \mathrm{E} \text { of } \mathrm{CL} \text { at } 33+589 \\
110 \mathrm{cmbs}\end{array}$ & 84 & 63.2 & 46.6 & 12.6 & Perferated oyster shell, with a small $(4.2 \mathrm{~mm})$ round hole cut into it. Figure $5-31 \mathrm{~d}$; \\
\hline $14.5 \mathrm{~m} \mathrm{E}$ of CL at $34+136$ & 114 & 58.0 & 39.4 & 9.9 & Perferated oyster shell, with hole $11.4 \mathrm{~mm}$ in diameter, broken across hole; \\
\hline $14.5 \mathrm{~m} \mathrm{E}$ of CL at $34+136$ & 114 & 79.2 & 46.8 & 19.5 & Perferated oyster shell, with hole $14.8 \mathrm{~mm}$ in diameter, broken across hole; \\
\hline $14.5 \mathrm{~m} \mathrm{E}$ of $\mathrm{CL}$ at $34+136$ & 114 & 58.8 & 31.1 & 9.5 & Perferated oyster shell, with hole $13.3 \mathrm{~mm}$ in diameter, broken across hole; \\
\hline $14.5 \mathrm{~m} \mathrm{E}$ of CL at $34+136$ & 114 & 53.3 & 38.8 & 19.4 & Perferated oyster shell, with hole $12.3 \mathrm{~mm}$ in diameter, broken across hole; \\
\hline $14.5 \mathrm{~m} \mathrm{E}$ of $\mathrm{CL}$ at $34+136$ & 114 & 63.6 & 35.6 & 10.1 & Perferated oyster shell, with hole $15.6 \mathrm{~mm}$ in diameter, broken across hole; \\
\hline
\end{tabular}


Table 5-3. Continued...

\begin{tabular}{|c|c|c|c|c|c|}
\hline Provenience & Feature & $\begin{array}{c}\text { Length } \\
(\mathrm{mm})\end{array}$ & $\begin{array}{l}\text { Width } \\
(\mathrm{mm})\end{array}$ & $\begin{array}{l}\text { Wgt. } \\
\text { (g) }\end{array}$ & Notes \\
\hline \multicolumn{6}{|c|}{ Eastern Oyster (Crassostrea virginica) } \\
\hline \multicolumn{6}{|r|}{ Perforated } \\
\hline $14.5 \mathrm{~m} \mathrm{E}$ of CL at $34+136$ & 114 & 49.1 & 34.3 & 6.4 & Perferated oyster shell, with hole $12.2 \mathrm{~mm}$ in diameter, broken across hole; \\
\hline $14.5 \mathrm{~m} \mathrm{E}$ of CL at $34+136$ & 114 & 41.8 & 35.5 & 5.1 & Perferated oyster shell, with hole $8.9 \mathrm{~mm}$ in diameter, broken across hole; \\
\hline \multicolumn{6}{|c|}{ Southern Quahog (Mercenaria campechiensis) } \\
\hline $\begin{array}{l}11.7 \mathrm{~m} \mathrm{~W} \text { of } \mathrm{CL} \text { at } 34+017 \\
79 \mathrm{cmbs}\end{array}$ & 148 & 47.4 & 45.7 & 16.6 & $\begin{array}{l}\text { Quahog shell shaped into a rough triangle by grinding. The entire shell has } \\
\text { considerable patination and some encrustation. The grinding and shape of this } \\
\text { shell is remanisenct of "adzes" made from large Lightning Whelk body whorls. } \\
\text { Figure 5-32a; }\end{array}$ \\
\hline \multicolumn{6}{|c|}{ Banded Tulip (Fasciolaria lilium) } \\
\hline $\begin{array}{l}12.9 \mathrm{~m} \mathrm{E} \text { of CL at } 33+905 \\
113-122 \mathrm{cmbs}\end{array}$ & 53 & 15.0 & 5.0 & & $\begin{array}{l}\text { Banded tulip shell with a rectangular section cut from outer body whorl. } \\
\text { Figure 5-32b; }\end{array}$ \\
\hline \multicolumn{6}{|c|}{ Florida Horse Conch (Pleuroploca gigantea) } \\
\hline $\begin{array}{l}13.02 \mathrm{~m} \mathrm{E} \text { of } \mathrm{CL} \text { at } 33+942, \\
130 \mathrm{cmbs}\end{array}$ & - & 276.6 & 127.8 & 508.8 & $\begin{array}{l}\text { Moderate sized Horse Conch. Opened in } 2 \text { body whorls presumably to } \\
\text { access meat. Most of outer body whorl removed by bashing (most likely for } \\
\text { "adzes". Side opposite where the two whorls were opened has been used for } \\
\text { grinding something; }\end{array}$ \\
\hline
\end{tabular}

The specimen shown in Figure 5-26c is another type of chipped shell. It is rectangular and ws chipped along one edge and at least part of an adjacent edge, almost forming a right angle where they meet. The fourth tool Figure 5-26d is made on a thin, blade-like shell flake rather than the entire shell valve. It has bifacial chipping along opposing long edges. Remnants of the outer shell are visible along one end.

\section{Modified Lightning Whelk Shells}

The several modified Lightning Whelk tools can be divided into four principal groups: cups/scoopers $(n=4)$, gouges $(\mathrm{n}=7)$, scrapers/smoothers $(\mathrm{n}=3)$, and adze blanks $(\mathrm{n}=2)$.

"Cups/scoopers". These artifacts were made by cutting off the columnella at the point where the last body whorl narrows to form the outer edge of the siphonal canal. It is usually supposed that these shells were used as cups, scoops, or dippers. The edge of the body whorl would be too fragile to use this tool as a digger.

Four cup/scoops were identified during the project (see Table 5-3), of which one (Figure 5-27) is an almost complete example. This artifact was deliberately broken, with three areas of impact damage, one of which broke through the outer body whorl.

"Gouges". Most modified Lightning Whelks appear to have been used as some type of gouge or awl. The end of the siphon canal of a Lightning Whelk is semicircular and has fairly sharp edges, which would make a reasonable gouge unmodified, however unmodified it would be very susceptible to breakage. Most gouge-like modifications on the siphon canal consist of grinding away the outer edge, leaving the main body of the columnella, and then shaping the end into one of three types: 1) a sharp, rounded point; 2) a blunt rounded point (possibly very worn examples of \#1); and c) a flatten blunt point. Sometimes these shells are left almost unmodified except for the end of the columnella and the rim of the outer body whorl. More often, the most or all of the body whorls are removed, leaving only the columnella, which is smoothed by grinding. When this is the case, the columnellas are often bi-pointed.

The specimen pictured in Figure 5-28a is an example of a shell with minimal modification. The rim of the body whorl has been cut evenly and smoothed and the remaining portion of the columnella smoothed into a fairly flat, oval point. This artifact resembles the "cup" type, such as Figure 5-27, except for the shaping of the columnella, and may have been used for multiple purposes. The specimen in Figure 5-28b is another minimally modified shell with the columnella shaped into a sharp point and with the outer edge of the siphon canal ground to a sharp edge. This tool would have been a very effective gouge or awl, but only for very soft materials, as the shell is quite fragile. The specimen in Figure 5-28c is a broken tool with all the body whorls removed, leaving only a slight ridge, which was then smoothed carefully, and with the end shaped into a 


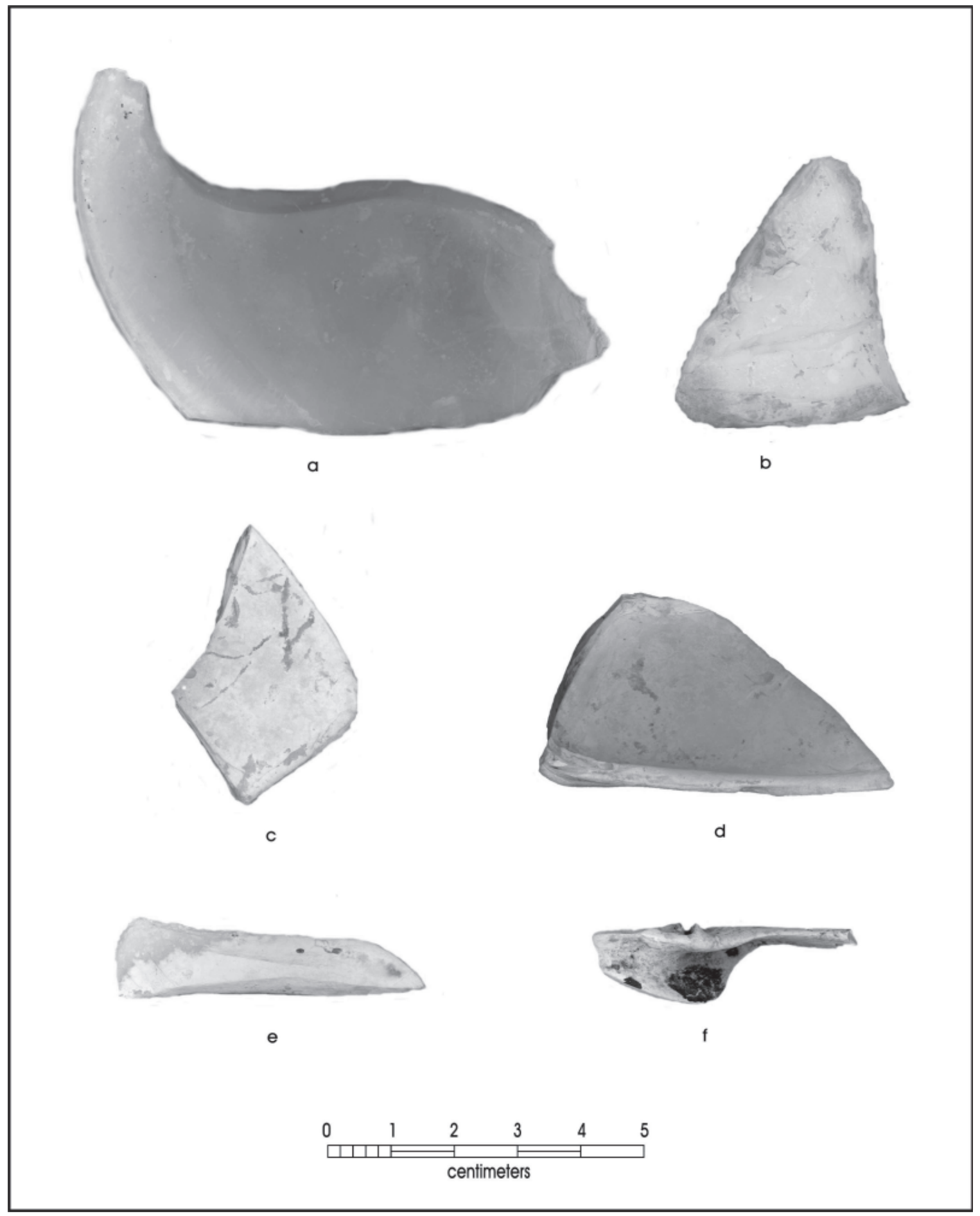

Figure 5-25. Ground shell tools: a) large tool modified along one edge; b) triangular tool, Feature 76; c) rectangular tool, Feature 65; d) tool made from umbo of Sunray, Feature 98; e) blade-like tool, Feature 170; f) long thin point ground from hinge plate of Sunray, Feature 151.

blunt point. The item in Figure 5-28d is a complete tool with body whorls removed and the columnella smoothed. The end is a sharp point. The tool in Figure 5-28e is a example of a bi-pointed columnella specimen with sharp points on both ends. The tool shown in Figure 5-28f is also bi-pointed, but in this case some of the body whorl was left unsmoothed, with the proximal end shaped into a blunt point and the distal end shaped into a flat point that has broken. The specimen shown in Figure 5-28g is a fragment of a columnella that has been shaped into a blunt point, 


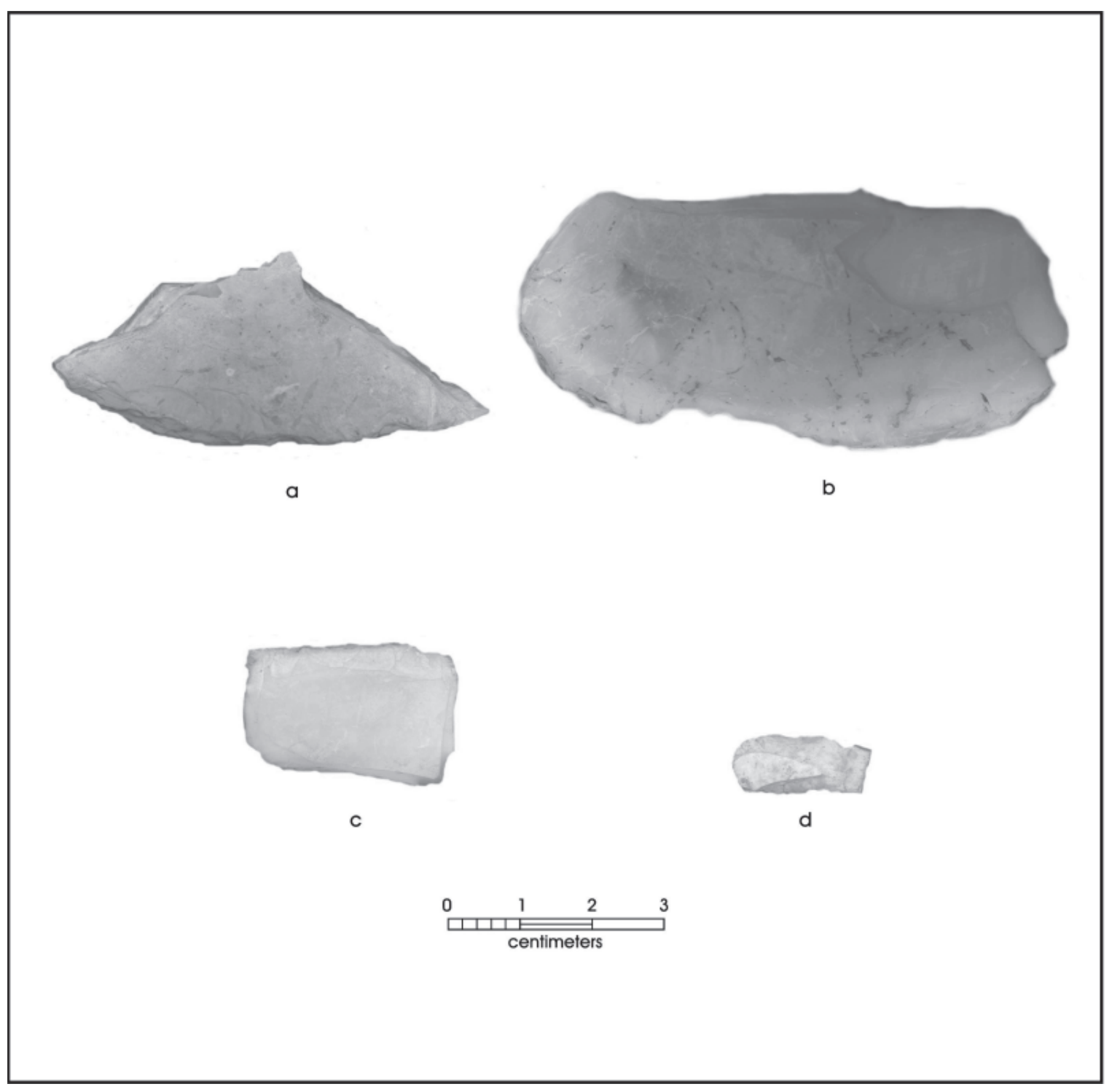

Figure 5-26. Chipped Sunray shell tools: a) fragment of tool, Feature 74; b) fragment of tool from surface of North Dune; c) modified shell fragment; d) small bifacially flaked blade-like tool, Feature 100.

with a remnant of the outer edge of the siphon canal left in place and shaped to form a sort of "tooth" near the point.

Scrapers and "Smoothers". Lightning Whelk scrapers are made by removing a section of outer body whorl, leaving a "ledge" near the suture, which is then smoothed into a relatively sharp edge. These tools would have been held by the columnella and pulled toward the worker. "Smoothers" is a name given to shells with the outer body whorl removed to the suture and exhibiting heavy polish along the suture. In some cases, it appears that a tool starts out as a scraper but is later used as a smoother as the edge is broken away. Many shells modified to act as scrapers or smoothers have also had the end of the columnella modified to a point. These tools come in many sizes.
The tools shown in Figures 5-29a and 5-29b are scrapers. The columnella of Figure 5-29a does not appear to have been altered. Note that the right side of the specimen in Figure 5-29b shows a broken body whorl while the left side shows the shaping associated with a scraper. The specimen in Figure 5-29c is classified as "smoother", with no fragment of the body whorl remaining and the junction at the suture showing considerable smoothing and polish. The end of the columnella has been shaped into a point.

"Adze Blanks". Artifacts referred to as "adzes" are not uncommon in sites in the Coastal Bend area. These are sections of shell, usually removed from the outer body whorl of a large Lightning Whelk or Horse Conch (and very occasionally other species, see below), and shaped into a 


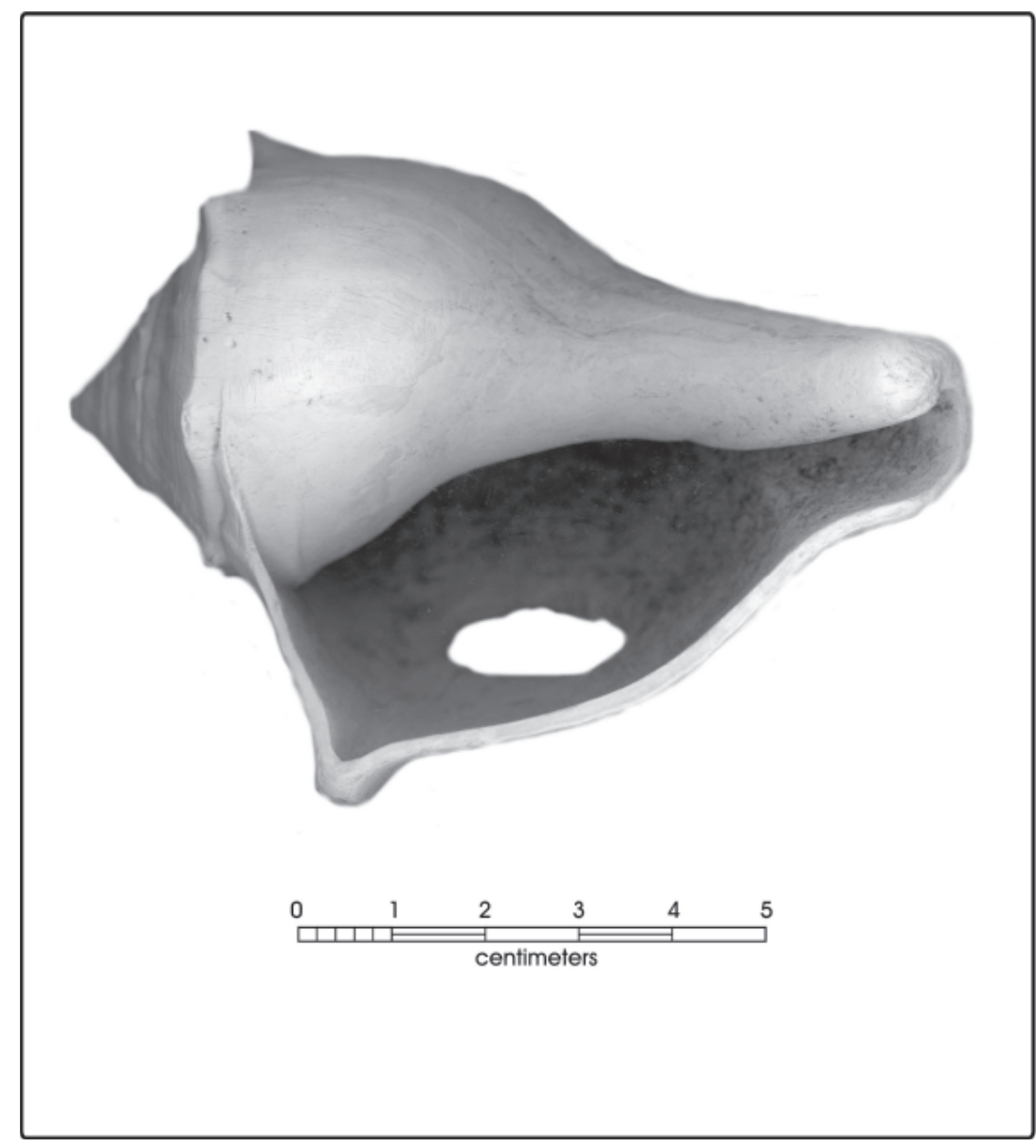

Figure 5-27. A Lightning Whelk shell modified to form a cup or scoop, Feature 88 .

roughly triangular shape with the wide end ground to make an edge. While the exact purpose of these tools is unknown, we will continue to call them "adzes" as this is the term used in the literature (Ricklis 2004:Figure 5.14). An adze "blank" is a section of large gastropod that shows evidence of having been deliberately removed from the body whorl, but does not show any other modifications. Two such artifacts were recovered during the project (Table 5-3), they are not shown due to their fragmentary condition.

\section{Modified Oyster Shells}

One fragment of oyster shell was recovered with clear grinding along two edges (Figure 5-30a). The purpose of this artifact is unknown, as oyster shell has a tendency to fragment and is not often used for tools. It may be part of an object shaped by grinding for another purpose, such as decoration.

Ten perforated oysters were recovered from the site. These are common artifacts along the coast (Ricklis 2004:Figure 5.6). It is generally assumed that the oysters serve as weights, possibly for nets. The specimens shown in Figures 5-30b through 5-31d are examples of these artifacts.

\section{Modified Quahog Shell}

A single modified quahog shell was identified (Figure 31a). It was shaped into a rough triangle by grinding, and appears to be an example of an "adze", though most adzes recorded in the area are made from the body whorl of Lightning Whelks. Rather than use the nature thinning at the ventral edge of the shell, the adjacent edge was ground to serve at the bit for the "adze'. The entire shell has considerable patination and some encrustation. The shell had been in water after the death of the animal, as it exhibits a large number of worm holes and two large holes probably made by sea fauna.

\section{Modified Banded Tulip Shell}

A single Banded Tulip shell was modified by the cutting out of a rectangular piece of the outer body whorl (Figure 5-31b). The removed section of shell is only 5 by $15 \mathrm{~mm}$ and the purpose it may have been put to is unknown, but it may have been used for decoration.

\section{Modified Florida Horse Conch Shell}

One medium-sized Florida Horse Conch was recovered that shows use for a number of purposes (Figure 5-32). Two body whorls in the spire had been broken open, presumably to help remove the conch meat. The entire outer body whorl was removed, apparently in two sections, probably for use in manufacturing "adzes". In addition, the protuberances along the top of the last body whorl have been worn smooth, evidence that the shell was used for grinding. 


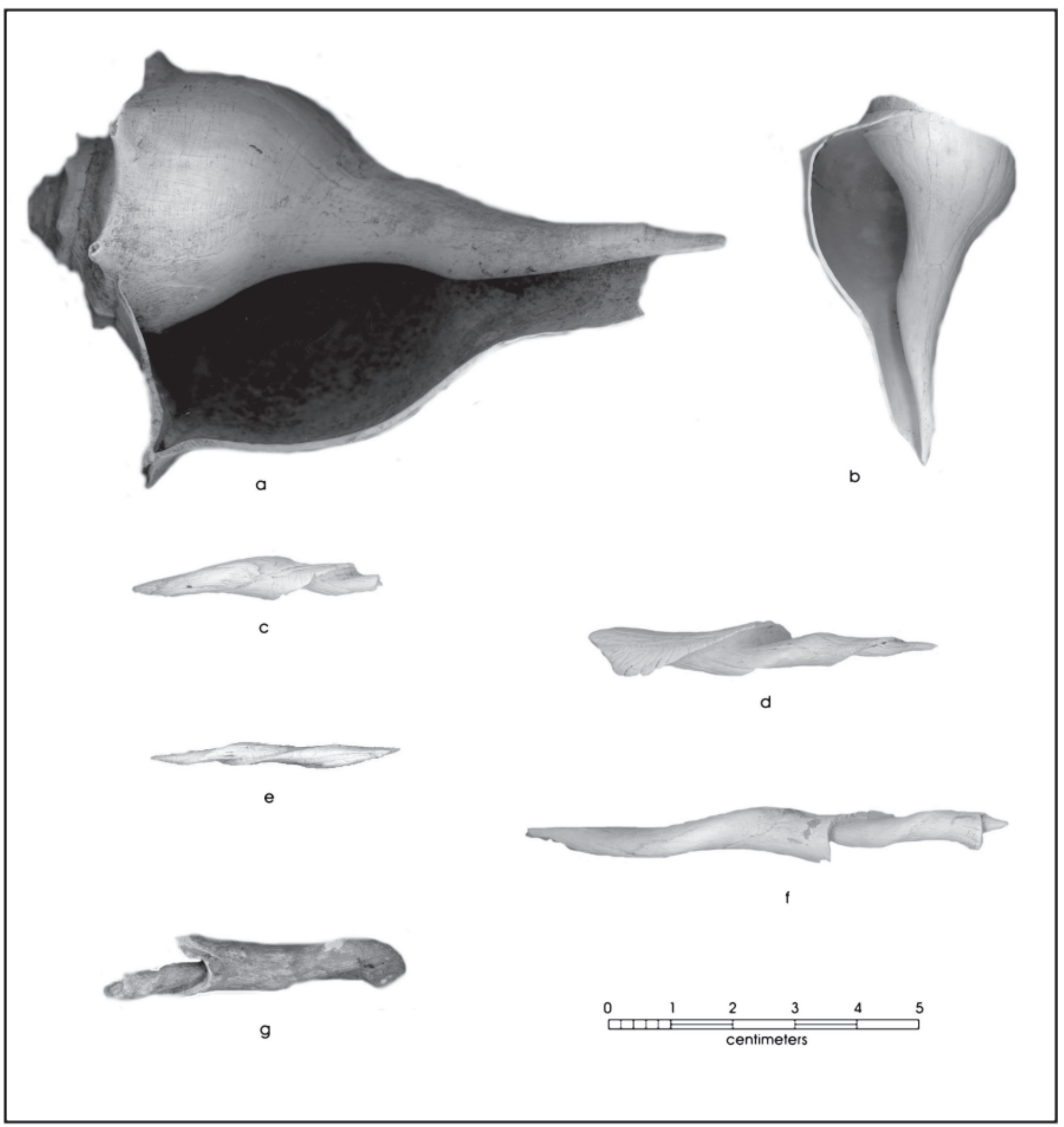

Figure 5-28. Lightning Whelk Gouges: a) collumnella shaped into flat point, Feature 163; b) small whelk with collumnella shaped into a point; c) columnella fragment ground into a blunt point; d) columnella tool shaped into a sharp point; e) bi-pointed columnella tool; f) columnella fragment with a broken flat point on one end and a blunt point on the other; $g$ ) columnella fragment with shaped "tooth". 


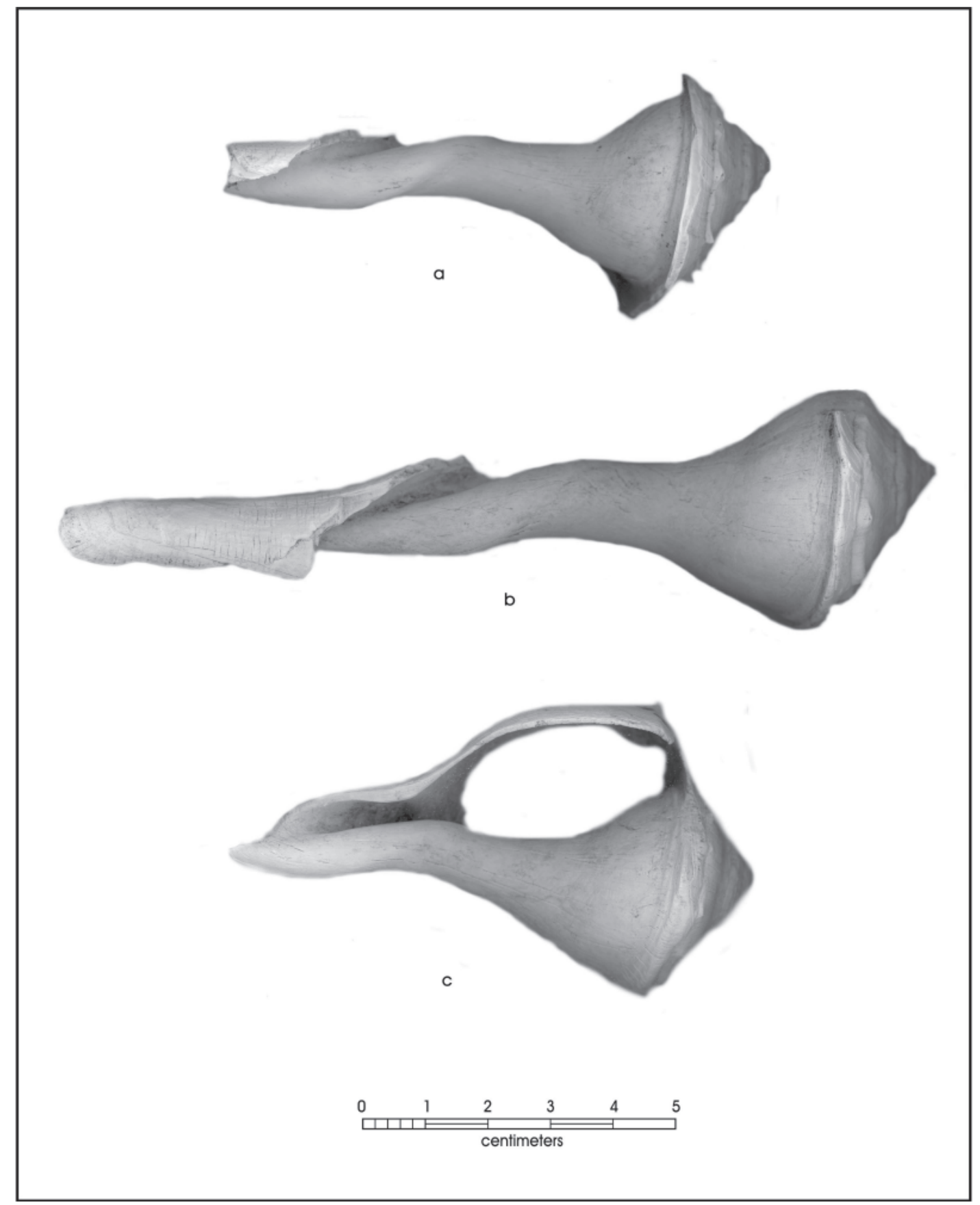

Figure 5-29. Lightning Whelk scrapers and "smoothers": a-b) scrapers; c) a "smoother". 


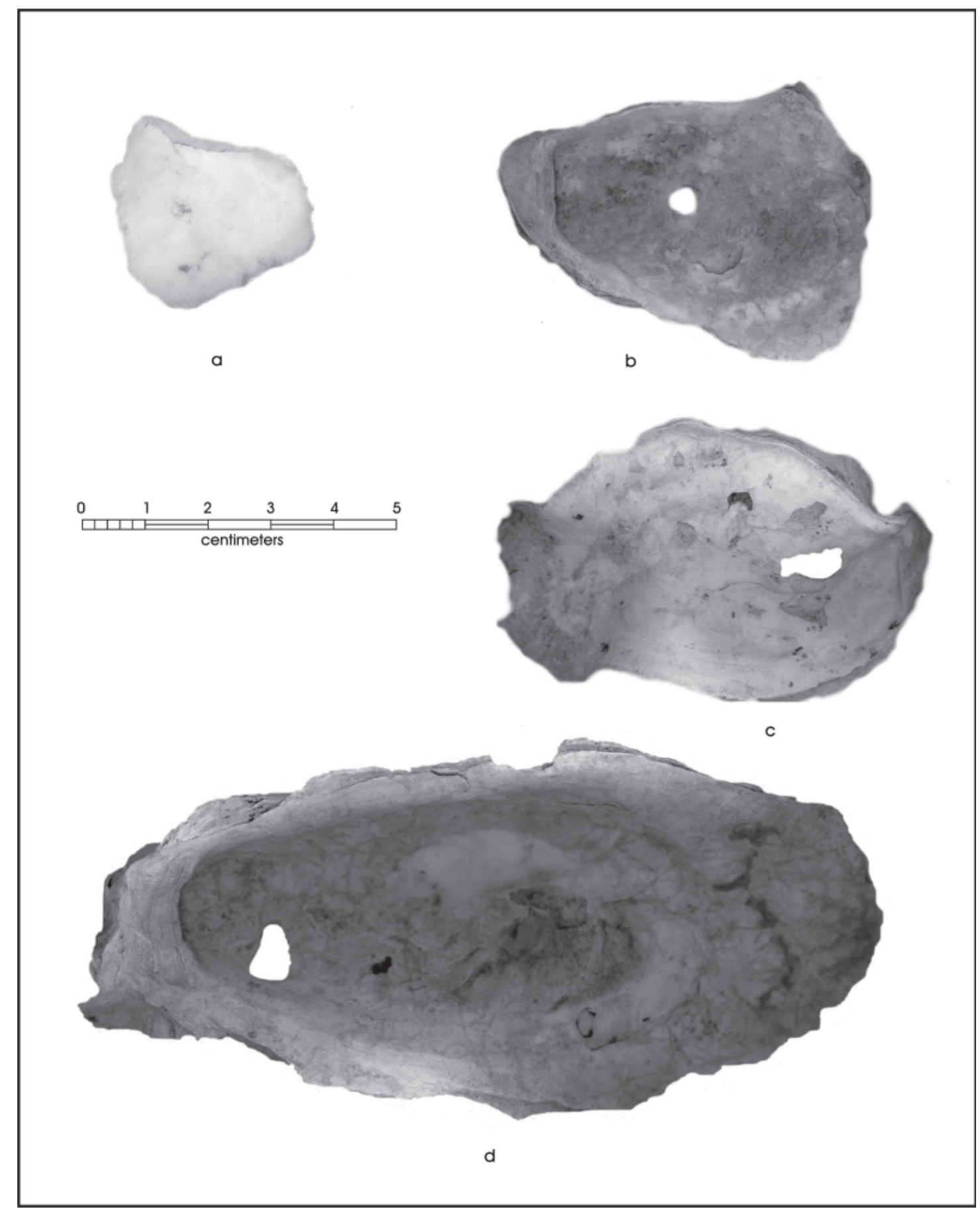

Figure 5-30. Modified Easter Oysters: a) a fragment of oyster shell with two ground edges; $b-d$ ) perforated oysters. 


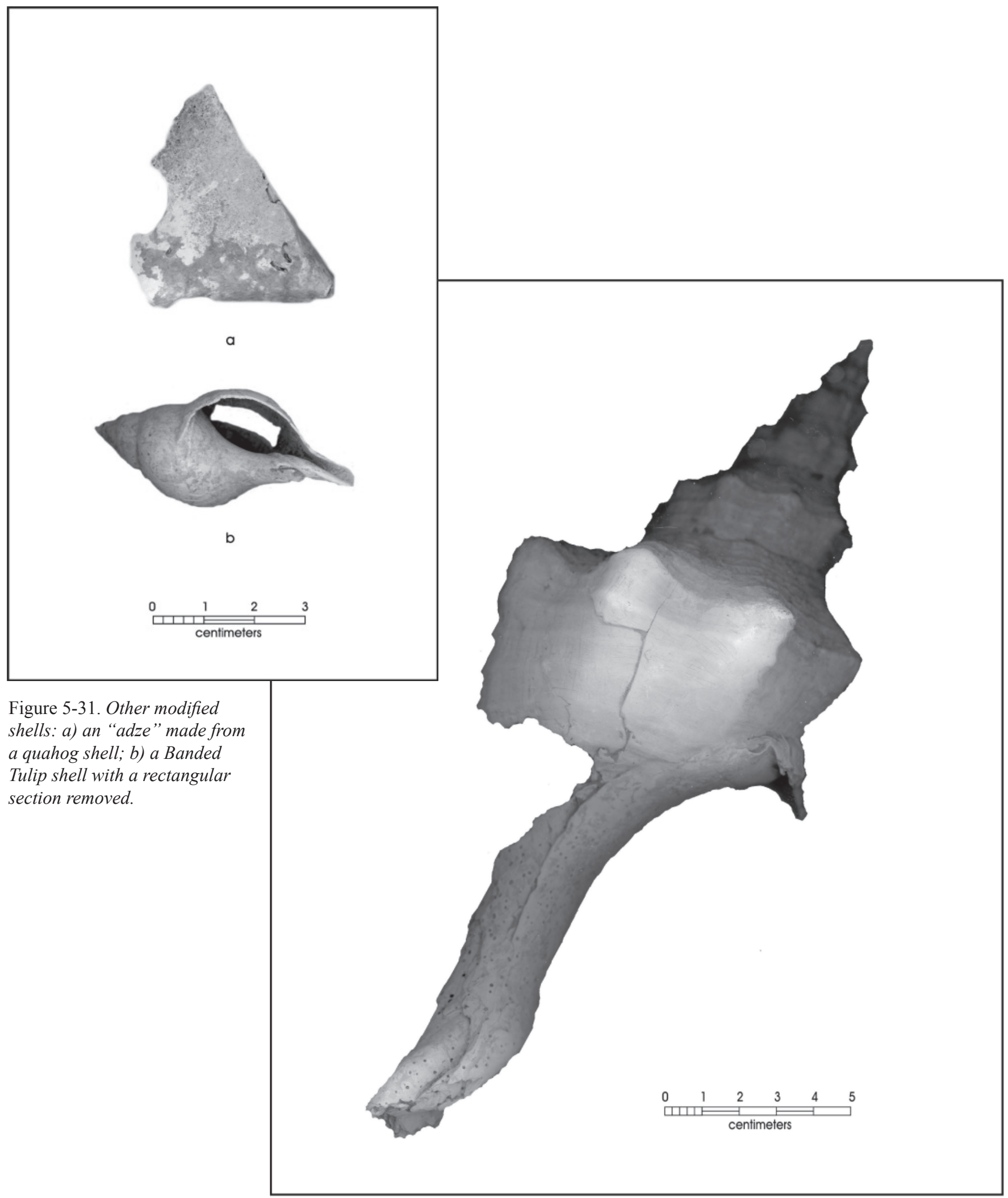

Figure 5-32. A Florida Horse Conch showing extensive modifications. 


\title{
Chapter 6: Radiocarbon Dates, Feature Descriptions and Occupation Zones
}

\author{
Barbara M. Meissner and Raymond P. Mauldin
}

This chapter provides a summary of the radiocarbon results, along with descriptive data on 164 features, and 11 occupation zones, documented at 41NU2 during the monitoring project. The focus on the radiocarbon discussion is on comparing dates derived form 40 samples, 20 of which were derived from marine shell and 20 of which represent assays from charcoal or organic sediment. The paired samples were primarily derived from individual features or areas of dense accumulations of cultural debris termed occupation zones. Our comparison shows that in 11 of the 20 pairings, the corrected, calibrated date ranges derived from shell do not overlap at 2 sigma with date ranges provided by charcoal or organics from the same provenience. Nevertheless, a comparison of the mid-points of the two sigma ranges for the individual dates shows, with one exception, a strong relationship. We conclude that marine shell can provide accurate, precise dates in the absence of other dating materials. Appendix G supports the radiocarbon section. Following the radiocarbon results, we summarize the 164 features documented on the project. We present a feature typology based primarily on feature content (e.g. shell clusters, charcoal and burnt clay clusters) and overall form. Finally, the chapter concludes with a discussion of the 11 occupation zones identified at the site during the monitoring.

\section{Radiocarbon Dates}

Fifty-eight radiocarbon dates were acquired during this project. This number includes 12 humate dates associated with coring activities, 40 dates from features, and 6 dates from other contexts. This section concentrates on the 46 dates derived primarily from features and occupation zones. The 12 humate dates will be discussed in the context of the paleoenvironmental data (Appendix F). Forty of the 46 dates considered here represent paired samples of marine shell and organics selected from the same provenience, occupation zone or feature. The paired samples were designed to assess the reliability of marine shell as a dating material, as well as to provide basic site chronology.

The original sample selection strategy had three principal goals. First, we wanted to date as many features as possible with multiple samples to determine whether features represented relatively short-term use or repeated reuse. Second, date the tops and bottoms of thick organically enriched and poor zones to define ages and accumulation rates. Finally, whenever possible, we wanted to date paired charcoal and shell samples to examine the correspondence between the dates. This strategy resulted in a preliminary list of 110 samples. Given that the costs associated with such a large sample size were prohibitive, TxDOT-ENV and CAR developed an alternate sampling strategy with less ambitious goals that preserved some of the original goals, but at a reduced cost. The final dating strategy consisted of the selection of samples from two sequences of features. One sequence was to be selected from the north dune $(n=3)$ and one from the south dune $(n=3)$. In addition, paired samples were selected from 20 features or locations, one sample consisting of charcoal $(n=20)$ and the other of marine shell $(n=20)$. This revised strategy allowed for investigation of the correspondence between charcoal and shell dates, as well as a coarse-grained dating of the stratigraphic sequences noted in each of the two dunes.

\section{Results}

Beta Analytic of Miami, Florida ran all samples. Appendix G provides details on all 58 samples. Table 6-1 summarizes the results of the 46 samples considered here. The CAR sample number in Table 6-1 (e.g., 371) is an abbreviated version of the sample number referenced in Appendix G (e.g., 41NU2371). All samples have been corrected and calibrated, and in the following discussion, we will primarily use the two sigma range, or the midpoints of that range.

Using the midpoint of the two sigma span, the radiocarbon dates in Table 6-1 range from 5930 B.P. (5990-5870 B.P.) on shell from Feature 49 to around 905 B.P. (1010-800 B.P.) on shell from Feature 54. The early Feature 49 shell date (Table 6-1; Sample \# 426) is roughly 2400 years older than any other date from the site. In addition, the date is about 4150 years older than the paired sample, run on organics, from this feature (Table 6-1; Sample \# 381), which has a date range of 1870 to 1700 B.P. It is likely that the shell date is unreliable. We have chosen to eliminate sample 426 from additional consideration.

Figure 6-1 shows the distribution of the remaining 45 radiocarbon dates plotted at a two sigma range. Examination of the figure suggests that the site was minimally occupied from around 3500 B.P. to about 900 B.P. Note that there are two periods without dates during this sequence. There is a small gap just after 1500 B.P. and a roughly 400 year gap between 3400 B.P. and just after 3000 B.P. To the degree that these dates on 23 features and three occupation zones reflect overall site use, it appears that the occupation of 41 NU2 began after 3500 
Table 6-1. Radiocarbon Results from Features and Occupation Zones

\begin{tabular}{|c|c|c|c|c|c|c|c|}
\hline $\begin{array}{c}\text { CAR } \\
\text { Sample \# }\end{array}$ & Feature & Provenience & $\begin{array}{c}\text { Depth } \\
\text { (cm bgs) }\end{array}$ & Dune & Material Used & $\begin{array}{c}2 \text { Sigma Cal. } \\
\text { (B.P.) }\end{array}$ & $\begin{array}{c}\text { Conv. RC Age } \\
\text { (B.P.) }\end{array}$ \\
\hline 371 & 2 & $11.5 \mathrm{~m} \mathrm{~W}$ of $\mathrm{CL}$ at $33+509$ & 30 & $\mathrm{~S}$ & Charcoal & $1170-960$ & $1140+/-40$ \\
\hline 436 & 2 & $11.5 \mathrm{~m} \mathrm{~W}$ of $\mathrm{CL}$ at $33+509$ & 30 & $\mathrm{~S}$ & Macrocallista nimbosa & $980-840$ & $1370+/-40$ \\
\hline 418 & 7 & $11.7 \mathrm{~m}$ of $\mathrm{CL}$ at $33+475$ & 245 & $\mathrm{~S}$ & Charcoal & $3470-3350$ & $3190+/-40$ \\
\hline 416 & 10 & $11.0 \mathrm{~m}$ of $\mathrm{CL}$ at $33+590$ & 90 & $\mathrm{~S}$ & Charcoal & $2710-2350$ & $2440+/-40$ \\
\hline 437 & 16 & $10.2 \mathrm{~m}$ of $\mathrm{CL}$ at $33+549$ & 96 & $\mathrm{~S}$ & Busycon sinistrum & $1160-960$ & $1510+/-40$ \\
\hline 375 & 16 & $10.2 \mathrm{~m}$ of $\mathrm{CL}$ at $33+549$ & 96 & $\mathrm{~S}$ & Organic sediment & $1300-1180$ & $1320+/-40$ \\
\hline 430 & 18 & $25.5 \mathrm{~m} \mathrm{~N}$ of CL at $3+325$ & 75 & $\mathrm{~N}$ & Macrocallista nimbosa & $1690-1510$ & $2030+/-40$ \\
\hline 376 & 18 & $25.5 \mathrm{~m} \mathrm{~N}$ of $\mathrm{CL}$ at $3+325$ & 75 & $\mathrm{~N}$ & Organic sediment & $1940-1740$ & $1910+/-40$ \\
\hline 420 & 31 & $12.00 \mathrm{~m} \mathrm{E}$ of CL at $33+894$ & 86 & out & Crassostrea virginica & $1770-1560$ & $2090+/-40$ \\
\hline 377 & 31 & $12.00 \mathrm{~m} \mathrm{E}$ of CL at $33+894$ & 86 & out & Organic sediment & $1820-1600$ & $1780+/-40$ \\
\hline 380 & 46 & $11.17 \mathrm{~m} \mathrm{E}$ of CL at $34+022$ & 70 & $\mathrm{~N}$ & Charcoal & $2050-1880$ & $2010+/-40$ \\
\hline 428 & 46 & $11.17 \mathrm{~m} \mathrm{E}$ of CL at $34+022$ & 70 & $\mathrm{~N}$ & Busycon sinistrum & $2340-2150$ & $2590+/-40$ \\
\hline 381 & 49 & $11.33 \mathrm{~m} \mathrm{E}$ of CL at $34+021.5$ & 59 & $\mathrm{~N}$ & Organic sediment & $1870-1700$ & $1840+/-40$ \\
\hline 426 & 49 & $11.33 \mathrm{~m} \mathrm{E}$ of $\mathrm{CL}$ at $34+021.5$ & 59 & $\mathrm{~N}$ & Macrocallista nimbosa & $5990-5870$ & $5540+/-40$ \\
\hline 419 & 54 & $12 \mathrm{~m} \mathrm{E}$ of CL at $33+813.7$ & 56 & out & Busycon sinistrum & $1010-800$ & $1390+/-40$ \\
\hline 382 & 54 & $12 \mathrm{~m} \mathrm{E}$ of CL at $33+813.7$ & 56 & out & Organic sediment & $1290-1160$ & $1290+/-40$ \\
\hline 425 & 63 & $11.0 \mathrm{~m} \mathrm{E}$ of $\mathrm{CL}$ at $34+059.5$ & 57 & $\mathrm{~N}$ & Macrocallista nimbosa & $2720-2480$ & $2850+/-40$ \\
\hline 384 & 63 & $11.0 \mathrm{~m} \mathrm{E}$ of CL at $34+059.5$ & 57 & $\mathrm{~N}$ & Organic sediment & $3070-2800$ & $2830+/-50$ \\
\hline 417 & 81 & $14.95 \mathrm{~m} \mathrm{E}$ of CL at $33+564$ & 80 & $\mathrm{~S}$ & Charcoal & $1350-1270$ & $1390+/-40$ \\
\hline 438 & 84 & $14.5 \mathrm{~m} \mathrm{E}$ of $\mathrm{CL}$ at $33+584.5$ & 110 & $\mathrm{~S}$ & Crassostrea virginica & $2290-2060$ & $2500+/-40$ \\
\hline 387 & 84 & $14.5 \mathrm{~m} \mathrm{E}$ of CL at $33+584.5$ & 110 & $\mathrm{~S}$ & Charcoal & $2740-2460$ & $2510+/-40$ \\
\hline 431 & 103 & $14.7 \mathrm{~m} \mathrm{E}$ of CL at $34+019$ & 80 & $\mathrm{~N}$ & Macrocallista nimbosa & $1970-1800$ & $2270+/-40$ \\
\hline 391 & 103 & $14.7 \mathrm{~m} \mathrm{E}$ of CL at $34+019$ & 80 & $\mathrm{~N}$ & Organic sediment & $2300-1990$ & $2120+/-40$ \\
\hline 393 & 108 & $14.6 \mathrm{~m} \mathrm{E}$ of CL at $34+091.8$ & 37 & $\mathrm{~N}$ & Organic sediment & $1410-1300$ & $1470+/-40$ \\
\hline 440 & 110 & $14 \mathrm{~m} \mathrm{E}$ of $\mathrm{CL}$ at $33+572$ & 155 & $\mathrm{~S}$ & Crassostrea virginica & $3630-3440$ & $3640+/-40$ \\
\hline 396 & 110 & $14 \mathrm{~m} \mathrm{E}$ of $\mathrm{CL}$ at $33+572$ & 155 & $\mathrm{~S}$ & Charcoal & $3630-3440$ & $3300+/-40$ \\
\hline 412 & 113 & $14.4 \mathrm{~m} \mathrm{E}$ of CL at $34+111.7$ & 98 & $\mathrm{~N}$ & Charcoal & $2130-1930$ & $2060+/-40$ \\
\hline 397 & 115 & $14.8 \mathrm{~m} \mathrm{E}$ of CL at $34+138$ & 70 & $\mathrm{~N}$ & Organic sediment & $2770-2720$ & $2610+/-40$ \\
\hline 429 & 115 & $14.8 \mathrm{~m} \mathrm{E}$ of CL at $34+138$ & 70 & $\mathrm{~N}$ & Macrocallista nimbosa & $2950-2760$ & $3090+/-40$ \\
\hline 434 & $33 / 121$ & $14.1 \mathrm{~m} \mathrm{E}$ of CL at $33+901$ & 120 & out & Crassostrea virginica & $2540-2300$ & $2700+/-50$ \\
\hline 398 & $33 / 121$ & $14.1 \mathrm{~m} \mathrm{E}$ of CL at $33+901$ & 120 & out & Charcoal & $2730-2360$ & $2470+/-40$ \\
\hline 433 & 122 & $14.7 \mathrm{~m} \mathrm{E}$ of CL at $33+907$ & 110 & out & Busycon sinistrum & $2010-1840$ & $2310+/-40$ \\
\hline 399 & 122 & $14.7 \mathrm{~m} \mathrm{E}$ of CL at $33+907$ & 110 & out & Charcoal & $2320-2060$ & $2180+/-40$ \\
\hline 432 & 123 & $14.5 \mathrm{~m} \mathrm{E}$ of CL at $33+915$ & 85 & $\mathrm{~N}$ & Busycon sinistrum & $1050-900$ & $1430+/-40$ \\
\hline 400 & 123 & $14.5 \mathrm{~m} \mathrm{E}$ of CL at $33+915$ & 85 & $\mathrm{~N}$ & Charcoal & $1170-960$ & $1140+/-40$ \\
\hline 415 & 137 & $8 \mathrm{~m} \mathrm{~W}$ of $\mathrm{CL}$ at $34+152$ & 140 & $\mathrm{~N}$ & Charcoal & $2730-2350$ & $2450+/-50$ \\
\hline 422 & 153 & $12.1 \mathrm{~m} \mathrm{~W}$ of $\mathrm{CL}$ at $34+067.3$ & 44 & $\mathrm{~N}$ & Busycon sinistrum & $1790-1580$ & $2100+/-40$ \\
\hline 403 & 153 & $12.1 \mathrm{~m} \mathrm{~W}$ of CL at $34+067.3$ & 44 & $\mathrm{~N}$ & Organic sediment & $2300-2000$ & $2140+/-40$ \\
\hline 423 & 155 & $12.1 \mathrm{~m} \mathrm{~W}$ of $\mathrm{CL}$ at $34+083.2$ & 48 & $\mathrm{~N}$ & Crassostrea virginica & $2310-2110$ & $2540+/-40$ \\
\hline 405 & 155 & $12.1 \mathrm{~m} \mathrm{~W}$ of CL at $34+083.2$ & 48 & $\mathrm{~N}$ & Organic sediment & $2480-2340$ & $2370+/-40$ \\
\hline 427 & $\mathrm{n} / \mathrm{a}$ & $14.8 \mathrm{~m} \mathrm{E}$ of CL at $34+079$ & 60 & $\mathrm{~N}$ & Macrocallista nimbosa & $1880-1590$ & $2110+/-40$ \\
\hline 424 & $\mathrm{n} / \mathrm{a}$ & $14.8 \mathrm{~m} \mathrm{E}$ of CL at $34+079$ & 50 & $\mathrm{~N}$ & Macrocallista nimbosa & $1880-1700$ & $2200+/-40$ \\
\hline 388 & $\mathrm{n} / \mathrm{a}$ & $14.8 \mathrm{~m} \mathrm{E}$ of CL at $34+079$ & 50 & $\mathrm{~N}$ & Organic sediment & $1930-1730$ & $1900+/-40$ \\
\hline 389 & $\mathrm{n} / \mathrm{a}$ & $14.8 \mathrm{~m} \mathrm{E}$ of CL at $34+079$ & 60 & $\mathrm{~N}$ & Charcoal & $1980-1820$ & $1940+/-40$ \\
\hline 439 & $\mathrm{n} / \mathrm{a}$ & $14.0 \mathrm{~m} \mathrm{E}$ of CL at $33+567$ & 124 & $\mathrm{~S}$ & Crassostrea virginica & $2280-2030$ & $2480+/-40$ \\
\hline 373 & $\mathrm{n} / \mathrm{a}$ & $14.0 \mathrm{~m} \mathrm{E}$ of CL at $33+567$ & 124 & $\mathrm{~S}$ & Organic sediment & $2360-2200$ & $2310+/-40$ \\
\hline
\end{tabular}




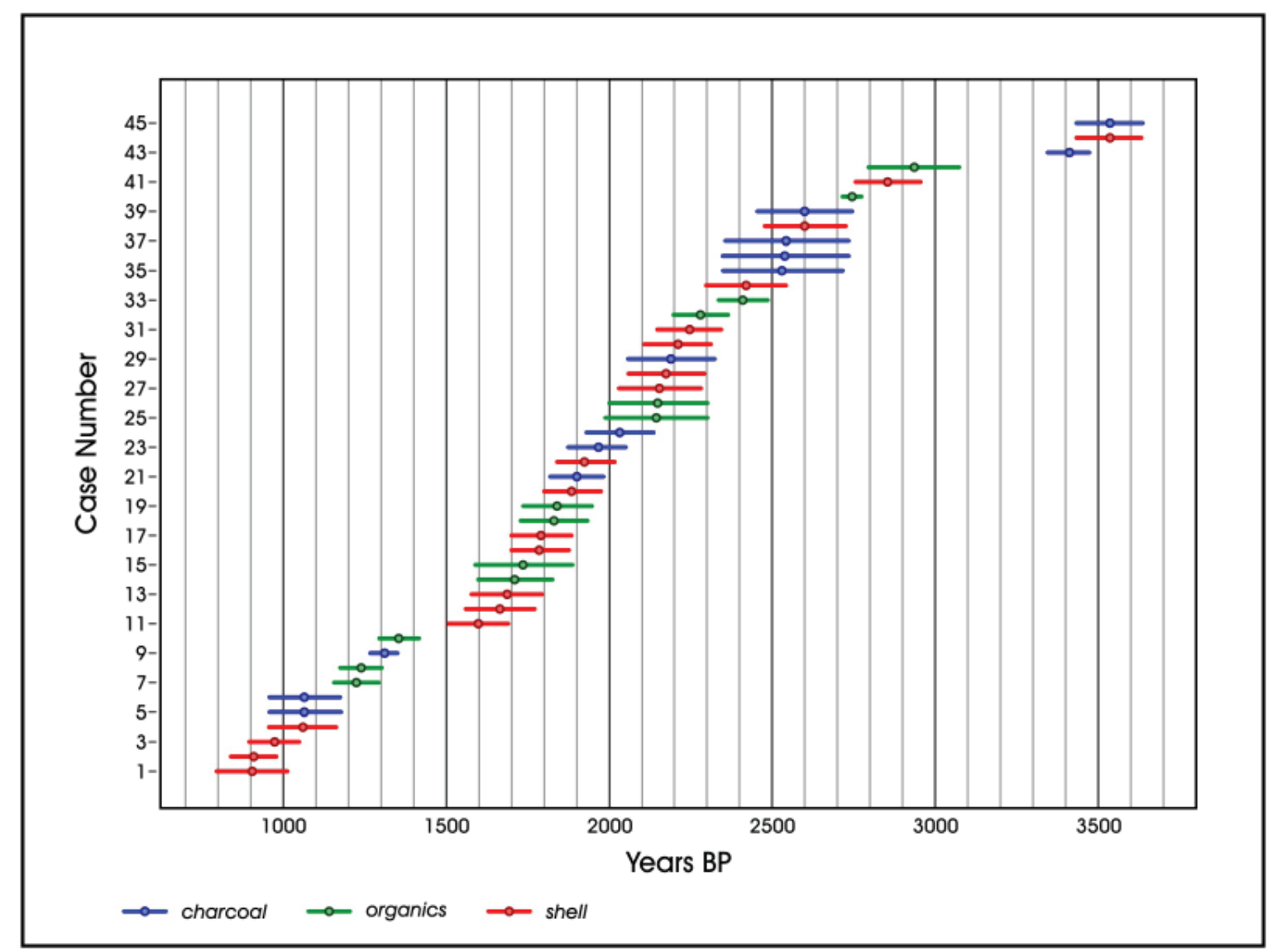

Figure 6-1. Radiocarbon dates associated with monitoring at 41NU2. Plotted at 2-sigma.

B.P., as represented by a cluster of dates from Features 7 and 110. Most occupation of the site falls between 3000 and 1600 B.P, with no evidence of site use after 900 B.P.

Figure 6-2 shows the distribution of dates from the North (top) and South dunes (bottom). Both dunes show roughly similar occupation patterns. The primary difference between the dunes appears to be that all three pre-3000 B.P. dates (Table 6-1; Samples 418, 440, and 396) are from the South dune.

\section{Assessing Marine Shell Dates}

One of the primary interests of the revised dating strategy noted above was to investigate the utility of radiocarbon dates on marine shell for age determination. Researchers have debated the accuracy of shell dates for decades (e.g., Anderson and Libby 1951; Berger et al. 1964; Gillespie and Polach 1979; Head 1982; Johnson 1955; Keith et al. 1964). Early comparisons of charcoal and shell dates from the same context frequently produced discrepancies of several hundred years, with uncorrected shell dates often being significantly older than charcoal dates. Marine shellfish produce shell from both organic carbon, derived primarily from diet, as well as inorganic carbon derived from ocean water. Radiocarbon analysis has focuses primarily on the inorganic component, essentially monitoring the ${ }^{14} \mathrm{C}$ activity of the ocean water in which the shell formed. One of the major sources of error in the accuracy of marine shell dates is, then, related to delays in exchanges between atmospheric $\mathrm{CO}_{2}$ and ocean carbonates, as well as impacts related to upwelling of older ocean waters and those related to fractionation (see Berger et al. 1966; Mangerud 1972; Stuckenrath 1977; R.E. Taylor 1987). Shell carbonates are also particularly susceptible to postdepositional recrystallisation, a process that can dramatically alter the dating accuracy (see Goslar and Pazdur 1985).

While the accuracy of marine shell dates will remain suspect, researchers have made significant advances understanding the sources of errors and developed corrections for those impacts (see R.E. Taylor 1987). Differences in fractionation are well understood and can be corrected, and shell dates are routinely calibrated against a marine calibration curve. Figure 6-3 presents a section of that curve, along with the associated atmospheric curve (Ramsey 2003). A comparison of the two curves shows that for the same radiocarbon determination (Y-Axis), the calibrated date 


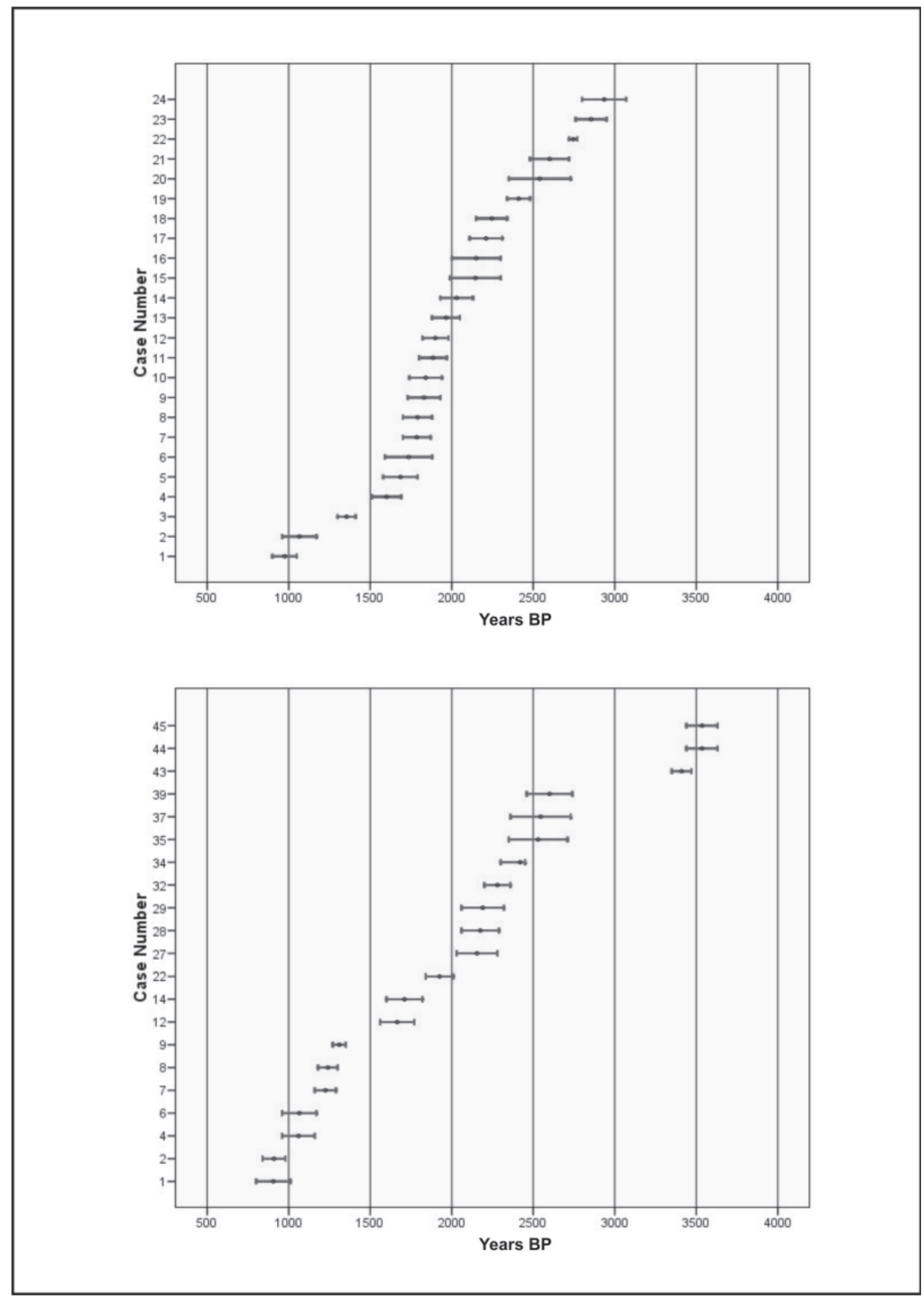

Figure 6-2. Top - Radiocarbon dates from the North Dune. Bottom - Radiocarbon dates from the South Dune and Beaumont Ridge. Plotted at 2-sigma. 


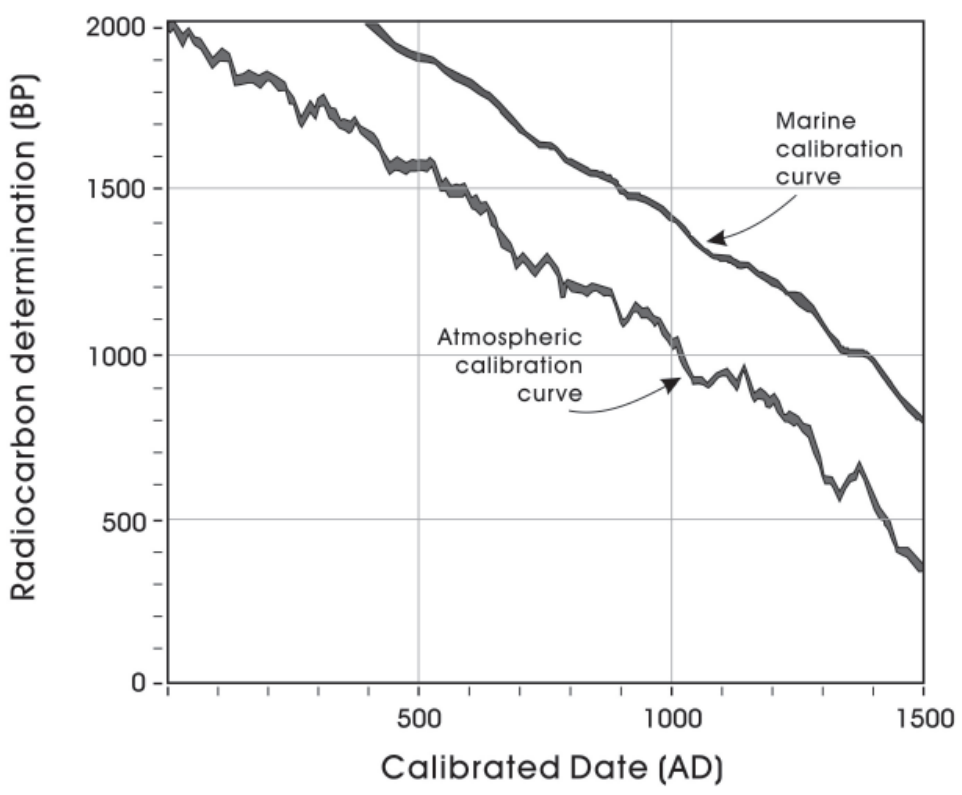

Figure 6-3. Comparison of marine (blue) and atmospheric (red) calibration curves from A.D. 1 to A.D. 1500.

Table 6-2. Dates for Matched Samples (Organics - Shell) at 2-Sigma, 41NU2

\begin{tabular}{|c|c|c|c|c|}
\hline $\begin{array}{c}\text { Feature } \\
\text { or FS \# }\end{array}$ & $\begin{array}{c}\text { Orgainics or } \\
\text { Charcoal 2 Sigma } \\
\text { Cal. (B.P.) }\end{array}$ & $\begin{array}{c}\text { Marine Shell } \\
\text { 2 Sigma Cal. } \\
\text { (B.P.) }\end{array}$ & $\begin{array}{c}\text { Overlap } \\
\text { Between Date } \\
\text { Ranges }\end{array}$ & Marine Shell Species \\
\hline 2 & $1170-960$ & $980-840$ & YES & Macrocallista nimbosa \\
\hline 16 & $1300-1180$ & $1160-960$ & NO & Busycon sinistrum \\
\hline 18 & $1940-1740$ & $1690-1510$ & NO & Macrocallista nimbosa \\
\hline 31 & $1820-1600$ & $1770-1560$ & YES & Crassostrea virginica \\
\hline 46 & $2050-1880$ & $2340-2150$ & NO & Busycon sinistrum \\
\hline 49 & $1870-1700$ & $5990-5870$ & NO & Macrocallista nimbosa \\
\hline 54 & $1290-1160$ & $1010-800$ & NO & Busycon sinistrum \\
\hline 63 & $3070-2800$ & $2720-2480$ & NO & Macrocallista nimbosa \\
\hline 84 & $2740-2460$ & $2290-2060$ & NO & Crassostrea virginica \\
\hline 103 & $2300-1990$ & $1970-1800$ & NO & Macrocallista nimbosa \\
\hline 110 & $3630-3440$ & $3630-3440$ & YES & Crassostrea virginica \\
\hline 115 & $2770-2720$ & $2950-2760$ & YES & Macrocallista nimbosa \\
\hline $121 / 33$ & $2730-2360$ & $2540-2300$ & YES & Crassostrea virginica \\
\hline 122 & $2320-2060$ & $2010-1840$ & NO & Busycon sinistrum \\
\hline 123 & $1170-960$ & $1050-900$ & YES & Busycon sinistrum \\
\hline 153 & $2300-2000$ & $1790-1580$ & NO & Busycon sinistrum \\
\hline 155 & $2480-2340$ & $2310-2110$ & NO & Crassostrea virginica \\
\hline FS 71 & $2360-2200$ & $2280-2030$ & YES & Crassostrea virginica \\
\hline FS 270 & $1980-1820$ & $1880-1590$ & YES & Macrocallista nimbosa \\
\hline FS 271 & $1930-1730$ & $1880-1700$ & YES & Macrocallista nimbosa \\
\hline
\end{tabular}

(X-Axis) differs by about 400 years. In addition, the Figure 6-3 curves also show at least one advantage to dating shell. Because of the effects of the oceanic reservoir, the marine calibration curve lacks the wiggles that are common in the curve used for terrestrial samples. Shell dates should produce calibrated dates that are more precise than dates derived from charcoal of other organics that rely on the atmospheric calibration.

For the $41 \mathrm{NU} 2$ comparisons, 20 charcoal or organic sediment samples were paired with 20 marine shell samples collected from the same feature or occupation zone. Table 6-2 presents the 2-sigma ranges for dates on organics and the associated shell counterpart for a given provenience. Assuming that the charcoal or organic dates are an accurate reflection of the true date, and using the 2-sigma range, only $45 \%$ ( 9 of 20) of the shell date ranges overlap their charcoal or organic counterparts (Table 6-2). Frequently, the corrected, calibrated shell dates are more recent than the date obtained from their charcoal/organic sediment counterpart.

The Table 6-2 results suggest that the 2-sigma date range on shell does not provide an accurate match with the charcoal/organic sediment date at 41NU2. However, note that some shell species, such as Crassostrea virginica, have relatively good correspondence, with a success rate of four overlaps in six comparisons $(66.7 \%)$. Conversely, only in 1 of $6(16.7 \%)$ cases did the date ranges of Busycon sinistrum overlap with the range for the paired organic sample. While sample sizes are small, and while additional comparisons will be necessary, these data suggest that relatively good success rates might be anticipated by focusing on shell from Crassostrea virginica.

Finally, Figure 6-4 considers the relationship between paired samples in a slightly different way. Here we use the midpoint of the 2-sigma spread and plot the corrected, calibrated shell dates (Y-Axis) against the midpoints for the organic sediment or 


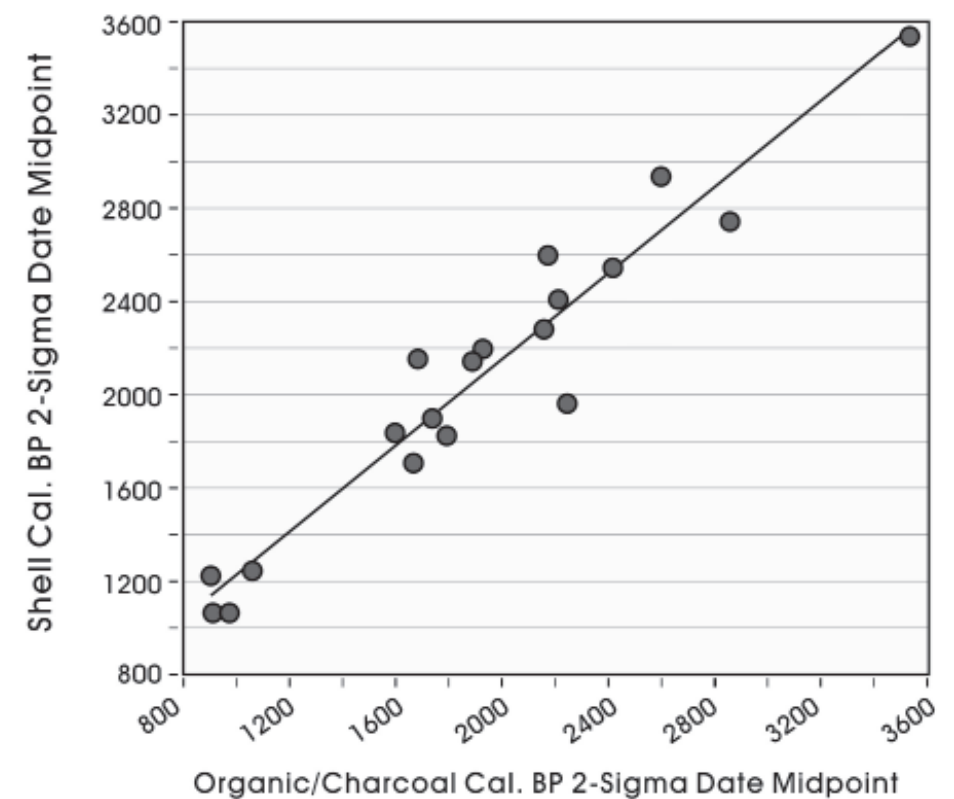

Figure 6-4. Plot of mid-point of the 2-sigma range for paired marine shell and organic samples from $41 N U 2$.

charcoal dates (X-Axis). We eliminated one matching pair (Feature 49, samples 381 and 426, Table 6-1) which formed a significant outlier. Clearly, the figure shows a strong, linear relationship for the remaining 19 pairs. Pearson's correlation coefficient for the 19 cases is .965 . Shell midpoints are, on average, about 160 years more recent than corresponding charcoal dates.

The systematic difference shown in Figure 6-4 may hint at local corrections that need to be made in the overall marine curve. However, the charcoal/organic sediment dates may also be overestimating the true feature age. We lack any details on the particular type of charcoal or organic sediment dates, and it is certainly possible that long-lived tree species make up a significant component of the samples dated. While old wood is unlikely to account for differences on the order of 160 years in the coastal region, as our paired samples lack any information on species it is probable that the true dates of feature use may be more recent than the charcoal/organic dates.

\section{Summary}

Radiocarbon dates from features and occupation zones collected during the $41 \mathrm{NU} 2$ monitoring project suggest that the earliest documented occupation of the site was about 3500 B.P. Occupation seems to increase after around
3000 B.P., a time frame for the possible coalescence of the barrier islands. After about 900 B.P. we lack any radiocarbon dates, suggesting that the site was not extensively used. While comparison of shell and organic dates from the same context shows that in most cases there was no overlap between date ranges, our results do suggest that certain species of shell may be more reliable as a dating tool. In addition, there is a strong linear relationship between the midpoints of date ranges derived from paired shells and organics. If we assume that the organic dates reflect the true age of a feature, then corrections on the order of 160 years may be required for shell dates to accurately reflect feature ages. However, given that the organic samples probably contain wood of varying ages, it is probable that the organic ages overestimate the true feature age. Shell dates, then, especially from Crassostrea virginica, have a high probability of providing accurate dates with good precision.

\section{Features}

One hundred and seventy features were defined in the field during this project. Of these, two (Features 4 and 6) were removed from the list because of changes in the definition of feature (see Chapter 4; see also Meissner 2000:5-6). Another (Feature 30), was removed because it was clearly historic or modern. In addition, two cultural manifestations originally defined as features were later shown to be part of an occupation zone and not distinct features (Features 84 and 129). Finally, Features 33 and 121 were combined into a single feature. The remaining 164 features are described in this section. For each of the four areas of the site (South Dune, Beaumont Ridge, North Dune, Pond and Northwest Ridge), a table of basic data is presented. In these tables, the features are not considered by the sequential number given to them.

During analysis, a list of feature types was defined based on 1) content or use, such as shell clusters, hearths and pits; 2) in some cases, a size category; 3 ) other characteristics that were found in multiple cases. For instance, many hearths did not seem to be associated with large amounts of shells, while others of the same type were. Another example is a type of shallow pit with a flat bottom, completely filled with shells, most of which were small 
and consisted of a single species. A list of Feature Types with a definition for each is provided in Table 6-3. A brief description of each Feature Type listed in Table 6-3 is given below, followed by a listing of features found in each zone. Features that are simply scatters of shell, small surficial hearths, or other common and non-distinctive types will be listed in tabular form. Only if the feature presents unique characteristics or has been carbon dated, will a more detailed description be completed within the zone segments. Feature locations are shown in Figures 6-5 though 6-9.

\section{Feature Types Found at 41NU2}

Table 6-3 presents a list of Feature Types with definitions. Here a more detailed description of the most common and least distinctive types of features will be presented, with examples.

\section{Shell Concentrations}

Shell concentrations were clusters of marine/estuarine and/ or land invertebrate shells, of varying density, usually with well-defined borders, and without evidence of a hearth or a pit. During Phase I, only concentrations containing charcoal were considered features in order to limit the number of features that had to be excavated. Shell concentrations were the most common feature, constituting 42.1\% (69/164) of the features recorded at $41 \mathrm{NU} 2$. These concentrations were frequently mixtures of species, but occasionally consisted almost exclusively of a single species. Some shell concentrations were not homogenous, showing clusters of a particular shell surrounded by a more generalized scatter of different species.

Shell concentrations varied widely in size, from about 25 $\mathrm{cm}$ to as much as 5 or $6 \mathrm{~m}$ in diameter (see Table 6-3). An

Table 6-3. Feature Types Defined at 41NU2

\begin{tabular}{|c|c|c|}
\hline Feature Type & Count & Definition \\
\hline Shell Concentrations & 69 & $\begin{array}{l}\text { Descrete cluster of marine or land invertebrates. May or may not include animal bone, charcoal, or burned clay } \\
\text { flecks or nodules; }\end{array}$ \\
\hline Type 1 & 36 & Feature area is less than $10,000 \mathrm{~cm}^{2}$ \\
\hline Type 2 & 19 & Feature area is between 10,000 and $25,000 \mathrm{~cm} 2$ \\
\hline Type 3 & 14 & Feature area is more than $25,000 \mathrm{~cm} 2$ \\
\hline Hearths & 57 & $\begin{array}{l}\text { Descrete area in which a combination of charcoal and burned clay suggest that a fire was built at that location. } \\
\text { May or may not have been placed in a basin dug for the purpose; }\end{array}$ \\
\hline Surficial-Type 1 & 11 & Hearth with no sign of a basin. Few or no shell associated; \\
\hline Surficial-Type 2 & 11 & Hearth with no sign of a basin. A significant number of shells or bones are closely associated; \\
\hline Basin-Type 1 & 17 & Basin is clearly visible. Few or no shells or bone associated. Less than $15 \mathrm{~cm}$ deep; \\
\hline Basin-Type 2 & 11 & Basin is clearly visible. A significant number of shells or bone is closely associated. Less than $15 \mathrm{~cm}$ deep; \\
\hline Basin-Type 3 & 2 & Basin is large and $>15 \mathrm{~cm}$ deep. Few or no shells or bone associated; \\
\hline Basin-Type 4 & 1 & Basin is large and $>15 \mathrm{~cm}$ deep. A significant number of shells or bone are closely associated; \\
\hline Multiple & 4 & $\begin{array}{l}\text { A group of two or more closely associated, surficial hearths, surrounded by a thin scatter of charcoal and } \\
\text { shell fragments; }\end{array}$ \\
\hline Pits & 20 & Areas where a pit can be defined. Most are densely packed with shells, and charcoal; \\
\hline Type 1 & 10 & Pit is no more than $15 \mathrm{~cm}$ deep filled with charcoal and/or shell and animal bone; \\
\hline Type 2 & 4 & Deeper than $15 \mathrm{~cm}$, filled with charcoal and/or shell and animal bone; \\
\hline Type 3 & 4 & $\begin{array}{l}\text { Small, shallow }(3-5 \mathrm{~cm}) \text { pit densely packed with shell most a single small shell species, most of which are whole, with } \\
\text { a few other species, most of which are are highly fragmented; }\end{array}$ \\
\hline Type 4 & 1 & Pit of any size or depth that is empty or only has a few shell or charcoal flecks in fill; \\
\hline Multiple & 1 & A group of two or more closely associated pits surrounded by shell and charcoal; \\
\hline Other Feature Types & 18 & Miscellaneous features other than shell concentrations, hearths and pits; \\
\hline Bone fragment scatter & 7 & $\begin{array}{l}\text { Often fairly dense but thin layers of highly fragmented or small bone with charcoal and usually a few fragmented } \\
\text { shells. Usually consists largely of small fish bone; }\end{array}$ \\
\hline Bone bed & 2 & Group of large, largely intact bones, with or without marine shells; \\
\hline Charcoal cluster & 4 & Cluster of very dense charcoal with no associated burned clay, and few or no associated shells; \\
\hline Rabdotus cluster & 2 & Dense cluster with few or no marine shells; \\
\hline Burial pit & 3 & Pit dug to interred human remains; \\
\hline
\end{tabular}




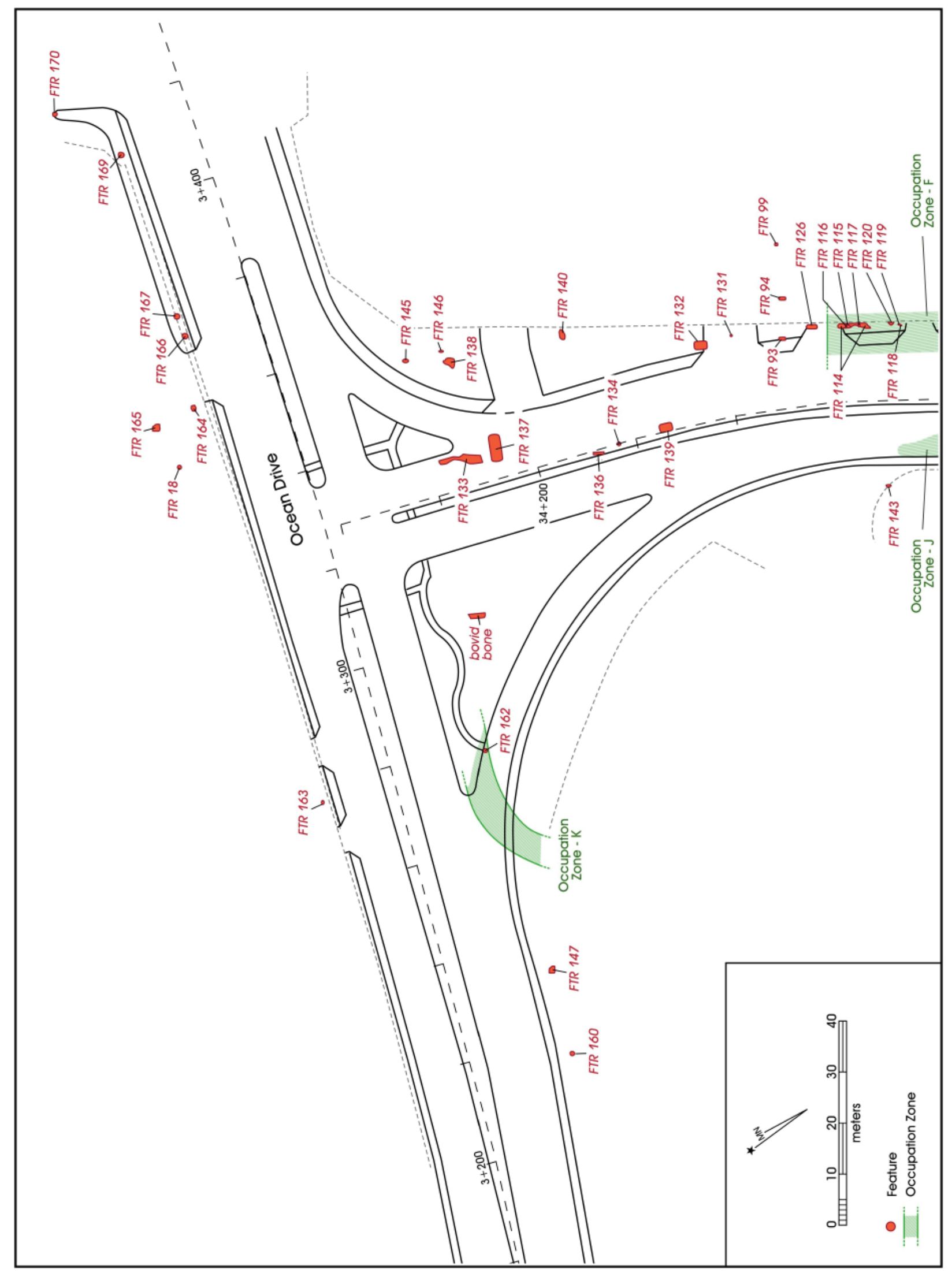

Figure 6-5. Detail of project map between $34+120$ and 34+325 showing locations of features and occupation zones. 


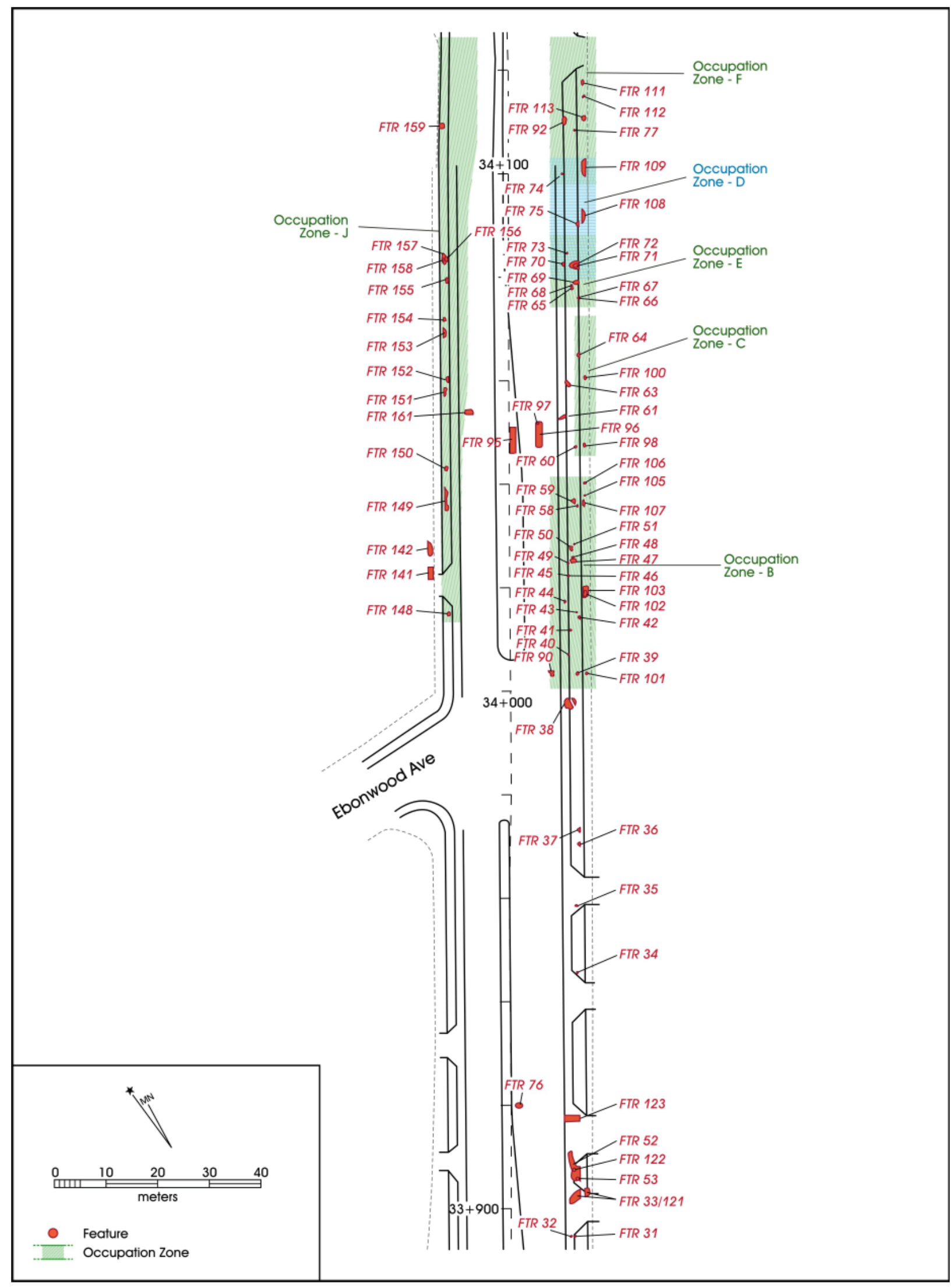

Figure 6-6. Detail of project map between $33+900$ and $34+120$ showing locations of features and occupation zones. 


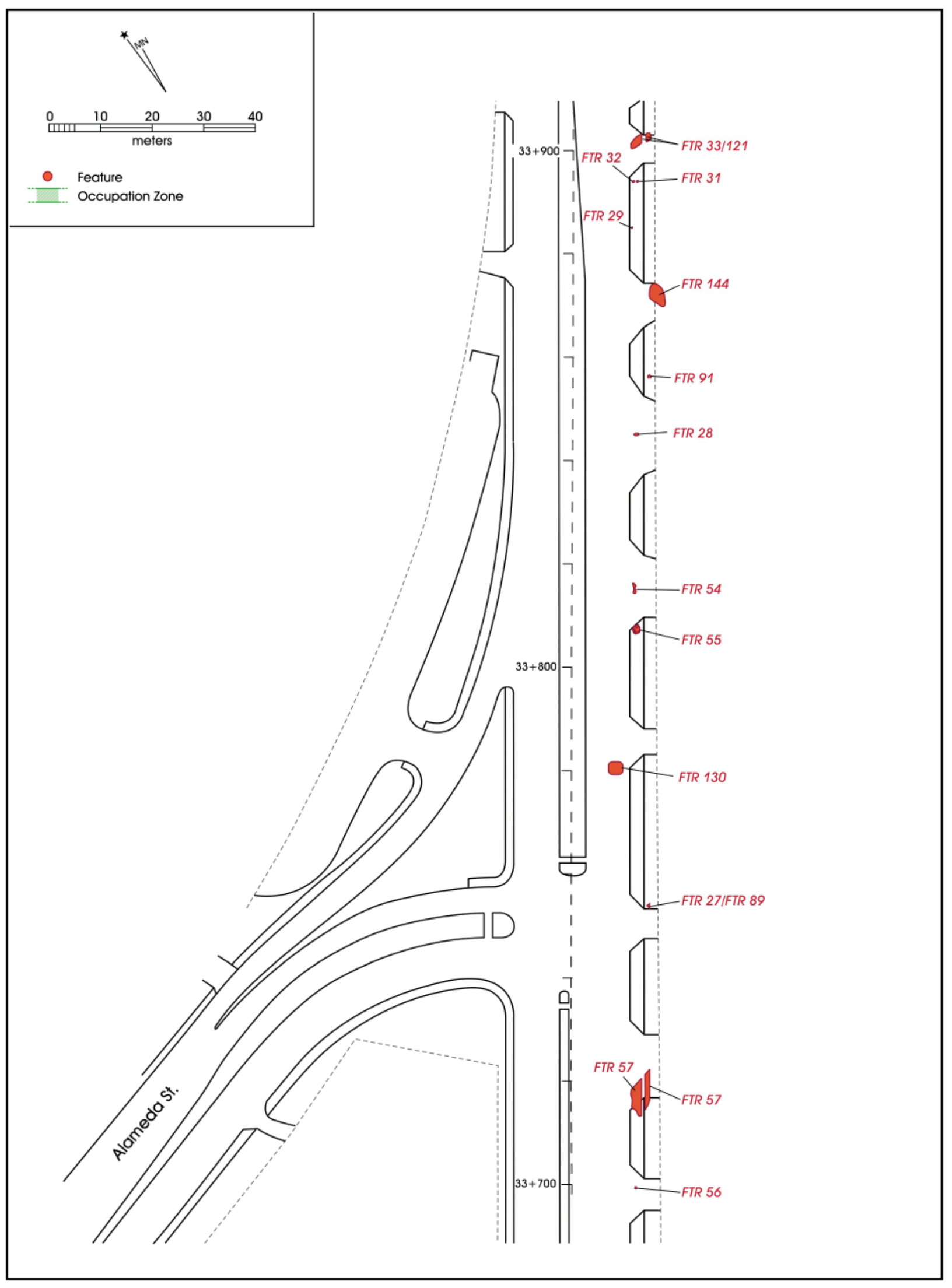

Figure 6-7. Detail of project map between $34+120$ and 33+700 showing locations of features and occupation zones. 


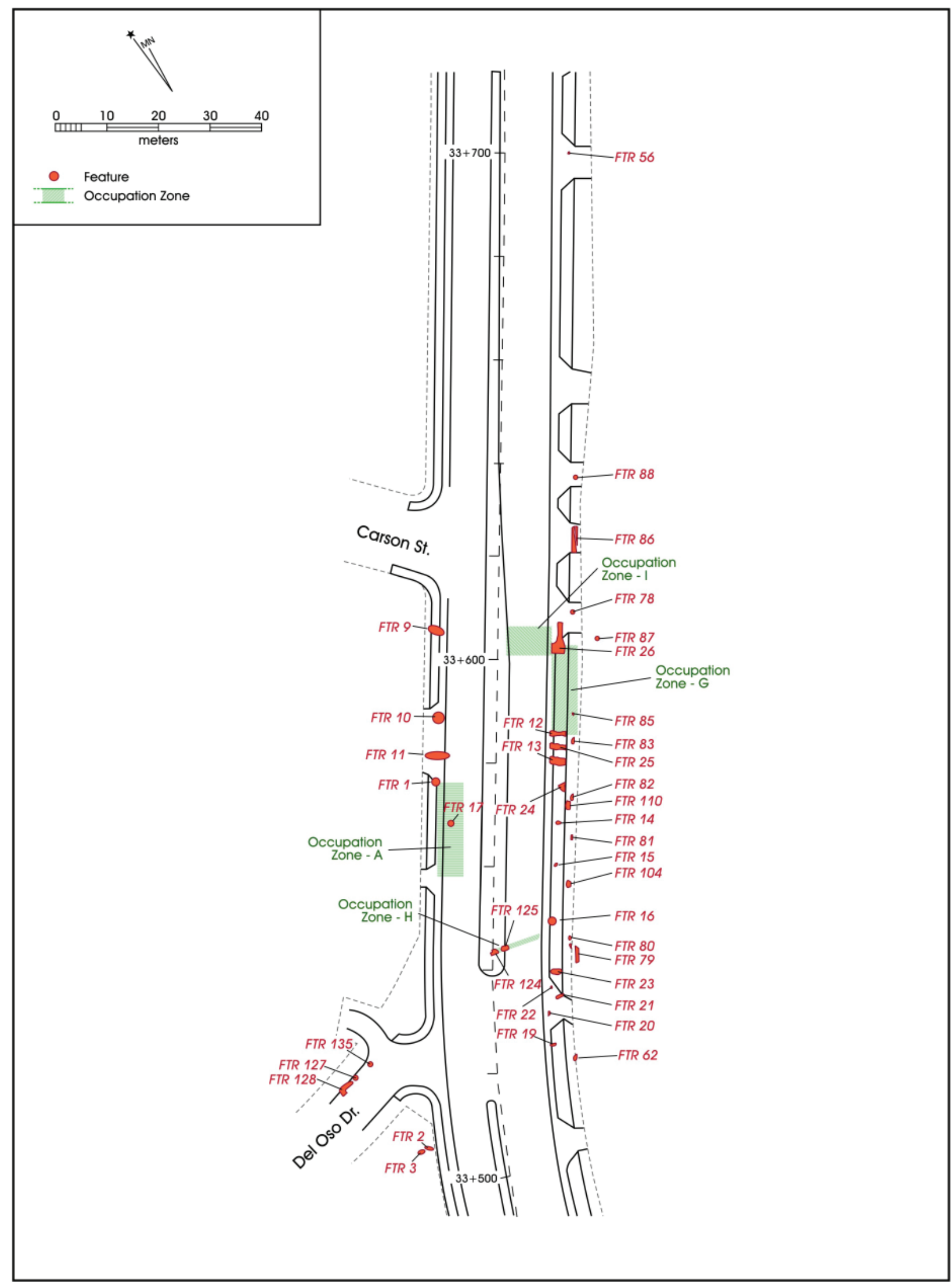

Figure 6-8. Detail of project map between $33+500$ and $33+700$ showing locations of features and occupation zones. 


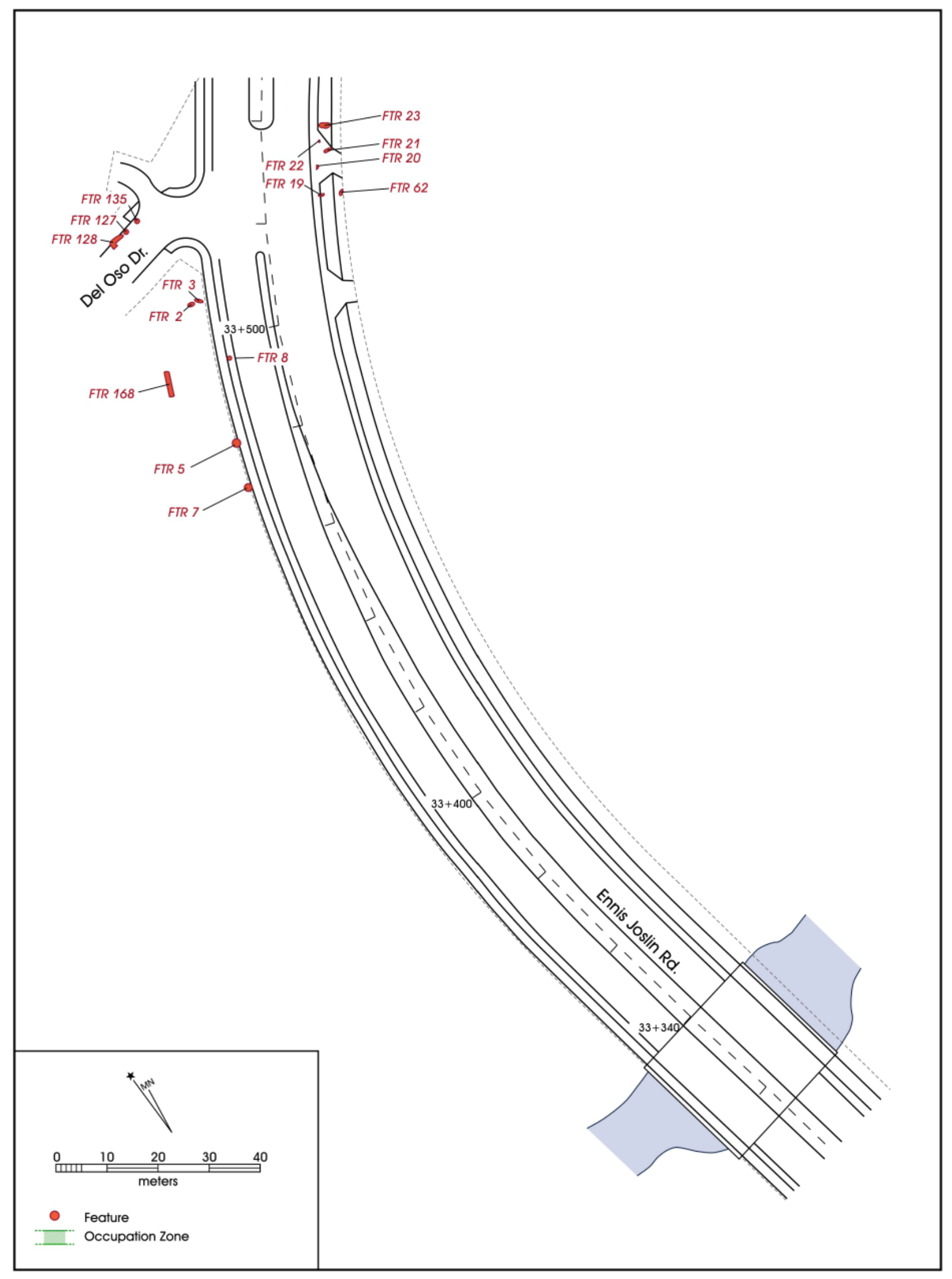

Figure 6-9. Detail of project map between $33+320$ and $33+500$ showing locations of features and occupation zones. 
estimated area for each shell concentration was calculated using the formula: $\mathrm{A}=\pi(\mathrm{X} / 2)$ $(\mathrm{Y} / 2)$, where $\mathrm{A}$ is the area, $\mathrm{X}$ is the longest radius and $\mathrm{Y}$ is the shortest radius. Shell concentration areas varied from less than 500 $\mathrm{cm}^{2}$ to more than $141,000 \mathrm{~cm}^{2}$. A histogram of the areas of the shell features fell into one of three distinct groupings. There were 36 Type 1 shell concentrations, each less than 10,000 $\mathrm{cm}^{2}$, constituting of 52.2 percent of the shell concentrations. Nineteen shell concentrations were between $10,000 \mathrm{~cm}^{2}$ and $25,000 \mathrm{~cm}^{2}, 27.5$ percent of the shell concentration features. The 14 shell concentration features measured more than $25,000 \mathrm{~cm}$ in area and made up 20.3 percent of the shell concentration features.

Some concentrations were relatively thin, discrete, scatters. Others were very dense (Figure 6-10). Although most were a single shell deep, a few contained several layers of shell. Most were round to oval in outline.

\section{Hearths}

Hearths were defined when it appeared that a fire was built at a location. No hearthstones were seen due to lack of rock in the environment. Hearths comprised $34.8 \%(57 / 164)$ of the features identified during the project (Table 6-3). A dense deposit of shells surrounded some hearths. Others had little or no associated shell. In four cases, there where multiple hearths, that is two or more distinct hearth areas in close association, usually less than a meter apart.

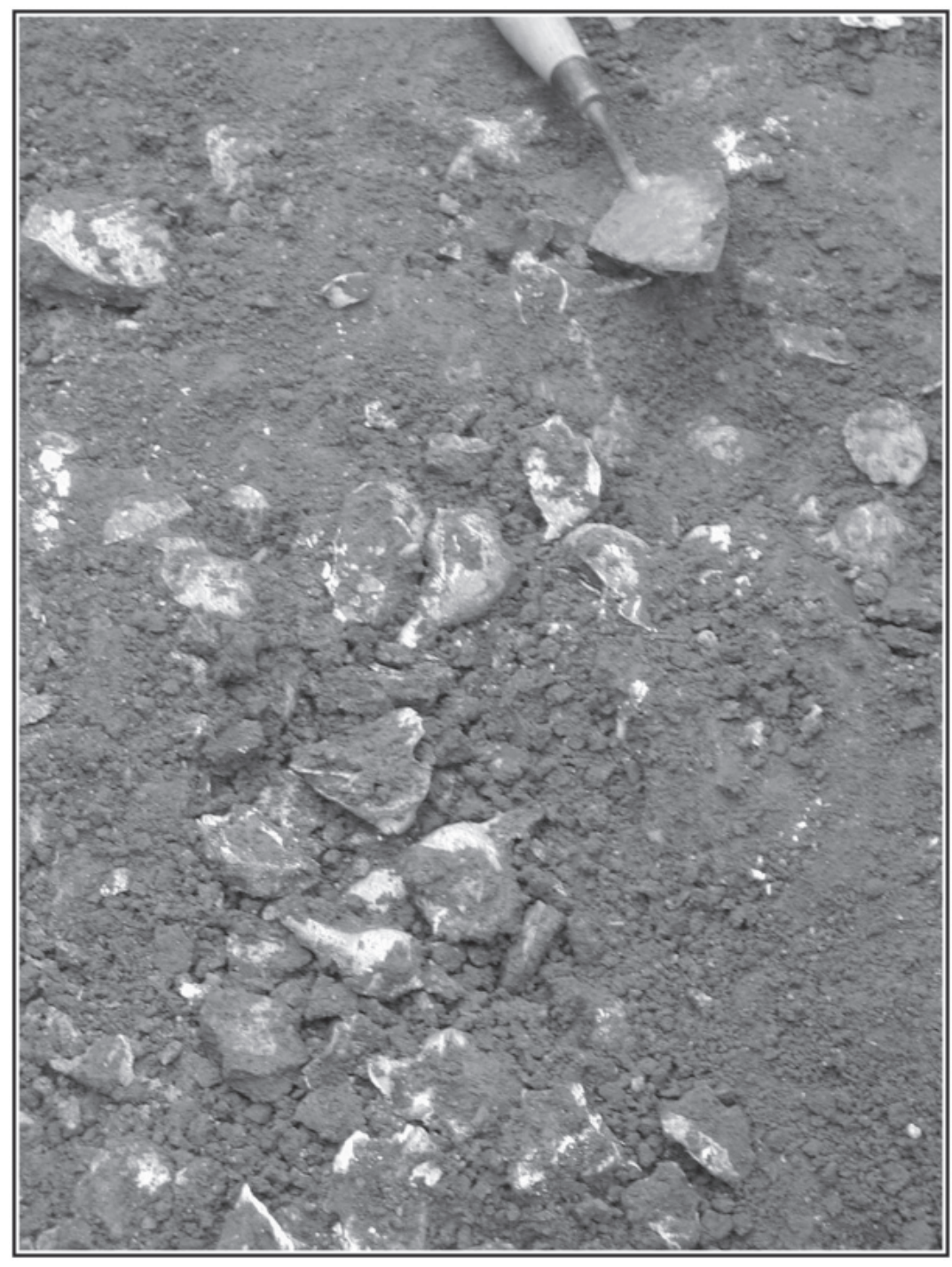

Figure 6-10. Feature 38, showing an example of a dense shell cluster.
There were 22 hearths that appeared to have been built on the ground surface, with no pit. They comprised $41.5 \%$ of features with single hearths (Table 6-3). Hearths in a basin made up the remaining $58.5 \%$ (31/53) of features with single hearths. Surficial hearths consisted of a concentration of charcoal and burned clay that was usually only $1-3 \mathrm{~cm}$ deep (Figure 6-11). The surficial hearths were always small, usually no more than $30 \mathrm{~cm}$ in diameter, with dense charcoal and burned clay.

Basin hearths are locations where a pit was dug in the ground surface before the fire was built. Most of these pits were shallow, with 90.3 percent $(28 / 31)$ of basin hearths less than $15 \mathrm{~cm}$ deep (Table 6-3). They were occasionally dug much deeper. Figure 6-12 shows a plan and profile of Feature 67, an example of a shallow basin hearth.

\section{Pits}

Features were defined as pits when a basin was clearly present and it did not appear to have been dug for a hearth (e.g. Figure 6-13). There were 20 pits identified during the project, they constituted $12.2 \%$ of the features. In many cases, pits were originally defined as small shell concentrations, and then, as the Gradall or backhoe continued digging through the feature, it could be seen that it was a pit. Feature forms were modified when this occurred.

Most pits were 5 to $15 \mathrm{~cm}$ deep and packed densely with shell (Figure 6-13b). Some were dug from paleosols into a light clay layer. Some pits had large quantities of animal bones among the shells. One type, Pit Type 3 (Table 6-3), consisted of small, shallow pits packed with charcoal, fragments of marine shell, and large numbers of a single species of small 


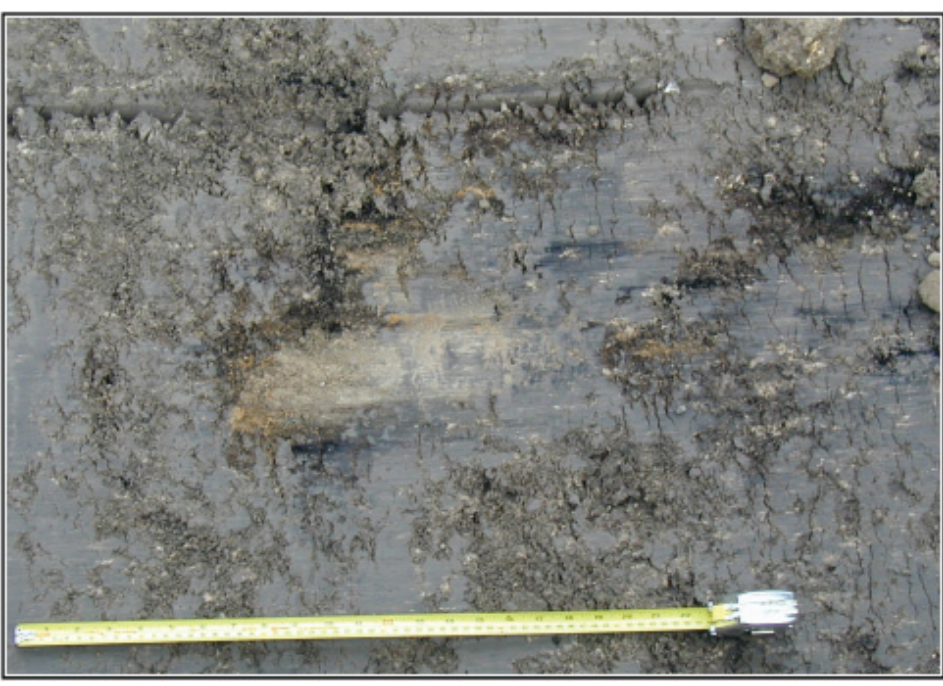

Figure 6-11. Feature 27, an example of a small surficial hearth.

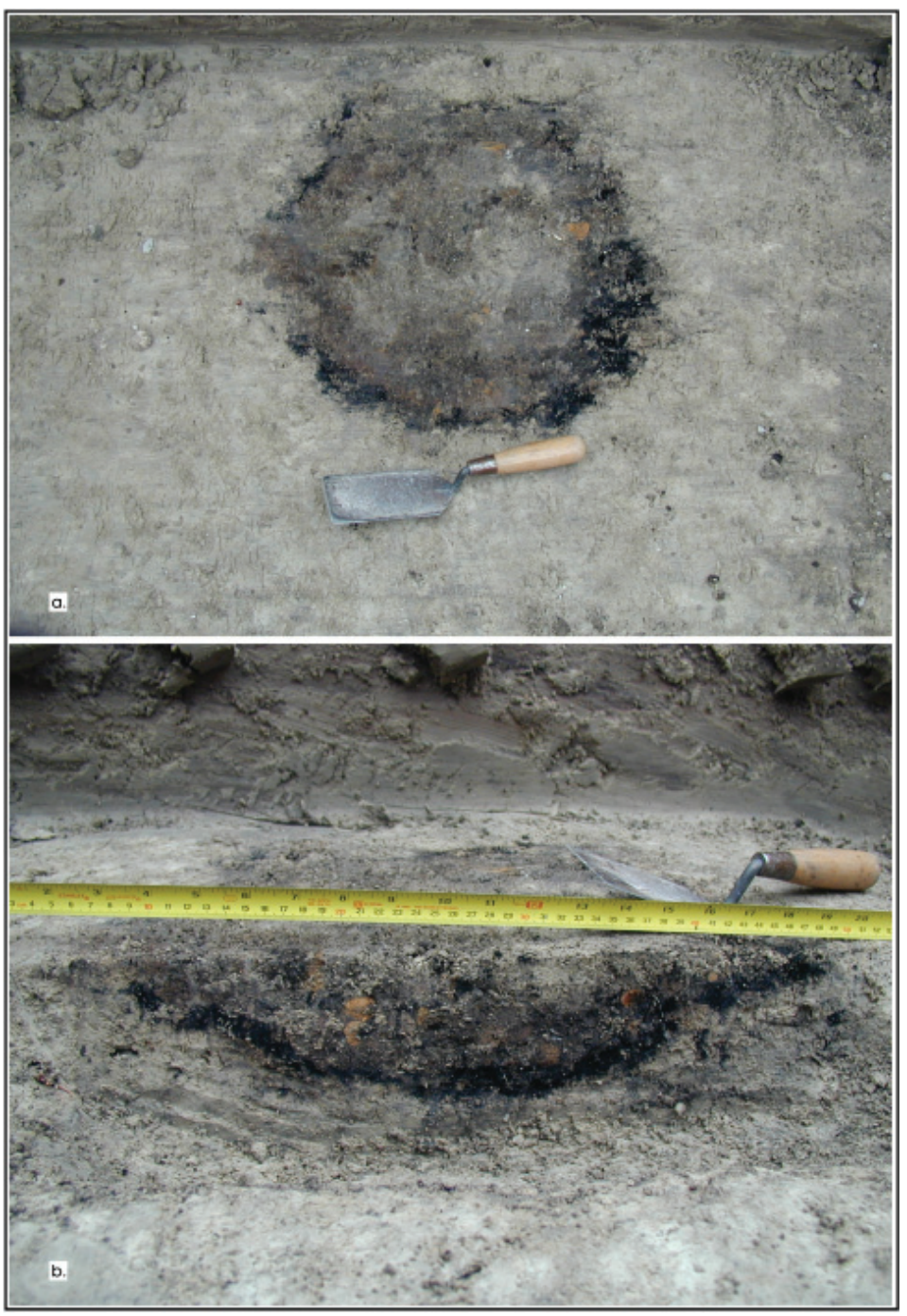

Figure 6-12. Feature 67, an example of a shallow basin hearth: a) plan view; b) profile. shell, either Crossbar Venus (Chione cancellata) clams or Rabdotus (sp.) land snails.

\section{Other Feature Types}

Over $89 \%$ of the features fell into one of the feature types listed above. Other, less common feature types, are described below.

Bone Fragment Scatters. These features were distinctive clusters of bone, charcoal, and usually a few scattered and fragmented marine shells. They ranged in size from a tiny cluster measuring only $15 \times 15 \mathrm{~cm}$ to a $550 \times 200$ $\mathrm{cm}$ area with a thin layer of dense bone.

Bone Bed. Bone beds are areas with many largely intact bones. There were two such features defined during the project, Features 13 and 170. Both bone bed features are described in detail below.

Charcoal cluster. These four features consisted of very dense clusters of charcoal but no evidence of burnt soil. Typically, a thin scatter of shell was associated with the charcoal.

Rabdotus cluster. This feature type does not include pits in which Rabdotus shells were packed. In these features hundreds, and in the case of Feature 107 (Figure 6-14), perhaps thousands of Rabdotus were present.

Burial Pit. A burial pit is defined as a pit in which human remains were interred. Three such pits were recorded during this project, Feature 61 (Burial 2), Feature 136 (Burial 4), and Feature 139 (Burials 6 and 7). These were discussed in the previous chapter.

\section{Features in the South Dune}

The 40 features described in this section were found on both sides of the road within the South Dune area. These 40 features represent $24.2 \%$ of the features encountered during the project. One was located in a pit dug for a manhole box, and the rest were found in trenches. Table 6-4 presents basic data on these features organized by location, south to north, and includes an in-field estimate of the kinds of shells found in each. Artifacts found in these features were discussed in the previous chapter. Aanalysis of the faunal remains is included in Chapter 11. Feature locations can be found on Figures 6-8 and 6-9. Samples from five features, from a cluster of shell and 


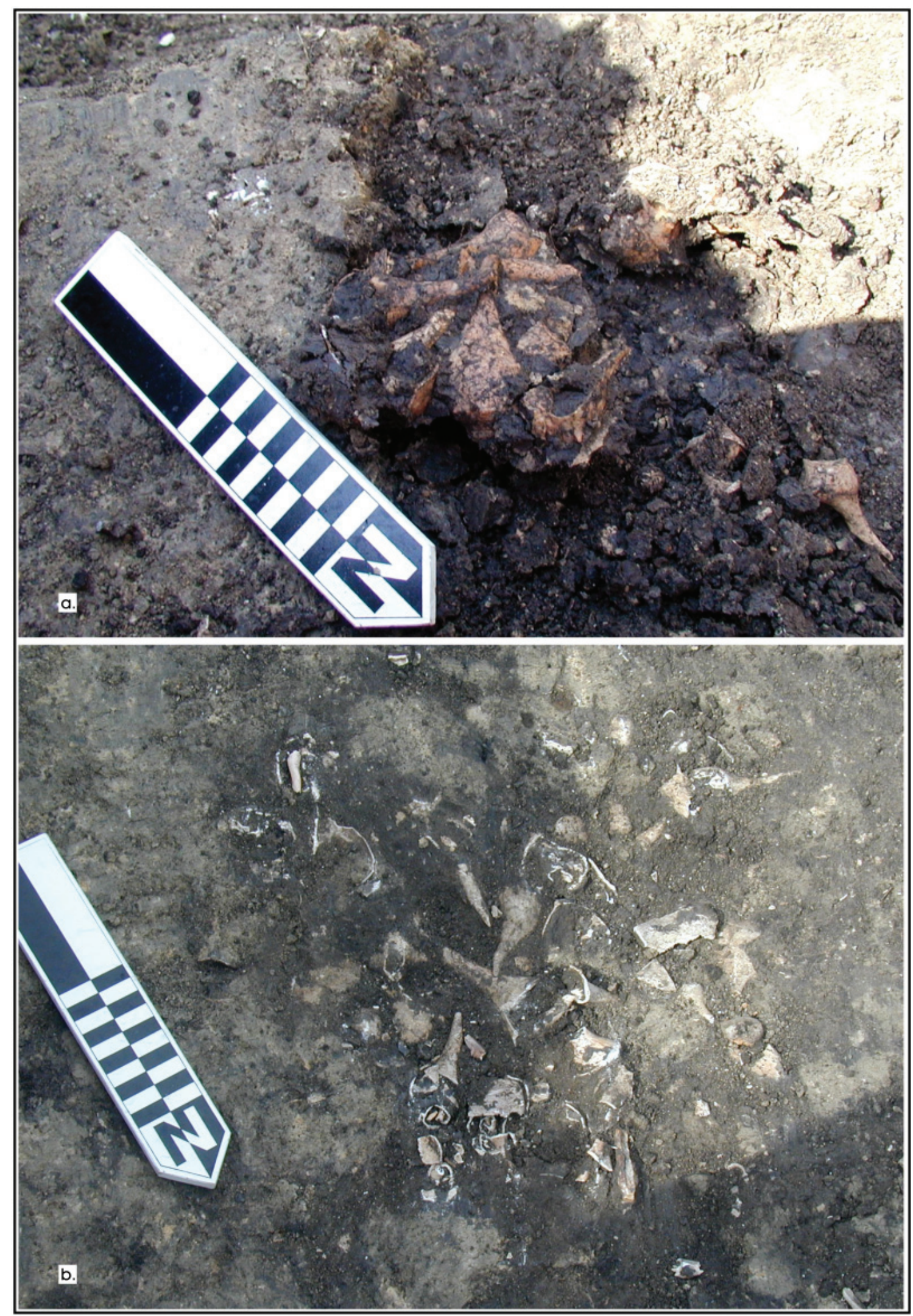

Figure 6-13. Feature 102, a small pit densely packed with Lightning Whelks: a) surface of pit (note pit was dug into light sediments); b) Pit fill from Feature 102, showing dense packing of shells. 


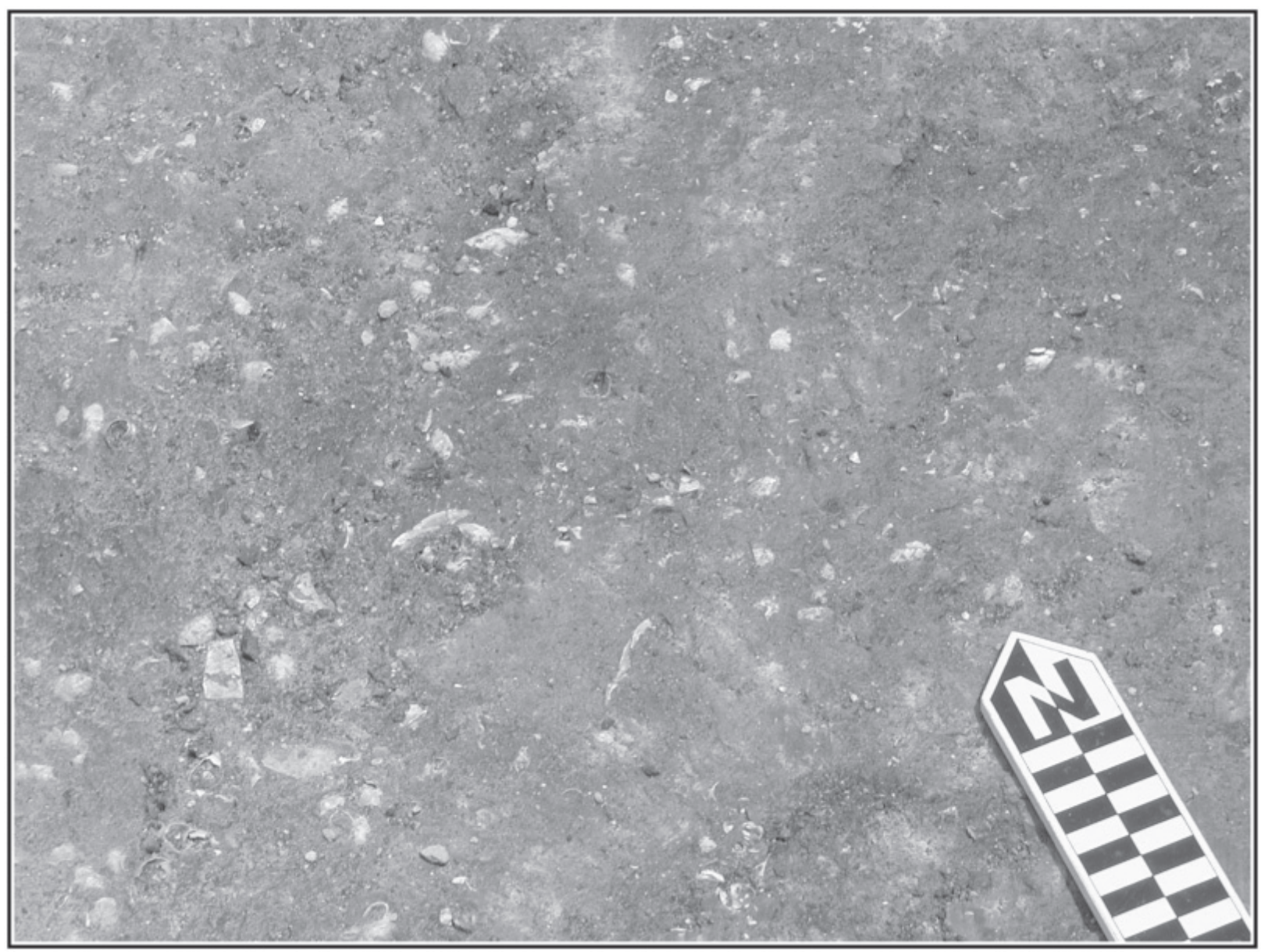

Figure 6-14. Close up of Feature 107, showing masses of Rabdotus shells.

Table 6-4. Features in the South Dune

\begin{tabular}{|c|c|c|c|c|c|c|c|c|c|c|c|c|c|c|c|}
\hline \multirow[b]{2}{*}{ Feature } & \multirow[b]{2}{*}{ Feature Type } & \multicolumn{4}{|c|}{ Description } & \multicolumn{10}{|c|}{ Estimated \% of Common Shells* } \\
\hline & & 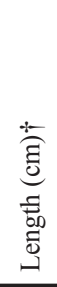 & 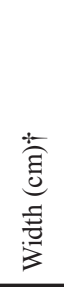 & 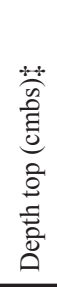 & 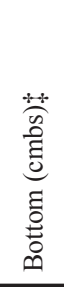 & 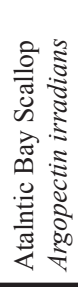 & 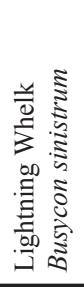 & 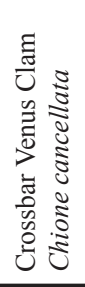 & 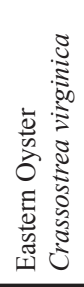 & 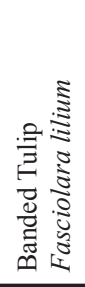 & 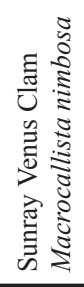 & 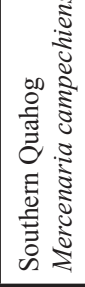 & 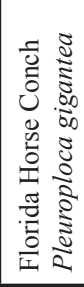 & 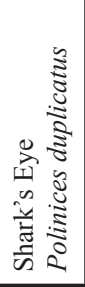 & 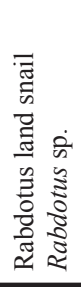 \\
\hline 7 & Rabdotus cluster & 60 & 30 & 242 & 245 & + & + & - & - & - & - & - & - & - & + \\
\hline 5 & Bone fragment scatter & 15 & 15 & 240 & 245 & - & - & - & - & - & - & - & - & - & + \\
\hline 168 & Shell Concentration- Type 3 & 470 & 100 & 60 & 67 & - & 10 & - & - & - & 90 & - & - & - & - \\
\hline 8 & \begin{tabular}{|l|} 
Shell Concentration-Type 1 \\
\end{tabular} & 40 & 30 & 45 & 55 & - & 27 & - & - & - & 73 & - & - & - & - \\
\hline 2 & Shell Concentration- Type 1 & 120 & 40 & 30 & 40 & - & - & - & - & - & 100 & - & - & - & - \\
\hline 3 & Shell Concentration-Type 1 & 100 & 80 & 40 & 45 & - & - & - & - & - & 100 & - & - & - & - \\
\hline
\end{tabular}

$\dagger$ Measurements within the boundaries of the trench.

\$ Vertical datum in the field was the road or ground surface.

* Estimates based on observation in the field. Actual counts from sampling are included in Fauna section of Chapter 11.

"+" sign means presence mentioned in notes; "- -" sign means absent/not observed. 
Table 6-4. Continued...

\begin{tabular}{|c|c|c|c|c|c|c|c|c|c|c|c|c|c|c|c|}
\hline \multirow[b]{2}{*}{ Feature } & \multirow[b]{2}{*}{ Feature Type } & \multicolumn{4}{|c|}{ Description } & \multicolumn{10}{|c|}{ Estimated \% of Common Shells* } \\
\hline & & 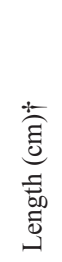 & 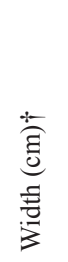 & 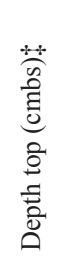 & 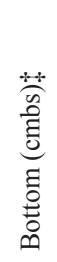 & 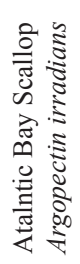 & 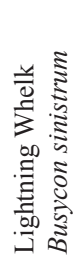 & 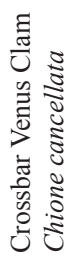 & 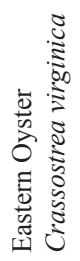 & 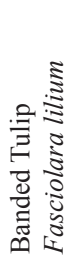 & 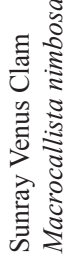 & 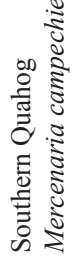 & 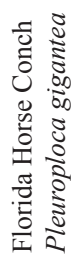 & 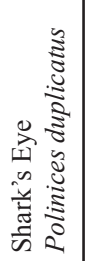 & 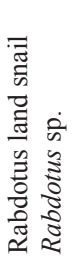 \\
\hline 135 & Shell Concentration- Type 1 & 30 & & 80 & 87 & - & + & - & + & - & - & + & - & - & - \\
\hline 19 & Bone fragment scatter & 150 & 75 & 165 & 172 & & - & - & - & - & - & - & - & - & - \\
\hline 62 & Hearth, Basin-Type 1 & 15 & $?$ & 244 & 247 & & - & - & - & - & - & - & - & - & - \\
\hline 128 & Shell Concentration- Type 1 & 100 & 100 & 60 & 74 & - & - & - & - & - & - & 95 & - & - & - \\
\hline 127 & Shell Concentration- Type 2 & 300 & 100 & 72 & 87 & + & + & - & + & - & - & - & - & - & - \\
\hline 20 & Shell Concentration- Type 1 & 75 & 75 & 160 & 168 & 10 & 60 & - & 5 & - & 20 & + & - & + & - \\
\hline 21 & Shell Concentration- Type 1 & 150 & 75 & 175 & 185 & - & 48 & - & + & - & 48 & - & - & + & - \\
\hline 22 & Shell Concentration- Type 2 & 175 & 178 & 30 & 40 & 80 & 8 & - & - & - & - & 8 & + & - & - \\
\hline 23 & Shell Concentration- Type 2 & 200 & 100 & 175 & 178 & 20 & 57 & + & 10 & - & - & 10 & - & - & - \\
\hline 79 & Shell Concentration- Type 2 & 310 & 80 & 45 & 57 & - & 90 & - & - & - & + & - & - & + & - \\
\hline 124 & Hearth, Surficial-Type 2 & 100 & 100 & 90 & 92 & - & + & - & - & - & + & - & - & - & - \\
\hline 80 & Bone fragment scatter & 70 & 60 & 127 & 130 & & - & - & - & - & - & - & - & - & - \\
\hline 125 & Hearths, Multiple & 80 & 80 & 150 & 153 & & - & - & - & - & - & - & - & - & - \\
\hline 16 & Shell Concentration - Type 1 & 70 & 55 & 93 & 99 & - & 95 & - & + & - & - & - & - & + & - \\
\hline 104 & Shell Concentration- Type 1 & 130 & 80 & 145 & 160 & - & 23 & - & - & - & 70 & 5 & - & - & + \\
\hline 15 & Shell Concentration- Type 1 & 40 & 30 & 143 & 148 & + & - & - & + & - & + & + & - & - & - \\
\hline 81 & Hearth, Basin-Type 2 & 90 & 20 & 80 & 85 & - & 95 & - & - & - & - & - & - & + & - \\
\hline 14 & Bone fragment scatter & 50 & 50 & 125 & 135 & - & - & - & + & - & - & - & - & 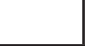 & + \\
\hline 17 & Shell Concentration- Type 2 & 150 & 150 & 85 & 95 & 10 & 80 & 5 & & - & - & - & - & - & - \\
\hline 110 & Pit-Type 1 & 100 & 40 & 150 & 165 & - & + & - & 45 & - & - & 45 & + & + & + \\
\hline 82 & Pit-Type 1 & 100 & 50 & 135 & 140 & - & + & - & + & - & - & - & - & - & - \\
\hline 24 & Shell Concentration- Type 2 & 150 & 120 & 91 & 97 & - & - & 85 & - & - & - & 15 & - & - & - \\
\hline 1 & Shell Concentration- Type 1 & 80 & 55 & 75 & 100 & 65 & + & - & 10 & - & 20 & + & - & - & - \\
\hline 11 & Shell Concentration- Type 2 & 300 & 80 & 85 & 110 & 10 & 23 & + & 36 & - & + & 24 & + & - & - \\
\hline 13 & Bone bed & 170 & 160 & 132 & 150 & + & 8 & & 67 & 4 & 5 & 14 & & + & + \\
\hline 25 & Shell Concentration- Type 2 & 300 & 100 & 85 & 94 & + & - & - & 95 & - & - & + & - & - & - \\
\hline 83 & Shell Concentration- Type 1 & 120 & 80 & 45 & 60 & - & 80 & - & - & - & 15 & - & - & - & - \\
\hline 12 & Shell Concentration- Type 2 & 300 & 80 & 90 & 110 & + & + & - & 92 & - & + & 6 & - & - & - \\
\hline 10 & Shell Concentration- Type 1 & 150 & 80 & 80 & 100 & - & - & - & 95 & - & + & + & - & - & - \\
\hline 85 & Hearth, Surficial— Type 1 & 37 & 23 & 65 & 67 & - & + & & - & - & - & - & - & - & - \\
\hline 87 & Shell Concentration- Type 1 & 60 & 40 & 100 & 103 & - & - & - & + & + & - & + & - & - & - \\
\hline 26 & Shell Concentration- Type 3 & 600 & 300 & 120 & 138 & 15 & 30 & - & 50 & - & - & 5 & - & - & - \\
\hline 9 & Shell Concentration- Type 2 & 300 & 60 & 50 & 60 & 17 & 58 & + & 17 & - & - & - & - & - & + \\
\hline 78 & Shell Concentration- Type 1 & 160 & 60 & 71 & 80 & + & + & - & + & + & & - & - & - & - \\
\hline
\end{tabular}

$\dagger$ Measurements within the boundaries of the trench.

$\$$ Vertical datum in the field was the road or ground surface.

* Estimates based on observation in the field. Actual counts from sampling are included in Fauna section of Chapter 11.

"+" sign means presence mentioned in notes; "- - sign means absent/not observed. 
charcoal at $124 \mathrm{cmbs}$, and from OZ-G, were radiocarbon dated. In this section, we only report the dates derived from charcoal or organic sediment. No shell dates are used. Of particular interest among the South Dune features are Features 7, 2, 16, 81, and 10, which are dated, and Feature 13, which is a bone bed.

\section{Feature 7}

Feature 7 is an example of the Rabdotus cluster feature type (Table 6-3). It is a small cluster of Rabdotus land snails with a few broken Lightning Whelks (Busycon sinistrum) and Bay Scallops (Argopectin irradians), and a scatter of charcoal (Table 6-4). Feature 7 is the southern-most and deepest of the features recorded on the site, and was dated to a time (3470 - 3350 B.P.) when the barrier islands may not have fully developed.

\section{Feature 2}

Feature 2 is a thin, linear concentration of Sunray Venus clams (Macrocallista nimbosa), most of which are in fragments (Table 6-4). Feature 2 was dated to 1170-960 B.P. (2 Sigma Calibration), making it, along with Feature 123 on the north dune, one of the youngest feature recorded on the site.

\section{Feature 16}

Feature 16 was a relatively small concentration of 68 Lightning Whelks with a few other marine shells (Table 6-4) and a small amount of bone, including some from a deersized artiodactyls. It was dated to $1300-1180$ B.P.

\section{Feature 81}

Feature 81 , only about $15 \mathrm{~m}$ north of Feature 16 on the slope of the dune, had a similar date of 1350 - 1270 B.P. Feature 81 was a small, shallow basin hearth with a few scattered shells (Table 6-4).

\section{Feature 10}

Feature 10 is a small but dense concentration of oyster shell (Crassostrea virginica) with a few other shells (Table 6-4), and large numbers of small bone fragments, including those of fish, a rabbit (Sylvilagus sp.), and a rattlesnake (Crotalus sp.). It dates from 2710 to 2350 B.P.

\section{Feature 13}

This feature was a collection of horse (Equus caballos) bones found piled in the bottom of a large erosional gully, filled with laminated layers of sand and very fine dark clay (Figure 6-15a). The bones continued into the wall of the trench. Feature 13 was re-located during Phase III, while realigning Trench B. The bones were, for the most part, disarticulated and in a jumbled pile several bones deep in the narrow bottom of the gully, which extended to $150 \mathrm{cmbs}$ (Figure 6-15b). The bones are those of an adult horse, and represents an MNI of 1. One rib bone has evidence that it was broken and healed completely, with bone smoothly remodeled. There are no butcher marks on the bones. There is no evidence of chewing by either rodents or carnivores. The absence of chewing marks and lack of evidence of atmospheric weathering suggests the bones were buried soon after deposit.

The lowest layer of bones included a humerus and radio-ulna that remained in anatomical position and were probably still articulated when the bone reached the bottom of the gully. The two femurs were not far apart, and in roughly anatomical position, with the right innominate located nearby. The bones were in excellent condition. Eight species of marine shells were identified in close proximity to the horse bones (Figure 6-15b), including an unusual number $(\mathrm{n}=11)$ of banded tulips (Fasciolaria lillium), a species that is only occasionally found in features at the site. Also present were a number of Lightning Whelks, and more than 300 oyster shell fragments, representing at least 41 individuals. The presence of so many shells, as well as the charcoal and burned clay, may be the result of deflation. However, the presence of at least a few articulated bones (Figure 6-15c), the uncommon shell type, and the generally good condition of the bone suggests that the contents could not have suffered significant movement after deposition. It is possible that a horse was buried soon after its death.

\section{Features on the Beaumont Ridge}

The south dune is separated from the north dune by a remnant ridge of Beaumont Clay. When undisturbed, this Pleistocene clay has a layer of cumulic sandy clay above it (Ricklis 1997:17). Within this cumulic clay, usually sitting directly above the Beaumont clay, 19 features were encountered during the project (Table 6-5). Feature locations are shown on Figures 6-6 and 6-7. Of particular interest are Features 28, 31, 33/121, 53, 54, 57 and 122. Features 31, 54, 33/121, and 122 have associated charcoal dates. The features are discussed below as they occurred, south to north.

\section{Feature 57}

Feature 57, the largest feature in the Beaumont Ridge area, was a moderately thick concentration composed mostly of oysters, with an area on the northern end that was almost entirely scallops (Figure 6-16; Table 6-5). 

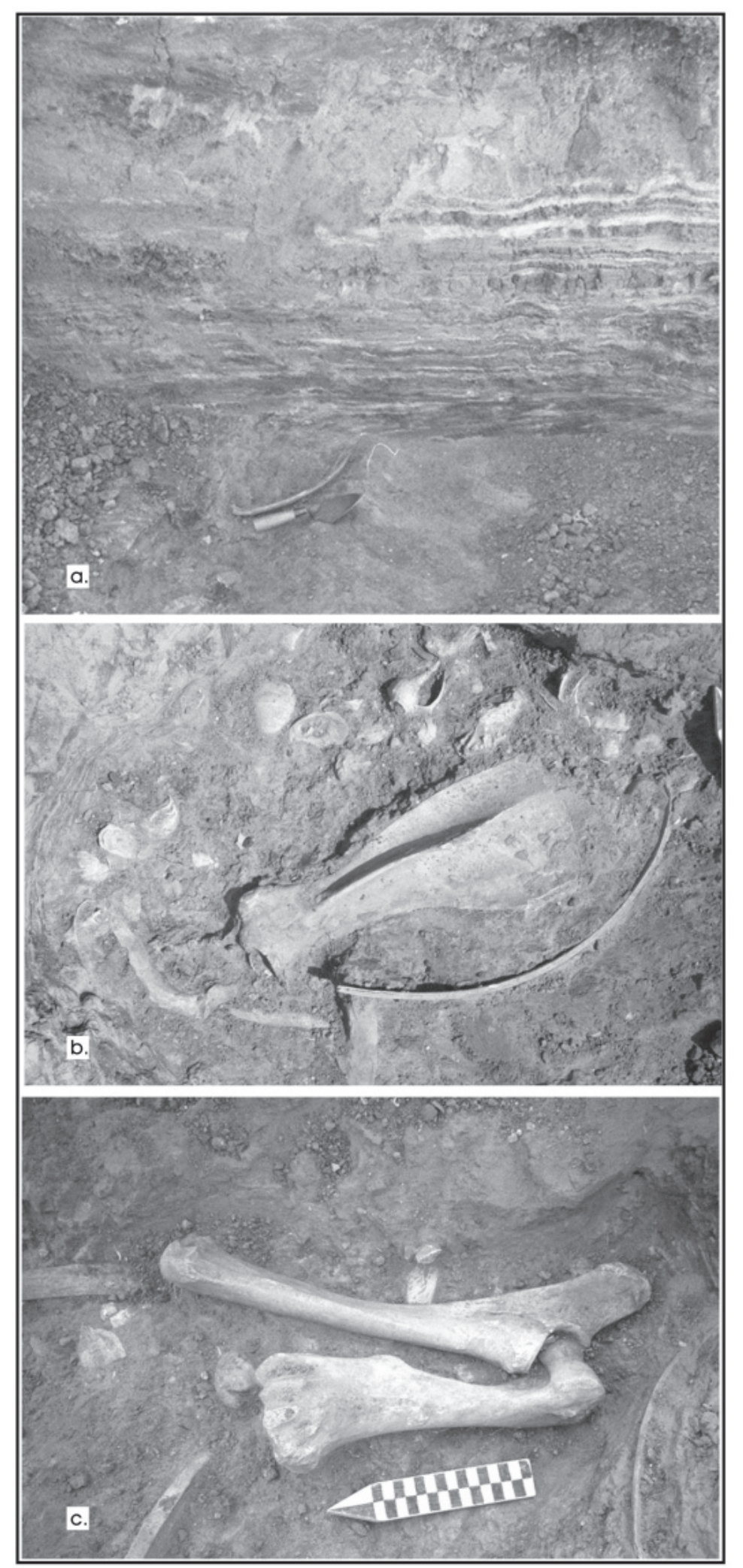

Figure 6-15. Feature 13: a) profile showing the naturally filled gully in which Feature 13 was located; b) after clearing of the upper layer of horse bones; c) the lower level of horse bones. Note that the humerus and radio-ulna are in anatomical position.

\section{Feature 54}

Feature 54 was one of the more interesting features at the site. First seen as a dark stain in medium light clay, truncated on the northwest by the digging of the western half of Trench B (Figure 6-17a), it was found to be a large, complex basin hearth, dug into the Beaumont clay (Figure 6-17b). The south half had a layer of charcoal lining the basin that was at least $2 \mathrm{~cm}$ thick and was filled with lumps of burned clay and charcoal. The north basin appeared to have had a similar charcoal lining at one time, but it had been dug out, leaving layers of ash, charcoal, and a few Lightning Whelk shells (Table 6-5). The charcoal in this feature dated to 1290 - 1160 B.P.

\section{Feature 28}

Feature 28 was not immediately noticed among the scattered shells just above the Beaumont, but was conveniently cut in half by the Gradall, providing an excellent profile. It was dug more than $15 \mathrm{~cm}$ into the Beaumont clay and filled with oyster shell (Table 6-5). Besides oysters there were only a few other marine shell fragments, a few flecks of burned clay, and charcoal in the pit fill.

\section{Feature 31}

Feature 31 was a fairly large hearth (Table 6-5) with a shallow (ca. $6 \mathrm{~cm}$ ) basin. It was dug from the cumulic sandy clay almost to the top of the Beaumont clay. The basin looks as if it had been scooped out at least once (Figure 6-18). When abandoned, it was left packed with charcoal and small (ca. 1-2 cm), soft burned clay nodules. This feature was dated to $1820-1600$ B.P.

\section{Feature 33/121}

Feature 33 and 121, defined separately in the field were actually the same feature, and will be considered together here and in Table 6-5. In Trench B, Feature 33 appeared to be a pile of Lightning Whelk shells. As it extended to the east, however in Trench I, this western pile was seen to be the largest of three whelk shell piles surrounded by a thinner scatter of oysters and quahogs (Table 6-5). The eastern part of this feature was dated to $2730-2360$ B.P.

\section{Feature 53}

Feature 53 was a fairly large pit with flat bottom and uneven walls, $10 \mathrm{~cm}$ deep and completely packed with shell. Most of thes shells are large Rabdotus land 
Table 6-5. Features on the Beaumont Ridge

\begin{tabular}{|c|c|c|c|c|c|c|c|c|c|c|c|c|c|c|c|}
\hline \multirow[b]{2}{*}{ Feature } & \multirow[b]{2}{*}{ Feature Type } & \multicolumn{4}{|c|}{ Description } & \multicolumn{10}{|c|}{ Estimated \% of Common Shells* } \\
\hline & & 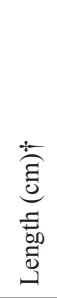 & $\begin{array}{l}\text { 䓂 } \\
\text { 吾 } \\
\text { s. }\end{array}$ & 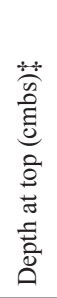 & 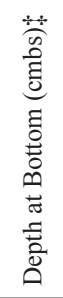 & 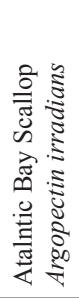 & 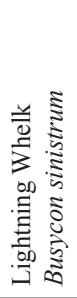 & 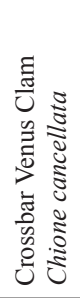 & 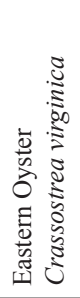 & 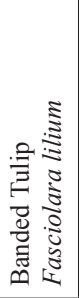 & 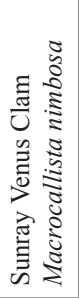 & 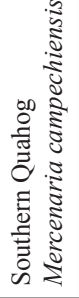 & 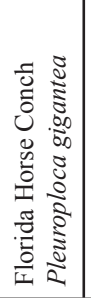 & 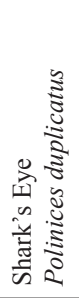 & 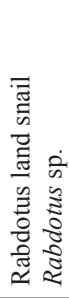 \\
\hline 86 & Shell Concentration- Type 3 & 400 & 100 & 37 & 53 & 5 & - & - & 20 & - & - & 75 & - & - & - \\
\hline 88 & Shell Concentration- Type 1 & 78 & 65 & 92 & 110 & - & - & - & 50 & - & - & 45 & - & - & - \\
\hline 56 & Hearth, Basin - Type 1 & 30 & 30 & 46 & 60 & - & - & - & - & - & - & - & - & - & - \\
\hline 57 & Hearth Basin —-Type 1 & 500 & 200 & 60 & 68 & 20 & 5 & - & 70 & - & - & - & - & - & - \\
\hline 27 & Hearth, Surficial—-Type 1 & 40 & 40 & 65 & 80 & - & + & - & + & - & - & - & - & - & - \\
\hline 89 & Shell Concentration-Type 1 & 75 & 42 & 67 & 69 & - & - & - & - & - & - & - & - & - & - \\
\hline 130 & Shell Concentration- Type 3 & 260 & 200 & 50 & 60 & - & + & - & - & - & + & + & - & - & - \\
\hline 55 & Hearths, Multiple & 140 & 120 & 43 & 45 & - & - & - & - & - & - & - & - & - & - \\
\hline 54 & Hearth, Basin-Type 2 & 160 & 75 & 53 & 80 & - & + & - & - & - & - & - & - & - & - \\
\hline 28 & Pit-Type 1 & 58 & 28 & 55 & 70 & 10 & - & - & 90 & - & - & - & - & - & - \\
\hline 91 & Hearth, Basin-Type 2 & 95 & 95 & 75 & 108 & - & - & - & - & - & - & - & - & - & - \\
\hline 144 & Hearth, Basin-Type 2 & 380 & 300 & 25 & 28 & - & + & - & - & - & 70 & 20 & - & - & - \\
\hline 29 & Hearth, Basin-Type 1 & 40 & 30 & 72 & 89.3 & - & + & - & + & - & - & - & - & - & - \\
\hline 31 & Hearth, Basin-Type 1 & 50 & 50 & 84 & 90 & - & + & - & + & - & - & - & - & - & - \\
\hline 32 & Hearth, Basin-Type 1 & 150 & 150 & 70 & 78 & - & 30 & - & 60 & - & - & - & - & - & - \\
\hline $33 / 121$ & Shell Concentration- Type 2 & 200 & 140 & 105 & 125 & + & 48 & - & 25 & - & - & 25 & - & - & - \\
\hline 53 & Pit-Type 3 & 60 & 40 & 113 & 124 & + & 15 & - & 10 & + & - & - & - & - & 70 \\
\hline 122 & Pit-Type 1 & 80 & 30 & 105 & 125 & - & 95 & - & 4 & - & - & - & - & - & + \\
\hline 52 & Shell Concentration- Type 3 & 500 & 200 & 56 & 60 & - & 60 & - & 10 & - & - & 29 & + & - & - \\
\hline
\end{tabular}

$\dagger$ Measurements within the boundaries of the trench.

\$Vertical datum in the field was the road or ground surface.

* Estimates based on observation in the field. Actual counts from sampling are included in Fauna section of Chapter 11.

"+" sign means presence mentioned in notes; "- - sign means absent/not observed.

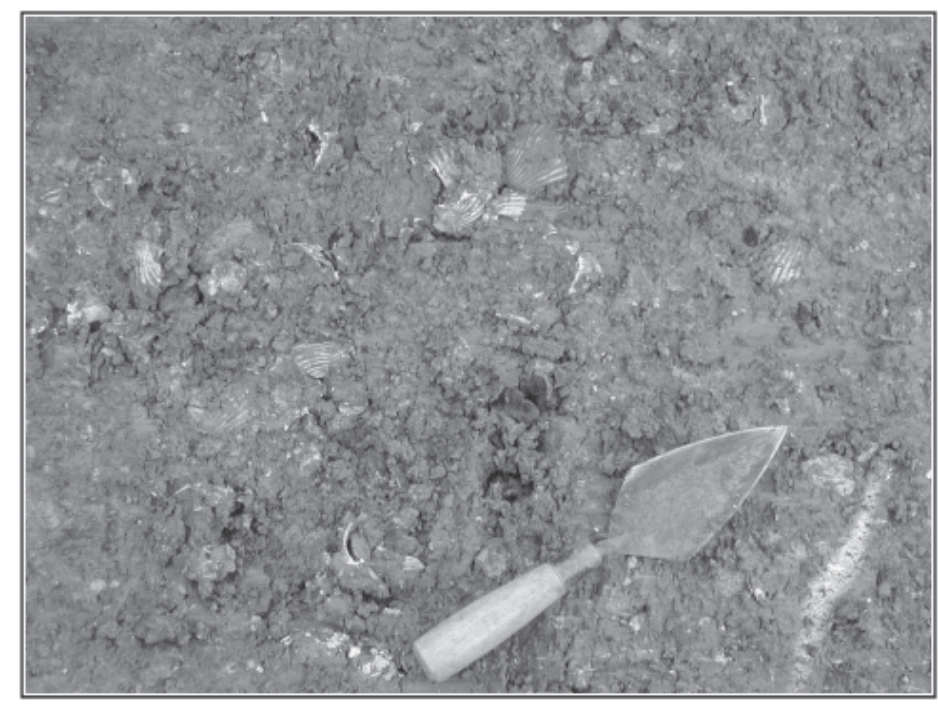

Figure 6-16. The numerous scallops in the north end of Feature 57, in the Beaumont Ridge area. Note the numerous burned clay nodules. snails, but fragments of marine shells were also present (see Table 6-5). Charcoal and small (ca. $1 \mathrm{~cm}$ ) burned clay nodules were present in the fill.

\section{Feature 122}

Feature 122 is an example of a pit packed with shells that were also piled above and around the pit. In this case, the shells were Lighting Whelk, with a scatter of Rabdotus and a few oysters (Table 6-5). The feature was dated to 2320 - 2060 B.P.

\section{Features in the North Dune}

Table 6-6 presents basic data on the 103 features in the north dune, as well as on 2 features $(147,162)$ in the pond area. Locations of features are shown on Figures 6-5 and 6-6. The discussion is organized by location, 


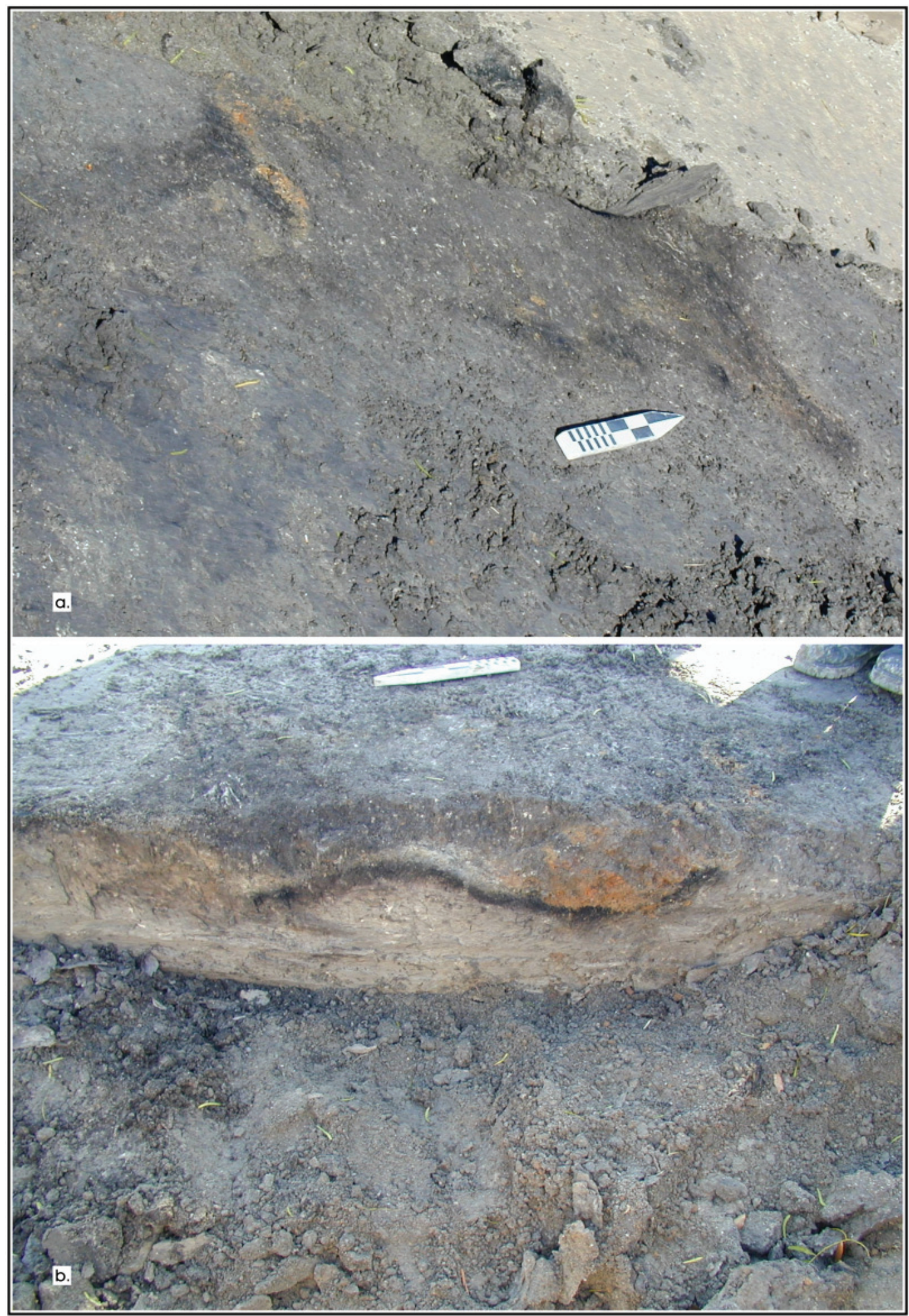

Figure 6-17. Feature 54, a large hearth in the Beaumont Ridge area: a) the top of Feature 54 (note western half of Trench B, visible at the top of the picture, had reached the Beaumont, truncating the northern corner of the feature); b) a profile showing the double basin and the layer of charcoal in the southern basin that was partially removed in the northern basin. 


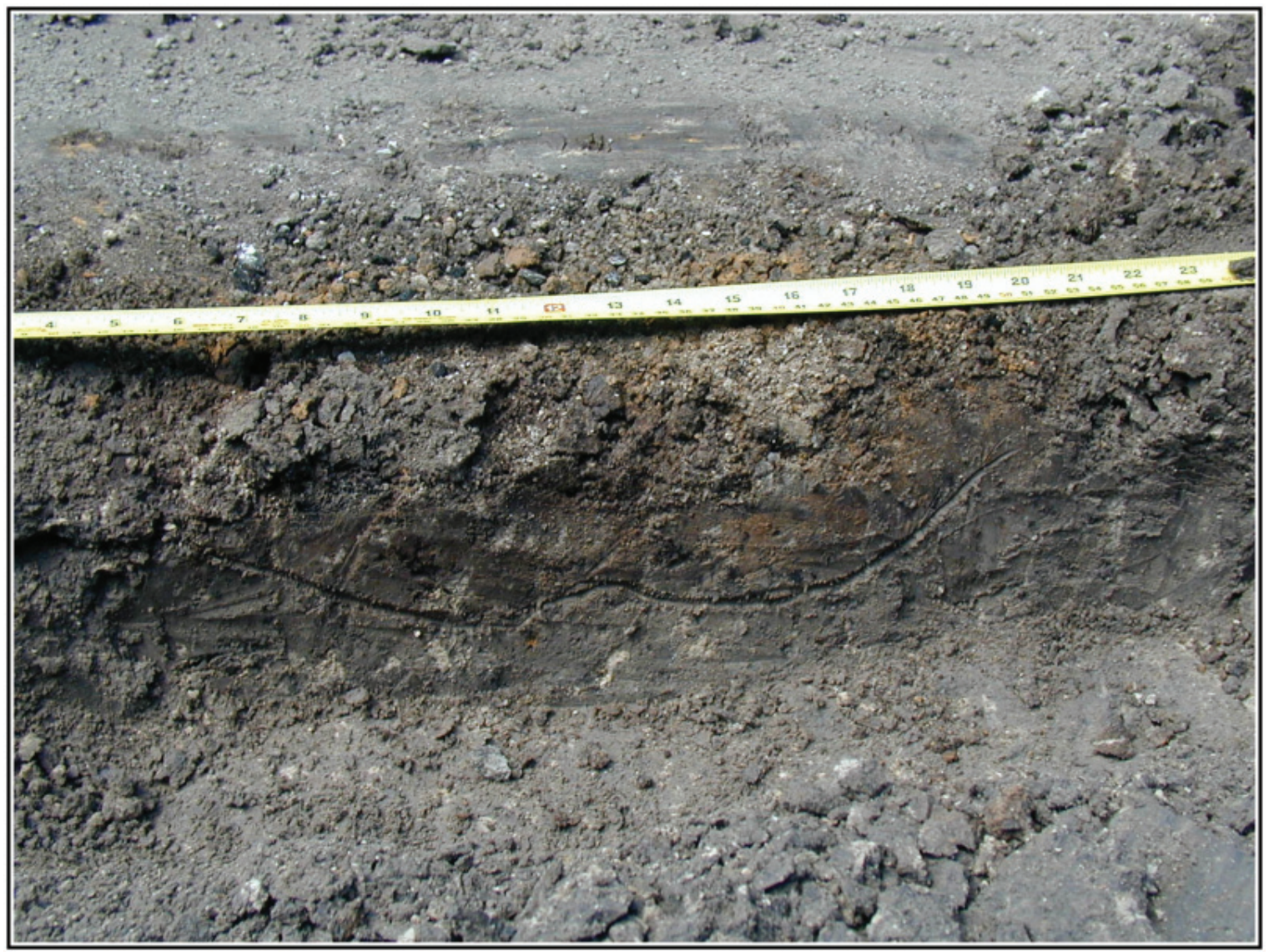

Figure 6-18. Profile of Feature 31, showing hearth filled with burned clay nodules and charcoal.

Table 6-6. Features in North Dune and the Pond/ Northwest Ridge Area

\begin{tabular}{|c|c|c|c|c|c|c|c|c|c|c|c|c|c|c|c|}
\hline \multirow[b]{2}{*}{ Feature } & \multirow[b]{2}{*}{ Feature Type } & \multicolumn{4}{|c|}{ Description } & \multicolumn{10}{|c|}{ Estimated \% of Common Shells* } \\
\hline & & 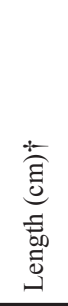 & $\begin{array}{l}\text { 䓂 } \\
\text { 吾 } \\
\text { 豙 }\end{array}$ & 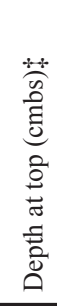 & 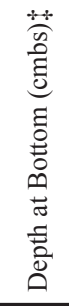 & 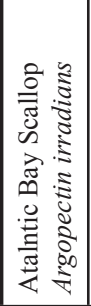 & 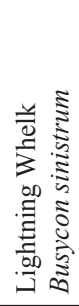 & 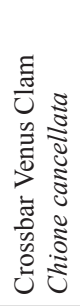 & 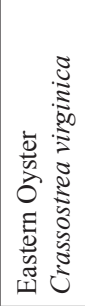 & 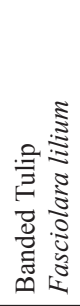 & 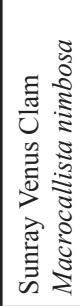 & 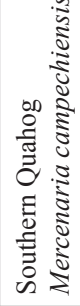 & 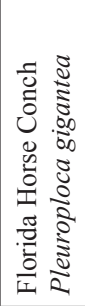 & 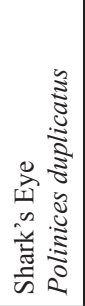 & 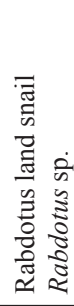 \\
\hline 123 & Shell Concentration- Type 2 & 140 & 120 & 65 & 85 & - & 90 & - & - & - & 5 & 5 & - & - & - \\
\hline 76 & Cluster of sunray shell chipping & 150 & 150 & 95 & 100 & 一 & 一 & - & - & 一 & + & - & - & - & - \\
\hline 34 & Hearth, Surficial— Type 1 & 30 & 30 & 74 & 76 & - & - & - & - & - & - & - & - & - & - \\
\hline 35 & Hearth, Basin-Type 1 & 50 & 50 & 98 & 124 & - & 一 & - & - & - & - & - & - & - & - \\
\hline 36 & Shell Concentration- Type 1 & 70 & 58 & 59 & 62 & - & 90 & - & - & - & - & - & - & + & + \\
\hline 37 & Hearth, Surficial- Type 2 & 75 & 75 & 56 & 60 & - & 90 & - & + & 一 & 一 & 一 & - & + & + \\
\hline 38 & Shell Concentration- Type 3 & 220 & 220 & 113 & 118 & - & 15 & 一 & 80 & 一 & 一 & + & 一 & + & + \\
\hline 157 & Shell Concentration- Type 1 & 100 & 100 & 150 & 153 & - & + & - & 95 & - & - & - & - & - & - \\
\hline
\end{tabular}

$\dagger$ Measurements within the boundaries of the trench.

\$ Vertical datum in the field was the road or ground surface.

* Estimates based on observation in the field. Actual counts from sampling are included in Fauna section of Chapter 11.

"+" sign means presence mentioned in notes; "- -" sign means absent/not observed. 
Table 6-6. Continued...

\begin{tabular}{|c|c|c|c|c|c|c|c|c|c|c|c|c|c|c|c|}
\hline \multirow[b]{2}{*}{ Feature } & \multirow[b]{2}{*}{ Feature Type } & \multicolumn{4}{|c|}{ Description } & \multicolumn{10}{|c|}{ Estimated \% of Common Shells* } \\
\hline & & 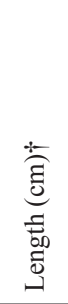 & 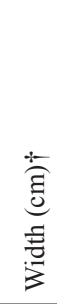 & 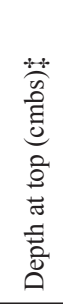 & 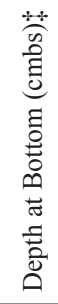 & 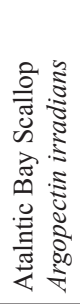 & 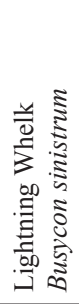 & 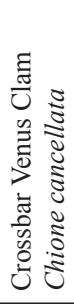 & 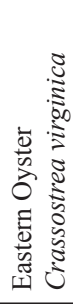 & 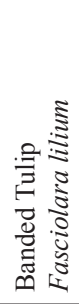 & 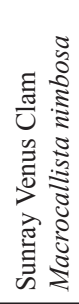 & 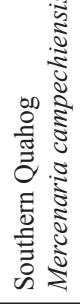 & 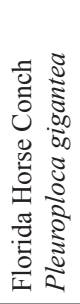 & 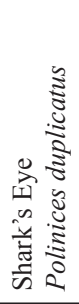 & 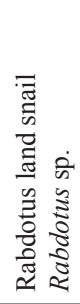 \\
\hline 90 & Shell cluster & - & - & 90 & 110 & - & + & - & 95 & - & - & + & + & + & + \\
\hline 101 & Hearth, Basin- Type 2 & 70 & 70 & 78 & 83 & - & + & - & 一 & 一 & 一 & - & - & 一 & - \\
\hline 39 & Hearth, Surficial— Type 1 & 60 & 50 & 87 & 88 & - & - & - & - & 一 & - & 一 & - & 一 & - \\
\hline 137 & Hearth, Basin- Type 2 & 500 & 265 & 138 & 145 & - & - & - & - & - & - & - & - & - & - \\
\hline 41 & Pit_-Type 3 & 30 & 30 & 74 & 78 & - & 30 & 50 & 15 & - & - & - & - & - & + \\
\hline 148 & Pit-Type 1 & 40 & 40 & 78 & 84 & - & 35 & - & 60 & - & - & + & - & + & - \\
\hline 42 & Hearth, Surficial— Type 1 & 50 & 28 & 74 & 76 & - & - & - & - & - & - & - & - & - & - \\
\hline 43 & Hearth, Surficial—-Type 1 & 30 & 30 & 72 & 74 & - & + & - & - & - & - & - & - & - & - \\
\hline 44 & Hearth, Surficial—-Type 1 & 60 & 50 & 78 & 83 & - & + & - & + & - & - & - & - & - & - \\
\hline 102 & Pit-Type 1 & 100 & 75 & 61 & 71 & - & 85 & - & - & - & 10 & 一 & - & - & 5 \\
\hline 103 & Shell Concentration- Type 2 & 200 & 100 & 80 & 82 & - & 80 & - & 10 & - & 10 & - & - & - & - \\
\hline 45 & Hearth, Surficial—-Type 1 & 30 & 20 & 52 & 55 & - & - & - & - & - & - & - & - & - & - \\
\hline 46 & Hearth, Basin-Type 1 & 30 & 30 & 70 & 75 & - & + & - & - & - & - & - & - & - & - \\
\hline 141 & Shell Concentration- Type 2 & 350 & 50 & 95 & 105 & - & 5 & - & 一 & 一 & 90 & - & 5 & - & - \\
\hline 49 & Hearth, Basin-Type 1 & 37 & 32 & 58 & 62 & - & + & - & + & - & - & - & - & - & - \\
\hline 47 & Shell Concentration- Type 1 & 94 & 65 & 60 & 62 & - & - & - & + & - & - & - & - & - & - \\
\hline 48 & Hearth, Basin-Type 4 & 79 & 70 & 58 & 75 & - & - & - & - & - & - & - & - & - & - \\
\hline 50 & Hearth, Basin-Type 1 & 60 & 57 & 64 & 66 & - & - & - & - & - & - & - & - & - & - \\
\hline 51 & Pit-Type 3 & 20 & 10 & 59 & 63 & - & - & - & - & - & - & - & - & - & + \\
\hline 142 & Shell Concentration- Type 3 & 410 & 300 & 15 & 31 & 5 & 85 & - & - & - & - & 5 & - & - & 5 \\
\hline 58 & Hearth, Basin - Type 2 & 40 & 20 & 67 & 73 & - & - & - & - & 一 & + & - & - & - & - \\
\hline 107 & Rabdotus cluster & 120 & 40 & 65 & 68 & - & - & - & - & - & - & - & - & - & 85 \\
\hline 59 & Hearth, Basin - Type 1 & 90 & 80 & 93 & 99 & - & + & - & - & 一 & + & - & - & - & - \\
\hline 105 & Hearth, Surficial— Type 1 & 40 & 40 & 60 & 62 & - & - & - & - & - & - & - & - & - & - \\
\hline 106 & Hearth, Basin - Type 2 & 100 & 80 & 95 & 102 & - & - & - & - & - & - & - & - & - & - \\
\hline 98 & Hearth, Surficial- Type 2 & 60 & 45 & 40 & 45 & - & + & - & - & - & + & + & + & - & - \\
\hline 60 & Hearth, Basin - Type 1 & 60 & 40 & 210 & 215 & - & - & - & + & 一 & - & - & - & - & - \\
\hline 96 & Bone fragment scatter & 550 & 200 & 40 & 43 & - & - & - & - & - & - & - & - & - & - \\
\hline 95 & Shell Concentration- Type 3 & 400 & 150 & 60 & 70 & - & 50 & - & + & + & 40 & 8 & - & - & - \\
\hline 61 & Burial pit & 175 & 75 & 54 & 73 & - & - & - & - & - & + & - & - & - & - \\
\hline 161 & Shell Concentration- Type 1 & 160 & 60 & 25 & 30 & - & 20 & - & 80 & 一 & - & - & - & - & - \\
\hline 97 & Hearth, Surficial- Type 2 & 100 & 100 & 42 & 45 & - & 80 & - & - & - & 20 & - & - & - & - \\
\hline 151 & Shell Concentration- Type 1 & 150 & 50 & 57 & 62 & - & - & - & - & - & - & - & - & - & 40 \\
\hline
\end{tabular}

$\dagger$ Measurements within the boundaries of the trench.

$\$$ Vertical datum in the field was the road or ground surface.

* Estimates based on observation in the field. Actual counts from sampling are included in Fauna section of Chapter 11.

"+" sign means presence mentioned in notes; "- - sign means absent/not observed. 
Table 6-6. Continued...

\begin{tabular}{|c|c|c|c|c|c|c|c|c|c|c|c|c|c|c|c|}
\hline \multirow[b]{2}{*}{ Feature } & \multirow[b]{2}{*}{ Feature Type } & \multicolumn{4}{|c|}{ Description } & \multicolumn{10}{|c|}{ Estimated \% of Common Shells* } \\
\hline & & 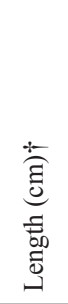 & 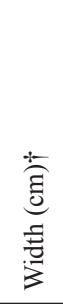 & 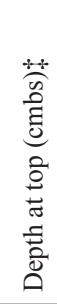 & 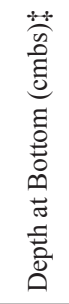 & 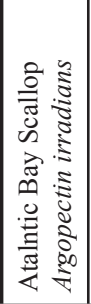 & 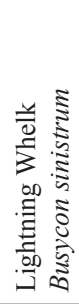 & 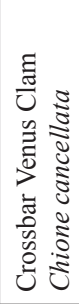 & 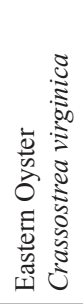 & 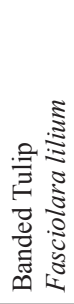 & 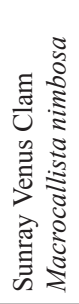 & 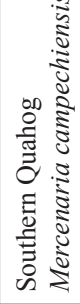 & 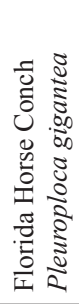 & 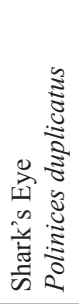 & 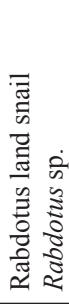 \\
\hline 63 & Charcoal cluster & 108 & 80 & 57 & 60 & - & - & - & - & - & + & - & - & - & + \\
\hline 152 & Shell Concentration-Type 1 & 40 & 30 & 160 & 168 & - & 一 & - & 100 & - & 一 & - & - & - & - \\
\hline 100 & Shell Concentration-Type 1 & 100 & 20 & 42 & 48 & - & + & 一 & - & 一 & 25 & 一 & - & 一 & 70 \\
\hline 64 & Hearth, Basin- Type 1 & 70 & 40 & 65 & 80 & - & 一 & - & - & 一 & 一 & 一 & - & 一 & - \\
\hline 153 & Shell Concentration- Type 1 & 170 & 5 & 44 & 50 & - & - & 一 & + & - & 95 & - & - & 一 & - \\
\hline 154 & Hearth, Surficial— Type 2 & 70 & 50 & 46 & 52 & 一 & 50 & 一 & - & 一 & 50 & 一 & 一 & 一 & 一 \\
\hline 67 & Hearth, Basin- Type 1 & 43 & 37 & 120 & 130 & - & - & - & - & - & 一 & - & - & - & - \\
\hline 65 & Shell Concentration- Type 1 & 50 & 40 & 50 & 52 & + & + & - & + & + & + & - & - & - & + \\
\hline 69 & Pit-Type 4 & 140 & 80 & 50 & 240 & - & - & - & - & - & 一 & - & - & 一 & - \\
\hline 68 & Hearth, Basin-Type 1 & 40 & $?$ & 112 & 119 & - & - & - & - & - & - & - & - & - & - \\
\hline 70 & Charcoal cluster & 60 & 45 & 60 & 62 & - & - & - & - & 一 & + & - & + & - & - \\
\hline 71 & Hearth, Surficial— Type 1 & 30 & 30 & 144 & 147 & 一 & 一 & 一 & 一 & 一 & 一 & 一 & 一 & 一 & - \\
\hline 72 & Hearths, Multiple & 200 & 200 & 119 & 123 & 一 & + & 一 & 一 & - & + & - & - & 一 & - \\
\hline 73 & Pit-Type 3 & 33 & 27 & 45 & 48 & - & - & - & - & - & - & - & - & - & 90 \\
\hline 158 & Shell Concentration-Type 1 & 30 & 20 & 180 & 183 & - & - & - & 100 & - & - & - & - & - & - \\
\hline 156 & Hearth, Basin- Type 2 & 70 & 50 & 42 & 55 & 一 & 20 & 一 & 50 & - & - & 10 & - & 一 & 20 \\
\hline 75 & Pit-Type 1 & 67 & $?$ & 57 & 90 & - & + & - & + & - & + & - & + & - & - \\
\hline 108 & Hearth, Surficial- Type 2 & 300 & 70 & 35 & 39 & - & 80 & - & - & 一 & 10 & - & - & - & 10 \\
\hline 74 & Pit-Type 1 & 45 & 30 & 60 & 63 & - & + & - & 一 & - & - & - & - & - & + \\
\hline 109 & Shell Concentration- Type 2 & 350 & 80 & 70 & 90 & 一 & 80 & 一 & 5 & - & 15 & - & - & 一 & - \\
\hline 77 & Shell Concentration- Type 1 & 30 & 30 & 220 & 223 & 一 & 一 & 一 & 一 & 一 & 一 & 一 & - & 一 & 一 \\
\hline 92 & Shell Concentration-Type 2 & 140 & 140 & 240 & 260 & 60 & + & - & 35 & 一 & - & - & - & - & - \\
\hline 159 & Pit-Type 1 & 150 & 100 & 30 & 50 & 一 & 10 & - & 45 & - & 45 & - & - & 一 & - \\
\hline 113 & Hearth, Surficial- Type 2 & 60 & 30 & 98 & 104 & - & 90 & - & 一 & - & 10 & - & - & - & - \\
\hline 112 & Hearth, Surficial— Type 2 & 20 & 20 & 117 & 118 & 一 & 一 & 一 & 一 & - & - & - & - & 一 & - \\
\hline 111 & Pit-Type 1 & 70 & 45 & 80 & 85 & - & 90 & - & - & 一 & 10 & - & - & 一 & - \\
\hline 143 & Shell Concentration- Type 1 & 50 & $?$ & 121 & 130 & 一 & + & 一 & 一 & 一 & - & 95 & - & 一 & + \\
\hline 118 & Hearth, Basin - Type 1 & 20 & 20 & 50 & 53 & 一 & + & 一 & 一 & - & 一 & 一 & - & 一 & - \\
\hline 119 & Hearth, Basin- Type 1 & 35 & 25 & 70 & 77 & - & - & - & 一 & - & - & - & - & - & - \\
\hline 120 & Shell Concentration-Type 1 & 100 & 50 & 68 & 74 & - & 37 & - & + & 一 & 60 & - & - & 一 & - \\
\hline 114 & Hearths, Multiple & 650 & 100 & 18 & 29 & 一 & 一 & 一 & 一 & - & 一 & 一 & - & - & - \\
\hline 117 & Pit-Type 1 & 130 & 50 & 32 & 42 & + & + & 一 & 一 & 一 & - & 一 & 一 & 一 & + \\
\hline 115 & Hearth, Basin- Type 1 & 70 & 40 & 70 & 72 & - & - & - & - & - & - & - & - & - & - \\
\hline
\end{tabular}

$\dagger$ Measurements within the boundaries of the trench.

\$ Vertical datum in the field was the road or ground surface.

* Estimates based on observation in the field. Actual counts from sampling are included in Fauna section of Chapter 11.

"+" sign means presence mentioned in notes; "- -" sign means absent/not observed. 
Table 6-6. Continued...

\begin{tabular}{|c|c|c|c|c|c|c|c|c|c|c|c|c|c|c|c|}
\hline \multirow[b]{2}{*}{ Feature } & \multirow[b]{2}{*}{ Feature Type } & \multicolumn{4}{|c|}{ Description } & \multicolumn{10}{|c|}{ Estimated \% of Common Shells* } \\
\hline & & 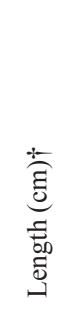 & $\begin{array}{l}\text { 泀 } \\
\text { 吾 } \\
3 \\
3\end{array}$ & 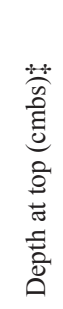 & 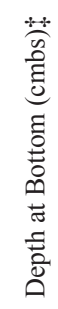 & 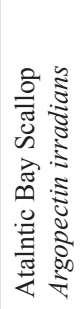 & 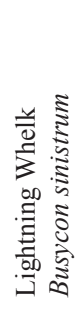 & 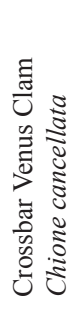 & 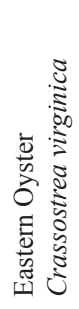 & 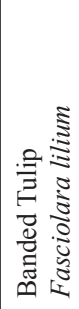 & 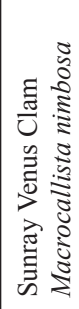 & 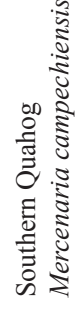 & 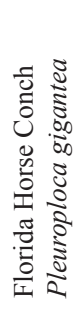 & 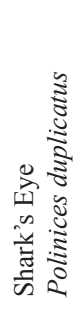 & 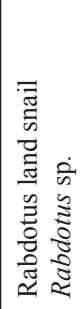 \\
\hline 116 & Hearth, Surficial— Type 2 & 100 & 60 & 105 & 107 & - & - & - & - & - & - & - & - & - & + \\
\hline 126 & Shell Concentration- Type 2 & 200 & 150 & 50 & 52 & - & - & - & - & - & - & - & - & - & - \\
\hline 93 & Shell Concentration- Type 1 & 140 & 80 & 50 & 53 & - & 24 & - & 24 & - & 24 & 24 & - & - & + \\
\hline 94 & Hearth, Basin - Type 2 & 350 & 200 & 90 & 120 & - & 12 & - & 50 & - & 35 & - & - & - & + \\
\hline 99 & Shell Concentration - Type 1 & 60 & 23 & 69 & 79 & - & 35 & - & 55 & - & 10 & - & - & - & - \\
\hline 131 & Hearth, Basin - Type 1 & 25 & 20 & 94 & 96 & - & - & - & - & - & - & - & - & - & - \\
\hline 132 & Shell Concentration- Type 3 & 220 & 200 & 46 & 63 & 一 & + & - & 一 & - & - & 一 & 一 & + & - \\
\hline 139 & Shell Concentration- Type 3 & 250 & 150 & 55 & 65 & - & + & 一 & + & - & + & 一 & - & & - \\
\hline 134 & Shell Concentration- Type 2 & 250 & 100 & 40 & 55 & - & 50 & - & 50 & - & - & 一 & - & - & - \\
\hline 136 & $\begin{array}{l}\text { Old backhoe trench containing } \\
\text { disarticulated human bones } \\
\text { (Burial \#4) }\end{array}$ & 220 & 50 & 30 & 110 & - & - & - & - & - & - & - & - & - & - \\
\hline 140 & Charcoal cluster & 150 & 75 & 72 & 73 & - & - & - & - & - & - & - & - & - & + \\
\hline 146 & Hearth, Basin-Type 2 & 80 & 50 & 60 & 64 & - & - & - & - & - & - & - & - & - & - \\
\hline 138 & $\begin{array}{l}\text { Burial pit containing Burials } \\
6 \text { and } 7\end{array}$ & 60 & 45 & 80 & 85 & - & - & - & - & - & - & - & - & - & - \\
\hline 133 & Hearth, Surficial— Type 2 & 800 & 150 & 65 & 68 & - & 5 & - & - & - & 95 & - & - & - & - \\
\hline 145 & Bone fragment scatter & 150 & 100 & 70 & 73 & - & - & - & - & - & - & - & 一 & - & - \\
\hline 149 & Shell Concentration- Type 3 & 500 & 100 & 52 & 55 & 一 & 30 & - & 70 & 一 & - & - & - & - & - \\
\hline 66 & Hearth, Surficial— Type 1 & 58 & 38 & 60 & 62 & - & - & - & & - & - & - & - & - & - \\
\hline 155 & Pit-Type 1 & 70 & 40 & 46 & 50 & - & 10 & - & 50 & - & - & - & - & - & 40 \\
\hline 40 & Hearth, Surficial— Type 2 & 30 & 20 & 83 & 86 & - & - & - & + & - & - & 一 & - & - & - \\
\hline 150 & Shell Concentration- Type 1 & 75 & 60 & 45 & 60 & 一 & + & 一 & 95 & 一 & 一 & 一 & - & - & - \\
\hline 160 & Shell Concentration- Type 1 & 50 & 40 & 45 & 47 & - & 70 & - & - & - & - & 30 & - & - & - \\
\hline 147 & Pit, Multiple & 200 & 100 & 15 & 60 & - & 30 & - & 60 & - & + & + & + & - & - \\
\hline 163 & Pit-Type 1 & 40 & 20 & 30 & 40 & - & 60 & - & 25 & - & - & 10 & 5 & - & - \\
\hline 162 & Shell Concentration- Type 1 & 75 & 75 & 70 & 72 & - & 70 & - & 30 & 一 & 一 & 一 & - & - & - \\
\hline 18 & Shell Concentration- Type 3 & 300 & 300 & 70 & 80 & 5 & 15 & - & - & - & 80 & - & - & - & - \\
\hline 165 & Shell Concentration- Type 2 & 300 & 90 & 35 & 40 & - & 10 & - & - & + & 85 & - & - & - & - \\
\hline 164 & Bone fragment scatter & 180 & 90 & 40 & 50 & - & - & - & - & - & - & 一 & - & - & - \\
\hline 166 & Hearth, Basin - Type 2 & 100 & 100 & 50 & 53 & - & - & - & - & - & - & - & - & - & - \\
\hline 167 & Shell Concentration- Type 2 & 200 & 100 & 50 & 56 & 一 & + & - & + & - & - & - & - & - & + \\
\hline 169 & Shell Concentration- Type 1 & 120 & 100 & 140 & 145 & - & - & - & - & - & - & - & - & - & + \\
\hline 170 & Bone bed & 80 & 70 & 85 & 110 & - & - & - & - & - & - & - & - & - & - \\
\hline
\end{tabular}

$\dagger$ Measurements within the boundaries of the trench.

$\$$ Vertical datum in the field was the road or ground surface.

* Estimates based on observation in the field. Actual counts from sampling are included in Fauna section of Chapter 11.

"+" sign means presence mentioned in notes; "- -" sign means absent/not observed. 
south to north, and includes an in-field estimate of the kinds of shells found in each. Artifacts located in these features were discussed in the previous chapter. Analysis of the faunal remains will be included in Chapter 11. Of particular interest are Features 18, 41, 46, 49, 63, 64, 72, 75, 76, 103, 108, 109, $113,115,116,123,137,153,155$, and 170.

\section{Feature 123}

Feature 123 was located at the southern end of the north dune and consisted of a $10 \mathrm{~cm}$ thick layer of Lightning Whelks (Table 6-6), charcoal, and burned clay nodules. Charcoal from this feature dated to $1170-960$ B.P.

\section{Feature 76}

Feature 76 consisted of a small scatter of charcoal, one broken Sunray shell tool (see Artifacts Section, Chapter 5) and about 8-10 thin flakes of Sunray shell, broken in a way that was not commonly seen. In the field it was considered possible that they were the debitage from manufacture of chipped shell tools. Examination of the these shell fragments in the lab, under a microscope did not provide proof that they were, indeed, shell debitage, but the fact remains that Sunray shells normally break perpendicular to the thickness of the shell, while these chips were broken longitudinally along the thickness of the shell. It remains possible, therefore that these shell fragments were deliberately struck from Sunray shells in the process of shell modification.

\section{Feature 137}

Feature 137 was a small basin hearth surrounded by animal bone and a few shell fragments (Table 6-6). Most of the animal bone appeared to be deer-sized, but it was highly fragmented. The features dated to $2730-2350$ B.P.

\section{Feature 41}

Feature 41 is an example of Pit Type 3, a shallow, flatbottomed pit filled with charcoal and shells, but this feature was unique. The feature was roughly $30 \mathrm{~cm} \times 30 \mathrm{~cm}$, about 5-6 cm deep, and had a roughly square shape (Figure 6-19). Twenty four species with an MNI of 98 were identified in this small space (Table 6-6). Most were small species, many of which were only found in this feature. Even the examples of larger species were generally very young and small. The two species that were by far the most common were oysters, many of which were no bigger than "spats", the size at which oysters cease floating and seek out a permanent location, and Crossbar Venus (Chione cancellata). The later is a common species, but is generally no bigger than $4.4 \mathrm{~cm}(1.75 ")$, and is thus not considered a significant food resource. Details about the species richness in this feature are discussed in Chapter 11.

\section{Feature 103}

Feature 103 was a distinct but thin shell concentration, consisting mostly of Lightning Whelks, with a few oysters and Sunray Venus shells (Table 6-6). Charcoal from this feature dated to 2300-1900 B.P.

\section{Feature 46}

Feature 46 was a typical shallow basin hearth with a few shells scattered nearby. It was dated to 2050-1880 B.P.

\section{Feature 49}

Feature 49 is also a shallow basin hearth, much smaller than Feature 46. Its $3-4 \mathrm{~cm}$ basin is filled with charcoal and a few shells. It dates to $1870-1700$ B.P.

\section{Feature 63}

Feature 63 is an example of a charcoal scatter that does not appear to be a hearth. There was a dense patch of charcoal and a few shells surrounded by a thinner scatter of charcoal. This feature was dated to $3070-2800$, and is the oldest dated feature in the North Dune.

\section{Feature 64}

Feature 64 is perhaps the best example of a basin hearth filled with numerous burned clay nodules and charcoal (Figure 6-20). The nodules range in size from $2-7 \mathrm{~cm}$ in maximum dimension.

\section{Feature 153}

Feature 153 was located on the west side of Ennis Joslin Road, in a paleosol above the dark layer containing OZ-J. It was a dense layer of Sunray Venus clam shells, all laying interior-down and piled several deep (Table 6-6). This feature was dated to $2300-2000$ B.P.

\section{Feature 72}

Feature 72 is an unusual feature because it was found in a light clay layer, while most cultural manifestations at $41 \mathrm{NU} 2$ were found in dark paleosols. The feature consists of 2 surficial hearths and 2 charcoal concentrations, all 


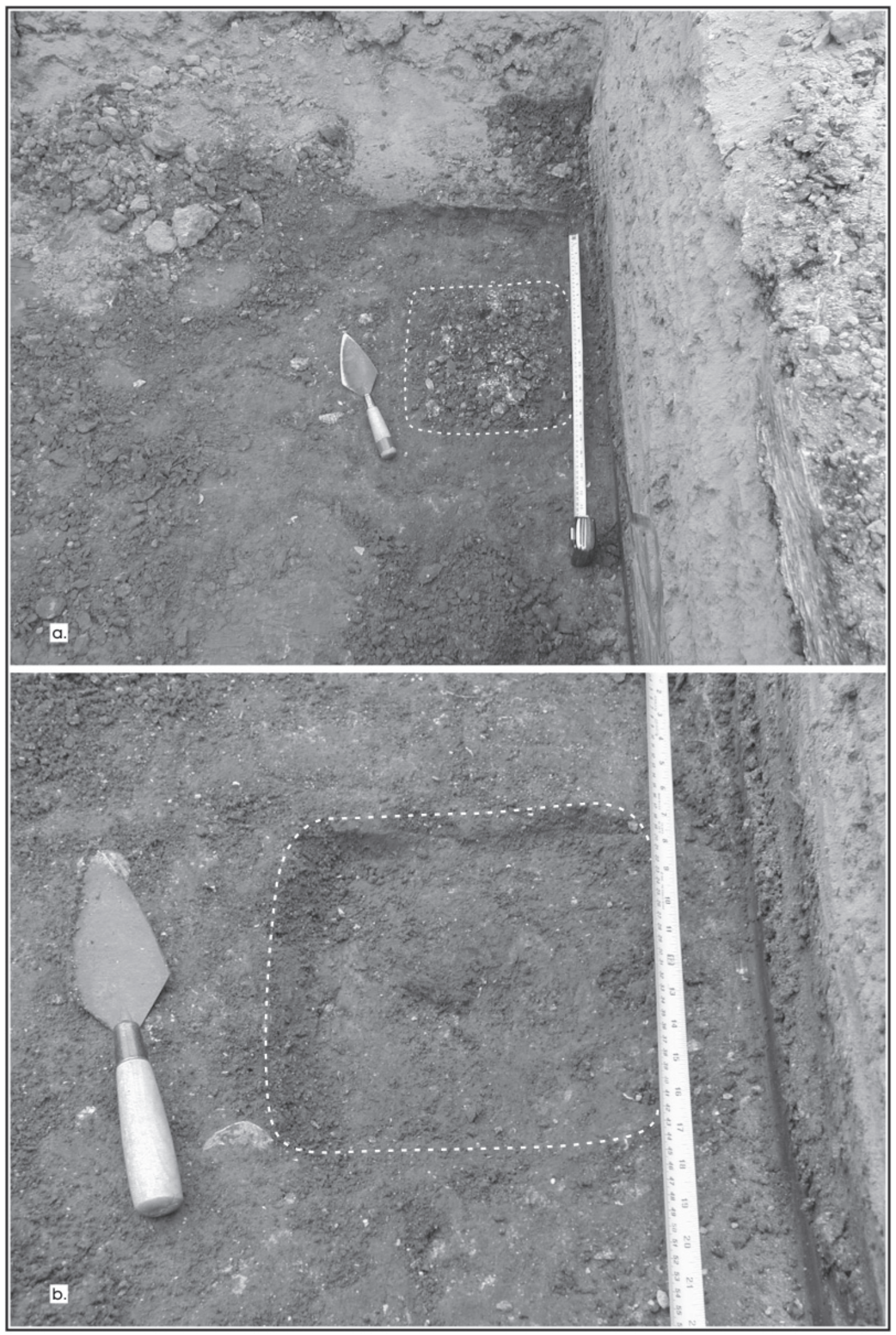

Figure 6-19. Feature 41: a) when first located; b) after removal of contents. Note the unusually square shape. 
within $2 \mathrm{~m}$ of each other and surrounded by a scatter of unusually large lumps of charcoal.

\section{Feature 75}

This pit was dug from the center level of OZ-D, but the original shape cannot be determined because the upper part of the pit was not noticed among the general shell and charcoal scatter typical of this occupation zone. The pit was identified when the digging reached the light clay layer, where several large shells were seen (Figure 6-21a). The walls of the pit were then visible in the trench wall (Figure 6-21b). The upper part is mostly charcoal, burned clay, animal bones (including several deer bones), with some fragmented shell. Lower part is crammed with whole shells, an extremely large Lightning Whelk, and many other species (Table 6-6).

\section{Feature 108}

Feature 108 was small surficial hearth with a dense scatter of shell, consisting mostly of Lightning Whelks, although some parts of the feature had large numbers of Rabdotus (Table 6-6). This feature was in a paleosol that had been removed by road construction in most of Trench B, and lays above OZ-D. It was dated to $1410-1300$ B.P.

\section{Feature 109}

Feature 109 was a $10-\mathrm{cm}$ thick pile of Lightning Whelks, with a few oyster and Sunray shells laying directly on a slight mound of light-colored clay (Table 6-6). This feature was an unusually thick and dense shell accumulation in which most of the shells were abnormally large.

\section{Feature 113}

Feature 113 was a small surficial hearth surrounded by Lightning Whelks and a large number of fish and mammal bones. Two large sea catfish otoliths were found side-by-side in this feature. It was dated to 2130-1930 B.P.

\section{Feature 115}

Feature 115 is a small (ca. $20 \mathrm{~cm}$ in diameter) hearth surrounded by a thin scatter of charcoal and shell, in a relatively light clay layer. It dated to $2770-2720$ B.P.

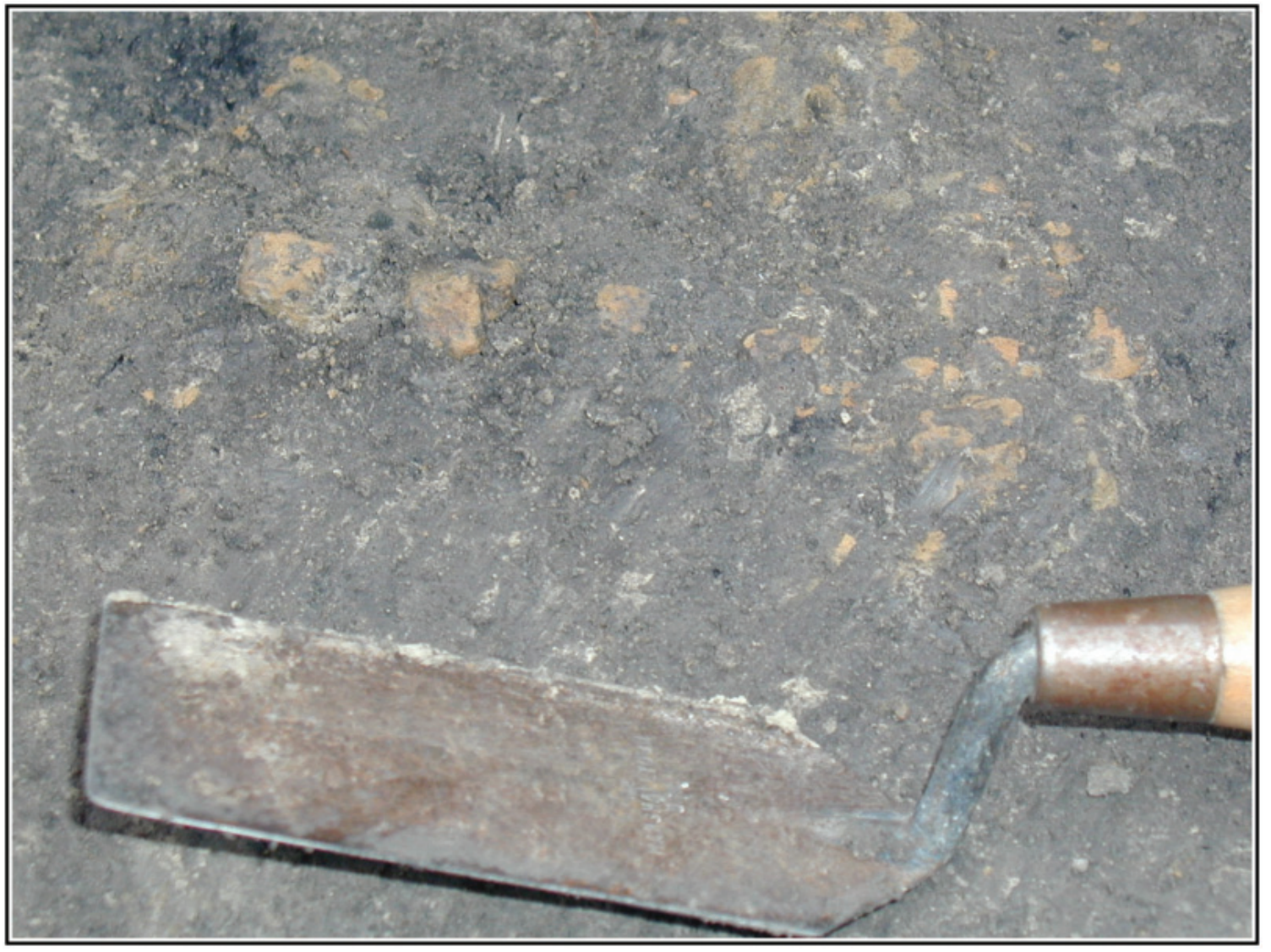

Figure 6-20. Feature 64, showing close-up of hearth basin filled with burned clay nodules. 


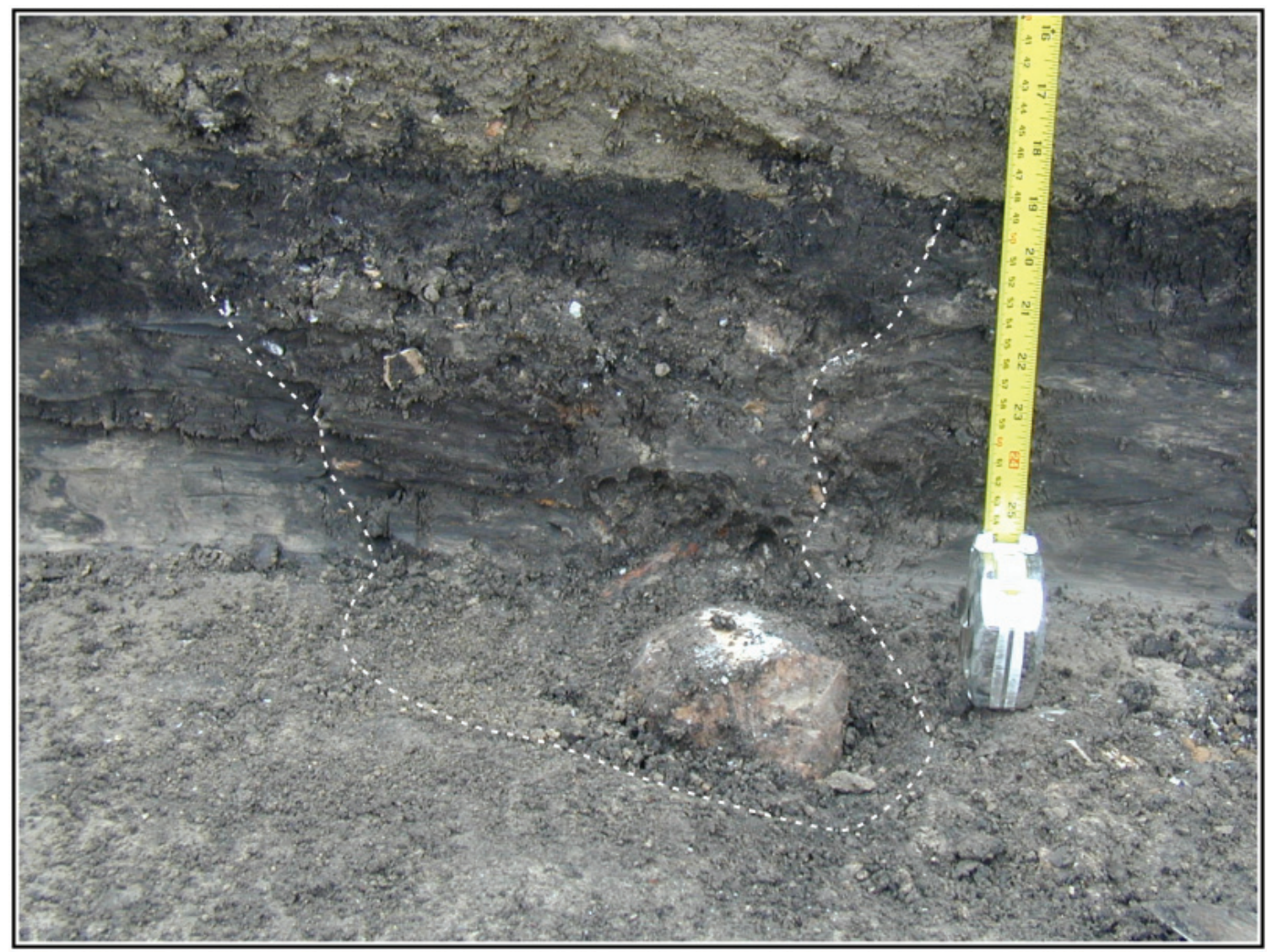

Figure 6-21. Feature 75: a) when first observed; b) east wall of trench showing the profile of the pit, dug from OZ D.

\section{Feature 116}

Feature 116 was located $30 \mathrm{~cm}$ below Feature 115, in a light clay layer. It consists of a small hearth, with a scatter of charcoal, bone, Rabdotus and Sunray Venus fragments. In many ways, it is reminiscent of Feature 72 in that it was found in a light clay layer and the charcoal fragments are unusually large. The lowest part of the feature contained large bone fragments, large charcoal pieces and a cluster of Rabdotus shells (Table 6-6).

\section{Feature 155}

Feature 155 was a small, dense concentration of oysters, Rabdotus, and Lightning Whelk shells (Table 6-6). The feature dated to 2480-2340 B.P.

\section{Feature 170}

As mentioned in the narrative for Trench $\mathrm{T}$ in the previous chapter, Feature 170 was discovered when the backhoe operator dug a large scoop of sediment from beneath a curb in the parking lot north of Ocean Drive. This was not the usual procedure, but the operator had been requested to avoid breaking the curb in this location. In order to dig beneath it, he was forced to dig out a larger-than-normal scoop. When this bucked was emptied, numerous large bones were observed. These were collected, and the area under the curb was examined. The bone bed was found to consist of the lower legs of bovids, most of which were still articulated. The bone bed extended into the east wall of the trench.

Most of the articulated segments ended at the proximal end of the metapodials, though a few carpals and tarsals were also present. Table 6-7 is a complete list of bones recovered within Trench T. All bones identifiable to the Genus taxonomic level were Bos taurus. The bones were in a sandy matrix unlike the clay dune surrounding the area. Further excavation the next morning exposed more articulated bone (Figure 6-22), as well as several cranium fragments, and three horn cores, including one that was $10 \mathrm{~cm}$ in diameter and extended $45 \mathrm{~cm}$ within the trench and continued into the eastern wall. This horn made it likely that the bones were cattle (Bos taurus), as bison (Bison bison) horns are never that long. Unfortunately, all horn cores disintegrated when they were removed. 
Table 6-7. Bovid Elements Identified from Feature 170

\begin{tabular}{|c|c|c|c|c|}
\hline Element & $\mathbf{L}$ & $\mathbf{R}$ & Total & Notes \\
\hline \multicolumn{5}{|c|}{ ELEMENTS AT OR NEAR MATURE SIZE, MNI $=6$} \\
\hline Maxilla (fragment) & 1 & - & 1 & - \\
\hline 2+3 Carpal & - & 1 & 1 & - \\
\hline Auxillary Carpal & - & 1 & 1 & - \\
\hline Metacarpal & 5 & 5 & 10 & One has unsealed distal epiphysis, $\mathrm{MNI}=6$; \\
\hline Central +4th Tarsal & 1 & - & 1 & Chopped with large, sharp metal tool; \\
\hline $2+3$ Tarsal & 2 & - & 2 & - \\
\hline Metatarsal & 2 & 5 & 7 & One is unsealed and very small; \\
\hline 1st Phalange & - & - & 29 & Two are unsealed (<18 mo. old); \\
\hline 2nd Phalange & - & - & 27 & Three are partially sealed (ca. 18 mo. Old); \\
\hline 3rd Phalange & - & - & 16 & - \\
\hline Proximal Sesmoids & - & - & 20 & - \\
\hline Distal Sesmoids & - & - & 8 & - \\
\hline Fragments & - & - & 8 & - \\
\hline Total & 11 & 12 & 131 & - \\
\hline \multicolumn{5}{|c|}{ PERINATAL ELEMENTS, MNI = 1} \\
\hline Radial Carpal & 1 & - & 1 & - \\
\hline Metatarsal & 1 & - & 1 & Very small, central diaphysis very thin, distal epiphyses unsealed; \\
\hline Metapodial Epiphyses & - & - & 3 & - \\
\hline 1st Phalange & - & - & 4 & - \\
\hline 2nd Phalange & - & - & 6 & $\mathrm{MNI}=1$ \\
\hline 3rd Phalange & - & - & 6 & - \\
\hline Proximal Sesmoids & - & - & 1 & - \\
\hline Distal Sesmoids & - & - & 1 & - \\
\hline Fragments & - & - & 9 & - \\
\hline Total & 2 & - & 32 & - \\
\hline \multicolumn{5}{|c|}{ FETAL ELEMENTS, MNI = 1} \\
\hline Cranium & - & - & 5 & - \\
\hline Humerus & 1 & - & 1 & Proximal epiphysis; \\
\hline Radius (fragment) & 1 & - & 1 & - \\
\hline Lumbar Vertebra & - & - & 1 & Unsealed epiphysis of centrum; \\
\hline Femur & 1 & 1 & 2 & - \\
\hline Tibia & 1 & 1 & 2 & - \\
\hline Ischium & 1 & - & 1 & - \\
\hline 1st Phalange & - & - & 1 & - \\
\hline 2nd Phalange & - & - & 1 & - \\
\hline 3rd Phalange & - & - & 3 & - \\
\hline Fragments & - & - & 19 & - \\
\hline Total & 5 & 2 & 37 & - \\
\hline Overall total & 18 & 14 & 200 & - \\
\hline Total MNI & - & - & 8 & - \\
\hline
\end{tabular}




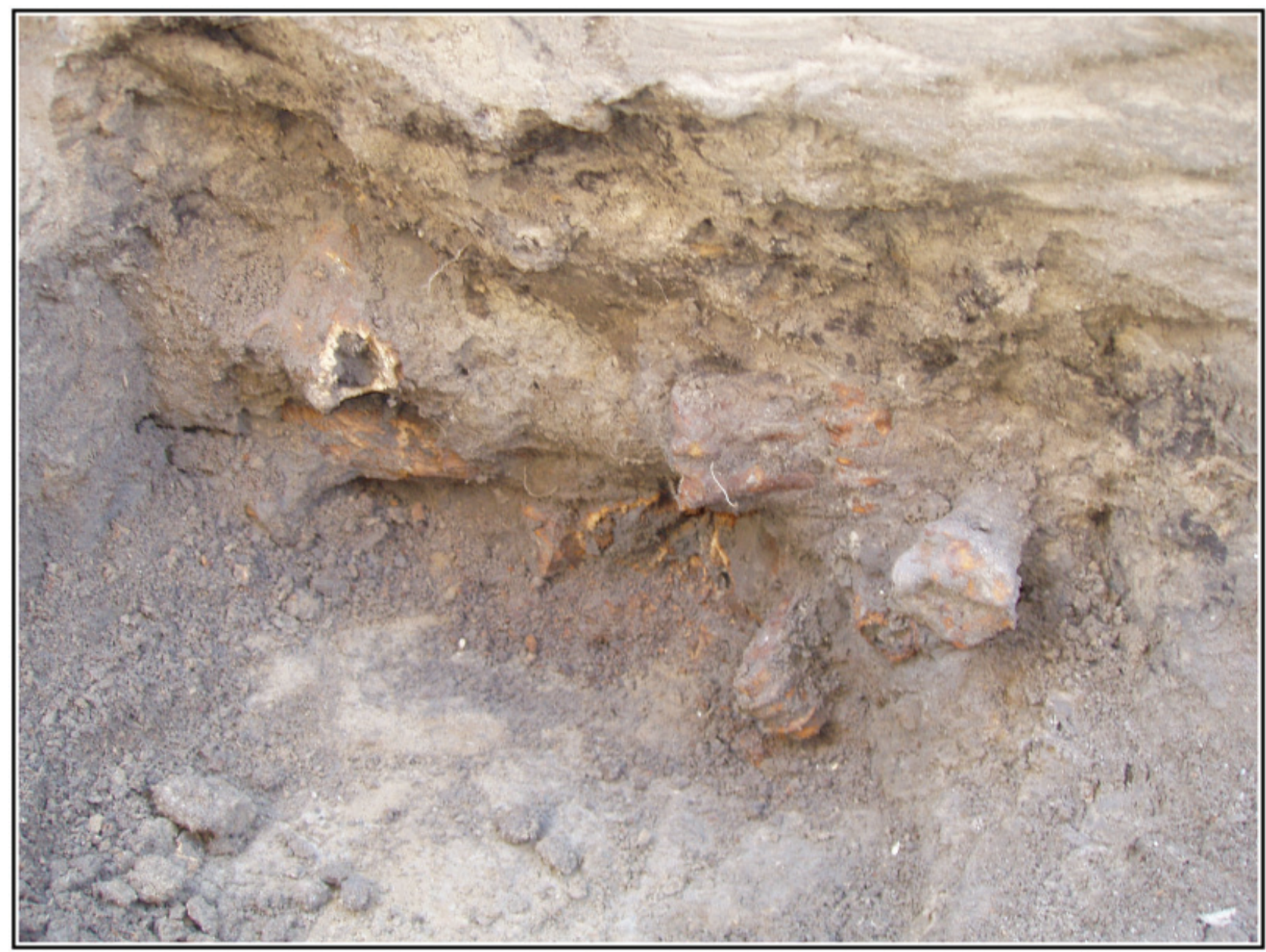

Figure 6-22. Feature 170: a) wall of gully after removal of bone within Trench T. Note laminated sand and clay fill and white sand beneath bone bed.

Included in the bone bed were the lower leg bones of at least two juvenile animals, one of which was very small and probably of perinatal age, and the other was closer to adult size. Three $2^{\text {nd }}$ phalanges were partially sealed, indicating an age of about 18 months for at least one individual. A complete fetus was also discovered. Though much too small to identify its species, it was also likely cattle. The fetus was in fragile condition, due to the incomplete ossification of its skeleton, and only a few of the larger long bones, a few phalanges, and a few cranial fragments were recovered partially intact (Table 6-7).

Further clearing of the bone bed made it clear that the bones lay in a pile at the bottom of a gully that had eroded the edge of the dune (see Figure 6-22). The sand matrix was laminated with thin layers of clay, indicating that the gully had filled in naturally and that the bone was not deliberately buried at the time of disposal. This was confirmed by evidence of extensive atmospheric weathering on one side of some of the bone. The bone bed continued into the east wall of the trench and remains beneath the driveway of the restaurant north of Ocean Drive.

\section{Feature 18}

Feature 18 was a thin scatter of broken shell and charcoal surrounding a dense concentration consisting mostly of Sunray Venus (Macrocallista nimbosa) clam shells, all laying interior down and stacked as much as 5 or 6 deep. The Sunray shells are unusually large, with many $10-$ to $12 \mathrm{~cm}$ long. Mixed with them are a few Lightning Whelks and Bay Scallops (Table 6-6). This feature was dated to 1940-1740 B.P.

\section{Features in the Pond and Northwest Ridge Area}

Two features in the northern part of the site were not in a clay dune setting. Feature 147 was on the slope of the Beaumont ridge in the northwest part of the site, and Feature 
162 was located immediately adjacent to the west of the pond sediments.

\section{Feature 147}

Feature 147 was located in the dark cumulic sediment just above the Beaumont clay, situated west of the ephemeral pond. This was not in the north dune, which did not extend west of the pond in this area. Feature 147 consisted of a series of 4 shallow pits filled with oyster and Lightning Whelk shell and surrounded by a thick layer of shell (Table 6-6). Three of the pits were 5 to $7 \mathrm{~cm}$ deep, stopping at the Beaumont clay, but the fourth was $15 \mathrm{~cm}$ deep and was dug into the light Beaumont layer.

\section{Feature 162}

Feature 162 was an unusually dense collection of oyster and Lightning Whelk shell located with OZ-K on the western edge of the ephemeral pond in the northern part of the site (Table 6-6). The feature was badly impacted by the original construction of Ocean Drive, and by the scraping of the new free right turn lane on to Ennis Joslin being constructed.

\section{Occupation Zones}

During the digging of Trench B north of about $34+000$ and roughly $70 \mathrm{~cm}$ below the road surface, monitors noticed a continuous, thin layer of scattered shell, small flecks of charcoal, burned clay, and animal bone in one of the dark clay paleosols. Within this layer were a number of features, including hearths, pits filled with shell, and areas of dense shell accumulation, each surrounded by the thinner, more generalized scatter of cultural remains. Although the dark clay paleosol extended farther north, the cultural deposit ended at about 34+042. In later excavations, similar deposits were seen, especially farther north, where as many as three strata containing such sheet midden deposits were observed in a single profile. These areas of cultural deposits were distinctive, always seen in dark sediment layers, and seemed to represent areas of general occupation refuse within which distinctive, well-defined features could sometimes be identified. These areas often extended more than $10 \mathrm{~m}$ within the trench, and although the density of deposits varied over that distance, they were usually clearly definable both vertically and horizontally. These areas were eventually designated Occupation Zones $(\mathrm{OZ})$ and were given letter designations. In all, 11 such zones were identified on the project. The locations of the occupation zones are shown on Figures 6-5, 6-6, and 6-8.

\author{
Occupation Zone A \\ Location: Trench C \\ Extent: $33+558$ to $33+576$ \\ Depth: $70-80 \mathrm{~cm}$ \\ Feature(s): 17 \\ Estimated Date: Unknown
}

OZ-A was defined retrospectively, long after it was observed. Field notes described in the second interim report (Meissner 2003) took on a new meaning in the light of the Occupation Zones that had been defined while Trench B was excavated. These notes recorded a paleosol in Trench $\mathrm{C}$ that contained a thin scatter of shell, charcoal, burned clay flecks and numerous highly fragmented animal bones. This scatter remained consistent for $18 \mathrm{~m}$ in Trench C. Although the density of cultural remains varied, it was never defined enough to consider it a feature. This description clearly matched the definition of Occupation Zone developed while digging Trench $\mathrm{B}$. The $\mathrm{OZ}$ in Trench $\mathrm{C}$ was therefore designated OZ-A. Within this thin scatter one feature, Feature 17 , was defined.

\author{
Occupation Zone B \\ Location: Trenches B, I \\ Extent: $34+000$ to $34+042$ \\ Depth at Top: $70-80 \mathrm{~cm}$ \\ Feature(s): 40-43, 45, 46 and 103 \\ Estimated Date: $2300-1880$ B.P.
}

OZ-B was a layer about $10-12 \mathrm{~cm}$ thick of scattered shell, small fragments of fish and deer-sized mammal bone, charcoal flecks, and burned clay flecks extending $42 \mathrm{~m}$ in Trench B in a dark clay paleosol that also extended east into Trench I in the southern-most part of the zone. The degree of shell concentration varied over the length of the zone, but was never dense (Figure 6-23). As discussed previously, a dart point that is probably a heavily resharpened Matamoros point was found in OZ-B near its southern end. The surface of the paleosol dropped slowly to the north, so that the top was at $70 \mathrm{~cm}$ brs in the southern end and $80 \mathrm{~cm}$ brs at the northern end in Trench B and somewhat lower in Trench I.

The features in OZ-B included seven small hearths, three of which were built directly on the ground surface with no pit, while two had a $5 \mathrm{~cm}$ basin. Feature 40 was a shallow pit, dug from OZ-B and filled with numerous small shells and charcoal. Charcoal from Feature 46 dates OZ-B to 2050 - 1880 B.P. (2 Sigma Cal.), while organic sediment from Feature 103 was dated slightly older at $2300-1900$ B.P. 


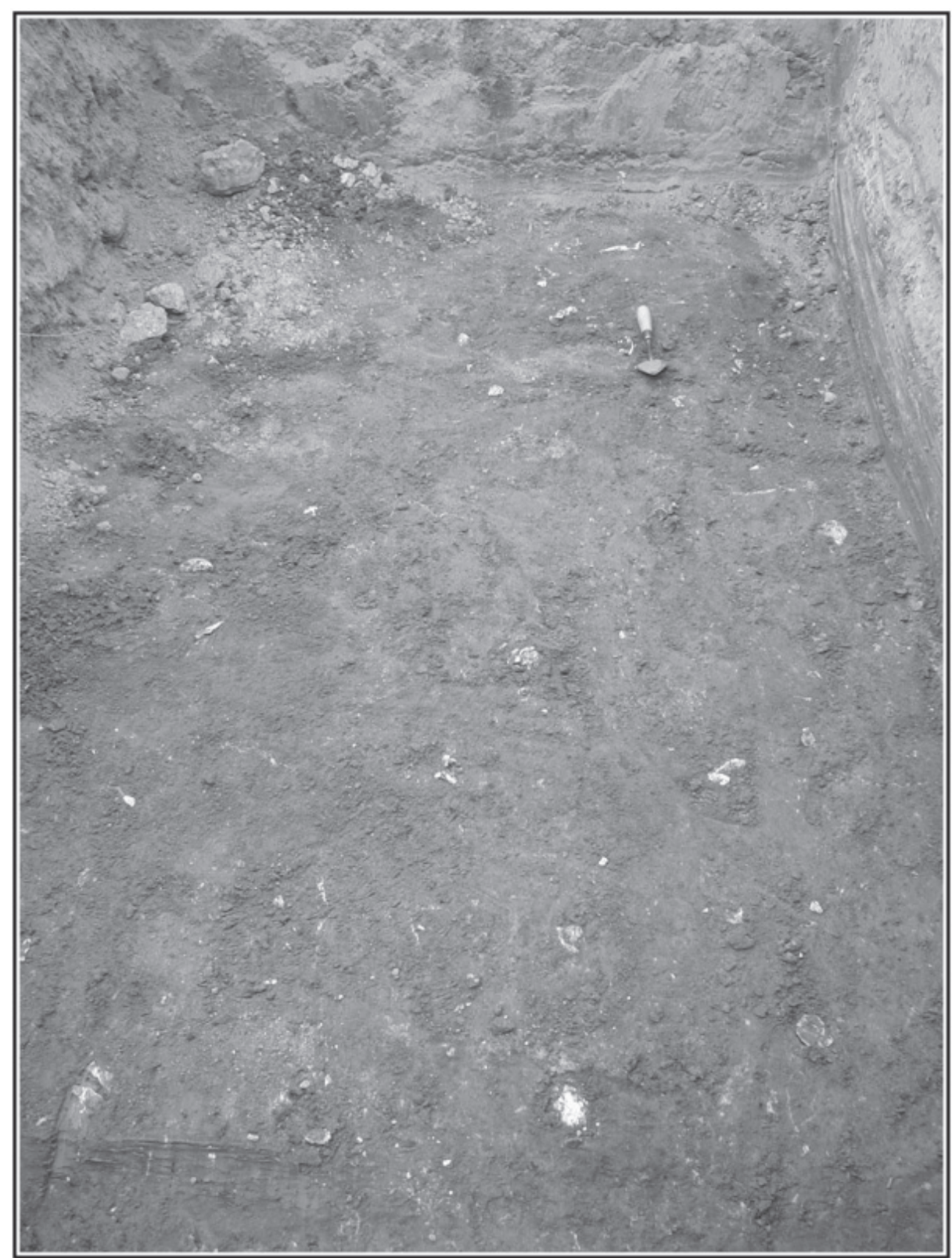

Figure 6-23. Scattered shell, charcoal and bone fragments in OZ-B.
Trench I, it was truncated on the west by the setting trench for the curb on the eastern edge of Alameda. The zone contained Features 98 and 100. It is suspected that portions of $\mathrm{OZ}-\mathrm{C}$ did at one time extend farther to the west, but were truncated by construction of Alameda Street. It is possible that Feature 73 , seen in Trench B located in a dark sediment sometimes seen above OZ-D, was part of OZ-C before the building of Ennis Joslin.

\section{Occupation Zone D}

Location: Trenches B, I

Extent: $34+078$ to $34+103$

Depth: $50-60 \mathrm{~cm}$

Feature(s): 65, 69 (?), and 75

Estimated Date: 1930-1730 B.P.

This occupation zone varied in density more than most of the zones identified. It covered nearly $40 \mathrm{~m}$ and consisted of a layer of shell, small fragments of animal bone, charcoal and burned clay. It often seemed to be ending, then would become denser again. It contained Features 65 and 75. Feature 69 may or may not be associated with OZD. It was an almost 2-m-wide pit that appeared to have been dug from the top of the paleosol containing OZ-D. However, it is possible that it was dug through the lighter sediments above OZ-D and was modern in origin. Organic sediments taken from OZ-D were dated 1930-1730 B.P. (2 Sigma Cal.).

\section{Occupation Zone C}

Location: Trench I

Extent: $34+045.5$ to $34+073$

Depth: $70-80 \mathrm{~cm}$

Feature(s): 98, 100

Estimated Date: Unknown

\section{Occupation Zone E}

Location: Trenches B, I

Extent: $34+080.3$ to $34+087$

Depth: $60-65 \mathrm{~cm}$

Feature(s): 70

Estimated Date: 1980-1820 B.P.
This zone consisted of a dense layer of shell, animal bone fragments, and charcoal. The western edge of the zone was often clearly seen in the trench (Figure 6-24). The eastern edge (within the trench) was truncated by an old gas pipe trench, and when the zone did extend completely across
OZ-E was relatively small for an OZ, but otherwise was similar to OZ-D just above it. Only one feature, Feature 70, was defined within this OZ. OZ-D and -E were separated by a light sediment layer. While OZ-E seemed to lay on a relatively flat sediments, it is clear 


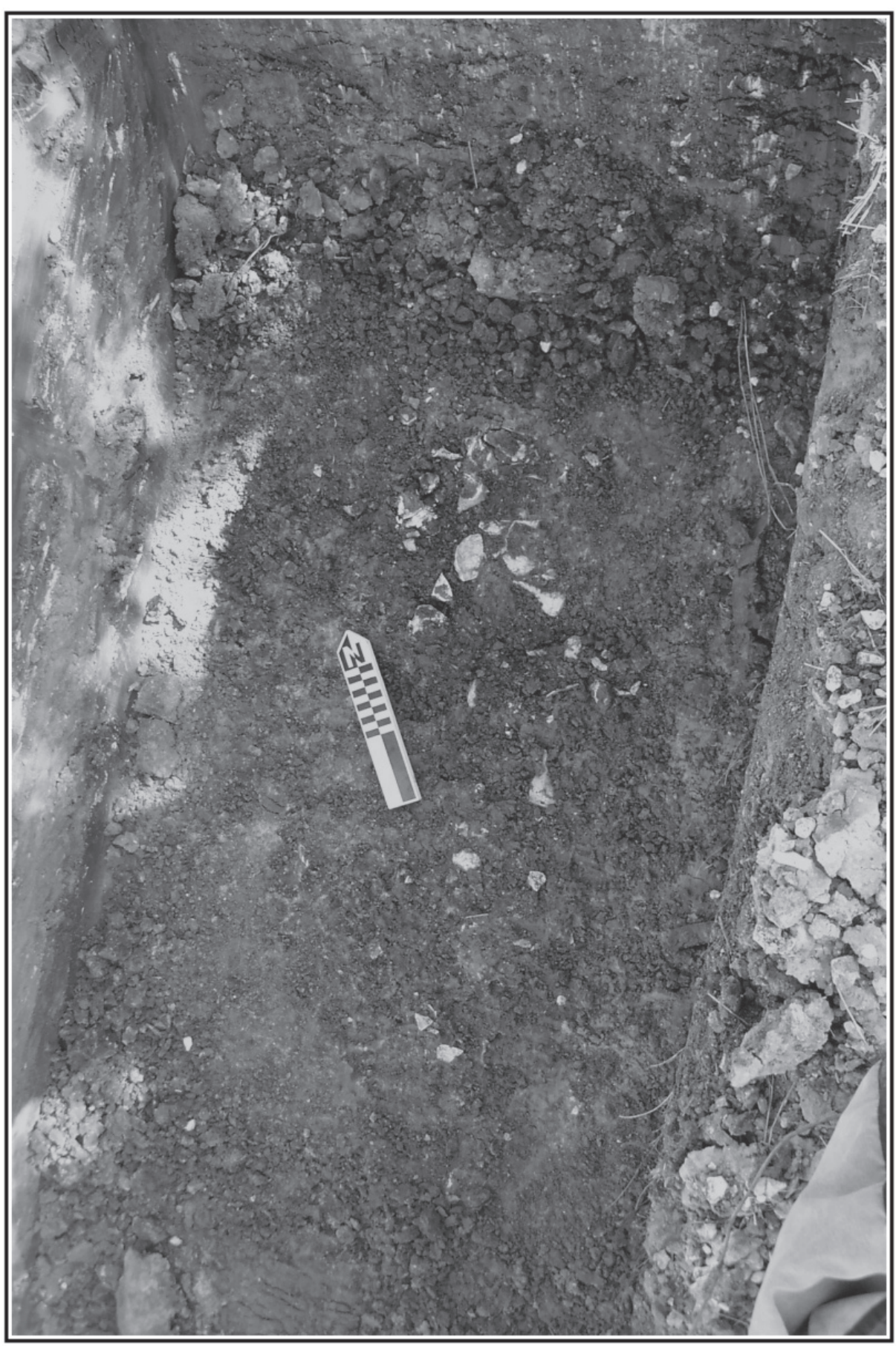

Figure 6-24. OZ-C in Trench I, showing density of shells and sharply delineated western edge.

that the light sediments that built up between OZ-D and -E were deeper to the west, so that OZ-D developed on more sloped sediments. To the east, in Trench I, it was sometime difficult, given the method of excavation, to separate them.

Organic sediments in OZ-D and charcoal from OZ-E, respectively, yielded dates of 1930-1730 B.P. (2 Sigma
Cal.) for OZ-D and 1980-1820 (2 Sigma Cal.) for OZ-E. Though the two layers are clearly distinct stratigraphically, the dates cannot be separated statistically, indicating that the two OZs developed in a short time span, separated by a rapid accumulation of light clay deposits between them.

\section{Occupation Zone F}

Location: Trenches B, I

Extent: $34+097.5$ to $34+140$

Depth: $65-80 \mathrm{~cm}$

Feature(s): 74, 109, 111 and 115

Estimated Date: 2770 - 2720 B.P.

OZ-F was a large, extremely dense sheet midden, appearing to be nearly paved with shell (Figure 6-25). The depth of this $12-15 \mathrm{~cm}$ thick zone varied from 65 to $80 \mathrm{~cm}$ brs due to the slope of the paleosol.

The southern part of OZ-F lies beneath OZ-D, with a clear separation of light clay between them (Figure 6-25). Within OZ-F, there were numerous areas where concentrations of charcoal and burned clay were denser than the overall concentration. However, these were poorly defined and could not be easily separated from the general high density of shell and charcoal in this zone. Thus, only four separate features (Features $74,109,111$ and 115) were defined within OZ-F.

\section{Occupation Zone G}

Location: Trench I

Extent: $33+584.5$ to $33+603$

Depth: $80-110 \mathrm{~cm}$

Feature(s): 84 (renamed OZ-G)

Estimated Date: $2740-2460$ B.P.

OZ-G was located only in Trench I in the field, although subsequent examination of a profile of the part of Trench B dug during Phase I suggests that it may have extended south at least to $33+556$. It was first identified as Feature 84 near the bottom of the trench at $110-140 \mathrm{~cm}$ bgs, but as its extent 


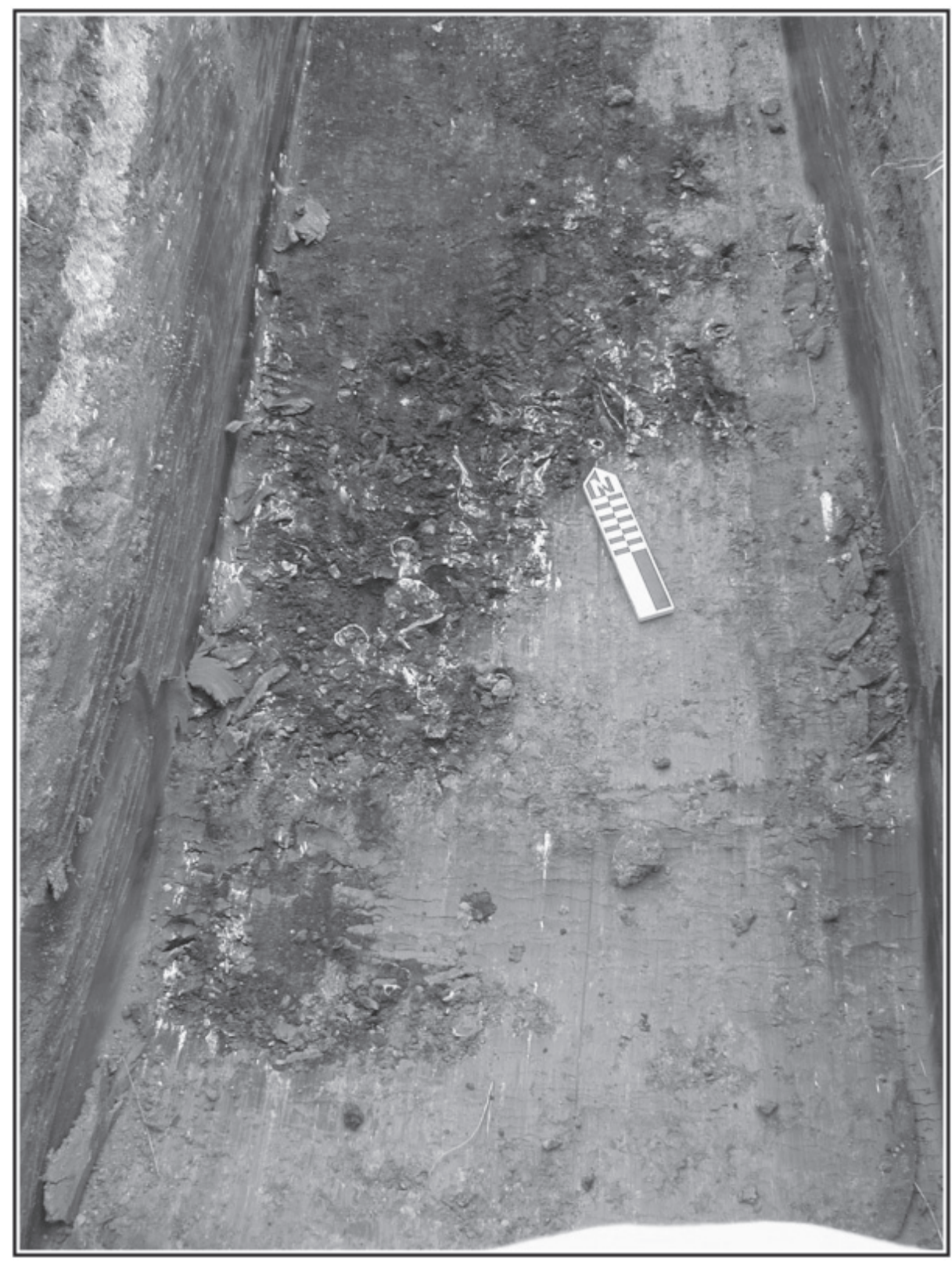

Figure 6-25. The bottom of OZ F in Trench I, showing the density of shell frequently seen in this $\mathrm{OZ}$.

became clear, Feature 84 was renamed OZ-G. As OZ-G continued north, however, it became increasingly shallower and thinner, until at the northern end it was only about 7-10 $\mathrm{cm}$ thick, $80 \mathrm{~cm}$ bgs, directly beneath a layer of fill and laying directly on top of Beaumont clay.

OZ-G was found throughout an unusually thick (as much as $30 \mathrm{~cm}$ ) paleosol, with frequent scatters of shell, charcoal and burned clay. OZ-G was deepest and thickest at the south end and gradually rose and thinned as it continued north, becoming very thin at about $33+601$, at which point it was sitting directly on top of the Beaumont clay formation. During most of its extent, OZ-G was fairly dense and was much thicker than most of the Occupation Zones.

\section{Occupation Zone $\mathbf{H}$}

Location: Trench L

Extent: 0 to $6 \mathrm{~m}$ east of centerline at $33+541$

Depth: $150-155 \mathrm{~cm}$

Feature(s): 125

Estimated Date: Unknown

OZ-H was located in Trench L, near the centerline of Ennis Joslin road. The depth of this zone below road surface was 150 to $155 \mathrm{~cm}$, making it by far the deepest occupation zone. OZ-H was a distinct, yet relatively thin layer of broken shell, mammal bone fragments and charcoal. A single small hearth (Feature 125) was found within this zone. This zone was located at the top of a dark clay layer and the sediments that contained the occupation debris were distinctly sandier than the rest of the dark clay band.

\section{Occupation Zone I}

Location: Ennis Joslin Rd. Extent: $33+600$ to $33+608$

Depth: $55-60 \mathrm{~cm}$

Feature(s): 129 (renamed OZ-I)

Estimated Date: Unknown

OZ-I was observed just beneath the roadbed during scraping of the eastern half of Ennis Joslin to lower the road to the new grade, prior to addition of new road base materials. It was approximately $55-60 \mathrm{~cm}$ below the old road surface, and extended across most of the area being graded, although it was distinctly denser along the western edge of the area, near the centerline. It was originally designated Feature 129 , but when it became clear that it covered such a large area, it was renamed OZ-I.

Most of OZ-I appeared highly disturbed, with apparently undisturbed portions only seen on the western edge, roughly 
2-4 m east of the centerline. The remains of OZ-I visible just to the west of Trench B were extremely thin which explains why it was not noticed in Trench B.

\author{
Occupation Zone J \\ Location: Trench $\mathrm{G}$ \\ Extent: $34+012$ to $34+130$ \\ Depth: $40-55 \mathrm{~cm}$ \\ Feature(s): 148-152, 154-156, 159, and 161 \\ Estimated Date: 2480-2340 B.P.
}

OZ-J was located on the western side of Ennis Joslin, in the northern dune deposit. It was clearly defined within Trench $\mathrm{G}$, between stations $34+012$ and $34+120$. When the road surface on the west side of Ennis Joslin was removed and the previously undisturbed dune surface scraped down approximately $5 \mathrm{~cm}$, the surface of OZ-J was revealed across the entire western half of Ennis Joslin between approximately $34+100$ and $34+130$. Very large numbers of shell, scattered animal bone (most of which was fish bone), charcoal and other evidence of occupation was clearly visible in this area, and one dense concentration of shell was so well defined that it was given a feature number, Feature 161.

OZ-J and its associated features were across the street from the area in which the dense occupation debris seen in Trenches B and I were located, including OZ- B, -D, -E, and -F. In the field, is was considered possible that OZ-J is a continuation of OZ-D, based on depth below ground surface, general character of cultural materials, and the density of features in the zone. However, the radio carbon dating of samples from the five OZs made it clear that they were not related, as OZ-J was dated 2480-2340 B.P., while OZ-D was dated 1930-1730. OZ-F was dated 2770-2720 B.P.

OZ-B is directly across the street from OZ-J, but is considerably deeper below the road surface. This did not rule out a connection with OZ-J, however, because the paleosols in the northern dune deposits can be seen to descend to the east toward the False Oso mudflats. The charcoal sample from OZ-B was dated 2300-1880 B.P., making it possible, though not certain, that the two OZs are temporally related.

\author{
Occupation Zone K \\ Location: Trench N and Ocean Dr. \\ Extent: $33+558$ to $33+576$ \\ Depth:70-80 cm \\ Feature(s): 162 \\ Estimated Date: Unknown
}

OZ-K was observed when the new free right turn from eastbound Ocean onto Ennis Joslin was graded. This is an area that lies between the dense black clay of the pond deposits and the Beaumont Clay formation that rises from beneath the pond to the west. OZ-K is a narrow band (ca. $5 \mathrm{~m}$ across) that extended across the new turn lane. Although it was observed in Trench N, it was recognized at the time only as a thin scatter of shell and charcoal flecks too ephemeral to call a feature. In the context of the observations in the adjacent turn lane, however, it appears that the shell scatter seen in Trench $\mathrm{N}$ was part of OZ-K.

OZ-K appears to be a band of cultural materials that surrounds the northern edge of the pond. A similar deposit was not seen along the southern edge of the pond in Trench N. In fact, no evidence of cultural activity, except for an occasional shell, was seen in Trench $\mathrm{N}$ until OZ-K was encountered at $3+260$. This may, however, be the result of previous grading of the area near the southern end of Trench $\mathrm{N}$ that may have removed the thin scatter of shell and charcoal seen in OZ-K. The northwestern edge of the pond deposit had been seriously disturbed by extensive previous utility construction, so that the absence of cultural deposits does not necessarily mean that they did not, at one time, exist there. In any case, OZ-K is not evidence of extensive occupation along the north edge of the pond. Although there is one area of shell in the zone that was distinct enough to define as a feature (Feature 162), the cultural material in this occupation zone was not very dense, compared to some of the occupation zones to the south on Ennis Joslin.

\section{Summary}

This chapter has provided a summary of the radiocarbon results from 41NU2. Dates show that while earlier occupations are present, the site was primarily occupied between 3000 and 900 B.P. The beginning date of this more intensive occupation is consistent with some estimates of when the barrier islands formed. An investigation of paired shell and organic dates showed that corrected, calibrated shell dates were often younger than their organic counterparts. Date ranges (2-sigma) on shell frequently did not overlap those derived from paired charcoal or organic sediment. However, a comparison of the mid-points of the two sigma ranges for the individual dates shows, with one exception, a strong relationship. We conclude that marine shell can provide accurate, precise dates in the absence of other dating materials. This may especially be the case if samples of Crassostrea virginica are selected for dating. We also provided basic descriptive data on the 164 features as well as 11 occupation zones documented at the site during this monitoring project. Aspects of the feature and occupation zone data, especially from dated contexts, will be used in subsequent chapters. 


\title{
Chapter 7: Theoretical Framework: Modeling Hunter-Gatherer Adaptations
}

\author{
Steve A. Tomka
}

In this chapter we review the ethnohistoric record to extract some broad patterns about hunter-gatherer adaptations in the Gulf Coastal Plains and Marshes during the early sixteenth century. We look specifically at information about diet, land use, mobility and seasonal and inter- and intra-regional variability in these patterns.

\section{Coastal Hunter-Gatherer Adaptations: The Ethnohistoric Record}

Given early Spanish interest in Texas, followed by French and later Euro-American explorations into present-day Texas, a relatively large number of ethnohistoric accounts exist describing various features of the landscape, including sometimes its indigenous population. Of these accounts, the focus here will be on one source that provides details on indigenous groups specifically within the project area and the broader Gulf Coastal Plains and Marshes. We speak of Álvar Núñez Cabeza de Vaca and his account of the seven years (1528-1535) he and his companions Andrés Dorantes, Alonso del Castillo, and a Moorish slave named Estebanico spent among indigenous groups of the barrier islands and the coastal plains. Cabeza de Vaca published an account of those years, La relacion que dio Aluar nuñez cabeça de vaca de lo acaescido en las Indias en la armada donde yua por gouernador Panphilo de Narbaez desde el año de veynte y siete hasta el año de treynta y seys quo bolvio a Seuilla con tres de su compañia (usually called la Relación), in 1542. In 1547 a joint account by the three Spanish survivors, originally given to the Viceroy in Santo Domingo, was published in the third edition of Historia General y Natural de los Indias by Gonzalo Fernández de Oviedo y Valdéz (Oviedo y Valdéz 1923). We rely on the Oviedo account and the revised version of La Relación published in 1555 . Scanned images, page by page, of the 1555 publication of La Relación with a new translation into English is available online (Cabeza de Vaca 1555). It is this translation that we rely on throughout this section, with page numbers reflecting the page numbers in the original 1555 Spanish edition. In addition, we also refer to T.N. and T. J Campbell's (1988) discussion of the Cabeza de Vaca account to guide us in locating the groups mentioned in the account and providing region-specific observations.

There are obvious biases in the account and, not surprisingly, detailed observations are missing on many aspects of indigenous life. In addition, it is a single account written from the perspective of a single individual with input from his surviving mates. Nonetheless, given that these individuals lived with several indigenous groups distributed across what we assume to be the Gulf Coastal Plains and Marshes and for several years (Cabeza de Vaca 1555), the account provides us not only detail on several groups living in distinct settings but also some degree of long-term perspective that is not present in brief expedition accounts of indigenous groups.

Careful scrutiny of the La Relación and Oviedo's account reveals that at the time of Cabeza de Vaca's shipwreck, the Gulf Plains and Marshes region was occupied by numerous indigenous groups practicing a number of different landuse strategies. There appeared to be four land use patterns in operation during the early sixteenth century: (1) a littoral pattern with intermittent and/or regular trips to inland highly productive resource patches; (2) a river valleybased pattern with specialized trips to neighboring highly productive inland and coastal resource patches; (3) a mixed oak woodlands-prairie margins pattern with at least seasonal bison exploitation; and (4) an inland pattern devoid of perennial riverine resources. These land use patterns appear to differ in character primarily because of differences in the nature of the resources available for exploitation. We focus here on a description of the first two patterns because several historians agree that Cabeza de Vaca made landfall on or near Galveston Island and he spent the longest time with groups located either on the island or on the coast in nearby river valleys and therefore the two land use patterns have greatest relevance to our reconstructions of historic hunter-gatherer land use and mobility practices.

\section{The Littoral Pattern}

The littoral pattern appears to have been one where the bulk of the resources at least during certain seasons of the year were obtained from the beaches and waters of the Gulf of Mexico and the river valleys that empty into bays along the Gulf. Gulf resources were extracted either while on what Cabeza de Vaca (1555:39) called Malhado Island or on the shores of the mainland itself. In the case of some groups, movement into inland portions of the coastal prairies appears to have been limited or absent, at least as exemplified by Cabeza de Vaca's descriptions of the land use pattern of the groups from Malhado Island. In the case of other groups, movement into inland highly productive resource patches, particularly along river courses, might have been a common practice. For instance, Campbell (1988:74) reports that a number of coastal groups made incursions into the Central Coastal Plains region as far as Bastrop County, in pursuit of bison and probably 
other terrestrial resources. Most cultural detail provided by Cabeza de Vaca refers to this land use strategy.

The shipwrecked individuals joined the island natives in early November 1528 and almost immediately experienced the effects of a strong cold front that deflated fish densities and made the harvest of plant roots difficult (Cabeza de Vaca 1555:38). The island was inhabited on occasion by native groups from at least two language groups. They each appear to have followed similar land use practices, alternating between the island and mainland camps situated along the bay (Cabeza de Vaca 1555:42). The group Cabeza de Vaca was with remained on the island from October-February. During the early part of this period they trapped fish with cane weirs and pulled roots from underwater, but later the fish were no longer abundant and the people were more heavily dependent on the roots (Cabeza de Vaca 1555:39).

At the end of February, when the roots they were eating began to sprout, the group left the island and traveled to the shores of the nearby bays using canoes (Cabeza de Vaca 1555:42). The houses built there were woven mats wrapped over bent cane poles set on piles of oyster shells (Cabeza de Vaca 1555:41). These oyster piles appear to be much like the oyster lenses or concentration noted by Martin (1930), Jackson (Jackson et al. 2004) and others found the dune sites, including 41NU2, overlooking the shore. Cabeza de Vaca (1555:41) mentions that "firewood is scarce, but mosquitoes are plentiful". He also mentioned that fresh water was scarce during the months spent eating oysters (Cabeza de Vaca 1555:41). They stayed on the shores of the estuaries where they could procure oysters until April, then traveled back to the island to eat the large numbers of ripe blackberries available (Cabeza de Vaca 1555:41).

Early summer months were spent eating roots, and a variety of small prey including lizards, snakes, rats, and spiders. The final two months of the annual round (i.e., August-September) they live on fish and the roots of partially submerged plants.

The indigenous groups on the island are described as having animal hides for cover and using arrows that were most likely poisoned. Oviedo y Valdez (1923:23) indicates that "at times there are deer, which they kill from canoes."

\section{The Riverine Pattern}

It appears that at least in some cases, populations living immediately inland from coastal bays were oriented towards the exploitation of inland rather than coastal resources. The Mariames and Avavares are perhaps the two best examples of this inland, riverine land use system. Cabeza de Vaca spent 18 months with the Mariames and approximately eight months among the Avavares. T.N. amd T.J. Campbell (1988:2528; and Campbell 1988:49-50) places the Mariames in the vicinity of the San Antonio and Guadalupe Rivers. It is likely that along the lower Guadalupe their territory extended to the coastal bays (i.e., San Antonio Bay) since the bays are described as being used to trap large numbers of game (Oviedo y Valdéz 1923:110).

Cabeza de Vaca's descriptions clearly indicate that the Mariames occupied and exploited a bilobate (Campbell 1988:47) area, composed of two distinct inland segments located some 80 miles $(129 \mathrm{~km})$ apart and connected by a narrow travel corridor. The lower Guadalupe River portion of their range might have included portions of present-day northwest Calhoun County, northeast Refugio County, and southern Victoria County. Apparently, for nine months of the year, during the fall, winter, and spring, the Mariames inhabited and exploited the resources of this area.

Their diet consisted of a broad range of foodstuffs with some emphasis upon highly productive plant resources as they became available during the year. Pecans constituted the dominant foodstuff for one to two months in the fall season although, as Cabeza de Vaca (1555:47) mentions, pecans provide high yields only in alternate years. During years when pecan patches were highly productive, groups came from as far as 50 to 75 miles away (distances calculated based on Campbell's [1988] reconstruction of group territories). While some of the nut meat was consumed immediately without any processing, Cabeza de Vaca also mentions that some nut meat was ground with small seeds (granillo) of some sort and eaten in this fashion (Cabeza de Vaca 1555:47). Although highly productive and probably capable of excess yields, no mention is made of the storage of excess nuts among the Mariames or neighboring groups.

During the winter months the primary foodstuffs consisted of the roots of two to three plants (Cabeza de Vaca 1555:52). These roots ranged from smaller than pecan to slightly larger sizes and some are described as very bitter causing the abdomen to swell. The roots were thinly distributed, hard to find, and difficult to dig (Cabeza de Vaca 1555:52). Women often foraged as far as 8 to $13 \mathrm{~km}$ ( 5 to 8 miles) from their settlements in search of these roots (Campbell 1988:50). It is not possible to discern whether these search costs are incurred within rather depleted resource patches or are due to seasonal fluctuations. In addition, to render them edible, the roots required substantial processing, including cooking for two days in some type of oven. Apparently, women invested a substantial amount of effort each night in the preparation of ovens for baking roots (Cabeza de Vaca 1555:52-53). These 
high processing costs significantly reduce the post-encounter return rates for these food items and lower the ranking of such resources. Deer were hunted, both locally and by traveling out onto the prairie. The latter was done only two or three times a year because firewood and water had to be carried on these trips and mosquitoes were a serious nuisance (Cabeza de Vaca 1555:54).

Cabeza de Vaca (1555:53) claimed that intermittent food shortages were common among the Mariames, especially during the winter season. Apparently they moved every two or three days in search of food (Cabeza de Vaca 1555:53). The list of foodstuffs consumed by the Mariames includes snakes, rats and mice, various insects, some in larval forms, ant eggs, frogs, lizards, salamanders, and spiders. The bones of snakes were pulverized and eaten (Cabeza de Vaca 1555:52). It is not clear whether the diet breadth indicated by this list was a seasonal pattern reflecting starvation diets or the consumption of this range of food stuffs occurred year around.

Fish were likely obtained from the Guadalupe and San Antonio Rivers, however, it is unclear what, if any, facilities or tools were used. Apparently freshwater fish were eaten in quantity mainly during April and May following the seasonal floods when the fish could be obtained from shallow floodplain pools after the floodwaters subsided (Campbell 1988:50). Presumably the same tactic could have been employed during the fall flooding season during the second wet period of the year. Fish bones, like snake bones, were also pulverized and eaten (Campbell 1988:50).

The remainder of the year (summer) the Mariames were at the prickly pear area, placed by Campbell in the eastern portion of Duval County and Jim Wells County where the plant grew in great abundance (T.N and T.J. Campbell 1988:9). Apparently the fruit ripened at different times for a period of about three months, between late May/early June and late August. Given that few perennial streams existed in the prickly pear grounds, the people drank ponded rainwater when it was available and prickly pear fruit juice when water was not available (Cabeza de Vaca 1555:56). The prickly pear fruit was eaten immediately after it was picked or shortly thereafter. Unlike in the case of the pecans, however, there is mention of some of the prickly-pear fruit being dried for consumption during the return trip to the lower Guadalupe River. The juice of the fruit was squeezed out, the fruit was opened, dried in the sun, and thereafter carried in some kind of flexible container. Mention is also made of the peelings of the prickly pear being ground into a powder (Cabeza de Vaca 1555:53). Although much of the discussion about prickly pear use focuses on this fruit, Oviedo also mentions that snails were eaten while the Mariames were in the prickly pear grounds "snails were searched for carefully' (Oviedo y Valdez 1923).

Although there is no mention of deer being hunted while in the prickly pear area, it is likely that if the large congregation of people did not frighten away the deer those that were encountered were hunted while in the region. What is clear is that immediately preceding the move to the prickly pear area, and before moving away from the coastal bays the Mariames organized a communal deer drive during which large number of deer and other animals trapped in front of the drivers were herded into the bay and kept there until they drowned and washed ashore. This method of hunting tended to yield large number of animals. In one case 60 men took between 200-300 deer, while at another occasion a total of 500 deer were taken (T.N. and T.J. Campbell 1988:18). On the other hand, some communal hunts resulted in few or no deer. It is possible that if this hunting technique was timed to take place immediately before the move to the prickly pear area, it was designed to provision the population with meat while in this patch for 1.5 to 3 months.

The Avavares are the third group with which Cabeza de Vaca spends extended time. They are briefly mentioned here because they may be the group that was most closely associated with the project area. According to Campbell, the Avavares may have inhabited the area between present-day Lake Corpus Christi and Copano Bay and possibly adjacent areas in Bee and Refugio counties northwest of Corpus Christi Bay. Other researchers place the Avavares on both sides of the lower Nueces River in parts of Duval, Jim Wells, and San Patricio Counties. They were an inland group living west and immediately inland from the coastal Quitoles (T.N. and T.J. Campbell 1988:25). They appear to represent a variant of the riverine pattern with perhaps lower reliance on coastal resources compared to the Mariames.

Based on Cabeza de Vaca's and Oviedo's descriptions, it is clear that at least during the summer the Avavares lived in or immediately adjacent to the prickly pear area. One cannot make a clear distinction between their summer and winter ranges indicating perhaps that they inhabited the same general area throughout the year. Other than prickly pear, the record is unclear what resources were exploited by these people. There is specific mention that they did not have fish, or collect pecans or acorns (T.N. and T.J. Campbell 1988:26). However, since one of the seasons is identified as the time when the fish die, it is puzzling why fish are not mentioned as one of the available resources. This would suggest that they did inhabit a river valley (e.g., the lower Nueces River), although if this was the case, it would be puzzling that no other 
river bottom resources are mentioned as being systematically exploited (T.N. and T.J Campbell 1988:26).

During six of the eight months (Sept. 1534-June 1535) Cabeza de Vaca and his fellow Spaniards were with the Avavares they all experienced severe shortages of food and suffered hunger. Winters were apparently particularly difficult in terms of foodstuff availability. Much of the summer subsistence was geared towards the exploitation of prickly pear. In late summer they are described as being in the prickly pear patch searching for prickly pear that escaped harvest by other groups. On another occasion when several days of searching produced no ripe fruit, the Avavares went to a stream valley, to gather seed pods from trees whose pods the Spanish described as like "hieros" (vetches or lentils). This tree has been identified as the Texas ebony (Ebenopsis ebano), which holds its seedpods into the winter season (T.N. and T.J. Campbell 1988:26). According to Oviedo, during the winter months, the Avavares ate mainly roots. (Oviedo y Valdéz 1923). Deer were hunted and Cabeza de Vaca mentions that at one point the Avavares gave them so much venison that "we did not know where to put the meat" (Cabeza de Vaca 1555:58). It is not known whether the meat was sun dried or other wised preserved or fresh. It also is unclear as to whether the food scarcity described among the Avavares is due to the likelihood that they inhabited more xeric settings or whether it was the product of the typical seasonal fluctuation in resources.

Apparently, their annual land use system was closely tied to the succession of the seasons and the various foodstuffs that became available. It is perhaps because the lands around the Avavares are described as having few resources, that mobility was relatively high among them. Their houses are said to have been like those of the Mariames, a bent-pole framework covered by mats. When they moved their camps, as often as every three days, they dismantled it and transported it to the new location (Cabeza de Vaca 1555; Oviedo y Valdéz 1923). Again, it would be great to know if the frequency in moves is the typical year round pattern or applies only to a particular season of the year (i.e., very early or late summer).

The previous review of historic period adaptations by indigenous groups along the Gulf coast provides a surprising amount of information on the subsistence and mobility of hunter-gatherers living within or in the vicinity of the project area. We have learned that the Middle GulfCoast was inhabited by a large number of groups positioned adjacent to each other along the coastal belt and immediately inland. Some portions of the landscape and resources appear to have been shared by multiple groups (i.e., prickly pears and pecans) while access to others may have been restricted to specific groups (i.e., coastal strips). Mobility was in general high and included both logistical (i.e., deer and/or bison hunting parties on the prairie) and residential moves (i.e., camp movements every three days). Daily foraging rounds may have varied between 8-13 km and long distance travel to shared resource patches may have encompassed as much as 113-129 km (figures calculated based on group locations identified by T.N. and T.J Campbell (1988) based on the Cabeza de Vaca account [version unknown]). Hunting may have focused on medium body size game acquired either through communal efforts, small logistically organized hunting parties or individual pursuit hunting. Some long distance hunting expeditions may have been undertaken to pursue bison. Campbell (1988) for instance, surmises that some coastal groups may have penetrated far inland to hunt bison on a seasonal basis. Plant resource acquired included roots and tubers, prickly pear, pecans, and seeds. Oysters, fish, waterfowl, and a variety of amphibians, reptiles and rodents supplemented the diet. While this is a welcome amount of detail, that serves as an important window into the past, as with any historical account, it does not help us understand why land use and subsistence practices were organized the way they appeared to have been. To begin to define what were the broad conditioning factors underlying this ethnohistoric landscape and how they operated, we turn to models provided by human behavioral ecology.

\section{Models from Behavioral Ecology}

The theoretical position we adopt in this document to investigate prehistoric hunter-gather adaptations on the Gulf Coastal Plains and Marshes is human behavioral ecology. Human behavioral ecology (HBE) is a subset of evolutionary ecology that focuses on the explanation of variability in human behavior through the principles of natural selection. Its starting position is that human behavior is the product of a number of evolutionary mechanisms and processes operating at different temporal and spatial scales. That is, while a wide range of behaviors exists within the human repertoire at any one time, over time, natural selection will favor those sets of behaviors that tend to be optimal or more precisely optimal within certain constraints (Foley 1985; Winterhalder and Kennett 2006:11). The constraints derive from the fact that a multitude of factors such as lack of full information, lag time between resource states and behavior adjustments, idiosyncratic differences in skill levels and cognitive differences between individuals, result in less than perfect match or synchronicity between resource states and hunter-gatherer behavior.

Four fundamental concepts underlie the optimization premise: (1) any given behavioral alternative has opportunity costs; (2) all human behavior has some degree of risk; (3) continuous 
and/or repeating human behavior has a marginal value; and (4) rewards for future behaviors with uncertain outcomes have lesser value than behaviors with immediate and certain outcomes (Winterhalder and Kenneth 2006). Employing these underlying premises, the intention of HBE analysis is to determine through cost/benefit analysis the best combination of alternative sets of resource procurement behaviors given a set of constraints (e.g., resources available at a given time, technological means, etc), an assumed set of goals (e.g., maximize energy capture, minimize risk), as measured using a given currency (e.g., Kcal, time, mating success, prestige, etc). Because optimization modeling is a key framework used by HBE studies to develop expectations regarding huntergatherer behavior, we briefly review some optimal foraging models and propose that one in particular, the habitat choice model, with some modifications is appropriate for the study of prehistoric hunter-gatherer foraging strategies in the Gulf Coastal Plains and Marshes.

\section{General Background to Optimal Foraging Models}

In Chapter 2, we identified the Gulf coastal strip as a highly diverse mosaic of resources. Within this mosaic, we have defined five relatively homogenous habitats each with its own mix of biological communities (see Chapter 2). Seasonal changes and long-term modifications in climatic conditions, coupled with unpredictable weather episodes strongly influence the types of resources available within each habitat, their seasonal or longterm availability, their relative abundance, and their nutritional condition. Specific aspects of the resources present in these habitats and fluctuations in their availability are discussed in greater detail in the next chapter.

Among hunter-gatherers, problems created by spatial variation in resources are commonly solved by changes in mobility strategies and adjustments in group size (e.g., fissioning and aggregating; Kelly 1995:213-216). Mobility strategies have several components that can vary, including the frequency of moves, the distance moved, and the organization (e.g., logistically organized task groups, higher residential mobility) of the moves. Similarly, the temporal fluctuations in resources, including seasonal changes in resource availability and quality (e.g., molluscs, seeds, nuts), year-to-year fluctuations in resource density (i.e., nuts), and longer-term changes in resource structure (e.g., increases or shrinkages in arboreal vegetation communities vis a vis grasslands), are commonly solved by changes in diet, shifts in mobility strategies, fluctuations in group composition and size, and technological adjustments including the use of storage.

Since the 1970s, optimal foraging models adapted by anthropologists and archeologists from animal behavioral ecology have been one of the main approaches used to model hunter-gatherer behavior. Since the tendency for optimal behavior is conditioned by long-term evolutionary forces, optimal foraging theory has become the principal methodological tool employed by human behavioral ecologists to study prehistoric hunter-gatherer adaptations. Two principal models, a "Prey Choice Model" which was explicitly developed for a single predator pursuing a single prey in a homogenous environment (Charnov et al. 1976; MacArthur and Pianka 1966; Winterhalder 1981), and a "Patch Choice Model," designed for situations where multiple prey are clustered in a more heterogeneous setting (Charnov 1976; Kaplan and Hill 1992), have been developed to account for foraging behaviors.

As we have argued elsewhere (see Tomka et al. 2004), while many assumptions of these foraging models are clearly violated by hunter-gatherers, and while parameters specified for analysis (e.g., caloric content; post-encounter return rate) are often difficult to estimate in archeological situations, we find the models appealing as they provide an explicit cost/ benefit framework for analysis. Also, we recognize that by their very nature these models are simplified versions of more complex hunter-gatherer behaviors. Models are simplified versions of reality with understood and often quantified relationships between conditioning factors and behavioral outcomes. We compare the material signatures and adaptive stances reconstructed from the archeological record to these models to search for agreements and disagreements between them. These comparisons often result in refinements of the models and greater understanding of prehistoric huntergatherer foraging patterns.

Applications of foraging models (see Stephens and Krebs 1986) in hunter-gatherer studies typically quantify costs as time expended in searching for, pursuing, capturing, and processing food items and the benefits as energy (kilocalories [kcal]) obtained from the acquired food (but see Jochim 1981; Speth and Spielmann 1983). Maximization models assume that foragers attempt to maximize average return rates in the context of different cost/benefit outcomes for different prey. Search costs reflect the amount of time spent looking for game or resource patches, and handling costs include the amount of time required to pursue, capture, and process foods. For hunters and gatherers, we also include in handling costs time associated with production of tools (e.g., raw material acquisition, tool shaping, maintenance, production of ceramics; Bousman 1993), and the manufacture of facilities and features employed in resource processing (e.g., hearths, hot rock ovens).

A critical element of all foraging models is the ranking of prey alternatives. Potential prey items are ranked in terms of 
post-encounter return rates (i.e., $\mathrm{Kcal} / \mathrm{hr}$ ). For animals, this ranking is strongly correlated with body size since largerbodied animals (e.g., mammoths, bison) are more profitable (higher returns relative to handling costs) than smaller-sized animals such as a deer, rabbit or mouse (see Kaplan and Hill 1992: Figure 6.1; Simms 1987: Table 5). Even though some plant resources have higher caloric content then meat, plants usually rank below animals primarily because of their smaller package size, though there are exceptions. This general trend in ranking can be seen in Figure 7-1. Here we present box plots for a series of post-encounter return rates gathered from a variety of experimental and ethnographic sources (see Kelly 1995; Simms 1987). The rates have been grouped by body size for animals and roughly by seed size for plants. Clearly, when seen strictly in terms of handling costs, the return rates on large mammals in this example are extremely high, while the return rates for collecting and processing small seeds are extremely low.

Although, as noted, search costs, are not taken into account in prey profitability rankings, these costs do play a critical role in determining the actual diet of hunter-gatherers since they represent energy expended in capturing a prey and therefore enter into the calculation of the overall energy balance of the individual. Because search costs are treated separately from handling costs, it is possible to study the effect of prey abundance or changes in search techniques on prey selection. In the classic Prey Choice Model, as more resource types are added to the diet, search costs decline because resources are more frequently encountered. However, these new resources, being lower ranked, have higher handling costs and/or lower caloric benefits (lower profitability). Foraging models predict a tradeoff, then, between handling cost, energy benefits, and search costs that will maximize the average return and produce an optimal diet (see Figure 7-2). These models predict that foragers will continue to add lower-ranked resources to the diet, increasing the diet breadth, so long as the overall profitability of the diet, seen in terms of total costs and benefits, is increased. Furthermore, resource types should be dropped from the diet, reducing the diet breadth, when doing so would increase overall profitability.

From this perspective, the decision to include or exclude a given resource type is determined not by the density or profitability (i.e., net energy gain per pursuit/handling cost per pursuit) of that resource type, but by the density and profitability of

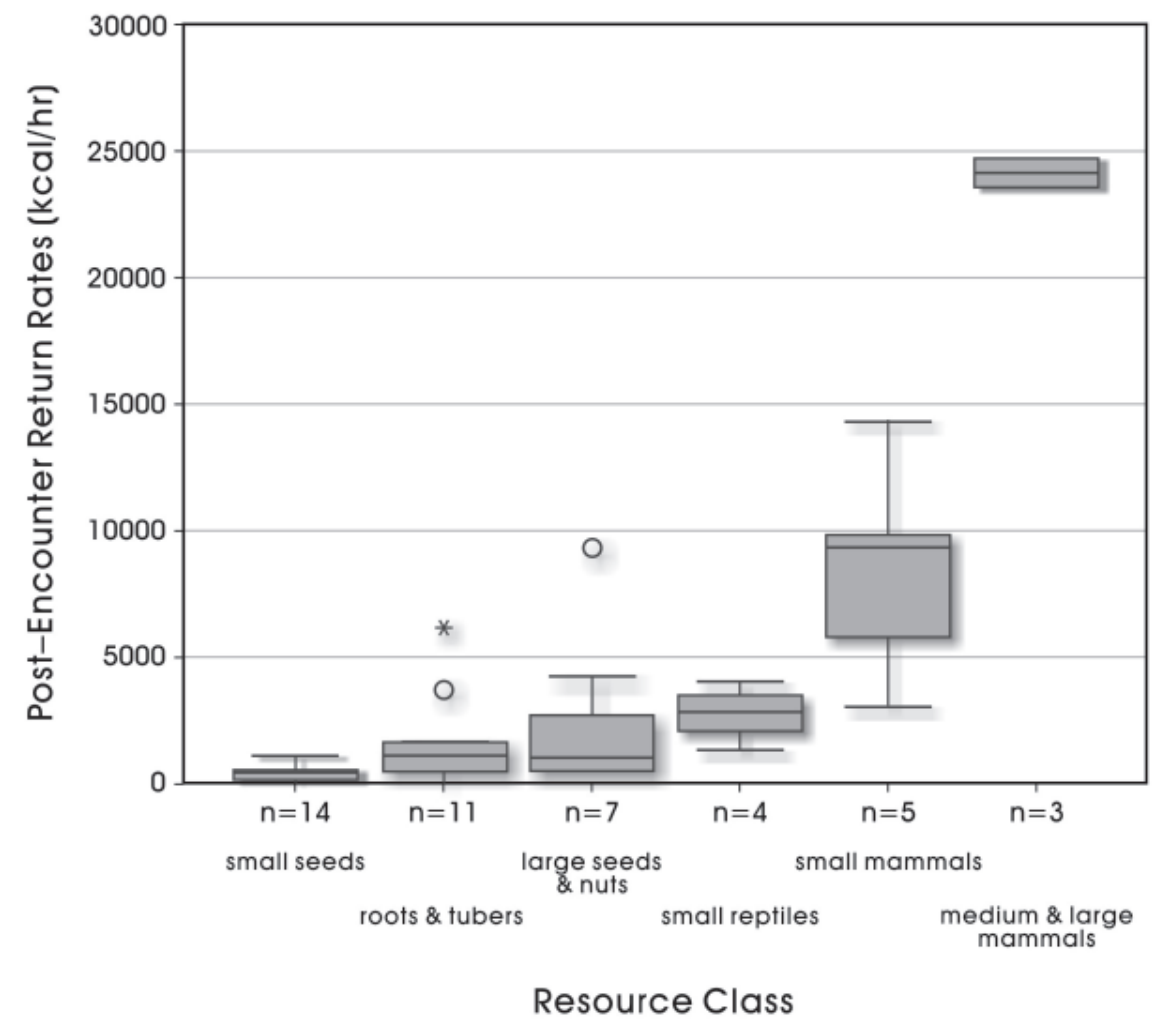

Figure 7-1. Return rates by resource class (from Cane 1987; Kelly 1995; Simms 1987). 


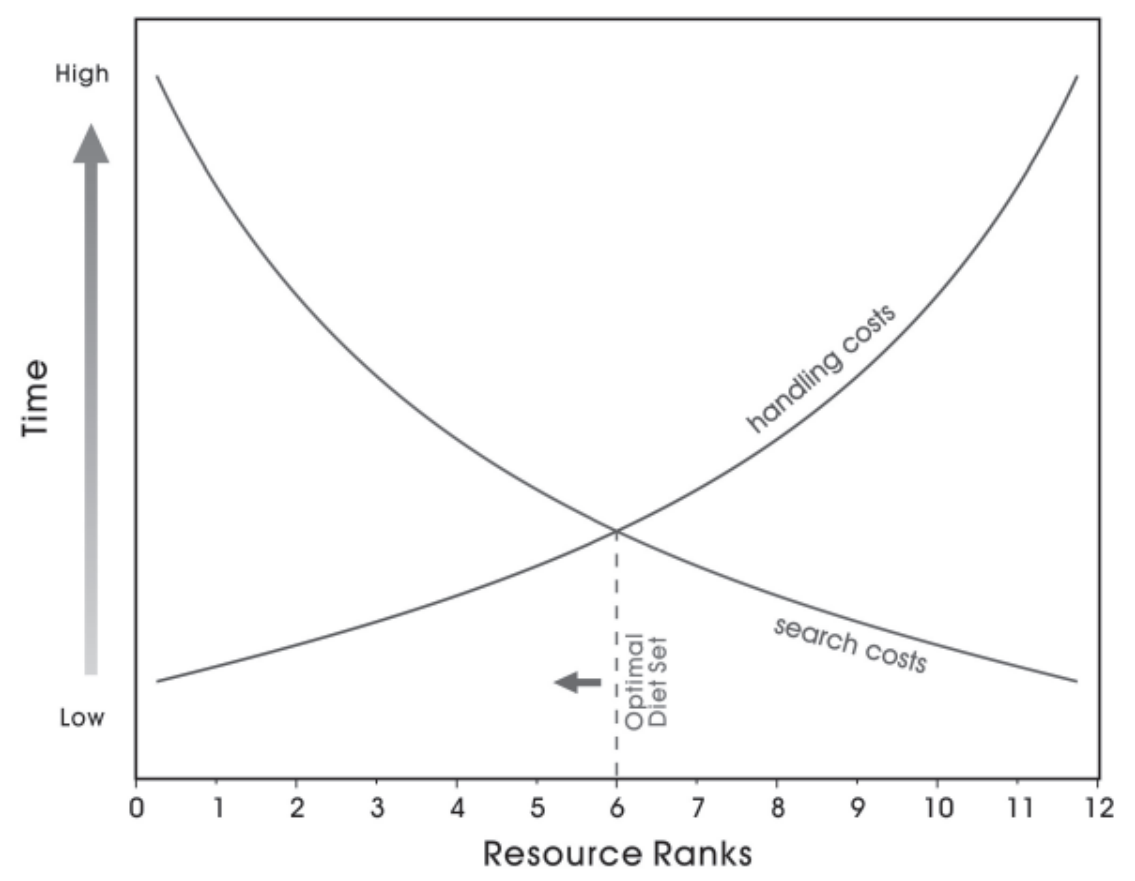

Figure 7-2. Optimal diet set as defined in Prey Model (after MacArthur and Pianka 1966).

higher ranked prey items. In situations where the frequency of higher ranked items increases, lower ranked resources could be dropped from the diet, thus increasing the average return.

While the Prey Choice Model assumes that the goal of the forager is to maximize the rate of energy intake, a substantial body of cross-cultural data suggests that human male and female foragers target different resources on their daily foraging trips (see Bird 1999). Female foragers tend to harvest prey packages that are smaller than those pursued by men, have a relatively low risk of pursuit failure, and often consist of resources that have high processing costs (Bird 1999:66). In contrast, men pursue prey that are larger, have a higher risk of failure, and are associated with lower processing costs (Bird 1999:66). The two foraging tactics are partially overlapping and highly complementary in having the overall effect of dampening some day-to-day fluctuations that may otherwise result from the high failure rates of hunting large- or medium-size prey. This contrast between model expectations and behavior suggests that actual hunter-gatherer behavior may be conditioned by a combination of factors (i.e., rate maximization, risk minimization, and others) particularly in environmental contexts where the daily caloric intake may be subject to significant variability (Levins 1968:10-38).
Over time and as a product of repeated applications of optimization approaches in both animal and human ecology, new models have been developed to address a broad range of resource procurement behaviors and models have become more capable of addressing real-world complex scenarios. For instance, the Patch Choice Model relies on the marginal value theorem to highlight that harvests will continually decline with increasing patch residence time leading to an inverse relationship between patch residence time and return rates over time (Stephens and Krebs 1986). The model predicts that a given forager will leave a patch when the rate of return in that patch has dropped to the mean return rate for all other patches that are available for exploitation. Two possible patch utilization approaches may be optimal under this model. The first consists of short patch residence time targeting the harvest of the most profitable prey accompanied by rapid movement between patches as the most profitable resources are depleted in each patch. The second approach involves longer residence in each patch while resources are utilized to the point of near sub-optimality followed by longer travel distances to new patches because a larger area surrounding the residential camp has been depleted of resources.

The Central Place Foraging Model also deals with forager decision making relative to multiple competing resource 
patches exploited from a centrally located camp (Orians and Pearson 1979). Rather than narrowly limiting foraging behavior to sequential foraging from one patch to another, this model allowed for the exploitation of multiple patches from the same central location. The critical variable introduced in this model is the role of roundtrip travel and transportation costs. The expectation derived from this model is that as roundtrip travel costs increase, in particular as a result of successfully acquired prey or resources, the forager should become more and more selective about what he/she will harvest. A number of studies have used this model to explain the differential transport of resources from hunting or procurement localities to the base camp (Bettinger and Malhi 1997; Bird and Bliege Bird 1997; Metcalfe and Barlow 1992). Others (Brannan 1992; Jones and Madsen 1989; Rhode 1990) have attempted to model the effect of resource transportation costs on settlement location vis a vis resource patches with distinct post-encounter return rates.

For instance, Zeanah (2000) considers the issues of where to locate a camp when faced with the choice of two highly ranked resources (i.e., large mammal versus hyper-productive seed patches) located at some distance from each other yet harvested during the same season. The quantitative model suggests that transportation costs have a significant impact on the optimal solution for camp location. Specifically, when the contribution of a highly ranked target resource to the diet of a forager is high, and the prey is profitable due to frequent encounter rates, the forager should reside in close proximity to that target prey. Close proximity and high encounter rates should ensure high after-transport profitability. However, as encounter rates decrease, the after-transport profitability of the target prey also will begin the decrease ultimately leading to a widening of the diet breath to include the next highest ranked resource. If the contribution of this new resource to the caloric intake of the forager increases beyond that of the first resource due to higher after-transport profitability, the forager should relocate in its proximity. That is, the relative ranking of the two camp locations should switch Zeanah (2000:11). Of the two, the prey that makes up the lower contribution to the diet may still be procured through logistical organization while daily foraging trips from a central place camp should be used to access the prey that represents the highest contribution to the diet.

Oneway in which hunter-gatherers may decrease transportation costs is through field processing. However, field processing itself has a caloric cost that can decrease the net caloric gain from a target prey when included in prey profitability calculations. In the end, while field processing may reduce transportation costs through lighter loads, it may severely lower the transportation threshold for given prey species due to its energetic costs. In considering the field processing of acorns and mussel shell, Bettinger and Malhi (1997) conclude that high field-processing costs severely deflate the transport threshold and for acorns only minimal field processing should be carried out otherwise a negative energy balance will quickly be reached. In contrast, the procurement and transportation of some mussels should involve no field processing to maintain a positive energy balance while the exploitation of other species may be profitable even following complete field processing. The choice between these two alternatives is conditioned by roundtrip travel distance, the productivity of different mussel colonies (i.e., abundance of mussels and size of meat-package), the caloric yield from different mussel species and the costs of field processing the different species. These same factors underlie the differences in optimal field processing-transportation strategies between acorns and mussels.

Responses to changing diet breadth can elicit changes not only in the frequencies and distances one moves between resource patches but also the overall organization of mobility. Binford (1980) suggested that new insights may be gained regarding land use and technological organization by viewing hunter-gatherer mobility systems as representing an organizational continuum encompassing "foragers" and "collectors". Collector resource procurement strategies have low residential mobility and rely on task-specific groups sent from central camps to obtain distant resources in settings with high temporal or spatial disparity in resources. Foragers, frequently move residential locations to acquire food within environments characterized by ubiquitous, low-density resources (Binford 1980; Kelly 1995). Bettinger and Malhi (1997:897) note that field processing and transportation costs can significantly influence these organizational strategies. Specifically, they suggest that logistically organized procurement that involves field processing is in general a costlier strategy than the procurement of the same resource through residential mobility where foragers map onto a productive resource. They also suggest that as residential mobility decreases and hunter-gatherers become increasingly more tethered to staple resources, logistical procurement strategies will be employed to take lower ranked resources less profitably (Bettinger and Malhi 1997:897).

The final optimization model mentioned here and discussed in more detail in the next section is the Habitat Selection Model (otherwise known as the ideal free distribution model; Kennett et al. 2006; Sutherland 1996). The underlying assumption of this model is that individual foragers and foraging populations should choose to occupy the patch where suitability (i.e., fitness, breeding success, or rate of intake) is highest (Sutherland 1996:14). In the model, patches are defined as more or less heterogeneous aggregates of resources and the forager is faced with deciding where to locate. The quality of the habitat depends on resource abundance and the 
density of the population inhabiting and using it (Winterhalder and Kennett 2006:16). The model predicts that habitats will be occupied in their rank order and also factors in that certain human behaviors may have advantageous consequences (e.g., creation of clearings) while other behaviors may have negative consequences on the ranking of the habitat (e.g., settlement at high population densities and resulting resource depletion).

Several key assumptions underlie the ideal free distribution model (Sutherland 1996). The first of these assumptions is that as the number of competitors increases within a patch, the suitability (read return rate) of that patch declines (Sutherland 1996:9) as a result of negative feedback. Interference is one form of negative feedback and results in short-term decline in intake rate due to the presence of others in the patch who may interfere with a forager's ability to carry out optimal solutions (Sutherland 1996:15-19; i.e., conflicts among neighboring groups may prevent access to desired patches). Population dynamics suggest that with weak interference foragers will tend to aggregate within the habitats with highest prey densities, however, as forager population densities increase, increased interference will lead to a more even distribution of the foraging population into other habitats resulting in a relatively even intake rate in all habitats (Sutherland 1996:17). Depletion, the second form of negative feedback, refers to the actual removal of prey, and can clearly impact potential return rates within a habitat (Sutherland 1996:32-37). Modeling of depletion dynamics suggests that while foragers will always aggregate into the most productive habitats (i.e., the one with the highest density of prey), as prey densities are depleted to levels equaling those of the next richest habitat, foragers will begin to use both habitats. The ideal free distribution also assumes that patches may differ in quality (i.e., suitability, return rate) and the manner in which they are used depends upon the density of competitors (Sutherland 1996:7). In species with territoriality or dominance hierarchies, the ideal distribution no longer applies because individuals are not free to move between patches. However, the concept of the ideal despotic distribution may be used to describe the expected distribution between patches (Sutherland 1996:910). The ideal despotic distribution recognizes that the first forager to occupy a habitat may gain higher return rates than later arrivals. Therefore, the suitability (read return rate) of the patch or habitat declines for each new forager arriving into the patch. However, the newly arriving foragers do not necessarily decrease the suitability of the patch for those foragers that were already there because through dominance or territorial behavior the original settlers can or may maintain exclusive control of their patch.

The model has been used to investigate population dynamics and animal behavior (Sutherland 1996), and trends in the colonization of Oceania (Kennett et al. 2006). One particularly useful aspect of the model is that while most applications of Optimal Foraging Theory have been at the scale of the individual prey or patch, the habitat selection model can be applied with equal interpretive success to larger analytical units such as a habitat and allows the study of not only individual but population foraging behavior. We propose to look at hunter-gatherer adaptations at this scale because we feel that it more accurately reflects the scale at which decisions regarding subsistence and mobility are managed among hunter-gatherers.

In addition, the model expressly takes into account not only prey ranking but also the role of certain population dynamics such as interference, depletion, and the buffer effect to generate expectations regarding patch use and residence time. The inclusion of population dynamics in turn broadens the range of phenomena that can be modeled or studied well beyond subsistence and settlement practices and allows forces other than climatic phenomena to impart changes in resource density and distribution, and patch rank. It is because of these features and its close theoretical relationship to the broad family of optimal foraging models that we propose to employ it to model coastal hunter-gatherer land-use and subsistence strategies, particularly as they are manifest at the $41 \mathrm{NU} 2$ site.

\section{Technological Adjustments}

In addition to changing diet breadth in an effort to stay within the optimal zone, technological responses may also be taken to maximize the average return rate. For example, the abandonment of complex, expensive technologies in favor of simpler, less costly processing methods, or abandonment of specialized search methods, may be a viable option under some conditions of increasing frequency of higher ranked resources. Conversely, decreasing abundance of highly ranked prey may lead to a series of technological responses such as: (1) the adoption of more expensive technology in order to increase the kill ratio, and thereby increase the profitability of the less frequently encountered higher ranked prey; (2) the use of technologies that will allow more intensive processing of the prey thereby extracting more nutrients than was previously possible; (3) the shift in technology that increases the encounter rate of that prey type (i.e., snow mobiles). Search strategies may also shift to alternative resources with similar return rates.

Technological adjustments that can aid in increasing return rates to make a resource more profitable can also be made by major shifts in the organization of procurement. For instance, game drives can result in the aggregation of large numbers of highly ranked prey resulting in high return rates even when game population densities are low. The 
ethnohistoric mentions of fire-aided game drives on the Gulf Coast may actually be examples of this type of technological adjustment to low game densities. Similarly, if the density of lower ranked prey increases (anchovies and other schooling fish) certain capture methods and facilities can result in the acquisition of large numbers of small meat packages that when treated as a single unit captured during a single even will significantly raise the return rate for that food resource (Madsen and Schmitt 1998). Facilities and tactics such as nets, weirs, and fish poisoning can serve to increase capture rates for a given lower ranked food resource. The increase in return rates with increasing abundance of otherwise lowranked resources derives from dramatic reductions in pursuit time. The en-mass capture of large numbers of small prey items (e.g., a basket full of anchovies) with not much more than the same effort that it would take to capture a single prey item, results in a significant increase in calories contributed without a proportional increase in calories expended in securing the prey items therefore resulting in a significant increase in post-encounter return rates. As Ugan (2005) and Ugan et al. 2003, show, however, sucjh gains would be realized only if the procurement technology is not overly expensive to manufacture and there is minimal to no energy expended in processing the harvest.

\section{Summary}

In this chapter, we have reviewed data on sixteenth century hunter-gatherers as they were described in the written records produced by Cabeza de Vaca (1555) and Oviedo y Valdéz (1923), one of his companions. We also relied on Campbell (1988) and his research related to the reconstruction of the route taken by Cabeza de Vaca on his way back to Pánuco. We realize that much of the picture presented above relies on best-guess reconstructions of where the shipwrecked party landed, where it came to shore and the routes of their travels. Similarly, the locations of the named groups and the regional mobility patterns are best-guess estimates. Nonetheless, few historians would argue that the hunter-gatherers described lived somewhere on the coastal stretch and utilized both marine, freshwater and terrestrial resources. Therefore, the picture that we are able to extract from the accounts mentioned is an example of hunter-gatherer adaptations to resource structures that are not unlike what we would expect Gulf Coastal groups would have faced during the Late Prehistoric and Historic Periods, if not even earlier.

The ethnohistoric data suggests a high population density packed along the coastal corridor. Several resource extraction strategies appear to have been practiced by these groups. We focused on the detailed discussion of two of them, the littoral and riverine pattern. Following the review of the ethnohistoric record, we looked at optimal foraging models derived from human behavioral ecology to begin assembling the theoretical toolkit that will allow us to generate expectation regarding prehistoric hunter-gatherer land use and subsistence.

We outlined the underlying assumptions of the prey selection, patch choice, central place foraging models and proposed that aspects of all of them can be used in conjunction with the habitat selection model to construct expectations regarding the positioning of hunter-gatherer populations across the landscape, their mobility and diet breadth, as well as prehistoric population dynamics within the Corpus Christi area. In the next chapter (Chapter 8) we summarize the resource base and its spatial and temporal structure to provide a foundation that will anchor specific expectations regarding hunter-gatherer adaptations that we propose in Chapter 9. 


\title{
Chapter 8: Resource Structure and Nutrition
}

\author{
Steve A. Tomka and Jennifer A. Thompson
}

In this chapter we describe the broad range of resources that would likely have been available to prehistoric huntergatherers of the coast and coastal plains and provide nutritional information from published sources for some species. In addition to compiling an inventory of potential resources, our initial goal was to also pull together information on nutrition and population dynamics for the selected resources. This search was intended as a pilot project to determine what was and what was not available in terms of data types that would allow archeologists to pursue quantified research in optimal foraging and human behavioral ecology.

The coast represents a rich mosaic of niches with unique but complementary resources for plant and animal species. Since hunter-gatherer groups would have used both freshwater and marine aquatic and terrestrial resources, our review will include the range of potentially available resources within both environments. Our goal in providing this review is to identify the principal potential resources and define their spatial and temporal structure and the factors that may cause predictable or unpredictable fluctuations in their availability. However, knowledge of variations in available amounts of resources will not necessarily provide an explanation of subsistence variation or relative dietary importance of any single species. Many have turned to economic analysis of resource procurement calculating net energy and time costs for hunting and processing in order to explore unexpected relationships between resource abundance, the assumed dietary importance, and the archeological record (Reidhead 1976, Perlman 1976, Osborn 1977, Glassow and Wilcoxon
1988). Any such economic study should include nutritive values per unit of weight as well as fluctuation between age, sex, and season of available resources. However, this data is difficult to come by. Many case studies refer to Watt and Merrill (1963) for nutrition information, finding the nearest applicable item listed (Glassow and Wilcoxon 1988, Reidhead 1981), submit samples for nutritional analysis as part of the research, or rely on other published sources and adjusting data to include factors that would effect the nutritional gain of a given resource. Relying on general data such as from Watt and Merrill (1963) disregards specific nutrition information at the species level, age group, season, and habitat of the resource, a sacrifice most researchers find prudent as finding sources reporting nutrition information specific to seasonal or age fluctuations is even more problematic. Submitting samples of possible resources for nutrition analysis was not possible for this study. Therefore, the literature search serves to assess the availability nutritional data at the species level for resources available prehistorically along the Central Texas Coast.

\section{Terrestrial Mammals, Reptiles, and Amphibians}

Table 8-1 presents the 51 mammalian species found within the Coastal Prairies sub-region of the Gulf Coastal Plains, including the areas surrounding the numerous bays of the Gulf. The table also includes a column describing the preferred settings within which the species is encountered. The data were compiled from the mammalian species distribution

Table 8-1. Mammalian Species Found in Terrestrial Settings of the Gulf Coastal Plains and Marshes

\begin{tabular}{|c|c|c|c|c|c|c|c|}
\hline Size & Taxa/Species & $\begin{array}{c}\text { Weight } \\
\text { (g) }\end{array}$ & Found In & $\begin{array}{l}\text { Calories } \\
\text { (or Kcals) }\end{array}$ & $\begin{array}{l}\text { Protein } \\
\text { Content } \\
\text { (kg) }\end{array}$ & Unit Size & Reference \\
\hline \multirow{3}{*}{ 总 } & Bison & 600000 & prairies/open fields; open woodlands?; & - & - & - & - \\
\hline & Mountain Lion & 157250 & $\begin{array}{l}\text { sandstone/limestone ledges, bluffs; thickets; wooded } \\
\text { slopes; open woodlands; }\end{array}$ & - & - & - & - \\
\hline & Black Bear & 125000 & open woodlands; wooded slopes; glades; & 134.29 & 23 & $100 \mathrm{~kg}$ units & Reidhead 1981 \\
\hline \multirow{7}{*}{$\stackrel{\Xi}{:}$} & Jaguar & 52800 & open woodlands; thickets; & 214.24 & 20.6 & $100 \mathrm{~kg}$ units & Reidhead 1981 \\
\hline & White-tailed Deer & 50000 & open woodlands; glades; thickets; disturbed grounds; & 334.17 & 17 & $100 \mathrm{~kg}$ units & Reidhead 1981 \\
\hline & Pronghorn & 45000 & prairies/open fields; xeric habitats; & 254.22 & 19.4 & $100 \mathrm{~kg}$ units & Reidhead 1981 \\
\hline & Red Wolf & 30000 & $\begin{array}{l}\text { open woodlands; wooded slopes; prairies/open fields; } \\
\text { glades; }\end{array}$ & - & - & - & - \\
\hline & Collared Peccary & 19000 & thickets; xeric habitats; barrens; & - & - & - & - \\
\hline & American Beaver & 18000 & marshes, sloughs, ponds; alluvial stream bottoms; & 125.75 & 21 & $100 \mathrm{~kg}$ units & Reidhead 1981 \\
\hline & Coyote & 17000 & $\begin{array}{l}\text { open woodlands; glades; thickets; wooded slopes; } \\
\text { prairies/open fields; disturbed grounds; xeric habitats; }\end{array}$ & 138.43 & 20.8 & $100 \mathrm{~kg}$ units & Reidhead 1981 \\
\hline
\end{tabular}


Table 8-1. Continued...

\begin{tabular}{|c|c|c|c|c|c|c|c|}
\hline Size & Taxa/Species & $\begin{array}{l}\text { Weight } \\
\text { (g) }\end{array}$ & Found In & $\begin{array}{l}\text { Calories } \\
\text { (or Kcals) }\end{array}$ & $\begin{array}{l}\text { Protein } \\
\text { Content } \\
(\mathrm{kg})\end{array}$ & Unit Size & Reference \\
\hline \multirow{21}{*}{ 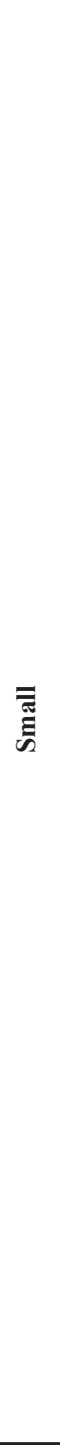 } & Common Raccoon & 8500 & $\begin{array}{l}\text { open woodlands; glades; wooded slopes; marshes, } \\
\text { slough, ponds;alluvial stream bottoms; }\end{array}$ & 255.55 & 17.6 & $100 \mathrm{~kg}$ units & Reidhead 1981 \\
\hline & Porcupine & 8000 & $\begin{array}{l}\text { sandstone/limestone ledges, bluffs; wooded slopes; open } \\
\text { woodlands; }\end{array}$ & 198.34 & 19.2 & $100 \mathrm{~kg}$ units & Reidhead 1981 \\
\hline & American Badger & 7000 & $\begin{array}{l}\text { prairies/open fields; xeric habitats - occupy entire range } \\
\text { for prairie dogs and ground squirrels; }\end{array}$ & 1258 & - & $1 \mathrm{~kg}$ & Simms 1984 \\
\hline & Bobcat & 7000 & $\begin{array}{l}\text { sandstone/limestone ledges, bluffs; thickets; wooded } \\
\text { slopes; open woodlands; }\end{array}$ & - & - & - & - \\
\hline & River Otter & 6500 & marshes, sloughs, ponds; alluvial stream bottoms; & - & - & - & - \\
\hline & White-Nosed Coati & 4500 & $\begin{array}{l}\text { open woodlands; wooded slopes; sandstone/limestone } \\
\text { ledges, bluffs; }\end{array}$ & 200.09 & 21.9 & $100 \mathrm{~kg}$ units & Reidhead 1981 \\
\hline & Common Gray Fox & 4000 & open woodlands; thickets; wooded slopes; xeric habitats; & - & - & - & - \\
\hline & Stripped Skunk & 4000 & open woodlands; glades; wooded slopes; thickets; & - & - & - & - \\
\hline & $\begin{array}{l}\text { Black-tailed Jack } \\
\text { Rabbit }\end{array}$ & 3250 & $\begin{array}{l}\text { xeric habitats; barrens; sandstone/limestone ledges, } \\
\text { bluffs; }\end{array}$ & 134.29 & 23 & $100 \mathrm{~kg}$ units & Reidhead 1981 \\
\hline & Opossum & 3150 & $\begin{array}{l}\text { open woodlands; glades; prairies/open fields; marshes, } \\
\text { sloughs, ponds;alluvial stream bottoms; }\end{array}$ & 373.67 & 15.9 & $100 \mathrm{~kg}$ units & Reidhead 1981 \\
\hline & Swamp Rabbits & 2250 & marshes, sloughs, ponds; alluvial stream bottoms; & 441.37 & 13.8 & $100 \mathrm{~kg}$ units & Reidhead 1981 \\
\hline & $\begin{array}{l}\text { Common Hog- } \\
\text { nosed Skunk }\end{array}$ & 1900 & open woodlands; glades; wooded slopes; thickets; & 326.43 & 17.3 & $100 \mathrm{~kg}$ units & Reidhead 1981 \\
\hline & Eastern Cottontail & 1500 & open woodlands; disturbed grounds; glades; open fields; & - & - & - & - \\
\hline & $\begin{array}{l}\text { Black-tailed Prairie } \\
\text { Dog }\end{array}$ & 1500 & prairies/open fields; & - & - & - & - \\
\hline & Ringtail & 1250 & $\begin{array}{l}\text { sandstone/limestone ledges, bluff; wooded slope/slope } \\
\text { bases; barrens; }\end{array}$ & - & - & - & - \\
\hline & $\begin{array}{l}\text { Eastern Fox } \\
\text { Squirrel }\end{array}$ & 950 & $\begin{array}{l}\text { open woodlands; glades; alluvial stream bottoms; } \\
\text { wooded slopes/slope bases; }\end{array}$ & - & - & - & - \\
\hline & Common Muskrat & 881 & marshes, sloughs, ponds; alluvial stream bottoms; & - & - & - & - \\
\hline & Mink & 782 & alluvial stream bottoms; marshes, sloughs, ponds; & - & - & - & - \\
\hline & $\begin{array}{l}\text { Eastern Spotted } \\
\text { Skunk }\end{array}$ & 565 & $\begin{array}{l}\text { open woodlands; glades; prairies/open fields; wooded } \\
\text { slopes; sandstone/limestone ledges, bluffs; }\end{array}$ & - & - & - & - \\
\hline & $\begin{array}{l}\text { Eastern Gray } \\
\text { Squirrel }\end{array}$ & 445.6 & open woodlands; thickets; marshes?; & 1078 & & $1 \mathrm{~kg}$ & Simms 1984 \\
\hline & Long-tailed Weasel & 400 & coextensive with pocket gophers and ground squirrels; & - & - & - & - \\
\hline \multirow{8}{*}{ 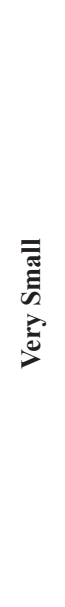 } & Eastern Woodrat & 275 & $\begin{array}{l}\text { alluvial stream bottoms; marshes, sloughs,ponds;open } \\
\text { woodlands; sandstone/limestone ledges, bluffs, prairies/ } \\
\text { open fields; }\end{array}$ & 134.29 & 23 & $100 \mathrm{~kg}$ units & Reidhead 1981 \\
\hline & $\begin{array}{l}\text { Southern Plains } \\
\text { Woodrat }\end{array}$ & 257.5 & thickets; xeric habitats; barrens; & 169.71 & 22 & $100 \mathrm{~kg}$ units & Reidhead 1981 \\
\hline & $\begin{array}{l}\text { Mexican Ground } \\
\text { Squirrel }\end{array}$ & 213 & prairies/open fields; xeric habitats; & 262.38 & 19.2 & $100 \mathrm{~kg}$ units & Reidhead 1981 \\
\hline & $\begin{array}{l}\text { Thirteen-lined } \\
\text { Ground Squirrel }\end{array}$ & 157 & prairies/open fields; & 207.7 & 20.9 & $100 \mathrm{~kg}$ units & Reidhead 1981 \\
\hline & Hispid Cotton Rat & 115 & prairies/open fields; barrens; disturbed grounds; & - & - & - & - \\
\hline & Eastern Mole & 75 & prairies/open fields; glades; open woodlands; & - & - & - & - \\
\hline & $\begin{array}{l}\text { Eastern Flying } \\
\text { Squirrel }\end{array}$ & 54 & open woodlands; wooded slopes/slope bases; & 135 & - & $100 \mathrm{~g}$ raw & $\begin{array}{l}\text { Watt and } \\
\text { Merrill } 1963\end{array}$ \\
\hline & $\begin{array}{l}\text { Gulf Coast } \\
\text { Kangaroo Rat }\end{array}$ & 52 & barrens; disturbed grounds; & 1078 & - & $1 \mathrm{~kg}$ & Simms 1984 \\
\hline
\end{tabular}


Table 8-1. Continued...

\begin{tabular}{|c|c|c|c|c|c|c|c|}
\hline Size & Taxa/Species & $\begin{array}{c}\text { Weight } \\
(\mathrm{g})\end{array}$ & Found In & $\begin{array}{c}\text { Calories } \\
\text { (or Kcals) }\end{array}$ & $\begin{array}{c}\text { Protein } \\
\text { Content } \\
(\mathrm{kg})\end{array}$ & Unit Size & Reference \\
\hline \multirow{12}{*}{ 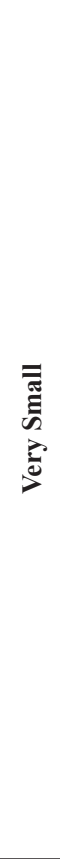 } & Marsh Rice Rat & 51 & $\begin{array}{l}\text { marshes, sloughs, ponds; open fields; rarely open } \\
\text { woodlands; }\end{array}$ & - & - & - & - \\
\hline & Cotton Mouse & 42.5 & open woodlands; glades; & - & - & - & - \\
\hline & $\begin{array}{l}\text { Hispid Pocket } \\
\text { Mouse }\end{array}$ & 38.5 & $\begin{array}{l}\text { open woodlands; glades; wooded slopes; disturbed } \\
\text { grounds; }\end{array}$ & - & - & - & - \\
\hline & $\begin{array}{l}\text { Southern Short- } \\
\text { tailed Shrew }\end{array}$ & 23 & open woodlands; glades; prairies/open fields; & 117.44 & 19.9 & $100 \mathrm{~kg}$ units & Reidhead 1981 \\
\hline & Deer Mouse & 22.5 & $\begin{array}{l}\text { prairies/open fields; open woodlands; xeric habitats; } \\
\text { disturbed grounds; wooded slopes; }\end{array}$ & - & - & - & - \\
\hline & $\begin{array}{l}\text { White-footed } \\
\text { Mouse }\end{array}$ & 22 & $\begin{array}{l}\text { alluvial stream bottoms; open woodlands; wooded } \\
\text { slopes/slope bases; }\end{array}$ & - & - & - & - \\
\hline & $\begin{array}{l}\text { Fulvous Harvest } \\
\text { Mouse }\end{array}$ & 18 & $\begin{array}{l}\text { open woodlands; alluvial stream bottoms; rare in } \\
\text { prairies/open fields; }\end{array}$ & - & - & - & - \\
\hline & $\begin{array}{l}\text { Eastern Harvest } \\
\text { Mouse }\end{array}$ & 12.5 & prairies/open fields; disturbed grounds; thickets; & - & - & - & - \\
\hline & $\begin{array}{l}\text { Plains Harvest } \\
\text { Mouse }\end{array}$ & 8 & prairies/open fields; & - & - & - & - \\
\hline & $\begin{array}{l}\text { Northern Pygmy } \\
\text { Mouse }\end{array}$ & 8 & prairies/open fields; open woodlands; disturbed grounds; & - & - & - & - \\
\hline & Desert Shrew & 6.5 & xeric habitats; & - & - & - & - \\
\hline & Least Shrew & 5.75 & prairies/open fields; & 1078 & - & $1 \mathrm{~kg}$ & Simms 1984 \\
\hline
\end{tabular}

maps presented by Davis and Schmidly (1994), and exclude bats. The occurrence of members in the Ursidae (bear), Antilocapridae (antelope), and Bison (buffalo) families is based on former distributions reconstructed by Weniger (1997). The distribution of the members in the remaining families is based on present distributions.

Table 8-2 groups the 51 species inhabiting the Gulf Plains and Marshes into body size categories. It indicates that as body size decreases the number of species in each size category increases, with the exception of small (25) to very small (20). Three species are grouped into the large body size category: bison, black bear, and mountain lion. Seven species are in the medium body size category (e.g., white-tailed deer, pronghorn, wolf, collared peccary (javelina), 21 in the small category (e.g., squirrels, skunks, opossum, rabbits), and 20 species are in the very small body size category (e.g., gophers, rats, mice).

Nutritional data of interest to us was not found in the available literature for the species living along the Texas Coast, though some data is reported for the same species living elsewhere. Likewise, no data is reported here on seasonal fluctuations. Reidhead (1976) does report nutritional data on species in Indiana (mostly from Watt and Merrill 1963) and uses fat grams reported there to determine seasonal fluctuations of protein which is then used to determine other micro-nutrient values mathematically.
Deer was likely the principal medium body size mammal within the coastal plains. As such, it is worth discussing in some detail the possible population dynamics that may have influenced availability and nutritional condition and therefore procurement practices and reliance on alternative resources. Statistics provided by the Texas Parks and Wildlife Department indicate that the Gulf Coastal Plains and Marshes vegetation region of the state is ranked second among the ten vegetation regions of the state in terms of the number of deer killed annually per 1,000 acres, with 6.3 deer/1,000 acres harvested per year. The number of deer killed by hunters is dependent on several factors, including the number of hunters. The number of hunters, however, is controlled at the state level through the issuance of licenses with the number of licenses issued dependent on densities of deer within these broad vegetation regions. The number of kills, then,

Table 8-2. Breakdown of Mammalian Species by Body Size Category

\begin{tabular}{|l|c|}
\hline \multicolumn{1}{|c|}{ Size Category } & Totals \\
\hline Large $(>100,000$ g.) & 3 \\
\hline Medium $(53,000-10,000$ g.) & 7 \\
\hline Small $(8,500-400$ g.) & 21 \\
\hline Very Small $(275-5$ g.) & 20 \\
\hline Totals & 51 \\
\hline
\end{tabular}

(Compiled from Davis and Schmidly 1994) 
may roughly approximate relative trends in deer populations within a region.

The food supply found within a deer's home range tends to be the principal factor limiting deer population sizes (Leopold et al. 1947; Walsh 1985:115). According to Hiller (1996:19) forbs, such as weeds and broadleaf flowering plants, are the preferred and principal food (60-80\% of diet) of whitetail deer in the Coastal Bend. Browse, the tender leaves and young shoots of woody plants, tends to also be important while the tender green growth of cool-season grasses represents only roughly $15 \%$ of the mid-to late-winter diet. Armstrong and Young (2001:11) have noted the critical importance of browse, especially the mast (nuts) production during the fall, because it provides the key fat reserves that allow deer to over-winter without starving Given the winter nutritional bottleneck and the role of sufficient high quality browse and mast crop for deer survival, the annual number of deer killed may be roughly correlated with total deer populations within each region, and this in turn is conditioned by the amount of total browse and mast production the year before within each vegetation region.

This observation seems to be supported by estimated whitetail deer populations in the Gulf Coastal Plains compared to the South Texas Plains. Between 1974 and 1978, it has been estimated that the coastal plains supported a mean total deer population of 81,309 deer. In contrast, it was estimated that within the South Texas Plains and Brush Country, the mean deer population was 652,566 during the same period (Liebow et al. 1980:242), an eight-fold difference. Present estimates of deer population densities also support the regional differences in deer densities. The Quality Deer Management Association's Whitetail Map Guide (2008) shows that on the Edwards Plateau, deer densities tend to be greater than 45 animals per square mile. In contrast, deer densities drop to around 30-45 animals per square mile on the Coastal Plain and the South Texas Plains and Brush Country has even lower densities (15-30 deer/sq. mile).

The apparent correlation between mast production and deer population densities also suggests that deer population densities will vary to some extent by habitat distribution. That is, deer will more likely be encountered in higher densities in the prairie-riverine interface habitat and in oak motts and stands scattered across the prairie habitat than on the open prairie, especially during the winter. Support for this proposition is found in deer population estimates for a number of the counties in the Gulf Plains and Marshes. For instance, between 1977 and 1978 deer populations of San Patricio and Refugio Counties were estimated at a mean of 90.8 and 50.8 animals per 1,000 acres, respectively. Significantly, in 1976 the total area of each county occupied by fluvial woodlands and oak motts combined was approximately $35.1 \mathrm{mi}^{2}$ (San Patricio) and $18.0 \mathrm{mi}^{2}$ (Refugio), respectively (extrapolated, based on figures provided in Brown et al. 1976). In contrast, Aransas County, has a total of approximately $13 \mathrm{mi}^{2}$ of fluvial woodlands and oak motts, had an estimated mean of 17.1 deer per 1,000 acres (Liebow et al. 1980:240-241; Brown et al. 1976:Table 7).

Studies of deer population behavior on the more open Gulf Plains and Marshes also indicate that during the daytime hours deer tend to spend more time in brush-heavy areas and feed in more open areas only very early or very late in the day when they are under the cover of low light conditions (Walsh 1985). The role of vegetation cover is so critical for deer densities that Steuter and Wright (1980) concluded after studying deer population densities on the Piloncillo Ranch in Dimmit and Webb Counties that as brush cover decreased whitetail deer densities also declined across the ranch. In addition to lower population densities, deer in the Gulf Coastal Plains and Marshes tend to be smaller and therefore weigh less than deer in the Edwards Plateau (D. Forrester, personal communication November 2006). While influenced by deer population management strategies, bucks on the Edwards Plateau are estimated to weigh roughly $135 \mathrm{lb}$. In contrast, bucks on the Coastal Plains rarely exceed $110 \mathrm{lb}$. (M. Lockwood, personal communication November 2006; D. Forrester, personal communication November 2006). The final characteristic of deer populations worth highlighting is their seasonal weight change that tends to be particularly noticeable among bucks. Deer managers and hunters have estimated that during the rut, bucks may loose as much as 20$30 \%$ of their body weight while does will loose a much lower percentage (e.g., 5-10\%; D. Forrester, personal communication November 2006). The timing of breeding season in white tail deer can vary a great deal, depending on environment. Even within Texas, for instance, there is considerable variation in the timing of the rut, from roughly mid-November to the end of December in the Trans Pecos area to September to October in the northern part of the Gulf Prairies and Marshes area (see Texas Parks and Wildlife 2005).

All of the above can inform estimates of deer population change during climate changes of the past, suggesting that during more xeric periods, the deer population in the vicinity of 41NU2 would have been much lower, and, especially during the fall and winter months, largely confined to densely covered areas close to the rivers and creeks, where oak and other mast producing species would still be present. In contrast, during more mesic periods, the number of deer as well as their size and ubiquity would increase, due to the increased cover and increased area covered by mast producing species. 
While the open prairie may not be the preferred habitat for deer it would have been prime habitat for pronghorn antelope. Therefore, as suggested by historic distribution data (Weniger 1997:43), it is likely that prior to its extermination from the region, the Gulf Plains and Marshes region supported a viable antelope population. Furthermore, given its habitat preference for wide open country with high visibility, it is likely that antelope densities would have been high exactly in those segments of the prairie habitat that would be less preferred by deer and populations would have been higher in more xeric climates when deer populations would be lower.

The Gulf Coastal Plains and Marshes region is at the hypothetical southern edge of the Plains historic bison distribution (Figure 8-1). Nonetheless, it is likely that the prairie with an abundance of big bluestem and other native tall and mid grasses, dissected by numerous perennial streams, would have offered ideal habitat for bison herds. Therefore, it is necessary to consider their presence in the region as a significant part of any models attempting to reconstruct prehistoric hunter-gatherer adaptations in the region.

In addition to the mammals mentioned above, reptiles and amphibians often can represent an additional source of protein that can be acquired while on foraging trips (Cabeza de Vaca 1555:52; T.N. and T.J. Campbell 1988:20; Marshall
1976). Data from Brown (1950:Table III) indicates that 23 species of amphibians (e.g., salamanders and frogs) and 67 species of reptiles (e.g., lizards, snakes, alligators and turtles) are present within the Post Oak Belt of Texas, a region that is roughly equivalent to the Gulf Coastal Plains. Among the amphibians there are 17 species of frogs, while among the reptiles, snakes ( 38 species), and turtles ( 15 species) have the highest species diversity.

\section{Estuary and Freshwater Fish}

\section{Bay Estuary-Lagoon Species}

A review of the marine fishes that can be found in estuarine settings summarized by Hoese and Moore (1977) indicates that 14 species of fish are regularly present in the bay systems of the Texas coast. They include: black drum (Pogonias cromis), spotted seatrout (Cynoscion nebulosus), sand seatrout (Cynoscion arenorius), sea catfish (Arius felis), Gafftopsail catfish (Bagre marinuis), pinfish (Lagodon rhomboids), spot (Leiostomus xanthurus), red drum or redfish (Sciaenops ocellata), sheepshead (Arcosargus probatocephalus), Gulf menhaden (Brevoortia patronus), southern and Gulf flounder (Paralichthys lethostigma), Atlantic croaker (Micropogonias undulates), striped mullet (Mugil cephalus) and the bay anchovy (Anchoa mitchilli).

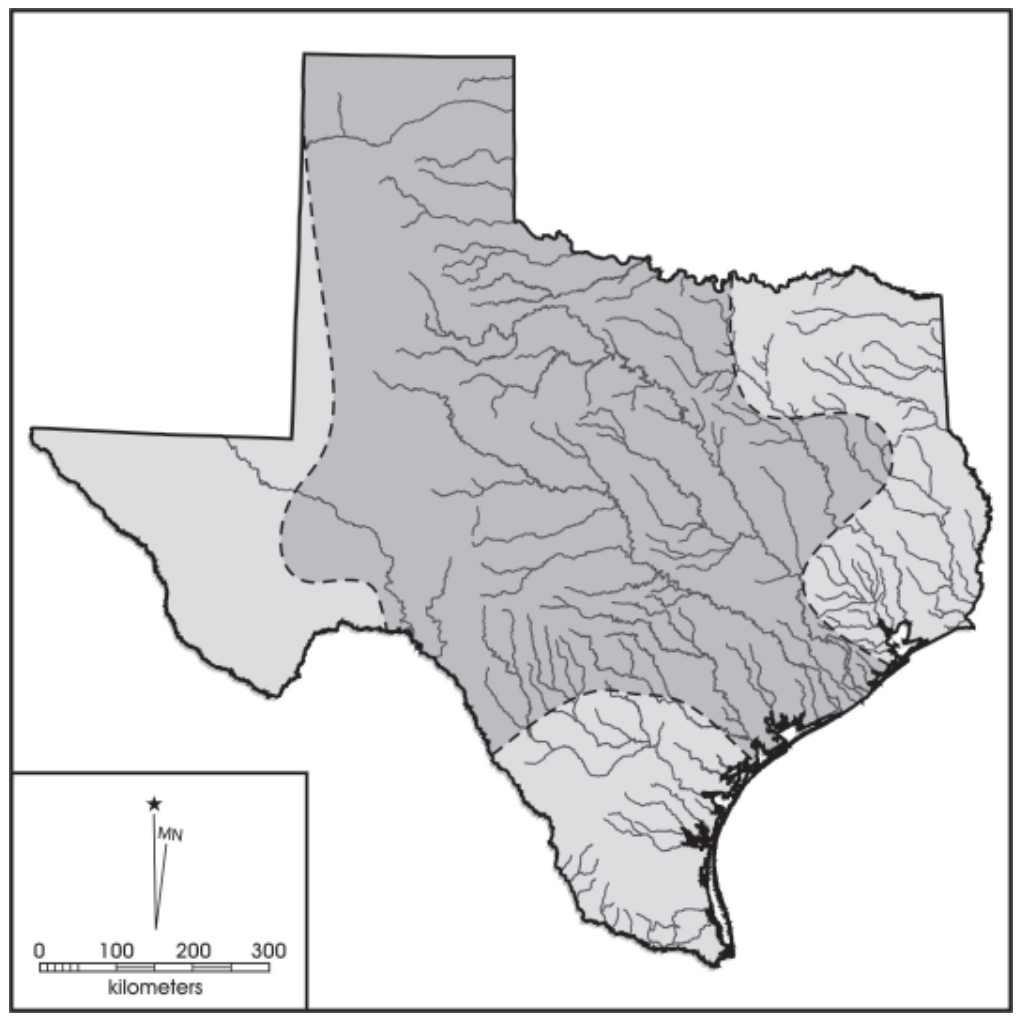

Figure 8-1. Hypothesized historic bison population distribution across Texas (based on data from Weniger 1997).
In addition to the number of economically significant species found within the region, the Laguna Madre and Corpus Christi Bay are locations where the highest densities of Black Drum have been noted in surveys and Matagorda Bay is considered a nursery area for bay anchovy. Interestingly, however, of these 15 species, only spotted seatrout, Atlantic croaker, black drum, red drum and sheepshead have been consistently recovered in archeological sites on the coast (Ricklis 1997; Zimmerman 1997).

Table 8-3 presents a summary of the habitat conditions, specifically salinity and temperature ranges, tolerated and preferred by these species as well as spawning periods and settings and juvenile and adult presence in accessible bay estuary-lagoon settings. The size range of adult fish is also provided for each of the species. They range from $45-970 \mathrm{~mm}$ in size. The data have been compiled from Hoese and Moore (1977) and individual species life histories produced by the Coastal Ecology Group Waterways Experimental Station (Collins 1985; Johnson and Seaman 1986; Lassuy 1983a, 1983b; Morton 1989; Reagan 1985; Reagan and Wingo 1985; Sutter and Mcllwaine 1987; Sutter et al. 1986). 
Table 8-3. List of Marine Fish that Regularly Invade Gulf Coast Freshwater Habitats

\begin{tabular}{|c|c|c|c|c|c|c|c|c|c|c|c|}
\hline \multirow[b]{2}{*}{ Species } & \multicolumn{2}{|c|}{ Salinity (ppt) } & \multicolumn{2}{|c|}{ Temperature $\left({ }^{\circ} \mathrm{C}\right)$} & \multirow[b]{2}{*}{$\begin{array}{l}\text { Spawning } \\
\text { Period }\end{array}$} & \multirow{2}{*}{$\begin{array}{c}\text { Age } \\
\text { Group in } \\
\text { Estuary }\end{array}$} & \multirow[b]{2}{*}{ When in Estuary } & \multirow{2}{*}{$\begin{array}{l}\text { Adult } \\
\text { Size } \\
\text { Range } \\
(\mathrm{mm}) \\
\end{array}$} & \multirow[b]{2}{*}{$\begin{array}{l}\text { Additional } \\
\text { information }\end{array}$} & \multirow{2}{*}{$\begin{array}{c}\text { Calories } \\
\text { in } 100 \mathrm{~g} \\
\text { raw }\end{array}$} & \multirow[b]{2}{*}{ Reference } \\
\hline & Tolerates & Pref. & Tolerates & Pref. & & & & & & & \\
\hline $\begin{array}{l}\text { Atlantic } \\
\text { Croaker }\end{array}$ & $0-70$ & $15-19$ & $3-36$ & $13-28$ & $\begin{array}{l}\text { Sept-Mar; } \\
\text { Nov peak }\end{array}$ & $\begin{array}{c}\text { Juveniles } \\
\text { and adults }\end{array}$ & Apr-Aug & $195-610$ & Lassuy 1983a & 96 & $\begin{array}{c}\text { Watt and } \\
\text { Merrill } \\
1963\end{array}$ \\
\hline $\begin{array}{l}\text { Bay } \\
\text { Anchovy }\end{array}$ & $0-45$ & $9-35$ & $5-40$ & $12-27$ & Mar-May & $\begin{array}{c}\text { Juveniles } \\
\text { and adults }\end{array}$ & All year & $45-100$ & Robinette 1983 & - & - \\
\hline $\begin{array}{l}\text { Black } \\
\text { Drum }\end{array}$ & $0-80$ & $9-26$ & $2.7-36$ & $12-33$ & Feb-Mar; & $\begin{array}{c}\text { Juveniles } \\
\text { and adults }\end{array}$ & $\begin{array}{l}\text { Juveniles remain } \\
\text { until maturity. Adults } \\
\text { April-Feb }\end{array}$ & $285-990$ & $\begin{array}{l}\text { Sutter et al. } \\
\quad 1986\end{array}$ & 80 & $\begin{array}{c}\text { Watt and } \\
\text { Merrill } \\
1963\end{array}$ \\
\hline $\begin{array}{l}\text { Gafftopsail } \\
\text { Catfish }\end{array}$ & $0-40$ & $5-30$ & $20-35$ & $25-37$ & May-Aug & $\begin{array}{c}\text { Juvenile } \\
\text { and adult }\end{array}$ & Feb-Nov & $150-571$ & $\begin{array}{l}\text { Muncy and } \\
\text { Wingo } 1983\end{array}$ & - & - \\
\hline $\begin{array}{l}\text { Gulf } \\
\text { Flounder }\end{array}$ & $6-35^{\prime}$ & $22-35$ & $8.3-32.5$ & $>23$ & Oct-Dec & $\begin{array}{c}\text { Juveniles } \\
\text { and adults }\end{array}$ & $\begin{array}{l}\text { Juveniles remain } \\
\text { until mature; Adults } \\
\text { Mar-Oct }\end{array}$ & $100-500$ & Gilbert 1986 & - & - \\
\hline $\begin{array}{l}\text { Gulf } \\
\text { Menhaden }\end{array}$ & $0-75$ & $20-60$ & $5-35$ & $23-30$ & Oct-Mar & $\begin{array}{l}\text { Juvenile } \\
\text { to adult }\end{array}$ & Mar-Sept & $255-455$ & Lassuy $1983 b$ & - & - \\
\hline Pinfish & $0-75$ & $0-35$ & $10-36$ & $18-23$ & $\begin{array}{l}\text { Sept-Dec, } \\
\text { Oct peak }\end{array}$ & $\begin{array}{l}\text { Juvenile } \\
\text { to adult } \\
\text { (except } \\
\text { during }\end{array}$ & $\begin{array}{l}\text { Juveniles remain } \\
\text { until mature; Adults: } \\
\text { Jan-Aug }\end{array}$ & $115-240$ & Muncy 1984 & - & - \\
\hline Red Drum & $0-50$ & $10-20$ & $2-37$ & $13-28$ & Aug-Dec & $\begin{array}{c}\text { Juveniles, } \\
\text { young } \\
\text { adults } \\
\end{array}$ & $\begin{array}{l}\text { Juveniles may remain } \\
\text { all year, young adults } \\
\text { Jan-July }\end{array}$ & $283-970$ & Reagan 1985 & 80 & $\begin{array}{c}\text { Watt and } \\
\text { Merrill } \\
1963\end{array}$ \\
\hline $\begin{array}{l}\text { Sand } \\
\text { Seatrout }\end{array}$ & $0-45$ & $0-35$ & $5-35$ & $20-30$ & $\begin{array}{l}\text { Mar-May; } \\
\text { Aug-Sept }\end{array}$ & $\begin{array}{c}\text { Juveniles } \\
\text { and adults }\end{array}$ & $\begin{array}{l}\text { All year, though } \\
\text { some adults spawn } \\
\text { in Gulf }\end{array}$ & $140-342$ & $\begin{array}{c}\text { Sutter and } \\
\text { McIlwain } 1987\end{array}$ & - & - \\
\hline $\begin{array}{l}\text { Sea } \\
\text { Catfish }\end{array}$ & $0-40$ & $30-40$ & $5-37$ & $25-37$ & May-Aug & $\begin{array}{c}\text { Juvenile } \\
\text { and adult }\end{array}$ & Feb-Nov & $120-495$ & $\begin{array}{l}\text { Muncy and } \\
\text { Wingo } 1983\end{array}$ & - & - \\
\hline Sheephead & $0-35$ & $5-30$ & $5-35$ & $8-29$ & Mar-May & $\begin{array}{c}\text { Juveniles } \\
\text { and adults }\end{array}$ & Jun-Nov & $200-720$ & Jennings 1985 & 113 & $\begin{array}{c}\text { Watt and } \\
\text { Merrill } \\
1963\end{array}$ \\
\hline $\begin{array}{l}\text { Southern } \\
\text { Flounder }\end{array}$ & $0-36$ & $15-35$ & $5-35$ & $14-22$ & Oct-Dec & $\begin{array}{c}\text { Juveniles } \\
\text { and adults }\end{array}$ & $\begin{array}{l}\text { Juveniles Feb-Nov; } \\
\text { Adults Apr-Nov }\end{array}$ & $84-480$ & $\begin{array}{l}\text { Reagan and } \\
\text { Wingo } 1985\end{array}$ & - & - \\
\hline Spot & $0-66$ & - & $6-36.7$ & $10-30$ & Dec-Mar & $\begin{array}{c}\text { Juveniles } \\
\text { and adults }\end{array}$ & Apr-Dec & $130-210$ & $\begin{array}{c}\text { Hales and Van } \\
\text { Den Avyle } 1989\end{array}$ & 219 & $\begin{array}{c}\text { Watt and } \\
\text { Merrill } \\
1963\end{array}$ \\
\hline $\begin{array}{l}\text { Spotted } \\
\text { Seatrout }\end{array}$ & $0-77$ & $15-35$ & $5-35$ & $15-27$ & Mar-Sept & $\begin{array}{c}\text { Juvenile } \\
\text { and adults }\end{array}$ & $\begin{array}{l}\text { Juveniles remain } \\
\text { until maturity. Adults } \\
\text { move in and out of } \\
\text { estuary throughout } \\
\text { the year depending } \\
\text { on temperature and } \\
\text { salinity. }\end{array}$ & - & $\begin{array}{c}\text { Johnson and } \\
\text { Seaman } 1986\end{array}$ & - & - \\
\hline $\begin{array}{l}\text { Striped } \\
\text { Mullet }\end{array}$ & $0-75$ & $0-35$ & $10-33$ & $16-30$ & $\begin{array}{l}\text { Oct-Feb; } \\
\text { Nov-Dec } \\
\text { peak }\end{array}$ & $\begin{array}{c}\text { Juveniles } \\
\text { and adults }\end{array}$ & $\begin{array}{l}\text { Juveniles remain } \\
\text { until maturity. Adults } \\
\text { Mar-Sept }\end{array}$ & $195-300$ & Collins 1985 & 146 & $\begin{array}{c}\text { Watt and } \\
\text { Merrill } \\
1963\end{array}$ \\
\hline
\end{tabular}

Marine fishes that range into the Texas estuaries must tolerate a wide range of temperature and salinity conditions. Striped Mullet is considered to be more tolerant of temperature changes than many other species. In contrast, the Gulf menhaden is less tolerant of rapid changes in temperature and salinity than other species and the black drum and bay anchovies have narrower tolerance ranges of salinity and water temperature conditions. This is exemplified by the fact that when hypersaline conditions prevailed in the Laguna Madre during the severe drought in 1953 some black drum moved upstream into tributary streams of Baffin Bay. During this period, fish moved into Corpus Christi, Aransas and San Antonio Bays and black drum moved upstream into Oso Creek to escape from hypersaline conditions in the upper 
Laguna Madre (Simmons and Breuer 1982:69). Episodes of mass mortality have been reported among Gulf menhaden under hypersaline conditions reaching $80 \mathrm{ppt}$ or higher (Simmons 1957).

The same response is elicited by more sudden, less predictable changes in ambient temperature as well. For instance, red drum and spotted seatrout move to deeper waters within bays or offshore during blizzards. The consequences of not relocating during sudden cold spells can be disastrous as in 1940 when a large number of spotted seatrout were killed by a cold wave in January (Gunter 1941). Temperatures fell to $39^{\circ} \mathrm{F}$ on the open bay and thousands of fish were killed. A similarly massive fish kill was recorded in 1951 (Gunter and Hildebrand 1951). That year a cold wave that hit the coast between the January 28 and the February 3 resulted in a drop in open bay temperatures to $38^{\circ} \mathrm{F}$ and ice had formed along large portions of the shore. Speckled trout, sheepshead, drum, croakers, pin fish, shad and anchovies were among the thousands of dead fish. The Game Fish and Oyster Commission reported that between 60 and 90 million pounds of fish were killed in 1951 (Gunter and Hildebrand 1951). Hurricanes are another source of fish movements (Hoese 1960).

In the majority of the species that use the estuaries as nurseries for juvenile fish, spawning tends to occur in the late summer through winter although sand and silver seatrout may have a summer spawning period (Sutter and McIlwain 1987:5) and black drum may spawn into June (Sutter et al. 1986:3). Most species spawn in off-shore settings (Sutter and McIlwain 1987:5; Sutter et al. 1986:3) although spotted seatrout spawn in estuaries (Hoese and Moore 1977:204-205; Johnson and Seaman 1986:4). Estuaries serve as sanctuaries for many other juvenile fish species as well (Hoese and Moore 1977:205; Morton 1989:6; Reagan 1985:4; Sutter et al. 1986:4). While adult Gulf menhaden are rarely present in estuarine settings (Lassuy 1983b:4-5), adult Atlantic croaker (Hoese and Moore 1977:204), black drum (Hoese and Moore 1977:204), red drum (Hoese and Moore 1977:205), spotted seatrout (Hoese and Moore 1977:204-205), and stripped mullet (Collins 1985:3) are present year-round. Adult spot are present in estuaries during summer and fall (Hoese and Moore 1977:206), and southern flounder are in estuarine systems during the winter and well into the summer (Hoese and Moore 1977:258).

Because many species tend to seek deeper, warmer waters as water temperatures decrease during the winter (Gunter 1938; Gelwick et al. 2001), it has been suggested that seasonal changes in ambient and water temperature are responsible for the immigration and emigration of fish to and from estuaries into offshore waters. For instance, juveniles of the Atlantic croaker return to the estuaries in spring as ambient and water temperatures rise and begin their seaward migration in October-November during the period of greatest average drop in surface water temperature between successive months (Lassuy 1983a:4). Similarly, post larvae southern flounder also move into estuaries in late February followed by adults in April-June as water temperatures rise above $16^{\circ} \mathrm{C}$ (Reagan and Wingo 1985:3).

In studying seasonal variations in the abundance of estuarine and marine fishes in Barataria Bay on the Gulf of Mexico in Louisiana, Gunter (1938:342) has found that in the case of some species of fish, migrations between more open gulf waters and the bay "was a recurrent, sequential phase in the life history or annual cycle of the fish..." The life cycle pattern is also likely tied to changes in the seasonal abundance of food and is in turn a product of long-term evolutionary adaptations to a variety of factors (i.e., food availability, salinity, temperature, etc).

Gunter (1938), based on catch statistics with otter trawls in bay and gulf settings, demonstrates that with a few exceptions (i.e.,yellowtail [Bairdiella chrysura]; spot [Leiostomus xanthurus]; spotted trout [Cynoscion nebulosus]; menhaden [Brevoortia patronus]; anchovies [Anchoviella epsetus]; and hardhead [Galeichtys felis]), the bulk of the species are not present in large numbers in the bays and estuaries during the winter months between November and February. During these months both adults and small and juvenile fish are found in the deeper waters of the Gulf rather than the shallow waters of the bays and estuaries. In the case of these species, they register peaks in abundance in bays and estuaries from the early spring and through the summer months beginning with the rise in water temperature and salinity and the increase in food availability (Gunter 1938:Figures 2-3, 7, 9-11,14). The croaker (Micropogon undulatus) is a good example of this pattern (Gunter 1938:322-324). The adults spawn outside of the bays near passes during late fall and winter and come into them in large schools between February and July. The abundance of croakers peaks between February and March as the very small and small specimens come into the fishery and nursery bays and estuaries.

A number of variations are apparent among the species that tend to be residents of the bays during the winter (i.e., yellowtail, menhaden, and anchovies). For instance, the spot and the spotted trout spawn from late December through March. The spot may spawn either in the bays or the open gulf (Gunter 1938:326-328), while the spotted trout typically spawns in the bays (Gunter 1938:330-331). The bay spawning of the spot and the spotted trout results in large numbers of adult animals present in the bays during the winter (Gunter 
1938:Figures 6 and 8). Menhaden and anchovies spawn during the summer in the gulf and the small and juvenile fish form a pronounced peak in abundance in the bays and estuaries during the winter months (Gunter 1938:335-336:Figure 12; 337, Figure 13).

During spawning or the migration of very small to juvenile fish in or out or the bays and estuaries many species form large schools of individuals. This schooling of fish is an important behavior that results in the concentration and enmass movement of large numbers of fish. Adult spotted sea trout and bay anchovy school as do juvenile red drum and Gulf menhaden. This behavior results in high densities of fish that enhances their efficient procurement even with the most rudimentary technologies (e.g., baskets, trays; B. Ojeda, personal communication 1979, based on observation on the Pacific coast of Peru). In effect, schooling fish represent hyper-productive resources that can be efficiently procured with relatively rudimentary technologies.

Overall, these patterns suggest that contrary to expectations, fish populations are not available year-round and that extreme variability exists in their seasonal occurrence as well as in their abundance and age profile during the year within the bays and estuaries that would be most easily accessible by prehistoric hunter-gatherers. Cabeza de Vaca himself hinted at such seasonal changes in availability when he noted that while fish were taken with cane wears between October and February, by the later part of this period fish were no longer abundant (see Chapter 7).

\section{Freshwater Fish}

Presently, 72 species of freshwater fishes occur in the streams cross-cutting the Coastal Plains and emptying into the Gulf of Mexico (Lee et al. 1980). Of these, 28 species have average standard lengths or total lengths (Table 8-4) of $115 \mathrm{~mm}$ or greater, or equivalent to the smallest adult marine fish that may be captured in Corpus Christi Bay. In addition, several of these (i.e., freshwater drum, smallmouth buffalo, black buffalo, bowfin and spotted gar) can get as large as $500 \mathrm{~mm}$ or more, well exceeding the maximum size of nearly all marine species that frequent primary and secondary bays. The larger species tend to be limited to the larger permanent streams. Smaller species can survive in intermittent prairie streams were small pools or pockets of standing water can provide protection for enough individuals to repopulate the stream when it is flowing again (Meador et al. 1990). It is expected that some degree of seasonal behavior and variation in abundance is exemplified by freshwater species as well driven by water temperature and life cycle factors. At a minimum, it is expected that during the colder months, fish will tend to migrate to deeper pools of water that will provide some insulation and fish abundances will be higher during the May-June or October rainy season (Chapter 2; Figure 2-5).

Table 8-4. Freshwater Fish Species within the Gulf Coastal Plains and Marshes

\begin{tabular}{|l|l|c|c|c|}
\hline \multicolumn{1}{|c|}{ Common Name } & \multicolumn{1}{|c|}{ Scientific Name } & Length (mm) & Calories in 100 g raw & Reference \\
\hline Freshwater Drum & Aplodinotus grunniens & $10000 \mathrm{~g}$ & 121 & Watt and Merrill \\
\hline Spotted Gar & Lepisosteus oculatus & $850 \mathrm{SL}$ & - & - \\
\hline Smallmouth Buffalo & Ictiobus bubalus & $585 \mathrm{TL}$ & 113 & Watt and Merrill \\
\hline Bowfin & Amia calva & $534 \mathrm{TL}$ & - & - \\
\hline Black Buffalo & Ictiobus niger & $521 \mathrm{TL}$ & 113 & Watt and Merrill \\
\hline Spotted Bass & Micropterus punctulatus & $300 \mathrm{SL}$ & - & - \\
\hline Largemouth Bass & Micropterus salmoides & $410 \mathrm{TL}$ & 104 & Watt and Merrill \\
\hline Longnose Gar & Lepisosteus osseus & $360 \mathrm{TL}$ & - & - \\
\hline White Bass & Morone chrysops & $348 \mathrm{TL}$ & 98 & Watt and Merrill \\
\hline River Carpsucker & Carpiodes carpio & $343 \mathrm{TL}$ & - & - \\
\hline Gizzard Shad & Dorosoma cepedianum & $288 \mathrm{TL}$ & 200 & Watt and Merrill \\
\hline West Mexican Redhorse & Moxostoma congestum & $278 \mathrm{SL}$ & 98 & Watt and Merrill \\
\hline Black Crappie & Pomoxis nigromaculatus & $275 \mathrm{TL}$ & 79 & Watt and Merrill \\
\hline Blue Sucker & Cylcleptus elongatus & $245 \mathrm{SL}$ & 104 & Watt and Merrill \\
\hline Silver Chub & Hybopsis storeriana & $231 \mathrm{TL}$ & 145 & Watt and Merrill \\
\hline Green Sunfish & Lepomis cyanellus & $200 \mathrm{TL}$ & - & - \\
\hline Redear Sunfish & Lepomis microlophus & $192 \mathrm{TL}$ & - & - \\
\hline
\end{tabular}

$\mathrm{SL}=$ standard length, measured from tip of snout to posterior end of caudal skeleton, does not include tail fin.

$\mathrm{TL}=$ total length, measured from tip of snout to posterior end of tail fin.

SL was used when possible, lengths are averages.

Note: length not given for freshwater drum - average weight in grams is given instead. 83 species total. 
Table 8-4. Continued...

\begin{tabular}{|c|c|c|c|c|}
\hline Common Name & Scientific Name & Length (mm) & Calories in $100 \mathrm{~g}$ raw & Reference \\
\hline Bluegill & Lepomis macrochirus & $191 \mathrm{TL}$ & - & - \\
\hline Striped Mullet & Mugil cephalus & $190 \mathrm{SL}$ & 146 & Watt and Merrill \\
\hline Blue Catfish & Ictalurus furcatus & $170 \mathrm{SL}$ & 103 & Watt and Merrill \\
\hline Warmouth & Lepomis gulosus & $168 \mathrm{TL}$ & - & - \\
\hline White Crappie & Pomoxis annularis & $165 \mathrm{SL}$ & 79 & Watt and Merrill \\
\hline Common Carp & Cyprinus carpio & $151 \mathrm{SL}$ & 115 & Watt and Merrill \\
\hline American Eel & Anguilla rostata & $138 \mathrm{TL}$ & 233 & Watt and Merrill \\
\hline Stoneroller & Campostoma anomalum & $133 \mathrm{SL}$ & - & - \\
\hline Channel Catfish & Ictalurus punctatus & $127 \mathrm{SL}$ & 103 & Watt and Merrill \\
\hline Flathead Catfish & Pylodictis olivaris & $122 \mathrm{SL}$ & 103 & Watt and Merrill \\
\hline Longear Cunfish & Lepomis megalotis & $121 \mathrm{SL}$ & - & - \\
\hline Threadfin Chad & Dorosoma petense & $110 \mathrm{SL}$ & 170 & Watt and Merrill \\
\hline Golden Chiner & Notemigonus crysoleucas & $101 \mathrm{SL}$ & - & - \\
\hline Black Bullhead & Ictalurus melas & $99 \mathrm{SL}$ & 72 & Watt and Merrill \\
\hline Spotted Sunfish & Lepomis punctatus & $98 \mathrm{SL}$ & - & - \\
\hline Guadalupe Bass & Micropterus treculi & $93 \mathrm{SL}$ & - & - \\
\hline Mexican Tetra & Astyanax mexicanus & $79 \mathrm{SL}$ & - & - \\
\hline Plains Killfish & Fundulus zebrinus & $69 \mathrm{TL}$ & - & - \\
\hline Yellow Bullhead & Ictalurus natalis & $64 \mathrm{SL}$ & 84 & Watt and Merrill \\
\hline Central Silvery Minnow & Hybognagthus nuchalis & $63 \mathrm{SL}$ & - & - \\
\hline River Darter & Percina shumardi & $63 \mathrm{SL}$ & - & - \\
\hline Blackspot Shiner & Notropis atrocaudalis & $62 \mathrm{SL}$ & - & - \\
\hline Bigscale Logperch & Percina macrolepida & $62 \mathrm{SL}$ & - & - \\
\hline Blackstripe Topminnow & Fundulus notatus & $60 \mathrm{TL}$ & - & - \\
\hline Blacktail Shiner & Notropis venustus & $60 \mathrm{SL}$ & - & - \\
\hline Sailfin Molly & Poecilia latipinna & $60 \mathrm{SL}$ & - & - \\
\hline Weed Shiner & Notropis texanus & $58 \mathrm{SL}$ & - & - \\
\hline Sand Shiner & Notropis stramineus & $57 \mathrm{SL}$ & - & - \\
\hline Texas Shiner & Notropis amabilis & $55 \mathrm{SL}$ & - & - \\
\hline Dusky Darter & Percina sciera & $55 \mathrm{SL}$ & - & - \\
\hline Bantam Sunfish & Lepomis symmetricus & $54 \mathrm{SL}$ & - & - \\
\hline Orangethroat Darter & Etheostoma spectabile & $54 \mathrm{SL}$ & - & - \\
\hline Roundnose Minnow & Dionda apiscopa & $52 \mathrm{SL}$ & - & - \\
\hline Ironcolor Shiner & Notropis chalybaeus & $50 \mathrm{TL}$ & - & - \\
\hline Pallid Shiner & Notropis amnis & $50 \mathrm{SL}$ & - & - \\
\hline Beautiful Shiner & Notropis formosus & $49 \mathrm{SL}$ & - & - \\
\hline Shaprnose Shiner & Notropis oxyrhynchus & $48 \mathrm{SL}$ & - & - \\
\hline Freckled Madtom & Notorus nocturnus & $48 \mathrm{SL}$ & - & - \\
\hline Ribbon Shiner & Notropis fumeus & $47 \mathrm{SL}$ & - & - \\
\hline Silverband Shiner & Notropis shumardi & $47 \mathrm{SL}$ & - & - \\
\hline Red Shiner & Notropis lutrensis & $46 \mathrm{SL}$ & - & - \\
\hline Bluntnose Darter & Etheostoma chlorosomum & $46 \mathrm{SL}$ & - & - \\
\hline
\end{tabular}

$\mathrm{SL}=$ standard length, measured from tip of snout to posterior end of caudal skeleton, does not include tail fin.

$\mathrm{TL}=$ total length, measured from tip of snout to posterior end of tail fin.

SL was used when possible, lengths are averages.

Note: length not given for freshwater drum - average weight in grams is given instead. 83 species total. 
Table 8-4. Continued...

\begin{tabular}{|l|l|c|c|c|}
\hline \multicolumn{1}{|c|}{ Common Name } & \multicolumn{1}{|c|}{ Scientific Name } & Length (mm) & Calories in 100 g raw & Reference \\
\hline Chub Shiner & Notropis potteri & $45 \mathrm{SL}$ & - & - \\
\hline Tadpole Madtom & Notorus gyrinus & $44 \mathrm{SL}$ & - & - \\
\hline Sheephead Minnow & Cyprinodon variegatus & $43 \mathrm{SL}$ & - & - \\
\hline Bullhead Minnow & Pimephales vigilax & $42 \mathrm{SL}$ & - & - \\
\hline Pugnose Minnow & Notropis emiliae & $41 \mathrm{SL}$ & - & - \\
\hline Mimic Shiner & Notropis volucellus & $37 \mathrm{SL}$ & - & - \\
\hline Rainwater Killfish & Lucania parva & $37 \mathrm{SL}$ & - & - \\
\hline Ghost Shiner & Notropis buchanani & $35 \mathrm{SL}$ & - & - \\
\hline Speckled Chub & Hybopsis aestivalis & $34 \mathrm{SL}$ & 145 & Watt and Merrill \\
\hline Slough Darter & Etheostoma gracile & $33 \mathrm{SL}$ & - & - \\
\hline Cypress Darter & Etheostoma proeliare & $33 \mathrm{SL}$ & - & - \\
\hline Backwater Darter & Etheostoma zoniferum & $32 \mathrm{SL}$ & - & - \\
\hline Greenthroat Darter & Etheostoma lepidum & $32 \mathrm{SL}$ & - & - \\
\hline Mosquitofish & Gambusia affinis & $28 \mathrm{TL}$ & - & - \\
\hline
\end{tabular}

$\mathrm{SL}=$ standard length, measured from tip of snout to posterior end of caudal skeleton, does not include tail fin.

$\mathrm{TL}=$ total length, measured from tip of snout to posterior end of tail fin.

SL was used when possible, lengths are averages.

Note: length not given for freshwater drum - average weight in grams is given instead. 83 species total.

\section{Estuary and Freshwater Molluscs}

The role of shellfish in prehistoric diets has received much attention since the 1970s and gone from marginal resource status to important source of protein (Erlandson 1988), calories, carbohydrates (Claassen (1986), or other mineral nutrients supplementing terrestrial resources during lean months. Though the prehistoric groups consuming these items likely were not cognizant of the specific nutrition they were or were not getting from shellfish, they were likely aware of their fitness levels and how diet effected it.

The nutritional data that was gathered through a search of the available literature on individual species was in no case derived from species collected from the Gulf of Mexico. This fact shows the lack of quantified nutritional data on this as well as the bulk of potential resources that may have been used by prehistoric hunter-gatherers of the region. Much of the nutritional information we present in subsequent tables was compiled from Watt and Merrill (1963) and we can only assume that since the data refers to many of the same species as those found in the Gulf, the information is roughly applicable.

Freshwater Mussels are sessile filter feeders that burrow into the substratum with a large muscular foot that is also used for locomotion. Generally, though, as most bivalves, these spend most of their lives in a small area Freshwater mussels are quite long-lived, reaching 10-80 years. Hard clams inhabit subtidal regions of bays and estuaries to $15 \mathrm{~m}$ deep in firm bottom mud flats or areas of sand and shell. They can tolerate a wide range of salinities. Oysters are usually found in groups as oyster reefs formed by oysters furrowing on a foundation of dead shells. Clusters join to form large continuous groups. They also provide habitats for other marine resources. Scallops prefer shallow marine habitats with lots of sea grass. These can move considerable distances within and between habitats unlike other bivalves (Pearse et al. 1987).

We do not account for the size or seasonal fluctuation of the species though we acknowledge that these are critical to the nutritional content of the individual. Accordingly, Parmalee and Klippel (1974) collected freshwater mussels in the Midwest to report the nutritional value of shellfish. Of relevance here is the wide range of size, weight, and meat to shell ratio between and within freshwater mussels that certainly would affect nutritional value. Their study included the range and mean weights and measurements of mussel species collected. While only seven of the species collected from the Mississippi River area are also in the present study region, we can assume that variability in specimen sizes will be found in our study area.

Shellfish are general a poor source of calories and pursuit of mollusks to meet caloric needs would likely result in overharvesting. Most groups will likely get their calories from plants and other animals. Those relying on carbohydrates for calories would need a balanced amount of protein that shellfish in part could provide under optimal conditions (Erlandson 1988). Case studies in areas other than the gulf coast have shown minimum daily requirements of protein 
can be collected from shellfish in a relative short time (D.W. Bird 1996), particularly in spring when carbohydrate and protein content may peak prior to the reproductive season (Erlandson 1988).

\section{Bay-Estuary-Lagoon Molluscs}

The list of bay-estuary-lagoon system molluscs provided in Table 8-5 was compiled based on Andrews (1977) and is limited to species with adult maximum length dimensions larger than $35 \mathrm{~mm}$. It is assumed that while smaller species may turn up in archeological assemblages it is most likely that they were incidentally recovered due to harvesting methods employed rather than purposefully harvested for food. We assume that the amount of meat present in such small species would provide very low returns making the systematic harvest of such small species extremely inefficient. The species of molluscs noted in archeological assemblages (Ricklis 1997; Zimmerman 1997) are identified by a checkmark.

Seventy-three species are listed in the table with the top 38 on the list being species that are regularly found in bayestuary-lagoon settings and would be readily accessible to hunter-gatherers. The bottom 35 species inhabit offshore environments and may be less accessible to collectors. The 73 species that fit the size cutoff compares well with results of systematic sampling of Corpus Christi Bay between 1981 and 1982 (Castiglione 1983). That survey yielded a total of 165 species of molluscs of which 89 species were gastropods and 76 were pelecypods, also called bivalves (Castiglione 1983). Similarly, a three-year survey (1972-1975) of molluscs in Corpus Christi Bay, Copano Bay and Aransas Bay identified 68 species of pelecypods (Holland et al. 1973, 1974, and 1975). The Bureau of Economic Geology (BEG) sponsored a similar survey of Copano Bay between 1976 and 1977; it identified 33 species of pelecypods (Calnan 1980). The smaller number of species is most likely reflective of the single bay system surveyed. In terms of mollusc densities, Castiglione (1983:52) found that the average total number of individuals for six of the more common species found in samples from three distinct localities ranged from 427 to 992 specimens per meter square (April 1991 to March 1992). A total mean number of $1988 / \mathrm{m}^{2}$ molluscs of these six species were recovered at the three seagrass-dominated sample localities during the year.

In general, sediment type (i.e., substrate) and diversity, organic content, and predation coupled with levels of salinity strongly influence the species composition and density of mollusc assemblages encountered at any one time and in any one place within coastal bay-estuary-lagoon habitat (Holland et al. 1975). For instance, Castiglione (1983) found that portions of Corpus Christi Bay with high proportions of sand in the substrate had low mollusc productivity (yearly mean of 150 molluscs $/ \mathrm{m}^{2}$ ) but high species diversity. In contrast, a sample area with $90 \%$ mud substrate had both low productivity (yearly mean of 28 molluscs $/ \mathrm{m}^{2}$ ) and diversity. Areas with mixed substrate of shell, sand and mud had low species diversity but high productivity with a small number of species dominating mollusc assemblages (Castiglione 1983:90-91).

As with other resources already discussed, seasonal variation in availability and nutritional condition is also present among estuarine mollusks. Castiglione (1983), for instance, found that the highest population densities occur during the months of February-April. Carbohydrate and protein content may peak during spring prior to the reproductive season. Mollusc population densities decreased during the summer and fall (Castiglione 1983:91). An influx of young individuals during the spring followed by a peak in mortality rates accounts for the trend. These data support Texas coastal marine subsistence studies that find a reliance of fish and shellfish during winter months (Ricklis1996). Shellfish gathering would also be more efficient when tides are lowest during daylight hours, which occur during winter.

In addition to seasonal variability in abundance, levels of salinity and water temperature significantly influence the residence time and degree of mobility of mollusc populations within and between estuary and offshore settings. In addition to preferred substrate/habitat information for each common species, Table 8-5 also presents the salinity tolerance limits and preferred substrate for the principal mollusc species of potential economic utility to human inhabitants of the coast. The majority can tolerate a wide range of salinity conditions and most importantly can live and reproduce in high-salinity environments. Only three bay-estuarine-lagoon bivalve species (Polymesoda caroliniana; Rangia cuneata, and R.. flexuosa) are adapted to low (5-19 ppt) salinity. Twenty-three species tolerate a broad range (15-40 ppt) of salinity values although their preferred range is in the lower half, while 48 species are adapted to a narrower, higher range of salinity (25-40 ppt) preferring habitats with salinity values in the upper half of this range.

While the differences in tolerated and preferred salinity levels are critical in understanding the settings where particular species may be harvested, they are also important as barometers of changes in habitat conditions over time or in space (Parker 1955). Studies of changes in mollusc assemblages of coastal bays and estuaries during significant short and long-term weather events or climatic changes have demonstrated that mollusc assemblages are quite vulnerable 
Table 8-5. Common Molluscs Species Present in the Bay-Estuary-Lagon Habitat

\begin{tabular}{|c|c|c|c|c|c|c|c|c|c|c|c|}
\hline $\begin{array}{l}\text { Common } \\
\text { Name }\end{array}$ & $\begin{array}{l}\text { Scientific } \\
\text { Name }\end{array}$ & $\begin{array}{l}\text { Size } \\
\text { Range } \\
(\mathbf{m m})\end{array}$ & Substrate/Habitat & Salinity & Locality & Type & $\begin{array}{c}\text { Calories } \\
\text { (C) }\end{array}$ & $\begin{array}{l}\text { Protein } \\
\text { (g) }\end{array}$ & $\begin{array}{l}\text { Fat } \\
\text { (g) }\end{array}$ & $\begin{array}{c}\text { Carbs } \\
(\mathrm{g})\end{array}$ & Reference \\
\hline $\begin{array}{l}\text { Atlantic Bay } \\
\text { Scallop }\end{array}$ & $\begin{array}{l}\text { Argopected } \\
\text { irradians }\end{array}$ & $50.8-76$ & bays and open lagoons & $15-40 \%$ & entire & Scallops & 81 & 15.3 & 0.2 & 3.3 & $\begin{array}{l}\text { Watt and Merrill } \\
: 56 \text { item } 2023\end{array}$ \\
\hline Eastern Oyster & $\begin{array}{l}\text { Crassostrea } \\
\text { virginica }\end{array}$ & $51-150$ & $\begin{array}{l}\text { brackish bays and } \\
\text { estuaries }\end{array}$ & $15-40 \%$ & entire & \begin{tabular}{|l|} 
Oyster- \\
eastern
\end{tabular} & 66 & 8.4 & 1.8 & 3.4 & \begin{tabular}{|l|} 
Watt and Merrill \\
1963:42 item 1443
\end{tabular} \\
\hline $\begin{array}{l}\text { Fallen Angel } \\
\text { Wings }\end{array}$ & Barnea truncata & 71 & clay bottoms of bays & $15-40 \%$ & central & Clams & 49 & 6.5 & 0.4 & 4.2 & $\begin{array}{l}\text { Watt and Merrill } \\
\text { 1963:25 item } 770\end{array}$ \\
\hline Texas Venus & $\begin{array}{l}\text { Callocardia } \\
\text { texaniana }\end{array}$ & $38-76$ & $\begin{array}{l}\text { clay lagoon centers and } \\
\text { along clay shores }\end{array}$ & $25-40 \%$ & entire & Clams & 49 & 6.5 & 0.4 & 4.2 & \begin{tabular}{|l|} 
Watt and Merrill \\
1963:25 item 770
\end{tabular} \\
\hline $\begin{array}{l}\text { Giant Atlantic } \\
\text { Cockle }\end{array}$ & $\begin{array}{l}\text { Laevicardium } \\
\text { robustum }\end{array}$ & $76-101$ & $\begin{array}{l}\text { close-to-shore and inlet- } \\
\text { influenced areas }\end{array}$ & $25-40 \%$ & entire & Clams & 49 & 6.5 & 0.4 & 4.2 & $\begin{array}{l}\text { Watt and Merrill } \\
\text { 1963:25 item } 770\end{array}$ \\
\hline Stout Tagelus & Tagelus plebeius & $50-68$ & $\begin{array}{l}\text { enclosed lagoons, bay } \\
\text { margins }\end{array}$ & $15-40 \%$ & entire & Clams & 49 & 6.5 & 0.4 & 4.2 & \begin{tabular}{|l|} 
Watt and Merrill \\
1963:25 item 770
\end{tabular} \\
\hline $\begin{array}{l}\text { Carolina } \\
\text { Marsh Clam }\end{array}$ & $\begin{array}{l}\text { Polymesoda } \\
\text { caroliniana }\end{array}$ & $25-38$ & estuaries & $5-19 \%$ & $\begin{array}{c}\text { Matagorda } \\
\text { Bay and east }\end{array}$ & Clams & 49 & 6.5 & 0.4 & 4.2 & $\begin{array}{l}\text { Watt and Merrill } \\
1963: 25 \text { item } 770\end{array}$ \\
\hline Thick Lucina & Lucina pectinata & $25-63$ & $\begin{array}{l}\text { grass flats in open-bay } \\
\text { margins and hypersaline } \\
\text { lagoons }\end{array}$ & $15-40 \%$ & entire & Clams & 49 & 6.5 & 0.4 & 4.2 & $\begin{array}{l}\text { Watt and Merrill } \\
\text { 1963:25 item } 770\end{array}$ \\
\hline \begin{tabular}{|l|} 
Horse or \\
Crested Oyster
\end{tabular} & Ostrea equestris & $25-51$ & high-salinity oyster reefs & $15-40 \%$ & entire & $\begin{array}{l}\text { Oyster- } \\
\text { eastern }\end{array}$ & 66 & 8.4 & 1.8 & 3.4 & \begin{tabular}{|l|} 
Watt and Merrill \\
1963:42 item 1443
\end{tabular} \\
\hline $\begin{array}{l}\text { Common } \\
\text { Jingle Shell }\end{array}$ & Anomia simplex & $25-51$ & $\begin{array}{l}\text { hypersaline oyster or } \\
\text { rock reef }\end{array}$ & $15-40 \%$ & entire & \begin{tabular}{|l|} 
Oyster- \\
eastern
\end{tabular} & 66 & 8.4 & 1.8 & 3.4 & \begin{tabular}{|l|} 
Watt and Merrill \\
1963:42 item 1443
\end{tabular} \\
\hline \begin{tabular}{|l} 
Flat Tree \\
Oyster \\
\end{tabular} & \begin{tabular}{|l|}
$\begin{array}{l}\text { Isognomon } \\
\text { alatus }\end{array}$ \\
\end{tabular} & $50.8-76$ & in crevices on jetties & $25-40 \%$ & southern & \begin{tabular}{|l|}
$\begin{array}{l}\text { Oyster- } \\
\text { eastern }\end{array}$ \\
\end{tabular} & 66 & 8.4 & 1.8 & 3.4 & \begin{tabular}{|l|} 
Watt and Merrill \\
1963:42 item 1443
\end{tabular} \\
\hline $\begin{array}{l}\text { Mahogany } \\
\text { Date Mussel }\end{array}$ & $\begin{array}{l}\text { Lithophaga } \\
\text { bisculta }\end{array}$ & $25-38$ & $\begin{array}{l}\text { in rocks in both shallow } \\
\text { and deep water }\end{array}$ & $25-40 \%$ & entire & Mussel & 66 & 9.6 & 1.4 & 3.1 & $\begin{array}{l}\text { Watt and Merrill } \\
\text { 1963:40 item } 1363\end{array}$ \\
\hline $\begin{array}{l}\text { Scissor Date } \\
\text { Mussel }\end{array}$ & $\begin{array}{l}\text { Lithophaga } \\
\text { aristata }\end{array}$ & $25-38$ & $\begin{array}{l}\text { in rocks in both shallow } \\
\text { and deep water }\end{array}$ & $25-40 \%$ & $\begin{array}{c}\text { central and } \\
\text { south }\end{array}$ & Mussel & 66 & 9.6 & 1.4 & 3.1 & \begin{tabular}{|l|} 
Watt and Merrill \\
1963:40 item 1363
\end{tabular} \\
\hline $\begin{array}{l}\text { Atlantic } \\
\text { Cyclinella }\end{array}$ & $\begin{array}{l}\text { Cyclinella } \\
\text { tenuis }\end{array}$ & $25-50$ & $\begin{array}{l}\text { inlet-influenced areas and } \\
\text { bay margins }\end{array}$ & $25-40 \%$ & $\begin{array}{c}\text { entire more } \\
\text { south }\end{array}$ & - & - & - & - & - & - \\
\hline Yellow Cockle & $\begin{array}{l}\text { Trachycardium } \\
\text { muricatum }\end{array}$ & 51 & $\begin{array}{l}\text { inlet-influenced areas, } \\
\text { bay margins }\end{array}$ & $15-40 \%$ & entire & Clams & 49 & 6.5 & 0.4 & 4.2 & \begin{tabular}{|l} 
Watt and Merrill \\
1963:25 item 770
\end{tabular} \\
\hline $\begin{array}{l}\text { Buttercup } \\
\text { Lucina }\end{array}$ & $\begin{array}{l}\text { Cyclinella } \\
\text { tenuis }\end{array}$ & $38-51$ & $\begin{array}{l}\text { inlet-influenced areas, } \\
\text { bay margins, hypersaline } \\
\text { lagoons }\end{array}$ & $25-40 \%$ & entire & - & - & - & - & - & - \\
\hline $\begin{array}{l}\text { White Crested } \\
\text { Tellin }\end{array}$ & \begin{tabular}{|l} 
Tellidora \\
cristata
\end{tabular} & up to 37 & inlets and channels & $15-40 \%$ & entire & Clams & 49 & 6.5 & 0.4 & 4.2 & \begin{tabular}{|l|} 
Watt and Merrill \\
1963:25 item 770
\end{tabular} \\
\hline \begin{tabular}{|l} 
Green \\
JackKnife \\
Clam
\end{tabular} & Solen viridis & up to 51 & inlets, near shore & $15-40 \%$ & east & Clams & 49 & 6.5 & 0.4 & 4.2 & $\begin{array}{l}\text { Watt and Merrill } \\
\text { 1963:25 item } 770\end{array}$ \\
\hline $\begin{array}{l}\text { Transverse } \\
\text { Ark }\end{array}$ & $\begin{array}{l}\text { Anadara } \\
\text { transversa }\end{array}$ & $12-36$ & litoral to $10.8 \mathrm{~m}$ & $25-40 \%$ & entire & Clams & 49 & 6.5 & 0.4 & - & - \\
\hline $\begin{array}{l}\text { White Bearded } \\
\text { Ark }\end{array}$ & $\begin{array}{l}\text { Barbatia } \\
\text { candida }\end{array}$ & $\begin{array}{l}25.4- \\
50.8\end{array}$ & on rocks beyond low tide & $25-40 \%$ & $\begin{array}{l}\text { Port } \\
\text { Aransas } \\
\text { south }\end{array}$ & Clams & 49 & 6.5 & 0.4 & 4.2 & $\begin{array}{l}\text { Watt and Merrill } \\
\text { 1963:25 item } 770\end{array}$ \\
\hline $\begin{array}{l}\text { Rough Jingle } \\
\text { Shell }\end{array}$ & $\begin{array}{l}\text { Popodesmus } \\
\text { rudis }\end{array}$ & up to 51 & $\begin{array}{l}\text { on rocks in inlet } \\
\text { influenced areas }\end{array}$ & $25-40 \%$ & southern & \begin{tabular}{|l|} 
Oyster- \\
eastern
\end{tabular} & 66 & 8.4 & 1.8 & 3.4 & $\begin{array}{l}\text { Watt and Merrill } \\
\text { 1963:42 item } 1443\end{array}$ \\
\hline Mossy Ark & Arca imbricata & $25-38$ & $\begin{array}{l}\text { on rocks or firm } \\
\text { substratum }\end{array}$ & $15-40 \%$ & entire & Clams & 49 & 6.5 & 0.4 & 4.2 & $\begin{array}{l}\text { Watt and Merrill } \\
\text { 1963:25 item } 770\end{array}$ \\
\hline $\begin{array}{l}\text { Scorched } \\
\text { Mussel }\end{array}$ & $\begin{array}{l}\text { Brachidontes } \\
\text { exustus }\end{array}$ & $18-38$ & $\begin{array}{l}\text { on rocks or oyster reefs } \\
\text { in bays }\end{array}$ & $15-40 \%$ & entire & Mussel & 66 & 9.6 & 1.4 & 3.1 & $\begin{array}{l}\text { Watt and Merrill } \\
\text { 1963:40 item } 1363\end{array}$ \\
\hline Turkey Wing & Arca zebra & 50.8 & on rocks, shell, roots & $25-40 \%$ & southern & Clams & 49 & 6.5 & 0.4 & 4.2 & \begin{tabular}{|l} 
Watt and Merrill \\
1963:25 item 770
\end{tabular} \\
\hline Paper Shell & $\begin{array}{l}\text { Amygdalum } \\
\text { papyria }\end{array}$ & $25-38$ & $\begin{array}{l}\text { open bays and inlet } \\
\text { influenced areas }\end{array}$ & $15-40 \%$ & entire & Mussel & 66 & 9.6 & 1.4 & 3.1 & $\begin{array}{l}\text { Watt and Merrill } \\
\text { 1963:40 item } 1363\end{array}$ \\
\hline Texas Quahog & \begin{tabular}{|l|} 
Mercenaria \\
camperchinesis \\
texana
\end{tabular} & $76-127$ & $\begin{array}{l}\text { open bays and inlet } \\
\text { influenced areas }\end{array}$ & $15-40 \%$ & entire & Clams & 49 & 6.5 & 0.4 & 4.2 & $\begin{array}{l}\text { Watt and Merrill } \\
\text { 1963:25 item } 770\end{array}$ \\
\hline $\begin{array}{l}\text { Purplish } \\
\text { Tagelus }\end{array}$ & Tagelus divisus & $25-38$ & open lagoon margins & $15-40 \%$ & entire & - & - & - & - & - & - \\
\hline
\end{tabular}


Table 8-5. Continued...

\begin{tabular}{|c|c|c|c|c|c|c|c|c|c|c|c|}
\hline $\begin{array}{c}\text { Common } \\
\text { Name }\end{array}$ & $\begin{array}{c}\text { Scientific } \\
\text { Name }\end{array}$ & $\begin{array}{c}\text { Size } \\
\text { Range } \\
(\mathbf{m m})\end{array}$ & Substrate/Habitat & Salinity & Locality & Type & $\begin{array}{c}\text { Calories } \\
\text { (C) }\end{array}$ & $\begin{array}{c}\text { Protein } \\
\text { (g) }\end{array}$ & $\begin{array}{l}\text { Fat } \\
\text { (g) }\end{array}$ & $\begin{array}{c}\text { Carbs } \\
(\mathrm{g})\end{array}$ & Reference \\
\hline $\begin{array}{l}\text { Fragile Atlantic } \\
\text { Mectra }\end{array}$ & Mactra fragilis & $38-63$ & open-bay margins & $15-40 \%$ & southern & Clams & 49 & 6.5 & 0.4 & 4.2 & - \\
\hline $\begin{array}{l}\text { Constricted } \\
\text { Macoma }\end{array}$ & $\begin{array}{l}\text { Macoma } \\
\text { constricta }\end{array}$ & $25-63$ & $\begin{array}{l}\text { open-bay margins and } \\
\text { centers }\end{array}$ & $15-40 \%$ & entire & Clams & 49 & 6.5 & 0.4 & 4.2 & \begin{tabular}{|l} 
Watt and Merrill \\
1963:25 item 770 \\
\end{tabular} \\
\hline Angel Wing & $\begin{array}{l}\text { Cyrtopleura } \\
\text { costata }\end{array}$ & 177 & $\begin{array}{l}\text { open-bay margins inlet } \\
\text { infl-areas; }\end{array}$ & $15-40 \%$ & entire & Clams & 49 & 6.5 & 0.4 & 4.2 & \begin{tabular}{|l} 
Watt and Merrill \\
1963:25 item 770 \\
\end{tabular} \\
\hline $\begin{array}{l}\text { False Angel } \\
\text { Wing }\end{array}$ & \begin{tabular}{|l|}
$\begin{array}{l}\text { Petricola } \\
\text { pholadiformis }\end{array}$ \\
\end{tabular} & up to 50 & $\begin{array}{l}\text { open-bay margins, inlet } \\
\text { infl areas }\end{array}$ & $15-40 \%$ & entire & Clams & 49 & 6.5 & 0.4 & 4.2 & \begin{tabular}{|l|} 
Watt and Merrill \\
1963:25 item 770 \\
\end{tabular} \\
\hline $\begin{array}{l}\text { Channel Duck } \\
\text { Clam }\end{array}$ & Raeta plicatella & $50-76$ & outer surf & $25-40 \%$ & entire & Clams & 49 & 6.5 & 0.4 & 4.2 & \begin{tabular}{|l} 
Watt and Merrill \\
1963:25 item 770 \\
\end{tabular} \\
\hline $\begin{array}{l}\text { Hooked } \\
\text { Mussel }\end{array}$ & $\begin{array}{l}\text { Ischadium } \\
\text { recurvum }\end{array}$ & $\begin{array}{c}25.6- \\
63.5 \\
\end{array}$ & $\begin{array}{l}\text { oyster reefs in low- } \\
\text { salinity bays }\end{array}$ & $15-40 \%$ & entire & Mussel & 66 & 9.6 & 1.4 & 3.1 & \begin{tabular}{|l|} 
Watt and Merrill \\
1963:40 item 1363 \\
\end{tabular} \\
\hline $\begin{array}{l}\text { Common } \\
\text { Rangia }\end{array}$ & Rangia cuneata & $25-63$ & river-influenced areas & $5-19 \%$ & central & clams & 49 & 6.5 & 0.4 & 4.2 & $\begin{array}{l}\text { Watt and Merrill } \\
\text { 1963:40 item 1363 }\end{array}$ \\
\hline Brown Rangia & Rangia flexuosa & $25-38$ & river-influenced areas & $5-19 \%$ & $\begin{array}{c}\text { entire, more } \\
\text { east }\end{array}$ & clams & 49 & 6.5 & 0.4 & 4.2 & \begin{tabular}{|l|} 
Watt and Merrill \\
1963:25 item 770 \\
\end{tabular} \\
\hline Ribbed Mussel & $\begin{array}{l}\text { Geukensia } \\
\text { demissa } \\
\text { granosisima }\end{array}$ & $\begin{array}{c}50.8- \\
101\end{array}$ & salt marshes & $15-40 \%$ & east & Mussel & 66 & 9.6 & 1.4 & 3.1 & $\begin{array}{l}\text { Watt and Merrill } \\
\text { 1963:40 item } 1363\end{array}$ \\
\hline $\begin{array}{l}\text { Alternate } \\
\text { Tellin } \\
\end{array}$ & Tellina alternata & 70 & $\begin{array}{l}\text { sand near shore, bay } \\
\text { margins, inlets }\end{array}$ & $25-40 \%$ & \begin{tabular}{|c} 
entire more \\
east
\end{tabular} & Clams & 49 & 6.5 & 0.4 & 4.2 & \begin{tabular}{|l} 
Watt and Merrill \\
1963:25 item 770 \\
\end{tabular} \\
\hline Tiger Lucina & \begin{tabular}{|l} 
Codakia \\
orbicularis
\end{tabular} & $63-87$ & shallow flats in sand & $25-40 \%$ & southern & Clams & 49 & 6.5 & 0.4 & 4.2 & $\begin{array}{l}\text { Watt and Merrill } \\
\text { 1963:25 item } 770\end{array}$ \\
\hline Sunray Venus & $\begin{array}{l}\text { Callista } \\
\text { nimbosa }\end{array}$ & $101-127$ & $\begin{array}{l}\text { shallow sandy bottoms, } \\
\text { inlet-infl areas }\end{array}$ & $\mathrm{n} / \mathrm{a}$ & $\begin{array}{c}\text { entie more } \\
\text { south }\end{array}$ & Clams & 49 & 6.5 & 0.4 & 4.2 & $\begin{array}{l}\text { Watt and Merrill } \\
1963: 25 \text { item } 770\end{array}$ \\
\hline $\begin{array}{l}\text { Red Brown } \\
\text { Ark }\end{array}$ & $\begin{array}{l}\text { Barbatia } \\
\text { cancellaria }\end{array}$ & $\begin{array}{c}25.4- \\
38.1 \\
\end{array}$ & offshore & $25-40 \%$ & entire & Clams & 49 & 6.5 & 0.4 & 4.2 & $\begin{array}{l}\text { Watt and Merrill } \\
\text { 1963:25 item } 770\end{array}$ \\
\hline $\begin{array}{l}\text { Doc Bales' } \\
\text { Ark }\end{array}$ & Barbatia tenera & $25-38$ & offshore & $25-40 \%$ & entire & Clams & 49 & 6.5 & 0.4 & 4.2 & \begin{tabular}{|l} 
Watt and Merrill \\
1963:25 item 770
\end{tabular} \\
\hline $\begin{array}{l}\text { Saw-Tooth } \\
\text { Pen Shell }\end{array}$ & Atrina serrata & $\begin{array}{l}\text { up to } \\
250\end{array}$ & offshore & $25-40 \%$ & entire & - & - & - & - & - & - \\
\hline $\begin{array}{l}\text { Atlantic Pearl } \\
\text { Oyster }\end{array}$ & $\begin{array}{l}\text { Pinctada } \\
\text { imbricata } \\
\end{array}$ & $38-76$ & offshore & $25-40 \%$ & southern & $\begin{array}{l}\text { Oyster- } \\
\text { eastern }\end{array}$ & 66 & 8.4 & 1.8 & 3.4 & \begin{tabular}{|l|} 
Watt and Merrill \\
1963:42 item 1443 \\
\end{tabular} \\
\hline Calico Scallop & $\begin{array}{l}\text { Argopecten } \\
\text { gibbus }\end{array}$ & $25-50.8$ & offshore & $25-40 \%$ & entire & Scallops & 81 & 15.3 & 0.2 & 3.3 & $\begin{array}{l}\text { Watt and Merrill } \\
: 56 \text { item } 2023\end{array}$ \\
\hline Lion's Paw & $\begin{array}{l}\text { Lyropecten } \\
\text { nodusus }\end{array}$ & $76-152$ & offshore & $25-40 \%$ & southern & Scallops & 81 & 15.3 & 0.2 & 3.3 & $\begin{array}{l}\text { Watt and Merrill } \\
: 56 \text { item } 2023\end{array}$ \\
\hline $\begin{array}{l}\text { Ravenel's } \\
\text { Scallop }\end{array}$ & Pecten raveneli & $25-51$ & offshore & $25-40 \%$ & southern & Scallops & 81 & 15.3 & 0.2 & 3.3 & $\begin{array}{l}\text { Watt and Merrill } \\
: 56 \text { item } 2023\end{array}$ \\
\hline \begin{tabular}{|l|} 
Atlantic \\
Thorny Oyster
\end{tabular} & \begin{tabular}{|l} 
Spondylus \\
americanus
\end{tabular} & 76-101 & offshore & $25-40 \%$ & southern & $\begin{array}{l}\text { Oyster- } \\
\text { eastern }\end{array}$ & 66 & 8.4 & 1.8 & 3.4 & \begin{tabular}{|l|} 
Watt and Merrill \\
1963:42 item 1443 \\
\end{tabular} \\
\hline Spiny Lima & Lima lima & $25-51$ & offshore & $25-40 \%$ & southern & - & - & - & - & - & - \\
\hline $\begin{array}{l}\text { Atlantic Left- } \\
\text { Handed Jewel } \\
\text { Box }\end{array}$ & $\begin{array}{l}\text { Pseudochama } \\
\text { radians }\end{array}$ & $25-76$ & offshore & $25-40 \%$ & entire & - & - & - & - & - & - \\
\hline Prickly Cockle & \begin{tabular}{|l} 
Trachycardium \\
isocardia \\
\end{tabular} & 76 & offshore & $25-40$ & \begin{tabular}{|c} 
central and \\
south
\end{tabular} & Clams & 49 & 6.5 & 0.4 & 4.2 & $\begin{array}{l}\text { Watt and Merrill } \\
\text { 1963:25 item } 770\end{array}$ \\
\hline $\begin{array}{l}\text { Common Egg } \\
\text { Cockle }\end{array}$ & $\begin{array}{l}\text { Laevicardium } \\
\text { laevigatum }\end{array}$ & $25-51$ & offshore & $25-40 \%$ & $\begin{array}{c}\text { central and } \\
\text { south }\end{array}$ & Clams & 49 & 6.5 & 0.4 & 4.2 & $\begin{array}{l}\text { Watt and Merrill } \\
1963: 25 \text { item } 770\end{array}$ \\
\hline $\begin{array}{l}\text { Atlantic } \\
\text { Sanguin }\end{array}$ & $\begin{array}{l}\text { Sanguinolaria } \\
\text { sanguainolenta }\end{array}$ & $38-50$ & offshore & $25-40 \%$ & $\begin{array}{c}\text { central and } \\
\text { south }\end{array}$ & Clams & 49 & 6.5 & 0.4 & 4.2 & $\begin{array}{l}\text { Watt and Merrill } \\
\text { 1963:25 item } 770\end{array}$ \\
\hline Calico Clam & $\begin{array}{l}\text { Callista } \\
\text { maculata }\end{array}$ & $38-63$ & offshore & $25-40 \%$ & southern & Clams & 49 & 6.5 & 0.4 & 4.2 & $\begin{array}{l}\text { Watt and Merrill } \\
\text { 1963:25 item } 770\end{array}$ \\
\hline $\begin{array}{l}\text { Elegant } \\
\text { Dosinia } \\
\end{array}$ & Dosinia elegans & $50-76$ & offshore & $25-40 \%$ & southern & Clams & 49 & 6.5 & 0.4 & 4.2 & - \\
\hline $\begin{array}{l}\text { Clench's } \\
\text { Chione }\end{array}$ & Chione clenchi & $25-63$ & offshore & $25-40 \%$ & $\begin{array}{l}\text { entire more } \\
\text { south }\end{array}$ & Clams & 49 & 6.5 & 0.4 & 4.2 & - \\
\hline $\begin{array}{l}\text { Southern } \\
\text { Quahog }\end{array}$ & $\begin{array}{l}\text { Mercenaria } \\
\text { camperchinesis }\end{array}$ & $76-152$ & offshore & $25-40 \%$ & entire & Clams & 49 & 6.5 & 0.4 & 4.2 & $\begin{array}{l}\text { Watt and Merrill } \\
\text { 1963:25 item } 770\end{array}$ \\
\hline
\end{tabular}


Table 8-5. Continued...

\begin{tabular}{|c|c|c|c|c|c|c|c|c|c|c|c|}
\hline $\begin{array}{c}\text { Common } \\
\text { Name }\end{array}$ & $\begin{array}{l}\text { Scientific } \\
\text { Name }\end{array}$ & $\begin{array}{c}\text { Size } \\
\text { Range } \\
(\mathbf{m m})\end{array}$ & Substrate/Habitat & Salinity & Locality & Type & $\begin{array}{c}\text { Calories } \\
\text { (C) }\end{array}$ & $\begin{array}{l}\text { Protein } \\
(\mathrm{g})\end{array}$ & $\begin{array}{c}\text { Fat } \\
(\mathrm{g})\end{array}$ & $\begin{array}{c}\text { Carbs } \\
(\mathrm{g})\end{array}$ & Reference \\
\hline Geoduck & $\begin{array}{l}\text { Panopea } \\
\text { bitruncata }\end{array}$ & $127-228$ & offshore & $25-40 \%$ & southern & Clams* & - & - & - & - & - \\
\hline $\begin{array}{l}\text { Campeche } \\
\text { Angel Wing }\end{array}$ & $\begin{array}{l}\text { Pholas } \\
\text { camechinensis }\end{array}$ & $\begin{array}{l}\text { up to } \\
128\end{array}$ & offshore & $25-40 \%$ & entire & Clams & 49 & 6.5 & 0.4 & 4.2 & - \\
\hline $\begin{array}{l}\text { Half-Naked } \\
\text { Pen Shell }\end{array}$ & Atrina seminuda & $235-250$ & $\begin{array}{l}\text { offshore and inlet } \\
\text { influenced bays }\end{array}$ & $15-40 \%$ & entire & - & - & - & - & - & - \\
\hline $\begin{array}{l}\text { Purplish } \\
\text { Semele }\end{array}$ & \begin{tabular}{|l} 
Semele \\
purpurascens
\end{tabular} & $25-38$ & $\begin{array}{l}\text { offshore and sandy } \\
\text { bottoms and banks }\end{array}$ & $25-40 \%$ & southern & Clams & 49 & 6.5 & 0.4 & 4.2 & - \\
\hline $\begin{array}{l}\text { Atlantic } \\
\text { Winged } \\
\text { Oyster }\end{array}$ & Pteria colymbus & $38-76$ & offshore reefs & $25-40 \%$ & southern & $\begin{array}{l}\text { Oyster- } \\
\text { eastern }\end{array}$ & 66 & 8.4 & 1.8 & 3.4 & $\begin{array}{l}\text { Watt and Merrill } \\
\text { 1963:42 item } 1443\end{array}$ \\
\hline $\begin{array}{l}\text { Tagelus-Like } \\
\text { Macoma }\end{array}$ & \begin{tabular}{|l} 
Macoma \\
tageloformis
\end{tabular} & up to 63 & offshore, 3.6-19.8 meters & $25-40 \%$ & entire & Clams & 49 & 6.5 & 0.4 & 4.2 & - \\
\hline Taylor's Tellin & $\begin{array}{l}\text { Tellina alternata } \\
\text { tayloriana }\end{array}$ & 63 & $\begin{array}{l}\text { offshore, 3.6-21.6 meters; } \\
\text { inlet areas }\end{array}$ & $25-40 \%$ & entire & Clams & 49 & 6.5 & 0.4 & 4.2 & \begin{tabular}{|l|} 
Watt and Merrill \\
1963:25 item 770
\end{tabular} \\
\hline $\begin{array}{l}\text { Pulley's } \\
\text { Macoma }\end{array}$ & Macoma pulleyi & $42-55$ & $\begin{array}{l}\text { offshore, delta-influenced } \\
\text { waters }\end{array}$ & $25-40 \%$ & east & Clams & 49 & 6.5 & 0.4 & 4.2 & $\begin{array}{l}\text { Watt and Merrill } \\
\text { 1963:25 item } 770\end{array}$ \\
\hline \begin{tabular}{|l} 
Lady-in- \\
Waiting Venus
\end{tabular} & \begin{tabular}{|l} 
Chione \\
intapurpurea
\end{tabular} & $25-38$ & offshore; 3.6-21.6 m & $25-40 \%$ & entire & Clams & 49 & 6.5 & 0.4 & 4.2 & - \\
\hline $\begin{array}{l}\text { Atlantic Surf } \\
\text { Clam }\end{array}$ & \begin{tabular}{|l} 
Apisula \\
solidissima
\end{tabular} & $101-127$ & offshore; 3.6-21.6 meters & $25-40 \%$ & entire & Clams & 49 & 6.5 & 0.4 & 4.2 & $\begin{array}{l}\text { Watt and Merrill } \\
\text { 1963:25 item } 770\end{array}$ \\
\hline $\begin{array}{l}\text { Smooth Duck } \\
\text { Clam }\end{array}$ & Anatina anatina & $50-76$ & offshore; 3.6-21.6 meters & $25-40 \%$ & entire & Clams & 49 & 6.5 & 0.4 & 4.2 & \begin{tabular}{|l|} 
Watt and Merrill \\
1963:25 item 770
\end{tabular} \\
\hline Disk Dosinia & Dosinia discus & $50-76$ & offshore; 3.6-21.6 meters & $25-40 \%$ & entire & Clams & 49 & 6.5 & 0.4 & 4.2 & $\begin{array}{l}\text { Watt and Merrill } \\
\text { 1963:25 item } 770\end{array}$ \\
\hline Tulip Mussel & \begin{tabular}{|l|} 
Modiolus \\
americanus
\end{tabular} & $25-101$ & $\begin{array}{l}\text { offshore; below low } \\
\text { water mark }\end{array}$ & $25-40 \%$ & entire & Mussel & 66 & 9.6 & 1.4 & 3.1 & \begin{tabular}{|l|} 
Watt and Merrill \\
1963:40 item 1363
\end{tabular} \\
\hline $\begin{array}{l}\text { Leafy Jewel } \\
\text { Box }\end{array}$ & $\begin{array}{l}\text { Chama } \\
\text { macerophylla }\end{array}$ & $25-76$ & $\begin{array}{l}\text { offshore; deeper } \\
\text { calcarous banks }\end{array}$ & $25-40 \%$ & southern & $\begin{array}{l}\text { Oyster- } \\
\text { eastern }\end{array}$ & 66 & 8.4 & 1.8 & 3.4 & $\begin{array}{l}\text { Watt and Merrill } \\
\text { 1963:42 item } 1443\end{array}$ \\
\hline $\begin{array}{l}\text { Cut-Ribbed } \\
\text { Ark }\end{array}$ & $\begin{array}{l}\text { Anadara } \\
\text { floridana }\end{array}$ & $\begin{array}{l}63.5- \\
127\end{array}$ & offshore; deeper water & $25-40 \%$ & $\begin{array}{l}\text { central and } \\
\text { south }\end{array}$ & Clams & 49 & 6.5 & 0.4 & 4.2 & $\begin{array}{l}\text { Watt and Merrill } \\
\text { 1963:25 item } 770\end{array}$ \\
\hline Blood Ark & Anadara ovalis & $38-59$ & offshore; just & $25-40 \%$ & entire & Clams & 49 & 6.5 & 0.4 & 4.2 & $\begin{array}{l}\text { Watt and Merrill } \\
\text { 1963:25 item } 770\end{array}$ \\
\hline Ponderous Ark & \begin{tabular}{|l|} 
Noetia \\
ponderosa
\end{tabular} & $\begin{array}{l}50.8- \\
63.5\end{array}$ & offshore; sandy bottoms & $15-40 \%$ & entire & Clams & 49 & 6.5 & 0.4 & 4.2 & $\begin{array}{l}\text { Watt and Merrill } \\
\text { 1963:25 item } 770\end{array}$ \\
\hline $\begin{array}{l}\text { Incongruous } \\
\text { Ark }\end{array}$ & $\begin{array}{l}\text { Anadara } \\
\text { brasiliana }\end{array}$ & $25-38$ & offshore; shallow water & $25-40 \%$ & entire & Clams & 49 & 6.5 & 0.4 & 4.2 & $\begin{array}{l}\text { Watt and Merrill } \\
\text { 1963:25 item } 770\end{array}$ \\
\hline
\end{tabular}

to extreme fluctuations in salinity and temperature (Hoese 1960). Shallow bays such as Oso Bay and Corpus Christi Bay are especially vulnerable to long-term and short-term changes in climatic condition since the salinity levels and temperature of shallow bodies of water can be changed more rapidly and dramatically even during short climatic perturbations (e.g., cold fronts and sudden downpours) than deep bodies of water.

\section{Freshwater Molluses}

Twenty-seven species of freshwater mussel occur in small and large streams that empty into bays on the Gulf of Mexico and in ponds and lakes found across the Coastal Plains. (Table 8-6; Howells et al. 1996:14). A few of the 27 species (Uniomerus spp.) can inhabit intermittent streams and temporary ponds (Howells et al. 1996:14). However, mussels primarily inhabit flowing waters with substrates of mud, sand, gravel, and cobbles or any combination of these. In areas of strong currents flow obstructions such as fallen trees or gravel bars provide protected areas for mussels. Within Nueces, San Patricio and Refugio counties oxbow lakes (old channels) provide the most suitable habitat for mussels in addition to the free-flowing portions of the river (Neck and Metcalf 1988). Deep soft silts, deep shifting sands, and bedrock or heavy boulder bottoms are limiting habitats and are generally poorly populated (Howells et al. 1996:15). Occurrence of individuals may be sporadic or dense populations may occur in suitable locations. Densities of 81 specimens $/ \mathrm{m}^{2}$ have been reported for wild populations (Howells et al. 1996:21). Large numbers of crayfish and a variety of small and juvenile fish are found in association with stable mussel beds. 
Table 8-6. Common Freshwater Molluscs Found in the Streams, Lakes and Ponds of the Gulf Coastal Plains and Marshes

\begin{tabular}{|c|c|c|c|c|c|c|c|}
\hline Common Name & Scientific Name & $\begin{array}{l}\text { Length } \\
\text { (mm) }\end{array}$ & $\begin{array}{c}\text { Calories } \\
\text { (C) }\end{array}$ & $\begin{array}{l}\text { Protein } \\
\text { (g) }\end{array}$ & $\begin{array}{l}\text { Fat } \\
\text { (g) }\end{array}$ & $\begin{array}{l}\text { Carbs } \\
\text { (g) }\end{array}$ & Source \\
\hline Threeridge & Amblema plicata & 148 & 66 & 9.6 & 1.4 & 3.1 & Watt and Merrill 1963:40 item 1363 \\
\hline Giant Floater & Anadonta grandis & 170 & 66 & 9.6 & 1.4 & 3.1 & Watt and Merrill 1963:40 item 1363 \\
\hline Paper Pondshell & Anodonta imbecillis & 90 & 66 & 9.6 & 1.4 & 3.1 & Watt and Merrill 1963:40 item 1363 \\
\hline Rock Pocketbook & Arcidens confragosus & 160 & 66 & 9.6 & 1.4 & 3.1 & Watt and Merrill 1963:40 item 1363 \\
\hline Tampico Pearlymussel & Crytonaias tampicoensis & 143 & 66 & 9.6 & 1.4 & 3.1 & Watt and Merrill 1963:40 item 1363 \\
\hline Round Pearlshell & Glebula rotunda & 95 & 66 & 9.6 & 1.4 & 3.1 & Watt and Merrill 1963:40 item 1363 \\
\hline Texas Fatmucket & Lampsilis bracteata & 90 & 66 & 9.6 & 1.4 & 3.1 & Watt and Merrill 1963:40 item 1363 \\
\hline Louisiana Fatmucket & Lampsilis hydiana & 95 & 66 & 9.6 & 1.4 & 3.1 & Watt and Merrill 1963:40 item 1363 \\
\hline Yellow Sandshell & Lampsilis teres & 145 & 66 & 9.6 & 1.4 & 3.1 & Watt and Merrill 1963:40 item 1363 \\
\hline White Heelsplitter & Lasmagona complanata & $167 *$ & 66 & 9.6 & 1.4 & 3.1 & Watt and Merrill 1963:40 item 1363 \\
\hline Fragile Papershell & Leptodea fragilis & 133 & 66 & 9.6 & 1.4 & 3.1 & Watt and Merrill 1963:40 item 1363 \\
\hline Pond Mussel & Ligumia subrostrata & 74 & 66 & 9.6 & 1.4 & 3.1 & Watt and Merrill 1963:40 item 1363 \\
\hline Washboard & Megalonaias nervosa & 215 & 66 & 9.6 & 1.4 & 3.1 & Watt and Merrill 1963:40 item 1363 \\
\hline Pink Papershell & Potamilus ohienis & 141 & 66 & 9.6 & 1.4 & 3.1 & Watt and Merrill 1963:40 item 1363 \\
\hline Bleufer & Potamilus purpuratus & 178 & 66 & 9.6 & 1.4 & 3.1 & Watt and Merrill 1963:40 item 1363 \\
\hline Southern Mapleleaf & Quadrula apiculata & 118 & 66 & 9.6 & 1.4 & 3.1 & Watt and Merrill 1963:40 item 1363 \\
\hline Golden Orb & Quadrula aurea & 77 & 66 & 9.6 & 1.4 & 3.1 & Watt and Merrill 1963:40 item 1363 \\
\hline Smooth Pimpleback & Quadrula boustonensis & 66 & 66 & 9.6 & 1.4 & 3.1 & Watt and Merrill 1963:40 item 1363 \\
\hline Texas Pimpleback & Quadrula petrina & 87 & 66 & 9.6 & 1.4 & 3.1 & Watt and Merrill 1963:40 item 1363 \\
\hline False Spike & Quincuncina mitchelli & 132 & 66 & 9.6 & 1.4 & 3.1 & Watt and Merrill 1963:40 item 1363 \\
\hline Squawfoot & Strophitus undulatus & 92 & 66 & 9.6 & 1.4 & 3.1 & Watt and Merrill 1963:40 item 1363 \\
\hline Lilliput & Toxolasma parvus & 30 & 66 & 9.6 & 1.4 & 3.1 & Watt and Merrill 1963:40 item 1363 \\
\hline Texas Lilliput & Toxolasma texasensis & 62 & 66 & 9.6 & 1.4 & 3.1 & Watt and Merrill 1963:40 item 1363 \\
\hline Pistolgrip & Tritogonia verrucosa & 170 & 66 & 9.6 & 1.4 & 3.1 & Watt and Merrill 1963:40 item 1363 \\
\hline Texas Fawnsfoot & Truncilla macrodon & 45 & 66 & 9.6 & 1.4 & 3.1 & Watt and Merrill 1963:40 item 1363 \\
\hline Tapered Pondhorn & Uniomerus declivis & 121 & 66 & 9.6 & 1.4 & 3.1 & Watt and Merrill 1963:40 item 1363 \\
\hline Pondhorn & Uniomerus tetralasmus & 141 & 66 & 9.6 & 1.4 & 3.1 & Watt and Merrill 1963:40 item 1363 \\
\hline
\end{tabular}

* shell length

Little is known about variability in the seasonal availability of freshwater mussels (Howells et al. 1996:21). Freshwater mussels occur at varying depths but rarely below about seven and a half meters except during cold weather when some species move to deeper water for protection. Many mussel species can survive for several months during periods of drought by burrowing into the substrate (Howells et al. 1996:18).

\section{Birds}

The mosaic of niches found along the coastal bays and estuaries provides a mix of habitats well suited for roosting, resting, foraging, and breeding for a variety of aquatic bird species. As a result, the riverine settings, estuaries and beaches of the Gulf coast represent some of the most important habitat for migrating North America shorebirds (Senner and Howe 1984). In 2006, 247 species were identified by bird watchers in the Corpus Christi area (Corpus Christi Daily 2006). A bird check list for the Naval Air Station, Corpus Christi, located on the eastern shore of Oso Bay and Corpus Christi Bay lists 310 bird species that have been identified there over the years (U.S. Navy and the National Fish and Wildlife Foundation 2006).

Other than the gallinaceous birds such as the wild turkey and quail that are most common within the prairie habitat, the most economically important group of birds is waterfowl, specifically the family Anatidae (ducks and geese) that are most abundant in the marshes of the beach-fluvial interface and the prairie-riverine habitat. Waterfowl are relatively large bodied water birds that are found in highest frequencies on the margins of marshes, ponds, lakes, streams, and the coastline (Texas Game, Fish, and Oyster Commission 1945; Rappole and Blacklock 1994). There are at least 28 species of ducks and geese that migrate through the Gulf coastal regions each fall and winter, or are permanent residents. Most species eat water plants and grasses in areas of shallow 
water, but a few species that eat fish prefer deeper waters. Ducks and geese travel in large flocks with up to tens of thousands of individuals in the case of geese. They usually nest on the ground and the number of eggs ranges from 6 to 18 . Many species of ducks and geese can be encouraged to land in specific areas by the use of decoys. In the case of some species, such as geese, these decoys can be as simple as fluttering white pieces of paper or cloth (Texas Game, Fish, and Oyster Commission 1945).

A recent study of avian abundance and richness (Carillo 2000) in the area of the Blind (False) Oso indicates that during the 13-month study period more than 33,700 aquatic birds, 77 species, visited the tidal pond, the mudflats and open bay. The highest species richness as well as number of birds was noted in the open bay ( $n=70$ species, 16,123 birds), followed by the wind-tidal flat ( $\mathrm{n}=49$ species, 11,201 birds, and tidal pond ( $n=46$ species, 6,418 birds). Figure 8-2 shows the abundance of all birds during the one-year study period. The peak in species richness and abundance occurred in the spring (February-late March) in response to the presence of springmigrating birds. Species richness and abundance declined between May and early July with the departure of waterfowl and shorebirds for their breeding grounds. A second peak in richness and abundance occurred between late July and November as fall-migrating species passed through the region. The abundance of birds in different guilds was variable. For instance, wading birds (e.g., reddish and Snowy egrets) were most abundant between November and December. Waterfowl (e.g., Northern shoveler, gadwall, American wigeon, greenwinged teal and ruddy duck) were most abundant between October and January (Carillo 2000:129). Gulls and turns (e.g., laughing gull, herring gull, royal turn, black skimmer) were most abundant between late January and late February with a smaller peak between August and November (Carillo 2000:130). Finally, shorebirds (e.g., dowitchers, peeps, stilt sandpipers) were abundant in July and August and again between January and April.

Withers and Chapman (1993) found a similar pattern in an earlier study of seasonal abundance of shorebirds on an Oso Bay mudflat. They documented 26 species of shorebirds during the study year. They found that the winter and early spring (January-March) was the period of highest densities of birds in the study area but the highest species richness was noted during the fall migration (September to October). Low shorebird abundance and diversity were seen during the summer (Withers and Chapman 1993:385-387).

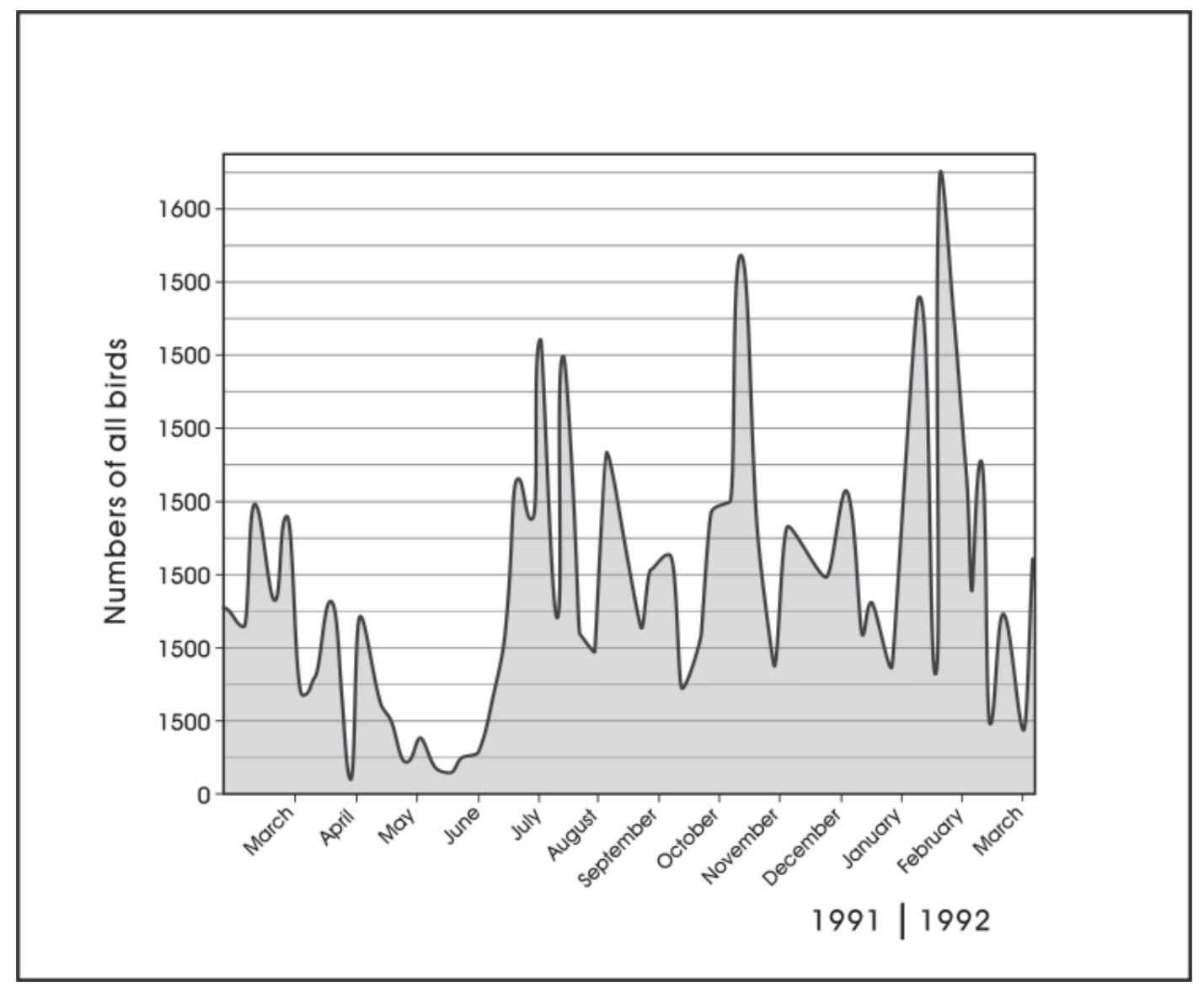

Figure 8-2. Abundance of all birds in the Blind Oso, Oso Bay, Texas (March 1991-March 1992). 
While birds offer a ready source of protein and their eggs can provide additional nutrients, the nutritional condition of some species of over-wintering shorebirds is relatively poor and they may not be highly desirable dietary component. For instance, White and Mitchell (1990) have found that the body mass and lipid content of long-billed dowitchers and western sandpipers declined between $44-70 \%$ from the time they arrived on the coast in early autumn to their departure in mid-February. The study suggests that at least the members of these species of shorebirds do not acquire substantial fat deposits before their northward migration from the Gulf Coast. However, the reasons for this pattern may be the high overall shorebird densities on the coast at the time and the consequent depletion of food supplies, adverse weather conditions in winter and the possibility that the cost of storing and carrying fat reserves may not exceed the benefits (White and Mitchel 1990:451).

\section{Plant Resources}

In general, edible plant resources can be grouped into five major categories depending on the portion of the plant being harvested and consumed. These groups consist of tubers (including bulbs and roots) fruits, nuts, seeds, and pot-greens. Several publications are available summarizing plant species and their distributions in the state and in South Texas, in particular. The edible plant distribution patterns discussed below are based on reviews of selected ethnobotanical references concerning edible plant species in Texas (Cheathum et al. 1995; Tull 1999), and surrounding states and regions (Ebling 1986; Elliott 1976; Fernald and Kinsey 1943; Kindscher 1987; King 1976; Yarnell 1964).

Figure 8-3 is a graphic representation derived from the above combined references of the number of edible plant species grouped into resource types and broken down by season of availability. The number of plant species utilized as potgreens is highest during the spring, experiencing a steady drop approaching the fall or autumn months, and declining to a minimum by the winter. Plant species with edible tubers, bulbs, rhizomes, and corms have a bimodal distribution reaching an early peak in the spring, dropping somewhat in the summer, and peaking even higher during the fall before dropping to an annual low during the winter. Plant species with edible fruits tend to peak in the summer and are still relatively common during the fall but occur only in small numbers in

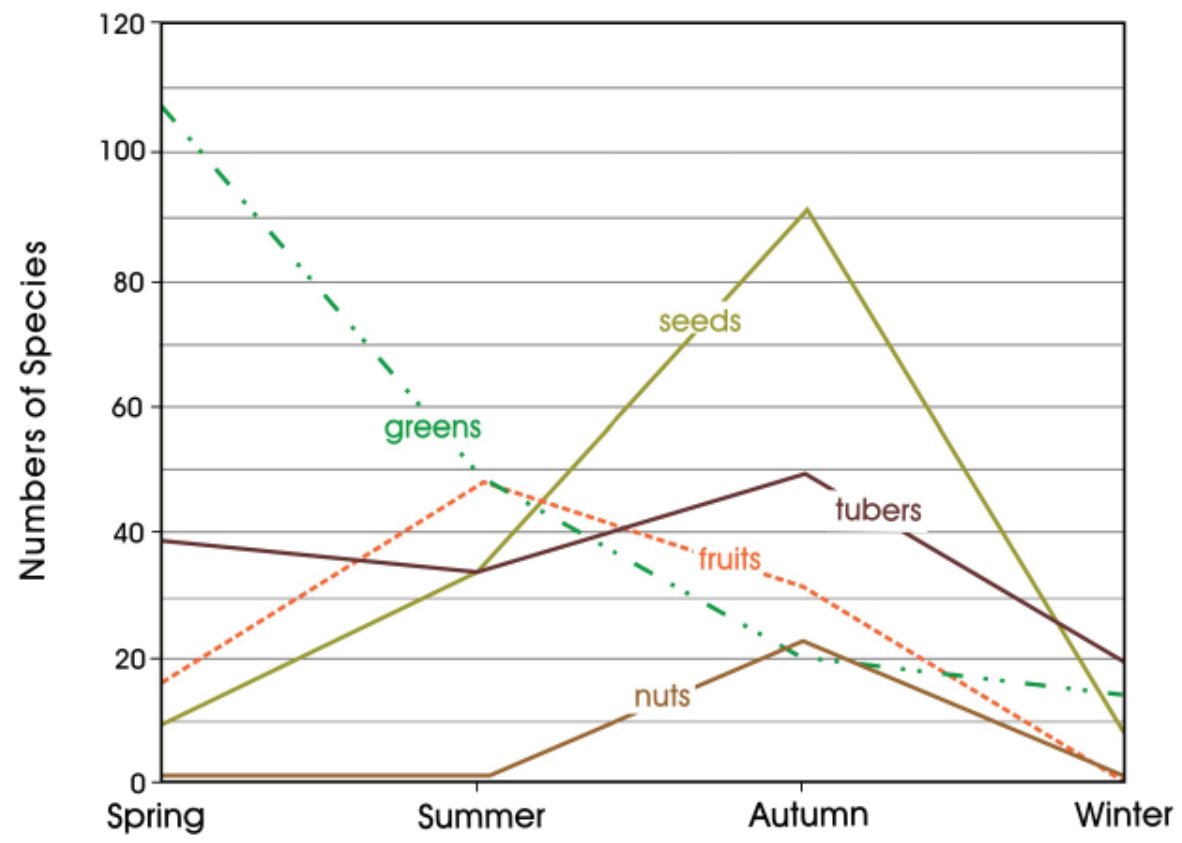

Figure 8-3. Changes in the number of edible plant species by season of availability. 
the winter. Species with edible seeds tend to be relatively low in number during the spring, but increase steadily from the late spring, through the summer and peak during the fall. Nuts derived from nut-bearing trees are available primarily during the fall months, peaking in the number of available species between September and October.

Sixty-nine plant species and varieties have been identified as having edible tubers, rhizomes, bulbs, and/or corms. A moderate number of the species are available throughout the year; however, many of these species are apparently more palatable or have higher nutrient contents during either the spring or fall. Prairie (27) and alluvial stream bottom and gravel bar (18) settings contain the highest number of edible tuber species. Open woodlands (15), glades (14), and marshes, sloughs and ponds (14) contain moderate numbers of species with edible tubes, while other habitats have significantly lower numbers.

One hundred and six plant species with edible seeds have been identified. Alluvial stream bottoms and gravel bars are the richest habitats ( 55 species) for edible seed plant species, followed by marshes, sloughs, and ponds (45), and prairie (40) settings. Glades (28), and sandstone/limestone ledge and bluff (26) settings, and disturbed grounds contain moderate numbers of species, while other habitats have lower numbers of species with edible seeds.

Plant species with edible leaves, shoots, flowers, and buds tend to be relatively abundant ( $\mathrm{n}=286$ species) within the Gulf Coastal Plains. The largest number (46) of species is found in alluvial stream bottom and gravel bar settings, prairies and open fields (44), and open woodlands (42). Glades (34), thickets (27), marshes, sloughs, and ponds (17), sandstone/ limestone ledges and bluffs (17), xeric habitats (16), disturbed grounds (15), and barrens (14), contain moderate numbers of resource types. Other habitats (e.g., wooded slopes and slope bases and waste grounds) are home to few species with edible leaves, shoots, flowers, and buds.

Seventy-eight plant species and varieties produce edible fruits are present within the Gulf Coastal Plains at large. The highest numbers of species are found along the borders of open woodlands (19), and in alluvial stream bottoms and gravel bars (18). Prairies (15), sandstone/limestone ledges and ridges (13), glades (12), and the borders of thickets (10) have moderate numbers of fruit-bearing species. Other habitats have few or no edible fruit-bearing species.

Twenty-three nut producing species are present in the broad coastal plains region. Of these, 13 are nut-bearing (e.g., hickory, walnut), and 10 are acorn producing species.
Although these species begin production in the spring, most yields are not ready for harvest until the fall. Rich alluvial river bottom settings (12 spp.) and limestone and sandstone ledges and slopes (12 spp.) are the two most preferred habitats. Eight species are found primarily on wooded slopes and in the more mesic settings at the bases of slopes. Nut -bearing species are less common in other habitats.

Fruit and pecan yield statistics between 1919-1989 (Texas Crop and Livestock Reporting Service, 1984:17 see also Hall 1995b:643) show that (1) the Central Coastal Plains counties produce extremely high quantities, and (2) pecan production is characterized by cyclical highs and lows. Years with high nut yields are followed by 1-3 year periods of lower yields. Annual nut yields also are affected by more proximate factors such as the timing and amount of rainfall, the timing of the first and last frosts, defoliation caused by various agents, and insect infestation and disease (Hall 1995b:641; Rector 1996). An example of the effect of excessive rains could be seen in 1985, when rainfall during November and December hampered harvesting activities and caused the sprouting and loss of some nuts on the ground.

In addition to annual fluctuations in yield, the seasonal availability of nuts to humans is dependent on various factors including the length of the ripening period, the date or period when the nuts fall, and the length of time the nuts are on the ground and are available before they are consumed or are carried away by competing animals (Talay et al. 1984). Observations of dates of nut dropping in hickory and walnuts in Indiana indicated considerable similarity between individual trees (Talay et al. 1984). Texas pecan harvesting activity data for 1984 and 1985 indicate that harvesting tends to begin about the tenth of October and the bulk (about 50 percent) of the crops are harvested in November and early December. These patterns indicate that a considerable crop is usually available relatively soon after the ripening date of a particular species. A large number of animals, such as squirrels, deer, bears, a variety of small rodents, and even turkeys consume nuts. Of these, squirrels are the most significant competitors because they begin consuming nuts while they are still green and on the trees. There is evidence that most squirrels tend to consume thinner shelled, larger nut species first before switching to the consumption of thickershelled smaller species (see Talay et al. 1984:347). This type of selection might also occur among smaller mammals even less capable of gnawing through thicker nut shells. An additional potential source of nut loss, particularly among acorns, are the numerous acorn-attacking insects that infest a crop particularly while on the ground. Both the potential losses due to mammals and insects place a premium upon aboriginal efforts to closely monitor nut availability and be in the nut producing patches immediately prior to the nut dropping or soon after. 
Selected species distribution maps provided by Little (1971), and species ranges given in the checklist of vascular plants indicate that hickory (Carya texana), pecan (Carya illinoiensis), Blackjack oak (Q. marilandica), bur oak $(Q$. macrocarpa), and Coastal live oak ( $Q$. virginiana), have the broadest habitat ranges occurring in river bottom settings in the coastal prairies and marshes, oak-hickory forests, and river valleys crossing the prairie. Other species have a more limited habitat range, occurring mainly in one or two vegetation regions of the state (e.g., Mockernut hickory in the oak-hickory forest, Shagbark hickory in the coastal prairies and marshes, and the three species of piñon found only on the Edwards Plateau.

When the seasonal availability of all of these plant resource types is considered together and across the Gulf Coastal Plains, it becomes evident that the highest number of edible species (216) are available in the fall. Spring and summer resources include somewhat lower and nearly equal numbers of resource types (171, and 163, respectively), while the smallest number of edible species are available during the winter (44). These figures support the general impression derived from ethnohistoric records (see Chapter 7) that the leanest season during the annual subsistence cycle was winter and the most productive one was fall.

The overall richness of the habitats, in terms of numbers of resource types, indicates that alluvial stream bottomland and gravel bar settings are the richest (149), followed by prairies (127). Open woodlands (94), glades (90), and marshes, sloughs, and ponds (77), have moderate numbers of species with edible parts. Smaller numbers of edible plant species are found in xeric habitats (60), thickets (56), disturbed grounds (46), wooded slopes (40), and barrens (37). The smallest number of species with edible parts is found in waste grounds. Importantly, while alluvial stream bottoms represent the single richest habitat, all upland settings (e.g., prairies, woodlands, glades, ledges and bluffs) combined have a higher number of edible species than riverine habitats. Importantly, the exploitation of these resources would require greater mobility compared to the exploitation of the single riverine habitat.

\section{Summary of Resource Structure}

Based on the brief sketches of resource types and their availability presented earlier, it is now possible to summarize the resource structure that characterizes the Gulf Prairies and Marshes region. A mosaic of small inter-fingering biotic and biological assemblages on the coast offers a high diversity of resources in close proximity to each other. A high diversity of aquatic resources such as fish, molluscs, offshore birds and their eggs found in the bay-estuary-lagoon habitat and to a lesser degree in the beach-prairie fluvial interface and beach-beach proximate habitats, represent resources that can be procured at lower energy costs. The primary biomass (submerged grasses, algae, etc,) in these settings is less accessible to human consumers but the secondary biomass is rich in density, species diversity (i.e., molluses, fish) and is highly accessible with low energy expenditures, with the possible exception of birds.

Seasonal changes in ambient temperature, water temperature, salinity and the life cycles of species will impact the resource base in predictable manner by either reducing the density of potential prey within the overall region (i.e., seasonal migrations of shorebirds) or changing the species composition, density and/or age profile of taxa within specific habitats (i.e., estuaries, bays, marshes) and overall within the region (e.g., seasonal migrations). In addition to these seasonally predictable fluctuations, unpredictable weather phenomena such as sudden drops in temperature associated with northern cold fronts or high rainfall events can result in major die-offs of a number of species that have a narrower tolerance range (i.e., molluscs and fish). Such die-offs may have provided very abundant although less predictable resources for populations exploiting the coastal bay-estuary-lagoon habitat.

Long-term and relatively gradual changes in climatic conditions also can be expected and should result in major spatio-temporal reorganizations of biological assemblages within the bay-estuary-lagoon habitat in particular. For instance, the formation of the barrier islands off the coast of the Gulf of Mexico has significantly affected salinity levels within Corpus Christi Bay and its secondary bays such as Oso Bay. We can relatively safely assume that short term predictable phenomena, short term unpredictable episodes, as well as long term gradual changes in climatic condition are likely to have reoccurred repeatedly within the region over time resulting in different scales of adjustments to the changing resource base by hunter-gatherers utilizing the bayestuary-lagoon habitat.

Riverine corridors, such as those that are found at the center of the prairie-riverine habitat offer linear arrangements of diverse biological assemblages cross-cutting otherwise homogenous terrestrial upland settings. The primary biomass of prairie-riverine habitats is high as a product of nut-bearing tree communities, a diversity of tubers and bulbs, and seedbearing plant species. With appropriate food processing techniques and technology, this biomass is accessible to human consumers. However, the processing costs involved in making at least some of the biomass (i.e., tubers) consumable is energetically expensive. The secondary biomass of such riverine corridors is relatively high as well (e.g., deer, etc) 
but some of its components (e.g., squirrels) may be less accessible to human consumers. In general, the prairie-riverine plant communities and biological assemblages may be less susceptible to minor, short term, perturbations than the coastal aquatic zone because the vegetation is supported by high water tables. However, some of its most productive species (i.e., nutbearing species) have natural lows and peaks in year-to-year production that add a certain degree of potentially predictable variation in hunter-gatherer resource procurement. Most of the terrestrial species that gravitate to these prairie-riverine habitats have broader tolerance limits compared to those inhabiting bay estuary-lagoon habitats and the co-occurrence of a mix of both aquatic and terrestrial taxa creates a relatively species diverse context buffered to a certain degree from seasonal fluctuations in resources due to the more moisture-abundant setting. For instance, aquatic resources such as freshwater fish and molluscs are affected only by sudden changes in temperature rather than both temperature and salinity conditions. In addition, stream bottoms provide a broader range of micro-habitat variations (distinct depths of water and sediment conditions) that will allow both fish and molluses to find appropriate habitat conditions with greater ease than within some coastal bays that cover hectares and have a mean depth of less than one meter.

Long-term changes in climatic conditions (e.g., the onset of xeric or mesic conditions) can result in slow and gradual changes in biological assemblages even in these more stable (e.g., prairie-riverine) habitats. For instance, it has been well documented that extreme long-duration xeric conditions tend to result in the replacement of arboreal communities (i.e., woodlands) by grasslands. In contrast, prolonged mesic periods will result in the expansion of woodlands at the expense of grassland prairie communities. It is expected that riverine biological assemblages found in the Gulf Coastal Plains would be similarly affected by these long-term and persistent changes in climatic conditions. Extended mesic periods would lead to the expansion of stream bottom woodlands onto the prairie margin and the formation of oak motts across the open prairie. Both of these phenomena could potentially lead to increased mast production and potentially greater deer population densities. Mesic conditions may also improve forage quality on the open prairie attracting higher densities of large-bodied prey (i.e., bison) as well as prairie adapted antelope. Extended xeric conditions may increase the preferred habitat for antelope but other large and mediumbodied species may decline in response.

Seasonal changes in climatic conditions also impact the biological assemblages found within the prairie habitat. Grasslands represent a relatively homogenous vegetation community but the presence of scattered stands of oaks and oak motts and ponds and depressions provide niches for a range of wildlife and would be critical to deer, one of the two medium body mammals present on the prairie. Primary and secondary producers in these settings are well adapted to these seasonal shifts in temperature and available moisture. These ebbs and flows result in predictable changes in the amounts and types of resources available to human consumers. Unpredictable phenomena, such as prairie fires can result in dramatic changes in the types and quantities of available resources. At least some of these phenomena can have long-term beneficial effects on some biological communities (e.g., the artificial deflation of woody invaders, introduction of nutrients into the soil.). Long-term processes and forces can have even more dramatic effects on upland biological assemblages given their relative homogeneity and reduced moisture availability. Prairie margin settings will be subject to fluctuations in community boundaries while the species composition of vegetation communities may change (woodlands vs grass vegetation communities) in more homogeneous settings.

\section{Conclusion}

Our goal in providing this review is to identify the principal potential resources and define their spatial and temporal availability as well as their potential contributions to the nutritional intake of hunter-gatherer populations. It would be necessary to compile an exhaustive database of the nutritive value of all the edible species available within the region to conduct quantified analyses of the hunter-gatherer behavior at the level of $41 \mathrm{NU} 2$ and the region. Unfortunately, after extensive search of the topical and regional literature, it is apparent that the nutritive values per unit of weight as well as fluctuation between age, sex, and season of available resources are unavailable or deeply buried in the literature for the study area. In some cases, information is available for the same species in a different location but the goal of this research module was to determine the specific costs and benefits of hunting and gathering within this study area. Many case studies elsewhere refer to Watt and Merrill (1963) for nutrition information, finding the nearest applicable item listed (Glassow and Wilcoxon 1988, Reidhead 1981), submit samples for nutritional analysis as part of the research, or rely on other published sources, adjusting data to include factors that would effect the nutritional gain of a given resource. Relying on general data such as from Watt and Merrill (1963) disregards specific nutrition information at the species level, age group, season, and habitat of the resource, a sacrifice most researchers find prudent as finding sources reporting nutrition information specific to seasonal or age fluctuations is even more problematic.

In addition to concluding that nutritional data for most Texas and coastal species that we are targeting is sorely lacking or scarce, we are also forced to conclude that the necessary 
information related to population dynamics of many of the potential economically useful species is also lacking or is at best incomplete. For instance, even information related to deer densities across the state is inadequate when it comes to seasonal variability in population densities across the state. Data on population densities of smaller, economically less significant species are even sketchier and quantified data on species that are no longer present in the region (i.e., pronghorn antelope and bison) are entirely absent. The same limitations exist with regard to economically useful plant species as well. More importantly, it is necesary to ask whether is it even worth gathering sufficient data on modern resource distributions across the state, particularly in light of the changes such distributions have gone through during historic times.

While we recognize that historic and modern land use practices and developments have dramatically impacted the densities of economically useful species of plants and animals, it is our sentiment that the distribution of plants and animals is determined by long-term evolutionary relationships between soil types, hydology and vegetation cover and therefore they are basic to spcific organisms and communities of organisms (i.e., relationship of water table to tree species; relationship between mast production and deer population). There is no doubt that in some parts of the state, developments and modern land use have altered the composition of vegetation communities and removed certain animal species. Yet, based on the basic relationship between mast production and deer feeding habits, we can still be reasonably confident in the assumption that deer population densities were relatively higher on the Edwards Plateau than the South Texas Plains and Brush Country even during prehistoric times. Similarly, some of the seasonal changes in the characteritics of the prey species exploited by prehistoric hunter-gatherers respond to seasonal changes in the broader environment (i.e., seasonal variability in available moisture and changes in tempreature). As a result, we can be safe in assuming that seasonal changes in prey characterstics (i.e., variation in nutritional composition of plants, changes in the weight and fat reserves of deer), were as much a factor prehistorically as they are today.The point of establishing baselines in resource distribution is not to define exact number of species that may have been present in a particular setting 500 years ago. Instead, the goal is to define the rankings of the habitats based on relative densities of prey species. 



\title{
Chapter 9: Modeling, Archeological Expectations and the Archeological Record
}

\author{
Steve A. Tomka and Charles Frederick
}

In Chapter 7 we identified a theoretical perspective, human behavioral ecology, a family of models, optimal foraging, and a specific model, habitat selection that we propose to employ to investigate the foraging behavior of prehistoric hunter-gatherer populations in the project area. In Chapter 8 we described the structure of the natural and biological communities within the Corpus Christi area and the nutritional contributions of selected resources to huntergatherer subsistence. We lumped the multitude of niches present in the vicinity of Corpus Christi Bay into five habitats consisting of distinct relatively homogeneous groupings of biological communities. In this chapter, we develop a regionspecific set of expectations regarding hunter-gatherer foraging strategies based on the principles of the habitat model and using the selected optimal foraging models described above. In proposing a series of expectations regarding huntergatherer land use and subsistence practices, we also define sets of methodological approaches and analytical tools that will be needed to study the data types recovered from 41NU2 and comparative data from regional sites to search for the predicted/expected patterning.

\section{Applying the Habitat Choice Model to Coastal Hunter-Gatherers}

In Chapter 2 we have briefly outlined the spatial distribution of the 36 natural environments and biological assemblages present in the Corpus Christi area. We combined these assemblages into five habitats that contain adjoining and similar economically usable resources. We have already mentioned in Chapter 2 that we perceive of a habitat as an aggregation of biological communities that is larger than what would be encompassed within a resource patch, that contains a relatively homogenous group of resources that is the product of long-term evolutionary forces, and that as an aggregate are more similar to each other based on the niche requirements of the resident biological assemblages than to adjacent habitats. We add here that from the perspective of scale, a habitat is larger than the resource patches that would be exploited during a daily foraging round and more than one resident forager group may be present within it at any one time.

As in the prey and patch choice models, the first step in operationalizing the model is to determine the ranking of the habitats. Sutherland (1996:6-7) uses the concept of suitability along which to rank patches. The patch concept is similar to habitats in our definition (see Sutherland
1996:7) and the suitability concept takes into account a broader range of conditions that affect the life-conditions of an organism. Suitability is organism-specific and in our case we are interested in the suitability of the habitat for huntergatherer occupation and exploitation. Many aspects of an environment affect its suitability including prey density, intake rate, availability of critical resources such as water and fuel, etc.

To develop a ranking of the five habitats present within the Corpus Christi area and in other bay-associated settings across the Gulf of Mexico, we use the general methodology of rank order determinations for individual prey. As we mentioned before, in energetic terms, post-encounter prey rank is a quantified measure of handling costs compared to $\mathrm{Kcal} / \mathrm{hr}$ derived from the consumable portion of the prey. Also as we noted before, at the most basic and simplified level, there is a strong relationship between the body size of the prey and its ranking (see Figure 7-1). While handling costs factor into the final determination of ranking, these components rarely shift the ranking of plant species above animal prey or of one animal species above another except in instances of technological adjustments that significantly decrease pursuit or processing cost (i.e., procurement of fish with baskets; making fish-meal rather than individually processing each fish).

Employing these underlying assumptions, we propose to rank each of the five habitats identified in Chapter 2 based on the density of prey in the largest body size class present in each habitat. Unfortunately, even after a concerted effort to compile such information, at this time we do not have quantified data on actual densities of deer, or other mammals within each of the habitats. Instead, we use the concept of potential return rate rather than actual return rate. The potential return rate is estimated based on the assumption that all other things being equal the density of a species within its preferred habitat will always be higher than its density in marginal environments. So that, areas of higher prey density (i.e., deer) will have higher potential return rates than areas of lower prey density. In addition, while the distribution of taxa often extends beyond the boundaries of each habitat, we can reasonably assume that the densities of any given species will be highest in their preferred habitat and lower outside of it (refer to the discussion of deer distribution in Chapter 2). This assumption is important because we do not have density data for specific prey species and therefore have to rely on differences in relative abundance rather than absolute abundance of prey 
of different rank (i.e., different size classes). In addition, because the density of some prey species changes seasonally as already mentioned, the ranking of individual habitats also has the potential to change if seasonal changes occur in the density of the dominant mammalian species that determines the habitat's ranking.

Table 9-1 presents the ranking of the five habitats found within the Corpus Christi area. The rankings are derived from and correlated with the body size of the dominant animal taxa present in the habitat.

Table 9-1. Ranking of Habitats by Potential Intake Rate

\begin{tabular}{|l|c|}
\hline \multicolumn{1}{|c|}{ Habitat } & Rank \\
\hline Prairie-Riverine & 1 \\
\hline Prairie & 2 \\
\hline Beach-Fluvial Interface & 3 \\
\hline Bay-Estuary-Lagoon & 4 \\
\hline Beach and Beach Proximate & 5 \\
\hline
\end{tabular}

Based on the abundance of deer, the largest size class mammal present year-round in the river bottoms crossing the prairie, we propose to rank the prairie-riverine habitat as having the highest potential return rate. While large size class mammals (i.e., antelope and deer) are present on the prairie proper as well, their densities are not expected to match those of the prairie-riverine habitat for two reasons: (1) the Gulf Coastal Plains and Marshes are on the eastern fringe and outside the recorded range of antelope therefore their densities are not expected to be as high as further west; and (2) deer tolerate and adapt to more open range but the reduced mast resources and cover will maintain their densities below those in the prairie-riverine habitat. For these reasons, we suggest that the prairie habitat ranks second in potential return rate. It is important to note, however, that the prairie habitat is the preferred habitat of bison and therefore, when bison are present in the region on a seasonal basis or during an extended time, the prairie will move up to the number one rank in terms of potential return rate.

The beach-prairie fluvial habitat (i.e., marshes) is home to no large size class mammals and only one medium size class species (i.e., the beaver) is found there in low densities. In contrast, a diverse group of small size class mammalian species are common in this habitat and in combination with high densities of large fish and large birds they contribute to the third rank in terms of potential return rate. The fourth ranked habitat in terms of potential return rates is the bay-estuary-lagoon habitat on the strength of high densities of small and large fish, shorebirds and waterfowl, molluscs, amphibians and reptiles that represent small prey packages. The beach-beach proximate habitat is the lowest ranked habitat in potential return rates found in the Corpus Christi area. The principal prey species consist of small packages (i.e., amphibians and snakes) and they occur in relatively low densities compared to the neighboring bayestuary-lagoon habitat.

Because of the seasonal nature of the biological assemblages, no habitat contains the totality of resources needed by human populations at all times (see Chapter 8). Seasonal climatic changes that precipitate the immigration or emigration of species from a habitat can affect the ranking of the habitat since they can result in increases or decreases in the density of high ranked resources. As mentioned above, seasons of bison abundance on the prairie may cause the ranking of the prairie to increase above that of the prairie-riverine habitat. In contrast, high human population densities and hunting pressures within the prairie-riverine habitat may drive out deer into less preferred neighboring habitats. However, immigration or emigration of species from the other three habitats are not expected to affect their ranking because these migratory patterns are temporally/seasonally synchronized so that bird migrations or the spawning migration of fish will occur and impact all three remaining habitats at the same time. In addition, even with the influx of high numbers of large fish and birds, the ranking of these three habitats will not climb to that of the top two habitats unless deer densities in these other two drop catastrophically. While edible plant resources occur in each of the five habitats, their ranking is so low compared to animal packages that they make no significant impact on the overall ranking of the habitat itself.

\section{Region-Specific Modeling and Expectations}

\section{The Regional Land-Use and Subsistence Model}

In this section, we define a series of expectations regarding hunter-gatherer regional land-use patterns and subsistence strategies through space and time. While the discussion addresses regional-scale patterns, we will also focus on how these patterns may implicate changes in the use and function of $41 \mathrm{NU} 2$ over time.

Earlier in this chapter, we proposed that when bison are present only in low numbers or are absent (i.e., latter part of the Early Archaic and Middle Archaic periods) on the Coastal Plains and Marshes the prairie-riverine habitat would be ranked highest in terms of potential intake rates based on high population densities of deer. Based on the habitat choice model, because the prairie-riverine habitat offers the highest 
potential intake rate we would expect that the earliest huntergatherer populations coming into the region would situate themselves in this most productive prairie- riverine habitat.

Therefore, we would expect that some of the oldest traces of occupation within the region (i.e., residential campsites) would be found within the prairie-riverine habitat. Daily foraging trips would be contained within the river valley and may access resources upstream and downstream as well as at the ecotone between the woodlands and the grassland prairie. Differences in site size may be due to differences in occupation length, which may in turn be conditioned by the productivity of certain resources within the habitat. Similarly, the presence of hyper-productive resources (e.g., pecan groves, oak motts) may facilitate the formation of seasonal population aggregation sites such as those hinted to in the Cabeza de Vaca accounts (see Chapter 7). Aggregation sites may be identified through the presence of features, facilities (e.g., hot rock ovens) and/or a preponderance of tools employed in bulk processing (e.g., grinding stones), temporary storage facilities for processed resources, and a higher richness of tool stone sources present in the unmodified lithic debitage than in residential sites. Of course, the bulk exploitation of certain resources may not require a specialized tool kit (i.e., the exploitation of prickly pear patches described by Cabeza de Vaca) and therefore may leave few technological or archeological indicators.

During the early stages of prairie-riverine habitat occupation, subsistence practices would be focused on the hunting of deer from residential camps during daily foraging trips. Given high return rates and reduced transportation costs, no field processing of the carcass is expected. As, intrahabitat return rates decline and foraging radii increase, field processing may be adopted with low meat-utility elements being discarded in the field rather than returned to residential camps (Bettinger and Malhi 1997). Low ranked animal species may be included in the diet when captured during daily foraging trips. The species of plants and low ranked animals represented in the faunal assemblage of individual prairie-riverine foraging sites will depend on the season of occupation and the post-encounter ranking of the resource or its hyper-productive status, or may be totally unrelated to its ranking based on return rates if obtained by women and children during daily foraging trips.

The habitat selection model predicts that as hunter-gatherer population densities increase friction between groups will begin to interfere with efficient foraging and depletion of resources will cause the widening of the diet breadth. Although, it is expected that initial increases in diet breadth will result in decreased search costs, over time, as more lower ranked resources are incorporated into the diet, neighboring habitats may provide higher encounter rates for lower ranked prey types if they represent the prey's preferred habitat. Initially, adjustments in resource procurement may simply consist of increases in daily foraging trip lengths and greater residential mobility (e.g., both the length and frequency of moves). Logistical mobility may also be employed to reach more distant but more profitable resources such as deer, pronghorn or bison. Such increase in range of mobility may reach a point where some of the species that are included in the diet will come to represent a large proportion of the optimal diet. If the preferred habitat of these species is outside of the prairie-riverine habitat, human populations may relocate to the new habitat. In addition, when the optimal diet has broadened to this extent, either as a result of interference or resource depletion, it is expected that newly arriving huntergatherer groups will begin to settle in the habitat with the second highest potential return rate.

As the diet breadth widens, animal species that rank immediately lower than deer will be pursued by hunters and included in the optimal diet. Deer will continue to be pursued when encountered but because encounter rates are expected to be depressed within the prairie-riverine habitat, it is likely that their representation in faunal assemblages will be biased by field processing in response to greater travel distances. The logistical procurement of deer and pronghorn antelope from the neighboring prairie may further influence the portions of the carcass represented at residential sites. A broad range of plant resources and small-bodied animal species may be included in the diet to alleviate significant day-to-day and seasonal fluctuations in caloric intake.

We would expect the prairie habitat to be the place to draw the next waive of hunter-gatherers coming into the region. However, characteristics of the prairie proper related to its suitability for habitation, such as lack of freshwater and decreased availability of fuel may detract from the intensive residential use of this habitat. However, heavily wooded patches, such as oak motts found near springs or other sources of freshwater, may provide favorable habitation locales. Nonetheless, given its high potential return rate, we expect that the exploitation of high ranked mammalian species through logistically organized mobility will occur within the prairie habitat. As suggested under the discussion of central place foraging, logistical mobility can be a profitable strategy through which to procure high-caloric-yield resources when their density is below the threshold that would encourage nearby settlement. Cabeza de Vaca (1555) describes what appear to be small logistical groups venturing onto the prairie to hunt deer during three-day forays. In addition, however, communal drives that resulted in the impounding of large numbers of deer are also described (see Chapter 7). These 
communal drives that relied on fire to concentrate prey and lead to their impoundment, may have been practiced because of low deer population densities in portions of the Coastal Plains under which individual pursuit or ambush hunting may have only lead to low encounter rates. Communal drives, on the other hand, as we mentioned earlier, can result in high return rates especially when all of the prey secured is seen as the product of a single procurement episode.

Even when bison were present on the prairie and the habitat attained the highest rank in terms of potential intake rate, hunter-gatherer groups may have faced the same habitat suitability constraints. It is therefore possible that even under such circumstances, the intensity of habitat use was less than expected or the organization of habitat use was different from that of the prairie-riverine habitat. That is, the exploitation of the prairie habitat may have taken place under logistical organization rather than through residential mobility.

Population packing in the prairie-riverine habitat in combination with the unfavorable living conditions on the prairie proper may have pushed human populations into lower ranked beach-fluvial interface (i.e., the marsh) habitat. The exploitation of the beach-fluvial interface habitat may have most likely occurred from the nearby prairie-riverine habitat because marshy areas are rarely suitable for human habitation. Nonetheless, the presence of small prey species in conjunction with high encounter rates result in moderate potential intake rates in this habitat. We expect that the exploitation of this habitat would increase as the diet breadth increases in the prairie-riverine habitat and as the resources that are incorporated into the wider diet within that habitat approach the return rates for species present in the beach-fluvial interface habitat. Given the low suitability of this habitat for human settlement, we would not expect that under conditions of increased population packing, new immigrant groups or fissioning groups would flock to the beach-fluvial habitat unless regional population densities reach a level where interference or depletion severely lower the potential rate of intake within the two higher ranked habitats. Given the presence of fish and waterfowl it is likely that this habitat would have been exploited by both male and female foragers. There may have been more overlap in prey species procured by men and women from this habitat than in the previous two because the encounter rate of higher ranked prey species is expected to have been lowest of the three habitats discussed so far.

By definition, the diet of groups inhabiting the beach-fluvial interface habitat would include a preponderance of lower ranked prey species. Nonetheless, deer/antelope may be present since hunter-gatherers are expected to pursue these species when encountered. Low densities of these animals in this habitat may translate to higher transportation costs upon a successful kill leading to field processing prior to transport. Given the seasonal abundance of migratory waterfowl as well as some schooling fish species, we expect some degree of seasonal emphasis on the procurement of fish and waterfowl. The seasonal procurement of partially submerged tuberous/ bulbous plant species should serve as a key supplement to a diet consisting primarily of lower-ranked food items. Again, Cabeza de Vaca (see Chapter 7) describes a concerted effort on the part of hunter-gatherer groups to target partially submerged edible plants as well as the effort necessary to process these species for consumption.

While the processing of some plant species appears to have been extremely energy-intensive, the potential to procure large quantities of low return rate resources (i.e., schooling fish; bird eggs) with minimal or low amounts of energy input may have made this habitat a critical resource at least on a seasonal basis when the diet breadth was very broad due to lowered encounter rates with higher ranked species. The use of technologies that would allow bulk procurement (e.g. netting for fowl, baskets for schooling fish, and fishing nets) even when these resources have subsequent processing costs (e.g., sun-drying salted fish) may have still made the strategy profitable if sufficiently large number of prey were encountered and procured. In addition, the availability of large quantities of resources that have no or minimal processing costs would also have added to the attractiveness of the habitat for foragers. In light of recent research in optimal foraging of small bodied prey species (Ugan et al. 2003; Ugan 2005), it is important to recognize that the potential ranking of schooling fish as a highly profitable resource would be dependent on the size of the fish as well as the technological investment in procurement and processing technologies. That is, the procurement of anchovie-sized fish is not energetically profitable if a great degree of effort is invested in the manufacture of nets and post-encounter processing (i.e., grinding salted fish for fishmeal). On the other hand, however, the harvesting of larger fish and reductions of effort invested in procurement (baskets as opposed to nets) and processing (sun-drying rather than grinding) technology has the effect of greatly increasing the energetic ranking of these resources.

The bay-estuary-lagoon habitat is fourth among the five coastal habitats in terms of potential intake rate. The bayestuary-lagoon habitat proper is not directly habitable, therefore we expect that typically it was utilized while populations lived on the nearby shores. On a seasonal basis intermittent creeks flowed into the estuaries from the nearby uplands, and may have allowed occupation adjacent to the mouths of such creeks. This would have offered a rare source 
of freshwater that appears to have been of short supply in this habitat. Exploitation of the small to very small prey species present in this habitat could have occurred on a seasonal basis when potential return rates in neighboring habitats would have been depressed due to low encounter rates with higher ranked resources. We expect foragers to have been present on the shores of these estuaries on a daily basis. The archeological signatures of such low-intensity and intermittent presence along the shores of estuaries may over time combine into a palimpsest of features and occupation debris. The debris may be the product of short term (i.e., daycamp) use and specialized processing stations if the fieldprocessing of molluses and fish contributed to the lowering of transportation costs and increased maximum travel distance. At points along the shores of estuaries, where intermittent creeks flowed into these bodies of water, the availability of drinking water may have contributed to longer settlement and systematic reuse during the rainy season.

As in the beach-fluvial interface habitat, within the bayestuary-lagoon habitat the availability of migratory prey species and schooling fish species has the potential to increase encounter rates leading to highly profitable bulk procurement episodes. Rudimentary technology (e.g., baskets) and minimal post-encounter processing (consuming sun-dried fish) can further increase the profitability of these prey species or resources. The availability of low ranked resources that can be bulk-procured may in fact raise the ranking of the habitat particularly on a seasonal basis (but see Ugan 2005). It is therefore possible that this habitat may have been exploited on a seasonal basis even when human populations were concentrated in higher ranked habitats such as the prairie-riverine zone. Short-term exploitation episodes targeting lower ranked resources harvested/procured in bulk would have left little residential refuse and minimal signs of bulk processing if such processing was rather low intensity (i.e., sun-drying).

The beach and beach-proximate habitat is the lowest ranked among the five defined on the coast. It has a low potential return rate but portions of it are in the vicinity of the bay-estuarylagoon habitat and therefore it may serve as staging grounds for short procurement trips into the estuaries or processing stations for resources identified for transport. For instance, Cabeza de Vaca (1555) indicates that groups inhabited the barrier islands and the account suggests that access to some parts of the coast may have been limited to certain groups. We do not know whether this reflects the presence of territorial groups on the coast but beachfronts, more than many other resource configurations, may be territorially defendable at reasonable energetic costs. Groups along beachfronts may not have owned the resources within these bodies of water, but control of the access points to those resources may have ar least limited where the resources were harvested from. The large prickly pear patches and highly productive, though cyclical, pecan forests also were not owned as far as we can establish from the accounts reviewed. Regardless of whether access was controlled or not, the presence of cemeteries on the coast as well as inland in the vicinity or within pecan forests may be related to the development of territoriality and may be intended to mark territorial boundaries or possession of a spot on the landscape. Alternatively, rather than reflecting territoriality, the presence of cemeteries may be a signal of usufruct rights to specific parts of the landscape, habitats and perhaps patches of resource.

\section{Hypothesized Changes in Function and Use at $41 \mathrm{NU} 2$}

Having presented a broad model of regional land use and subsistence strategies by coastal hunter-gatherers, we can now present a series of hypotheses regarding the role the Cayo del Oso site may have played in this model, how the role may have changed over time, and how the material remains found at the site may be reflective of the pattern of site use and subsistence practices at 41NU2, the Cayo del Oso site.

In Chapter 1, we described that the site sits on the shore of a shallow estuary bay, False Oso Bay, less than one kilometer from Corpus Christi Bay. A small intermittent creek, the False Oso Creek drains into False Oso Bay near the southern end of the site. The location fronts the Bay-Estuary-Lagoon habitat and the Prairie habitat surrounds it on land. These habitat conditions have most likely changes dramatically over time significantly influencing the resource base and structure in the vicinity of the site. Ricklis focuses on the development of estuarine habitats as the primary factor conditioning an intensified use of the margins of Corpus Christi Bay after about 3000 years B.P. Nuclei of transgressive barriers may have begun establishing estuarine conditions within the bays of the coast even as early as 6800 B.P. although changes in sea level may have influences the productivity of proto-bays and lagoons favoring human exploitation or abandonment as suggested by the hiatus of C-14 dates between $6800-5900$ and 4200-3000 B.P. In addition, Albert's (2006) analysis of pollen spectra from Swan Lake and Nueces Bay indicates that several periods of sub-tropical to tropical conditions may have alternated with more mesic conditions between 7100 B.P. and modern conditions leading to shifts between rather wooded and more open grassland terrestrial conditions in the Copano and Nueces Bay areas. We mentioned earlier that the prairie habitat may shift in potential return rate between the top two ranks dependent on the presence or absence of bison. We also indicated that certain features of the prairie habitat, such as lack of drinkable water, lack of firewood, make it less attractive for human habitation unless oak motts 
and sources of drinking water can be located. Finally, we also mentioned that mast production may be one of the key resources influencing deer population densities. Given the effect of these changes to both the estuarine habitat and to the structure of the resources and the potential return rate of terrestrial habitats, it is critical that the climatic conditions and vegetation communities present in the vicinity of $41 N U 2$ be defined. Depending on which climatic/vegetation conditions prevailed and how they shifted over time, several potential reconstructions of the occupation history of $41 \mathrm{NU} 2$ are likely.

If estuarine conditions were not fully developed until sometime after 3000 B.P., prior to this date human populations would have likely concentrated in the prairieriverine habitat located well upstream of the site. Protoestuarine conditions may have resulted in increased biomass that may have been accessible to human populations from the shores of Corpus Christi Bay using specialized technologies such as canoes and netting. Therefore, under these conditions we hypothesize that human occupation of $41 \mathrm{NU} 2$ would have occurred primarily during periods of higher effective moisture and would have been of a short-term extractive nature where foraging groups would have reached the locality through overnight foraging forays from inland residential camps located in prairie-riverine settings. The distance from the mouth of the Nueces River to the site is approximately $35 \mathrm{~km}$, slightly outside of the typical daily foraging distance. During such extractive forays, gathering groups would have concentrated on the procurement of low ranked resources such as birds, fish and molluscs.

From this hypothesis we can derive a series of specific expectations regarding the nature of change in occupation of 41NU2. Specifically they include the following:

(1) the earliest occupation of 41NU2 may well predate the formation of the barrier islands therefore the oldest dates should fall prior to 3000 B.P.;

(2) the material remains associated with these early occupations would consist of limited debris from the extraction and processing of small quantities of resources at day-camps (i.e., shell concentrations; small thermal features);

(3) resource extraction would have focused on fish, mollusks and birds;

(4) in the absence of suitable watercraft and technology to allow the efficient exploitation of deeper waters, molluscs and fish otoliths would reflect the exploitation of shallows as opposed to deep aquatic environments;

(5) repeated seasonal use of the site would lead to palimpsest occupation surfaces resulting from multiyear reuses of the locality;

(6) extended periods of higher effective moisture on a seasonal basis would lead to systematic re-occupation of the site, the accumulation of abundant organic debris from site use, food preparation and discard; and

(7) such periods should correspond to higher richness in prey species representing the systematic exploitation of both terrestrial and aquatic species and greater density of features;

(8) an increase in deer skeletal specimens in the faunal assemblage should correlate with such occupations;

(9) the increased role of hunting would result in higher numbers of projectile points in assemblages;

(10) seasonal short-term occupations of the site should generate lithic tool assemblages characterized by low richness due to the relatively narrow range of activities carried out on site; and

(11) lithic resources would be dominated by materials obtained further upstream where stone tool materials are more common and of larger size.

We expect that until the establishment of the hyper-productive bay-estuary-lagoon system or major shifts in regional climatic regimes, the exploitation and use of $41 \mathrm{NU} 2$ would be characterized by short-term intermittent (i.e., opportunistic) and systematic seasonally recurrent strategies. The focus of residentially mobile populations would be the prairie-riverine habitat and the exploitation of the 41NU2 site would be in a supportive and seasonal role. We suggest that the preferred seasons of visits to and exploitation of the coast (i.e. the area of 41NU2) would potentially be conditioned by the resources being targeted for extraction. For example, fall and spring exploitation of the coastal belt would provide access and opportunities for the en-mass extraction of schooling fish and congregating birds. Exploitation of coastal areas near the ends of the seasonal rainy seasons would increase access to fish populations that may be trapped in shallow pools of water as these dry up and become less numerous. Winter and mid-summer (i.e. around July) exploitation of the coastal 
habitats would provide easier access to molluses and the few winter-spawning fish that would be found in the shallows.

Over time, increased human population densities in the prairieriverine habitat would result in lower potential intake rates through interference and depletion of resources. How long it would take for a noticeable decrease in resources depends on the density of human population and the density of resources within habitats, as well as a variety of other factors including extractive technologies employed, mobility strategies practiced and the potential of resources to regenerate. The depletion of resources will favor the "colonization" or movement of new or fissioning population segments from the prairie-riverine habitat into the vicinity of the bay-estuarylagoon habitat and to the area of 41NU2. Although such a population influx into the habitat may happen even before the establishment of full-blown estuarine conditions (i.e., the formation of barrier islands), it is most likely that the bayestuarine-lagoon habitat will reach its highest potential return rates once the estuaries are established and high effective moisture conditions prevail across the region. We perceive this full-scale shift of human populations into the habitat as triggered by population packing and reduced potential return rates in higher ranked habitats and the increase in potential return rates in the bay-estuary-lagoon habitat brought on by the establishment of estuarine conditions and long-term high effective moisture regimes (i.e., mesic climatic regime). The change in land use orientation would be brought on by resource depletion in the prairie-riverine habitat and reinforced by the increase in potential return rates in the bay-estuary-lagoon habitat. Such a shift would represent a dramatically different use of the habitat and the site itself. That is, in contrast to the previous pattern, the bay-estuarylagoon habitat and its proximity will represent the focus of year-round resource extraction and mobility with logistical moves outside of it to obtain higher-ranked resources from neighboring habitats.

We propose the following series of specific hypotheses regarding this shift in the nature of occupation of the bayestuary-lagoon habitat and of 41NU2, itself:

(1) the shift in intensity and the nature of occupation of 41NU2 should occur as a result of out-migration of hunter-gatherer populations from the prairie-riverine habitat and would be made feasible by the formation of the barrier island and therefore should post-date 3000 B.P.;

(2) the archeological remains associated with these occupations should consist of abundant debris derived from a combination of extraction and processing of seasonally available hyper-productive resources (i.e., molluscs, fish and birds) and residential occupations associated with seasonal exploitation of the resources found in the habitat;

(3) resource extraction would have focused on fish, mollusks, birds and small to very small terrestrial species secured during daily foraging trips;

(4) some hyper-productive resources found within the habitat (i.e., schooling fish) may provide systematic opportunities for bulk extraction and this in turn may lead to the construction of facilities (i.e., drying facilities) and use of technologies (i.e., grinding) that facilitate bulk processing (i.e., fish meal) and perhaps even storage facilities (see Ugan 2005, however);

(5) highly ranked resources such as deer, antelope and bison would be obtained through logistical excursions into the prairie-riverine and prairie habitats;

(6) due to the greater transportation costs involved, skeletal elements of highly ranked mammalian species found at 41NU2 would be biased in favor of high-meat utility elements as lower ranked elements are discarded during field processing;

(7) as a result of longer seasonal occupations, a greater variety of activities would be carried out on-site leading to increased richness in feature types;

(8) similarly, an increased richness in functional tool forms is expected as a result of the greater variety of activities and longer site occupation;

(9) as in the previous instance, lithic resources would be dominated by materials obtained further upstream where stone tool materials are more common and of larger size; the procurement of such resources would be imbedded in the long-distance logistical forays;

(10) because of longer term use of the habitat, however, it is expected that the stone tools discarded under such occupations would be more heavily reduced and a greater emphasis would be placed on rejuvenation and recycling of artifacts.

Albert's (2006:172) pollen spectra suggest that the modern still stand period from approximately 3050 B.P. to modern 
times is characterized by high effective moisture levels. The formation of full-scale estuarine conditions sometime after 3000 B.P. would have created conditions that favored intensive utilization of the bay-estuary-lagoon habitat, particularly if population packing in the prairie-riverine habitat had a negative effect on potential return rates for hunter-gathers. As a result, the depositional zones accumulated following 3000 B.P. should be rich in organic materials, artifacts and features and such zones should not oscillate with less organic depositional zones because the favorable resource conditions would have persisted during the remainder of the Late Archaic and Late Prehistoric periods, according to Albert (2006).

Finally, population packing, high population densities, and the potential to control access to seasonally hyperproductive resources may have brought together a series of factors that favored the establishment of some degree of territoriality and the control of access to coastal resources by limiting access to stretches of the coast. If such was the case, the establishment of cemeteries may have potentially served as a strong symbolic marker of a certain usufructright to the resources of a locality, if not out-and-out ownership of the access routes to those resources. On the other hand, the multiple sites containing cemeteries within the Coastal Plains region may simply be the product of repeated revisiting and extended stays in localities endowed by a predictable food supply.

\section{Defining Research Problems, Data Types and Analytical Approaches}

Unlike typical research designs where much effort is spent in identifying analytical units, in our case, given the nature of the monitoring project, we will work with features and aggregates of features (i.e., multiple features composed of distinct, thin scatter of shell, small flecks of charcoal and burned clay, and animal bone, all confined to a specific paleosol) that form occupation zones, as the basic analytical unit. Therefore, the discussion of research problems and analytical approaches that follows is not tied to the typical analytical units expected to derive from most data recovery projects.

The discussion of the research problems begins with a brief statement regarding the relationship of the needed research to the overall study. This is followed by a number of specific research questions for which answers will be sought and the listing of the analytical approaches that were proposed in the research design to answer the questions and address the overall research problem. Each section is closed with a brief discussion of the data types used and the actual analyses performed.

\section{Research Problem: The Need For a Site- Specific Paleoclimate Record}

Earlier in this chapter, we presented a general model of the land use and subsistence practices that we expect to have occurred on the middle portion of the Gulf Coastal Plains and Marshes. We also developed a series of specific expectation regarding changes in site function, site use and concomitant material correlates that we should encounter in the materials recovered from 41NU2. Underlying these specific expectations are three key factors, oscillations between tropical and moisture rich periods, human population packing and concomitant reductions in return rates within given habitats, and the formation of barrier islands, that have influenced and conditioned the types of prehistoric resources and their structure which in turn influenced the types and nature of human occupation of $41 \mathrm{NU} 2$.

Given the critical role of environmental conditions, and because Albert's (2006) analysis is the first and only regionspecific reconstruction of terrestrial conditions, we propose that one of the first research needs is the development of a site-specific paleoclimatic sequence.

\section{Associated Research Questions:}

(1) What is the paleoclimatic record as manifested at $41 \mathrm{NU} 2$ and how does it compare with sequence established by Albert (2006)and does it have any implications for the periodic sea level changes suggested by Ricklis (2004)?

(2) Do the trends in site-specific paleoclimatic conditions correspond with changes in the structure of the economically usable resources proposed in the broader regional model?

(3) Do the oscillations in sparse- and heavy-organic content strata at $41 \mathrm{NU} 2$ reflect periods of rapid and slow deposition, respectively or do they represent different intensities of site use?

Proposed Research: A variety of analytical approaches and archeological data types can provide primary or secondary proxy information on climatic conditions. Those approaches and data types that we hoped to recovered from 41NU2 are briefly reviewed below.

Pollen, primarily from bogs and dry caves in Central, North, and far West Texas, has been used extensively to reconstruct past climates within the state (e.g., Bousman 1994, 1998; Bryant and Shafer 1977; Camper 1991; Potzger and Tharp 
1943, 1947). Under conditions of constant moisture, slightly acidic soils, and rapid burial, pollen preservation is often excellent, and when dates are available, pollen can provide detailed reconstructions of vegetation communities. Unfortunately, pollen does not seem to preserve well in open sites, in locations with alkaline sediments, or locations that experience frequent shifts in moisture. In these settings, pollen samples are likely to be characterized by low grain counts and selected preservation of certain, hardy spores (see Bryant and Holloway 1985; Bryant et al. 1994; Holloway 1989). While characterized by alkaline sediments, the overall conditions at $41 \mathrm{NU} 2$ suggest that pollen may be preserved, especially in the pond sediment. Although preservation of pollen within the dune may be less likely (as Kibler 1994 found), pollen has been found preserved within clay dune deposits elsewhere (e,g, Rhodes and Rich 2004) and it would be worth checking the buried soils within the dunes to see if pollen has been preserved. If this is the case, the analysis of pollen from this region may prove to be a significant addition to our understanding of past climate in this region.

Diatoms are microscopic, unicellular photosynthetic algae that are found in a wide variety of damp terrestrial and aquatic settings. With silica cell walls, diatoms are resistant to many chemical and mechanical processes that differentially destroy pollen. As such, they have high recovery potential in many archeological settings. As a group, diatoms appear to be found over a wide range of environments (see Battarbee et al. 2001; Patrick 1977; Owens et al. 2004). While not extensively used in Texas, there are several studies within the state that attempt to use diatoms for the reconstruction of past environments (e.g., Winsborough, 2004, 2007). Diatoms are used extensively in paleoenvironmental reconstruction in other regions (e.g., Weckstrom et al. 2006). Several individual species of diatoms have specific tolerances to factors such as $\mathrm{pH}$, salinity, pollutants, water temperatures, and water depth, and the presence of specific species, as well as shifts in the number and overall richness of species (see Bloom et al. 2003; Cumming and Smol 1993; Kindt and Small 2002). As such, an analysis of diatoms may provide important data on local as well as regional conditions. There is a high probability that diatoms will be recovered from the cores, especially in the pond setting. If so, their analysis may potentially provide direct information on moisture regimes, temperature, and salinity levels, all of which have implications for resource structure.

Opal phytoliths are, in effect, copies of plant cells and intercellular spaces that are produced as a result of plants ingesting water that has dissolved silica present. Phytoliths form in a variety of plants, though they are best studies in grasses. A wide variety of shapes may be associated with a given species, and roughly similar shapes can occur in unrelated species. Nevertheless, it appears that classes of shapes and relative frequencies of phytoliths can be used, in several cases, to identify grass and other plants at the species level (Ollendorf et al. 1988; Piperno 1988; Rovner 1983). Several phytolith studies focused on reconstructing paleovegetation, and by extension paleoclimate, have been undertaken in Texas. Robinson's work $(1979,1982)$ in coastal and near coastal settings has been discussed previously. Additional studies have been conducted in the Rolling Plains region of Texas (Fredlund et al. 1998), central Texas (Fredlund 1994), and in far west Texas (Buck 1993). Phytoliths share some similarities with diatoms in that they are composed of silica and are, therefore, resistant to decomposition. As such, they have a high probability of being recovered from most contexts, and there is a high probability that phytoliths will be recovered from our cores. If so, their analysis should provide direct information on vegetation present, as well as changes in that vegetation. In that regard, phytolith analysis would prove complementary to the analysis of pollen by providing a direct measure of local vegetation shifts.

Ostracods are small aquatic crustaceans that secrete a bivalved shell made of low magnesium calcite and they are a common component in aquatic deposits in general (cf. Holmes and Chivas 2002a; Boomer 2002) and have been previously examined in this region (cf. Cronin 1986). Although the paleoenvironmental record provided by ostracods is often less detailed than that offered by diatoms, these microfossils are quite easily used to distinguish between major environmental shifts such as are locally present (e.g. marine, lagoonal and freshwater) and these microfossils may be preserved in the pond sediment. Although the late Holocene changes in ostracod fauna within the pond are expected to be minimal, there may be a climate signal associated with drier periods, when more marine taxa may be present owing to eolian transportation. For this reason, it may be worth characterizing the pond ostracod fauna. A second reason to examine the ostracods is that their shells may be used to provide a chronology. The biogenic calcite shell or test of ostracods has been successfully radiocarbon dated previously and appears to yield reliable radiocarbon ages (Holmes and Chivas 2002b:199).

In addition to microfossil proxy records of environmental and climatic change, the lithological sequence of dune growth and stability, as denoted by the presence of alternating bands of light colored pedogenically unaltered dune sediment, and weakly developed buried soils within the clay dunes may provide a record that is climatically sensitive. Clay dunes, lunettes, or lomas, as they are locally known, are a form of source-border dune that are formed from the deflation of sand sized aggregates of mud from fringing mud flats. The production of sand-sized clay aggregates that are available 
for wind transport is facilitated by salt crystal growth in the drying mud flat. The driving force in clay dune formation is clearly one of local hydrology (cf. Bowler 1973; 1983) but studies of some dunes (e.g. Holliday 1997:67) have concluded that because local hydrology responds to region climate, the lithological record of such dunes may have regional paleoenvironmental significance. Huffman and Price (1949:120) note that the formation of clay dunes on the Texas coast is strongly related to climate:

\begin{abstract}
"In south Texas, movement of the clay pellets begins in the month of March and continues until November when the growth of the dunes is arrested by winter precipitation and reduced evaporation. Their growth is most rapid during the drier summer months and during periods of prolonged drought."
\end{abstract}

An example of how much sediment may accumulate in a drought was provided by Price and Kornicker (1961:249) who noted that in the 7 year drought of the 1950 s, some dunes accumulated a foot or more of fresh sediment. Price and Kornicker (1961:246) have also noted a climatic influence on the size of clay dunes with the dunes being highest near the Rio Grande Delta and lower toward the progressively more humid climates to the north and south. Given these observations it stands to reason that the periods of dune growth and development may provide a climatically sensitive record, whereby the dune grows during periods of relative aridity and become stabilized during more moist periods when soils form. Erosion of dune surfaces may also occur during periods of high effective moisture or isolated rain events that occur during dry periods as suggested by erosional features detected across the northern and southern dunes at $41 \mathrm{NU} 2$.

One way of testing this hypothesis is to compare the stratigraphy of the two different dunes, and radiocarbon date the buried soil A horizons. Kibler (2006, personal communication; 1994) obtained a sequence of radiocarbon dates on bulk soil A-horizons within clay dunes near the Rio Grande delta and the dates appeared to yield a reasonably good chronology that was consistent with the interbedded archeology. If climate is the driving force behind periods of dune aggradation, then the two dunes can be expected to yield comparable paleosol sequences (in terms of the number of buried soils and their radiocarbon age). If, however, there are significant differences in the soil stratigraphy between the dunes, then other, possibly local, factors other than climate may be critical in the sequence of growth and stability of these clay dunes. Furthermore, if the sequence of dune growth and stability is a regional climate record, the record from the Oso Bay dunes should bear a strong similarity to the record obtained by Kibler (1994) in Hidalgo and Willacy County, near the Rio Grande Delta. Finally, it was hoped that if a pollen record can be derived from the pond, comparison of the dune lithological record with the pollen record may provide a useful test of the hypothesis.

Because the primary goal of the 41NU2 monitoring project was to rapidly document features and exhume human remains when encountered, none of the data types listed above were available to CAR at the end of the monitoring project to adequately address the reconstruction of the paleoenvironment at $41 \mathrm{NU} 2$. Therefore, in the subsequent research design, we proposed to recover six soil columns, two each from the northern and southern dunes on site and two from the buried pond deposit immediately northwest of the site.

At the time of the writing of the research design we also proposed to conduct macrobotanical analysis to identify elements of the vegetation community that was present in the vicinity of $41 \mathrm{NU} 2$. In addition, we hoped that the macrobotanical analysis would identify charred mesquite fragments. Dering (2002:206-7) has developed a technique for measuring the amount of rainfall available during the life of mesquite trees, by studying the variations in the anatomical characteristics of the xylem preserved by charring. Noting that mesquite can adapt to ranges of annual rainfall average of from $20 \mathrm{~cm}$ to $102 \mathrm{~cm}$, Dering (2002:207) states "such adaptability requires a certain plasticity of growth form, and it is these adaptive responses to precipitation that we wish to measure".

Finally, to compliment these data types, we also proposed to carry out the systematic analysis of shell species composition of feature fill from distinct occupation zones as well as of fish otoliths recovered from floated feature fill samples to obtain a profile of changes in species over time. We hoped that such trends would reflect changes in nearby habitat conditions for those organisms. While we recognize that the mollusc and fish species present in thermal features have been influenced by the filter of human selection, we hoped that strong consistent patterns in mollusc and/or fish species representation also may be reflective of changes in habitat conditions (i.e., salinity, stratum).

In proposing these wide ranging research approaches focused on paleoclimatic reconstruction, our hope was that the analyses of multiple independent data sets would provide a more robust foundation from which to reconstruct paleoclimatic conditions. The different data types have different paces and time-lags in responding to changes in climatic conditions and 
as such their composite may provide a more accurate picture of when and how climatic conditions changed on the coast.

Available Data and Analyses Conducted: To systematically investigate changes in paleoclimate and to establish a sitespecific record, TxDOT-ENV accepted CAR's proposal to return to the site and extract the sediment cores that would be critical to the investigation of the paleoenvironmental research problem.

In August 2007, using a Eijkelkamp percussion drilling set and its accompanying gouges, the project geomorphologist, assisted by CAR staff, extracted three soil sediment cores, one each from the pond, and the north and south dunes. Subsequently, the geomorphologist subsampled the cores/ columns to produce samples intended for the analysis of diatoms, pollen, phytoliths, ostracods and a variety of geomorphological aspects. Humate samples were also pulled to allow the dating of the depositional sequences. The potential contribution of each of these specialized analyses to paleoenvironmental reconstructions is briefly outlined below.

To obtain secondary proxy data on paleoclimate heavy fraction from 66 flotation samples of feature fill were submitted to Dr. Phil Dering of Shumla Archeobotanical Laboratory for macrobotanical analysis. Unfortunately, while we had recovered a large number of charcoal samples during the project, and the macrobotanical analysis did identify some mesquite pieces, much of the charcoal consisted of small fragments that were too small to allow for the anticipated xylem analysis. Some of the larger pieces of charcoal that were recovered from the site were not feature-associated and therefore we chose not to submit them for xylem analysis.

The final dataset used in this analysis consisted of the molluscs and otoliths that were extracted from the same 66 feature fill samples floated from the macrobotanical analysis and five additional proveniences derived from occupation zones. In total, therefore, the mollusk and otolith samples from 71 heavy fraction samples were used as proxy data for paleoclimatic interpretations.

\section{Research Problem: Dating of the Human Occupation Sequences Present At 41NU2}

In addition to constructing a regional paleoclimatic sequence, we also need to be able to anchor the climatic phenomenon and human occupation sequences at 41NU2 in time. The earlier presented model and site-specific expectations have made it clear that we expect significant changes in hunter-gatherer habitat preference and site use over time in part due to changes in potential return rates and broad population dynamics and their influence on habitat ranking. It is clear that dating the occupation sequences present at $41 \mathrm{NU} 2$ is critical in terms of the general model and the site-specific expectations.

\section{Associated Research Questions:}

(1) What are the ages of the components identified at $41 \mathrm{NU} 2$ ?

(2) Are there components that predate the formation of the coastal barrier islands indicating that human occupation began prior to dramatic changes in estuary conditions?

(3) How much time elapsed between the formation of organic-sparse and organic-rich zones at 41NU2?

(4) Are dates obtained on oyster shell reliable in the absence of charcoal dates?

Research Proposal: As a primary goal of this research problem, in the original research design, we proposed to submit feature-associated charcoal samples from the tops and bases of each of the organically enriched strata identified at $41 \mathrm{NU} 2$. We also proposed to date multiple features from each occupation zone to ascertain the formation history of the zone. Finally, we hoped to be able to submit multiple samples from a select number of features to determine how long the features may have been in use.

This initially proposed sampling strategy resulted in the identification of 110 samples to be submitted for radiocarbon dating. It quickly became evident that it was financially prohibitive to submit this number of samples. Therefore, upon meeting with TxDOT-ENV staff and discussing the goals and scope of the dating strategy, CAR in collaboration with TxDOT-ENV revised the dating approach.

Available Data and Analyses Conducted: The final dating strategy consisted of the selection of samples from two sequences of features one from each of the north and south dunes. The features were selected in such a manner that they provided a sequence of dates from the top to the bottom of the stratigraphic column of each of the respective dunes. Using this approach, 40 samples were submitted from features. The samples consisted of 20 pairs, one consisting of charcoal and the other of shell (preferably of the same species). In addition, six other samples also were submitted from occupation zones identified during monitoring to define the ages of these proveniences. Finally, 12 humate samples 
were also submitted, four from each of the three geomorphic cores extracted from 41NU2. Two of the cores came from the respective dunes and one was extracted from the pond.

The charcoal and shell samples submitted were considered as paired when the feature-associated charcoal sample derived from soil matrix captured within the valve of a shell or when the charcoal adhered directly to a valve. Such paired samples provide the impression that they are more securely associated with each other than samples derived from within $5 \mathrm{~cm}$ of each other from within the same hearth. Unfortunately, we cannot think of any recovery context that can provide the full-proof evidence of direct association implied for instance by a projectile point stuck into a piece of bone, which is what would be necessary to investigate the reliability of dates derived from shell versus charcoal. Nonetheless, the above described criteria were the closest approximation of such parameters proposed by TxDOT-ENV.

Overall, this revised strategy resulted in the submission of 58 samples and allowed for the coarse-grained dating of the stratigraphic sequence noted in each of the two dunes and also contributed to the investigation of the correspondence between charcoal and shell dates (see Ricklis 2004:157-161). In addition, it allowed us to relate the stratigraphic sequences noted in the geomorphic cores to the ages of the occupations within each dune.

\section{Research Problem: Developing a Quantified Set of Optimal Foraging Models and Expectations}

The model and site-specific expectations are based on the size-related ranking of broad prey/resource classes. For a model and related expectations to be truly quantified and testable, a great deal of information needs to be gathered regarding the caloric yield and density of the prey, costs incurred in harvesting and processing the prey/resource for consumption, and other factors. Such detailed data for the regional resources that would have been available to inhabitants of $41 \mathrm{NU} 2$ could not be located at the time of the writing of the research design. However, recent HBE and Optimal Foraging Studies have shown a great deal of promise in the quantified investigation of hunter-gatherers as well as food producers (see Kennett and Winterhalder 2006 and references therein).

\section{Associated Research Questions:}

(1) What are the caloric contents of distinct potentially economically useful species of animal and plant resources present within the Corpus Christi area?
(2) How does the caloric content of these potentially economically useful species of animal and plant resources vary over the year?

(3) What is the density of the potentially economically useful species of animals within the distinct habitats of the Corpus Christi area?

(4) How do the densities of potentially economically useful species of animals vary during the year?

Proposed Research: The development of solid expectations that are regionally specific has to come from actual quantifiable data on prey densities, caloric content of different prey sources, and time-motion experiments that replicate procurement and processing of regional prey using traditional technologies. As a first step toward the development of a database that will allow the quantification of basic prey characteristics, we proposed to conduct a systematic search to compile an exhaustive database containing information on caloric content of the principal mammalian and plant resources that would have been consumed by prehistoric peoples living at 41NU2. During the research design phase of the project, we had established that some of this data already existed and has been gathered by nutritionists for a limited number of plants and animals. We also knew that in other instances, resources would have to be acquired and submitted for nutritional analysis. TxDOT-ENV staff assessed this portion to be too ambitious and suggested that instead of an exhaustive search, we initiate a pilot project to systematically review and compile the nutritional information that already exists to establish what data exists and what are the gaps in information.

Available Data Needs and Analyses Conducted: As part of the revised approach, we set out to compile information on four distinct characteristics of regional food resources: (a) the caloric content; (b) fat content; (c) protein content; and (d) carbohydrate content. Because the faunal resources are ranked so much higher than most plants, and because our habitat rankings are based on the rankings of animals, we focused our search on the nutritional characteristics of prey animals. We collected information on the (a) caloric; (b) protein, (c) fat, and (d) carbohydrate content of animal flesh of all species that may have been employed as a food source prehistorically. Because of the scarcity of data for species inhabiting the study region specifically, often we had to rely on information for the same or similar species from other regions. 


\section{Research Problem: Reconstruction of Regional Land Use Patterns}

We have discussed earlier that the timing and nature of the occupations of 41NU2 may have been conditioned by various regional-scale dynamics including human population densities, regional climatic conditions, and habitat productivity/profitability. When 41 NU2 began to be occupied and how that occupation may have changed over time can be understood only within broader regional context of hunter-gatherer exploitation of coastal resources.

\section{Associated Research Questions:}

(1) Does the prairie-riverine habitat have the oldest archeological components?

(2) What is the density of archeological sites in the five different habitats?

(3) What was the periodicity of site occupation?

(4) How did this site articulate with other sites within the four other habitats in this region?

(5) Does the repeated occupation and abandonment of the $42 \mathrm{NU} 2$ site represent a response to oscillations in regional climatic episodes?

Proposed Research: In the research design we proposed to conduct two scales of analysis, one site-specific and the other regional in scale. At the site-specific level, we propose to examine the available faunal assemblages to compare the species represented with the ones that are expected based on the model presented earlier in this chapter. We hoped that this inventory would provide us an approximation of the range of habitats accessed by hunter-gatherers from 41NU2. Also, we anticipated that the faunal assemblage may help identify the procurement seasons for the prey represented and this should serve as a proxy for the season of site occupation. We also proposed to determine what was the range of raw materials represented in the collection of lithic artifacts from the site. Minimum Analytic Nodules were to be defined through the study of the color and inclusions present in the lithic artifacts.

At the regional level, we proposed to compile information of site distributions within Refugio, Aransas, Nueces, and San Patricio Counties to serves as a regional database for the investigation of land use. In addition, we proposed to collected detailed information on a number of well reported archeological sites and/or components from within the Coastal Plains and Marshes region.

Available Data and Analyses Conducted: Faunal remains identified in the 71 heavy fraction samples, and all other tools collected during the monitoring project constituted the samples of site-specific materials used in this analysis. Only 33 lithic artifacts were present in the 41NU2 assemblage. The majority are lithic debitage $(n=23)$, and only two are projectile points. In addition, a handful of bone $(n=8)$ and a moderate number of modified shell $(n=83)$ tools also were recovered during the project. These tools, lithic artifacts and faunal remains were the focus of the site-specific analysis.

The small sample of debitage was not grouped into homogeneous categories based on color, texture as was proposed in the original research design. The specimens were for the most part so small that it was felt that they were note necessarily representative of the larger cobles they derived from. Instead, a number of attributes, including the maximum dimension and cortex availability of each piece was noted to define what stage of reduction the specimen represents. The dart points were examined (i.e., various metric attributes) to document their heavy rejuvenation.

As part of the regional-level analysis, we compiled data on the following aspects of sites present in the four counties: (a) the number of sites found within each county; (b) site size; (c) age of component(s); (d) assemblage content by major material culture categories (e.g., chipped lithics; if available, number and types of features and facilities; faunal remains). Using these data on a GIS platform we linked the distribution of sites to precise locations on maps of the region to quantify the following characteristics of site location: (a) distance to nearest freshwater stream; (2) habitat type where site is located; and (3) distances to the nearest habitats.

Finally, we collected information from a small number of previously excavated and reported archeological sites and/ or components within the region to serve as the basis of a comparative analysis of the artifact and faunal assemblages. The 18 sites and/or components were: 41NU11, 41NU184, 41NU221, 41NU266, 41NU267, 41NU268, 41NU276, 41SP15, 41SP43, 41SP120, 41SP136, 41SP148, 41SP149, 41SP153, 41SP156, 41SP177, 41AS3 and 41AS16. Information on these sites and their components is presented in series of technical reports mentioned in Ricklis (2004). The data that was collected included: (a) lithic artifacts present; (b) number and types of worked shell; (c) number and types of worked bone; (d) number and types of ceramics; and (e) mammals and vertebrate and invertebrate taxa present. 
The comparative study relied purely on already published information.

\section{Research Problem: Reconstruction of Subsistence Practices}

The model presented in the first part of this chapter identified a series of hypotheses regarding changes in the manner in which the bay-estuary-lagoon habitat was exploited over time. These changes would have impacted the diet of the hunter-gatherer population as well as the material signatures left behind at 41NU2. Once the effect of differential preservation is allowed for, the faunal and macrobotanical assemblages should play an important role in reconstructing hunter-gatherer diet and resource base at 41NU2.

\section{Associated Research Questions:}

(1) Do the economically useful resources recovered from $41 \mathrm{NU} 2$ reflect the diet breadth expected based on the optimal foraging model and expectations?

(2) What was the role of marine resource in the diet of the prehistoric inhabitants and did this change over time?

(3) Was there a major change in the diet of coastal huntergatherers following the formation of the barrier islands?

(4) Are deer present in faunal assemblages from coastal sites and, if so, what is the meat utility of the skeletal elements present?

(5) Are there economically useful plants that are present at the site?

(6) How does the composition of faunal assemblages vary across the research area as exemplified by comparative assemblages from different habitats?

Proposed Research: As in the case of the land use research problem, in the research design we proposed to conduct two scales of analysis related to hunter-gatherer subsistence, one site-specific and the other regional in scale. At the sitespecific level, we proposed to focus on the materials from heavy fraction samples derived from the flotation of feature matrix.

In addition to this site-specific data, to place the site within a regional context, we proposed to collect data on subsistence resources present within the assemblages of the sites that were also used in the investigation of regional land use patterns. If and when available, we proposed to collect data on the following aspects of the assemblages: (a) proportion of marine and terrestrial fauna represented in the assemblage; (b) taxa present by prey size classes (small, medium and large mammals); (c) distribution of taxa by habitat within each assemblage; (d) if feasible, we proposed to investigate the potential for field processing of resources by determining the skeletal elements represented at each site as well as the mollusc species present and their caloric yield.

Available Data and Analyses Conducted: Seventy-one heavy fraction samples were used for this analysis. They consisted of the 66 samples submitted for macrobotanical analysis and five other float samples not from feature contexts. The mollusc samples derived from the heavy fractions were sorted into species. Animal bone was analyzed to determine the species represented. Unfortunately, the bulk of the sample was unidentifiable to the taxa level. The small amount of mammalian bone recovered from 41NU2 was not quantified by size category into very large, large, medium, small and very small groups as was proposed in the research design. Also, because none of the mammalian bone could be identified to element, the meat utility of the skeletal elements was not determined. Finally, while in the original research design we proposed to submit for macrobotanical analysis all charcoal samples that were not needed for paired sample analysis, this was not done. Instead, we limited the macrobotanical analysis to heavy fraction samples obtained from well provenienced feature-associated contexts (i.e., the 66 samples mentioned above).

To address the regional-level research objectives, we collected the data proposed in the research design from the same 18 sites used in the regional land use investigation. The 18 sites and/or components were: 41NU11, 41NU184, 41NU221, 41NU266, 41NU267, 41NU268, 41NU276, 41SP15, 41SP43, 41SP120, 41SP136, 41SP148, 41SP149, 41SP153, 41SP156, 41SP177, 41AS3 and 41AS16. Some data types that were originally proposed (i.e., breakdown of skeletal elements) could not be collected due to lack of information or necessary detail in the reports.

\section{Research Problem: Relationship Between Distribution of Cemetery Sites and Territoriality}

Given the prevalence of cemetery sites and sites with human burials within the Coastal Plains and Marshes region, and given the cemetery that has been documented at $41 \mathrm{NU} 2$, a better understanding of the role of cemetery sites may improve our understanding of the function of $41 \mathrm{NU} 2$. 


\section{Associated Research Questions:}

(1) What is the distribution of sites with burials across the Gulf Coastal Plains and Marshes region?

(2) What are the ages of the cemetery components or burials present at each site?

(3) What are the habitats that contain sites with burials?

(4) Are sites with individual or small numbers of burials distributed differently in space and time than sites with recognized cemeteries?

(5) Are there differences in burial practices between sites with small numbers of interments versus sites with cemeteries?

(6) Are there any indicators of status differentiation between individual burials in cemetery sites?

(7) What is the incidence of violent deaths in cemetery sites and is there any temporal or spatial patterning in the data?

Proposed Research: In the project research design, we proposed to create a comprehensive Geographic Information System database containing information on all sites with human remains identified throughout the Gulf Coastal Plains and Marshes and immediately surrounding regions (e.g., South Texas; South-central Texas). This database was to include information on individual interments at cemetery sites (e.g., age, sex, orientation, associated grave goods, association with other individual). Additionally, we proposed to collect information on the ages of cemetery-associated components, site size, habitat where site is found; and whether the site had a habitation component. The database was to be employed in spatial analysis to determine whether there are any trends in the spatial distribution of burial-associated sites and whether there are any temporal trends in the numbers and/ or types in associated grave goods and the incidences of violent deaths.
Available Data and Analyses Conducted: The CAR monitoring project identified and exhumed six human remains and Ricklis (1997) also found one. In addition to this small sample, CAR also obtained information on an additional 103 individuals buried at the site and later exhumed by Jackson (see Jackson et al. 2004). These data were added to the regional database. The regionalscale comparative database was compiled from the existing literature on burial sites distributed across the Gulf Coastal Plains and Marshes. We relied on a number of very comprehensive recent summaries compiled by Hall (1995b, 1998) and Perttula (2001) and augmented them by a thorough search of the Texas Archeological Sites Atlas.

\section{Research Problem: Completion of the Inventory of Human Remains for NAGPRA Purposes}

One of the main tasks associated with this project was the completion of the inventory of human remains recovered by CAR during its road construction monitoring activities. This was important because of TxDOT-ENV's obligations regarding the Native American Graves Protection and Repatriation Act.

Proposed Research: In the research design CAR proposed to conduct a 100 percent inventory of human remains from seven individuals uncovered and returned to the CAR laboratory during the project.

Available Data and Analyses Conducted: The complete this requirement, standard osteometric analyses were conducted on the human remains recovered by CAR. The analyses were conducted in accordance with the criteria set forth in the Standards (Buikstra and Ubelaker 1994). The forensic data was compiled for and evaluated in the Forensic Database (ForDisc v.2.0) maintained by the University of Tennessee at Knoxville (Moore-Jansen et al. 1994). The staff human osteologist/physical anthropologist carried out these analyses. The inventory was submitted to TxDOT-ENV under a separate cover. 



\section{Chapter 10: Paleoclimate}

\author{
Steve A. Tomka and Raymond P. Mauldin
}

\section{Previous Reconstructions Of Paleoclimate}

The data on the modern climate described in Chapter 2 suggest that the climate currently associated with $41 \mathrm{NU} 2$ reflects a relatively warm environment with variable monthly and yearly precipitation. However, the degree to which these general climate characteristics are reflective of the past is unclear. While research, particularly during the past decade, has contributed immensely toward understanding the paleoenvironment of the state (e.g., Bousman 1998; Caran 1998; Cooke 2005; Frederick 1998; Fredlund et al. 1998; Nordt et al. 1994; 2002), much of that research has focused on Central, South-Central, and Northern Texas. With a few exceptions, most of which are primarily concerned with shifts in sea levels during the Holocene (e.g., Albert 2006; Blum et al. 2002; Ricklis 2004; Ricklis and Blum 1997; Ricklis and Cox 1998), southern and especially gulf coastal areas have not been extensively studied, a phenomenon clearly tied to a lack of appropriate data sets in these areas of the state. Consequently, what we currently think we know about paleoenvironments in coastal and near coastal settings of Texas is primarily dependent on studies in other portions of the state, as well as on phytolith research conducted along the coast roughly 25 years ago (Robinson 1979, 1982).

Recent overviews of paleoclimate in other portions of the state are available (e.g., Bousman 1998; Cooke 2005; Nickels and Mauldin 2001; Nordt et al. 2002). Figure 10-1 presents a comparison of several of these climate summaries derived from 1) soil organic carbonate from south-central Texas (ca. $200 \mathrm{~km}$ to the north of 41NU2), 2) carbon isotope measurements of humic deposits in Hall's cave (ca. $340 \mathrm{~km}$ to the northwest of 41NU2), and 3) arboreal and grass pollen from bog deposits (ca. $300 \mathrm{~km}$ north of 41NU2). These data sets should all be responding to vegetation changes, though the precise temporal and spatial scale of the shifts in climate variables relative to shifts in these climate proxy data sets is unclear. While these sequences differ in some details, the general pattern that emerges from these (Figure 10-1), as well as earlier studies, is one in which the Early Holocene (ca. 10,000-8,000 B.P.) reflects a cooler, mesic climate, with a slight, gradual drying trend reflected in some data sets throughout the 2,000 year period. A warm and dry Middle Holocene (ca. 8,000-4,000 B.P.) follows, perhaps with a brief mesic period sometime around 7,000 to 6,000 or 5,000 B.P. A return to xeric conditions between 5,000 and 4,000 B.P. follows that mesic interval. The Late Holocene (ca. 4,000 to 0 B.P.) is thought to be generally cooler and/or wetter, with a return to more xeric conditions within the last few hundred years, though this is beyond the scope of the data set.

Coastal climate research is difficult to interpret in light of these more general, statewide patterns. For example, Robinson (1979) discusses the opal phytolith records from two sites (41GD21, 41GD21A) on Colette Creek in South Texas (Robinson 1979:111) that are located roughly $100 \mathrm{~km}$ to the north of 41NU2. Eight samples were processed from six different contexts on these sites. Like those data sets shown in Figure 10-1, shifts in opal phytoliths are reflective of shifts in vegetation. Unfortunately, dating of most of these sample contexts is problematic. Samples 6 and 5 can only be assigned dates of older than about 4,450 B.P., while Sample 4 is associated with a c14 date of $4,260+/-250$, a date that translates into a roughly 900 year range (5,300- 4,400 B.P.) at 1-sigma. Sample 3, again based on radiocarbon dates, can be placed between 5,300-4,400 B.P. and 3,350-2,300 B.P., while two samples (designated sample 2, 2a), can be placed sometime within a 1,050 year period (3,350-2,300 B.P.). Finally two samples designated sample 1 and 1 a are associated with Late Prehistoric material, though that material is also mixed with historic remains. Robinson's data (1979), then, suggest that sometime before about 4,850 B.P., phytoliths from the deepest sample (Sample 6) are reflective of a well developed forest in this region. A more recent sample, but one that also dates sometime before 4,850 B.P., produced phytoliths that suggest an extremely dry period was present. Sometime between 5,300 and 4,400 B.P., there appears to have been a brief mesic period, followed by a dry climate sometime between 4,850 and 3,350 B.P. At around 2,825 B.P. (samples 2, 2a), phytoliths suggest a mesic interval, with a more xeric mixture of both wet and dry species present during the late prehistoric or historic periods.

Additional phytolith work has been conducted by Robinson (1982) at Choke Canyon on sites located roughly $110 \mathrm{~km}$ to the northwest of 41NU2. Using a variety of samples, Robinson (1982:598) infers a cool, mesic climatic regime that shifts to a more arid period sometime prior to 5,300 B.P., a pattern that continued between about 5,300 and 4,300 B.P. He then suggests a return to both cooler and wetter conditions by 3,250 B.P. The Choke Canyon analysis points to mesic conditions (similar to today's) by about 2,540 B.P. (Robinson 1982:598-599). Afterward, a shift to more xeric conditions occurred by about 1,000 B.P., but Robinson suggests that they may have been more mesic than modern conditions (Robinson 1982:599). Unfortunately, like the Colleto Creek 


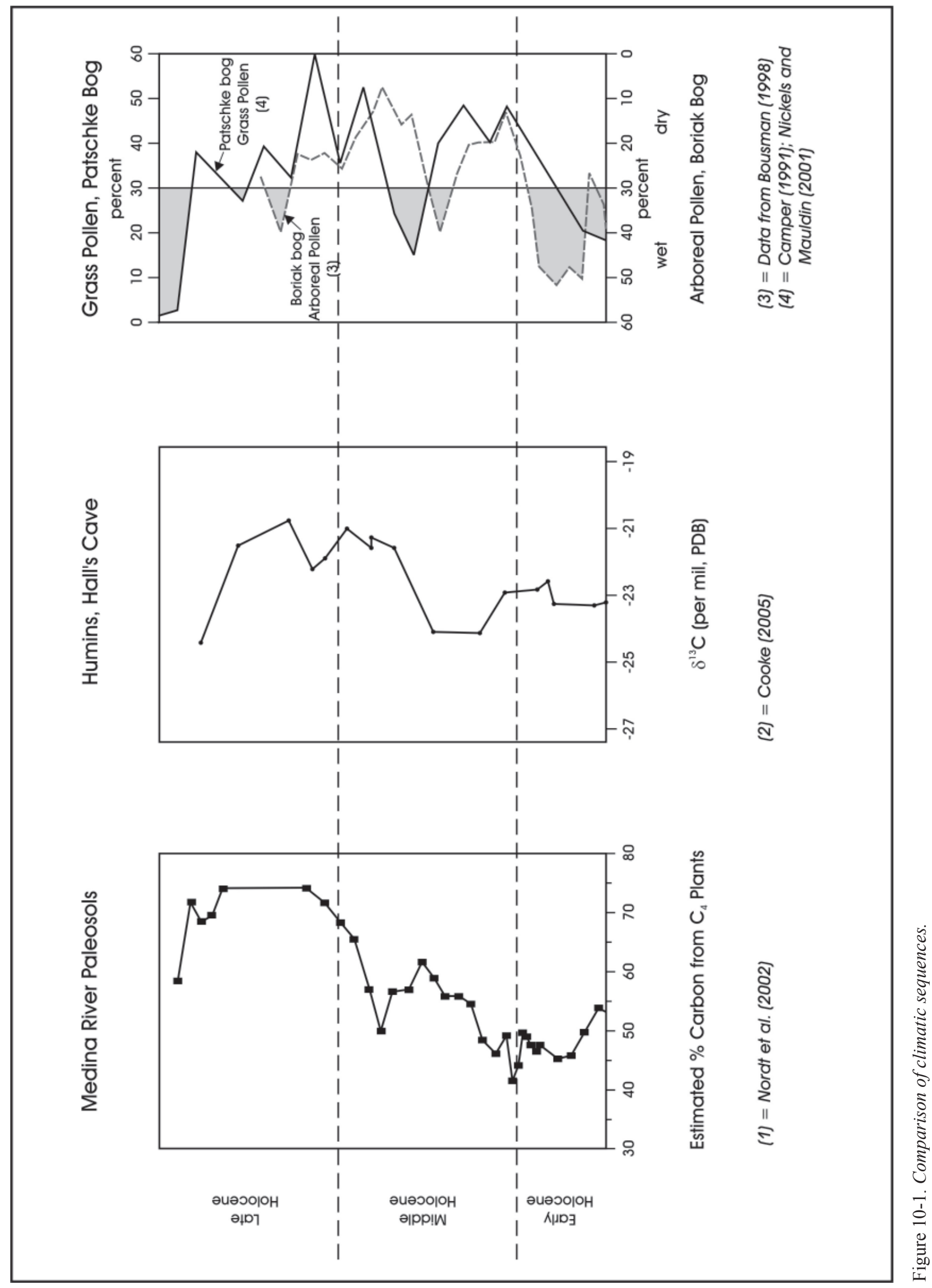


work discussed previously, the samples from Choke Canyon are poorly dated and underreported. It is difficult, therefore, to rely heavily on Robinson's work.

K.A Cox and S.A. Cox (1993) and Ricklis and Cox (1998) present a study of oyster habitat characteristics and growth patters from a series of sites in the Middle Coast. They suggest that estuarine salinity, measured by reference to an ordinal scale developed from the presence and characteristics of oysters, was highest between about 5,000 and 3,700 years ago, with declining salinity after 3,700 B.P. They suggest that these patterns may be a result of low freshwater discharge between 5 and $3.7 \mathrm{Kya}$, and increasing freshwater runoff, probably reflecting increasing rainfall, after 3,700 B.P. K.A. Cox and S.A. Cox (1993:94-95) and Ricklis and Cox (1998:129) suggest that these patterns may be indicative of a dry Middle Holocene, with increasing moisture present in the Late Holocene. Ricklis and Cox (1998) also use the percentage of oyster shells from an assemblage that have "readable" winter seasonality indicators in growth rings. Oyster assemblages with high "readability" were probably formed during cooler periods, while growth of oysters in assemblages dominated by low readability probably occurred during periods of warmer temperatures. Assemblages with high readability percentages, and by extension cooler temperatures, occur at around 7,200 B.P., 5,100 B.P., and between about 2,750 and 1,750 B.P. Conversely, warmer temperatures are indicated from about 4,600 to about 3,000 B.P. (Ricklis and Cox 1998:132). While the connections are tentative, if changes in oyster habitat and seasonality indicate differing rainfall and temperature regimes, the patterns presented by Ricklis and Cox (1998) are consistent with the general patterns outlined previously in which a mesic Early Holocene yields to a xeric Middle Holocene, possibly with a brief mesic interval sometime around 5 to 6 Kya. An initial mesic interval in the Late Archaic follows the warm, dry Middle Holocene.

\section{Coastal Occupation Patterns and Paleoenvironmental Conditions}

Additional paleoenvironmental research, primarily concerned with documenting Holocene sea level changes and proposed development of coastal landscapes, has been conducted in many coastal settings, including the Texas Gulf Coast (e.g., Albert 2006; Anderson and Thomas 1991; Curray 1960; Nelson and Bay 1970; Wilkinson and Basse 1978). In the current context, these Holocene sea level shifts are of considerable interest as Ricklis $(1995,2004)$ has suggested that prehistoric occupation patterns of coastal areas in Texas are closely tied to shoreline shifts. In his view, periods of sea level standstill provided opportunities for the evolution of lagoon/estuary systems along the Texas coast that are highly productive settings for hunters and gatherers. Conversely, periods of rapid seal level rise would have damaged these aquatic ecosystems through increased salinity and disruption of nutrient rich shallows (see discussion in Ricklis 1995, 2004; Ricklis and Blum 1997).

Figure 10-2 is based on calibrated, corrected radiocarbon dates taken from shell and charcoal samples presented in Ricklis and Blum (1997:Table 1). These dates are primarily from archeological sites in Nueces, San Patrice, Refugio, and Calhoun Counties of the Middle Coast. The plot was constructed by using 78 of the 80 dates; two dates with large sigmas were eliminated. The 78 dates were then calibrated using OxCal (Ramsey 2003), and plotted at a 2-sigma range. These plots were then converted into a line graph with an interval of 200 years. One count was made for each time that a date range fell within a given 200 year period. To the degree that the resulting plots reflect Middle Coast occupation patterns, the data clearly suggest two periods of absence, with the most recent occurring between about 3,800 and 3,400 B.P., and the other occurring between 6,700 and 6,000 B.P. Ricklis (1995; 2004; Ricklis and Weinstein 2005; see also Ricklis and Blum 1997) correlate these two absence periods with periods of rapid sea level rises, and periods of occupation with periods of sea level standstill or slow sea level rise. He concludes that by 3,000 B.P., sea levels stabilized near their modern position, allowing development of the modern barrier islands that protect the lagoons and bays and decreased the salinity of the bay waters, resulting in a dramatic increase in aquatic productivity. Using a variety of measures of occupational intensity, Ricklis $(1995 ; 2004)$ further shows that a dramatic increase in the intensity of human use of shorelines does occur after 2,000 B.P., an increase consistent with the model. The Figure 10-2 data also suggest increased occupational intensity after around 2,000 B.P.

While it is clearly the case that occupational intensity does vary in this section of the coast, and while the patterns presented by Ricklis are striking, the proposed explanation linking varying rates of sea level increases and periods of standstill with high or low estuary productivity, and associated occupation to take advantage of that productivity, appear to rely exclusively on one of several competing models of sea level changes. In fact, most recent studies of sea level curves for the gulf coast, as well as data from Bermuda, Barbados, and Belize see Gischler and Hudson 2004; Mackinnon and Jones 2001; Parkinson and White 1994) suggest a model quite different from that used by Ricklis. These more recent models note relatively rapid, continuous and early rise is sea levels up to sometime around 5,000 to 6,000 years ago, with slow increases after that point (see Blum et al. 2002; Otvos 2004; Törnqvist et al. 2004). That is, these models appear to eliminate any prolonged periods of standstills, especially prior to about 2,000 to 3,000 years ago 


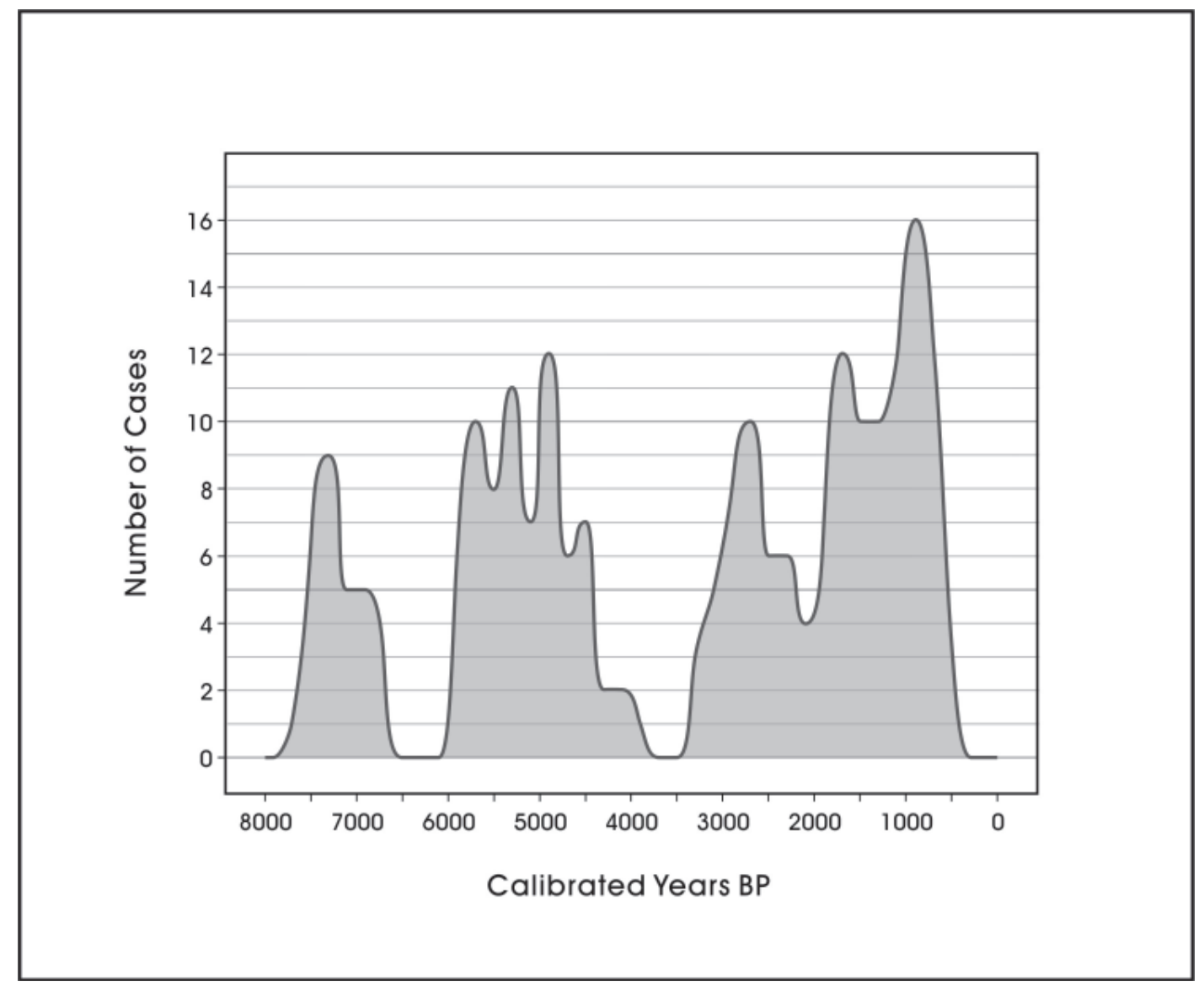

Figure 10-2. Corrected radiocarbon dates from shell and charcoal samples reflecting middle coast occupation.

when essentially modern shore lines may be achieved. They also eliminate any dramatic, rapid alterations in sea level rise that would produce the ecological consequences suggest by Ricklis to have caused abandonment of the Middle Coast at various points.

A recent study of pollen from soil cores taken at the Swan Lake site (41AS5) in Aransas County (Albert 2006) indicates a vegetation history that, at first glance, seems to support Ricklis' (1995; 2004; Ricklis and Weinstein 2005; see also Ricklis and Blum 1997) model. Albert (2006) found that the pollen in the soil cores, radiocarbon dated to approximately the last 7000 years, indicated fluctuations in plant communities forming 6 "pollen zones" (Albert 2006:166). Pollen Zones 1 (7100-6650 B.P.), 3 (4900-3850 B.P.), and 5 (ca. 3450 B.P.) have a high percentage of pollen from the Chenopodiaceae family. Pollen Zones 2 (5800-5400 B.P.), 4 (ca. 3650 B.P.) and 6 (3050 to the present) have low percentages of Chenopodiacea and higher percentages of oak (Quercus), and various grass and forb pollen (Albert 2006:166-172). He interprets these patterns as indicative of changing sea levels in which the wetlands at 41AS5 were invaded by rising sea levels during Zones 1, 3, and 5, turning the area in to a salt marsh, and reducing overall productivity. He believes the higher percentage of arboreal and forb pollen in pollen Zones 2,4 , and 6 indicate a period of sea level stand still, during which the area is a freshwater wetland and the productivity increases substantially (Albert 2006). Albert (2006:173174) suggests that periods in which the pollen data indicate that the Swan Lake area was a salt marsh roughly correlate with Ricklis' estimations of periods during which the coast populations were low or non-existent. However, Ricklis (1995:277) identified two periods of abandonment, one between 6800 and 5800 B.P., and a second between 4200 and 3100 B.P. (see also Figure 3-10). The initial abandonment does have a significant overlaps with Albert's Zones 1 (71006650). The second period of abandonment (4200-3100 B.P.), however, overlaps with Zones 3, 4, and 5- (ca. 4900-3450), and encompasses periods of both low and high productivity.

While, on the whole, modern climate conditions along the coast are wetter and warmer than the rest of the state, the area associated with 41NU2, located in the southern section of the Middle Coast, is warm and dry, with high variability in 
precipitation. The degree to which these modern patterns were altered by changing climate regimes over the last 10,000 years is not clear as there are significant gaps in our understanding of critical paleoclimate parameters in the coastal region. While innovative phytolith research along the coast, conducted by Robinson $(1979,1982)$, suggests that significant alterations in vegetation structure has occurred over time, the studies lack good temporal control and are difficult to interpret. Preliminary work on oyster growth patterns and measures of salinity conducted by K.A. Cox and S.A. Cox (1993) and Ricklis and Cox (1995) near 41NU2 seem to be consistent with other, better controlled paleoclimate investigations that suggest a warm and dry Middle Holocene and a more mesic Late Holocene. These poorly documented shifts in climate, and associated vegetation shifts, should have produced differing mixes of plants and animals for exploitation by hunters and gatherers. An overview of occupation on the coast using radiocarbon dates, as well as volumetric comparisons of archeological materials from coastal sites conducted by Ricklis (1995, 2004; Ricklis and Blum 1997), suggest that the coast was used, at varying levels of intensity, over much of the Middle and Late Holocene, with increasing use present after about 2,000 B.P. A model (see Ricklis and Blum 1997) linking occupational intensity with varying rates of sea level increases and periods of sea level standstill, however, uses Holocene sea level curves that have recently been questioned by a number of researchers. While additional work on this problem is clearly necessary, the most recent models of sea level changes in the Texas Gulf do not seem to support the stepped pattern suggested by earlier researchers. That is, shifts in productivity do not follow the most recent sea level curves. Of course, a variety of factors other than major shifts in sea level could impact estuary productivity. These factors include shifts in the frequency and intensity of storms, the formation or destruction of barrier islands, and inland shifts in rainfall and runoff. Clearly, additional work, along the lines undertaken by Albert (2006) is warranted to explore Ricklis' model.

\section{The Data from 41NU2}

During August 2007, six cores were extracted from the ROW of Ennis Joslin and within the boundaries of 41NU2 (Figures $5-1,5-2,5-4)$. These cores were inspected in the field to determine the amount of intact deposits they sampled. Of the six cores, three contained intact stratigraphic column and were subsequently sub-sampled at the CAR laboratory. The sub-samples included matrix for pollen and phytolith analyses, ostrocod and mollusc analysis, diatom analysis and lithological analyses. Core 2, was extracted from within the limits of a pond deposit previously identified near the intersection of Ennis Joslin and Ocean Drive. Core 4 was recovered from the east ROW of the north dune near station $34+050$. Core 6 was recovered from the east ROW of Ennis Joslin near station $34+550$.
The remaining portion of the chapter pulls together the interpretations derived from the specialized analyses and compliments this with the paleoenvironmental implications of the data collected from the analysis of the molluscs and fish otholiths. We begin with the consideration of the results of each core before we shift to the discussion of the entire site.

\section{Core 2}

Cummings et al., (Appendix A, this volume) divide the pollen record of this core into five zones (E-A). Poaceae, Chenoam and High-spine Ateraceae are the three co-dominants representing grasses, members of the goosefoot families and likely amaranth, and a large group of plants that include the sunflower family. Significant shifts in microscopic charcoal relative to quantities of pollen are noted throughout the record. Both the pollen and phytolith records show some subtle and other long-term environmental changes as well as punctuated events and/or short term changes detectable even at the course-scale sampling strategy employed. The Zone E pollen record contains alder and birch suggesting their regional presence. Bryant (Appendix B, this volume) suggests that the identification of these species may be mistaken due in part to the degraded condition of the pollen. Another possible explanation comes from Frederick's (Appendix F, this volume) findings. His stable carbon isotope analysis of Core 6 from the southern end of the site suggests that at the bottom of the stratigraphic profile, dated to around 4000 yrs B.P., a woodland environment may have been present. He suggests, however, that this stable carbon isotopic signature may the product of the deflation of the former Pleistocene surface. Getting back to the Core 2 record, the presence of small quantities of Pinus and Quercus pollen within Zone E of Core 2 may suggest that these species have been present in the regional vegetation since at least 3,000 years ago. The vegetation community may have consisted of mesic habitats, woodland margins and freshwater marsh habitats. The phytolith record from this zone appears to be indicative of a coastal freshwater marsh/pond lake/stream habitat. Forest edge and understory grasses are very low in occurrence while sandy soil grass and shoreline and emergent aquatic grasses are fairly high in abundance. Overall, the pollen and phytolith record from Zone E represents an expansive freshwater marsh habitat with dunes and tidal mudflats extending beyond their modern limits likely due to the somewhat lower sea levels (approx., 1.0 meters; see Flemming et al. 1998; Milne et al. 2005).

The pollen record from Zone D contains indicators of beach and grasslands and thickets. The presence of Persicaria pollen suggests periodic changes in water levels or wave action that creates a linear continually disturbed zone along the shore. The phytolith record from the zone supports the suggestion of favorable coastal freshwater conditions. The recovery 
of freshwater sponges may correspond with increased precipitation, a rising water table, or potentially less saline conditions in ponds and the surrounding environment. The slight increase in the bilobate phytolith from forest edge and understory grasses also supports the interpretation that precipitation may be on the increase. The only zone in which Isoetes (quillwort) pollen is present. The presence of the pollen suggests cooler than modern temperatures and the combined pollen and phytolith record suggests cooler and wetter conditions than current conditions (perhaps even stormier).

The Zone C pollen assemblage (predates 1300+/-40 RCYBP comes from the base of Zone B) suggest the expansion of the freshwater marshes. The frequencies of bilobate indicators of grasses that prefer sandy substrates is at an abundance in contrast to the forest edge and scrubland grass phytolith. The patterns may correspond with increases in storm frequencies during the depositions of Zones $\mathrm{C}$ and $\mathrm{D}$. This is supported by the fact that Zones $\mathrm{C}$ and $\mathrm{D}$ exhibit the highest rates of sedimentation $(10.6$ years $/ \mathrm{cm})$.

The base of the Zone B dates to $1300+/-40$ RCYBP. The pollen assemblage is consistent with a drying trend. The phytolith record indicates the development of slightly brackish marsh conditions. Bilobate grass taxa associated with forest edge scrubland ecotones reach their peak in this zone. Phytolith assemblage is also suggestive of more brackish marsh conditions potentially coupled with warmer and drier conditions that I the underlying zone.

The top of the stratigraphic column in Zone A is dated to $550+/-40$ RCYBP. Its pollen assemblage is characterized by an increase in Quercus, Cheno-am and Cyperaceae pollen and the appearance of Prosopis pollen. The phytolith assemblage suggests a decrease in the extent of the brackish marsh habitat and an increase in the drier habitats such as sand dunes in the environment. Phytolith from dry habitat grasses that prefer sandy soil substrate increase in frequency. The zone also contains the highest levels of charcoal and oak in the pollen record.

Winsborough's (Appendix C, this volume) analysis of the diatom record from Core 2 indicates that the pond was likely a shallow body of water sustaining a somewhat polluted freshwater habitat with small to moderate levels of salt. The substrate appears to have been somewhat muddy and water levels fluctuated seasonally suggesting that freshwater was only available on a seasonal basis and during the warm dry season (summer) the pond may have drier out entirely.

Palacios-Fest's (Appendix E, this volume) analyses of Core 2 samples contained no marine ostrocods. The foraminifera and mollusc records were poor from Core 2 though the patterns are consistent with the ostrocod record indicating that the pond was a source of fresh water throughout its existence. The fauna of Core 2 may have been transported into the pond. Particle size analysis conducted by Palacios-Fest as part of the extraction of the faunal record suggests that overall the inflow of water into the pond was slow. The sediment particle analysis indicated that there were two episodes of rapid influx based on the coarsening of the sediments, one between 2970 and approximately 2500 B.P., and the latest between $700 \mathrm{yrs}$. B.P. and the present. Two episodes of slower discharge are also suggested by the particle size analysis. The first occurs around 2500 B.P. following the rapid discharge and the second around 1000 B.P., prior to the rapid discharge episode mentioned above. It is difficult to determine whether these coarse and fine deposits reflect different depositional regimes (i.e., slope wash from the dunes or eolian sedimentation from the nearby mudflat or differences in the sources of the parent materials being transported by wind onto the dunes (Frederick 2008, Personal Communication). The Core 2 paleosalinity pattern is only available for the later part of the chronological sequence and for the period between 1300 and $550 \mathrm{yrs}$ B.P, it shows relatively low salinity brackish conditions. Again, this pattern may be derived from the decreased salinity of the source deposits in the mudflat or an increase in the influx of fresh water due to increased precipitation in the region.

Frederick's lithological analysis (Appendix F, this volume) of Core 2 samples indicates a pattern similar to that noted by Palacios-Fest. The percentage of sand is high and steadily decreasing between $2970+/-40$ B.P. and $2240+/-40$ B.P. The proportion of sand-sized particles remains relatively low with occasional small increases only until around 1000 yrs B.P. at which point it again increases until the present.

\section{Core 4}

Cummings et al. (Appendix A, this volume) note that the Core 4 pollen and phytolith record has been severely affected by silica dissolution. One sample (\#182) recovered from $40-43 \mathrm{cmbs}$ and dated to approximately 500 RCYBP, is equivalent to Zone A or above in Core 2. The phytolith record from this sample suggests a sand dune or wet meadow interdune environment with a relatively brackish and shallow watertable. Grasses that were well adapted to sandy substrate dominated the vegetation.

The diatom assemblage from Core 4 is very small and is likely the result of wind transport from the nearby lagoon (Winsborough Appendix C, this volume). The small assemblage confirms that the water level and the edge of the lagoon shifted over time at times getting closer to the sample locality while at other times receding to some distance. The 
assemblage also suggests that the lagoon may have oscillated either seasonally or for extended time, between containing water, becoming muddy and even entirely drying out.

The Core 4 samples contained a variety of ostrocods mainly of marine origin most likely deposited through wave action, according to Palacios-Fest. While the edge of the bay could have been sufficiently close to influence the edge of the dune, it is more likely, that eolian deposition is responsible for the presence of these marine ostrocods in the dune sediments. The foraminifera record from the core was consistent with the ostrocod assemblage. On the other hand, the mollusc record was poor from Core 4 but showed that only marine species occurred in samples from this core. Again, these molluscs were likely present in the source materials that were eroded through wind action to contribute to the building of the dune. Palacios-Fest's particle size analysis from Core 4 shows three periods of sediment coarsening. The oldest occurs around 3620 B.P., the second around 2110 B.P. and the most recent sometime after 1060 B.P. The period between the first and second coarse sediment deposits appears to have been characterized by slow fine sediment deposition resulting in the accumulation of primarily clayey sediments. Palacios-Fest suggests that the fauna recovered from Core 4 indicate that the periods of coarse sediment deposition were the result of freshwater inflows. However, given Frederick's conclusion that the sediments composing the dune are eolian in origin, it is more likely that the coarsening of the deposits is due to a change in the character of the parent materials that contributed sediments to the dune. The clayey sediments are also the product of eolian deposition and again may reflect a fining of the parent materials contributing sediment to the dune. The paleosalinity data supports this interpretation.

Frederick's lithological analysis (Appendix F, this volume) of Core 4 samples indicates that sand-sized particles were most common prior to $3620+/-40 \mathrm{yrs}$ B.P. and that the sediments began to become finer likely beginning around $4000 \mathrm{yrs}$ B.P. Between $3620+/-40$ yrs B.P. and $2110+/-40$ yrs B.P. sediments tend to remain clay dominated although there is a small peak in sand-sized particles around $2880+/-40$ yrs B.P. Sand-sized particles again increase in proportion between $2110+/-40$ B.P. only to begin declining before $1060+/-40$ B.P.

\section{Core 6}

Only four of the 16 samples examined by Cummings et al. (Appendix A, this volume) from Core 6 yielded statistically significant phytolith counts. The deepest of the phytolith assemblages comes from Zone $\mathrm{G}$ which pre-dates $3770+/$ 40 RCYBP. The phytolith assemblage is unlike any modern Gulf Coast habitat assemblage. Phytolith diagnostic to the palm family were the most abundant form and may derive from dwarf palmetto or Rio Grande palmetto. The presence of this phytolith suggests that a maritime forest of freshwater swamp with an arboreal canopy was the dominant vegetation community around $4000 \mathrm{RCYBP}$. The phytolith assemblage from Zone $\mathrm{F}$ of the core is severely affected by silica dissolution. Keeping in mind that the record that remains is heavily biased toward certain more resistant morphotypes, the assemblage continues to indicate the presence of a forested canopy with a palm component around 3770+/-40 RCYBP. The base of the core has reached the top of the Beaumont Clay and therefore it is possibility that deflated Pleistocene phytoliths are being sampled by this zone.

Cummings et al. (Appendix A, this volume) were able to define a Zone E phytolith assemblage from the Core 6 samples. The severely affected assemblage dates to around $2760+/-40$ RCYBP and appears to be roughly contemporaneous with Zone $\mathrm{E}$ in Core 2 . The degraded phytolith assemblage seems to suggest that by this time, the vegetation community has changed to an expansive freshwater marsh. The surviving phytolith sample from a soil sample that is equivalent to Zone $\mathrm{D}$ from Core 2, suggests the presence of a sand dune habitat with a shallow watertable at around 1770+/-40 RCYBP. Samples from what would be equivalent to Zone $\mathrm{C}$ in Core 2 are also heavily affected by silica dissolution. The biased record suggests the existence of moist sand dune/interdune conditions. Samples for what would be equivalent to Zone B in Core 2 are radiocarbon dated to $1280+/-40$ RCYBP. The affected partial record suggests that a salt marsh existed in the area around that time. The best preserved phytolith assemblage comes from Zone A which is roughly contemporaneous with Zone A from Core 2. The record suggests the presence of a dune habitat with elevated watertable. Moist interdune meadows may have been present nearby. In combination, the Zone $\mathrm{B}$ and A records suggest a pattern of increased drying beginning during the upper levels of Zone $\mathrm{B}$ and proceeding through Zone A and perhaps representing the shift from a salt marsh to a drier sand dune environment. This trend is analogous to that noted in the equivalent zones of Core 2 and potentially contrary to the stable carbon isotope data.

The diatom assemblage from Core 6, analyzed by Winsborough (Appendix D, this volume), contrasts with that of Core 2. The Core 6 assemblage reflects the sandy substrate that characterized the edge of the dune from where the core samples originated. The species reflect seasonally wet conditions and the absence of muddy substrate species indicates that water accumulations were short lived and may have occurred in clay-lined depressions or swales in the sand.

Core 6, similar to Core 4, contained a variety of ostrocods mainly of marine origin most likely deposited through eolian 
transport although wave action cannot be entirely ruled out. Core 6 contained a varied foraminifera record consistent with the ostrocod assemblages. The mollusc record was poor but only marine species occurred in the samples. The fauna from Core 6 indicates that the sediments sampled by the core may have received a relatively constant input of freshwater. This is consistent with the location of the core on the bank of a small arroyo that probably carried water during rain events and wet periods. The faunal record does indicate that the largest pulses of freshwater came between 3770 and 2760 B.P. The strongest seawater influence appears to have occurred sometime just after $1770+/-40$ yrs B.P. perhaps representing a dry period characterized by an increase in eolian deposition. In general, the Core 6 paleosalinity pattern suggests that this location was much more susceptible to freshwater influxes that the locality adjacent to Core 4 .

Palacios-Fest's particle size analysis of the sediments from this core show an increase in sand-sized particles around 2760+/40 B.P. A period of clayey particle deposition occurs between about $1770+/-40$ B.P. and 1280+/-40 B.P. which is followed by a peak in coarse particle deposition. The most evident increase in coarse particles in the Core 6 data in Frederick's analysis occurs between about $2760+/-40$ B.P. and about 1770+/-40 B.P. Between 1760+/-40 B.P. and 1280+/-40 B.P. sediments tend to consist of clayey particles. This period is followed by a period of increase in particle size. The results of the two particle size analyses are very similar.

\section{The Combined Picture: Patterns and Disagreements}

Based on the analysis of the pollen and phytolith samples from the three cores from 41NU2, Cummings et al. (Appendix A, this volume) define seven climatic, habitat and landscapelevel changes at the site. The oldest, dating to around 4000 yrs B.P. is manifested in Core 6 and suggests the presence of a maritime forest or fresh water swamp with an arboreal canopy flourishing under mesic and warm conditions. This forested swamp community appears to have persisted until at least 3770+/-40 B.P. under wet but possibly cooler conditions that may have resulted in the thinning of the arboreal canopy. By 2970+/-40 yrs B.P., the freshwater pond just north of $41 \mathrm{NU} 2$ begins to accumulate water and may be at the center of a sedge or freshwater marsh. The forested swamp at the south end of the site continues to thin and gradually changes to a relatively open freshwater marsh by around $2670+/-40$ yrs B.P. Between $2240+/-40$ yrs B.P. and $1280+/-40$ yrs B.P. the water level within the pond at the north end of the site fluctuates and becomes increasingly shallower and more brackish and the marsh at the south end becomes a salt marsh. Rainfall appears to increase during this period while temperatures may become cooler. After about $1280+/-40$ B.P. a trend that may have begun as early as $1800+/-40$ B.P. sees the increase in oak and cattail pollen. Sand dunes are well established by 550+/-40 B.P. and the pond supports a brackish marsh and moist interdune areas may be present as temperatures appear to increase and precipitation decreases leading to the formation of the scrublands community characterizing the area today.

Overall, the diatom assemblages from the three cores (Winsborough Appendix D, this volume) indicate that rain was episodic and seasonal resulting in temporary accumulations of fresh water in the pond. However, it is likely that these accumulations did not last through the dry season. These conditions suggests that unless fresh water was transported into the locality, its seasonal availability would have favored and limited the occupation of the site to the wet season or season, namely Spring and Fall and following episodic occurrences brought on by hurricanes.

According to Palacios-Fest (Appendix E, this volume), the paleosalinity patterns in combination with the ostrocod, foraminifera and mollusk data allow the definition of three paleoecological zones characterized by more or less saline conditions. The reconstruction offered by these data types is quite different from that based on the pollen and phytoliths offered by Cummings et al. (Appendix A, this volume). High salinity, reflecting xeric conditions appears to have dominated the area before 3600 years B.P. The interval between 3600 and 1300 B.P. appears to have been one of transition from xeric to more mesic conditions while the last 1300 years are characterized by relatively mesic conditions. Unfortunately, much of this reconstruction is derived from Cores 4 and 6 and even within them, substantial variation is present that is related to their location in relationship to topographic features such as crest of dune, distance to nearby arroyo, etc.

Frederick's analysis of delta 13 carbon from Cores 4 and 6 from the north and south dunes respectively, provides an additional composite image of paleoenvironmental conditions in the vicinity of 41NU2. His analysis indicates that the vegetation community characterizing the site vicinity was more mesic adapted around 4000 yrs B.P. However, between about $3770+/-40$ yrs B.P. and 1000 B.P. there was a steady movement in the composition of the vegetation community to a greater and greater proportion of arid-adapted species. A slight shift back to more mesic-adapted vegetation seems to characterize the last 1000 years.

Overall these diachronic trends appear to correspond well with the reconstructions based on pollen and phytoliths offered by Cummings et al. (Appendix A, this volume). 
The maritime forest or arboreal community surrounding a freshwater swamp present near the site around 4000 B.P. gradually becomes more open over time giving way to sand dunes with moist interdune settings as precipitation decreases. The return of the woody vegetation during the last 1000 years of the sequence may reflect a combination of increased moisture and historic impacts on vegetation communities. The findings by Dering (Appendix C, this volume) of mesquite (Prosopis glandulosa), carbonized fragments of a woody legume (Prosopis or Acacia sp.), and oak (Quercus sp.), coupled with the oak pollen identified by Cummings et al. (Appendix A, this volume) support the trends in the stable carbon isotope data. Dering identified mesquite in five features (Features 102, 114, 156, 165, and 168) and woody legume fragments in fourteen features. None of the features containing mesquite have been dated but two of the woody legume containing-features have dates. Feature 121 returned a date of $2740+/-40$ B.P. while Feature 54 produced a date of $1290+/-40$ B.P. Dering (Appendix $C$, this volume) concludes that the few species of plants identified in the macrobotanical samples are consistent with the Tamaulipan Thornscrub community that has been present in the regions for the past 3,000 years. None of the samples that he analyzed came from the deepest recovery contexts and therefore no evidence corroborating the significant vegetation shift noted by the pollen/phytolith analysis exists.

\section{Other Proxy Data Types and Trends}

\section{Molluscs}

Seventy-one heavy fraction samples derived from the flotation of feature fill matrix were sorted for macrobotanical remains. It was hoped that these samples will produce a large collection of invertebrate and vertebrate fauna that could be employed as proxy data for interpretations regarding subsistence patterns and paleoclimate. To define some analytical units that would be meaningful in searching for diachronic trends in the data, we plotted the two sigma date ranges of each of the features. Based on this plot, we identified four clusters of date ranges with the oldest predating 2700 B.P. containing a single feature (Feature 7). Given the small number of faunal elements in the feature it was not used in subsequent analyses. The next oldest cluster dating from $2300-2700$ B.P. included 15 features $(11,12,74,84,121,148-152,154-156$, 159 , and 161). The youngest groups included six features $(2,16,55,57,89$, and 114) and post-dated 1700 B.P. The cluster of features dating between 1700-2300 B.P. contained 3 features $(41,75,153)$ and faunal materials recovered from $\mathrm{OZ} \mathrm{B}$ and $\mathrm{OZ} \mathrm{D}$, since organics from these two occupation zones were dated to $1900+/-40$ B.P. (OZ D) and 1840+/-40 B.P. and 2010+/-40 B.P. (OZ B), respectively.
The samples of faunal remains derived from the features grouped into these three main clusters of units indicated that only seven species of invertebrate taxa occur in sample sizes equal to or greater than 20 minimum number of individuals (MNI). They are the Crossbar Venus (Chione cancellata), Bay Scallop (Argopected irradians), Lightning Whelk (Busycon sinistrum), Oyster (Crassostrea virginica), Sunray Venus (Macrocallista nimbosa), and Quahog (Mercenaria campechiensis). Rabdotus (Rabdotus sp.) snails are also included in the figure given their correlation with climatic conditions (Brown 1999; Malof 2001).

In general, oysters, scallops, sunray venus, quahog and lightning whelk are considered moderate -to high-salinity species (see Table 8-5) preferring salinity ranges between $25-40 \%$. Rabdotus snails are commonly assumed to prefer semi-arid open grassy areas although they can also be found clinging to the stems of brushy vegetation such as found in the South Texas brush county (Personal Observations, Spring 2007, Wilson County).

Figure 10-3 is a plot of the MNI counts by species by time period. Several trends can be noted in this figure. For instance, oysters and Lightning Whelks decrease between 2300 and 1700 B.P. but increase after 1700 B.P. Sunray Venus and Quahog decrease over time, with the later decreasing dramatically between 2300 and 1700 B.P. Bay Scallops and Crossbar Venus fluctuate over time with their highest numbers being found between 2300-1700 B.P. Rabdotus snails decrease dramatically between 2300 and 1700 B.P. and continue to decline in numbers even after 1700 B.P.

What do these trends mean? We are aware that interpreting these patterns strictly from a paleoenvironmental perspective under estimates the possible effect of changes in huntergatherer exploitation practices upon the invertebrate fauna of the site. At the broadest level the dramatic decrease in oysters between the 2300-2700 B.P. and 1700-2300 B.P. temporal clusters suggests that conditions in Corpus Christi Bay may be changing from moderate salinity to significantly reduced salinity. This would be expected given the assumption that the barrier islands would have begun to form around 3000 B.P. and should have begun to decrease the salinity of the bay waters through reduced exchange with the open Gulf. The frequency of lightning whelk molluscs parallels the pattern in oysters, as does the occurrence of sunray venus between the two temporal clusters. Interestingly, the subsequent increase in oysters and lightning whelks after 1700 B.P. suggests that habitat conditions in the bays may have become more saline and closer to the preferred conditions of these species. Since the coalescence of the barrier islands should lead to decreased salinity within the bays, the sudden increase in the frequency of these species may reflect either a shift in the 


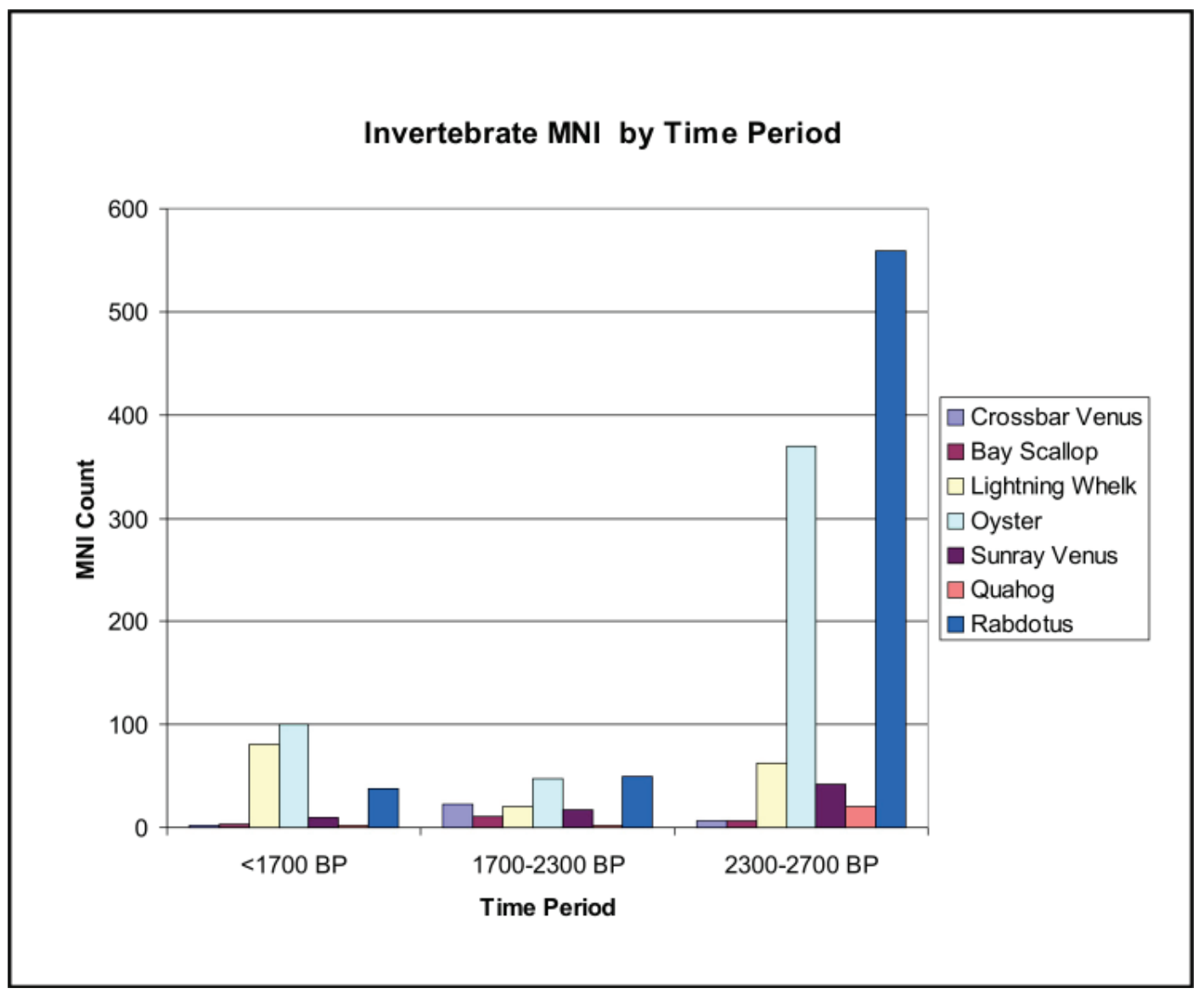

Figure 10-3. Plot of mni counts of seven invertebrate species by time period.

species targeted by foragers or perhaps a period of extended decrease in freshwater influx into the bays. It is worth noting that the most recent temporal cluster, is a composite of trends and therefore represents an average of a number of possible fluctuations in climatic conditions. With this in mind, we note that Core 2 and Core 6 particle size data obtained by both Frederick and Palacios-Fest seem to suggest that a period of steady fine-grained particle size deposition occurred beginning around $1770+/-40$ B.P. and continued until around $1280+/-40$ to $1300+/-40$ B.P. Frederick's stable carbon isotope data also shows that until around 1000 B.P. the vegetation structure of the region was steadily moving toward an aridadapted composition. Palacios-Fest's paleosalinity data from Core 6 also indicates that sometime around 1770+/-40 B.P. and until sometime before $1280+/-40$ B.P. the salinity of the deposits was more marine than brackish. Finally, Cummings' et al. phytolith based climatic reconstructions also suggest that precipitation was decreasing around $1280+/-40$ B.P. although it was apparently preceded by a period of increased precipitation between $2670+/-40$ and $1770+/-40$ B.P. In short, some degree of correspondence exists between the different data types in support of an extended period of decreased precipitation leading to increased bay salinity for some period after 1770+/-40 B.P. Given this conclusion, the decrease in Rabdotus numbers over time is somewhat unexpected for two reasons. First, increased aridity and the establishment of more grass-dominated habitats should favor Rabdotus colonization. Second, the repeated reoccupation of the site by huntergatherers and the formation of several organically enriched paleosols and features should also have made conditions more rather than less favorable for the species over time.

An additional perspective on paleoclimatic conditions comes from a look at changes in species richness over time. As mentioned, the samples described above derive from a total of 26 features. Overall, the species richness among invertebrates within these 26 features fluctuates over time and this fluctuation does not seem to be related to sample size at least in terms of the number of features contributing specimens to the trend. For instance, the fifteen features grouped within the 2700-2300 B.P. temporal cluster have a combined richness of 26 species. The five features and two occupation zones grouped within the 2300-1700 cluster have a richness of 27 species. Finally, the six features post-dating 1700 B.P. have a richness of 19 species. Therefore, when considering all invertebrates present in these temporally specific subsamples, 
it is clear that there is a significant decrease in species richness following 1700 B.P. This decrease may signals a reduction in the habitat conditions present within the bays exploited by the hunter-gatherers living at 41NU2. Such narrowing would result in the abandonment of the habitat by some species of invertebrates over time. Twelve species present in the samples between 2300 and 1700 B.P. drop out of the sample following 1700 B.P. Two of the new species (Brachidontes sp. and Suturoglypta iontha) that appear after 1700 B.P. were not present in the collections prior to 1700 B.P. The paleoclimatic implications of this trend are unclear at this time. One other aspect related to molluscs is worth mentioning, the entire absence of Rangia sp. molluscs from the 41NU2 sample. Rangia molluscs are brackish habitat preferring species and their absence is surprising given the site's proximity to what we assume to have been a brackish water bay. Rangia clamshells were common at the Mustang Lake site (41CL3) in Late Prehistoric deposits (Ricklis 2004:167) and their absence in an even more enclosed setting at 41NU2 suggests and implies that the salinity of the bays remained high throughout the sequence of human occupation especially considering how near the shore of Corpus Christi Bay the site is located and how small the freshwater contribution of the small ephemeral drainage at the south of the site may have been. Perhaps sites found closer to the mouth of the Nueces River would contain sizable Rangia samples.

\section{Otholiths and Vertebrates}

Unfortunately, while we hoped for large samples of otholiths from the heavy fraction samples, only 32 fish otholiths were identified during the sort of these samples. Fourteen (44\%) of these were from unidentified bony fish leaving only 18 that were identified to taxa. The eighteen include Sea Catfish ( $\mathrm{n}=7$ ), Black Drum ( $\mathrm{n}=3$ ), Red Drum $(\mathrm{n}=2)$, Spotted Seatrout $(n=2)$, Sand Seatrout $(n=2)$, Sheepshead $(n=1)$, and Atlantic Croaker $(n=1)$. As the sample sizes show, none of these occurred in sufficiently large numbers to provide any meaningful statements regarding changes in their frequencies over time. Similarly, only 20 vertebrate faunal remains were identified to taxa. Again, none of the taxon occurs in sufficient numbers to describe statistically significant patterns.

\section{Disagreements in Pollen Analysis}

Finally, having discussed the various data types that contribute the picture on paleoclimate we have to also emphasize that major disagreements exist between the pollen data of Cummings et al. (Appendix A, this volume) and Vaughn Bryant's analysis (Appendix B, this volume). Specifically, Bryant's analyses concluded that the pollen samples from Core 2 represented highly degraded pollen assemblages that were not representative of the original vegetation communities that inhabited the site and its environs. Therefore, he concluded that an extensive analysis of the samples was not warranted because it would result in a faulty and biased reconstruction. In addition, he suggested that the interpretation of highly degraded pollen samples is also fraught with danger in that pollen grains can be easily misidentified leading to further errors in reconstructions.

While Cummings et al. (Appendix A, this volume) have mentioned in several instances the degraded nature of the pollen samples particularly in sediment samples from Cores 4 and 6, they present a detailed reconstruction of paleoenvironmental conditions much of it based on the sequence from Core 2, and the specific samples that were judged too heavily degraded to warrant analysis. The differences in assessments, results and conclusions between the two laboratories are dramatic and necessitate systematic appraisal.

\section{Summary}

This chapter summarized the results of specialized analyses reported in several appendixes found at the back of this report including pollen and phytoliths (Appendix A and B), macrobotanical (Appendix C), diatoms (Appendix D), ostrocods (Appendix E), and geoarcheological (Appendix F). We also attempted to merge the various results into one more or less corresponding reconstruction of paleoenvironmental conditions that existed at and in the vicinity of the site between $2700+/-40$ and the present. Finally, we incorporated what evidence was available from other proxy data types that had implications for paleoclimatic reconstructions including primarily the molluscs. In the process we have provided a paleoclimatic record for the site and discussed the manner in which the apparent changes in conditions may have affected the available resources and/or themselves reflect the changes noted. The archeological record is simply not long enough to have provided information on sea level changes but it did implicate changes in near-site habitat conditions that affected the resource base particularly when it comes to the salinity of the bays and the molluscs populations they maintained. The stratigraphy of the site is composed of alternating organicrich (darker colored) and organic-poor (lighter colored) zones. The darker zones clearly represent periods of dune stabilization and are the products of both anthropogenic as well as climatic factors.

The paleoclimatic record as it could be reconstructed from the composite of data types (which are not always in agreement), seems to show that early in the archeological sequence, perhaps around 4000 B.P., the site and its vicinity were dominated by more mesic-adapted plant communities but the 
composition of this community began to shift to a greater proportion of xeric-adapted species sometime around 3000 B.P. This trend in composition, that also affected the structure of the communities, continued until about 1000 B.P. at which point there seems to have been a small shift back to mesic conditions. Albert's (2006) reconstruction of the period from 3050-0 B.P. characterizes it as shifting from mesic to subtropical. As such, this general reconstruction seems to agree with that seen in the $41 \mathrm{NU} 2$ record with the exception of the minor shift very late in the sequence.

The two pollen analyses conducted by Cummings et al. (Appendix A) and Bryant (Appendix B) come to dramatically different conclusions about the pollen assemblages present in the sites's sediments and specifically those from Core 2 recovered from the pond near the north end of 41NU2. The principal disagreements lie in the assessments of the preservation conditions of the pollen assemblages and their feasibility for paleoenvironmental reconstructions. The disagreements severely undermine the results of the analyses and some of the main lines of evidence used in the reconstruction of paleovegetation at and near the site. The principal differences seem to derive from disagreements as to what level of pollen degradation is needed before an assemblage is considered unreliable in providing a representative reconstruction of past vegetation communities and paleoclimate. Both pollen extraction and identification methods also are implicated in this question. Therefore, given the importance of pollen studies to paleoclimatic reconstructions and the lack of reliable records in Texas outside of a handful of bogs, it is recommended that TxDOTENV pursue a systematic resolution of these disagreements to establish the source of the different study results and reestablish confidence in the methods employed in the extraction and analysis of pollen assemblages. 


\title{
Chapter 11: 41NU2 and Regional Subsistence Practices
}

\author{
Barbara M. Meissner and Jennifer A. Thompson
}

\section{Analysis of Faunal Remains from 41NU2}

The cultural materials that were and are at the Cayo del Oso site consist overwhelmingly of faunal remains. Most features include large numbers of shell and/or bone. Some levels in the trenches were completely paved with layers of invertebrate shells.

The nature of the project at 41NU2, however, resulted in very limited collection of faunal materials. With the exception of the first 16 features, faunal remains were rarely collected except within soil samples. Even this collection has been limited, as only soil samples associated with features were floated, and the faunal materials in the heavy fraction analyzed. The fauna described in this section of the report, therefore, can be considered no more than an incomplete record of the fauna exploited by the early inhabitants of Cayo del Oso.

The taxonomic nomenclature used in this report is that of the Integrated Taxonomic Information System (ITIS). It is available online (ITIS 2008). In most cases, the names of taxa listed here are the same as those found in any faunal report of the coastal area. However, the taxonomic names of some species, in particular invertebrate species, vary a great deal in the literature. A good example is the Lightning Whelk, one of the most common shells found along the central Texas Coast. At various times the species has been referred to as Busycon perversum, B. contrarium, and B. sinistrum, all of which make reference to the fact that the Lightning Whelk is one of the few snail species in the world that twists to the left instead of the right. The confusion of names is the result of a certain amount of uncertainty on the part of biologists concerning how many species of Lightning Whelks there are, and where they are, but also because various analysts of faunal materials from coastal sites have used various reference materials as authorities. We will use Busycon sinistrum in this report, following ITIS (2008), though most of the interim reports used B. perversum.

\section{Invertebrates}

The vast majority of faunal remains collected during this project were the shells of mollusks. As noted in Chapter 2 and in other sections of this report, the estuarine environment in the immediate vicinity of $41 \mathrm{NU} 2$ provides an abundance of marine resources. The inhabitants of 41NU2 made use of many species, naturally concentrating on the larger and most easily acquired. The floatation of a total 318.8 liters of soil samples from features resulted in the recovery of 16,665 identifiable invertebrates, weighing $26,935.38 \mathrm{~g}$. In addition, a total of $1,114.35 \mathrm{~g}$ of shell could not be identified. Table $11-1$ is a list of the 45 invertebrate taxa identified from the heavy fraction of soil samples, with counts and weights of each. The majority of the invertebrates were from the Phylum Mollusca $(n=16,421)$, however there are also Crustaceans from the Phylum Arthropod $(\mathrm{n}=231)$, and Annelid worms from the Phylum Annelida ( $\mathrm{n}=3$ ) in this collection.

Table 11-1. Invertebrate Species Identified from Heavy Fraction Floatation Samples

\begin{tabular}{|c|c|c|c|}
\hline Taxon & Common Name & Count & Weight (g) \\
\hline \multicolumn{4}{|c|}{ Phylum Mollusca } \\
\hline \multicolumn{3}{|c|}{ Class Bivalvia: Marine Bivalves } & \\
\hline Abra aequalis & Atlantic Abra & 1 & 0.03 \\
\hline Amygdalum papyrium & Atlantic papermussel & 90 & 6.71 \\
\hline Anadara brasiliana & Incongrous Ark & 1 & 0.09 \\
\hline Anadara transversa & Transverse Ark & 4 & 0.98 \\
\hline Anodontia alba & Buttercup Lucina & 2 & 0.34 \\
\hline Anomalocardia auberiana & Pointed Venus & 1 & 0.05 \\
\hline Anomia simplex & Common Jingle Shell & 1 & 0.54 \\
\hline Argopecten irradians & Atlantic Bay Scallop & 252 & 148.52 \\
\hline Brachidontes sp. & Scorched Mussels & 3 & 0.66 \\
\hline Carditamera floridana & Broad-Ribbed Cardita & 1 & 0.05 \\
\hline Chione cancellata & Crossbar Venus & 169 & 103.96 \\
\hline Codakia oribicularis & Tiger Lucine & 1 & 0.03 \\
\hline Crassostrea virginica & Eastern Oyster & 8,222 & $11,101.58$ \\
\hline Dinocardium robustum & Giant Atlantic Cockle & 74 & 58.60 \\
\hline Diplodonta punctata & Atlantic Diplodon & 1 & 0.25 \\
\hline Dosinia discus & Disk Dosina & 1 & 0.03 \\
\hline Eucrassatella speciosa & Beautiful Crassatella & 1 & 0.04 \\
\hline Ischadium recurvum & Hooked Mussel & 42 & 3.39 \\
\hline Lucine amianta & Lovely Lucine & 2 & 0.05 \\
\hline Macoma constricta & Constricted Macoma & 2 & 0.02 \\
\hline Macrocallista nimbosa & Sunray Venus & 2,614 & 4875.03 \\
\hline Mercenaria campechiensis & Southern Quahog & 344 & 1357.34 \\
\hline Mulina lateralis & Dwarf Surfclam & 1 & 0.08 \\
\hline Mytilidae & Saltwater Mussels & 52 & 34.43 \\
\hline Noetia ponderosa & Poderous Ark & 2 & 0.61 \\
\hline Nuculana acuta & Pointed Nutclam & 2 & 0.02 \\
\hline Semele bellastriata & Cancellate Semele & 2 & 0.02 \\
\hline Spisula raveneli & Southern Surfclam & 1 & 0.02 \\
\hline Strigilla carnaria & Large Strigilla & 1 & 0.78 \\
\hline Trachycardium sp. & Prickly Cockles & 4 & 0.78 \\
\hline Tracycardium egmontianum & Florida Prickly Cockles & 1 & 0.66 \\
\hline & Total Marine Bivalves & 11,895 & $17,695.69$ \\
\hline \multicolumn{4}{|c|}{ Class Gastropoda: Marine Gastropods } \\
\hline Busycon sinistrum & Lightning Whelk & 1,638 & 7451.46 \\
\hline Busycotypus canaliculatus & Channeled Whelk & 5 & 59.56 \\
\hline Busycotypus spiratus & Pear Whelk & 4 & 2.91 \\
\hline
\end{tabular}


Table 11-1. Continued...

\begin{tabular}{|c|c|c|c|}
\hline Taxon & Common Name & Count & Weight (g) \\
\hline \multicolumn{4}{|c|}{ Phylum Mollusca } \\
\hline \multicolumn{4}{|c|}{ Class Gastropoda: Marine Gastropods } \\
\hline Busycon sinistrum & Lightning Whelk & 1,638 & 7451.46 \\
\hline Busycotypus canaliculatus & Channeled Whelk & 5 & 59.56 \\
\hline Busycotypus spiratus & Pear Whelk & 4 & 2.91 \\
\hline Cerithiopsis greenii & Green's Cerith & 1 & 0.03 \\
\hline Crepidula depressa & Faded Slippershell & 21 & 2.16 \\
\hline Crepidula fornicata & Common Slippershell & 34 & 1.82 \\
\hline Crepidula plana & Eastern White Slippershell & 1 & 0.03 \\
\hline Crepidula sp. & Slippershells & 1 & 0.02 \\
\hline Fasciolaria lilium & Banded Tulip & 38 & 127.79 \\
\hline Marshallora nigrocinta & Black Lined Triphora & 2 & 0.03 \\
\hline Pleuroploca gigantea & Florida Horse Conch & 12 & 93.26 \\
\hline Polinices duplicatus & Shark's eye & 30 & 159.52 \\
\hline Suturoglypta iontha & Lineate Dovesnail & 3 & 0.1 \\
\hline \multirow[t]{2}{*}{ Terebra dislocata } & Common Atlantic Auger & 2 & 0.21 \\
\hline & Total Marine Gastropods & 1,792 & $7,898.90$ \\
\hline \multicolumn{4}{|c|}{ Class Gastropoda: Terrestrial Gastropods } \\
\hline Rabdotus sp. & Rabdotus snails & 2,733 & 1315.32 \\
\hline \multicolumn{2}{|r|}{ Total Gastropods } & 4,525 & $9,214.22$ \\
\hline \multicolumn{4}{|c|}{ Class Scaphopoda } \\
\hline Dentalium americanum & American Tusk shell & 1 & 0.03 \\
\hline \multicolumn{2}{|r|}{ Total Mollusks } & 16,421 & $26,909.94$ \\
\hline \multicolumn{4}{|c|}{ Phylum Arthropoda } \\
\hline Balanomorpha & Acorn Barnacles & 229 & 0.22 \\
\hline Decopoda & Crabs & 2 & 24.13 \\
\hline & Total Arthropods & 231 & 24.35 \\
\hline \multicolumn{4}{|c|}{ Phylum Annelida } \\
\hline \multicolumn{4}{|c|}{ Class Polychaeta: Polychete worms } \\
\hline Sabellaria sp. & Sandtube Worms & 3 & 1.09 \\
\hline & Total Annelids & 3 & 1.09 \\
\hline & Total Invertebrates & 16,655 & $26,935.38$ \\
\hline
\end{tabular}

The most common shells recovered during processing of the heavy fractions were Eastern Oysters (Crassostrea virginica; $\mathrm{n}=8,222$ ), Sunray Venus (Macrocallista nimbosa; $\mathrm{n}=2,614$ ); Rabdotus land snails ( $\mathrm{n}=2733$ ) and Lightning Whelks (Busycon sinistrum; $\mathrm{n}=1,638$ ). Together these four species make up 91.3 percent of the total invertebrates in this collection and 91.9 percent of the identified shell weight. With the exception of the Rabdotus, this is not surprising, as these are all quite large species, relatively easy to acquire. Other species large enough to eat were collected and brought to 41NU2 as well. As Table 11-1 shows, Atlantic Bay Scallops (Argopectin irradians), and the Southern Quahog (Mercenaria campechiensis) were exploited. Another, less common, large species was the Giant Atlantic Cockle (Dinocardium robustus). The Florida Horse Conch (Pleuroploca gigantea), though by far the largest invertebrate available to the inhabitants of 41NU2 (Andrews 1977: 146), is not common in the Corpus Christi Bay area today and the relatively small numbers $(n=12)$ recovered from the soil samples suggests that this was true in the past as well. On the other hand, the Sunray Venus clam, the second most-commonly identified shell in the collection, no longer lives along the Texas coast (Andrews 1977:242), though it is still well represented in the waters of Florida's bays and a new industry of commercial farming of the species is under development there (Sturmer 2007).

The presence of large number of Rabdotus shell in some of the features is not easy to explain. These land snails are much smaller than most of the marine species in terms of the amount of food-value per individual. While they could represent low ranked food items (Malof 2001) we did not conduct research to attempt to test this possibility associated with this project. The fact that these species feed on and are attracted to organic-rich deposits may also indicate that the clusters of snails in features may represent die-offs rather than discarded consumption debris.

Soils matrix from 61 features were floated and Table 11-2 shows the number of samples in which each taxon was identified, and the percent of the 61 heavy fraction samples in which each was noted. If we look at the relative ubiquity of the 45 species recovered, we can see that, again, oysters were the most ubiquitous species. The presence of acorn barnacles in 18 of the samples and in relatively large numbers $(n=229)$ is interesting. They were probably attached to the oysters that were collected, and may even have been eaten along with other invertebrates collected during trips to the oyster reefs.

Another species that is fairly ubiquitous is the Crossbar Venus. This relatively small clam is often no bigger than $15 \mathrm{~mm}$ and can probably serve as a lower size boundary of species that might have been actively gathered for food, though the low number of shells in most features suggests they were usually picked up incidentally, as a result of their association with oyster reefs (Kilgen and Dugas 1989:45).

Twenty-two species were found only in a single soil sample. Of these, it is interesting that 8 were found only in Feature 41. In fact, Feature 41 had 24 identified species, with a total count of 1,022 identified shells. Feature 41 was a small pit, about $30 \mathrm{~cm}$ on a side, and only about $5 \mathrm{~cm}$ deep (see Figure 6-19). The remarkable number and diversity of species found in this one feature make it unique.

\section{Vertebrates}

Although at least some bone was visible in most features and in large areas of Occupation Zones, it was for the most part fragmented into tiny pieces, and much of it was the bone of small fish that more or less disintegrated when disturbed, no matter how carefully the bone was handled. Even bones of large, deer-sized mammals were usually highly fragmented 
Table 11-2. Invertebrate Taxa from 41NU2, Showing the Ubiquity of Each, and Noting Association with Oyster Reefs

\begin{tabular}{|c|c|c|c|}
\hline Taxon & $\begin{array}{c}\text { Number of } \\
\text { Features Where } \\
\text { Present }\end{array}$ & $\begin{array}{c}\text { Percent of } \\
\text { Features }\end{array}$ & $\begin{array}{c}\text { Found on Oyster } \\
\text { Reefs }\end{array}$ \\
\hline Crassostrea virginica & 45 & $73.8 \%$ & Yes \\
\hline Busycon sinistrum & 44 & $72.1 \%$ & Yes \\
\hline Rabdotus sp. & 38 & $62.3 \%$ & \\
\hline Macrocallista nimbosa & 36 & $59.0 \%$ & \\
\hline Balanomorpha & 18 & $29.5 \%$ & Yes \\
\hline Mercenaria campechiensis & 17 & $27.9 \%$ & Yes \\
\hline Argopectin irradians & 11 & $18.0 \%$ & \\
\hline Polinices duplicatus & 11 & $18.0 \%$ & Yes \\
\hline Chione cancellata & 10 & $16.4 \%$ & Yes \\
\hline Dinocardium robustum & 10 & $16.4 \%$ & \\
\hline Crepidula fornicata & 8 & $13.1 \%$ & Yes \\
\hline Decapoda & 8 & $13.1 \%$ & \\
\hline Amygdala papyrium & 7 & $11.5 \%$ & \\
\hline Faciolara lillium & 7 & $11.5 \%$ & \\
\hline Pleuroplaca gigantea & 7 & $11.5 \%$ & \\
\hline Crepidula depressa & 5 & $8.2 \%$ & Yes \\
\hline Mytilidae & 5 & $8.2 \%$ & Yes \\
\hline Ishadium recurvum & 4 & $6.6 \%$ & Yes \\
\hline Sabellaria sp. & 3 & $4.9 \%$ & Yes \\
\hline Anadara transversa & 2 & $3.3 \%$ & Yes \\
\hline Brachidontes sp. & 2 & $3.3 \%$ & Yes \\
\hline Marshallora nigracintus & 2 & $3.3 \%$ & \\
\hline Trachycardium sp. & 2 & $3.3 \%$ & Yes \\
\hline Abra aequalis & 1 & $1.6 \%$ & Yes \\
\hline Anodontia alba & 1 & $1.6 \%$ & \\
\hline Anomalocardia auberiana & 1 & $1.6 \%$ & \\
\hline Anomia simplex & 1 & $1.6 \%$ & Yes \\
\hline Busycotypus canaliculatus & 1 & $1.6 \%$ & \\
\hline Busycotypus spiratus & 1 & $1.6 \%$ & \\
\hline Carditamera floridana & 1 & $1.6 \%$ & \\
\hline Codakia oricularis & 1 & $1.6 \%$ & \\
\hline Dentalium americanum & 1 & $1.6 \%$ & \\
\hline Diplodonta punctata & 1 & $1.6 \%$ & \\
\hline Dosinia discus & 1 & $1.6 \%$ & \\
\hline Eucrassatella speciosa & 1 & $1.6 \%$ & \\
\hline Lucine amianta & 1 & $1.6 \%$ & \\
\hline Macoma constricta & 1 & $1.6 \%$ & \\
\hline Mulina lateralis & 1 & $1.6 \%$ & Yes \\
\hline Noetia ponderosa & 1 & $1.6 \%$ & Yes \\
\hline Nuculana acuta & 1 & $1.6 \%$ & \\
\hline Semele bellastriata & 1 & $1.6 \%$ & \\
\hline Spisula raveneli & 1 & $1.6 \%$ & \\
\hline Strigilla carnaria & 1 & $1.6 \%$ & \\
\hline Suturoglypta iontha & 1 & $1.6 \%$ & \\
\hline Terebra dislocata & 1 & $1.6 \%$ & \\
\hline
\end{tabular}

(see Figure 6-23). Yet the few large pieces of bone from mammals were often found in good to excellent condition, suggesting that the mammal bone had been fragmented as part of the butchering process and before deposition.

The total of identified bone from the soil samples that were floated was 3,717 pieces amounting to a total identified bone weight of $362.9 \mathrm{~g}$. Table 11-3 shows a complete list of vertebrate remains that could be identified in feature soil samples. The vast majority of bone from the heavy fraction was in pieces less than $20 \mathrm{~mm}$ and was often hardly more than bone "dust". No attempt was made to count unidentifiable bone, though it was weighed and totaled $241.70 \mathrm{~g}$.

Table 11-3. Vertebrate Species Identified from Heavy Fraction of Floatation Samples

\begin{tabular}{|c|c|c|c|}
\hline Taxon & Common Name & Count & Wgt. (g) \\
\hline \multicolumn{4}{|c|}{ Mammals } \\
\hline Bovinae & Bison or Cattle & 3 & 7.3 \\
\hline Odocoileus virginianus & Whitetailed Deer & 12 & 64.62 \\
\hline Artiodactyla & Deer or antelope-sized & 8 & 40.85 \\
\hline Taxidea taxus & American Badger & 1 & 0.07 \\
\hline Carnivora & Unidentified Carnivore tooth & 1 & 0.05 \\
\hline Neotoma sp. & Packrats & 3 & 0.12 \\
\hline Sigmodon hispidus & Hispid Cotton Rat & 1 & 0.03 \\
\hline Rodentia & Unidentified Rodents & 21 & 0.54 \\
\hline Mammal-V. Lg. & Bison, Cattle, or Horse-sized & 30 & 18.12 \\
\hline Mammal-Lg. & Deer-sized & 42 & 38.74 \\
\hline Mammal-Medium & Dog, Coyote-sized & 5 & 29.1 \\
\hline Mammal-Sm. & Rabbit-sized & 1 & 1.03 \\
\hline Mammal-V. Sm. & Rat-sized & 2 & 0.05 \\
\hline Mammal & Size Indeterminate & 15 & 0.58 \\
\hline \multicolumn{2}{|r|}{ Total Mammals } & 145 & 201.2 \\
\hline \multicolumn{4}{|c|}{ Birds } \\
\hline Aves-Small & Robin-sized & 2 & 0.06 \\
\hline Aves & Size Indeterminate & 26 & 0.78 \\
\hline \multicolumn{2}{|r|}{ Total Birds } & 28 & 0.84 \\
\hline \multicolumn{4}{|c|}{ Reptiles } \\
\hline Serpentes & Unidentified Snake & 1 & 0.02 \\
\hline Testudines & Unidentified Turtle & 5 & 0.58 \\
\hline \multicolumn{2}{|r|}{ Total Reptiles } & 6 & 0.6 \\
\hline \multicolumn{4}{|c|}{ Fish } \\
\hline Archosargus probatocephalus & Sheepshead & 2 & 0.34 \\
\hline Ariopsis felis & Sea Catfish & 27 & 4.04 \\
\hline Bairdiella chrysoura & Silver Perch & 1 & 0.06 \\
\hline Cynoscion arenarius & Sand Sea Trout & 14 & 1.51 \\
\hline Cynoscion nebulosa & Spotted Sea Trout & 3 & 0.23 \\
\hline Micropogonais undalatus & Atlantic Croaker & 2 & 0.3 \\
\hline Pogonias cromis & Black Drum & 5 & 3.29 \\
\hline Sciaenops ocellata & Red Drum & 7 & 0.75 \\
\hline Osteichthyes & Unidentified Boney Fish & 3,477 & 149.74 \\
\hline \multicolumn{2}{|r|}{ Total Fish } & 3,538 & 160.26 \\
\hline \multicolumn{2}{|r|}{ Overall Total } & 3,717 & 362.90 \\
\hline
\end{tabular}


In the field it was possible to see in some features layers of fish bone as much as $50 \mathrm{~mm}$ thick spread across areas of a meter or more. The diameters of the centrums of the vertebrae in these lenses of fish bone usually were no more than $30 \mathrm{~mm}$ suggesting fairly small fish species. The presence of such dense layers of recognizable fish bones does suggest that the fish has undergone relatively little processing before consumption. Reduced processing costs, within the context of mass-procurement would make such resources relatively highly ranked as mentioned before. Unfortunately, while these dense deposits of fish bones represent significant information, the data becomes what Lyman and O'Brien (1987) called "analytically absent" because all attempts to remove them from the surrounding clay matrix or otherwise quantify them based only a profile exposure either fail or are inadequate. Even attempts to photograph these beds of fish bone were not very successful. It is not possible, therefore, to quantify, even very roughly, the degree to which the inhabitants of 41NU2 made use of small fish in their diet. Fish comprise 95.2 percent of the identifiable vertebrate bone (Table 11-3), and given all data available, both quantitative and subjective observation in the field, it is likely that, at least at times, fish was an even more important part of the diet than shell fish.

\section{Discussion}

In considering the result of the analysis of the faunal material in the heavy fractions of the soil samples from 41NU2, the limitations of the data, especially concerning vertebrate fauna, are striking. The soil samples were often only a very small percentage of the total feature, and since larger features were not always uniform in structure or contents, the samples do not always reflect the total species diversity and relative dietary importance. This is especially true in features where there were a great number of small fish bones, which could not be adequately enumerated. Oso Bay would have been a perfect place for netting, using weirs, or even scooping into baskets to collect the many species of fish that spend their juvenile years in these shallows, but we have only the massive numbers of tiny fish bones observed in the field, which cannot be enumerated in a satisfactory way, to show that this was done.

The fish species identified at 41NU2 area listed in Table 114 , with information on the annual presence/absence of these species in the bays. In six features (Features 73, 75, 114, 117,155 , and 156), two or more species of fish were found together. Comparing the presence data for the fish in question (Table 11-4) allows us to suggest when these features might have been in use (Table 11-5). As Table 11-5 shows, all of these features are likely to have been utilized during the spring. This data is insufficient to suggest with any degree
Table 11-4. Seasonal Presence and Absence in Estuaries for Eight Fish Species

\begin{tabular}{|l|l|}
\hline \multicolumn{1}{|c|}{ Species } & \multicolumn{1}{c|}{ Presence/Absence in Bays } \\
\hline Sheepshead & Absent mid-summer into fall (Jun.-Nov.) \\
\hline Sea Catfish & Absent mid-summer into fall (Jun.-Nov.) \\
\hline Silver Perch & Year round, into shallows and rivers in summer \\
\hline Sand Sea Trout & Absent only in mid-winter (Nov.-Feb.) \\
\hline Spotted Sea Trout & $\begin{array}{l}\text { Juveniles remain year-round; Adults move in and } \\
\text { out depending on temperature and salinity }\end{array}$ \\
\hline Atlantic Croaker & Late spring through summer \\
\hline Black Drum & Juveniles all year; Adults absent Feb-April \\
\hline Red Drum & Juveniles all year; Adults absent July-Jan. \\
\hline
\end{tabular}

Table 11-5. Six Features, the Multiple Fish Species Present, and Estimate Months of Utilization

\begin{tabular}{|c|l|c|}
\hline Feature & \multicolumn{1}{|c|}{ Fish Species Present } & $\begin{array}{c}\text { Estimated Months of } \\
\text { Utilization }\end{array}$ \\
\hline 73 & Sea Catfish; Red Drum & Feb. to April \\
\hline 75 & $\begin{array}{l}\text { Sheepshead; Sea Catfish; Spotted } \\
\text { Sea Trout }\end{array}$ & Dec. to April \\
\hline 114 & $\begin{array}{l}\text { Sea Catfish; Spotted Sea Trout; } \\
\text { Red Drum }\end{array}$ & Feb. to April \\
\hline 117 & $\begin{array}{l}\text { Sea Catfish; Silver Perch; Sand } \\
\text { Sea TroutSpotted Sea Trout }\end{array}$ & March to April \\
\hline 155 & $\begin{array}{l}\text { Sea Catfish; Spotted Sea Trout; } \\
\text { Red Drum }\end{array}$ & March to April \\
\hline 156 & Spotted Sea Trout; Red Drum & March to April \\
\hline
\end{tabular}

of certainty when in the annual round 41NU2 was occupied or if the season of occupation changed over time. Several other forms of seasonality estimation and more dating of features would be required to answer this question with any confidence. However, two other types of evidence do suggest that the site was frequently inhabited during a time of the year when large-bodied food resources were scarce or absent, forcing the inhabitants to turn to procurement of resources that would be far lower ranked.

The first indication that habitation at 41NU2 was frequently during the late winter and/or early spring is the presence of the large numbers of tiny fish bones evident in many of the features. As has been noted above, these remains of these fish were observed frequently in the field, often in a thin layer of extremely dense fishbone, all or most of which were very small, with most representing fish less than $10 \mathrm{~cm}$ in length and many at least half that size. Clearly, catching such fish on an individual basis would be energetically far too expensive and would yield low returns. However, the application of technology, in the form of basket scoops can increase the capture rate significantly, although it may also increasing overall technology costs. 
(Bettinger et al. 2006; Ugan 2005:80; Ugan et al. 2003). The fact that such small fish were probably eaten whole, with or without cooking, thus reducing processing cost significantly, adds to the potential return rate (Ugan 2005:86). The presence of so many small fish in multiple features across the site also may suggest that other, more highly ranked food resources were not available or were scarce.

Another indication that habitation at 41NU2 often took place during times of the year when many food resources were scarce is the fact that in most features and Occupation Zones, deersized animal bone is present, but has been reduced to small splinters. The undisturbed, well-sealed context in which most features were found, and the many small hearths and small shell clusters indicate that any given habitation at 41NU2 was usually brief. It is unlikely, then, that the extreme fragmentation of most animal bone seen on the site was caused by trampling or by post-depositional disturbances. It appears, therefore that the bone was fragmented as part of the butchering process. While not enumerated, field observations and examination of the small percentage of bone that was returned to the lab and analyzed supports the hypothesis that most of the fragmentation was done while the bone was fresh. This may be an indication that those portions of large-bodied animals that were brought to the site were processed for bone grease.

The extraction of bone grease involves breaking fat-rich elements, such as the ends of long bones, into small pieces and then boiling the bone fragments until the fat in them melts and floats to the surface of the water, where it is scooped up (Brink 1997; Vehik 1977). This is a labor and fuel intensive process with a relatively small yield. Yet Brink (1997:271) has pointed out that at certain times of the year in particular, the need for even a little fat can become paramount. The human body cannot process protein without fat (Brink 1997; Speth and Spielman 1983:149-159). Since most animals are very lean during the late Winter/early Spring, or during prolonged droughts, it is during these times that the fat in bones will seem important enough to make the effort (Brink 1997:271). Vehik (1997) has presented characteristics one would explect to see if bone has been processed for bone grease. The characteristics include large numbers of very small fragments of bone which appear to be from deer or bison-sized animals and an absence or near absence of identifiable long bone ends and the centrums of vertebrae. Although the overall faunal collection at 41NU2 does contain some bison-sized bone found in relatively large pieces, the vast majority of the bones of deer or larger mammals are extremely fragmented and very few fragments of articular ends were observed.

Examining the small quantity of mammalian bone is of limited value, as the sample size is so small and since provenience information indicates it comes from several thousand years of occupation. By grouping mammals by size class, that is by bison-sized, deer-sized and smaller than deersized, and by comparing the bone weights of these groups as a percentage of their total bone weight, we can state with some confidence that deer-sized animals are the most common fauna represented at 41NU2 (Table 11-6).

Table 11-6. Mammalian Bone Weight in Three Size Categories

\begin{tabular}{|l|c|c|}
\hline \multicolumn{1}{|c|}{ Body-Size Category } & Bone Wgt. (g) & Percent of Total \\
\hline Bison-sized & 25.42 & $14.8 \%$ \\
\hline Deer-sized & 144.21 & $84.1 \%$ \\
\hline Smaller than Deer-sized & 1.89 & $1.1 \%$ \\
\hline Total & 171.52 & $100.0 \%$ \\
\hline
\end{tabular}

Shell fishing seems to have been the most important gathering activity practiced by inhabitants, though the few features that consisted largely of bone suggest that this was not always the case. The inhabitants of 41NU2 had two major shell fishing options, the oyster reefs in Corpus Christi Bay, and the mud bottoms and sea grass beds of Oso Bay. In fact, of the species found in at least 10 soil samples, the only species not commonly associated with oyster reefs are large species with considerable food value, and the Rabdotus land snail (Table 11-2). The only major species that is not associated at least partially with oyster reefs is the Sunray Venus. This clam would have likely been common in the mudflats of Oso Bay. Lightning Whelks would have preyed on both oysters and on the bivalves in mudflat and sea grass beds, and would thus have been readily collected while looking for clams or while harvesting the oyster reefs. Although there is no oyster reef near Oso Bay in Corpus Christi Bay today, as recently as 1961 two oyster reefs were identified just offshore of the entrance to Oso Bay (Martinez 1961:2). Martinez (1961:1) noted that most of the oysters he encountered during his survey of Corpus Christi Bay were dead. At that time the only viable reef (i. e. a reef large enough to warrant commercial shellfishing) was at the northern end of the bay, near the entrance to Nueces Bay (Martinez 1961:1). Martinez (1961) attributed the small number of living oysters to the use of dredges for oyster collecting, which had been the practice for some 70 years (Townsend 1893:414) and had only recently been discontinued (Martinez 1961:1). Another possible cause may have been a recent large influx of freshwater from storms. The salinity of Corpus Christi Bay is often lowered to the point that oysters cannot survive after such an influx (Townsend 1893:414).

\section{Comparative Sites}

In order to compare the subsistence practices observed at $41 \mathrm{NU} 2$ with other sites in the region, as defined in the 
Research Design (Tomka et al. 2006), the work authorization for this report required a detailed literature review and collection of data on 13 sites in the general vicinity of 41NU2: 41AS3, 41NU184, 41NU221, 41NU266, 41SP15, 41SP43, 41SP120, 41SP136, 41SP148, 41SP149, 41SP153, 41SP156, and 41SP177.

During the examination of the literature it was discovered that no report concerning an excavation at site 41SP15 was available, other than mention of a brief visit and acquisition of a sample for radiocarbon dating (Ricklis 1993). While attention to vertebrate fauna in many of the other sites was minimal, most provided data on the numbers of invertebrates at the site, though in most cases, only large and/or readily identifiable species were reported. In one case, site 41AS3, the available reports did not have an analysis of the faunal material, merely mentioning the presence of a given species (Campbell 1955; Cox and Smith 1988; Jurgens and Whitsett 1982; Ward and McGraw 1993). Since neither 41AS3 nor 41SP15 had useable faunal data, they were removed from this study.

In order to make the comparison of 41NU2 with other sites more comprehensive, site 41NU11, which had excellent data available (Hedrick 1993), was added. Site 41AS16, located on low mounds in a marshy grass flat area in Copano Bay was also added (Prewitt et al. 1984). In addition, the report on the excavation of 41NU266 showed that sites 41NU267 and 41NU268 were less than $100 \mathrm{~m}$ from $41 \mathrm{NU} 266$ and that $41 \mathrm{NU} 278$ was closer to Locus 3 in 41NU266 than Locus 1 and 2 were. In order to add to the sample sizes, these three sites, all occupying the same knoll as 41 NU266, were also added to the database.
Thus, in the remaining portion of this chapter the faunal data from 41NU2 will be combined with sixteen other sites: seven in the Bay-Fluvial habitat, two in the marshy Grass Flats habitat, and seven in the Prairie-Riverine habitat. Table 11-7 shows the sites chosen for the comparative study, including a brief description of their location, the habitat category in which they have been placed, and the literature from which the data was acquired. Appendix $\mathrm{H}$ presents the complete faunal database from the 17 sites, including 41NU2, used in the following discussion. The data presented in Appendix $\mathrm{H}$ include: site number, time period, taxa, and counts either as NISP or MNI when reported. The mammals and birds were grouped by body size. Reptiles were reported by Order and Suborder (i.e. "Turtles", "Snakes", and "Lizards"). Invertebrates were reported by Genera or Species whenever possible.

The three site habitats mentioned above describe in a general way the setting in which the sites were located. Sites 41AS16 and 41SP177 were located on low mounds at the edge of a bay (Copano and Nueces, respectively), surrounded by extensive salt marshes, in the Grass Flats habitat. Sites 41NU11, 41NU184, 41NU221, 41NU266, 41NU267, 41NU268, and 41NU278 were located on terraces above the Nueces River floodplain. Though all are today some distance from the mouth of the river, the original valley was both deeper and narrower, and it was the development of the Nueces delta and the extension of that delta towards Nueces Bay that has resulted in the site settings setting seen today. In the past, the river mouth would have been closer and the water more brackish than today, as evidenced by the presence of oyster and Lightning Whelk, as well as the low salinity Rangia

Table 11-7. Sites Used in Comparison of Regional Subsistence Practices, Including Their Habitat and References Used for Data Collection

\begin{tabular}{|c|l|l|l|}
\hline Site & \multicolumn{1}{|c|}{ Description of Location } & Site Habitat & \multicolumn{1}{|c|}{ References } \\
\hline 41AS16 & $\begin{array}{l}\text { On two relict Pleistocene knolls surrounded by low salt marsh at the point where Swan } \\
\text { Lake enters Copano Bay; }\end{array}$ & Grass Flats & $\begin{array}{l}\text { Prewitt et al. 1984; Paine } \\
1987\end{array}$ \\
\hline 41NU11 & On a clay dune located just south of the entrance of Oso Creek into Oso Bay; & Prairie-Riverine & Headrick 1993 \\
\hline 41NU184 & Uplands of dissected Pleistocene terrace above floodplain of Nueces River; & Prairie-Riverine & Ricklis and Gunter 1984 \\
\hline 41NU221 & Uplands overlooking the modern Nueces River floodplain; & Prairie-Riverine & Ricklis 1986, 1988 \\
\hline $\begin{array}{c}\text { 41NU266/NU267/ } \\
\text { NU268/NU276 }\end{array}$ & $\begin{array}{l}\text { Uplands overlooking the modern Nueces River floodplain. The 4 sites are all within 100 } \\
\text { m of each other; }\end{array}$ & Prairie-Riverine & $\begin{array}{l}\text { Ricklis 1995; Warren } \\
1993,1994\end{array}$ \\
\hline 41SP43 & $\begin{array}{l}\text { On low bluff immediately adjacent to Ingleside Cove (Corpus Christi Bay). Sites SP43 } \\
\text { and SP120 are probably the same occumpations; }\end{array}$ & Bay-Fluvial & $\begin{array}{l}\text { Corbin 1963; Ricklis } \\
1993 ; \text { Story 1968 }\end{array}$ \\
\hline 41SP120 & $\begin{array}{l}\text { On low bluff above Ingleside cove (Corpus Christi Bay). Sites SP43 and SP120 are } \\
\text { probably the same occumpations; }\end{array}$ & Bay-Fluvial & $\begin{array}{l}\text { Prewitt 1984; Ricklis } \\
1990\end{array}$ \\
\hline 41SP136 & Uplands immediately adjacent to partially infilled cove of Nueces Bay; & Bay-Fluvial & Ricklis 1993 \\
\hline 41SP148 & Uplands immediately adjacent to partially infilled cove of Nueces Bay; & Bay-Fluvial & Ricklis 1993 \\
\hline 41SP149 & Uplands immediately adjacent to partially infilled cove of Nueces Bay; & Bay-Fluvial & Ricklis 1993 \\
\hline 41SP153 & Uplands immediately adjacent to partially infilled cove of Nueces Bay; & Bay-Fluvial & Ricklis 1993 \\
\hline 41SP156 & On knoll that is remaining portion of Pleistocene terrace; & Bay-Fluvial & Ricklis 1993 \\
\hline 41SP177 & Marshy area at foot of Plesitocene uplands, near small creek; & Grass Flats & Ricklis 1993 \\
\hline
\end{tabular}


clams found, sometimes in great numbers, at these sites (Ricklis 1995, 1986, 1988, 1990; Ricklis and Gunter 1986). These Prairie-Riverine habitat sites had the resources of both the river and environs, and the prairies that surrounded them. Only in the earliest levels of these sites are more marine fauna seen. This will be considered below.

Sites 41SP43, 41SP120, 41SP136, 41SP148, 41SP1149, $41 \mathrm{SP} 1153$, and 41SP156, as well as 41NU2, are located on bluffs above a bay, in areas where there is a freshwater influence nearby. These Bay-Fluvial habitat sites can take advantage of the increased marine resources available is such habitats (Stickney 1984:39).

\section{Analytic problems}

It is important to understand that the level of reporting of faunal remains in the literature concerning these sites is extremely variable. This is largely due to three factors: a change over time in the understanding of the importance of faunal analysis in the investigation of past lifeways; the availability at the time of faunal experts to make the analysis; and the difficulties of finding funding for such analyses. As a result the level of expertise used in identification of the animal remains at the sites under consideration was variable. This is an unfortunate, but inevitable, consequence of using data from more than fifty years of reports, and from both relatively amateur to professional faunal analysts. Short of the reanalysis of the collections chosen for this comparative study by a single analyst or team of analysts using the same criteria, there is no way around this problem.

In addition it must be noted that using NISP as a measure of dietary importance has some obvious drawbacks. NISP is simply the number of identified specimens in a given sample. From NISP you cannot determine if the 20 bison bones came from 1 or 20 animals. More importantly, the NISP of 20 bison bones and 20 rat bones suggests a diet comprised of equal amounts of bison and rat. Clearly this is not the case, as each bison bone represents a much larger amount of meat than each rat bone.

Various ways to compensate for this analytical weakens of NISP have been devised. In certain limited circumstances, the Minimum Number of Individuals (MNI) can be a useful method for reconstructing the diet represented by bone recovered from archaeological sites. In most circumstances the use of bone weight is probably the best method to gauge the relative importance of various mammalian species to a diet. If large numbers of non-mammalian species are present, it is best to use the allometric formulae devised by Reitz (Reitz and Wing 1999:22-231) to achieve the best fit of estimated biomass (and thus relative dietary importance). Unfortunately, very few of the reports listed in Table 11-7 mention the weight of the bone recorded. We are forced to use NISP, with, perhaps, an eye to the relative size of the animals in question. Therefore, all identified mammal bone was divided into five body-size classes, representing bison-sized, deer-sized, coyote-sized, rabbitsized, and rat-sized animals.

The invertebrates recorded in the reports listed in Table 11-7 are different. In each report, shell fragments that did not contain a substantial portion of the umbo or columnella of the shell were not counted. Thus the counts are either the MNI in the case of Gastropods, or $1 / 2$ the MNI in the case of Bivalves. It would probably be better to weigh the shells in this case, as well, to get a better sense of the overall importance of various species, as oysters that were no bigger than a thumb nail would be counted the same as oysters $20 \mathrm{~cm}$ long. An estimate of "meat-weight" represented by a given shell might be possible, if data on this can be located for enough of the most common species.

In any case, comparing the bones of vertebrates with the shells of invertebrates is not straightforward. In the circumstances, NISP is probably the best method to use, but it should not be supposed that if a given site has 100 mammal bones and 900 shells, that shellfish were nine-tenths of the diet. Instead, we can examine the differences, first by habitat, and then by time, in the relationship between the animal remains in the various vertebrate and invertebrate categories.

\section{Comparing Subsistence in Three Habitats}

\section{Vertebrates}

There are a number of ways to compare the evidence of subsistence identified in the sites listed above. To begin with, we can look at the vertebrate species. Table 11-8 shows the combined total of vertebrates, excluding fish, from the sites in each category for each habitat. Fish will be considered separately, as they are (with one exception, see below) an exclusively marine resource, while the other vertebrates are terrestrial or riverine resources. A possible exception to this would be marine turtles, however, no marine turtles were identified at any of the sites.

Figure 11-1 shows the difference in the relative use of three classes of vertebrates, mammals, birds and reptiles, in the site grouped into the three habitat types. The sites in the Prairie-Riverine habitat have the smallest total numbers, with Mammals (53.2 percent) and Reptiles (43.1 percent) dominating (Figure 11-1). The Grass Flats sites show a similar 
Table 11-8. Counts of Selected Vertebrates from 17 Coastal Sites Grouped by Habitat

\begin{tabular}{|c|c|c|c|}
\hline \multirow[b]{2}{*}{ Selected Vertebrates* } & \multicolumn{3}{|c|}{ Site Habitat } \\
\hline & 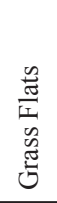 & 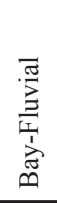 & 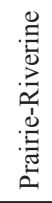 \\
\hline V. Large (Bison-sized) & 0 & 42 & 31 \\
\hline Large (Deer-sized) & 115 & 766 & 30 \\
\hline Medium (Coyote-sized) & 0 & 11 & 2 \\
\hline Small (Rabbit-sized) & 10 & 13 & 9 \\
\hline Very Small (Rat-sized) & 19 & 79 & 28 \\
\hline Total Mammals & 144 & 911 & 100 \\
\hline V. Large (Turkey, Heron-sized) & 0 & 0 & 1 \\
\hline Large (Duck-sized) & 1 & 9 & 2 \\
\hline Small (Robin-Sized) & 0 & 2 & 0 \\
\hline Total Birds & 1 & 11 & 3 \\
\hline Alligator & 1 & 1 & 2 \\
\hline Turtles & 140 & 47 & 68 \\
\hline Snakes & 137 & 21 & 15 \\
\hline Lizards & 1 & 0 & 0 \\
\hline Total Reptiles & 279 & 69 & 85 \\
\hline $\begin{array}{r}\text { Total of Selected } \\
\text { Vertebrates }\end{array}$ & 424 & 991 & 188 \\
\hline
\end{tabular}

*excludes fish

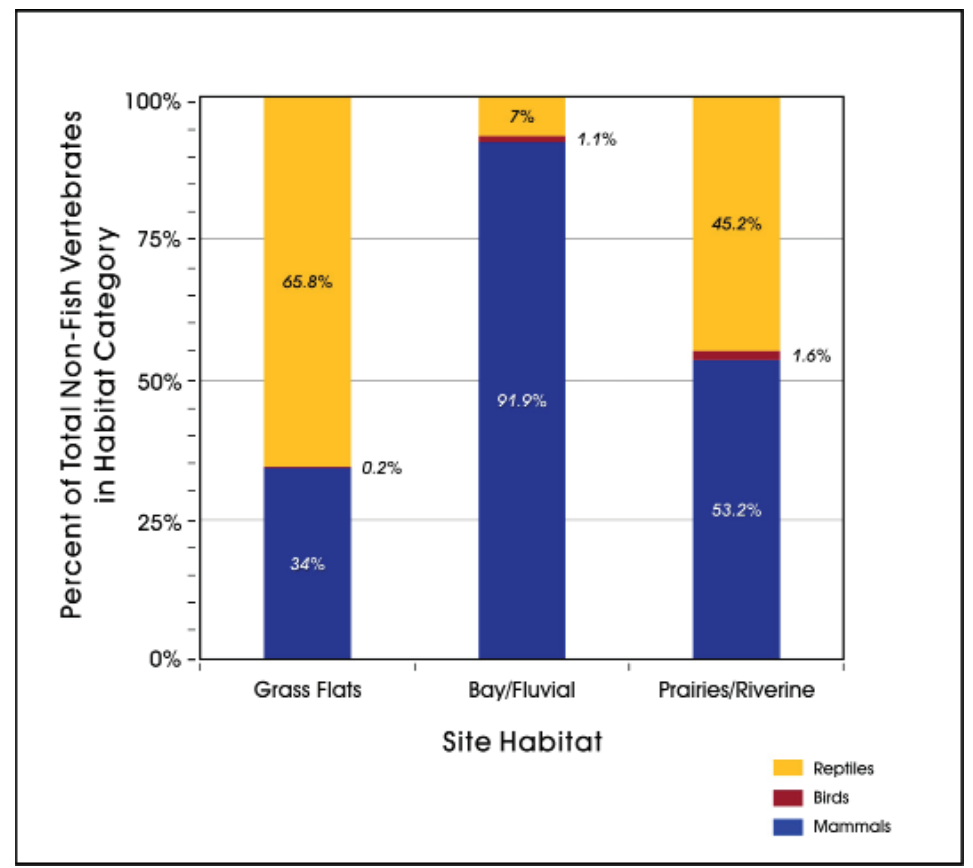

Figure 11-1. Percentage of identified vertebrate species (excluding fish) from $41 N U 2$ and 17 comparative sites grouped into habitat type categories. picture, with Mammals and Reptiles together comprising all but 0.2 percent of the total (Figure 11-1). The sites in the BayFluvial areas are very different. In these sites 91.9 percent of the selected vertebrates are in the Mammal category, Reptiles are only 7.0 percent and birds are 1.1 percent.

The relatively low numbers of birds at all the sites was also noted at $41 \mathrm{NU} 2$. Though large numbers of birds are present in the area today, especially during nesting season and during the spring and fall migrations, very few bird bones were recovered from any of the sites in the comparative data set. At $41 \mathrm{NU} 2$, not only were there very few bird bones recovered $(n=28)$, but no egg shell was found. As noted in Chapter 8 , the numbers of birds, and the richness of species varies a great deal over the year, yet even in the period when the bird populations are smallest (i.e. April to July) bird species, many of which are in the medium to large category, are still available (Carrilo 2000; see also discussion in Chapter 8).

The question of why so few bird remains are found in these coastal sites may have to do with the difficulty of catching them, compared to the relative ease of digging clams and oysters out of the bays, and it may not be a coincidence that it is the Prairie-Riverine habitat, where mollusks are limited to the narrow river and thus are easily over-exploited, that bird bone was the most common (Figure 11-1). In this environment, mollusks of reasonable size would have been much less readily available than they are in either the Grass Flats or Bay-Fluvial habitats.

This might place birds slightly higher on the resource status list when these sites were inhabited.

A closer look at the kinds of Mammals being hunted in the three habitats reveals an interesting pattern. Figure 11-2 shows the breakdown of the mammal category by body-size. In this case, it is the Grass Flats and BayFluvial habitats that are very similar in the percentage of each body-size, though the Bay-Fluvial category shows more presence of rabbit- and rat-sized bones than the Grass Flats Category. The Prairie-Riverine habitat bears no resemblance to the others. Relatively large percentages of bison- and deer-sized bones are present, along with a percentage of rat-sized bones that is nearly as large as the bison-sized and deer-sized bones. It is clear that close to the bays, the emphasis in mammal hunting is on deer-sized animals, with other mammals a more or less incidental presence. In the Prairie-Riverine sites, bones come from all categories, especially bison-, deer-, and rat-sizes. If we presume that bison would always be high on the resource status list, with deer and similar-sized animals considered secondary, whenever bison were available, Figure 11-2 suggests that bison 


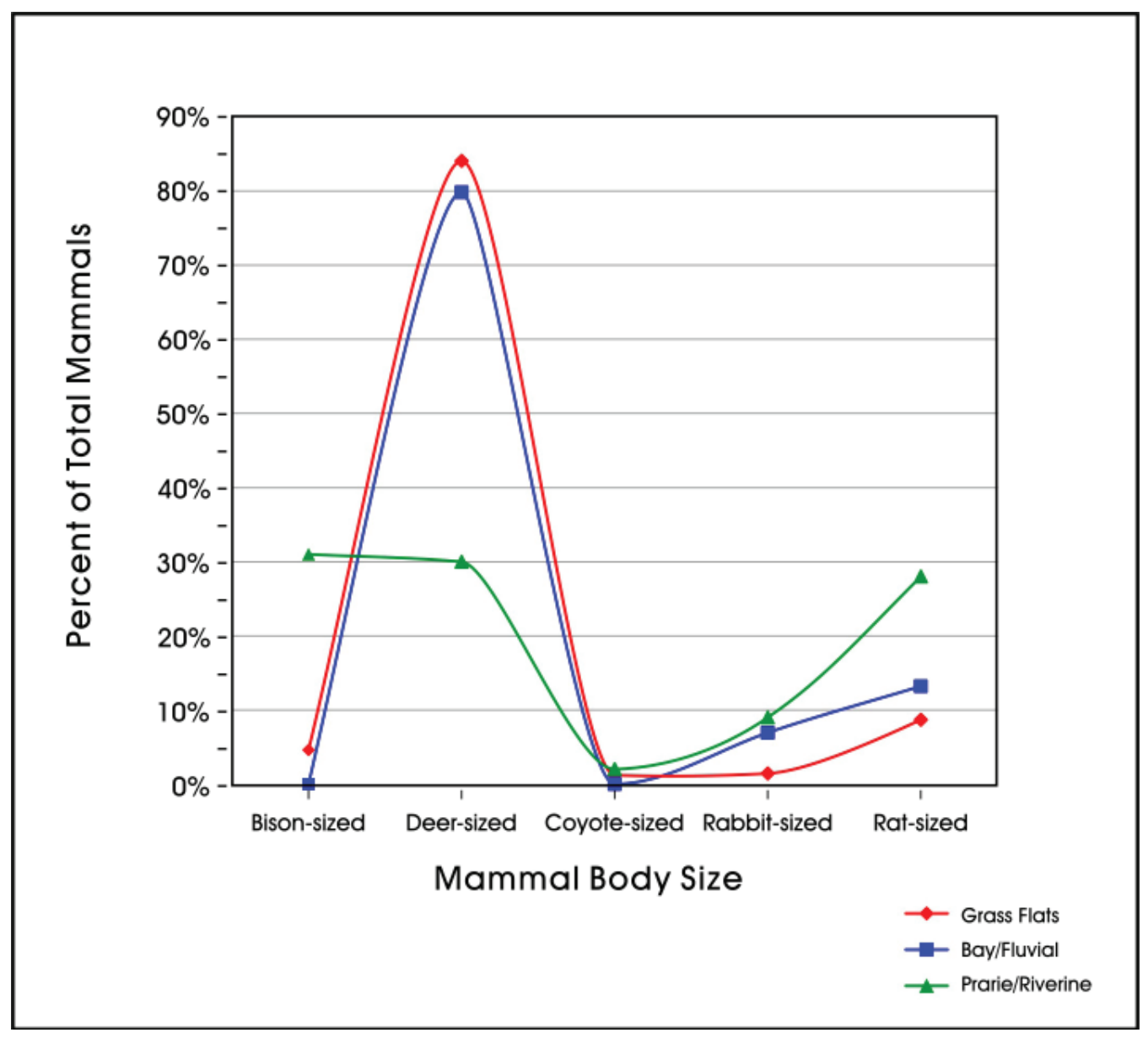

Figure 11-2. Comparison of the relative utilitzation of mammals in five body-size categories in sites in the three habitat types.

were only occasionally available near the bays, and rare or never found near the Grass Flats sites. In general, however the people inhabiting the Bay-Fluvial habitat concentrated on deer, to the near exclusion of smaller mammals, or, indeed, reptiles or birds (see Figure 11-1). Given that the amount of meat represented by each bone is larger in Large mammal bones than in the smaller categories, this emphasis on deer can be presumed to be even large than Figure 11-1 indicates, though the relative importance of Very Large mammals should be increased as well. In Bay-Fluvial sites, it appears that rabbit and rat-sized animals are replaced with molluscs in the hierarchy of resource status.

In the Reptile Category, turtles and snakes are the most prevalent, as Table 11-8 shows. By far the largest number of turtle and snake bones were found in the Grass Flat sites. Both types of reptiles would be common in the marshes, but it is a little surprising to find so many snakes. The only time when snakes would be relatively easy to catch would be on cold days, when they would have difficulty moving fast enough to get away from humans. Both snakes and turtles would be less readily available near Bay-Fluvial sites and the numbers in Table 11-8 show this. Sites in the Prairie-Riverine habitat have many turtle bones, but few snake bones. This probably reflects the relative densities of the two types of reptiles in the riverine environment. While terrestrial turtles and tortoises, as well as snakes, would have been plentiful on the prairies, they would have been much harder to find in the large prairie setting. Finding turtles in the confines of the riverine setting would have been easier.

Fish are the final category of vertebrates. The complete list of identified taxa is available in Appendix H. For this discussion we will concentrate on the more common fish identified to at least Genus. Table 11-9 shows the eight genera of fish that had more than 25 bones in the sites of at least one of the three habitats. Surprisingly, they include Gars (Lepisosteus sp.) at one Grass Flats site (see Appendix H) Gars are a freshwater fish in four species, two of which are common in the rivers and larger creeks of Texas, and one of which, the Spotted Gar (L. oculatus) is common in the lower rivers as far west as the Nueces, and has been found in brackish water 
Table 11-9. Count of Bones from Selected Species of Fish from Sites by Habitat

\begin{tabular}{|c|c|c|c|c|c|c|c|c|}
\hline \multirow[b]{2}{*}{ Site Habitat } & \multicolumn{8}{|c|}{ Fish Species } \\
\hline & $\begin{array}{c}\text { Gars } \\
\text { (freshwater) }\end{array}$ & Sea Catfish & Sheepshead & Sea Trout & $\begin{array}{l}\text { Atlantic } \\
\text { Croaker }\end{array}$ & $\begin{array}{l}\text { Black } \\
\text { Drum }\end{array}$ & Red Drum & $\begin{array}{c}\text { Total Identified } \\
\text { Fish }\end{array}$ \\
\hline Grass Flats & 28 & 92 & 18 & 45 & 3 & 39 & 14 & 239 \\
\hline Bay-Fluvial & 0 & 126 & 2 & 349 & 572 & 529 & 344 & 1,922 \\
\hline Prairie-Riverine & 0 & 22 & 5 & 13 & 7 & 20 & 7 & 74 \\
\hline Totals & 28 & 240 & 25 & 407 & 582 & 588 & 365 & 2,207 \\
\hline
\end{tabular}

(NatureServe Explorer 2008). This would be especially likely in the aftermath of large rain events, when the salinity of the bays has been lowered.

The remaining fish in Table 11-9 are all common in estuarine waters of the Gulf of Mexico today (Stickney 1984:204). These seven fish genera were consistently the most commonly identified fish in all the comparative sites. In fact the total number of fish in the comparative study that were within these seven genera was 2,249, while the total number of fish identified that were not in these genera was 68 (Appendix H). One reason for this is probably their size. By examining the data in Table 8-3, we can see that the average size of fish in the seven genera in Table 11-9 is $424.1 \mathrm{~mm}$, while the average size of the 7 remaining species shown in Table 8-3 is $229.2 \mathrm{~mm}$. However, it is important to note that we cannot assume that these seven genera were actually the most commonly chosen as prey by the inhabitants of the sites in this study. The large size of adults of these species probably put them higher on a food resource value list, but their large size also makes them more identifiable and makes them seem a larger portion of the fish diet than they may have been. It is possible that, as at 41NU2, large numbers of small fish were exploited, gathered in the shallow waters near the Grass Flats and Bay-Fluvial sites but remain unidentified during faunal analysis.

We are again hampered in our analysis by the "analytical absence" (Lyman and O'Brien 1987) of small fish, due to the extreme friability of their bone. Field observations at $41 \mathrm{NU} 2$, as noted above, showed that in some locations there were layers of fish bone representing hundreds or possibly thousands of small fish. The fragility of their bone prevented enumeration, however. Bone stable enough to survive the disturbance of collection and floating could be found with the centrums of vertebrae from about $5 \mathrm{~mm}$ to almost microscopic. This is no surprise. All of the fish listed in Table 8-3 spend all or the majority of their juvenile period in the shallow waters of the Corpus Christi Bay system, joined by at least nine species of fish, Order Cyprinodontiformes, that are all small fish that live year-round and are abundant in the shallow estuarine waters as well (Stickney 1984:210-211). At some times of the year the biomass of small or even tiny fish available by scooping up in baskets must have been worth the effort, as the layers of small fish bone at 41NU2 suggest.

We are left, then, to note that the identifiable fish were all large. Like all marine fish that live part of their lives in estuaries, they can all tolerate low salinity, in most cases even freshwater. All are tolerant of at least mildly hypersaline conditions and three can tolerate extreme hypersalinity (Table 8-3). All can tolerate low water temperatures, and all can tolerate water temperatures of $35^{\circ} \mathrm{C}\left(95^{\circ} \mathrm{F}\right)$ or above. Their ability to withstand these extremes of salinity and temperature, at least for a while, is necessary, given the extreme variability of these factors in estuaries, especially estuaries like the Corpus Christi Bay system, which is fed only by rivers and creeks running through arid regions which are not infrequently deluged by massive rain events.

The two most common species are the Black Drum (Pogonias cromis) and the Atlantic Croaker (Micropogonias undulates), possibly because these two fishes are especially tolerant of both low and high salinities, and low and high water temperatures (Table 8-3) making them potentially available even during weather extremes.

\section{Invertebrates}

A total of 38 different mollusc genera were identified in the 17 sites in the comparative database (see Appendix H). However, as mentioned at the beginning of this study, the expertise of the faunal analyst in the reports that provided the data used here was variable, as was the interest in smaller shells that were unlikely to have been deliberately gathered for food. Again, all we can do is make use of the data we have, keeping in mind this caveat.

The species include very small molluscs that were probably not directly collected for food, as well as large clams or gastropods. The land snail of the Rabdotus genus is not included in this study, since, while most reports mention the 
presence of this snail, only a few enumerate them, making it difficult to know if the large numbers recovered from 41NU2 was an anomaly or a common phenomenon.

Species richness in the three habitats within which the sites are located is variable, with the Bay-Fluvial sites having 37 genera, while the Grass Flats have 18 genera and the PrairieRiverine sites have only 10 genera. This variability is very likely the result of availability. The narrow range of habitat conditions favorable for mollusks in the Prairie-Riverine habitat is expected to suppress species richness. In contrast, the variety of estuarine habitats available to most of the BayFluvial sites would include a wide variety of potential prey.

Table 11-10 is a breakdown of 19 mollusc genera recovered from the sites in the comparative database. Species smaller than the Crossbar Venus clam are excluded, as they are all very small and we assume not to have been systematically harvested for food. It is interesting that not one of the genera presented in Table 11-10 can be found in even roughly similar numbers across all three habitats. In fact six genera appear in only two habitats and five were found in only one habitat.

In order to have a better understanding of what estuarine habitats were being exploited by the inhabitants of the sites in the comparative database, we grouped the sites within habitat categories and assigned the mollusks in Table 11-10 to an estuarine habitat. Figure 11-3 shows where the inhabitants of the sites in each habitat concentrated their collection of mollusks. The mollusks from Prairie-Riverine habitats are, not surprisingly, almost exclusively from a brackish to riverine environment. The inhabitants of the Grass Flats sites concentrated on genera found around oyster reefs and, to a much lesser degree, mudflats. The Bay-Fluvial site inhabitants made extensive use of Oyster Reefs and Seagrass Beds, with lesser use of mudflats.

Note that the three genera listed as inhabiting Oyster Reefs, Mudflats, and Seagrass Beds are all predatory gastropods that can be found hunting their prey in these three environments. The presence of so many Lightning Whelks in most BayFluvial sites is probably a reflection of the shell fishing concentrated in the three environments that are also the hunting grounds for these common carnivorous snails.

This exploitation pattern suggests that hunter-gatherers tended to focus on estuarine habitats that were closest to their sites for harvesting mollusks. The data seem to indicate that the transportation of mollusks across habitats was not practiced or if it was, it occurred after some field

Table 11-10. Counts of Marine Shells from 17 Sites Grouped by Habitat

\begin{tabular}{|c|c|c|c|c|c|}
\hline \multirow[b]{2}{*}{ Taxa } & \multirow[b]{2}{*}{ Estuarine habitats } & \multicolumn{3}{|c|}{ Site Habitat } & \multirow[b]{2}{*}{ Total } \\
\hline & & Bay-Fluvial & Grass Flats & Prairie-Riverine & \\
\hline Amygdalum papyrium & Seagrass flats & 90 & 0 & 0 & 90 \\
\hline Argopecten irradians & Seagrass flats & 8,287 & 387 & 0 & 8,674 \\
\hline Atrina serrata & Mudflats & 99 & 588 & 0 & 687 \\
\hline Brachidontes sp. & Oyster Reefs & 3 & 0 & 0 & 3 \\
\hline Chione cancellata & Oyster Reefs & 1,541 & 130 & 1 & 1,672 \\
\hline Crassostrea virginica & Oyster Reefs & 17,427 & 10,545 & 491 & 28,463 \\
\hline Dinocardium robustum & Mudflats & 80 & 0 & 3 & 83 \\
\hline Ischadium recurvum & Oyster Reefs & 100 & 47 & 71 & 218 \\
\hline Littorina irrorata & Saltmarshes & 101 & 5 & 1 & 107 \\
\hline Macrocalista nimbosa & Mudflats & 3,075 & 111 & 2 & 3,188 \\
\hline Mercenaria campechiensis & Oyster Reefs & 935 & 16 & 0 & 951 \\
\hline Noetia ponderosa & Oyster Reefs & 75 & 0 & 0 & 75 \\
\hline Ostrea eqestris & Oyster Reefs & 0 & 160 & 0 & 160 \\
\hline Rangia sp. & Brackish to fresh & 277 & 9 & 14,608 & 14,894 \\
\hline Busycon sinistrum & Oyster Reefs; Seagrass & 5,562 & 82 & 0 & 5,644 \\
\hline Busycotypus sp. & Seagrass & 77 & 4 & 0 & 81 \\
\hline Fasciolaria sp. & Seagrass & 260 & 25 & 0 & 285 \\
\hline Pleuroploca gigantea & Oyster Reefs; Seagrass & 87 & 8 & 0 & 95 \\
\hline Polinices duplicatus & Oyster Reefs; Seagrass & 621 & 0 & 0 & 621 \\
\hline Total "Food-size" molluses & & 38,697 & 12,117 & 15,177 & 65,991 \\
\hline
\end{tabular}




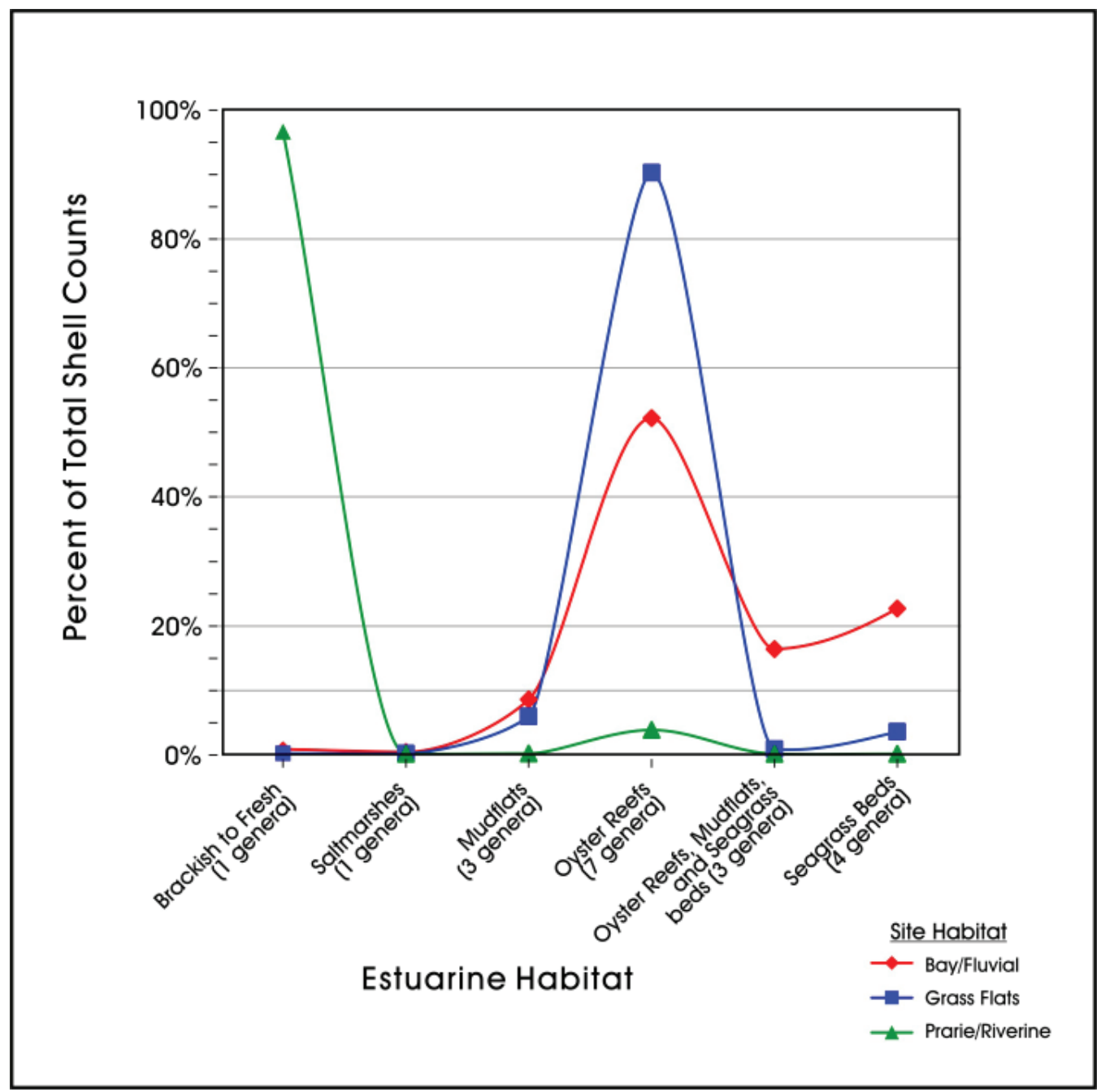

Figure 11-3. Percent of total NISP of shells in each of the three site habitat categories that were derived from each of six estuarine habitats.

processing for transportation. The later possibility is rather unlikely given the small size of most species involved and the theoretical expectation that such field-processing would most likely occur in the case of larger, heavier, species.

\section{Comparing Use of Terrestrial, Riverine-to-Brackish, and Marine Resources}

Using NISP to compare Terrestrial to Estuarine resources is highly problematic. Only using the best estimates of average calories provided per unit of weight of the remains being studied could come close to providing a reasonable estimation of relative importance in the diet. While data on the calories (and various nutrients) per gram of useable food is available or can be reasonably estimated for most species (see Chapter 8), there is no way to derive reliable estimates of the weight of useable food available to prehistoric peoples that is represented by the only materials generally available to archaeologists: highly fragmented bones and shells. This is the perennial problem for faunal analysts (Lyman 1987, 1994; Reitz and Wing 1999): how do you estimate in a reasonable way, the dietary importance of the species you find in archaeological sites? It becomes really difficult when the faunal remains span not only Class and Order, but even Phylum.

This is not to say that there is no point in looking at the difference in NISP in the three habitats by large faunal groups. It is necessary to realize that future methods devised to increase the reliability of our interpretation of these data may someday be available, allowing much more sophisticated interpretations of available data. In the mean time we present the data we have.

Our primary interest here is to understand the relative importance of fauna collected from various ecosystems available to prehistoric inhabitants in the vicinity of 
Corpus Christi Bay. Simply dividing the various taxa into vertebrate/invertebrate or mammal/fish/invertebrate will not accomplish this. It is necessary to be more specific, and assign taxa to a habitat: Terrestrial, Marine, and a third category, Riverine-to-Brackish (see Table 11-11). The latter intended to encompass those species that are most common in rivers and the boundary conditions in deltas and where the bay water is heavily influenced by freshwater input from a major creek or river. In some cases assignment of a taxa to one of these categories is not straight forward. Whether birds can be considered "Terrestrial" or "Riverine-to-Brackish" would be problematic in any case, and when so few of the bird bones were identifiable to Genus ( $n=13$ of 190 bird bones in entire database) it becomes even more difficult. Somewhat arbitrarily, then, all birds were assigned to Riverine-to-Brackish, based the increased likelihood of catching them when they are in riverine or deltaic settings. Turtles, though some may have been tortoises from the nearby Prairie habitat, have been placed in the Riverine-to-Brackish category as well, based on the assumption that riverine turtles are far more common
Table 11-11. Fauna Assigned to Faunal Habitat

\begin{tabular}{|l|l|}
\hline \multicolumn{1}{|c|}{ Faunal Habitat } & \multicolumn{1}{c|}{ Fauna Assigned to Habitat } \\
\hline Terrestrial & All mammals, snakes, lizards \\
\hline $\begin{array}{l}\text { Riverine-to- } \\
\text { Brackish }\end{array}$ & $\begin{array}{l}\text { All birds, alligators, turtles, Gars, and } \\
\text { brackish-water clams (Rangia } \text { sp.) }\end{array}$ \\
\hline Marine & All fish except Gars, all marine molluscs \\
\hline
\end{tabular}

and more likely to be caught than completely terrestrial species. Table 11-11 shows what types of fauna were placed in which of these three categories.

Figure 11-4 shows the relative reliance, based entirely on NISP, of inhabitants in each of the site habitats to faunal from the three faunal habitats. From this figure we can see that inhabitants of the Bay-Fluvial and Grass Flats used the marine mollusc far more than any other fauna type, while the Prairie-Riverine depended on fauna from the Riverine-to-Brackish setting.

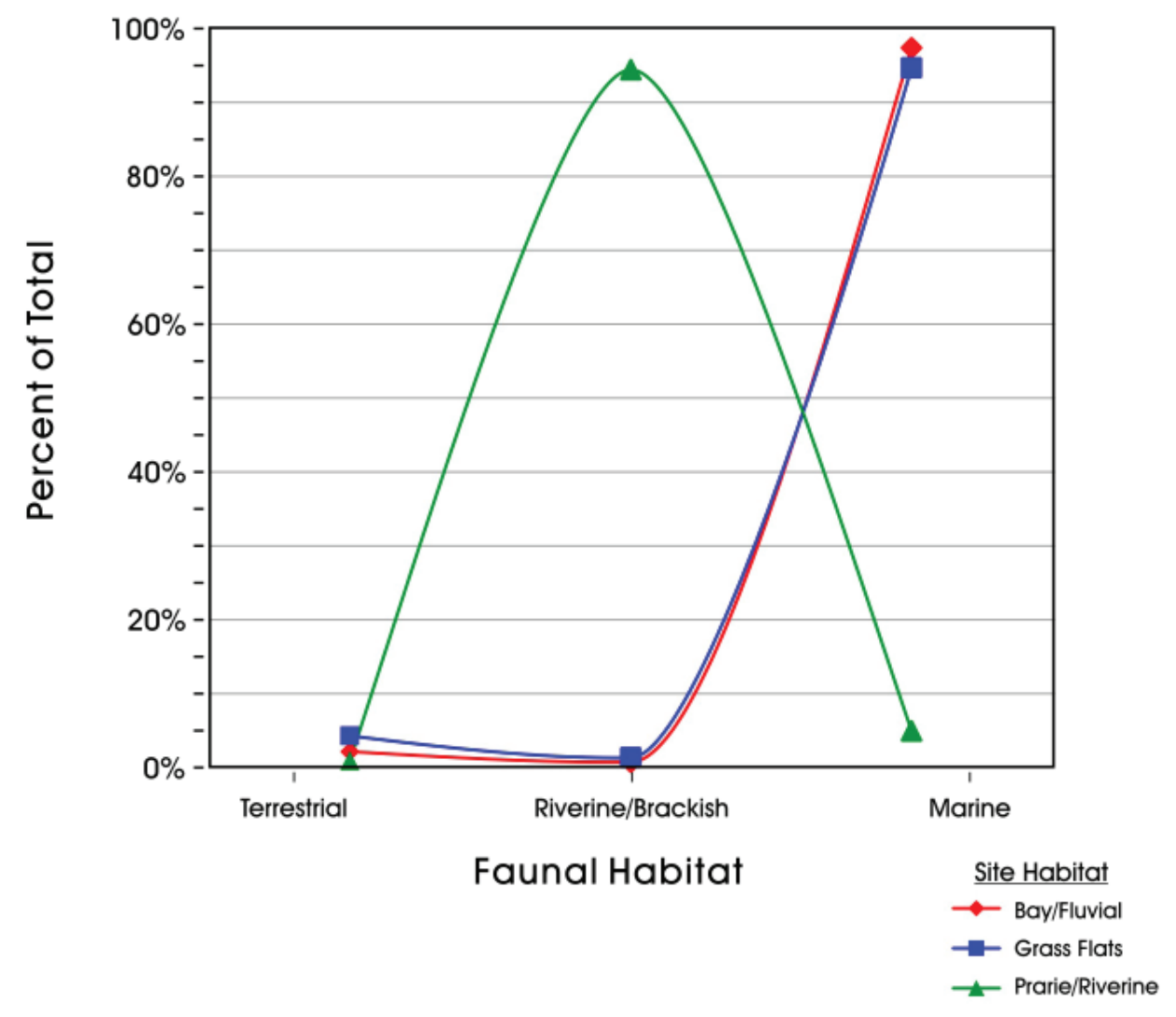

Figure 11-4. Percent of Total NISP of species found in the sites in the three habitat categories categorized into Terrestrial, Riverine/Brackish, and Marine environments 
It is interesting to consider the Riverine-to-Brackish category in more detail. In Table 11-12 we can see that the inhabitants of the Prairie-Riverine sites made use of a great deal of invertebrates, just as those living at the Bay-Fluvial and Grass Flats sites did, however it was the Rangia (Rangia sp.) clam that they concentrated on. Though adults of both clams can withstand sudden changes in salinity and temperature, the Common Rangia (Rangia cuneata) needs a salinity range of 0 to $10 \%$ for the survival of larva (Andrews 1977:200-221). The Brown Rangia (Rangia flexuosa) prefers more salinity, but it too is more common in deltaic and other heavily river-influenced areas (Andrews 1977:200-221). Thus the inhabitants of the Prairie-Riverine sites were not as different in the kinds of foods they ate as Figure 11-4 suggests.
They, too, ate large quantities of molluses with other faunal resources making up a small percentage of the NISP.

Table 11-12. Distribution of Fauna from Riverine-to-Brackish Habitat by Site Habitat

\begin{tabular}{|c|c|c|c|}
\hline \multirow{2}{*}{$\begin{array}{c}\text { Fauna from Riverine-to- } \\
\text { Brackish Habitat }\end{array}$} & \multicolumn{3}{|c|}{ Site Habitat } \\
\hline & Bay-Fluvial & Grass Flats & Prairie-Riverine \\
\hline Birds & 110 & 69 & 11 \\
\hline Alligators & 1 & 1 & 2 \\
\hline Turtles & 1 & 140 & 137 \\
\hline Fish (gars) & 0 & 28 & 0 \\
\hline Invertebrates (Rangia sp.) & 277 & 9 & 14,608 \\
\hline Totals & 389 & 247 & 14,758 \\
\hline
\end{tabular}




\section{Chapter 12: Regional Land Use Patterns \\ Jennifer A. Thompson, Leonard Kemp and Barbara M. Meissner}

\section{The Regional Land Use and Subsistence Model}

In Chapter 9, we defined a series of expectations regarding hunter-gatherer regional land-use patterns through space and time in the five ranked habitats in the Coast Plains and Marshes region.

Briefly, we proposed that when bison are present only in low numbers or are absent (i.e., latter part of the Early Archaic and Middle Archaic periods) on the Coastal Plains and Marshes the Prairie-Riverine habitat would be ranked highest in terms of potential intake rates based on high population densities of deer. Based on the habitat choice model, because the PrairieRiverine habitat offers the highest potential intake rate we suggested that the earliest hunter-gatherer populations coming into the region would settle in this habitat. Therefore, we would expect that some of the oldest traces of occupation within the region (i.e., residential campsites) would be found within the Prairie-Riverine habitat.

Daily foraging trips would be contained within the river valley and may access resources upstream and downstream as well as at the ecotone between the woodlands and the grassland prairie. During the early stages of Prairie/Rriverine habitat occupation, subsistence practices would be focused on the hunting of deer from residential camps during daily foraging trips. Given high return rates and reduced transportation costs, no field processing of the carcass would be expected. As intra-habitat return rates decline and foraging trips increase in length, field processing may be adopted with low meat-utility elements being discarded in the field rather than returned to residential camps. Low ranked animal species may be included in the diet when captured by women during their daily foraging trips.

Based on the habitat selection model, we predicted that as hunter-gatherer population densities increased, friction between groups would lead to resource depletion and the widening of the diet breadth. As lower ranked resources are incorporated into the diet, neighboring habitats may provide higher encounter rates for lower ranked prey types if they represent the prey's preferred habitat. Initially, adjustments in resource procurement may simply consist of increases in daily foraging trip lengths and greater residential mobility (e.g., both the length and frequency of moves). Logistical mobility may also be employed to reach more distant but more profitable resources such as deer or pronghorn. Eventually, to more efficiently exploit the broader range of lower ranked resources, human populations may begin to shift residential foraging to the new habitat.

Due to the low suitability of the prairie habitat, we proposed that although it is the second highest ranked habitat, it would not be the focus of settlement. Rather, we suggested that human populations would reorient their subsistence focus to the next lower ranked habitat, namely the beach-fluvial interface (i.e., the marsh). The exploitation of the beachfluvial interface habitat would most likely have occurred from the nearby Prairie-Riverine setting because marshy areas are rarely suitable for human habitation. The diet of groups inhabiting the beach-fluvial interface would likely include a preponderance of lower ranked prey species some of which could be effectively procured en-mass with rudimentary technologies (i.e., technology that does not have high energy costs to manufacture) and would entail minimal or no processing costs. It is likely that the prairie would continue to be exploited through logistically organized mobility to target highly ranked resources.

The Bay-Estuary-Lagoon or Grass Flats habitat, the fourth ranked among the five coastal habitats, would be accessed from the nearby shores and habitation would have centered near the mouths of freshwater intermittent creeks that emptied into the lagoons and provided a seasonal source of water. The shores of ephemeral ponds and seasonal lakes may also have attracted occupation. As in the case of the Beach-Fluvial habitat, the availability of migratory birds and schooling fish could have led to increased encounter rates and to highly profitable bulk procurement episodes.

The lowest ranked habitat in the region is the beach and beach-proximate zone. Nonetheless, because it is near the Bay-Estuary-Lagoon habitat, it could have served as staging grounds for short procurement trips into the estuaries or processing stations for resources identified for transport. Field processing would rarely be expected since it would not be profitable to spend energy field-processing most lower ranked resources.

\section{Regional Land Use Patterns}

To examine regional land use we created a database containing information on a four-county region surrounding 41NU2. It was built from data gathered from the Texas Archeological Sites Atlas. The four counties include Refugio, 
Aransas, Nueces, and San Patricio. The data collected on all prehistoric and protohistoric sites includes information on site size, age of components, artifact assemblage content, and distance to water when noted on the site survey forms.

The site locations were brought into a GIS database and mapped onto regional maps showing the distribution of habitats across the four county area (see Figure 2-12a-b). Once geo-referenced, we defined the boundaries of the different habitats found across the region (the Prairie, PrairieRiverine, Beach-Fluvial Interface or Estuary, and Beach or Grass Flats) (Figure 2-13) and calculated their aerial extent. The boundaries of the Prairie-Riverine habitat were artificially set at 500 meters on either side of the course of the stream.
When temporal assignments were present either on the Survey Forms or the technical reports we incorporated them into the database without changes. When no temporal affiliation was provided for a site or component, we reviewed the projectile points recovered and assigned a time period, if feasible.

The four-county GIS dataset includes 553 sites: 97 from Aransas County, 266 from Nueces County, 18 from Refugio County, and 172 from San Patricio County. Figure 12-1 shows the distribution of the sites across the four-county region. It is evident that by far the largest habitat is the Prairie. The Beach-Fluvial interface (i.e., the marsh) is a distant second followed by the open bay. The Prairie-Riverine habitat is not substantially larger than the beach and grass flats habitats.

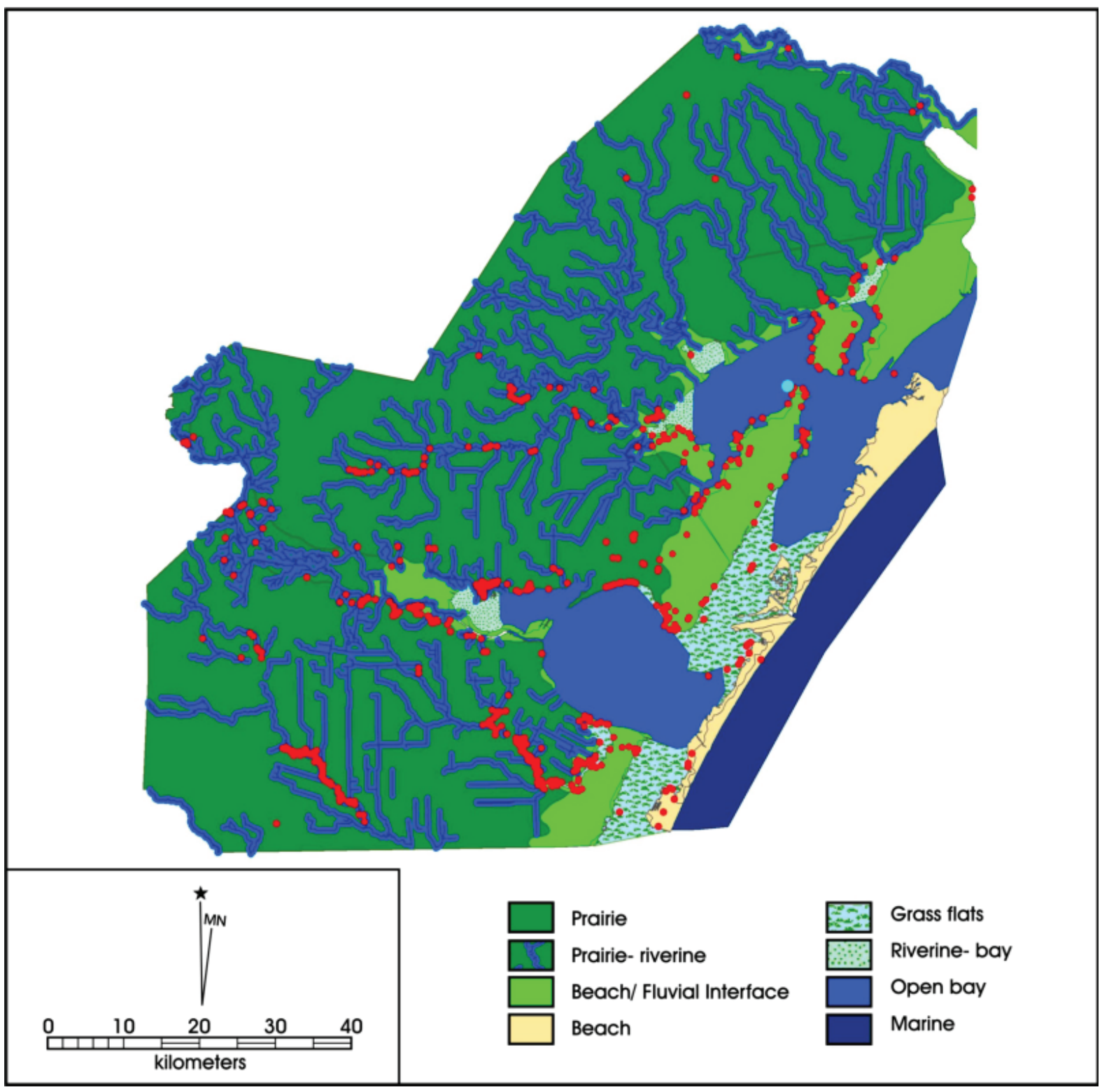

Figure 12-1. Site distribution across habitats in Aransas, Nueces, Refugio and San Patricio Counties. 
Although it is the third smallest, the Prairie-Riverine habitat contains the highest site density with nearly one site per square kilometer. Among the three terrestrial habitats, the Prairie has the lowest site density. For obvious reasons, site densities are very low in the grass flats and open bay although the presence of some sites that had been recorded while water levels were very depressed does indicate that these areas were exploited when conditions allowed.

The low density of sites on the prairie may lend support to the model's assertion that the habitat was not well suited to habitation. In contrast, the fact that the highest density of sites is found in the Prairie-Riverine habitat seems to agree with the models expectation that given its high potential return rate it will be the focus of human occupation of the region. Interestingly, the Beach-Fluvial interface (i.e., the margins of the marshes), contain the second highest site density. This finding seems to again corroborate the model's expectation that outside of the Prairie-Riverine habitat beach-fluvial settings may be the most actively utilized as stations from which to exploit the resources of the Bays-Estuaries and Lagoons.

While these patterns may accurately reflect prehistoric land use practices, they may also be a product of sampling bias. That is, river valleys tend to be some of the most intensively surveyed environments because they are considered to be high-probability settings for archeological sites. The calculation of site densities by survey areas size is one way in which such a bias may be gauged. Unfortunately, such data was not readily available for the four-county region and therefore these calculations could not be performed.

The four-county database also allowed us to explore in greater detail spatial relationships of sites to freshwater sources. As an aspect of habitat unsuitability and to highlight the challenges faced by hunter-gatherers in utilizing habitats outside of the Prairie-Riverine zone, we have already highlighted the critical importance of freshwater resources. The four-county GIS database allows us to actually quantify this aspect. Table 12-1 shows that by definition the shortest distance from sites to freshwater is found in the Prairie-Riverine habitat. While the prairie lacks localized freshwater resources, the sites found within this habitat are on the average no more than 1915 meters from the nearest stream. This two kilometer distance is less than the typical daily foraging round trip distance of 6-8 kilometers. The shorter distance may be in response to the added costs of transporting water to sustain foraging or short term logistical forays onto the prairie margins. Table 12-1 also shows that sites on the Beach-Fluvial habitat are on the average nearly five kilometers from freshwater and the beaches fronting the bays and lagoons place hunter-gatherers nearly 14 kilometers from the nearest source of freshwater.

It is worth noting here that freshwater is defined as a flowing stream and we recognize that many localized sources of fresh or brackish water would likely have been available to huntergatherers exploiting resources in the Beach-Fluvial habitat or on the beach. These sources would have consisted of ox bow lakes, ponds such as the one north of 41NU2, playa lakes, and small ephemeral drainages that carried runoff during the rainy season. The Beaumont Clay underlying parts of the landscape itself could have contributed to the pooling of water across the landscape. So, access to freshwater may not have been as major a challenge as suggested by the figures in Table 12-1. It is nonetheless true, that while localized freshwater sources may perhaps been available during the wet season, during seasonal periods of low rainfall, between late June and midAugust and again between November and March (see Figure 2-3), coastal populations would have had a more difficult time securing freshwater in these coastal habitats particularly when the ponds dried out. The diatom research on Core 2 from the pond does indicate that particularly during the later part of the paleoclimatic sequence the pond may have experienced seasonal drying (see Winsborough, Appendix D this volume). Such seasonal diminishing of freshwater across these coastal habitats would have severely limited the exploitation of the beach-fluvial and estuary resources to no more than a few days at a time.

To further explore trends in the regional site distribution data, we examined patterns in site sizes across the habitats. Of the 553 sites in the database, $337(60 \%)$ have data on site size. Table 12-2 presents the breakdown of sites by size groupings within the regional habitats. Due to small sample sizes we combined the beach and grass flats habitats into one group. Also, to insure reasonable sample sizes in most of the cells of the table, we combined site sizes into four rather large groupings. We also calculated the adjusted residuals for the table (see Everitt 1977; Haberman 1973). Adjusted residuals

Table 12-1. Geographical Habitat Information

\begin{tabular}{|l|c|c|c|c|c|c|}
\hline \multicolumn{1}{|c|}{ Attribute } & Prairie & Prairie-Riverine & Beach-Fluvial & Beach & Grass Flats & Open Bay \\
\hline Area $\left(\mathrm{km}^{2}\right)$ & 5462.3 & 288.32 & 952.37 & 215.64 & 279.1 & 790.67 \\
\hline Number of sites & 135 & 239 & 145 & 9 & 25 & 15 \\
\hline Site density & 0.02 & 0.83 & 0.15 & 0.04 & 0.09 & 0.02 \\
\hline Distance to Fresh Water $(\mathrm{m})$ & 1915 & 206 & 4790 & 13956 & 11998 & 7091 \\
\hline
\end{tabular}


Table 12-2. Breakdown of Sites by Size Group within Four Habitats

\begin{tabular}{|c|c|c|c|c|c|c|c|c|c|}
\hline Site Size Group & Prairie & $\begin{array}{l}\text { Adjusted } \\
\text { Residual }\end{array}$ & Prairie-Riverine & $\begin{array}{l}\text { Adjusted } \\
\text { Residual }\end{array}$ & $\begin{array}{l}\text { Beach- } \\
\text { Fluvial }\end{array}$ & $\begin{array}{l}\text { Adjusted } \\
\text { Residual }\end{array}$ & $\begin{array}{l}\text { Beach and } \\
\text { Grass Flats }\end{array}$ & $\begin{array}{c}\text { Adjusted } \\
\text { Residual }\end{array}$ & Totals \\
\hline$<1,000 \mathrm{sq} \mathrm{m}$ & 34 & 1.02 & 49 & -2.51 & 25 & 2.49 & 6 & -0.37 & 114 \\
\hline $1,001-5,000 \mathrm{sq} \mathrm{m}$ & 26 & -0.18 & 58 & 1.18 & 13 & -0.76 & 4 & -1 & 101 \\
\hline $5,001-10,000 \mathrm{sq} \mathrm{m}$ & 9 & -1.22 & 31 & 1.99 & 5 & -0.93 & 2 & -0.53 & 47 \\
\hline$>10,000 \mathrm{sq} \mathrm{m}$ & 20 & 0.06 & 39 & -0.1 & 8 & -1.22 & 8 & 1.97 & 75 \\
\hline Totals & 89 & & 177 & & 51 & & 20 & & 337 \\
\hline
\end{tabular}

* residuals that are higher or lower than $+/-1.96$ are statistically significant at the .05 level

determine the contribution of each individual cell within a contingency table to the overall significance of the table. That is, when a chi-square value is significant, it is often due to the patterns within a limited number of the cells of a table. A deviations of $+/-1.96$ from expected frequencies signals a statistically significant divergence from expectations at a probability beyond the .05 level. The table indicates that the counts of sites diverge from expectations based on sample sizes in four cells. Sites smaller than $1,000 \mathrm{~m} 2$ are significantly under-represented in the Prairie-Riverine habitat while sites measuring between 5,001 and 10,000 $\mathrm{m} 2$ are over-represented. That is, fewer small sites are found than expected and a greater number of large sites are present than expected based on regional site size patterns. In the Beach-Fluvial habitat, small sites are over-represented in contrast to the Prairie-Riverine zone. Finally, in the Beach and Grass Flat habitat, very large sites measuring more than $10,000 \mathrm{~m} 2$ are over-represented although sample sizes are rather small overall.

The under-representation of small sites within the PrairieRiverine habitat may be due to the relative abundance of resource. That is, relatively higher resource abundance allows longer-term occupations and also potentially more frequent reoccupations of sites due to more rapid regeneration of plant communities. The repeated reoccupation of terraces would result in gradually increasing site sizes and an overall increase in the frequency of large sites, exactly the pattern noted in the table. Occupation of the margins of the BayEstuary-Lagoon habitat to facilitate the exploitation of the abundant but lower ranked resources may explain the over-representation of small sites within the Beach-Fluvial habitat. In addition, the pattern may also be due to the episodic and short-term nature of the visits to this habitat to exploit resources in an opportunistic manner. Given that the lack of freshwater resources does not provide a settlement anchor that would favor the re-occupation of specific spots in the habitat, the use of the Beach-Fluvial zone may be more extensive depending on which part of the Bay-EstuaryLagoon provides an abundance of resources at the time of the visit. Finally, the over-representation of large sites in the combined Beach and Grass Flats habitat may reflect the fact that dunes on the beach may represent settlement magnets that would be reoccupied on a systematic basis leading to increases in site size over time. Alternatively, large sites may not only be confined to the dunes but may also result from the intermittent use of different parts of the beach over time. These occupations can eventually coalesce into what appear to be low density material distributions spread over large areas. The key difference between these large sites and those in the Prairie-Riverine habitat is that the coastal ones are a product of the slow merging of small intermittent reoccupations spread linearly along the beach. In the case of the Prairie-Riverine habitat, the abundance of resources actually encourages re-settlement of productive spots on the landscape.

In the research design developed for this project, we suggested based on the Habitat Choice Model that the habitat that would show the earliest signs of occupation would be the Prairie-Riverine zone. Only after resource depletion and the gradual reduction of highly ranked resource from the habitat would hunter-gatherers begin to move out into neighboring habitats with similar rankings.

To explore temporal changes in settlement across the coastal zone, we compared the ages of components at each site in the GIS dataset across habitats to assess the expectation that the oldest sites in the region are in the Prairie-Riverine habitat. Of the 553 sites in the database, only 214 components have temporal affiliations defined in broad terms (i.e., Paleoindian, Archaic, or Late Prehistoric). Only 74 components have information that allows them to be dated to finer-scaled temporal units (i.e., sub-periods) such as Early, Middle and Late Archaic and Initial and Terminal Late Prehistoric. Table 12-3 presents the breakdown of sites within the habitats identified by temporal affiliation.

Looking at the coarse-grained temporal divisions (i.e. Paleoindian, Archaic and Late Prehistoric), the oldest sites within the dataset are in the Prairie-Riverine habitat. Given the geological history of the coast, however, it is likely that many other Paleoindian sites are found currently submerged 
Table 12-3. Components per Habitat Through Time

\begin{tabular}{|l|c|c|c|c|c|c|c|}
\hline \multirow{2}{*}{\multicolumn{1}{c|}{ Time Period }} & \multicolumn{7}{c|}{ Primary Habitat } \\
\cline { 2 - 9 } & Prairie & Prairie-Riverine & Beach-Fluvial & Beach & Grass Flats & Open Bay & Grand Total \\
\hline Early Archaic & 2 & 4 & 1 & 0 & 1 & 1 & 9 \\
\hline Middle Archaic & 4 & 6 & 3 & 0 & 2 & 1 & 16 \\
\hline Late Archaic & 11 & 22 & 8 & 0 & 1 & 0 & 42 \\
\hline Initial Late Prehistoric & 0 & 3 & 0 & 0 & 0 & 0 & 3 \\
\hline Terminal Late Prehistoric & 0 & 3 & 0 & 1 & 0 & 0 & 4 \\
\hline Archaic & 23 & 54 & 15 & 2 & 2 & 1 & 97 \\
\hline Late Prehistoric & 23 & 53 & 25 & 4 & 6 & 3 & 114 \\
\hline Paleoindian & 0 & 2 & 1 & 0 & 0 & 0 & 3 \\
\hline
\end{tabular}

on the continental shelf. Therefore and given the small sample size, the Paleoindian settlement, while being the earliest, it is not representative of the overall coastal settlement during the period. The pattern that is perhaps more meaningful is that beginning with the Early Archaic sub-period, and continuing into the Late Archaic, the number of sites in the Prairie-Riverine habitat are consistently higher than in any other single habitat in the region. This pattern suggests that throughout the earliest intensive occupations of the habitats examined, the Prairie-Riverine habitat was the one that was the focus of settlement and exploitation. Again, the possibility that the pattern is the product of more numerous surveys within the habitat cannot be ruled out.

Even more telling is the pattern that during the Late Prehistoric Period there is a virtual explosion in the use and exploitation of resources (habitats) outside of the PrairieRiverine habitat (see Table 12-3, see sites assigned to a broad Late Prehistoric affiliation). While the initial stages of this reorientation in settlement and resource extraction strategy may be noted during the Late Archaic (Table 12-3, see sites assigned to the Late Archaic sub-period), the shift becomes even more amplified during the subsequent Late Prehistoric. Interestingly, the exploitation of the Prairie habitat is consistent through the Archaic and Late Prehistoric Periods.

The Late Archaic and Late Prehistoric reorientation in settlement and resource extraction strategies agrees well with expectations derived from recently evaluated models of intensification of resource extraction by hunter-gatherers in Texas (Johnson and Hard 2008). The population growth rate model considered by Johnson and Hard (2008:Figure 4) indicates that the Lower and Central Coast of Texas should be locations where under packed conditions intensification of extraction is highly anticipated. Furthermore, Johnson and Hard (2008:143) expect that it is exactly on the Lower and Central Texas Coast, where the modeled value of dependence on aquatic resources exceeds 30 percent, that prehistoric hunter-gatherer groups should turn to the intensification of aquatic resources rather than terrestrial resources. Unfortunately, we do not have population estimates that can inform us about rates of population growth and packing. Nonetheless, the regional settlement pattern data reviewed above does suggest that, in concordance with the expectations of the Habitat Choice Model, the Late Archaic and Late Prehistoric reorientation in settlement pattern from the Prairie-Riverine to more beach-proximate habitats may be indicative of the aquatic intensification expected based on the population growth model.

\section{What the Faunal Data Shows}

In Chapter 11, we discussed our reconstructions of regional subsistence practices based on the faunal data compiled from eighteen excavated sites in San Patricio, Refugio, Nueces, and Aransas Counties. Clearly, this information also has some bearing on general patterns of land use within the broader region. Specifically, we noted that inhabitants of sites located in the Grass Flats, Bay-Fluvial and Prairie-Riverine habitats exploited a similar set of vertebrate subsistence resources (see Table 11-8) and they all utilized estuarine resources (see Figure 11-3). Nonetheless, some degree of resource emphasis is evident. For example, inhabitants of sites located in habitat use resources from fewer of the estuarine habitats (see Figure 11-3) than populations living in greater proximity to the estuaries. Furthermore, it is the brackish to fresh water habitat that is the one most often exploited from sites in the habitat. A similar pattern is evident in terms of faunal habitats exploited (see Figure 11-4). The inhabitants of sites located in the habitat tend to focus on faunal resources found in the riverine/brackish habitat and the exploitation of fauna in the marine and terrestrial habitats appears to be de-emphasized.

In summary, while a range of resources representing terrestrial, riverine and marine habitats, are being consumed by populations inhabiting the, Grass Flats and Bay-Fluvial habitats, there appears to be an emphasis on the consumption of more localized resources in greater proximity of each site 
within each habitat. This general observation is supported by the study of bone stable carbon and nitrogen isotopes derived from a series of Texas prehistoric cemeteries (Johnson and Hard 2008:145-146). The data show clear divisions in isotope values between inland, coastal and riverine populations. While the distinctions in isotope values between these populations are somewhat surprising, they do suggest that these populations to a large extent focused their subsistence strategies and dietary intake on resources found within their immediate vicinity.

\section{Conclusions}

Our analysis of regional settlement patterns began with a look at site densities across the different habitats present within the four-county region encompassed by Nueces, Refugio, Aransas and San Patricio counties. While intriguing, the highest density of sites in the Prairie-Riverine habitat may a product of the greater number of archeological surveys conducted in this habitat driven by more intensive regional developments. Unfortunately, while the number of sites by acre surveyed could provide an unbiased estimate of site densities by habitat, we could not gather this data in time for this report. Based on the data we were able to collect, it appears that through time the Prairie-Riverine habitat maintained the highest density of sites in the region. This is an expected pattern given that it was the habitat with the highest potential intake rate for hunting and gathering. Based on the Habitat Choice Model, only when the highest ranked resources in this habitat were unavailable would we expect populations to shift to using other habitats. Identifying shifts in residential locales because of changing food availability is difficult to determine by examining site distribution because of the small sample of sites with detailed sub-period level temporal affiliation and faunal data. Nonetheless, the regional distribution of sites within the Prairie-Riverine setting, vis a vis other habitats, between the Early and Late Archaic sub-periods does appear to support the expectation that the Prairie-Riverine setting was the focus of settlement and extractive activities. Similarly, the broadening of site distributions during the Late Prehistoric to include sites in all other habitats outside of the Prairie-Riverine setting seems to suggest that by this time lower ranked resources were regularly incorporated in the diet of hunter-gatherers. 


\section{Chapter 13: Territoriality and Cemeteries}

\section{Steve A. Tomka, Jennifer A. Thompson and Leonard Kemp}

Volume I of this series summarized the explorations of the prehistoric cemetery at 41NU2 (Jackson et al. 2004). The stratigraphic distribution of the burials in conjunction with the temporal diagnostics recovered suggests that the cemetery was utilized during the Middle Archaic and Late Archaic sub-periods and Late Prehistoric Period. The cemetery at $41 \mathrm{NU} 2$ is only one of a number of sites containing human remains across South Texas and the Central Coastal Plains. To provide a broader context within which to interpret the significance of the cemetery at the site, this chapter discusses the distribution of archeological sites containing human burials across a large study area from the coast to the Edwards Plateau. The discussion and review of the regional data focuses on whether the distribution of sites with human interments may be reflective of incipient territoriality among prehistoric indigenous groups or whether it is the product of re-occurring sue of selected places across the landscape.

\section{Theoretical Background and Texas Patterns}

There is extensive anthropological literature discussing various case studies of territoriality among hunter-gatherer groups (Bishop 1970; Blundell 1980; Cashdan 1983; Dyson-Hudson and Smith 1978). These researchers define territoriality primarily as limiting access to an area in order to control the exploitation of one or more resources (see Cashdan 1983:47). Several factors appear to condition when territoriality emerges and what form it takes.

Territoriality usually results in some benefit to the group, and most often this benefit will be increased availability of resources or increased foraging efficiency. However, these increased benefits also come with costs. The defense of a territory is energetically costly and the larger the territory the greater the costs of its defense. The density of resources affects the size of the territory being controlled. So that, the more abundant the resource, the smaller the area that needs to be defended, and concomitantly, the scarcer the resource becomes the greater the territory that will need to be defended to provide sufficient intake rates for survival. The predictability of the resources also affects tendencies for territoriality or ownership of resources. Usually, resources that tend to fluctuate wildly from year to year will not be defended but those that reoccur in a predictable fashion are defendable. Population density also interacts with territoriality to the degree that it has an effect on resource availability. Competition between populations will increase as resources become scarce. In general, dense and predictable resources will be the target of territorial defense while unpredictable scarce resources will not.

Territoriality and the control of resources can range from particular families controlling access to patches of dense oak forests and even individual oak trees (M. Anderson 2005:133134), and salmon fishing territories along streams (Ames 1994). According to Cashdan (1983:349), territorial control can take at least two forms: (1) the defense of the perimeter or boundary of the territory, and (2) the control of access through social boundary maintenance. That is, control can be achieved through physical exclusion or social exclusion. Perimeter or boundary defense is usually accompanied by the physical marking of the boundaries of a territory, or actual patrolling of the boundary or both. In either case, the defense of the territory tends to be relatively energy intensive either in terms of the energy expended in the actual defense or the construction of signals to ward off potential trespassers. Social boundary maintenance is practiced through marriage and other social means. The territorial markers for this type of control are much more subtle and typically involve natural features of the environment rather than constructed markers (Cashdan 1983:50). Bicchieri (1969) suggests that perimeter defense often develops in situations of resource depletion and geographical circumscription (Cashdan 1983:57). According to Cashdan 1983:63), perimeter defense should develop when resource abundance is high and competition is high while social boundary defense should be practiced when resource abundance is low but competition is high. Under low levels of competition, territoriality should not develop regardless of resource abundance.

In summary, discussions of territoriality identify two dimensions to the issue: (1) the types and characteristics of the resources targeted, and (2) the conditions that lead to territorial behavior. In terms of the first, resources that are highly productive and occur in reasonably well defined or localized parches are often the targets of access control. In terms of the second aspect, control of access to resources tends to emerge when populations tend to be spatially circumscribed leading to competition for limited resources potentially resulting in the depletion of critical resources.

In addition to the factors that may lead to territoriality it is also worth considering the factors that lead to the formation of cemetery sites. Be they modern, historic or prehistoric, it is relatively clear that cemeteries are the cumulative products of a series of short-, medium- and long-term 
decisions and processes. In discussing hunter-gatherer burials in southeastern Australia, Littleton (2007) defines the following short term actions associated with burial: the actual interment, and the period of mourning (Littleton 2007:Table 2 ). These actions remain in the consciousness of the relatives for approximately a year following the interment. Knowledge such as burial orientation and position, and visible markers of the interment such as a monument may typically be preserved for 1-4 generations, while landscape formation and climatic forces that may alter the look of a particular place beyond recognition or change the resource structure in its vicinity may take longer periods, unless they occur in a catastrophic manner (i.e., floods, earthquakes). The critical point is that cemeteries are likely to be the product of long-term processes that may take thousands of years during which time the utilization of the cemetery may not necessarily be continuous. We tend to view cemeteries from a contemporary ethnographic underpinning without necessarily recognizing the methodological difficulty faced by archaeologist that attempt to relate specific death events to long term process that result in the accumulation of interments and the formation of what we as archaeologists define as cemeteries (see also Littleton and Allen 2006). Because of exactly this difficulty, several archeologists have begun to reframe the interpretive perspective of cemeteries as not necessarily representing signals of territoriality but rather "persistent places." Schlanger (1992:92) defines persistent places as cultural features that structure the use and reuse of landscapes. Persistent places may be formed through three processes including recognition of unique qualities of locales suited for certain activities, the accumulation of remains, features and facilities that attract reuse and reoccupation, and through long-term occupation and/or revisitation (1992:92). From the perspective of site formation processes, the concept of persistent places offers an elegant explanation for the creation of cemetery archeological sites and is being used as a feasible interpretive framework in a number of contexts (Jacobs 1995, Walthall 1999).

\section{Perspectives on Texas Cemetery Sites}

With these general theoretical roadmaps we now turn to the discussion and examination of the Texas cemetery site distribution. There seems to be agreement among scholars that the development of cemeteries in this study area is an indicator of population growth and the establishment of territories (Prewitt 1981; Story 1995; Hall 1995a; Hall 1995b; A. J. Taylor 1998). Cemeteries as markers for territories could indicate a region had a high population density and low abundance of optimal resource patches. Conversely, areas lacking cemeteries may have been less populous, less productive, or were used only by relatively more mobile groups and saw less competition for resources. Two broad regional studies of central and South Texas cemeteries have been conducted in the context of site 41LK28, the Loma Sandia site (A.J. Taylor and Highley 1995, Taylor 1998). More recently, Perttula (2001) reviewed mortuary data from thirty years of excavations of hunter-gatherer sites across the Rio Grande and Central Coastal Plains.

These reviews show similar trends and could support the idea of territories tied to the most productive resource bases and marked by cemeteries in the Late Archaic and Late Prehistoric. There is little evidence of Paleoindian and Early Archaic territoriality in the archeological record in South Texas (A.J. Taylor 1998). Cemetery sites cluster along the Nueces River and Corpus Christi Bay, the lower Pecos River, the lower Guadalupe, and the Colorado and Brazos River basins, that is, riverine setting in the Coastal Plain (Perttula 2001). These riverine setting have large cemeteries in both Late Archaic and Late Prehistoric whereas other areas only support large cemeteries in either the Late Archaic or the Late Prehistoric. The Central Texas Coastal Plains region has very few sites with burials.

A.J. Taylor (1998) identifies territoriality in part by distribution of cultural materials. After 3000 B.C., projectile point distributions begin to show some patterning, especially among the Tortugas, Nolan, and Travis types (A.J. Taylor 1998). The initial appearance of extensive burial sites in southern Texas dates to about this same time (2500 to 3000 B.C.).

Also related to territoriality studies is population density. Some interpret an increase in the amount of "habitational debris" at interior sites in South Texas during the Middle and Late Archaic (Hall et al. 1986: and Black 1989: 49, 51) to an increase in population density. Late Archaic coastal sites also show a marked increase in cultural material. A rise in site numbers and richness could be attributable in part to the establishment of the barrier islands, marshlands, and estuaries which in turn could have promoted population growth. Also during the Late Archaic, A.J. Taylor (1998) reports an increase in the number of large mortuary sites in South Texas and along the Texas Gulf Coastal Plain and views the development of extensive hunter-gatherer cemeteries as territorial markers. Hall (1998) interprets the increased reliance on aquatic resources and increase in the number of cemeteries on population pressure on the food base. He ties the distribution of territories and cemeteries to patchy but abundant resources like pecans (and other nuts), acorns, prickly pear, and acquatic resources in the coastal estuaries-bays and lagoons. Reciprocal alliances between territories allowed food surpluses in one territory to spread to others. 


\section{The Methodological Approach}

Given these two dimensions of territoriality, to begin to investigate and explain the distribution of prehistoric sites with interments, we first devided the Coastal Plains and Marshes and South Texas Brush Country regions into broad habitats that were characterized by different resource availabilities. Because the scale of this analysis is larger than the four-county area we focused on in the previous land use discussion, our broad habitats are not the same as those discussed in Chapter 12. Rather, the larger region is divided into five habitats consisting of: (1) the South Texas Brush Country; (2) Prairie; (3) Oak Woodlands; (4) Oak Woodlands-Prairie Riverine; and (5) Beach-EstuaryMarsh. As much as possible, we tried to incorporate the finer-scale habitats employed in Chapter 12 in these groupings to allow for continuity (Figure 13-1). The ecoregions illustrated in Figure 13-1 are those defined by the United States Environmental Protection Agency (USEPA) under Level III and IV. There are 12 Level III eco-regions and 56 Level IV eco-regions in Texas that continue into adjacent parts of the US and Mexico. The methods for defining these regions are in the National Atlas of the United States (2003).

Based on the extensive earlier discussions of resource potential, we would anticipate that the Oak Woodlands-Prairie Riverine habitat would be the most productive of the habitats followed by the Oak Woodlands. The South Texas Brush Country and the Prairie are assumed to be less productive with the exception of linear corridors along streams that cross through them. As we described in Chapter 8, the Beach-EstuaryMarsh (same as the Bay-Estuary-Lagoon) habitat can be productive when it comes to small and very small prey that can occur there seasonally in large quantities.

Having briefly summarized our perception of the ranking of the habitats based on potential resource availability (much of it described in detail in Chapter 8), we now turn to the second dimension of territoriality mentioned above, population dynamics. Several archeologists have in the past attempted to estimate trends in population densities across Texas (Prewitt 1985; Skinner 1981; Weir 1976). These attempts focused primarily on Central Texas and for the sake of expediency we employ Prewitt's (1985) estimates as applicable to the study region. Using the ratio of component occurrences to the duration of a component in years, Prewitt's (1985:Figure 6) estimate shows several peaks in population densities over time. The most dramatic of them occurs in the Late Archaic and is followed by a drop during the Austin Phase of the Late Prehistoric only to subsequently rise, although not nearly to Late Archaic levels.

Given the expectations derived from the general anthropological theory and based on the resource potential of the larger region and the relative population densities estimated by Prewitt (1985), we would expect that territoriality should emerge among Texas hunter-gatherers in the Oak-Woodlands-Prairie Riverine habitat. The Oak Woodlands habitat away from the river valleys may not see an extension of territorial control of its resources. A second area where territorial control may emerge is on the coastal strip, and specifically in the vicinity of the Beach-EstuaryMarsh habitat. We would expect, however, that the emergence of signs of territoriality would occur much later in time in the coastal zone compared to the Oak Woodlands-Prairie Riverine habitat. Finally, we anticipate that the hypothesized strong increase in relative population densities during the Late Archaic would spur the earliest signs of territoriality. Divergence from these expectations may suggest that the emergence of cemetery sites is not linked to the establishment of territoriality among Texas hunter-gatherers.

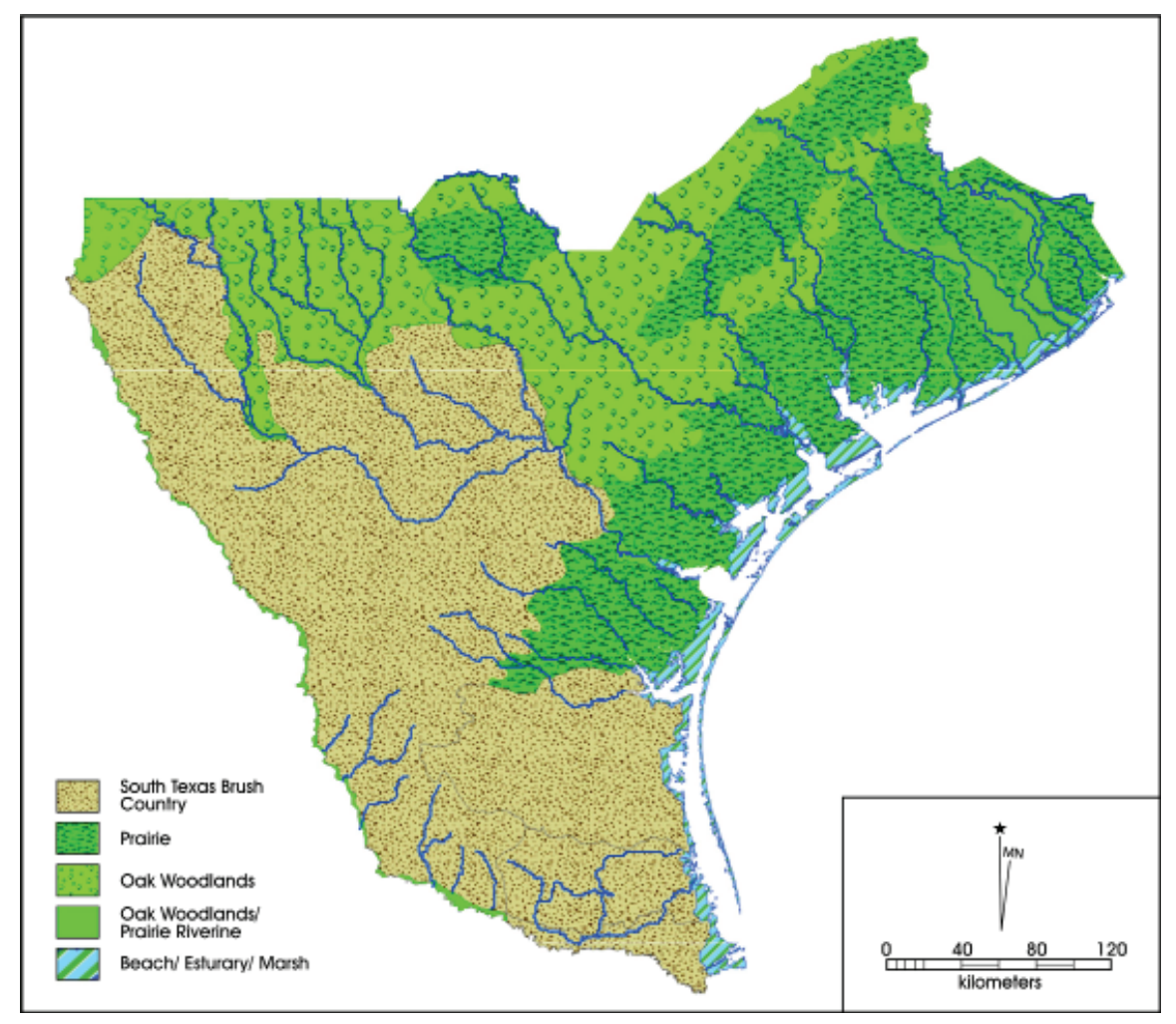

Figure 13-1. Habitat map. 
For analytical purposes, we assume that cemeteries represent a visual signal of territoriality. It is our impression that the presence of a single interment at a site has different implications than that of multiple interments. That is, we assume that there are semiotic differences between a single human interment versus the presence of an actual cemetery (i.e., multiple human interments).

\section{GIS Database}

A mortuary database was compiled in the Geographic Information System program that includes data from the five major physiographic regions including the Gulf Coastal Plains and Marshes, Blackland Prairie, Edwards Plateau, Central Texas Plains and South Texas Plains. The database includes site name and trinomial, site size, provenience information, habitat as defined above, presence of grave goods, population estimates including the presence of multiple versus single graves, evidence of violent death, age, sex, and interment orientation, cultural period, and radiocarbon dates. Dates and cultural period assignments are specific to the burial component; sites listed may contain components/dates not listed because no burials were associated.

\section{Distribution of Burial Sites Across the Study Area}

The study area includes portions of the Edwards Plateau, the Blackland Prairie, Central Texas Plains, the Gulf Coastal Plains and Marshes, and the South Texas Plains physiographic regions and includes 186 sites reported to have human burials (Figure 13-2, Table 13-1). The Gulf Coastal Plains and Marshes region contains almost half $(\mathrm{n}=99)$ of the sites with human burials. They are distributed in four habitats within this physiographic region: the Beach-Estuary-Marsh $(\mathrm{n}=25)$, Oak Woodlands-Prairie Riverine $(\mathrm{n}=18)$, Prairie $(\mathrm{n}=40)$, and the South Texas Brush Country (16). The physiographic

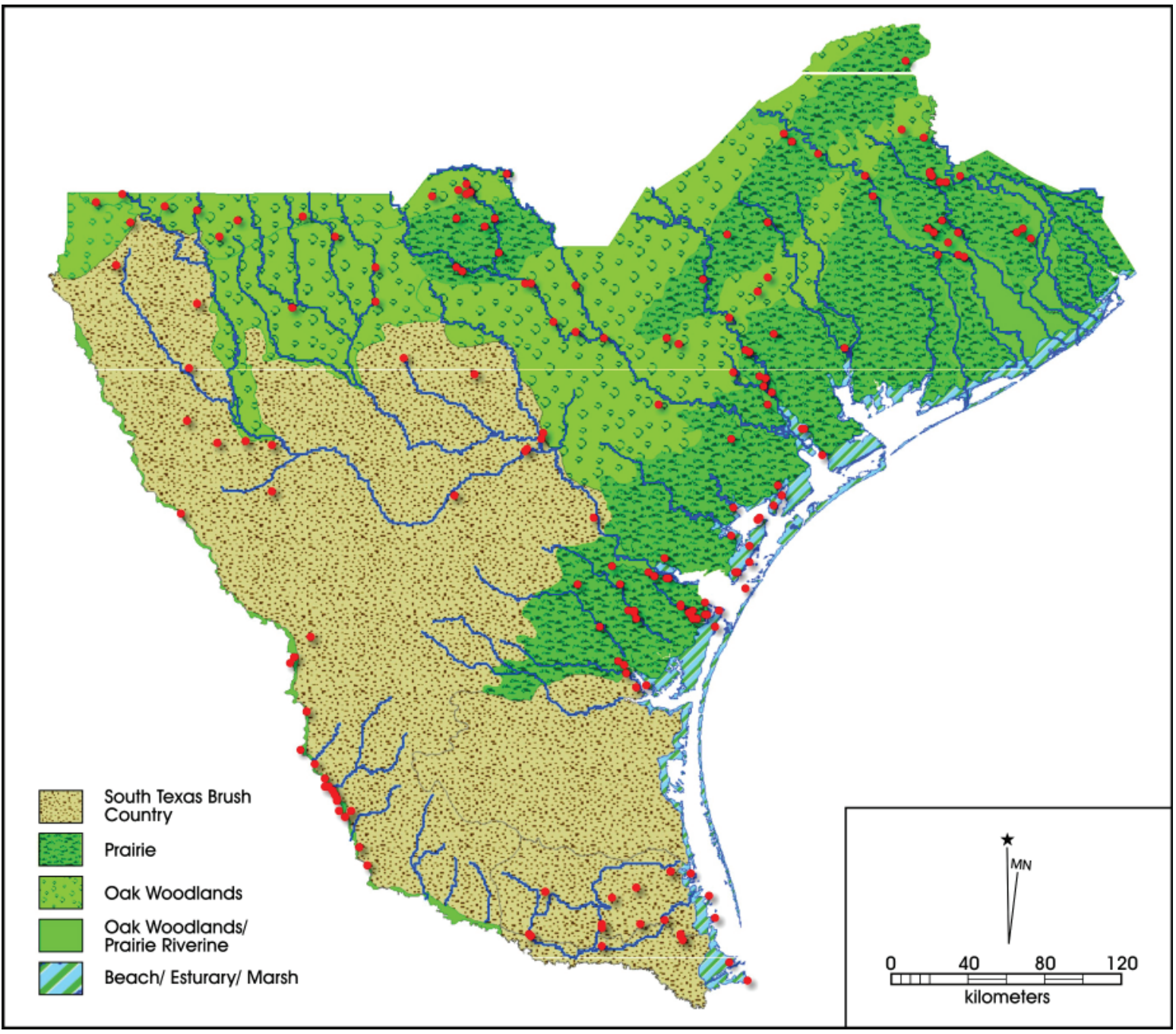

Figure 13-2. Distribution of burial sites across the study area. 
Table 13-1. Counts of Burial Sites Across the Study Area

\begin{tabular}{|l|l|c|}
\hline \multicolumn{1}{|c|}{ Major Physiographic Region (Gould 1975) } & \multicolumn{1}{c|}{ Habitats } & Total \\
\hline \multirow{2}{*}{ Blackland Prairie } & Oak Woodlands-Prairie Riverine & 1 \\
\cline { 2 - 3 } & Prairie & 11 \\
\hline \multirow{2}{*}{ Blackland Prairie Total } & Oak Woodlands & 17 \\
\hline \multirow{2}{*}{ Central Texas Plains } & Oak Woodlands-Prairie Riverine & 2 \\
\hline \multirow{2}{*}{ Central Texas Plains Total } & 19 \\
\hline Edwards Plateau & Oak Woodlands & 13 \\
\hline Edwards Plateau Total & 13 \\
\hline \multirow{3}{*}{ Gulf Coastal Plains and Marshes } & Beach-Estuary-Marsh & 25 \\
\cline { 2 - 3 } & Oak Woodlands-Prairie Riverine & 18 \\
\cline { 2 - 3 } & Prairie & 40 \\
\cline { 2 - 3 } & South Texas Brush Country & 16 \\
\hline Gulf Coastal Plains and Marshes Total & 99 \\
\hline \multirow{3}{*}{ South Texas Plains } & & 5 \\
\hline \multirow{2}{*}{ South Texas Plains Total } & 17 \\
\hline Grand Total & Oak Woodlands & 21 \\
\cline { 2 - 3 } & Oak Woodlands-Prairie Riverine & 43 \\
\cline { 2 - 3 } & South Texas Brush Country & 186 \\
\hline
\end{tabular}

region with the next highest count of cites with human remains is the South Texas Plains $(n=43)$, followed by the Central Texas Plains $(n=19)$. Other physiographic regions have smaller numbers (Table 13-1).

Looking at the distribution of sites with human remains by habitats across all the physiographic regions, most human burials are within the Prairie (51) habitat (Table 13-1). Across the remaining habitats, burial sites are evenly distributed with 37 sites in the South Texas Brush Country, 38 across the Oak Woodlands-Prairie Riverine habitat, and 35 in the Oak Woodlands. The Beach-Estuary-Marsh habitat has the fewest burial sites $(n=25)$.

These data present a rather complex picture, but at the most simplified level, it is evident from the distributions in Figure 13-2 that most sites with human interments are found along streams (i.e., the Prairie-Riverine habitat). These locations tend to be the highest ranked in terms of resource potential within each broad physiographic region. In addition, if these distribution patterns reflect territoriality, they suggest that the territories comprise portions of streams and potentially some areas along the valley margins or uplands. That is, if the distribution of sites does actually reflect group territories, the territories may consist of drainages or portions of drainages. This would suggest that the territories may have paralleled drainages and would have been oriented perpendicular to the coast.
However, before accepting these data as supporting the territorial hypothesis, it is important to recognize that the prehistoric cemeteries in this research area are characterized by relatively low visibility. That is, minimal effort that has been expended in making them serve as long-term signaling features. There were no visible markers found on surface or above ground at any of the cemetery sites prior to archeological excavations and the cemetery component was either an unexpected find or was know to exist due to the partial exposure of human remains through erosion. Sites with cemeteries occupy a variety of landforms from hills to sand dunes and stream terraces. While they tend to be more common in riverine settings (see Figure 13-2), they are by no means only found in the habitat with the highest potential return rate (i.e., the Prairie-Riverine habitat). Rather they are found in all riverine settings across a whole range of habitats suggesting that the factor that is conditioning their location is the mix of resources that are found in such settings rather than any one particular hyper-productive resource. The fact that few sites with human burials are found outside of riverine settings also supports the interpretation that localities with high rates of revisitation tend to have higher probabilities of cemetery sites compared to localities with lower rates of revisition. Again, the higher incidences of revisitation may be conditioned by the variety of economically significant resources found in riverine settings regardless of what physiographic region a human population may be exploiting. 


\section{Distribution of Burial Sites Across the Gulf Coastal Plains through Time}

Perttula's (2001) study of mortuary practices in South Texas found that burial sites in south central, inland central, and the Central Texas prairie had large cemeteries dating to both the Middle Archaic and the Late Prehistoric, while other sub-regions had large cemeteries in either one or the other of these periods. Of the 186 sites in the database, 108 sites have an assigned temporal affiliation (Figure 13-3, Table 13-2). A total of 128 prehistoric components are defined in the 108 sites in the database.

The Prairie region contains the highest number of both Late Archaic (16) and Late Prehistoric burials (16), followed by Late Prehistoric burial components in the Beach-EstuaryMarsh region $(\mathrm{n}=9)$, the Oak Woodlands-Prairie Riverine setting $(\mathrm{n}=7)$, and six sites each from the Oak Woodlands and the South Texas Brush Country. The Oak Woodlands and the South Texas Brush Country both have nine Late Archaic burials followed by four Late Archaic burials in the BeachEstuary-Marsh region.
The fact that the highest number of dated burial sites occurs during the Late Archaic ( $\mathrm{n}=48$ ) may be significant in light of the expectation that territorial marking would be likely to occur under conditions of increasing population density. The number of burial sites dated to the Middle Archaic is very low $(n=12)$ but it may also signal some correspondence with the peak in Middle Archaic population noted by Prewitt (1985).

\section{Distribution of Single and Multiple Interments at Burial Sites across the Gulf Coastal Plains through Time}

We also examined the distribution of single versus multiple interment sites across the region through time (Table 13-3; Figure 13-4). The number of graves, single versus multiple, per component shows even distributions among those sites with reported temporal affiliations. There are 30 Late Archaic cemetery sites with multiple burials compared to 27 for the Late Prehistoric. There are 14 and 16 sites with single graves dated to the same time periods, respectively. In contrast, ten of eleven Middle Archaic sites had multiple graves and all three Early Archaic components contained more than one grave. The proportion of multiple and single
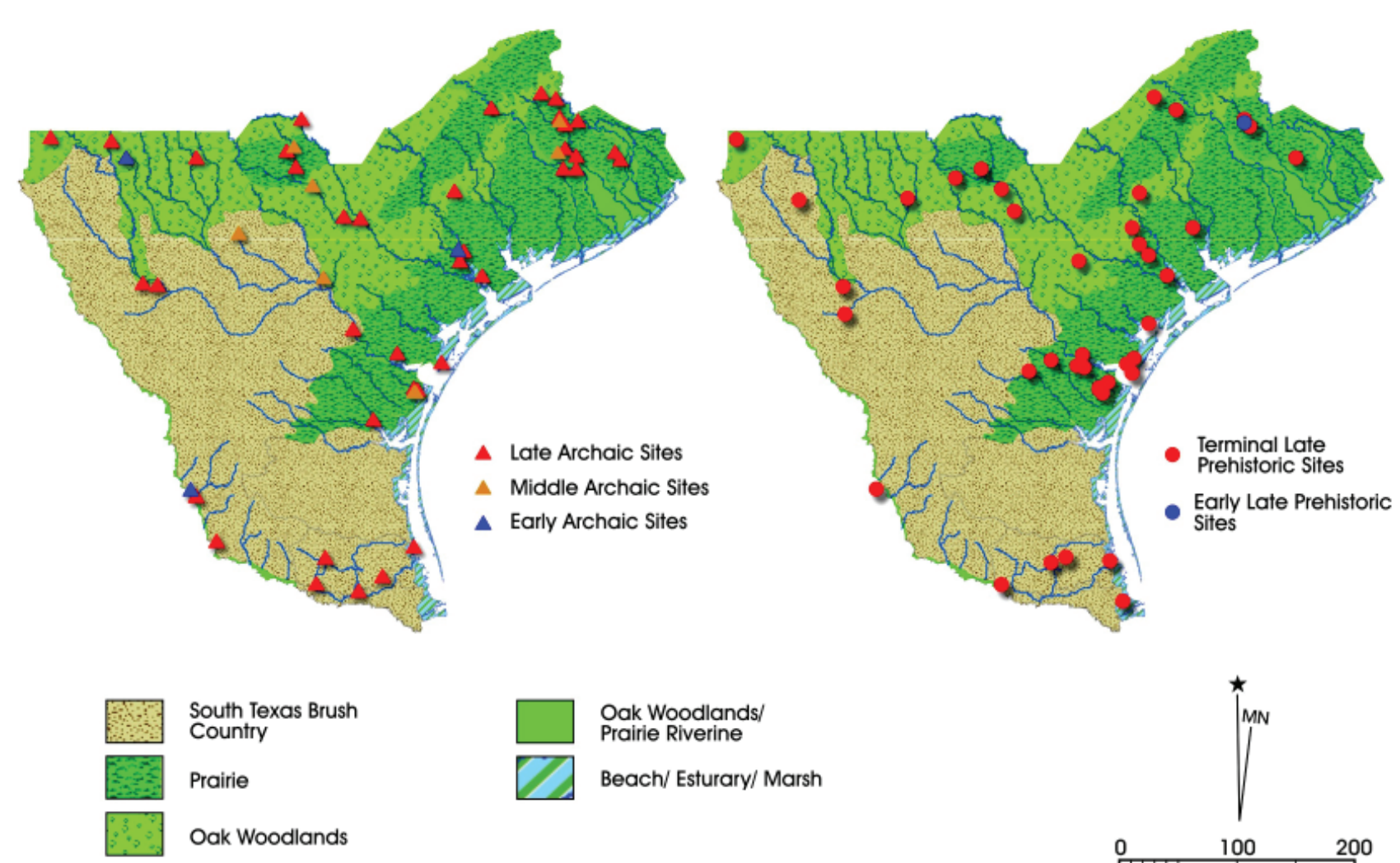

Oak Woodlands

Oak Woodlands/ Prairie Riverine

Beach/ Esturary/ Marsh

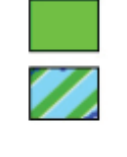

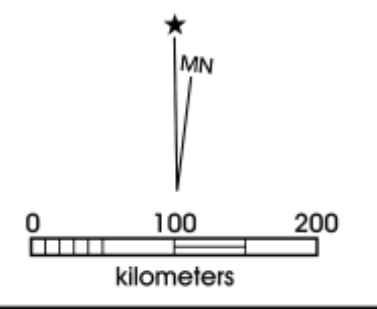

Figure 13-3. Distribution of burial sites through time. 
Table 13-2. Count of Sites through Time per Habitat

\begin{tabular}{|c|c|c|}
\hline Habitat & Time Period & $\begin{array}{l}\text { Count of } \\
\text { Sites }\end{array}$ \\
\hline \multirow{5}{*}{ Beach-Estuary-Marsh } & Late Prehistoric & 9 \\
\hline & Early Prehistoric & 0 \\
\hline & Late Archaic & 4 \\
\hline & Middle Archaic & 0 \\
\hline & Early Archaic & 0 \\
\hline \multirow{5}{*}{ Oak Woodlands } & Late Prehistoric & 6 \\
\hline & Early Prehistoric & 0 \\
\hline & Late Archaic & 9 \\
\hline & Middle Archaic & 4 \\
\hline & Early Archaic & 1 \\
\hline \multirow{5}{*}{$\begin{array}{l}\text { Oak Woodlands-Prairie } \\
\text { Riverine }\end{array}$} & Late Prehistoric & 7 \\
\hline & Early Prehistoric & 0 \\
\hline & Late Archaic & 10 \\
\hline & Middle Archaic & 0 \\
\hline & Early Archaic & 2 \\
\hline \multirow{5}{*}{ Prairie } & Late Prehistoric & 16 \\
\hline & Early Prehistoric & 1 \\
\hline & Late Archaic & 16 \\
\hline & Middle Archaic & 7 \\
\hline & Early Archaic & 0 \\
\hline \multirow{5}{*}{ South Texas Brush Country } & Late Prehistoric & 6 \\
\hline & Early Prehistoric & 0 \\
\hline & Late Archaic & 9 \\
\hline & Middle Archaic & 1 \\
\hline & Early Archaic & 0 \\
\hline \multicolumn{2}{|c|}{ Total Count of Late Prehistoric } & 44 \\
\hline \multicolumn{2}{|c|}{ Total Count of Early Prehistoric } & 1 \\
\hline \multicolumn{2}{|l|}{ Total Count of Late Archaic } & 48 \\
\hline \multicolumn{2}{|l|}{ Total Count of Middle Archaic } & 12 \\
\hline \multicolumn{2}{|l|}{ Total Count of Early Archaic } & 3 \\
\hline
\end{tabular}

grave cemeteries through time remains consistent during the Late Prehistoric and Late Archaic but sites with multiple interments greatly outnumber those with single burials during he Middle Archaic.

Across habitats then we would expect in general to see more multiple-grave sites than single-grave sites in each component. This remains true for all habitats except the South Texas Brush Country, where out of 16 reported sites, 12 are single-grave sites. Single-grave sites also are confined in the reported data to the Late Prehistoric and Late Archaic cultural periods in all habitats except the South Texas Brush Country where one single-grave site is reported for the Middle Archaic. Middle and Early Archaic components with multiple graves are present in the Oak
Table 13-3. Count of Interment Number through Time per Habitat

\begin{tabular}{|c|c|c|c|c|}
\hline Habitat & Time Period & $\begin{array}{c}\text { Multiple } \\
\text { Interment }\end{array}$ & $\begin{array}{c}\text { Single } \\
\text { Interment }\end{array}$ & Total \\
\hline \multirow{5}{*}{$\begin{array}{l}\text { Beach-Estuary- } \\
\text { Marsh }\end{array}$} & Late Prehistoric & 8 & 1 & 9 \\
\hline & Early Prehistoric & 0 & 0 & 0 \\
\hline & Late Archaic & 3 & 1 & 4 \\
\hline & Middle Archaic & 0 & 0 & 0 \\
\hline & Early Archaic & 0 & 0 & 0 \\
\hline \multirow{5}{*}{ Oak Woodlands } & Late Prehistoric & 3 & 3 & 6 \\
\hline & Early Prehistoric & 0 & 0 & 0 \\
\hline & Late Archaic & 6 & 3 & 9 \\
\hline & Middle Archaic & 4 & 0 & 4 \\
\hline & Early Archaic & 1 & 0 & 1 \\
\hline \multirow{5}{*}{$\begin{array}{l}\text { Oak Woodlands- } \\
\text { Prairie Riverine }\end{array}$} & Late Prehistoric & 5 & 2 & 7 \\
\hline & Early Prehistoric & 0 & 0 & 0 \\
\hline & Late Archaic & 7 & 2 & 9 \\
\hline & Middle Archaic & 0 & 0 & 0 \\
\hline & Early Archaic & 2 & 0 & 2 \\
\hline \multirow{5}{*}{ Prairie } & Late Prehistoric & 10 & 5 & 15 \\
\hline & Early Prehistoric & 1 & 0 & 1 \\
\hline & Late Archaic & 11 & 2 & 13 \\
\hline & Middle Archaic & 6 & 0 & 6 \\
\hline & Early Archaic & 0 & 0 & 0 \\
\hline \multirow{5}{*}{$\begin{array}{l}\text { South Texas } \\
\text { Brush Country }\end{array}$} & Late Prehistoric & 1 & 5 & 6 \\
\hline & Early Prehistoric & 0 & 0 & 0 \\
\hline & Late Archaic & 3 & 6 & 9 \\
\hline & Middle Archaic & 0 & 1 & 1 \\
\hline & Early Archaic & 0 & 0 & 0 \\
\hline \multicolumn{2}{|c|}{ Total Count of Late Prehistoric } & 27 & 16 & 43 \\
\hline \multicolumn{2}{|c|}{ Total Count of Early Prehistoric } & 1 & 0 & 1 \\
\hline \multicolumn{2}{|c|}{ Total Count of Late Archaic } & 30 & 14 & 44 \\
\hline \multicolumn{2}{|c|}{ Total Count of Middle Archaic } & 10 & 1 & 11 \\
\hline \multicolumn{2}{|c|}{ Total Count of Early Archaic } & 3 & 0 & 3 \\
\hline
\end{tabular}

Woodlands, the Oak Woodlands-Prairie Riverine, and the Prairie habitats.

\section{Conclusions}

The GIS database of mortuary sites across the Gulf Coastal Plains shows the highest number of burials occurring in the Prairie during the Late Archaic and Late Prehistoric. Throughout the Late Archaic and Late Prehistoric, more sites contained multiple interments than single burials. The South Texas Brush Country is the only habitat to contain more single interment sites than multiple interment sites. All but one of the single interment sites dates to the Late Archaic or Late Prehistoric, while several multiple interment sites date earlier in the Oak Woodlands, Prairie-Riverine and Prairie habitats. 


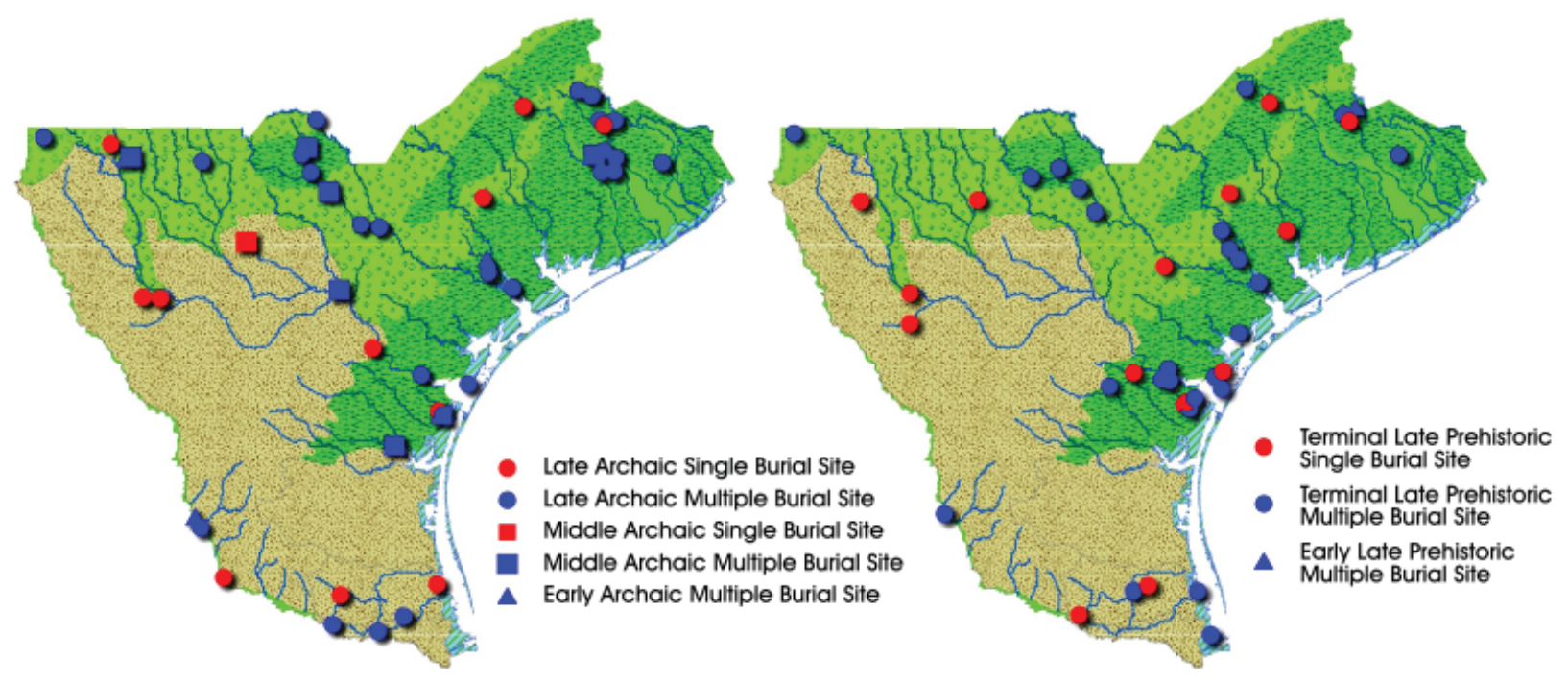

$\begin{array}{ll}\text { South Texas Brush } & \square \\ \text { Country } & \begin{array}{l}\text { Oak Woodlands/ } \\ \text { Prairie Riverine }\end{array} \\ \text { Prairie } & \text { Beach/ Esturary/ Marsh }\end{array}$

Oak Woodlands

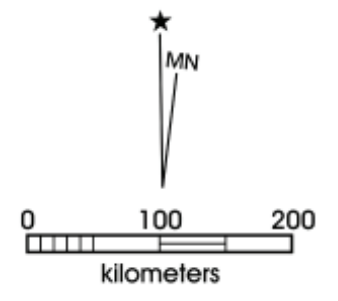

Figure 13-4. Distribution of single and multiple interment sites across time and habitat.

While the majority of the cemetery sites are located within a riverine setting, they are not necessarily clustered within the most productive habitats at the regional level. That is, if the placement of cemeteries was intended to mark territorial ownership of hyper-productive resources, we would expect that sites with human interments would be primarily found in the Prairie-Riverine habitat of the Coastal Plains and Marshes physiographic region. Instead, sites with human interments are distributed across a broad range of physiographic regions including the South Texas Brush Country, the Prairie, and the Oak Woodlands. This broad distribution shows that the locations of cemeteries are not exclusive to hyper-productive resource zones. Instead, they appear to be located in all settings that are favorable to re-occupation and/or revisitation conditioned by a mix of resources that is typical of all riverine settings. Such a distributional pattern favors the interpretation that sites with human interments are located in "persistent places," settings that are intermittently or regularly revisited and reoccupied sometimes continuously for generations while other times forgotten and reoccupied after centuries of abandonment. As such, the creation of cemetery sites as recognized by archeologists is more likely to represent a combination of short term processes that reflect cultural memory and identity and long term processes and conditions that favor reoccupation of landscape features conditioned by resource availability. 


\title{
Chapter 14: Summary and Conclusions
}

\author{
Steve A. Tomka
}

The Cayo del Oso site (41NU2) has a long history of archeological work dating back to the early 1900's. A comprehensive summary of the early investigations at the site has been provided by the Center for Archaeological Research in the first of the two volume series published four years ago (Jackson et al. 2004). The present report represents the second and final volume in the series focused on archeological work conducted at the site.

This volume summarizes the archeological monitoring conducted in association with improvements made by TxDOT to Ennis Joslin Road and Ocean Drive in the vicinity of 41NU2. The archeological work was necessary to address the requirements of Section 106 of the National Historic Preservation Antiquities Code of 1966, as amended, the implementing regulations of 36 CFR Part 800, and the Texas Antiquities Code; because, the construction impacts land owned by the State of Texas and because the Federal Highways Administration (FHWA) is partially funding the project.

The archeological work carried out in support of the construction work consisted of monitoring of the excavation of trenches intended for utility line placement or relocation. The fieldwork began in August of 2000 and continued through February 2006. The purpose of the monitoring was to identify any cultural remains that may be within areas of impact and to "... complete the documentation of features and the exhumation of any human burials as quickly as possible to allow the construction contractors to regain access to the area." The work was conducted under WA \#57311SA002, established between the University of Texas at San Antonio and the Texas Department of Transportation.

In the introductory chapters of this document we provide background to the history of the construction project (Chapter 1), the geology, climate and environmental setting of the site (Chapter 2) and briefly review the culture history of the project area (Chapter 3). In the next three chapters we focus on the monitoring activities carried out at $41 \mathrm{NU} 2$. In Chapter 4 we summarize the field methods and the monitoring protocol that was initially instituted and later modified as the project became more complicated due to the consistent finding of unmapped buried utility lines. In Chapter 5 we provide detailed descriptions of the monitoring efforts carried out during the project and each of the trenches that were inspected. We also describe the finding of six sets of human remains and of a relatively small number of artifacts that were collected during feature documentation episodes. The human remains consisted of one complete, intact burial
(Burial 2), three collections of disturbed, disarticulated human skeletal remains (Burials 3, 4, and 5), and two collections of partially disturbed human remains (Burials 6 and 7). In addition to these six, Ricklis (2004) recovered the remains of one more individual for a total of seven burials documented in association with the road improvements along Spur 3. The analysis and a complete description of these remains was completed by CAR under a separate report in compliance with the NAGPRA inventory of human remains from the site. This report was submitted to the TxDOT-ENV as part of a separate deliverable of this project. The small assemblage of artifacts contains worked shell, worked bone, two fragments of Native American ceramics (Rockport), and chipped stone artifacts. The two projectile points recovered are Late Archaic in age.

In Chapter 6 we discuss the results of a brief study of the relationship between paired sets of radiocarbon dates, one on carbonized wood and the other on shell. We conclude that marine shell can provide accurate, precise dates in the absence of other dating materials. This may especially be the case if samples of Crassostrea virginica are selected for dating. We also provided basic descriptive data on the 164 features as well as 11 occupation zones documented at the site during this monitoring project.

In the next three chapters we develop the theoretical framework (Chapter 7), describe the spatial and temporal structure of the resources (Chapter 8) and develop general and some specific expectations regarding the land use and subsistence strategies of prehistoric hunter-gatherers. In Chapter 7 we provide a detailed review of hunter-gatherer land use during the early $16^{\text {th }}$ century as seen from the ethnohistoric record and describe the basics of human behavioral ecology that serves as the foundation of the theoretical models developed in Chapter 9. Chapter 8 is an exhaustive summary of regional resource structure and Chapter 9 develops some general expectations based on the habitat choice model and identifies some specific expectations regarding land use and subsistence at $41 \mathrm{NU} 2$. In Chapter 9 we also develop some research problems and proposed avenues of research to guide the analytical approaches that were followed in the remaining chapters of the report. The next four chapters contain the results of site-specific and regional-scale analyses, including paleoclimate (Chapter 10), subsistence (Chapter 11), land use (Chapter 12), and mortuary practices (Chapter 13).

Several distinct data types are brought together to investigate trends in paleoclimate including pollen, 
phytoliths, marcobotanical remains, diatoms, ostrocods, and geomorphological data. The results of these specialized analyses are provided in individual appendixes (A-F). The paleoclimatic investigations center of soil columns obtained from three locations at or near the site. It is difficult to find correspondence between the various data sets across all three locations. Nonetheless, the data seem to indicate some broad changes in climate over time from relatively mesic conditions and mesic-adapted vegetation communities to more xeric conditions over time, with a brief shift back to more mesic conditions in the last 1000 years. The dune cores (Cores 4 and 6) document very localized geomorphic processes that make the patterns they reflect more indicative of small-scale processes rather than regional trends. The analysis of the pollen from Core 2 by two different laboratories resulted in dramatically different conclusions emphasizing the need to further investigate the nature of the differences to ensure that the results of future analyses are reliable.

Chapter 11 reports on the analysis of the faunal remains recovered from heavy fractions derived from the floatation of feature fill. The analysis of the species of fish present in the deposits suggests a late winter/early spring season of acquisition and site use. The splintered nature of the deersized faunal remains may be indicative of bone grease processing or some degree of nutritional stress experienced by the site's inhabitants. Numerous lenses of fish bone across different parts of the dunes indicate that small to medium fish were commonly procured and perhaps minimally processed. The comparison of subsistence practices at the regional level indicates that mammals, birds, fish and molluscs have been incorporated in the diet of hunter-gatherers living in the Grass Flats, the Bay-Fluvial and Prairie/Riverine habitats. Nonetheless, the data also suggests that the hunter-gatherers living in each of these habitats tended to emphasize the exploitation of resources found within them. This pattern is supported by the results of stable carbon and nitrogen isotope analyses of coastal, riverine, and inland populations (Johnson and Hard 2008) and also matches the available ethnohistoric information (Ricklis 1996).

Chapter 12 indicates that regional land use was very much centered on prairie-riverine habitats and the earliest occupations across the region occurred in this habitat. Site sizes, on the average, tend to be larger in the riverine setting than in any other habitat and small sites are under-represented in this setting. In the beach-fluvial habitat sites tend to be dominated by small sites but the mean site size increases on the beach most likely due to the merging of palimpsest occupations. A gradual reorientation in the use of coastal habitats is noted in the Late Archaic and this pattern changes to a significant shift to the exploitation of coastal aquatic resources during the Late Prehistoric Period. This change may have been prompted by population packing within the Prairie/Riverine habitat and may be a reflection of huntergatherer intensification of aquatic resource extraction.

The analysis of hunter-gatherer mortuary practices through sites containing human remains shows that the bulk of the sites with human remains are found in the Oak Woodlands/Prairie Riverine habitat. The linear arrangement of cemetery sites suggests that hunter-gatherer territories, if present, centered on stream valleys and drainages. The temporal patterning of the sites with human remains does suggest that the increase in sites with human interments corresponds to increases in population densities. However, the fact that cemetery sites are found in riverine settings throughout the broad South Texas Plains, the Oak Woodlands and Prairie does not conform to the expectation that they should be primarily limited to hyper-productive habitats if they are intended as territorial signals. The occurrence of cemetery sites in riverine settings cutting across physiographic regions characterized by low productivity suggests that cemetery formation is a product of the repeated reuse of selected places across the landscape. Overall, the distribution of cemetery sites suggests that they are created in settings that are revisited and reoccupied repeatedly either because they contain resources, facilities or other features that draw populations to them over long periods of time (generations).

Overall, the lengthy project produced little data compared to other archeological projects of comparable duration. However, this is understandable given the monitoring focus of the investigations. The site-specific paleoenvironmental results are encouraging although somewhat troubling. The regional-scale analyses produced a mixed bag of results with some very intriguing patterns that support expectations derived from the model and other that simply did not produce sufficient data to adequately test and investigate its implications.

It is possible that different monitoring protocols could have produced more systematic and larger amounts of data. Construction monitoring was driven by the knowledge that human burials may be found anywhere within the project limits. Therefore, archeological monitoring was a necessity. However, and as amply evident in the report, limiting data collection to the context of monitoring has reduced the quantity, quality and variety of data types that could be obtained. During the early phases of the project longer stoppages in construction activities allowed for more complete sampling of features but these stoppages understandably tended to interfere with the pace of the construction. This is the classical dilemma of "rescue archeology' within the context of Cultural Resource Management. Features are 
excavated and documented as they are encountered and there is a premium on time since construction crews and equipment remain idle while archeologists are at work.

One approach that could have been used in conjunction with or perhaps in advance of construction monitoring would have been to design an overall project schedule that allowed time for more intensive investigation of material-rich portions of the Right-of-Way well in advance of the construction activities. Hand-excavations in portions of the ROW not scheduled for immediate construction impact would have allowed detailed investigations of some areas that would have yielded representative and statistically significant amounts of data for comparative analyses while at the same time not interfering with construction schedules. Perhaps such an approach would have then allowed for monitoring to focus on potential human remains and no attempts to collect data on features and occupation zones that would have been adequately sampled during the pre-construction phase of the archeological investigations. To implement such a strategy would have required extensive planning well in advance of the construction and the availability of personnel for both monitoring and data-recovery activities.

One of the glaring weaknesses of the report is that while we hoped to quantitatively test some expectations derived from the Habitat Choice Model through cost-benefit analysis, early on it became evident that the necessary data is simply not available in the State. Quantitative tests of some of the premises of Optimal Foraging Models have proven to be very instructive and have yielded new insights into the parameters and expectations derived from them (see Bettinger et al. 2006; Ugan 2005; Zeanah 2000). They clearly provide worthwhile avenues of future research and if archeologists in the State are to take full advantage of them, the systematic collection of appropriate data (i.e., caloric yield data) combined with experimental cost-benefit analysis (i.e., quantifying the energetic costs of certain extractive activities) is greatly desired. Similarly, detailed understanding of the structure of the economically significant resources available to prehistoric hunter-gatherers is also lacking. And, while modern resource structure does not necessarily reflect prehistoric resource availability and distribution, we need to continue to strive to understand how resources may have changed over time to be able to construct more realistic models for understanding hunter-gatherer behavior. To this end, we need to continue to search for and collect data that will allow us to reconstruct in increasingly greater detail regionally specific climatic sequences that in turn will allow us to more precisely approximate past resource structure.

In addition to collecting new data types, it is also important to present data from ongoing and new testing and data recovery projects in a consistent and systematic manner. The study of regional-scale phenomena is hampered at this time by the difficulty of extracting the desired data from technical reports. When one is finally able to locate it, it is often not analyzed in a consistent manner or not presented in sufficient detail. Some degree of standardization of research and analytical approaches is needed to allow researchers the opportunity to take advantage of the growing set of data being collected with each cultural resource management testing and data recovery project. While standardization cannot stifle creativity and openness to trying new research avenues, it is necessary to allow archeologists to investigate hunter-gatherer adaptations and behavior at the regional-scale.

The Texas Archeological Sites Atlas is a good beginning towards a repository of data associated with projects and individual sites. However, the data is not research-friendly and often those using the information are left to print out site forms and extract relevant site and project characteristics by hand to build usable databases. Similarly, many of the testing and data recovery reports are available only in a limited manner (the THC library), and comprehensiveness of one's regional comparisons often depend on how complete the company's research library is. It is hoped that this will be rectified as the Texas Historical Commission moves to make pdf copies of all reports available.

Having outlined in general terms some of the weaknesses of this report and also having described the data gaps that have influenced the quality of the product, it is important to indicate that these omissions are not provided as excuses for the quality of the final product. Archeological knowledge is to a large extent cumulative and it is hoped that researchers using this report can build on the current state of knowledge as we have attempted to add to the research of others who are interested in coastal archeology. 



\section{References}

Albert, B.M.

Holocene Pollen Data for Sea Level and Climate Change at Swan Lake, Aransas County, Texas, and the Implications for the Cultural Ecology of the Central Texas Coast. Bulletin of the Texas Archaeological Society 77:161-177.

Ames, K.M.

1994 The Northwest Coast: Complex Hunter-Gatherers, Ecology, and Social Evolution. Annual Review of Anthropology 23:209-229.

Anderson, A.A.

1960 Marine Resources of the Corpus Christi Area. Bureau of Business Research. Monograph No. 21. The University of Texas at Austin.

Anderson, M.K.

2005 Tending the Wild Native American Knowledge and the Management of California's Natural Resources. University of California Press, Berkeley.

Anderson, E.C. and W.F. Libby

1951 World-wide distribution of natural radiocarbon. Physical Review 81: 64-69.

Anderson, J.B. and M.A. Thomas

1991 Marine ice-sheet decoupling as a mechanism for rapid, episodic sea-level change: The record of such events and their influence on sedimentation in the record of sea-level fluctuations: Sedimentary Geology 70: 87-104.

Andrews, J.

1977 Shells and Shores of Texas. The University of Texas Press, Austin.

Armstrong, W.E. and E.L. Young

2001 White-tailed Deer Management in the Texas Hill Country. Texas Parks and Wildlife, Austin.

Baird, M.

2006 Tribal Leaders Rebut Confederation. Corpus Christi Caller-Times, January 5, 2006.

Battarbee, R.W., V.J. Jones, R.J. Flower, N.G. Cameron, H. Bennion, L. Carvalho, and S. Juggins

2001 Diatoms. in Developments in Paleoenvironmental Research. Vol. 3, Tracking Environmental Change Using Lake Sediments: Terrestrial, Algal, and Siliceous Indicators. Edited by J.P. Smol, H.J.B. Birks, and W.M. Last, pp: 155-202. Kluwer Academic Publishers. New York.

Bell, A.L. [translator]

1987 Voyage to the Mississippi through the Gulf of Mexico, 1687. In La Salle, the Mississippi and the Gulf, Three Primary Documents, edited by R.W. Weddle, pp. 225-258. Texas A \& M University Press, College Station.

Berger, R., A.G. Horney, and W.F. Libby

1964 Radiocarbon dating of bone and shell from their organic components. Science 144: 999-1001. 
Berger, R., R.E. Taylor, and W.F. Libby

1966 Radiocarbon content of marine shell from the California and Mexico west coast. Science 153:864-866.

Bettinger, R.L., and R. Malhi

1997 Central Place Models of Acorn and Mussel Processing. Journal of Archaeological Science 24:887-899.

Bettinger, R.L., B. Winterhalder, and R. McElreath

2006 A Simple Model of Technological Intensification. Journal of Archeological Science 33:538-545.

Bicchieri, M.G.

1969 A Cultural Ecological Comparative Study of Three African Foraging Societies. In Contributions to Anthropology:

Band Societies, edited by D. Damas, pp. 172-183. Bulletin 228. National Museum of Canada. Ontario.

Binford, L.R.

1980 Willow Smoke and Dogs’ Tails: Hunter-Gatherer Settlement Systems and Archaeological Site Formation. American Antiquity 45:4-20.

Bird, D.W.

1996 Intertidal Foraging Strategies Among the Meriam of the Torres Strait Islands, Australia: An Evolutionary Ecological Approach to the Ethnoarchaeology of Tropical Marine Subsistence. Ph.D. dissertation, University of California, Davis.

Bird, D.W., and R.L. Bliege Bird

1997 Contemporary Shellfish Gathering Strategies among the Meriam of the Torres Strait Islands, Australia: Testing Predictions of a Central Place Foraging Model. Journal of Archaeological Science 24:39-63.

Bird, R.

1999 Cooperation and Conflict: The Behavioral Ecology of the Sexual Division of Labor. Evolutionary Anthropology $8: 65-75$.

Bishop, C.A.

1970 The emergence of hunting territories among the northern Ojibwa. Ethnology 9:1-15.

Black, S.L.

1989 South Texas Plains. In From the Gulf to eh Rio Grande: Human Adaptation in Central, South, and Lower Pecos Texas, by T.R. Hester, S.L. Black, D.G. Steele, B.W. Olive, S.S. Fox, K.L. Reinhard, and L.C. Bement, pp 39-62. Research Series 33. Arkansas Archeological Survey, Fayetteville.

Bloom, A.M., K.A. Moser, D.F. Princhu and G.M. MacDonald

2003 Diatom-Inference Models for Surface-Water Temperature and Salinity Developed From a 57-Lake Calibration Set From the Sierra Nevada, California, USA. Journal of Paleolimnology 29(2):235-255.

Blundell, V.

1980 Hunter-gatherer territoriality: Ideology and behavior in Northwest Australia. Ethnohistory 27:103-117.

Blum, M.D., A.E. Cater, T. Zayac, and R. Goble

2002 Middle Holocene Sea-Level and Evolution of the Gulf of Mexico Coast (USA). Journal of Coastal Research, Special Issue 36:65-80. 
Bousman, C.B.

1993 Hunter-Gatherer Adaptations, Economic Risk, and Tool Design. Lithic Technology 18:59-86.

1994 The Central Texas Pollen Record: A Reinterpretation. Current Research in the Pleistocene 11:79-81.

1998 Paleoenvironmental Change in Central Texas: The Palynological Evidence. Plains Anthropologist 43(164):201-219.

Boomer, I.

2002 Environmental Applications of Marine and Freshwater Ostracod. In Quaternary Environmental Micropaleontology, edited by S. K. Haslett, pp. 115-138. Arnold, London.

Bowler, J.M.

1973 Clay Dunes: Their occurrence, formation and environmental significance. Earth-Science Reviews 9:315-338.

1983 Lunettes as indices of hydrologic change: A review of Australian evidence. Proceedings of the Royal Society of Victoria 95:147-168.

Brannan, J.A.

1992 On Modeling Resource Transportation Costs: Suggested Refinements. Current Anthropology 33(1):56-60.

Brink, J.W.

1997 Fat Content in Leg Bones of Bison bison, and Applications to Archaeology. Journal of Archaeological Science 24:259274.

Brown, B.C.

1950 An Annotated Checklist of the Reptiles and Amphibians of Texas. Baylor University Press, Waco.

Brown, K.M.

1999 Snails from the Quarter-inch and Eight-inch Screens. In The Smith Creek Bridge Site (41DW270) A Terrace Site in DeWitt County, Texas. D. Hudler, K. Prilliman, and T. Gustavson authors, pp. 213-275. Texas Archeological Research Laboratory. Studies in Archeology, No. 35. Archeology Studies Program, Report Number 17. Texas Department of Transportation. Environmental Affairs Division, Austin.

Brown, L.F., J.L. Brewton, J.H. McGowen, T.J. Evans, W.L. Fisher, and C.G. Gorat

1976 Environmental Geological Atlas of Texas: Corpus Christi Area. Bureau of Economic Geology, The University of Texas at Austin.

Bryant, V.M., Jr., and R.G. Holloway

1985 A Late-Quaternary Paleoenvironmental Record of Texas: An Overview of the Pollen Evidence. in Pollen Records of Late-Quaternary North American Sediments. V.M. Bryant Jr., and R.G. Holloway (eds.), pp: 39-70. American Association of Stratigraphic Palynologists Foundation.

Bryant, V.M., Jr., R.G. Holloway, J.G. Jones, and D.L. Carlson

1994 Pollen Preservation in Alkaline Soils of the American Southwest. In Sedimentation of Organic Particles, edited by A. Traverse, pp. 47-58. Cambridge University Press. Cambridge.

Bryant, V.M., Jr., and H.J. Shafer

1977 The Late Quaternary Paleoenvironment of Texas: A Model for the Archeologist. Bulletin of the Texas Archeological Society 48:1-25. 
Buck, B.J.

1993 Phytolith Analysis of Buried Soils in the Fort Bliss Reservation, El Paso, Texas. In Soil-Geomorphic and Paleoclimate Characteristics of the Fort Bliss Maneuver Areas, Southern New Mexico and Western Texas, by H.C. Monger, pp. 117-132. Historic and Natural Resources Report No. 10, Cultural-Resource Management Program, Directorate of Environment.

Buikstra, J.E., and D.H. Ubelaker (editors)

1994 Standards for Data Collection from Human Skeletal Remains: Proceedings of a Seminar at the Field Museum of Natural History Organized by Jonathan Haas. Research Series No. 44, Arkansas Archeological Survey, Fayetteville.

Cabeza de Vaca, A.N.

1555 La relacion y comentarios del gouernador Aluar nuñez cabeça de vaca, de lo acaescido en las dos jornadas que hizo a las Indias. Published under Royal Authorization at Valladolid, Spain. Scanned copy with English translation by M.A. Favata and J.B. Fernández is available online at http://www.library.txstate.edu/swwc/cdv/index.html. Accessed July $11,2008$.

Calnan, T.R.

1980 Molluscan Distribution in Copano Bay, Texas. Report of Investigations No. 103. Bureau of Economic Geology, The University of Texas at Austin.

Campbell, R.B. 2003

2003 Gone to Texas: A History of the Lone Star State. Oxford University Press, Oxford.

Campbell, T.N.

1955 The Kent-Crane Site: A Shell Midden of the Texas Coast. Bulletin of the Texas Archeological and Paleontological Society 23:39-77.

1988 The Indians of Southern Texas and Northeastern Mexico: Selected Writings of Thomas Nolan Campbell. Texas Archeological Research Laboratory, The University of Texas at Austin.

Campbell, T.N., and T.J. Campbell

1981 Historic Indians of the Choke Canyon Reservoir and Surrounding Area, Southern Texas. Choke Canyon Series, No. 1. Center for Archaeological Research, The University of Texas at San Antonio.

Camper, H.A.

1991 Pollen analysis of Patschke Bog. Unpublished M.S. thesis, Department of Botany, Texas A\&M University, Bryant. Data archived at the World Data Center for Paleoclimatology Data. NOAA/NGDC Paleoclimatology Program, Boulder.

Caran, S.C.

1998 Quaternary Paleoenvironmental and Paleoclimatic Reconstruction: A Discussion and Critique, with Examples from the Southern High Plains. Plains Anthropologist (43)164:111-124.

Carrillo, T.A.B.

2000 Historical Vegetation Changes in the Blind Oso (Oso Bay) Texas: Avian Abundance and Habitat Use of the Resulting Wetland Mosaic. Unpublished Master's Thesis, Texas A \& M University, Corpus Christi.

Cashdan, E.

1983 Territoriality Among Human Foragers: Ecological Models and an Application to Four Bushman Groups. Current Anthropology 24:47-66. 
Castiglione, M.C.

1983 The Distribution and Ecology of the Molluscs of Corpus Christi Bay, Texas. Unpublished Master's Thesis, Corpus Christi State University.

Chabreck, R.H.

1990 Creation, Restoration, and Enhancement of Marshes of the Northcentral Gulf coast. In Wetland Creation and Restoration: The Status of the Science, edited by J.A. Kusler, M.E. Kentula, pp. 125-142. Island Press, Washington, DC.

Chandler, C.K.

1984 Lithic Resources in the Texas Coastal Bend. La Tierra 11(1):26-27.

Charnov, E.L.

1976 Optimal Foraging, the Marginal Value Theorem. Theoretical Population Biology 9(2):129-136.

Charnov, E.L., G.H. Orians, and K. Hyatt

1976 Ecological Implications of Resource Depression. The American Naturalist 110(972):247-259.

Cheatham, S.M., C. Johnston, and L. Marshall

1995 The Useful Wild Plants of Texas, The Southeastern and Southwestern United States, The Southern Plains, and Northern Mexico. Volume 1. Useful Wild Plants, Inc., Austin.

Claassen, C.

1986 Shellfishing Seasons in the Prehistoric Southeastern United States. American Antiquity 51:21-37.

Collins, M.R.

1985 Species Profiles: Life Histories and Environmental Requirements of Coastal Fishes and Invertebrates (South Florida):Striped Mullet. Biological Report 82(11.33) Army Corps of Engineers TR EL-82-4. Fish and Wildlife Service, U. S. Department of the Interior, Washington, DC.

Cook, M.J.

2005 Soil Formation and Erosion in Central Texas: Insights from Relic Soils and Cave Deposits. Unpublished Doctoral Dissertation, The University of Texas at Austin.

Coopwood, B.

1898 The Route of Cabeza de Vaca, Part 1. Southwestern Historical Quarterly Online 3(2):108-140. Available at http:// www.tshaonline.org/shqonline/apager.php?vol=003\&pag=111. Accessed March 31, 2008.

Corpus Christi Daily

2006 Corpus Christi Recognized as Birdiest City. Corpuschristidaily.com. Accessed November 18, 2006.

Cox, K.A., and S.A. Cox

1993 Oyster Analysis at White's Point. In A Model of Holocen Environmental and Human Adaptive Change on the Central Texas Coast: Geoarchaeological Investigations at White's Point, Nueces Bay, and Surrounding Area, edited by R.A. Ricklis, pp. 81-122. Coastal Archaeological Studies, Corpus Christi.

Cox, K.A. and H.A. Smith

1988 Kent-Crane Revisited. La Tierra 15(3):24-38. 
Cronin, T.M.

1986 Ostracods from Late Quaternary Deposits, South Texas Coastal Complexes. In Stratigraphic Studies of a Late Quaternary Barrier-Type Coastal Complex, Mustang Island-Corpus Christ Bay Area, South Texas Gulf Coast, edited by G.L Shideler, pp. 33-64. U.S. Geological Survey Professional Paper 1328, U. S. Government Printing Office, Washington, D.C.

Cumming, B.F. and J.P. Smol

1993 Development of Diatom-Based Salinity Models for Paleoclimatic Research from Lakes in British Columbia (Canada). Hydrobiologia 269/270:179-196.

Curray, J.R.

1960 Sediments and History of Holocene Transgressions, Continental Shelf, Northwest Gulf of Mexico. In Recent Sediments, Northwest Gulf of Mexico, edited by F.P. Shepard, R. B. Phleger, and T. H, Van Andel, pp. $221-255$. American Association of Petroleum Geologists. Tulsa.

Davis, W.B. and D.J. Schmidly

1994 The Mammals of Texas. Texas Parks and Wildlife, Austin.

Dering, J.P.

2002 Rainfall Reconstruction Using Mesquite Wood Charcoal from Archeological Site in Southern Texas. In Archeological Data Recovery Excavations along Becerra Creek (41WB556), Webb County, Texas, by R.B. Mahoney, R.P. Mauldin, and S.A. Tomka, pp. 206-216. Archeological Studies Program, Report No. 44, Environmental Affairs Division, Texas Department of Transportation, Austin, and Archaeological Survey Report No. 321, Center for Archaeological Research, The University of Texas at San Antonio.

Dyson-Hudson, R., and E.A. Smith

1978 Human territoriality: An ecological reassessment. American Anthropologist 80:21-41.

Ebeling, W.

1986 Handbook of the Indian Foods and Fibers of Arid America. University of California Press, Berkeley.

Elliott, D.B.

1976 Roots: An Underground Botany and Forager's Guide. Chatham, Old Greenwich, Connecticut.

Erlandson, J.M.

1988 The Role of Shellfish in Prehistoric Economies. American Antiquity 53: 102-109.

Everitt, B.S.

1977 The Analysis of Contingency Tables. Chapman and Hall, London.

Fernald, M.L., and A.C. Kinsey

1943 Edible Wild Plants of Eastern North America. Idlewild. Cornwall-on-Hudson. New York.

Fisk, H.N.

1959 Padre Island and the Laguna Madre Flats, Coastal South Texas. Reprinted from National Academy of SciencesNational Research Council, $2^{\text {nd }}$ Coastal Geography Conference, National Academy of Sciences, Washington, D.C.

Flemming, K., P. Johnston, D. Zwartz, Y. Yokoyama, K. Lambeck and J. Chappell

1998 Refining the eustatic sea-level curve since the Last Glacial Maximum using far-and intermediate-field sites. Earth and Planetary Science Letters 163:327-342. 
Foley, R.L.

1985 Optimality Theory in Anthropology. Man 20:222-242.

Foster, W.C. [editor]

1998 The La Salle Expedition to Texas: The Journal of Henri Joutel, 1684-1687, translated by J.S. Warren. Texas Historical Commission, Austin.

Frederick, C.D.

1998 Late Quaternary Clay Dune Sedimentation on the Llano Estacado. Plains Anthropologist (43)164:137-156.

Fredlund, G.

1994 The Phytolith Record at the Wilson-Leonard Site. Program and Abstracts, 52nd Plains Conference, 65th Annual Meeting of the Texas Archaeological Society. Lubbock.

Fredlund, G.G., C.B. Bousman, and D.K. Boyd

1998 The Holocene Phytolith Record from Morgan Playa in the Rolling Plains of Texas. Plains Anthropologist (43)164:187200.

Gelwick, F.P., and S. Akin, D.A. Arrington, and K.O. Winemiller

2001 Fish Assemblage Structure in Relation to Environmental Variation in a Texas Gulf Coastal Wetland. Estuaries 24(2):285-296.

General Land Office (GLO)

2008 Matagorda Area to Mustang Island Area. Available online at http://www.glo.state.tx.us/ energy/ellis/maps/ Panel3.pdf . Accessed April 4, 2008.

Gillespie, R. and H.A. Polach

1979 The suitability of marine shells for radiocarbon dating of Australian prehistory. Radiocarbon Dating. Proceedings of the 9th International Conference on Radiocarbon Dating, edited by R. Berger and H.E Suess, pp. 404-21. University of California Press.

Gischler, E., and J.H. Hudson

2004 Holocene development of the Belize Barrier Reef. Sedimentary Geology 164: 223-236.

Glassow, M.A. and L.R. Wilcoxon

1988 Coastal Adaptation Near Point Conception, California, with Particular Regard to Shellfish Exploitation, American Antiquity 53:36-51.

Goslar, T. and M.F. Pazdur

1985 Contamination studies on mollusk shell samples. Radiocarbon 27: 33-42.

Greaves, R.D.

2004 Geoarcheological Investigations. In Third Interim Report on Archeological Monitoring at the Cayo Del Oso Site (41NU2), Corpus Christi, Texas, by B.A. Meissner. Manuscript on file, Center for Archaeological Research, the University of Texas at San Antonio.

Gunter, G.

1938 Seasonal Variations in Abundance of Certain Estuarine and Marine Fishes in Louisiana, with Particular Reference to Life Histories. Ecological Monographs 8(3):314-346. 
1941 Death of Fishes Due to Cold on the Texas Coast, January, 1940. Ecology 22:203-208.

Gunter, G. and H.H. Hildebrand

1951 Destruction of Fishes and Other Organisms on the South Texas Coast by the Cold Wave of January 28-February 3, 1951. Ecology 32(4):731-736.

Haberman, S.J.

1973 The Analysis of Residuals in Cross-classified Tables. Biometrics 29:205-220.

Hall, G.D.

1995a Descriptions and Chronology of Some Prehistoric Cemeteries in Texas. In Archaeological Investigations at the Loma Sandia Site (41LK28): A Prehistoric Campsite in Live Oak County, Texas, Volume 1, by Taylor, A.J., and C.L. Highley, pp. 47-57. Studies in Archeology No. 20. Texas Archeological Research Laboratory, The University of Texas at Austin.

1995b Prehistoric Cemeteries on the Texas Central Coastal Plain: Interpretations and Hypotheses. In Archaeological Investigations at the Loma Sandia Site (41LK28): A Prehistoric Campsite in Live Oak County, Texas, Volume 1, by A.J. Taylor and C.L. Highley, pp. 633-647. Studies in Archeology No. 20. Texas Archeological Research Laboratory, The University of Texas at Austin.

1998 Prehistoric Human Food Resource Patches on the Texas Coastal Plain. Bulletin of the Texas Archeological Society 69:1-10.

2000 Pecan Food Potential in Prehistoric North America. Economic Botany 54(1):103-112.

Hall, G.D., T.R. Hester, and S.L. Black (editors)

1986 The Prehistoric Sites at Choke Canyon Reservoir, Southern Texas: Results of the Phase II Archaeological Investigations. Choke Canyon Series, No. 10. Center for Archaeological Research, The University of Texas at San Antonio.

Harwood, R.J.

1980 Community Reconstruction in Benthic Paleoenvironments: Tropic Structure in Living and Dead Macroenvironment Associations, Corpus Christi and Aransas Bay Systems, Texas. Unpublished Ph.D. Dissertation. Department of Marine Sciences, The University of Texas at Austin.

Head, M.J.

1982 The degree of degradation of fossil material from archaeological sites: Can the influence of past environments be defined? In Archaeometry: An Australian Perspective, edited by W. Ambrose and P. Duerden, pp. 220-227. ANU Press.

Headrick, P.

1993 The Archeology of 41NU11, The Kirchmeyer Site, Nueces County, Texas: Long-Term Utilization of A Coastal Clay Dune. Studies in Archeology No. 15. Texas Archeological Research Laboratory, The University of Texas at Austin.

Hiller, I.

1996 The White-tailed Deer. Texas A\&M University Press, College Station.

Hoese, H.D.

1960 Biotic Changes in a Bay Associated with the End of a Drought. Limnology and Oceanography 5(3):326-336. 
Hoese, H.D. and R.H. Moore

1977 Fishes of the Gulf of Mexico: Texas, Louisiana, and Adjacent Waters. Texas A \& M University Press, College Station.

Holland, J.S., N.J. Maciole, R.D. Kalke, and C.H. Oppenhiemer

1973 A Benthos and Plankton Study of the Corpus Christi, Copano and Aransas Bay Systems: Report on the Methods Used and Data Collected during the Period July 1972-April 1974. First Annual Report to the Texas Water Development Board. University of Texas Marine Sciences Institute, Austin.

1974 A Benthos and Plankton Study of the Corpus Christi, Copano and Aransas Bay Systems: Report on the Methods Used and Data Collected during the Period July 1973-April 1974. Second Annual Report to the Texas Water Development Board. University of Texas Marine Sciences Institute, Austin.

1975 A Benthos and Plankton Study of the Corpus Christi, Copano and Aransas Bay Systems: Report on the Data Collected during the Three Year Project. First Annual Report to the Texas Water Development Board. University of Texas Marine Sciences Institute, Austin.

Holliday, V.T.

1997 Origin and Evolution of Lunettes on the High Plains of Texas and New Mexico. Quaternary Research 47: 54-69.

Holloway, R.G.

1989 Experimental Mechanical Pollen Degradation and Its Application to Quaternary Age Deposits. Texas Journal of Science 41(2):131-145.

Holmes, J.A., and A.R. Chivas, (editors),

2002a The Ostracoda: Applications to Quaternary Research Geophysical Monograph 131, American Geophysical Union, Washington, D.C.

Holmes, J.A., and A.R. Chivas,

2002b Ostracod Shell Chemistry - Overview. In The Ostracoda: Applications to Quaternary Research, edited by J.A. Holmes, and A.R. Chivas, pp. 185-204. Geophysical Monograph 131, American Geophysical Union, Washington, D.C.

Howells, R.G., R.W. Neck, and H.D. Murray

1996 Freshwater Mussels of Texas. Texas Parks and Wildlife Division, Austin.

Huffman, G.G., and W.A. Price

1949 Dune Clay formation Near Corpus Christi, Texas. Journal of Sedimentary Petrology 19(3):118-127).

IT IS (Integrated Taxonomic Information System)

2008 Integrated Taxonomic Information System. Available at http://www.itis.gov/index.html. Accessed January 27, 2009.

Jackson, A.T., S.A. Tomka, R.B. Mahoney, and B.A. Meissner

2004 The Cayo del Oso Site (41NU2). Volume I: A Historical Summary of Explorations of a Prehistoric Cemetery on the Coast of False Oso Bay, Nueces County, Texas. Archaeological Studies Program Report No.68, Environmental Affairs Division, Texas Department of Transportation, Austin, and Archaeological Survey Report No. 350, Center for Archaeological Research, The University of Texas at San Antonio.

Jacobs, K.

1995 Returning to Oleni'ostrov: Social, Economic and Skeletal Dimensions of a Boreal Forest Mesolithic Cemetery. Journal of Anthropological Archaeology 14:359-403. 
Jochim, M.A.

1981 Strategies for Survival: Cultural Behavior in an Ecological Context. Academic Press. New York.

Johnson, A.L., and R.J. Hard

2008 Exploring Texas Archaeology with a Model of Intensification. Plains Anthropologist 53(205):137-153.

Johnson, D.R. and W. Seaman

1986 Species Profiles: Life Histories and Environmental Requirements of Coastal Fishes and Invertebrates (Gulf of Mexico): Spotted Seatrout. Biological Report 82(11.43). Army Corps of Engineers TR EL-82-4. Fish and Wildlife Service, U. S. Department of the Interior, Washington, D.C.

Johnson, F.

1955 Reflections upon the significance of radiocarbon dates. In Radiocarbon Dating, edited by W F. Libby, pp. 141-161. University of Chicago Press.

Jones, K.T., and D.B. Madsen

1989 Calculating the Cost of Resource Transportation: A Great Basin Example. Current Anthropology 30:529-534.

Jurgens, C.J. and W.H. Whitsett

1982 Cultural Resources Inventory and Assessment of Proposed Wastewater Facilities, Aransas County Conservation and Reclamation District, Aransas County, Texas. Texas Department of Water Resources, Austin.

Kaplan, H., and K. Hill

1992 The Evolutionary Ecology of Food Acquisition. In Evolutionary Ecology and Human Behavior, edited by E.A. Smith and B. Winterhalder, pp. 167-202. Aldine and Gruyter. New York.

Kelly, R.L.

1995 The Foraging Spectrum: Diversity in Hunter-Gatherer Lifeways. Smithsonian Institution Press. Washington DC.

Keith, M.L. G.M. Anderson, and R. Eichler

1964 Carbon and oxygen isotope composition of mollusk shells from marine and fresh-water environments. Geochimica et Cosmochimica Acta 28:1757-86.

Kennett, D.J., and B. Winterhalder, (editors)

2006 Behavioral Ecology and the Transition to Agriculture. University of California Press, Berkeley.

Kennett, D.J., A. Anderson, and B. Winterhalder

2006 The Ideal Free Distribution, Food Production, and the Colonization of Oceania, In Behavioral Ecology and the Transition to Agriculture, edited by D.J. Kennett and B. Winterhalder, pp. 25-48. University of California Press, Berkeley.

Kibler, K.W.

1994 Archeological and Geomorphological Investigations at Prehistoric Sites 41 WY50 and 41WY60, Willacy County, Texas. Reports of Investigations, No. 95. Prewitt and Associates, Inc., Austin.

Kier, R.S. and W.A. White

1978 Land and Water Resources of the Corpus Christi Area, Texas. Report of Investigations No. 95, Bureau of Economic Geology. The University of Texas at Austin. 
Kilgan, R.H. and R.J. Dugas

1989 The Ecology of Oyster Reefs of the Northern Gulf of Mexico: An Open File Report. National Wetlands Research Center, Fish and Wildlife Service, U. S. Department of the Interior. Washington, D.C.

Kindscher, $\mathrm{K}$.

1987 Edible Wild Plants of the Prairie: An Ethnobotanical Guide. University Press of Kansas. Lawrence.

Kindt, A.C. and P.F. Small

2002 Correlation Between Temperature, Colonization Rate, and Population Density of the Diatom Cocconeis placentula in Freshwater Streams. Journal of Freshwater Ecology 17(3):441-445.

King, F.B.

1976 Potential Food Plants of the Western Missouri Ozarks. In Prehistoric Man and His Environments: A Case Study in the Western Ozark Highlands, edited by W.R. Wood, pp. 249-260. Academic Press. New York.

Lassuy, D.R.

1983a Species Profiles: Life Histories and Environmental Requirements (Gulf of Mexico):Atlantic Croaker. TR EL-82-4. Fish and Wildlife Service, U. S. Department of the Interior.

1983b Species Profiles: Life Histories and Environmental Requirements (Gulf of Mexico): Gulf Menhaden. FWS/OBS82/11.2. Army Corps of Engineers TR EL-82-4. Fish and Wildlife Service, U. S. Department of the Interior, Washington, D.C.

Lee, D.S., C.R. Gilbert, C.H. Hocutt, R.E. Jenkins, D. E., McAllister, and J.R. Stauffeer, Jr.

1980 Atlas of North American Freshwater Fishes. North Carolina Biological Survey Publication 1980-12. North Carolina State Museum of Natural History.

Leopold, A., L.K. Sowles, and D.K. Spencer

1947 A Survey of Over-Populated Deer Ranges in the United States. Journal of Wildlife Management 11:162-177.

Levins, R.

1968 Evolution in Changing Environments Some Theoretical Explorations. Princeton University Press, Princeton.

Liebow, E.B., K.S. Butler, T.R. Plaut, V.L. Arnold, G.H. Ford, T.D. Kahn, M.A. Klien, C. Allday-Bondy, and V. Parker 1980 Texas Barrier Islands Regions Ecological Characterization: A Socioeconomic Study, Volume 2: Data Appendix. Bureau of Land Management, U. S. Department of the Interior, Washington, D.C.

Little, E.L.

1971 Atlas of United States Trees: Vol. 1, Conifers and Important Hardwoods. U.S. Department of Agriculture Forest Services. No. 1146. Washington D.C.

Littleton, J. 2007 From the Perspective of Time: Hunter-Gatherer Burials in South-Eastern Australia. Antiquity 81:1013-1028.

Littleton, J., and H. Allen

2006 Hunter-Gatherer Burials and the Creation of Persistent Places in Southeastern Australia. Journal of Anthropological Archaeology 26:283-298. 


\section{Lyman, R.L.}

1987 Zooarchaeology and Taphonomy: A General Consideration. Journal of Ethnobiology 7(1):93-117.

1994 Vertebrate Taphonomy. Cambridge University Press, Cambridge.

Lyman, R.L. and M.J. O’Brien

1987 Plow-Zone Zooarchaeology: fragmentation and identifiability. Journal of Archaeological Science 16:293-317.

MacArthur, R.H., and E.R. Pianka

1966 On Optimal Use of Patchy Environments. The American Naturalist 100:603-609.

Mackinnon, L. and B. Jones

2001 Sedimentological evolution of North Sound, Grand Cayman- A freshwater to marine carbonate succession driven by Holocene sea-level rise. Journal of Sedimentary Research 71: 568-580.

Madsen, D.B. and D. Schmitt

1998 Mass Collecting and the Diet Breadth Model: A Great Basin Example. Journal of Archaeological Science 25:445-455.

Mahoney, R.B. and H.J. Shafer

2003 Bioarcheological Analysis of a Prehistoric Burial from Callo del Oso, 41NU2, Nueces County, Texas. Texas Department of Transportation, Contract No. 570XXPD004. Center for Archaeological Research, The University of Texas at San Antonio.

Malof, A.F.

2001 Feast or Famine: The Dietary Role of Rabdotus Species Snails in Prehistoric Central Texas. Unpublished Master's Thesis. Department of Anthropology, The University of Texas at San Antonio.

Mangerud, J.

1972 Radiocarbon dating of marine shells, including a discussion of apparent ages of recent shells from Norway. Boreas 1 (143-72).

Marshall, L.

1976 The !Kung of Nyae Nyae. Harvard University Press, Cambridge.

Martin, G.C.

1930 Two Sites on the Callo del Oso, Nueces County, Texas. Bulletin of the Texas Archeological and Paleontological Society 2:7-17.

Martin, G.C. and W.H. Potter

n.d. Preliminary Archaeological Survey of a Portion of the Texas Coast Made By George C. Martin and Wendell H. Potter, 1927-8-9. Parts 1 and 2. Privately published.

Martinez, R.

1961 Survey of Exposed Oyster Reefs in Corpus Christi Bay. Available on line at http://coastal.tamug.edu/ CoastalFisheries/1960-1961/CoastalFisheries1960-1961-Martinez03.pdf. Accessed January 27, 2009.

Meador, M.R., B.E. Arambula, and L.G. Hill

1990 Fish Assemblage Structure in an Intermittent Texas Stream. Texas Journal of Science 42(2):159-165. 
Meissner, B.A.

2000 Interim Report on Archeological Investigations at the Callo el Oso Site (41NU2), Corpus Christi, Texas. Manuscript on file, Center for Archaeological Research, the University of Texas at San Antonio.

2003 Second Interim Report on Archeological Investigations at the Callo el Oso Site (41NU2), Corpus Christi, Texas. Manuscript on file, Center for Archaeological Research, the University of Texas at San Antonio.

2004 Third Interim Report on Archeological Monitoring at the Cayo Del Oso Site (41NU2), Corpus Christi, Texas. Manuscript on file, Center for Archaeological Research, the University of Texas at San Antonio.

2005 Fourth Interim Report on Archeological Monitoring at the Cayo Del Oso Site (41NU2), Corpus Christi, Texas. Manuscript on file, Center for Archaeological Research, the University of Texas at San Antonio.

Metcalfe, D., and K.R. Barlow

1992 A Model for Exploring the Optimal Tradeoff Between Field Processing and Transport. American Anthropologist 94:340-356.

Miller, K.A., J. Gibbs and J. Lowe

2006 Archaeological Monitoring at Ennis Joslin/Spur 3 and 41NU2, the Cayo del Oso Site, City of Corpus Christi, Nueces County, Texas. SWCA Cultural Resources Report No. 2006-230. Unpublished manuscript on file at the Center for Archaeological Research, the University of Texas at San Antonio.

Milne, G.A., A.J. Long and S.E. Bassett

2005 Modeling Holocene relative sea-level observations from the Caribbean and South America. Quaternary Science Reviews 24:1183-1202.

Moore-Jansen, P.M., S.D. Ousley, and R.I. Jantz

1994 Data Collection Procedures for Forensic Skeletal Material. Report of Investigations No. 48. Department of Anthropology, University of Tennessee, Knoxville.

Morton, T.

1989 Species Profiles: Life Histories and Environmental Requirements of Coastal Fishes and Invertebrates (Gulfof Mexico): Bay Anchovy. Biological Report 82(11.97) Army Corps of Engineers TR EL-82-4. Fish and Wildlife Service, U. S. Department of the Interior, Washington, D.C.

Morton, R.A. and J.G. Paine

1984 Historic Shoreline Changes in Corpus Christi, Oso and Nueces Bays, Texas Gulf Coast. Geological Circular 84-6, Bureau of Economic Geology, University of Texas at Austin.

Morton, R.A. and M.J. Pieper

1977 Shoreline Changes on Mustang Island and North Padre Island (Aransas Pass to Yarborough Pass)--An Analysis of Historical Changes of the Texas Gulf Shoreline. Geological Circular 7701, Bureau of Economic Geology, The University of Texas at Austin.

National Atlas of the United States

2003 NationalAtlas.gov accessed online at http://nationalatlas.gov.

National Climatic Data Center (NCDC)

2004 Monthly Station Climate Summaries, 1971-2000, Texas. Climatology of the United States, No. 20. NOAA, NCDC, Asheville. 
NatureServe Explorer

2008 Spotted Gar. NatureServe Explorer. Available online at http://www.natureserve.org/explorer/servlet/NatureServe?sear chName=Lepisosteus\%20oculatus. Accessed June 25, 2008.

Neck, R.W., and A.L. Metcalf

1988 Freshwater Bivalves of the Lower Rio Grande, Texas. Texas Journal of Science 40:259-268.

Nelson, H.F. and E.E., and N.W. Bay

1970 Stratigraphy and History of the Holocene Sediments in the Sabine-High Island Area, Gulf of Mexico. In Deltaic Sedimentation, Modern and Ancient, edited by J.P. Morgan and R.H. Shaver, pp. 48-77. Special Publication 15. Society of Economic Paleontologists and Mineralogists.

Newcomb, W.W. Jr.,

1983 Karankawa. In Handbook of North American Indians. Vol. 10., edited by A. Ortiz, pp. 359-367. Smithsonian Institution. Washington, D.C.

Nickels, D.L., and R.P. Mauldin

2001 Chapter 3: The Project Environment. In An Archaeological Survey of Twin Buttes Reservoir, Tom Green County, Texas, Volume 1, by R.P. Mauldin and D.L. Nickels, pp. 25-38. Archaeological Survey Report, No. 300. Center for Archaeological Research, The University of Texas at San Antonio.

Nordt, L.C., T.W. Boutton, J.S. Jacob, and R. Mandel

1994 Late Quaternary Climates of Central Texas Based on the Stable Isotopic Composition of Organic Carbon. Program and Abstracts, 52nd Plains Conference, 65th Annual Meeting of the Texas Archeological Society, Lubbock.

$2002 \mathrm{C}_{4}$ Plant Productivity and Climate- $\mathrm{CO}_{2}$ Variations in South-Central Texas during the Late Quaternary. Quaternary Research 58(2):182-188.

Ollendorf, A.L., S.C. Mulholland, and G. Rapp Jr.

1988 Phytolith analysis as a means of plant identification: Arundo donax and Phragmites communis. Annals of Botany 61:209-214

Orians, G.H. and N.E. Pearson

1979 On the Theory of Central Place Foraging. In Analysis of Ecological Systems, edited by D.J. Horn, G.R. Stairs and R.D. Mitchell, pp. 155-177. Ohio State University Press, Columbus.

Osborn, A.J.

1977 Aboriginal Exploitation of Marine Food Resources. Unpublished Ph.D. dissertations. Department of Anthropology, University of New Mexico. University Microfilms, Ann Arbor.

Otvos, E.G.

2004 Holocene Gulf Levels: Recognition Issues and an Updated Sea-Level Curve. Journal of Coastal Research 20(3): 680-699.

Oviedo y Valdes, G.F.

1923 The Expedition of Pánfilo de Narváez, Chapter IV, translated and edited by H. Davenport. Southwestern Historical Quarterly 27(4):276-304.

Owen, R.B., R.W. Renaut, V.C. Hover, G.M. Ashley and A.M. Musaya 2004 Swamps, Springs and Diatoms: Wetlands of the Semi-Arid Bogoria-Baringo Rift, Kenya. Hydrobiologia 518(1-3):59-78. 
Paine, J.G.

1987 The Swan Lake Site (41AS16) and the Holocene Highstand Hypothesis. In: National Register Assessments of the Swan Lake Site, 41AS16, on Copano Bay, Aransas County, Texas, by E.R. Prewitt, S.V. Lisk, and M.A. Howard, pp.242-253. Reports of Investigations 56. Prewitt and Associates, Inc., Austin.

1991 Late Quaternary Depositional Units, Sea Level, and Vertical Movement Along the Central Texas Coastal Plain. Unpublished Ph.D. Dissertation, The University of Texas at Austin.

Parker, R.H.

1955 Changes in the Invertebrate Fauna, Apparently Attributable to Salinity Changes, in the Bays of Central Texas. Journal of Paleontology 29(2):193-211.

Parkinson, R.W. and J.R. White

1994 Late Holocene erosional shoreface retreat within a siliciclastic-to-carbonate transition zone, east central Florida, USA. Journal of Sedimentary Research 64:408-415.

Parmalee, P.W. and W.E. Klippel

1974 Freshwater Mussels as a Prehistoric Food Resource. American Antiquity 39:421-434.

Patrick, R.

1977 Ecology of Freshwater Diatoms and Diatom Communities. In The Biology of Diatoms, edited by Dietrich Werner, Botanical Monographs 13:284-332.

Pearse, V., J. Pearse, M. Buchsbaum, and R. Buchsbaum 1987 Living Invertebrates. The Boxwood Press, Pacific Grove.

Perlman, S.M.

1976 Optimum Diet Models and Prehistoric Hunter-Gatherers: A Test on Martha's Vineyard. Ph.D.. Dissertation, Department of Anthropology. University of Massachusetts. University Microfilms, Ann Arbor.

Perttula, T.K.

2001 Hunter-Gatherer Mortuary Practices in the Rio Grande Plains and Central Coastal Plains Archeological Regions of Texas. La Tierra 28(3-4):2-83.

Piperno, D.R.

1988 Phytolith Analysis: An Archaeological and Geological Perspective. Academic Press, New York.

Potzger, J.E., and B.C. Tharp

1943 Pollen records of Canadian Spruce and Fir from a Texas Bog. Science 98:584.

1947 Pollen Profile from a Texas Bog. Ecology 28:274-280.

Prewitt, E.R.

1981 Cultural Chronologies in Central Texas. Bulletin of the Texas Archeological Society 52:65-89.

1985 From Circleville to Toyah: Comments on Central Texas Chronology. Bulletin of the Texas Archeological Society 54:201-238 
Prewitt, E.R., S.V. Lisk, and M.A. Howard

1984 National Register Assessments of the Swan Lake Site, 41AS16, on Copano Bay, Aransas County, Texas. Reports of Investigations, No. 36, Prewitt and Associates, Austin.

Price, W.A. and L.S. Kornicker

1961 Marine and Lagoonal Deposits in Clay Dunes, Gulf Coast, Texas. Journal of Sedimentary Petrology 31: $245-255$.

Quality Deer Management Association

2008 Whitetail Map Guide. http://www.i-maps.com accessed April 2008.

Ramsey, C.B.

2003 OxCAL Radiocarbon Calibration Program. Version 3.9.

Rappole, J.H., and G.W. Blacklock

1994 Birds of Texas. Texas A\&M University Press, College Station.

Reagan, R.E.

1985 Species Profiles: Life Histories and Environmental Requirements of Coastal Fishes and Invertebrates (Gulf of Mexico): Red Drum. Biological Report 82(11.36) Army Corps of Engineers TR EL-82-4. Fish and Wildlife Service, U. S. Department of the Interior, Washington, D.C.

Reagan, R.E. and W.M. Wingo

1985 Species Profiles: Life Histories and Environmental Requirements of Coastal Fishes and Invertebrates (Gulf of Mexico): Southern Flounder. Biological Report 82(11.30) Army Corps of Engineers TR EL-82-4. Fish and Wildlife Service, U. S. Department of the Interior, Washington, D.C.

Rector, R.R.

1996 Live Oak Acorn Yield Studies in Relation to Prehistoric Hunting and Gathering Population in Central Texas. Unpublished Master's Thesis. The University of Texas at San Antonio.

Reidhead, V.A.

1976 Optimization and Food Procurement at the Prehistoric Leonard Haag site, Southeastern Indiana: a linear programming approach. Unpublished Ph.D. dissertation, Indiana University. Retrieved April 4, 2008, from Proquest Digital Dissertations database. (Publication No. AAT 7710972).

1981 Optimization and Food Procurement at the Prehistoric Leonard Haag Site, Southeastern Indiana: A Linear Programming Approach. Prehistory Research Series No. 6 (1). Indiana Historical Society, Indianapolis.

Reitz, E.J. and E.S. Wing

1999 Zooarchaeology. Cambridge University Press, Cambridge.

Rhode, D.

1990 On Transportation Costs of Great Basin Resources: An Assessment of the Jones-Madsen Model. Current Anthropology 31(4):413-419.

Rhodes, D.D. and F.J. Rich,

2004 Luminescence Dating and Palynology of the Soda Lake Clay Dune Complex, Carrizo Plain, San Luis Obispo County, California. Abstracts with Programs - Geological Society of America (November 2004), 36(5):513. 
Ricklis, R.A.

1988 Archeological Investigations at the McKinzie Site (41NU221), Nueces County, Texas: Description and Contextual Interpretations. Bulletin of the Texas Archeological Society 58(for 1987):1-76.

1990 A Historical Cultural Ecology of the Karankawa Indians of the Center Texas Coast: A Case Study in the Tools of Adaptive Change. Ph.D. dissertation, Department of Geography. The University of Texas, Austin.

1993 A Model of Environmental and Human Adaptive Change on the Central Texas Coast: Geoarchaeological Investigations at White's Point, Nueces Bay, and Surrounding Area. Coastal Archaeological Studies, Inc. Corpus Christi.

1995a Prehistoric Occupation of the Central and Lower Texas Coast: A Regional Overview. Bulletin of the Texas Archeological Society 66:265-300.

1995b Environmental and Human Adaptive Change on the Nueces Bay Shoreline: Phase I Archaeological Data Recovery, Koch Refinery Middle Plant, Nueces County, Texas. Corpus Christi, Texas: Coastal Archaeological Research, Corpus Christi.

1996 The Karankawa Indians of Texas: An Ecological Study of Cultural Tradition and Change. The University of Texas Press, Austin.

1997 Archaeological Testing at the Callo del Oso Site, 41NU2, Nueces County, Texas. Coastal Archaeological Research, Corpus Christi.

2004 Prehistoric Occupation of the Central and Lower Texas Coast: A Regional Overview. In The Prehistoric of Texas, ed. T.K. Pertulla, pp. 125-171. Texas A\&M University Press, College Station.

Ricklis R.A. and M.D. Blum

1997 The Geoarchaeological Record of Holocene Sea Level Change and Human Occupation of the Texas Gulf Coast. Geoarchaeology: An International Journal 12 (4): 287-314.

Ricklis, R.A., and K.A. Cox

1998 Holocene Climatic and Environmental Change in the Texas Coastal Zone: Some Geoarchaeological and Ecofactual Indicators. Plains Anthropologist (43)164:125-136.

Ricklis, R.A. and R.R. Gunter

1986 Archaeological Investigations at the Means Site (41NU184) Nueces County, Texas. La Tierra 13(1): 15-32.

Ricklis, R.A. and R.A. Weinstein

2005 Sea-Level Rise and Fluctuation on the Central Texas Coast: Exploring Cultural-Ecological Correlates. In Gulf Coast Archaeology: The Southeastern United States and Mexico, edited by N.M. White, pp.108-154. University of Florida Press, Gainsville.

Robinson, R.L.

1979 Biosilica and Climatic Change at 41GD21 and 41GD21A. In Archaeological Investigations of Two Prehistoric Sites on the Colette Creek Drainage, Goliad County, Texas, edited by D.E. Fox, pp. 102-113. Archaeological Survey Report, No. 69. Center for Archaeological Research, The University of Texas at San Antonio. 
1982 Biosilica Analysis of Three Prehistoric Archaeological Sites in the Choke Canyon Reservoir, Live Oak County, Texas: Preliminary Summary of Climatic Implications. In Archaeological Investigations at Choke Canyon Reservoir, South Texas: The Phase I Findings, edited by G.D. Hall, S.L. Black, and C. Graves, pp. 597-610. Choke Canyon Series, No. 5. Center for Archaeological Research, The University of Texas at San Antonio.

Rovner, I.

1983 Plant Opal Phytolith Analysis: Major Advances in Archaeobotonical Research. In Advances in Archaeological Method and Theory. Volume 6, edited by M.B. Schiffer, pp. 225-266. Academic Press, New York.

Sayles, E. B.

n.d Unpublished 41NU2 site summary manuscript. Filed in the E.B. Sayles Folder at the Texas Archeological Research Laboratory, The University of Texas at Austin.

Schlanger, S.

1992 Recognizing Persistent Places in Anasazi Settlement Systems. In Space, Time and Archaeological Landscapes, edited by J. Rossignol and L. Wandsnider, pp. 91-112. Plenum Press, New York.

Senner, S.E., and M.A. Howe

1984 Conservation of Neararctic Shorebirds. In Behavior of Marine Animals. Vol. 5. Shorebirds: Breeding Behavior and Populations, edited by J. Burger and B.L. Olla, pp. 379-421. Plenum Press. New York.

Simmons, E.G.

1957 An Ecological Survey of the Upper Laguna Madre of Texas. Publications of the Institute for Marine Sciences, University of Texas 4(2):156-200.

Simmons , E.G., and J.P. Breuer.

1982 Fish Tagging on the Texas Coast. In Coastal Fish Project Reports. , p. 66-107. Texas Parks and Wildlife Report. Available online at http://coastal.tamug.edu/CoastalFisheries/1976/ CoastalFisheries1976-pg066.pdf. Accessed December 8, 2006.

Simms, S.R.

1987 Behavioral Ecology and Hunter-Gatherer Foraging: An Example from the Great Basin. BAR International Series 381.Oxford.

Skinner, S.A.

1981 Aboriginal Demographic Changes in Central Texas. Plains Anthropologist 26(92):111-118.

Speth, J.D., and K.A. Spielmann

1983 Energy source, protein metabolism and hunter-gatherer subsistence strategies. Journal of Anthropological Archaeology 2:1-31.

Stephens, D.W., and J.R. Krebs

1986 Foraging Theory. Monographs in Behavior and Ecology. Princeton University Press. Princeton.

Steuter, A.A., and H.A. Wright 1980 White-tailed Deer Densities and Brush Cover on the Rio Grande Plains. Journal of Range Management 33:328-331.

Stickney, R.R. 1984 Estuarine Ecology of the Southeastern United States and Gulf of Mexico. Texas A \& M University Press, College Station. 
Story, D.A.

1985 Adaptive Strategies of Adaptive Cultures of the West Gulf Coastal Plain. In Prehistoric Food Production in North America, edited by R.I. Ford, pp.19-56. Anthropological Paper 75. Museum of Anthropology, University of Michigan, Ann Arbor.

Stuckenrath, R.

1977 Radiocarbon: Some notes from Merlin's diary. Annals of the New York Academy of Sciences 288: 181-188.

Sturmer, L.

2007 Shellfish Aquaculture Research and Extension. Water Works: Newsletter of the UF/IFAS Department of Fisheries and Aquatic Sciences. Available online at http://fishweb.ifas.ufl.edu/WaterWorks06/WaterWorksOct07.pdf. Accessed February 2, 2009.

Suhm, D.A., and E.B. Jelks

1962 Handbook of Texas Archeology: Type Descriptions. The Texas Archeological Society Special Publication No. 1 and Texas Memorial Museum Bulletin No. 4. The Texas Archeological Society and the Texas Memorial Museum, Austin.

Sutherland, W.J.

1996 From Individual Behavior to Population Ecology. Oxford University Press. Oxford.

Sutter, F.C. and T.D. McIlwain

1987 Species Profiles: Life Histories and Environmental Requirements of Coastal Fishes and Invertebrates (Gulf of Mexico): Sand Seatrout and Silver Seatrout. Biological Report 82(11.72). Army Corps of Engineers TR EL-82-4. Fish and Wildlife Service, U. S. Department of the Interior, Washington, D.C.

Sutter, F.C., R.S. Waller, and T.D. McIlwain.

1986 Species Profiles: Life Histories and Environmental Requirements of Coastal Fishes and Invertebrates (Gulfof Mexico): Black Drum. Biological Report 82(11.51) Army Corps of Engineers TR EL-82-4. Fish and Wildlife Service, U. S. Department of the Interior, Washington, D.C.

Talaley, L., D.R. Keller, and P.J. Munson

1984 Hickory Nuts, Walnuts, Butternuts, and Hazelnuts: Observations and Experiments Relevant to their Aboriginal Exploitation in Eastern North America. In Experiments and Observations on Aboriginal Wild Plant Food Utilization in Eastern North America, edited by P.J. Munson, pp. 317-337. Indiana Historical Society, Indianapolis.

Taylor, A.J.

1998 Mortuary Practices and Territoriality: Archaic Hunter-Gatherers of Southern Texas and the Loma Sandia Site (41LK28). Ph.D. dissertation, The University of Texas at Austin.

Taylor, A.J., and C.L. Highley

1995 Archaeological Investigations at the Loma Sandia Site (41LK28): A Prehistoric Campsite in Live Oak County, Texas, 2 volumes. Studies in Archeology No. 20. Texas Archeological Research Laboratory, The University of Texas at Austin.

Taylor, R.E.

1987 Radiocarbon Dating: An archaeological perspective. Academic Press, Orlando.

Texas A \& M University—Corpus Christi (TAMU—CC)

2007 History. In TAMU—CC Master Plan Update 2007. Available online at http://ppl.tamucc.edu/ pdf/Master/history.pdf. Accessed April 9, 2008. 
Texas Crop and Livestock Reporting Service

1984 Texas Fruit and Pecan Statistics. Texas and U.S. Department of Agriculture. Austin and Washington D.C.

Texas Game, Fish, and Oyster Commission

1945 Principal Game Birds and Mammals of Texas. Texas Game, Fish, and Oyster Commission, Austin.

Texas Historical Commission (THC)

2008 Texas Historic Commission Archeological Site Atlas. Available online at http://nueces.thc.state.tx.us/. Accessed April 4, 2008.

Texas Parks and Wildlife

2005 Breeding Dates for White-tailed Deer in Texas, TPWD Statewide Deer Breeding Chronology Study. Texas Parks and Wildlife. Available online at http://www.tpwd.state.tx.us/huntwild/hunt/ planning/rut_whitetailed_deer/table/\#coast. Accessed January 26, 2007.

Thomas, M.A. and M.A. Anderson

1994 The Impact of Long-Term and Short-term Sea-Level Changes on the Evolution of the Wisconsinan-Holocene Trinity/ Sabine Incised-Valley System, Texas Continental Shelf. In Incised-Valley Systems: Origin and Sedimentary Sequences, edited by R. Boyd, B.A. Zaitlin and R. Dalrymplen, pp. 63-82. Special Publication 51, Society of Economic Paleontologists and Mineralogists, Tulsa.

Thoms, A.

2008 Learning from Cabeza de Vaca. Texas Beyond History. Available online at http://www. texasbeyondhistory.net/ cabeza-cooking/index.html. Accessed April 10, 2008.

Tomka, S.A.

2002 Chapter 9: Projectile Points and Beveled Tools An Assessment of Typology and Function. In Archeological Data Recovery Excavations along Becerra Creek (41WB556), Webb County, Texas. by R.B. Mahoney, R.P. Mauldin, and S.A. Tomka, pp. 71-132. Texas Department of Transportation, Environmental Affairs Division. Archeological Studies Program, Report No. 44. Archaeological Survey Report, No. 321. Center for Archaeological Research, The University of Texas at San Antonio.

Tomka, S.A., B.A. Meissner, R.P. Mauldin, and C.D. Frederick

2006 A Research Design for Analysis of Material Collected from the Cayo del Oso Site (41NU2), Corpus Christi, Nueces County, Texas 2000-2006. Manuscript on file, Center for Archaeological Research, the University of Texas at San Antonio.

Tomka, S.A., R.P. Mauldin, and R.D. Greaves

2004 Research Design for Analysis of Testing and Data Recovery Materials from 41ZV202, Zavala County, Texas. Report on file, Center for Archaeological Research, The University of Texas at San Antonio.

Törnqvist, T. E., J.L. González, L.A. Newsom, K. van der Borg, A.F.M. de Jong and C.W. Kurnick

2004 Deciphering Holocene Sea-Level History on the U. S. Gulf Coast: A High-Resolution Record from the Mississippi Delta. Geological Society of America Bulletin 116(7/8):1026-1039.

Townsend, C.H.

1893 U.S. Commission of Fish and Fisheries Report 1889-91. U.S. Government Printing Office, Washington, D.C.

Tull, D.

1999 Edible and Useful Plants of Texas and the Southwest: A Practical Guide. The University of Texas Press, Austin. 
Ugan, A.

2005 Does Size Matter? Body Size, Mass Collecting, and Their Implications for Understanding Prehistoric Foraging Behavior. American Antiquity 70(1):75-89).

Ugan, A., J. Bright and A. Rogers

2003 When is Technology worth the Trouble? Journal of Archaeological Science 30:1315-1329.

U.S. Navy and the National Fish and Wildlife Foundation

2006 Checklist of Birds, Naval Air Station Corpus Christi. Available online at https://www.denix.osd. mil/denix/Public/ ES-Programs/Conservation/Bird-Checklist/ccna/ccna.html. Accessed November 15, 2006.

Vehik, S.C.

1977 Bone Fragments and Bone Grease Manufacturing: A Review of their Archaeological Use and Potential. Plains Anthropologist 22(77):169-182.

Walsh, P.B.

1985 Habitat Use and Population Fluctuations of White-Tailed Deer at La Copita Research Area, Jim Wells County, Texas. Unpublished Master's Thesis, Texas A \& M University. College Station.

Walthall, J.

1999 Mortuary Behavior and Early Holocene Land Use in the North American Midcontinent. North American Archaeologist 20:1-30.

Ward, C.G. and A.J. McGraw

1993 Archaeological Investigations at 41SP158 and the Kent-Crane Site, 41AS3, on Live Oak Peninsula Along the Middle Texaw Coast. Environmental Affairs Division, Texas Department of Transportation, Austin.

Watt, B. K. and A.L. Merrill

1963 Composition of foods- raw, processed, prepared. USDA Agriculture Handbook 8.

Weckström, J., A. Korhola, P. Erästö and L. Holmström

2006 Temperature patterns over the past eight centuries in Northern Fennoscandia inferred from sedimentary diatoms. Quaternary Research 66:78-86.

Weddle, R.S and P.R. Lemée

2003 Exploring the Texas Coast: Bellisle, Berangier and La Harpe 1719-1721. In The French in Texas: History, Migrations, Culture, edited by F. Lagarde, pp.20-34. The University of Texas Press, Austin.

Weir, F.A.

1976 The Central Texas Archaic. Unpublished Ph.D. dissertation, Department of Anthropology. Washington State University, Pullman.

Weniger, D.

1997 The Explorer's Texas, Volume 2: The Animals They Found. Eakin Press, Austin.

White, D.H., and C.A. Mitchell

1990 Body Mass and Lipid Content of Shorebirds Overwintering on the South Texas Coast. Journal of Field Ornithology 61:445-452. 
Wilkinson, R.H. and R.A. Basse

1978 Late Holocene History of the Central Texas Coast from Galveston Island to Pass Cavallo. Geological Society of America, Bulletin 89:1592-1600.

Winsborough, B.M.

2006 Appendix H: Diatom Paleoecology of Burned Clay Samples from 41MM341. In Data Recovery Excavations at the J.B. White Site (41MM341), Milam County, Texas. E.F. Gadus, R.C. Fields, and K.W. Kibler authors, pp. 299-317. Reports of Investigations, Number 145. Prewitt and Associates, Inc., and Archeological Studies Program, Report No. 87. Environmental Affairs Division. Texas Department of Transportation, Austin.

2008 Appendix A: Diatom Paleoenvironmental Analysis of Sediments from Archeological Site 41HA1, in Plainview, Texas. In A Geoarcheological Survey of the Proposed Plainview Hike and Bike Trail, Hale County, Texas, C.D. Frederick, J.L. Thompson, and K.J. Córdova authors, pp.59-68. Center for Archaeological Research, Archaeological Report, No. 396, The University of Texas at San Antonio.

Winterhalder, B.

1981 Optimal Foraging Strategies and Hunter Gatherer Research in Anthropology: Theory and Models. In Hunter-Gatherer Foraging Strategies: Ethnographic and Arcaheological Analyses, edited by B. Winterhalder and E.A. Smith, pp. 1335. The University of Chicago Press. Chicago.

Winterhalder, B., and D.J. Kennett

2006 Behavioral Ecology and the Transition from Hunting and Gathering to Agriculture. In Behavioral Ecology and the Transition to Agriculture, edited by D.J. Kennett and B. Winterhalder, pp. 1-21. University of California Press. Berkeley.

Withers, K. and B.R. Chapman

1993 Seasonal Abundance and Habitat Use of Shorebirds on an Oso Bay mudflat, Corpus Christi, Texas. Journal of Field Ornithology 64:382-39269.

Yarnell, R.A.

1964 Aboriginal Relationships Between Culture and Plant Life in the Upper Great Lakes Region. Anthropological Papers 23:44-80; 205-218. The University of Michigan, Ann Arbor.

Zeanah, D.W.

2000 Transport costs, central place foraging, and hunter-gatherer alpine land use strategies. In: Intermountain Archaeology, edited by D.B. Madsen and M.D. Metcalfe, pp. 1-14, Vol. 122, University of Utah Anthropological Papers, Salt Lake City.

Zimmerman, L.S.

1997 Dietary Reconstruction and Subsistence Strategies of Prehistoric Hunter Gatherers of the Texas Gulf Coast. Unpublished Doctoral Dissertation, UMI No. 9815871. Texas A \& M University. College Station. 


\section{APPENDIX A: \\ Pollen and Phytolith Analysis of Stratigraphic Core Samples from the Cayo Del Oso Site (41NU2), Copus Christi, Texas}

Linda Scott Cummings, Chad Yost, and R.A. Varney

Paleo Research Institute

Golden, Colorado 


\section{Introduction}

Pollen and phytolith analysis was conducted on three stratigraphic core samples from the Cayo del Oso site (41NU2). The site is located along the northwestern shore of Oso Bay, Corpus Christi, Texas. Previous excavations have indicated that the site was a prehistoric campsite and cemetery. Radiocarbon dates from the test units and the burial ranged from 4400 B.P. to 1300 B.P. Core samples submitted for analysis were derived from pond sediments (Core 2) and dune deposits (Cores 4 and 6). Pollen and phytolith analysis of these samples was undertaken to provide paleoenvironmental reconstruction data for the Oso Bay Site and coastal South Texas.

\section{Methods}

\section{Pollen}

A chemical extraction technique based on flotation is the standard preparation technique used in this laboratory for the removal of the pollen from the large volume of sand, silt, and clay with which they are mixed. This particular process was developed for extraction of pollen from soils where preservation has been less than ideal and pollen density is lower than in peat.

Hydrochloric acid (10\%) is used to remove calcium carbonates present in the soil, after which the samples are screened through 150 micron mesh. The samples are rinsed until neutral by adding water, letting the samples stand for 2 hours, then pouring off the supernatant. A small quantity of sodium hexametaphosphate is added to each sample once it reaches neutrality, then the samples are allowed to settle according to Stoke's Law in settling columns. This process is repeated with ethylenediaminetetraacetic acid (EDTA). These steps remove clay prior to heavy liquid separation. The samples are then freeze dried under a partial vacuum. Sodium polytungstate (SPT), with a density 1.8 , is used for the flotation process. The samples are mixed with SPT and centrifuged at $1500 \mathrm{rpm}$ for 10 minutes to separate organic from inorganic remains. The supernatant containing pollen and organic remains is decanted. Sodium polytungstate is again added to the inorganic fraction to repeat the separation process. The supernatant is decanted into the same tube as the supernatant from the first separation. This supernatant is then centrifuged at $1500 \mathrm{rpm}$ for 10 minutes to allow any silica remaining to be separated from the organics. Following this, the supernatant is decanted into a $50 \mathrm{ml}$ conical tube and diluted with distilled water. These samples are centrifuged at $3000 \mathrm{rpm}$ to concentrate the organic fraction in the bottom of the tube. After rinsing the pollen- rich organic fraction obtained by this separation, all samples receive a short (20-30 minute) treatment in hot hydrofluoric acid to remove any remaining inorganic particles. The samples are then acetolated for 3-5 minutes to remove any extraneous organic matter.

A light microscope is used to count the pollen to a total of approximately 200 pollen grains at a magnification of 500x. Pollen preservation in these samples varied from good to poor. Comparative reference material collected at the Intermountain Herbarium at Utah State University and the University of Colorado Herbarium was used to identify the pollen to the family, genus, and species level, where possible.

Pollen aggregates were recorded during identification of the pollen. Aggregates are clumps of a single type of pollen and may be interpreted to represent pollen dispersal over short distances or the introduction of portions of the plant represented into an archeological setting. Aggregates were included in the pollen counts as single grains, as is customary. The presence of aggregates is noted by an " $A$ " next to the pollen frequency on the pollen diagram. Pollen diagrams are produced using Tilia, which was developed by Dr. Eric Grimm of the Illinois State Museum. Total pollen concentrations are calculated in Tilia using the quantity of sample processed in cubic centimeters (cc), the quantity of exotics (spores) added to the sample, the quantity of exotics counted, and the total pollen counted and expressed as pollen per cc of sediment.

Indeterminate pollen includes pollen grains that are folded, mutilated, and otherwise distorted beyond recognition. These grains are included in the total pollen count since they are part of the pollen record. The microscopic charcoal frequency registers the relationship between pollen and charcoal. The total number of microscopic charcoal fragments was divided by the pollen sum, resulting in a charcoal frequency that reflects the quantity of microscopic charcoal fragments observed, normalized per 100 pollen grains.

Pollen analysis also includes examination for and identification of starch granules to general categories, if they are present. Starch granules are a plant's mechanism for storing carbohydrates. Starches are found in numerous seeds, as well as in starchy roots and tubers. The primary categories of starches include the following: with or without visible hila, hilum centric or eccentric, hila patterns (dot, cracked, elongated), and shape of starch (angular, ellipse, circular, eccentric). Some of these starch categories are typical of specific plants, while others are more common and tend to occur in many different types of plants. 


\section{Phytoliths}

A pressurized (closed) microwave digestion technique was used to oxidize the majority of the organic fraction of the sediment samples. Specific protocols were developed by PRI that were based on a few previous studies (Parr, et al. 2001; Parr, et al. 2004). One gram of sediment was placed in a glass vial with $4 \mathrm{ml}$ nitric acid $\left(\mathrm{HNO}_{3}\right), 2 \mathrm{ml}$ hydrochloric acid $(\mathrm{HCl})$, and $1 \mathrm{ml}$ of hydrogen peroxide $\left(\mathrm{H}_{2} \mathrm{O}_{2}\right)$. Each glass vial was placed and sealed into a Teflon vessel with outer casement and screw cap seal. One vessel was connected to a pressure sensor transducer for real-time pressure monitoring by the in-built microwave computer system (Floyd Inc. Remote Microwave System 150). Samples were programmed for exposure to $40 \mathrm{psi}$ at a dwell time of 60 minutes, using $100 \%$ magnetron power, then allowed to cool and depressurize. Samples were then removed from the microwave and rinsed to neutral in $50 \mathrm{ml}$ centrifuge tubes (4X $3000 \mathrm{rpm}$ for $2 \mathrm{~min}$ ). One $\mathrm{ml}$ of ethylenediaminetetraacetic acid (EDTA) was added to each sample, which was then placed in an ultrasonic bath and sonicated for approximately three minutes. EDTA aids in the removal of trace metals and humic substances undigested by acid oxidation. Samples were then rinsed to neutral.

Because sediment deposits from the Oso Bay Site contained a large fraction of silt-sized particles, many of which are similar in size to our target phytoliths, standard PRI phytolith methodology had to be customized. After the EDTA treatment, samples were sieved through a $50 \mu \mathrm{m}$ mesh into $50 \mathrm{ml}$ centrifuge tubes, rinsed to neutral $(4 \mathrm{X} 3000 \mathrm{rpm}$ for $2 \mathrm{~min}$ ), transferred to $15 \mathrm{ml}$ centrifuge tubes, and then dried using a partial vacuum drying system (lyophilization). The lyophilized samples were then subjected to heavy liquid flotation to separate silica phytoliths from non-silica particles. Separation trials were run using sodium polytungstate densities of 2.3, 2.2 and 2.1 and Cadmium iodide at densities of 2.2 and 2.15. All samples were then treated with cadmium iodide at a density of 2.15 , as this was found to provide the best separation of phytoliths from the silt fraction with very little loss of phytoliths to the heavy fraction. Samples were mixed with cadmium iodide and centrifuged at $1500 \mathrm{rpm}$ for 10 minutes. The supernatant containing phytoliths was decanted. Cadmium iodide was again added to the heavy fraction to repeat the separation process. The supernatant was decanted into the same tube as the supernatant from the first separation. This supernatant was then centrifuged at $1500 \mathrm{rpm}$ for 10 minutes to allow any non-phytolith silica and other particles remaining to be separated from the phytoliths. Following this, the supernatant was decanted into a new centrifuge tube, then diluted with distilled water and centrifuged at $3000 \mathrm{rpm}$ for 10 minutes to concentrate the phytolith fraction in the bottom of the tube. Additional rinses were then conducted to wash any remaining heavy liquid from the sample. Because of the initial small sample size started, most of the clay-sized particle fraction was removed during previous rinse and centrifugation steps. If necessary, the remaining clay-sized particles were removed with shorttime centrifugation in $15 \mathrm{ml}$ tubes (typically 1 or 2 spins at 3000 RPM for $1.5 \mathrm{~min}$ ). After several alcohol rinses, samples were transferred to storage vials, and a small portion mounted in Cargille Type-A immersion oil (refractive index 1.515), with two opposite coverslip corners affixed with nail polish to allow for controlled phytolith rotation and counting with a light microscope at a magnification of 500x.

\section{Phytolith Review}

Phytoliths are silica bodies produced by plants when soluble silica in the ground water is absorbed by the roots and carried up to the plant via the vascular system. Evaporation and metabolism of this water result in precipitation of the silica in and around the cellular walls. Opal phytoliths, which are distinct and decay-resistant plant remains, are deposited in the soil as the plant or plant parts die and break down. They are, however, subject to mechanical breakage and erosion and deterioration in high $\mathrm{pH}$ soils. Phytoliths are usually introduced directly into the soils in which the plants decay. Transportation of phytoliths occurs primarily by animal consumption, gathering of plants by humans, or by erosion or transportation of the soil by wind, water, or ice.

The three major types of grass short-cell phytoliths include festucoid, chloridoid, and panicoid. Smooth elongate phytoliths are of no aid in interpreting either paleoenvironmental conditions or the subsistence record because they are produced by all grasses. Phytoliths tabulated to represent "total phytoliths" include the grass short-cells, buliform, trichome, elongate, and dicot forms. Frequencies for all other bodies recovered are calculated by dividing the number of each type recovered by the "total phytoliths".

The festucoid class of phytoliths is ascribed primarily to the Subfamily Pooideae and occur most abundantly in cool, moist climates. However, Brown (1984) notes that festucoid phytoliths are produced in small quantity by nearly all grasses (mostly rondel-type phytoliths). Therefore, while they are typical phytoliths produced by the Subfamily Pooideae, they are not exclusive to this subfamily. Chloridoid phytoliths (short saddles) are found primarily in the Subfamily Chloridoideae, a warm-season grass that grows in arid to semi-arid areas and require less available soil moisture. Chloridoid grasses are the most abundant in the American Southwest (Gould and Shaw 1983:120). Bilobates and polylobates (lobates) are produced mainly by panicoid grasses, although a few of the festucoid grasses also produce these forms. Panicoid 
phytoliths occur in warm-season or tall grasses that frequently thrive in humid conditions. Twiss (1987:181) also notes that some members of the Subfamily Chloridoideae produce both bilobate (Panicoid) and Festucoid phytoliths. "According to (Gould and Shaw 1983:110) more than 97\% of the native US grass species $(1,026$ or 1,053$)$ are divided equally among three subfamilies Pooideae, Chloridoideae, and Panicoideae" (Twiss 1987:181).

Buliform phytoliths are produced by grasses in response to wet conditions and are to be expected in wet habitats of floodplains and other places. Trichomes represent silicified hairs, which may occur on the stems, leaves, and the glumes or bran surrounding grass seeds.

Conifers produce opal silica phytoliths in their inner bark and needles. Polyhedral phytoliths are noted to be observed in leaves (Bozarth 1993), while the authors have observed the blocky forms in bark reference samples.

A rapidly growing body of phytolith studies, many of which using three-dimensional typological descriptions, are allowing a much finer resolution of taxa identification, often to the subfamily and genus level. This is especially true with the grass family, where diagnostic forms are now accepted for many additional subfamlies and genera such as: Bambusoideae (bamboo), Erhartoideae (rice), tribe Oryzeae (Oryza, Zizania), Aristidoideae (threeawn, needlegrass), Arundinoideae (reeds), and Zea maize (maize, corn) (Piperno 2006). Determining local and regional levels of diagnostic morphotypes can also greatly improve taxa identification.

\section{Lobate Phytolith Classification}

Study areas, such as this one, with an abundance of lobate phytoliths (e.g., bilobates, polylobates) allow for the use of a detailed lobate phytolith classification. Lobate phytoliths are most characteristic of the grass subfamily Panicoideae (e.g., warm and moist season tall grass prairie species, sugarcane, millet), but are also sometimes found in the Chloridoideae (e.g., warm and dry season short grass prairie species, cord grass), Erhartoideae (e.g., white rice, North American wild rice) and Bambusoideae (bamboos). Lobate phytoliths are typically comprised of two lobes joined by a shank, and have been described as resembling a dumbbell. The lobate phytolith classification used here is based on: (1) the length of the lobate shank and (2) the shape of the outer margin of the two lobes. This lobate classification follows that used by $\mathrm{Lu}$ and $\mathrm{Lu}$ (2003) and their analysis of 250 modern grass species. Their work demonstrated a link between lobate phytolith morphology, grass taxonomy and environmental conditions. Detailed bilobate phytolith classification can potentially detect the presence of economically and culturally significant grass species. In addition, detailed bilobate classification is more sensitive to subtle ecological and precipitation change than that detectable by traditional festucoid, chloridoid and panicoid relative abundance. Bilobate classification graphs of relative abundance are summed independently, but are based on the overall phytolith count (typically 300 grains).

\section{Other Siliceous Microfossils}

Diatoms and sponge spicules also were noted. Pennate diatoms are cosmopolitan, occurring in many sediments, and they indicate at least some soil moisture. Sponge spicules represent fresh water sponges. Diatoms are single-celled algae with a siliceous cell wall. They grow in a wide range of aerophilous habitats, including on wet plants and rocks, in damp soils, marshes, wetlands, mudflats, and all types of standing and flowing aquatic habitats. Their silica cells often are preserved in sedimentary deposits. Because individual taxa have specific requirements and preferences with respect to water chemistry, hydrologic conditions, and substrate characteristics, the presence (and subsequent identification to the species level) of diatoms in paleoenvironmental context can provide information about the nature of the local environment. These data, coupled with input about local geology, hydrology, soil characteristics, pollen and phytoliths, provide evidence of the paleoenvironmental setting. In the context of phytolith samples, diatoms are noted but not identified beyond the split of "pennate" and "centric" forms. Centric diatoms often indicate wet conditions, while at least some of the pennate diatoms are cosmopolitan, occurring nearly everywhere. Both diatoms and sponge spicules can be transported with sediment. As an illustration, recovery of sponge spicules in upland soils is noted to accompany loess deposits derived from floodplains in Illinois (Jones and Beavers 1963).

\section{Discussion}

Pollen and phytolith analysis was conducted on three stratigraphic core samples (Table A-1) from the Cayo Del Oso site (41NU2). The site is located along the northwestern shore of Oso Bay, Corpus Christi, Texas. The modern climate is considered subtropical and semi-arid. Mean annual precipitation for the area averages $74 \mathrm{~cm}$ per year. Mean annual evaporation rates average from 90 to $115 \mathrm{~cm}$ per year, but may range as high as $150 \mathrm{~cm}$ per year during times of drought. Southeasterly prevailing winds are characteristic of the Texas Gulf coast for most of the year. Strong northerly frontal passages are common in winter (Nicolau 2001). An ecological gradient exists along the Texas coast, with higher rainfall amounts and greater freshwater inflows 
Table A-1. Provenience Data for Samples from the Cayo del Oso Site (41NU2)

\begin{tabular}{|c|c|c|c|c|c|c|}
\hline $\begin{array}{c}\text { Sample } \\
\text { No. }\end{array}$ & $\begin{array}{l}\text { Core } \\
\text { No. }\end{array}$ & Segment & Zone & $\begin{array}{c}\text { Depth } \\
\text { within } \\
\text { segment }\end{array}$ & Description & Analysis \\
\hline 103 & 2 & 1 & 8 & $97-101$ & & Pollen \& Phytolith \\
\hline 104 & 2 & 2 & 8 & $8-13$ & & Pollen \& Phytolith \\
\hline 105 & 2 & 2 & 9 & $18-23$ & & Pollen \& Phytolith \\
\hline 106 & 2 & 2 & 9 & $28-32$ & & Pollen \& Phytolith \\
\hline 107 & 2 & 2 & 9 & $37-41$ & & Pollen \& Phytolith \\
\hline 108 & 2 & 2 & 10 & $46-51$ & & Pollen \& Phytolith \\
\hline 109 & 2 & 2 & 10 & $56-61$ & & Pollen \& Phytolith \\
\hline 110 & 2 & 2 & 10 & $65-70$ & & Pollen \& Phytolith \\
\hline 111 & 2 & 2 & 10 & $74-79$ & & Pollen \& Phytolith \\
\hline 112 & 2 & 2 & 10 & $84-89$ & & Pollen \& Phytolith \\
\hline 113 & 2 & 2 & 10 & $96-101$ & & Pollen \& Phytolith \\
\hline 114 & 2 & 3 & 10 & $28-32$ & & Pollen \& Phytolith \\
\hline 115 & 2 & 3 & 10 & $35-40$ & & Pollen \& Phytolith \\
\hline 116 & 2 & 3 & 11 & $44-48$ & & Pollen \& Phytolith \\
\hline 117 & 2 & 3 & 11 & $53-57$ & & Pollen \& Phytolith \\
\hline 182 & 4 & 1 & 5 & $40-43$ & & Phytolith \\
\hline 183 & 4 & 1 & 6 & $46-49$ & & Phytolith \\
\hline 184 & 4 & 1 & 8 & $57-60$ & & Phytolith \\
\hline 185 & 4 & 1 & 9 & $68-70$ & & Phytolith \\
\hline 186 & 4 & 1 & 11 & $77-80$ & & Phytolith \\
\hline 187 & 4 & 1 & 12 & $85-87$ & & Phytolith \\
\hline 188 & 4 & 1 & 13 & $90-93$ & & Phytolith \\
\hline 189 & 4 & 2 & 14 & $0-3$ & & Phytolith \\
\hline 190 & 4 & 2 & 16 & $12-14$ & & Phytolith \\
\hline 191 & 4 & 2 & 17 & $20-23$ & & Phytolith \\
\hline 192 & 4 & 2 & 17 & $30-33$ & & Phytolith \\
\hline 193 & 4 & 2 & 18 & $35-38$ & & Phytolith \\
\hline
\end{tabular}


Table A-1. Continued...

\begin{tabular}{|c|c|c|c|c|c|c|}
\hline $\begin{array}{c}\text { Sample } \\
\text { No. }\end{array}$ & $\begin{array}{c}\text { Core } \\
\text { No. }\end{array}$ & Segment & Zone & $\begin{array}{c}\text { Depth } \\
\text { within } \\
\text { segment }\end{array}$ & Description & Analysis \\
\hline 194 & 4 & 2 & 19 & $46-49$ & & Phytolith \\
\hline 195 & 4 & 2 & 20 & $53-56$ & & Phytolith \\
\hline 196 & 4 & 2 & 21 & $56-59$ & & Phytolith \\
\hline 197 & 4 & 2 & 22 & $59-63$ & & Phytolith \\
\hline 198 & 4 & 2 & 23 & $70-73$ & & Phytolith \\
\hline 199 & 4 & 2 & 23 & $80-83$ & & Phytolith \\
\hline 200 & 4 & 2 & 24 & $92-95$ & & Phytolith \\
\hline 201 & 4 & 3 & 25 & $7-10$ & & Phytolith \\
\hline 202 & 4 & 3 & 26 & $14-17$ & & Phytolith \\
\hline 203 & 4 & 3 & 26 & $25-28$ & & Phytolith \\
\hline 204 & 4 & 3 & 27 & $35-38$ & & Phytolith \\
\hline 279 & 6 & 1 & 4 & $28-30$ & & Phytolith \\
\hline 280 & 6 & 1 & 5 & $32-34$ & & Phytolith \\
\hline 281 & 6 & 1 & 6 & $40-42$ & & Phytolith \\
\hline 282 & 6 & 1 & 7 & $47-49$ & & Phytolith \\
\hline 283 & 6 & 1 & 8 & $53-55$ & & Phytolith \\
\hline 284 & 6 & 1 & 9 & $70-73$ & & Phytolith \\
\hline 285 & 6 & 1 & 9 & $80-83$ & & Phytolith \\
\hline 286 & 6 & 1 & 9 & $90-93$ & & Phytolith \\
\hline 287 & 6 & 1 & 10 & $53-56$ & & Phytolith \\
\hline 288 & 6 & 2 & 11 & $75-78$ & & Phytolith \\
\hline 289 & 6 & 2 & 18 & $88-90$ & & Phytolith \\
\hline 290 & 6 & 3 & 13 & $5-8$ & & Phytolith \\
\hline 291 & 6 & 3 & 14 & $25-28$ & & Phytolith \\
\hline 292 & 6 & 3 & 15 & $42-45$ & & Phytolith \\
\hline 293 & 6 & 3 & 16 & $59-62$ & & Phytolith \\
\hline 294 & 6 & 3 & 17 & $70-73$ & & Phytolith \\
\hline
\end{tabular}


in the northern half of the coastal region giving rise to the establishment of salt marshes dominated by smooth cordgrass (Spartina alterniflora, subfamily Chloridoideae). In the south, low annual rainfall and very little freshwater inflow result in the creation of vast areas of algal flats (wind-tidal flats) with little to no emergent salt marsh vegetation. The Corpus Christi Bay Complex, positioned just south of the midway point on the Texas Gulf coast, serves as the ecotone between these two distinct habitat types. Stands of Spartina alterniflora become less common from Corpus Christi Bay south, and are replaced by algal flats, which become larger and more common. Between 9,000 and 3,000 B.P. sea level rose unevenly (stable, slow and rapid), after approximately 3,000 B.P. sea level has been at about its modern level (Ricklis n.d.). Previous archeological excavations from the 1920s have indicated that the site was a prehistoric campsite and cemetery. Radiocarbon dates from test units and a burial ranged from 4,400 B.P. to 1,300 B.P. Construction activities associated with road improvements have required recent and ongoing excavations and monitoring to mitigate damage to the site. Since 2000, monitoring and excavations have yielded intact stratified cultural deposits and multiple features and burials. In addition, an area of pond sediments and two dune deposits with up to 12 identifiable paleosols have been identified. Core samples submitted for pollen and phytolith analysis are derived from pond sediments (Core 2) and dune deposits (Cores 4 and 6). Pollen and phytolith analysis of these samples should provide paleoenvironmental reconstruction data for the Oso Bay Site and coastal South Texas.

Phytolith interpretations from south and southeastern coastal sediments of North America have been greatly enhanced by the work of Lu and Liu $(2003 ; 2003 ; 2005)$. They have expanded our knowledge of phytolith production in many common coastal plants, especially within the grasses (Poaceae), and have associated modern phytolith assemblages with major coastal vegetation zones (salt marsh, braskish/fresh marsh, swamps, forests, interdune meadows, sand dunes). They have also developed a bilobate phytolith classification that can be used to detect environmental change. This classification was employed here to detect changes in grass species associated with forest edge / scrubland ecotones, sandy soils and shallow water/shoreline margins. This was made possible here after matching bilobate morphotypes and their associated grass species with habitat preference information.

\section{Core 2 (pond sediments)}

Core 2 was collected in pond sediments to interpret paleoenvironmental conditions in this area by examining several different data sets. Pollen and phytoliths were extracted from a set of stratigraphic samples from this core to obtain information concerning the local and regional vegetation communities.

Plants considered typical along the northern Gulf Coast (including Texas) include beach pioneers and plants growing in humid and "wet slack" areas. Beach plants of this group (excluding grasses) are represented in the pollen record as: Brassicaceae (perhaps Cakile sp.), Onagraceae (perhaps Oenothera), and Sesuvium. Plants (excluding grasses) that grow in humid slacks and on beaches where the ground water table is high include Cyperaceae, Hydrocotyle bonariensis (Apiaceae), and Salicornia bigelovii (a Cheno-am). Recovery of pollen from these families does not necessarily indicate that these specific genera or species are represented. Humic slacks support grasses, sedges, and Salicornia bigelovii (a Cheno-am). Grasslands and thickets include grasses, prickly pear cactus (Opuntia), and a variety of plants not represented in the pollen record. The wide variety of grasses growing in the area limit the use of Poaceae pollen to interpret the vegetation community represented. Instead, the strength of the phytolith will be used to interpret the presence of specific groups of grasses (Moreno-Casasola 1988).

The pollen record exhibits Poaceae, Cheno-am, and Highspine Asteraceae pollen (Figure A-1, Table A-2) as the three co-dominants, representing grasses, various members of the goosefoot families and perhaps amaranth that include at least Salicornia bielovii, which is noted to grow in the area today in humic slacks and on beaches. The High-spine Asteraceae is a large group of plants including most of the sunflower family that is not accounted for in the Liguliflorae (chicory tribe) or Low-spine Asteraceae (ragweed, cocklebur, bursage, and marshelder).

The pollen and phytolith records are both divided into matching zones for ease of discussion of the interpretations. General trends in the pollen record include large changes in the microscopic charcoal record (Figure A-1). Quantities of microscopic pieces of charcoal, which are calculated relative to the quantity of pollen in each sample, are moderately small in Zone E, increasing in Zone $\mathrm{D}$, and generally higher in Zone $\mathrm{C}$, declining in Zone $\mathrm{B}$, then increasing in Zone $\mathrm{A}$, with a decline noted in the uppermost sample. From the microscopic charcoal record alone, it is not possible to identify whether these fluctuations correspond with human activity and represent short distance wind transport as ash released from hearths or whether they represent longer distance transport from local or regional wild fires.

The phytolith record indicates that there has been some subtle, long-term environmental change as well as a few punctuated events and/or short term changes strong 


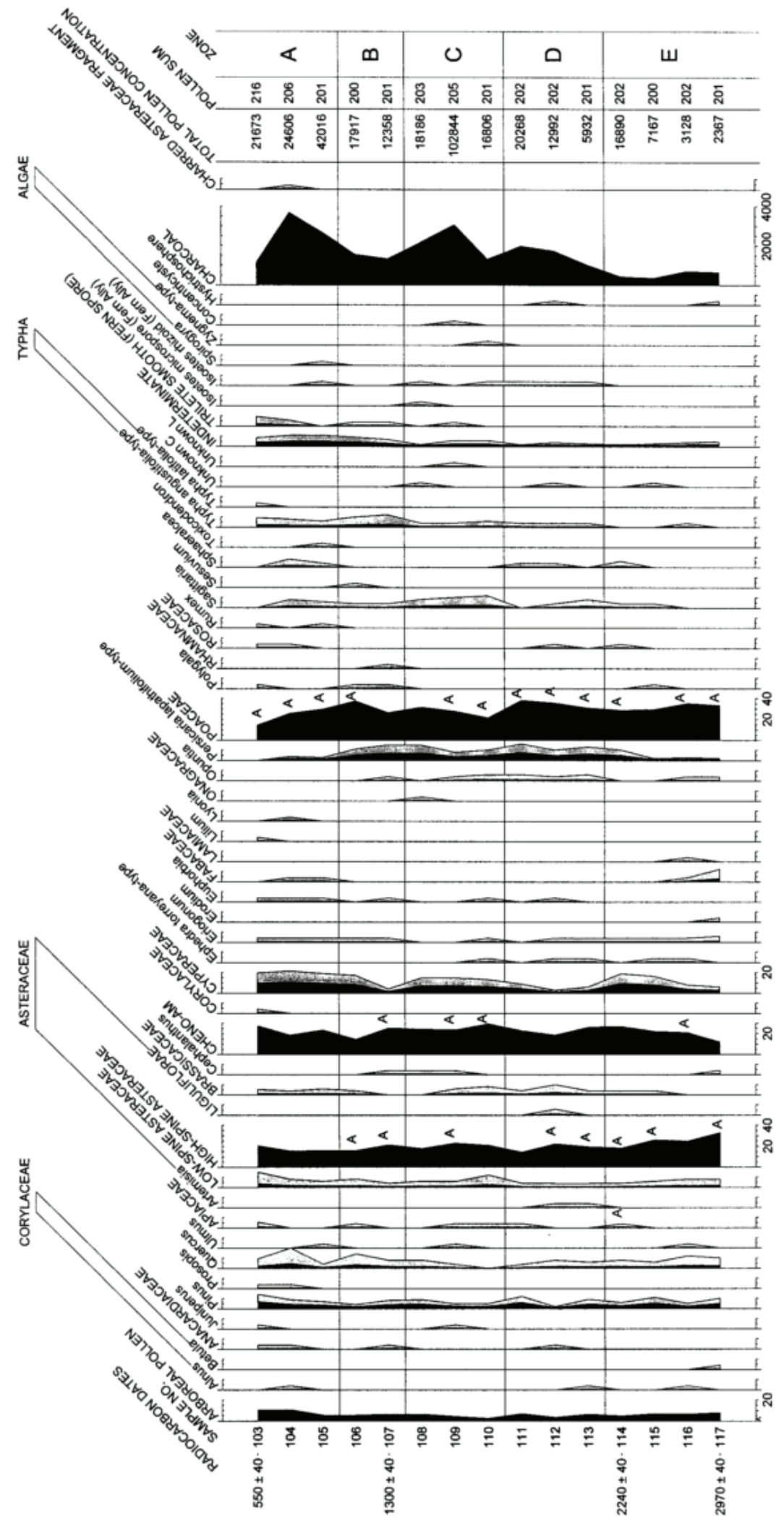

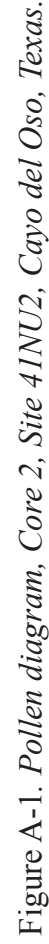


Table A-2. Pollen Types Observed in Samples from the Cayo del Oso Site (41NU2).

\begin{tabular}{|c|c|}
\hline Scientific Name & Common Name \\
\hline \multicolumn{2}{|l|}{ ARBOREAL POLLEN: } \\
\hline Anacardiaceae & Sumac family \\
\hline Corylaceae: & Birch family \\
\hline Alnus & Alder \\
\hline Betula & Birch \\
\hline Juniperus & Juniper \\
\hline Pinus & Pine \\
\hline Prosopis & Mesquite \\
\hline Quercus & Oak \\
\hline Ulmus & Elm \\
\hline \multicolumn{2}{|l|}{ NON-ARBOREAL POLLEN: } \\
\hline Asteraceae: & Sunflower family \\
\hline Artemisia & Sagebrush \\
\hline Low-spine & Includes ragweed, cocklebur, sumpweed \\
\hline High-spine & $\begin{array}{l}\text { Includes aster, rabbitbrush, snakeweed, } \\
\text { sunflower, etc. }\end{array}$ \\
\hline Liguliflorae & Chicory tribe, includes dandelion and chicory \\
\hline Brassicaceae & Mustard family \\
\hline Cephalanthus & Buttonbush \\
\hline Cheno-am & Includes the goosefoot family and amaranth \\
\hline Corylaceae & Hazel family \\
\hline Cyperaceae & Sedge family \\
\hline $\begin{array}{l}\text { Ephedra torreyana-type (includes E. torreyana, } \\
\text { E. trifurca, and E. antisyphilitica) }\end{array}$ & Ephedra, Jointfir, Mormon tea \\
\hline Eriogonum & Wild buckwheat \\
\hline Erodium & Storksbill, Heron-bill, Filaree \\
\hline Fabaceae: & Bean or Legume family \\
\hline Lamiaceae & Mint family \\
\hline Lilium & Lilley \\
\hline Lyonia & staggerbush \\
\hline
\end{tabular}


Table A-2. Continued...

\begin{tabular}{|c|c|}
\hline Scientific Name & Common Name \\
\hline Onagraceae (Gaura) & Evening primrose family \\
\hline Opuntia & Prickly pear cactus \\
\hline Persicaria-tapanthifolium-type & Knotweed, Spotted lady's thumb \\
\hline Poaceae & Grass family \\
\hline Polygala & Milkwort \\
\hline Rhamnaceae & Buckthorn family \\
\hline Rosaceae: & Rose family \\
\hline Rumex & Dock \\
\hline Sagittaria & Arrowweed \\
\hline Sesuvium & Sea purslane \\
\hline Sphaeralcea & Globe mallow \\
\hline Toxicodendron & Poison ivy \\
\hline Typha angustifolia - type & Cattail \\
\hline Typha latifolia - type & Cattail \\
\hline Indeterminate & Too badly deteriorated to identify \\
\hline \multicolumn{2}{|l|}{ SPORES: } \\
\hline Trilete Smooth & Fern spore \\
\hline Isoetes Microspores & Fern Ally \\
\hline Isoetes Rhizoid & Fern Ally \\
\hline \multicolumn{2}{|l|}{ ALGAE: } \\
\hline Spirogyra & $\begin{array}{l}\text { Algal body representing a filamentous green algae } \\
\text { common in freshwater habitats }\end{array}$ \\
\hline Zygnema-type & Algal body \\
\hline \multicolumn{2}{|l|}{ OTHER: } \\
\hline Concentricyste & Fungal spore, indicator of wet, oxidized conditions \\
\hline Hystrichosphere & Geologic plankton \\
\hline Charcoal & Microscopic charcoal fragment \\
\hline Charred Asteraceae tissue fragment & $\begin{array}{l}\text { Charred tissue fragment from a member of } \\
\text { the sunflower family }\end{array}$ \\
\hline Total pollen concentration & $\begin{array}{l}\text { Quantity of pollen per cubic centimeter (cc) } \\
\text { of sediment. }\end{array}$ \\
\hline
\end{tabular}


enough to be detectable with the sampling interval strategy employed (Figure A-2). The large sampling intervals, both within and between samples, limits the availability to detect punctuated events and has an overall smoothing effect on the environmental record. Despite being limited to a course-scale, the bilobate phytolith classification allows us additional interpretive data, and likewise indicates both longterm trends and short-term events (Figure A-3). Conjoining samples exhibiting similar phytolith assemblages have been grouped together into zones. Discussion will start with the chronologically lowest zone.

Radiocarbon dates of $2970 \pm 40$ RCYBP and $2240 \pm 40$ RCYBP bracket Zone $\mathrm{E}$ at the base of the stratigraphic record. This interval exhibits relatively stable Poaceae pollen frequencies and declining High-spine Asteraceae and increasing Chenoam and Cyperaceae pollen frequencies. Small quantities of Alnus and Betula pollen noted low in this unit indicate the regional presence of alder and birch. Recovery of small quantities of Pinus and Quercus pollen throughout this zone and the remainder of the pollen record indicate the pines and oak grew as part of the regional vegetation throughout the past approximately 3,000 years. Ulmus pollen was observed once in this zone. Low-spine Asteraceae, Brassicaceae, Cephalanthus, Eriogonum, Erodium, Fabaceae, Lamiaceae, Opuntia, Polygala, Rosaceae, and Sphaeralcea pollen are noted in small quantities, indicating local growth of marshelder and similar plants, members of the mustard family, buttonbush, wild buckwheat, filaree, legumes, members of the mint family, prickly pear cactus, milkwort, members of the rose family, and globe mallow grew in the area. Increasing quantities of Persicaria lapathifolium-type and Smilax pollen, and the intermittent presence of Typha pollen represents a knotweed (pale persicaria or a similar plant) that prefers mesic habitats, greenbriar, which typically grows at the margins of woodlands, and cattails, which grows primarily in freshwater marsh habitats. Recovery of a small quantity of Ephedra torreyana pollen in this and succeeding levels of this record probably represents long distance wind transport from populations growing in drier habitats.

Samples from Zone E exhibit a phytolith assemblage that suggests a coastal freshwater marsh/pond habitat existed, as evidenced by the high abundance of bilobates (called dumbells by Lu and Liu, 2005), smooth elongates, echinate elongates (called sinuate elongates by Lu and Liu, 2005), and buliforms (called squares and rectangles by Lu and Liu, 2005). Tribe Oryzeae morphotypes are also relatively abundant in this zone and are likely derived from aquatic/wetland grasses Zizaniopsis miliacea (giant cutgrass) and Leersia spp. (Indian cutgrass). This zone also exhibited the highest relative abundance of pennate diatoms, usually associated with freshwater habitats of lakes and streams. Bilobate indicators of forest (scrub) edge and understory grasses are in very low abundance, with bilobate indicators of sandy soil (beach and dune) grasses and shoreline and emergent aquatic grasses fairy high in abundance (Figure A-3). Beach and dune grass phytoliths are likely derived from Panicum amarum, Uniola paniculata, Aristida desmantha, Cenchrus spp. and Spartina spp. Phytoliths from wetland grasses are likely derived from Leersia spp. and Zizaniopsis miliacea. Thus, Zone E likely represents an expansive freshwater marsh habitat with dunes and tidal mudflats extending further than they do today because of slightly lower sea levels. In fact, at approximately 3,000 B.P., sea levels may have dipped slightly $(\approx-1.0 \mathrm{~m})$ from their long-term slowly rising trend since the Last Glacial Maximum (Flemming, et al. 1998; Milne, et al. 2005).

Zone $\mathrm{D}$ is marked by a continuation of the decline in High-spine Asteraceae pollen. Quantities of Cheno-am and Poaceae pollen fluctuate slightly in this zone. Cyperaceae pollen declines, then rises toward the top of this zone. Both Opuntia and Persicaria lapathifolium-type pollen increase and Smilax pollen retains its presence throughout most of this zone. Typha pollen is present in every sample. Pollen recovered from this zone exhibits indicators of beach and grasslands and thickets through the presence of Opuntia pollen. Persicaria grows along disturbed margins of wetlands, lakes and rivers. Its presence suggests periodic water level change and/or the presence of enough open water to create wave action, resulting in a margin of disturbance. The viney growth habit of Smilax and its current distribution in East Texas and the southeastern United States suggests wetter conditions, i.e. a positive water balance, than what exists today. Typha thrives in freshwater marshes. Isoetes (quillwort) rhizoids make their first appearance in Zone D. Nearly 150 species of quillworts are known. They grow in conditions from aquatic to semi-aquatic to drying mudflats and are considered to be a fern-ally.

Samples from Zone D exhibit a phytolith assemblage that suggests the continuation of coastal freshwater conditions; however, pond and surrounding marsh water levels may have been changed to levels more favorable to Tribe Oryzeae grasses and freshwater sponge spicules. In fact, Zone D contains the highest relative abundance of freshwater siliceous sponge spicules. The spicules observed here were in good states of preservation and are not likely to have be redeposited through wind deposition or erosion. Freshwater sponges can occur in soils, streams and lakes, but may be more prolific in lake water depths of greater than 1 meter (Rader 1984), ponds and soils with higher organic matter content, and mesic soils (Schwandes and Collins 1994). This may indicate increased precipitation, a rising water table, or possibly less saline conditions for the pond and surrounding environments. Tribe Oryzeae bilobate phytolith 


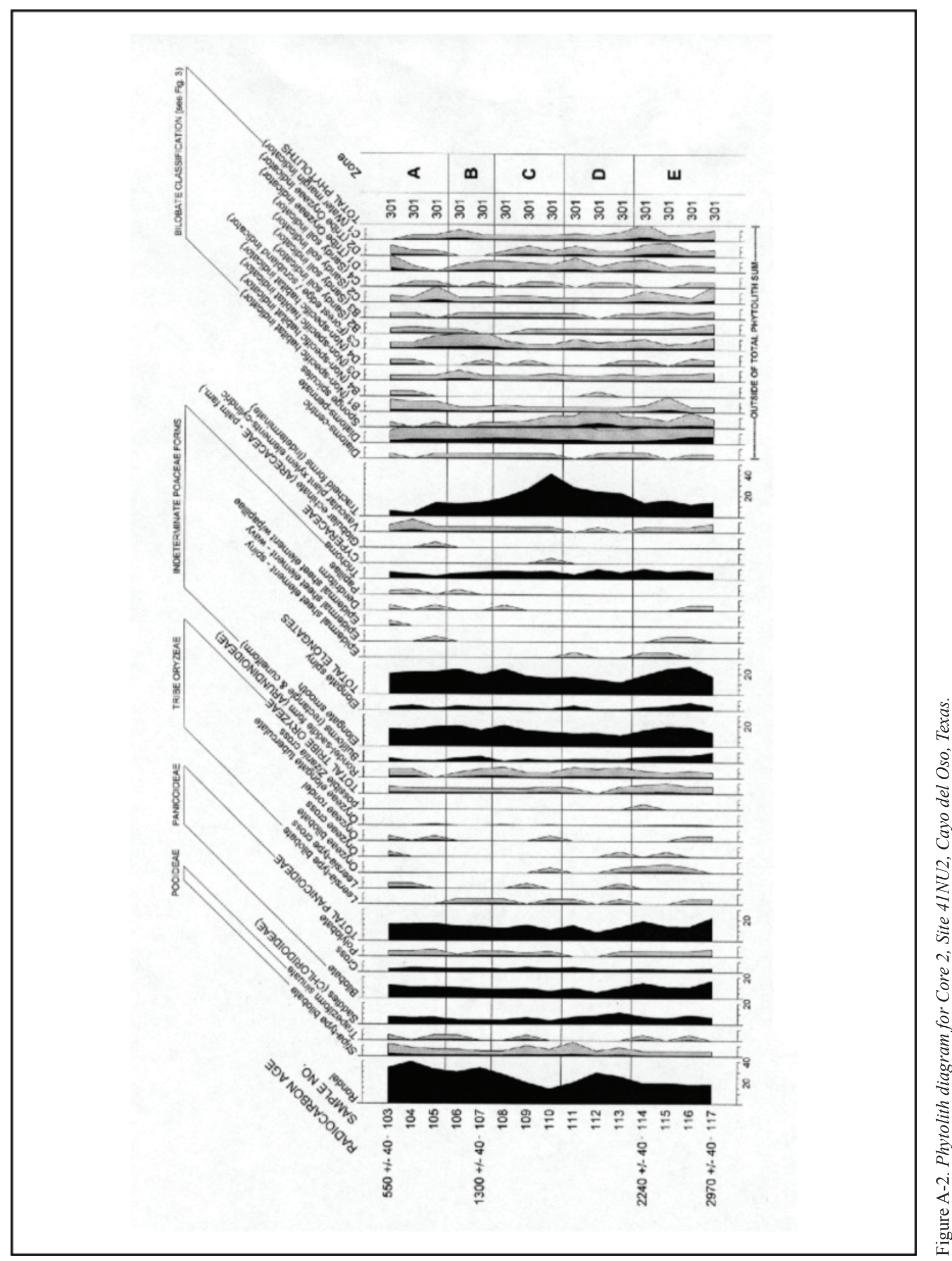




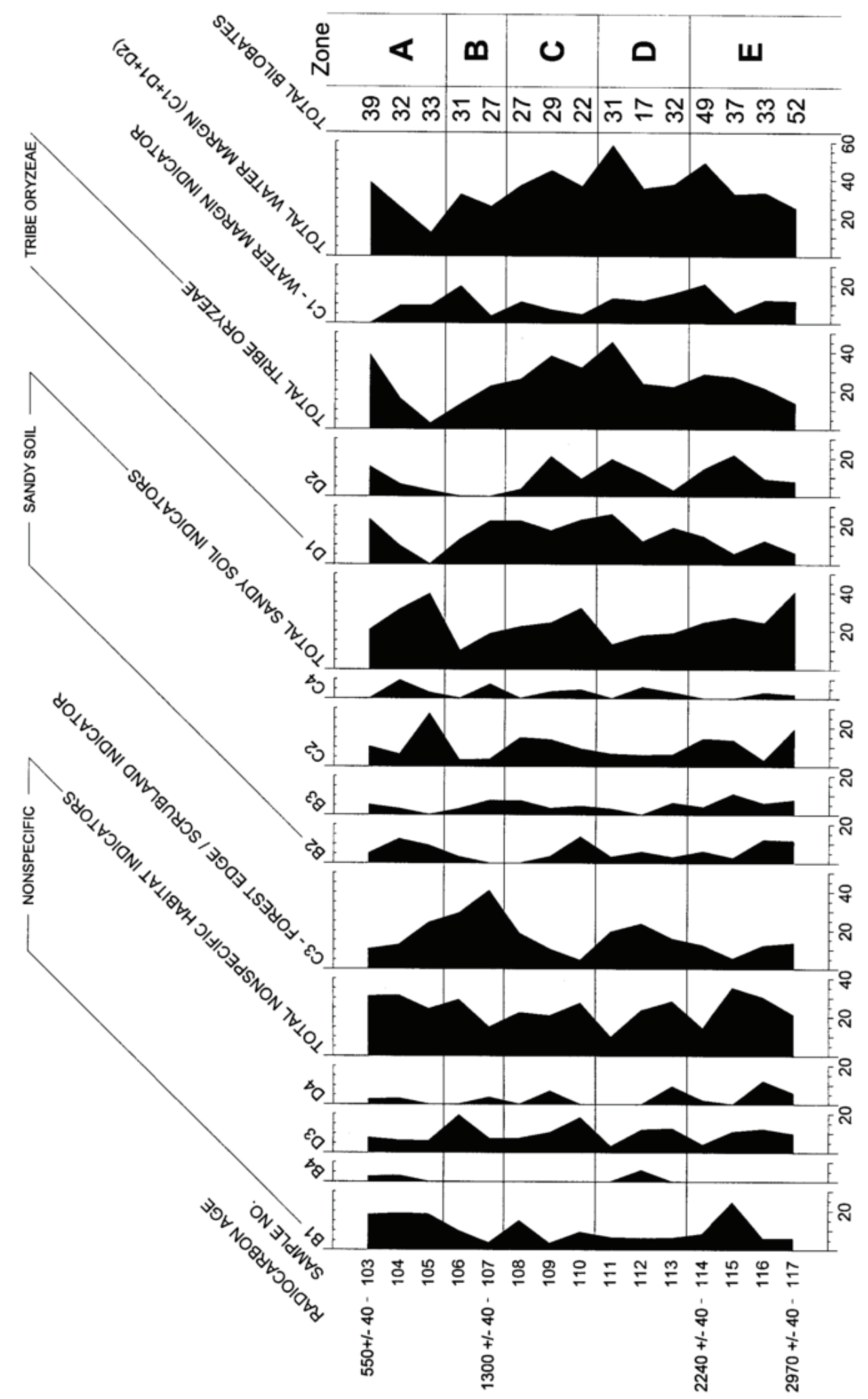


indicators reach their highest relative abundance at the top of this zone. Leersia prefers moist soils to shallow aquatic habitats. Zizaniopsis prefers shallow marshes, lakes and streams, and can tolerate somewhat brackish conditions. In general, tribe Oryzeae taxa can proliferate under conditions of periodic disturbance. Bilobate indicators of forest (scrub) edge and understory grasses are slightly elevated in abundance and may indicate increased precipitation. From the bottom to the top of Zone D there is an increasing abundance of fragmented faceted phytoliths, likely derived from tracheid elements of dicotyledonous trees and shrubs; however, they are indeterminate to any particular family. Some of these forms may also represent tracheid element fragments from the aquatic lycopod Isoetes (quillwort). Isoetes tends to be excluded from environments were temperatures exceed $20^{\circ} \mathrm{C}$ and precipitation is less than $60 \mathrm{~cm}$ per year (Sawada, et al. 2003). The pollen record (Figure A-1) contains its first occurrences of Isoetes in this zone, further supporting a slightly cooler and wetter environment at this time. Thus, the phytolith record for Zone D suggests that shallow freshwater pond conditions may have predominated, with periods of disturbance under slightly cooler, wetter, and perhaps stormier conditions than today.

Zone $\mathrm{C}$ predates the radiocarbon date of $1300 \pm 40$ RCYBP reported at the base of Zone B. This zone exhibits reduced quantities of Poaceae and Quercus pollen accompanied by increases in Cyperaceae, Sagittaria, and Smilax, representing sedges, arrowhead, and greenbriar. Although Persicaria lapathifolium-type pollen continues to be present, the frequencies are not quite as high as they were in Zone D. Typha pollen continues, as do Isoetes rhizoids. Isoetes microspores appear in sample 108 for the first and only time. The pollen record signals an expansion of the freshwater marshes.

Samples from Zone $\mathrm{C}$ exhibit a phytolith record dominated by a peak in occurrence of the indeterminate tracheid form discussed in the previous zone. Grass short-cell rondel phytoliths are at their lowest level of relative abundance, but this is, of course, a result of the high peak in tracheid elements and likely does not represent a decline in their absolute abundance. Wetland tribe Oryzeae phytoliths, both diagnostic morphotypes (bilobates, cross and rondels in Figure A-2) and those that are highly distinctive to diagnostic for the tribe (bilobates in Figure A-3), are still observed. Bilobate indicators of forest edge and scrubland grasses are at a very low level of abundance, concomitant with a fairly high occurrence of bilobate indicators of grasses that prefer sandy substrates. It is possible that this zone represents a climax in storm surge conditions. Lu and Liu (2005) demonstrated the feasibility of detecting the frequency of hurricane overwash deposition from inland lacustrine sediments. They were finding phytolith assemblages typical of dunes and outer bank islands within sand lenses from inland lake cores. It is possible that the large sampling intervals (both within sample and between samples) employed here are smoothing (averaging) a record of increased storm frequency and intensity for Zones $\mathrm{C}$ and D. Deposition of the peak in indeterminate tracheid phytolith fragments may be related to plant accommodations to storm surge deposition. Radiocarbon dates supplied by the principle investigators for Core 2 bulk sediments were used to calculate approximate sedimentation rates (Table A-3) Zones $\mathrm{C}$ and $\mathrm{D}$ exhibited the highest rates of sedimentation $(10.6$ years per $\mathrm{cm})$, thus adding further support for increased precipitation and/or storm surges. Thus, the phytolith record for Zone $\mathrm{C}$ suggests that shallow, slightly more brackish pond conditions may have predominated, with increased disturbance and storm intensity, under slightly cooler and wetter periods than today.

Zone $\mathrm{B}$ is anchored by a radiocarbon date of $1300 \pm 40$ RCYBP at its base. This zone notes a rise in Cyperaceae pollen and a concomitant decline in Persicaria lapathifolium-type, Opuntia, and Sagittaria pollen, suggesting drying conditions. Typh a pollen increases and Isoetes rhizoids disappear from the record. Smilax pollen is present in sample 106, but not 107, indicating local growth of greenbriar at the forest margin.

Samples from Zone B exhibit a phytolith record suggestive of a slightly brackish marsh (Lu and Liu, 2005), as evidenced by an increase in smooth elongates, rondels and buliforms. Coastal freshwater marshes tend to have a greater representation of echinate elongates and bilobates, and salt marshes tend to have a greater representation of short-saddles from saltgrass (Spartina alterniflora). Tribe Oryzeae phytoliths are much reduced in abundance, as are bilobates associated with grass taxa that favor sandy soil substrates. Bilobates associated with grass taxa that favor forest edge and scrubland ecotones reach their highest levels for the entire record within this zone. The increase in smooth elongates and rondels actually starts within the topmost sample of Zone C. This rise is also analogous to the rise in Persicaria lapathifolium-type Polygonaceae pollen. Although Persicaria amphibia, the most hydrophytic of the native North American smartweeds, can occur in moist prairies to shallow ponds and is reported to be tolerant of slightly brackish conditions and as well as eutrophic conditions (Partridge 2001), it is not represented by P. lapathifolium-type pollen, as it has a distinct morphology type. This knotweed/smartweed is not known to grow in brackish conditions. The reduction in P. lapathifolium-type and Sagittaria pollen, might reflect more brackish conditions, since Typha pollen, representing cattail, which is capable of tolerating brackish conditions, increases slightly in this level. Thus, the phytolith record and other supporting evidence for Zone B suggests that slightly brackish marsh conditions existed at this time, possibly under slightly warmer and drier conditions than that for the previously discussed zones. 
Table A-3. Data for Samples from the Cayo del Oso Site (41NU2)

\begin{tabular}{|c|c|c|c|c|c|c|c|}
\hline Zone & $\begin{array}{l}\text { Pollen } \\
\text { Core } 2 \\
\end{array}$ & $\begin{array}{l}\text { Phytolith } \\
\text { Core } 2 \\
\end{array}$ & $\begin{array}{c}\text { Sed } \\
\text { Rate } \\
\text { Core } \\
\mathbf{2} \\
\end{array}$ & $\begin{array}{c}\text { Phytolith } \\
\text { Core } 4\end{array}$ & \begin{tabular}{|c} 
Phytolith \\
Core 6
\end{tabular} & Climate & Landscape \\
\hline$A$ & $\begin{array}{l}550 \pm 40 \\
\text { Increasing } \\
\text { oak, sedge } \\
\text { marsh }\end{array}$ & $\begin{array}{l}550 \pm 40 \\
\text { Drier brackish } \\
\text { marsh }\end{array}$ & \multirow[b]{2}{*}{$\varepsilon$} & \multicolumn{2}{|c|}{$\begin{array}{l}\text { Sand dune } w / \text { moist } \\
\text { interdune areas }\end{array}$} & \multirow{2}{*}{ 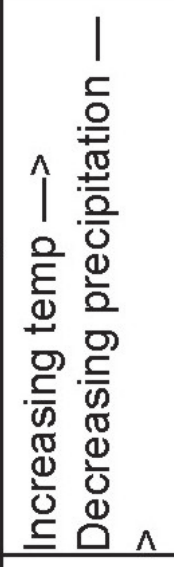 } & \multirow{2}{*}{ 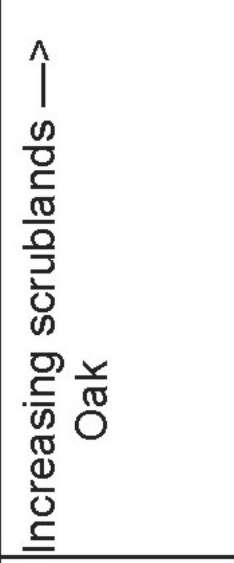 } \\
\hline B & $\begin{array}{l}\text { Some oak, } \\
\text { cattails, } \\
\text { sedge marsh, } \\
\text { shallow \& } \\
\text { stable }\end{array}$ & $\begin{array}{l}\text { Brackish Marsh } \\
1800 \pm 40\end{array}$ & & & $\begin{array}{l}80 \pm 40 \\
\text { It marsh }\end{array}$ & & \\
\hline C & $\begin{array}{l}\text { Increasing } \\
\text { sedges, } \\
\text { shallow, } \\
\text { dunes }\end{array}$ & $\begin{array}{l}\text { Shallow } \\
\text { brackish pond }\end{array}$ & \multirow[b]{2}{*}{ 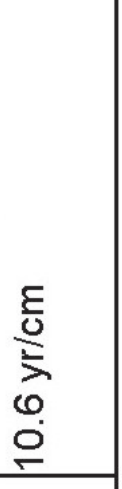 } & \multirow{2}{*}{\multicolumn{2}{|c|}{\begin{tabular}{|l}
$\begin{array}{l}\text { Possible sand } \\
\text { dune w/ moist } \\
\text { interdune } \\
1770 \pm 40\end{array}$ \\
$\begin{array}{l}\text { Sand dune } \\
\text { w/moist } \\
\text { interdune } \\
\text { habitat }\end{array}$ \\
\end{tabular}}} & \multirow{2}{*}{ 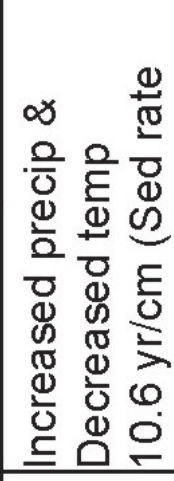 } & \multirow{2}{*}{ 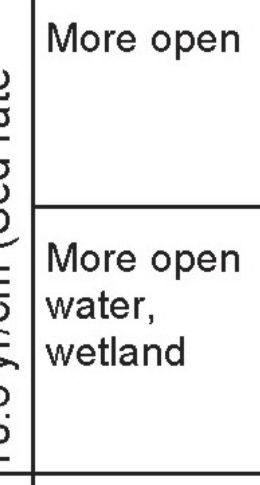 } \\
\hline D & $\begin{array}{l}\text { Pond, more } \\
\text { disturbance, } \\
\text { fluctuating } \\
\text { water depth, } \\
\text { dunes }\end{array}$ & $\begin{array}{l}\text { Freshwater } \\
\text { pond }\end{array}$ & & & & & \\
\hline$E$ & $\begin{array}{l}2240 \pm 40 \\
\text { Possible } \\
\text { sedge marsh } \\
2970 \pm 40 \\
\end{array}$ & $\begin{array}{l}2240 \pm 40 \\
\text { Freshwater } \\
\text { marsh } \\
2970 \pm 40 \\
\end{array}$ & 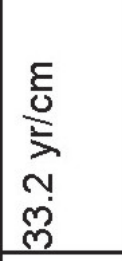 & \multicolumn{2}{|c|}{$\begin{array}{l}2670 \pm 40 \\
\text { Possible } \\
\text { freshwater } \\
\text { marsh } \\
\text { Dissolution }\end{array}$} & 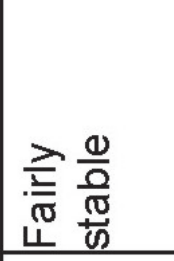 & $\begin{array}{l}\text { More open, } \\
\text { canopy } \\
\text { thinning }\end{array}$ \\
\hline$F$ & No samples & No samples & & \multicolumn{2}{|c|}{\begin{tabular}{|l} 
Fresh- \\
brackish \\
$3770 \pm 40$ \\
swamp \\
w/arboreal \\
canopy
\end{tabular}} & 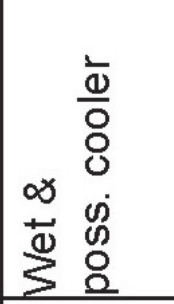 & $\begin{array}{l}\text { Some } \\
\text { canopy, } \\
\text { increase in } \\
\text { water table }\end{array}$ \\
\hline G & No samples & No samples & & & $\begin{array}{l}\text { aritime } \\
\text { est OR } \\
\text { shwater } \\
\text { lamp w/ } \\
\text { boreal } \\
\text { nopy }\end{array}$ & $\sum_{3}^{\frac{E}{5}}$ & $\begin{array}{l}\text { Closed } \\
\text { canopy }\end{array}$ \\
\hline
\end{tabular}


The pollen record for Zone A exhibits increases in Quercus, Cheno-am, and Cyperaceae pollen, as well as reductions in Persicaria lapathifolium-type and Poaceae pollen. Smilax pollen rises slightly, then disappears at the top of the record, while Typha pollen remains relatively static in frequency. Sample 103 at the top of this zone is the only one to exhibit even a small quantity of Prosopis pollen, indicating that mesquite was present in the local vegetation. It is possible that mesquite joined this vegetation community relatively late. Isoetes appears in sample 105 at the base of this level. A radiocarbon date of $550 \pm 40 \mathrm{RCYBP}$ is reported for sample 103 at the top of the stratigraphic column. A very small quantity of microscopic charred Asteraceae tissue fragments are observed in sample 104, indicating burning herbaceous or shrubby plants at the site.

Samples from Zone A exhibit a phytolith record suggestive of a decreasing, slightly brackish marsh habitat, and an increasing area of drier habitats, possibly sand dunes, nearby. This is supported by a phytolith assemblage for Zone A which resembles that reported from modern Gulf Coast sand dunes samples (H. Lu and K.-b. Liu 2003; Lu and Liu 2005). Rondel phytoliths are at their highest levels of relative abundance here, and are common for both brackish marsh and sand dune habitats (Figure A-2). These rondels are likely derived from dry habitat grasses Aristida desmantha Uniola paniculata, Distichlis spicata, Sporobolus virginicus, and tribe Oryzeae marsh grasses Leersia spp. and Zizaniopsis miliacea. The slight increase in Chloridoideae short-saddle phytoliths are likely derived from the brackish marsh grass Spartina patens and Eragrostis spp. of sand dune areas. Bilobates associated with forest edge and scrubland grasses decrease rapidly throughout this zone, concomitant with some of the highest levels of bilobates associated with grasses that prefer sandy soil substrates (Figure A-3). Tribe Oryzeae bilobates rise throughout this zone, possibly colonizing once-submerged areas of the marsh margins. A few globular echinate phytoliths diagnostic of the palm family (Arecaceae) were also noted in Zone A, and are likely derived from dwarf palmetto (Sabal minor) or Mexican palmetto (Sabal mexicana). Drier and warmer conditions for Zone A are also supported by the highest levels of charcoal and oak (Quercus spp.) abundance from the pollen record. Thus, the phytolith record for Zone A suggests increasingly dry and warm conditions at this time, resulting in a reduction of the slightly brackish marsh area and an expansion of dry habitats, most likely sand dunes.

\section{Core 4 (dune deposits)}

The phytolith record for Core 4 was severely affected by silica dissolution. Originally, a total of 23 phytolith samples were submitted for analysis. Ten samples underwent phytolith extraction and were scanned for phytolith recovery (Samples 182 through 191). All of the samples were found to have experienced either mild dissolution (Sample 182) or severe dissolution (Sample 183 -191). Only Sample 182 yielded a reliable phytolith assemblage count (Figure A-4). Phytolith preservation and dissolution depends on 1) the particular type of phytolith and 2) the chemical and physical characteristics of the depositional environment (Piperno 2006). A third factor in preservation is the resident time in a particular environment. Relatively young calcareous sediments may still yield well preserved phytoliths. Thinly silicified phytoliths, particularly epidermal sheet elements and cell casts are readily dissolved in a wide variety of paleoecological contexts. More robust infillings of specialized plant silica cells, such as grass silica short cells, vascular tissue buliform cells and elongates are much more resistant to dissolution. In fact, buliform cells and elongates are often the only identifiable phytoliths in highly alkaline soils subjected to periodic moisture. In extreme cases, such as perennially moist calcareous soils, phytoliths will often be completely dissolved, with no recovery possible.

The samples from Core 4 varied in color from light gray to grayish black, all of which with evidence for varying degrees of calcium carbonate nodule formation. All of the samples were moderately to severely reactive when tested with hydrochloric acid, indicating the highly calcareous nature of these dune deposits. The phytolith record from Sample 182 exhibits an assemblage with characteristics fairly analogous to that reported by Lu (2005) from some of their modern Gulf Coast sand dune habitats. After two hours of scanning, only five phytoliths were recovered from Sample 183. Evidence for severe dissolution was observed in the form of large dissolved pits completely covering the phytoliths observed. As a result of this evidence and the high reactivity of the remaining samples in HCL, Samples 184 through 191 were scanned to assess the likelihood of phytolith recovery. It was determined that the remaining samples would not yield enough phytoliths to provide an unbiased and statistically significant assemblage. Although Sample 182 was highly reactive in $\mathrm{HCL}$, residence time was apparently not long enough to severely affect phytolith preservation. Sample 182 was recovered from a depth 40 to $43 \mathrm{~cm}$. The closest date comes from the 65 to $68 \mathrm{~cm} \mathrm{level,} \mathrm{and} \mathrm{is} \mathrm{reported} \mathrm{as}$ 1,060 +/-40 years. An estimate for the age of Sample 182 would be approximately 500 RCYBP. This would place the sample either above or within Zone A previously discussed. Sample 182 likely represents a sand dune or wet meadow interdune environment with a relatively brackish and shallow watertable. The vegetation was likely dominated by dune grasses Uniola paniculata and Aristida desmantha. Despite poor phytolith preservation, it is likely that pollen is preserved in these sediments and would be recoverable by Paleo Research Institute. 


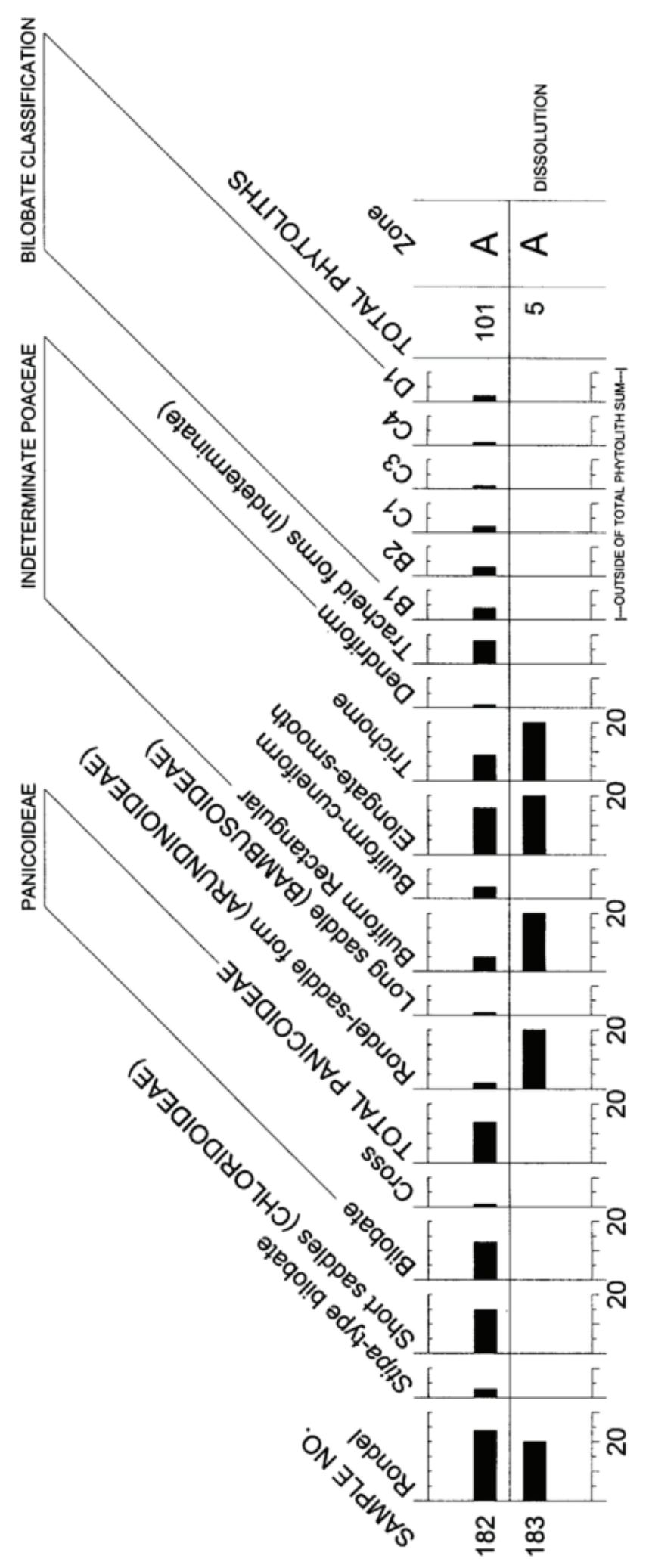




\section{Core 6 (dune deposits)}

The phytolith preservation and recovery from Core 6 sediment samples was mixed. A total of 16 samples were submitted for analysis, 4 of which yielded statistically insignificant phytolith counts, two of which yielded no phytolith recovery. Because of the mixed recovery record and the disjunct nature of statistically significant counts, a bar histogram rather than a silhouette-style graph was used (Figure A-5). Likewise a separate bilobate classification graph was not created. Most of the sediments contained calcium carbonate nodules. Samples exhibiting low reactivity with HCL yielded good phytolith preservation $(279,280,287)$. Samples exhibiting moderate to high reactivity with HCL yielded little to no phytolith recovery. The one exception was Sample 294, which was highly reactive to HCL, but exhibited good phytolith preservation with some evidence of dissolution. It is possible that Sample 294 phytoliths preserved as a result of limited exposure to moisture. Zonation for Core 6 was primarily based on chronological and assemblage association with that for Core 4. Older and non-analong assemblages were given additional zone designations.

Sample 294, the only sample from Zone G, exhibits a phytolith assemblage that does not fit well with any of the Gulf Coast habitat phytolith assemblages described by Lu and Liu (2003, 2005). The closest analogs are described from Juncus/sedge fen, maritime forest, and freshwater lake habitats $(\mathrm{H} . \mathrm{Lu}$ and K.-b. Liu 2003; Lu and Liu 2005). Globular echinate phytoliths diagnostic to the palm family (Arecaceae) were the most abundant form, and are likely derived from dwarf palmetto (Sabal minor) and/or Rio Grande palmetto (Sabal mexicana). Dwarf palmettos grow to 4 or 5 feet, require part sun to shade, and prefer neutral to alkaline soils of swamps and river bottoms. Rio Grande palmetto, also called Texas palm, grows to 50 feet, requires full sun to part shade, and can adapt to moist or dry soils. The presence of either species suggests that forest-type vegetation was dominant in the area at this time. Indeterminate grass phytolith buliforms and elongates are also very abundant. Although phytolith preservation was generally very good, evidence for dissolution was observed. It is likely that lightly silicified faceted phytoliths diagnostic of leafy dicot trees and some grass silica short cell phytoliths were lost to dissolution. Maritime forests and swamps are comprised of a number of tree species and understory grasses from the Pooideae and Bambusoideae subfamilies. Trapeziform sinuates and long saddles, diagnostic of the Pooideae and Bambusoideae respectively, were observed, but in low abundance, possibly due to dissolution. Although no date is closely associated with this sample, it is likely older than 4,000 RCYBP, and at a time when sea levels may have been a meter or more lower. Thus, the phytolith record for Zone G suggests that a maritime forest, or freshwater swap with an arboreal canopy was the dominant vegetation type at this time.

Samples from Zone F exhibited evidence of severe silica dissolution; however, some phytoliths were well preserved, or at least identifiable. As a result, preservation may have been biased towards certain morphotypes, and may account for the high abundance of indeterminate tracheid fragments. As discussed for Core 2 samples, the possibly fractured nature of this morphotype makes differentiation between monocot (grass) and dicot (tree, shrub, forb) xylem ambiguous. Despite this, enough phytoliths were observed to provide an informative and interpretive assemblage. Zone F exhibits characteristics similar to Zone $G$, but overall vegetation species richness may be greater. Trapeziform sinuates, long saddles, and globular echinates, diagnostic of the Pooideae, Bambusoideae and Arecaceae respectively, were observed and suggest that some degree of a forested canopy with a palm component existed. However, the presence of tribe Oryzeae and Cyperaceae (Juncus/sedge) phytoliths, as well as diatoms and sponge spicules, suggest that moisture levels may have been higher than that experienced for Zone G. This may be the result of a shallow watertable, or the presence of open water. The upper portion of Zone $\mathrm{F}$ has an associated radiocarbon date of 3770 +/40 B.P. Thus, the phytolith record for Zone F suggests that a fresh/brackish swamp with an arboreal canopy was the dominant vegetation type at this time.

Samples from Zone E exhibited evidence of severe silica dissolution, with little to no phytolith recovery. The upper portion of the zone has an associated radiocarbon date of 2760 +/-40 B.P. The phytolith assemblage from Sample 289, and the chronological association of the zone suggests an expansive freshwater marsh habitat affinity with Zone E from Core 2 (Figure A-2); however, the likely biased nature of preservation/ dissolution makes an accurate interpretation uncertain.

Sample 287 represents a single sample that may share a chronological affinity with Zone D from Core 2 , interpreted as a freshwater pond habitat. However, a lack of diatoms and sponge spicules, and a higher percentage of sandy soil bilobate indicators (not graphed separately) suggests that this location (Core 6) may have been drier than Zone D from Core 2. The presence of a few tribe Oryzeae phytoliths suggests that these may have been moist soils. A few globular echinates diagnostic to the palm family (Arecaceae) were also noted and could possibly be derived from Texas palm (Sabal mexicana). The upper boundary of this zone has an associated radiocarbon date of 1,770 +/-B.P. Thus, the phytolith record for Zone D suggests the presence of a sand dune habitat with a shallow watertable at this time. 


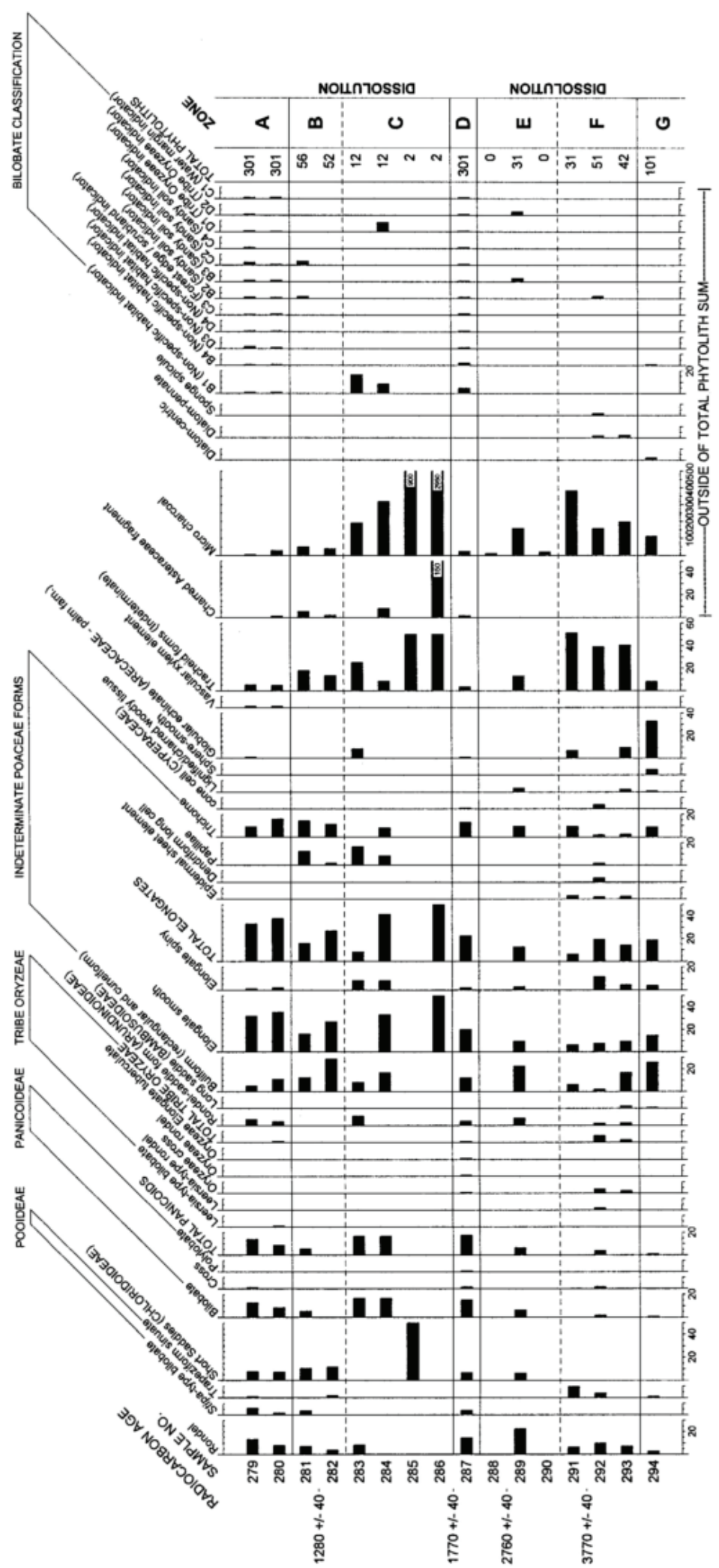


Samples from Zone $\mathrm{C}$ exhibited evidence of severe silica dissolution, resulting in very little phytolith recovery. Samples from this zone share a chronological affiliation with Zone C from Core 2, a shallow brackish pond or marsh; however, the upper boundary designation is somewhat uncertain (Figure A-5 dashed line). Sample 283 from the top of the zone yielded a few phytoliths diagonistic of the Arundinoideae, and likely derived from common reed (Phragmites australis), an obligate wetland plant tolerant of slightly brackish conditions. The poor phytolith recovery from Zone $\mathrm{C}$ sediments make an accurate interpretation very difficult; however, the presence of common reed, and the likely existence of moist sediment conditions necessary for phytolith dissolution may indicate the existence of moist sand dune/interdune conditions at this time.

Samples from Zone B exhibited evidence of moderate silica dissolution, but not enough to make phytolith identification impossible. This zone shares a chronological affiliation with Zone B from Core 2, interpreted as a slightly brackish marsh. A radiocarbon date of $1,280+/-40$ B.P. is associated with this zone. The phytolith assemblage, as evidenced by the high proportion of saddles and buliforms and the low proportion of rondels and bilobates ( $\mathrm{Lu}$ and Liu 2005), and the absence of common reed (Phragmites australis) suggests that a Spartina alterniflora dominated salt marsh existed here at this time.

Samples from Zone A yielded phytoliths that were well preserved, with no evidence of dissolution. This zone shares a chronological affiliation with Zone A from Core 2, interpreted as a contracting brackish marsh habitat experiencing increasing temperatures and decreasing precipitation. The phytolith assemblage here shares characteristics for both dune and interdune meadow habitats as reported by $\mathrm{Lu}$ $(2003 ; 2005)$. The phytolith assemblage here suggests a dune habitat with an elevated watertable, as evidenced by a high proportion of bilobates and rondels, and a moderate amount of short saddles. The bilobate classification assemblage (not graphed independently) is dominated by sandy soil indicators. The presence of phytoliths diagnostic of Phragmites australis (Arundinoideae) and palm (Arecaceae), suggest the presence of moist, interdune meadows nearby. It appears that this area may have been experiencing a drying trend, starting from the upper level of Zone B (Sample 281), and proceeding through Zone A, as salt marsh converted to a drier sand dune environment. This warming and drying trend seems to be analogous to that reported for Zones B and A from Core 2.

\section{Summary and Conclusions}

Companion pollen and phytolith analysis of Core 2 yielded evidence of local and regional vegetation that included a variety of trees such as pine, juniper, alder, birch, a member of the sycamore family, mesquite, oak, and elm. The most visible elements of the local vegetation included grasses, various members of the sunflower family, members of the Cheno-am group, and sedges. Beyond this, smartweed/ knotweed, prickly pear cactus, and cattails also would have been visible. Mustards might well have colored the vegetation community during the spring when they flower. Arrowhead was important locally intermittently, primarily between approximately 2240 and 1300 RCYBP. Poison ivy is present in the record, but not well represented, which is often the case, as this pollen tends to be under represented. Dominant grasses varied as dune/interdune and marsh areas expanded and contracted in response changing moisture availability and levels of salinity. Beach, dune and interdune areas were likely dominated by grasses Panicum amarum, Uniola paniculata, Aristida desmantha, Cenchrus spp. Spartina spp., and occasional clusters of dwarf palmetto and possibly Texas palm. Pond and marsh habitats were likely dominated by Leersia spp. and Zizaniopsis miliacea, with Phragmites australis and Spartina spp. also present. Forest understory and shaded areas of forest edge and scrubland were likely occupied by Panicum and subfamily Pooideae and Bambusoideae species.

The phytolith record from Core 4 was severely affected by silica dissolution, likely due to perennially moist conditions of calcareous (alkaline) soils. These conditions are well known to dissolve many, and sometimes all phytolith types. At a minimum they tend to present a biased record of phytolith occurrence. The area represented by Core 4 was likely a sand dune and moist interdune environment with a shallow brackish watertable. The vegetation would have been dominated by grasses and other dune plants. Despite poor phytolith preservation, it is likely that pollen is preserved in these sediments and would be recoverable by Paleo Research Institute, thus providing a better record of the sand dune vegetation community.

Although the Core 6 phytolith record was also affected by silica dissolution, enough phytoliths were recovered to provide an accurate interpretation. The area represented by Core 6 sediments provided some of the most dramatic evidence of long-term habitat change. Initially a landscape dominated by a closed canopy forest of trees, shrubs and vines (> 4,000 RCYBP) gave way to slightly more open marsh-type vegetation of shrubs, grasses, sedges and dwarf palms ( $\approx 2670$ RCYBP), and then opened-up to a drier and salt tolerant grass and herb dominated sand dune and interdune environment ( $\approx 800$ RCYBP).

A tabular summary of habitat, climate and landscape-level change spanning the last approximately 4,000 RCYBP for the Cayo Del Oso site is presented in Table A-3 and summarized 
here. An expansive maritime forest or freshwater swamp dominated by a closed arboreal (possibly palm dominated) canopy at approximately 4,000 RCYBP opened-up slightly to a fresh or brackish swamp with dwarf palms, shade tolerant grasses and aquatic emergent grasses in more open areas. By around 3,000 RCYBP, the shady swamp habitat gave way to a more open marsh habitat with emergent aquatic and water margin grasses proliferating. Arboreal trees such as oak and elm were still present, but perhaps more scattered. This marsh may have been expansive, possibly due to a slight dip in sea-level. Dune areas may have also been expansive at this time of possibly warmer and drier conditions. At approximately 2,200 RCYBP, precipitation, sedimentation rates, and possibly storm frequency/intensity increased. This increase in precipitation may have resulted in freshwater pond development from the previous marsh habitat. A rising water table may have caused less tolerant trees to give way to wetland plants and other plants adapted to colonizing disturbed areas along marsh and pond margins such as Isoetes, Persicaria, Sagittaria, Phragmites, Leersia, Zizaniopsis and members of the Apiaceae and Cyperaceae families. Sandy soil areas closer to the bay and ocean may have lost some stabilizing vegetation, resulting in increased dune activity and annual plants such as members of the Cheno-Am and Brassicaceae families more adapted to frequent disturbance events. This environment may have persisted until around 1,300 RCYBP, when the apparent disturbance period subsided. Precipitation may have decreased and been accompanied by a slight increase in temperature. A lowering of the watertable may have caused pond habitats to convert to shallow brackish water marsh habitats. Cyperaceae taxa such as sedges and rushes became increasingly abundant, as do cattails. The cattail pollen is likely derived from Typha domingensis, a wetland plant that prefers brackish or nutrient-enriched wetlands. Typha is also not very tolerant of rapidly fluctuating water levels and further indicates a more stable environment after 1,300 RCYBP. Generally, this habitat persists for the remainder of the pollen and phytolith record which ends at approximately 550 RCYBP; however, tribe Oryzeae grasses (Leersia and Zizaniopsis), oak trees (Quercus), pine trees (Pinus) and mesquite (Prosopis) increase towards the top of the record which ends at approximately 550 RCYBP. Oaks, pines and mesquite are perhaps becoming more competitive from increased temperature, periodic wild fires and drier conditions. Oryzeae genera are perhaps colonizing once saturated marsh habitats.

Paleo pond sediments from the Cayo Del Oso site present a uniqueopportunity forphytolithandpollenpaleoenvironmental reconstruction for coastal South Texas. The phytolith and pollen record indicates that there has been some subtle, longterm environmental change as well as a few punctuated events and/or short term changes strong enough to be detectable with the sampling interval strategy employed. The large sampling intervals, both within and between samples, limits the ability to detect punctuated events and has an overall smoothing effect on the environmental record. In particular, additional phytolith sampling of smaller interval pond sediments has the potential to detect hurricane storm frequency for South Texas. Also, there is a high likelihood that pollen is preserved in dune and interdune deposits and recoverable by personnel at Paleo Research Institute. Analyzing additional samples from these deposits could greatly enhance temporal resolution of the paleoenvironmental record for Cayo Del Oso and coastal South Texas.

\section{References}

Bozarth, S.

1993 Biosilicate Assemblages of Boreal Forests and Aspen Parklands. In MASCA Research Papers in Science and Archaeology, edited by D. M. Pearsall and D. R. Piperno, pp. 95-105. vol. 10. The University of Pennsylvania Museum of Archaeology and Anthropology, University of Pennsylvania, Philadelphia.

Brown, D. A.

1984 Prospects and Limits of Phytolith Key for Grasses in the Central United States. Journal of Archeological Science 11:345-368.

Flemming, K., P. Johnston, D. Zwartz, Y. Yokoyama, K. Lambeck and J. Chappell

1998 Refining the eustatic sea-level curve since the Last Glacial Maximum using far-and intermediate-field sites. Earth and Planetary Science Letters 163:327-342.

Gould, F. N. and R. B. Shaw

1983 Grass Systematics. Texas A\&M University Press, College Station. 
Jones, R. L. and A. H. Beavers

1963 Sponge Spicules in Illinois Soils. Soil Science Proceedings:438-440.

Lu, H. and K.-B. Liu

2003 Morphological Variations of Lobate Phytoliths from Grasses in China and the South-Eastern United States. Diversity and Distributions 9:73-87.

Lu, H. and K.-b. Liu

2003 Phytoliths of Common Grasses in the Coastal Environments of Southeastern USA. Estuarine and Coastal Marine Science 58:587-600.

Lu, H.-Y. and K.-B. Liu

2005 Phytolith assemblages as indicators of coastal environmental change and hurricane overwash deposition. The Holocene 15(7):965-972.

Milne, G. A., A. J. Long and S. E. Bassett

2005 Modelling Holocene relative sea-level observations from the Caribbean and South America. Quaternary Science Reviews 24:1183-1202.

Moreno-Casasola, P.

1988 Patterns of plant species distribution on coastal dunes along the Gulf of Mexico. Journal of Biogeography 15(5/6):787-806.

Nicolau, B. A.

2001 Water quality and biological characterization of Oso Creek \& Oso Bay, Corpus Christi, Texas. Copies available from Center for Coastal Studies, Texas A\&M University, Report \# TAMUCC-0102-CCS.

Parr, J. F., V. Dolic, G. Lancaster and W. E. Boyd

2001 A microwave digestion method for the extraction of phytoliths from herbarium specimens. Review of Palaeobotany and Palynology 116:203-212.

Parr, J. F., K. H. Taffs and C. M. Lane

2004 A microwave digestion technique for the extraction of fossil diatoms from coastal lake and swamp sediments. Journal of Paleolimnology 31:383-390.

Partridge, J. D.

2001 Persicaria amphibia (L.) Gray (Polygonum amphibium (L.). The Journal of Ecology 89(3):487-501.

Piperno, D. R.

2006 Phytoliths: A Comprehensive Guide for Archaeologists and Paleoecologists. Alta Mira Press, Lanham, MD.

Rader, R. B.

1984 Factors affecting the distribution of a freshwater sponge. Freshwater Invertebrate Biology 3(2):86-97.

Ricklis, R. A.

n.d. Prehistoric and early historic people and environment in the Corpus Christi Bay area. Texas Archaeological Research Laboratory. Online publication prepared for Coastal Bend Bays \& Estuaries Program. URL: http://www.cbbep.org/ publications/virtuallibrary/ricklis.html. Accessed Dec. 2007. 
Sawada, M., A. E. Viau and K. Gajewski

2003 The biogeography of aquatic macrophytes in North America since the Last Glacial Maximum. Journal of Biogeography 30:999-1017.

Schwandes, L. P. and M. E. Collins

1994 Distribution and significance of freshwater sponge spicules in select Florida soils. Transactions of the American Microscopical Society 113(3):242-257.

Twiss, P. C.

1987 Grass-Opal Phytoliths as Climatic Indicators of the Great Plains Pleistocene. In Quaternary Environments of Kansas, edited by W. C. Johnson, pp. 179-188. 5 ed. Kansas Geological Survey Guidebook Series. 



\title{
APPENDIX B: \\ Pollen Analysis Of Pond Core Samples: Oso Bay Site, Nueces County, Texas
}

\author{
Vaughn M. Bryant
}

Palynology Laboratory

Texas A\&M University

College Station, Texas 


\section{Introduction}

\section{Data Base}

The current study focuses on 24 pollen samples collected from a sediments core extracted north of the Cayo del Oso Site (41NU2). The archaeological site is located on the shores of the False Oso Bay and is only about 50 meters from Corpus Christi Bay. Various cores were collected from a pond north of the site using an Eijkelkamp percussion drilling set operated by Charles Frederick. The cores were later split open in the lab, samples were extracted, and the dirt from 23 individual levels was sent to us for processing and fossil pollen studies (Table B-1). No surface soil control samples were collected.

\section{Pollen Extraction}

There are a number of articles, chapters, and even books detailing the methods that one can use to successfully extract fossil pollen from various types of sediments (Hunt 1985; Riding and Kyffin-Hughes 2006), including some articles that focus specifically on techniques used for archaeological sediments (Bryant 1988; Bryant and Holloway 1983; Coil et al. 2003).

Pollen extraction is a critical part of any project because the use of the wrong acids and methods can lead to the loss of fossil pollen, while other methods may not remove enough of the detritus to permit accurate identification of the fossil pollen in the remaining residue. For these reasons it is essential that reports, such as this one, include the precise methods used during the extraction procedure. In this way the reader may be assured that pollen recovery was maximized and that fossil pollen was not inadvertently destroyed or lost during processing.

During the work for this project, all procedures were conducted under a fume hood using sterile, surgical gloves in our sealed Palynology Laboratory. In addition, glycerine-coated slides are routinely left exposed in various locations within the lab. These slides are checked weekly for any signs of outside pollen contamination. None was noted during or after this project was being conducted. Thus, I am certain that none of the pollen I found in these samples came from contamination in our facility. The extraction procedure I used for these samples is consistent with procedures detailed in many reports and ones that we have used successfully for several decades. The precise processing steps and the sequence in which they were used on all samples are listed below:

1. From each of the core samples I removed 20 grams of soil. The soil from each sample was placed in a sterile 800 $\mathrm{ml}$ plastic beaker. Next, I added $50 \mathrm{ml}$ of concentrated $\mathrm{HCl}$ to dissolve any calcium carbonates in the samples. At that time I also added two Lycopodium tablets to each of the samples. Each Lycopodium tablet contained 13,500 tracer spores. The use and amount of tracer spores that should be added to archaeological and other types of pollen samples has been extensively studied and reviewed by Louis Maher (1981). He notes that the ratio of tracer spores added to samples should be in a ratio of between 1:1 and 1:2 (tracer spores vs. fossil pollen) in order to achieve statistically accurate calculations of fossil pollen concentrations per gram or milliliter of sediment. The ideal, according to Dr. Maher, is to try to achieve as close to a $1: 2$ ratio as possible without exceeding it. Once the ratio of tracer spores vs. fossil pollen exceeds the 1:2 ratio significant statistical errors often occur, as discussed by Jones and Bryant (2007). I use Lycopodium spores as a tracer in most sediment studies from sites located in the temperate and arid regions of the American Southwest and Texas because it is extremely rare to find naturally occurring Lycopodium plants growing anywhere in those regions. Therefore, the only potential sources of these spores come from those that have been added.

2. After all reaction with the $\mathrm{HCl}$ had stopped, I filled the beakers with distilled water and allowed the beakers to stand for a period of four hours. After that, the liquid portion was carefully siphoned off. Pollen will remain suspended in water for various periods depending on the temperature and salinity. Nevertheless, after four hours, all fossil pollen will settle to the bottom of a container and thus the liquid portion can be carefully poured or siphoned off without loss of fossil pollen, provided the sediment at the bottom of the beaker remains undisturbed (Lentfer et al. 2003). The remaining sediment in each beaker was then poured into $50 \mathrm{ml}$ centrifuge tubes (CT) and spun down for 3 minutes at a speed of 2,500 rpm. The liquid was then

Table B-1. Pollen samples collected and processed from core sediments extracted from the pond located north of the Cayo del Oso Site (41NU2)

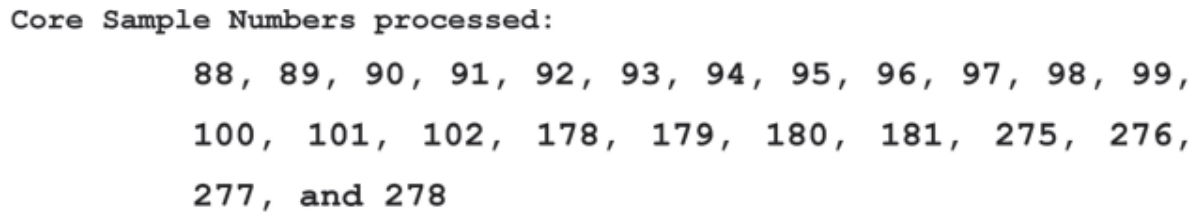


poured off. This process was repeated until all sediment from each beaker had been concentrated in each CT.

3. The collected sediment from each centrifuge tube was then placed into a clean $800 \mathrm{ml}$ plastic beaker. Because these sediments contained a high clay content, I needed to disperse and deflocculate the sediments. This step is essential because fine-grained minerals, such as clays, may form clumps that trap pollen and spores inside. Often, clumps form because particles in suspension have atoms of unsatisfied valances, thus they attract other ions and form clumps. There are a number of dispersing agents that tend to work effectively as a deflocculant. I have found that one of the best is a $5 \%$ solution of Calgon water softener containing sodium pyrophosphate (Na4O7P2). Not all types of Calgon contain sodium pyrophosphate so one must choose the correct one. Once the 5\% solution was mixed, I added $700 \mathrm{ml}$ to each beaker, stirred them once each hour for four hours and then let the samples sit over night without being stirred again. The next day after all the clay had been dispersed, the liquid portion was siphoned off without loss of fossil pollen.

4. Next, I added $100 \mathrm{ml}$ of concentrated HF (58\%) to the sediment in each beaker, stirred the sample, covered them to prevent potential contamination and let them sit overnight in the fume hood. I might caution others that this is very dangerous and that the HF must be added very slowly at the rate of only $1-2 \mathrm{ml}$ at a time. The sample must then be thoroughly stirred and allowed to sit for one minute before adding more HF. After HF is added, it will slowly heat the sediment as it begins to react with the silicates. Some types of sediment, especially those containing fine-grained clays and mica, will react violently to the HF. This reaction, however, does not occur at first, it occurs only after the sediment reaches a high temperature above $150 \mathrm{oF}$. If one adds too much $\mathrm{HF}$ at first, once it heats, the HF reaction occurs so rapidly that the liquid will bubble rapidly and can flow out of the beaker. I use HF only with the greatest degree of caution because it can cause permanent injury or in extreme cases can cause death to an individual. Medical reports state that if $2 \%$ or more of one's body comes in direct contact with liquid HF, the result is always fatal. There is no adequate antidote for that type of HF exposure. The HF process removes most of the fine-grained silicates from the sample and does not damage the pollen. After stirring the HF in each sample they were covered and allowed to sit in the fume hood overnight. The next day I filled each beaker with distilled water, stirred each sample and let it sit for four hours before siphoning off the liquid. Once the remaining liquid was spun down in a $50 \mathrm{ml} \mathrm{CT}$, each sample was rinsed twice with distilled water, and then the CT was filled with concentrated $\mathrm{HCl}$. This $\mathrm{HCl}$ step is necessary to ensure removal of potential fluorosilicates in each sample, which often form during the HF treatment. Sometimes two or three $\mathrm{HCl}$ rinses are needed before all fluorosilicates are dispersed and the samples can be rinsed again in distilled water and neutralized.

5. I then transferred the material in each sample to a 15 $\mathrm{ml} \mathrm{CT}$ and added $10 \mathrm{ml}$ of $5 \% \mathrm{KOH}$. Each sample was stirred and then heated in a heating block for 10 minutes at $180 \mathrm{oF}$. This was followed by two washes in distilled water. Next, I added $10 \mathrm{ml}$ of concentrated $\mathrm{HCl}$ and heated each sample for one minute. I then spun down the sample, poured out the liquid, and again rinsed the sample twice in distilled water. This $\mathrm{HCl}$ step is essential to remove any remaining humic acids and dissolved compounds that might be present in each sample after completing the $\mathrm{KOH}$ treatment.

6. Each sample was then rinsed in glacial acetic acid, centrifuged, and the glacial acetic acid was carefully poured off.

7. Next, I added $10 \mathrm{ml}$ of a mixture of 1 part sulfuric acid to 9 parts acetic anhydride. This is known as the acetolysis process (Erdtman 1960). After heating each sample in a heating block at $180 \mathrm{oF}$ for 10 minutes, I centrifuged the solution and then poured off the liquid.

8. I then rinsed each sample in glacial acetic acid and after centrifuging, I poured off the glacial acetic acid. I want to warn others that it is essential to rinse the sample in glacial acetic acid both before and after the acetolysis process. The acetolysis mixture does not mix with water and will react violently if it comes in contact with any water. The glacial acetic acid will remove excess water from samples.

9. Next, the samples were rinsed twice in distilled water.

10. The next step was to fill each CT one-half full of zinc bromide having a specific gravity of 2.0. That solution was thoroughly mixed with each sample for 30 seconds on a vortex stirrer to ensure complete mixing of all solid material in the CT. The samples were then placed in a test tube rack and allowed to sit for 5 minutes. After that, I then spun the samples at 500 RPMs for 5 minutes. This was followed by a spin of 5 minutes at 2,500 RPMs. I find that by doing the separation using these three steps (one resting and two stages at two different centrifuge speeds) I get a much better separation of pollen from the mineral and remaining silicate detritus in samples. When this was completed, I very carefully pipetted off the upper layer of the zinc bromide, which contained all of the pollen. The zinc bromide solution containing the pollen was placed into a $100 \mathrm{ml}$ beaker and $80 \mathrm{ml}$ of $95 \%$ ETOH was added to reduce the specific gravity and permit the pollen to sink during centrifuging. All of the solution from each sample was carefully spun down in CTs. 
11. I then repeated step 10 using the sediment that has not floated during step 10. This second zinc bromide treatment ensures that any remaining trapped pollen and spores will be liberated and allowed to float to the surface and be removed at the end of the procedure. I then checked the material that remained at the bottom of each $\mathrm{CT}$ to ensure that no pollen or tracer spores were lost after completion of this second procedure. None was found.

The final step consisted of rinsing the residue in each sample twice in water, twice in ETOH, adding two drops of safranin- 0 stain, stirring the sample, and finally rinsing each $\mathrm{CT}$ once more in $\mathrm{ETOH}$. The remaining residue was then pipetted into a one-dram, glass vial with a screw top. Five drops of glycerine was added to each sample and the samples were placed on a warming plate to enable the remaining $\mathrm{ETOH}$ to evaporate overnight.

\section{Pollen Counting and Identification}

\section{Pollen Counting}

When the remaining ETOH had evaporated in each of the processed samples, I carefully stirred the residue in each vial and added additional glycerine, if needed, to thin the solution. I then prepared several individual slides from each sample using the technique explained in the paper by Jones and Bryant (2001). As they explain and demonstrate through testing, incorrect methods of sub sampling can skew pollen counting results from individual samples. Pollen counting was performed using a Nikon Optiphot binocular microscope at magnifications ranging from 400x-1000x and all photographs were taken at 400x using a Nikon 950 Coolpik camera attached to a trinocular head. Identifications of pollen and spore types in each sample were checked against modern pollen reference materials, which now number more than 20,000, and are on file in the Texas A\&M Palynology Laboratory. These modern pollen reference materials include the Texas A\&M Modern Pollen Reference Collection, the Mobil Oil Modern Pollen Reference Collection, the Meredith Lieux Modern Pollen Reference Collection, and the AMOCO Modern Pollen Reference Collection.

\section{How Many Pollen Grains to Count}

How many pollen grains one should count in a sample has been the subject of much debate among palynologists (Barkley 1934). For pollen wash samples one usually counts all of the recovered pollen, unless there is an excessive amount of pollen and residue recovered. For all types of non pollen wash samples I usually count between 200-300 pollen grains because counts of this size have been shown to be adequate for these types of studies. As noted in Traverse (2007), the standard deviation in a 100 grain pollen count for a pollen type that might appear in a normal percentage as low as $1 \%$ is $100 \%$, thus the probability of finding that pollen type in any given 100 grain pollen count from the same sample would be between $0-2 \%$ in two-thirds of the additional pollen counts from that one sample. Even if pollen counts were increased to 1,000 pollen grains per sample, a pollen type occurring in a normal percentage of $1 \%$ would still have a standard deviation of $30 \%$, meaning that in two-thirds of all additional 1,000 grain pollen counts of the same sample that pollen type would occur within the range of .3-1.3\%. In terms of time and costs, the higher pollen counts are not normally justified, unless they are considered critical and worth the added cost. Jones and Bryant (2001) conducted experiments to test this hypothesis and discovered that the only significant thing usually gained by increasing to larger pollen counts above 200 grains per sample is the potential for finding additional, rare taxa, which normally occur in very low frequencies. Furthermore, as they showed in their experiments, even with high pollen counts, the percentages of the primary pollen taxa in a sample remain statistically similar in repeated counts at the 200 grain level, provided each count came from slides that were sub sampled correctly (Jones and Bryant 1998).

\section{Pollen Identification}

Pollen identification of fossil material in these samples was often quite difficult to determine because of the high degree of pollen alteration and degradation caused by unfavorable depositional conditions at the site where the cores were extracted. As noted in the pollen micrographs (Figs. 1-5) of fossil material examined from these samples, many of the pollen grains are so altered that they only vaguely resemble their original shapes or ornamentation. The highly degraded pollen grains that could not be identified with any degree of certainty are listed in the pollen counts as "degraded." They are included in the pollen counts of all samples because accurate pollen concentration values can only be derived when "all" of the fossil pollen is recorded whether or not it can be identified to family, genus, or species. Cushing (1966) was the first to test and report that a failure to include all degraded pollen in the actual pollen counts will produce unreliable and inaccurate pollen concentration values. To calculate fossil pollen concentration values in these and all other samples one must know three points of reference: 1) how many tracer spores have been added to the sample and how many were counted during the actual pollen count, 2) exactly how much sample material was used in each sample and how was it measured in grams or cubic centimeters, and 3 ) how many fossil pollen grains were counted in each sample including both identifiable and degraded pollen.

Fossil pollen preservation in all of these samples was marginal at best. Because I have been examining these types of highly 
degraded fossil samples from sites throughout Texas, the Middle East, and the American Southwest for more than 40 years I have learned to recognize and correctly identify many highly degraded examples of pollen, which might not be recognized by others fairly new at working with these types of deposits. Regardless of how badly degraded some of the fossil pollen appeared in these samples, if I could be certain of the grain's original identity, I counted it as a pollen grain in that taxon, not at a degraded pollen grain. Only the pollen grains in these samples that were beyond any possibility of identification were listed as degraded. Some examples of those are illustrated in Figure B-1.

Because the pollen in these samples were so badly degraded, if I found a fragment of a pollen grain that represented more than approximately one-fourth of the original pollen grain, I counted that fragment as a whole grain of that taxon. Individual pine bladders, or the body of a pine pollen grain were each recorded as one-half a pine pollen grain.

\section{Scale for all photos: Space between numbers is equal to 25 microns.}
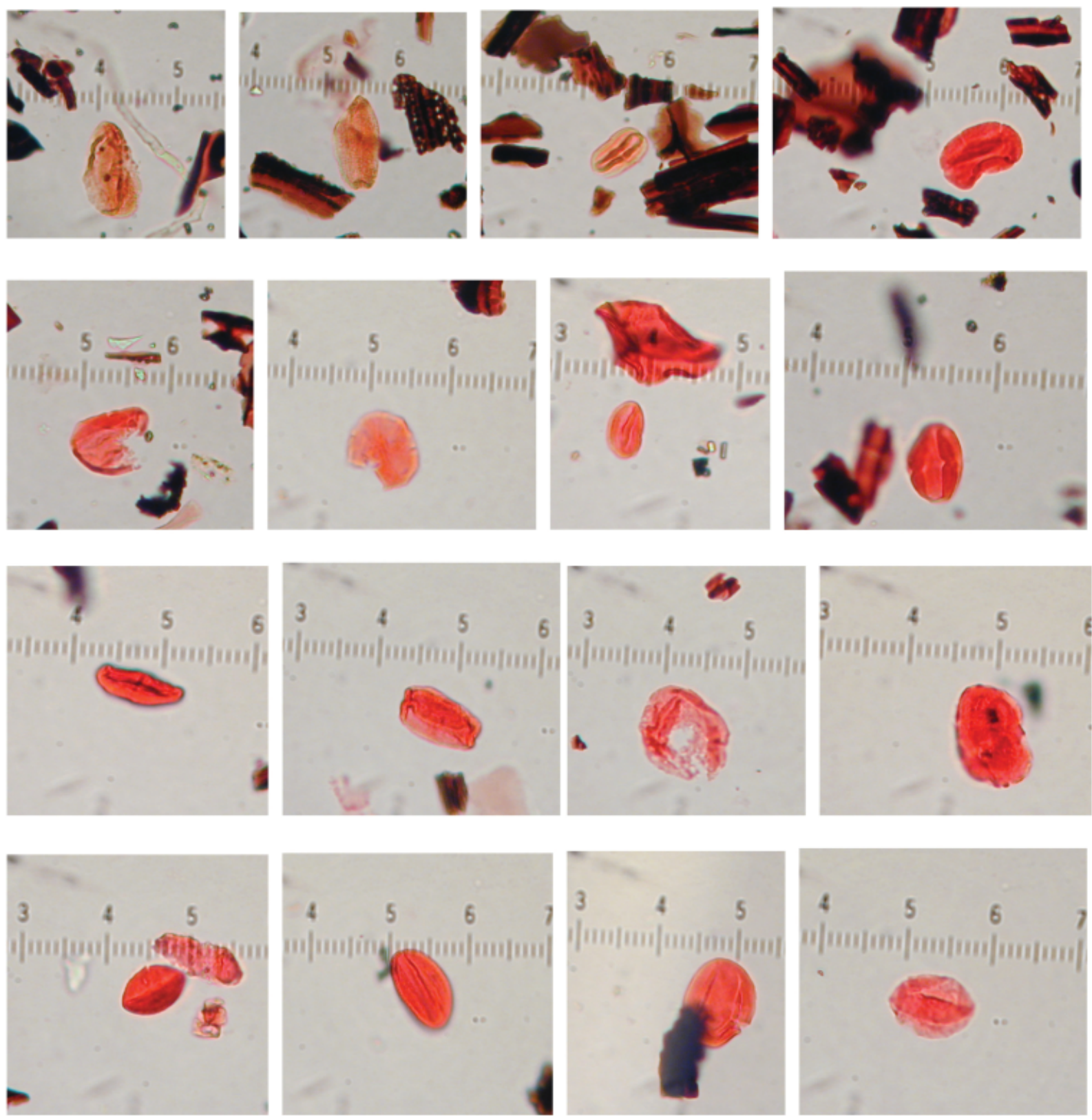

Figure B-1. Examples of Degraded Pollen Beyond Recognition in the Core Samples. 
During the pollen counting of these samples I had to make important decisions in terms of how to combine certain categories of fossil pollen. For example, the Asteraceae plant family contains more than 1,500 genera and more than 22,000 species that grow in almost every known habit (Mabberley 1997). Asteraceae pollen can be divided into certain categories, most of which occurred in these samples. One primary group, which is insect-pollinated, is called the "high-spine" group because their pollen grains have a surface morphology consisting of long spines greater than 2.5 microns in length (Martin, 1963). These pollen types are very durable and even when degraded they can often be recognized (Fig. 2). Three other major pollen groups within the composite family are fairly easy to separate into distinct categories. The pollen types that are similar to and include ragweed are all wind-pollinated and are assigned to the category called "low-spine" types because their surface spines are shorter than $2.5 \mathrm{um}$ in length (Martin, 1963). Another group of composites have fenestrate pollen grains and belong in the tribe Lactuceae (Fig. 5). The final group containing Artemisia is a group of wind-pollinated composites that all have a very distinct type of morphology and thus can be separated into this one genus. There are other pollen types produced by plant genera within the composites that are also distinctive enough that they can often be identified and listed separately as a genus, provided they are not severely degraded. Several of these other taxa include Centaurea (star thistle), Cirsium (thistle), and Mutisia (mutisia). For most of the genera and species in the Asteraceae family their pollen morphology is not distinctive enough to warrant separation into a genus or species without extensive regional pollen keys produced at the resolution level of a scanning electron (SEM) or transmission electron microscope (TEM).

Paul S. Martin (1963), while examining deposits from sites in the American Southwest was the first to propose the term "Cheno-Ams" for the combined groups of pollen in the family Chenopodiaceae and the genus Amaranthus in the Amaranthaceae family. Pollen grains in both of these groups are nearly identical in appearance because all the types are similar in size and shape and all are periporate (having many pores on the surface). These characteristics generally make the genera in this group indistinguishable using LM (light microscopy), unless extensive regional studies of specific taxa in these plant groups have been conducted and the pollen grains categorized according to their cord/diameter ratios (McAndrews and Swanson 1967). I have followed the use of Martin's category of Cheno-Ams for these types of pollen grains found in the samples of this study.

The genus Pinus (pines) contains more than 90 species that can be divided into two major groups based on various characteristics including their leaf morphology and their pollen types. In pine pollen the presence or absence of verracae on the underside (distal surface) of the pine pollen grain in the germinal furrow region between the bladders will identify to which of the two major categories the taxon belongs. The two major groups of pines were first separated into "diploxylon" (those species with pollen having no distal verracae) and "haploxylon" (those species having distal verracae) pollen categories by Uneo (1958). In this present study I found the majority of the pine pollen was of the diploxylon variety. I did not find any grains that were of the haploxylon type. In a few cases where the area of the germinal furrow was obscured, I assumed those grains were also of the diploxylon variety and thus added them to that category. Likewise, when individual pine bladders were found, they were also counted as coming from diploxylon pines. If one finds that my category assumption for all the pine pollen in these samples is troublesome, then one should consider all of the pine pollen as being unclassified as to specific pine category.

Ephedraceae (joint fir) pollen occurred as single grains in only two of the samples in this study (Sample 95 and 101). This plant family contains only one genus with about 65 different species. The pollen in the single genus Ephedra (joint fir) can be divided into four major groups (Steeves and Barghoorn 1959). Two of the four major groups are common in North America and the pollen grains in both groups look similar, yet each has some unique morphological characteristics. The first of these two, the Ephedra nevadensis group, contains a number of individual species. Each of those species produces pollen with fewer furrows and many of the raised ridges, called plica, have furrows with hyalines. The second of these two is called the Ephedra aspera group and it also contains a number of individual species. The species in this second group produce pollen grains that have more plica and furrows but none have hyalines. Although both the join fir pollen grains found in this study were degraded, both appear to come from the E. aspera group (Fig. 5).

\section{Pollen Rain and Pollen Preservation}

The pollen rain includes all of the pollen that is dispersed and deposited at a given locale. One can examine and discuss the pollen rain of a large geographical region, or focus on the pollen rain deposited in a very tiny geographical area, depending on the objectives of the pollen study. At any given location, such as location of the cores in this study, the eventual interpretation of recovered pollen data must account for all factors that may have influenced the composition of the original pollen rain, and later for the factors that may have affected and altered the initial composition of the buried pollen assemblage. 
During the last 50 years, palynologists have learned there are many complex factors that determine the original pollen rain in a region. These include factors such as: 1) types of pollination; 2) differences in pollen production; 3) differential dispersion patterns; and 4) the size, weight, and aerodynamic ability of pollen types to remain airborne. In addition, for some locations, pollen deposition will also be influenced by the activities of animals, birds, or humans using the site area. Once deposited, other factors influence the eventual loss or recovery of specific pollen types. These factors include: 1) pollen recycling and/or mixture due to wind, water, humans, or burrowing animals; 2) the chemical composition of a pollen grain's wall [exine]; 3) the morphological shape and surface ornamentation type of each pollen type; and 4) the susceptibility of each pollen type to various types of degradation processes including those from mechanical, chemical, or biological agents (Bryant 1978, 1988; Bryant et al. 1994; Bryant and Hall 1993; Havinga 1964, 1984; Holloway 1989; King et al. 1975; O’Rourke 1990).

As noted by Jackson and Lyford (1999) and others, there are substantial differences among plant taxa in terms of their pollen production, methods of dispersal, and in the ability of their pollen grains to remain aloft and travel various distances from their dispersal source. These differences create an uneven distributional relationship between the amount of pollen that will fall to the ground (pollen rain) and the actual vegetational coverage of each plant taxon. Adding to this problem is the knowledge that a large number of plants produce small amounts of pollen that rarely is cast adrift into the atmosphere because the plants rely on insect or animal pollinators. These pollen types are seldom found in the normal pollen rain of a region even though the plants that produce them may compose a major portion of the vegetational coverage. Finally, animals and humans gathering plants for food or processing them for other purposes can artificially introduce additional amounts and types of pollen into the pollen rain of a specific location or region. For archaeologists, those "pollen additions," which are frequently found in the deposits of archaeological sites, can become useful clues used to infer various types of cultural activities.

Once deposited, pollen is subjected to a host of potential factors that will determine whether they will remain preserved over time. Another problem is that not all pollen types are created equal; therefore, some types will succumb to destruction much more rapidly than will other more durable types. That type of differential pollen preservation can create patterns of fossil pollen recovery in the sedimentary record, which might be easily misinterpreted by those with minimal knowledge of botany or palynology (Bryant et al. 1993; Reinhard et al. 2007).
One of the first agents that can affect pollen grains is mechanical degradation of the exine (pollen wall). After pollen is released from its source, it can become abraded or broken during the transportation phase before it falls to the ground and becomes part of the pollen rain. These alterations can result from impact or from changes in climatic conditions. Studies by Duhoux (1982), for example, have shown that atmospheric changes from low to high humidity can result in large numbers of exine ruptures in thin-walled pollen taxa such as those produced by plants in the Cupressaceae (Juniperus, and Thuja). Later, after being deposited, many of the thin-walled pollen types, as well as other pollen types, can become further abraded by various activities such as natural events (hurricanes, earthquakes, tornadoes) and animal disturbances (burrowing). The cultural practices of humans can also affect the preservation of deposited pollen. For example human events such as grassland burning, land surface modifications (temple building, irrigation systems, roadways, etc.), construction activities (house and temple building, pueblos, retaining walls, animal pens, etc.), and agricultural practices (slash-and-burn land clearing, plowing, surface flooding, etc.) will each alter the pollen rain and pollen deposition in different ways.

Mechanical abrasion of pollen can also occur during its dispersion cycle by various events including impact against objects, exposure to water, recycling, wind erosion, changes in temperature, changes in atmospheric or soil moisture levels, volcanic eruptions, and soil movement caused by earthquakes, creep, faulting, or uplifts.

The morphological structure and ornamentation of pollen walls seem to be important factors in determining their potential susceptibility to mechanical degradation. For example, protruding structures such as the bladders attached to the pollen grains of many conifer species (pine, spruce, fir), or the spines on the surface of some pollen types (composites, cotton, mallows, morning glory, etc.) have a tendency to break or erode through a variety of mechanical processes. In some cases, the actual appearance of a pollen grain may become so altered after the loss of an appended structure, or structures, that accurate identification is no longer possible. In addition, structural alteration by mechanical processes can cause cracks or exine weakening, thereby hastening the eventual destruction of the entire grain through other processes. An analogy would be the difference between a whole egg and one that had a hairline crack. The whole egg is much stronger and more durable than the one with even a tiny crack!

Soil chemistry, acting on the natural chemical composition of a pollen grain's exine is another factor that often plays an important role in determining pollen preservation. Although 
the exine is composed mostly of cellulose and various types of proteins, there are also interlocking strands of a highly durable, polymer type material called sporopollenin. Early studies by chemists and palynologists including Brooks and Shaw (1968), Shaw (1971), Rowley and Prijanto (1977), and Rowley et al. (1990) have discovered a critical link between sporopollenin and the ability of a pollen type to become preserved. They found that differences in the amount of sporopollenin and differences in the specific molecular structure of variations of sporopollenin within the pollen exine enable some taxa to become preserved while other taxa with different variations and amounts of sporopollenin undergo rapid deterioration.

One of the primary indications of potential pollen preservation in sediments can be gained by determining the soil $\mathrm{pH}$. By itself, $\mathrm{pH}$ is not entirely responsible for pollen destruction, but it is an important factor. As early as the 1950s, Dimbleby (1957) searched for causes of pollen deterioration in various types of soils. His experiments and research were the first to chart differences in pollen preservation caused by soil chemistry. His research revealed that most soils with an acidic $\mathrm{pH}$ seem to provide ideal conditions for pollen preservation. However, he noted that once acidic soils reach a $\mathrm{pH}$ level of being only weakly acidic (around 6.0), then significant pollen destruction begins to occur. Dimbleby even cautioned that attempts to recover fossil pollen from any soils with a $\mathrm{pH}$ greater that 6.0 would most probably result in failure. Since Dimbleby's original study, other studies by palynologists including Bryant et al. (1994), Hall (1981), and Martin (1963) have demonstrated that fossil pollen can be recovered in some alkaline soils with a $\mathrm{pH}$ as high as 8.9. Nevertheless, as noted by Bryant and Hall (1993), in most cases fossil pollen recovered from alkaline sediments is poorly preserved, is highly deteriorated, and frequently documents evidence of differential taxa preservation (i.e., many of the fragile pollen types have disappeared leaving behind only the most durable pollen types).

Related to Dimbleby's (1957) initial study on soil $\mathrm{pH}$ is Tschudy's (1969) later research on the effects of Eh (oxidation potential) on pollen preservation. Tschudy noted that Eh seems to be a better indicator for potential pollen preservation than $\mathrm{pH}$. Sediments with a low Eh (from -1 to 0 ) represent a reducing, anaerobic type of condition where carbon dioxide and hydrogen sulfide are often present from the by-products of microbial respiration. This combination decreases the levels of oxygen and lowers the $\mathrm{pH}$ values. Thus, the creation of a negative Eh value generally results in the formation of a strongly reducing environment (Tschudy 1969). Because a reducing environment retards oxygen retention, which plays a key role in oxidizing organic compounds, it is ideal for pollen preservation. In addition, reducing environments present unfavorable habitats for most microbes such as bacteria and fungi, some of which are known to feed on pollen. Therefore, a low Eh in a soil or sediment environment is ideal for pollen preservation.

One of the common types of sediments with a low Eh potential is an acidic peat bog, which is known to be one of the best places to recover fossil pollen. Likewise, as the Eh potential of sediments rises from 0 toward +1 , it indicates oxidizing conditions that will speed the destruction of pollen. Oxidizing condition create two types of destruction for fossil pollen. First, direct oxidation occurs when pollen grains come in contact with free oxygen. Second, indirect oxidation occurs when pollen grains come in contact with oxygenated water that percolates downward into sub-surface levels from the surface. This second type of oxidation is often the most destructive factor for fossil pollen and is especially common in the sediments of shallow ponds and lakes found in temperate environments or in well-drained sandy loam soils. The oxygenation of sub-surface soil and shallow lake deposits also provides an ideal habitat for species of polleneating bacteria and fungi.

Not all pollen types are created equal. The chemical composition of the pollen walls of some plant species is not nearly as durable as they are in other taxa. In addition, the structural morphology of the pollen wall plays an important role in determining whether a specific type of pollen grain will remain preserved in various types of sediments. In a 20year study beginning in 1964 and ending in 1984, Havinga (1964, 1984) reported that the relationship between the morphological structure and percentage of sporopollenin in the wall composition of pollen grains seems to determine their susceptibility to eventual destruction by oxidation. He found, for example, that pollen grains having higher ratios of sporopollenin/cellulose in their walls tended to remain preserved much longer, even in soils with high $\mathrm{pH}$ and high Eh values. Likewise, those pollen taxa with thin walls and walls containing minimal amounts of sporopollenin tended to decompose very quickly in soils with either or both high $\mathrm{pH}$ and high Eh values. Subsequent to Havinga's 20-year study, additional research by Rowley et al. (1990) produced detailed scanning (SEM) and transmission (TEM) electron microscopy studies of how various types of decomposition occur in the pollen walls of different pollen taxa. The SEM and TEM studies by Rowley and his colleagues provide some of the most detailed images and explanations yet published outlining the destructive processes that affect pollen in various types of soil environments.

Biological agents including certain species of fungi and bacteria can cause damage to pollen grains that will speed their eventual destruction. Studies by Holloway (1981, 
1989) noted that some species of Phycomycete fungi will seek out and feed on the nutrient materials in the cytoplasm of recently-deposited pollen grains. His experimental studies show that the filamentous threads of fungi, called hyphae, will often enter a pollen grain through one of the grain's natural aperture openings. Nevertheless, at other times the fungal hyphae seem to have the ability to dissolve areas of the pollen wall in order to provide an opening into the pollen grain. Both types of fungal attacks will weaken the wall structure of pollen and speed the grain's eventual destruction by other forms of chemical and mechanical degradation.

Some years earlier, Goldstein (1960) conducted experiments with various species of Phycomycete fungi and found that they were a causative factor in the destruction of fossil pollen. His original study revealed that certain species of Phycomycetes are selective in their preference for pollen types. One type of Phycomycetes, for example, would infect and fed only on certain types of conifer pollen grains even when a variety of other pollen types were more plentiful and more available in the substrate. That type of selective pollen destruction by certain species of fungi becomes an important factor to consider when trying to estimate the potential impact of differential pollen loss in certain sediments. Unlike Holloway's later study in 1989, Goldstein did not focus on how fungi actually damaged pollen grains. Instead, Goldstein was primarily concerned only with the percentage of pollen grains that were potentially infected and which pollen taxa were the most susceptible to fungal attack.

There were a number of fungal spores found in the samples I examined for this study. Nevertheless, I am not certain whether or not any of these may have been a contributing factor leading to the destruction and damage of fossil pollen in those samples.

Elsik (1966) was the first to note that bacterial degradation of pollen grains occurs. He found that certain bacteria, especially species of Actinomycetes, have an ability to degrade pollen. He found that even though much of the bacterial infection of pollen seems to occur soon after pollen grains are dispersed and when the pollen still contains cytoplasm, additional bacterial destruction continues to occur long after the pollen grains have lost their cytoplasm and have become part of the fossil record.

Finally, one of the most destructive forces for fossil pollen in sediments seems to come from repeated cycles of wetting and drying (Campbell and Campbell 1994). The walls of many pollen grains are elastic, which enable the fresh, viable pollen grains to expand and contract without destruction. Depending upon the changing levels of atmospheric humidity some pollen grains may expand and contract dozens of times before they either reach their intended destination and begin the fertilization process, or fall to the surface as part of the pollen rain. For those that fall to the surface, they continue to expand and contract as moisture levels change. Eventually, this process weakens the grain and causes it to rupture or crack. Once weakened, pollen grains are much more susceptible to other processes of mechanical destruction.

\section{Discussion}

In their article Bryant and Hall (1993) discuss the validity aspects of fossil pollen samples and note that fossil pollen records should be suspect when they contain all three of the following: 1) fossil pollen from only a few plant taxa are represented, especially when the most abundant pollen taxa are from the most durable types of pollen with very distinctive and easy-to-recognize morphological features; 2) when a sample contains a high percentage of degraded and indeterminable pollen grains beyond recognition, and 3) when fossil pollen concentration levels are below 1,000 grains/gram or 2,500 grains/cubic centimeter of sediment. Two of those three aspects are present in all of the samples I examined for this project and all three aspects are present in 35\% (8/23) of the total number of sediment samples I examined.

I found only 11 different fossil pollen taxa during the study of these samples (Tables B-2 through B-7). Not all 11 of those pollen taxa were found in any one of the individual samples. Because we do not have any control samples, it is difficult to guess the number of "expected" pollen taxa in that region of Texas. However, when working in the desert regions of the Big Bend National Park in West Texas we did compare the expected numbers of pollen taxa to the actual number of fossil pollen taxa recovered (Bryant et al. 1994). In that study we found that each of the fossil pollen samples contained approximately one-third or less of the expected diversity of pollen types normally found in the 89 surface samples examined from those same desert habitats. I would expect a higher and more diverse flora in the vegetation of Nueces County than is found in the desert regions of the Big Bend; therefore, control surface samples collected near the core sampling location should contain a wide diversity of pollen types. If so, then the 11 total fossil taxa recovered during this study may reflect, as it did in the Big Bend region, only one-third or less of the total number of original pollen taxa present in these deposits. This suggests, as it did for the Big Bend region, that we are recovering pollen evidence from only one-third or less of the original plant types that contributed pollen to these deposits. Therefore, like the Big Bend study, the recovered pollen record from the Oso Bay study has little validity in terms of presenting a true reflection 
Table B-2. Fossil Pollen Recovered from Core Samples 88, 89, and 90

\begin{tabular}{|c|c|c|c|c|c|c|}
\hline \multirow{2}{*}{$\begin{array}{c}\text { Dso IBay Samples } \\
\text { Pollen Taxa }\end{array}$} & \multirow[t]{2}{*}{88} & \multirow{2}{*}{\multicolumn{2}{|c|}{89}} & \multicolumn{3}{|c|}{90} \\
\hline & & & & $\%$ & & $\%$ \\
\hline & Total & & Total & & Total & \\
\hline APIACEAE (umbels) & 0 & $0.0 \%$ & 0 & $0.0 \%$ & 1 & $0.5 \%$ \\
\hline ASTERACEAE (sunflower-type) & 40 & $19.7 \%$ & 26 & $12.7 \%$ & 12 & $5.8 \%$ \\
\hline ASTERACEAE (ragweed type) & 16 & $7.9 \%$ & 11 & $5.4 \%$ & 14 & $6.8 \%$ \\
\hline Cheno-Ams (goosefoot) & 38 & $18.7 \%$ & 36 & $17.6 \%$ & 52 & $25.2 \%$ \\
\hline ONAGRACEAE (evening primrose) & 0 & $0.0 \%$ & 0 & $0.0 \%$ & 0 & $0.0 \%$ \\
\hline Opuntia (prickly pear cactus) & 0 & $0.0 \%$ & 0 & $0.0 \%$ & 0 & $0.0 \%$ \\
\hline Pinus (diploxylon pine) & 4 & $2.0 \%$ & 7 & $3.4 \%$ & 3 & $1.5 \%$ \\
\hline POACEAE (grass) & 24 & $11.8 \%$ & 32 & $15.6 \%$ & 24 & $11.7 \%$ \\
\hline \multirow[t]{2}{*}{ Polygonum (knotweed) } & 0 & $0.0 \%$ & 3 & $1.5 \%$ & 3 & $1.5 \%$ \\
\hline & & & 0 & & 0 & \\
\hline \multirow[t]{2}{*}{ UNKNOWN } & 0 & $0.0 \%$ & 0 & $0.0 \%$ & 0 & $0.0 \%$ \\
\hline & & & 0 & & 0 & \\
\hline Degraded pollen beyond recognition & 81 & $39.9 \%$ & 90 & $43.9 \%$ & 98 & $47.6 \%$ \\
\hline TOTAL POLLEN COUNTED & 203 & $100.0 \%$ & 205 & $100.0 \%$ & 206 & $100.0 \%$ \\
\hline Lycopodium Tracer Spores Counted & 10 & & 6 & & 11 & \\
\hline Pollen Concentration/gram & 27,405 & & 46,125 & & 25,281 & \\
\hline
\end{tabular}

Table B-3. Fossil Pollen Recovered from Core Samples 91, 92, and 93

\begin{tabular}{|c|c|c|c|c|c|c|}
\hline Dso IBay Samples & 91 & & 92 & \multicolumn{3}{|c|}{93} \\
\hline \multirow[t]{2}{*}{ Pollen Taxa } & \multicolumn{3}{|c|}{$\%$} & $\%$ & & $\%$ \\
\hline & Total & & Total & & Total & \\
\hline Alnus (alder) & 0 & $0.0 \%$ & 0 & $0.0 \%$ & 0 & $0.0 \%$ \\
\hline ASTERACEAE (sunflower-type) & 15 & $7.1 \%$ & 11 & $5.3 \%$ & 16 & $7.5 \%$ \\
\hline ASTERACEAE (ragweed type) & 11 & $5.2 \%$ & 15 & $7.2 \%$ & 22 & $10.4 \%$ \\
\hline Cheno-Ams (goosefoot) & 42 & $20.0 \%$ & 31 & $14.8 \%$ & 47 & $22.2 \%$ \\
\hline Ephedra (joint fir) & 0 & $0.0 \%$ & 0 & $0.0 \%$ & 0 & $0.0 \%$ \\
\hline ONAGRACEAE (evening primrose) & 0 & $0.0 \%$ & 0 & $0.0 \%$ & 0 & $0.0 \%$ \\
\hline Opuntia (prickly pear cactus) & 0 & $0.0 \%$ & 0 & $0.0 \%$ & 0 & $0.0 \%$ \\
\hline Pinus (diploxylon pine) & 4 & $1.9 \%$ & 3 & $1.4 \%$ & 2 & $0.9 \%$ \\
\hline POACEAE (grass) & 35 & $16.7 \%$ & 44 & $21.1 \%$ & 24 & $11.3 \%$ \\
\hline Polygonum (knotweed) & 2 & $1.0 \%$ & 4 & $1.9 \%$ & 3 & $1.4 \%$ \\
\hline & & $0.0 \%$ & & & & \\
\hline UNKNOWN & 0 & $0.0 \%$ & 0 & $0.0 \%$ & 0 & $0.0 \%$ \\
\hline Degraded pollen beyond recognition & 101 & $48.1 \%$ & 101 & $48.3 \%$ & 98 & $46.2 \%$ \\
\hline TOTAL POLLEN COUNTED & 210 & $100.0 \%$ & 209 & $100.0 \%$ & 212 & $100.0 \%$ \\
\hline Lycopodium Tracer Spores Counted & 14 & & 12 & & 6 & \\
\hline Pollen Concentration/gram & 20,250 & & 47,700 & & 21,021 & \\
\hline
\end{tabular}


Table B-4. Fossil Pollen Recovered from Core Samples 94, 95, and 96

\begin{tabular}{|c|c|c|c|c|c|c|}
\hline \multirow{3}{*}{$\begin{array}{c}\text { Dso Bay Samples } \\
\text { Pollen Taxa }\end{array}$} & 94 & & 95 & \multicolumn{3}{|c|}{96} \\
\hline & & $\%$ & & $\%$ & & $\%$ \\
\hline & Total & & Total & & Total & \\
\hline Alnus (alder) & 0 & $0.0 \%$ & 2 & $0.9 \%$ & 0 & 0 \\
\hline ASTERACEAE (sunflower-type) & 18 & $8.3 \%$ & 21 & $9.9 \%$ & 23 & $11.4 \%$ \\
\hline ASTERACEAE (ragweed type) & 21 & $9.7 \%$ & 12 & $5.6 \%$ & 18 & $8.9 \%$ \\
\hline Cheno-Ams (goosefoot) & 49 & $22.6 \%$ & 54 & $25.4 \%$ & 31 & $15.3 \%$ \\
\hline Ephedra (joint fir) & 0 & $0.0 \%$ & 1 & $0.5 \%$ & 0 & $0.0 \%$ \\
\hline ONAGRACEAE (evening primrose) & 0 & $0.0 \%$ & 1 & $0.5 \%$ & 0 & $0.0 \%$ \\
\hline Opuntia (prickly pear cactus) & 0 & $0.0 \%$ & 2 & $0.9 \%$ & 1 & $0.5 \%$ \\
\hline Pinus (diploxylon pine) & 5 & $2.3 \%$ & 6 & $2.8 \%$ & 2 & $1.0 \%$ \\
\hline POACEAE (grass) & 31 & $14.3 \%$ & 33 & $15.5 \%$ & 44 & $21.8 \%$ \\
\hline Polygonum (knotweed) & 4 & $1.8 \%$ & 6 & $2.8 \%$ & 2 & $1.0 \%$ \\
\hline UNKNOWN & 0 & $0.0 \%$ & 0 & $0.0 \%$ & 0 & $0.0 \%$ \\
\hline Degraded pollen beyond recognition & 89 & $41.0 \%$ & 77 & $36.2 \%$ & 81 & $40.1 \%$ \\
\hline TOTAL POLLEN COUNTED & 217 & $100.0 \%$ & 213 & $100.0 \%$ & 202 & $100.0 \%$ \\
\hline Lycopodium Tracer Spores Counted & 14 & & 15 & & 16 & \\
\hline Pollen Concentration/gram & 21,021 & & 19,170 & & 17,043 & \\
\hline
\end{tabular}

Table B-5. Fossil Pollen Recovered from Core Samples 97, 98, and 99

\begin{tabular}{|c|c|c|c|c|c|c|}
\hline \multirow{3}{*}{$\begin{array}{c}\text { Dso IBay Samples } \\
\text { Pollen Taxa }\end{array}$} & \multirow[t]{2}{*}{97} & \multirow{2}{*}{\multicolumn{2}{|c|}{98}} & \multicolumn{3}{|c|}{99} \\
\hline & & & & $\%$ & & $\%$ \\
\hline & Total & & Total & & Total & \\
\hline Alnus (alder) & 0 & $0.0 \%$ & 0 & $0.0 \%$ & 0 & $0.0 \%$ \\
\hline ASTERACEAE (sunflower-type) & 12 & $5.9 \%$ & 16 & $7.3 \%$ & 37 & $16.1 \%$ \\
\hline ASTERACEAE (ragweed type) & 14 & $6.9 \%$ & 22 & $10.1 \%$ & 30 & $13.0 \%$ \\
\hline Cheno-Ams (goosefoot) & 41 & $20.1 \%$ & 51 & $23.4 \%$ & 66 & $28.7 \%$ \\
\hline Ephedra (joint fir) & 0 & $0.0 \%$ & 0 & $0.0 \%$ & 0 & $0.0 \%$ \\
\hline ONAGRACEAE (evening primrose) & 0 & $0.0 \%$ & 0 & $0.0 \%$ & 0 & $0.0 \%$ \\
\hline Opuntia (prickly pear cactus) & 0 & $0.0 \%$ & 1 & $0.5 \%$ & 0 & $0.0 \%$ \\
\hline Pinus (diploxylon pine) & 4 & $2.0 \%$ & 2 & $0.9 \%$ & 2 & $0.9 \%$ \\
\hline POACEAE (grass) & 28 & $13.7 \%$ & 44 & $20.2 \%$ & 34 & $14.8 \%$ \\
\hline Polygonum (knotweed) & 6 & $2.9 \%$ & 2 & $0.9 \%$ & 1 & $0.4 \%$ \\
\hline Ulmus (elm) & 0 & $0.0 \%$ & 0 & $0.0 \%$ & 1 & $0.4 \%$ \\
\hline UNKNOWN & 0 & $0.0 \%$ & 0 & $0.0 \%$ & 0 & $0.0 \%$ \\
\hline Degraded pollen beyond recognition & 99 & $48.5 \%$ & 80 & $36.7 \%$ & 59 & $25.7 \%$ \\
\hline TOTAL POLLEN COUNTED & 204 & $100.0 \%$ & 218 & $100.0 \%$ & 230 & $100.0 \%$ \\
\hline Lycopodium Tracer Spores Counted & 10 & & 12 & & 14 & \\
\hline Pollen Concentration/gram & 27,540 & & 24,525 & & 22,178 & \\
\hline
\end{tabular}


Table B-6. Fossil Pollen Recovered from Core Samples 100, 101, and 102

\begin{tabular}{|c|c|c|c|c|c|c|}
\hline Dso Bay Samples & 100 & & 101 & & 102 & \\
\hline Pollen Taxa & & $\%$ & & $\%$ & & $\%$ \\
\hline & Total & & Total & & Total & \\
\hline Alnus (alder) & 0 & $0.0 \%$ & 0 & $0.0 \%$ & 0 & $0.0 \%$ \\
\hline ASTERACEAE (sunflower-type) & 29 & $13.1 \%$ & 39 & $17.6 \%$ & 29 & $13.2 \%$ \\
\hline ASTERACEAE (ragweed type) & 19 & $8.6 \%$ & 18 & $8.1 \%$ & 19 & $8.7 \%$ \\
\hline Cheno-Ams (goosefoot) & 62 & $28.1 \%$ & 55 & $24.8 \%$ & 29 & $13.2 \%$ \\
\hline $\begin{array}{l}\text { Ephedra (joint fir) } \\
\text { ONAGRACEAE (evening }\end{array}$ & 0 & $0.0 \%$ & 1 & $0.5 \%$ & 0 & $0.0 \%$ \\
\hline primrose) & 0 & $0.0 \%$ & 0 & $0.0 \%$ & 0 & $0.0 \%$ \\
\hline Opuntia (prickly pear cactus) & 1 & $0.5 \%$ & 0 & $0.0 \%$ & 0 & $0.0 \%$ \\
\hline Pinus (diploxylon pine) & 0 & $0.0 \%$ & 3 & $1.4 \%$ & 1 & $0.5 \%$ \\
\hline POACEAE (grass) & 65 & $29.4 \%$ & 29 & $13.1 \%$ & 39 & $17.8 \%$ \\
\hline Polygonum (knotweed) & 1 & $0.5 \%$ & 0 & $0.0 \%$ & 1 & $0.5 \%$ \\
\hline Ulmus (elm) & 0 & $0.0 \%$ & 0 & $0.0 \%$ & 0 & $0.0 \%$ \\
\hline & 0 & $0.0 \%$ & 0 & $0.0 \%$ & 0 & $0.0 \%$ \\
\hline UNKNOWN & 0 & $0.0 \%$ & 0 & $0.0 \%$ & 0 & $0.0 \%$ \\
\hline & 0 & $0.0 \%$ & 0 & $0.0 \%$ & 0 & $0.0 \%$ \\
\hline Degraded pollen beyond recognition & 44 & $19.9 \%$ & 77 & $34.7 \%$ & 101 & $46.1 \%$ \\
\hline TOTAL POLLEN COUNTED & 221 & $100.0 \%$ & 222 & $100.0 \%$ & 219 & $100.0 \%$ \\
\hline Lycopodium Tracer Spores & & & & & & \\
\hline Counted & 16 & & 36 & & 80 & \\
\hline Pollen Concentration/gram & 18,646 & & 8,325 & & 3,695 & \\
\hline
\end{tabular}

Table B-7. Fossil Pollen Recovered from Core Samples 178, 179, 180, 181, 275, 276, 277, and 278

\section{Dso Bay Samples $\quad \begin{array}{llllllll}178 & 179 & 180 & 181 & 275 & 276 & 277 & 278\end{array}$ \\ Pollen Taxa}

$\begin{array}{lllllllll}\text { ASTERACEAE (sunflower-type) } & \mathbf{0} & \mathbf{0} & \mathbf{0} & \mathbf{0} & \mathbf{0} & \mathbf{2} & \mathbf{2} & \mathbf{0} \\ \text { ASTERACEAE (ragweed type) } & \mathbf{0} & \mathbf{0} & \mathbf{0} & \mathbf{0} & \mathbf{0} & \mathbf{0} & \mathbf{1} & \mathbf{0} \\ \text { ASTERACEAE (dandelion type) } & \mathbf{0} & \mathbf{0} & \mathbf{0} & \mathbf{0} & \mathbf{1} & \mathbf{0} & \mathbf{0} & \mathbf{0} \\ \text { Cheno-Ams (goosefoot) } & \mathbf{1} & \mathbf{0} & \mathbf{0} & \mathbf{0} & \mathbf{3} & \mathbf{2} & \mathbf{0} & \mathbf{0} \\ \text { Pinus (diploxylon pine) } & \mathbf{2} & \mathbf{0} & \mathbf{0} & \mathbf{0} & \mathbf{1} & \mathbf{0} & \mathbf{0} & \mathbf{0} \\ \text { POACEAE (grass) } & \mathbf{0} & \mathbf{0} & \mathbf{0} & \mathbf{0} & \mathbf{2} & \mathbf{2} & \mathbf{3} & \mathbf{0} \\ \text { Quercus (oak) } & \mathbf{0} & \mathbf{0} & \mathbf{1} & \mathbf{0} & \mathbf{0} & \mathbf{0} & \mathbf{0} & \mathbf{0} \\ \text { Ulmus (elm) } & \mathbf{0} & \mathbf{1} & \mathbf{0} & \mathbf{1} & \mathbf{0} & \mathbf{0} & \mathbf{0} & \mathbf{0}\end{array}$

Lycopodium Tracer Spores

Counted

$\begin{array}{rrrrrrrr}50 & 50 & 50 & 50 & 50 & 50 & 50 & 50 \\ 54 & 27 & 27 & 27 & 189 & 162 & 162 & 0\end{array}$

Pollen concentration/gram 
of the actual pollen record that was first deposited in these core samples as part of the regional pollen rain.

Other evidence of the severity of pollen destruction in the core samples examined for this project is the high numbers of degraded grains in each sample (Figure B-1). The percentage of degraded pollen, ranging from a low of $19 \%$ to a high of $48 \%$ in these samples represent pollen grains that are recognizable only as being pollen at one time but are now so altered that their identification is not possible. As first noted by Dean (1991) in most fossil pollen studies when the percentage of indeterminate and highly degraded pollen exceeds $10 \%$ in an individual sample, then that sample's pollen data should come under serious question and should not be considered an accurate reflection of the true pollen record.

A third line of evidence is generally the actual pollen concentration value of each sample. The pollen concentration values found in these 23 samples ranged from a low of 0 fossil pollen grains/gram of sediment to a high of 47,700 fossil pollen grains/gram of sediment. Under most circumstances fossil pollen concentration values near $50,000 /$ gram in a sample would be considered excellent for interpretative purposes. However, in sample \# 93, which contained the highest fossil pollen concentration value of in this study, $46 \%$ of those pollen grains were degraded beyond recognition as to which taxon they belonged. Thus, even with what is often considered an "outstanding" pollen concentration value, the total number of degraded pollen grains is nearly $50 \%$ and the total number of pollen taxa found in the sample was only five types. In circumstances, such as this one, the high fossil pollen concentration value is meaningless as an indication of preservation because so much of the original pollen is missing or is highly degraded. Control surface samples from this same region would have enabled us to determine an approximate modern pollen concentration value for the normal pollen rain at the coring locale.

\section{Pollen Types}

There are only 11 different pollen types represented in the fossil record of these samples. Of those types, the three dominant pollen taxa are types from the composites, ChenoAms, and grasses.

Asteraceae: There are hundreds of species of composites growing throughout the region of South Texas. Some of those species, such as those identified as belonging to the "ragweed type" produce vast numbers of wind-dispersed pollen. Other composite species produce flowers that are insect-pollinated. Sunflowers and other composites that are closely related to them produce flowers that are insect-pollinated. Those pollen types are recorded in this study as belonging to the primary category termed "sunflower-type." Although ethnographic sources record that a number of composite species were selected and used as food by aboriginal cultures in Texas and throughout much of western North America (Castetter 1935; Moerman 1998; Palmer 1887), a few species of composites get the most attention because they were often sought for their seeds, which are rich in fats and oil (Moerman 1998). Whether or not the presence of both ragweed and sunflower types of pollen in these core deposits reflect the use of these plants by some of the early cultures living at or near the Cayo del Oso Site (41NU2) is not known and cannot be proven by the pollen record from these core samples. Although both of these pollen types (Figure B-2) individually exceed $10 \%$ of the total pollen in many of these samples, this may not be an accurate record of the abundance of these plants in the ancient environment. In fossil deposits where there is a high degree of pollen degradation the high levels of composite pollen often is not an accurate reflection either of their economic use or the abundance of those plants in the local environment. Bryant and Hall (1993) note that all forms of composite pollen are among the "most durable" pollen types found in the Holocene fossil record and that those pollen grains are often identifiable even when most other fossil pollen taxa have deteriorated under unfavorable conditions of preservation. Therefore, as a general rule, when organic preservation is poor, composite pollen tends to become "overrepresented" in terms of its recovered presence, as opposed to its original presence in the ancient pollen rain of the sampled locale.

Cheno-Ams: The fossil pollen in this category of plants may have come from a wide variety of species many of which are drought resistant, or tolerance of saline environments, or grow quickly and flourish in disturbed soils. These are the types of plants that will often replace grasses, forbs, and even small bushes when environmental conditions become harsh or after vegetational changes occur as a result of fires, erosion, hurricanes, or encroachment from marine environments. Most of the plants in the Cheno-Ams category produce large quantities of small and very durable windpollinated pollen grains that are easily dispersed by the wind. The mature plants also produce thousands of small seeds, which were often gathered and eaten by many prehistoric and historic cultures living throughout the American Southwest and northern Mexico (Feweks 1896; Moerman 1998). Therefore, as with the records of Asteraceae pollen, it is temping to infer that the parent plants producing the ChenoAms pollen were widespread near the Cayo del Oso Site and that perhaps ancient cultures collected and used the seeds. On the other hand, I personally believe that the high percentages of fossil Cheno-Ams pollen in these core samples (Figure B-3) result from the destruction and elimination of other less durable pollen types in these sediments. That type of condition, confirmed by the high percentage of degraded and 


\section{Scale for all photos: Space between numbers is equal to 25 microns.}
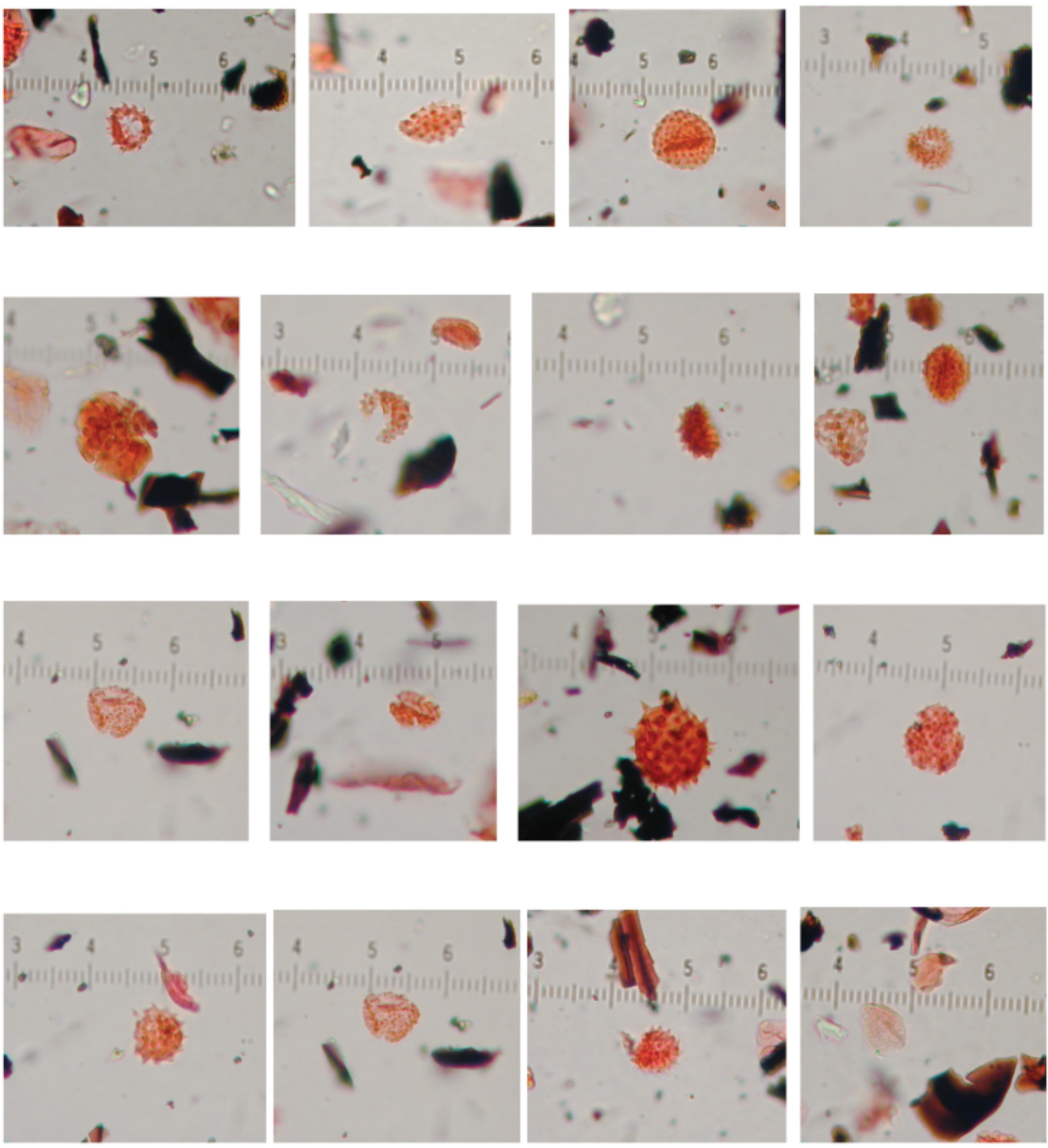

Figure B-2. Fossil Asteraceae Pollen Types Recovered from the Core Samples.

indeterminate fossil pollen in every sample examined, would enable Cheno-Ams fossil pollen to become over represented because they are durable types that remains identifiable even with badly degraded.

Poaceae: We know from ethnographic reports and from studies of human coprolites found throughout West Texas and the American Southwest (Bryant and Williams-Dean 1975; Chamberlin 1911; Moerman 1998; Stock 1983; Sobolik
1991) that Native Americans collected and ate various types of grass seeds including those from foxtail barley, wild-rye, and millets. Although it is possible that some of the fossil grass pollen found in the soils of these core samples may have come from species that could be considered economically important for ancient cultures, it is more probable that the pollen came from natural sources (Figure B-4). Grasses are a common plant growing around the edges of small ponds, such as the one sampled for these core samples, and along the shorelines of marine and brackish inlets. Grasses also flourish 


\section{Scale for all photos: Space between numbers is equal to 25 microns.}
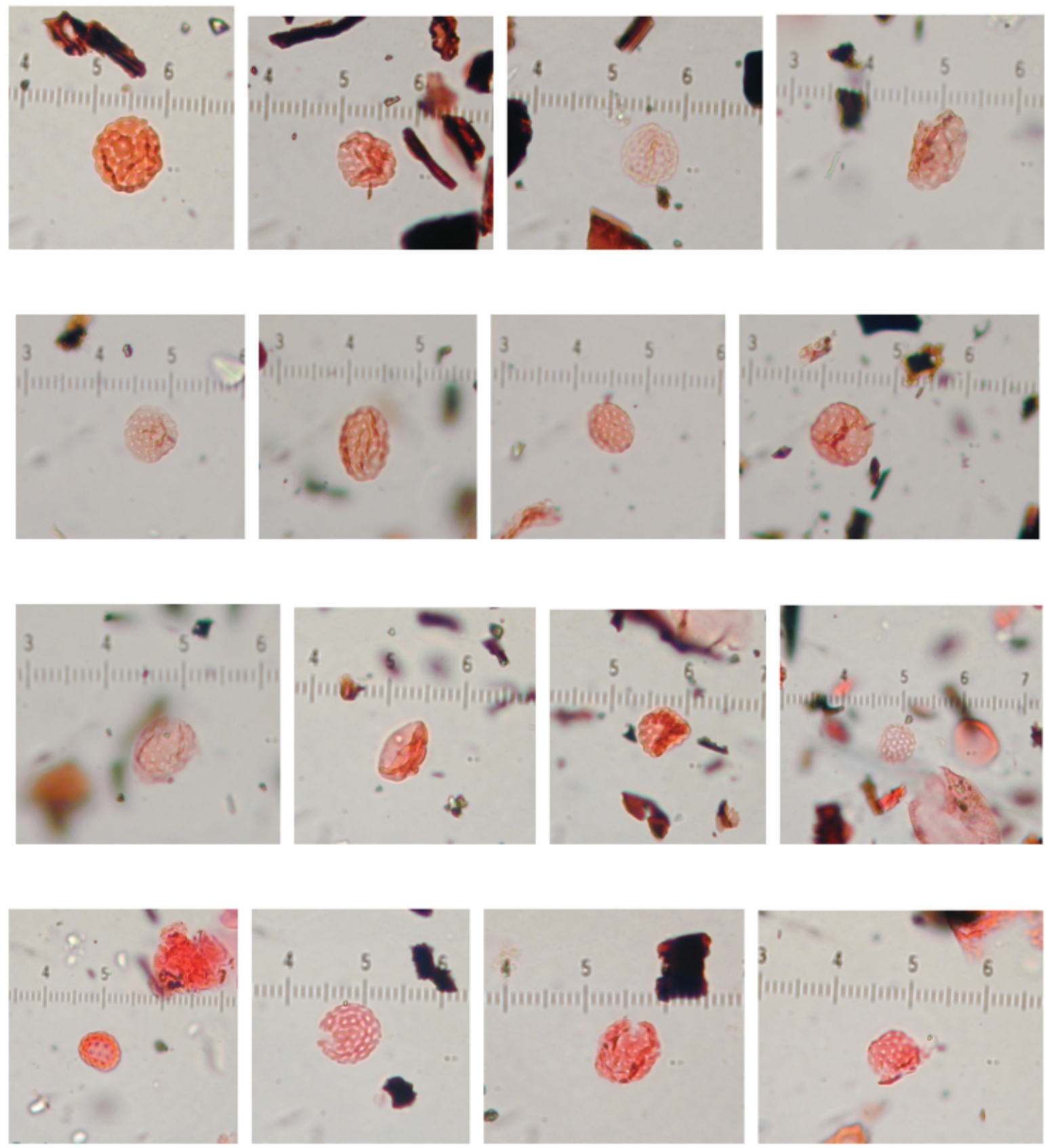

Figure B-3. Fossil Cheno-Ams Pollen Types Recovered from the Core Samples.

in coastal areas, such as the region around the Cayo del Oso Site. Finally, like the pollen from species of composites and the pollen from species of Cheno-Ams, grass pollen is fairly durable and is often recognizable in the fossil record even though the grains have become severely degraded, as noted by Bryant and Hall (1993).

Ephedra: Ephedra plants grow well in hot climates where water is at a premium. They can also grow at various altitudes, which make them a common plant throughout many of the arid regions in the western portion of the United States. However, even though joint fir pollen was found in two of the 23 samples, I doubt any of that pollen came from local sources (Figure B-5). That suggests that the wind-dispersed grains of joint fir pollen probably came from some far distant source before being deposited in the pond where the core samples were collected. It is also important to remember that Bryant and Hall (1993) note 


\section{Scale for all photos: Space between numbers is equal to 25 microns.}
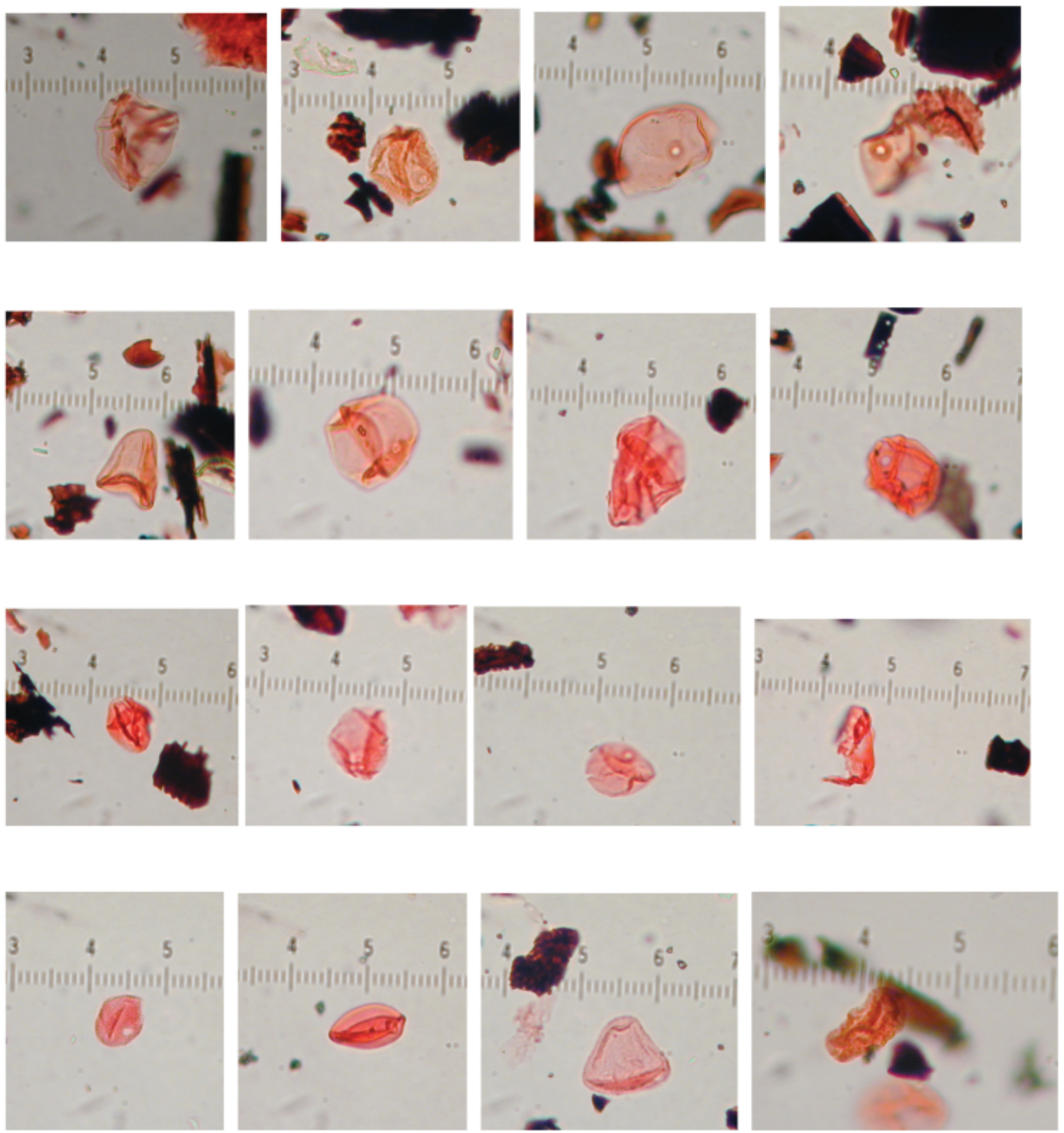

Figure B-4. Fossil Poaceae Pollen Types Recovered from the Core Samples.

that joint fir plants produce one of the most durable types of pollen grains and that it is able to survive in soils long after many fragile pollen types have become severely weathered or have completely disappeared.

Miscellaneous pollen types: There are a few other fossil pollen taxa represented in the pollen record of these core samples, some of which may reflect local parent plants (Figure B-5). Traces of prickly pear cactus (Opuntia) pollen were found in
4 of the 23 samples. Individual pollen grains from prickly pear cactus are very large and fragile. Even under "good" depositional conditions because of the fragile nature of prickly pear cactus pollen many of the grains become broken and fragmented. Once broken, many of the small pieces of prickly pear cactus pollen are still recognizable even though most of the grain has been degraded. All of the cactus pollen represented in the pollen counts of these core samples were fragments of grains rather than whole cactus pollen grains. 
Scale for all photos: Space between numbers is equal to 25 microns.

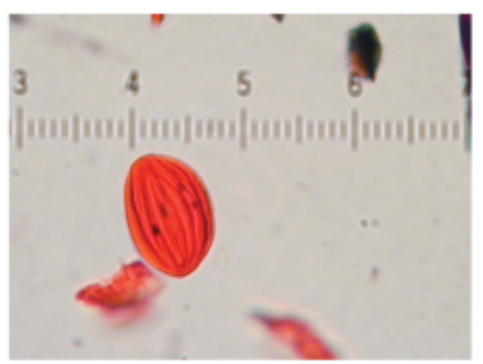

Ephedra

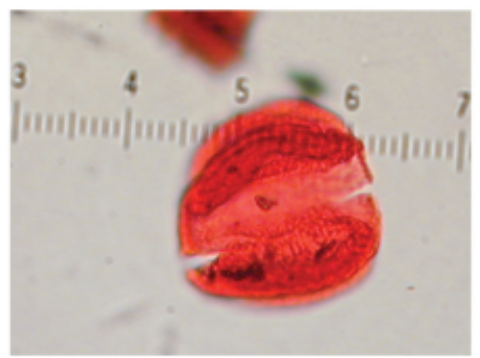

Pinus

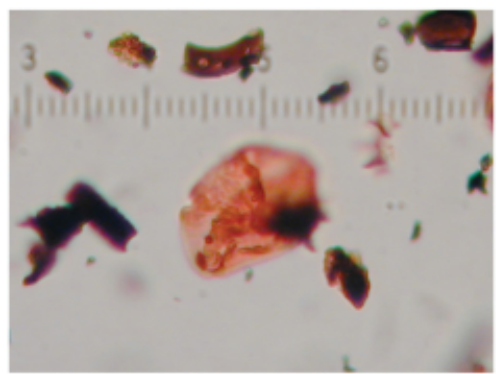

Ulmus

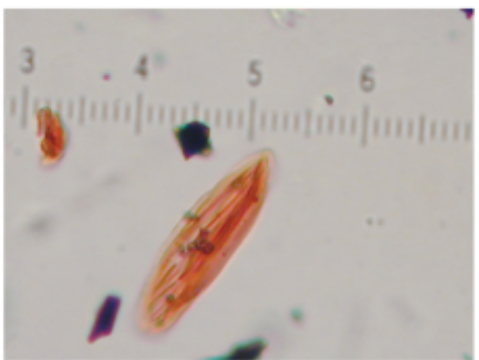

Ephedra

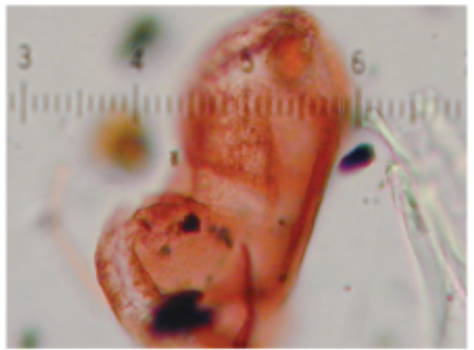

Pinus

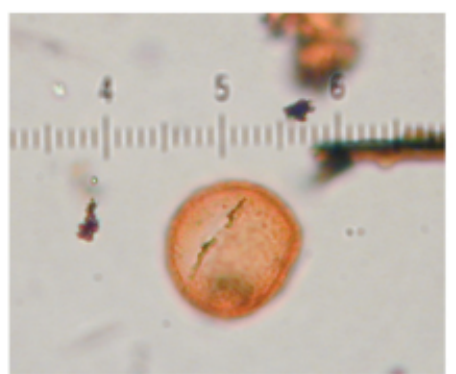

Quercus

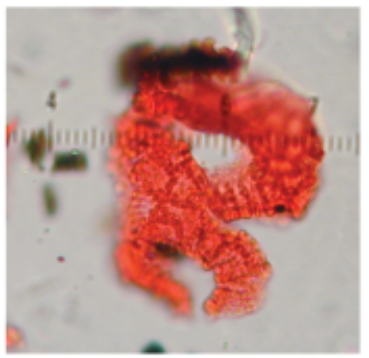

Opuntia fragments

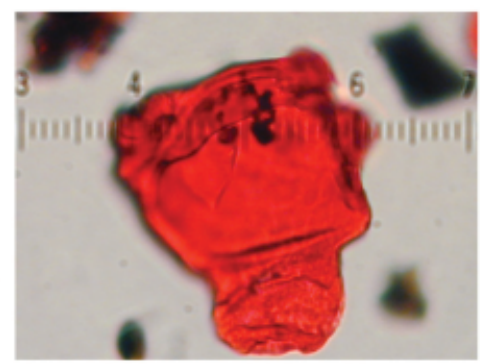

Onagraceae

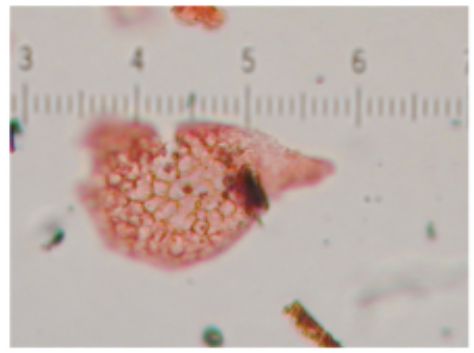

Pinus bladder

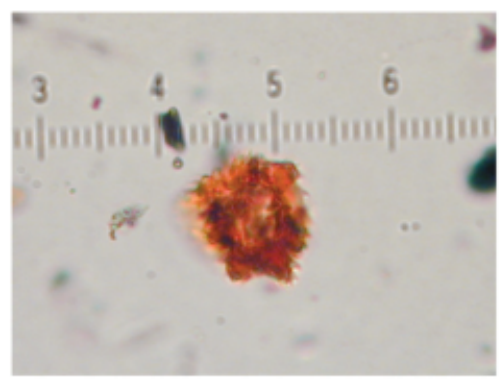

Asteraceae (dandelion type)
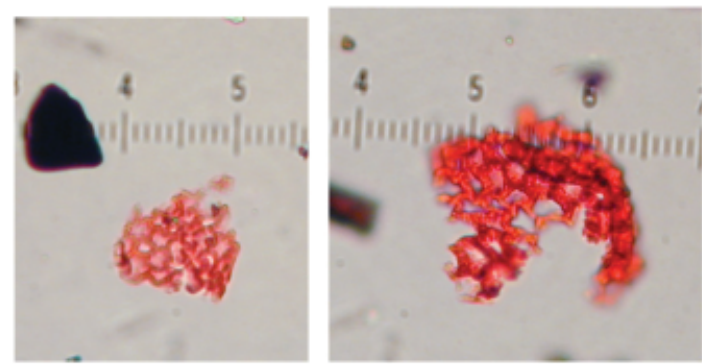

Polygonum fragments

Figure B-5. Fossil Pollen Types from Various Taxa Recovered from the Core Samples.

There were also fragments of knotweed (Polygonum) pollen found in 13 of the 23 samples. Knotweeds are common plant that grow well in disturbed areas and are common in modern agricultural fields where they are considered a weed. These plants can tolerate many different conditions, but prefers moist soils. Today they are common throughout most regions of the eastern and central North America. They are also very common throughout most areas of Texas. The pollen grains of some species of knotweed, such as those of Polygonum longistylum, have a fairly unique morphology, therefore even when the pollen grains have been broken into small fragments, many of the fragments can still be identified. The 
majority of the knotweed pollen found in the 13 core samples consisted of fragments of pollen grains rather than the whole pollen grains.

These samples contained a few pollen grains from arboreal sources such as pines, oaks, and elms. Sixteen out of the 23 samples contained at least one pine pollen grain. Pines do not grow naturally in Nueces County, the location of the core samples. However, pine trees produce copious amounts of pollen that have air sacs and are designed to travel easily on air currents. It is not uncommon for a few pine pollen grains to travel hundreds of miles from their site of dispersion. Thus, I suspect that the few pine pollen grains found in these samples are the result of long distance transport rather than coming from trees growing locally. The single oak pollen grain found in sample 180 is most probably a contaminant rather than a pollen grain that was originally deposited in the sediments of that sample. Oak trees produce large quantities of pollen that are airborne and can travel long distances. Nevertheless, because the single oak pollen grain was the only pollen grain found in sample 180 and because it was in pristine condition, I suspect that at some point it may have been incorporated into the sample, perhaps when the sub sample was being removed from the core for pollen studies. Single pollen grains of elm were found in three samples and may have come from local elm trees. Today elm trees are common in the vegetation of Nueces County and I suspect they were probably present in the region in prehistoric times as well.

\section{Summary}

Unfortunately, the recovered pollen from all of the core samples I examined reflect severe cases of pollen degradation and the probable loss of a large number of pollen taxa and pollen grains between the time the pollen rain was originally deposited and the time the samples were collected and examined for fossil pollen. When destruction of fossil pollen is as severe as it appears to be in these samples, little interpretative value can be gleaned from the resulting data. To use the pollen data otherwise would result in speculations based on unsupported assumptions.

\section{References}

Barkley, F.A.

1934 The statistical theory of pollen analysis. Ecology 47:439-447.

Brooks, J. and Shaw, G.

1968 Chemical structure of the exine of pollen walls and a new function for carotenoids in nature. Nature 219:523-524.

Bryant, V.M.

1978 Palynology: a useful method for determining paleoenvironments. Texas Journal of Science 45:1-45.

1988 Preservation of biological remains from archaeological sites. In: Interdisciplinary Workshop on the Physical-ChemicalBiological Processes Affecting Archaeological Sites (C. Mathewson, Ed.). U.S. Army Corp of Engineers Waterways Experiment Station, Vicksburg, pp. 85-115.

Bryant, V. M. and S. Hall

1993 Archaeological palynology in the USA: a critique. American Antiquity 58 (2):277-286.

Bryant, V.M. and R.G. Holloway

1983 The role of palynology in archaeology. In: Advances in Archaeological Method and Theory 6 (M. Schiffer, Ed.). Academic Press, New York, pp. 191-224.

Bryant, V. M., R. Holloway, J. Jones, \& D. Carlson

1994 Pollen preservation in alkaline soils of the American Southwest. In: Sedimentation of Organic Particles (A. Traverse, Ed.). Cambridge University Press, London. pp. 47-58. 
Bryant, V. M., \& G. Williams-Dean

1975 The coprolites of man. Scientific American 232:100-109.

Campbell, I and Campbell, C

1994 Pollen preservation: experimental wet-dry cycles in saline and desalinated sediments. Palynology 18:5-10.

Castetter, E.F.

1935 Uncultivated Native Plants used as Sources of Food. New Mexico University Bulletin, No. 266.

Chamberlin, R..V.

1911 The ethnobotany of the Gosiute Indians of Utah. Memoir of the American Anthropology Association 2:331-405.

Coil, J., M. A. Korstanje, S. Archer, and C. A. Hastorf

2003 Laboratory goals and considerations for multiple microfossil extraction in archaeology. Journal of Archaeological Science 30:991-1008.

Dean, G.

1991 Archaeobotanical analysis of pollen and phytolith samples from prehistoric structural and agricultural features at LA 2742, LA 70577, LA 71189, and LA 71190, Pot Creek Project, Taos County, New Mexico. Technical Report 303, Castetter Laboratory for Ethnobotanical Studies, Albuquerque. 38 p.

Dimbleby, G.W.

1957 Pollen analysis of terrestrial soils. New Phytologist 56:12-28.

Duhoux. E.

1982 Mechanism of exine rupture in hydrated taxoid type of pollen. Grana 21:1-7.

Elsik, W. K.

1966 Biologic degradation of fossil pollen grains and spores. Micropaleontology 12:515-518.

Erdtman, G.

1960 The acetolysis method: a revised description. Svensk Botanisk Tidskrift 54:561-564.

Fewkes, J.W.

1896 A contribution to ethnobotany. American Anthropologist 9:14-21.

Goldstein, S.

1960 Destruction of pollen by Phycomycetes. Ecology 41:543-545.

Hall, S.A.

1981 Deteriorated pollen grains and the interpretation of Quaternary pollen diagrams. Review of Paleobotany and Palynology 32:193-206.

Havinga, A.J.

1964 Investigations into the differential corrosion susceptibility of pollen and spores. Pollen et Spores 6:621-635.

1984 A 20-Year experimental investigation into the differential corrosion susceptibility of pollen and spores in various soil types. Pollen et Spores 26:541-558. 
Holloway, R.G.

1981 Preservation and experimental diagenesis of the pollen exine. Ph.D. Dissertation, Texas A\&M University (Botany), College Station, Texas, $317 \mathrm{p}$.

1989 Experimental mechanical pollen degradation and its application to Quaternary age deposits. Texas Journal of Science 41:131-145.

Hunt, C. O.

1985 Recent advances in pollen preparation techniques: a brief review. British Archaeological Review International Series (Archaeological Series) 266:181-187.

Jackson, S. T. and M. E. Lyford

1999 Pollen dispersal models in Quaternary plant ecology: assumptions, parameters, and prescriptions. The Botanical Review 65 (1): 39-75.

Jones, G. and V. Bryant

1998 Are all counts created equal? . In: New Developments in Palynomorph Sampling, Extraction, and Analysis (V. Bryant \& J. Wrenn, eds.), pp 115-120, AASP Contribution Series \# 33. American Association of Stratigraphic Palynologists, Dallas.

2001 Is one drop enough?: In: Proceedings of the IX International Palynological Congress, Houston, Texas, U.S.A., 1996, (D. K. Goodman \& R. T. Clarke, Eds.) American Association of Stratigraphic Palynologists Foundation, Dallas, pp. 483-487.

2007 A comparison of pollen counts: light versus scanning electron microscopy. Grana 46:20-33.

King, J., W.E. Klippel, and R. Duffield

1975 Pollen Preservation and Archaeology in Eastern North America. American Antiquity 40 (2):180-190.

Lentfer, C. J., M. M. Cotter, and W. E. Boyd

2003 Particle settling times for gravity sedimentation and centrifugation: a practical guide for palynologists. Journal of Archaeological Science 30:149-168

Mabberley, D. J.

1997 The Plant-Book. Cambridge Press, Cambridge, United Kingdom.

Maher, L. J. Jr.

1981 Statistics for microfossil concentration measurements employing samples spiked with marker grains. Review of Palaeobotany and Palynology 32:153-191.

Martin, P. S.

1963 The Last 10,000 Years: A Fossil Pollen Record of the American Southwest. University of Arizona Press, Tucson.

McAndrews and Swanson

1967 The pore number of periporate pollen with special references to Chenopodium. Review of Palaeobotany and Palynology 3:105-117.

Moerman, D. E.

1998 Native American ethnobotany. Timber Press. Portland, Oregon. 
O'Rourke, M.K.

1990 Pollen reentrainment: contributions to the pollen rain in an arid environment. Grana 29:147-152.

Palmer, E.

1887 Plants used by Indians of the United States. American Naturalist 12:593-606.

Reinhard, K.J., V.M. Bryant, and S. D. Vinton

2007 Interpreting the pollen data from Dos Cabezas. International Journal of Osteoarchaeology 17:531-541.

Riding, J. B. and J. E. Kyffin-Hughes

2007 Further testing of a non-acid palynological preparation procedure. Palynology 30:69-87.

Rowley, J.R. and B. Prijanto

1977 Selective destruction of the exine of pollen grains. Geophytology 7:1-23.

Rowley, J.R., J.S. Rowley and J. Skvarla

1990 Corroded exines from Havinga’s leaf mold experiment. Palynology 14:53-80.

Shaw, G.

1971 The chemistry of sporopollenin. In: Sporopollenin. (J.Brooks, P.Grant, M.Muir, P. van Gijzel, and G. Shaw, Eds.). Academic Press, New York, pp. 305-350.

Sobolik, K.

1991 Nutritional analysis of diet as revealed in prehistoric human coprolites; Texas Journal of Science, 42 (1): 23-36.

Steeves, M. W. and E. S. Barghoorn

1959 The pollen of Ephedra. Journal of the Arnold Arboretum 11:221-255.

Stock, J.A.

1983 The Prehistoric Diet of Hinds Cave (41VV456), Val Verde County, Texas: The Coprolite Evidence. M.A. Thesis, on file at the Texas A\&M University Library, College Station.

Traverse, A.

2007 Paleopalynology (2nd ed.). Springer, Dordrecht, The Neatherlands. 813 p.

Tschudy, R.H.

1969 Relationship of palynomorphs to sedimentation. In: Aspects of Palynology. (R. Tschudy \& R. Scott, Eds.). Wiley \& Sons, New York, pp. 79-96.

Uneo, J.

1958 Some palynological observations of Pinaceae. Journal of the Institute of Polytechnics, Series D, 9:163-177. 



\title{
APPENDIX C: \\ Plant Remains from 41NU2
}

\author{
J. Philip Dering \\ Shumla Archeobotanical Services \\ Comstock, Texas
}


The purpose of this analysis is to provide an assessment of the botanical assemblages from 41NU2, the Cayo del Oso site. A total of 66 flotation samples were submitted for analysis. The data will be utilized to assess the nature and condition of the plant remains from these sites and provide some evidence for plant utilization and local environmental conditions.

\section{Methods}

Flotation is a method of recovering organic remains from archeological sediments by using water to separate heavy or soluble inorganic particles from plant parts and small animal bone. The material floating to the surface is called the light fraction, and this is caught on a fine mesh screen or strainer. The material that sinks to the bottom is the heavy fraction and it is also caught on a fine mesh screen. Most of the soil including clay and silt is suspended in water and passes through the screens and is either recycled or discarded. In this study, the light fractions were submitted for analysis.

The analysis followed standard archeobotanical laboratory procedures. The volume of the light fraction is first measured. In most cases up to $100 \mathrm{ml}$ of light fraction from each sample is set aside for analysis. Then the portion to be analyzed is passed through a nested set of screens of $4 \mathrm{~mm}$, $2 \mathrm{~mm}, 1 \mathrm{~mm}$, and $0.450 \mathrm{~mm}$ mesh and examined for charred material, which is separated for identification. The heavy fraction is also scanned for charcoal, which is set aside for identification. The results are combined with identifications from each corresponding light fraction. In the current study, charred plant material was so scarce that I sorted through the entire volume of each light fraction that was submitted for analysis.

Plant material is sorted into two categories-woody fragments, and seed/fruit fragments including maize or agave parts when present. Identification of carbonized wood was accomplished by using the snap technique, examining the fragments at 8 to 45 magnifications with a hand lens or a binocular dissecting microscope, and comparing the material to samples in the archeobotanical herbarium. All seed identifications were made using seed manuals and reference collections at Shumla Archeobotanical Services. Only charred plant material is included in the analysis, because uncarbonized material is consumed by insects, fungi and bacteria and does not survive more than a few years in the deposits of open sites.

Up to 25 wood charcoal fragments large enough to be manipulated are examined and identified from each flotation sample. Fragments smaller than 2- or 3- mm are difficult to manipulate, and are usually placed in the indeterminate category. When a sample contains more than 25 fragments, the rest of the material is scanned to make sure that no other taxa are present. Then the volume of the charcoal is measured and included along with its weight in the report. Due to the scarcity of carbonized plant remains in the Cayo del Oso samples, all the charred material was examined carefully. The results for each sample are presented in tabular format.

Disturbance Indicators. Sample content may be affected by various biological disturbance factors, including insect or small mammal activity, and plant root growth. In an effort to assess this impact, the amounts of insect parts, termite pellets, gastropods, mammal remains (including fecal pellets), and modern uncharred seeds are estimated for each flotation sample. These amounts are reported on a scale of 1-5 (+), 6-25 (++), 26-50 (+++), and over 50 $(++++)$. Termite pellets occur in higher numbers when samples are taken from an area containing wood that has been exposed to the elements for a long time before burning. In the desert, this can occur in dead trees or roots, in which case the termite pellets can appear in any locus that this wood is burned, such as in a hearth or roasting pit. However, evidence of termite infestations seems to be more frequent and intense in samples drawn from the remains of burned prehistoric habitations with vertical elements constructed of wood.

\section{Results and Discussion}

Results of the analysis are presented in Tables C-1 and C-2. Table $\mathrm{C}-1$ lists the sample proveniences along with charred seed taxa counts and total charred seed counts from each sample. Identifications and counts of plant material recovered from each sample, including the macrobotanical sample, appear in Table C-2. Recovery of charred plant material in the flotation samples generally sparse. The total charcoal in each sample varied from 0 or $<.01 \mathrm{~g}$ to $1.1 \mathrm{~g}$. Disturbance indicators were abundant, and sand, usually absent from light fractions, was present in many samples. Roots and gastropods constituted the majority of the disturbance indicators, and several samples contained uncharred seeds. Some of the light fractions submitted for analysis were very small; in fact, 24 of the unsorted light fractions measured less than 10-ml, and four measured 1-ml or less.

Three samples contained seeds or fruits; seeds identified in the samples include cheno-am and prickly pear. Wood charcoal was widespread, in small quantities, throughout the samples, occurring in 36 samples. Thirty samples contained either charcoal flecks or no carbonized plant material. 
Table C-1. Flotation Sample Summary

\begin{tabular}{|c|c|c|c|c|c|c|c|c|}
\hline $\begin{array}{c}\text { Flot } \\
\text { Sample } \\
\text { Number }\end{array}$ & $\begin{array}{c}\text { FS } \\
\#\end{array}$ & Feature & $\begin{array}{c}\text { Light } \\
\text { fraction } \\
\text { vol. }(\mathrm{mL}) \text {, } \\
\text { wt. }(\mathrm{g})\end{array}$ & $\begin{array}{c}\text { Roots (r), } \\
\text { Insect } \\
\text { Parts (ip), } \\
\text { Gastropods } \\
\text { (g) }\end{array}$ & $\begin{array}{l}\text { Uncharred } \\
\text { Seeds }\end{array}$ & $\begin{array}{c}\text { Number } \\
\text { of } \\
\text { Charred } \\
\text { Seed } \\
\text { Taxa ( } \\
\text { Agave, } \\
\text { Yucca) }\end{array}$ & $\begin{array}{l}\text { Total } \\
\text { Charred } \\
\text { Seeds }\end{array}$ & $\begin{array}{c}\text { Total } \\
\text { Charcoal } \\
\text { (g) }\end{array}$ \\
\hline 1 & 7 & 1 & $27 ; 1.9$ & r+++ & 0 & 0 & 0 & 0 \\
\hline 2 & 48 & 9 & $17 ; 3.6$ & sand & 0 & 0 & 0 & $<0.1$ \\
\hline 3 & 65 & 13 & $35,7.7$ & $\mathrm{r+++}$ (sand) & 0 & 0 & 0 & $<0.1$ \\
\hline 4 & 73 & 14 & $10 ; 3.1$ & r+++ & 0 & 0 & 0 & 0.1 \\
\hline 5 & 128 & 40 & $4 ; 0.1$ & sand & 0 & 0 & 0 & 0 \\
\hline 6 & 144 & 48 & $6 ; 0.7$ & rt++ & 0 & 0 & 0 & 0.2 \\
\hline 7 & 147 & 51 & $30 ; 7.2$ & sand & 0 & 0 & 0 & 0.2 \\
\hline 8 & 149 & 53 & $8.2 ; 41$ & $\begin{array}{l}\mathrm{g}++++ \\
\text { (sand) }\end{array}$ & 0 & 0 & 0 & $<0.1$ \\
\hline 9 & 154 & 54 & $24 ; 6.5$ & $\mathrm{r+++}, \mathrm{g+}$ & 0 & 0 & 0 & 1.1 \\
\hline 10 & 155 & 54 & $2 ;<1$ & sand & 0 & 0 & 0 & 0 \\
\hline 11 & 175 & 61 & $12 ; 2.7$ & $r+++$ & 0 & 0 & 0 & $<0.1$ \\
\hline 12 & 199 & 73 & $31 ; 16.2$ & $\begin{array}{l}\text { g+++, } \\
\text { (sand) }\end{array}$ & 0 & 0 & 0 & 0 \\
\hline 13 & 209 & 75 & $33 ; 8.3$ & $r++, g+++$ & 1 & 0 & 0 & $<0.1$ \\
\hline 14 & 222 & 74 & $37 ; 2.2$ & $\mathrm{r}+, \mathrm{g}++$ & 0 & 0 & 0 & 0.2 \\
\hline 15 & 227 & 78 & $15 ; 1.2$ & $\mathrm{r}^{+++}, \mathrm{g}+$ & 0 & 0 & 0 & $<0.1$ \\
\hline 16 & 232 & 84 & $29 ; 7.4$ & $\mathrm{r+++}, \mathrm{g}+$ & 0 & 0 & 0 & 0 \\
\hline 17 & 238 & 57 & $18 ; 1.6$ & $\mathrm{r+++}, \mathrm{g}+$ & 0 & 0 & 0 & 0 \\
\hline 18 & 239 & 57 & $12 ; 3.6$ & $\mathrm{rt++} ; \mathrm{g}^{+}$ & 0 & 1 & 1 & $<0.1$ \\
\hline 19 & 240 & 88 & $12 ; .8$ & $\mathrm{r+++}$ & 0 & 0 & 0 & 0 \\
\hline 20 & 242 & 89 & $24 ; 0.8$ & r+++ & 0 & 0 & 0 & 0 \\
\hline 21 & 246 & 90 & $6 ; 0.6$ & $\mathrm{r++++}$ (sand) & 0 & 0 & 0 & 0 \\
\hline 22 & 249 & 92 & $17 ; 3.9$ & $\mathrm{rt++}, \mathrm{g}+$ & 0 & 0 & 0 & 0 \\
\hline 23 & 251 & 93 & $12 ; .4$ & $\mathrm{r+++}$ & 0 & 0 & 0 & 0.1 \\
\hline 24 & 252 & 94 & $4 ; 0.8$ & $\mathrm{rt++}, \mathrm{g}+$ & 0 & 0 & 0 & 0 \\
\hline 25 & 260 & 99 & $24 ; 4.1$ & $\mathrm{r+++}$ & 0 & 0 & 0 & $<0.1$ \\
\hline 26 & 261 & 100 & $15.4 ; 97$ & $\mathrm{r+++}, \mathrm{g+}$ & 0 & 0 & 0 & 0.1 \\
\hline 27 & 270 & 65 & $87 ; 9.3$ & $\mathrm{r+++} ; \mathrm{g}^{+}$ & 0 & 0 & 0 & $<0.1$ \\
\hline 28 & 275 & 102 & $54 ; 13.2$ & $\mathrm{r+++} ; \mathrm{g}^{+}$ & 0 & 0 & 0 & $<0.1$ \\
\hline 29 & 276 & 102 & $79 ; 16.2$ & $\mathrm{r+++}, \mathrm{g}++$ & 0 & 0 & 0 & 0.2 \\
\hline 30 & 332 & 121 & $4 ; 3.1$ & $\mathrm{~g}+$ & 0 & 0 & 0 & $<0.1$ \\
\hline 31 & 333 & 121 & $6 ; .2$ & $\mathrm{~g}+$ & 0 & 0 & 0 & $<0.1$ \\
\hline 32 & 341 & 125 & $14 ; 7.1$ & $\mathrm{r+++}$ & 0 & 0 & 0 & $<0.1$ \\
\hline 33 & 400 & 136 & $8 ; 0.9$ & $\mathrm{r+++}($ sand $)$ & 0 & 0 & 0 & 0 \\
\hline 34 & 391 & 133 & $17 ; 0.7$ & $\mathrm{r+++}, \mathrm{g}+$ & 0 & 0 & 0 & 0 \\
\hline 35 & 452 & 140 & $4 ; 0.2$ & $\mathrm{r+++}$ & 0 & 0 & 0 & 0 \\
\hline 36 & 457 & 141 & $3 ; 03$ & $\mathrm{r+++}($ sand $)$ & 0 & 0 & 0 & 0 \\
\hline 37 & 434 & 139 & $19 ; 1.2$ & $\mathrm{r+++}, \mathrm{g}+$ & 0 & 0 & 0 & 0 \\
\hline 38 & 462 & 144 & $0.8 ;<0.1$ & $r+++$ & 0 & 0 & 0 & 0 \\
\hline 39 & 459 & 143 & $12 ; 0.6$ & $\mathrm{r+++}$ & 0 & 0 & 0 & $<0.1$ \\
\hline 40 & 313 & $? ? ?$ & $12 ; 1.6$ & $\mathrm{r+++}, \mathrm{g}+$ & 0 & 0 & 0 & $<0.1$ \\
\hline 41 & 319 & 114 & $100 ; 8.8$ & $\mathrm{r+++}, \mathrm{g}+$ & 0 & 0 & 0 & 0.5 \\
\hline 42 & 321 & 117 & $100 ; 8.1$ & $\mathrm{r+++}, \mathrm{g}+++$ & 0 & 0 & 0 & $<.1$ \\
\hline
\end{tabular}


Table C-1. Continued...

\begin{tabular}{|c|c|c|c|c|c|c|c|c|}
\hline $\begin{array}{c}\text { Flot } \\
\text { Sample } \\
\text { Number }\end{array}$ & $\begin{array}{c}\text { FS } \\
\#\end{array}$ & Feature & $\begin{array}{c}\text { Light } \\
\text { fraction } \\
\text { vol. }(\mathrm{mL}) \text {, } \\
\text { wt. }(\mathrm{g})\end{array}$ & $\begin{array}{c}\text { Roots (r), } \\
\text { Insect } \\
\text { Parts (ip), } \\
\text { Gastropods } \\
\text { (g) }\end{array}$ & $\begin{array}{c}\text { Uncharred } \\
\text { Seeds }\end{array}$ & $\begin{array}{c}\text { Number } \\
\text { of } \\
\text { Charred } \\
\text { Seed } \\
\text { Taxa ( } \\
\text { Agave, } \\
\text { Yucca) }\end{array}$ & $\begin{array}{c}\text { Total } \\
\text { Charred } \\
\text { Seeds } \\
\end{array}$ & $\begin{array}{c}\text { Total } \\
\text { Charcoal } \\
\text { (g) }\end{array}$ \\
\hline 43 & 474 & 147 & $97 ; 9.8$ & $\mathrm{r+++}($ sand $)$ & 4 & 0 & 0 & 0.1 \\
\hline 44 & 485 & 149 & $6 ; 0.3$ & $\mathrm{r+++}$ & 0 & 0 & 0 & $<0.1$ \\
\hline 45 & 488 & 150 & $17 ; 2.0$ & $\mathrm{r+++}$ (sand) & 0 & 0 & 0 & $<0.1$ \\
\hline 46 & 497 & 152 & $3 ; 0.2$ & $\mathrm{r+++}$ & 0 & 0 & 0 & 0 \\
\hline 47 & 494 & 151 & $27 ; 12.7$ & $\mathrm{r+++}, \mathrm{g}++$ & 0 & 0 & 0 & 0 \\
\hline 48 & 505 & 155 & $14 ; 3.2$ & $\mathrm{r+++}, \mathrm{g}+$ & 4 & 0 & 0 & 0 \\
\hline 49 & 507 & 156 & $19 ; 1.2$ & $\mathrm{r+++}$ & 2 & 1 & 1 & $<0.1$ \\
\hline 50 & 510 & 157 & $3 ; 0.1$ & $\mathrm{r+++}$ & 0 & 0 & 0 & 0 \\
\hline 51 & 511 & 158 & $<0.1 ;<0.1$ & sand & 0 & 0 & 0 & 0 \\
\hline 52 & 514 & 159 & $20 ; 1.1$ & $\mathrm{r+++}$ & 0 & 0 & 0 & 0 \\
\hline 53 & 502 & 154 & $5 ; 0.7$ & $\mathrm{r+++}, \mathrm{g}+$ & 0 & 0 & 0 & 0 \\
\hline 54 & 516 & 161 & $15 ; 1.3$ & $\mathrm{r+++}$ & 0 & 0 & 0 & 0 \\
\hline 55 & 519 & 162 & $2 ;<0.1$ & $\mathrm{r+++}$ & 0 & 0 & 0 & 0 \\
\hline 56 & 524 & 163 & $21 ; 1.3$ & $\mathrm{r+++}, \mathrm{l++}$ & 0 & 0 & 0 & 0 \\
\hline 57 & 530 & 164 & $22 ; 2.2$ & $\mathrm{r+++}$ & 0 & 0 & 0 & $<0.1$ \\
\hline 58 & 532 & 165 & $12 ; 2.1$ & $\mathrm{r+++}$ & 1 & 0 & 0 & 0.2 \\
\hline 59 & 551 & 170 & $4 ; .3$ & $\mathrm{r}+($ sand $)$ & 0 & 0 & 0 & 0 \\
\hline 60 & 534 & 166 & $8 ; 1.3$ & $\mathrm{r+++}$ & 0 & 0 & 0 & 0 \\
\hline 61 & 536 & 167 & $7 ; 0.3$ & $\mathrm{r+++}, \mathrm{g}+$ & 0 & 0 & 0 & $<0.1$ \\
\hline 62 & 541 & 168 & $32 ; 4.1$ & $\mathrm{r+++}$ & 0 & 0 & 0 & 0.2 \\
\hline 63 & 546 & 169 & $1 ; 0.2$ & sand & 0 & 0 & 0 & 0 \\
\hline 64 & 248 & 92 & $17 ; 0.8$ & $\mathrm{r+++}$ & 0 & 0 & 0 & 0.2 \\
\hline 65 & 477 & 148 & $0.5 ;<0.1$ & $\mathrm{r}+$ & 0 & 0 & 0 & $<0.1$ \\
\hline 66 & 499 & 153 & $7 ; 1.1$ & $\mathrm{r+++}, \mathrm{g}+$ & 0 & 0 & 0 & 0 \\
\hline
\end{tabular}

\section{Taxa Summaries: Wood}

Five wood taxa, mesquite (Prosopis glandulosa), woody legume (Prosopis or Acacia spp.), lotebush (Ziziphus obtusifolia), oak (Quercus sp.), and brasil (Condalia sp.) were identified in the samples, as noted in Table C-2. Woody legume is a general wood type that includes both mesquite and several species of acacia. The wood anatomy of these trees or shrubs is similar and often small fragments of charcoal are difficult to distinguish. In addition to the identified material several very small fragments of wood were placed in the indeterminate category. Two of these wood types, oak and mesquite, have been recorded in archeological sites and ethnographic or historic records. Brasil and lotebush were likely used for wood, and lotebush produces a small, edible fruit, but we have no ethnographic mention of their use by Native Americans.

These taxa are typical components of Taumalipan Thornscrub vegetation which dominates the clay dunes and sand sheets of the Texas and Mexican coastal plain from the Coastal Bend to southern Tamaulipas, Mexico.

Mesquite and Woody Legume. Carbonized mesquite wood fragments were identified in five features and woody legume in 14 features. Unfortunately, no seeds or pod fragments were found in samples from 41NU2. Very few flotation samples have been examined from sites located in the Coastal Bend or southern Texas. Perhaps for this reason, archeologists have not recovered much evidence for the use of mesquite as food in southern Texas. However, mesquite seeds have been identified from three sites in Maverick County near Eagle Pass, 41MV136, 41MV160, and 41MV164 (Dering 2005). Mesquite charcoal has been identified from the Hinojosa site in Jim Wells County (Jones 1986). Mesquite wood charcoal also has been identified from several sites in southern Texas, including 41ZP364 in Zapata County and the Lino site in Webb County, (Dering 2000a and b). 
Table C-2. Plant Remains Ordered by Feature Number

\begin{tabular}{|c|c|c|c|c|c|c|c|}
\hline $\begin{array}{c}\text { Flot } \\
\#\end{array}$ & FS \# & Feature & Taxon & Common & Part & Count & $\begin{array}{l}\text { Wt } \\
(\mathrm{g})\end{array}$ \\
\hline 1 & 7 & 1 & No carbonized plant remains & & & & \\
\hline 2 & 48 & 9 & Indeterminate & NA & Wood & 1 & $<0.1$ \\
\hline 3 & 65 & 13 & Fabaceae & Woody legume & Wood & 2 & $<0.1$ \\
\hline 4 & 73 & 14 & Fabaceae & Woody legume & Wood & 10 & 0.1 \\
\hline 5 & 128 & 40 & No carbonized plant remains & & & & \\
\hline 6 & 144 & 48 & Fabaceae & Woody legume & Wood & 11 & 0.2 \\
\hline 7 & 147 & 51 & Fabaceae & Woody legume & Wood & 14 & 0.2 \\
\hline 8 & 149 & 53 & Indeterminate & NA & Wood & 3 & $<0.1$ \\
\hline 9 & 154 & 54 & Fabaceae & Woody legume & Wood & 24 & 1.1 \\
\hline 10 & 155 & 54 & No carbonized plant remains & & & & \\
\hline 11 & 175 & 61 & Indeterminate & NA & Wood & 1 & $<0.1$ \\
\hline 12 & 199 & 73 & No carbonized plant remains & & & & \\
\hline 13 & 209 & 75 & Cheno-am & $\begin{array}{l}\text { Chenopodium or } \\
\text { Amaranthus }\end{array}$ & Seed (fruit) & 1 & $<0.1$ \\
\hline 13 & 209 & 75 & Fabaceae & Woody legume & Wood & 5 & $<0.1$ \\
\hline 13 & 209 & 75 & Indeterminate & NA & Wood & 24 & $<0.1$ \\
\hline 14 & 222 & 74 & Indeterminate & NA & Wood & 22 & $<0.1$ \\
\hline 14 & 222 & 74 & Quercus sp. & Oak & Wood & 9 & 0.1 \\
\hline 15 & 227 & 78 & Fabaceae & Woody legume & Wood & 3 & $<0.1$ \\
\hline 16 & 232 & 84 & No carbonized plant remains & & & & \\
\hline 17 & 238 & 57 & No carbonized plant remains & & & & \\
\hline 18 & 239 & 57 & Cheno-am & $\begin{array}{l}\text { Chenopodium or } \\
\text { Amaranthus }\end{array}$ & Seed (fruit) & 1 & $<0.1$ \\
\hline 18 & 239 & 57 & Indeterminate & NA & Wood & 5 & $<0.1$ \\
\hline 19 & 240 & 88 & No carbonized plant remains & & & & \\
\hline 20 & 242 & 89 & No carbonized plant remains & & & & \\
\hline 21 & 246 & 90 & No carbonized plant remains & & & & \\
\hline 22 & 249 & 92 & No carbonized plant remains & & & & \\
\hline 23 & 251 & 93 & Indeterminate & NA & Wood & 5 & 0.1 \\
\hline 24 & 252 & 94 & No carbonized plant remains & & & & \\
\hline 25 & 260 & 99 & Fabaceae & Woody legume & Wood & 6 & $<0.1$ \\
\hline 25 & 260 & 99 & Indeterminate & ??????????? & ??????? & 1 & $<0.1$ \\
\hline 26 & 261 & 100 & Indeterminate & NA & Wood & 13 & 0.1 \\
\hline 27 & 270 & 65 & Indeterminate & $\mathrm{NA}$ & ??????? & & $<0.1$ \\
\hline 28 & 275 & 102 & Indeterminate & $\mathrm{NA}$ & Wood & 8 & $<0.1$ \\
\hline 28 & 275 & 102 & Zea mays? & Maize & Cupule? & 1 & $<0.1$ \\
\hline 29 & 276 & 102 & Indeterminate & NA & Wood & 6 & $<0.1$ \\
\hline 29 & 276 & 102 & Prosopis glandulosa & Mesquite & Wood & 11 & 0.2 \\
\hline 29 & 276 & 102 & Ziziphus obtusifolia & Lotebush & Wood & 3 & $<0.1$ \\
\hline 30 & 332 & 121 & Indeterminate & $\mathrm{NA}$ & Wood & 7 & $<0.1$ \\
\hline 31 & 333 & 121 & Fabaceae & Woody legume & Wood & 8 & $<0.1$ \\
\hline 32 & 341 & 125 & Fabaceae & Woody legume & Wood & 11 & $<0.1$ \\
\hline 33 & 400 & 136 & No carbonized plant remains & & & & \\
\hline 34 & 391 & 133 & No carbonized plant remains & & & & \\
\hline 35 & 452 & 140 & No carbonized plant remains & & & & \\
\hline 36 & 457 & 141 & No carbonized plant remains & & & & \\
\hline 37 & 434 & 139 & No carbonized plant remains & & & & \\
\hline
\end{tabular}


Table C-2. Continued...

\begin{tabular}{|c|c|c|c|c|c|c|c|}
\hline $\begin{array}{c}\text { Flot } \\
\#\end{array}$ & FS \# & Feature & Taxon & Common & Part & Count & $\begin{array}{l}\text { Wt } \\
\text { (g) }\end{array}$ \\
\hline 38 & 462 & 144 & No carbonized plant remains & & & & \\
\hline 39 & 459 & 143 & Fabaceae & Woody legume & Wood & 1 & $<0.1$ \\
\hline 40 & 313 & ??? & Indeterminate & NA & Wood & 6 & $<0.1$ \\
\hline 41 & 319 & 114 & Prosopis glandulosa & Mesquite & Wood & 14 & 0.5 \\
\hline 42 & 321 & 117 & Fabaceae & Woody legume & Wood & 5 & $<0.1$ \\
\hline 42 & 321 & 117 & Indeterminate & NA & Wood & 18 & $<0.1$ \\
\hline 43 & 474 & 147 & Indeterminate & NA & Wood & & 0.1 \\
\hline 44 & 485 & 149 & Indeterminate & NA & Wood & 1 & $<0.1$ \\
\hline 45 & 488 & 150 & Indeterminate & NA & Wood & 2 & $<0.1$ \\
\hline 46 & 497 & 152 & No carbonized plant remains & & & & \\
\hline 47 & 494 & 151 & No carbonized plant remains & & & & \\
\hline 48 & 505 & 155 & No carbonized plant remains & & & & \\
\hline 49 & 507 & 156 & Opuntia sp. & Prickly Pear & Seed & 1 & $<0.1$ \\
\hline 49 & 507 & 156 & Prosopis glandulosa & Mesquite & Wood & 5 & $<0.1$ \\
\hline 50 & 510 & 157 & No carbonized plant remains & & & & \\
\hline 51 & 511 & 158 & No carbonized plant remains & & & & \\
\hline 52 & 514 & 159 & No carbonized plant remains & & & & \\
\hline 53 & 502 & 154 & No carbonized plant remains & & & & \\
\hline 55 & 519 & 162 & No carbonized plant remains & & & & \\
\hline 56 & 524 & 163 & No carbonized plant remains & & & & \\
\hline 57 & 530 & 164 & Indeterminate & NA & Indeterminate & 4 & $<0.1$ \\
\hline 58 & 532 & 165 & Prosopis glandulosa & Mesquite & Wood & 22 & 0.2 \\
\hline 58 & 532 & 165 & Condalia sp. & Brasil & Wood & 3 & $<0.1$ \\
\hline 59 & 551 & 170 & No carbonized plant remains & & & & \\
\hline 60 & 534 & 166 & No carbonized plant remains & & & & \\
\hline 61 & 536 & 167 & Fabaceae & Woody legume & Wood & 2 & $<0.1$ \\
\hline 62 & 541 & 168 & Prosopis glandulosa & Mesquite & Wood & 13 & 0.2 \\
\hline 63 & 546 & 169 & No carbonized plant remains & & & & \\
\hline 64 & 248 & 92 & Fabaceae & Woody legume & Wood & 6 & 0.1 \\
\hline 64 & 248 & 92 & Indeterminate & NA & Wood & 9 & 0.1 \\
\hline 65 & 477 & 148 & Indeterminate & NA & Wood & 2 & $<0.1$ \\
\hline 66 & 499 & 153 & No carbonized plant remains & & & & \\
\hline
\end{tabular}

Throughout its distribution, mesquite was a vital resource for food, fuel, medicine, and implement-making. Cabeza de Vaca, traveling through either southern Texas or northern Mexico in the 1520's, is the first European to observe and record the use of mesquite by Native Americans. While he was living among the Cuchendados, he observed how they prepared mesquite pods for food. They dug a pit and filled it with pods, and then pounded them with a wooden pestle as thick as a man's thigh. They mixed the pod meal with handfuls of earth and consumed it raw, discarding the seeds and woody casings (Campbell and Campbell 1981; Krieger 2002).

Oak. Oak wood was identified in single sample from Feature 74. Oaks grow in small, densely packed mottes on sandy soils in the region. The most common of these, Quercus fusiformis, also grows on the Edwards Plateau and adjacent South Texas Plains.

Cabeza de Vaca did not mention the use of oak or acorns in his account, however, oak wood is a very common component in archeological sites on and near the Edwards Plateau. In samples I analyzed from 41BX100 a small heating feature contained over 50 charred acorn cotyledons (Dering 2001). The presence of oak in the Cayo del Oso samples suggests that it was used for firewood, and it is possible that acorns also were harvested in the area. However, because of the small size of the oak mottes and abundance of other food resources, oak probably was not a staple or even a preferred food. 
Brasil and Lotebush. Both brasil (Condalia sp.) and lotebush (Ziziphus obtusifolia) were identified in the Cayo del Oso samples. Some species of Condalia (brasil) produce small edible fruit, and the wood provides an adequate source of fuel. Lotebush produces a small edible fruit that was utilized by Native Americans across the greater Southwest.

The small wood fragments recovered from Feature 165 were likely used as fuel in a small heating feature. They constitute the first identification of brasil from an archeological site in southern Texas. However, Condalia seeds were noted in 3,000 year-old deposits in the well-preserved rockshelter deposits of Hinds Cave in the Lower Pecos, located on the far western edge of the South Texas Plains (Dering 1979). The Maricopa, Mohave, and Pima gathered lotebush fruits and ate them raw or boiled them into a syrup (Castetter and Bell 1951; Curtin 1984; Russell 1908).

\section{Seeds and Other Plant Parts}

Cheno-am. Many plants of the two genera Chenopodium (goosefoot) and Amaranthus (pigweed or amaranth) produce seeds that are quite similar and difficult to separate, especially when carbonized or partially decomposed. They also have similar growth habits and economic uses. When seeds are recovered that could be identified to either genus, the term "cheno-am" is used (cf. Adams 1994:177). Thererfore, Cheno-am refers to the seed-like fruit of either goosefoot (Chenopodium) or pigweed (Amaranthus). When the fruit has been modified by charring it is often difficult or impossible to identify to the genus level, and it is placed in the artificial category cheno-am. Both plants were utilized in a similar fashion, and both contributed fruit and greens to the diet of Native Americans throughout the greater Southwest. Several charred seeds identified as Chenopodium berlandieri were recovered from Late Prehistoric contexts at the Hinojosa Site (41JW8) in Jim Wells County (Jones 1986), and more recently cheno-am seeds were noted in samples from 41MV164 in Maverick County near Eagle Pass (Dering 2006).

Prickly pear. A carbonized prickly pear seed was recovered from Feature 156. In southern Texas the most common species of prickly pear is Opuntia engelmannii, which can grow into dense stands covering large tracts of land, although the largest stands are inland. On the coast, prickly pear can grow dense enough to provide shelter for wildlife. Prickly pear seeds have been recovered from 41UV68 in Uvalde County and 41MV164 in Maverick County (Dering 2006a and b). Cabeza de Vaca, the first European to cross Texas in the $16^{\text {th }}$ century, observed that the Native Americans would squeeze the juice out of the fruit and dry the pulp and skin (Covey 1983). The stems or pads were also edible, and could be gathered and baked in an earth oven.
Indeterminate. A single carbonized plant fragment from Feature 102 has the appearance of a small maize cupule fragment. It measures about 3-mm by 1-mm and has a corky tissue adhering to one side. I can not confirm its identity, however, because it is small and fragmentary and because other parts of plants, either vegetative or reproductive, can resemble small eroded cupules. The location of this site, potentially within the Gilmore corridor, makes it necessary to mention this fragment. But I doubt that we can confirm its identity, and a single maize cupule can not demonstrate the presence of the Gilmore corridor.

\section{Conclusion}

The ephemeral nature of the occupations, the clay dunes and sand sheets, and the alkaline nature of the soils do not provide a good preservation environment for carbonized plant remains. Most of the 66 light fractions submitted for analysis were unusually small, and disturbance indicators, especially roots, were abundant. Of the 66 samples, 30 contain no carbonized plant material or only unidentifiable charcoal flecks. Three samples contain seeds, and one sample contains a fragment that resembles a maize cupule. However, small vegetative parts of plants can sometimes resemble maize cupules.

The wood charcoal is represented by five taxa, mesquite (Prosopis glandulosa), woody legume (Prosopis or Acacia spp.), lotebush (Ziziphus obtusifolia), oak (Quercus sp.), and brasil (Condalia sp.). This is the first report of brasil and lotebush wood from a southern Texas site. Two seed taxa, prickly pear and cheno-am also were identified in the samples, as noted in Table C-2. They provide the first direct archeological evidence for the use of cheno-ams and prickly pear on the middle Texas coast. The data, while sparse and not easily recovered, provide the first direct glimpse into plant use on the middle Texas coast. The presence of chenoam seeds (fruits) is particularly interesting given its long history of use in both Mesoamerica and North America, and it adds another dimension to our understanding of land use in the Coastal Bend.

The taxa represented in the features are indicative of a local vegetation dominated by elements of the Tamaulipan Thornscrub. These elements include mesquite, several species of acacia, lotebush, brasil, prickly pear on the clay dunes, and oak on the sandy soils. Some other woody species, such as the Texas sabal palm, may have grown nearby, but I do not have direct evidence for its presence. It is likely that the area around Cayo del Oso has had similar taxa growing on it for the past 3,000 years. 


\section{References}

Adams, K.

1994 Macrobotanical Analyses. In The Roosevelt Rural Sites Study: Changing Land Use in the Tonto Basin, Volume 3, edited by Richard Ciolek-Torello and John R. Welch, pp. 167-188. Statistical Research Technical Series No. 28. Tucson, Arizona

Bell, W., and E. Castetter

1941 Ethnobiological Studies in the American Southwest. Vol. VII. The Utilization of Yucca, Sotol, and Beargrass by the Aborigines in the American Southwest. University of New Mexico bulletin, Biological Series 5(5).

Bell, Willis H. and Edward F. Castetter

1937 The Utilization of Mesquite and Screwbean by the Aborigines in the American Southwest. Ethnobiological Studies in the American Southwest, vol. V. The University of New Mexico Bulletin 5 (2). University of New Mexico Press Albuquerque, New Mexico.

Campbell, Thomas N. and T. J. Campbell

1981 Historic Indian Groups of the Choke Canyon Reservoir and Surrounding Area, Southern Texas. Choke Canyon Series, Vol. 1, Center for Archaeological Research, the University of Texas at San Antonio.

Castetter E. F., and Morris Opler

1936 The Ethnobiology of the Chiricahua and Mescalero Apache. A. The Use of Plants for Foods, Beverages, and Narcotics.

Ethnobiological Studies in the American Southwest. Vol. III. The University of New Mexico Bulletin, Biological Series 4(5). Albuquerque.

Dering, J.P.

2001 Plant Remains from 41BX100. Report submitted to the Texas Archeological Research Laboratory, The University of Texas. Austin, Texas.

2006a Macrobotanical Remains from 41MV164. Report submitted to GTI Environmental Company. Austin, Texas.

2006b Macrobotanical Remains from 41UV68. Report submitted to Hicks and Company. Austin, Texas.

\section{Felger, R.S.}

1977 Mesquite in Indian Cultures of Southwestern North America. In Mesquite: Its Biology in Two Desert Ecosystems, edited by B.B. Simpson, pp. 150-176. Dowden, Hutchinson, and Ross, Inc., Stroudsburg, Pennsylvania.

Jones, J.G.

1986 Macrobotanical Materials. In The Clemente and Herminia Hinojosa Site, 41JW8: A Toyah Horizon Campsite in Southern Texas, by Stephen L. Black, pp. 137- 144. Center for Archaeological Research, Special Report No. 18. The University of Texas at San Antonio. San Antonio, Texas.

Krieger, Alex D.

2002 We Came Naked and Barefoot: The Journey of Cabeza de Vaca across North America. University of Texas Press. Austin. 


\title{
APPENDIX D: \\ Diatom Paleoenvironmental Analysis of Core Sediments from the Cayo Del Oso Site, 41NU2, Nueces County, Texas
}

\author{
Barbara Winsborough \\ Winsborough Consulting \\ Leander, Texas
}




\section{Introduction}

Diatoms are single celled algae with a siliceous cell wall. They grow in aerophilous settings, such as damp soils, wet plants and rocks, marshes, wetlands and mudflats as well as in all types of standing and flowing aquatic habitats. Their silica cells are often preserved in sedimentary deposits if water chemistry allows. Because individual taxa have specific requirements and preferences with respect to water chemistry, hydrologic conditions and substrate characteristics, diatoms are used as proxy indicators to reconstruct the paleoenvironmental and climatic changes throughout the Holocene. Fossil diatoms in lake sediments can provide sensitive high-resolution records of salinity and lake level changes, which are mainly associated with fluctuations in climate conditions such as precipitation and evaporation rates. These data are particularly useful when coupled with input about local geology and hydrology, soil characteristics, pollen, and phytoliths.

This study is part of an interdisciplinary investigation of the Cayo Del Oso Site, 41NU2. The site, a prehistoric campsite and cemetary, is located along the northwestern shore of Oso Bay from the area north of the mouth of an unnamed drainage to the shore of Corpus Christi Bay immediately west of Oso Bay. Surface and near-surface geology in the vicinity of the site consists of Holocene clay dune deposits, the Pleistocene Beaumont Clay Formation, and ephemeral ponds that developed between dune deposits and the Beaumont ridge.

The goal of this investigation is to provide information that contributes to reconstruction of the paleo-climate profile and environmental setting at the time of occupation. In the present study a total of 51 sediment samples from three cores collected at 41NU2 were submitted to Winsborough Consulting for diatom analysis. This report details the results of these analyses.

\section{Methods}

Samples were cleaned of organic material and acid-soluble minerals in preparation for microscopic analysis by boiling first in hydrogen peroxide and then in hydrochloric acid. The oxidized, decalcified material was rinsed repeatedly until a $\mathrm{pH}$ of about 6-7 was reached. A few drops of the cleaned material was air-dried on to glass coverslips and mounted on glass slides using NAPHRAX a resin with a high index of refraction. A slide of each sample was scanned at $1500 \mathrm{x}$, until 500 diatoms were recorded, or the entire slide examined.

\section{Results}

The samples for diatom analysis were collected from three cores, numbers 2, 4, and 6 , at $41 \mathrm{NU} 2$. There were clear differences among the kinds and numbers of diatoms found in the three different cores from the Oso site. Of the three cores, Core 2 was the most diatomaceous. Smaller numbers of diatoms were found in the other cores.

\section{Core 2}

Fifteen samples for diatom analysis were submitted from three separate segments of Core 2. All of the samples were diatomaceous and 500 diatoms were counted from all except the lowest sample, which had fewer diatoms per amount of sediment than the other samples. Table D-1 contains a complete list of samples analyzed from Core 2 with the abundances of each of the diatoms found. A total of 7,195 diatoms representing 45 taxa were recorded in the 15 samples analyzed. In decreasing order of abundance, the most commonly occuring species are Hantzschia abundans LangeBertalot, Luticola mutica (Kützing) Mann, Aulacoseira italica (Ehrenberg) Simonsen (status semilaevis), Diadesmis confervacea Kützing, Eunotia minor (Kützing) Grunow, Gomphonema angustatum (Kützing) Rabenhorst, Craticula cuspidata (Kützing) Mann, Luticola goeppertiana (Bleisch) Mann, Pinnularia borealis Ehrenberg and Eunotia bilunaris (Ehrenberg) Mills.

Of these diatom species, $H$. abundans, L. mutica, $D$. confervacea, E. minor, C. cuspidata, L. goeppertiana, P. borealis and $E$. bilunaris are aerophils, found characteristically living as aerophils on mud and moist vegetation. They can survive under aquatic conditions but grow best when not permanently submerged. The other two species, $A$. italica (status semilaevis) and G. angustatum are aquatic, benthic species living attached to sand grains or submerged vegetation. The semilaevis form of $A$. italica is thought to be a resistant form adapted to the osmotic stress of drying conditions. Overall the diatoms indicate a shallow, somewhat polluted, freshwater habitat, with small to moderate amounts of salt. The $\mathrm{pH}$ was around 7 or above. All of the diatoms prefer circumneutral to alkaline, HARD water. The substrate was muddy, with some submerged vegetation, and the water was seasonal, decreasing substantially to moist or dry conditions for part of the year. The diatoms were heavily diluted with muddy, and silty sediments. Some of the large diatoms were broken, suggesting grazing activity by invertebrates or fish. This core represents a pond/mudflat or grassy marsh habitat that held water for part of the year and was damp to dry the rest of the time. The water temperature probably varied widely, depending on season and water depth and the diatoms are 
Table D-1. Absolute Abundance of Diatoms in Core 2 from Site 41NU2

\begin{tabular}{|c|c|c|c|c|c|c|c|c|c|c|c|c|c|c|c|}
\hline Segment & 1 & 2 & 2 & 2 & 2 & 2 & 2 & 2 & 2 & 2 & 2 & 3 & 3 & 3 & 3 \\
\hline Zone & 8 & 8 & 8 & 8 & 9 & 9 & 10 & 10 & 10 & 10 & 10 & 10 & 10 & 11 & 11 \\
\hline Depth (cm) & $94-96$ & $6-8$ & $14-16$ & $24-26$ & $34-36$ & $44-46$ & $52-54$ & $62-64$ & $72-74$ & $82-84$ & $94-96$ & $24-26$ & $32-34$ & $42-44$ & $52-54$ \\
\hline Sample \# & 73 & 74 & 75 & 76 & 77 & 78 & 79 & 80 & 81 & 82 & 83 & 84 & 85 & 86 & 87 \\
\hline Amphora veneta & & 1 & & & & & & & & & & & & & \\
\hline Anomoeoneis sphaerophora & & & & & & & & 1 & & & & & 1 & & \\
\hline Aulacoseira italica & 1 & 2 & 14 & 49 & 65 & 100 & 91 & 58 & 79 & 65 & 105 & 65 & 34 & 13 & 8 \\
\hline Cocconeis placentula & & & & & & & & & & & 1 & & 1 & & \\
\hline Craticula cuspidata & 12 & 11 & 2 & & 2 & 5 & 2 & 10 & 2 & 4 & 9 & 10 & 14 & 15 & 4 \\
\hline Denticula kuetzingii & & & & & & & & & & & 2 & & & & 2 \\
\hline Diadesmis confervacea & 2 & & 10 & 16 & 47 & 63 & 59 & 81 & 56 & 78 & 82 & 59 & 75 & 58 & 37 \\
\hline Diadesmis contenta & & & & & & & & & & & 13 & & 2 & & \\
\hline Diploneis puella & 2 & & & & & & & & & & & & & & \\
\hline Encyonema silesiaca & & & 2 & & & & 2 & & & & & 4 & & & \\
\hline Epithemia turgida & & & & & & & & & & & & & 2 & & \\
\hline Eunotia bilunaris & & & & 6 & 5 & 8 & 17 & & 8 & & 3 & 4 & 19 & 2 & \\
\hline Eunotia minor & 3 & & 17 & 30 & 51 & 34 & 24 & 24 & 26 & 24 & 30 & 30 & 37 & 36 & 4 \\
\hline Eunotia pectinalis & & 5 & & & 2 & & & & & & & & & & \\
\hline Fragilaria fasciculata & & 1 & & & & & & & & 1 & 6 & & & & \\
\hline Gomphonema angustatum & 1 & 1 & 1 & 11 & 15 & 15 & 7 & 10 & 8 & 11 & 17 & 24 & 30 & 24 & 9 \\
\hline Gomphonema gracile & & & & & & & & & & 2 & 4 & & & & 1 \\
\hline Gomphonema intricatum & & & & & & & & & & & & 2 & & & \\
\hline Gomphonema parvulum & & & & & & & & & & & & 12 & & & \\
\hline Gomphonema pumilum & & & & & & & & 2 & & & 2 & & & & \\
\hline Hantzschia abundans & 363 & 358 & 313 & 293 & 210 & 225 & 202 & 230 & 210 & 202 & 171 & 201 & 217 & 301 & 103 \\
\hline Luticola goeppertiana & 7 & 7 & 3 & 6 & 5 & & 1 & 13 & & 36 & 1 & 5 & 6 & 2 & \\
\hline Luticola mutica & 73 & 90 & 116 & 51 & 77 & 45 & 68 & 59 & 80 & 44 & 8 & 55 & 40 & 30 & 26 \\
\hline \multicolumn{16}{|l|}{ Navicula oblonga } \\
\hline Neidium iridis & 1 & & & & & & & & & & & & & & \\
\hline Nitzschia amphibia & 7 & 1 & 2 & 11 & 4 & 1 & 5 & & 3 & & 2 & 6 & 3 & 11 & \\
\hline Nitzschia palea & & & & & & & & & 4 & & & & & & \\
\hline Nitzschia pseudocommunis & & & 3 & & & & 12 & & 2 & 10 & & 2 & 4 & & \\
\hline Nitzschia vitrea & 1 & & & & & & & & & & & & & & \\
\hline Pinnularia acrosphaeria & & & & & & & & & & 2 & & & & & \\
\hline Pinnularia appendiculata & & & & 2 & & & & & & 5 & 2 & & & & \\
\hline Pinnularia borealis & 17 & 9 & 9 & 8 & 5 & 3 & 4 & 4 & 4 & 7 & 3 & 6 & 3 & 1 & 1 \\
\hline Pinnularia braunii & & & & & & & & 3 & & & 2 & & & & \\
\hline Pinnularia gibba & & & & & & & & & & & 4 & & & & \\
\hline Pinnularia microstauron & & & & & & & & & 2 & & & & & & \\
\hline Pinnularia subcapitata & & 4 & & 2 & 2 & & 2 & & & & & & & & \\
\hline Pinnularia viridis & & & 1 & 2 & & & 1 & 1 & 3 & & 4 & & & 1 & \\
\hline Rhopalodia gibba & 3 & 4 & & & & & & & & & 2 & & & & \\
\hline Sellaphora laevissima & & & & 5 & 2 & & 2 & & 4 & & 1 & 6 & 4 & & \\
\hline Stauroneis anceps & 5 & & & & & & & & & & & & & & \\
\hline Stauroneis obtusa & 2 & 1 & 6 & 2 & 8 & & & & & 8 & & 8 & 2 & & \\
\hline Stauroneis phoenicentron & & & 1 & & & 1 & & & & & 16 & & 1 & 4 & \\
\hline Surirella brebissonii & & 3 & & & & & & & & & & & & & \\
\hline Synedra ulna & & 1 & & 6 & & & 1 & 1 & 9 & 1 & 10 & 1 & 5 & 2 & \\
\hline Tryblionella debilis & & 1 & & & & & & & & & & & & & \\
\hline Total counted: & 500 & 500 & 500 & 500 & 500 & 500 & 500 & 500 & 500 & 500 & 500 & 500 & 500 & 500 & 195 \\
\hline
\end{tabular}


taxa adapted to these fluctuating conditions. The remaining diatom species, present in smaller numbers, confirm this paleoenvironmental interpretation.

\section{Core 6}

The 16 samples, from the 3 segments from Core 6, contained 431 diatoms representing 33 species (Table D-2). Most of these came from zone 9 of segment 1 (357 diatoms). The most abundant, in decreasing order, are Achnanthidium minutissimum (Kützing) Czarnecki, Cymbella delicatula Kützing, Synedra ulna (Nitzsch) Ehrenberg, Achnanthidium biasolettianum (Grunow) Lange-Bertalot, Cocconeis placentula Ehrenberg, Encyonopsis evergladianum Krammer, Denticula kuetzingii Grunow and Gomphonema angustatum. These are small, aquatic, benthic, attached species known to be primary colonizers in seasonally wet, well-aerated, sunny habitats. There are almost no aerophilic or mud species, in contrast to Core 2. The diatoms indicate that the substrate was sandy, and not muddy. There was probably limited vegetation and the water was circumneutral to slightly

Table D-2. Absolute Abundance of Diatoms in Core 6 from Site 41NU2

\begin{tabular}{|c|c|c|c|c|c|c|c|c|c|c|c|c|c|c|c|c|}
\hline Segment & 1 & 1 & 1 & 1 & 1 & 1 & 1 & 2 & 2 & 2 & 2 & 3 & 3 & 3 & 3 & 3 \\
\hline Zone & 4 & 6 & 7 & 8 & 9 & 9 & 9 & 10 & 10 & 11 & 12 & 13 & 14 & 15 & 16 & 17 \\
\hline Depth (cm) & $31-33$ & $38-39$ & $48-49$ & $55-56$ & $72-73$ & $82-83$ & $92-93$ & $42-43$ & $60-62$ & $81-82$ & 93-94 & $3-4$ & $20-21$ & $40-41$ & 63-64 & $75-78$ \\
\hline Sample \# & 309 & 310 & 311 & 312 & 313 & 314 & 315 & 316 & 317 & 318 & 319 & 320 & 321 & 322 & 323 & 324 \\
\hline Achnanthidium biasolettianum & & & & 8 & 8 & 12 & & & & & & & & & & \\
\hline Achnanthidium minutissimum & & & & & 42 & 61 & 34 & 8 & & & 2 & 4 & 4 & & 6 & \\
\hline Amphora pediculus & & & & & 2 & & & & & & & & & & & \\
\hline Cocconeis placentula & & & & & 9 & 2 & 2 & 2 & & & & & 12 & & & \\
\hline Craticula halophila & & & & & & 1 & & & & & & & & & & \\
\hline Cymbella affinis & & & & 2 & & & & & & & & & & & & \\
\hline Cymbella delicatula & & 4 & & 12 & 30 & 2 & & & & & & 2 & 2 & & & \\
\hline Cymbella kolbei & & & & & & & & 4 & & & 2 & & & & 2 & \\
\hline Cymbella laevis & & & & & 6 & & & & & & & & & & & \\
\hline Denticula kuetzingii & & & & & 15 & & & & & & & & & & & \\
\hline Diploneis puella & & & 1 & & & & & & & & & & & & & \\
\hline Encyonema silesiacum & & & & & 2 & & & & & & & & & & & \\
\hline Encyonopsis evergladianum & & & 2 & & 9 & 2 & 2 & & & & & & & & & \\
\hline Encyonopsis microcephala & & & & & 2 & & & & & & & 2 & & & & \\
\hline Eunotia pectinalis & & & & & 1 & & & & & & & & & & & \\
\hline Fragilaria capucina & & & 3 & & & 8 & & & & & & & & & & \\
\hline Gomphonema affine & & & & & 2 & & & & & & & & & & & \\
\hline Gomphonema angustatum & & 6 & & & 5 & & & 1 & & & & & 2 & & & \\
\hline Gomphonema parvulum & & & & & & & & 2 & & & & & & & & \\
\hline Gomphonema pumilum & & & & & 4 & & & & & & & & & & & \\
\hline Luticola mutica & & & & & & & & 1 & & & & & & & & \\
\hline Navicula antonii & & & & & & & & 4 & & & & & & & & \\
\hline Navicula capitatoradiata & & & & & 1 & & & & & & & & & & & \\
\hline Navicula cincta & & & & & 1 & & & & & & & & & & & \\
\hline Navicula cryptotenella & & & & & 1 & & & & & & & & & & & \\
\hline Navicula menisculus & & & & & 2 & & & & & & & & & & & \\
\hline Nitzschia amphibia & & & & & 9 & & & & & & & & & & & \\
\hline Nitzschia amphibioides & & & & & 2 & & & & & & & & & & & \\
\hline Nitzschia frustulum & & & & & & & & 12 & & & & & & & & \\
\hline Rhoicosphenia abbreviata & & 4 & & & & & & & & & & & & & & \\
\hline Sellaphora laevissima & & & & & 1 & & & & & & & & & & & \\
\hline Sellaphora stroemii & & & & & 2 & & & & & & & & & & & \\
\hline Synedra ulna & & & & 3 & 17 & & 13 & & & & & & & & & \\
\hline Total: & 0 & 14 & 6 & 25 & 173 & 88 & 51 & 34 & 0 & 0 & 4 & 8 & 20 & 0 & 8 & 0 \\
\hline
\end{tabular}


alkaline (depending on amount of submerged vegetation), with rather low nutrients, but elevated salt concentrations. Evidence of grazing was not apparent.

\section{Core 4}

There were very few diatoms in Core 4 (Table D-3). Seven species were found in the 20 samples analyzed, but only 14 individual diatoms were recorded. Two of the diatoms, Amphora pediculus (Kützing) Grunow and Brachysira vitrea (Grunow) Ross are small, halophilic (salt loving), aquatic species not recorded from the other cores, but their presence is not incongruent with that of the other diatoms from the site. The assemblage as a whole suggests that the water source was fresh in origin, with elevated salt concentrations, as might be found around the saline margins of a drying habitat. The diatoms were not broken or corroded indicating that they did not travel far, but they may have been transported by winds from a nearby source.

\section{Conclusions}

In summary, the diatoms associated with the pond interval of Core 2 at the Oso site indicate that the general climate was not one with regular, seasonally predictable rainfall. Rain was episodic and only those diatoms capable of lasting through dry intervals and growing rapidly during wet periods were able to persist in this somewhat osmotically stressed habitat. There was drinkable water available seasonally during the interval identified as the pond deposit. It was hard water but there is no evidence of pollution or brackish water conditions. The absence of planktonic diatoms means that the pond was shallow, reasonably clear and probably somewhat low in nutrients. The few diatoms found in the sandy material of Cores 4 and 6 indicate standing water that could have been associated with a clay-lined depression or swale in the sands, in contrast to the muddy pond sediments. The water source supplying the diatoms found in Cores 4 and 6 may not have lasted more than a few weeks, however, and there was no soil or mud to support any aerophilic taxa. The greater diversity in diatom species in the pond deposit is probably due to the presence of more different microhabitats, greater depth, and longer residence time of the water, providing more available niches for diatoms to colonize, within the broader pond environment.

Table D-3. Absolute Abundance of Diatoms in Core 4 from Site 41NU2

\begin{tabular}{|c|c|c|c|c|c|c|c|c|c|c|c|c|c|c|c|c|c|c|c|c|}
\hline Segment & 1 & 1 & 1 & 1 & 1 & 1 & 1 & 1 & 2 & 2 & 2 & 2 & 2 & 2 & 2 & 2 & 2 & 3 & 3 & 3 \\
\hline Zone & 5 & 6 & 7 & 8 & 9 & 10 & 12 & 13 & 15 & 16 & 17 & 18 & 19 & 23 & 23 & 24 & 25 & 26 & 27 & 28 \\
\hline Depth (cm) & $\begin{array}{l}39- \\
44\end{array}$ & $\begin{array}{c}44- \\
49\end{array}$ & $\begin{array}{l}52- \\
54\end{array}$ & $\begin{array}{l}54- \\
60\end{array}$ & $\begin{array}{c}65- \\
70\end{array}$ & $\begin{array}{c}74- \\
76\end{array}$ & $\begin{array}{l}83- \\
87\end{array}$ & $\begin{array}{c}90- \\
94\end{array}$ & $6-10$ & $\begin{array}{l}10- \\
13\end{array}$ & $\begin{array}{l}23- \\
30\end{array}$ & $\begin{array}{l}34- \\
38\end{array}$ & $\begin{array}{c}42- \\
46\end{array}$ & $\begin{array}{c}63- \\
70\end{array}$ & $\begin{array}{c}78- \\
88\end{array}$ & $\begin{array}{l}92- \\
96\end{array}$ & $\begin{array}{l}96- \\
100\end{array}$ & $\begin{array}{l}20- \\
30\end{array}$ & $\begin{array}{l}30- \\
40\end{array}$ & $\begin{array}{l}50- \\
60\end{array}$ \\
\hline Sample \# & 351 & 352 & 353 & 354 & 355 & 356 & 357 & 358 & 359 & 360 & 361 & 362 & 363 & 364 & 365 & 366 & 367 & 368 & 369 & 370 \\
\hline $\begin{array}{l}\text { Achnanthidium } \\
\text { biasolettianum }\end{array}$ & & & & & & & & & & & & & & & & & & & & 3 \\
\hline $\begin{array}{l}\text { Achnanthidium } \\
\text { minutissimum }\end{array}$ & & & & & & & & & & & & & & & & 2 & & & & \\
\hline Amphora pediculus & & & & & & & & & & & & & & & 2 & & & & & \\
\hline Brachysira vitrea & & 2 & & & & & & & & & & & & & & & & & & \\
\hline Fragilaria fasciculata & & 1 & & & & & & & & & & & & & & & & & & \\
\hline Hantzschia abundans & 1 & & & & & & & & & 1 & & & & & & & & & & \\
\hline Synedra ulna & & 1 & & & & & & & & & & & & & & & & & & 1 \\
\hline Total counted: & 1 & 4 & 0 & 0 & 0 & 0 & 0 & 0 & 0 & 1 & 0 & 0 & 0 & 0 & 2 & 2 & 0 & 0 & 0 & 4 \\
\hline
\end{tabular}





\section{APPENDIX E: \\ Late Holocene Paleoenvironmental History of Cayo Del Oso Bay, Nueces County, Texas: Geoarchaeological Implications}

Manuel R. Palacios-Fest

Terra Nostra Earth Sciences Research

Tucson, Arizona 


\section{Introduction}

Understanding human occupation in southern Texas requires an understanding of the current and past conditions of the area. Environmental factors do not necessarily rule the course of human adaptation, but they do impose constraints and set parameters that affect people's lives and their use of resources. This paper focuses on the micropaleontological analysis of three cores collected within a small water body at Cayo del Oso Bay, Nueces County, Texas. To achieve this goal Terra Nostra Earth Sciences Research staff analyzed the microfossil contents of three cores $(2,4$, and 6$)$ obtained at site $41 \mathrm{NU} 2$ in the summer of 2007 . The results were compared and contrasted with previous work in the region to establish the paleoenvironmental patterns that characterized the area during the late Holocene. The sections below summarize the main features of the three biological groups found during this research: ostracodes, foraminifera, and molluscs.

Marginal marine environments (estuaries and lagoons) provide a unique source of information about short- (e.g., seasonality, human activity) and long-term (e.g., isostatic or eustatic sea level change) continental and marine cycles that have affected human adaptation. Sedimentation in estuaries and lagoons is influenced by a complex combination of tidal currents, oceanic waves, locally generated waves, river discharge (into estuaries), precipitation, temperature, and local flora and fauna (Clifton 1982). Also important are geologic agents like tectonism, subsidence, isostatic and eustatic changes of sea level, climate change, and human activities that have altered the hydrology, drainage, and topography.

Lagoons differentiate from estuaries both physically and ecologically. Lagoons are closed marine shallow embayments, less affected by fluvial discharge than estuaries (although, many estuaries form lagoonal environments). A major difference between the two is that whereas estuaries are elongated perpendicular to the coastline and form deltas, lagoons are elongated parallel to the coastline separated from the ocean by sand barriers. Ecologically, lagoons include a mostly marine, poorly diverse faunal assemblage consisting of ostracodes, foraminifera, diatoms, molluscs, and other groups. Estuaries, by contrast, contain a poorly abundant but diverse assemblage that include both marine and nonmarine species of many groups that have representatives in both realms, mainly ostracodes, molluscs, and diatoms.

\section{Ostracodes Biology and Ecology}

The Ostracoda belong to the phylum Arthropoda (Figure E-1). Microcrustaceans provided with a calcium carbonate carapace, ostracodes occur in almost any water environment

\section{$150 x$}

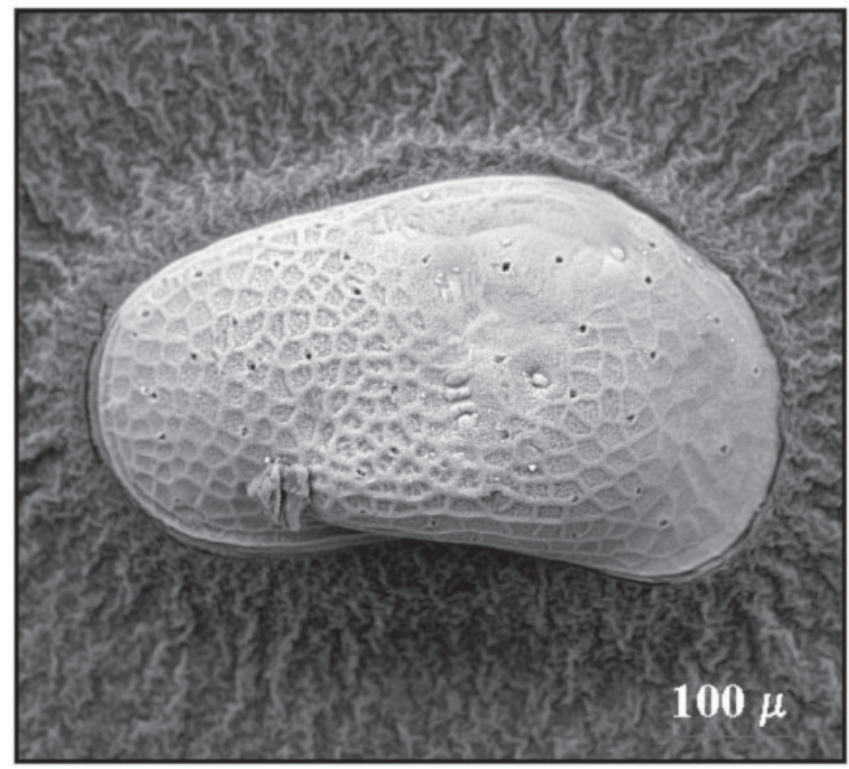

Figure E-1. Limnocythere staplini, euryhaline continental water ostracode common in marginal marine systems. Female, right valve view. (Image by Manuel R. Palacios-Fest, TNESR.)

from the ocean to rivers, lakes, ponds, springs and even in some tropical forest soils like in the Amazon. As other crustaceans, ostracodes require to grow by shedding their exoskeleton about nine times before becoming adults. During the interval before calcification they grow to reach the next stage. Both adult and juvenile valves (named instars) may be preserved as fossils, and both are useful for paleontologic studies. The carapace morphology and shape are both environmentally and genetically controlled (Pokorný 1978).

Ostracodes are widely distributed in the marine and freshwater environments, normally under well-oxygenated conditions. Marginal marine species are also abundant. Although all modern families have marine and freshwater representatives, distinctive species are characteristic of each environment. Only brackish-water ostracodes occur in continental saline or marginal marine environments. Water chemistry and the sediment and nutrient properties of the environment may impose a mechanism of control on them. Estuarine ostracodes may be represented by a combination of marine, brackishand freshwater species under certain circumstances.

Marinov (1964; in: Puri et al. 1969) recognized four categories of ostracode distribution according to their origin in the Black Sea estuaries, as follows: 1) Freshwater species which have also been found in the brackish-water basins. Most of the species found belonged to the genera Ilyocypris, Candona, Limnocythere, Cypridopsis and Darwinula; 2) 
typical brackish-water species, mainly represented by several species of the genus Cyprideis and some other genera like Hemicythere and Potamocypris; 3) ultrahaline species represented by the genus Eucypris; and 4) Sea-euryhaline species which are open sea forms that have adapted themselves in mesohaline waters represented among other genera by Cytheridea, Pterygocythereis, Hemicytherura, Loxoconcha, Xestoleberis and Paradoxostoma. A similar pattern from Texas is discussed in this study, although the freshwater assemblage is absent and the ultrahaline is represented by a single specimen of the genus Limnocythere.

Ostracode studies of southern Texas are numerous, among which of particular interest to this study are the works of Van den Bold (1977), Cronin (1986), Garbett and Maddocks (1979), King and Kornicker (1970), and Swain (1955). For example, Cronin (1986), studying the micropaleontological record of six cores from Mustang Island, Corpus Christi Bay, identified ostracode assemblages that permitted him to infer episodes of freshwater-fluvial input alternating with upper bay, mid-bay, lower bay-inlet, and sublittoral environments during the Quaternary. His work is of significant value to this study because it is the first attempt to reconstruct the Quaternary paleoenvironments of deposition in Corpus Christi Bay.

\section{Foraminifera Biology and Ecology}

The Foraminifera belong to the phylum Sarcomastigophora (Figure E-2). Foraminifera are found in all marine environments, they may be planktic or benthic in mode of life. These unicellular organisms are provided with a calcareous or agglutinated test that preserves to the geologic record. The morphology of foraminifera tests varies enormously, but in terms of classification two features are important: chamber arrangement and aperture type (for details see Boersma 1978; http://www.ucl.ac.uk/GeolSci/micropal/foram.html 2007). The benthic forms are the most common and abundant in marginal marine environments (e.g., estuaries, lagoons).

Benthic foraminifera are most commonly used for paleobathymetric reconstructions because of the specific depth range of many species. Some of which are restricted to nearshore, reefal, or lagoonal environments; while other are limited to deeper open ocean conditions. These organisms are divided into morphogroups based on the test shape allowing researchers to identify paleohabitats and substrates. For example, infaunal species tend to be elongate and streamlined in order to burrow into the sediments; whereas epifaunal species are more globular with one relatively flatter side in order to facilitate movement on top of the substrate. In addition, the test wall type (e.g., porcelaneous, hyaline, agglutinated) also indicates paleodepths and salinity (Boersma 1978; http:// www.ucl.ac.uk/GeolSci/micropal/foram.html 2007).

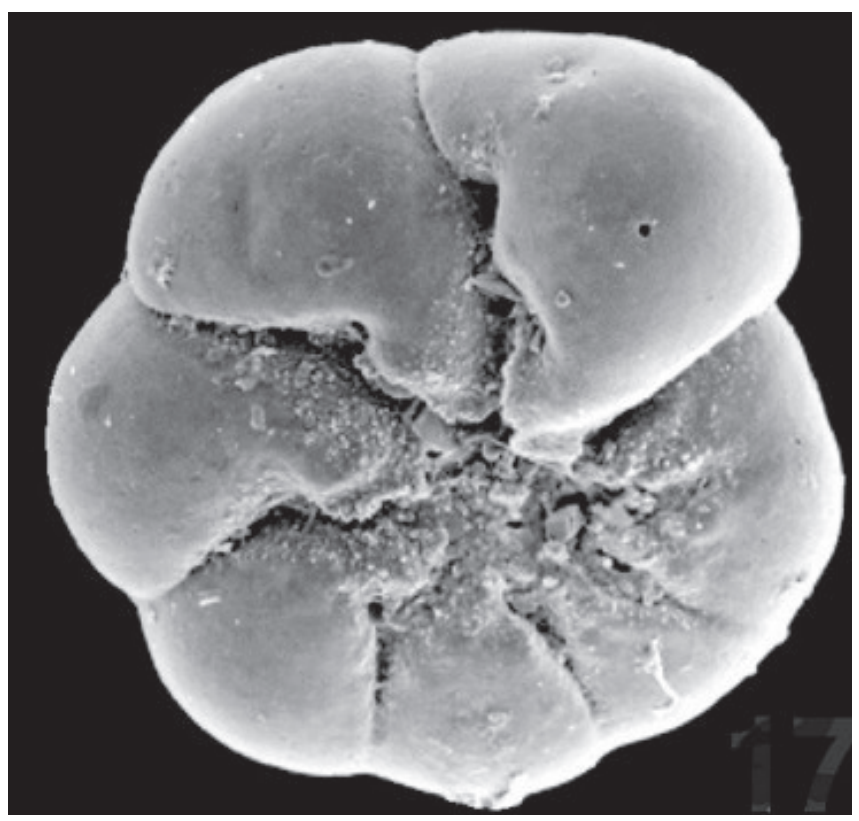

Figure E-2. Ammonia beccarii, benthic foraminifera common in nearshore, lagoonal, and estuarine environments. Umbilical view. (SEM image courtesy of Elisabeth Alve, University of Oslo, originally published in the Journal of Foraminiferal Research 31:1, used with permission.)

In a recent study, Ishman (1997) reported two main biofacies in the Biscayne Bay, Florida. An open-bay coarse-sediment, grassy biofacies containing abundant miliolid taxa and a restricted biofacies characterized by abundant Ammonia parkinsoniana, Elphidium galvestonense, and species associated with high salinity tolerance. A similar pattern from Texas is discussed in this study.

As for ostracodes, the work on foraminifers is abundant along the Texas Gulf Coast. The studies of Phleger $(1965,1970)$ are key for the paleoenvironmental reconstruction of Cayo del Oso Bay because they provide the modern distribution patterns of marginal marine foraminifers in the nearby Galveston Bay, an area dominated by Ammonia beccarii.

\section{Mollusc Biology and Ecology}

Molluscs belong to the phylum Mollusca (Figure E-3). It is a very large and diverse group of soft body organisms that include bivalves and gastropods, as well as other forms characterized by an internal shell. The first two are of primary interest to paleoenvironmental studies because they preserve well into the geologic record; therefore, this summary will concentrate in these groups. Molluscs are tripoblastic protostomes (incipient bilateral symmetry with three germ layers: ectoderm, mesoderm, and endoderm) and many demonstrate bilateral symmetry. They have a mantle lining 


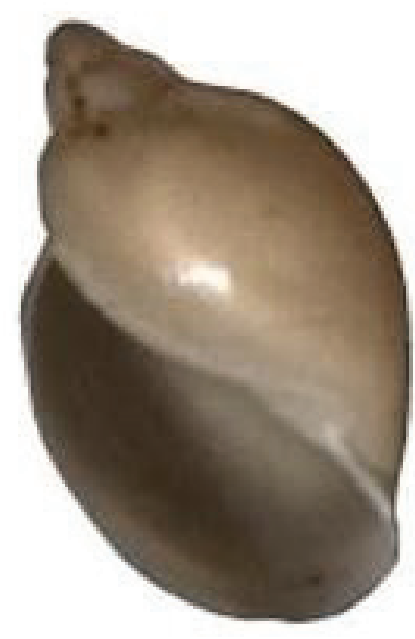

Figure E-3. Physa virgata, small freshwater gastropod common in continental and marginal marine environments. (Image by Manuel R. Palacios-Fest, TNESR.)

the shell and a muscular foot that in most species is used for locomotion. In most molluses the mantle secretes a calcium carbonate shell that preserves well into the geologic record since the Cambrian (Barnes 1987; Brusca and Brusca 1990).

Based on their diversity, molluscs are adapted to a wide variety of environments, both aquatic and terrestrial. In marginal marine environments both groups are equally important because their occurrence may indicate transgression/ regression events over time. Furthermore, aquatic forms may be represented by marine and nonmarine organisms that are also important indicators of environmental change. Sensitive to $\mathrm{pH}$, alkalinity, salinity, and temperature, molluscs are restricted by the conditions prevailing in a given area. Although modern families have marine, freshwater, and terrestrial representatives, distinctive species characterize each environment. Water chemistry and the sediment and nutrient properties of the environment may impose a mechanism of control on them. Terrestrial species may tolerate watersaturated soils; other may thrive in drier conditions (Barnes 1987; Brusca and Brusca 1990).

\section{Purpose of Study}

This study documents the occurrence of lagoonal or estuarine biofacies in site 41NU2 at Cayo del Oso Bay, Nueces County, Texas. Marine and continental assemblages randomly alternated in the stratigraphic record of Cayo del Oso during the last $\sim 3000$ years, before that, marine species dominated the record. Ostracode biofacies analysis defined environmental change during the late Holocene. Two main questions addressed in this research, are: 1) What was the aquatic environment met by prehistoric people around Cayo del Oso? And 2) Did the lagoon receive significant freshwater input over time?

\section{Area of Study}

Site 41NU2, Cayo del Oso, Nueces County, Texas, lies on clay dunes along the northwestern shore of Oso Bay and extends from a small creek that empties into the western side of Oso Bay approximately $920 \mathrm{~m}$ north to Corpus Christi Bay (see Figure 1-2, this volume). The site's width is known only to the northern border, on a bluff overlooking Corpus Christi Bay. At that point the site is approximately $200 \mathrm{~m}$ wide (Tomka et al. 2007).

Geologically, Corpus Christ Bay and the Oso Bay area began forming about 5000 years B.P. as the Padre Island sand barriers coalesced, a process that was completed about 2500 years B.P. forming Laguna Madre (Fisk 1959:123; Morton and Paine 1984:12). A shallow ( $<4 \mathrm{~m}$ deep) bay formed (Harwood 1980) receiving freshwater discharge from the Nueces River and Oso Creek, giving rise to the estuarine conditions prevailing today (Ricklis 1995:142). In historic time, two channels (Aransas Pass and Fish Pass) were opened to the ocean connecting Corpus Christi Bay to the Gulf of Mexico (Morton and Pieper 1977).

At the southwestern end of Corpus Christi Bay is Oso Bay, an enclosed, soft-sediment, estuary where the Oso Creek discharges (Tomka et al. 2007:9). The bay is less than $1 \mathrm{~m}$ deep, connected to Corpus Christi Bay by a small pass east of Ward Island. A small wind-flat, covering approximately 28 hectares, lies west of Ward Island, called False Oso or Blind Oso Bay. Site 41NU2 is located on the western shore of the False Oso Bay (Tomka et al. 2007:9).

Southern Texas is characterized by a mean annual precipitation of 28.86 in $(73 \mathrm{~cm})$ distributed in two seasons: late spring/ early summer, and fall (Kier and White 1978). Evaporation exceeds precipitation with rates between 90 and $115 \mathrm{~cm} /$ year (occasionally exceeding $150 \mathrm{~cm} /$ year). The atmospheric summer temperatures average $33.3^{\circ} \mathrm{C}$, while winter lows average $8.3^{\circ} \mathrm{C}$, while water temperatures in Corpus Christi Bay range from $7^{\circ} \mathrm{C}$ in the winter to $29^{\circ} \mathrm{C}$ in the summer (Harwood 1980).

Corpus Christi Bay is a hypersaline to brackish-water system where salinity ranges from 11 parts per thousand (ppt) to $45 \mathrm{ppt}$, with a mean value around $30 \mathrm{ppt}$ affected by the southeasterly 
winds during the summer and strong northerly fronts during the winter (Chabreck 1990). This condition has a great influence on the bay's ecology (for details see Tomka et al. 2007).

Three of six cores collected were used for this study $(2,4$, and 6$)$ (see Figure 5-1, 5-2 and 5-4, this volume). Core 2 was collected at the northwest end of the area of study in a freshwater pond near site 41NU2. The pond formed on and at the foot of the upland Beaumont Formation and behind the clay dunes well above sea level (Frederick, written communication, January 25, 2008). It possibly received some eolian component from Cayo del Oso Bay, runoff from the Beaumont Creek, and overwash from the bay and Gulf of Mexico during hurricanes. Cores 4 and 6 were collected along the north and south dunes that developed against a remnant ridge of Pleistocene Beaumont Clay exposed to the surface between them (Meissner, written communication, January 23, 2008).

\section{Materials and Methods}

The three cores $(2,4$, and 6$)$ were subsampled and the samples shipped to Terra Nostra Earth Sciences Research, LLC in Tucson, Arizona for micropaleontological analysis. A total of 45 samples ranging in size from 16 to $56 \mathrm{~g}$ were processed for this analysis.

All samples were processed for micro-invertebrate recovery following Palacios-Fest's (1994). Samples were weighed using an electronic balance and disaggregated in hot distilled water with Alconox (Sodium Hexametaphosphate). The sediments were then left to cool and let to sit at room temperature for eight days. They were washed using a set of three sieves $(>1$ $\mathrm{mm},>106 \mu \mathrm{m}$, and $>63 \mu \mathrm{m}$ ) for separating the three sand fractions, and rinsed with distilled water. The residues were let dry at room temperature for 48 hours and weighed to estimate the content of micro-invertebrates per gram of sediment. The rough particle-size analysis obtained during this phase of the study permits making an estimate of sediment input over time at Cayo del Oso Bay. Residues were examined under a low power stereoscopic microscope. Routine micropaleontologic analysis was performed to determine fossil content and faunal composition (ostracodes, foraminifera, and molluscs). The focus of the present study is ostracodes. Foraminifera and molluscs provided complementary data to support the ostracode records. Ostracode abundance ranged from extremely rare to moderately abundant ${ }^{1}$.

Ostracode paleoecologic assemblages were defined and grouped according to species abundance following Palacios-
Fest et al. (2006), Benson and Coleman (1963), and McKenzie and Swain (1967). To reconstruct the late Holocene history of Cayo del Oso Bay, a qualitative estimate of environmental change was obtained assigning to each species a relative value as determined by equation (1):

$$
\begin{aligned}
\mathrm{SI}= & {[3(\% \text { Cyprideis salebrosa })+2(\% \text { Cyprinotus glaucus })} \\
& +(\% \text { Candona rawsoni })]-[4(\% \text { Aurila laevicula })+ \\
& 3(\% \text { Radimella wantlandi })+2(\% \text { Perissocytheridea } \\
& \text { rugata })+(\% \text { Haplocytheridea proboscidiala })-(\% \\
& \text { Loxoconcha avellana })+2(\% \text { Cytherura sandbergi })+ \\
& 3(\% \text { Xestoleberis banda })]
\end{aligned}
$$

where the marine species (see Table E-4) were grouped from sublittoral-tolerant to upper bay-tolerant species and subtracted from the limnic species. The limnic species were ordered from higher salinity-tolerant to lower salinity-tolerant (see Table E-3).

In addition to the faunal composition, the taphonomic features were used to recognize degrees of transport and burial characteristics, like desiccation and sediment compaction. The rates of fragmentation, abrasion, and disarticulation are indicators of transport. Commonly, these parameters show increasing damage with increasing transport. One must be cautious in using these criteria; however, the nature of the deposits suggests that micro-invertebrates reflect the ecological properties of Cayo del Oso Bay. Deposition characteristics were determined by encrustation, coating, the redox index which reflect authigenic mineralization, wave action, and burial conditions, respectively. Disarticulation $(\mathrm{C} / \mathrm{V})$ and adulthood $(\mathrm{A} / \mathrm{J})$ ratios were used as indicators of biocenosis (Palacios-Fest et al. 2001).

\section{The Sedimentary and Faunal Records}

The cores used for the micropaleontological analysis are described by Frederick (Appendix F, this volume) the reader is invited to review that chapter for further reference. Table E-1 and Figure E-4 show the particle-size analysis obtained during the sample washing process. Core 2 consisted of very dark gray (5Y 3/1) to gray (5Y 6/1) clay $(>90 \%)$ except for a few intervals where silt increased $(>84 \%<90 \%)$. Core 4 had a more variable particle-size ranging from gray (5Y 6/1) to white (5Y 8/1) but mostly light gray (5Y 7/1) sandy silt to clay. Core 6 consisted of light gray $(5 \mathrm{Y} 7 / 1)$ occasionally alternating with gray $(5 \mathrm{Y}$ $6 / 1)$ or white (5Y 8/1) sandy silt to clay.

${ }_{1}$ Abundance explanation (number of individuals): Extremely abundant $(>(1001)$, very abundant $(>501<1000)$, abundant $(>101<500)$, moderately abundant $(>51<100)$, common $(>21<50)$, rare $(>6<20)$, and extremely rare $(<5)$. 


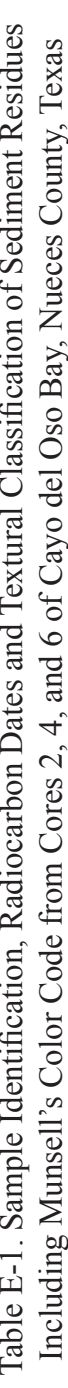

\begin{tabular}{|c|c|c|c|c|c|c|c|c|c|c|c|c|c|c|c|c|c|c|c|c|c|c|c|}
\hline$\frac{5}{0}$ & & & \begin{tabular}{|l|l} 
\\
0 \\
$\pi$
\end{tabular} & $\begin{array}{l}\overrightarrow{5} \\
\vdots \\
\end{array}$ & $\begin{array}{l}\overrightarrow{5} \\
\vdots \\
\vdots \\
\end{array}$ & \begin{tabular}{|l|}
$\overrightarrow{0}$ \\
$i$ \\
\end{tabular} & $\begin{array}{l}\text { 常 } \\
\text { in }\end{array}$ & 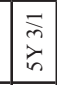 & 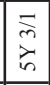 & \begin{tabular}{|l|} 
\\
\multirow{2}{7}{} \\
$\hbar$
\end{tabular} & $\begin{array}{l}7 \\
7 \\
\hbar \\
\end{array}$ & 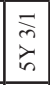 & \begin{tabular}{|l|} 
\\
$m$ \\
$i$ \\
$n$
\end{tabular} & \begin{tabular}{|l|l} 
\\
7 \\
$i$ \\
\end{tabular} & \begin{tabular}{|l|} 
\\
7 \\
$i$ \\
\end{tabular} & 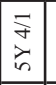 & $\begin{array}{l}\overline{5} \\
i \\
i\end{array}$ & \begin{tabular}{|l|}
\multirow{2}{*}{} \\
in \\
\end{tabular} & \begin{tabular}{|l|l} 
\\
$\infty$ \\
$i$ \\
\end{tabular} & \begin{tabular}{|l|} 
\\
$\infty$ \\
$\vdots$ \\
\end{tabular} & $\begin{array}{l}\text { 齐 } \\
\vdots\end{array}$ & $\begin{array}{l}\overrightarrow{5} \\
\hbar \\
\hbar\end{array}$ & 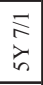 \\
\hline & & & 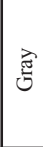 & 局 & 跑 & 店 & 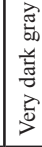 & 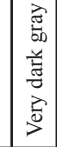 & 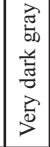 & 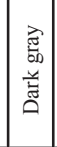 & 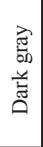 & 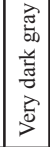 & 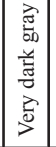 & 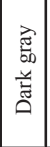 & 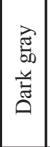 & 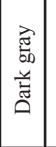 & 总 & 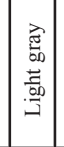 & $\frac{2}{\bar{z}}$ & $\mid$ & 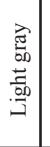 & 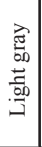 & 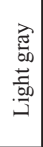 \\
\hline & 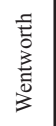 & 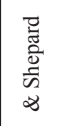 & $\vec{z}$ & 胥 & 疍 & 胥 & 렴 & 胥 & $\frac{\vec{\pi}}{U}$ & 黑 & $\frac{\vec{z}}{\mathrm{~J}}$ & $\mid$\begin{tabular}{|l|}
$\vec{E}$ \\
\end{tabular} & $\frac{\vec{z}}{\mathrm{~J}}$ & $\mid \begin{array}{l}\overrightarrow{\mathrm{E}} \\
\mathrm{U}\end{array}$ & $\mid \begin{array}{l}\vec{E} \\
\end{array}$ & $\frac{\vec{z}}{\tilde{u}}$ & 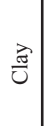 & 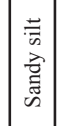 & 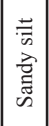 & 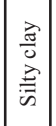 & 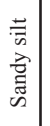 & 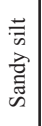 & 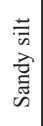 \\
\hline
\end{tabular}

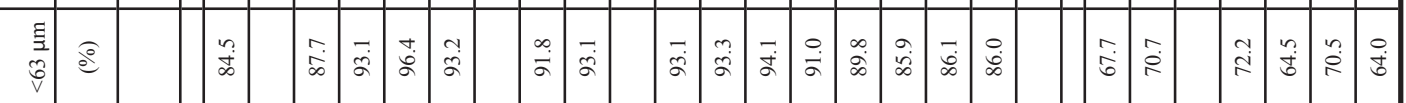

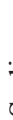

要

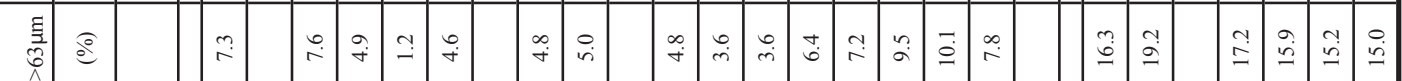

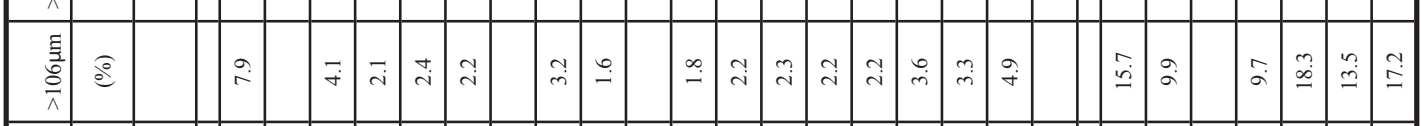

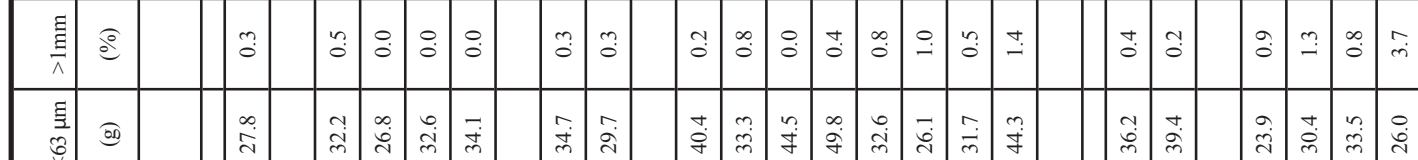

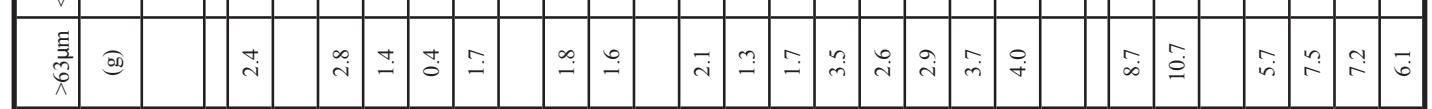

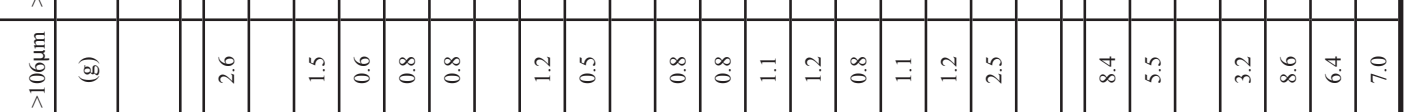

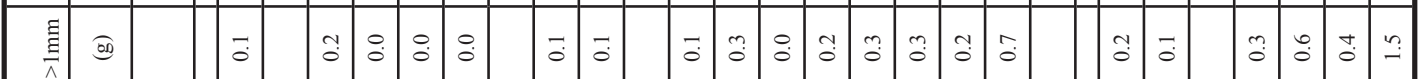

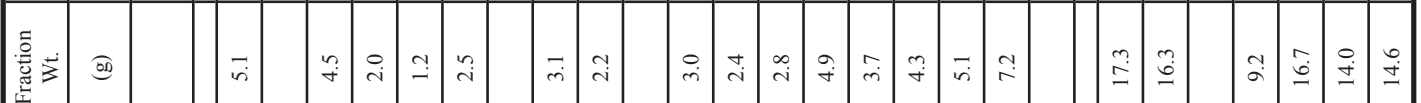

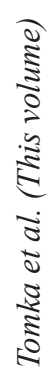

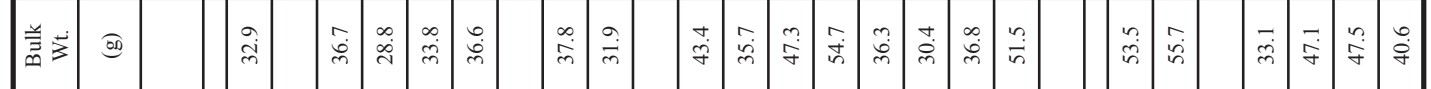

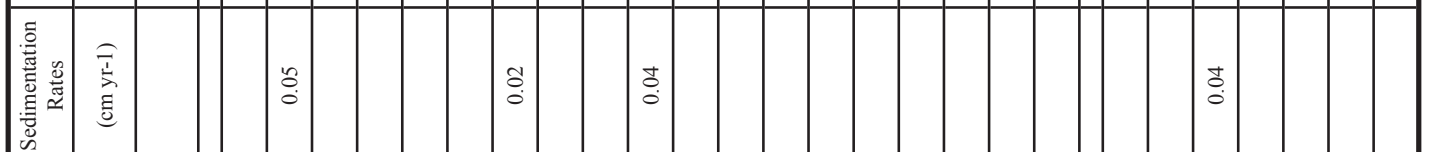

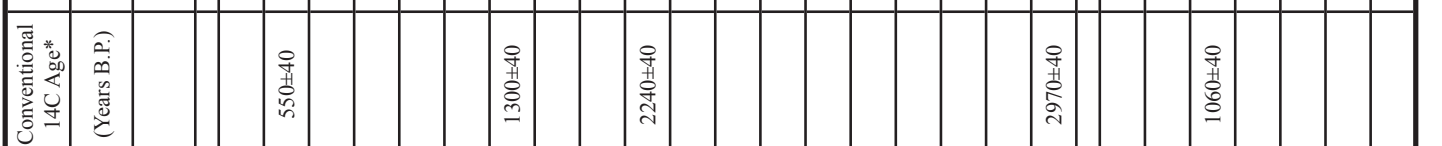

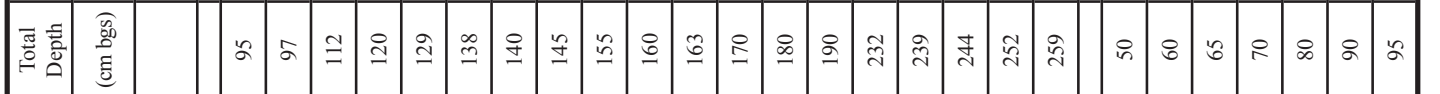

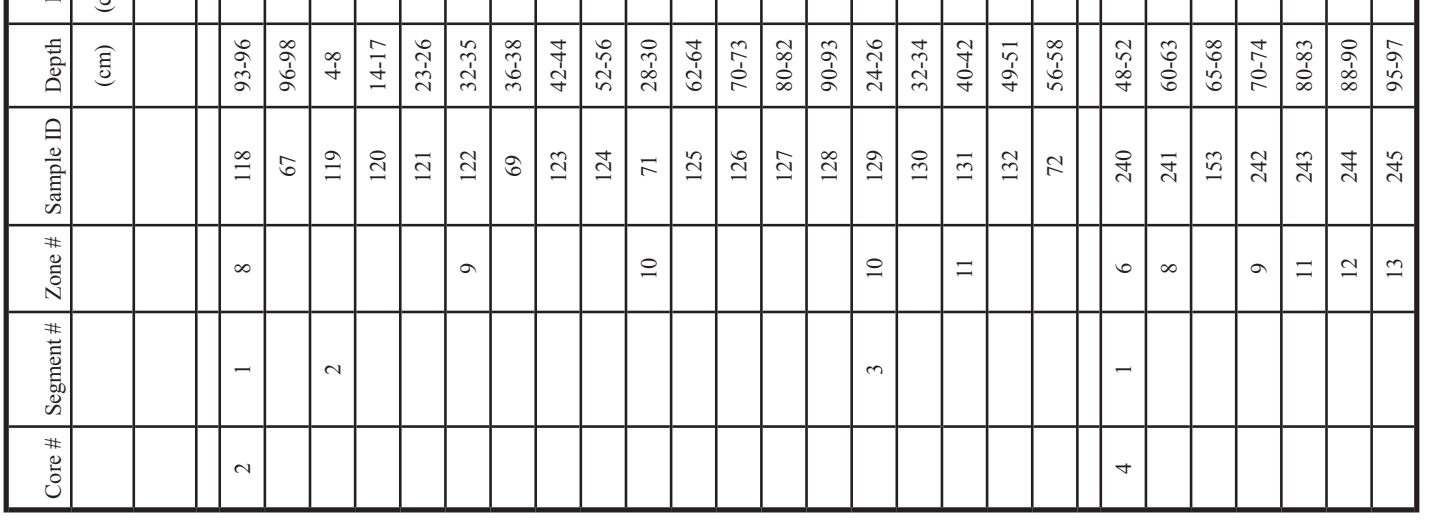




\begin{tabular}{|c|c|c|c|c|c|c|c|c|c|c|c|c|c|c|c|c|c|c|c|c|c|c|c|c|c|c|c|c|c|c|c|c|}
\hline 흥 & & & & \begin{tabular}{|l|}
5 \\
$i$ \\
\end{tabular} & \begin{tabular}{|l}
\multirow{2}{*}{} \\
in \\
$n$
\end{tabular} & \begin{tabular}{|l} 
\\
离 \\
\end{tabular} & \begin{tabular}{|l}
\multirow{2}{*}{} \\
竞 \\
\end{tabular} & & \begin{tabular}{|l} 
\\
ㄱ. \\
in \\
\end{tabular} & 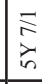 & \begin{tabular}{|l} 
\\
离 \\
\end{tabular} & & 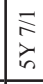 & 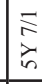 & \begin{tabular}{|l|} 
\\
$\infty$ \\
$\hbar$ \\
$\hbar$
\end{tabular} & \begin{tabular}{|l} 
亲 \\
in
\end{tabular} & \begin{tabular}{|l|}
$\vec{\infty}$ \\
$i$ \\
$\hbar$
\end{tabular} & & \begin{tabular}{|l|}
$\overrightarrow{0}$ \\
$\vdots$ \\
$\vdots$
\end{tabular} & \begin{tabular}{|l} 
\\
离 \\
\end{tabular} & \begin{tabular}{|l|}
\multirow{2}{*}{} \\
$i$ \\
\end{tabular} & $\begin{array}{l}\mathbf{1} \\
\vdots \\
\end{array}$ & & $\begin{array}{l}\Sigma \\
\vdots \\
i \\
\end{array}$ & $\begin{array}{l}\underset{1}{i} \\
\hbar\end{array}$ & \begin{tabular}{|l} 
\\
in \\
\end{tabular} & $\begin{array}{ll}5 \\
5\end{array}$ & \begin{tabular}{l|l}
$\grave{i}$ \\
\end{tabular} & & \begin{tabular}{|l|}
\multirow{2}{*}{} \\
in \\
\end{tabular} & $\begin{array}{l}\vec{\lambda} \\
i \\
i \\
\end{array}$ & $\begin{array}{l}\text { in } \\
\text { in } \\
\end{array}$ \\
\hline 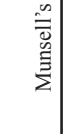 & & & & 递 & 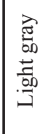 & 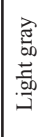 & 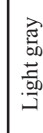 & & 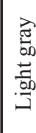 & 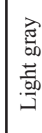 & 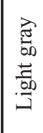 & & 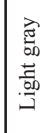 & 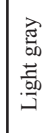 & 受 & 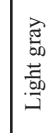 & $\frac{.}{\frac{2}{z}}$ & & 递 & 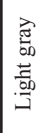 & 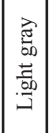 & 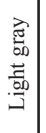 & & 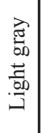 & 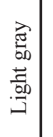 & & 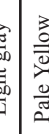 & 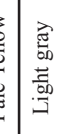 & & 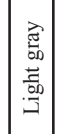 & 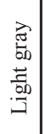 & 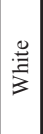 \\
\hline 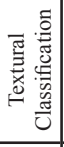 & 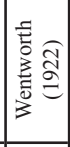 & 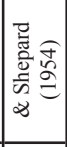 & & 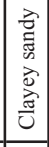 & 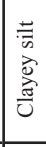 & 急 & 胥 & & 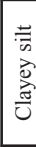 & 령 & 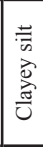 & & 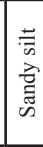 & 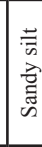 & 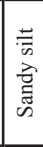 & 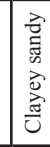 & 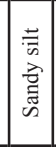 & & 居 & 离 & $\mid \begin{array}{l}\vec{\Xi} \\
\vec{E}\end{array}$ & $\stackrel{\vec{\Xi}}{\vec{U}}$ & & 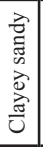 & 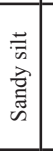 & 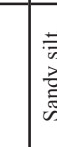 & & 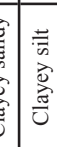 & & 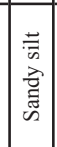 & 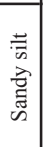 & 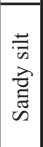 \\
\hline $\begin{array}{l}\text { 害 } \\
\hat{b}\end{array}$ & $\widehat{\varrho}$ & & & 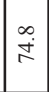 & 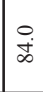 & $\begin{array}{l}m \\
\infty \\
\infty\end{array}$ & $\begin{array}{l}\mathcal{D}_{\infty} \\
\infty\end{array}$ & & $\mid \begin{array}{l}n \\
\infty \\
\infty\end{array}$ & $\begin{array}{l}1 \\
\stackrel{8}{\circ}\end{array}$ & $\vec{i}$ & & है & తి & 旾 & 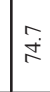 & $\mid \begin{array}{l}0 \\
\dot{i}\end{array}$ & & $\stackrel{\vec{\infty}}{\vec{\infty}}$ & $\vec{F}$ & $\begin{array}{l}\text { ठ } \\
\infty \\
\infty\end{array}$ & $\underset{\infty}{m}$ & & $\stackrel{\circ}{i}$ & $\stackrel{\circ}{\dot{H}}$ & {$\left[\begin{array}{l}\infty \\
\infty \\
\infty\end{array}\right.$} & $\begin{array}{l}\dot{b} \\
\dot{b}\end{array}$ & $\stackrel{\sim}{c}$ & & 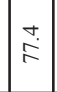 & $\begin{array}{l}n \\
\stackrel{n}{i}\end{array}$ & 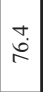 \\
\hline 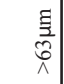 & 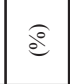 & & & $\stackrel{\circ}{\dot{I}}$ & $\infty$ & $\stackrel{\circ}{\circ}$ & $\vec{\infty}$ & & $\stackrel{?}{=}$ & $\stackrel{\circ}{\circ}$ & $n$ & & 吕 & $\stackrel{\infty}{\stackrel{\sim}{. ~}}$ & $\stackrel{n}{\sim}$ & $\stackrel{\text { I }}{\text { I }}$ & 足 & & $\stackrel{M}{\beth}$ & $\partial_{\infty}$ & 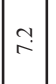 & $\overbrace{\infty}$ & & $\begin{array}{l}\infty \\
\dot{I}\end{array}$ & $\stackrel{\infty}{=}$ & $=$ & $=$ & $\stackrel{\infty}{ \pm}$ & & $\stackrel{I}{\Xi}$ & 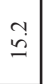 & 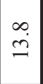 \\
\hline $\begin{array}{l}\text { 害 } \\
\frac{0}{\wedge}\end{array}$ & $\stackrel{\circ}{a}$ & & & $\stackrel{\sim}{\varrho}$ & $\cong$ & 3 & $\underset{\infty}{0}$ & & 2. & $a_{\infty}$ & $\stackrel{\text { Ö }}{\varrho}$ & & $\overrightarrow{0}$ & $\mid \begin{array}{l}n \\
n \\
n\end{array}$ & $\stackrel{\infty}{\mathfrak{I}}$ & $\underset{I}{\stackrel{\Xi}{I}}$ & $\left|\begin{array}{l}i \\
\stackrel{i}{ }\end{array}\right|$ & & $\vec{f}$ & : & $\mid \begin{array}{l}1 \\
\end{array}$ & $\rightleftarrows$ & & $\stackrel{\circ}{=}$ & $\underline{n}$ & $\stackrel{\nexists}{I}$ & 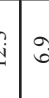 & $\exists$ & & $\stackrel{\infty}{\stackrel{\infty}{*}}$ & $\stackrel{\Delta}{*}$ & $\begin{array}{l}0 \\
\infty \\
\infty\end{array}$ \\
\hline 貝 & $\stackrel{\varrho}{\circ}$ & & & $\stackrel{.}{-}$ & $\underset{\infty}{\infty}$ & : & $\because$ & & 3 & 3 & $\cong$ & & $\therefore$ & 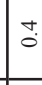 & 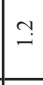 & $\stackrel{+}{\circ}$ & $\stackrel{\circ}{-}$ & & $=$ & $\stackrel{2}{\circ}$ & 3 & $\stackrel{3}{\circ}$ & & $n$ & $\hat{o}$ & 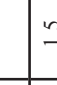 & 8 & $\hat{o}$ & & $\stackrel{0}{\circ}$ & $\dot{0}$ & $\cong$ \\
\hline ช8 & (30) & & & $\begin{array}{l}\mathcal{Y} \\
\dot{f}\end{array}$ & 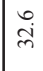 & $\frac{n}{\bar{N}}$ & $\stackrel{+}{\stackrel{d}{d}}$ & & $\underset{\grave{\sim}}{\stackrel{\sim}{\sim}}$ & 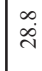 & $\stackrel{m}{m}$ & & $\hat{a}$ & $\stackrel{9}{I}$ & $\stackrel{\circ}{\vec{N}}$ & $\begin{array}{l}\infty \\
\stackrel{\infty}{\oplus}\end{array}$ & $\stackrel{\rho}{=}$ & & $\underset{\sim}{~}$ & ลั่ & $\mid \begin{array}{c}0 \\
\dot{i} \\
\text { in }\end{array}$ & $\underset{\vec{\lambda}}{\stackrel{+}{\Delta}}$ & & 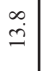 & $\stackrel{m}{=}$ & $\begin{array}{l}n \\
\infty \\
\infty\end{array}$ & 0 & $\dot{\vec{N}}$ & & $\stackrel{\grave{i}}{\grave{\lambda}}$ & 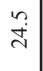 & $\stackrel{\vec{I}}{\mathrm{~d}}$ \\
\hline $\begin{array}{l}\text { : } \\
\vdots \\
\vdots \\
\vdots\end{array}$ & (0) & & & $\infty$ & $\vec{m}$ & i & $?$ & & ले & $\stackrel{\infty}{\infty}$ & $\stackrel{\circ}{+}$ & & $\underset{i}{\infty}$ & in & $\stackrel{n}{n}$ & $\mid \begin{array}{l}\infty \\
i\end{array}$ & 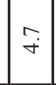 & & $\stackrel{m}{m}$ & $\vec{m}$ & $\vec{i}$ & $\hat{i}$ & & $\stackrel{\infty}{i}$ & ल & J & $f$ in & $\stackrel{+}{*}$ & & $\overrightarrow{i n}$ & $\stackrel{i}{i}$ & $\stackrel{n}{+}$ \\
\hline $\begin{array}{l}\frac{\Xi}{5} \\
\stackrel{0}{\wedge} \\
\end{array}$ & (0) & & & $\dot{0}$ & $\underset{i}{\infty}$ & $\stackrel{\circ}{-}$ & 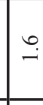 & & $\stackrel{+}{m}$ & $\underset{m}{m}$ & F & & $\stackrel{\stackrel{\circ}{i}}{ }$ & $\underset{+}{+}$ & ? & $\underset{\substack{\infty \\
\sim}}{ }$ & $\vec{i}$ & & $\stackrel{\Xi}{-}$ & i & $\stackrel{\infty}{-}$ & $\stackrel{3}{i}$ & & $\mathfrak{i}$ & $\ddot{q}$ & 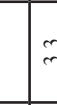 & $\dot{i}$ & \begin{tabular}{l|c}
$\mathrm{i}$ & $\stackrel{m}{2}$
\end{tabular} & & $\begin{array}{l}\infty \\
i\end{array}$ & $\vec{m}$ & $\stackrel{\infty}{i}$ \\
\hline 䒠 & का & & & $\begin{array}{l}0 \\
0\end{array}$ & 3 & - & $\stackrel{8}{\circ}$ & & $\overrightarrow{0}$ & $\overline{0}$ & $\because$ & & $\because$ & $\overrightarrow{0}$ & f. & $\overrightarrow{0}$ & $\stackrel{3}{0}$ & & 3 & $\vec{\circ}$ & $\overrightarrow{0}$ & $\overline{0}$ & & $\overrightarrow{0}$ & $\approx$ & $\stackrel{\square}{c}$ & to & $\stackrel{\partial}{b}$ & & 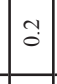 & 3 & 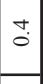 \\
\hline 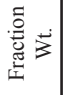 & (0) & & & $\begin{array}{l}\mathrm{I} \\
\end{array}$ & है & $\mid \stackrel{\circ}{\dot{f}}$ & $\vec{m}$ & & $\stackrel{+}{\stackrel{亠}{*}}$ & $\vec{r}$ & $\mid \begin{array}{l}\infty \\
\infty \\
\infty\end{array}$ & & fా & $\stackrel{+}{\circ}$ & $\stackrel{g}{=}$ & in & $\stackrel{?}{?}$ & & 'ึ) & 古 & $\stackrel{\circ}{\rightarrow}$ & $\overrightarrow{i n}$ & & $\vec{n}$ & $\stackrel{g}{r}$ & $\underset{\infty}{+}$ & $\dot{0}$ & 19 & & $\vec{\infty}$ & $\underset{\infty}{+}$ & $\because$ \\
\hline 善 & (D) & & & $\overrightarrow{i n}$ & \begin{tabular}{|l}
$\infty$ \\
$\infty$ \\
$\infty$
\end{tabular} & 先 & $\stackrel{\infty}{\infty}$ & & $\underset{\text { f }}{\stackrel{+}{+}}$ & 今े & $\overrightarrow{\mathrm{g}}$ & & $\overrightarrow{0}$ & $\stackrel{m}{2}$ & $\begin{array}{l}n \\
m \\
m\end{array}$ & in & $\check{g}$ & & 离 & $\underset{f}{f}$ & वे & $\begin{array}{l}\sim \\
i \\
i\end{array}$ & & $\stackrel{\infty}{\infty}$ & $\frac{a}{i}$ & gे & $\dot{v}$ & $\dot{i}$ & & $\mid \begin{array}{l}\infty \\
\infty \\
\tilde{m}\end{array}$ & iे & $\begin{array}{l}0 \\
\text { i } \\
\text {. }\end{array}$ \\
\hline 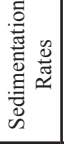 & $\begin{array}{l}\text { 咅 } \\
\text { 总 }\end{array}$ & & 苂 & & & & & is & & & & & & & & & & $\begin{array}{l}\infty \\
0 \\
0\end{array}$ & & & & & 苛 & & 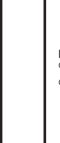 & & & & & & & \\
\hline 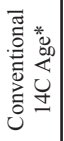 & 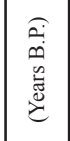 & & 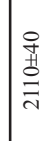 & & & & & 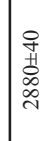 & & & & 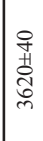 & & & & & & 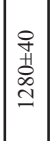 & & & & & 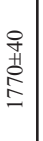 & & & & & & $\mid \begin{array}{l}\mid \\
\text { 龺 } \\
\text { 点 }\end{array}$ & & & \\
\hline 焉离 & 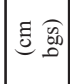 & & $\stackrel{\infty}{\circ}$ & $\equiv$ & $\exists$ & $\stackrel{0}{10}$ & $\stackrel{\overbrace{}}{\dddot{m}}$ & If & $\stackrel{8}{-}$ & 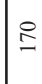 & $\stackrel{\infty}{\otimes}$ & $\stackrel{g}{g}$ & ঃ্ণ & I & 学 & $\approx$ & F & if & in & $\therefore$ & $\infty$ & 2 & $\cong$ & $\stackrel{\infty}{ \pm}$ & 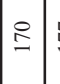 & $=\infty$ & $6 \stackrel{\sim}{\circ}$ & $\underset{\sim}{\infty}$ & 品 & $\vec{r}$ & $\overrightarrow{\mathrm{i}}$ & 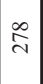 \\
\hline 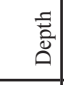 & 要 & & $\cong$ & 空 & $\begin{array}{l}\text { ते } \\
\text { ते }\end{array}$ & 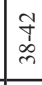 & \begin{tabular}{|l} 
\\
Gे \\
fo \\
\end{tabular} & $\begin{array}{l}\text { bे } \\
\text { in }\end{array}$ & 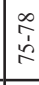 & \begin{tabular}{|l}
$\infty$ \\
$\infty$ \\
$\infty$ \\
$\infty$ \\
$\infty$
\end{tabular} & $\stackrel{\infty}{\circ}$ & $\begin{array}{l}0 \\
\\
\\
\end{array}$ & Iิ & 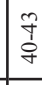 & \begin{tabular}{|l|}
$\infty$ \\
0 \\
0 \\
$i$ \\
$i n$ \\
\end{tabular} & 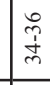 & \begin{tabular}{|l|}
\multirow{4}{*}{} \\
\multirow{\checkmark}{*}{} \\
\end{tabular} & \begin{tabular}{|l|l} 
\\
夺 \\
\end{tabular} & $\begin{array}{l}\tilde{n} \\
\hat{1} \\
\dot{n} \\
\end{array}$ & \begin{tabular}{|l}
0 \\
1 \\
0 \\
\end{tabular} & 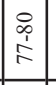 & \begin{tabular}{|c|} 
\\
1 \\
1 \\
$\infty$ \\
\end{tabular} & \begin{tabular}{c}
$\mathfrak{g}$ \\
\multirow{\sigma}{*}{} \\
\end{tabular} & 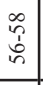 & 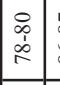 & 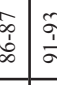 & $\frac{m}{2}$ & 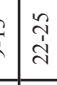 & 亲 & 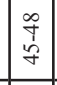 & $\begin{array}{l}\infty \\
\vdots \\
\vdots \\
\vdots \\
\\
\end{array}$ & $\begin{array}{l}n \\
c \\
c \\
c\end{array}$ \\
\hline 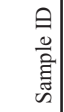 & & & $\stackrel{\circ}{n}$ & 竎 & 京 & ) & $\bar{్}$ & $\underline{n}$ & సิ & $\hat{\overbrace{}}$ & 芯 & $\stackrel{\infty}{\stackrel{\infty}{2}}$ & 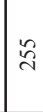 & ڤ̊ & in & ๙ิ & ¿̊. & ڤે̀ & 亏े & 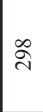 & वे & 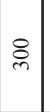 & $\stackrel{8}{\circ}$ & $\overrightarrow{\mathrm{d}}$ & ह్లి & $\vec{c}$ & $b_{0}^{t}$ & 占 & త్రి & 离 & 今 & 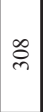 \\
\hline 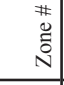 & & & & 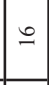 & $=$ & $\stackrel{\infty}{\infty}$ & 2 & त & $\pi$ & & 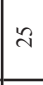 & i & $\stackrel{\sim}{2}$ & $\grave{\imath}$ & $\infty$ & in & 0 & - & $\infty$ & o & & & $\circ$ & & $=$ & $\simeq$ & $=$ & $= \pm$ & $\cong$ & & & $=$ \\
\hline 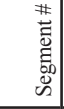 & & & 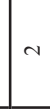 & & & & & & & & & $m$ & & & & - & & & & & & & $\sim$ & & & & $m$ & & & & & \\
\hline$\tilde{0}$ & & & ${ }^{+}$ & & & & & & & & & & & & & 6 & & & & & & & & & & & & & & & & \\
\hline
\end{tabular}


NW SE
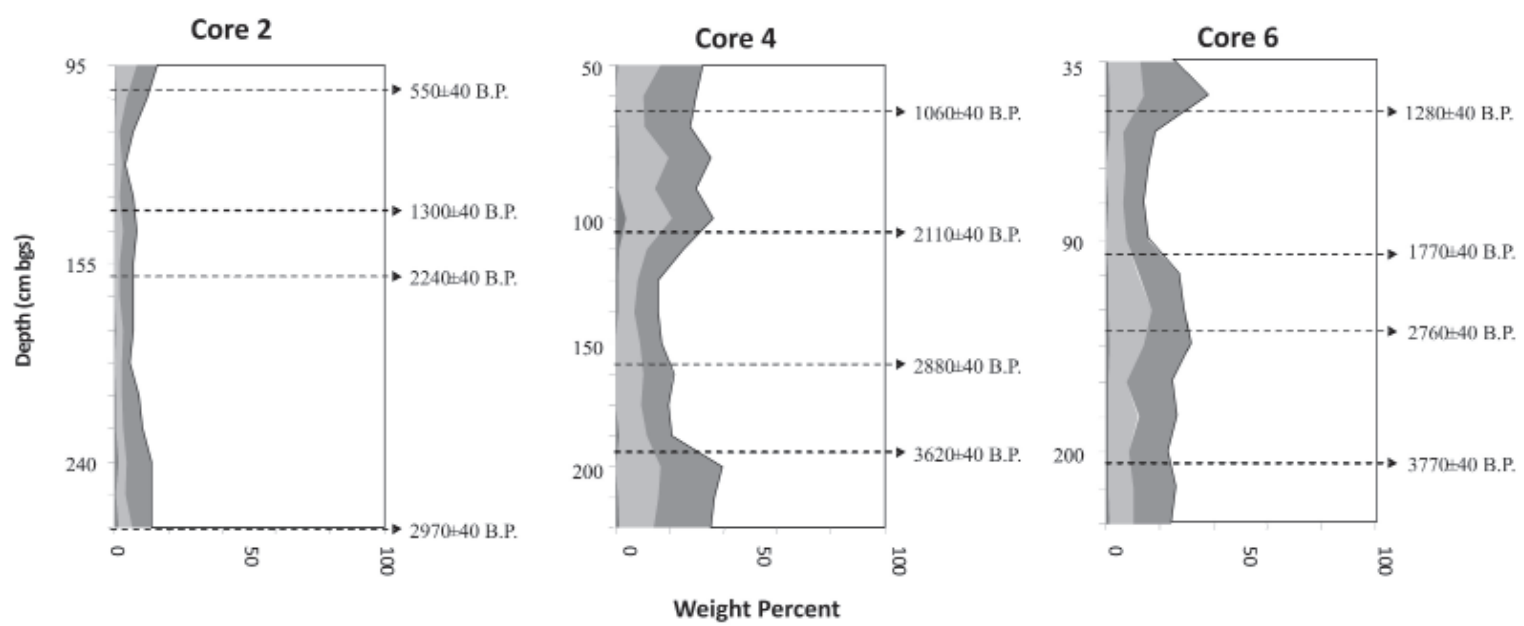

Silt and Clay

Fine Sand

Medium Sand

Coarse Sand

Figure E-4. Particle-size analysis from ostracode samples (cores 2, 4, and 6) for establishing the the site paleohydraulics with the micro-invertebrate and foraminifera populations.

A total of 45 sediment samples were analyzed for microinvertebrates of which 34 contained microfossils. Limnic ostracodes occurred in three samples of core 2 (15 samples), 11 of core 4 (16 samples), and eight of core 6 (14 samples). Marine ostracodes did not occur in core 2, but were present in 11 samples of core 4 and 12 of core 6 . Foraminifera did not occur in core 2, except for three specimens at sample 129, but were present in all samples of cores 4 and 6 . Molluscs occurred only once in core 2 but appeared in 13 samples of core 4 and ten samples of core 6 .

Table E-2 shows the faunal composition and taphonomic features (fragmentation, abrasion, encrustation, coating, redox index, and shell (or test) color) recorded at the three cores. Ostracodes, foraminifera, and molluscs occurred in Cayo del Oso Bay. Foraminifera were the most diverse and abundant biologic group in the cores (9 species, 3-606 specimens). This group occurred in cores 4 and 6; core 2 only contained nonmarine ostracodes and molluscs. Molluscs were scarce both in diversity and abundance (1-4 species, 1-17 specimens). Ostracodes were poorly to moderately diverse and abundant (1-10 species, 1-87 specimens).

Table E-3 documents the list of ostracode species identified from Cayo del Oso cores and the ecological parameters controlling their occurrence in the basin. Thirteen species were identified, five of which are common to fresh- to saline continental waters: Cyprideis salebrosa (Van den Bold, 1963), Cyprinotus glaucus (Furtos, 1933), Candona rawsoni (Tressler, 1957), Cypridopsis sp., and Limnocythere sp. cf. L. floridensis Keyser, 1975. The remaining eight species are all marine (common in estuarine, lagoonal, and nearshore open marine environments): Perissocytheridea rugata Swain, 1955, Radimella wantlandi Teeter, 1975, Cytherura sandbergi Morales, Loxoconcha avellana (Brady), Aurila laevicula (Edwards, 1944), Xestoleberis banda (Benson, 1959), Haplocytheridea proboscidiala (Edwards), and Cushmanidea sp. 
Table E-2. Micropaleontologic Composition of Cores 2, 4, and 6 from Cayo del Oso Bay, Nueces County, Texas, Including Taphonomic Parameters

\begin{tabular}{|c|c|c|c|c|c|c|c|c|c|c|c|c|c|c|c|}
\hline \begin{tabular}{|c|}
$\begin{array}{c}\text { Sample } \\
\text { ID }\end{array}$ \\
\end{tabular} & Depth & \begin{tabular}{|c|} 
Total \\
Depth \\
\end{tabular} & \begin{tabular}{|c|} 
Conventional \\
$14 \mathrm{C} \mathrm{Age}^{*}$
\end{tabular} & $\begin{array}{l}\text { Bulk } \\
\text { Wt. }\end{array}$ & \begin{tabular}{|c|}
$\begin{array}{c}\text { Fraction } \\
\text { Wt. }\end{array}$ \\
\end{tabular} & Foraminifera & Ostracodes & Mollusks & $\begin{array}{l}\text { Plant } \\
\text { Debris } \\
\end{array}$ & & & Taphonomy: & & & \\
\hline & $(\mathrm{cm})$ & $\begin{array}{l}\text { (cm } \\
\text { bgs) }\end{array}$ & (Years B.P.) & (g) & (g) & & & & & Fragmentation & Abrasion & Encrustation & Coating & $\begin{array}{l}\text { Redox } \\
\text { Index }\end{array}$ & \begin{tabular}{|l|} 
Shell \\
Color
\end{tabular} \\
\hline 118 & 93-96 & 95 & & 32.9 & 5.1 & & 4 & 2 & & 30 & 15 & 10 & 0 & 0 & White \\
\hline 67 & 96-98 & 97 & $550 \pm 40$ & & & & & & & & & & & & \\
\hline 119 & $4-8$ & 112 & & 36.7 & 4.5 & & 1 & & & 30 & 15 & 10 & 0 & 0 & White \\
\hline 120 & $14-17$ & 120 & & 28.8 & 2 & & & & & & & & & & \\
\hline 121 & $23-26$ & 129 & & 33.8 & 1.2 & & 1 & & & 0 & 0 & 0 & 0 & 0 & Clear \\
\hline 122 & $32-35$ & 138 & & 36.6 & 2.5 & & & & & & & & & & \\
\hline 69 & $36-38$ & 140 & $1300 \pm 40$ & & & & & & & & & & & & \\
\hline 123 & $42-44$ & 145 & & 37.8 & 3.1 & & & & & & & & & & \\
\hline 124 & $52-56$ & 155 & & 31.9 & 2.2 & & & & & & & & & & \\
\hline 71 & $28-30$ & 160 & $2240 \pm 40$ & & & & & & & & & & & & \\
\hline 125 & $62-64$ & 163 & & 43.4 & 3 & & & & & & & & & & \\
\hline 126 & $70-73$ & 170 & & 35.7 & 2.4 & & & & & & & & & & \\
\hline 127 & $80-82$ & 180 & & 47.3 & 2.8 & & & & & & & & & & \\
\hline 128 & $90-93$ & 190 & & 54.7 & 4.9 & & & & & & & & & & \\
\hline 129 & $24-26$ & 232 & & 36.3 & 3.7 & 3 & & & & 0 & 0 & 0 & 0 & 0 & White \\
\hline 130 & $32-34$ & 239 & & 30.4 & 4.3 & & & & & & & & & & \\
\hline 131 & $40-42$ & 244 & & 36.8 & 5.1 & & & & & & & & & & \\
\hline 132 & 49-51 & 252 & & 51.5 & 7.2 & & & & & & & & & & \\
\hline 72 & 56-58 & 259 & $2970 \pm 40$ & & & & & & & & & & & & \\
\hline 240 & $48-52$ & 50 & & 53.5 & 17.3 & 606 & 13 & 15 & & 15 & 10 & 0 & 5 & 0 & Clear \\
\hline 241 & $60-63$ & 60 & & 55.7 & 16.3 & 473 & 12 & 2 & $x$ & 10 & 10 & 0 & 5 & 0 & Clear \\
\hline 153 & $65-68$ & 65 & $1060 \pm 40$ & & & & & & & & & & & & \\
\hline 242 & $70-74$ & 70 & & 33.1 & 9.2 & 110 & 7 & 2 & $x$ & 15 & 10 & 0 & 5 & 0 & White \\
\hline 243 & $80-83$ & 80 & & 47.1 & 16.7 & 95 & 2 & & $x$ & 10 & 5 & 0 & 5 & 0 & Clear \\
\hline 244 & $88-90$ & 90 & & 47.5 & 14 & 44 & & 3 & $x$ & 15 & 10 & 0 & 5 & 0 & White \\
\hline 245 & 95-97 & 95 & & 40.6 & 14.6 & 14 & & 2 & $\mathrm{X}$ & 30 & 10 & 0 & 0 & 0 & White \\
\hline 156 & 13 & 108 & $2110 \pm 40$ & & & & & & & & & & & & \\
\hline 247 & $15-17$ & 111 & & 59.1 & 14.9 & 74 & 2 & 13 & $x$ & 15 & 10 & 0 & 5 & 0 & White \\
\hline 248 & $22-24$ & 117 & & 38.8 & 6.2 & 83 & 16 & 6 & $x$ & 15 & 10 & 10 & 5 & 0 & White \\
\hline 250 & $38-42$ & 130 & & 25.5 & 4 & 143 & 22 & 5 & $x$ & 10 & 5 & 0 & 5 & 0 & Clear \\
\hline 251 & 46-49 & 135 & & 18.5 & 3.1 & 87 & 13 & 4 & $x$ & 10 & 5 & 0 & 5 & 0 & Clear \\
\hline 157 & $59-61$ & 145 & $2880 \pm 40$ & & & & & & & & & & & & \\
\hline 252 & 75-78 & 160 & & 34.4 & 7.4 & 594 & 87 & 17 & $x$ & 5 & 5 & 0 & 5 & 0 & Clear \\
\hline 253 & $85-88$ & 170 & & 35.9 & 7.1 & 110 & 12 & 15 & $x$ & 5 & 5 & 0 & 5 & 0 & Clear \\
\hline 254 & $98-100$ & 180 & & 42.1 & 8.8 & 545 & 67 & 5 & $x$ & 5 & 5 & 0 & 5 & 0 & Clear \\
\hline 158 & 14-16 & 195 & $3620 \pm 40$ & & & & & & & & & & & & \\
\hline 255 & $17-20$ & 200 & & 16.1 & 6.4 & 9 & & & $x$ & 5 & 0 & 0 & 0 & 0 & Clear \\
\hline 256 & $40-43$ & 240 & & 28.3 & 10.4 & 13 & & 1 & $x$ & 15 & 10 & 0 & 5 & 0 & Clear \\
\hline 257 & $55-58$ & 255 & & 33.5 & 11.9 & 3 & & & $x$ & 15 & 10 & 0 & 5 & 0 & Clear \\
\hline 295 & $34-36$ & 35 & & 22.5 & 5.7 & 222 & 1 & 1 & $x$ & 5 & 0 & 0 & 0 & 0 & Clear \\
\hline 296 & $42-45$ & 42 & & 19.2 & 7.3 & 77 & 2 & 1 & $x$ & 5 & 0 & 0 & 0 & 0 & Clear \\
\hline 259 & $44-45$ & 45 & $1280 \pm 40$ & & & & & & & & & & & & \\
\hline 297 & $50-53$ & 50 & & 28.4 & 5.2 & 7 & & & $x$ & 0 & 0 & 0 & 0 & 0 & Clear \\
\hline 298 & $67-70$ & 70 & & 34.7 & 5.5 & 387 & 1 & 3 & $x$ & 5 & 5 & 0 & 0 & 0 & Clear \\
\hline 299 & $77-80$ & 80 & & 29 & 4 & 244 & 9 & 6 & $x$ & 5 & 0 & 0 & 0 & 0 & Clear \\
\hline 300 & $87-90$ & 90 & & 32.5 & 5.1 & 281 & 7 & 3 & $x$ & 5 & 5 & 0 & 0 & 0 & Clear \\
\hline 260 & $42-43$ & 133 & $1770 \pm 40$ & & & & & & & & & & & & \\
\hline 301 & 56-58 & 148 & & 18.9 & 5.1 & 144 & 6 & 2 & & 5 & 5 & 0 & 0 & 0 & Clear \\
\hline 302 & $78-80$ & 170 & & 27.2 & 7.9 & 162 & 11 & 4 & & 5 & 5 & 0 & 0 & 0 & Clear \\
\hline 261 & $86-87$ & 177 & $2760 \pm 40$ & & & & & & & & & & & & \\
\hline 303 & 91-93 & 183 & & 26.9 & 8.4 & 149 & 2 & & & 5 & 5 & 0 & 0 & 0 & Clear \\
\hline 304 & $9-13$ & 203 & & 28.9 & 7.1 & 60 & 1 & & & 5 & 5 & 0 & 0 & 0 & Clear \\
\hline 305 & $22-25$ & 228 & & 29.8 & 7.9 & 55 & 1 & 1 & $x$ & 5 & 5 & 0 & 0 & 0 & Clear \\
\hline 262 & $40-42$ & 245 & $3770 \pm 40$ & & & & & & & & & & & & \\
\hline 306 & $45-48$ & 251 & & 35.8 & 8.1 & 47 & 3 & 1 & & 5 & 5 & 0 & 0 & 0 & White \\
\hline 307 & $55-58$ & 261 & & 32.9 & 8.4 & 21 & 3 & 2 & & 5 & 5 & 0 & 0 & 0 & White \\
\hline 308 & 73-75 & 278 & & 32.6 & 7.7 & 17 & & & & 5 & 5 & 0 & 0 & 0 & White \\
\hline
\end{tabular}

* Radiocarbon dates obtained from humate samples. For details see Tomka et al. (This volume) 
Table E-3. Ecological Requirements of Ostracode Species Recovered from Site 41NU2, Cayo del Oso Bay, Nueces County, Texas

\begin{tabular}{|c|c|c|c|c|c|c|c|}
\hline \multirow{2}{*}{\begin{tabular}{|l|}
\multicolumn{1}{|c}{ Species } \\
Cyprideis salebrosa (Van den \\
Bold 1963)
\end{tabular}} & \multirow{2}{*}{\begin{tabular}{|c|} 
Habitat \\
Springs, streams, lakes
\end{tabular}} & \multirow{2}{*}{$\begin{array}{c}\text { Permanence } \\
\begin{array}{c}\text { Permanent or } \\
\text { ephemeral }\end{array}\end{array}$} & \multicolumn{2}{|c|}{ Temperature } & \multirow{2}{*}{\begin{tabular}{|c|} 
Salinity* \\
$100-4,000$ mg L-1
\end{tabular}} & \multicolumn{2}{|c|}{ Chemistry* } \\
\hline & & & $2-32^{\circ} \mathrm{C}$ & Eurythermic & & $0.10-50$ meq L-1 & Freshwater to Ca-rich \\
\hline Cyprinotus glaucus (Furtos, 1933) & Streams, lakes, ponds & $\begin{array}{c}\text { Permanent or } \\
\text { ephemeral }\end{array}$ & $6-18^{\circ} \mathrm{C}$ & Eurythermic & $100-4,000 \mathrm{mg} \mathrm{L}-1$ & $0.10-50.0$ meq L-1 & Freshwater to Ca-rich \\
\hline $\begin{array}{l}\text { Candona rawsoni (Tressler, } \\
\text { 1957) }\end{array}$ & Lakes, ponds & Permanent & $24-32^{\circ} \mathrm{C}$ & Eurythermic & $500-5,000 \mathrm{mg} \mathrm{L}-1$ & 0.10-4.0 meq L-1 & Freshwater to Ca-rich \\
\hline Limnocythere ? sp. & Springs, streams, lakes & $\begin{array}{c}\text { Permanent or } \\
\text { ephemeral }\end{array}$ & NA & Eurythermic & NA & NA & Freshwater to Ca-rich \\
\hline Cypridopsis sp. & Springs, streams, lakes & $\begin{array}{c}\text { Permanent or } \\
\text { ephemeral }\end{array}$ & NA & Eurythermic & NA & NA & Freshwater to Ca-rich \\
\hline $\begin{array}{l}\text { Perissocytheridea swaini } \\
\text { (Benson and Kaesler, 1963) }\end{array}$ & Estuarine or lagoonal & Permanent & & & & & \\
\hline Radimella confragosa (Edwards) & Estuarine or lagoonal & Permanent & & & & & \\
\hline Cytherura sandbergi Morales & Estuarine or lagoonal & Permanent & & & & & \\
\hline Loxoconcha avellana (Brady) & Estuarine or lagoonal & Permanent & & & & & \\
\hline Aurila conradi (Howe and McGuirt) & Estuarine or lagoonal & Permanent & & & & & \\
\hline Cushmanidea sp. & Estuarine or lagoonal & Permanent & & & & & \\
\hline Xestoleberis banda Benson, 1959 & Estuarine or lagoonal & Permanent & & & & & \\
\hline $\begin{array}{l}\text { Haplocytheridea proboscidiala } \\
\text { (Edwards) }\end{array}$ & Estuarine or lagoonal & Permanent & & & & & \\
\hline
\end{tabular}

\section{* NANODe}

Table E-4 shows the total population, total and relative abundance, disarticulation and adulthood ratios by species, and the paleosalinity index generated by equation (1). The paleosalinity index is a dimensionless number with no true salinity value obtained to produce the salinity patterns shown in Figures E-5 through E-7.

Table E-5 displays the list of foraminifera species identified from cores 4 and 6: Ammonia beccarii (Linné), Elphidium galvestonense Kornfeld, Elphidium gunteri Cole, 1931, Triloculina bicarinata (d'Orbigny), Triloculina linneiana (Brady, 1884), Quniqueloculina laevigata (d'Orbigny), Quinqueloculina seminulum (Linné, 1758), Hanzawaia sp. cf. H. tagaensis (Asano), and Cribroelphidium sp. All species are common to nearshore open marine, reefal, or lagoonal environments. Table E- 6 documents the total population and the total and relative abundance by species.

Table E-7 summarizes the ecological parameters controlling the occurrence of the seven mollusc species documented in this study. Table E-8 presents the list of mollusc species identified in all three cores and their total population, as well as total and relative abundance by species. The only nonmarine species was Physa virgata (Gould, 1855); the marine species consisted of Cerithidea (Cerithidopsis) pliculosa (Menke, 1892), Littoridina (Texadina) sphinctostoma (Abbot and Ladd, 1951), Polinices duplicatus (Say, 1822), Argopecten irradians (Lamarck, 1819), Chione latirilata (Conrad, 1841), and Callocardia (Agriopoma) texasiana (Dall, 1892).

\section{The Ostracode Record}

The ostracode population recorded at Cayo del Oso Bay indicates the basin received both seawater and freshwater overtime. Close to site $41 \mathrm{NU} 2$, core 2 contained no marine ostracodes. However, three specimens of the foraminifer $A$. beccarii intruded into the area suggesting eaolian transport. C. glaucus, C. rawsoni, and Cypridopsis sp. rarely entered the basin. The taphonomic parameters indicate the specimens were introduced by streamflow and were unable to settle and develop a biocenosis (Figure E-5). Fragmentation and abrasion were moderately high (15-30\%). The poor record is also an indication of a reworked fauna (Table E-2).

Core 4 contained a diverse assemblage mostly of marine species. A brackish-water ostracode alternated with the marine forms. C. salebrosa, a limnic to upper bay species, occurred throughout the core ranging from extremely rare (1) to common (22). Occasionally, it was the only species present in the sediments. The upper- and mid-bay ostracodes present at core 4 were $P$. rugata, $R$. wantlandi, A. laevicula, C. sandbergi, L. avellana, and more rarely $X$. banda, and $H$. proboscidiala. In general, the ostracode population at core 4 represented a biocenosis (Figure E-6). Fragmentation and abrasion ranged from low to moderately low (5-15\%), occasionally moderately high (30\%). Some shells showed evidence of coating (5\%) indicating shallow water and wave action (Table E-2). Both the marine and limnic populations established communities as indicated by the disarticulation and adulthood ratios (Table E-4). 


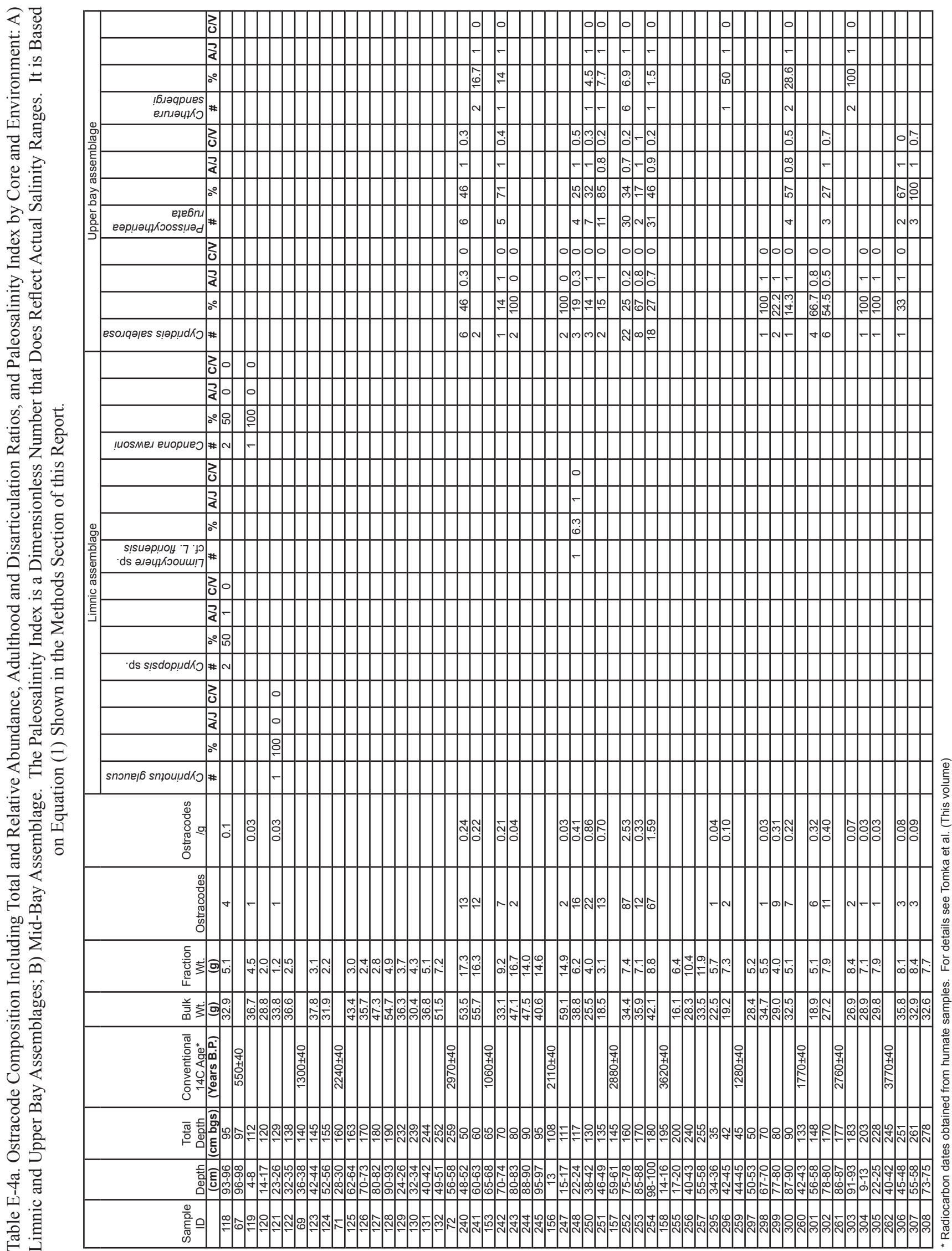




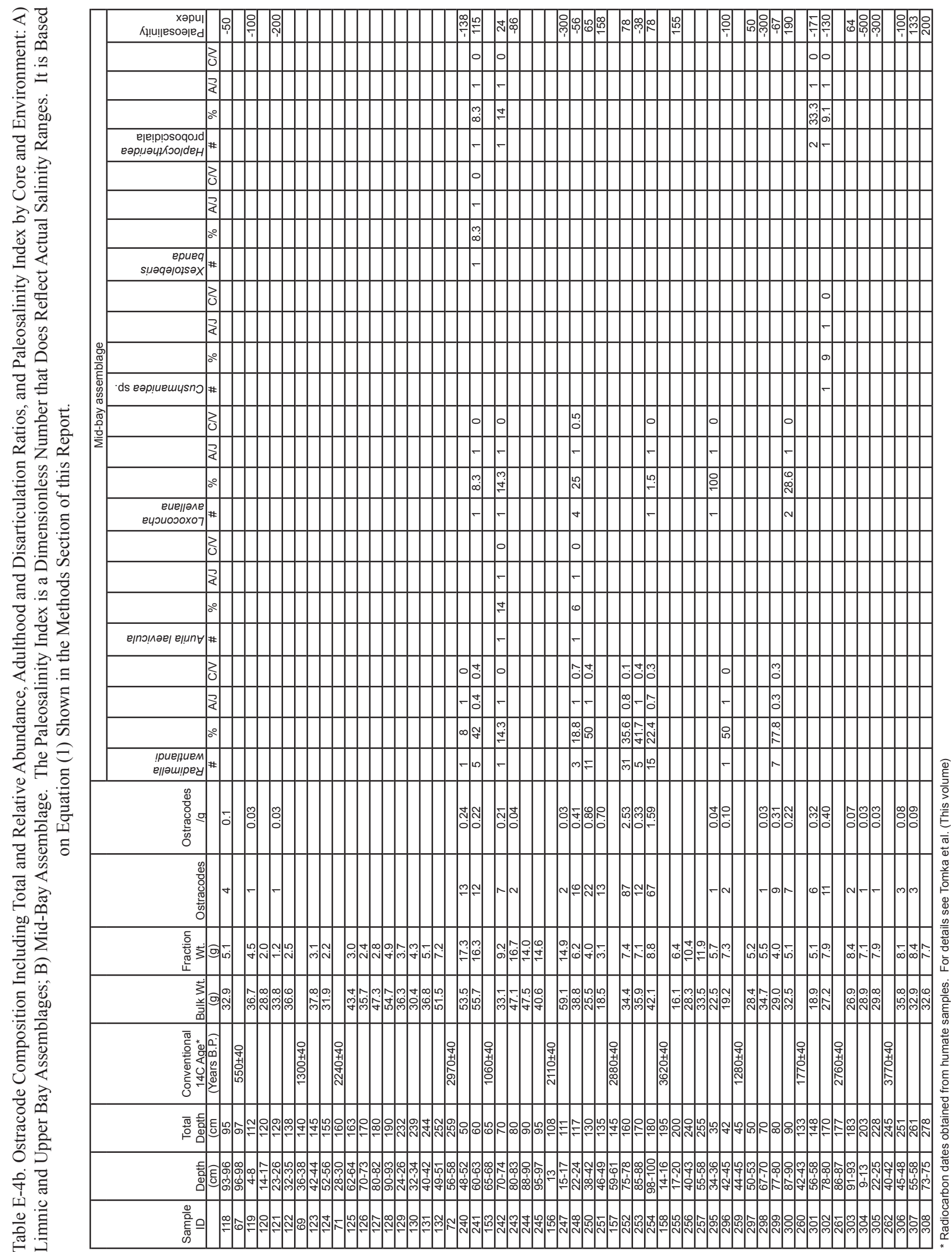




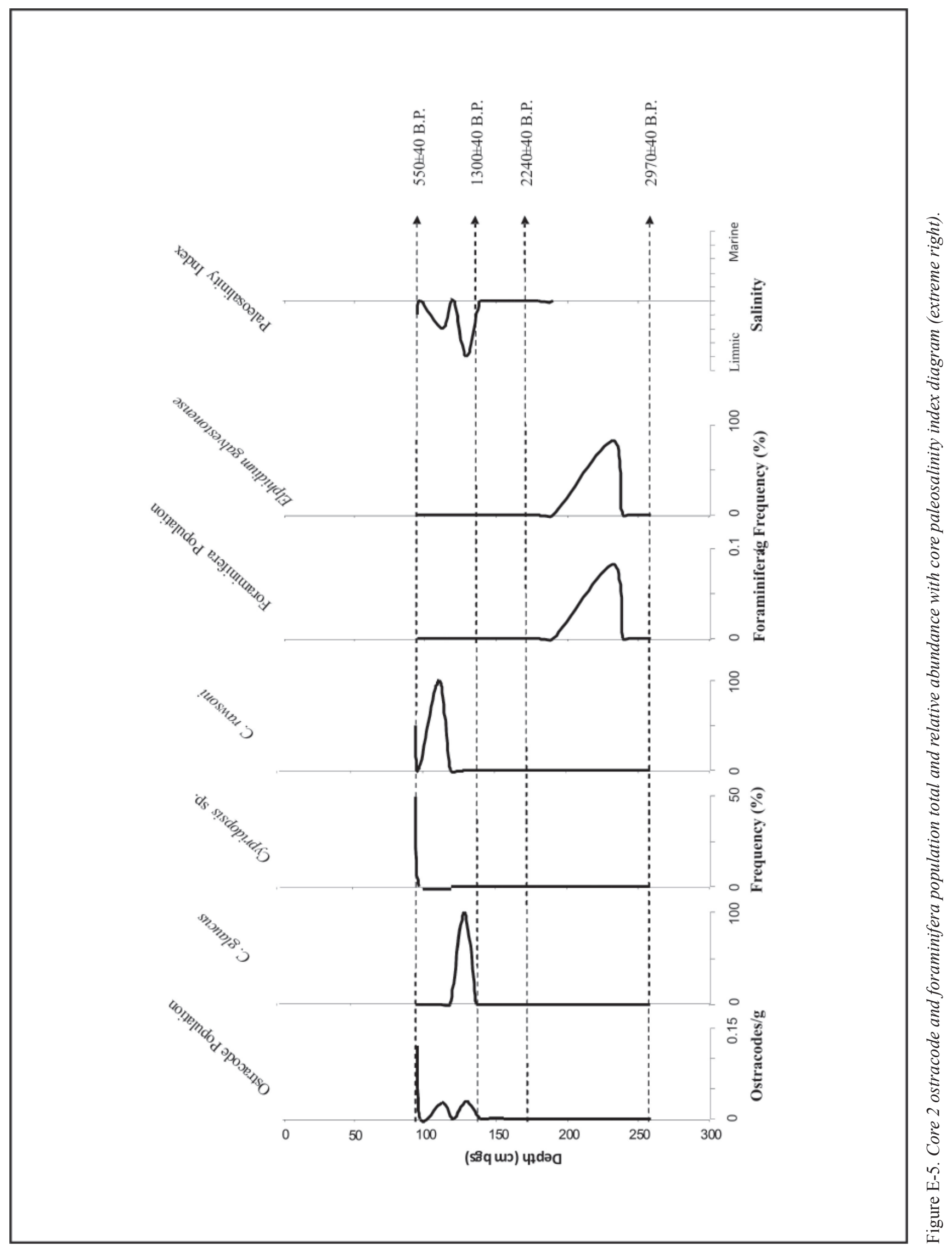




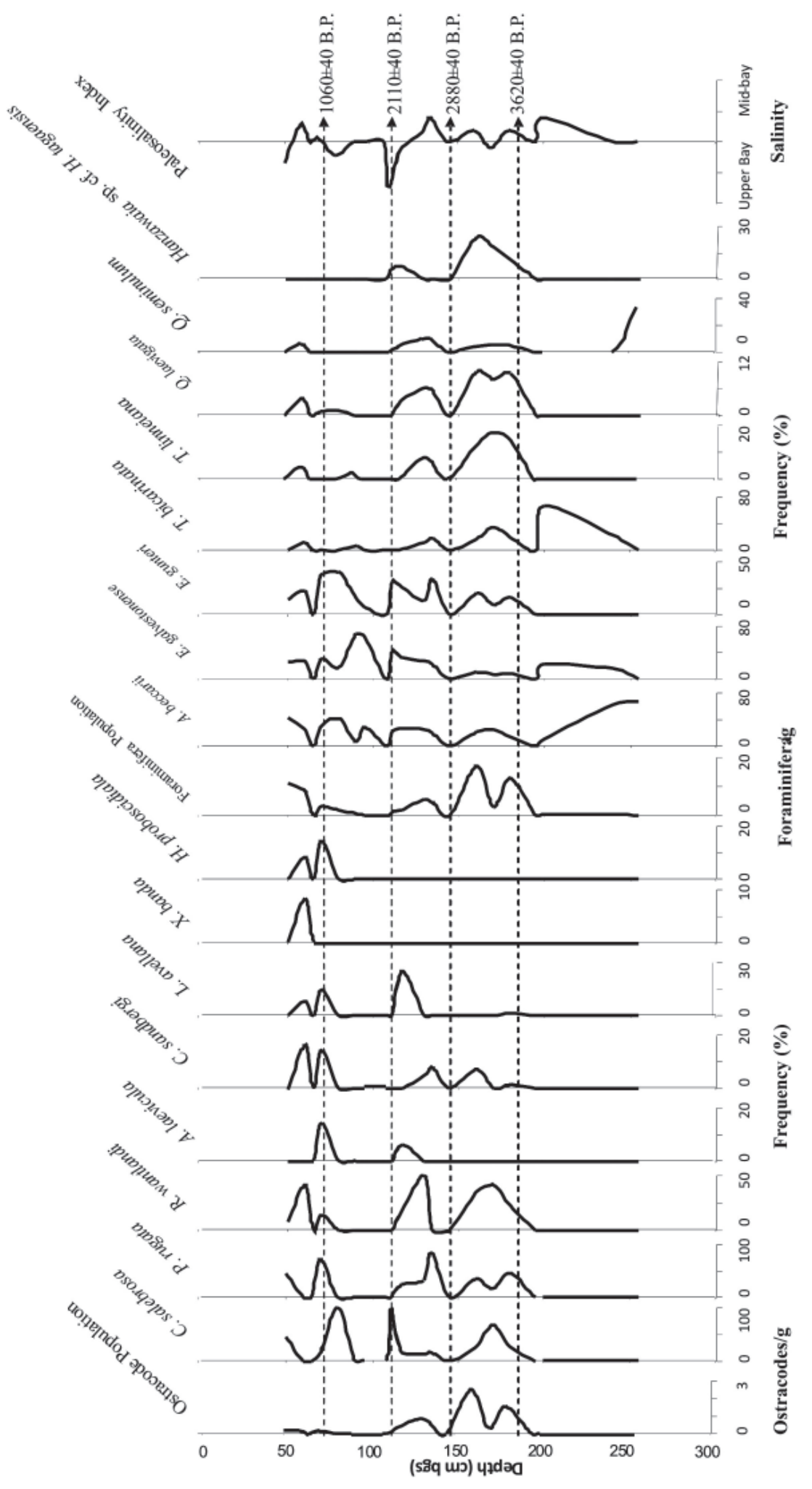




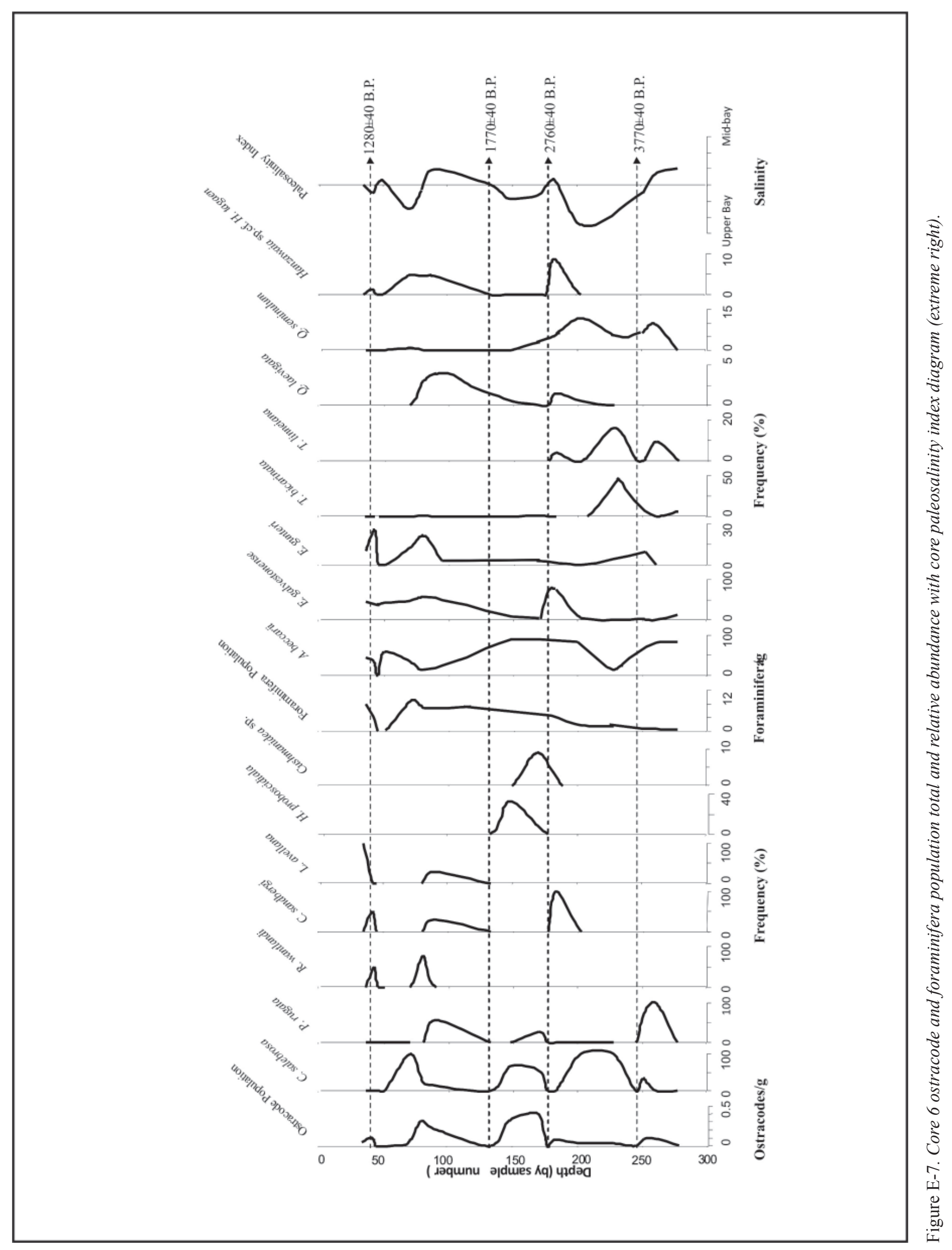


Table E-5. Ecological Requirements of Foraminifera Species Recovered from Site 41NU2, Oso Bay, Nueces County, Texas

\begin{tabular}{|l|l|}
\hline \multicolumn{1}{|c|}{ Species } & \multicolumn{1}{c|}{ Habitat } \\
\hline Ammonia beccarii (Linné) & Nearshore or lagoonal \\
\hline Elphidium galvestonense Kornfeld & Nearshore or lagoonal \\
\hline Elphidium gunteri Cole, 1931 & Nearshore or lagoonal \\
\hline Hanzawaia sp. cf. H. tagaensis (Asano) & Nearshore or lagoonal \\
\hline Triloculina bicarinata (d'Orbigny) & Reef or lagoonal \\
\hline Triloculina linneiana (Brady, 1884) & Reef or lagoonal \\
\hline Quinqueloculina laevigata (d'Orbigny) & Reef or lagoonal \\
\hline Quinqueloculina seminulum (Linné 1758) & Reef or lagoonal \\
\hline
\end{tabular}

Core 6 contained a diverse fauna as well, also consisting mainly of marine species. At this location, C. salebrosa was less abundant (1-6 specimens) suggesting higher seawater influence. However, its occurrence alternated with the marine forms like at core 4 . The alternating upper- and midbay species included $P$. rugata, $R$. wantlandi, C. sandbergi, L. avellana, H. proboscidiala, and Cushmanidea sp. (Figure E-7). Low fragmentation and abrasion $(<5 \%)$ characterized the specimens. No other taphonomic parameteres were recorded. The ostracode population also established a biocenosis (see Table E-4), with the possible exception of C. salebrosa that might have been transported to the site from areas that received freshwater discharge. As a result, its occurrence at core 6 indicates pulses of freshwater input.

\section{The Foraminifera Record}

The foraminifera population recorded at Cayo del Oso Bay indicates the basin received a strong marine influence throughout the record. Restricted to marine environments, only a few species may tolerate brackish-water conditions with a salinity range greater than $10 \%$ (parts per thousand). As indicated earlier, core 2 contained no marine forms except for interval 129 where three specimens of $A$. beccarii were identified (Figure E-5). The poor foraminifera record in core 2 also indicates that these organisms were introduced during a storm. The taphonomic parameters show moderately high fragmentation and abrasion (15-30\%) (Table E-2).

Core 4 contained a diverse and abundant population consisting of A.beccarii, E. galvestonense, E. gunteri, T. bicarinata, T. linneiana, $Q$. laevigata, $Q$. seminulum, and Hanzawaia sp.cf. H. tagaensis (Table E-5). The foraminiferal assemblage represented a biocenosis with a population size ranging from extremely rare ( 3 specimens) to very abundant (606 specimens) (Table E-2 and Figure E-6). Fragmentation and abrasion ranged from low to moderately low (5-15\%), occasionally moderately high $(30 \%)$. Some tests showed evidence of coating (5\%) consistent with shallow water and wave action. In general, A. beccarii $(>25 \%), E$. galvestonense $(>15 \%)$, and E. gunteri $(>10 \%)$ were the most common and abundant species, rarely overshadowed by $T$. bicarinata. Other species occurred randomly at lower concentrations (Table E-6).

Core 6 was equally diverse and abundant. The same eight species (Table E-5) occurred in the stratigraphic column. E. galvestonense was more abundant than $A$. beccarii in the upper part of the core (samples 295 to 300), but the latter was more abundant in the lower part of the core. E. gunteri was less abundant than in core 4 and the remaining species occurred in a patchy pattern (Table E-6). Low fragmentation and abrasion $(<5 \%)$ characterized the specimens. No other taphonomic parameteres were recorded. The foraminifera also established a biocenosis (Table E-4).

\section{The Mollusc Record}

By contrast with ostracodes and foraminifera, molluscs were less diverse and significantly rare. One freshwater gastropod and six marine gastropods and bivalves occurred in the Cayo del Oso cores. The freshwater snail $P$. virgata occurred once in core 2 (upper part). No other molluscs were recorded from core 2. The two specimens recovered showed evidence of fragmentation and abrasion suggesting they were introduced into the system.

The marine species that occurred in cores 4 and 6 only included: the gastropods $C$. (C.) pliculosa, $L$. (T.) sphinctostoma, $P$. duplicatus, and the bivalves $A$. irradians, $C$. latirilata, and C. (A.) texasiana. The mollusc population ranged from extremely rare ( 1 specimen) to rare $(<17$ specimens) (Table E-8). All six species were present in core 4 where Cerithidea 


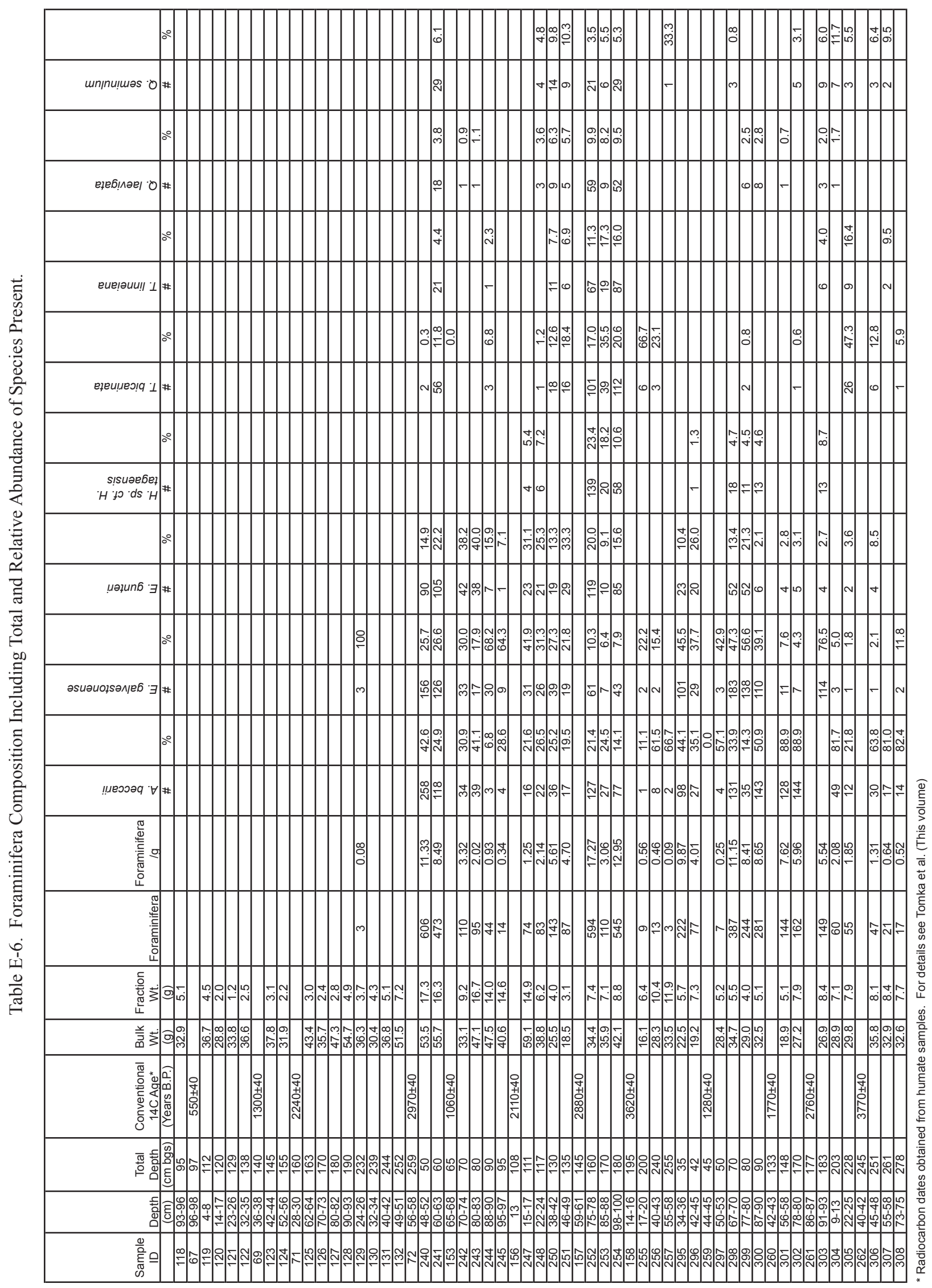


Table E-7. Ecological Requirements of Mollusc Species Recovered from Site 41NU2, Oso Bay, Nueces County, Texas

\begin{tabular}{|l|l|c|c|}
\hline \multicolumn{1}{|c|}{ Species } & \multicolumn{1}{|c|}{ Habitat } & Permanence & \multicolumn{1}{c|}{ Salinity } \\
\hline Physa virgata (Gould, 1855) & Slow flow to stagnat freshwater & Permanent & Fresh- to brackish-water \\
\hline Cerithidea (Cerithidopsis) pliculosa (Menke, 1892) & Mud flats. In bays and inlets & Permanent & Seawater \\
\hline Littoridina (Texadina) sphinctostoma (Abbot \& Ladd, 1951) & Soft mud in discharge influenced areas & Permanent & Brackish-water \\
\hline Polinices duplicatus (Say, 1822) & Along beaches and inlet areas in sand & Permanent & Seawater \\
\hline Argopecten irradians (Lamarck, 1819) & High salinity bays with seagrass meadows & Permanent & Seawater \\
\hline Chione latirilata (Conrad, 1841) & Nearshore and inlets. Infaunal & Permanent & Seawater \\
\hline Callocardia (Agriopoma) texasiana (Dall, 1892) & Clay lagoon sediments. Infaunal & Permanent & Seawater \\
\hline
\end{tabular}

Table E-8. Mollusc Composition Including Total and Relative Abundance of Species Present

\begin{tabular}{|c|c|c|c|c|c|c|c|c|c|c|c|c|c|c|c|c|c|c|c|c|c|c|c|c|c|c|c|c|}
\hline \multirow{3}{*}{$\begin{array}{c}\text { Sample } \\
\text { ID } \\
\end{array}$} & \multirow[b]{2}{*}{ Depth } & \multirow[b]{2}{*}{$\begin{array}{l}\text { Total } \\
\text { Depth }\end{array}$} & \multirow[b]{2}{*}{$\begin{array}{c}\text { Conventional } \\
14 \mathrm{C} \mathrm{Age}{ }^{*}\end{array}$} & \multirow[b]{2}{*}{$\begin{array}{c}\text { Bulk } \\
\text { Wt. }\end{array}$} & & & & & shwa & & & & & & & & & & Mar & ine & & & & & & & & \\
\hline & & & & & $\begin{array}{c}\text { Fraction } \\
\text { Wt. } \\
\end{array}$ & Mollusks & $\begin{array}{c}\text { Mollusks } \\
\mathrm{lg}\end{array}$ & 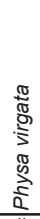 & & & 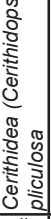 & & & 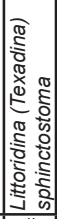 & & & 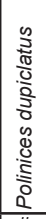 & & & $\begin{array}{l}\frac{\pi}{\pi} \\
\frac{\pi}{2} \\
\frac{\pi}{0} \\
\frac{0}{0} \\
\frac{0}{\pi} \\
\end{array}$ & & & 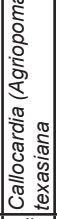 & & & 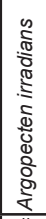 & & \\
\hline & $(\mathrm{cm})$ & (cm bgs $)$ & (Years B.P.) & (g) & \begin{tabular}{|l|} 
(g) \\
\end{tabular} & 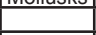 & & $\#$ & $\%$ & $\mathrm{~A} / \mathrm{J}$ & \# & $\%$ & $\mathrm{~A} / \mathrm{J}$ & $\#$ & $\%$ & $\mathrm{~A} / \mathrm{J}$ & $\#$ & $\%$ & $\mathrm{~A} / \mathrm{J}$ & $\#$ & $\%$ & $\mathrm{~A} / \mathrm{J}$ & $\#$ & $\%$ & A/J & $\#$ & $\%$ & $\bar{A} / \mathrm{J}$ \\
\hline 118 & $93-96$ & 95 & & \begin{tabular}{|l|}
32.9 \\
\end{tabular} & 5.1 & 2 & 0.06 & $\frac{\pi}{2}$ & 100 & 0 & & & & & & & & & & & & & & 10 & & & & \\
\hline 67 & $96-98$ & 97 & $550 \pm 40$ & & & & 0.00 & & 100 & & & & & & & & & & & & 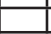 & & & - & & & & \\
\hline 119 & $4-8$ & 112 & & 36.7 & 4.5 & & & & & & & & & & & & & & & & ב & & & & & & & \\
\hline 120 & 14-17 & 120 & & \begin{tabular}{|l|}
28.8 \\
\end{tabular} & 2.0 & & & 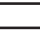 & & 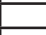 & - & & Z & & - & & - & & 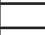 & - & 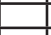 & - & Z & + & - & - & & - \\
\hline 121 & $23-26$ & 129 & & 33.8 & 1.2 & & & & & & & & 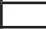 & & & & & & - & & 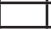 & & & 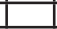 & & 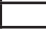 & & - \\
\hline 122 & $32-35$ & 138 & & 36.6 & 2.5 & & & & & & & & 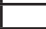 & & & & 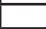 & & 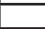 & & 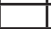 & & & 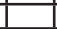 & 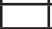 & 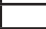 & & 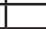 \\
\hline 69 & $36-38$ & 140 & $1300 \pm 40$ & & & & & & & & & & & & & & & & & & - & & & - & & & & \\
\hline 123 & $42-44$ & 145 & & \begin{tabular}{|l|}
37.8 \\
\end{tabular} & 3.1 & & & & & & & & & & & & & & & & & & & ב & & 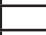 & & \\
\hline 124 & $52-56$ & 155 & & 31.9 & 2.2 & & & & & & & & 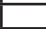 & & & & & & & & $\mathrm{E}$ & & & - & & & & 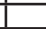 \\
\hline 71 & $28-30$ & 160 & $2240 \pm 40$ & & & & & & & 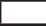 & & & 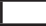 & & 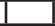 & 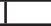 & 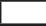 & $a_{1}$ & 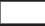 & 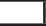 & 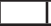 & - & 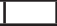 & +1 & 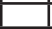 & 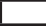 & 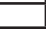 & - \\
\hline 125 & 62-64 & 163 & & 43.4 & 3.0 & & & & & & & & - & & & & - & & - & & $\square$ & - & & & & - & & \\
\hline 126 & \begin{tabular}{|l|}
$70-73$ \\
\end{tabular} & 170 & & 35.7 & 2.4 & & & & & & & & - & & 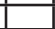 & 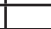 & 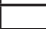 & 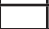 & 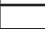 & 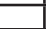 & 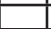 & 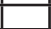 & 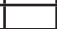 & 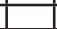 & 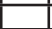 & 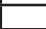 & 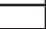 & 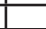 \\
\hline \begin{tabular}{|l|l|}
127 \\
127
\end{tabular} & $80-82$ & 180 & & \begin{tabular}{|l|}
47.3 \\
\end{tabular} & 2.8 & & & & & & & & - & & & & & & 筮 & & 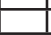 & & & - & & & & - \\
\hline 128 & $90-93$ & 190 & & \begin{tabular}{|l|}
54.7 \\
\end{tabular} & 4.9 & & & & & & & & & & & & & & & & & & & & & & & \\
\hline 129 & $24-26$ & 232 & & 36.3 & 3.7 & & & & & & & & 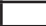 & & & & $\pi$ & & + & & 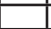 & 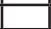 & 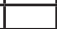 & 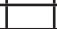 & 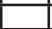 & - & & 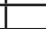 \\
\hline 130 & $32-34$ & 239 & & 30.4 & 4.3 & & & 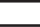 & & & & & - & & 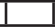 & 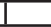 & 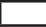 & & 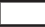 & 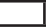 & + & - & - & 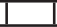 & 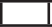 & 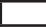 & 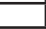 & - \\
\hline 131 & $40-42$ & 244 & & 36.8 & 5.1 & & & & & & & & & & & & - & & - & & 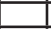 & - & & & - & - & & \\
\hline 132 & 49-51 & 252 & & \begin{tabular}{|l|}
51.5 \\
\end{tabular} & 7.2 & & & & & & & & & & & & & & & & & & & & & & & \\
\hline 72 & $56-58$ & 259 & $2970 \pm 40$ & & & & & & & & & & & & & & & & & & & & & & & & & \\
\hline 240 & $48-52$ & 50 & & 53.5 & 17.3 & 15 & 0.28 & & & & & & & & & & & & & 5 & 33.3 & 0 & 9 & 60 & 0 & 1 & 6.7 & 0 \\
\hline 241 & 60-63 & 60 & & \begin{tabular}{|l|}
55.7 \\
\end{tabular} & 16.3 & 2 & 0.04 & & & & & & & & & & & & & & דיבו & & 2 & 100 & 0 & & & \\
\hline 153 & \begin{tabular}{|c|}
$65-68$ \\
\end{tabular} & 65 & $1060 \pm 40$ & & & & & & & & & & & & & & & & & & & & & & & & & \\
\hline 242 & \begin{tabular}{|l|}
$70-74$ \\
\end{tabular} & 70 & & 33.1 & 9.2 & 2 & 0.06 & & & & & & -1 & & 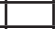 & & 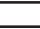 & & -5 & & - & 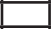 & 2 & 100 & 0 & 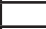 & & E \\
\hline 243 & $80-83$ & 80 & & 47.1 & 16.7 & & & & & & & & & & & & & & & & 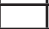 & & & & & & & \\
\hline 244 & $88-90$ & 90 & & \begin{tabular}{|l|}
47.5 \\
\end{tabular} & 14.0 & 3 & 0.06 & & & & & & & & & & & & & & $\square$ & 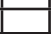 & 3 & 100 & 0 & & & - \\
\hline 245 & $95-97$ & 95 & & 40.6 & 14.6 & 2 & 0.05 & & & & 1 & 50 & 0 & & & & & & & & & & 1 & 50 & 0 & & & \\
\hline 156 & 13 & 108 & $2110 \pm 40$ & & & & & & & & & & & & & & & & & & & & & & & & & \\
\hline 247 & 15-17 & 111 & & \begin{tabular}{|l|l|}
59.1 \\
\end{tabular} & 14.9 & 13 & 0.22 & & & & 6 & 46.2 & 0 & 1 & 7.7 & \begin{tabular}{|l|} 
\\
\end{tabular} & & & & & & & & & & & & \\
\hline 248 & $22-24$ & 117 & & 38.8 & 6.2 & 6 & 0.15 & & & & 3 & 50 & 0 & 1 & 16.7 & 0 & 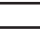 & & & & 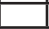 & & 2 & 33.3 & 0 & & & \\
\hline 250 & $38-42$ & 130 & & \begin{tabular}{|l|}
25.5 \\
\end{tabular} & 4.0 & 5 & 0.20 & & & & & & & 3 & 60 & 0 & & & & & 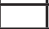 & & 2 & 40 & 0 & & & \\
\hline 251 & $46-49$ & 135 & & \begin{tabular}{|l|}
18.5 \\
\end{tabular} & 3.1 & 4 & 0.22 & & & & 1 & 25 & 0 & $\frac{3}{1}$ & \begin{tabular}{|l|}
25 \\
\end{tabular} & 0 & & & & & & & 2 & 50 & 0 & & & \\
\hline 157 & 59-61 & 145 & $2880 \pm 40$ & & & & & & & & & & & & & & & & & & & & & & & & & \\
\hline 252 & $75-78$ & 160 & & 34.4 & 7.4 & 17 & 0.49 & & & & 3 & 17.6 & 0 & 2 & 11.8 & 0 & 3 & 17.6 & 0 & 7 & 41.2 & 0 & 2 & 11.8 & 0 & & & \\
\hline 253 & $85-88$ & 170 & & \begin{tabular}{|l|}
35.9 \\
\end{tabular} & 7.1 & 15 & 0.42 & & & & $\frac{5}{3}$ & 20 & 0 & $\frac{4}{1}$ & 6.7 & \begin{tabular}{|l|l|}
0 \\
\end{tabular} & & & & 8 & 53.3 & 0 & 2 & 13.3 & 0 & & & \\
\hline 254 & $98-100$ & 180 & & \begin{tabular}{|l|}
42.1 \\
\end{tabular} & 8.8 & 5 & 0.12 & & & & 2 & 40 & 0 & & & & & & & 3 & 60 & 0 & & & & & & \\
\hline 158 & \begin{tabular}{|c|}
$14-16$ \\
\end{tabular} & 195 & $3620 \pm 40$ & & & & & & & & & & & & & & & & & & & & & & & & & \\
\hline 255 & $17-20$ & 200 & & \begin{tabular}{|l|}
16.1 \\
\end{tabular} & 6.4 & & & & & & & & & & & & & & & & - & & & & & & & \\
\hline 256 & $40-43$ & 240 & & \begin{tabular}{|l|}
28.3 \\
\end{tabular} & 10.4 & 1 & 0.04 & & & & 1 & 100 & \begin{tabular}{|l|}
0 \\
\end{tabular} & & & & & & & & & & & & & & & \\
\hline 257 & $55-58$ & 255 & & \begin{tabular}{|l|}
33.5 \\
\end{tabular} & 11.9 & & & & & & & & & & & & & & & & & & & - & & & & \\
\hline 295 & $34-36$ & 35 & & 22.5 & 5.7 & 1 & 0.04 & & & & 1 & 100 & 0 & & & & & & & & 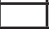 & & & 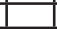 & & + & & 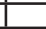 \\
\hline 296 & $42-45$ & 42 & & \begin{tabular}{|l|}
19.2 \\
\end{tabular} & 7.3 & 1 & 0.05 & & & & 1 & 100 & \begin{tabular}{|l|l|} 
\\
\end{tabular} & & & & & & & & & & & 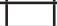 & & & & \\
\hline 259 & $44-45$ & 45 & $1280 \pm 40$ & & & & & & & & & & & & & & & & & & & & & & & & & \\
\hline 297 & $50-53$ & 50 & & \begin{tabular}{|l|}
28.4 \\
\end{tabular} & 5.2 & & & & & & & & & & & & & & & & & & & & & & & \\
\hline 298 & $67-70$ & 70 & & \begin{tabular}{|l|}
34.7 \\
\end{tabular} & 5.5 & 3 & 0.09 & & & & 1 & 33.3 & 0 & & & & & & & 2 & 66.7 & 0 & & 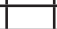 & & & & \\
\hline 299 & $77-80$ & 80 & & \begin{tabular}{|l|}
29.0 \\
\end{tabular} & 4.0 & 6 & 0.21 & & & & 2 & 33.3 & 0 & & & & & & & 4 & 66.7 & 0 & & & & & & \\
\hline 300 & $87-90$ & 90 & & 32.5 & 5.1 & 3 & 0.09 & & & & 1 & 33.3 & \begin{tabular}{|l|l|} 
\\
\end{tabular} & & & & & & & 2 & 66.7 & 0 & & & & & & \\
\hline 260 & $42-43$ & 133 & $1770 \pm 40$ & & & & & & & & & & & & & & & & & & & & & & & & & \\
\hline 301 & $56-58$ & 148 & & \begin{tabular}{|l|}
18.9 \\
\end{tabular} & 5.1 & 2 & 0.11 & & & & 1 & 50 & 0 & & & & & & & 1 & 50 & 0 & & - & & 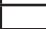 & & 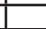 \\
\hline 302 & 78-80 & 170 & & \begin{tabular}{|l|}
27.2 \\
\end{tabular} & $\frac{3.1}{7.9}$ & $\frac{2}{4}$ & 0.15 & & & & & 30 & & & & & 1 & 25 & 0 & $\frac{1}{3}$ & \begin{tabular}{|l|l|}
75 \\
\end{tabular} & \begin{tabular}{|l|}
0 \\
\end{tabular} & & & & & & \\
\hline 261 & $86-87$ & 177 & $2760 \pm 40$ & & & & & & & & & & & & & & & & & & & & & & & & & \\
\hline 303 & 91-93 & 183 & & \begin{tabular}{|l|}
26.9 \\
\end{tabular} & 8.4 & & & & & & & & & & & & & & & & & & & 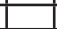 & & & & \\
\hline 304 & $9-13$ & 203 & & \begin{tabular}{|l|}
28.9 \\
\end{tabular} & 7.1 & & & & & & & & & & & & & & & & & & & & & + & & - \\
\hline 305 & $22-25$ & 228 & & 29.8 & 7.9 & 1 & 0.03 & & & & & & & & & & & & & 1 & 100 & 0 & & & & & & \\
\hline 306 & $45-48$ & 251 & & \begin{tabular}{|l|}
35.8 \\
\end{tabular} & 8.1 & 1 & 0.03 & & & & & & & & & & 1 & 100 & 0 & & 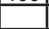 & & & 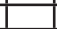 & & 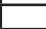 & & 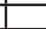 \\
\hline 307 & $55-58$ & 261 & & \begin{tabular}{|l|}
32.9 \\
\end{tabular} & 8.4 & 2 & 0.06 & & & & & & & & & & 1 & 50 & 0 & 1 & 50 & 0 & & & & & & \\
\hline 308 & \begin{tabular}{|c|}
$73-75$ \\
\end{tabular} & 278 & & \begin{tabular}{|l|}
32.6 \\
\end{tabular} & 7.7 & & & & & & & & & & & & & & & & & & & & & & & \\
\hline
\end{tabular}

* Radiocarbon dates obtained from humate samples. For details see Tomka et al. (This volume) 
(C.) pliculosa dominated throughout the stratigraphic column. Callocardia (A.) texasiana and Chione latirilata alternated with the former dominating the upper portion of the core, and the latter taking over the lower part of the core. Other species were extremely rare. Fragmentation and abrasion ranged from low to moderately low (5-15\%), occasionally moderately high (30\%). Some shells showed evidence of coating $(5 \%)$ as for ostracodes and foraminifera, this pattern is consistent with shallow water and wave action. It is unclear if molluscs succeeded in establishing a community; it is possible, however, that at some intervals (e.g., 240, 247, 252, and 253) some species settled a biocenosis.

Core 6 contained a poorer mollusc record than core 4 (Table E-8). Three species randomly occurred at the site where the core was obtained: the gastropods $C$. (C.) pliculosa and $P$. duplicatus, and the bivalve $C$. latirilata. Single specimens of $C$. latirilata only occurred at the lower portion of the core (samples 302 to 308). Low fragmentation and abrasion $(<5 \%)$ characterized the specimens. No other taphonomic parameters were recorded. Based upon the poor record it is unwarranted to infer if molluscs established a community.

\section{Interpretation}

Inferring environmental change in Cayo del Oso Bay (site 41NU2) required integrating the paleoecological signature of the micro-invertebrates found in the sediments. Ostracodes were the primary source for reconstructing the late Holocene history of the bay. The paleosalinity index generated from equation (1) was then compared with the foraminifera and mollusc signatures to establish the patterns of water salinization and dilution over time. The paleoenvironmental reconstruction of Cayo del Oso will be presented by core and summarized in the discussion.

Core 2. At the location of core 2 the particle-size analysis obtained from sample preparation shows that the area received a slow flow for the past 3000 years (Figure E-4). Sedimentation rates ranged from 0.02 to $0.05-\mathrm{cm} \mathrm{yr}^{-1}$. Small pulses of coarser grain-size at the base (between 2970 and 2500 years B.P.) and top (between 700 years B.P. and the present) of the stratigraphic column, respectively, might be the result of freshwater discharge into the bay. Two episodes of slower discharge into the bay were recorded at about 2500 years B.P. and 1000 years B.P. when clay concentration exceeded $94 \%$.

Biologically, core 2 was poor. All micro-invertebrates were extremely rare when present. Ostracodes, foraminifers, and molluscs indicate the fauna was transported into the site and failed to settle a biocenosis. This interpretation is supported by the poor preservation of the shells and tests. A preliminary paleosalinity index (Figure E-5), however, indicates that prior to 2500 years B.P. a storm deposited extremely rare foraminifers (E. galvestonense). Later, over the past 1000 years, freshwater input into the basin introduced a few ostracodes from upstream. The three species present are euryhaline (wide-salinity tolerant) (Table E-3); thus capable of tolerating dilute brackish-water conditions. Contemporary to ostracodes, extremely rare gastropods ( $P$. virgata) were introduced into the system as well. The paleoenvironmental inference of core 2 is limited and unwarranted.

Core 4. At the location of core 4 variable conditions were recorded by the particle-size analysis obtained from the sample preparation. Subject to sedimentation rates between 0.04 and $0.07-\mathrm{cm} \mathrm{yr}^{-1}$, at least three pulses of coarser sediments characterized the stratigraphic column during the past 3620 years (Figure E-4). Around 3700 years B.P. and between 2110 and 1060 years B.P. the most conspicuous episodes of sediment inflow occurred at the location of core 4. The interval between approximately 3500 and 2110 years B.P. shows a period of slow flow accumulating clayey sediments ( $>74 \%$ clay). The rest of the core mostly consisted of sandy silt (Table E-1).

Biologically, core 4 contained a moderately diverse and rich faunal assemblage including foraminifers, ostracodes, and molluscs. Foraminifera were the most abundant microfossils in the stratigraphic column indicating the strong marine and marginal marine influence into Cayo del Oso Bay. Ostracodes and molluses were not very abundant; diversity ranged from six to eight species most of them indicative of marine and marginal marine conditions. Amongst ostracodes, only $C$. salebrosa has limnic to upper bay affinities; hence it is interpreted as a brackish-water indicator associated with freshwater input. Its occurrence is consistent with the episodes of sediment coarsening approximately 3700 years B.P. and between 2110 and 1060 years B.P. During the interval of fine sedimentation upper bay to mid-bay ostracodes, foraminifers, and molluscs dominated the stratigraphic column (Tables E-4, E-6, and E-8).

Foraminifers were rare to very abundant. The estuarine species $A$. beccarii co-occurred with $E$. galvestonense and E.gunteri throughout most of the core. The porcelaneous forms of stronger marine affinities occurred in the lower part of the stratigraphic column (Figure E-6).

Ostracodes and foraminifers settled a biocenosis, as indicated by Tables E-4 and E- 6 . The taphonomic parameters show low to moderately high fragmentation and abrasion (5-30\%); low 
coating $(5 \%)$ and rare encrustation indicating alternating conditions between fresh- and seawater input (Table E-2). The ostracodes adulthood and disarticulation ratios are consistent with the establishment of a community. In addition, foraminifers ranged significantly in size, suggesting that the different species successfully settled in the vicinity of core 4. The paleosalinity index derived from ostracodes shows three main events of water dilution consistent with the occurrence of C. salebrosa and increasing grain-size (Figure E-6). Foraminifera were in good agreement with the ostracode paleosalinity index.

Core 6 . At the location of core 6 , variable conditions prevailed in the site. Five well-defined coarse grain pulses were briefly interrupted by intervals of fine sediment accumulation with the exception of the interval between 1770 and 1280 years B.P. where clay-rich $(>81 \%)$ sediments dominated the stratigraphic column. Four of the coarse-grain intervals occurred approximately between 4000 and 1770 years B.P. The last one was recorded more recently, after 1280 years B.P. (Table E-1 and Figure E-4).

Biologically, core 6 is similar to core 4. Ostracodes and foraminifers dominated; molluscs were rare to extremely rare. This association indicates a relatively stressful environment for ostracodes and molluscs. Foraminifera, however, thrived successfully in this environment. The ostracode C. salebrosa, was the only brackish-water species identified in the core. Upper bay ostracodes were not abundant either (extremely rare to rare) implying that salinity was greater than at core site 4. This interpretation is consistent with the abundance of foraminifers but not with the poor record of molluscs. By contrast with core 4 , the taphonomic parameters indicate low fragmentation and abrasion (5\%), the only features identified (Table E-2). In addition, the adulthood and disarticulation ratios of ostracode shells are consistent with a well-established biocenosis in the site (Table E-4).
A similar pattern is indicated by the abundant foraminifers that were composed of small and large specimens of the same species. Dominance of the estuarine species A. beccarii, associated with $E$. galvestonense and $E$. gunteri throughout most of the stratigraphic column indicates the constant input of freshwater into the system (Figure E-7). However, dominance of porcelaneous forms (e.g., T. bicarinata, $Q$. laevigata) in the lower part of the core suggests a stronger seawater influence prior to approximately 2000 years B. P. It is, however, at the interval between 3770 and 2760 years B.P. that the increasing population of C. salebrosa indicates the largest pulse of freshwater recorded at core 6 . Three more freshwater pulses were identified later in the stratigraphic column.

\section{Discussion}

Understanding human occupation at site Cayo del Oso (41NU2) requires a thorough reconstruction of the lagoon's paleoenviroments. Based upon Cronin's (1986) semiquantitative classification of biofacies based on fossil assemblages found in six cores around Mustang Island and Garbett and Maddocks (1979) modern distribution data, it was possible to establish some patterns of environmental fluctuations over the past 4,000 years (Table E-9). This approach is particularly useful because previous records do not focus in this area but in a much broader region including most of the state (e.g., Bousman 1998; Caran 1998; Cooke 2005; Frederick 1998 Fredlund et al. 1998; Nordt et al. 1994, 2002). A few exceptions, however, include studies on sea level change during the Holocene with little detail to the Corpus Christi Bay area (e.g., Albert 2006; Blum et al. 2002; Ricklis 2004; Ricklis and Blum 1997; Ricklis and Cox 1998). Tomka et al. (2007) summarized the paleoclimate history of southern Texas based on soil organic carbonates, carbon isotopes, and arboreal and grass pollen obtained by several authors (Bousman 1998; Camper 1991; Cooke 2005; Nickels

Table E-9. Quaternary Ostracode Assemblages Used in this Study to Identify Environments of Deposition (after Cronin, 1986)

\begin{tabular}{|l|l|l|}
\hline $\begin{array}{c}\text { Depositional } \\
\text { Environment }\end{array}$ & \multicolumn{1}{|c|}{ Salinity (ppt) } & \multicolumn{1}{c|}{ Ostracode Death Assemblage } \\
\hline Freshwater- fluvial & Limnic (0-0.5) & $\begin{array}{l}\text { Marine and bay taxa absent; nonmarine taxa present include Candona, Limnocythere, } \\
\text { Physocipria, Ilyocypris. }\end{array}$ \\
\hline Upper bay & Oligohaline (>0.5-5) & $\begin{array}{l}\text { Mixture of bay and freshwater taxa, including Limnocythere, Candona, Perissocytheridea, } \\
\text { Cyprideis salebrosa, Cytherura. }\end{array}$ \\
\hline Mid-bay & Mesohaline (>5-18) & $\begin{array}{l}\text { Bay species only, including Perissocytheridea, Cytherura, Megacythere repexa, Loxoconcha } \\
\text { moralesi. }\end{array}$ \\
\hline Lower bay-inlet & Polyhaline (>18-30) & $\begin{array}{l}\text { Mixture of bay and marine taxa, including Actinocythereis subquadrata, Peratocytheridea } \\
\text { bradyi, Proteoconcha spp., Cytherura spp., Hulingsina } \text { spp., Malzella littorala } .\end{array}$ \\
\hline Sublittoral & Euhaline (>30-36) & $\begin{array}{l}\text { Marine taxa only, including Actinocythereis, Malzella, Pellucistoma, Puriana, } \\
\text { Reticulocythereis, Hulingsina, Protocytheretta. } .\end{array}$ \\
\hline
\end{tabular}


and Mauldin 2001; Nordt et al. 2002). All of these data were collected around 200-300 km north from the gulf coast, hence providing a valuable but limited record.

In general, the region was subject to cooler, more mesic conditions during the Early Holocene (10,000-8000 B.P.) gradually drying towards the end of the 2000 year period. The Middle Holocene became drier and warmer (8000-4000 B.P.) briefly interrupted for relatively mesic conditions around 7000 to 6000 or 5000 years B.P., returning to xeric conditions between 5000 and 4000 years B.P. Paleoenvironmental proxy suggest that the Late Holocene (4000-0 B.P.) was cooler and/ or wetter throughout most of the record, returning to more xeric conditions within the last few hundred years. Is this signature of the Late Holocene depicted by the ostracode and foraminifera record obtained from cores 2, 4, and 6 at Cayo del Oso Bay site (41NU2)?

The answer is not straightforward! However, the faunal trends show patterns that may be associated with cycles of fresh- and seawater input over time for the past 4000 years. Twelve radiocarbon dates, four from each core, provided the geochronological record of Cayo del Oso Bay. Core 2, the closest to site $41 \mathrm{NU} 2$, shows the youngest dates ranging from $2970 \pm 40$ years B.P. (at $259 \mathrm{~cm}$ bgs) to $550 \pm 40$ years B.P. (at $97-\mathrm{cm}$ bgs). Two intermediate dates, $2240 \pm 40$ years B.P. (at $160-\mathrm{cm}$ bgs) and $1300 \pm 40$ years B.P. (at $140-\mathrm{cm}$ bgs), integrate the geochronometric record. Based on these dates, Core 2 indicates low to moderately low sedimentation rates ranging from 0.02 to $0.05-\mathrm{cm} \mathrm{yr}^{-1}$ (Table E-1). The increasing sedimentation rate values corresponded to episodes of increasing grain-size that, in turn, corresponded with the introduction of nonmarine ostracodes during the latest episode (a limnic assemblage; Table E-9). No evidence of ostracodes was recorded before 1300 years ago suggesting the organisms did not settle or arrive to the site or did not preserve. The poor record and poor preservation of the few valves recovered implies the organisms were introduced into the pond but failed to settle a community. In addition, three tests of $A$. beccarii obtained towards the base of the core more likely resulted from eolian transport or overwash from the Gulf of Mexico during hurricanes. No further discussion of Core 2 is warranted, except that the occurrence of the continental water species Cyprinotus glaucus, Candona rawsoni, Cypridopsis sp., and Limnocythere sp. cf. $L$. floridensis indicates pulses of freshwater discharge from the small drainages to the west.

The paleoenvironmental history of Cores 4 and 6 differs from Core 2 but compare well with each other. Based on Table E-9 biofacies models two assemblages were recognized in Cores 4 and 6 . Alternating occurrences of upper bay and midbay assemblages dominated the history of Cayo del Oso for the past 4000 years. No indication of other assemblages was obtained from these cores. A comparison of the paleosalinity indices for each core generated for this study shows the possible alternating intervals of fresh- and seawater input into the area during the late Holocene (Figure E-8). Core 2 only tangentially correlates with the other two cores but it is incorporated in the reconstruction and discussion because of its geographic proximity to Cores 4 and 6 and its implications for human activity.

Tentatively, three paleoecological zones at Cayo del Oso were identified, each with minor fluctuations. From base to top, a mid-bay assemblage dominated the area before 3600 years B.P. Between 3600 years B.P. and 1300 years B.P. an interval of rapidly changing from mid-bay to upper bay assemblages characterized the site. The last 1300 years were characterized by an upper bay assemblage suggesting higher freshwater discharge into the basin.

The patterns shown by the paleosalinity indices of Cores 4 and 6 compare well with those obtained by Bousman (1998), Camper (1991), and Nickels and Mauldin (2001) using grass pollen from Patschke, Boriak, and Weakly Bogs (300 km north of 41NU2). Prior to 3600 years B.P. xeric conditions prevailed in the area, less precipitation and runoff occurred in Cayo del Oso Bay. A mid-bay ostracode assemblage dominated and porcelaneous foraminifera were common. Between 3600 and 2800 years B.P. more mesic conditions affected the area as shown by the occurrence of upper bay ostracodes and the dominance of the foraminifer $A$. beccarii.

From 2800 to 2100 years B.P. alternating upper bay and midbay assemblages and foraminifera indicate rapidly fluctuating, from mesic to xeric to mesic, conditions. This pattern is partially in good agreement with Robinson's (1982:598) reconstruction of Choke Canyon using phytoliths. However, Robinson's poor dating and underreported data make difficult to compare results.

Between 2100 and 1700 years B.P., increasing mesic conditions are indicated by the dominance of an upper bay assemblage and the sharp decline in foraminifera that slowly recovered during this period. The interval from 1700 to 1000 years B.P. experienced a sharp decline in ostracodes. Only $C$. salebrosa was recorded in this interval in Core 4; however, at Core 6 P. rugata, $R$. wantlandi, $C$. sandbergi and L. avellana accompanied $C$. salebrosa suggesting an increasing mid-bay influence. Foraminifera continued its slow recovery. In other words, the time interval of 1700 to 1000 years B.P. gradually turned more xeric, but variable as shown by the paleosalinity index of Core 6 . The pattern shown by micro-invertebrates and foraminifera correlate well with the latest Holocene 


\section{Paleosalinity Index Correlation}

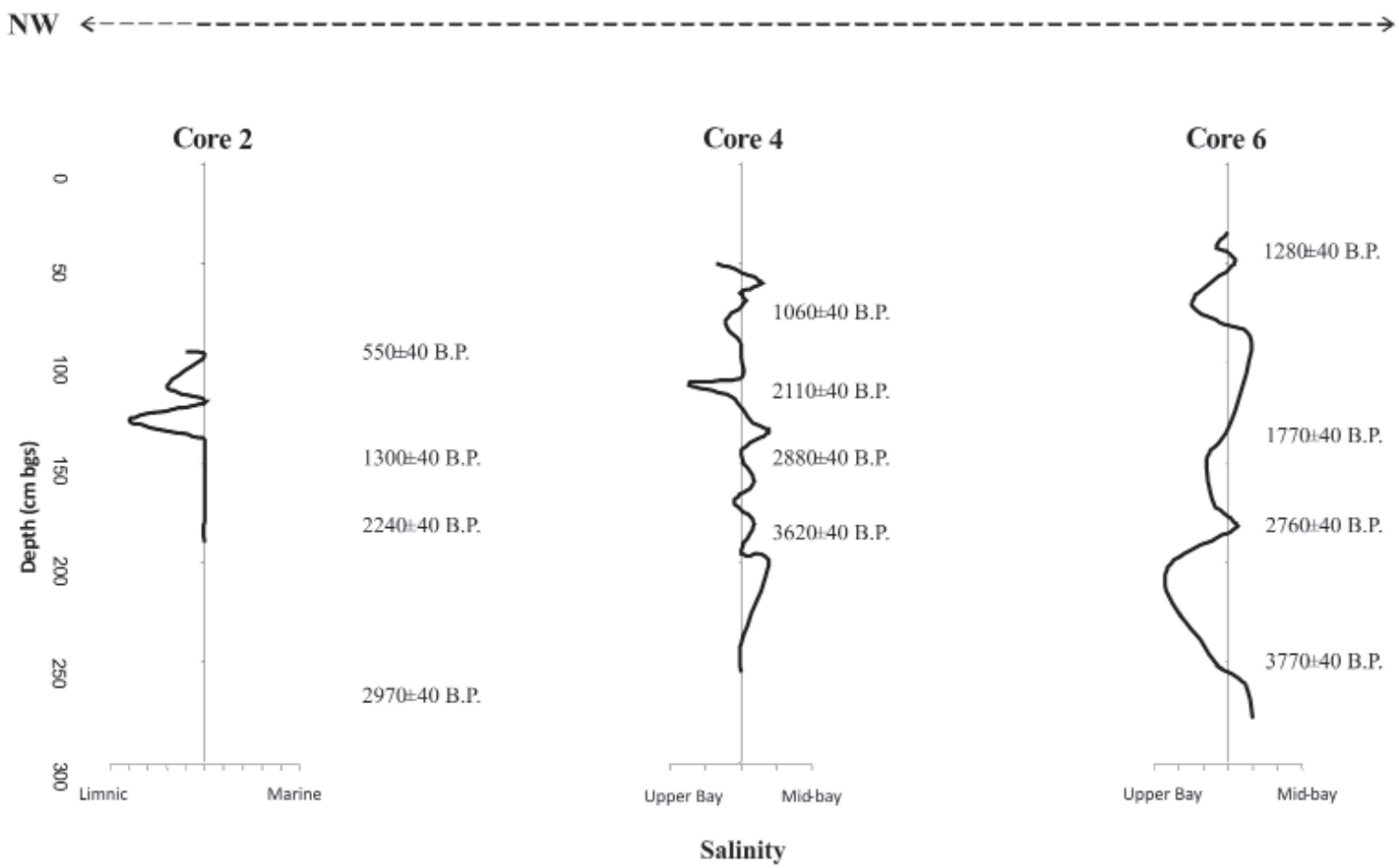

Figure E-8. Chronostratigraphic correlation of paleosalinity indices among the three cores from Cayo del Oso Bay, Nueces County, Texas.

grass pollen record at Patschke, Boriak, and Weakly bogs (Bousman 1998; Camper 1991; Nickels and Mauldin 2001).

The last 1000 years consisted of an incomplete record both at Cores 4 and 6 that provided weak evidence of increasing moisture. Core 2 might reflect better the increasing precipitation introducing limnic species into the pond north of Cores 4 and 6 . This pattern may correlate with the pollen records of Patschke, Boriak, and Weakly bogs (Bousman 1998; Camper 1991; Nickels and Mauldin 2001). However, ostracode abundance and diversity do not warrant the interpretation for the interval.

What is the impact of the environmental shift indicated by micro-invertebrates and foraminifera on human occupation? A comparison between the data generated for this study and that of Ricklis and Blum (1997; Table 1) suggests that humans encountered more favorable conditions during periods where the upper bay assemblage dominated in the environment. During xeric times (e.g., >3500 years B.P.; 2100-1700 years B.P.; around 1000 years B.P) human occupation was low; whereas during mesic intervals (e.g., 3500-2100 years B.P.;
1700-1200 years B.P.; <600 years B.P.) Ricklis and Blum (1997) found an increasing human population.

\section{Conclusions}

In summary, micro-invertebrate and foraminifera analysis of the Cayo del Oso Bay site (41NU2) demonstrated the value of these microfossils as proxy tools for the reconstruction of marginal marine ecosystems over time. Based on ostracode diversity and abundance it was possible to recognize nonmarine from marine conditions during deposition of sediment in the region. Core 2 positively compared to cores 4 and 6 , the combined signatures at the end of the record permitted a realistic, despite weak, reconstruction of the environment for the past 600 years. The close correlation between cores 4 and 6 confirmed field interpretations that both core sites would reflect similar conditions. However, minor variations between them were recognized that may be interpreted as micro-environmental variability.

The upper bay to mid-bay fluctuations recorded at Cayo del Oso Bay correlate well with pollen records from Central Texas 
(Bousman 1998; Camper 1991; Nickels and Mauldin 2001) indicating alternating episodes of xeric to mesic conditions in the region over time. Micro-invertebrate and foraminifera data also agree with episodes of human occupation responding to periods of increasing precipitation and freshwater input into the bay. Conversely, humans withdrew from the area during episodes of decreasing precipitation. The successful correlation between micro-invertebrates and the study of Ricklis and Blum (1997) on human population demonstrates the shifting environments prehistoric people faces in southern Texas.

\section{References}

Albert, B.M.

2006 Holocene Pollen Data for Sea Level and Climate Change at Swan Lake, Aransas County, Texas, and the Implications for the Cultural Ecology of the Central Texas Coast. Bulletin of the Texas Archaeological Society 77:161-177.

Anonymous

2007 Foraminifera. Department of Geological Sciences, University College of London (http://www.ucl.ac.uk/GeolSci/ $\underline{\text { micropal/foram.html) }}$

Barnes, R.D.

1987 Invertebrate Zoology. Fifth Edition. CBS College Publishing/Halt, Rinehart and Winston, Philadelphia, PA. Bullock, Theodore Holmes. 1990. Goals of neuroethology. Bioscience.

Benson, R.H., and G.L. Coleman III

1963 Recent Marine Ostracodes from the Eastern Gulf of Mexico.The University of Kansas Paleontological Contributions, Article No. 2, pp. 1-52.

Blum, M.D., A.E. Carter, T. Zayac, and R. Goble

2002 Middle Holocene Sea-Level and Evolution of the Gulf of Mexico Coast (USA). Journal of Coastal Research, Special Issue 36:65-80.

Boersma, A.

1978 Foraminifera, Ch. 2. In Introduction to Marine Micropaleontology, edited by Haq, B.U. and Boersma, A. Elsevier, New York: 19-78.

Bousman, C.B.

1998 Paleoenvironmental Change in Central Texas: The Palynological Evidence. Plains Anthropologist 43(164):201-219.

Brusca, R.C. and G.J. Brusca

1990 Invertebrates. Sinauer Associates, Inc. Sunderland, Mass.

Camper, H.A.

1991 Pollen Analysis of Patschke Bog. Unpublished M.S. Thesis, Department of Botany, Texas A\&M University, Bryant. Data archived at the World Data Center-A for Paleoclimatology Data. NOAA/NGDC Paleoclimatology Program, Boulder.

Caran, S.C.

1998 Quaternary Paleoenvironmental and Paleoclimatic Reconstruction: A Discussion and Critique, with Examples from the Southern High Plains. Plains Anthropologist 43(164):111-124. 
Chabreck, R.H.

1990 Creation, Restoration, and Enhancement of Marshes of the Northcentral Gulf Coast. In Wetland Creation and Restoration: The Status of Science, edited by J.A. Kusler, and M.E. Kentula, pp. 125-142. Island Press, Washington, D.C.

Clifton, H. E.

1982 Estuarine deposits. In: Sandstone Depositional Environments, edited by Scholle, P.A. and Spearing, D. American Association of Petroleum Geologists, Memoir 31:179-190.

Cooke, M.J.

2005Soil Formation and Erosion in Central Texas: Insights from Relic Soils and Cave Deposits. Unpublished Ph.D. Dissertation. The University of Texas at Austin.

Cronin, T.M.

1986 Ostracodes from Late Quaternary Deposits, South Texas Coastal Complex. In Stratigraphic Studies of a Late Quaternary Barrier-Type Coastal Complex, Mustang Island- Corpus Christi Bay Area, South Texas Gulf Coast, edited by Shideler, G. L. U.S. Geological Survey Professional Paper 1328: 33-63.

Fisk, H.N.

1959 Padre Island and the Laguna Madre Flats, Coastal South Texas. Reprinted from National Academy of SciencesNational Research Council, $2^{\text {nd }}$ Coastal Geography Conference, National Academy of Sciences, Washington, D.C.

Forester, R.M., Smith, A.J., Palmer, D.F., and Curry, B.B.

2005 North American Non-Marine Ostracode Database "NANODe" Version 1, December, http://www.kent.edu/NANODe, Kent State University, Kent, Ohio.

Frederick, C.D.

1998 Late Quaternary Clay Dune Sedimentation on the Llano Estacado. Plains Anthropologist 43(164):137-156.

Fredlund G.G., C.B. Bousman, and D.K. Boyd

1998 The Phytolith Record from Morgan Playa in the Rolling Plains of Texas. Plains Anthropologist 43(164):187-200.

Garbett, E.C. and R. F. Maddocks

1979 Zoogeography of Holocene Cytheracean Ostracods in the Bays of Texas. Journal of Paleoentology 53(4):841-919.

Hardwood, R.J.

1979 Community Reconstruction in Benthic Paleoenvironments: Trophic Structure in Living and Dead Macroenvironment Associations, Corpus Christi and Aransas Bay Systems, Texas. Unpublished Ph.D. Dissertation. Department of Marine Sciences, The University of Texas at Austin.

Ishman, S.E.

1997 Ecosystems of South Florida: Biscayne Bay Sediment Core Descriptions. U.S. Geological Survey Open-File Report 97-437: 15 pp.

Kier, R.S., and W.A. White

1978 Land and Water Resources of the Corpus Christi Area, Texas. Report of Investigations No. 95, Bureau of Economic Geology. The University of Texas at Austin.

King, C.E. and L.S. Kornicker

1970 Ostracoda in Texas Bays and Lagoons- An Ecological Study. Smithsonian Contributions to Zoology 24: 92 pp. 
McKenzie, K.G. and F.M. Swain

1967 Recent Ostracode from Scammon Lagoon, Baja California. Journal of Paleontology 41(2):281-305.

Morton, R.A. and J.G. Paine

1984 Historic Shoreline Changes in Corpus Christi, Oso and Nueces Bays, Texas Gulf Coast. Geological Circular 84-6, Bureau of Economic Geology, University of Texas at Austin.

Morton, R.A. and M.J. Piper

1977 Shoreline Changes on Mustang Island and North Padre Island (Aransas Pass to Yarborough Pass) - An Analysis of Historical Changes of the Texas Gulf Shoreline. GC7701 Bureau of Economic Geology, University of Texas at Austin.

Nickels, D.L., and R.P. Mauldin

2001 The Project Environment. In An Archaeological Survey of Twin Buttes Reservoir, Tom Green County, Texas, Volume 1, edited by R. P. Mauldin and D.L. Nickels. Archaeological Survey Report, No. 300. Center for Archaeological Research, The University of Texas at San Antonio.

Nordt, L.C., T.W. Boutton, J.S. Jacob, and R. Mandel

1994 Late Quaternary Climates of Central Texas Based on Stable Isotopic Composition of Organic Carbon. Program and Abstracts, $52^{\text {nd }}$ Plains Conference, $65^{\text {th }}$ Annual Meeting of the Texas Archaeological Society, Lubbock.

2002 C4 Plant Productivity and Climate-CO2 Variations in South-Central Texas during the Late Quaternary. Quaternary Research 58(2):182-188.

Palacios-Fest, M.R.

1994 Nonmarine ostracode shell chemistry from ancient Hohokam irrigation canals in Central Arizona: A paleohydrochemical tool for the interpretation of prehistoric human occupation of the Western United States; Geoarchaeology 9 (1):1-29.

Palacios-Fest, M.R., J.B. Mabry, F. Nials, J.P. Holmlund. E. Miksa, and O.K. Davis

2001 Early irrigation systems in Southeastern Arizona: The ostracode perspective. Journal of South American Earth Sciences 14 (5): 541-555.

Palacios-Fest, M.R., J.A. Homburg, E.C. Brevik, A.R. Orme, O.K. Davis, S.D. Shelley 2006 Late Quaternary Paleoecology of Ballona Lagoon in Southern California. Revista Ciencias Marinas 32(3):485-504.

Phleger, F.B.

1965 Patterns of Marsh Foraminifera, Galveston Bay, Texas. Limnology and Oceanography, Vol. 10, Supplement: Alfred C. Redfield 75th Anniversary Volume (Nov., 1965), pp. 169-184.

1970 Foraminiferal Populations and Marine Marsh Processes. Limnology and Oceanography, Vol. 15, No. 4 (Jul., 1970), pp. $522-534$.

Pokorný, V.

1978 Ostracodes, Ch. 4. In Introduction to Marine Micropaleontology, edited by Haq, B.U. and Boersma, A. Elsevier, New York: 109-150.

Puri, H. S., G. Bonaduce, and A.M. Gervasio

1969 Distribution of Ostracoda in the Mediterranean. In: The Ttaxonomy, Morphology and Ecology of Recent Ostracoda, edited by Neale, J.W. Oliver and Boyd, Edinburgh, 356-411. 
Ricklis, R.A.

1995 Prehistoric Occupation of the Central and Lower Texas Coast:ARegional Overview. Bulletin of the Texas Archaeological Society 66:265-300.

2004 Prehistoric Occupation of the Central and Lower Texas Coast: A Regional Overview. In The Prehistory of Texas, edited by T.K. Perttula, pp. 155-180.

Ricklis, R.A., and M.D. Blum

1997 1997The Geoarchaeological Record of Holocene Sea-Level Change and Human Occupation of the Texas Coast. Geoarchaeology 12:287-314.

Ricklis, R.A., and K.A. Cox

1997 Holocene Climatic and Environmental Change in the Texas Coastal Zone: Some Geoarchaeological and Ecofactual Indicators. Plains Anthropologist 43(164):125-136.

Robinson, R.L.

1982 Biosilica Analysis of Three Prehistoric Archaeological Sites in the Choke Canyon Reservoir, Live Oak County, Texas: Preliminary Summary of Climatic Implications. In Archaeological Investigations at Choke Canyon Reservoir, South Texas: The Phase I Findings, edited by G.D. Hall, S.L. Black, and C. Graves, pp. 597-610. Choke Canyon Series, No. 5. Center for Archaeological Research, The University of Texas at San Antonio.

Swain, F.M.

1955 Ostracoda of San Antonio Bay, Texas. Journal of Paleontology 29(4):561-646.

Tomka, S.A., R.P. Mauldin, and C.D. Frederick

2007 A Research Design for Analysis of Materials Collected from the Cayo del Oso Site (41NU2), Corpus Christi, Nueces County, Texas. Center for Archaeological Research, The University of Texas at San Antonio: 108 pp., tables and figures.

Van den Bold, W. A.

1977 Distribution of Marine Podocopida (Ostracoda) in the Gulf of Mexico and the Caribbean. In: Aspects on Ecology and Zoogeography of of Recent and Fossil Ostracoda, edited by Loeffler, H. and Danielopol, D. Proc. $6^{\text {th }}$ Internl. Symp. on Ostracoda. Saalfelden (Salzburg). Dr. W. Junk b.v. Publishers, The Hague: 175-186. 


\section{APPENDIX F: \\ Evaluating the Paleoclimatic Potential of Coastal Clay Dunes at the Cayo del Oso Site}

Charles D. Frederick

Dublin, Texas 


\section{Introduction}

The Cayo del Oso site is situated at the confluence of Oso Bay and Corpus Christi Bay (see Chapter 2, this volume for geographic details). The geologic history of this region and geographic setting of the site are discussed in detail in Chapter 2 (this volume) and will not be repeated here except to define specific points relevant to the chapter. A small spit has formed across the mouth of Oso Bay by longshore transport of sediment within Corpus Christi during the late Holocene (Morton and Payne 1984; Withers and Chapman 1993). This spit is now detached from the mainland and known as Ward Island. Two inlets are present either side of Ward Island that permit water flow between Corpus Christi Bay and Oso Bay: Oso Inlet and Blind Oso Inlet (Williams and Kraus 1998). To the southeast of Ward Island is the main entrance to Oso Bay is known as Oso Inlet. On the nowthwest side of Ward Island is a shallow, now largely dry mud flat that is locally referred to as the Blind Oso. The site (41NU2) is situated along the southeastern margin of the Beaumont Formation uplands adjacent to the Blind Oso. Along Corpus Christi Bay, both the Pleistocene upland and Ward Island are bordered by multiple linear offshore sand bars that Williams and Kraus (1998) determined have diminished in number over the last 60 years and slowly migrate offshore. Away from Corpus Christi Bay, the southeastern edge of the Pleistocene Beaumont uplands and Ward Island are bordered by an extensive clay wind-tidal mudflat that is now inundated by wind driven tides (Withers and Chapman 1993:383). Immediately west of Ward Island and the Blind Oso is a small drowned creek valley that is oriented roughly east-west. This unnamed drainage is relatively short and is incised into the Beaumont Formation (see USGS 1925).

Oso Creek has been a tributary of the Nueces River for at least the last glacial-interglacial cycle given that the lowest reach of the stream is incised at the contact between Encinal Peninsula (which is part of the Ingleside sand, a Pleistocene age barrier island associated with the Beaumont formation) and the Beaumont Formation (Shideler 1986:7). Ricklis (1993:8) notes that the Nueces River was incised as much as $60 \mathrm{~m}$ below modern sea level during the last glacial maximum, and it is likely that the Oso Creek valley was entrenched entrenched as well. Sheidler (1986) obtained a core from within Oso Bay, just off the southeast side of Ward Island (present site of Texas A \& M University, Corpus Christi) and identified approximately 2-3 m of Holocene sediment resting on top of Pleistocene fluvial deltaic sediments (see in particular Sheidler 1986:29, Fig. 4). This core (core A) was peripheral to the center of the Oso Creek valley and probably does not accurately reflect the depth of incision, but implies that Oso Creek may not have been very deeply incised at the point it joins present day Corpus Christi Bay. Morton and Payne (1984) mapped the base of the Pleistocene Nueces incised valley and this map suggests that the Oso Creek valley at the confluence with Corpus Christi bay was incised approximately $80 \mathrm{~m}$ below modern sea level. Rising sea level during the Holocene drowned the incised valleys of both streams before they could be completely filled with sediment during the Holocene.

\section{Clay Dune Formation}

Clay dunes, lunettes, or lomas, as they are locally known, are a form of source-border dune that form from the deflation of sand sized aggregates of mud from fringing mud flats. Were it not for the salt contained in the sediment, clay dunes would not form because it is the growth of salt crystals in the drying sediment that break up the mud cracks into the sand and silt sized aggregates that are capable of being entrained by wind. Clay dunes are frequently associated with playa lakes and pans where it is the presence of gypsum that facilitates clay pellet production and subsequent dune growth. But in coastal dunes it is the presence of halite in the salt water that promotes the formation of clay dunes. Coastal clay dunes typically form at the transition zone between wind-tidal flats and the uplands. As a form of eolian landform, clay dunes are rather anomalous because the clay aggregates, once moist, are sticky and adhere to one another, which results in the dunes being generally quite stable, or if they move they tend to migrate towards the sediment source rather than down wind, away from it.

The driving force in clay dune formation is clearly one of local hydrology (cf. Bowler 1973; 1983) but studies of some dunes (e.g. Holliday 1997:67; Frederick 1998) have concluded that because local hydrology responds to regional climate, the lithological record of such dunes may have regional paleoenvironmental significance. Indeed, in continental settings typical of pans and plays lakes, the growth of clay dunes is intimately tied to the hydrology of the pan, and the periods of dune growth are often linked to periods of arid climate. In the case of coastal clay dunes, the climatic linkage is considerably more complex as the sediment source areas are intermittently flooded and desiccated, mostly in response to wind and tidal influences.

Three specific factors affect the exposure and inundation of the Oso Bay mudflats: tides, long period tidal ranges, and wind. In the particular case of Oso Bay, the tidal range is very small, on the order of $20 \mathrm{~cm}$ (based upon the tidal range at the Naval Air Station-Corpus Christi, immediately southeast of Oso Bay; Williams and Kraus 1998:500) and Withers and Chapman (1993) note that tides alone have little influence on the exposure of the Blind Oso mudflats. In addition to the diurnal tides, Withers and Chapman (1993:394-385) note that there are long-period variations in the bay water level that 
leads to generally high water in late May and late October, and periods of extremely low water levels in late February and late July. Given the micro-tidal nature of the bay, tides alone are not the major factor in immersion or emergence of the mud flat. Rather, wind driven tides appear to be most significant. Withers and Chapman (1993:383) note that in the May-November period, the prevailing winds are southerly or southeasterly and during this period water often covers the mudflats near the dunes and surrounding Ward Island. Conversely, the northerly winds associated with cold frontal passages in the December to February period push water away from the Blind Oso mud flats.

Clearly, the hydrology affecting coastal dunes is considerably more complex than that of continental pans, but process related observations on coastal clay dunes by W. Armstrong Price $(1958 ; 1963)$ nevertheless led him to suggest that coastal clay dune deposition was climatically linked. In one paper, Huffman and Price (1949:120) note that the formation of clay dunes on the Texas coast is strongly related to climate:

"In south Texas, movement of the clay pellets begins in the month of March and continues until November when the growth of the dunes is arrested by winter precipitation and reduced evaporation. Their growth is most rapid during the drier summer months and during periods of prolonged drought."

In another paper, Price and Kornicker (1961:249) noted that in the seven-year drought of the 1950 s, some dunes accumulated a foot or more of fresh sediment. Price and Kornicker (1961:246) have also noted a climatic influence on the size of clay dunes with the dunes being highest near the Rio Grande Delta and lower toward the progressively more humid climates to the north and south.

\section{Potential of Coastal Clay Dunes to Yield Palaeoenvironmental Records}

Given these observations, it stands to reason that the periods of dune growth and development may provide a climatically sensitive record, whereby the dune grows during periods of relative aridity and become stablized during more moist periods when soils form. In order to test the paleoclimatic utility of coastal clay dunes we performed a comparision of the paleoenvironmental records of two adjacent clay dunes at the Cayo del Oso site. The two dunes, the North Dune and the South Dune, are separated by a low relief ridge of the Pleistocene Beaumont Formation.

For this project we compared the stratigraphy of the two different dunes, and radiocarbon date the buried soil A horizons. If climate is the driving force behind periods of dune aggradation, then the two dunes can be expected to yield comparable paleosol sequences (in terms of the number of buried soils and their radiocarbon age). Likewise, trends in dune texture and lithology (e.g. calcium carbonate content) are likely to be similar as well. If, however, there are significant differences in the soil stratigraphy between the dunes, then other, possibly local, factors other than climate may be critical in the sequence of growth and stability of these clay dunes. Furthermore, comparision of the dune lithological record with the pollen record from a pond that formed behind the North dune, may provide a useful test of the hypothesis as well.

\section{Methods}

\section{Field Methods}

An Eijkelkamp percussion drilling set was used to extract two adjacent cores from the north dune and the south dune adjacent to Ennis Joslin Road, and from a former pond that was situated at the southwest side of the intersection of Ennis Joslin Road and Ocean Drive. Cores were collected in $5 \mathrm{~cm}$ diameter PVC pipe that were labeled and capped following retrieval. At each locality, the two cores were collected approximately $1 \mathrm{~m}$ apart and coring was terminated upon reaching the Pleistocene Beaumont Formation. The north dune is represented by Core 4, which was collected from near the intersection of Ocean Drive and Enis Joslin Road. The south dune, represented by Core 6 , was cored along the south side of Enis Joslin Road near its intersection with Del Oso Road.

Upon completion the cores were taken to the Center for Archaeological Research at the University of Texas at San Antonio where they were cut open, cleaned, described and sampled for various paleoenvironmental analyses (e.g. pollen, phytolith, diatom, ostracod, radiocarbon, bulk lithology and micromorphology; see Figures F-1 and F-2 for graphic depictions of the core stratigraphy and the location of samples collected). At each locality, the most complete core was chosen for detailed analysis and description. The lithology and color of the strata present in each core was recorded, but pedogenic attributes such as structure was not recorded as it was difficult to evaluate from core samples. Only rudimentary descriptions were made for deposits judged to be disturbed or fill and these deposits were not sampled.

It is important to consider that the cores were collected from the project right-of-way immediately adjacent to Ennis Joslin Road, and not from the summit of each dune. It is not known how much, if any, effect this placement may have on 


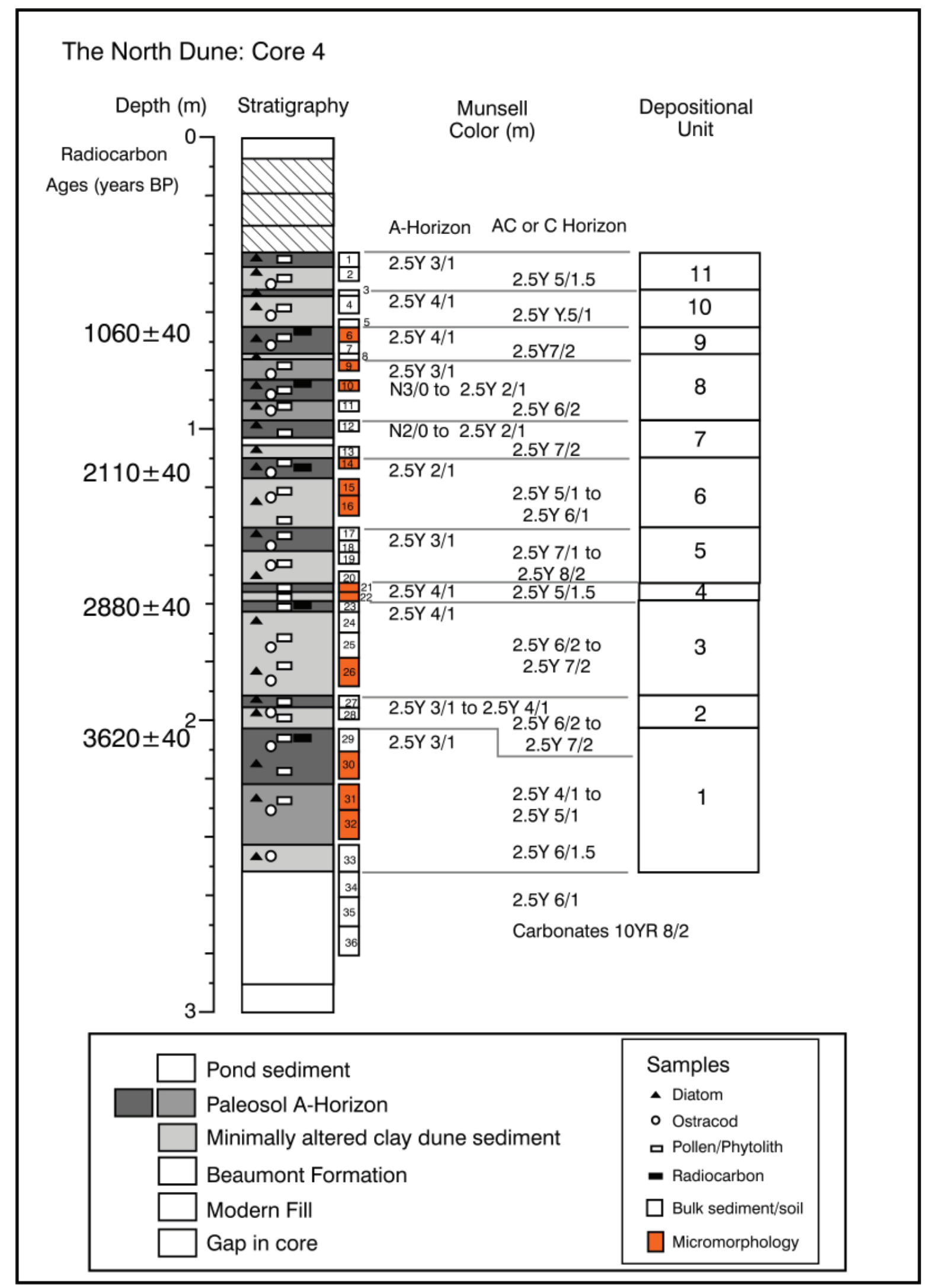

Figure F-1. An expanded drawing showing the core stratigraphy, Munsell color, and inferred depositional units in the North Dune core. 


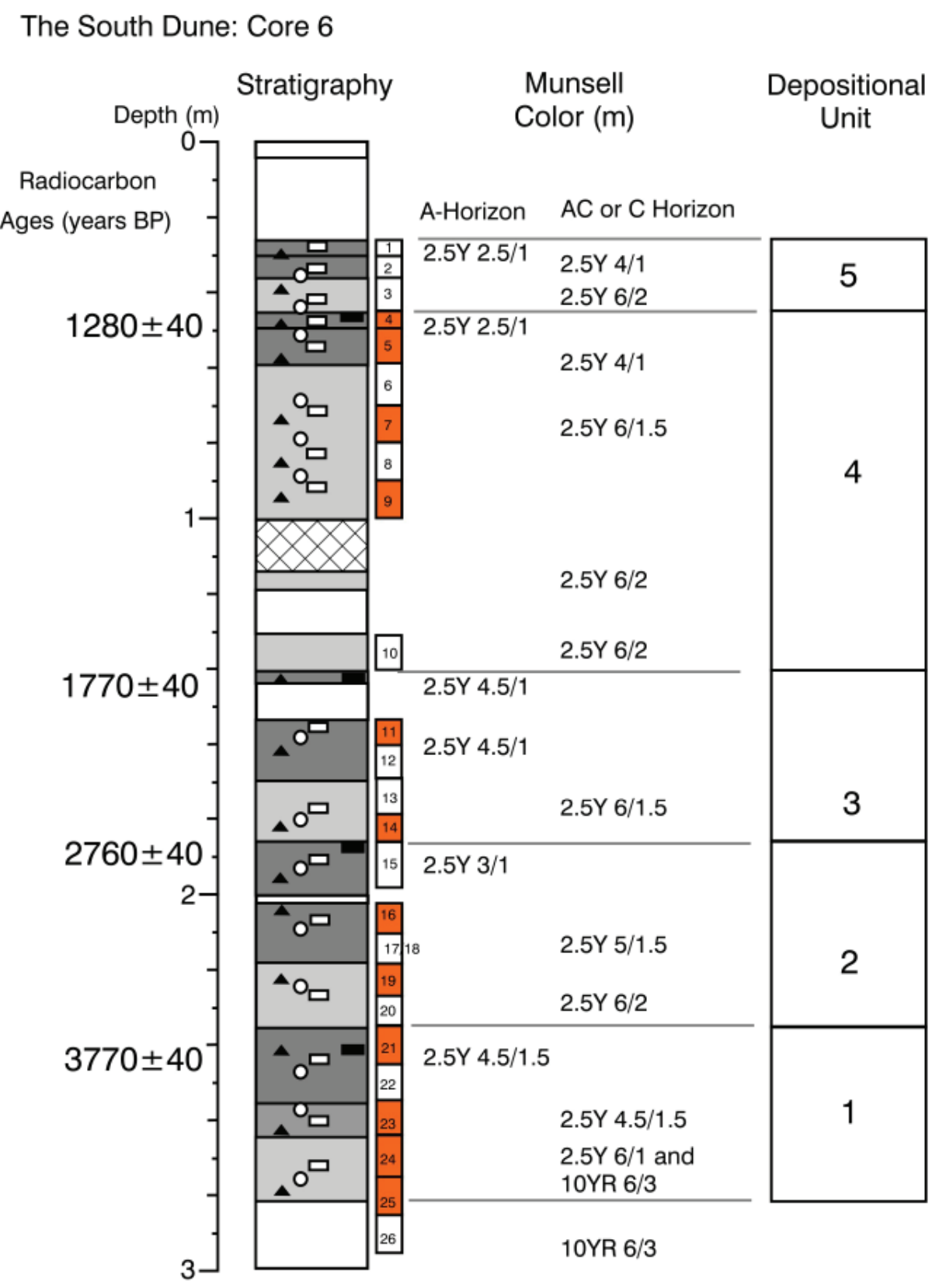

\begin{tabular}{|l|l|}
\hline Pond sediment & Samples \\
$\Delta$ Diatom \\
Paleosol A-Horizon & Ostracod \\
$\square$ Minimally altered clay dune sediment & Pollen/Phytolith \\
\hline Beaumont Formation & Radiocarbon \\
$\square$ Modern Fill & $\square$ Bulk sediment/soil \\
$\square$ Gap in core & $\square$ Micromorphology \\
\hline
\end{tabular}

Figure F-2. An illustration of the core stratigraphy, Munsell color, and inferred depositional units in the South Dune core. 
the stratigraphic results as there is little information in the literature on small scale variations in clay dune stratigraphy.

\section{Lab Methods}

A total of 82 bulk samples were analyzed from the three cores (36 from Core 4, 26 from Core 6, and 20 samples from pond deposits in core 2). For each sample the texture, organic carbon, calcium carbonate content, magnetic susceptibility, organic carbon content and stable carbon isotopic composition were determined. A select suite of samples was also collected for thin section preparation and soil micromorphological analysis. The details of the analytical methods employed are presented below, and the results of the lab work are presented in Tables F-1, F-2 and F-3.

\section{Particle Size Analysis (Texture)}

Texture analysis was performed using the hydrometer-sieve method (cf. ASTM 1985; Gee and Bauder 1986; Bouyoucos 1962). For this analysis the total sample was air dried and weighed, then crushed with a rubber pestle and mortar, and subsequently passed through a $2 \mathrm{~mm}$ sieve. Material caught on the $2 \mathrm{~mm}$ sieve, if detrital material, was then sieved at a 1 phi interval and the mass on each sieve recorded. A split of the $<2 \mathrm{~mm}$ size material (roughly 40 grams) was then soaked $50 \mathrm{ml}$ of a $5 \%$ sodium hexametaphosphate solution overnight, and then mixed in a mechanical mixer for 5 minutes before being diluted to 1 liter with distilled water. This mixture was placed in a 1 liter settling jar, mechanically agitated for 1 minute, and then set on a table, after which point hydrometer readings were made a different time intervals (specifically 1 ,

Table F-1. Results of Lab Work Obtained for Samples Derived from Core 4

\begin{tabular}{|c|c|c|c|c|c|c|c|c|c|c|c|c|c|c|c|c|c|c|}
\hline $\begin{array}{c}\text { Sample } \\
\text { No. }\end{array}$ & Rank & Depth & $\begin{array}{c}\% \\
\geq 63 \mu \\
\end{array}$ & $\begin{array}{c}\% \\
\geq 2 \mu\end{array}$ & $\begin{array}{c}\% \\
\text { gravel }\end{array}$ & $\begin{array}{c}\% \\
\text { sand }\end{array}$ & $\%$ silt & $\begin{array}{c}\% \\
\text { clay }\end{array}$ & $\begin{array}{c}\begin{array}{c}\text { Texture } \\
\text { (SCS) }\end{array} \\
\end{array}$ & mean & sd & skew & kurt & $\chi$ & $\begin{array}{c}\text { Organic } \\
\mathbf{C} \%\end{array}$ & $\delta \mathbf{1 3 C}$ & $\begin{array}{c}\mathrm{CCE} \\
\%\end{array}$ & $\begin{array}{c}\text { Depositional } \\
\text { Unit }\end{array}$ \\
\hline 205 & 1 & 42 & 33.35 & 57.77 & 0.00 & 33.35 & 24.42 & 42.23 & clay & 7.68 & 4.46 & 0.33 & 0.22 & 7.32 & 0.86 & -15.67 & 6.1 & 11 \\
\hline 206 & 2 & 47 & 31.26 & 55.60 & 0.00 & 31.26 & 24.34 & 44.40 & clay & 7.82 & 4.42 & 0.27 & 0.21 & 6.60 & 0.47 & -15.03 & 10.3 & 11 \\
\hline 207 & 3 & 53 & 31.89 & 60.22 & 0.00 & 31.89 & 28.33 & 39.78 & clay & 7.81 & 4.31 & 0.61 & 0.22 & 6.62 & 0.41 & -15.09 & 4.6 & 10 \\
\hline 208 & 4 & 57 & 29.01 & 53.97 & 0.00 & 29.01 & 24.96 & 46.03 & clay & 7.94 & 4.43 & 0.12 & 0.20 & 5.37 & 0.37 & -15.05 & 13.7 & 10 \\
\hline 209 & 5 & 64 & 28.83 & 61.56 & 0.00 & 28.83 & 32.73 & 38.44 & clay & 7.91 & 4.01 & 0.71 & 0.11 & 5.82 & 0.38 & -15.43 & 12.8 & 10 \\
\hline 210 & 6 & 67 & 25.54 & 61.35 & 0.00 & 25.54 & 35.81 & 38.65 & clay & 7.85 & 4.16 & 0.68 & 0.24 & 7.12 & 0.51 & -15.49 & 4.0 & 9 \\
\hline 211 & 7 & 72 & 29.45 & 58.87 & 0.00 & 29.45 & 29.42 & 41.13 & clay & 7.84 & 4.29 & 0.62 & 0.22 & 6.16 & 0.50 & -16.15 & 6.7 & 9 \\
\hline 212 & 8 & 75 & 33.35 & 81.95 & 0.00 & 33.35 & 48.60 & 18.05 & loam & 6.34 & 2.90 & 0.77 & 0.68 & 5.88 & 0.38 & -15.61 & 7.6 & 9 \\
\hline 213 & 9 & 78 & 31.3 & 66.10 & 0.00 & 31.30 & 34.80 & 33.90 & clay & 7.67 & 4.14 & 0.68 & 0.25 & 7.26 & 0.50 & -16.56 & 2.4 & 8 \\
\hline 214 & 10 & 85 & 34.4 & 62.17 & 0.00 & 34.40 & 27.77 & 37.83 & clay & 7.66 & 4.35 & 0.62 & 0.23 & 8.47 & 0.77 & -15.21 & 2.1 & 8 \\
\hline 215 & 11 & 92 & 37.02 & 61.27 & 0.00 & 37.02 & 24.25 & 38.73 & clay & 7.60 & 4.36 & 0.63 & 0.23 & 6.44 & 0.45 & -15.03 & 7.0 & 8 \\
\hline 216 & 12 & 98 & 32.75 & 58.37 & 0.00 & 32.75 & 25.62 & 41.63 & clay & 7.83 & 4.40 & 0.60 & 0.22 & 8.93 & 1.02 & -16.67 & 2.1 & 7 \\
\hline 217 & 13 & 108 & 28.28 & 57.93 & 0.00 & 28.28 & 29.65 & 42.07 & clay & 7.90 & 4.30 & 0.47 & 0.22 & 6.54 & 0.41 & -16.75 & 12.5 & 7 \\
\hline 218 & 14 & 112 & 29.07 & 59.35 & 0.00 & 29.07 & 30.28 & 40.65 & clay & 7.85 & 4.31 & 0.65 & 0.23 & 9.21 & 0.63 & -15.64 & 4.0 & 6 \\
\hline 219 & 15 & 120 & 22.36 & 49.06 & 0.00 & 22.36 & 26.70 & 50.94 & clay & 8.09 & 4.40 & -0.23 & 0.03 & 7.40 & 0.57 & -15.36 & 16.1 & 6 \\
\hline 220 & 16 & 126 & 17.79 & 44.18 & 0.00 & 17.79 & 26.39 & 55.82 & clay & 8.27 & 4.39 & -0.35 & 0.20 & 5.88 & 0.53 & -15.87 & 28.0 & 6 \\
\hline 221 & 17 & 136 & 16.12 & 43.51 & 0.00 & 16.12 & 27.39 & 56.49 & clay & 8.33 & 4.33 & -0.34 & 0.21 & 5.70 & 0.50 & -15.86 & 23.4 & 5 \\
\hline 222 & 18 & 140 & 15.34 & 42.14 & 0.00 & 15.34 & 26.80 & 57.86 & clay & 8.35 & 4.32 & -0.35 & 0.21 & 5.98 & 0.52 & -16.56 & 19.8 & 5 \\
\hline 223 & 19 & 144 & 14.44 & 39.63 & 0.00 & 14.44 & 25.19 & 60.37 & clay & 8.45 & 4.33 & -0.40 & 0.21 & 5.98 & 0.50 & -15.78 & 20.4 & 5 \\
\hline 224 & 20 & 150 & 14.06 & 44.88 & 0.00 & 14.06 & 30.82 & 55.12 & clay & 8.30 & 4.24 & -0.26 & 0.23 & 5.77 & 0.46 & -15.95 & 23.1 & 5 \\
\hline 225 & 21 & 154.5 & 21.69 & 48.94 & 0.00 & 21.69 & 27.25 & 51.06 & clay & 8.05 & 4.41 & -0.11 & 0.22 & 9.44 & 0.61 & -15.76 & 13.1 & 4 \\
\hline 226 & 22 & 157.5 & 22.05 & 53.79 & 0.00 & 22.05 & 31.74 & 46.21 & clay & 7.95 & 4.29 & 0.25 & 0.23 & 5.09 & 0.46 & -16.74 & 23.1 & 4 \\
\hline 227 & 23 & 162 & 22 & 49.68 & 0.00 & 22.00 & 27.68 & 50.32 & clay & 8.33 & 4.17 & -0.17 & -0.02 & 6.25 & 0.48 & -16.30 & 7.9 & 3 \\
\hline 228 & 24 & 166 & 16.97 & 41.01 & 0.00 & 16.97 & 24.04 & 58.99 & clay & 8.37 & 4.45 & -0.44 & 0.20 & 5.43 & 0.40 & -16.01 & 17.9 & 3 \\
\hline 229 & 25 & 174 & 18.29 & 43.28 & 0.00 & 18.29 & 24.99 & 56.72 & clay & 8.28 & 4.45 & -0.39 & 0.20 & 5.89 & 0.38 & -15.68 & 13.7 & 3 \\
\hline 230 & 26 & 184 & 18.59 & 44.47 & 0.00 & 18.59 & 25.88 & 55.53 & clay & 8.25 & 4.44 & -0.37 & 0.21 & 5.64 & 0.35 & -15.49 & 13.7 & 3 \\
\hline 231 & 27 & 194 & 18.18 & 48.81 & 0.00 & 18.18 & 30.63 & 51.19 & clay & 8.18 & 4.30 & -0.22 & 0.21 & 7.32 & 0.58 & -17.32 & 2.7 & 2 \\
\hline 232 & 28 & 198 & 17.11 & 43.45 & 0.00 & 17.11 & 26.34 & 56.55 & clay & 8.28 & 4.37 & -0.34 & 0.22 & 5.91 & 0.45 & -15.23 & 7.9 & 2 \\
\hline 233 & 29 & 216 & 36.51 & 70.06 & 0.00 & 36.51 & 33.55 & 29.94 & clay loam & 7.30 & 3.95 & 0.76 & 0.31 & 6.47 & 0.29 & -17.30 & 0.6 & 1 \\
\hline 234 & 30 & 224 & 35.18 & 65.53 & 0.00 & 35.18 & 30.35 & 34.47 & clay loam & 7.60 & 4.17 & 0.64 & 0.25 & 7.39 & 0.24 & -17.66 & 0.0 & 1 \\
\hline
\end{tabular}


Table F-1. Continued...

\begin{tabular}{|c|c|c|c|c|c|c|c|c|c|c|c|c|c|c|c|c|c|c|}
\hline $\begin{array}{c}\text { Sample } \\
\text { No. }\end{array}$ & Rank & Depth & $\begin{array}{c}\% \\
\geq 63 \mu\end{array}$ & $\begin{array}{c}\% \\
\geq 2 \mu\end{array}$ & $\begin{array}{c}\% \\
\text { gravel }\end{array}$ & $\begin{array}{c}\% \\
\text { sand }\end{array}$ & $\%$ silt & $\begin{array}{l}\% \\
\text { clay }\end{array}$ & $\begin{array}{l}\text { Texture } \\
\text { (SCS) }\end{array}$ & mean & sd & skew & kurt & $\chi$ & $\begin{array}{c}\text { Organic } \\
\text { C\% }\end{array}$ & $\delta \mathbf{1 3 C}$ & $\begin{array}{c}\text { CCE } \\
\%\end{array}$ & $\begin{array}{c}\text { Depositional } \\
\text { Unit }\end{array}$ \\
\hline 235 & 31 & 236 & 37.52 & 66.08 & 0.00 & 37.52 & 28.56 & 33.92 & clay loam & 7.56 & 4.19 & 0.67 & 0.25 & 7.05 & 0.18 & -20.01 & 0.3 & 1 \\
\hline 236 & 32 & 245 & 38.25 & 67.96 & 0.00 & 38.25 & 29.71 & 32.04 & clay loam & 7.51 & 4.15 & 0.79 & 0.26 & 6.76 & 0.12 & -18.28 & 0.0 & 1 \\
\hline 237 & 33 & 256 & 44.41 & 69.95 & 0.00 & 44.41 & 25.54 & 30.05 & clay loam & 7.44 & 4.12 & 0.80 & 0.15 & 6.55 & 0.09 & -18.21 & 0.6 & 1 \\
\hline 238 & 34 & 266 & 51.30 & 76.39 & 0.00 & 51.30 & 25.09 & 23.61 & $\begin{array}{c}\text { sandy clay } \\
\text { loam }\end{array}$ & 7.03 & 3.80 & 0.80 & 0.35 & 5.24 & 0.04 & -20.45 & 1.8 & Beaumont \\
\hline 239 & 35 & 275 & 44.82 & 71.58 & 0.00 & 44.82 & 26.76 & 28.42 & clay loam & 7.01 & 3.80 & 0.76 & 0.36 & 5.72 & 0.07 & -19.69 & 5.5 & Beaumont \\
\hline 258 & 36 & 285 & 34.54 & 62.93 & 0.00 & 34.54 & 28.39 & 37.07 & clay & 7.71 & 4.32 & 0.62 & 0.23 & 6.09 & 0.12 & -18.50 & 9.1 & Beaumont \\
\hline
\end{tabular}

Table F-2. Results of Lab Work Obtained for Samples Derived from Core 6

\begin{tabular}{|c|c|c|c|c|c|c|c|c|c|c|c|c|c|c|c|c|c|c|}
\hline $\begin{array}{c}\text { Sample } \\
\text { No. }\end{array}$ & Rank & Depth & $\% \geq 63 \mu$ & $\% \geq 2 \mu$ & $\begin{array}{c}\% \\
\text { gravel }\end{array}$ & $\%$ sand & $\%$ silt & $\%$ clay & $\begin{array}{l}\text { Texture } \\
\text { (SCS) }\end{array}$ & mean & sd & skew & kurt & $\chi$ & $\begin{array}{c}\text { Organic } \\
\mathbf{C} \%\end{array}$ & $\delta{ }^{13} \mathbf{C}$ & CCE \% & $\begin{array}{c}\text { Depositional } \\
\text { Unit }\end{array}$ \\
\hline 325 & 1 & 28 & 38.97 & 67.11 & 0 & 38.97 & 28.14 & 32.89 & clay loam & 7.50 & 4.23 & 0.66 & 0.26 & 7.20 & 0.60 & -15.34 & 0.91 & 5 \\
\hline 326 & 2 & 33 & 33.62 & 59.95 & 0 & 33.62 & 26.33 & 40.05 & clay & 7.79 & 4.38 & 0.63 & 0.22 & 6.46 & 0.42 & -14.88 & 3.64 & 5 \\
\hline 327 & 3 & 40 & 39.49 & 65.31 & 0 & 39.49 & 25.82 & 34.69 & clay loam & 7.62 & 4.23 & 0.79 & 0.24 & 6.16 & 0.35 & -14.98 & 5.47 & 5 \\
\hline 328 & 4 & 48 & 23.93 & 63.87 & 0 & 23.93 & 39.94 & 36.13 & clay loam & 7.79 & 4.05 & 0.69 & 0.25 & 8.33 & 0.64 & -15.08 & 1.52 & 4 \\
\hline 329 & 5 & 54 & 19.77 & 58.91 & 0 & 19.77 & 39.14 & 41.09 & clay & 8.20 & 3.96 & 0.58 & 0.03 & 6.56 & 0.48 & -17.39 & 9.42 & 4 \\
\hline 330 & 6 & 64 & 19.15 & 50.93 & 0 & 19.15 & 31.78 & 49.07 & clay & 8.14 & 4.31 & -0.15 & 0.22 & 6.21 & 0.34 & -17.12 & 11.84 & 4 \\
\hline 331 & 7 & 75 & 15.69 & 48.79 & 0 & 15.69 & 33.10 & 51.21 & clay & 8.27 & 4.25 & -0.22 & 0.24 & 6.24 & 0.30 & -16.16 & 13.67 & 4 \\
\hline 332 & 8 & 85 & 16.85 & 48.46 & 0 & 16.85 & 31.61 & 51.54 & clay & 8.23 & 4.29 & -0.24 & 0.23 & 6.41 & 0.30 & -15.55 & 10.93 & 4 \\
\hline 333 & 9 & 95 & 17.61 & 50.33 & 0 & 17.61 & 32.72 & 49.67 & clay & 8.13 & 4.23 & -0.19 & 0.23 & 6.33 & 0.28 & -15.29 & 9.42 & 4 \\
\hline 334 & 10 & 135 & 19.55 & 60.99 & 0 & 19.55 & 41.44 & 39.01 & clay & 7.90 & 4.04 & 0.13 & 0.25 & 6.48 & 0.30 & -15.97 & 5.16 & 4 \\
\hline 335 & 11 & 156 & 34.03 & 69.04 & 0 & 34.03 & 35.01 & 30.96 & clay loam & 7.27 & 3.99 & 0.53 & 0.31 & 7.20 & 0.38 & -16.33 & 1.82 & 3 \\
\hline 336 & 12 & 164 & 36.11 & 68.82 & 0 & 36.11 & 32.71 & 31.18 & clay loam & 7.30 & 4.11 & 0.56 & 0.29 & 7.24 & 0.36 & -16.75 & 7.29 & 3 \\
\hline 337 & 13 & 174 & 33.94 & 64.36 & 0 & 33.94 & 30.42 & 35.64 & clay & 7.46 & 4.30 & 0.38 & 0.25 & 6.93 & 0.24 & -15.01 & 9.11 & 3 \\
\hline 338 & 14 & 182 & 34.01 & 66.34 & 0 & 34.01 & 32.33 & 33.66 & clay loam & 7.37 & 4.21 & 0.38 & 0.29 & 6.43 & 0.22 & -15.66 & 9.11 & 3 \\
\hline 339 & 15 & 188 & 31.84 & 69.23 & 0 & 31.84 & 37.39 & 30.77 & clay loam & 7.41 & 3.97 & 0.58 & 0.17 & 10.22 & 0.37 & -17.31 & 4.56 & 2 \\
\hline 340 & 16 & 194 & 32.33 & 69.03 & 0 & 32.33 & 36.70 & 30.97 & clay loam & 7.44 & 3.96 & 0.59 & 0.31 & 9.58 & 0.33 & -18.49 & 6.68 & 2 \\
\hline 341 & 17 & 206 & 27.32 & 63.47 & 0 & 27.32 & 36.15 & 36.53 & clay loam & 7.66 & 4.09 & 0.30 & 0.27 & 7.82 & 0.33 & -18.20 & 14.58 & 2 \\
\hline 342 & 18 & 214 & 28.11 & 65.29 & 0 & 28.11 & 37.18 & 34.71 & clay loam & 7.61 & 4.05 & 0.33 & 0.27 & 7.64 & 0.28 & -17.55 & 12.76 & 2 \\
\hline 343 & 19 & 222 & 28.48 & 65.90 & 0 & 28.48 & 37.42 & 34.10 & clay loam & 7.57 & 4.02 & 0.27 & 0.28 & 6.76 & 0.27 & -17.16 & 14.88 & 2 \\
\hline 344 & 20 & 230 & 31.77 & 69.96 & 0 & 31.77 & 38.19 & 30.04 & clay loam & 7.40 & 3.93 & 0.58 & 0.32 & 6.91 & 0.22 & -17.58 & 13.36 & 2 \\
\hline 345 & 21 & 240 & 28.23 & 69.90 & 0 & 28.23 & 41.67 & 30.10 & clay loam & 7.44 & 3.86 & 0.53 & 0.32 & 9.29 & 0.28 & -16.87 & 6.68 & 1 \\
\hline 346 & 22 & 250 & 27.51 & 72.85 & 0 & 27.51 & 45.34 & 27.15 & clay loam & 7.29 & 3.71 & 0.59 & 0.36 & 9.95 & 0.34 & -17.13 & 4.25 & 1 \\
\hline 347 & 23 & 260 & 26.62 & 71.87 & 0 & 26.62 & 45.25 & 28.13 & clay loam & 7.54 & 3.60 & 0.68 & 0.23 & 10.16 & 0.26 & -18.96 & 5.77 & 1 \\
\hline 348 & 24 & 270 & 27.14 & 66.60 & 0 & 27.14 & 39.46 & 33.40 & clay loam & 7.63 & 4.04 & 0.61 & 0.28 & 9.34 & 0.15 & -18.68 & 9.72 & 1 \\
\hline 349 & 25 & 280 & 22.64 & 60.34 & 0 & 22.64 & 37.70 & 39.66 & clay & 7.85 & 4.17 & 0.17 & 0.25 & 8.47 & 0.21 & -24.95 & 16.10 & 1 \\
\hline 350 & 26 & 290 & 23.56 & 58.33 & 0 & 23.56 & 34.77 & 41.67 & clay & 7.89 & 4.23 & 0.10 & 0.23 & 8.08 & 0.10 & -18.36 & 18.53 & Beaumont \\
\hline
\end{tabular}

Table F-3. Results of Lab Work Obtained for Samples Derived from Core 2

\begin{tabular}{|c|c|c|c|c|c|c|c|c|c|c|c|c|c|c|c|c|c|c|}
\hline $\begin{array}{c}\text { Sample } \\
\text { No. }\end{array}$ & Rank & Depth & $\begin{array}{c}\% \\
\geq 63 \mu\end{array}$ & $\begin{array}{c}\% \\
\geq 2 \mu\end{array}$ & $\begin{array}{c}\% \\
\text { gravel }\end{array}$ & $\%$ sand & $\%$ silt & $\%$ clay & $\begin{array}{c}\text { Texture } \\
\text { (SCS) }\end{array}$ & mean & sd & skew & kurt & $\chi$ & $\begin{array}{c}\text { Organic } \\
\mathrm{C} \%\end{array}$ & $\delta^{13} \mathbf{C}$ & $\begin{array}{c}\mathrm{CCE} \\
\%\end{array}$ & $\begin{array}{c}\text { Depositional } \\
\text { Unit }\end{array}$ \\
\hline 132 & 1 & 97 & 25.27 & 55.38 & 0 & 25.27 & 30.11 & 44.62 & clay & 7.87 & 4.48 & 0.04 & 0.24 & 5.89 & na & na & 2.13 & Pond \\
\hline 133 & 2 & 108 & 12.45 & 45.95 & 0 & 12.45 & 33.50 & 54.05 & clay & 8.40 & 4.24 & -0.32 & 0.21 & 6.55 & 2.03 & -15.53 & 1.21 & Pond \\
\hline 134 & 3 & 118 & 7.63 & 38.79 & 0 & 7.63 & 31.16 & 61.21 & clay & 8.77 & 4.05 & -0.38 & 0.22 & 7.00 & 1.73 & -15.59 & 1.21 & Pond \\
\hline 135 & 4 & 128 & 6.41 & 37.63 & 0 & 6.41 & 31.22 & 62.37 & clay & 8.86 & 3.98 & -0.38 & 0.23 & 7.17 & 1.58 & -15.91 & 0.91 & Pond \\
\hline 136 & 5 & 139 & 5.94 & 37.24 & 0 & 5.94 & 31.30 & 62.76 & clay & 9.22 & 3.62 & -0.32 & 0.04 & 7.34 & 1.56 & -15.61 & 0.91 & Pond \\
\hline 137 & 6 & 146 & 6.53 & 34.93 & 0 & 6.53 & 28.40 & 65.07 & clay & 8.93 & 3.96 & -0.40 & 0.24 & 7.31 & 1.42 & -15.88 & 1.21 & Pond \\
\hline
\end{tabular}


Table F-3. Continued...

\begin{tabular}{|c|c|c|c|c|c|c|c|c|c|c|c|c|c|c|c|c|c|c|}
\hline $\begin{array}{c}\text { Sample } \\
\text { No. }\end{array}$ & Rank & Depth & $\begin{array}{c}\% \\
\geq 63 \mu\end{array}$ & $\begin{array}{c}\% \\
\geq 2 \mu\end{array}$ & $\begin{array}{c}\% \\
\text { gravel }\end{array}$ & $\%$ sand & $\%$ silt & $\%$ clay & $\begin{array}{c}\text { Texture } \\
\text { (SCS) }\end{array}$ & mean & sd & skew & kurt & $\chi$ & $\begin{array}{c}\text { Organic } \\
\text { C\% }\end{array}$ & $\delta^{13} \mathbf{C}$ & $\begin{array}{c}\mathrm{CCE} \\
\%\end{array}$ & $\begin{array}{c}\text { Depositional } \\
\text { Unit }\end{array}$ \\
\hline 138 & 7 & 156 & 7.36 & 36.60 & 0 & 7.36 & 29.24 & \begin{tabular}{|l|}
63.40 \\
\end{tabular} & clay & 8.87 & 4.00 & -0.40 & 0.23 & 7.44 & 1.42 & $\mid-15.80$ & 0.61 & Pond \\
\hline 139 & 8 & 166 & 9.44 & 36.13 & 0 & 9.44 & 26.69 & \begin{tabular}{|l|}
63.87 \\
\end{tabular} & clay & 8.83 & 4.04 & -0.41 & 0.24 & 7.45 & 1.22 & -15.77 & 1.21 & Pond \\
\hline 140 & 9 & 175 & 9.08 & 34.79 & 0 & 9.08 & 25.71 & $\mid 65.21$ & clay & 8.87 & 4.03 & -0.42 & 0.24 & 7.55 & 1.18 & -15.80 & 1.21 & Pond \\
\hline 141 & 10 & 184 & 7.55 & 35.60 & 0 & 7.55 & 28.05 & 64.40 & clay & 8.89 & 3.97 & -0.39 & 0.25 & 7.57 & 1.11 & -15.59 & 1.21 & Pond \\
\hline 142 & 11 & 195 & 9.01 & 39.76 & 0 & 9.01 & 30.75 & 60.24 & clay & 8.65 & 4.12 & -0.36 & 0.21 & 7.45 & 0.98 & -15.49 & 1.52 & Pond \\
\hline 143 & 12 & 227 & 8.93 & 41.83 & 0 & 8.93 & 32.90 & 58.17 & clay & 8.57 & 4.18 & -0.36 & 0.19 & 7.12 & 0.84 & -15.44 & 1.52 & Pond \\
\hline 144 & 13 & 235 & 14.74 & 48.40 & 0 & 14.74 & 33.66 & 51.60 & clay & 8.30 & 4.26 & -0.26 & 0.18 & 6.94 & 0.56 & -15.39 & 1.21 & Pond \\
\hline 145 & 14 & 244 & 16.79 & 48.63 & 0 & 16.79 & 31.84 & 51.37 & clay & 8.27 & 4.31 & -0.26 & 0.18 & 7.11 & 0.48 & -15.70 & 1.52 & Pond \\
\hline 146 & 15 & 253 & 16.38 & 42.87 & 0 & 16.38 & 26.49 & 57.13 & clay & 8.34 & 4.36 & -0.37 & 0.05 & 7.45 & 0.38 & -15.52 & 1.52 & Pond \\
\hline 147 & 16 & 261 & 18.54 & 50.80 & 0 & 18.54 & 32.26 & 49.20 & clay & 8.14 & 4.28 & -0.16 & 0.22 & 7.84 & 0.21 & -16.78 & 1.52 & Pond \\
\hline 148 & 17 & 269 & 31.64 & 59.48 & 0 & 31.64 & 27.84 & 40.52 & clay & 7.72 & 4.37 & 0.26 & 0.22 & 7.46 & 0.15 & -18.82 & 8.50 & Beaumont \\
\hline 149 & 18 & 277 & 38.1 & 67.57 & 0 & 38.1 & 29.47 & 32.43 & $\begin{array}{l}\text { clay } \\
\text { loam }\end{array}$ & 7.38 & 4.14 & 0.58 & 0.27 & 6.50 & 0.08 & -21.73 & 16.10 & Beaumont \\
\hline 150 & 19 & 286 & 39.35 & 70.96 & 0 & 39.35 & 31.61 & 29.04 & $\begin{array}{l}\text { clay } \\
\text { loam }\end{array}$ & 7.26 & 3.91 & 0.63 & 0.32 & 7.05 & 0.07 & -21.54 & 17.01 & Beaumont \\
\hline 151 & 20 & 295 & 39.21 & 71.61 & 0 & 39.21 & 32.40 & 28.39 & $\begin{array}{l}\text { clay } \\
\text { loam }\end{array}$ & 7.32 & 3.88 & 0.64 & 0.32 & 7.59 & 0.08 & -24.60 & 13.36 & Beaumont \\
\hline
\end{tabular}

$3.5,15,45,300$, and 1440 minutes). A control hydrometer and temperature reading on an empty jar with nothing but distilled water and the sodium hexametaphosphate solution was made at intervals throughout the analysis to permit calibration of the hydrometer. A small split of the $<2 \mathrm{~mm}$ soil was also oven dried to determine the moisture content and correct the sample mass used in the hydrometer analysis (hygroscopic moisture correction). After 24 hours, the contents of the hydrometer jar were wet sieved through 37 micron sieve, and the sand retained on the sieve was transferred to a beaker and oven dried at $105^{\circ} \mathrm{C}$. This sand was subsequently sieved at 0.5 phi intervals once dry and the mass retained on each sieve recorded. From these data the percentage of gravel, sand, silt and clay, as well as various descriptive statistics were calculated for the grain size distribution using a spreadsheet written by Paul Lehman.

\section{Calcium Carbonate Content (C.C.E)}

A $1.7 \mathrm{~g}$ split of the ground $<2 \mathrm{~mm}$ fraction of each soil sample was used to determine the calcium carbonate equivalent (C.C.E.) by means of a Chittick apparatus (Dreimanis 1962; Machette 1986). This sample was finely ground (to pass a $0.075 \mathrm{~mm}$ sieve), and then weighed, and placed into a small $(250 \mathrm{ml})$ Erlenmeyer flask. Once attached to the Chittick apparatus, the liquid level in the measuring burette was set to $-10 \mathrm{ml}$, then the stopcock was closed so no gas could leave the system, and the leveling bulb was dropped in order to establish a vacuum inside the sample chamber. At this point the barometric pressure and temperature in the room were recorded. Then $10 \mathrm{ml}$ of $50 \%$ hydrochloric acid (ca. $6 \mathrm{~N} \mathrm{HCl)} \mathrm{was} \mathrm{delivered} \mathrm{to} \mathrm{the} \mathrm{sample} \mathrm{flask,} \mathrm{which}$ was agitated intermittently until the reaction had ceased (usually 1-2 minutes). At this point, the leveling bulb was raised to the point that the liquid level inside of it was equal in elevation to the liquid in the burette, and the volume of gas evolved was then measured and the calcium carbonate equivalent calculated.

\section{Organic Carbon}

In order to determine the carbon content of each sample, splits of the $<2 \mathrm{~mm}$ size fraction were submitted to the Analytical Chemistry Lab at Institute of Ecology, University of Georgia. The carbon content was determined on a on a Micro-Dumas NA1500 Combustion Elemental $(\mathrm{C} / \mathrm{H} / \mathrm{N})$ Analyzer (Carlo Erba Strumentazione, Milan). Details of the procedures used at in the procedure may be found on the institute's web page (http://www.uga.edu/ sisbl/soilerb.html) and general aspects of the method are discussed by Schulte and Hopkins (1996). Organic carbon content was determined from a 2 gram split of the $<2 \mathrm{~mm}$ size soil was treated with $6 \mathrm{~N} \mathrm{HCl}$ to remove calcium carbonate, then rinsed repeatedly, subsequently dried at $105^{\circ} \mathrm{C}$, and then finely ground once dry.

\section{Stable Carbon Isotopic Composition}

The stable carbon isotopic value of the organic carbon for each sample was determined at the Stable Isotope/Soil Biology Laboratory at Institute of Ecology, University of Georgia. These values were determined from the carbonate free $<2$ $\mathrm{mm}$ soil used to determine the organic carbon content and were determined on a element ratio mass spectrometer by converting the organic carbon to a gas phase by extremely rapid and complete flash combustion of the sample material. 


\section{Magnetic Susceptibility}

The reversible, low frequency mass magnetic susceptibility of the samples were determined by filling a 1 inch plastic cube with air dried $<2 \mathrm{~mm}$ size material from each sample. The samples were then weighed and then the low frequency magnetic susceptibility was measured on a Bartington MS2 meter and MS2B sensor. Each value was measured twice and the average values were used to calculate the reversible, low frequency mass susceptibility $\left({ }_{\text {If }}\right.$ ) which are reported in SI units $\left(10^{-8} \mathrm{~m}^{3} \mathrm{~kg}^{-1}\right)$. The precise methods and equations used may be found in Gale and Hoare (1991:222-226).

\section{Petrographic Thin Sections}

Small blocks of sediment cut from the bulk samples were submitted National Petrographic Inc., for thin section preparation, and were subsequently examined at a range of magnifications. Low magnification examination was performed with a Leica S8 APO binocular microscope fitted with transmitted light base and polarizing filters. Higher magnification examination employed a Leica DMEP polarizing light microscope.

\section{Radiocarbon Dates}

Bulk soil samples were collected from buried A horizons within each core and were submitted to Beta Analytic for radiocarbon assay. The organic carbon dated in these soils is largely pedogenic in nature and for this reason, the ages serve as minimum ages for the deposition of the unit they cap, and maximum ages for the next younger phase of eolian deposition.

\section{Microfossils}

In addition to the aforementioned basic physical analyses, samples from the two clay dunes were submitted to specialist for ostracode and diatom analysis. Winsborough (Appendix $\mathrm{D}$; this volume) reports the results of the diatom analysis and, unfortunately, diatoms were rarely preserved in the clay dune deposits. Calcareous microfossils (ostracodes and foraminifera) were examined by Palacios-Fest (Appendix E; this volume). Although the preservation of these fossils was spotty as well, they were considerably more ubiquitious than the diatoms.

\section{Results}

\section{General Observations}

The dunes comprise approximately 2 to $3 \mathrm{~m}$ of alternating light and dark colored deposits which represent relatively unaltered eolian sediment and soil A-horizons that formed during periods of relative stability and/or infrequent eolian sedimentation. The raw sediment ( $\mathrm{C}$ horizons) ranges in color from light brownish gray $(2.5 \mathrm{Y} 6 / 2)$ to light gray $(2.5 \mathrm{Y} 6 / 1$ to $2.5 \mathrm{Y} 7 / 1)$, pale yellow $(2.5 \mathrm{Y} 8 / 2)$ and gray $(2.5 \mathrm{Y} 5 / 1.5)$. None of the deposits exhibited the pelletal structure they must have possessed at the time of deposition in either macroscopic or microscopic examination which suggests that these fabrics were relatively quickly changed by wetting and drying. The texture of the deposits ranged from clay to clay loam, with the deposits of the South Dune containing more silt and more often classified as clay loam rather than clay. The raw sediment appears to have contained between $0.3 \%$ and $0.4 \%$ organic carbon. The $\mathrm{C}$ horizons typically contained more calcium carbonate than the A horizons and significantly more calcareous microfossils than the pedogenically altered zones. This relationship is clear from Palacio-Fest's (Appendix E; this volume) counting and description of the foaminifera and ostracodes (see also Figure F-3 and Figure F-4) as well as the petrographic thin sections. Although the elevated calcium carbonate content within these zones is thought to be largely detrital, there was clear deposition of secondary calcium carbonate in the lowest soils in each core. The carbon isotopic composition of the pedogenically unaltered muds ranges from -18 to -24 in the earliest phase of deposition, and soon thereafter stablizes between-15 to -17 per mil.

The thin A horizons (paleosols) ranged in color from black ( $\mathrm{N} \mathrm{2/0}$ and $2.5 \mathrm{Y} \mathrm{2/1)}$, to very dark gray $(2.5 \mathrm{Y} 3 / 1)$ and gray $(2.5 \mathrm{Y} 4 / 1)$, and generally were slightly coarser textured than the underlying $\mathrm{C}$ horizons. The coarser texture is expressed as a slightly greater sand content, and as a clear increase in the coarse:fine ratio observable in thin section. Nearly all of the A horizons exhibited significant calcium carbonate depletion. The leaching of calcium carbonate from these soils clearly degraded the carbonate microfossil content of these deposits, and is probably responsible for the slightly coarser texture of these zones. The carbon enrichment of the A horizons was quite variable, reaching a maximum value of around $1 \%$, and a low of $0.3 \%$, which is quite close to the detrital carbon content of the pedogenically unaltered sediment. Most of the soils formed in clay dune sediment exhibit slightly isotopically lighter values than the sediment within which they have formed, which may reflect the contribution of woody plants growing on the dunes during periods of relative stability. Although the isotopic composition of the soils are fairly similar, there is a subtle trend towards more $\mathrm{C} 4$ values throughout the sequence with early soils ranging around -17 per mil and the modern soils exhibiting values between -15 to -16 per mil (discussed in greater detail, later). Although the organic carbon content is one of the best indicators of pedogenic alteration of the deposits, the A horizons consistently exhibited very subtle 

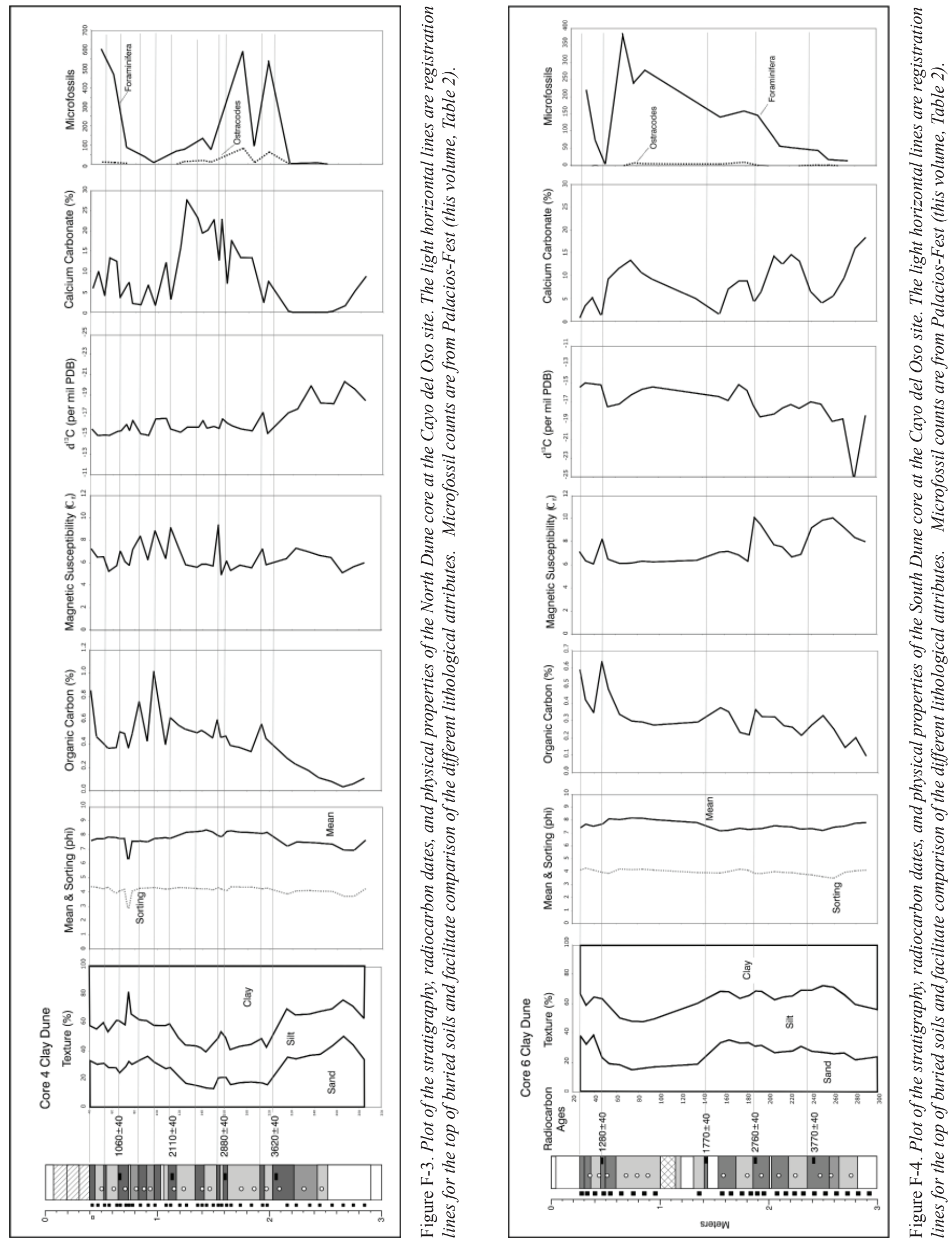
but clear magnetic susceptibility enhancement. Most of the A horizons also exhibited local re-organization of the clay groundmass into cutans around framework grains and an optically active fabric, which was generally absent from the $\mathrm{AC}$ and $\mathrm{C}$ horizons.

\section{A Comment on Chronology}

As process observations by W. Armstrong Price $(1958,1963)$ and his colleagues (Price and Kornicker 1961, Huffman and Price 1949) demonstrate, the period of time represented by any one phase of clay dune aggradation may have been very short. The paleosols, therefore, undoubtedly represent most of the time in these stratigraphic records. Our chronology was obtained from radiocarbon ages obtained for bulk soil organic matter collected from the top of buried A horizons, and these dates appear to yield a solid chronology. But because of the nature of the depositional record, these dates do not reflect the time of deposition for the depositional unit from which they were collected. Rather, they most likely approximate the time of deposition for the next younger unit, and serve as a minimum age for the depositional unit from which they were collected

In hind sight, examination of the petrographic thin sections and the results of the granulometric analyses demonstrates that there is sufficient sand within the dunes to permit optically stimulated luminescence dating (OSL), and ideally, a paired sequence of OSL dates from the $\mathrm{C}$ horizons (dating the period of eolian sedimentation) and radiocarbon dates from the buried soils would yield the most useful geochronologic record. It is unclear at this time if the sand within the clay dune sediment was sufficiently bleached to accurately record the time of deposition, but this could, at least in part, be assessed if single grain OSL dates were employed.

\section{The South Dune (Core 6)}

The south dune is perched on the upland margin immediately north of and close to the mouth of an unnamed drainage. The core revealed a series of 5 discrete eolian depositional events that occurred in the last 4 thousand years (see Figure F-2) for a schematic illustration of the stratigraphy, samples collected, the deposit color and stratigraphic location of each depositional unit. In a broad sense, this sequence exhibits three siginificant textural cycles, with the first three and the fifth depositional events being similarly textured, and the fourth being considerably finer textured. The majority of the microfossils recovered by Palacios-Fest (Appendix E; this volume) were present within the fourth depositional unit. Figure F-4 charts the lothologic variation of the south dune deposits.

Although we do not have a date for the base of this dune, Ricklis (1997) obtained a radiocarbon age from an oyster shell at the Beaumont-clay dune interface in this part of the site which yielded an age of 3,990 \pm 70 years B.P. (Beta099304) which places the onset of dune sedimentation right around 4,000 radiocarbon years B.P. The first phase of eolian deposition was approximately $50 \mathrm{~cm}$ thick and a bulk soil radiocarbon date of 3,770 \pm 40 years B.P. (Beta-235810) from the top of the A horizon suggests that this phase was short lived, perhaps only 250 years or less. The stable carbon isotopes from the first depositional phase reflect a woodland environment at the start of the phase (with values of -24.95 per mil) which may be an artifact of deflation of the former Pleistocene surface soil. Carbon isotopic values gradually increase to -18.5 to -19 in the core of the deposit. The soil formed at the top of the first phase of deposition exhibited a $\mathrm{d}^{13} \mathrm{C}$ value of -16.87 per mil reflecting that relatively few $\mathrm{C} 3$ plants colonized the dune crest at this time. Few microfossils were found by Palacios-Fest (Appendix D, this volume) within the deposits of the first depositional phase, which may indicate that the lagoonal environment was not yet fully established when the dune began to form.

The second phase of deposition (DU2) was also around 50 $\mathrm{cm}$ thick and the soil at the top of this deposit yielded an age

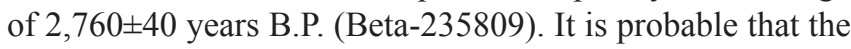
deposition of this unit occurred closer to the 3770 years B.P. Sediments forming the core of this deposit exhibited $\mathrm{d}^{13} \mathrm{C}$ values between -17 to -18.5 per mil, and the soil at the top of the deposit yielded a value of -17.31 per mil.

A radiocarbon age of $1,770 \pm 40$ years B.P. (Beta-235808) was obtained from soil at the top of the third depositional phase, which was around $40 \mathrm{~cm}$ thick. The fourth phase of dune aggradation was the thickest and finest textured in the entire sequence. A radiocarbon age obtained from the top of this deposit was $1280 \pm 40$ years B.P. (Beta-235807) and indicates that more than a meter of sediment accumulated in less than 500 years. A sharp change in the $\mathrm{d}^{13} \mathrm{C}$ values in the soil at the top of this depositional phase suggests that the vegetation may have shifted towards $\mathrm{C} 4$ plants while the dune was stabilized as the top two samples differ by approximately 2.2 per mil.

The fifth and last phase of dune sedimentation is undated, and the soil formed in this deposit is presumed to be the modern surface soil. The deposit is only $25 \mathrm{~cm}$ thick and it is considerably coarser than the deposits of the fourth depositional unit.

\section{The North Dune (Core 4)}

The north dune overlooks the Blind Oso Inlet and core 4 penetrated almost $2.2 \mathrm{~m}$ of clay dune deposits that were found resting upon an eroded Beaumont Formation surface. 
Although a similar lithologic record to the south dune was anticipated, the north dune revealed 11 depositional units (DU) and associated buried soils spanning approximately the same period of time as the south dune. Like the south dune, the north dune granulometry depicts three major cycles, starting with a relatively coarse phase, becoming finer textured between 3620 and 2110 years B.P., and becoming coarser again after 2110 years B.P. The following text describes trends plotted on Figure F-3.

The first phase of dune aggradation appears to be of similar age and magnitude as the first phase in the south dune. This deposit is approximately $50 \mathrm{~cm}$ thick and it is the thickest eolian deposit in the north dune record. A radiocarbon age from the top of this deposit yielded an age of $3620 \pm 40$ years B.P. (Beta-235806), and like depositional unit 1 in the south dune, Palacios-Fest found relatively few calcareous microfossils in this deposit. The $\mathrm{d}^{13} \mathrm{C}$ value of the buried $\mathrm{A}$ horizon found within this deposit was -17.30 per mil which is close to the value obtained for the soil in DU1 of the south dune.

Depositional Unit 2 was very thin $(<20 \mathrm{~cm})$ and consisted of an A-C soil. This deposit was not radiocarbon dated, and as such its age can be bracketed to the period between 3620 and 2880 years B.P. The subsequent phase of eolian sedimentation, DU3, was much thicker, and occurred sometime before 2880 years B.P. This deposit was approximately $30 \mathrm{~cm}$ thick and was capped by a very thin soil that was radiocarbon dated to $2880 \pm 40$ years B.P. (Beta-235805). The $\mathrm{d}^{13} \mathrm{C}$ values of the soil formed at the top of depositional unit 3 was -16.30 per mil. Samples from the $\mathrm{C}$ horizons of DU2 and DU3 contained numerous calcareous microfossils.

Three thin depositional units $(4,5 \& 6)$ were deposited in the 770 year period between 2880 and 2110 years B.P. The calcium carbonate content of the raw sediment increases dramatically during this period, but somewhat surprisingly, the ubiquity of calcareous microfossils drops off. At the same time, the $\mathrm{d}^{13} \mathrm{C}$ values of the soils become progressively heavier, ending with a value of -15.64 per mil at the top of DU6 which was radiocarbon dated to $2110 \pm 40$ years B.P. (Beta-235804).

In the approximately 1000 year period between 2110 and 1060 years B.P. another three thin eolian deposits accumulated on the north dune, comprising a total of about $50 \mathrm{~cm}$ of new sediment. Judging by the color and organic carbon content of the sediment, these deposits were significantly altered by pedogenesis and as a result they yielded few calcareous microfossils. The first of these, DU7, was less than $20 \mathrm{~cm}$ thick and capped by a very black, organic rich soil which yielded a $\mathrm{d}^{13} \mathrm{C}$ value of -16.67 , which is somewhat isotopically lighter than the soils that immediately precede or follow it suggesting that the climate may have been somewhat more moist at this time. The following two units (DU8 and DU9) are fairly similar in character, and the top of DU9 was radiocarbon dated to $1060 \pm 40$ years B.P. (Beta-235803).

The last two depositional units in the core 4 record were deposited in the last millennium and it is during this period that stable carbon isotopic values reach their maximum $(-15.49$ per mil, in the soil at the top of DU10). Both of these depositional units comprise mostly unaltered sediment and very thin A horizons, and not surprisingly, the $\mathrm{C}$ horizons of these deposits yielded significant numbers of calcareous microfossils. The soil at the top of the sequence in DU11, the modern soil, yielded a $\mathrm{d}^{13} \mathrm{C}$ value of -15.67 , which is slightly lighter than the soil in DU10, and this may reflect colonization of the dune by mesquite in the modern era.

\section{Comparing the Two Records}

\section{General Observations}

Even a cursory inspection of the two dune records (Figures F-3 and F-4) makes it clear that they are not reflecting the same sedimentation events and that some factor(s) other than climate must control dune sedimentation. None of the major lithological indices (texture, mean particle size, carbonate content) are consistent between the two dunes.

The textural composition of the dune deposits in both cores exhibit gradual, long term shifts which probably reflect changes in the nature of the mud flat adjacent to the dunes. Perversely, the lithology of the cores are out of synch with each other, with the core 4 record being clay dominated in the early period of dune formation, and becoming coarser textured in the later phases, whereas the core 6 record is just opposite of that, and is more coarse early on and becomes finer textured in the latter half of the record. Only the earliest and latest phases of deposition in each record appear to correlate, and one wonders if this would be the case if we had more accurate depostional ages for these sediments.

The microfossil work of Palacios-Fest (Appendix E; this volume) further supports this point. It was assumed that since these two dunes front the same mudflat (ostensibly the same sediment source), that the microfossil records contained with the dune sediment would be similar. But as Palacios-Fest has demonstrated, the two records are significantly different in both general trends (such as the paleosalinity index) and specific fauna present at any given time. It is clear that pedogenesis within the dunes is a major taphonomic factor controlling the preservation of ostracodes and foraminifera, 
but even the most basic details such as the periods when the most microfossil rich sediment was deposited are out of sync between the two dunes.

The fact that the two records are not parallel demonstrates the significant role sediment source plays in the growth and development of these dunes, and how changes in dune texture are largely irrelevant in interpreting coastal clay dune history except as it pertains to changes in the sediment source immediately adjacent to the dune. It is clear that long-term changes in sediment size are not demonstrably climatic in nature. This finding is consistent with comments made by Ricklis (1997:17) that

\begin{abstract}
"it is interesting and significant to note that a uniform stratigraphy across the area is not indicated. Rather, soil horizons tend to be horizontally localized, suggesting a complex history of clay dune formation, perhaps involving localized erosional events in which pre-existing sediments were partially removed prior to subsequent eolian deposition of new material."
\end{abstract}

Hence, the hypothesis that periods of clay dune sedimentation and stability preserved within coastal clay dunes may be used as a climatic proxy must be rejected. As noted by Bowler (1973) the hydrology of the mud flat is the dominant control on dune sedimentation, and as this work has demonstrated, two dunes forming from the same mud flat may have dramatically different depositional records.

The dramatic stratigraphic variation exhibited by these two dunes (and the photos taken during the fieldwork as well) raise questions about the sedimentary and stratigraphic structure of coastal clay dunes. Most of the literature on these dunes document the physical processes of sedimentation, not the stratigraphy, and where we have stratigraphic records they are like the ones described here, made from vertical profiles. What is missing is a more comprehensive elucidation of stratigraphic variation of within a single dune, in three dimensions (e.g. stoss to lee, as well as longitundinally). Meissner (Figure 5-6; and personal communication 1997) observed a range of small-scale features within these clay dunes that reflect erosion and deposition of the dunes associated with runoff of water and subsequent gully formation, and these features are not presently represented in the coastal clay dune literature, and a more comprehensive look at a clay dune in the future may yield a more nuanced paleoenvironmental record.

Despite these problems, that does not mean that clay dunes do not hold paleoenvironmental potential.

\section{Stable Carbon Isotopes}

The stable carbon isotopic record from the dunes is a complex issue which needs careful consideration prior to interpretation. The raw records as plotted on Figures F-3 and F-4 contain two distinct carbon isotopic signals: 1) the composition of the detrital muds from the mud flat, and 2) the compostion of the paleosol organic matter. Plotted together they show a complex back and forth pattern that appears to have little clear paleoenvironmental significance. But if the two signals are separated, a clear trend emerges. The upper panel of Figure F-5 plots the stable carbon isotopic ratio for soil organic matter in the top of the buried A horizons within the north and the south dunes. This plot uses the $\mathrm{d}^{13} \mathrm{C}$ values obtained by the University of Georgia lab, and not the values obtained by Beta Analytic for the radiocarbon ages. In the upper panel only soils for which radiocarbon ages are available have been used, with the exception of the uppermost soil which was assumed to be modern. It is clear that although the two records are relatively similar and depict similar trends, there are some differences in the soil carbon isotopic values at any one point in time. But the trend in both dunes is the same, namely a progressive shift towards a more arid adapted, C4 vegetation from 4000 to 1000 years B.P., and then a subtle shift back towards a slightly more $\mathrm{C} 3$ dominated mix in the recent period.

The lower panel of Figure F-5 plots show how the North dune record changes if all of the topsoil $\mathrm{d}^{13} \mathrm{C}$ values are plotted. This plot should be viewed with caution given that ages had to be assumed for soils for which radiocarbon ages are not available. The trend on this figure is essentially the same as the top panel with two notable exceptions. First, the anomalous value depositional unit 7, sometime after 2000 years B.P. The second is that the $\mathrm{d}^{13} \mathrm{C}$ maximum value is actually found in the soil of depositional unit 10, which dates sometime after 1060 years B.P.

From these plots it is apparent that the stable carbon isotopic record preserved by the buried soils within the clay dunes appears to preserve a record of gradually shifting vegetation conditions which are responding to climatic variation. The fortuitious preservation of numerous thin, short-term soils in the north dune appears to afford a reasonably well-resolved record of changing vegetation that, if were all radiocarbon dated may be useful in further understanding late Holocene climatic variation in this region.

\section{Conclusions}

The fundamental hypothesis tested by this study was that the lithological record of coastal clay dunes may be used as 

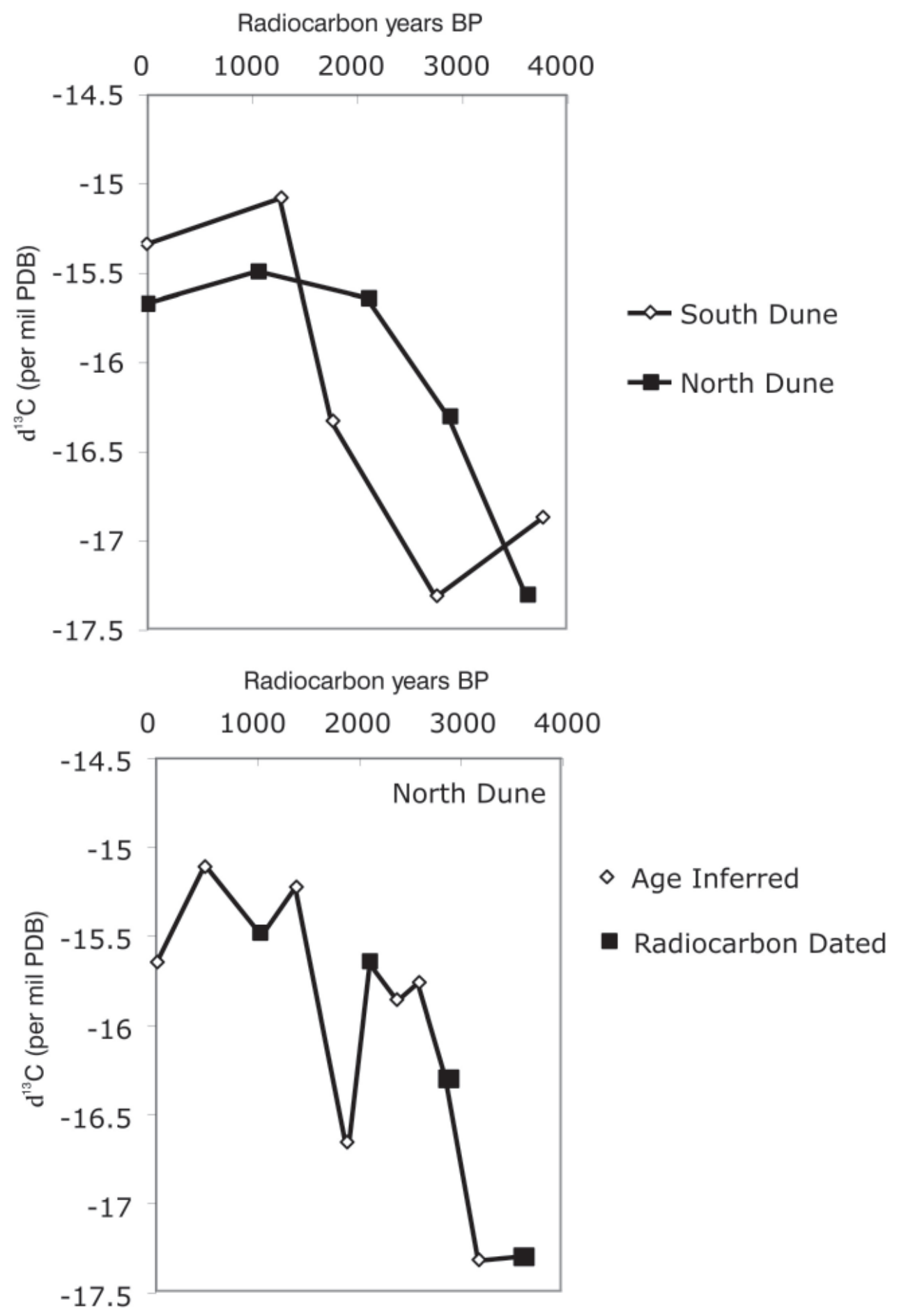

Figure F-5. Upper panel. Plot of $\delta 13 C$ for radiocarbon dated soils in the north dune and the south dune at 41NU2. The most recent values were both the uppermost soil in the clay dune sequence and were not radiocarbon dated but assumed to reflect modern values. Lowe panel: Plot of the $\delta 13 C$ for all of the soils in the North Dune profile with inferred ages used to plot the soils for which radiocarbon ages are not available. 
a climatic proxy. Detailed study of the lithological record of two dunes at the Cayo del Oso Site which have formed from a single mudflat on the western side of the Blind Oso, reveals that this hypothesis must be rejected. This work suggests that the lithological record of coastal clay dunes is intimately tied to the immediately adjacent wind-tidal flay and that even adjacent dunes may have significantly different sedimentary records which are largely driven by local factors other than climate. Microfossils which may provide details of the local sediment source returned variable results, with diatoms rarely preserved, and calcareous microfossils such as ostracodes and foraminifera best preserved in soil $\mathrm{C}$ horizons. Paleosol A horizons were typically leached of calcium carbonate and rarely preserved significant numbers of calcareous microfossils.

The most climatically sensitive record present within these deposits is the record of stable carbon isotopic composition of the paleosol organic matter. The soil carbon isotopic records obtained from the two dunes chart similar trajectories throughout the last 4,000 years, and appear to provide a fairly sensitive (yet basic) record of local vegetation change on the dunes.

\section{References}

American Society for Testing Materials (ASTM)

1985 Standard test method for particle size analysis of soils. D-422-63 (1972). 1985 Annual Book of ASTM Standards 04.08:117-127. American Society for Testing Materials, Philadelphia.

Bouyoucos, G.J.

1962 Hydrometer method improved for making particle size analyses of soils. Agronomy Journal 54:464-465.

Bowler, J.M.

1973 Clay Dunes: Their occurrence, formation and environmental significance. Earth-Science Reviews 9(4):315-338.

Bowler, J.M.

1983 Lunettes as indices of hydrologic change: A review of Australian evidence. Proceedings of the Royal Society of Victoria 95:147-168.

Dreimani, A.

1962 Quantitative gasometric determination of calcite and dolomite by using a Chittick apparatus. Journal of Sedimentary Petrography 32(3):520-529.

Frederick, C.D.

1998 Late Quaternary Clay Dune Sedimentation on the Llano Estacado, Texas. Plains Anthropologist 43:137-155.

Gale, S.J., and P.G. Hoare

1991 Quaternary Sediments: Petrographic Methods for the Study of Unlithified Rocks. London: Belhaven Press.

Gee, G.W., and J.W. Bauder

1986 Particle Size Analysis. In Methods of Soil Analysis, Part 1. Physical and Mineralogical Methods. Agronomy Monograph No. 9 (2nd Edition), edited by Arnold Klute, pp. 383-412. American Society of Agronomy - Soil Science Society of America, Madison, Wisconsin.

Holliday, V.T., 1997 Origin and Evolution of Lunettes on the High Plains of Texas and New Mexico. Quaternary Research 47: 54-69. 
Huffman, G.G. and W.A. Price.

1949 Clay dune formation near Corpus Christi, Texas. Journal of Sedimentary Petrology 19: 118-127

Machette, M.

1986 Calcium and Magnesium Carbonates. In Field and Laboratory Procedures Used in Soil Chronosequence Studies, edited by Michael J. Singer and Peter Janitzky, pp. 30-33. U.S. Geological Survey Bulletin 1648, United States Government Printing Office, Washington D.C.

Morton, R.A., and J.G. Paine,

1984 Historical shoreline changes in Corpus Christi, Oso, and Nueces bays, Texas Gulf Coast. Texas Bureau of Economic Geology Geological Circular No. 84-6, 66 p.

Palacios-Fest, M.R.

2008 Late Holocene Paleoenvironmental History of Cayo del Oso Bay, Nueces County, Texas: Geoarchaeological Implications. This volume.

Price, W.A.

1958 Sedimentology and quaternary geomorphology of South Texas. Transactions of the Gulf Coast Association of Geological Societies 8: 41-75.

1963 Physicochemical and environmental factors in clay dune genesis. Journal of Sedimentary Petrology 33: 766-778

Price, W. A., and L.S. Kornicker

1961 Marine and lagoonal deposits in clay dunes, Gulf Coast, Texas. Journal of Sedimentary Petrology 31: 245-255.

Ricklis, R.A.

1993 A Model of Holocene environmental and Human Adaptive Change on the Central Texas Coast: Geoarchaeological Investigations at White's Point, Nueces Bay, and Surrounding Area. Coastal Archaeological Studies, Inc., Corpus Christi, Texas.

1997 Archaeological Testing at the Callo del Oso Site, 41NU2, Nueces County, Texas. Coastal Archaeological Research, Inc., Corpus Christi, Texas.

Schulte, E.E., and B.G. Hopkins.

1996 Estimation of soil organic matter by weight by weight Loss-On-Ignition. p. 21-32. In: Soil Organic matter: Analysis and Interpretation. (ed.) F.R. Magdoff, M.A. Tabatabai and E.A.Hanlon, Jr. Special publication No. 46. Soil Sci. Soc. Amer. Madison, WI.

Shideler, G.L.

1986 Stratigraphic studies of a Late Quaternary Coastal Complex, South Texas - Introduction and Geological Framework. Part A of Stratigraphic Studies of a Late Quaternary Barrier-Type Coastal Complex, Mustang Island -Corpus Christi Bay Area, South Texas Gulf Coast, edited by Gerald L. Shidler, pp. 1-8. U. S. Geological Survey Professional Paper 1328. United States Government Printing Office, Washington D. C.

U. S. Geological Survey

1925 Oso Creek, Texas Topographic Quadrangle Map, 1:62,500 scale, surveyed in 1922. The University of Texas, Bureau of Economic Geology and Technology. 
Williams, D.D., and N.C. Kraus

1998 Nearshore Morphology and Sediment Characteritics Along Ward Island, Corpus Christi, Texas. Gulf Coast Association of Geological Societies Transactions XLVIII: 499-509.

Winsborough, B.

2008 Diatom Paleoenvironmental Analysis of Core Sediments from Cayo del Oso Site, 41NU2, Nueces County, Texas. This volume.

Withers, K., and B.R. Chapman

1993 Seasonal abundance and habitat use of shorebirds on an Oso Bay mudflat, Corpus Christi, Texas. Journal of Field Ornithology 64(3):382-392. 

APPENDIX G:

Radiocarbon Results

Darden Hood 
FROM: Darden Hood, Director (mailto: mailto:dhood@radiocarbon.com)

\section{(This is a copy of the letter being mailed. Invoices/receipts follow only by mail.)}

November 13, 2007

Dr. James Abbott

Texas Department of Transportation

Cultural Resource Management

Environmental Affairs Division

125 East 11th Street

Austin, TX 78701

RE: Radiocarbon Dating Results For Samples 41NU2-067, 41NU2-069, 41NU2-071, 41NU2-072, 41 NU2-153, 41 NU2-156, 41 NU2-157, 41 NU2-158, 41 NU2-259, 41 NU2-260, 41 NU2-261, 41NU2-262, 41 NU2-371, 41 NU2-373, 41 NU2-375, 41NU2-376, 41NU2-377, 41NU2-380, 41NU2-381, 41NU2-382, $41 N U 2-384,41$ NU2-387, 41 NU2-388, 41NU2-389, 41NU2-391, 41NU2-393, 41NU2-396, 41NU2-397, $41 N U 2-398,41 N U 2-399,41 N U 2-400,41 N U 2-403,41 N U 2-405,41 N U 2-412$, 41 NU2-415, 41NU2-416, 41NU2-417, 41NU2-418, 41 NU2-419, 41NU2-420, 41NU2-422, 41NU2-423, 41NU2-424, 41NU2-425, 41NU2-426, 41NU2-427, 41NU2-428, 41NU2-429, 41NU2-430, 41NU2-431, 41NU2-432, 41NU2-433, 41NU2-434, 41NU2-436, 41NU2-437, 41NU2-438, 41NU2-439, 41NU2-440

Dear Jim:

Enclosed are the radiocarbon dating results for 58 samples recently sent to us. They each provided plenty of carbon for accurate measurements and all the analyses proceeded normally. As usual, the method of analysis is listed on the report with the results and calibration data is provided where applicable.

As always, no students or intern researchers who would necessarily be distracted with other obligations and priorities were used in the analyses. We analyzed them with the combined attention of our entire professional staff.

If you have specific questions about the analyses, please contact us. We are always available to answer your questions.

Our invoice is enclosed. Please, forward it to the appropriate officer or send VISA charge authorization. Thank you. As always, if you have any questions or would like to discuss the results, don't hesitate to contact me.

Sincerely,

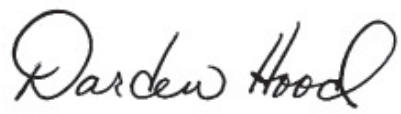


Dr. James Abbott

Texas Department of Transportation
Report Date: 11/13/2007

Material Received: 10/11/2007

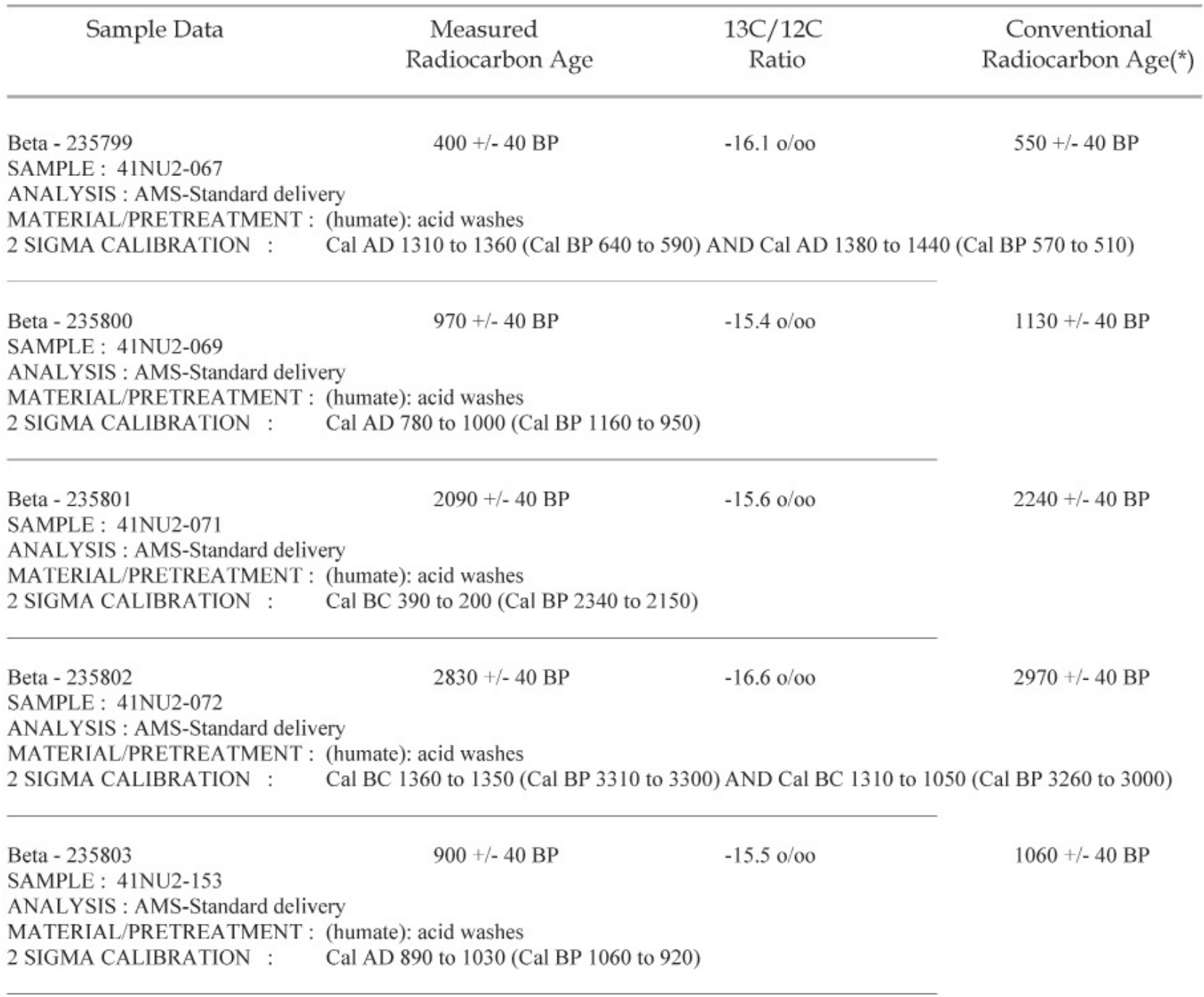




\begin{tabular}{|c|c|c|c|}
\hline Sample Data & $\begin{array}{c}\text { Measured } \\
\text { Radiocarbon Age }\end{array}$ & $\begin{array}{c}13 \mathrm{C} / 12 \mathrm{C} \\
\text { Ratio }\end{array}$ & $\begin{array}{c}\text { Conventional } \\
\text { Radiocarbon Age( }\left(^{*}\right)\end{array}$ \\
\hline $\begin{array}{l}\text { Beta - } 235804 \\
\text { SAMPLE : } 41 \text { NU2-156 } \\
\text { ANALYSIS : AMS-Standard d } \\
\text { MATERIAL/PRETREATMEN } \\
2 \text { SIGMA CALIBRATION : }\end{array}$ & $\begin{array}{l}2030+/-40 \mathrm{BP} \\
\text { : acid washes } \\
340 \text { to } 320(\mathrm{Cal} \mathrm{BP} 22\end{array}$ & $\begin{array}{l}-20.2 \mathrm{o} / \mathrm{oo} \\
\mathrm{AND} \mathrm{Cal} \mathrm{BC} 2\end{array}$ & P 2160 to 1990$)$ \\
\hline $\begin{array}{l}\text { Beta - } 235805 \\
\text { SAMPLE : } 41 \text { NU2-157 } \\
\text { ANALYSIS : AMS-Standard d } \\
\text { MATERIAL/PRETREATMEN } \\
2 \text { SIGMA CALIBRATION : }\end{array}$ & $\begin{array}{l}2710+/-40 \mathrm{BP} \\
1200 \text { to } 930 \text { (Cal BP } 3\end{array}$ & $-14.8 \mathrm{o} / \mathrm{oo}$ & $2880+/-40 \mathrm{BP}$ \\
\hline $\begin{array}{l}\text { Beta - } 235806 \\
\text { SAMPLE : } 41 \text { NU2-158 } \\
\text { ANALYSIS : AMS-Standard d } \\
\text { MATERIAL/PRETREATMEN } \\
2 \text { SIGMA CALIBRATION : }\end{array}$ & $\begin{array}{l}\quad 3470+/-40 \mathrm{BP} \\
: \text { acid washes } \\
130 \text { to } 2090(\mathrm{Cal} \mathrm{BP}\end{array}$ & $\begin{array}{l}-16.0 \mathrm{o} / \mathrm{oo} \\
\text { AND Cal BC }\end{array}$ & $\begin{array}{l}3620+/-40 \mathrm{BP} \\
\text { (Cal BP } 4000 \text { to } 3840)\end{array}$ \\
\hline $\begin{array}{l}\text { Beta - } 235807 \\
\text { SAMPLE : } 41 \text { NU2-259 } \\
\text { ANALYSIS : AMS-Standard d } \\
\text { MATERIAL/PRETREATMEN } \\
2 \text { SIGMA CALIBRATION : }\end{array}$ & $\begin{array}{l}1140+/-40 \mathrm{BP} \\
\text { : acid washes } \\
660 \text { to } 810(\mathrm{Cal} \mathrm{BP} 12\end{array}$ & $-16.2 \mathrm{o} / \mathrm{oo}$ & $1280+/-40 \mathrm{BP}$ \\
\hline $\begin{array}{l}\text { Beta - } 235808 \\
\text { SAMPLE : 41NU2-260 } \\
\text { ANALYSIS : AMS-Standard d } \\
\text { MATERIAL/PRETREATMEN } \\
2 \text { SIGMA CALIBRATION : }\end{array}$ & $\begin{array}{l}1650+/-40 \mathrm{BP} \\
\text { : acid washes } \\
140 \text { to } 380 \text { (Cal BP } 18\end{array}$ & $-17.5 \mathrm{o} / \mathrm{oo}$ & $1770+/-40 \mathrm{BP}$ \\
\hline
\end{tabular}




\begin{tabular}{|c|c|c|c|}
\hline Sample Data & $\begin{array}{c}\text { Measured } \\
\text { Radiocarbon Age }\end{array}$ & $\begin{array}{c}13 \mathrm{C} / 12 \mathrm{C} \\
\text { Ratio }\end{array}$ & $\begin{array}{c}\text { Conventional } \\
\left.\text { Radiocarbon Age( }{ }^{*}\right)\end{array}$ \\
\hline $\begin{array}{l}\text { Beta - } 235809 \\
\text { SAMPLE : } 41 \text { NU2-261 } \\
\text { ANALYSIS : AMS-Standard d } \\
\text { MATERIAL/PRETREATMEN } \\
2 \text { SIGMA CALIBRATION : }\end{array}$ & $\begin{array}{l}2690+/-40 \mathrm{BP} \\
\text { ): acid washes } \\
1000 \text { to } 820(\mathrm{Cal} \mathrm{BP} 2\end{array}$ & $-20.8 \mathrm{o} / \mathrm{oo}$ & $2760+/-40 \mathrm{BP}$ \\
\hline $\begin{array}{l}\text { Beta - } 235810 \\
\text { SAMPLE : } 41 \text { NU2-262 } \\
\text { ANALYSIS : AMS-Standard d } \\
\text { MATERIAL/PRETREATMEN } \\
2 \text { SIGMA CALIBRATION : }\end{array}$ & $\begin{array}{l}3650+/-40 \mathrm{BP} \\
\text { acid washes } \\
2300 \text { to } 2120(\mathrm{Cal} \mathrm{BP}\end{array}$ & $\begin{array}{l}-17.7 \mathrm{o} / \mathrm{oo} \\
\mathrm{AND} \mathrm{Cal} \mathrm{BC}\end{array}$ & $\begin{array}{c}3770+/-40 \text { BP } \\
\text { (Cal BP } 4040 \text { to } 3990 \text { ) }\end{array}$ \\
\hline $\begin{array}{l}\text { Beta - 235811 } \\
\text { SAMPLE : 41NU2-371 } \\
\text { ANALYSIS : AMS-Standard d } \\
\text { MATERIAL/PRETREATMEN } \\
2 \text { SIGMA CALIBRATION : }\end{array}$ & $\begin{array}{l}1130+/-40 \mathrm{BP} \\
\text { material): acid/alkali/s } \\
780 \text { to } 990 \text { (Cal BP } 11\end{array}$ & $-24.1 \mathrm{o} / \mathrm{oo}$ & $1140+/-40 \mathrm{BP}$ \\
\hline $\begin{array}{l}\text { Beta - } 235812 \\
\text { SAMPLE : 41NU2-373 } \\
\text { ANALYSIS : AMS-Standard d } \\
\text { MATERIAL/PRETREATMEN } \\
2 \text { SIGMA CALIBRATION : }\end{array}$ & $\begin{array}{l}2290+/-40 \text { BP } \\
\text { sediment): acid washe } \\
10 \text { to } 360 \text { (Cal BP } 23 \text { ( }\end{array}$ & $\begin{array}{l}-23.5 \mathrm{o} / \mathrm{oo} \\
\mathrm{AND} \mathrm{Cal} \mathrm{BC2}\end{array}$ & BP 2230 to 2200 ) \\
\hline $\begin{array}{l}\text { Beta - } 235813 \\
\text { SAMPLE : 41NU2-375 } \\
\text { ANALYSIS : AMS-Standard d } \\
\text { MATERIAL/PRETREATMEN } \\
2 \text { SIGMA CALIBRATION : }\end{array}$ & $\begin{array}{l}1290+/-40 \text { BP } \\
\text { sediment): acid washe } \\
650 \text { to } 770 \text { (Cal BP } 13\end{array}$ & $-23.0 \mathrm{o} / \mathrm{oo}$ & $1320+/-40 \mathrm{BP}$ \\
\hline
\end{tabular}




\begin{tabular}{|c|c|c|c|}
\hline Sample Data & $\begin{array}{c}\text { Measured } \\
\text { Radiocarbon Age }\end{array}$ & $\begin{array}{c}13 \mathrm{C} / 12 \mathrm{C} \\
\text { Ratio }\end{array}$ & $\begin{array}{c}\text { Conventional } \\
\text { Radiocarbon Age }(*)\end{array}$ \\
\hline $\begin{array}{l}\text { Beta - } 235814 \\
\text { SAMPLE : } 41 \text { NU2-376 } \\
\text { ANALYSIS : AMS-Standard d } \\
\text { MATERIAL/PRETREATMEN } \\
2 \text { SIGMA CALIBRATION : }\end{array}$ & $\begin{array}{l}1760+/-40 \mathrm{BP} \\
\text { sediment): acid washe } \\
10 \text { to } 210 \text { (Cal BP } 194 \text { ( }\end{array}$ & $-16.0 \mathrm{o} / \mathrm{oo}$ & $1910+/-40 \mathrm{BP}$ \\
\hline $\begin{array}{l}\text { Beta - } 235815 \\
\text { SAMPLE : } 41 \text { NU2-377 } \\
\text { ANALYSIS : AMS-Standard d } \\
\text { MATERIAL/PRETREATMEN } \\
2 \text { SIGMA CALIBRATION : }\end{array}$ & $\begin{array}{l}1670+/-40 \text { BP } \\
\text { sediment): acid washe } \\
130 \text { to } 350 \text { (Cal BP } 18\end{array}$ & $-18.4 \mathrm{o} / \mathrm{oo}$ & $1780+/-40 \mathrm{BP}$ \\
\hline $\begin{array}{l}\text { Beta - } 235816 \\
\text { SAMPLE : } 41 \text { NU2-380 } \\
\text { ANALYSIS : AMS-Standard d } \\
\text { MATERIAL/PRETREATMEN } \\
\text { 2 SIGMA CALIBRATION : }\end{array}$ & $\begin{array}{l}1990+/-40 \mathrm{BP} \\
100 \text { to } \mathrm{Cal} \text { AD } 70(\mathrm{Cal}\end{array}$ & $\begin{array}{l}-23.6 \mathrm{o} / \mathrm{oo} \\
1880)\end{array}$ & $2010+/-40 \mathrm{BP}$ \\
\hline $\begin{array}{l}\text { Beta - } 235817 \\
\text { SAMPLE : } 41 \text { NU2-381 } \\
\text { ANALYSIS : AMS-Standard d } \\
\text { MATERIAL/PRETREATMEN } \\
2 \text { SIGMA CALIBRATION : }\end{array}$ & $\begin{array}{l}1780+/-40 \mathrm{BP} \\
\text { sediment): acid washe } \\
80 \text { to } 250 \text { (Cal BP } 187\end{array}$ & $-21.3 \mathrm{o} / \mathrm{oo}$ & $1840+/-40 \mathrm{BP}$ \\
\hline $\begin{array}{l}\text { Beta - } 235818 \\
\text { SAMPLE : } 41 \text { NU2-382 } \\
\text { ANALYSIS : AMS-Standard d } \\
\text { MATERIAL/PRETREATMEN } \\
2 \text { SIGMA CALIBRATION : }\end{array}$ & $\begin{array}{l}1230+/-40 \text { BP } \\
\text { sediment): acid washe } \\
660 \text { to } 780 \text { (Cal BP } 12\end{array}$ & $-21.1 \mathrm{o} / \mathrm{oo}$ & $1290+/-40 \mathrm{BP}$ \\
\hline
\end{tabular}




\begin{tabular}{|c|c|c|c|}
\hline Sample Data & $\begin{array}{l}\text { Measured } \\
\text { Radiocarbon Age }\end{array}$ & $\begin{array}{c}13 \mathrm{C} / 12 \mathrm{C} \\
\text { Ratio }\end{array}$ & $\begin{array}{c}\text { Conventional } \\
\text { Radiocarbon } \operatorname{Age}\left(^{*}\right)\end{array}$ \\
\hline $\begin{array}{l}\text { Beta - } 235820 \\
\text { SAMPLE : } 41 \text { NU2-384 } \\
\text { ANALYSIS : AMS-Standard d } \\
\text { MATERIAL/PRETREATMEN } \\
2 \text { SIGMA CALIBRATION : }\end{array}$ & $\begin{array}{l}\quad 2780+/-50 \text { BP } \\
\text { sediment): acid washe: } \\
1120 \text { to } 890 \text { (Cal BP } 30\end{array}$ & $\begin{array}{l}-22.1 \mathrm{o} / \mathrm{oo} \\
\text { AND Cal BC }\end{array}$ & $\begin{array}{l}2830+/-50 \mathrm{BP} \\
1 \mathrm{BP} 2820 \text { to } 2800 \text { ) }\end{array}$ \\
\hline $\begin{array}{l}\text { Beta - } 235821 \\
\text { SAMPLE : } 4 \text { INU2-387 } \\
\text { ANALYSIS : AMS-Standard d } \\
\text { MATERIAL/PRETREATMEN } \\
2 \text { SIGMA CALIBRATION : }\end{array}$ & $\begin{array}{l}2520+/-40 \text { BP } \\
790 \text { to } 510(\mathrm{Cal} \text { BP } 274\end{array}$ & $-25.8 \mathrm{o} / \mathrm{oo}$ & $2510+/-40 \mathrm{BP}$ \\
\hline $\begin{array}{l}\text { Beta - } 235822 \\
\text { SAMPLE : 41NU2-388 } \\
\text { ANALYSIS : AMS-Standard d } \\
\text { MATERIAL/PRETREATMEN } \\
2 \text { SIGMA CALIBRATION : }\end{array}$ & $\begin{array}{l}1840+/-40 \mathrm{BP} \\
\text { sediment): acid washe } \\
20 \text { to } 220 \text { (Cal BP } 1930\end{array}$ & $-21.1 \mathrm{o} / \mathrm{oo}$ & $1900+/-40 \mathrm{BP}$ \\
\hline $\begin{array}{l}\text { Beta - } 235823 \\
\text { SAMPLE : 41NU2-389 } \\
\text { ANALYSIS : AMS-Standard d } \\
\text { MATERIAL/PRETREATMEN } \\
2 \text { SIGMA CALIBRATION : }\end{array}$ & $\begin{array}{l}1920+/-40 \mathrm{BP} \\
\text { material): acid/alkali/a } \\
30 \text { to } \mathrm{Cal} \mathrm{AD} 130(\mathrm{Cal}\end{array}$ & $-23.8 \mathrm{o} / \mathrm{oo}$ & $1940+/-40 \mathrm{BP}$ \\
\hline $\begin{array}{l}\text { Beta - } 235824 \\
\text { SAMPLE : 41NU2-391 } \\
\text { ANALYSIS : AMS-Standard d } \\
\text { MATERIAL/PRETREATMEN } \\
2 \text { SIGMA CALIBRATION : }\end{array}$ & $\begin{array}{l}2010+/-40 \text { BP } \\
\text { sediment): acid washe: } \\
50 \text { to } 300 \text { (Cal BP } 230\end{array}$ & $-18.0 \mathrm{o} / \mathrm{oo}$ & $2120+/-40 \mathrm{BP}$ \\
\hline
\end{tabular}




\begin{tabular}{|c|c|c|c|}
\hline Sample Data & $\begin{array}{c}\text { Measured } \\
\text { Radiocarbon Age }\end{array}$ & $\begin{array}{c}13 \mathrm{C} / 12 \mathrm{C} \\
\text { Ratio }\end{array}$ & $\begin{array}{c}\text { Conventional } \\
\text { Radiocarbon Age }\left(^{*}\right)\end{array}$ \\
\hline $\begin{array}{l}\text { Beta - } 235825 \\
\text { SAMPLE : } 41 \text { NU2-393 } \\
\text { ANALYSIS : AMS-Standard d } \\
\text { MATERIAL/PRETREATMEN } \\
2 \text { SIGMA CALIBRATION : }\end{array}$ & $\begin{array}{l}1360+/-40 \text { BP } \\
\text { sediment): acid washe } \\
540 \text { to } 650 \text { (Cal BP } 14\end{array}$ & $-18.3 \mathrm{o} / \mathrm{oo}$ & $1470+/-40 \mathrm{BP}$ \\
\hline $\begin{array}{l}\text { Beta - } 235826 \\
\text { SAMPLE : } 41 \text { INU2-396 } \\
\text { ANALYSIS : AMS-Standard d } \\
\text { MATERIAL/PRETREATMEN } \\
2 \text { SIGMA CALIBRATION : }\end{array}$ & $\begin{array}{l}3280+/-40 \mathrm{BP} \\
\text { material): acid } / \text { alkali/s } \\
1680 \text { to } 1500(\mathrm{Cal} \mathrm{BP} \text { ? }\end{array}$ & $-23.7 \mathrm{o} / \mathrm{oo}$ & $3300+/-40 \mathrm{BP}$ \\
\hline $\begin{array}{l}\text { Beta - } 235827 \\
\text { SAMPLE : 41NU2-397 } \\
\text { ANALYSIS : AMS-Standard d } \\
\text { MATERIAL/PRETREATMEN } \\
\text { 2 SIGMA CALIBRATION : }\end{array}$ & $\begin{array}{l}2510+/-40 \mathrm{BP} \\
\text { sediment): acid washe } \\
820 \text { to } 760 \text { (Cal BP } 27\end{array}$ & $-19.1 \mathrm{o} / \mathrm{oo}$ & $2610+/-40 \mathrm{BP}$ \\
\hline $\begin{array}{l}\text { Beta - } 235828 \\
\text { SAMPLE : 41NU2-398 } \\
\text { ANALYSIS : AMS-Standard d } \\
\text { MATERIAL/PRETREATMEN } \\
\text { 2 SIGMA CALIBRATION : }\end{array}$ & $\begin{array}{l}2440+/-40 \mathrm{BP} \\
780 \text { to } 410(\mathrm{Cal} \mathrm{BP} 27\end{array}$ & $-23.3 \mathrm{o} / \mathrm{oo}$ & $2470+/-40 \mathrm{BP}$ \\
\hline $\begin{array}{l}\text { Beta - } 235829 \\
\text { SAMPLE : } 41 \text { NU2-399 } \\
\text { ANALYSIS : AMS-Standard d } \\
\text { MATERIAL/PRETREATMEN } \\
2 \text { SIGMA CALIBRATION : }\end{array}$ & $\begin{array}{l}2190+/-40 \mathrm{BP} \\
\text { material): acid/alkali/s } \\
370 \text { to } 150 \text { (Cal BP } 232\end{array}$ & $\mathrm{ND} C \mathrm{Cal} \mathrm{BC}$ & BP 2090 to 2060 ) \\
\hline
\end{tabular}




\begin{tabular}{|c|c|c|c|}
\hline Sample Data & $\begin{array}{l}\text { Measured } \\
\text { Radiocarbon Age }\end{array}$ & $\begin{array}{c}13 \mathrm{C} / 12 \mathrm{C} \\
\text { Ratio }\end{array}$ & $\begin{array}{c}\text { Conventional } \\
\text { Radiocarbon Age }\left(^{*}\right)\end{array}$ \\
\hline $\begin{array}{l}\text { Beta - } 235830 \\
\text { SAMPLE : } 41 \text { NU2-400 } \\
\text { ANALYSIS : AMS-Standard d } \\
\text { MATERIAL/PRETREATMEN } \\
2 \text { SIGMA CALIBRATION : }\end{array}$ & $\begin{array}{l}1120+/-40 \mathrm{BP} \\
780 \text { to } 990 \text { (Cal BP } 11\end{array}$ & $-23.9 \mathrm{o} / \mathrm{oo}$ & $1140+/-40 \mathrm{BP}$ \\
\hline $\begin{array}{l}\text { Beta - } 235831 \\
\text { SAMPLE : } 41 \text { INU2-403 } \\
\text { ANALYSIS : AMS-Standard d } \\
\text { MATERIAL/PRETREATMEN } \\
2 \text { SIGMA CALIBRATION : }\end{array}$ & $\begin{array}{l}2040+/-40 \text { BP } \\
\text { c sediment): acid washe } \\
360 \text { to } 290 \text { (Cal BP } 230\end{array}$ & $\begin{array}{l}-18.8 \mathrm{o} / \mathrm{oo} \\
\text { AND Cal BC } 2\end{array}$ & $\begin{array}{l}2140+/-40 \mathrm{BP} \\
3 \mathrm{P} 2180 \text { to } 2000)\end{array}$ \\
\hline $\begin{array}{l}\text { Beta - } 235832 \\
\text { SAMPLE : } 41 \text { NU2-405 } \\
\text { ANALYSIS : AMS-Standard d } \\
\text { MATERIAL/PRETREATMEN } \\
2 \text { SIGMA CALIBRATION : }\end{array}$ & $\begin{array}{l}2280+/-40 \mathrm{BP} \\
\text { c sediment): acid washe } \\
530 \text { to } 390 \text { (Cal BP } 248\end{array}$ & $-19.3 \mathrm{o} / 00$ & $2370+/-40 \mathrm{BP}$ \\
\hline $\begin{array}{l}\text { Beta - } 235833 \\
\text { SAMPLE : } 41 \text { NU2-412 } \\
\text { ANALYSIS : AMS-Standard } \\
\text { MATERIAL/PRETREATMEN } \\
2 \text { SIGMA CALIBRATION : }\end{array}$ & $\begin{array}{l}2020+/-40 \mathrm{BP} \\
180 \text { to } \mathrm{Cal} \mathrm{AD} 20(\mathrm{Cal}\end{array}$ & $-22.6 \mathrm{o} / 00$ & $2060+/-40 \mathrm{BP}$ \\
\hline $\begin{array}{l}\text { Beta - } 235834 \\
\text { SAMPLE : } 41 \text { NU2-415 } \\
\text { ANALYSIS : AMS-Standard } \\
\text { MATERIAL/PRETREATMEN } \\
2 \text { SIGMA CALIBRATION : }\end{array}$ & $\begin{array}{l}2440+/-50 \mathrm{BP} \\
780 \text { to } 400 \text { (Cal BP } 273\end{array}$ & $-24.1 \mathrm{o} / \mathrm{oo}$ & $2450+/-50 \mathrm{BP}$ \\
\hline
\end{tabular}




\begin{tabular}{|c|c|c|c|}
\hline Sample Data & $\begin{array}{c}\text { Measured } \\
\text { Radiocarbon Age }\end{array}$ & $\begin{array}{c}13 \mathrm{C} / 12 \mathrm{C} \\
\text { Ratio }\end{array}$ & $\begin{array}{c}\text { Conventional } \\
\text { Radiocarbon Age }(*)\end{array}$ \\
\hline $\begin{array}{l}\text { Beta - } 235835 \\
\text { SAMPLE : 41NU2-416 } \\
\text { ANALYSIS : AMS-Standard c } \\
\text { MATERIAL/PRETREATMEN } \\
\text { 2 SIGMA CALIBRATION : }\end{array}$ & $\begin{array}{l}2420+/-40 \mathrm{BP} \\
760 \text { to } 400 \text { (Cal BP } 27\end{array}$ & $-23.9 \mathrm{o} / \mathrm{oo}$ & $2440+/-40 \mathrm{BP}$ \\
\hline $\begin{array}{l}\text { Beta - } 235836 \\
\text { SAMPLE : } 41 \text { INU2-417 } \\
\text { ANALYSIS : AMS-Standard } \\
\text { MATERIAL/PRETREATMEI } \\
2 \text { SIGMA CALIBRATION : }\end{array}$ & $\begin{array}{l}1360+/-40 \mathrm{BP} \\
\text { material): acid/alkali/s } \\
600 \text { to } 680 \text { (Cal BP } 13\end{array}$ & $-23.4 \mathrm{o} / \mathrm{oo}$ & $1390+/-40 \mathrm{BP}$ \\
\hline $\begin{array}{l}\text { Beta - } 235837 \\
\text { SAMPLE : 41NU2-418 } \\
\text { ANALYSIS : AMS-Standard } \\
\text { MATERIAL/PRETREATMEN } \\
\text { 2 SIGMA CALIBRATION : }\end{array}$ & $\begin{array}{l}3190+/-40 \mathrm{BP} \\
1520 \text { to } 1400 \text { (Cal BP }\end{array}$ & $-25.0 \mathrm{o} / \mathrm{oo}$ & $3190+/-40 \mathrm{BP}$ \\
\hline Beta - 235838 & $990+/-40 \mathrm{BP}$ & $\begin{array}{r}-0.4 \mathrm{o} / \mathrm{oo} \\
=-1.0 \mathrm{o} / \mathrm{oo}\end{array}$ & $1390+/-40 \mathrm{BP}$ \\
\hline $\begin{array}{l}\text { SAMPLE : 41NU2-419 } \\
\text { ANALYSIS : AMS-Standard } \\
\text { MATERIAL/PRETREATMEN } \\
2 \text { SIGMA CALIBRATION : }\end{array}$ & $\begin{array}{l}\text { acid etch } \\
940 \text { to } 1070(\mathrm{Cal} \text { BP I }\end{array}$ & & \\
\hline Beta - 235839 & $1690+/-40 \mathrm{BP}$ & $\begin{array}{l}-0.4 \mathrm{o} / \mathrm{oo} \\
+0.1 \mathrm{o} / \mathrm{oo}\end{array}$ & $2090+/-40 \mathrm{BP}$ \\
\hline
\end{tabular}

SAMPLE : 41 NU2-420

ANALYSIS : AMS-Standard delivery

MATERIAL/PRETREATMENT : (shell): acid etch

2 SIGMA CALIBRATION : $\quad$ Cal AD 180 to 390 (Cal BP 1770 to 1560 ) 


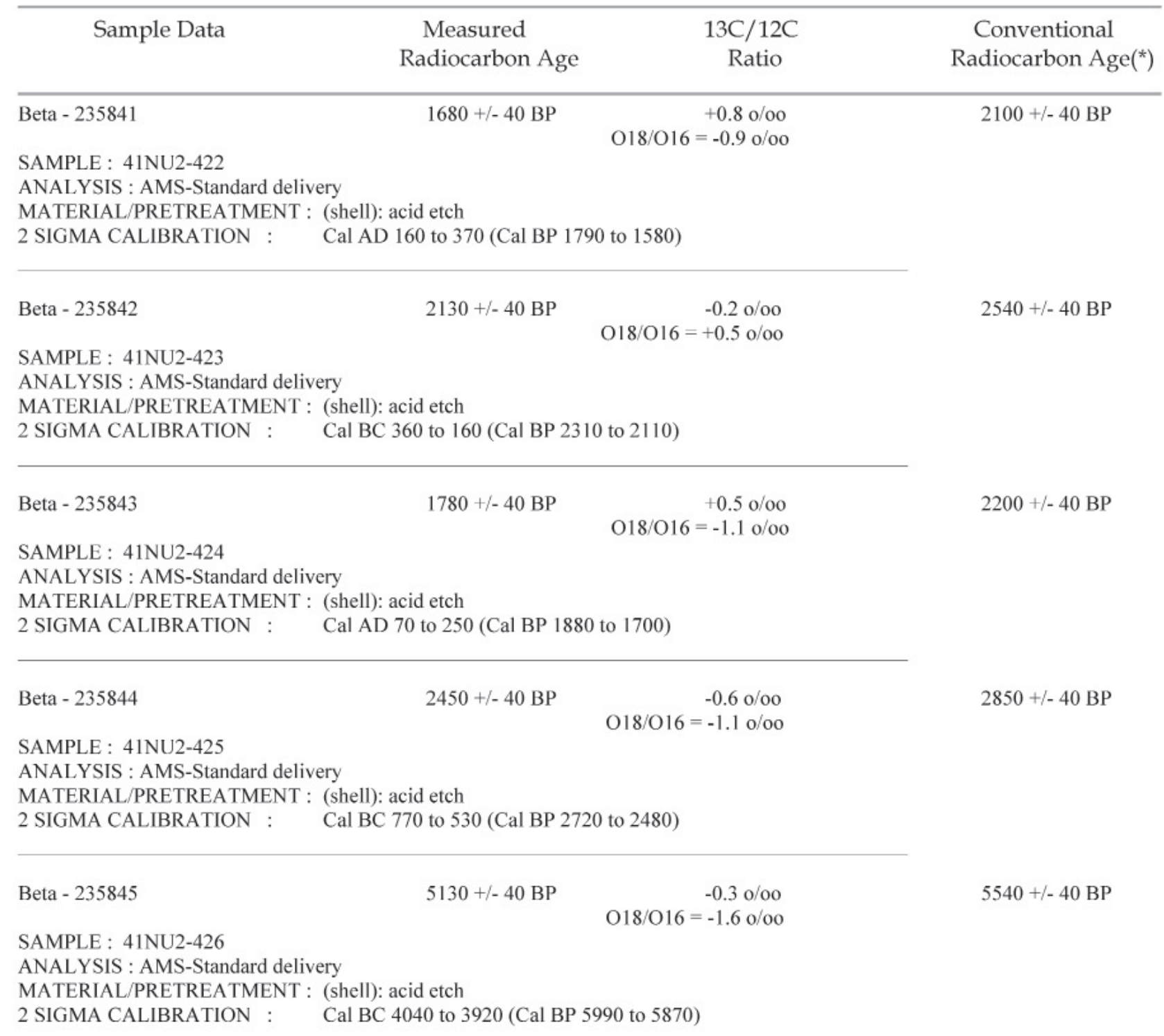




\begin{tabular}{lccc}
\hline Sample Data & $\begin{array}{c}\text { Measured } \\
\text { Radiocarbon Age }\end{array}$ & $\begin{array}{c}13 \mathrm{C} / 12 \mathrm{C} \\
\text { Ratio }\end{array}$ & $\begin{array}{c}\text { Conventional } \\
\text { Radiocarbon Age }\left(^{*}\right)\end{array}$ \\
\hline Beta -235846 & $1700+/-40 \mathrm{BP}$ & $+0.2 \mathrm{o} / \mathrm{oo}$ & $2110+/-40 \mathrm{BP}$ \\
& & O18/O16 $=-0.8 \mathrm{o} / \mathrm{oo}$ &
\end{tabular}

SAMPLE : 41NU2-427

ANALYSIS : AMS-Standard delivery

MATERIAL/PRETREATMENT : (shell): acid etch

2 SIGMA CALIBRATION : $\quad$ Cal AD 150 to 360 (Cal BP 1800 to 1590)

Beta - 235847

$2160+/-40 \mathrm{BP}$

$+1.0 \mathrm{o} / \mathrm{oo}$
$018 / 016=-0.2 \mathrm{o} / \mathrm{oo}$

$2590+/-40 \mathrm{BP}$

SAMPLE : 41 NU2-428

ANALYSIS : AMS-Standard delivery

MATERIAL/PRETREATMENT : (shell): acid etch

2 SIGMA CALIBRATION : $\quad$ Cal BC 390 to 200 (Cal BP 2340 to 2150)

Beta -235848

$2690+/-40 \mathrm{BP}$

$\mathrm{O} 18 / \mathrm{O} 16=\stackrel{-0.4 \mathrm{o} / \mathrm{oo}}{-1.0 \mathrm{o} / \mathrm{oo}}$

$3090+/-40$ BP

SAMPLE : 41NU2-429

ANALYSIS : AMS-Standard delivery

MATERIAL/PRETREATMENT : (shell): acid etch

2 SIGMA CALIBRATION : $\quad$ Cal BC 1000 to 810 (Cal BP 2950 to 2760)

Beta -235849

$1620+/-40 \mathrm{BP}$

$+0.1 \mathrm{o} / \mathrm{oo}$

$2030+/-40$ BP

SAMPLE : 41 NU2-430

ANALYSIS : AMS-Standard delivery

MATERIAL/PRETREATMENT : (shell): acid etch

2 SIGMA CALIBRATION : $\quad$ Cal AD 260 to 440 (Cal BP 1690 to 1510)

Beta -235850

$1850+/-40 \mathrm{BP}$

$+0.6 \mathrm{o} / \mathrm{oo}$
$018 / 016=-0.7 \mathrm{o} / \mathrm{oo}$

$2270+/-40$ BP

SAMPLE : 41NU2-431

ANALYSIS : AMS-Standard delivery

MATERIAL/PRETREATMENT : (shell): acid etch

2 SIGMA CALIBRATION : $\quad$ Cal BC 20 to Cal AD 150 (Cal BP 1970 to 1800) 


\begin{tabular}{lccc}
\hline Sample Data & $\begin{array}{c}\text { Measured } \\
\text { Radiocarbon Age }\end{array}$ & $\begin{array}{c}13 \mathrm{C} / 12 \mathrm{C} \\
\text { Ratio }\end{array}$ & $\begin{array}{c}\text { Conventional } \\
\text { Radiocarbon Age }\left(^{*}\right)\end{array}$ \\
\hline Beta -235851 & $1030+/-40 \mathrm{BP}$ & $\begin{array}{r}-0.5 \mathrm{o} / \mathrm{oo} \\
\text { O18/O16 }=-1.0 \mathrm{o} / \mathrm{oo}\end{array}$ & $1430+/-40 \mathrm{BP}$ \\
\hline
\end{tabular}

SAMPLE: 41NU2-432

ANALYSIS : Radiometric-Standard delivery

MATERIAL/PRETREATMENT : (shell): acid etch

2 SIGMA CALIBRATION : $\quad$ Cal AD 900 to 1040 (Cal BP 1050 to 900)

Beta -235852

$1910+/-40$ BP

$018 / 016=-0.8 \mathrm{o} / \mathrm{oo}$

$2310+/-40 \mathrm{BP}$

SAMPLE : 41NU2-433

ANALYSIS : AMS-Standard delivery

MATERIAL/PRETREATMENT : (shell): acid etch

2 SIGMA CALIBRATION : $\quad$ Cal BC 60 to Cal AD 120 (Cal BP 2010 to 1840)

Beta -235853

$2280+/-40 \mathrm{BP}$

$+0.1 \mathrm{o} / \mathrm{oo}$

$2700+/-50 \mathrm{BP}$

SAMPLE : 41NU2-434

ANALYSIS : Radiometric-Standard delivery

MATERIAL/PRETREATMENT : (shell): acid etch

2 SIGMA CALIBRATION : $\quad$ Cal BC 590 to 350 (Cal BP 2540 to 2300)

Beta -235855

$940+/-40$ BP

$+1.1 \mathrm{o} / 00$

$1370+/-40$ BP

SAMPLE : 41NU2-436

$018 / 016=-0.6 \mathrm{o} / \mathrm{oo}$

ANALYSIS : AMS-Standard delivery

MATERIAL/PRETREATMENT : (shell): acid etch

2 SIGMA CALIBRATION : $\quad$ Cal AD 970 to 1110 (Cal BP 980 to 840 )

Beta -235856

$1100+/-40 \mathrm{BP}$

$-0.3 \mathrm{o} / \mathrm{oo}$

$1510+/-40 \mathrm{BP}$

SAMPLE : 41NU2-437

$\mathrm{O} 18 / \mathrm{O} 16=0.0 \mathrm{o} / \mathrm{oo}$

ANALYSIS : AMS-Standard delivery

MATERIAL/PRETREATMENT : (shell): acid etch

2 SIGMA CALIBRATION : $\quad$ Cal AD 790 to 990 (Cal BP 1160 to 960) 


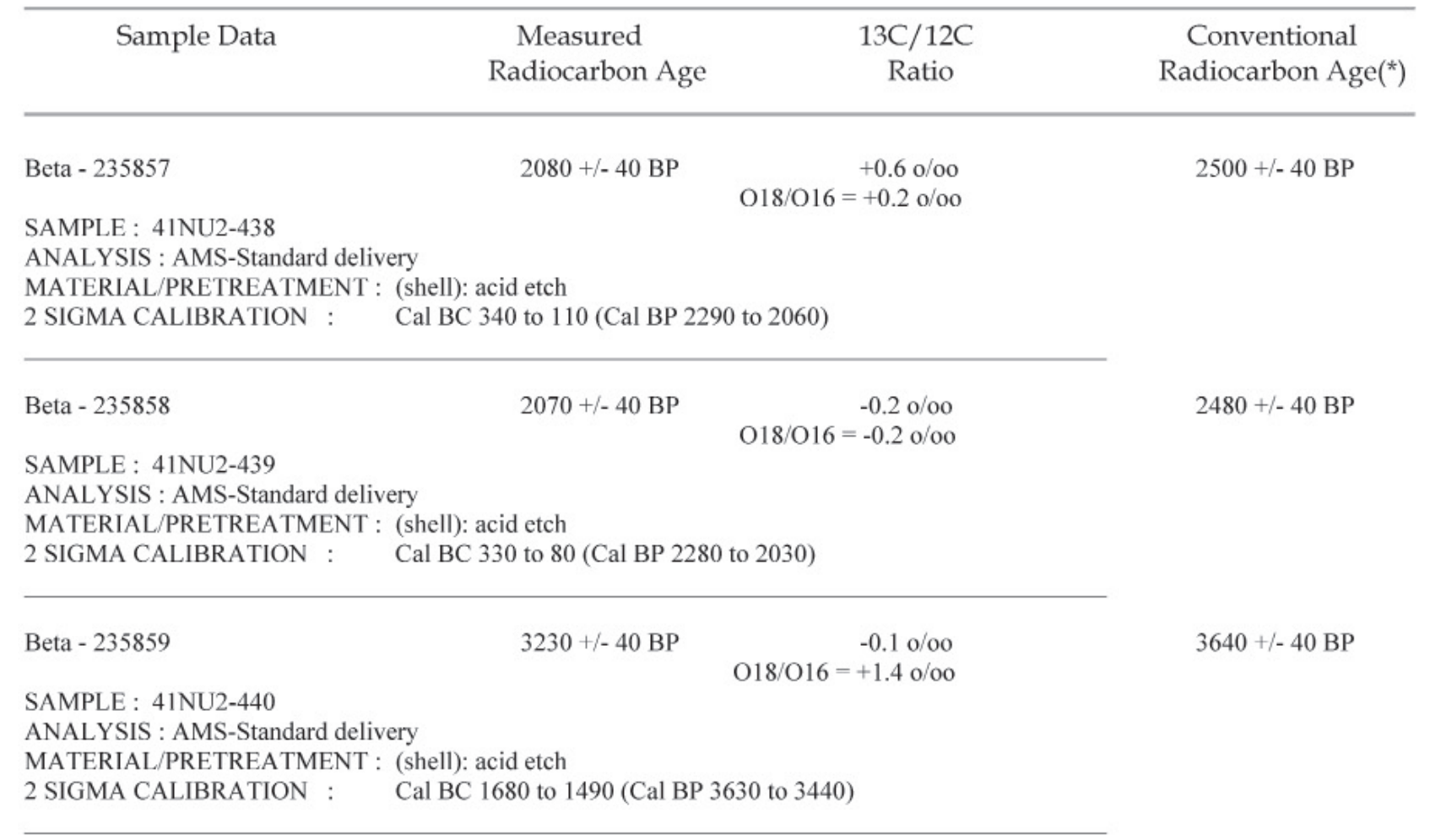




\section{CALIBRATION OF RADIOCARBON AGE TO CALENDAR YEARS}

(Variables: C13/C12=-16.1:lab. mult=1)

Laboratory number: Beta-235799

Conventional radiocarbon age: $\quad 550 \pm 40$ B P

2 Sigma calibrated results: Cal AD 1310 to 1360 (Cal BP 640 to 590) and

(95\% probability) Cal AD 1380 to 1440 (Cal BP 570 to 510$)$

Intercept data

Intercept of radiocarbon age

with calibration curve: Cal AD 1410 (Cal BP 540)

1 Sigma calibrated results: Cal AD 1330 to 1340 (Cal BP 620 to 610) and

(68\% probability) Cal AD 1400 to 1420 (Cal BP 560 to 530 )

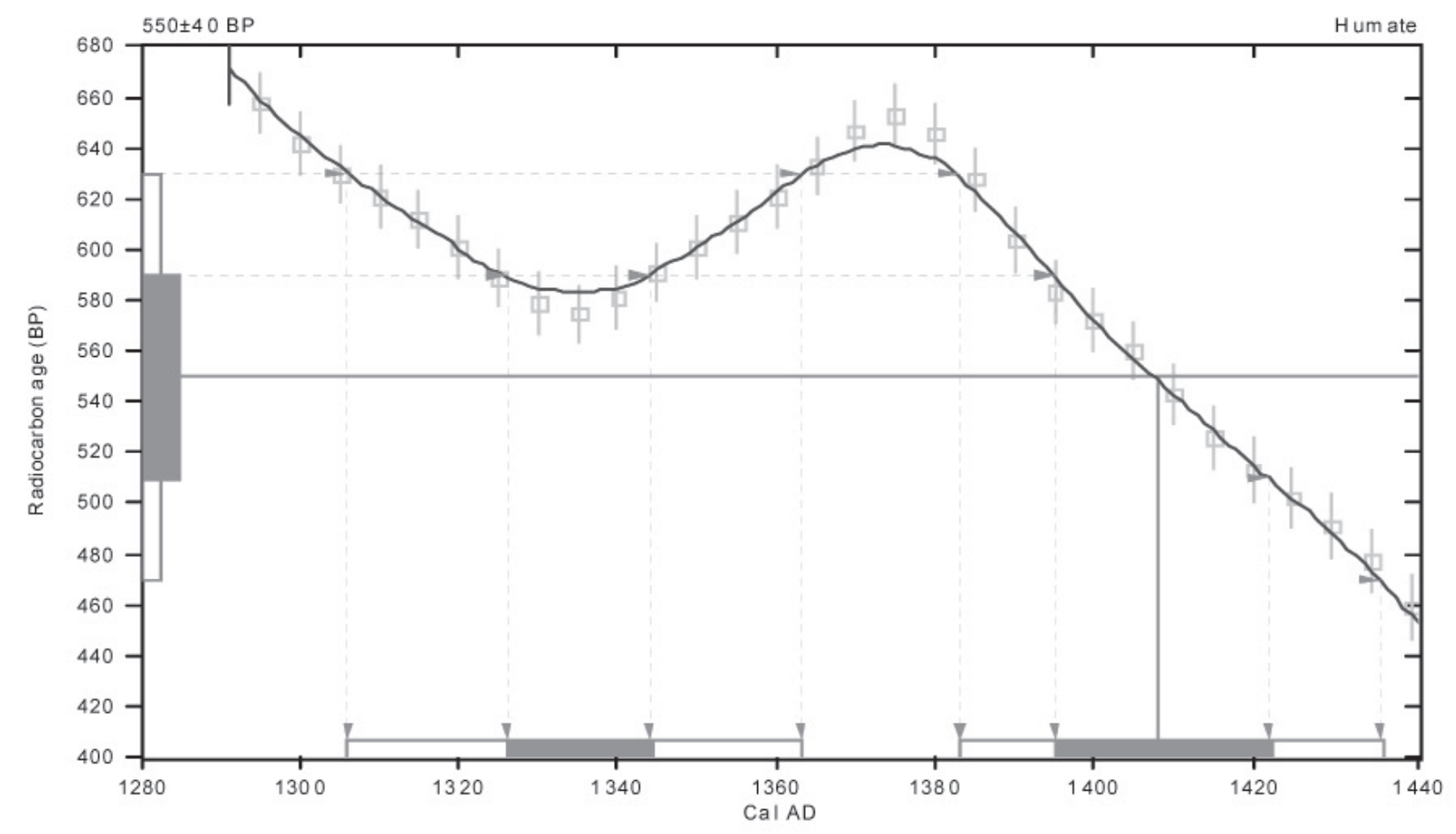

References:

Databas e us ed

IN TCA LO 4

Calib ration D atabase

INTCALO4 Radiocarbon Age Calibration

IntCal0 4: Calibration /s sue of Radio carbon (Volume 46, nr 3, 2004).

Ma them a tics

A Simplified A pproach to Calibrating C14 Dates

Talma, A. S., Vogel, J. C., 1993, Radiocarbon 35(2), p31 7-322

\section{Beta Analytic Radiocarbon Dating Laboratory}

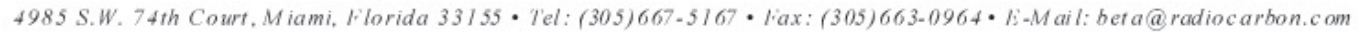




\section{CALIBRATION OF RADIOCARBON AGE TO CALENDAR YEARS}

(Variables: $\mathrm{C} 13 / \mathrm{C} 12=-15.4$ :lab. $\mathrm{mult}=1$ )

Laboratory number: Beta-235800

Conventional radiocarbon age: $1130 \pm 40 \mathrm{BP}$

2 Sigma calibrated result: Cal A D 780 to 1000 (Cal B P 1160 to 950) (95\% probability)

Intercept data

Intercept of radiocarbon age

with calibration curve: Cal AD 900 (Cal BP 1050)

1 Sigma calibrated result: Cal AD 880 to 980 (Cal BP 1070 to 970)

(68\% probability)

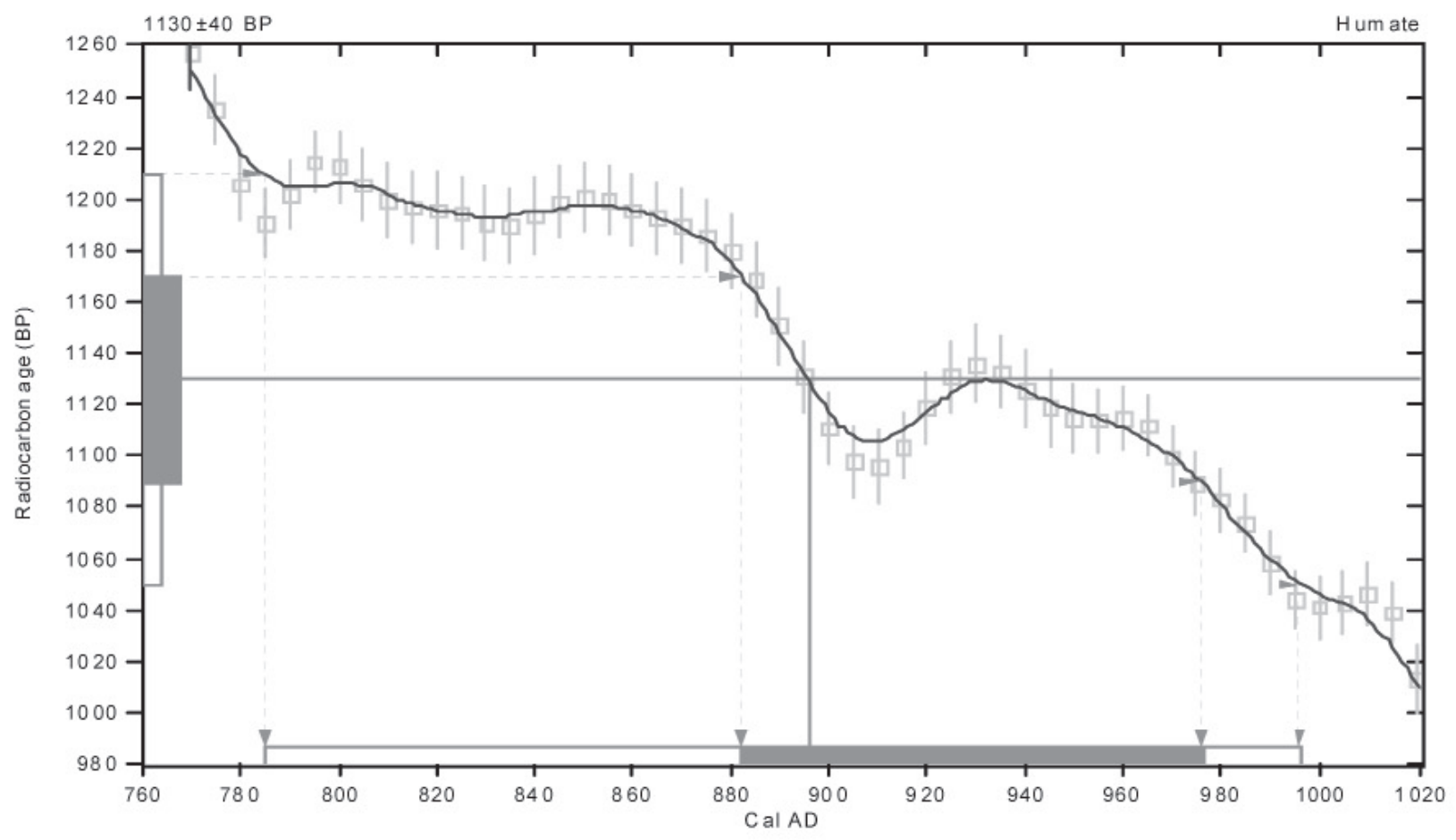

References:

Database used INTCA LO 4

Calib ration D ata base

INTCAL04 Radiocarbon Age Calibration

IntCal0 4: Calibration Is sue of Radio carbon (Volume 46, nr 3, 2004).

Ma them a tics

A Simplified A pproach to Calibrating C14 D ates Talma, A. S., Vogel, J. C., 1993, Radiocarbon 35(2), p317-322 


\section{CALIBRATION OF RADIOCARBON AGE TO CALENDAR YEARS}

(Variables: C13/C12=-15.6:lab. $\mathrm{mult}=1$ )

Laboratory number: Beta-235801

Conventional radiocarbon age: $2240 \pm 40 \mathrm{BP}$

2 Sigma calibrated result: Cal BC 390 to 200 (Cal B P 2340 to 2150)

(95\% probability)

Intercept data

Intercept of radiocarbon age

with calibration curve:

1 Sigma calibrated results: Cal BC 380 to 350 (Cal BP 2330 to 2300) and

(68\% probability) Cal BC 300 to 210 (Cal BP 2260 to 2160 )

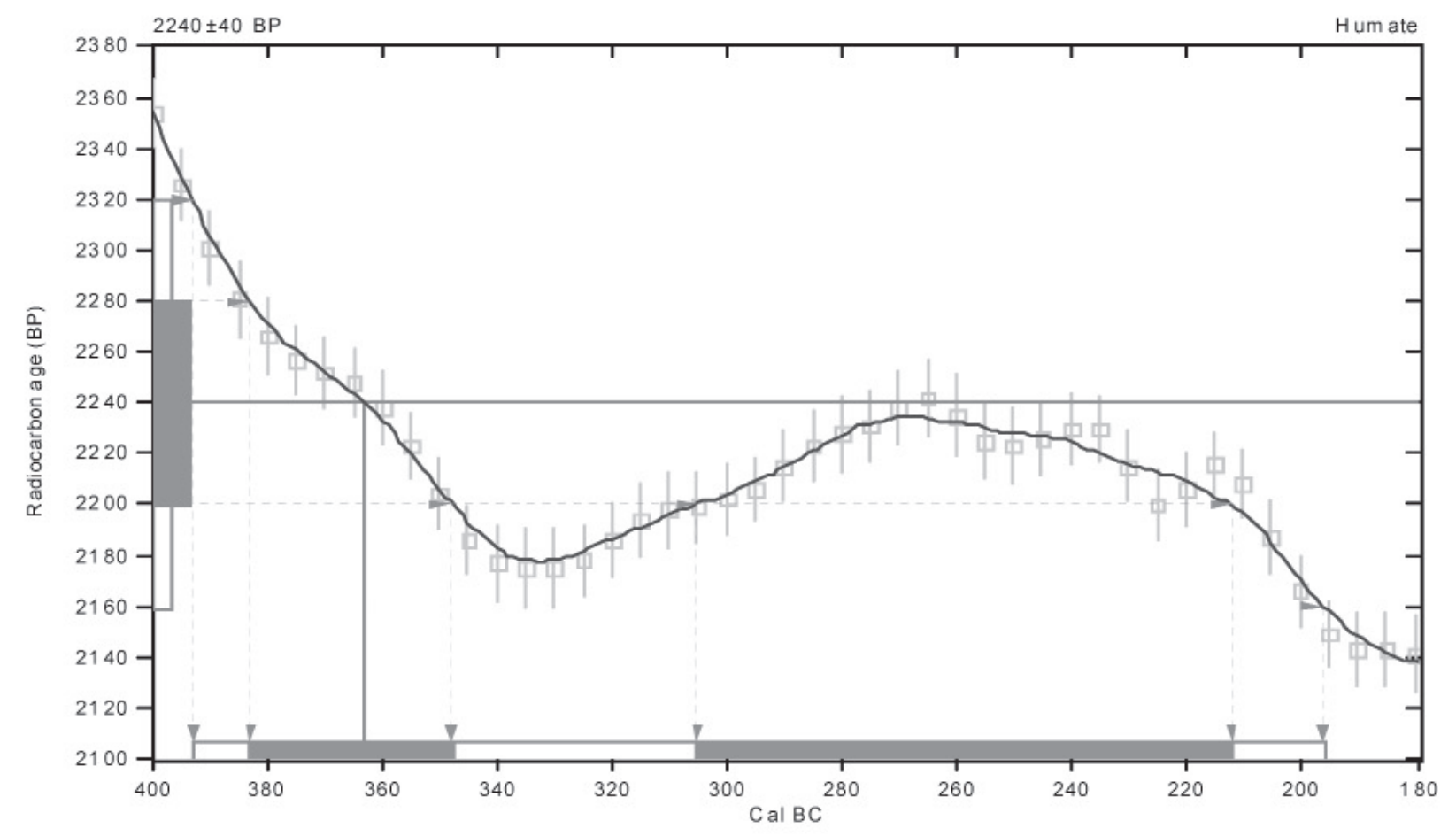

References:

Databas e us ed INTCA LO 4

Calib ration $D$ ata base

INTCALO4 Radiocarbon Age Calibration

IntCal0 4: Calibration /s sue of Radio carbon (Volume 46, nr 3, 2004).

Ma them a tics

A Simplified Approach to Calibrating C14 D ates Talma, A. S., Vogel, J. C., 1993, Radiocarbon 35(2), p31 7-322

\section{Beta Analytic Radiocarbon Dating Laboratory}

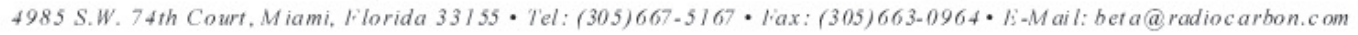




\section{CALIBRATION OF RADIOCARBON AGE TO CALENDAR YEARS}

(Variables: C13/C12=-16.6:lab. $\mathrm{mult}=1$ )

Laboratory number: Beta-235802

Conventional radiocarbon age: $2970 \pm 40 \mathrm{BP}$

2 Sigma calibrated results: Cal BC 1360 to 1350 (Cal BP 3310 to 3300 ) and

(95\% probability) Cal BC 1310 to 1050 (Cal B P 3260 to 3000 )

Intercept data

Intercept of radiocarbon age

with calibration curve: Cal BC 1210 (Cal BP 3160)

1 Sigma calibrated result: Cal BC 1270 to 1120 (Cal BP 3220 to 3070 ) ( $68 \%$ probability)

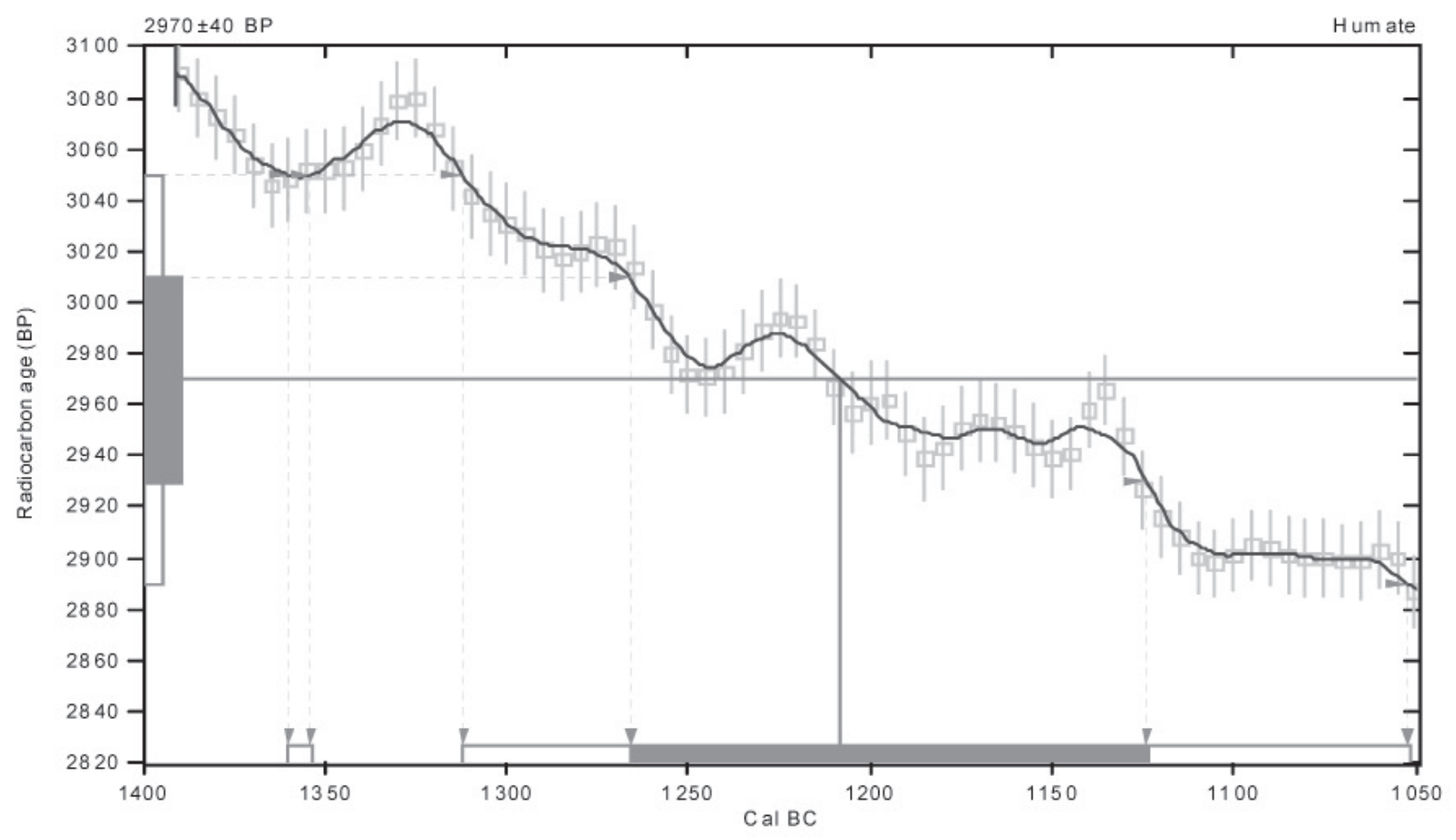

References:

Database us ed

INTCA LO 4

Ca lib ration Data base

INTCAL04 Ra diocarbon Age Calibration

IntCal0 4: Calibration Issue of Radio carbon (Volume 46, nr 3, 2004).

Ma them a tics

A Simplified A pproach to Calibrating C14 Dates Talma, A. S., Vo gel, J. C., 1993, Radiocarbon 35(2), p317-322 


\section{CALIBRATION OF RADIOCARBON AGE TO CALENDAR YEARS}

(Variables: $\mathrm{C} 13 / \mathrm{C} 12=-15.5:$ lab. $\mathrm{mult}=1$ )

Laboratory number: Beta-235803

Conventional radiocarbon age: $1060 \pm 40 \mathrm{BP}$

2 Sigma calibrated result: Cal AD 890 to 1030 (C al BP 1060 to 920)

( $95 \%$ probability)

Intercept data

Intercept of radiocarbon age with calibration curve:

Cal AD $990(\mathrm{Cal}$ BP 960)

1 Sigma calibrated result: Cal AD 970 to 1020 (Cal B P 980 to 930) (68\% probability)

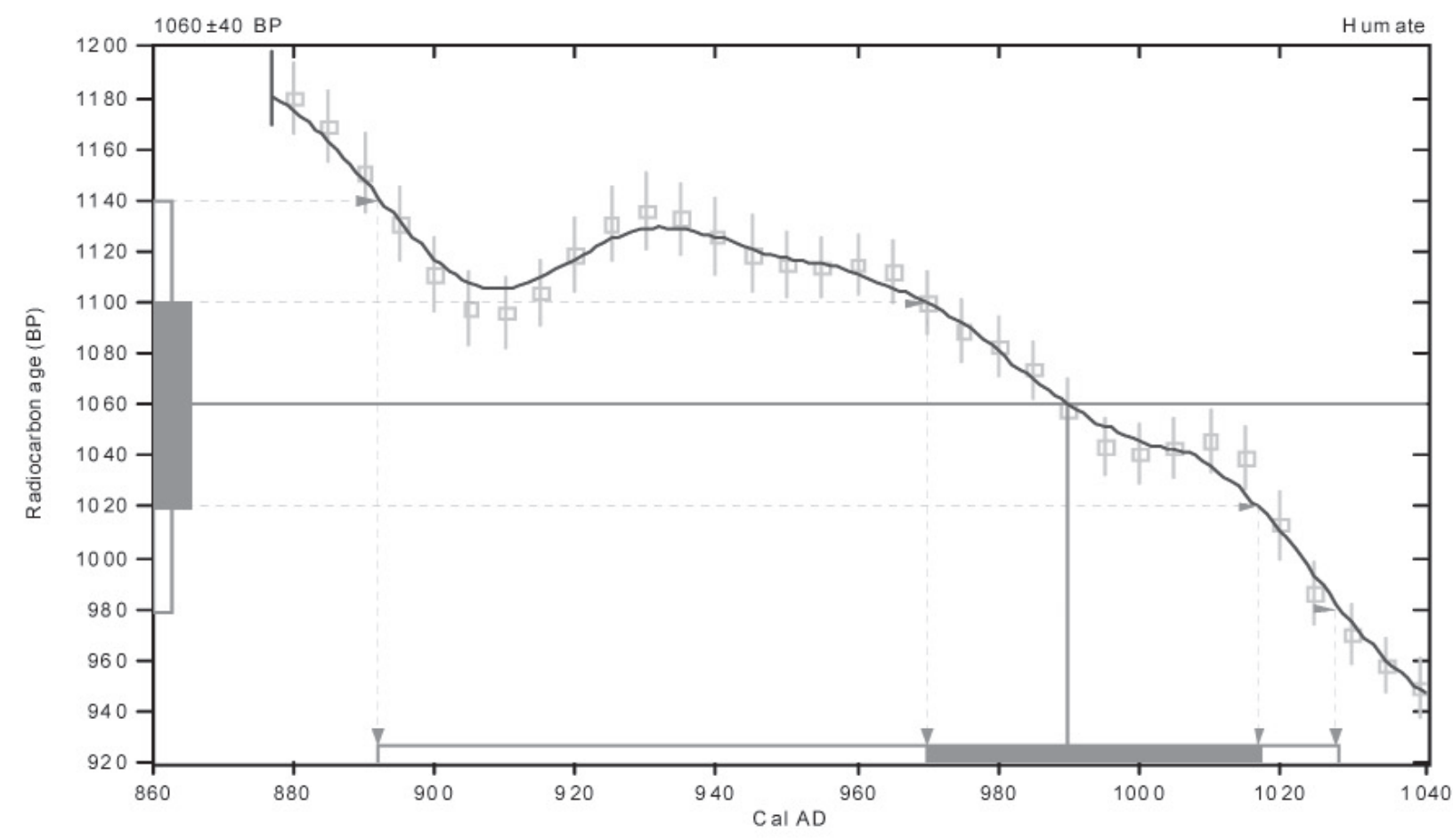

References:

Databas e us ed INTCALO 4

Ca lib ration $D$ ata base

INTCAL04 Radiocarbon Age Calibration

IntCal0 4: Calibration /s sue of Radio carbon (Volume 46, nr 3, 2004).

Ma them a tics

A Simplified A pproach to Calibrating C14 D ates

Talma, A. S., Vogel, J. C., 1993, Radiocarbon 35(2), p317-322

Beta Analytic Radiocarbon Dating Laboratory

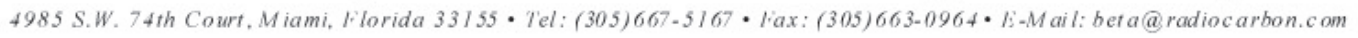




\section{CALIBRATION OF RADIOCARBON AGE TO CALENDAR YEARS}

(Variables: $\mathrm{C} 13 / \mathrm{C} 12=-20.2$ :lab. mult $=1$ )

Laboratory number: Beta-235804

Conventional radiocarbon age: $2110 \pm 40 \mathrm{BP}$

2 Sigma calibrated results: Cal BC 340 to 320 (Cal B P 2290 to 2270) and

(95\% probability) Cal BC 210 to 40 (C al BP 2160 to 1990)

Intercept data

Intercept of radiocarbon age

with calibration curve: Cal BC $160(\mathrm{Cal}$ BP 2110$)$

1 Sigma calibrated result: Cal BC 190 to 60 (Cal BP 2140 to 2010)

(68\% probability)

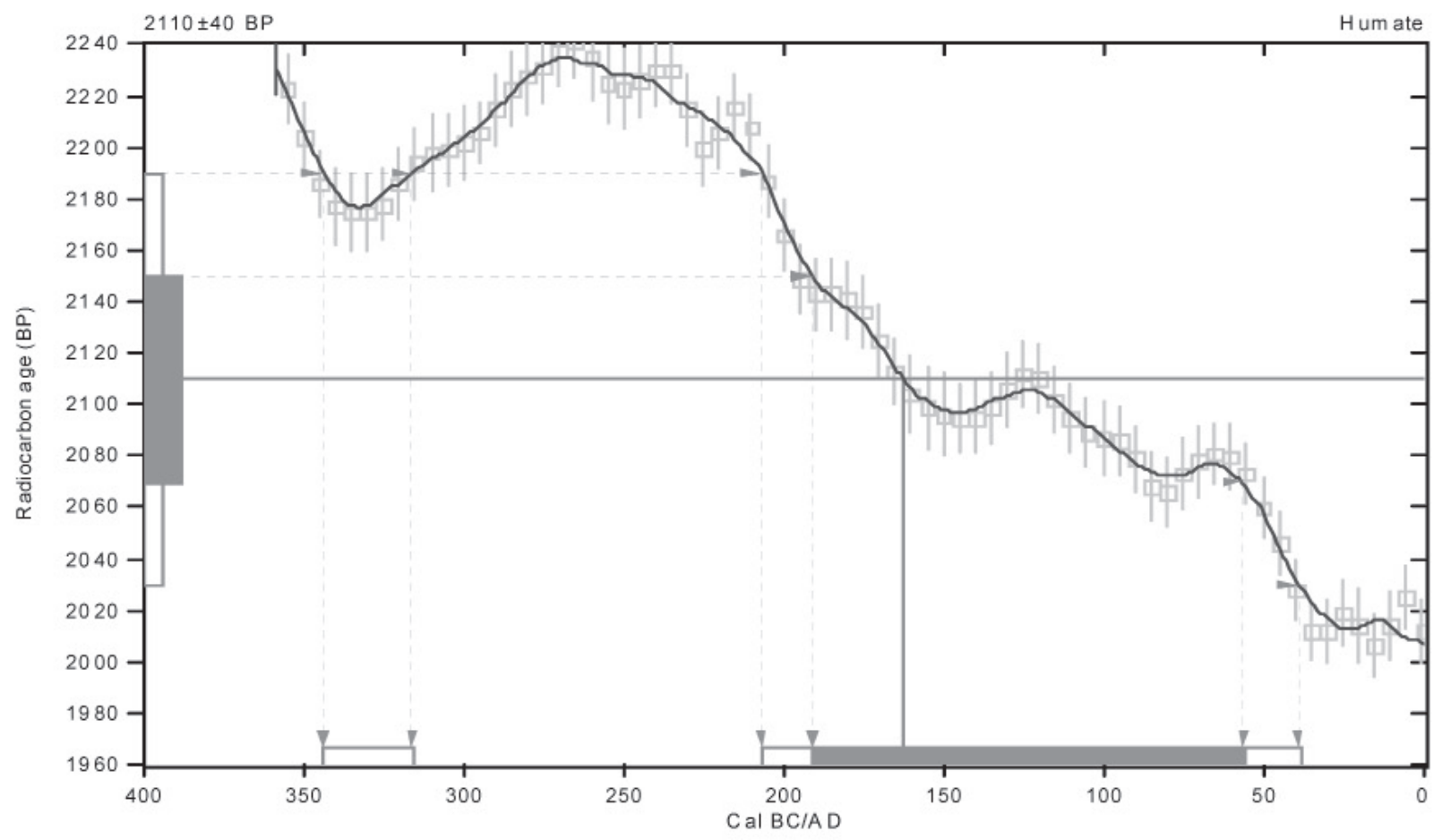

References:

Database used INTCA LO 4

Calib ration D ata base

INTCAL04 Radiocarbon Age Calibration

IntCal0 4: Calibration Is sue of Radio carbon (Volume 46, nr 3, 2004).

Ma them a tics

A Simplified Approach to Calibrating C14 D ates Talma, A. S., Vogel, J. C., 1993, Radiocarbon 35(2), p317-322 


\section{CALIBRATION OF RADIOCARBON AGE TO CALENDAR YEARS}

(Variables: C13/C12=-14.8:lab. mult=1)

Laboratory number: Beta-235805

Conventional radiocarbon age: $2880 \pm 40 \mathrm{BP}$

2 Sigma calibrated result: Cal BC 1200 to 930 (Cal BP 3150 to 2880) (95\% probability)

Intercept data

Intercept of radiocarbon age

with calibration curve: Cal BC 1040 (Cal B P 2990)

1 Sigma calibrated result: Cal BC 1120 to 1000 (Cal BP 3070 to 2950) (68\% probability)

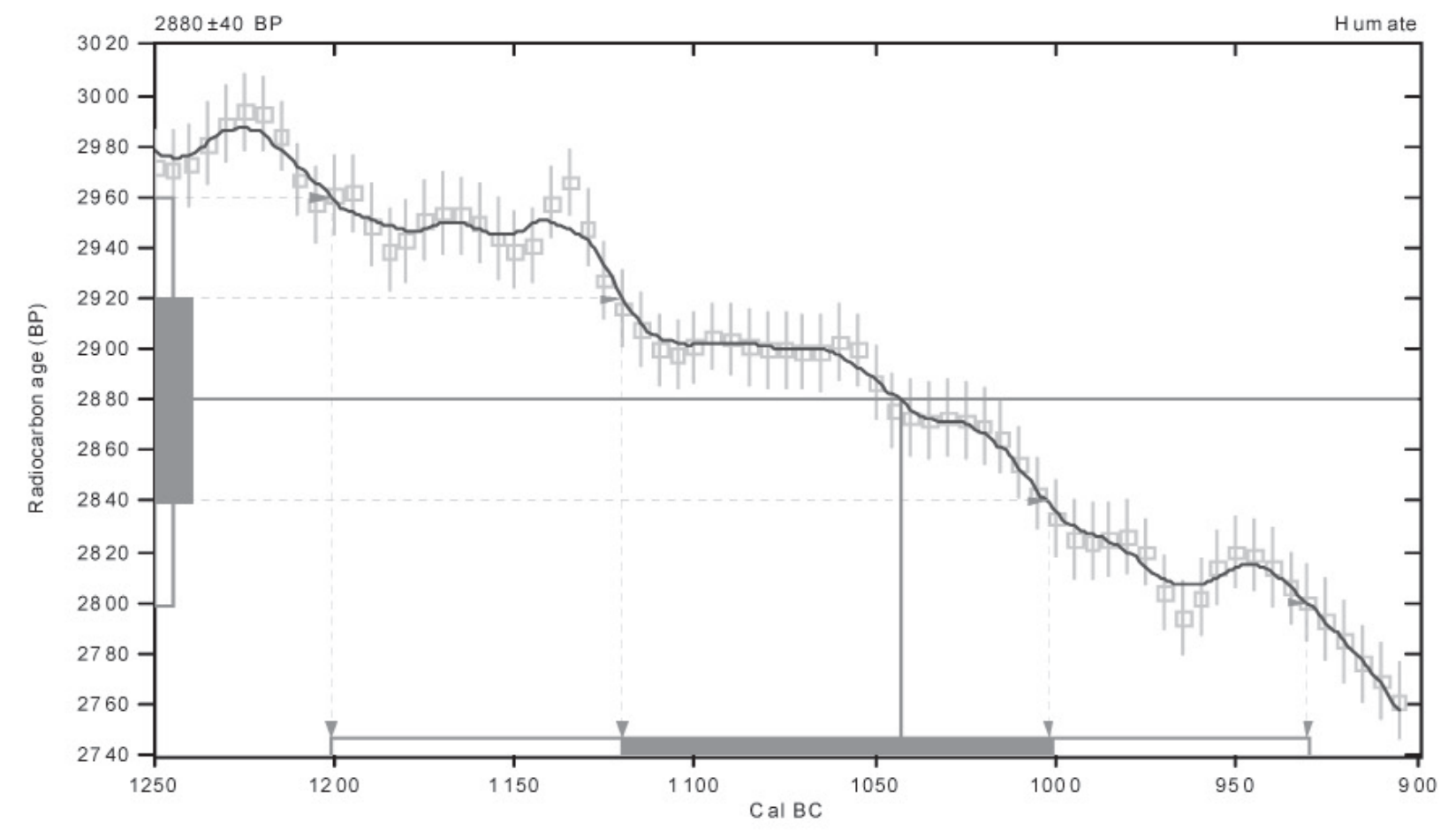

References:

Databas e us ed IN TCA LO 4

Calib ration $D$ ata base

INTCALO4 Radiocarbon Age Calibration

IntCal0 4: Calibration /ssue of Radiocarbon (Volume 46, nr 3, 2004 ).

Ma them a tics

A Simplified Approach to Calibrating C14 D ates Talma, A. S., Vogel, J. C., 1993, Radiocarbon 35(2), p31 7-322

\section{Beta Analytic Radiocarbon Dating Laboratory}

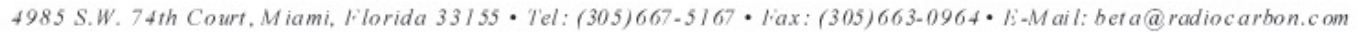




\section{CALIBRATION OF RADIOCARBON AGE TO CALENDAR YEARS}

(Variables: $\mathrm{C} 13 / \mathrm{C} 12=-16: 1 \mathrm{ab} . \mathrm{mult}=1$ )

Laboratory number: Beta-235806

Conventional radiocarbon age: $3620 \pm 40 \mathrm{BP}$

2 Sigma calibrated results: Cal BC 2130 to 2090 (Cal BP 4080 to 4040 ) and

(95\% probability) Cal BC 2050 to 1890 (Cal B P 4000 to 3840 )

Intercept data

Intercept of radiocarbon age

with calibration curve: Cal BC 1970 (Cal BP 3920)

1 Sigma calibrated result: Cal BC 2030 to 1930 (Cal BP 3980 to 3880 )

( $68 \%$ probability)

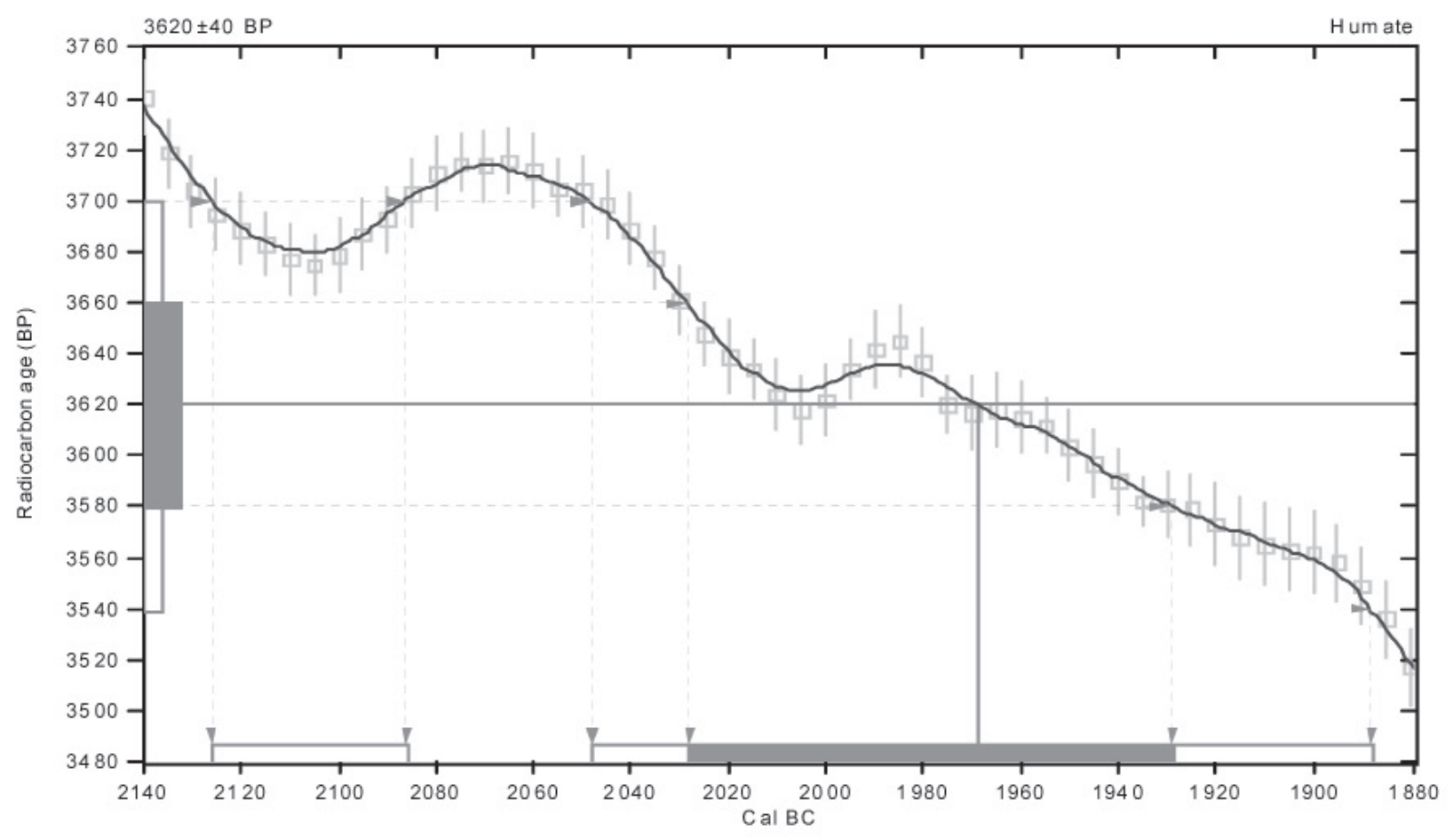

References:

Database us ed

INTCA LO 4

Ca lib ration Data base

INTCALO4 Radiocarbon Age Calibration

IntCal0 4: Calibration Issue of Radio carbon (Volume 46, nr 3, 2004).

Ma them a tics

A Simplified A pproach to Calibrating C14 Dates

Talma, A. S., Vogel, J. C., 1993, Radiocarbon 35(2), p317-322

Beta Analytic Radiocarbon Dating Laboratory

4985 S.W.74th Court, Miami, Florida 33155・Tel: (305)667-5167・Fax:(305)663-0964·li-Mail: beta@ radiocarbon.com 


\section{CALIBRATION OF RADIOCARBON AGE TO CALENDAR YEARS}

(Variables: $\mathrm{C} 13 / \mathrm{C} 12=-16.2:$ lab. $\mathrm{mult}=1$ )

Laboratory number: Beta-235807

Conventional radiocarbon age: $\quad 1280 \pm 40 \mathrm{BP}$

2 Sigma calibrated result: Cal A D 660 to 810 (Cal BP 1290 to 1140) (95\% probability)

Intercept data

Intercept of radiocarbon age with calibration curve: Cal AD 690 (Cal BP 1260)

1 Sigma calibrated result: Cal AD 670 to 770 (Cal BP 1280 to 1180) ( $68 \%$ probability)

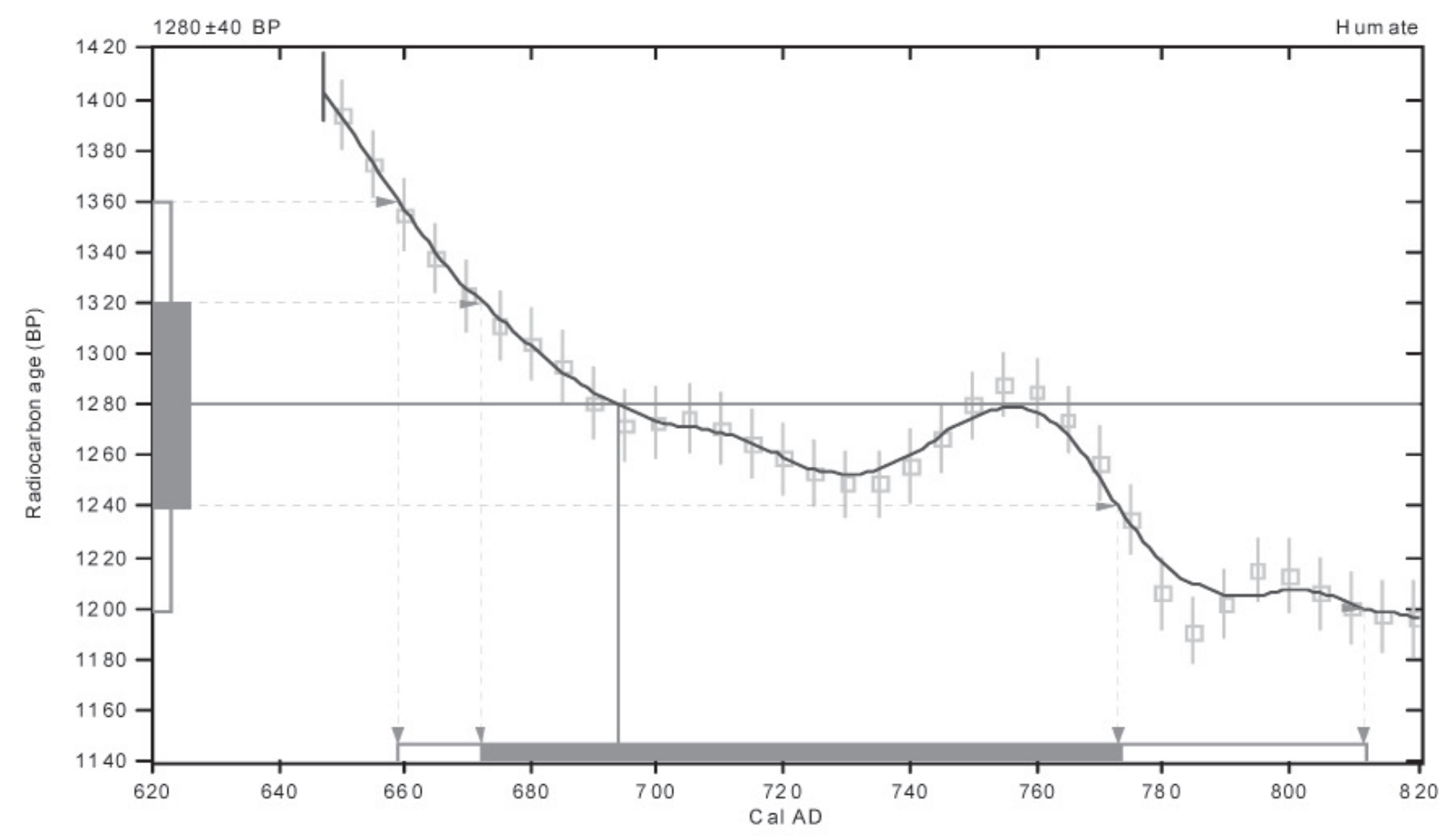

References:

Database us ed IN TCA LO 4

Ca lib ration $D$ ata base

INTCAL04 Radiocarbon Age Calibration

IntCal0 4: Calibration /ssue of Radio carbon (Volume 46, nr 3, 2004).

Ma them a tics

A Simplified A pproach to Calibrating C14 D ates

Talma, A. S., Vogel, J. C., 1993, Radiocarbon 35(2), p317-322

\section{Beta Analytic Radiocarbon Dating Laboratory}

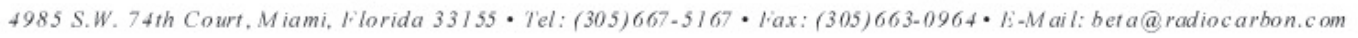




\section{CALIBRATION OF RADIOCARBON AGE TO CALENDAR YEARS}

(Variables: $\mathrm{C} 13 / \mathrm{C} 12=-17.5:$ lab. mult $=1$ )

Laboratory number: Beta-235808

Conventional radiocarbon age: $1770 \pm 40 \mathrm{BP}$

2 Sigma calibrated result: Cal AD 140 to 380 (Cal BP 1810 to 1570)

(95\% probability)

Intercept data

Intercept of radiocarbon age

with calibration curve: Cal AD 250 (Cal BP 1700)

1 Sigma calibrated results: Cal AD 230 to 260 (Cal BP 1720 to 1680) and

(68\% probability) Cal AD 280 to 330 (Cal BP 1670 to 1620$)$

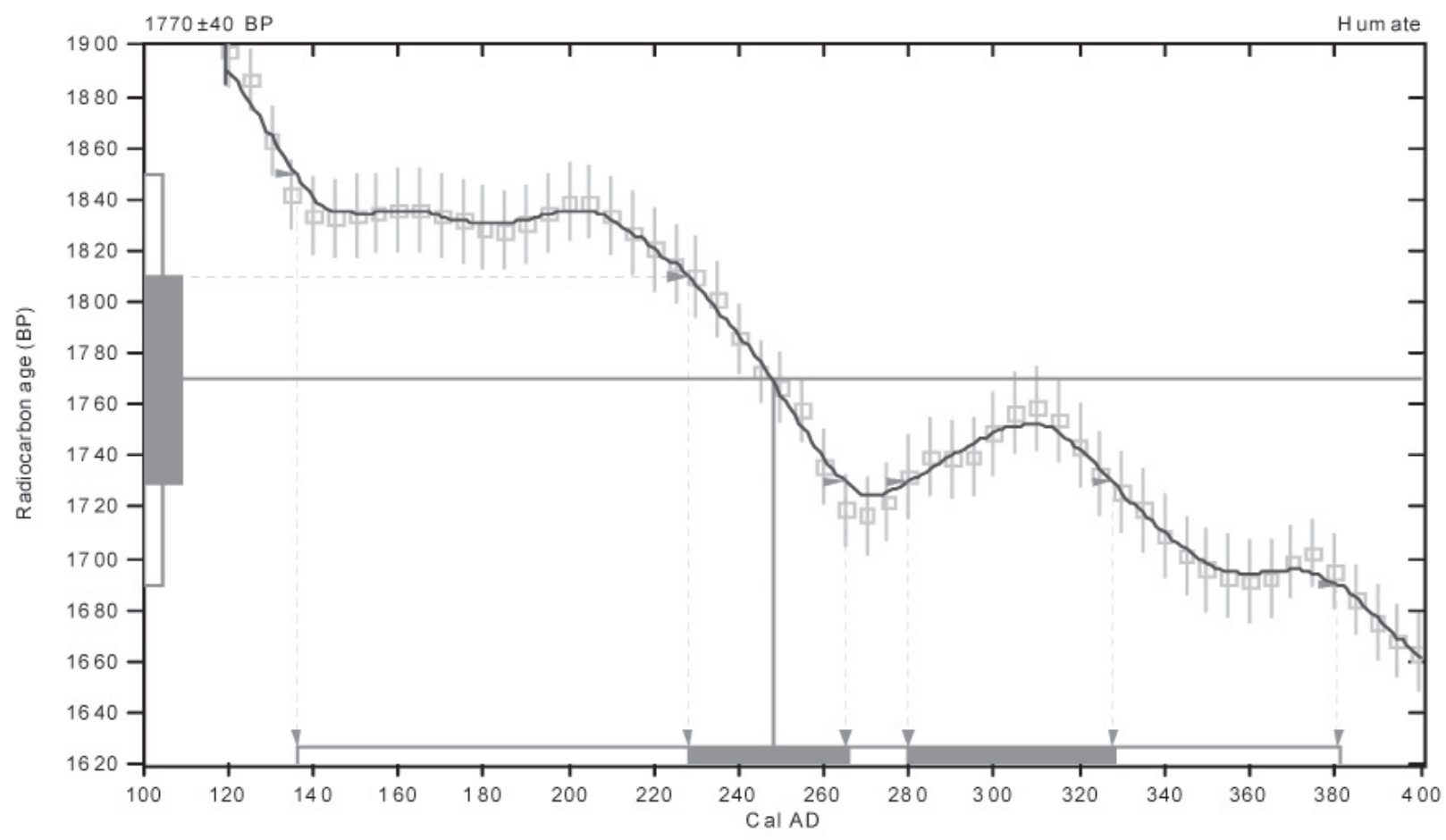

References:

Data bas e us ed

IN TCA LO 4

Calib ration $D$ ata base

INTCALO4 Radiocarbon Age Calibration

IntCal0 4: Calibration Is sue of Radiocarbon (Volume 46, nr 3, 2004).

Ma th em a tics

A Simplified A pproach to Calibrating C14 D ates Talma, A.S., Vogel, J. C., 1993, Radiocarbon 35(2), p31 7-322 


\section{CALIBRATION OF RADIOCARBON AGE TO CALENDAR YEARS}

(Variables: $\mathrm{C} 13 / \mathrm{C} 12=-20.8:$ lab. $\mathrm{mult}=1$ )

Laboratory number: Beta-235809

Conventional radiocarbon age: $2760 \pm 40 \mathrm{BP}$

2 Sigma calibrated result: Cal BC 1000 to 820 (Cal BP 2950 to 2770) ( $95 \%$ probability)

Intercept data

Intercept of radiocarbon age with calibration curve:

Cal BC 910 (Cal BP 2860)

1 Sigma calibrated result: Cal BC 930 to 840 (Cal BP 2880 to 2790) (68\% probability)

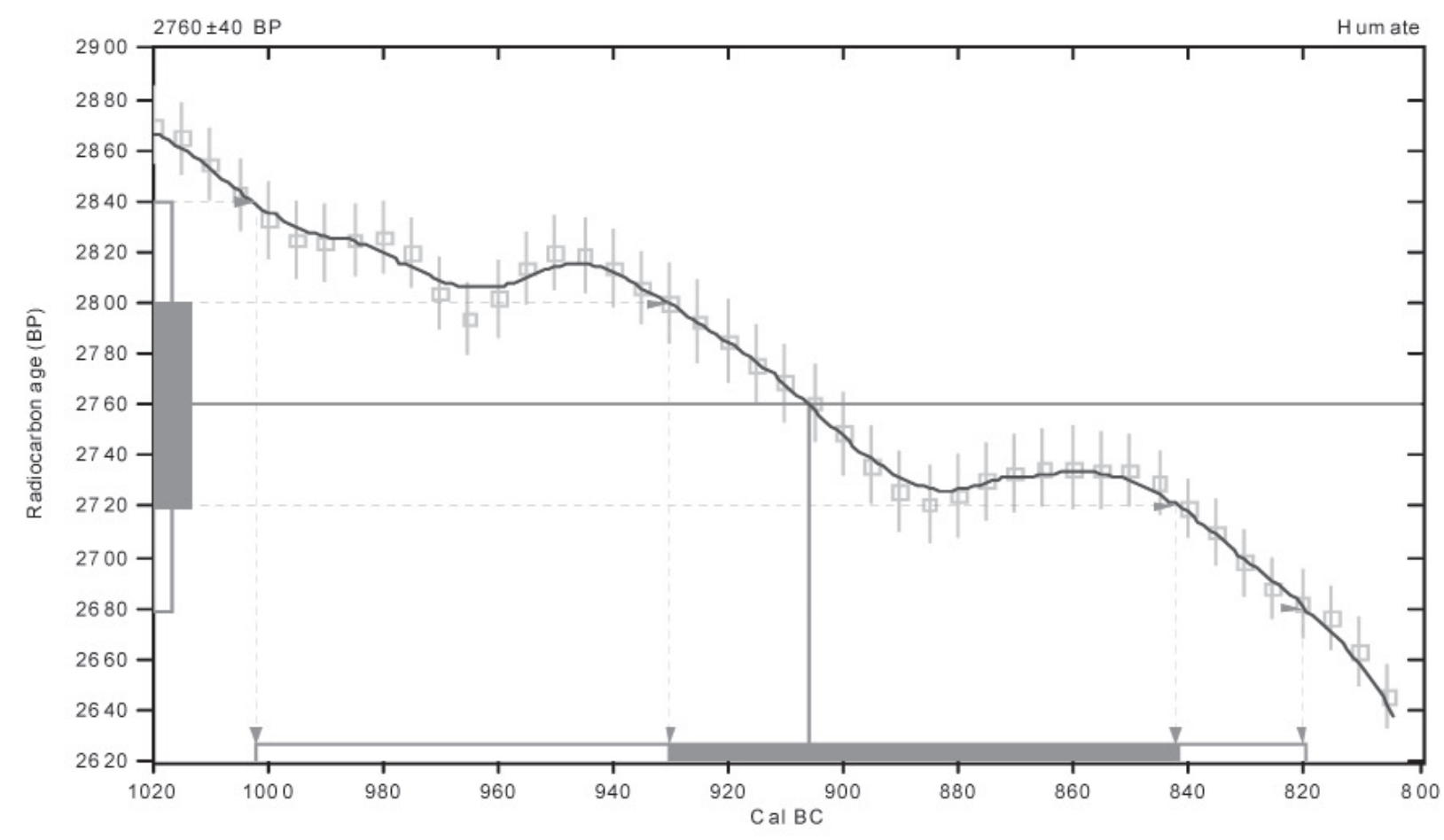

References:

Database used INTCALO 4

Ca lib ration $D$ ata base

INTCAL04 Radiocarbon Age Calibration

IntCal0 4: Calibration /s sue of Radio carbon (Volume 46, nr 3, 2004).

Ma them a tics

A Simplified A pproach to Calibrating C14 D ates

Talma, A. S., Vogel, J. C., 1993, Radiocarbon 35(2), p317-322

Beta Analytic Radiocarbon Dating Laboratory

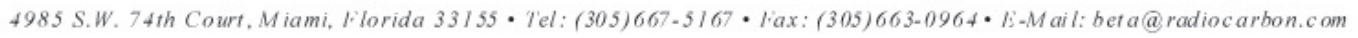




\section{CALIBRATION OF RADIOCARBON AGE TO CALENDAR YEARS}

(Variables: C13/C12=-17.7:lab. mult $=1$ )

Laboratory number: Beta-235810

Conventional radiocarbon age: $3770 \pm 40 \mathrm{BP}$

2 Sigma calibrated results: Cal BC 2300 to 2120 (Cal B P 4250 to 4070 ) and (95\% probability) Cal BC 2090 to 2040 (Cal B P 4040 to 3990)

Intercept data

Intercept of radiocarbon age

with calibration curve: Cal BC 2200 (Cal B P 4150)

1 Sigma calibrated results: Cal BC 2280 to 2250 (Cal BP 4230 to 4200 ) and

(68\% probability) Cal BC 2220 to 2140 (Cal BP 4160 to 4090$)$

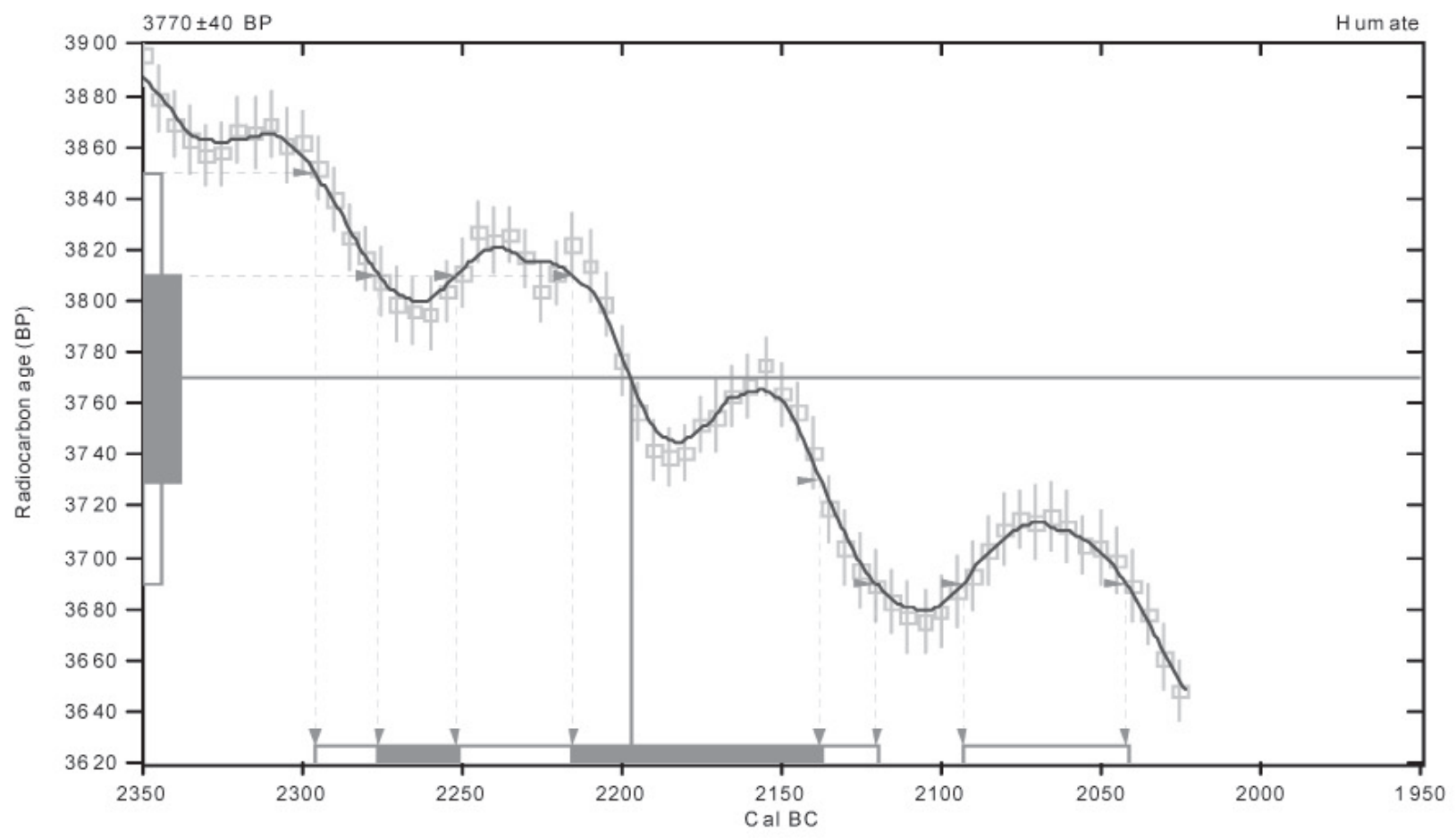

References:

Database used IN TCA LO 4

Calib ration D atabase

INTCALO4 Radiocarbon Age Calibration

IntCal0 4: Calibration Is sue of Radio carbon (Volume 46, nr 3, 2004).

Ma th em a tics

A Simplified A pproach to Calibrating C14 D ates Talma, A. S., Vogel, J. C., 1993, Radiocarbon 35(2), p317-322 


\section{CALIBRATION OF RADIOCARBON AGE TO CALENDAR YEARS}

(Variables: C13/C12=-24.1:lab. $\mathrm{mult}=1$ )

Laboratory number: Beta-235811

Conventional radiocarbon age: $1140 \pm 40 \mathrm{BP}$

2 Sigma calibrated result: Cal AD 780 to 990 (Cal BP 1170 to 960)

(95\% probability)

Intercept data

Intercept of radiocarbon age

with calibration curve: Cal AD 890 (Cal BP 1060)

1 Sigma calibrated result: Cal AD 880 to 970 (Cal BP 1070 to 980) (68\% probability)

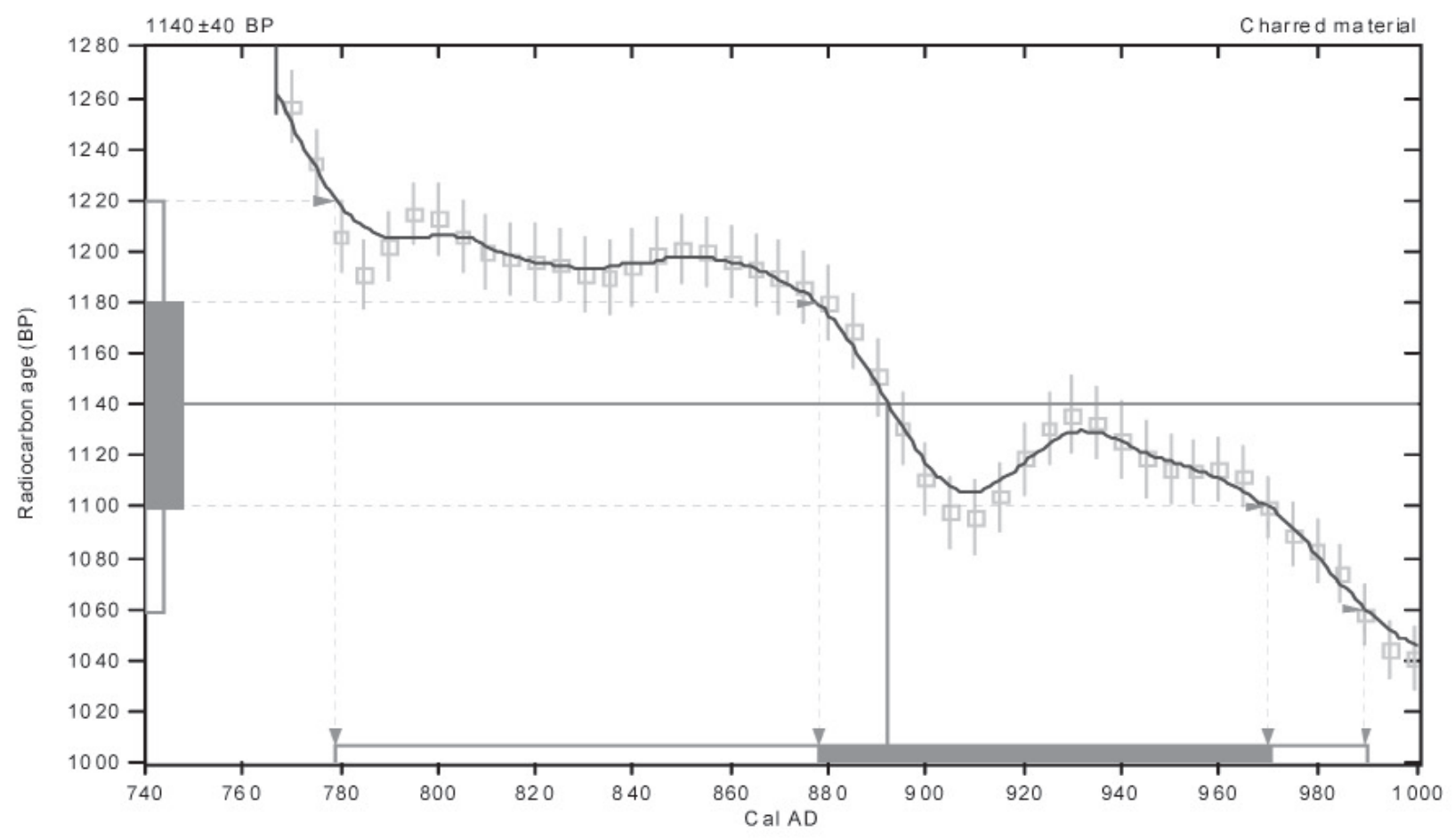

References:

Databas e us ed IN TCA LO 4

Calib ration $D$ ata base

INTCALO4 Radiocarbon Age Calibration

IntCal0 4: Calibration Issue of Radio carbon (Volume 46, nr 3, 200 4).

Ma them a tics

A Simplified Approach to Calibrating C 14 D ates Talma, A. S., Vogel, J. C., 1993, Radiocarbon 35(2), p31 7-322

\section{Beta Analytic Radiocarbon Dating Laboratory}

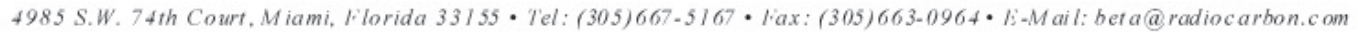




\section{CALIBRATION OF RADIOCARBON AGE TO CALENDAR YEARS}

(Variables: $\mathrm{C} 13 / \mathrm{C} 12=-23.5:$ lab. $\mathrm{mult}=1$ )

Laboratory number: Beta-235812

Conventional radiocarbon age: $2310 \pm 40 \mathrm{BP}$

2 Sigma calibrated results: Cal BC 410 to 360 (Cal BP 2360 to 2310) and

(95\% probability) Cal BC 280 to 260 (Cal B P 2230 to 2200)

Intercept data

Intercept of radiocarbon age

with calibration curve: Cal BC 390 (Cal BP 2340)

1 Sigma calibrated result: Cal BC 400 to 380 (Cal BP 2350 to 2330)

(68\% probability)

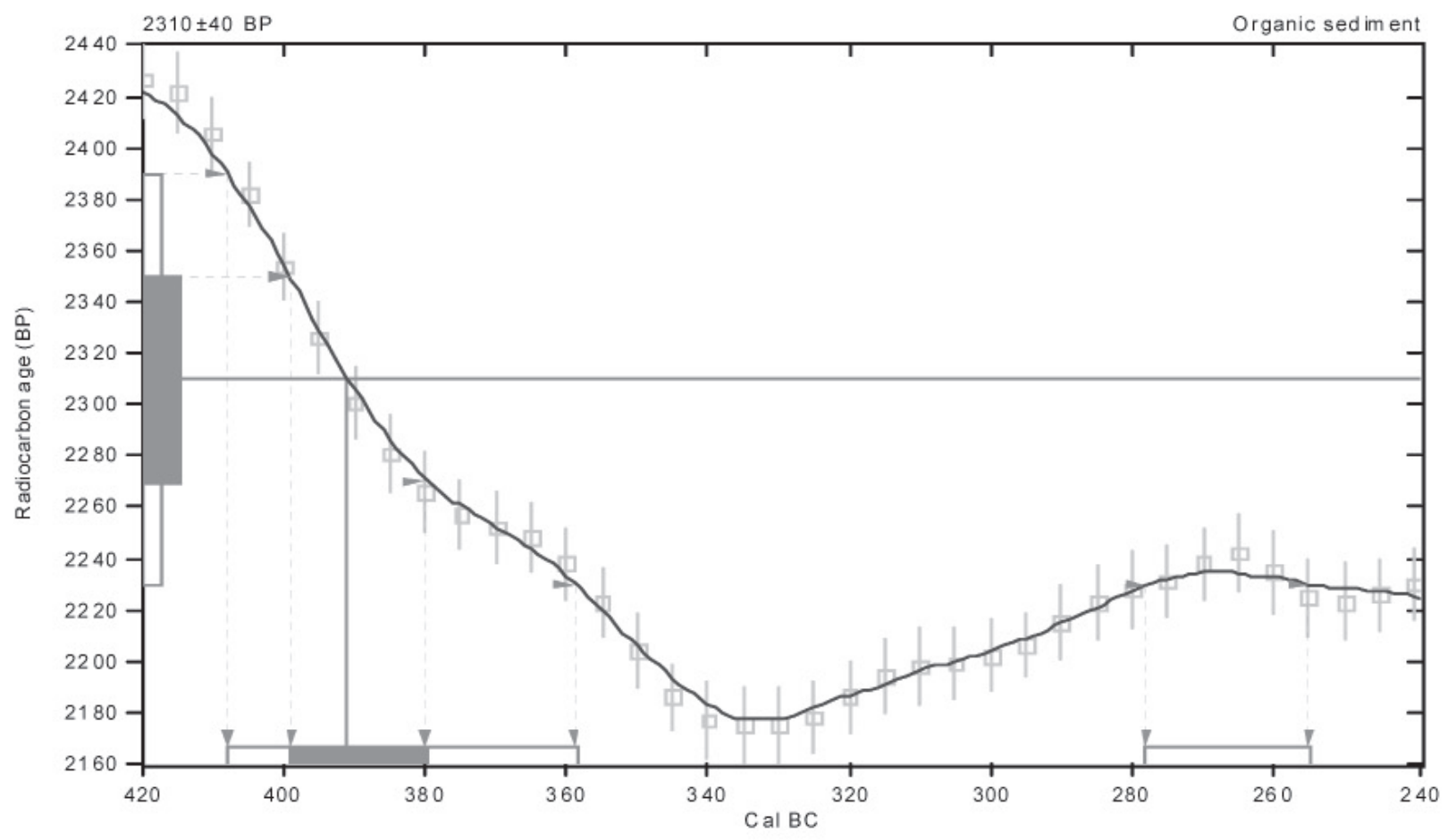

References:

Database used INTCA LO 4

Calib ration D ata base

INTCAL04 Radiocarbon Age Calibration

IntCal0 4: Calibration Is sue of Radio carbon (Volume 46, nr 3, 2004).

Ma them a tics

A Simplified Approach to Calibrating C14 D ates Talma, A.S., Vogel, J. C., 1993, Radiocarbon 35(2), p317-322 


\section{CALIBRATION OF RADIOCARBON AGE TO CALENDAR YEARS}

(Variables: C13/C12=-23:lab. mult $=1$ )

Laboratory number: Beta-235813

Conventional radiocarbon age: $1320 \pm 40 \mathrm{BP}$

2 Sigma calibrated result: Cal A D 650 to 770 (Cal BP 1300 to 1180)

(95\% probability)

Intercept data

Intercept of radiocarbon age

with calibration curve: Cal AD 670 (Cal BP 1280)

1 Sigma calibrated result: Cal AD 660 to 690 (Cal BP 1290 to 1260)

( $68 \%$ probability)

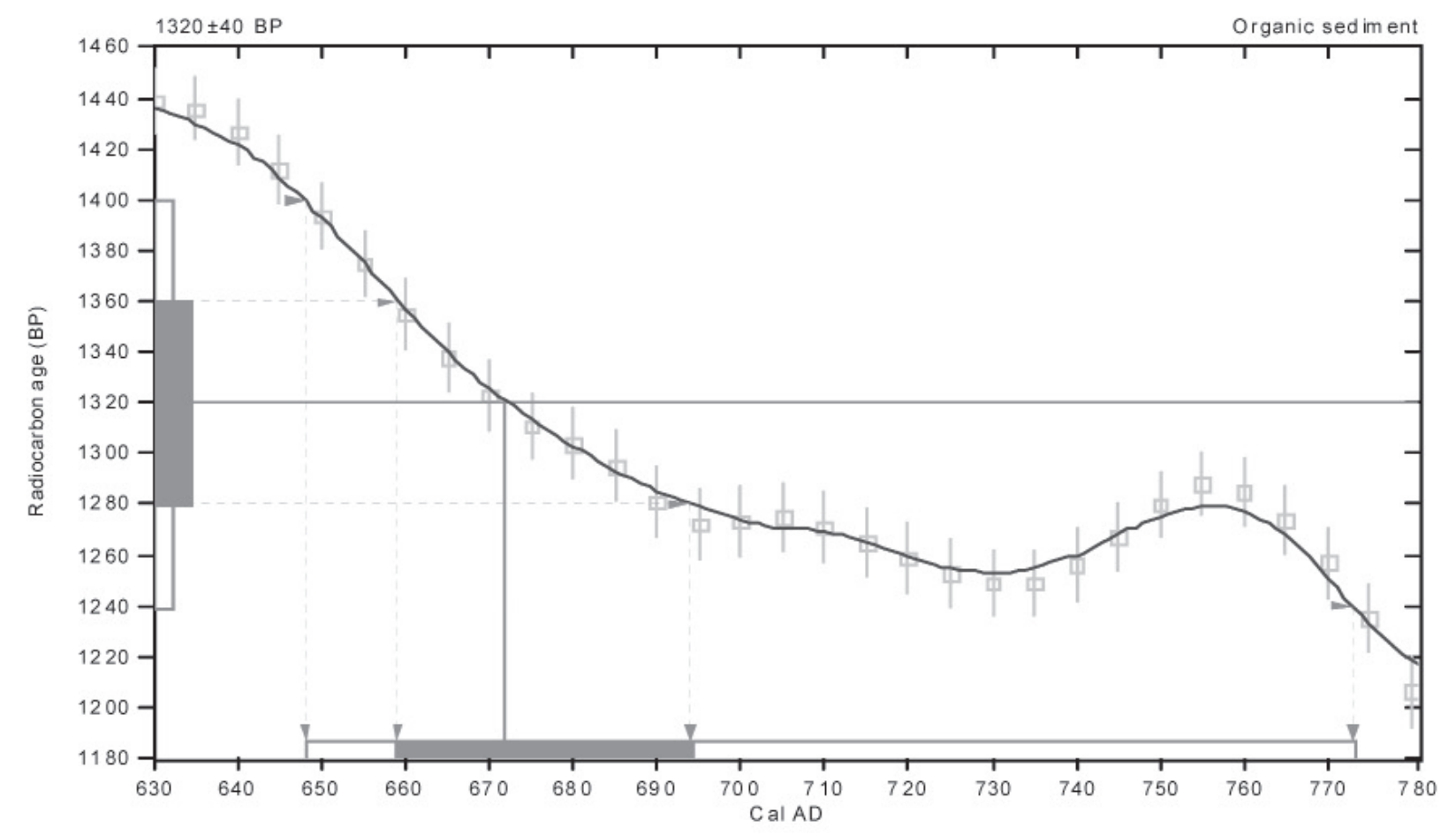

References:

Databas e us ed

INTCA LO 4

Calib ration D atabase

INTCALO4 Radiocarbon Age Calibration

IntCal0 4: Calibration Is sue of Radio carbon (Volume 46, nr 3, 2004 ).

Ma th em a tics

A Simplified Approach to Calibrating C14 D ates

Talma, A. S., Vogel, J. C., 1993, Radiocarbon 35(2), p31 7-322

\section{Beta Analytic Radiocarbon Dating Laboratory}

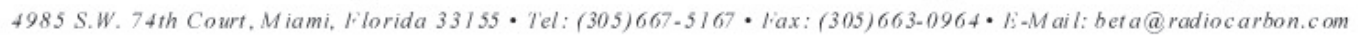




\section{CALIBRATION OF RADIOCARBON AGE TO CALENDAR YEARS}

(Variables: $\mathrm{C} 13 / \mathrm{C} 12=-16: 1 \mathrm{ab}$. mult $=1$ )

Laboratory number: Beta-235814

Conventional radiocarbon age: $1910 \pm 40 \mathrm{BP}$

2 Sigma calibrated result: Cal AD 10 to 210 (Cal B P 1940 to 1740)

(95\% probability)

Intercept data

Intercept of radiocarbon age

with calibration curve: Cal AD 80 (Cal BP 1870)

1 Sigma calibrated result: Cal AD 60 to 130 (Cal BP 1890 to 1820 )

(68\% probability)

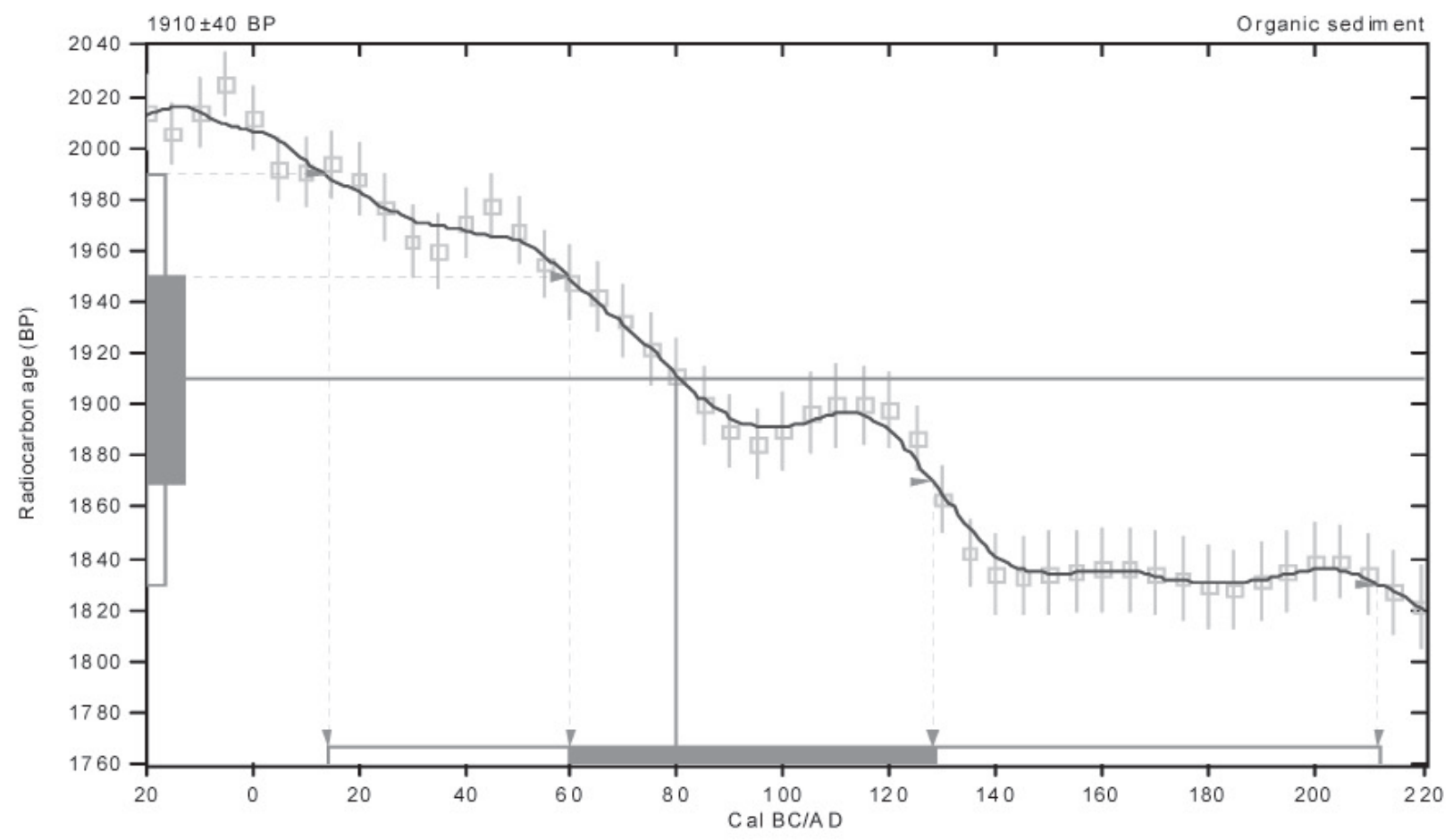

References:

Database us ed

INTCALO4

Ca lib ration $D$ ata base

INTCALO4 Radiocarbon Age Calibration

IntCal0 4: Calibration Is sue of Radio carbon (Volume 46, nr 3, 2004).

Ma them a tics

A Simplified A pproach to Calibrating C14 Dates

Talma, A.S., Vogel, J. C., 1993, Radiocarbon 35(2), p317-322

Beta Analytic Radiocarbon Dating Laboratory

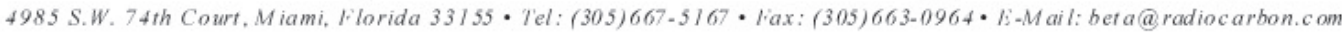




\section{CALIBRATION OF RADIOCARBON AGE TO CALENDAR YEARS}

(Variables: C13/C12=-18.4:lab. mult $=1$ )

Laboratory number: Beta-235815

Conventional radiocarbon age: $1780 \pm 40 \mathrm{BP}$

2 Sigma calibrated result: Cal AD 130 to 350 (Cal BP 1820 to 1600) (95\% probability)

Intercept data

Intercept of radiocarbon age with calibration curve: Cal AD 240 (Cal BP 1710)

1 Sigma calibrated results: Cal AD 220 to 260 (Cal BP 1730 to 1690) and (68\% probability) Cal AD 290 to 320 (Cal BP 1660 to 1630$)$

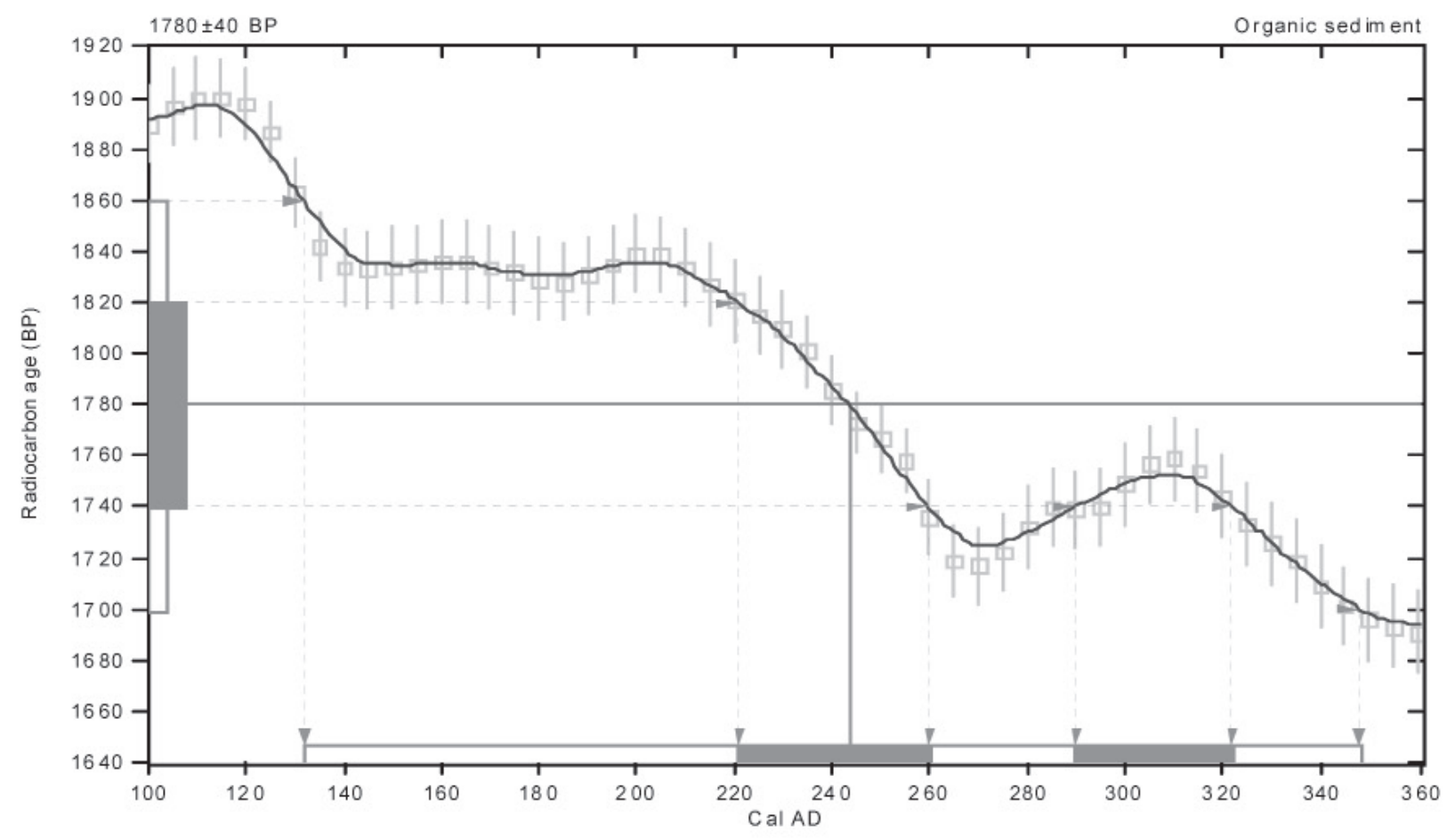

References:

Data bas e us ed INTCA LO 4

Calib ration Database

INTCALO4 Radiocarbon Age Calibration

IntCal0 4: Calibration Issue of Radio carbon (Volume 46, nr 3, 2004).

Ma th em a tics

A Simplified A pproach to Calibrating C14 D ates Talma, A. S., Vogel, J. C., 1993, Radiocarbon 35(2), p317-322 


\section{CALIBRATION OF RADIOCARBON AGE TO CALENDAR YEARS}

(Variables: $\mathrm{C} 13 / \mathrm{C} 12=-23.6$ :lab. $\mathrm{mult}=1$ )

Laboratory number: Beta-235816

Conventional radiocarbon age: $2010 \pm 40 \mathrm{BP}$

2 Sigma calibrated result: Cal BC 100 to Cal AD 70 (Cal BP 2050 to 1880) (95\% probability)

Intercept data

Intercept of radiocarbon age

with calibration curve: Cal BC 10 (Cal BP 1960)

1 Sigma calibrated result: Cal BC 50 to Cal AD 30 (Cal BP 2000 to 1920) (68\% probability)

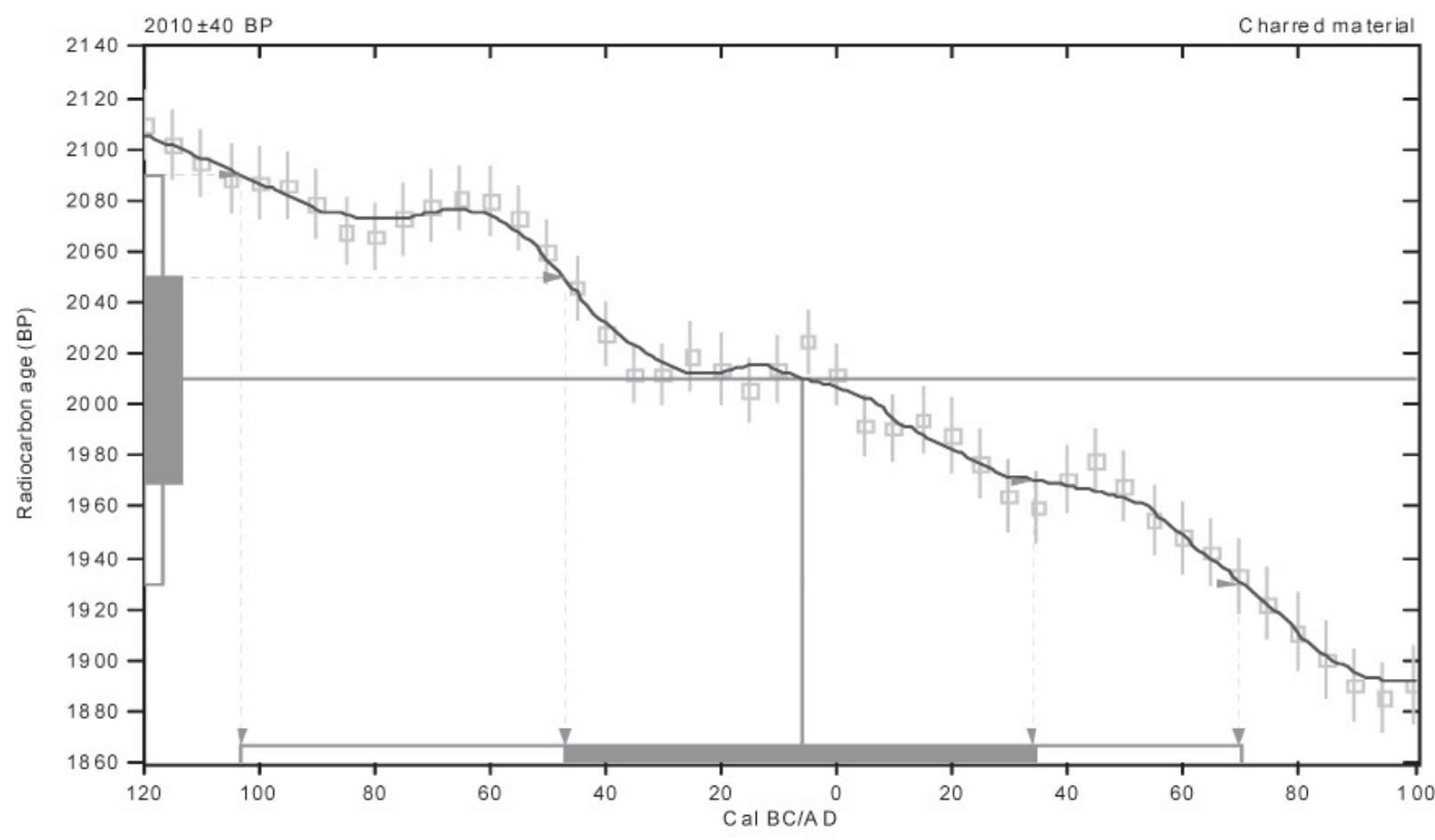

References:

Database used INTCA LO 4

Ca lib ration D ata base

INTCAL04 Radiocarbon Age Calibration

IntCal0 4: Calibration Is sue of Radio carbon (Volume 46, nr 3, 2004).

Ma them a tics

A Simplified A pproach to Calibrating C14 D ates Talma, A. S., Vogel, J. C., 1993, Radiocarbon 35(2), p317-322 


\section{CALIBRATION OF RADIOCARBON AGE TO CALENDAR YEARS}

(Variables: C13/C12=-21.3:lab. mult=1)

Laboratory number: Beta-235817

Conventional radiocarbon age: $1840 \pm 40 \mathrm{BP}$

2 Sigma calibrated result: Cal AD 80 to 250 (Cal B P 1870 to 1700)

(95\% probability)

Intercept data

Intercept of radiocarbon age

with calibration curve: Cal AD 140 (Cal BP 1810)

1 Sigma calibrated result: Cal AD 120 to 230 (Cal BP 1830 to 1720)

( $68 \%$ probability)

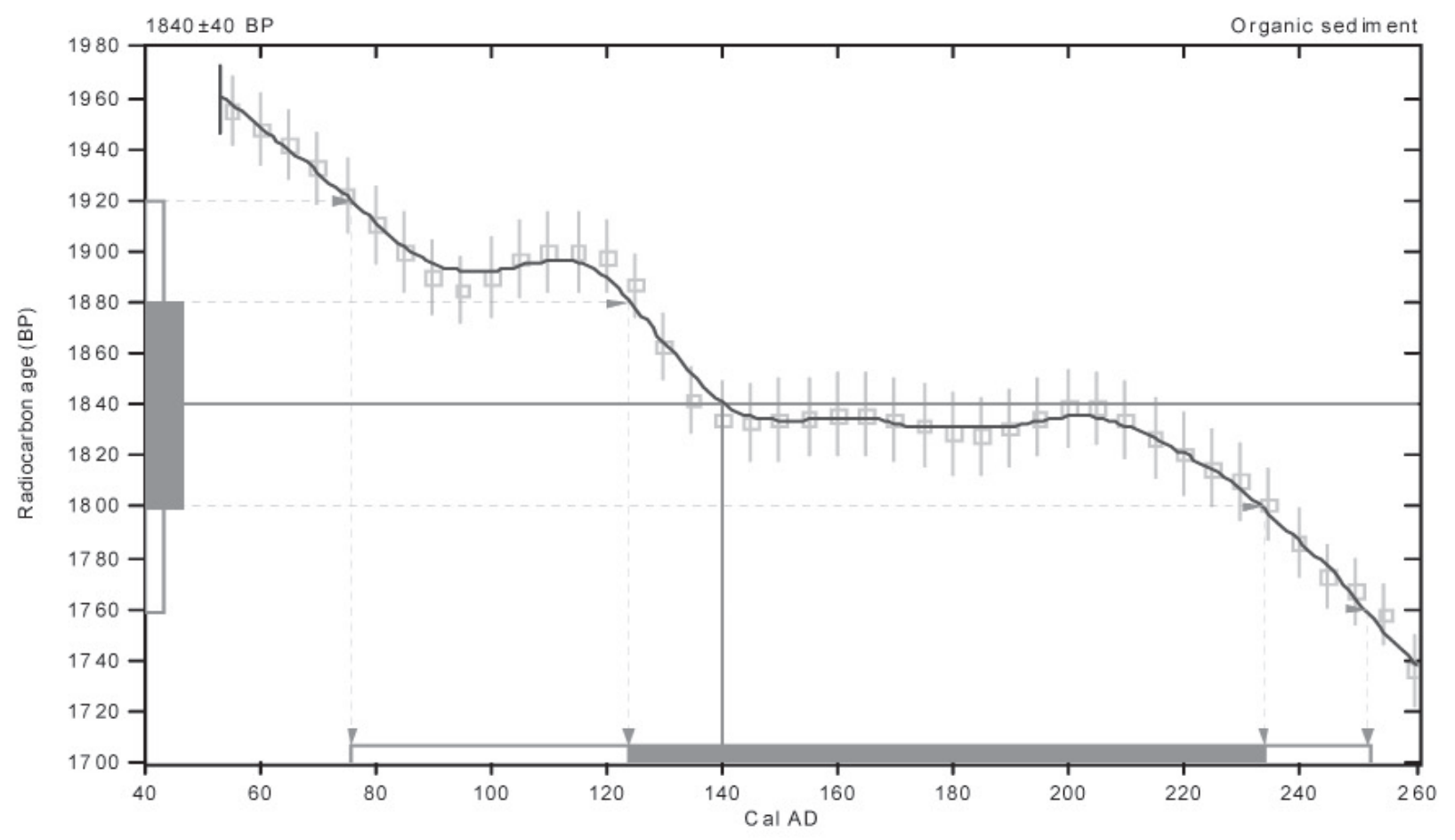

References:

Database us ed IN TCA LO 4

Calib ration $D$ ata base

INTCALO4 Radiocarbon Age Calibration

IntCal0 4: Calibration /s sue of Radio carbon (Volume 46, nr 3, 2004).

Ma them a tics

A Simplified Approach to Calibrating C14 D ates Talma, A. S., Vogel, J. C., 1993, Radiocarbon 35(2), p31 7-322

\section{Beta Analytic Radiocarbon Dating Laboratory}

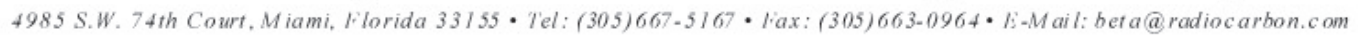




\section{CALIBRATION OF RADIOCARBON AGE TO CALENDAR YEARS}

(Variables: $\mathrm{C} 13 / \mathrm{C} 12=-21.1$ :lab. mult $=1$ )

Laboratory number: Beta-235818

Conventional radiocarbon age: $1290 \pm 40 \mathrm{BP}$

2 Sigma calibrated result: Cal A D 660 to 780 (Cal BP 1290 to 1160)

(95\% probability)

Intercept data

Intercept of radiocarbon age

with calibration curve: Cal AD 690 (Cal BP 1260)

1 Sigma calibrated result: Cal AD 670 to 770 (Cal BP 1280 to 1180)

(68\% probability)

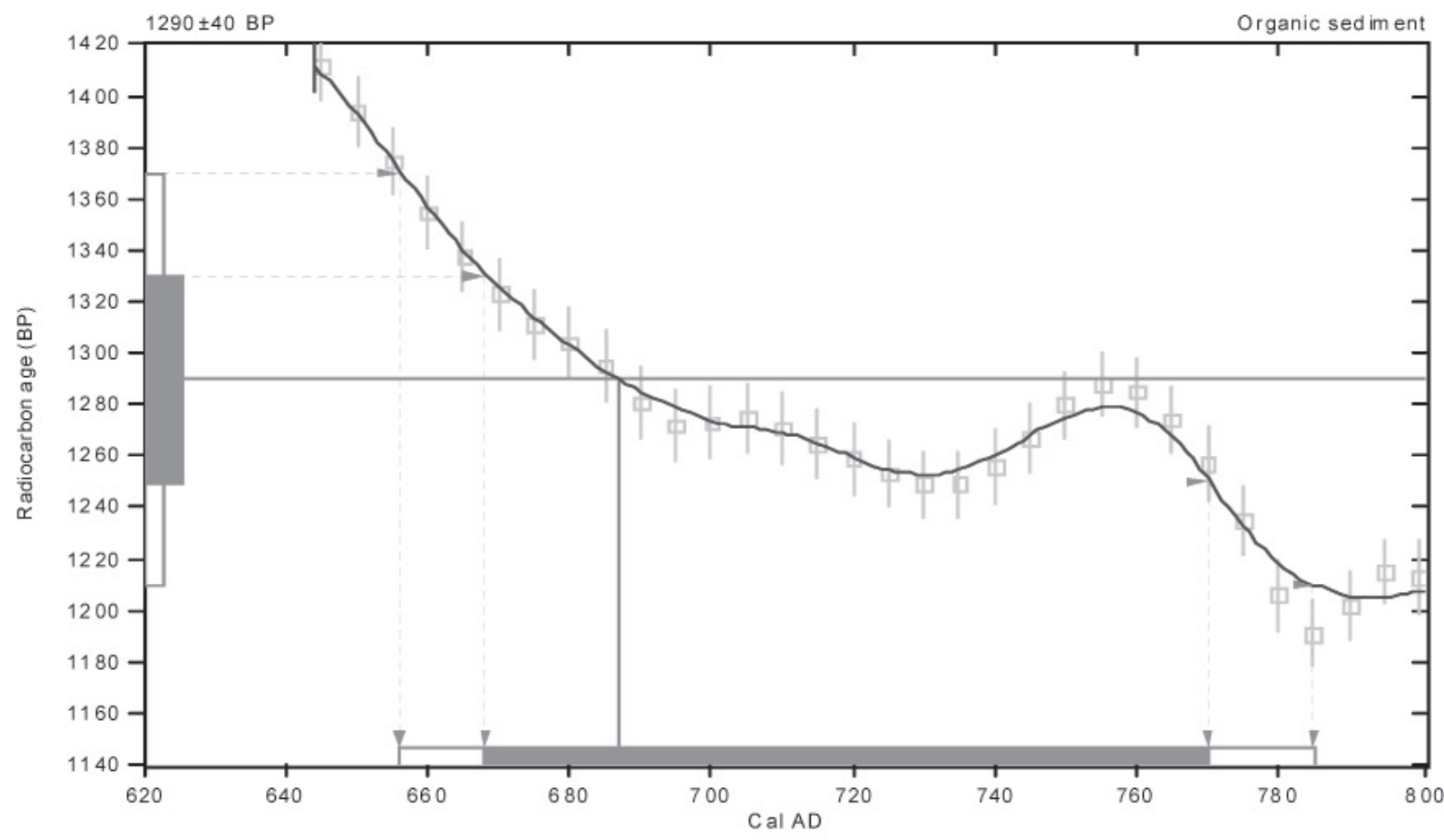

References:

Database used INTCA LO 4

Calib ration D ata base

INTCAL04 Radiocarbon Age Calibration

IntCal0 4: Calibration Is sue of Radio carbon (Volume 46, nr 3, 2004).

Ma them a tics

A Simplified A pproach to Calibrating C14 D ates Talma, A. S., Vogel, J. C., 1993, Radiocarbon 35(2), p317-322 


\section{CALIBRATION OF RADIOCARBON AGE TO CALENDAR YEARS}

(Variables: C13/C12=-22.1:lab. $\mathrm{mult}=1$ )

Laboratory number: Beta-235820

Conventional radiocarbon age: $2830 \pm 50 \mathrm{BP}$

2 Sigma calibrated results: Cal BC 1120 to 890 (Cal BP 3070 to 2840) and

(95\% probability) Cal BC 870 to 850 (Cal B P 2820 to 2800)

Intercept data

Intercept of radiocarbon age

with calibration curve: Cal BC 1000 (Cal B P 2940)

1 Sigma calibrated result: Cal BC 1040 to 920 (Cal BP 2990 to 2870)

( $68 \%$ probability)

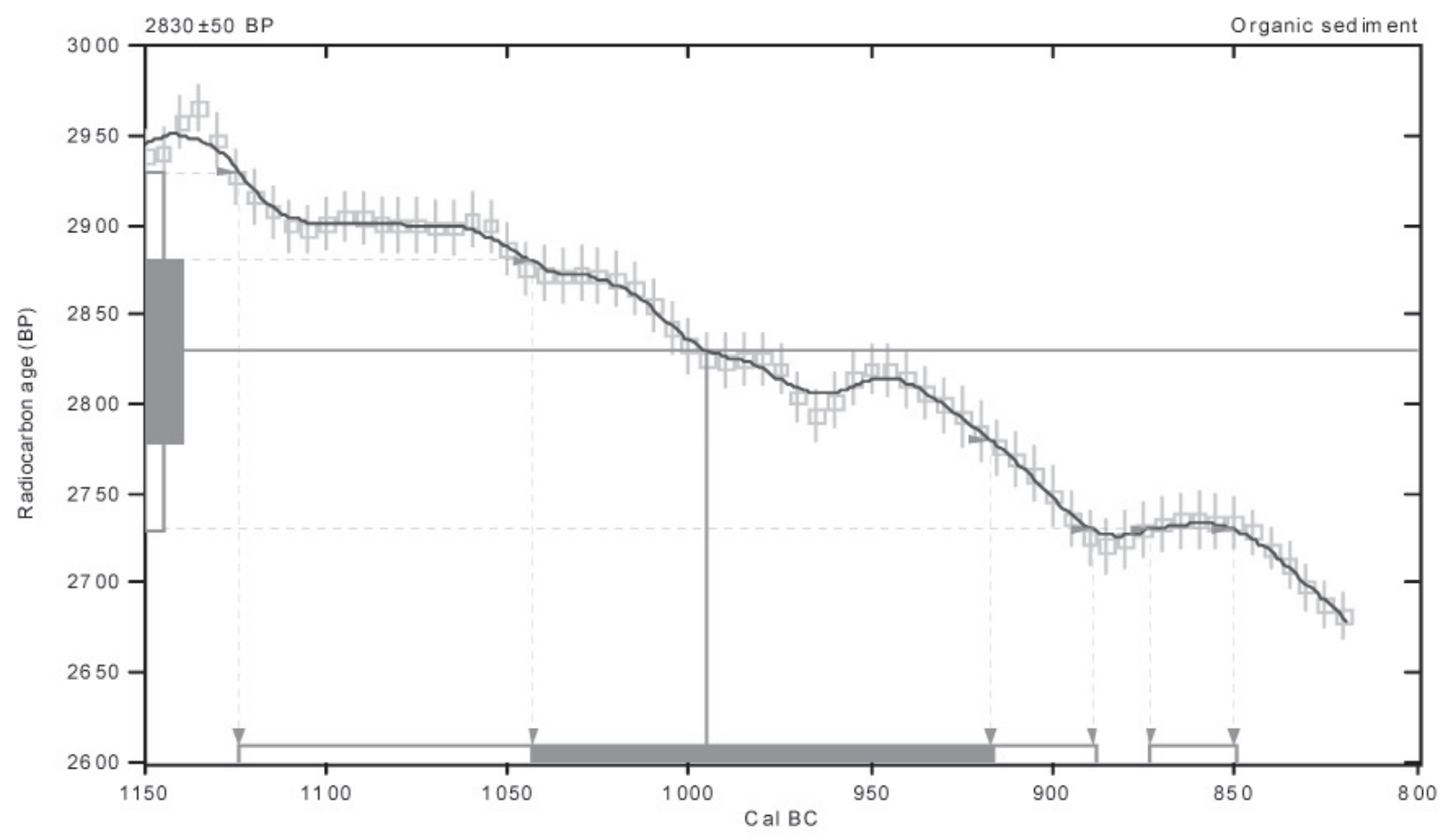

References:

Databas e us ed

IN TCA LO 4

Calib ration D atabase

INTCALO4 Radiocarbon Age Calibration

IntCal0 4: Calibration Is sue of Radio carbon (Volume 46, nr 3, 2004 ).

Ma them a tics

A Simplified Approach to Calibrating C14 D ates

Talma, A. S., Vogel, J. C., 1993, Radiocarbon 35(2), p31 7-322

\section{Beta Analytic Radiocarbon Dating Laboratory}

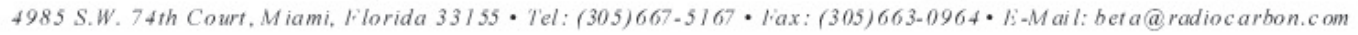




\section{CALIBRATION OF RADIOCARBON AGE TO CALENDAR YEARS}

(Variables: $\mathrm{C} 13 / \mathrm{C} 12=-25.8:$ lab. $\mathrm{mult}=1$ )

Laboratory number: Beta-235821

Conventional radiocarbon age: $2510 \pm 40 \mathrm{BP}$

2 Sigma calibrated result: Cal BC 790 to 510 (Cal B P 2740 to 2460)

(95\% probability)

Intercept data

Intercepts of radiocarbon age

with calibration curve: Cal BC $760(\mathrm{Cal} \mathrm{BP} 2710)$ and

Cal BC 680 (Cal BP 2630) and

Cal BC 670 (Cal BP 2620)

1 Sigma calibrated results: Cal BC 780 to 730 (Cal B P 2730 to 2680) and ( $68 \%$ probability) Cal BC 690 to 540 (Cal BP 2640 to 2500 )

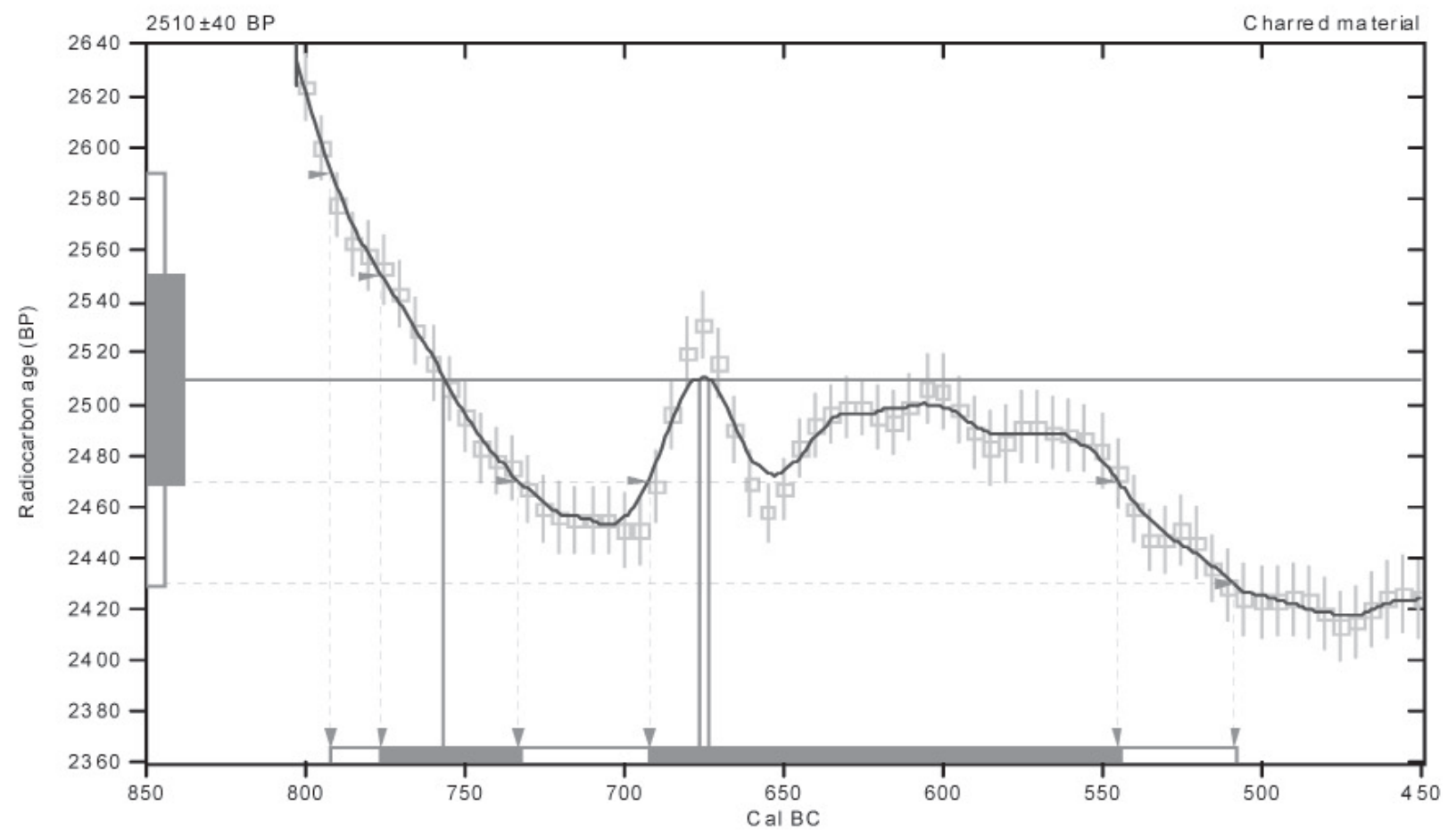

References:

Databas e us ed INTCA LO 4

Calib ration $D$ ata base

INTCAL04 Radiocarbon Age Calibration

Math em a tics

A Simplified A pproach to Calibrating C14 D ates Talma, A. S., Vogel, J. C., 1993, Radiocarb on 35(2), p31 7-322 


\section{CALIBRATION OF RADIOCARBON AGE TO CALENDAR YEARS}

(Variables: C13/C12=-21.1:lab. mult=1)

Laboratory number: Beta-235822

Conventional radiocarbon age: $1900 \pm 40 \mathrm{BP}$

2 Sigma calibrated result: Cal AD 20 to 220 (Cal B P 1930 to 1730)

(95\% probability)

Intercept data

Intercept of radiocarbon age

with calibration curve: Cal AD 90 (Cal B P 1860)

1 Sigma calibrated result: Cal AD 60 to 130 (Cal BP 1880 to 1820) ( $68 \%$ probability)

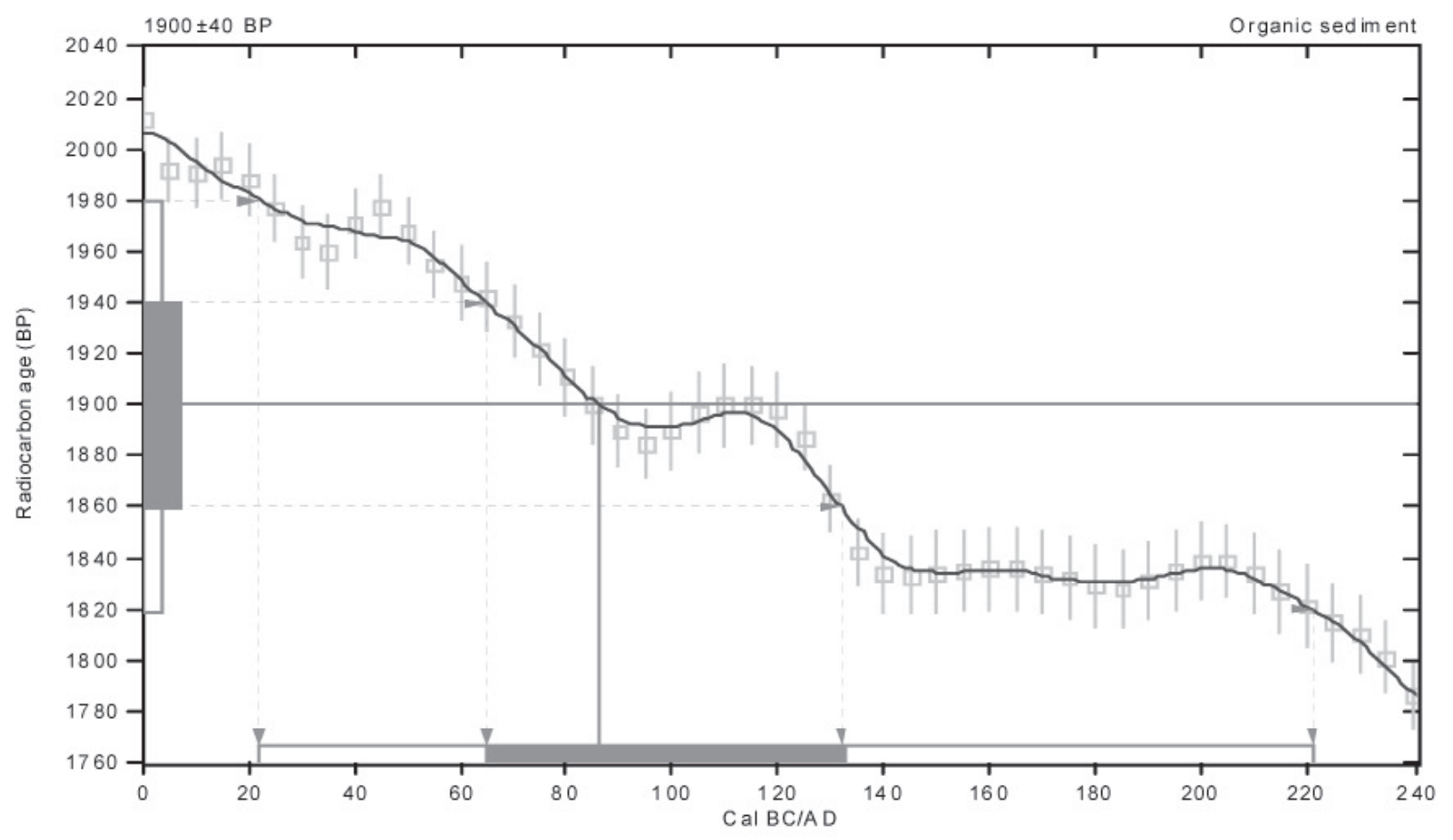

References:

Databas e us ed IN TCA LO 4

Calib ration $D$ ata base

INTCALO4 Radiocarbon Age Calibration

IntCal0 4: Calibration Issue of Radio carbon (Volume 46, nr 3, 200 4).

Ma them a tics

A Simplified Approach to Calibrating C 14 D ates Talma, A.S., Vogel, J. C., 1993, Radiocarbon 35(2), p317-322

\section{Beta Analytic Radiocarbon Dating Laboratory}

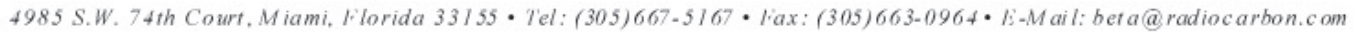




\section{CALIBRATION OF RADIOCARBON AGE TO CALENDAR YEARS}

(Variables: $\mathrm{C} 13 / \mathrm{C} 12=-23.8$ :lab. $\mathrm{mult}=1$ )

Laboratory number: Beta-235823

Conventional radiocarbon age: $1940 \pm 40 \mathrm{BP}$

2 Sigma calibrated result: Cal BC 30 to Cal AD 130 (Cal BP 1980 to 1820) (95\% probability)

Intercept data

Intercept of radiocarbon age

with calibration curve: Cal AD 60 (Cal BP 1880)

1 Sigma calibrated result: Cal AD 20 to 90 (Cal BP 1930 to 1860)

(68\% probability)

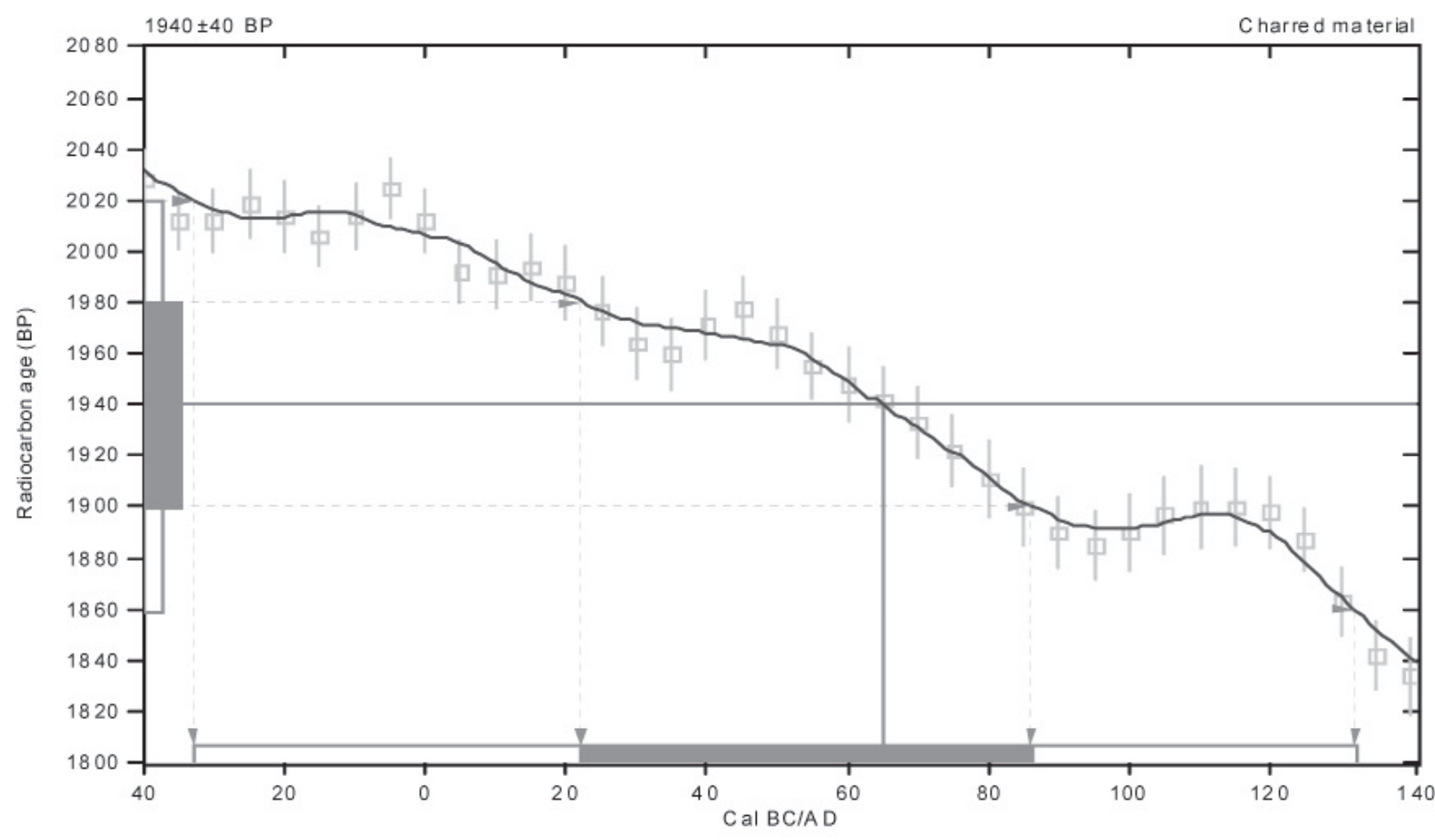

References:

Database used IN TCA LO 4

Calib ration D ata base

INTCAL04 Radiocarbon Age Calibration

IntCal0 4: Calibration Issue of Radio carbon (Volume 46, nr 3, 2004).

Ma th em a tics

A Simplified A pproach to Calibrating C14 D ates Talma, A. S., Vogel, J. C., 1993, Radiocarbon 35(2), p317-322 


\section{CALIBRATION OF RADIOCARBON AGE TO CALENDAR YEARS}

(Variables: C13/C12=-18:1ab. mult $=1$ )

Laboratory number: Beta-235824

Conventional radiocarbon age: $2120 \pm 40 \mathrm{BP}$

2 Sigma calibrated results: Cal BC 350 to 300 (Cal B P 2300 to 2260) and

(95\% probability) Cal BC 210 to 40 (C al BP 2160 to 1990)

Intercept data

Intercept of radiocarbon age

with calibration curve: Cal BC 170 (Cal BP 2120)

1 Sigma calibrated result: Cal BC 200 to 90 (Cal BP 2150 to 2040)

(68\% probability)

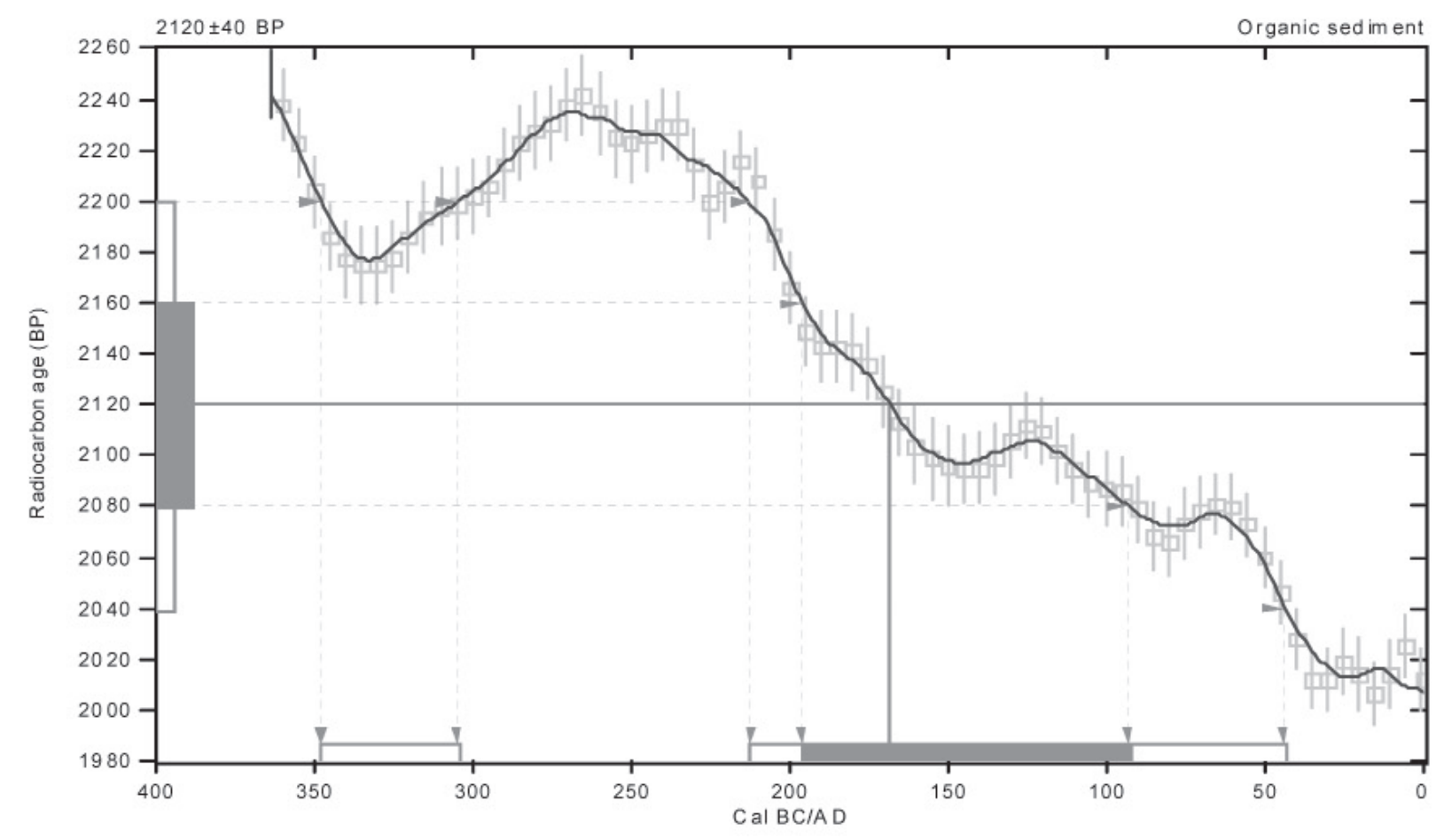

References:

Databas e us ed

IN TCA LO 4

Calib ration D atabase

INTCALO4 Radiocarbon Age Calibration

IntCal0 4: Calibration Is sue of Radio carbon (Volume 46, nr 3, 2004 ).

Ma them a tics

A Simplified Approach to Calibrating C14 D ates

Talma, A. S., Vogel, J. C., 1993, Radiocarbon 35(2), p31 7-322

Beta Analytic Radiocarbon Dating Laboratory

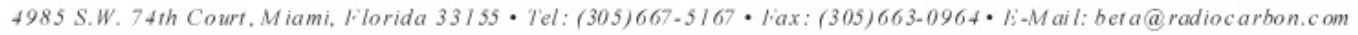




\section{CALIBRATION OF RADIOCARBON AGE TO CALENDAR YEARS}

(Variables: C13/C12=-18.3:lab. mult=1)

Laboratory number: Beta-235825

Conventional radiocarbon age: $1470 \pm 40 \mathrm{BP}$

2 Sigma calibrated result: Cal AD 540 to 650 (Cal BP 1410 to 1300)

(95\% probability)

Intercept data

Intercept of radiocarbon age

with calibration curve: Cal AD 600 (Cal BP 1350)

1 Sigma calibrated result: Cal AD 560 to 640 (Cal BP 1390 to 1320) ( $68 \%$ probability)

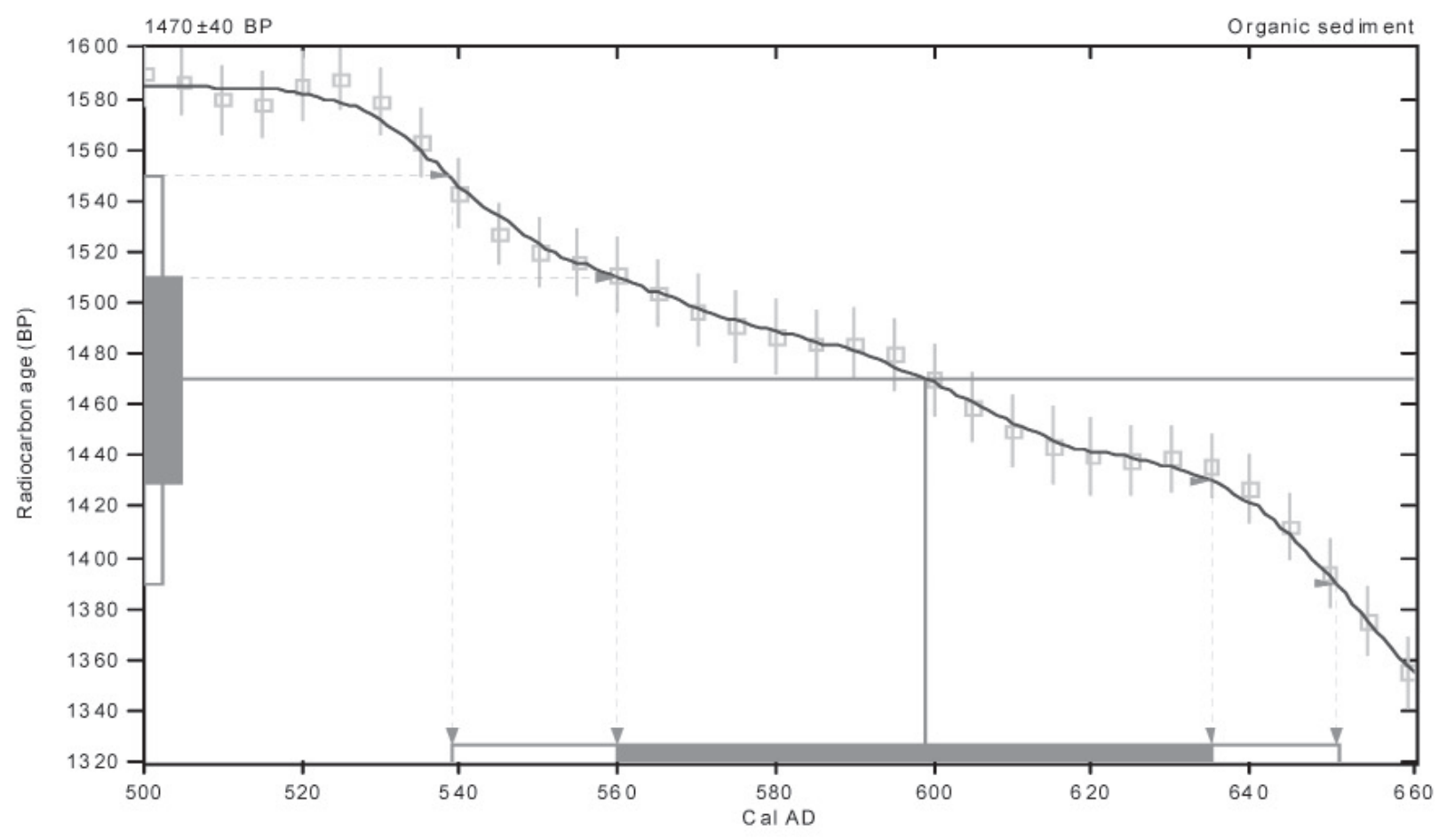

References:

Data bas e us ed

INT CA LO 4

Calib ration $D$ ata base

INTCALO4 Radiocarbon Age Calibration

IntCal0 4: Calibration Is sue of Radiocarbon (Volume 46, nr 3, 2004).

Ma th em a tics

A Simplified A pproach to Calibrating C14 D ates

Talma, A.S., Vogel, J. C., 1993, Radiocarbon 35(2), p31 7-322 


\section{CALIBRATION OF RADIOCARBON AGE TO CALENDAR YEARS}

(Variables: $\mathrm{C} 13 / \mathrm{C} 12=-23.7:$ lab. $\mathrm{mult}=1$ )

Laboratory number: Beta-235826

Conventional radiocarbon age: $3300 \pm 40 \mathrm{BP}$

2 Sigma calibrated result: Cal BC 1680 to 1500 (Cal B P 3630 to 3440)

(95\% probability)

Intercept data

Intercepts of radiocarbon age

with calibration curve:

Cal BC 1600 (Cal BP 3550$)$ and

Cal BC 1570 (Cal BP 3520$)$ and

Cal BC 1540 (Cal BP 3490)

1 Sigma calibrated result: Cal BC 1620 to 1520 (Cal BP 3570 to 3470 ) (68\% probability)

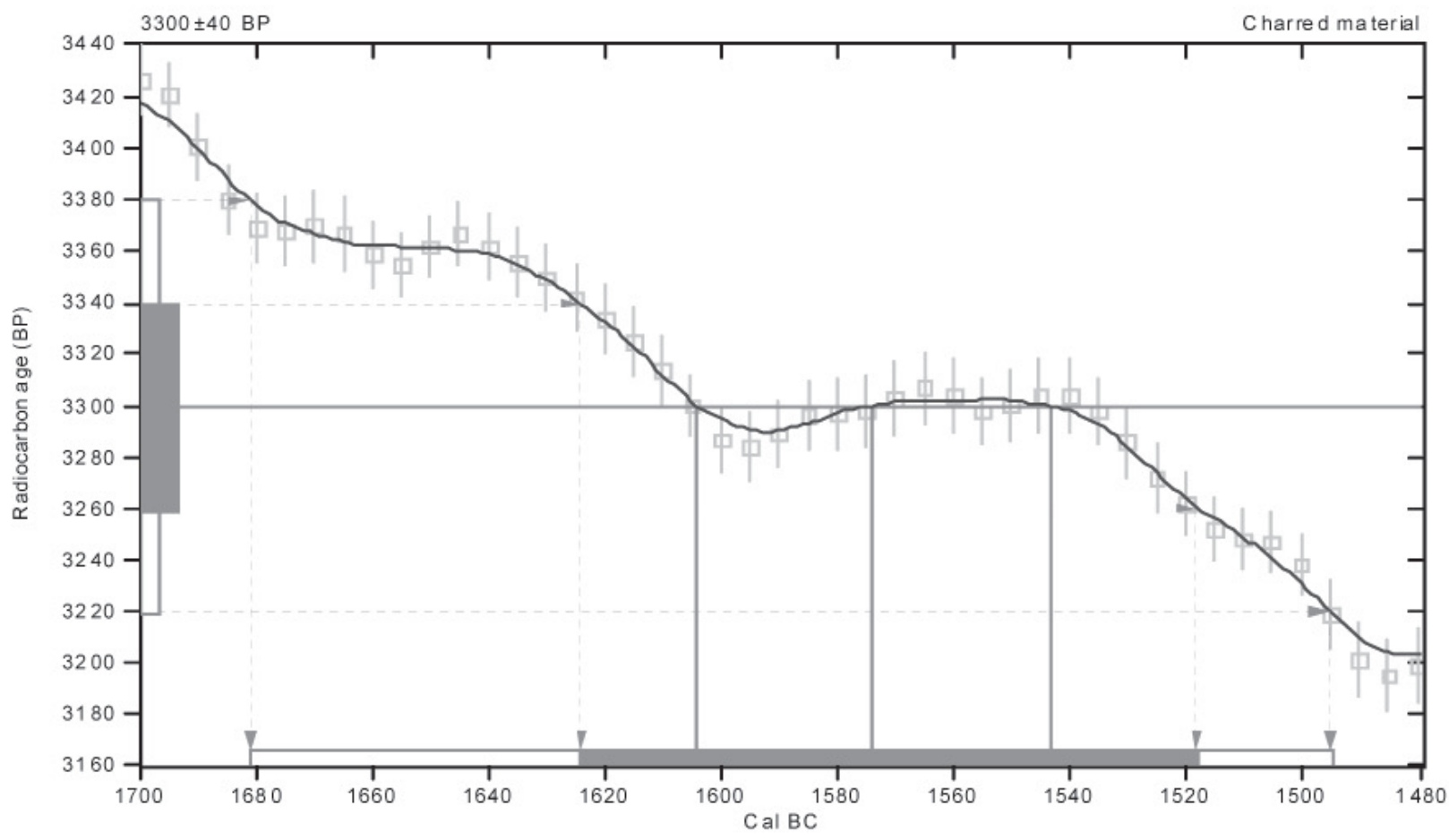

References:

Database us ed INTCALO 4

Ca lib ration $D$ ata base

INTCAL04 Radiocarbon Age Calibration

IntCal0 4: Calibration /s sue of Radio carbon (Volume 46, nr 3, 2004).

Ma them a tics

A Simplified Approach to Calibrating C14 D ates

Talma, A. S., Vogel, J. C., 1993, Radiocarbon 35(2), p317-322

Beta Analytic Radiocarbon Dating Laboratory

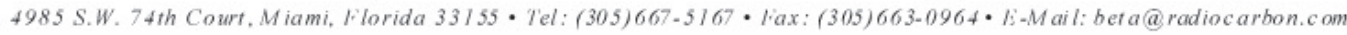




\section{CALIBRATION OF RADIOCARBON AGE TO CALENDAR YEARS}

(Variables: C13/C12=-19.1:lab. mult =1)

Laboratory number: Beta-235827

Conventional radiocarbon age: $2610 \pm 40 \mathrm{BP}$

2 Sigma calibrated result: Cal BC 820 to 760 (Cal B P 2770 to 2720)

(95\% probability)

Intercept data

Intercept of radiocarbon age

with calibration curve: Cal BC 800 (Cal BP 2750)

1 Sigma calibrated result: Cal BC 810 to 780 (Cal BP 2760 to 2740)

(68\% probability)

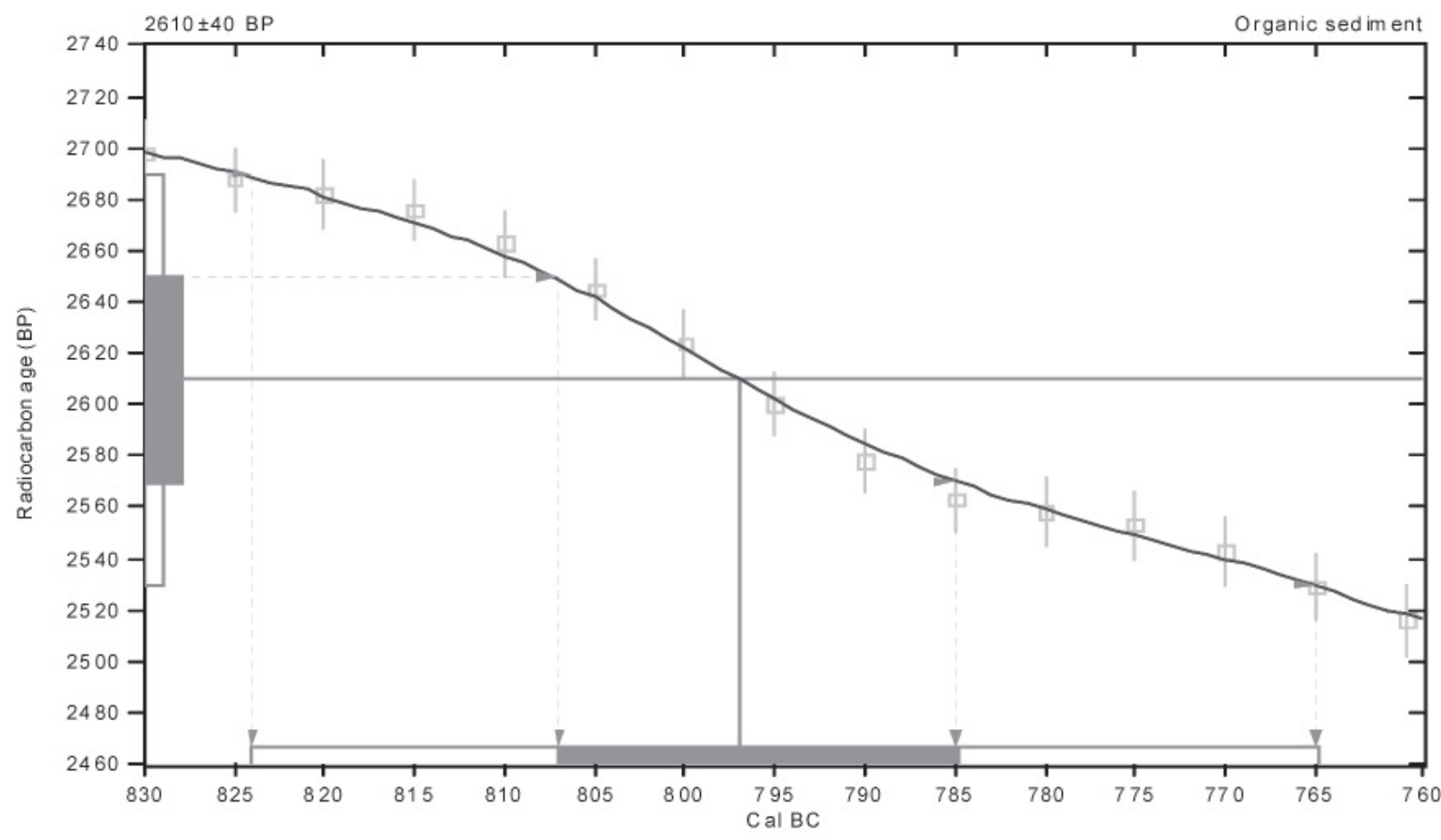

References:

Database used INTCA LO 4

Calib ration D ata base

INTCAL04 Radiocarbon Age Calibration

IntCal0 4: Calibration Is sue of Radio carbon (Volume 46, nr 3, 2004).

Ma th em a tics

A Simplified Approach to Calibrating C14 D ates

Talma, A. S., Vogel, J. C., 1993, Radiocarbon 35(2), p317-322

Beta Analytic Radiocarbon Dating Laboratory

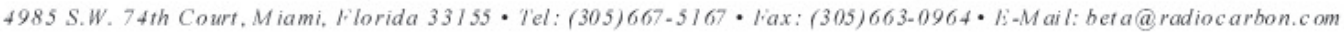




\section{CALIBRATION OF RADIOCARBON AGE TO CALENDAR YEARS}

(Variables: C13/C12=-23.3:lab. mult =1)

Laboratory number: Beta-235828

Conventional radiocarbon age: $2470 \pm 40 \mathrm{BP}$

2 Sigma calibrated result:

Cal BC 780 to 410 (Cal BP 2730 to 2360$)$

( $95 \%$ probability)

Intercept data

Intercepts of radiocarbon age with calibration curve:

Cal BC $730(\mathrm{Cal}$ BP 2680) and

Cal BC 690 (Cal BP 2640) and

Cal BC 540 (Cal BP 2500)

1 Sigma calibrated results: Cal BC 760 to 680 (Cal B P 2710 to 2630) and ( $68 \%$ probability) Cal BC 670 to 510 (Cal BP 2620 to 2460$)$

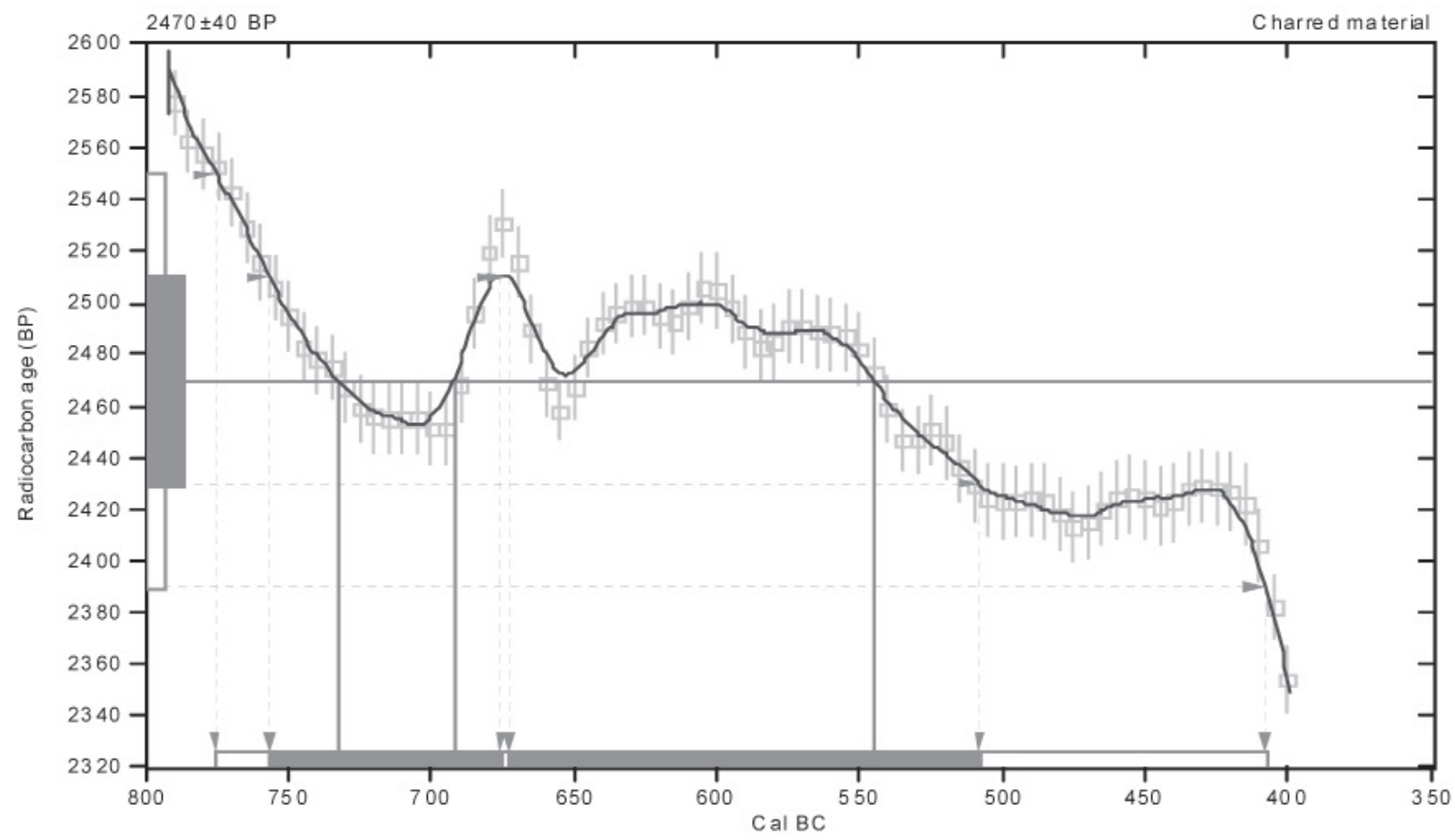

References:

Databas e us ed INTCA LO 4

Calib ration $D$ ata base

INTCALO4 Radiocarbon Age Calibration

IntCal0 4: Calibration Issue of Radio carbon (Volume 46, nr 3, 200 4).

Ma them a tics

A Simplified Approach to Calibrating C14 Dates Talma, A. S., Vogel, J. C., 1993, Radiocarbon 35(2), p31 7-322 


\section{CALIBRATION OF RADIOCARBON AGE TO CALENDAR YEARS}

(Variables: $\mathrm{C} 13 / \mathrm{C} 12=-25.7:$ lab. $\mathrm{mult}=1$ )

Laboratory number: Beta-235829

Conventional radiocarbon age: $2180 \pm 40 \mathrm{BP}$

2 Sigma calibrated results: Cal BC 370 to 150 (Cal BP 2320 to 2100 ) and

(95\% probability) Cal BC 140 to 110 (Cal B P 2090 to 2060)

Intercept data

Intercepts of radiocarbon age

with calibration curve: Cal BC 340 (Cal BP 2290) and

Cal BC 330 (Cal BP 2280) and

Cal BC 200 (Cal BP 2150)

1 Sigma calibrated results: Cal BC 360 to 290 (Cal BP 2300 to 2240) and

( $68 \%$ probability) Cal BC 240 to 180 (Cal BP 2180 to 2130 )

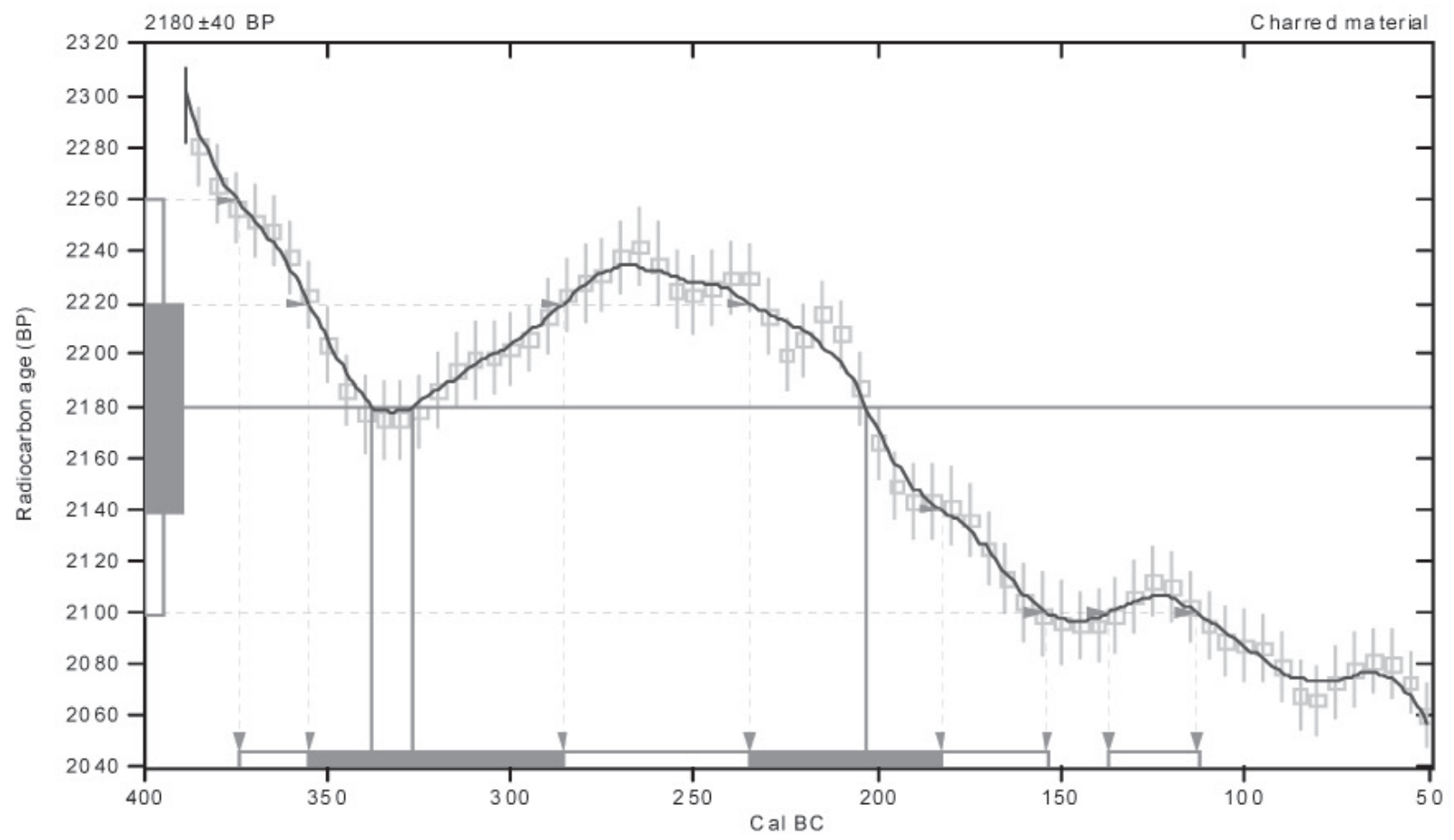

References:

Data bas e us ed

INT CA LO 4

Calib ration $D$ ata base

INTCALO4 Radiocarbon Age Calibration

IntCal0 4: Calibration Is sue of Radiocarbon (Volume 46, nr 3, 2004).

Ma them a tics

A Simplified A pproach to Calibrating C14 D ates Talma, A.S., Vogel, J. C., 1993, Radiocarbon 35(2), p31 7-322 


\section{CALIBRATION OF RADIOCARBON AGE TO CALENDAR YEARS}

(Variables: $\mathrm{C} 13 / \mathrm{C} 12=-23.9:$ lab. $\mathrm{mult}=1$ )

Laboratory number: Beta-235830

Conventional radiocarbon age: $1140 \pm 40 \mathrm{BP}$

2 Sigma calibrated result: Cal AD 780 to 990 (Cal BP 1170 to 960)

( $95 \%$ probability)

Intercept data

Intercept of radiocarbon age

with calibration curve: Cal AD 890 (Cal BP 1060)

1 Sigma calibrated result: Cal AD 880 to 970 (Cal BP 1070 to 980)

(68\% probability)

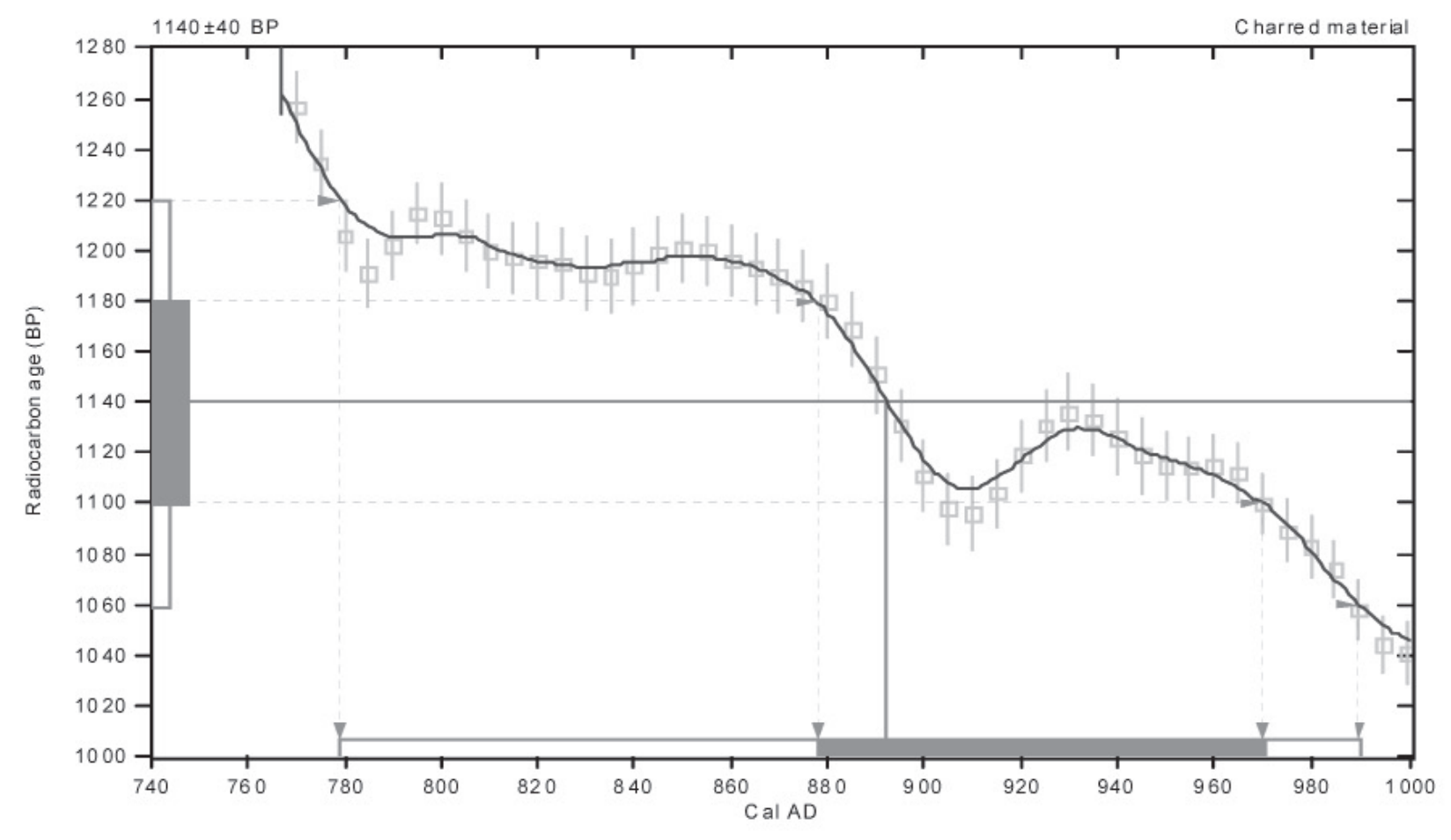

References:

Database us ed

IN TCA LO 4

Ca lib ration $D$ ata base

INTCALO4 Radiocarbon Age Calibration

IntCal0 4: Calibration /s sue of Radio carbon (Volume 46, nr 3, 2004).

Ma them a tics

A Simplified A pproach to Calibrating C14 D ates

Talma, A. S., Vogel, J. C., 1993, Radiocarbon 35(2), p317-322

\section{Beta Analytic Radiocarbon Dating Laboratory}

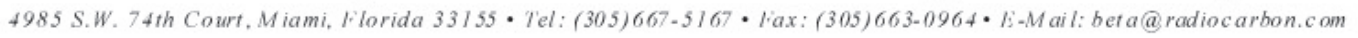




\section{CALIBRATION OF RADIOCARBON AGE TO CALENDAR YEARS}

(Variables: $\mathrm{C} 13 / \mathrm{C} 12=-18.8$ :lab. $\mathrm{mult}=1$ )

Laboratory number: Beta-235831

Conventional radiocarbon age: $2140 \pm 40 \mathrm{BP}$

2 Sigma calibrated results: Cal BC 360 to 290 (Cal B P 2300 to 2240) and (95\% probability) Cal BC 240 to 50 (C al B P 2180 to 2000)

Intercept data

Intercept of radiocarbon age

with calibration curve: Cal BC 180 (Cal BP 2130)

1 Sigma calibrated results: Cal BC 340 to 330 (Cal B P 2290 to 2280) and

(68\% probability) Cal BC 200 to 150 (Cal B P 2150 to 2100$)$ and

Cal BC 140 to 110 (Cal BP 2090 to 2060)

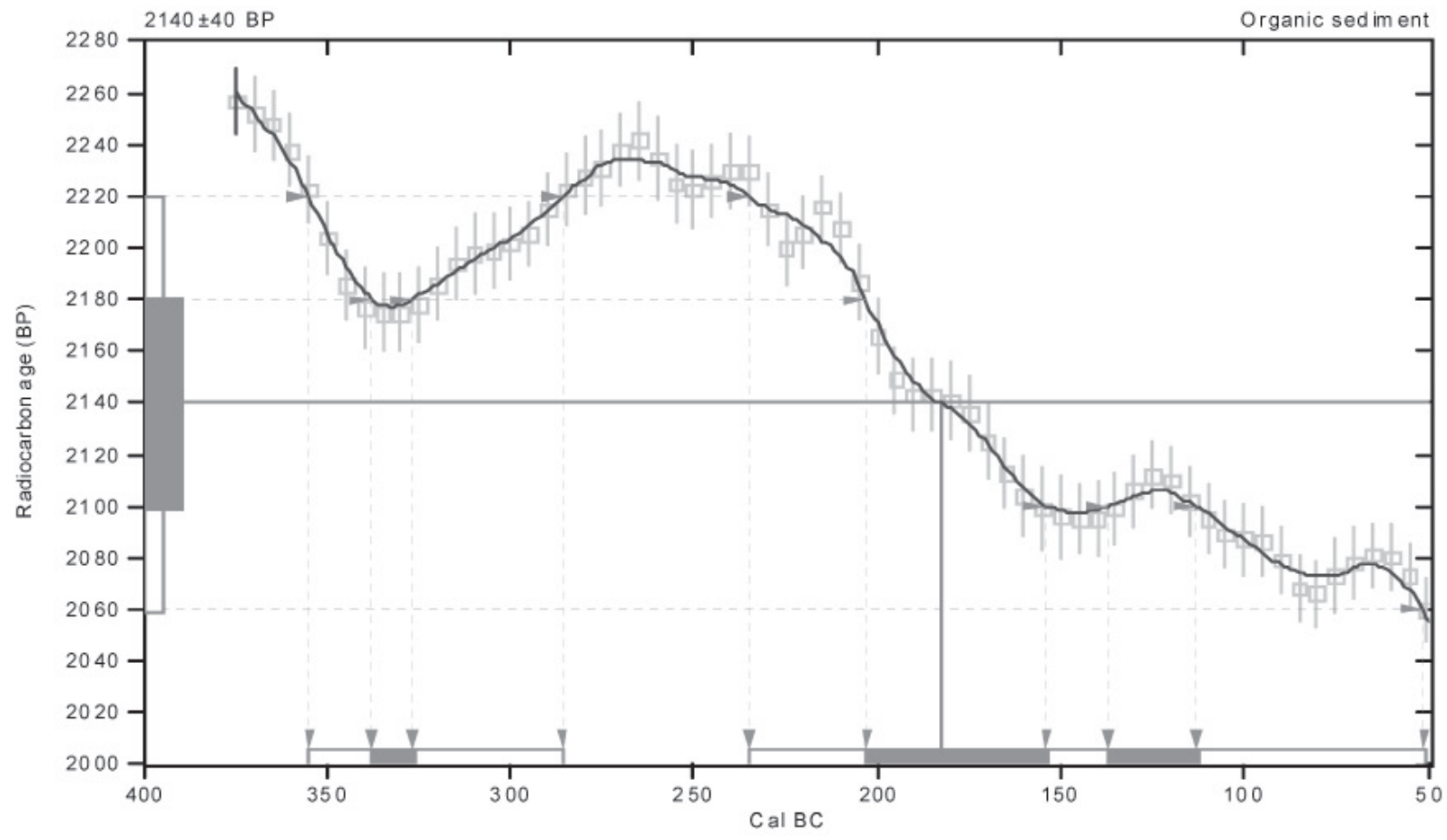

References:

Database used IN TCA LO 4

Ca lib ration D ata base

INTCAL04 Radiocarbon Age Calibration

Math em a tics

A Simplified A pproach to Calibrating C14 D ates Talma, A. S., Vogel, J. C., 1993, Radiocarbon 35(2), p31 7-322 


\section{CALIBRATION OF RADIOCARBON AGE TO CALENDAR YEARS}

(Variables: C13/C12=-19.3:lab. mult=1)

Laboratory number: Beta-235832

Conventional radiocarbon age: $2370 \pm 40 \mathrm{BP}$

2 Sigma calibrated result: Cal BC 530 to 390 (Cal B P 2480 to 2340)

(95\% probability)

Intercept data

Intercept of radiocarbon age

with calibration curve:

1 Sigma calibrated result: Cal BC 410 to 400 (Cal BP 2360 to 2340)

(68\% probability)

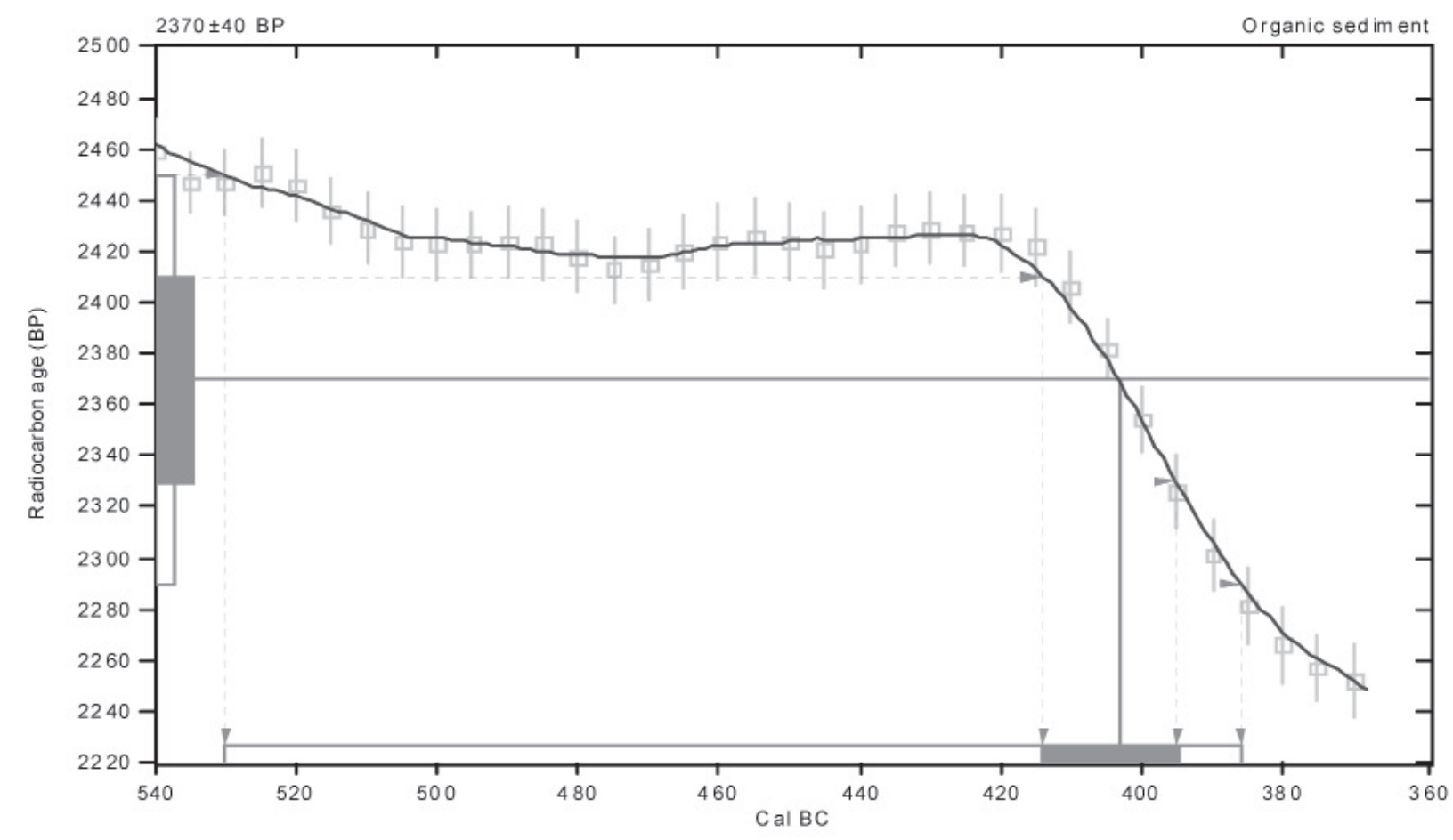

References:

Database us ed IN TCA LO 4

Calib ration $D$ ata base

INTCALO4 Radiocarbon Age Calibration

IntCal0 4: Calibration Is sue of Radio carbon (Volume 46, nr 3, 2004 ).

Ma them a tics

A Simplified A pproach to Calibrating C14 Dates Talma, A. S., Vogel, J. C., 1993, Radiocarbon 35(2), p31 7-322

\section{Beta Analytic Radiocarbon Dating Laboratory}

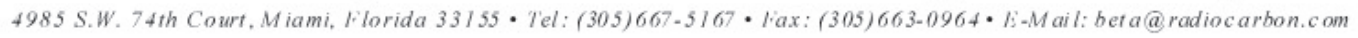




\section{CALIBRATION OF RADIOCARBON AGE TO CALENDAR YEARS}

(Variables: $\mathrm{C} 13 / \mathrm{C} 12=-22.6$ :lab. $\mathrm{mult}=1$ )

Laboratory number: Beta-235833

Conventional radiocarbon age: $2060 \pm 40 \mathrm{BP}$

2 Sigma calibrated result: Cal BC 180 to Cal AD 20 (Cal B P 2130 to 1930) (95\% probability)

Intercept data

Intercept of radiocarbon age

with calibration curve: Cal BC 50 (Cal BP 2000)

1 Sigma calibrated results: Cal BC 150 to 140 (Cal B P 2100 to 2090) and

(68\% probability) Cal BC 110 to 30 (Cal BP 2060 to 1980 )

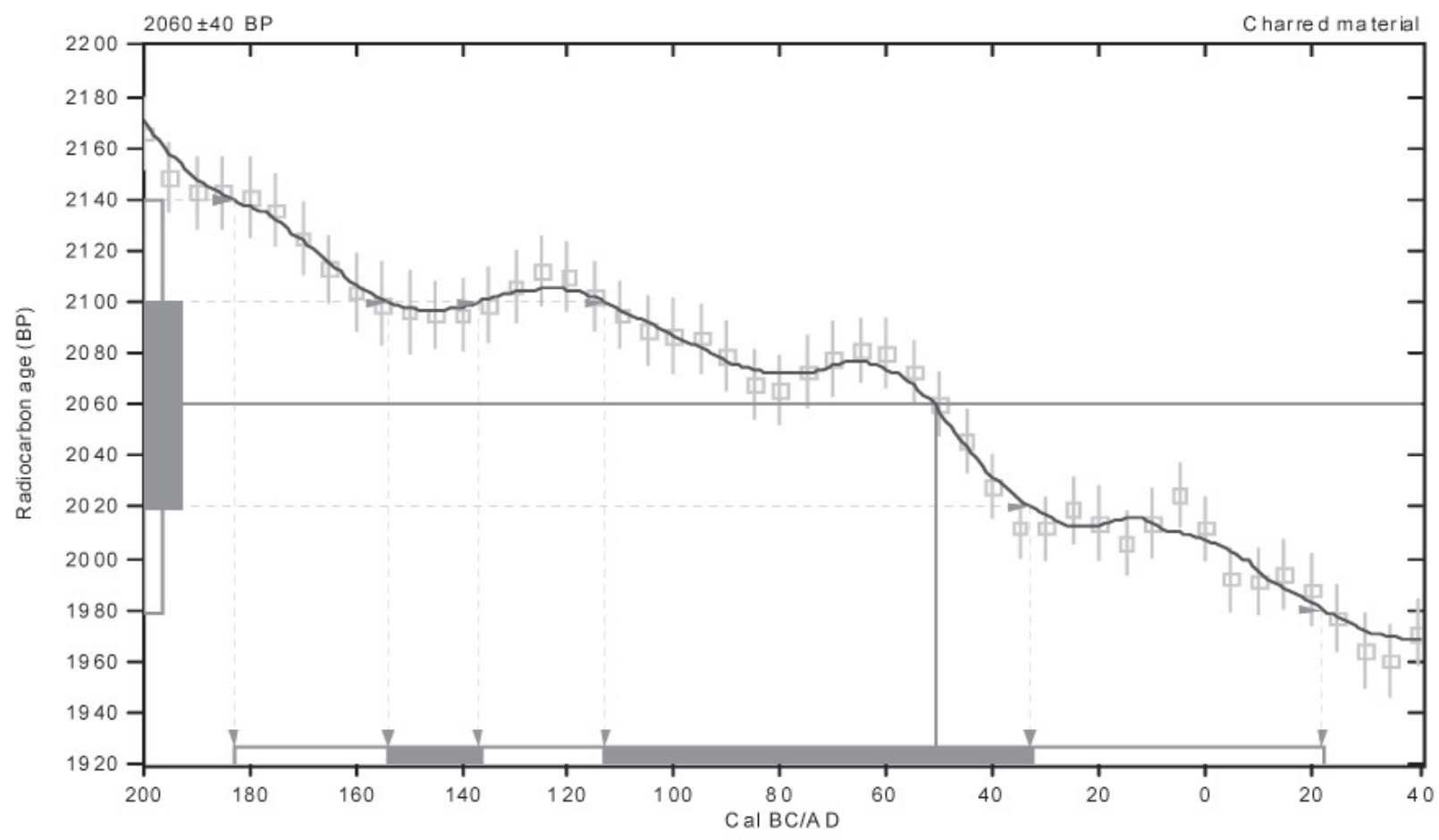

References:

Databas e us ed INTCA LO 4

Ca lib ration $D$ ata base

INTCAL04 Radiocarbon Age Calibration

IntCal0 4: Calibration Is sue of Radio carbon (Volume 46, nr 3, 2004).

Ma them a tics

A Simplified Approach to Calibrating C14 D ates Talma, A. S., Vogel, J. C., 1993, Radiocarbon 35(2), p317-322 


\section{CALIBRATION OF RADIOCARBON AGE TO CALENDAR YEARS}

(Variables: C13/C12=-24.1:lab. mult=1)

Laboratory number: Beta-235834

Conventional radiocarbon age: $2450 \pm 50 \mathrm{BP}$

2 Sigma calibrated result: Cal BC 780 to 400 (Cal B P 2730 to 2350)

(95\% probability)

Intercept data

Intercept of radiocarbon age

with calibration curve:

1 Sigma calibrated results: Cal BC 750 to 680 (Cal B P 2700 to 2630) and

(68\% probability) Cal BC 670 to 610 (Cal B P 2620 to 2560$)$ and

Cal BC 600 to 410 (Cal BP 2560 to 2360 )

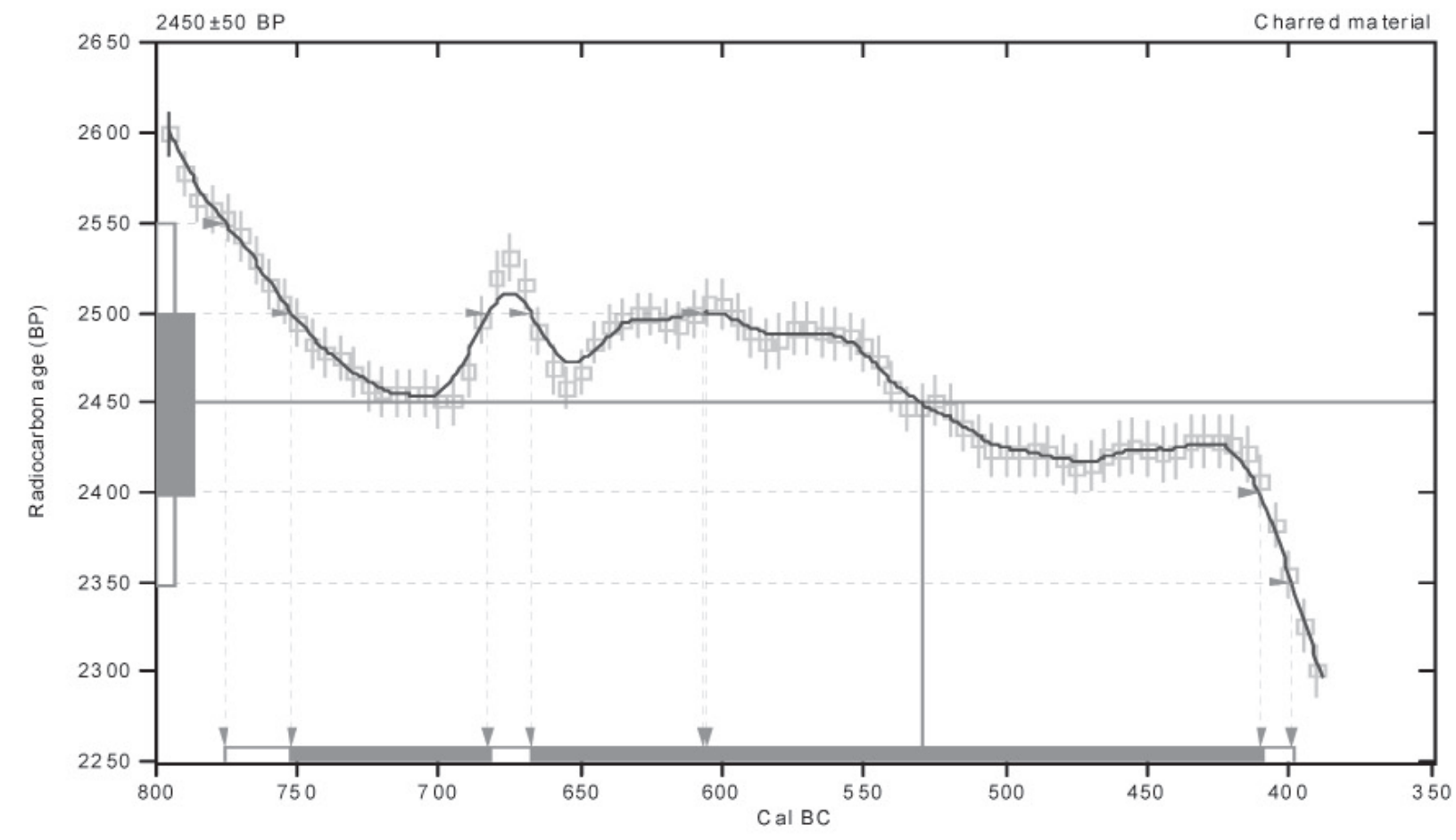

References:

Database us ed

IN TCA LO 4

Calib ration D atabase

INTCALO4 Radiocarbon Age Calibration

IntCal0 4: Calibration /s sue of Radio carbon (Volume 46, nr 3, 2004).

Ma them a tics

A Simplified Approach to Calibrating C14 D ates

Talma, A. S., Vogel, J. C., 1993, Radiocarbon 35(2), p31 7-322

\section{Beta Analytic Radiocarbon Dating Laboratory}

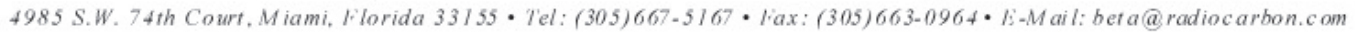




\section{CALIBRATION OF RADIOCARBON AGE TO CALENDAR YEARS}

(Variables: $\mathrm{C} 13 / \mathrm{C} 12=-23.9:$ lab. $\mathrm{mult}=1$ )

Laboratory number: Beta-235835

Conventional radiocarbon age: $2440 \pm 40 \mathrm{BP}$

2 Sigma calibrated result: Cal BC 760 to 400 (Cal B P 2710 to 2350)

(95\% probability)

Intercept data

Intercept of radiocarbon age

with calibration curve: Cal BC 520 (Cal BP 2470)

1 Sigma calibrated results: Cal BC 740 to 690 (Cal BP 2690 to 2640) and

(68\% probability) Cal BC 660 to 640 (Cal B P 2610 to 2590) and

Cal BC 550 to 410 (Cal BP 2500 to 2360 )

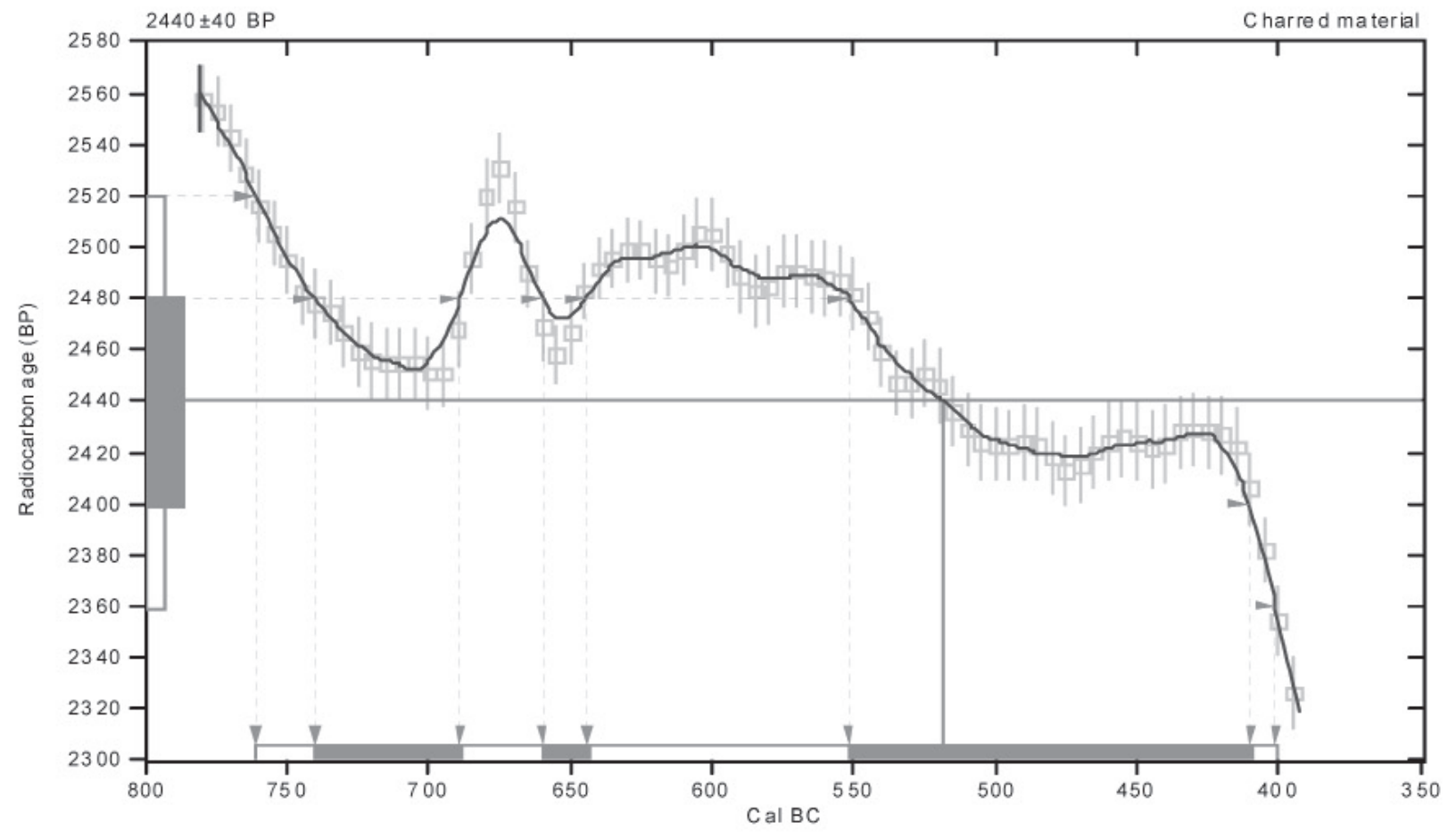

References:

Database used INTCA LO 4

Calib ration D ata base

INTCALO4 Radiocarbon Age Calibration

Math em a tics

A Simplified A pproach to Calibrating C14 D ates Talma, A.S., Vogel, J. C., 1993, Radiocarb on 35(2), p31 7-322 


\section{CALIBRATION OF RADIOCARBON AGE TO CALENDAR YEARS}

(Variables: C13/C12=-23.4:lab. mult =1)

Laboratory number: Beta-235836

Conventional radiocarbon age: $1390 \pm 40 \mathrm{BP}$

2 Sigma calibrated result: Cal AD 600 to 680 (Cal BP 1350 to 1270)

(95\% probability)

Intercept data

Intercept of radiocarbon age

with calibration curve: Cal AD 650 (Cal BP 1300)

1 Sigma calibrated result: Cal AD 640 to 660 (Cal BP 1320 to 1290) ( $68 \%$ probability)

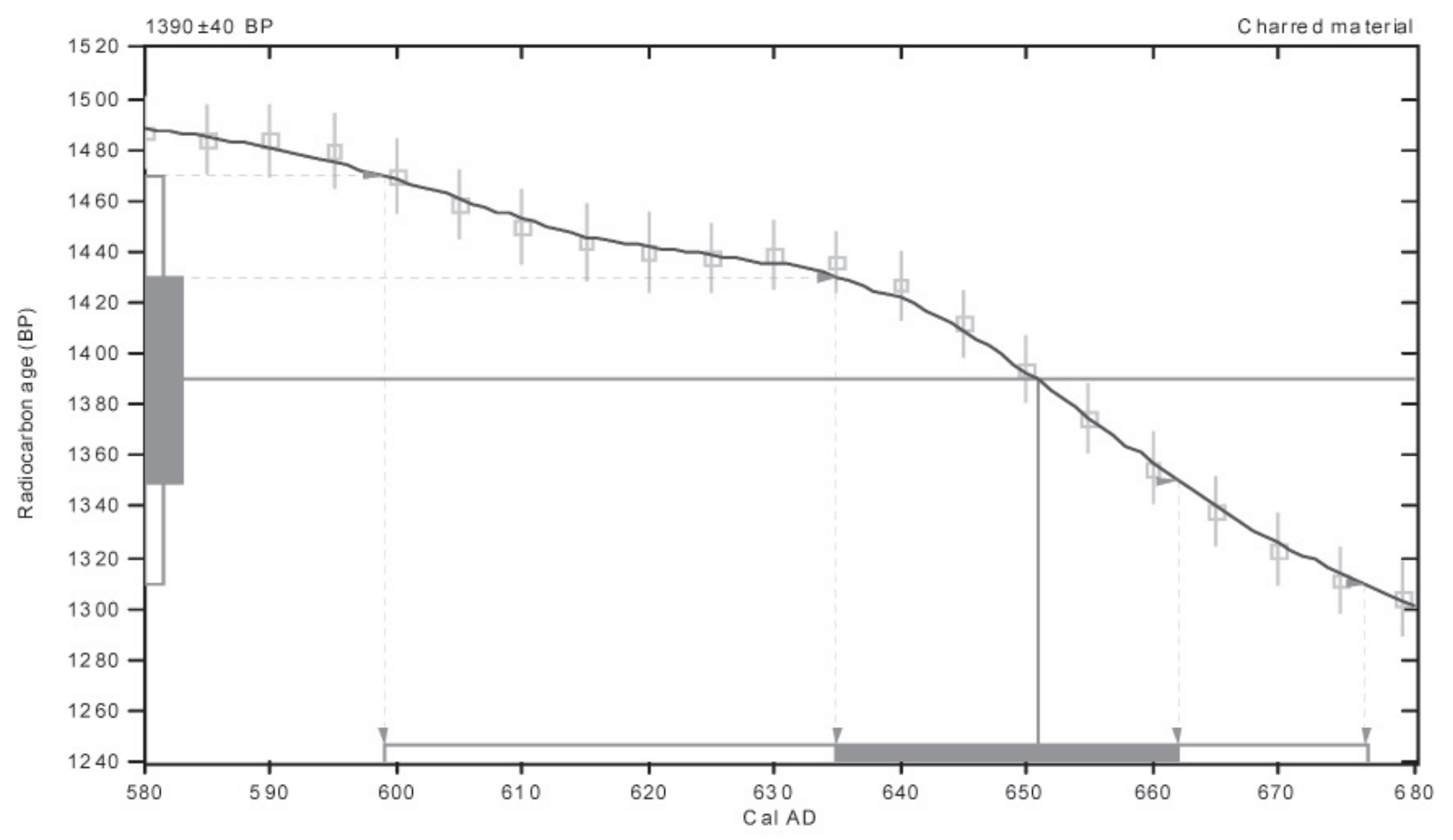

References:

Databas e us ed INTCA LO 4

Calib ration $D$ ata base

INTCALO4 Radiocarbon Age Calibration

IntCal0 4: Calibration Is sue of Radio carbon (Volume 46, nr 3, 2004 ).

Ma them a tics

A Simplified Approach to Calibrating C14 D ates Talma, A. S., Vogel, J. C., 1993, Radiocarbon 35(2), p31 7-322

\section{Beta Analytic Radiocarbon Dating Laboratory}

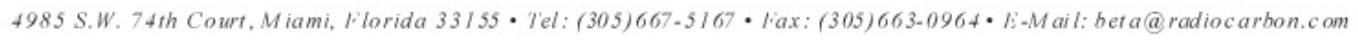




\section{CALIBRATION OF RADIOCARBON AGE TO CALENDAR YEARS}

(Variables: $\mathrm{C} 13 / \mathrm{C} 12=-25: 1 \mathrm{ab} . \mathrm{mult}=1)$

Laboratory number: Beta-235837

Conventional radiocarbon age: $3190 \pm 40 \mathrm{BP}$

2 Sigma calibrated result: Cal BC 1520 to 1400 (Cal BP 3470 to 3350 ) (95\% probability)

Intercept data

Intercept of radiocarbon age

with calibration curve: Cal BC 1450 (Cal BP 3400)

1 Sigma calibrated result: Cal BC 1500 to 1420 (Cal BP 3450 to 3370 ) (68\% probability)

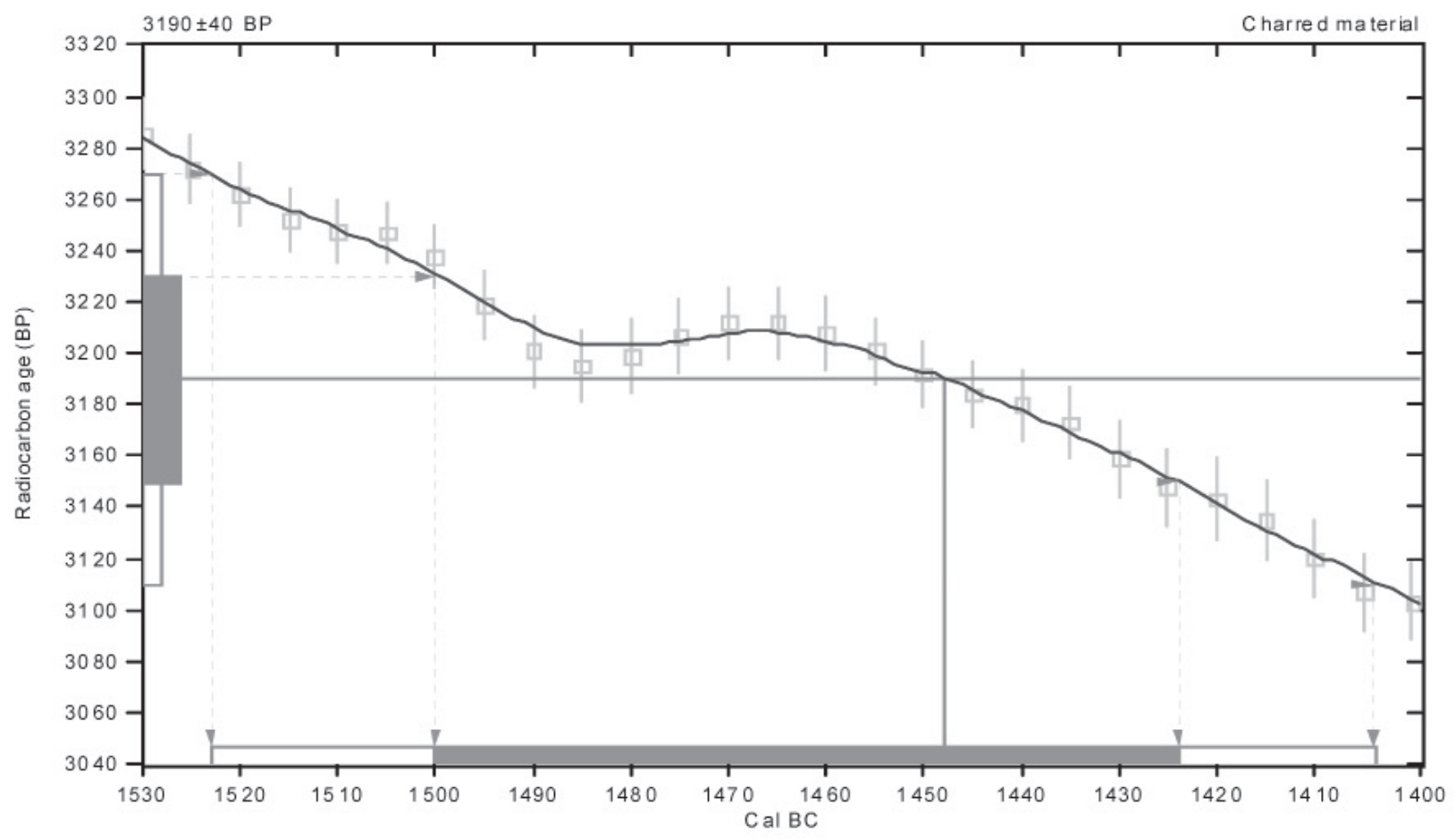

References:

Database used IN TCA LO 4

Calib ration D ata base

INTCALO4 Radiocarbon Age Calibration

IntCal0 4: Calibration Issue of Radio carbon (Volume 46, nr 3, 200 4).

Ma them a tics

A Simplified A pproach to Calibrating C14 D ates Talma, A.S., Vogel, J. C., 1993, Radiocarbon 35(2), p31 7-322 


\section{CALIBRATION OF RADIOCARBON AGE TO CALENDAR YEARS}

(Variables: $\mathrm{C} 13 / \mathrm{C} 12=-0.4: \mathrm{D}$ elta- $\mathrm{R}=0 \pm 0$ : Glob res $=-200$ to $500:$ lab. $\mathrm{mult}=1$ )

Laboratory number: Beta-235838

Conventional radiocarbon age: $1390 \pm 40 \mathrm{BP}$

(local reservoir correction not applied)

2 Sigma calibrated result: Cal AD 940 to 1070 (C al BP 1010 to 880)

( $95 \%$ probability)

Intercept data

Intercept of radiocarbon age

with calibration curve: Cal AD 1020 (Cal BP 930)

1 Sigma calibrated result: Cal AD 990 to 1040 (Cal B P 960 to 900)

(68\% probability)

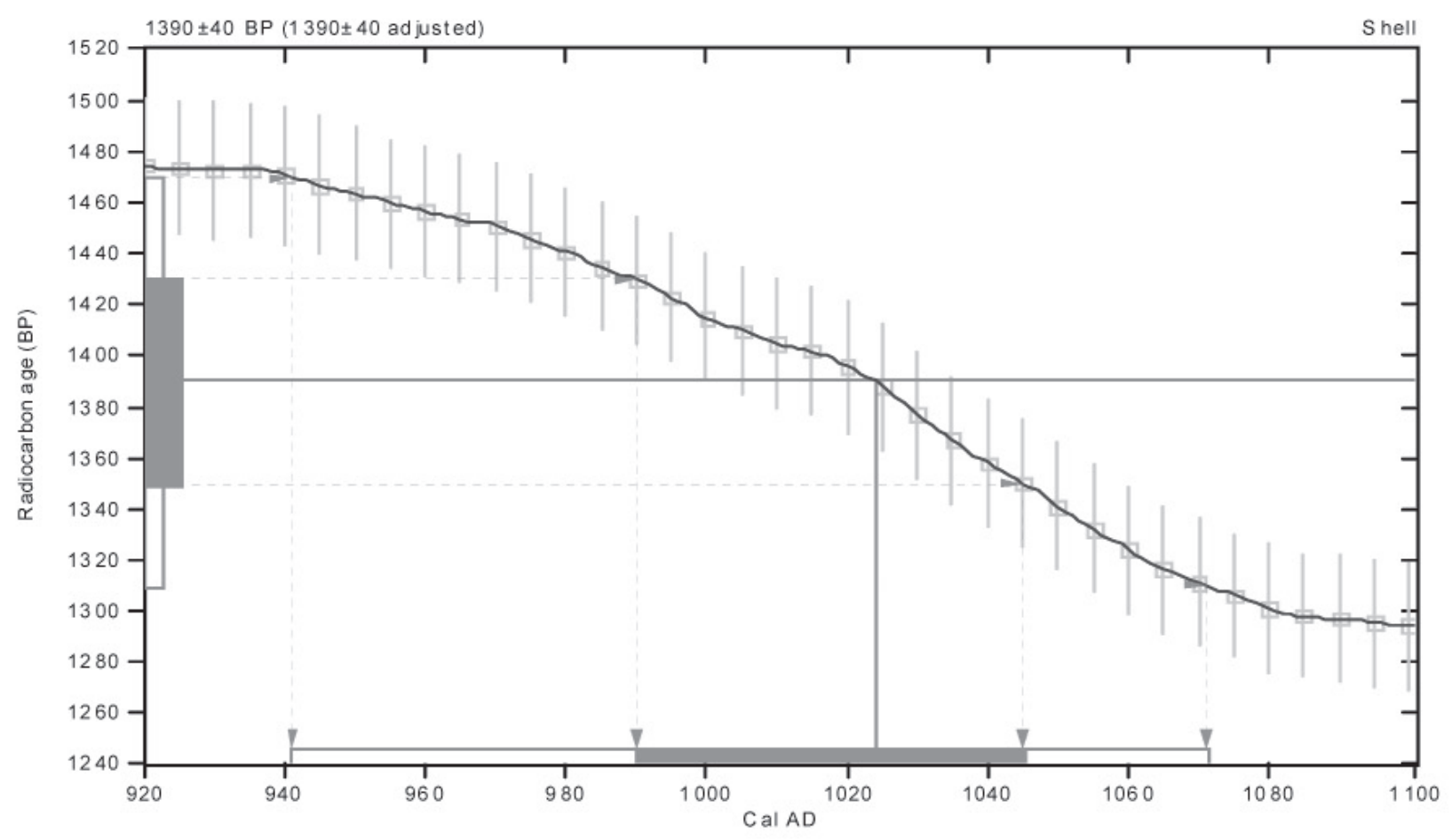

References:

Databas e us ed

MA RINE 04

Calib ration D atabase

INTCALO4 Radiocarbon Age Calibration

IntCal0 4: Calibration /ssue of Radiocarbon (Volume 46, nr 3, 2004 ).

Ma them a tics

A Simplified Approach to Calibrating C14 D ates

Talma, A. S., Vogel, J. C., 1993, Radiocarbon 35(2), p31 7-322

Beta Analytic Radiocarbon Dating Laboratory

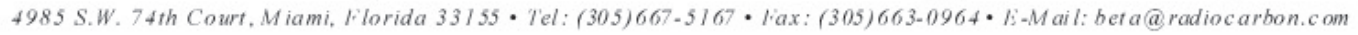




\section{CALIBRATION OF RADIOCARBON AGE TO CALENDAR YEARS}

(Variables: $\mathrm{C} 13 / \mathrm{C} 12=-0.4:$ elta- $\mathrm{R}=0 \pm 0:$ Glob res $=-200$ to $500:$ lab. $\mathrm{mult}=1$ )

Laboratory number: Beta-235839

Conventional radiocarbon age: $2090 \pm 40 \mathrm{BP}$

(local reservoir correction $n$ ot applied)

2 Sigma calibrated result: Cal AD 180 to 390 (Cal BP 1770 to 1560)

( $95 \%$ probability)

Intercept data

Intercept of radiocarbon age with calibration curve: Cal AD 270 (Cal BP 1680)

1 Sigma calibrated result: Cal AD 240 to 340 (Cal BP 1710 to 1610 ) (68\% probability)

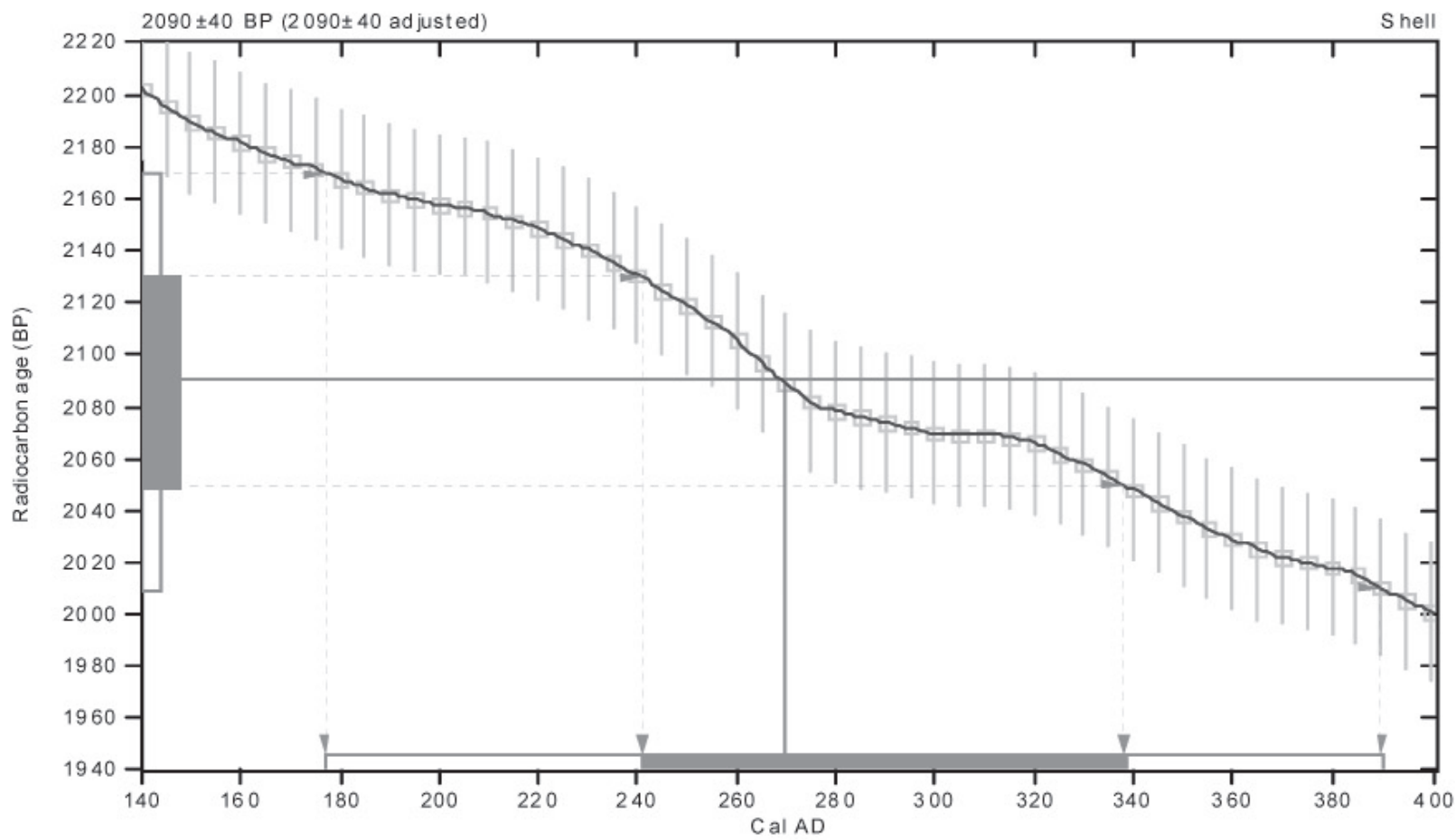

References:

Data bas e us ed MA RINE 04

Calib ration $D$ ata base

INTCALO4 Radiocarbon Age Calibration

IntCal0 4: Calibration Issue of Radiocarbon (Volume 46, nr 3, 2004).

Ma them a tics

A Simplified A pproach to Calibrating C14 D ates Talma, A. S., Vo gel, J. C., 1993, Radiocarbon 35(2), p317-322 


\section{CALIBRATION OF RADIOCARBON AGE TO CALENDAR YEARS}

(Variables: $\mathrm{C} 13 / \mathrm{C} 12=0.8:$ Delta $-\mathrm{R}=0 \pm 0:$ Glob res $=-200$ to $500: \mathrm{lab}$. $\mathrm{mult}=1$ )

Laboratory number: Beta-235841

Conventional radiocarbon age: $2100 \pm 40 \mathrm{BP}$

(local reservoir correction not applied)

2 Sigma calibrated result: Cal AD 160 to 370 (Cal BP 1790 to 1580) ( $95 \%$ probability)

Intercept data

Intercept of radiocarbon age

with calibration curve: Cal AD 260 (Cal BP 1690)

1 Sigma calibrated result: Cal AD 230 to 330 (Cal BP 1720 to 1620)

$(68 \%$ probability)

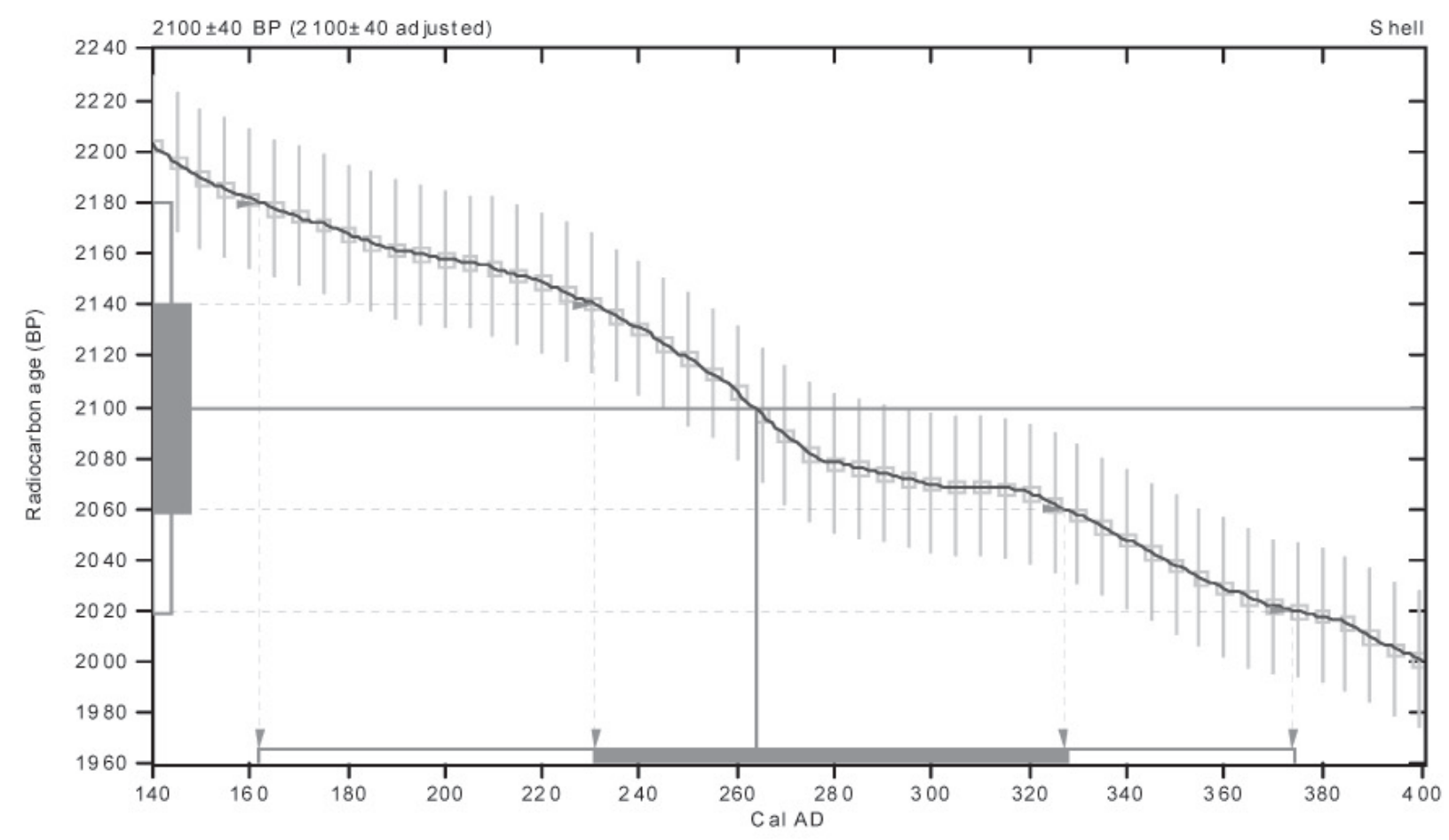

References:

Database us ed

$M A R I N E 04$

Ca lib ration D ata base

INTCALO4 Radiocarbon Age Calibration

IntCal0 4: Calibration /s sue of Radio carbon (Volume 46, nr 3, 2004).

Ma them a tics

A Simplified Approach to Calibrating C14 D ates

Talma, A. S., Vogel, J. C., 1993, Radiocarbon 35(2), p317-322

Beta Analytic Radiocarbon Dating Laboratory

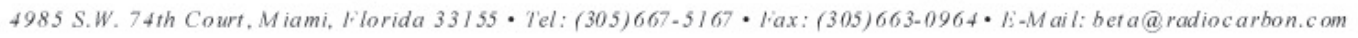




\section{CALIBRATION OF RADIOCARBON AGE TO CALENDAR YEARS}

(Variables: $\mathrm{C} 13 / \mathrm{C} 12=-0.2:$ Delta- $\mathrm{R}=0 \pm 0: \mathrm{Glob}$ res $=-200$ to $500: \mathrm{lab} . \mathrm{mult}=1$ )

Laboratory number: Beta-235842

Conventional radiocarbon age: $2540 \pm 40 \mathrm{BP}$

(local reservoir correction not applied)

2 Sigma calibrated result: Cal BC 360 to 160 (Cal BP 2310 to 2110)

( $95 \%$ probability)

Intercept data

Intercept of radiocarbon age

with calibration curve: Cal BC 290 (Cal BP 2240)

1 Sigma calibrated result: Cal BC 340 to 200 (Cal B P 2290 to 2150 )

(68\% probability)

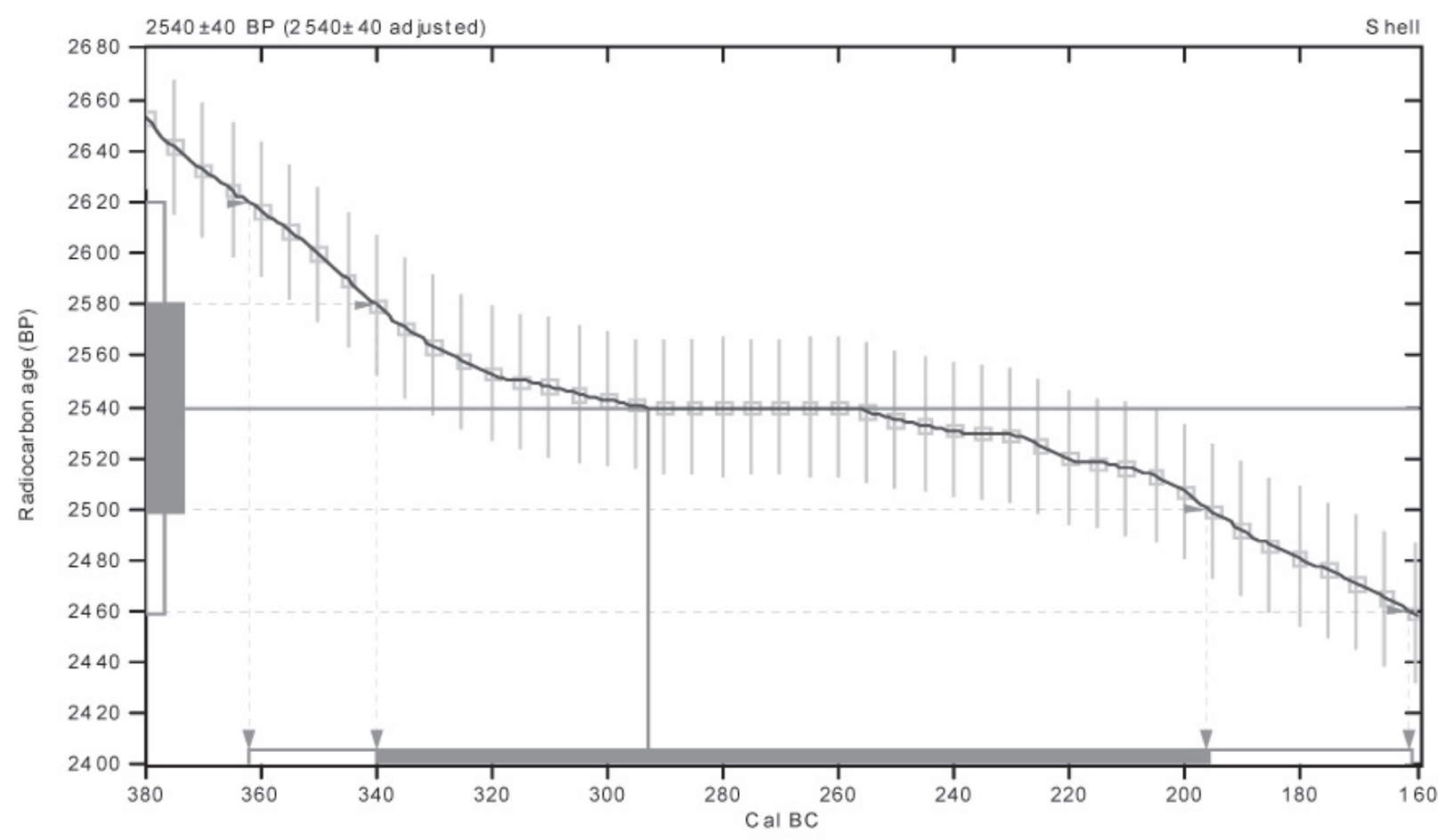

References:

Databas e us ed MARINE04

Ca lib ration D ata base

INTCAL04 Radiocarbon Age Calibration

IntCalo
Math em a tics

A Simplified Approach to Calibrating C14 D ates Talma, A. S., Vogel, J. C., 1993, Radiocarbon 35(2), p317-322 


\section{CALIBRATION OF RADIOCARBON AGE TO CALENDAR YEARS}

(Variables: $\mathrm{C} 13 / \mathrm{C} 12=0.5:$ Delta- $\mathrm{R}=0 \pm 0:$ Glob res $=-200$ to $500: \mathrm{lab} . \mathrm{mult}=1$ )

Laboratory number: Beta-235843

Conventional radiocarbon age: $2200 \pm 40 \mathrm{BP}$

(local reservoir correction not applied)

2 Sigma calibrated result: Cal AD 70 to 250 (Cal B P 1880 to 1700)

( $95 \%$ probability)

Intercept data

Intercept of radiocarbon age

with calibration curve: Cal AD 140 (Cal BP 1810)

1 Sigma calibrated result: Cal AD 100 to 190 (Cal BP 1850 to 1760)

(68\% probability)

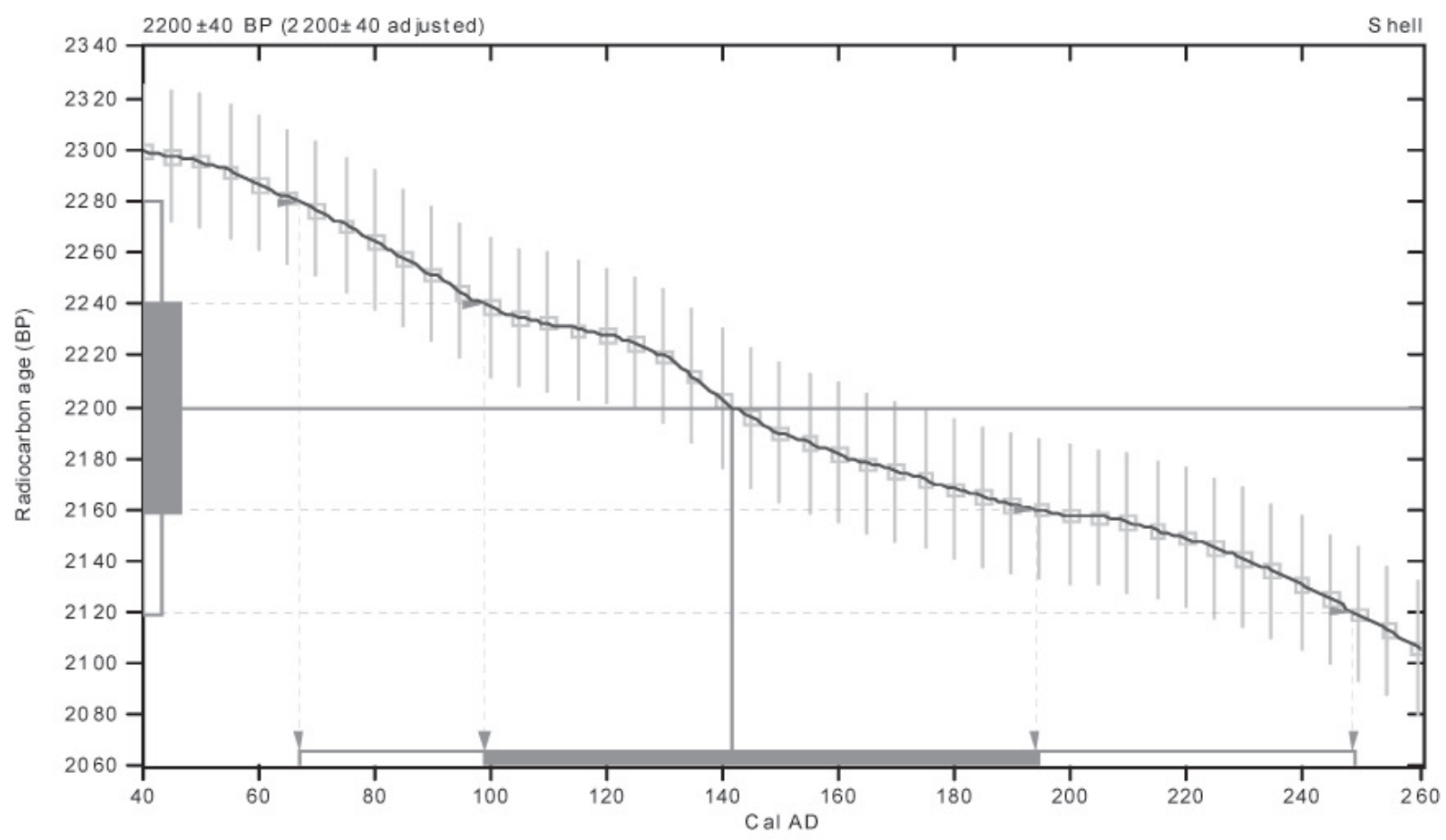

References:

Databas e us ed

$M A R I N E 04$

Calib ration D atabase

INTCALO4 Radiocarbon Age Calibration

IntCal0 4: Calibration Is sue of Radio carbon (Volume 46, nr 3, 2004 ).

Ma them a tics

A Simplified Approach to Calibrating C14 D ates

Talma, A. S., Vogel, J. C., 1993, Radiocarbon 35(2), p31 7-322

\section{Beta Analytic Radiocarbon Dating Laboratory}

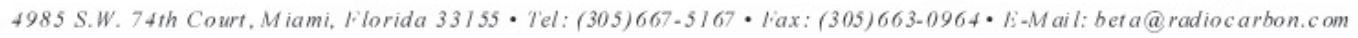




\section{CALIBRATION OF RADIOCARBON AGE TO CALENDAR YEARS}

(Variables: $\mathrm{C} 13 / \mathrm{C} 12=-0.6: \mathrm{D}$ elta- $\mathrm{R}=0 \pm 0: \mathrm{Glob}$ res $=-200$ to $500: \mathrm{lab} . \mathrm{mult}=1$ )

Laboratory number: Beta-235844

Conventional radiocarbon age: $2850 \pm 40 \mathrm{BP}$

(local reservoir correction not applied)

2 Sigma calibrated result: Cal BC 770 to 530 (Cal B P 2720 to 2480)

( $95 \%$ probability)

Intercept data

Intercept of radiocarbon age

with calibration curve: Cal BC 720 (Cal BP 2670)

1 Sigma calibrated results: Cal BC 740 to 640 (Cal B P 2690 to 2590) and

(68\% probability) Cal BC 640 to 630 (Cal B P 2590 to 2580 )

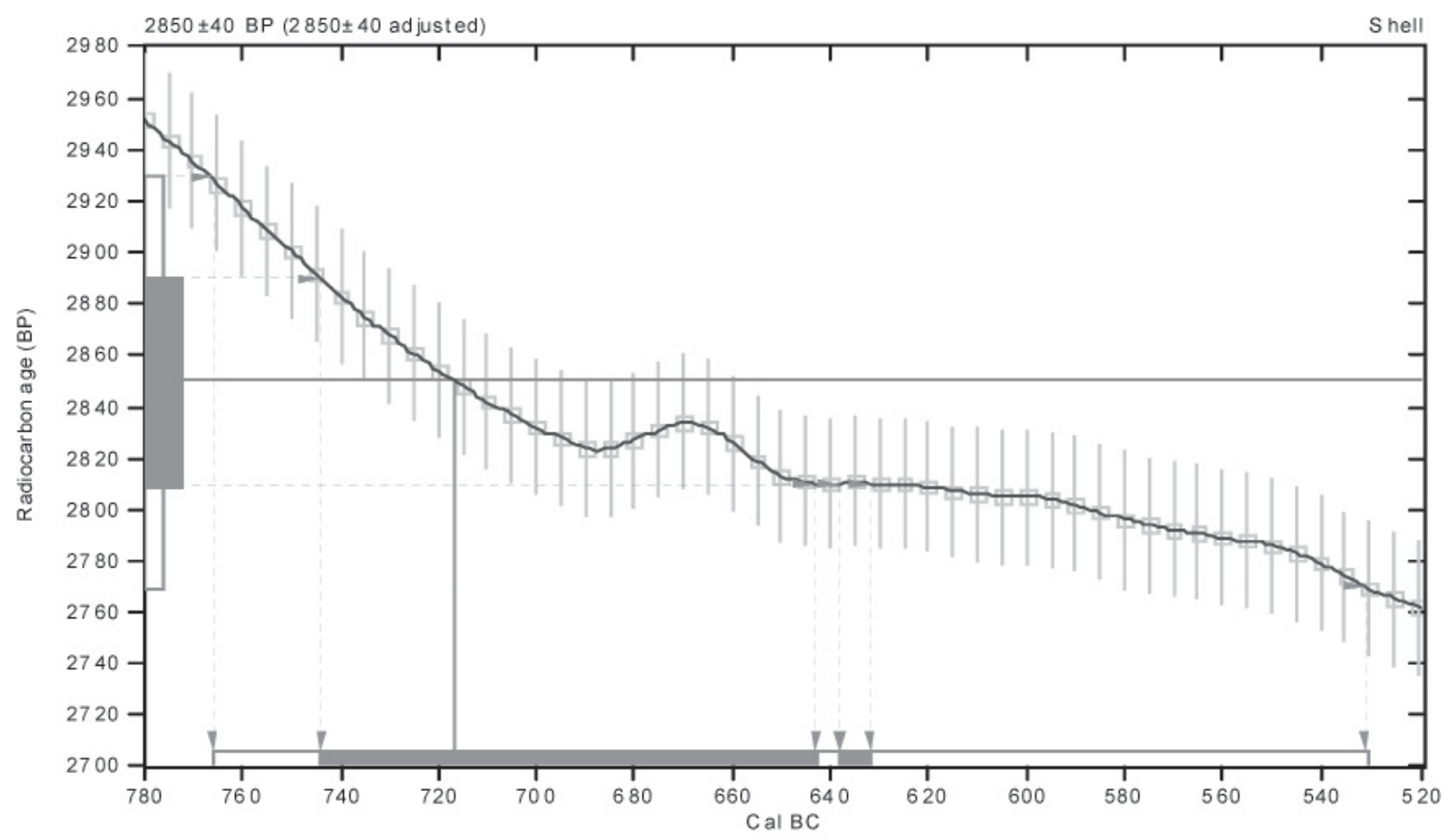

References:

Database used

MA RINE 04

Ca lib ration $D$ ata base

INTCAL04 Radiocarbon Age Calibration

IntCalo
Math em a tics

A Simplified A pproach to Calibrating C14 Dates

Talma, A. S., Vogel, J. C., 1993, Radiocarbon 35(2), p317-322

Beta Analytic Radiocarbon Dating Laboratory

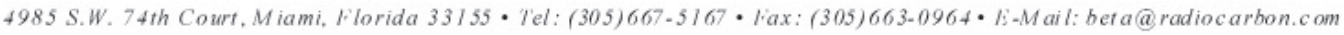




\section{CALIBRATION OF RADIOCARBON AGE TO CALENDAR YEARS}

(Variables: $\mathrm{C} 13 / \mathrm{C} 12=-0.3:$ Delta- $\mathrm{R}=0 \pm 0: \mathrm{Glob}$ res $=-200$ to $500:$ lab. $\mathrm{mult}=1$ )

Laboratory number: Beta-235845

Conventional radiocarbon age: $\mathbf{5 5 4 0 \pm 4 0 ~ B P}$

(local reservoir correction not applied)

2 Sigma calibrated result: Cal BC 4040 to 3920 (Cal B P 5990 to 5870)

( $95 \%$ probability)

Intercept data

Intercept of radiocarbon age

with calibration curve: Cal BC 3960 (Cal B P 5910)

1 Sigma calibrated result: Cal BC 4000 to 3940 (Cal BP 5950 to 5890 )

(68\% probability)

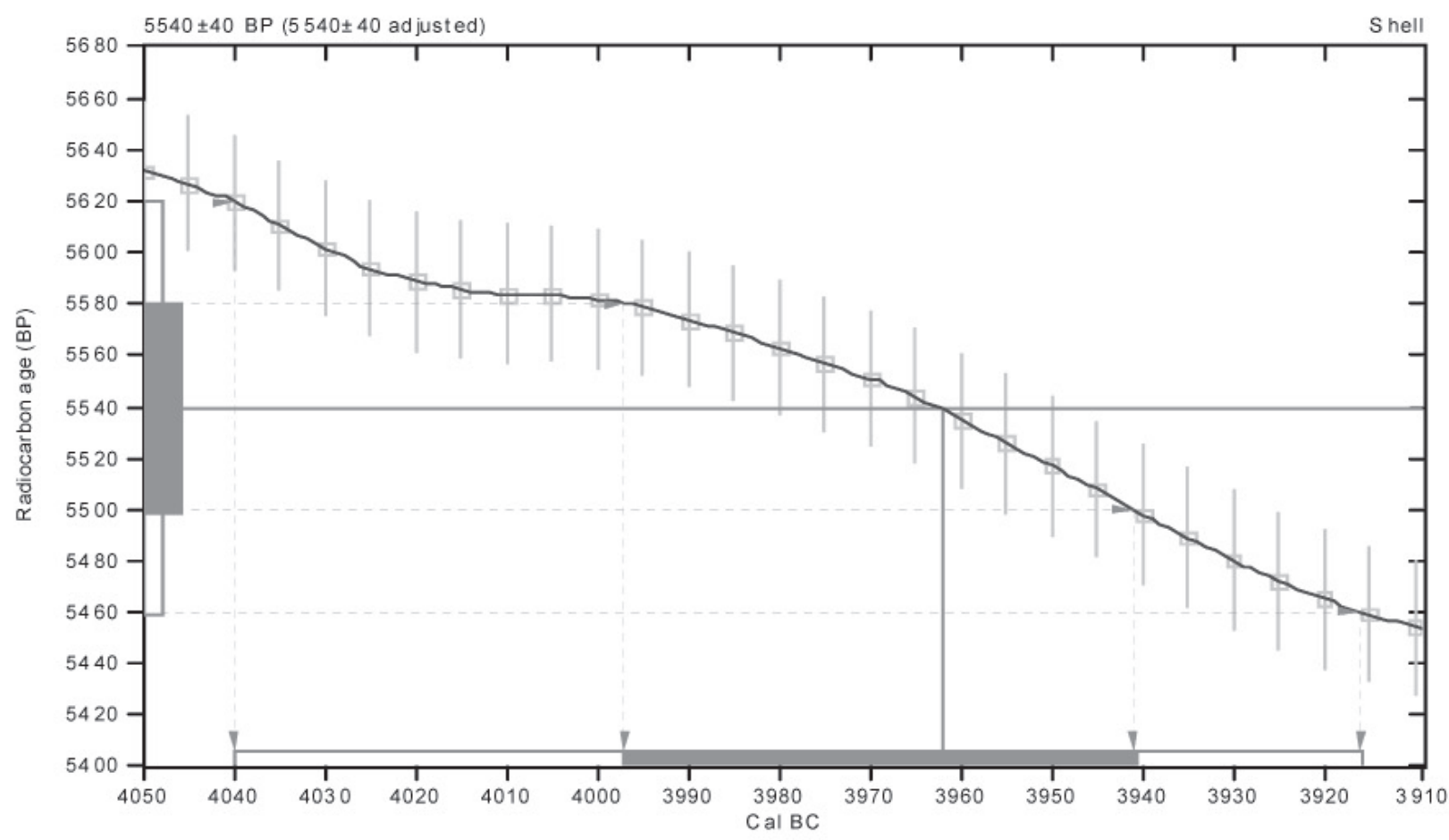

References:

Databas e us ed

$M A R I N E 04$

Calib ration D atabase

INTCALO4 Radiocarbon Age Calibration

IntCal0 4: Calibration /ssue of Radiocarbon (Volume 46, nr 3, 2004 ).

Ma them a tics

A Simplified A pproach to Calibrating C14 Dates

Talma, A. S., Vogel, J. C., 1993, Radiocarbon 35(2), p31 7-322

Beta Analytic Radiocarbon Dating Laboratory

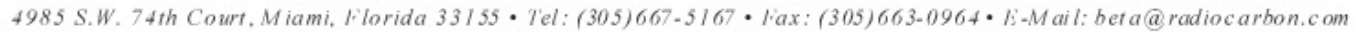




\section{CALIBRATION OF RADIOCARBON AGE TO CALENDAR YEARS}

(Variables: $\mathrm{C} 13 / \mathrm{C} 12=0.2$ : Delta- $\mathrm{R}=0 \pm 0:$ Glob res $=-200$ to $500: \mathrm{lab} . \mathrm{mult}=1$ )

Laboratory number: Beta-235846

Conventional radiocarbon age: $2110 \pm 40 \mathrm{BP}$

(local reservoir correction not applied)

2 Sigma calibrated result: Cal AD 150 to 360 (Cal BP 1800 to 1590)

( $95 \%$ probability)

Intercept data

Intercept of radiocarbon age

with calibration curve: Cal AD 260 (Cal BP 1690)

1 Sigma calibrated result: Cal AD 220 to 300 (Cal BP 1730 to 1650)

(68\% probability)

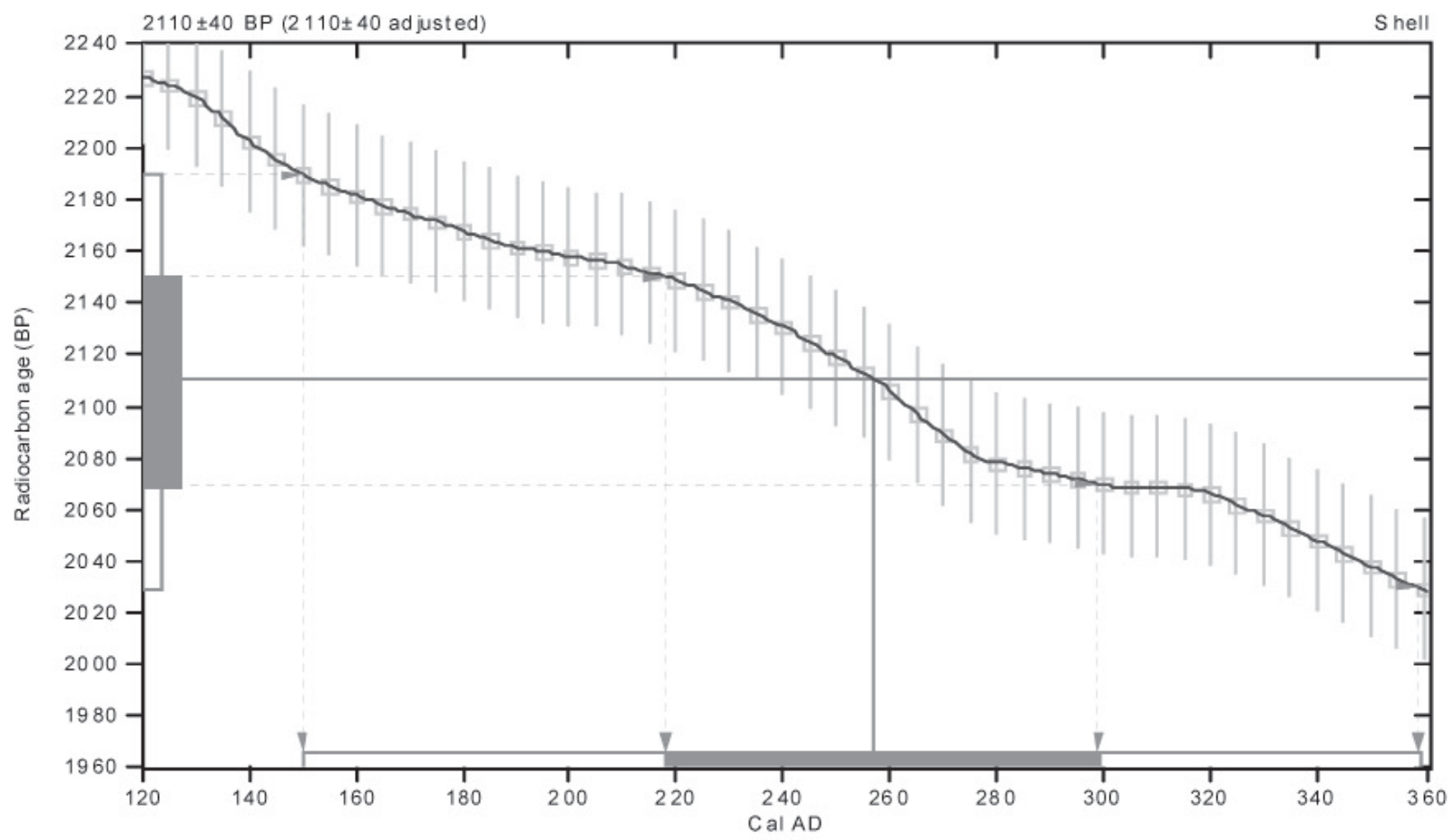

References:

Databas e us ed

$M A R I N E 04$

Calib ration D ata base

INTCALO4 Radiocarbon Age Calibration

IntCal0 4: Calibration Is sue of Radiocarbon (Volume 46, nr 3, 2004).

Math em atics

A Simplified A pproach to Calibrating C 14 D ates

Talma, A.S., Vogel, J. C., 1993, Radiocarb on 35(2), p31 7-322

Beta Analytic Radiocarbon Dating Laboratory

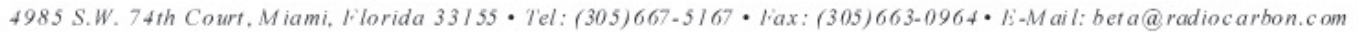




\section{CALIBRATION OF RADIOCARBON AGE TO CALENDAR YEARS}

(Variables: $\mathrm{C} 13 / \mathrm{C} 12=1:$ Delta $-\mathrm{R}=0 \pm 0: \mathrm{Glob}$ res $=-200$ to $500: \mathrm{lab}$. $\mathrm{mult}=1$ )

Laboratory number: Beta-235847

Conventional radiocarbon age: $2590 \pm 40 \mathrm{BP}$

(local reservoir correction not applied)

2 Sigma calibrated result: Cal BC 390 to 200 (Cal B P 2340 to 2150)

(95\% probability)

Intercept data

Intercept of radiocarbon age

with calibration curve:

1 Sigma calibrated result: Cal BC 370 to 320 (Cal BP 2320 to 2270)

(68\% probability)

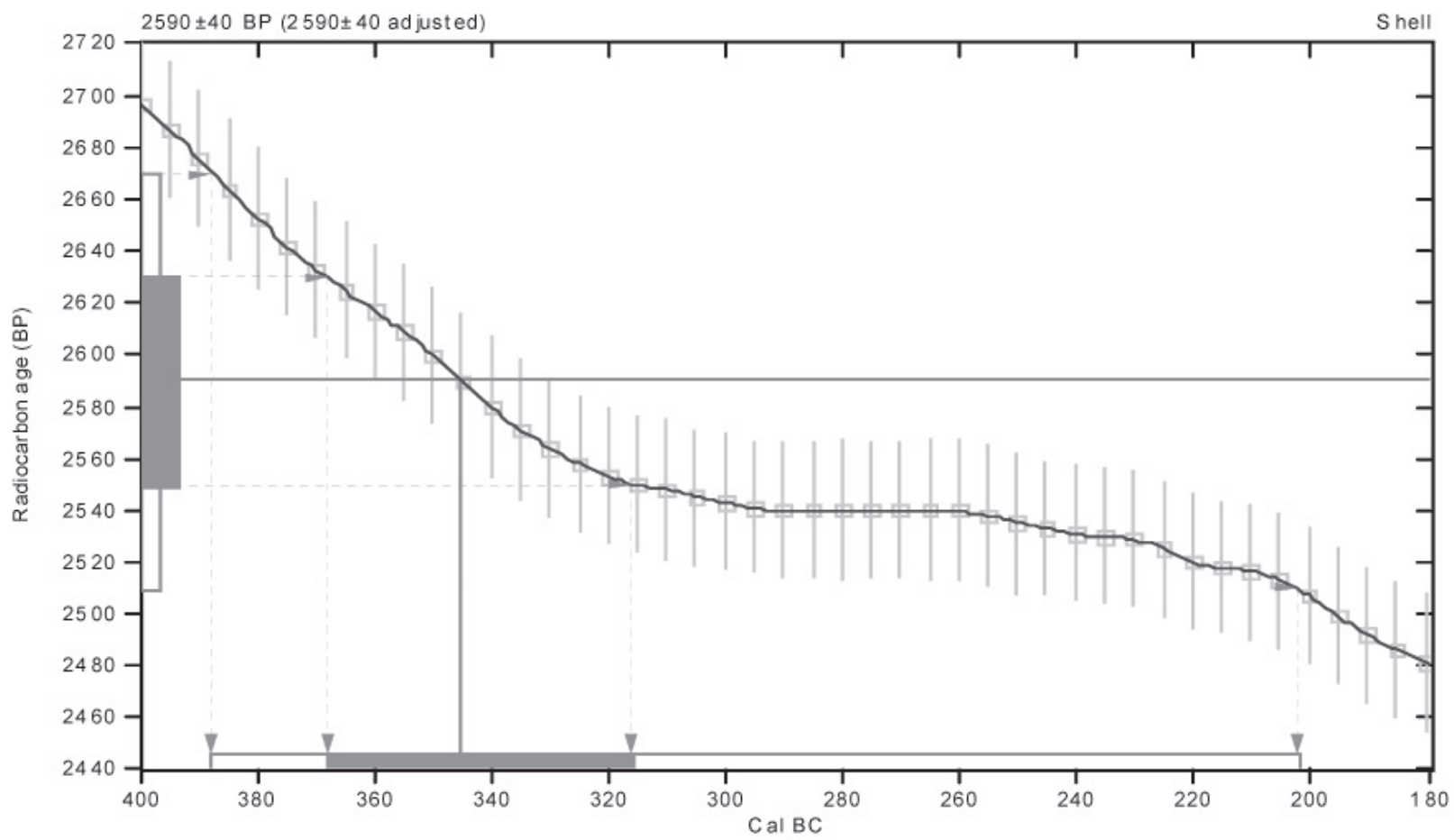

References:

Databas e us ed

MA RINE 04

Ca lib ration $D$ ata base

INTCAL04 Radiocarbon Age Calibration

IntCal0 4: Calibration Issue of Radio carbon (Volume 46, nr 3, 2004).

Ma them a tics

A Simplified A pproach to Calibrating C 14 D ates

Talma, A. S., Vogel, J. C., 1993, Radiocarbon 35(2), p31 7-322

\section{Beta Analytic Radiocarbon Dating Laboratory}

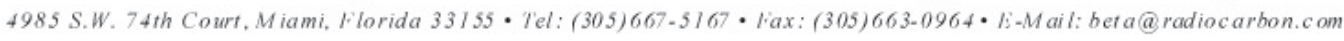




\section{CALIBRATION OF RADIOCARBON AGE TO CALENDAR YEARS}

(Variables: $\mathrm{C} 13 / \mathrm{C} 12=-0.4:$ Delta- $\mathrm{R}=0 \pm 0: \mathrm{Glob}$ res $=-200$ to $500:$ lab. $\mathrm{mult}=1$ )

Laboratory number: Beta-235848

Conventional radiocarbon age: $3090 \pm 40 \mathrm{BP}$

(local reservoir correction not applied)

2 Sigma calibrated result: Cal BC 1000 to 810 (Cal BP 2950 to 2760)

(95\% probability)

Intercept data

Intercept of radiocarbon age

with calibration curve: Cal BC 900 (Cal BP 2850)

1 Sigma calibrated result: Cal BC 960 to 860 (Cal BP 2910 to 2810 )

(68\% probability)

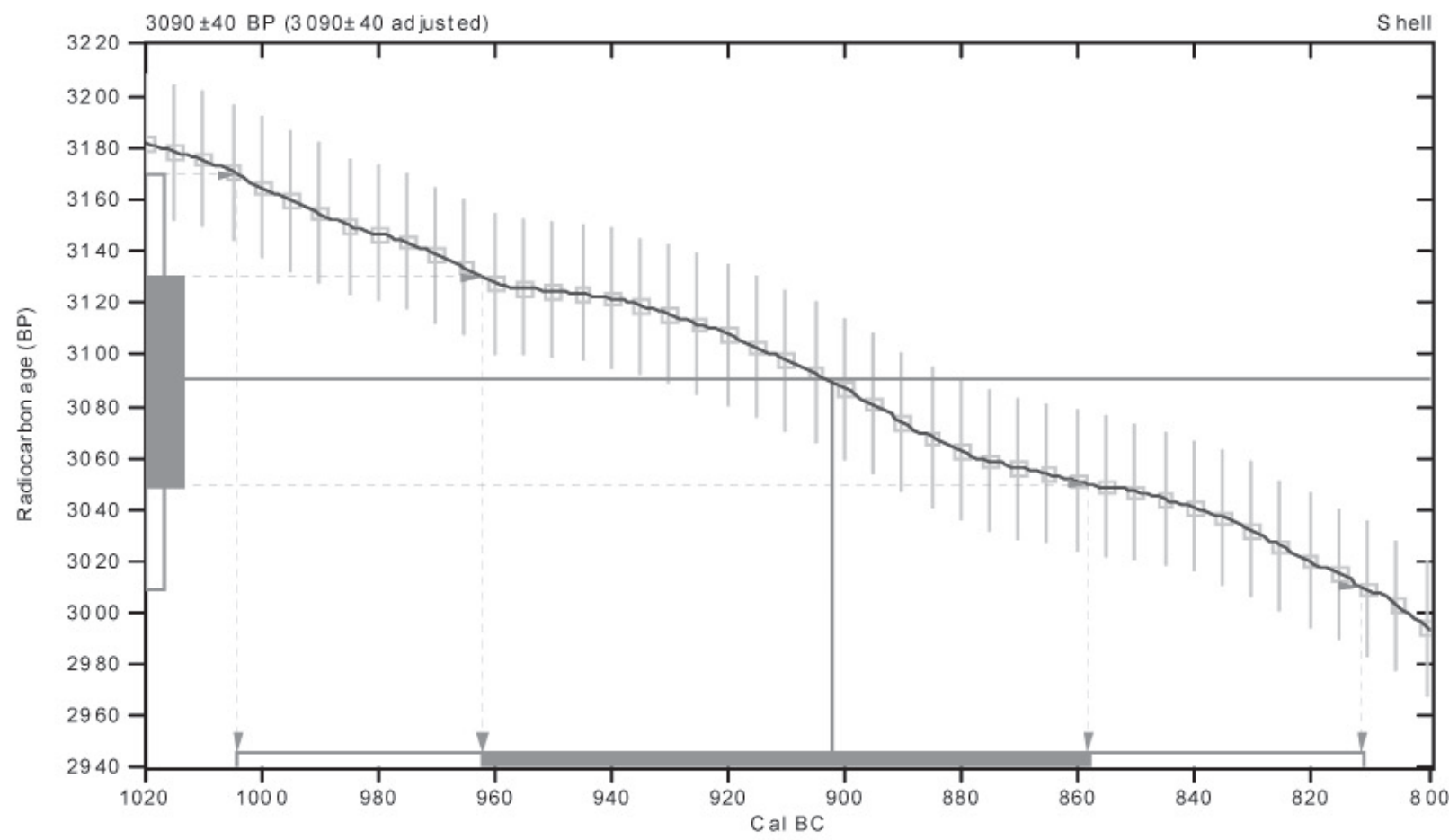

References:

Databas e used MARINE04

Ca lib ration $D$ ata base

INTCAL04 Radiocarbon Age Calibration

IntCal0 4: Calibration Is sue of Radio carbon (Volume 46, nr 3, 2004).

Ma them a tics

A Simplified A pproach to Calibrating C14 D ates Talma, A. S., Vogel, J. C., 1993, Radiocarbon 35(2), p317-322 


\section{CALIBRATION OF RADIOCARBON AGE TO CALENDAR YEARS}

(Variables: $\mathrm{C} 13 / \mathrm{C} 12=0.1$ :Delta- $\mathrm{R}=0 \pm 0:$ Glob res $=-200$ to $500: \mathrm{lab} . \mathrm{mult}=1$ )

Laboratory number: Beta-235849

Conventional radiocarbon age: $2030 \pm 40 \mathrm{BP}$

(local reservoir correction not applied)

2 Sigma calibrated result: Cal AD 260 to 440 (Cal BP 1690 to 1510)

(95\% probability)

Intercept data

Intercept of radiocarbon age

with calibration curve: Cal AD 360 (Cal BP 1590)

1 Sigma calibrated result: Cal AD 300 to 410 (Cal BP 1650 to 1540)

$(68 \%$ probability)

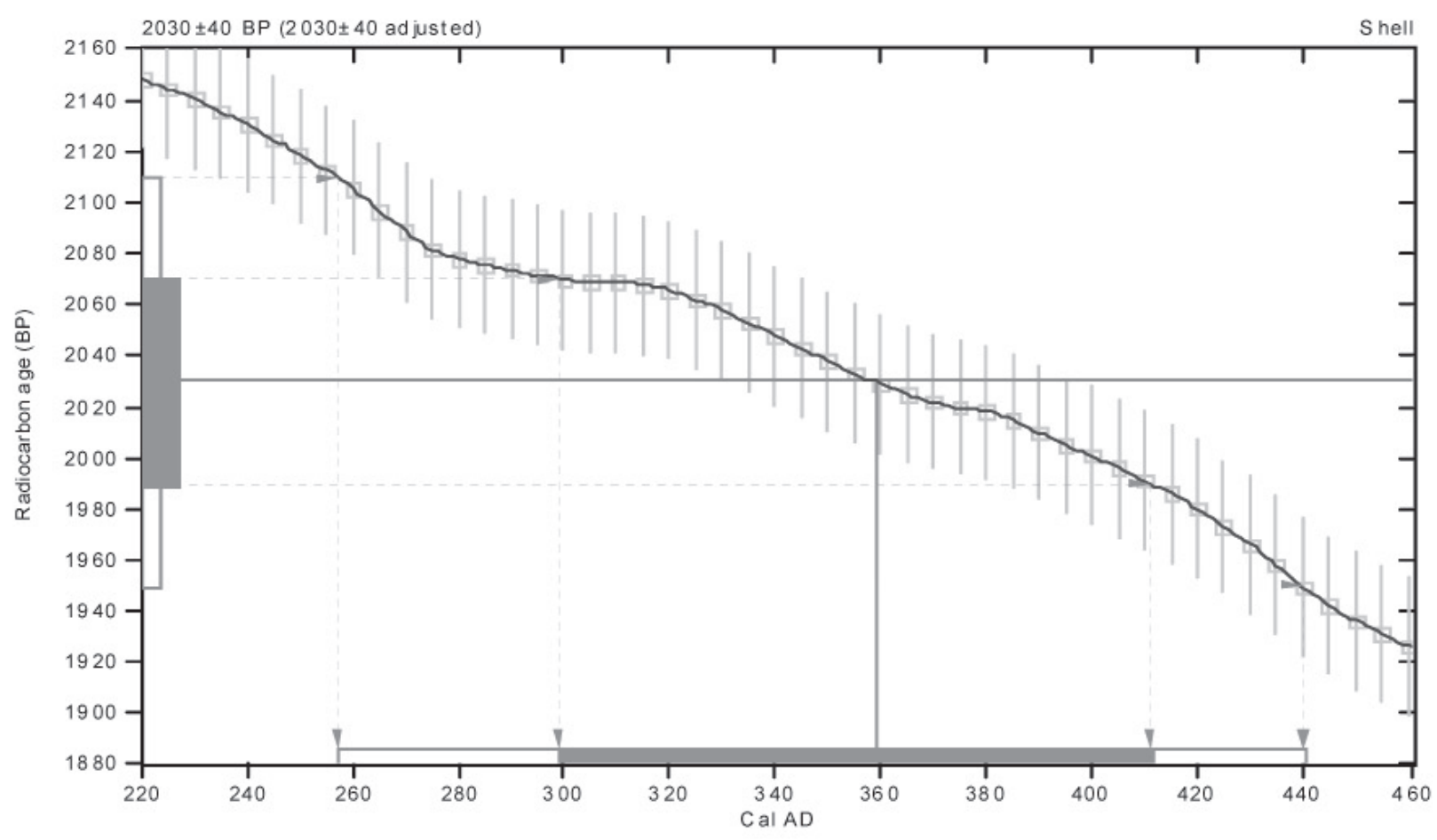

References:

Databas e us ed

MA RINE 04

Calib ration D atabase

INTCALO4 Radiocarbon Age Calibration

IntCal0 4: Calibration Is sue of Radiocarbon (Volume 46, nr 3, 2004 ).

Ma them a tics

A Simplified Approach to Calibrating C14 D ates

Talma, A. S., Vogel, J. C., 1993, Radiocarbon 35(2), p31 7-322

\section{Beta Analytic Radiocarbon Dating Laboratory}

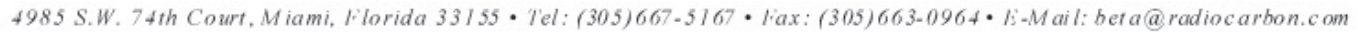




\section{CALIBRATION OF RADIOCARBON AGE TO CALENDAR YEARS}

(Variables: $\mathrm{C} 13 / \mathrm{C} 12=0.6$ : Delta $-\mathrm{R}=0 \pm 0:$ Glob res $=-200$ to $500: \mathrm{lab}$. $\mathrm{mult}=1$ )

Laboratory number: Beta-235850

Conventional radiocarbon age: $2270 \pm 40 \mathrm{BP}$

(local reservoir correction not applied)

2 Sigma calibrated result: Cal BC 20 to Cal AD 150 (Cal B P 1970 to 1800)

(95\% probability)

Intercept data

Intercept of radiocarbon age

with calibration curve: Cal AD 80 (Cal BP 1870)

1 Sigma calibrated result: Cal AD 30 to 120 (Cal BP 1920 to 1840)

(68\% probability)

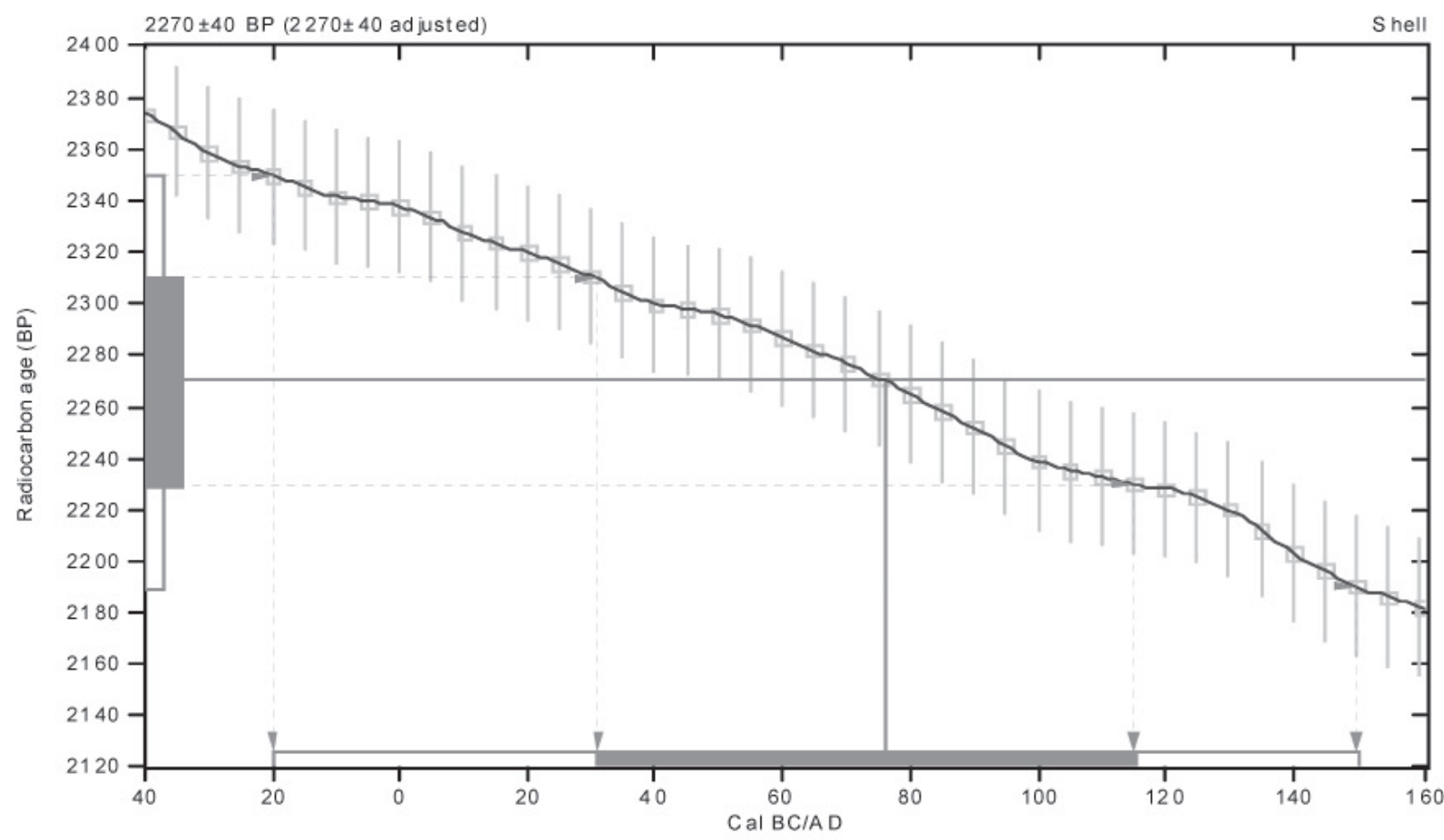

References:

Databas e used

MARINE04

Ca lib ration $D$ ata bas e

INTCAL04 Radiocarbon Age Calibration

IntCalo
Math em a tics

A Simplified A pproach to Calibrating C14 D ates

Talma, A.S., Vogel, J. C., 1993, Radiocarbon 35(2), p317-322

Beta Analytic Radiocarbon Dating Laboratory

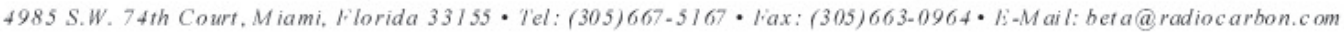




\section{CALIBRATION OF RADIOCARBON AGE TO CALENDAR YEARS}

(Variables: $\mathrm{C} 13 / \mathrm{C} 12=-0.5:$ Delta- $\mathrm{R}=0 \pm 0: \mathrm{Glob}$ res $=-200$ to $500:$ lab. $\mathrm{mult}=1$ )

Laboratory number: Beta-235851

Conventional radiocarbon age: $1430 \pm 40 \mathrm{BP}$

(local reservoir correction not applied)

2 Sigma calibrated result: Cal AD 900 to 1040 (C al B P 1050 to 900)

( $95 \%$ probability)

Intercept data

Intercept of radiocarbon age

with calibration curve: Cal AD 990 (Cal BP 960)

1 Sigma calibrated result: Cal AD 940 to 1020 (Cal B P 1010 to 930)

(68\% probability)

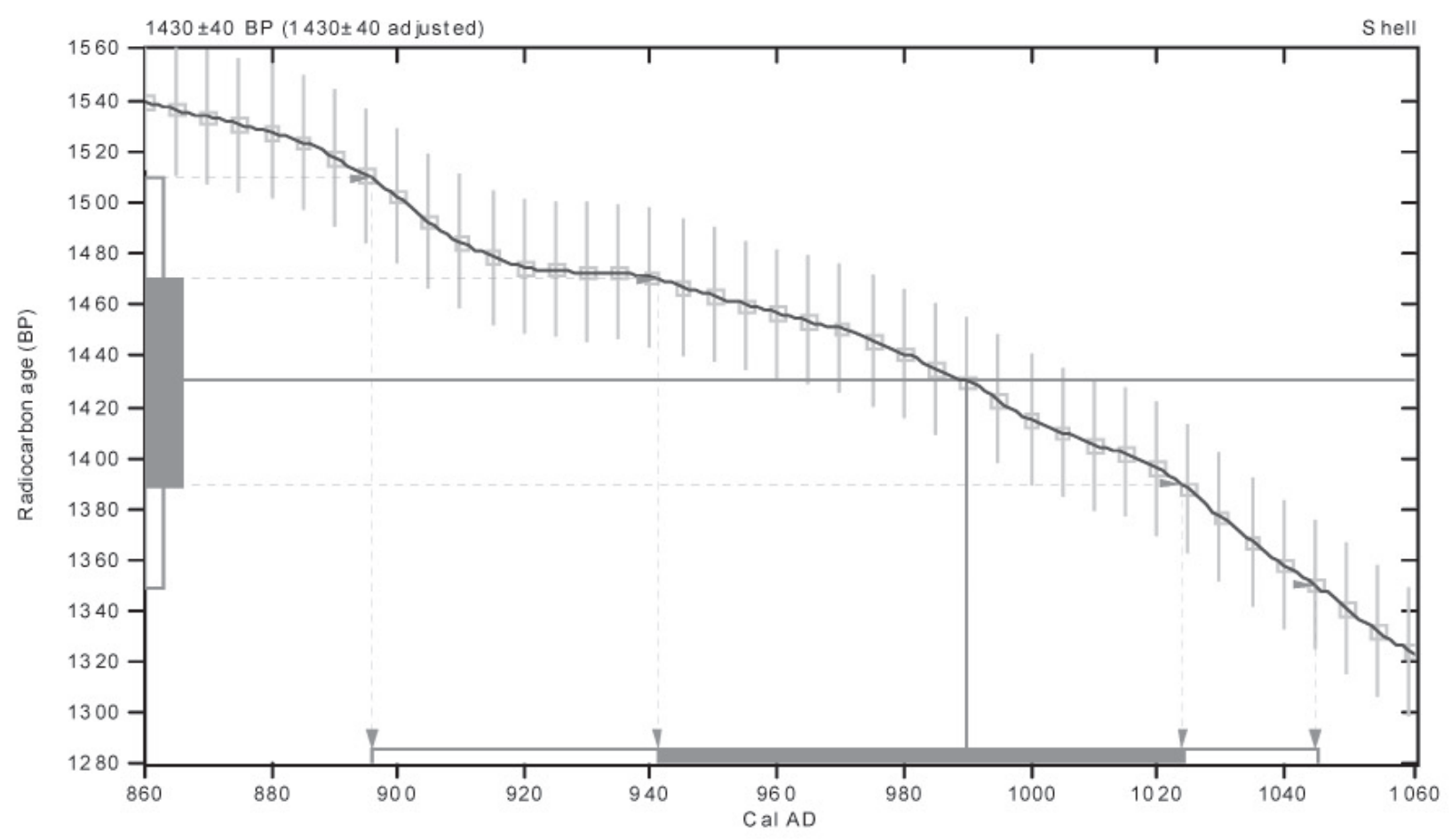

References:

Databas e us ed

MA RINE 04

Calib ration D atabase

INTCALO4 Radiocarbon Age Calibration

IntCal0 4: Calibration /ssue of Radiocarbon (Volume 46, nr 3, 2004 ).

Ma them a tics

A Simplified Approach to Calibrating C14 D ates

Talma, A. S., Vogel, J. C., 1993, Radiocarbon 35(2), p31 7-322

Beta Analytic Radiocarbon Dating Laboratory

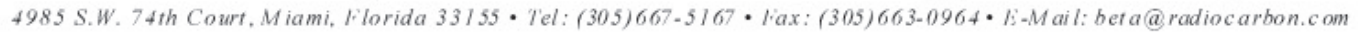




\section{CALIBRATION OF RADIOCARBON AGE TO CALENDAR YEARS}

(Variables: $\mathrm{C} 13 / \mathrm{C} 12=-0.8:$ Delta- $\mathrm{R}=0 \pm 0: \mathrm{Glob}$ res $=-200$ to $500: \mathrm{lab} . \mathrm{mult}=1$ )

Laboratory number: Beta-235852

Conventional radiocarbon age: $2310 \pm 40 \mathrm{BP}$

(local reservoir correction not applied)

2 Sigma calibrated result: Cal BC 60 to Cal AD 120 (Cal B P 2010 to 1840)

(95\% probability)

Intercept data

Intercept of radiocarbon age

with calibration curve: Cal AD 30 (Cal BP 1920)

1 Sigma calibrated result: Cal BC 20 to Cal AD 80 (Cal BP 1970 to 1870 )

(68\% probability)

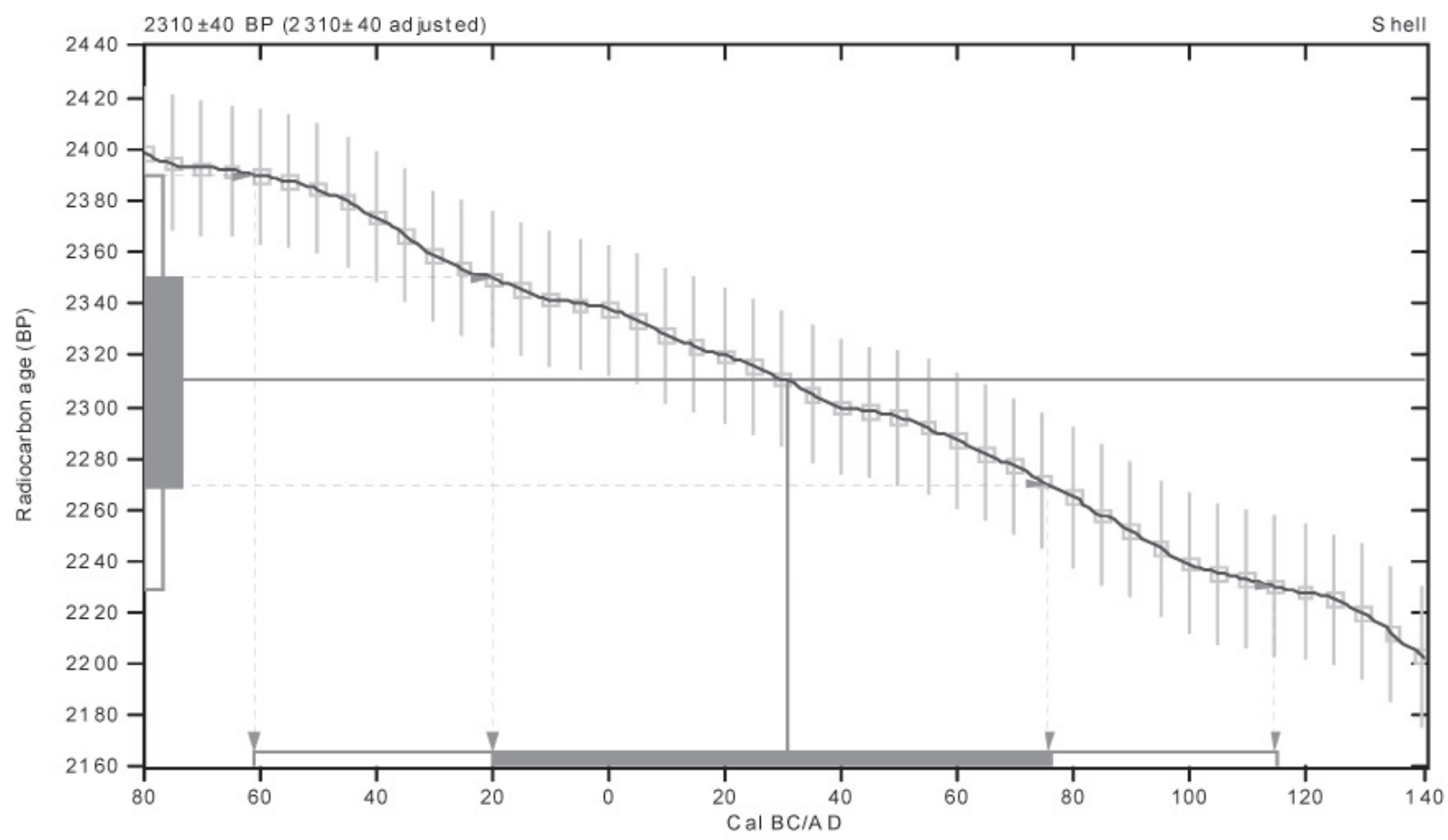

References:

Databas e used MARINE04

Ca lib ration D ata base

INTCAL04 Radiocarbon Age Calibration

IntCal0 4: Calibration Is sue of Radio carbon (Volume 46, nr 3, 2004).

Ma them a tics

A Simplified Approach to Calibrating C14 D ates Talma, A.S., Vogel, J. C., 1993, Radiocarbon 35(2), p31 7-322 


\section{CALIBRATION OF RADIOCARBON AGE TO CALENDAR YEARS}

(Variables: $\mathrm{C} 13 / \mathrm{C} 12=0.1$ :Delta- $\mathrm{R}=0 \pm 0:$ Glob res $=-200$ to $500: \mathrm{lab} . \mathrm{mult}=1$ )

Laboratory number: Beta-235853

Conventional radiocarbon age: $2700 \pm 50 \mathrm{BP}$

(local reservoir correction not applied)

2 Sigma calibrated result: Cal BC 590 to 350 (Cal B P 2540 to 2300)

( $95 \%$ probability)

Intercept data

Intercept of radiocarbon age

with calibration curve: Cal BC 400 (Cal BP 2350)

1 Sigma calibrated result: Cal BC 500 to 380 (Cal BP 2460 to 2330)

(68\% probability)

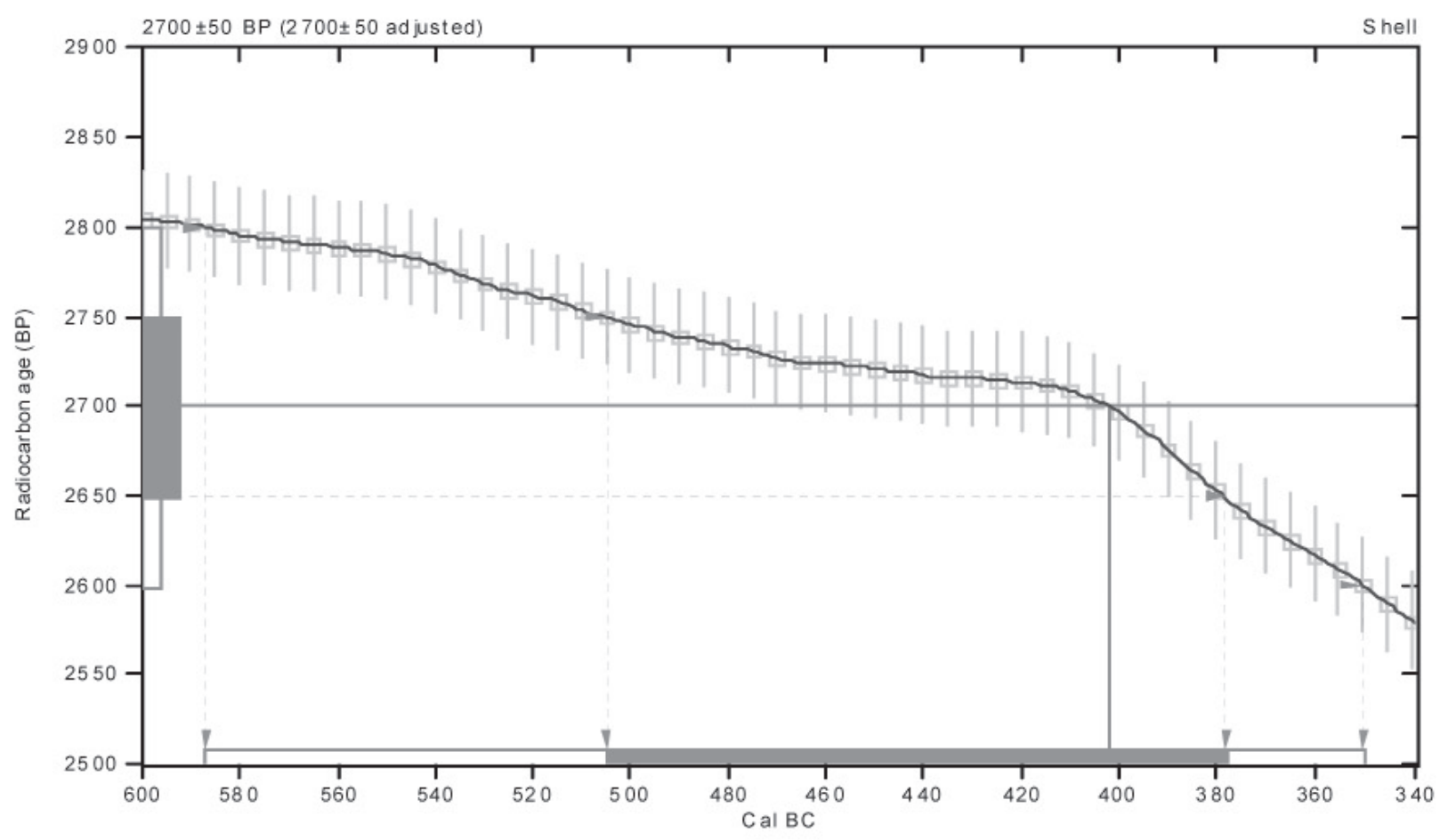

References:

Database us ed

$M A R I N E 04$

Calib ration D atabase

INTCALO4 Radiocarbon Age Calibration

IntCal0 4: Calibration /ssue of Radiocarbon (Volume 46, nr 3, 2004 ).

Ma them a tics

A Simplified A pproach to Calibrating C14 Dates

Talma, A. S., Vogel, J. C., 1993, Radiocarbon 35(2), p31 7-322

\section{Beta Analytic Radiocarbon Dating Laboratory}

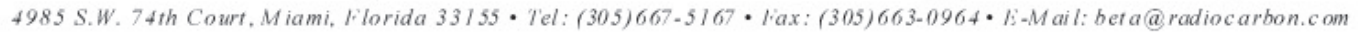




\section{CALIBRATION OF RADIOCARBON AGE TO CALENDAR YEARS}

(Variables: $\mathrm{C} 13 / \mathrm{C} 12=1.1$ :Delta $-\mathrm{R}=0 \pm 0:$ Glob res $=-200$ to $500: \mathrm{lab}$. $\mathrm{mult}=1$ )

Laboratory number: Beta-235855

Conventional radiocarbon age: $1370 \pm 40 \mathrm{BP}$

(local reservoir correction not applied)

2 Sigma calibrated result: Cal A D 970 to 1110 (C al B P 980 to 840)

(95\% probability)

Intercept data

Intercept of radiocarbon age

with calibration curve: Cal AD 1030 (Cal BP 920)

1 Sigma calibrated result: Cal AD 1000 to 1060 (Cal BP 940 to 890) (68\% probability)

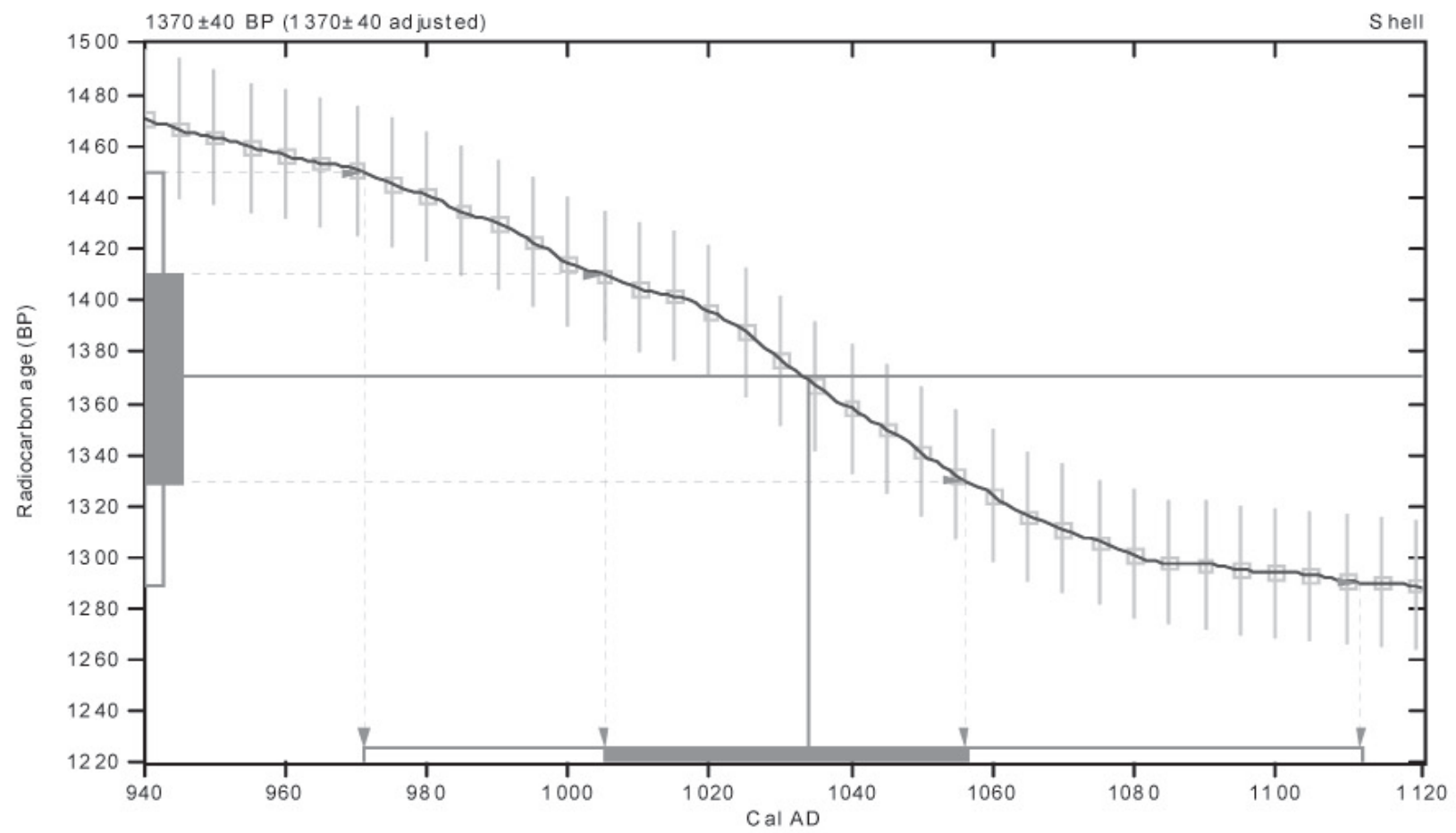

References:

Databas e us ed $M A R I N E 04$

Ca lib ration D ata base

INTCALO4 Radiocarbon Age Calibration

IntCalo
Ma th em a tics

A Simplified A pproach to Calibrating C14 D ates Talma, A.S., Vogel, J. C., 1993, Radiocarbon 35(2), p317-322 


\section{CALIBRATION OF RADIOCARBON AGE TO CALENDAR YEARS}

(Variables: $\mathrm{C} 13 / \mathrm{C} 12=-0.3: \mathrm{D}$ elta- $\mathrm{R}=0 \pm 0$ : Glob res $=-200$ to $500: \mathrm{lab}$. $\mathrm{mult}=1$ )

Laboratory number: Beta-235856

Conventional radiocarbon age: $1510 \pm 40 \mathrm{BP}$

(local reservoir correction not applied)

2 Sigma calibrated result: Cal AD 790 to 990 (Cal BP 1160 to 960)

( $95 \%$ probability)

Intercept data

Intercept of radiocarbon age

with calibration curve: Cal AD 900 (Cal BP 1050)

1 Sigma calibrated result: Cal AD 840 to 940 (Cal BP 1110 to 1010 )

(68\% probability)

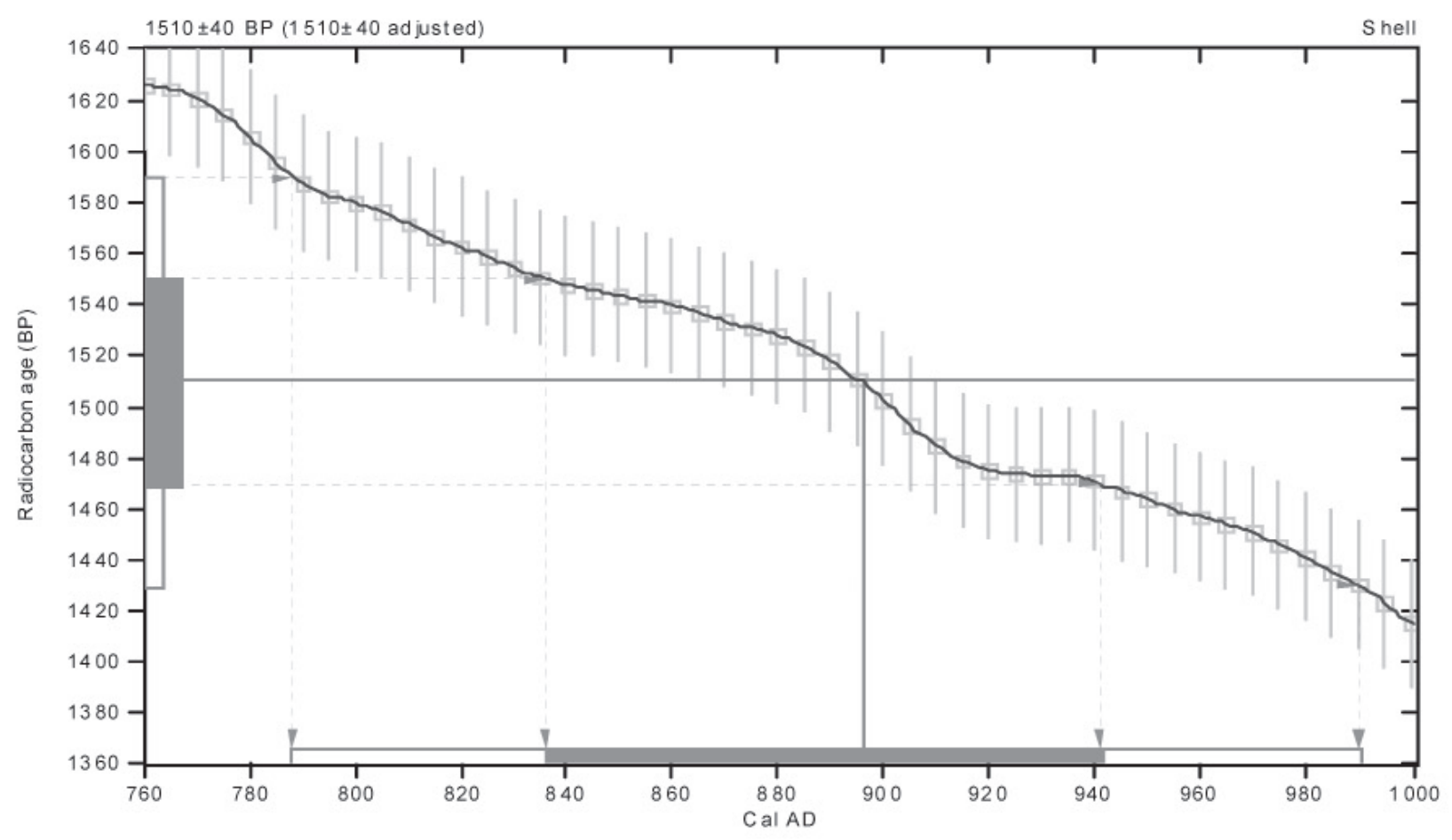

References:

Databas e us ed

MA RINE 04

Calib ration D atabase

INTCALO4 Radiocarbon Age Calibration

IntCal0 4: Calibration /ssue of Radiocarbon (Volume 46, nr 3, 2004 ).

Ma them a tics

A Simplified Approach to Calibrating C14 D ates

Talma, A. S., Vogel, J. C., 1993, Radiocarbon 35(2), p31 7-322

Beta Analytic Radiocarbon Dating Laboratory

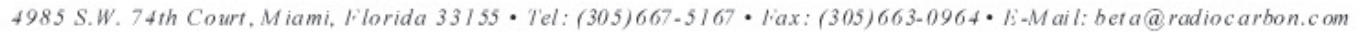




\section{CALIBRATION OF RADIOCARBON AGE TO CALENDAR YEARS}

(Variables: $\mathrm{C} 13 / \mathrm{C} 12=0.6$ : Delta- $\mathrm{R}=0 \pm 0: \mathrm{Glob}$ res $=-200$ to $500: \mathrm{lab}, \mathrm{mult}=1$ )

Laboratory number: Beta-235857

Conventional radiocarbon age: $2500 \pm 40 \mathrm{BP}$

(local reservoir correction not applied)

2 Sigma calibrated result: Cal BC 340 to 110 (Cal B P 2290 to 2060)

(95\% probability)

Intercept data

Intercept of radiocarbon age

with calibration curve: Cal BC 200 (Cal BP 2150)

1 Sigma calibrated result: Cal BC 290 to 160 (Cal BP 2240 to 2110 )

(68\% probability)

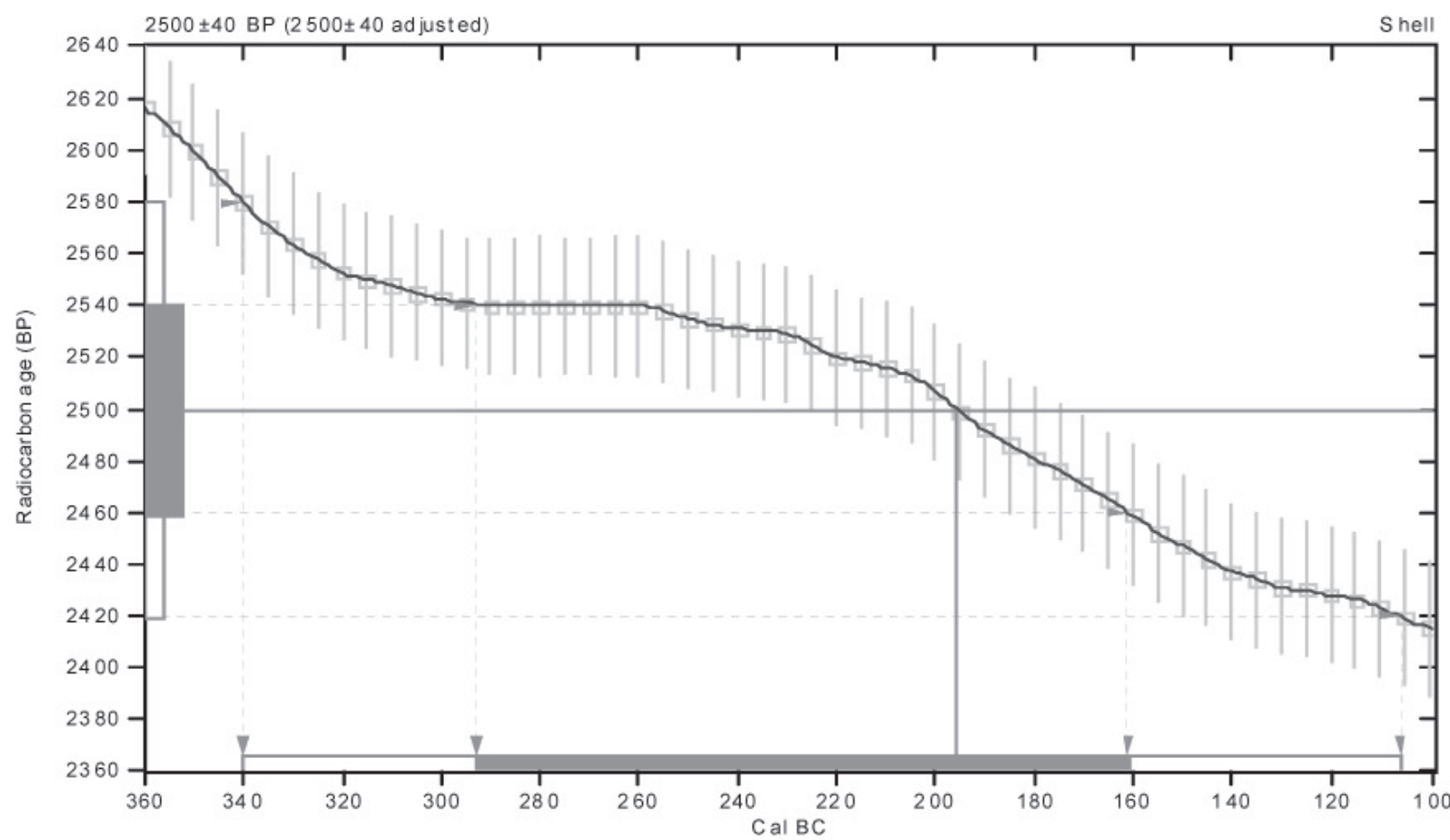

References:

Database us ed MA RINE 04

Calib ration D atabase

INTCALO4 Radiocarbon Age Calibration

IntCal0 4: Calibration Is sue of Radio carbon (Volume 46, nr 3, 2004).

Ma th em a tics

A Simplified A pproach to Calibrating C14 Dates

Talma, A.S., Vogel, J. C., 1993, Radiocarbon 35(2), p31 7-322

Beta Analytic Radiocarbon Dating Laboratory

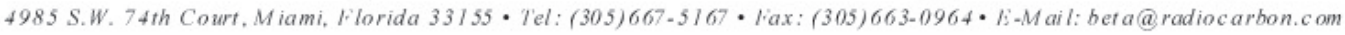




\section{CALIBRATION OF RADIOCARBON AGE TO CALENDAR YEARS}

(Variables: $\mathrm{C} 13 / \mathrm{C} 12=-0.2:$ Delta- $\mathrm{R}=0 \pm 0: \mathrm{Glob}$ res $=-200$ to $500:$ lab. $\mathrm{mult}=1$ )

Laboratory number: Beta-235858

Conventional radiocarbon age: $2480 \pm 40 \mathrm{BP}$

(local reservoir correction not applied)

2 Sigma calibrated result: Cal BC 330 to 80 (C al BP 2280 to 2030)

(95\% probability)

Intercept data

Intercept of radiocarbon age

with calibration curve: Cal BC 180 (Cal BP 2130)

1 Sigma calibrated result: Cal BC 220 to 140 (Cal BP 2170 to 2090) (68\% probability)

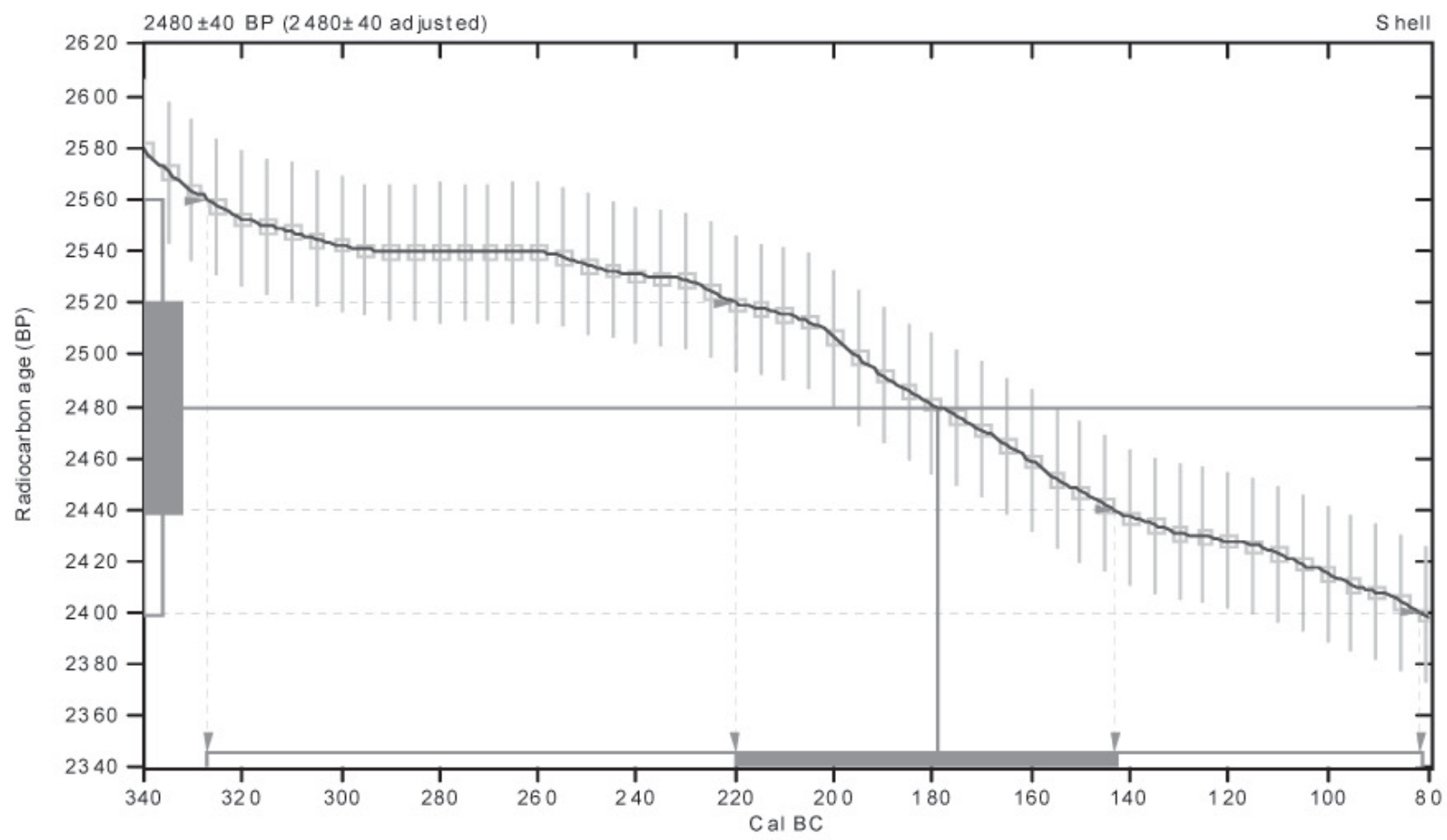

References:

Databas e us ed MA RINE 04

Ca lib ration $D$ ata base

INTCALO4 Radiocarbon Age Calibration

IntCal0 4: Calibration Issue of Radio carbon (Volume 46, nr 3, 2004).

Ma th em a tics

A Simplified Approach to Calibrating C14 Dates Talma, A. S., Vogel, J. C., 1993, Radiocarbon 35(2), p31 7-322 


\section{CALIBRATION OF RADIOCARBON AGE TO CALENDAR YEARS}

(Variables: $\mathrm{C} 13 / \mathrm{C} 12=-0.1:$ Delta- $\mathrm{R}=0 \pm 0: \mathrm{Glob}$ res $=-200$ to $500: \mathrm{lab} . \mathrm{mult}=1$ )

Laboratory number: Beta-235859

Conventional radiocarbon age: $3640 \pm 40 \mathrm{BP}$

(local reservoir correction not applied)

2 Sigma calibrated result: Cal BC 1680 to 1490 (Cal BP 3630 to 3440 )

(95\% probability)

Intercept data

Intercept of radiocarbon age

with calibration curve: Cal BC 1600 (Cal BP 3550)

1 Sigma calibrated result: Cal BC 1640 to 1530 (Cal BP 3590 to 3480 )

(68\% probability)

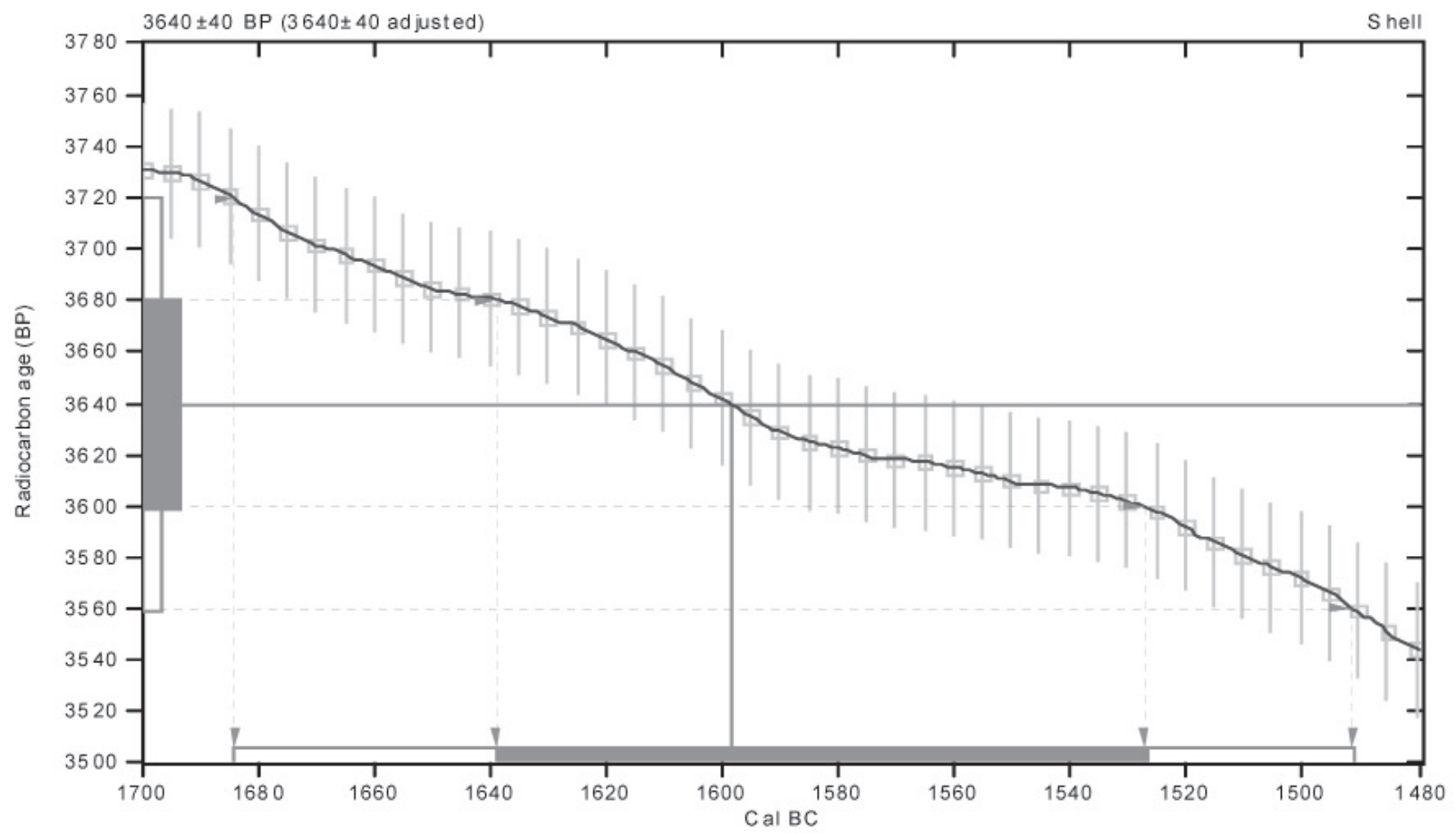

References:

Databas e used MARINE04

Ca lib ration D ata base

INTCALO4 Radiocarbon Age Calibration

IntCal0 4: Calibration Is sue of Radio carbon (Volume 46, nr 3, 2004).

Ma them a tics

A Simplified Approach to Calibrating C14 D ates

Talma, A. S., Vogel, J. C., 1993, Radiocarbon 35(2), p317-322

Beta Analytic Radiocarbon Dating Laboratory

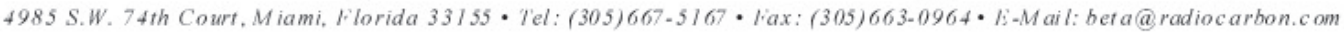

